\title{
A Avifauna Plistocénica de Portugal ESPECIFICIDADES EVOLUTIVAS, ANATÓMICAS E O SEU CONTEXTO PALEONTOLÓGICO, GEOLÓGICO E ARQUEOLÓGICO
}

Silvério Manuel Domingues Figueiredo
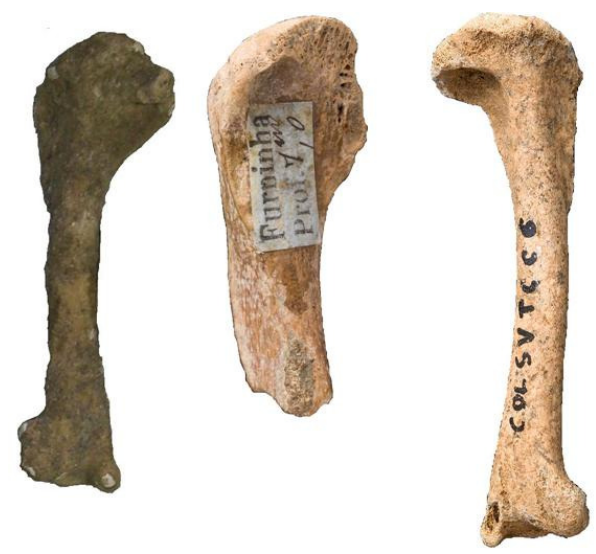

Facultad de Geografia e Historia Departamento de Prehistoria, Historia Antigua y Arqueologia (USAL)

Departamento de História (UAL) Lisboa - Salamanca 2010 


\title{
A Avifauna Plistocénica de Portugal ESPECIFICIDADES EVOLUTIVAS, ANATÓMICAS E O SEU CONTEXTO PALEONTOLÓGICO, GEOLÓGICO E ARQUEOLÓGICO
}

Silvério Manuel Domingues Figueiredo

\author{
Tese de Doutoramento em \\ Pré-História, História Antiga e Arqueologia \\ V.B. Professora Doutora Maria Soledad Corchón
}

Lisboa e Salamanca

Abril de 2010 


\author{
Universidad de Salamanca \\ Facultad de Geografia e Historia \\ Departamento de Prehistoria, Historia Antigua y Arqueologia \\ Universidade Autónoma de Lisboa \\ Departamento de História
}

\title{
A Avifauna Plistocénica de Portugal ESPECIFICIDADES EVOLUTIVAS, ANATÓMICAS E O SEU CONTEXTO PALEONTOLÓGICO, GEOLÓGICO E ARQUEOLÓGICO
}

Memória para obtenção do grau de doutor apresentada por Silvério Manuel Domingues Figueiredo, sob a orientação da Professora Doutora Maria Soledad Corchón

Facultad de Geografia e Historia

Departamento de Prehistoria, Historia Antigua y Arqueologia (USAL)

Departamento de História (UAL)

Lisboa - Salamanca

2010 
DEDICATÓRIA

Aos meus pais, à minha esposa, Luísa Madeira, ao meu filho Dinis e à minha irmã. 


\section{AGRADECIMENTOS}

Gostaria de agradecer a ajuda, as críticas e as opiniões de colegas e amigos que valorizaram a versão final desta tese.

Em primeiro lugar uma palavra de agradecimento ao Dr. Júlio Pinto, pela ajuda na revisão ortográfica dos textos e as sugestões dadas durante essa revisão, e ao Dr. Manuel Américo também pela ajuda na revisão e sugestões aos textos e pela ajuda na tradução do resumo em inglês.

Ao CIPA gostaria de agradecer a disposição da colecção de referência para o estudo osteológico, em especial ao Dr. Carlos Pimenta pela ajuda na identificação taxonómica de alguns ossos.

Ao Doutor Pedro Cunha, gostaria de agradecer a ajuda e as sugestões na elaboração dos textos sobre a caracterização geológica de Portugal, das jazidas e da interpretação paleoambiental.

Ao Doutor Miguel Ramalho, um agradecimento pela autorização do estudo dos materiais em depósito no MG e ao José António e ao Eng. Jorge Sequeira, a ajuda no acesso e na disposição dessas colecções.

Ao Dr. Luís Raposo, director do MNA, pela autorização do acesso aos restos osteológicos do Pego do Diabo e pela leitura e criticas dos textos sobre o Paleolítico de Portugal e a caracterização arqueológica das várias jazidas abordadas nesta tese.

Ao Doutor Pierluigi Rosina, gostaria de agradecer as sugestões dadas.

À Câmara Municipal do Bombaral, em especial à Dr.a Cláudia, o acesso aos materiais da Gruta Nova da Columbeira.

Gostaria também de agradecer à Doutora Liliana Povoas do MNHN, a disposição da colecção de microfauna da Gruta do caldeirão e a disposição dos meios para o estudo dessa colecção.

À Dr. a Vera Cabedal, um agradecimento pela ajuda na formatação dos textos, ao Dr. Mário Santos a ajuda no tratamento de alguns dados e na elaboração de alguns quadros e gráficos e à Liliana Faustino o tratamento de algumas das imagens.

À minha família e amigos tenho a agradecer o apoio que sempre me deram. 
"Aujourd'hui l'anatomie comparative a atteint un tel point de perfection que, après l'inspection d'un seul os, on peut souvent déterminer la classe, et parfois voire même le genre de l'animal auquel il a appartenu" Georges Cuvier

"O Universo é feito essencialmente de coisa nenhuma. Intervalos, distâncias, buracos, porosidade etérea. Espaço vazio, em suma. O resto, é a matéria.

Daí, que este arrepio, este chamá-lo e tê-lo, erguê-lo e defrontá-lo esta fresta de nada aberta no vazio, deve ser um intervalo." Poema "Máquina do Mundo" António Gedeão 


LISTA DE FIGURAS
LISTA DE QUADROS
LISTA DE GRÁFICOS
RESTA DE ABREVIATURAS
PASTRACT
INTRODUÇÃO

1 - ESTADO ACTUAL DO CONHECIMENTO .............................................................................................

1.1 - Enquadramento Evolutivo: aves ou dinossauros? problemática histórica, paleontológica e

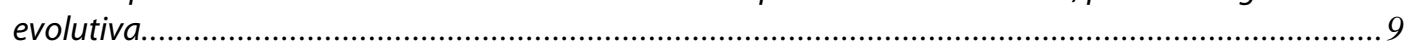

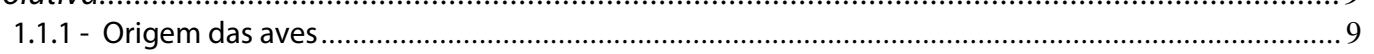

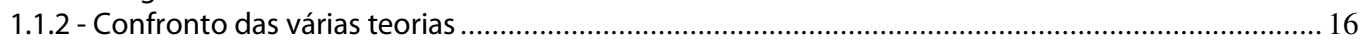

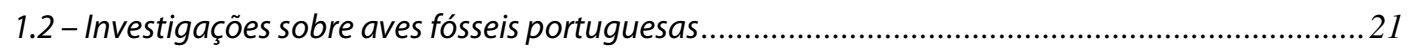

1.2 .1 - Investigações sobre aves meso-cenozóicas em Portugal ...........................................................2 21

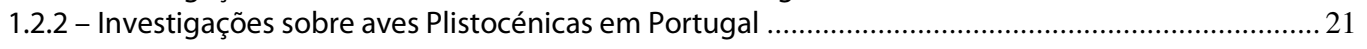

1.3 - Breve história das investigações das jazidas estudadas..........................................................25

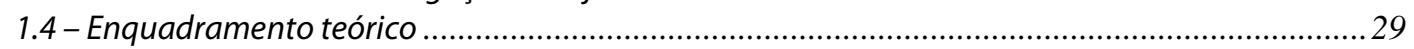

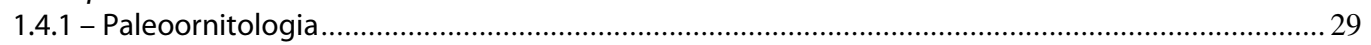

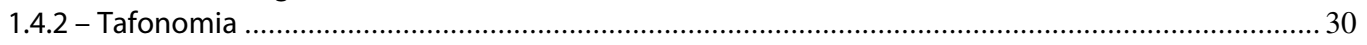

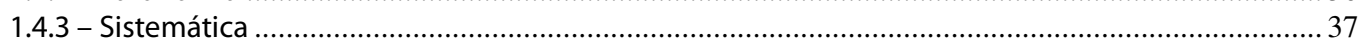

2 - ENQUAdRAMENTO GEOGRÁFICO E CRONOLÓGICO .......................................................................

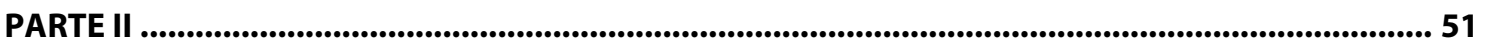

CONTEXTUALIZAÇÃO GEOLÓGICA, PALEONTOLÓGICA E ARQUEOLÓGICA ................................... 51

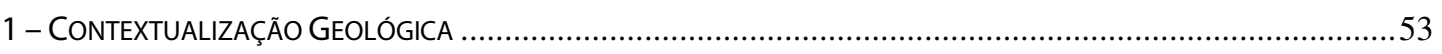

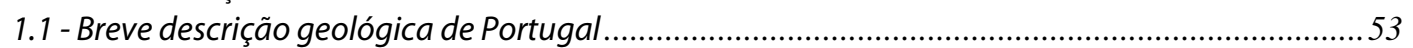

1.1.1 - O Mesozóico e o Cenozóico ..................................................................................................... 53

1.1.2 - As grandes unidades meso-cenozóicas de Portugal ...................................................................56

1.1.3 - Sequências Limitadas por Descontinuidades (SLD) .................................................................60

1.2 - Caracterização geográfica e geológica das jazidas estudadas..............................................6.63

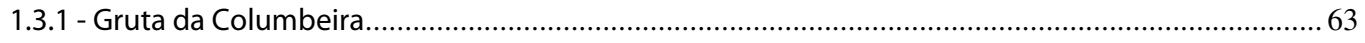

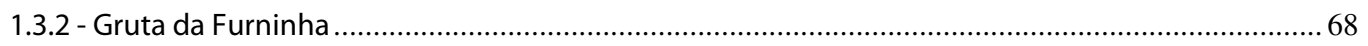

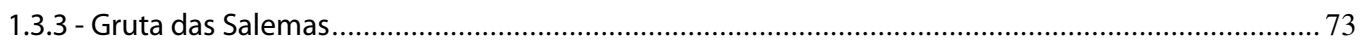

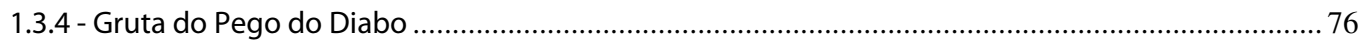

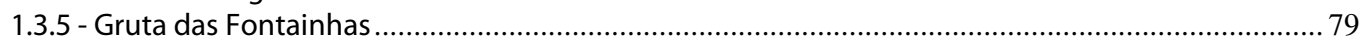

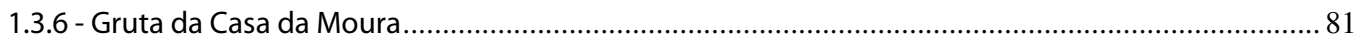

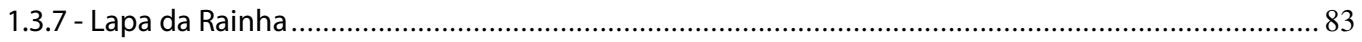

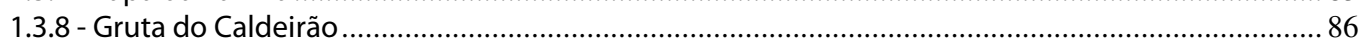

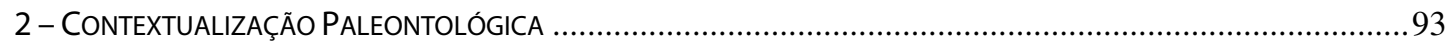

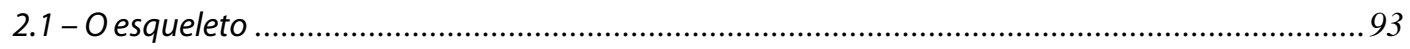

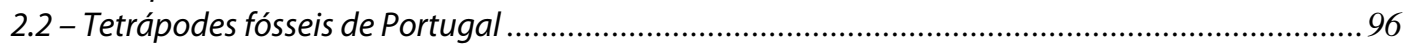

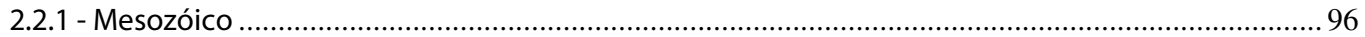

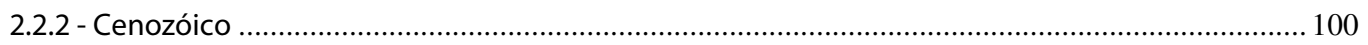

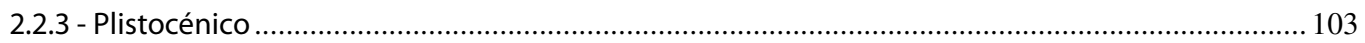




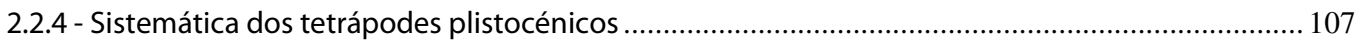

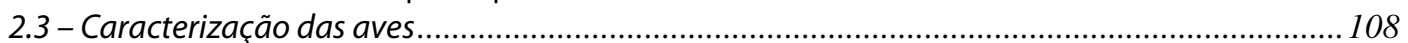

2.3.1. - Caracterização osteológica das aves: características gerais do esqueleto das aves .................... 113

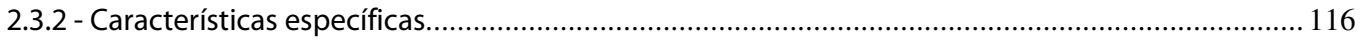

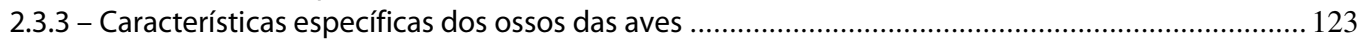

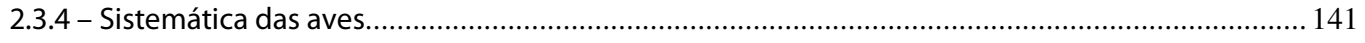

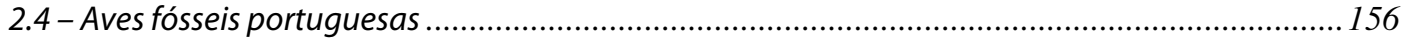

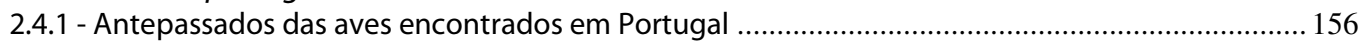

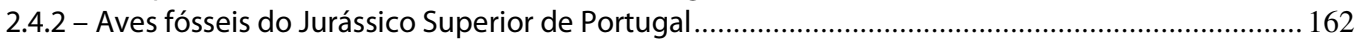

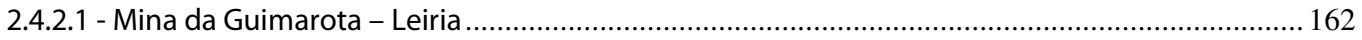

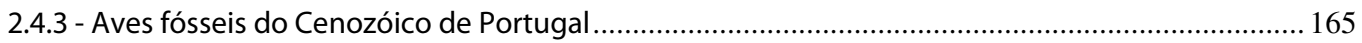

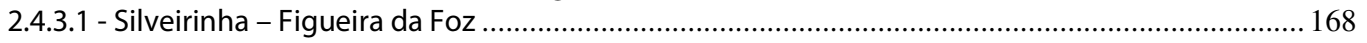

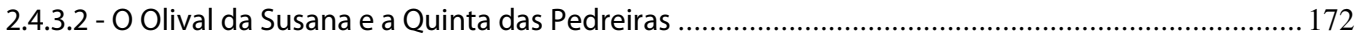

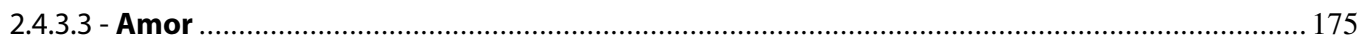

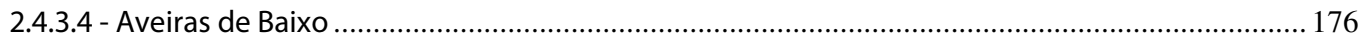

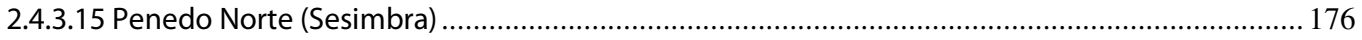

2.5 - Breve Referência à Paleoecologia do Plistocénico em Portugal e na Península lbérica ............. 177

2.5.1 - Caracterização paleoecológica do plistocénico português ............................................................. 177

2.6 - Caracterização paleontológica das jazidas estudadas........................................................ 179

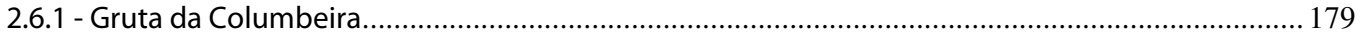

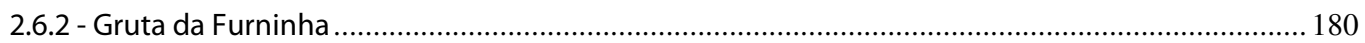

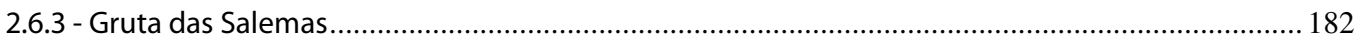

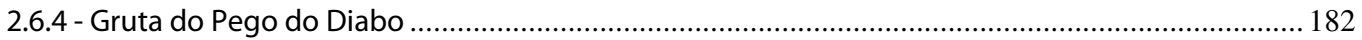

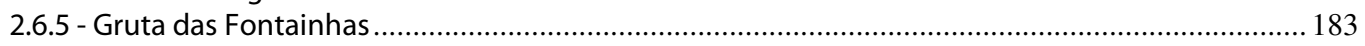

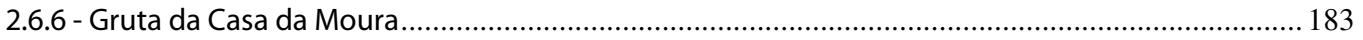

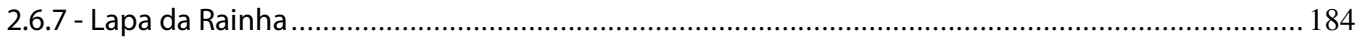

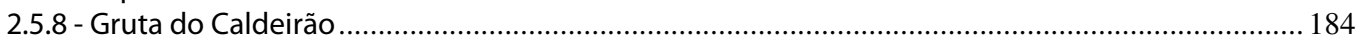

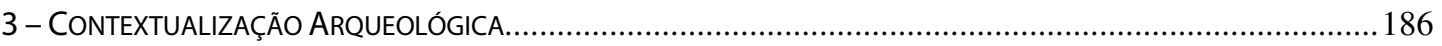

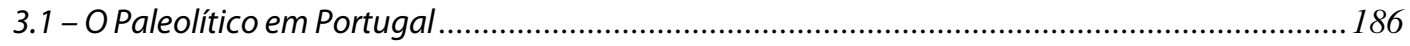

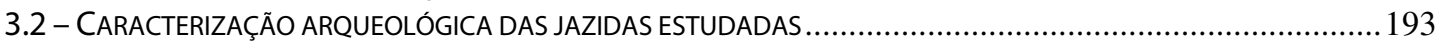

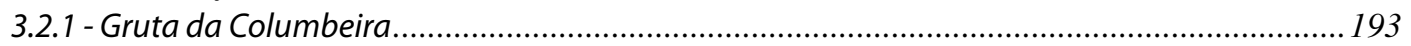

3.2.2 - Gruta da Furninha ....................................................................................................... 194

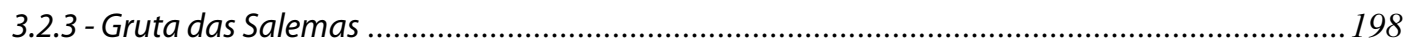

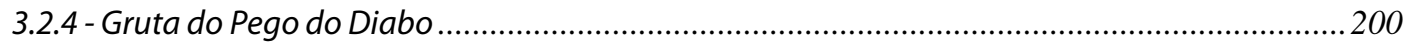

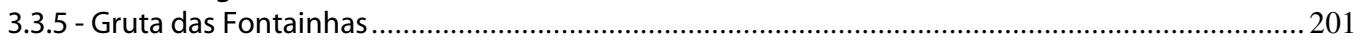

3.2.6 - Gruta da Casa da Moura ................................................................................................... 202

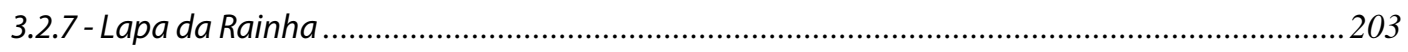

3.2.8 - Gruta do Caldeirão ...................................................................................................205

4 - CARACTERIZAÇÃo ARQUEOLÓGICA, GEOLÓGICA, PALEONTOLÓGICA E PALEOORNITOLÓGICA DAS JAZIDAS COM

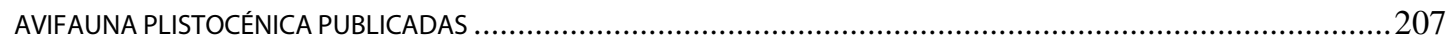

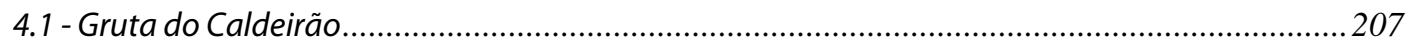

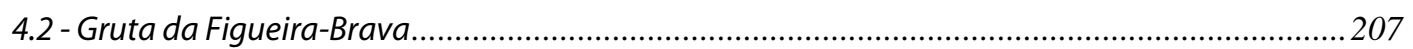

4.3 - Grutas do Almonda ........................................................................................................... 212

4.4 - Abrigo do Lagar Velho - Lapedo ........................................................................................... 215

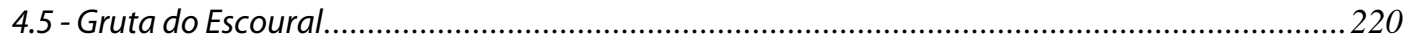

4.6 - Outras jazidas com referências à existência de avifauna .....................................................222

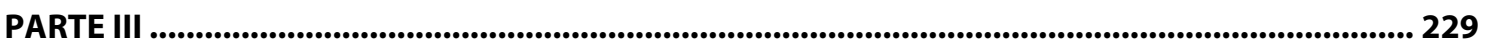

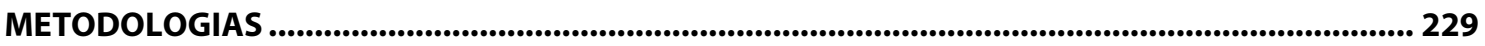

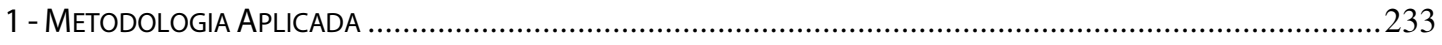

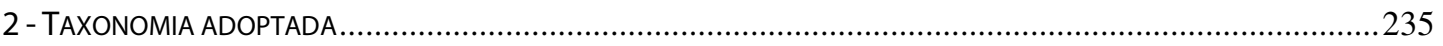

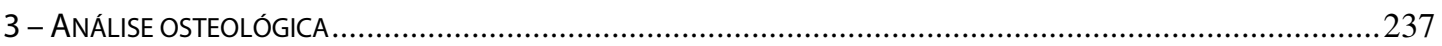

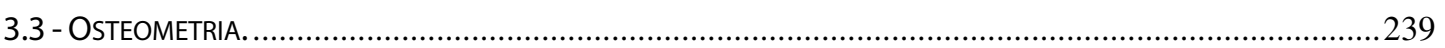

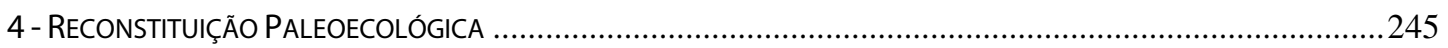

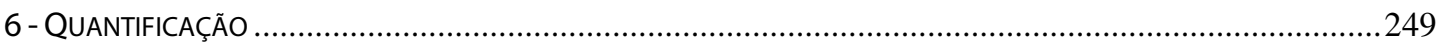

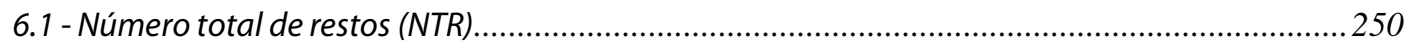

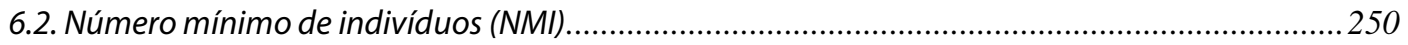




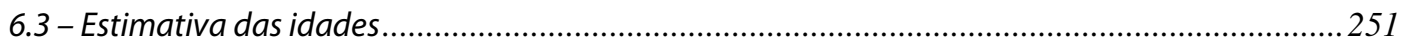

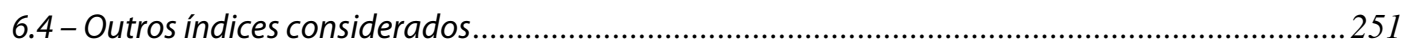

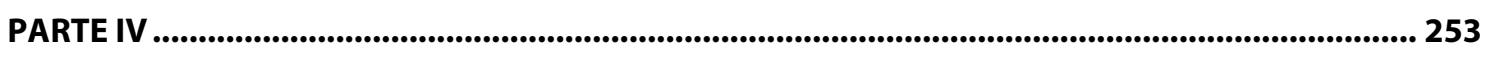

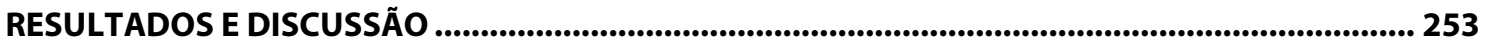

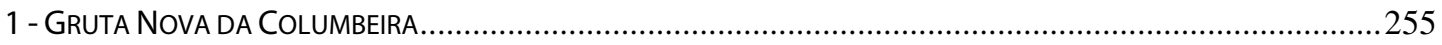

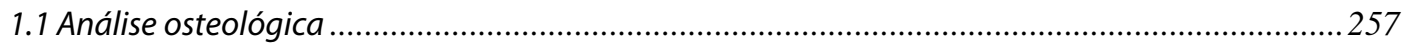

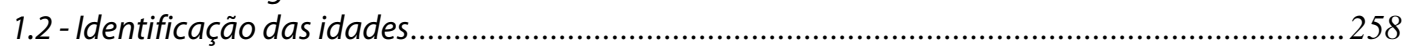

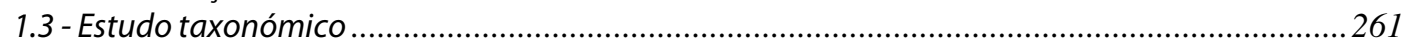

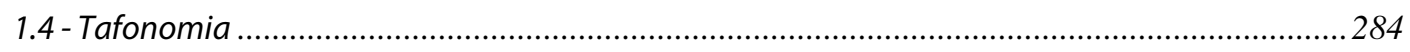

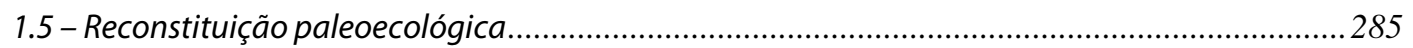

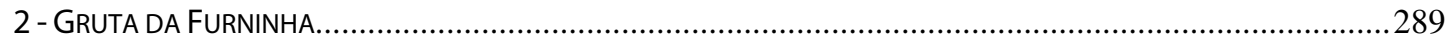

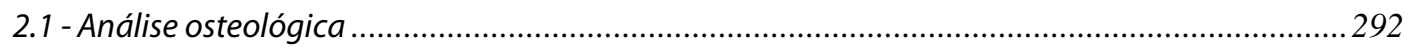

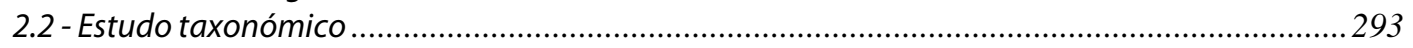

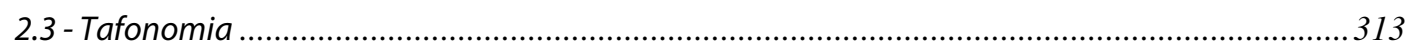

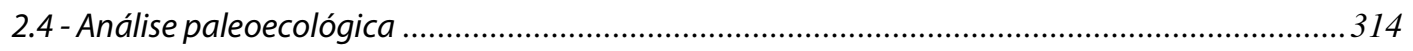

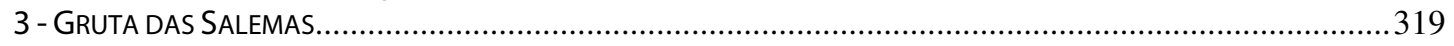

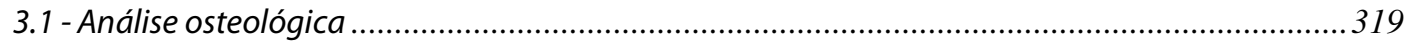

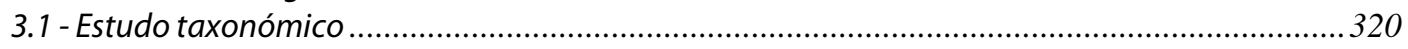

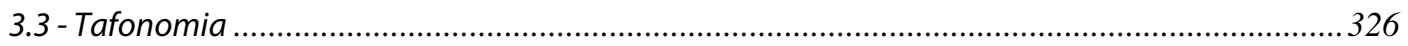

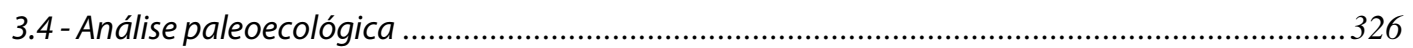

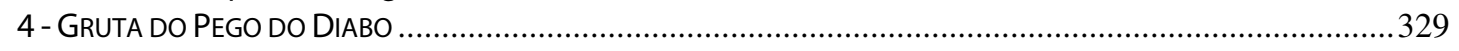

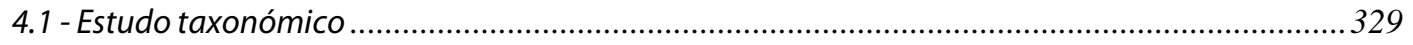

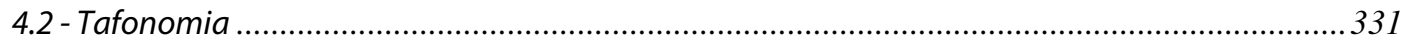

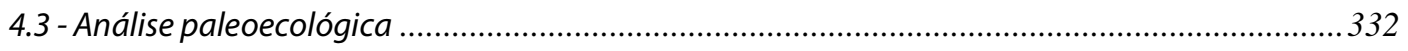

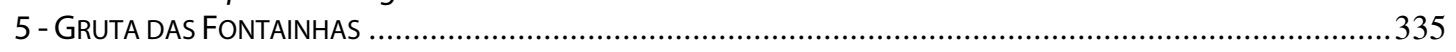

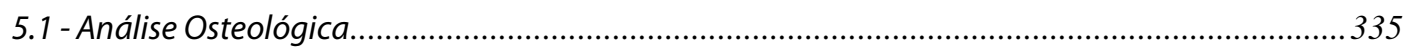

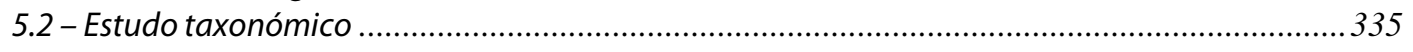

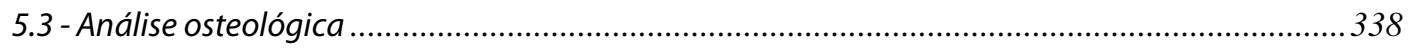

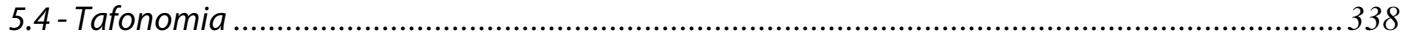

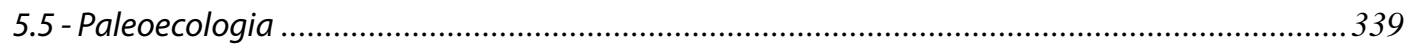

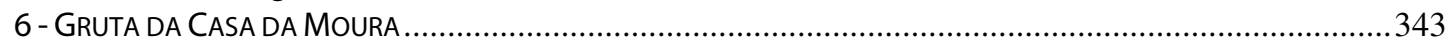

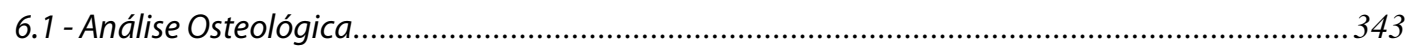

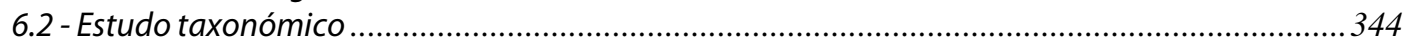

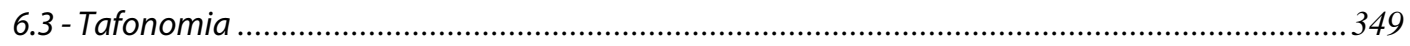

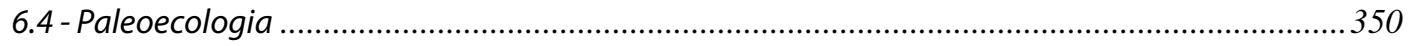

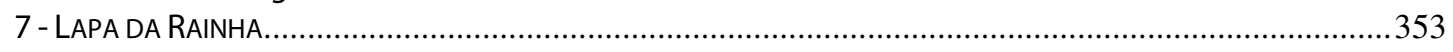

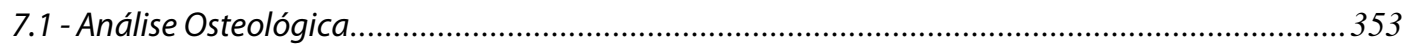

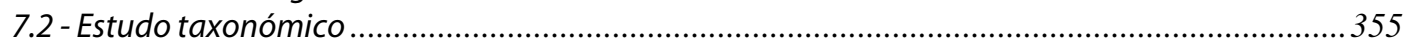

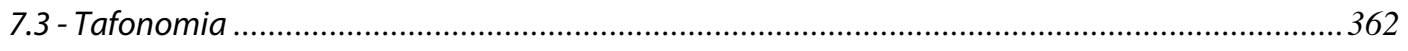

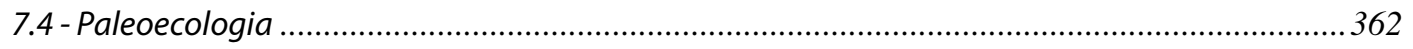

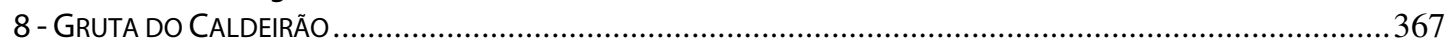

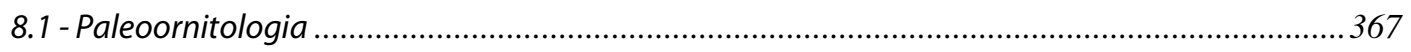

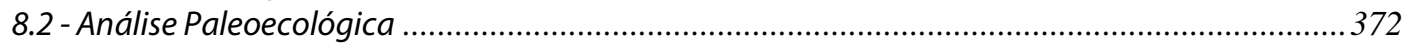

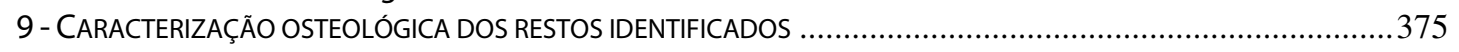

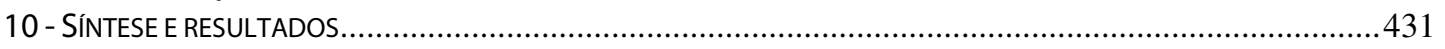

10.1 - Espécies identificadas e a sua distribuição por jazida .....................................................432

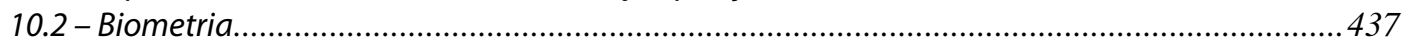

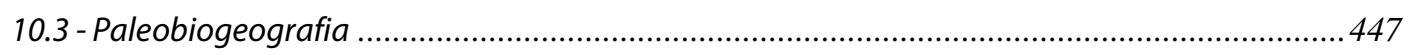

10.4 - Condicionantes Tafonómicas, Arqueológicas e Geológicas..................................................461

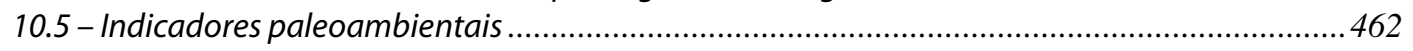

10.6 - Distribuição temporal das aves plistocénicas portuguesas...................................................465

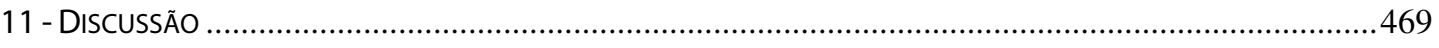

CONCLUSÕES ...................................................................................................................................... 487 


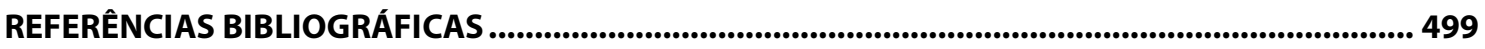

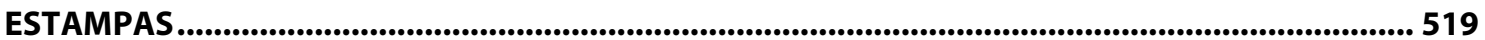

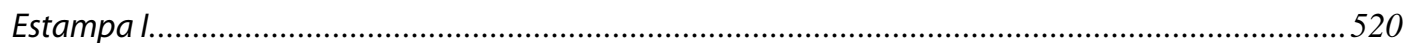

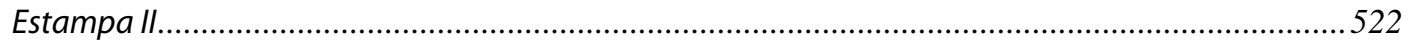

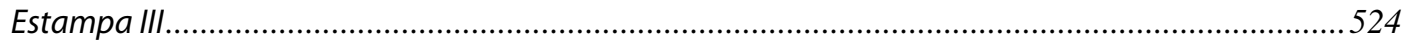

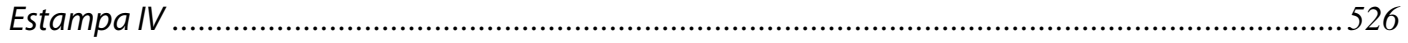

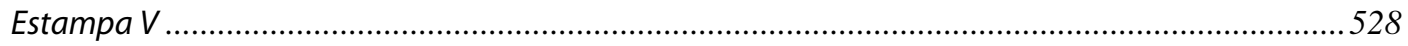

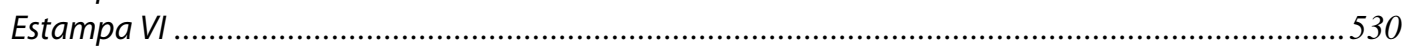

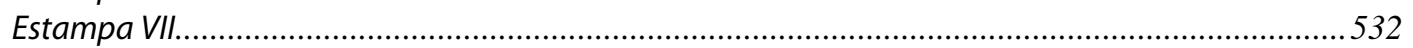

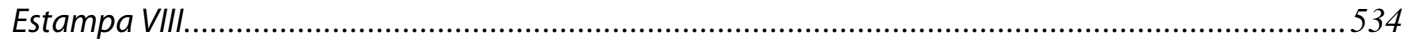

Estampa IX

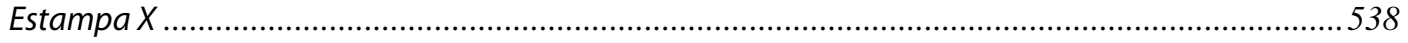

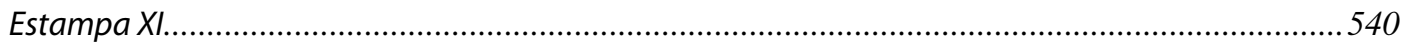

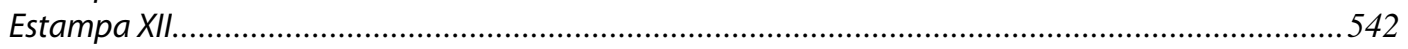

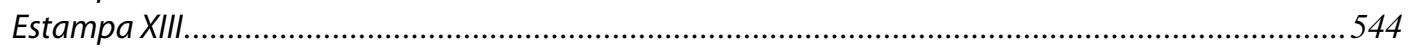

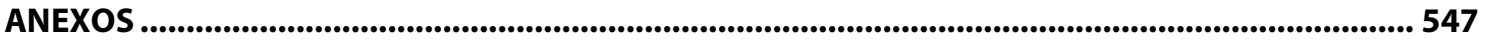


Fig. 1 - Desenho de oito dos nove especímenes de Archaeopterix conhecidos: a)Berlim / Munique (1860); b) Londres (1861); c) Haarlem (1855 - 1970); d) Berlim (1877); e) Maxberg (1956); i) Eichstall (1951); g) Solnhofen (1987); h) Munique (1992). Fonte: BENTON, 2005, p. $258 .$.

Fig. 2 - Comparação dos ossos dos membros anteriores entre alguns terópodes e as aves (adaptado de PADIAN \&

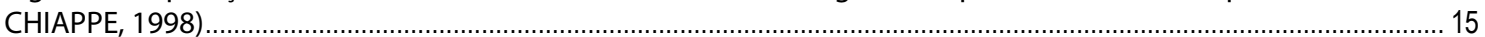
Fig. 3 - Cladograma com a relação das aves com os dinossauros (fonte: Figueiredo, 2008).................................. 16 Fig. 4 - Parentesco entre os diferentes grupos de répteis, segundo Cox, 1969 (edição brasileira de 1974). Podemos verificar nesta árvore evolutiva que as aves descendem dos arcossauros. Fonte: COX, 1974, pp. 120.................... 18 Fig. 5 - Comparação entre o esqueleto de um Compsognathus (em baixo), do Archaeopteryx (a meio) e de uma

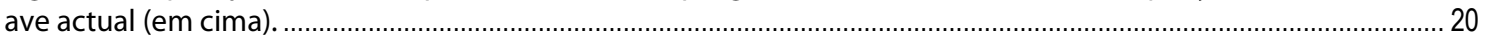
Fig. 6 - Esquema com o processo de estudo da tafonomia (construção do autor com base em Simões \& Holz, 2004,

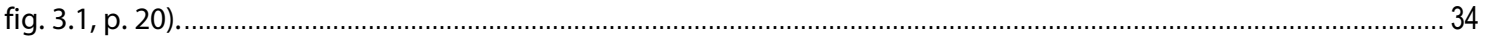

Fig. 7 - Esquemas da taxonomia cladística (construção do autor, com base em RIOS-NETTO, 2004)....................... 45 Fig. 8 - Relação (simplificada) entre dinossauros e aves, segundo os estudos de cladística........................................ 46 Fig. 9 - Mapa de localização geral dos sítios estudados (1 a 8) e seu enquadramento no contexto das jazidas plistocénicas com restos de aves, em Portugal (9 a 16): 1 - Gruta Nova da Columbeira; 2 - Gruta da Furninha; 3 Gruta das Salemas; 4 - Gruta do Pego do Diabo; 5 - Gruta das Fontainhas; 6 - Gruta da Casa da Moura; 7 - Lapa da Rainha; 8 - Gruta do Caldeirão; 9 - Gruta da Figueira-Brava; 10 - Gruta do Escoural; 11 - Grutas do Almonda; 12 - Abrigo do Lagar Velho; Lapa do Picareiro; 14 - Foz do Enxarrique; 15 - Buraca Escura. (Fonte: Grande Atlas Mundial - Selecções do Reader's Digest, 1978) .............................................................................................. 48 Fig. 10 - - Mapa com a localização das formações mesozóicas e cenozóicas em Portugal, Adaptado da Carta Geológica de Portugal Esc. 1:1 000 000, SGP, 1968.

Fig. 11 - Localização na Carta Militar de Portugal, à escala de 1:25000 (folha 350), da Gruta Nova da Columbeira.

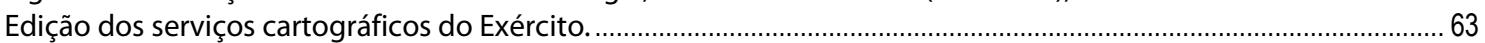
Fig. 12 - Placa sinalizadora da entrada da Gruta Nova da Columbeira (fotografia: S. Figueiredo)............................. 64 Fig. 13 - O Vale Roto visto a partir da actual entrada da Gruta Nova da Columbeira (fotografia: S. Figueiredo)....... 65 Fig. 14 - Representação estratigráfica do corte longitudinal, que serviu para a descrição da estratigrafia da gruta (excerto do caderno de campo de O. Da Veiga Ferreira, do seu seu arquivo pessoal), in CARDOSO, 2006...............66 Fig. 15 - Desenho do perfil do corte estratigráfico da Gruta Nova da Columbeira, segundo SANTOS, 1972 .............68 Fig. 16 - Localização na Carta Militar de Portugal, à escala de 1:25000 (folha 337), da Gruta da Furninha. Edição dos

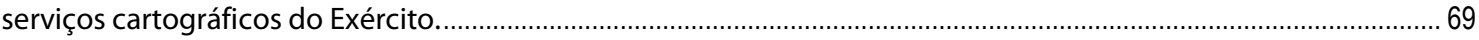
Fig. 17 - Corte longitudinal e planta da Gruta da Furninha, segundo DELGADO, 1884 (simplificado)..................... 70 Fig. 18- Localização na Carta Militar de Portugal, à escala de 1:25000 (folha 403), da Gruta das Salemas. Edição dos

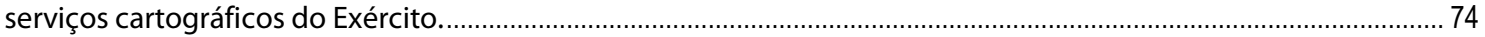
Fig. 19 - Representação da estratigrafia da Gruta das Salemas, segundo ROCHE \& FERREIRA, 1970......................... 76 Fig. 20 - Localização na Carta Militar de Portugal, à escala de 1:25000 (folha 403), da Gruta do Pego do Diabo. Edição dos serviços cartográficos do Exército. ............................................................................................................ 77 Fig. 21 - Desenho do corte estratigráfico longitudinal da Gruta do Pego do Diabo, com a indicação das camadas estratigráficas. Segundo ZILHÃO, 1997.................................................................................................................... 79 Fig. 22 - Localização na Carta Militar de Portugal, à escala de 1:25000 (folha 363), da Gruta das Fontainhas. Edição dos serviços cartográficos do Exército...................................................................................................................... 80 Fig. 23 - Localização na Carta Militar de Portugal, à escala de 1:25000 (folha 337) da Casa da Moura. Edição dos

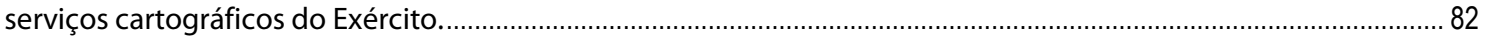
Fig. 24 - Representação do corte logitudinal da gruta da Casa da Moura, segundo ROCHE, 1951........................... 83 Fig. 25 - Localização na Carta Militar de Portugal, à escala de 1:25000 (folha 361), da Lapa da Rainha. Edição dos serviços cartográficos do Exército. 84 Fig. 26- Representação da estratigrafia da Lapa da Rainha, segundo ALMEIDA; SANTOS; ROCHE \& FERREIRA (1970). Fig. 27 - Localização na Carta Militar de Portugal, à escala de 1:25000 (folha 310), da Gruta do Caldeirão. Edição dos serviços cartográficos do Exército. ........................................................................................................................ 87 Fig. 28 - Planta da Gruta do Caldeirão, com a malha da quadriculagem e área escavada. (Adaptado de ZILHÃO,

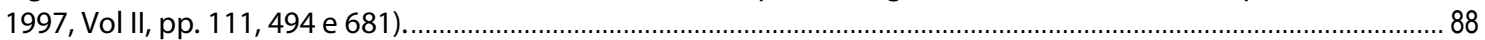
Fig. 29 - Esquema estratigráfico do perfil oeste, do quadrado P11 da Gruta do Caldeirão, segundo ZILHÃO, 1997,

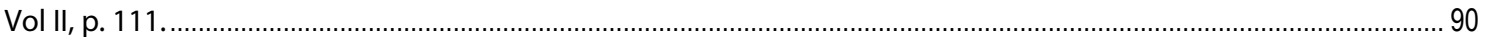
Fig. 30 - Desenho do corte longitudinal da Gruta do Caldeirão, dos quadrados Q-R, representando a respectiva estratigrafia, segundo ZILHÃO, 1997, vol. II, pp.683. 
Fig. 31 - As partes do esqueleto (adaptado de COHEN \& SERJEANTSON, 1996) ..........................................................95

Fig. 32 - Exemplos dos diferentes tipos de penas das aves (Fonte: HARRISON \& GREENSMITH, 1993 .....................112

Fig. 33 - Principais ossos do crânio de um Gallus gallus (construção do autor a partir de COHEN e SERJEANTSON, 1996)...

Fig. 34 - Principais ossos do esqueleto apendicular (construção do autor a partir de COHEN e SERJEANTSON,

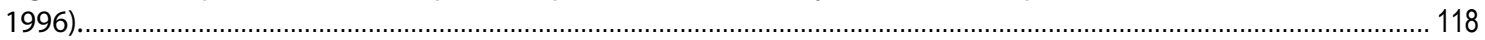

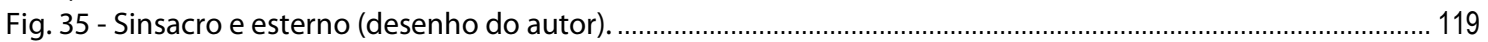

Fig. 36 - Representação esquemática da distribuição do centro de gravidade durante o voo e em terra firme, nas

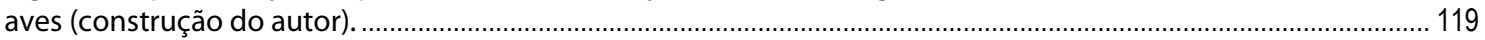

Fig. 37 - Destaque da quilha, no esterno (desenho do autor)........................................................................... 120

Fig. 38 - Composição do esqueleto de uma ave (gén. Columba). No canto inferior esquerdo estão assinalados os números dos diferentes tipos de vertas que constituem o sinsacro. (construção do autor a partir de Young, 1950).

Fig. 39 - Principais ossos e estruturas dos crânios das aves (adaptado de COHEN \& SERJEANTSON, 1996 e DRIESCH,

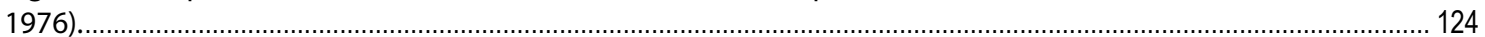

Fig. 40 - Principais estruturas da mandíbula (adaptado de COHEN \& SERJEANTSON, 1996).................................. 125

Fig. 41 - Principais estruturas do esterno das aves (adaptado de COHEN \& SERJEANTSON, 1996). ........................ 125

Fig. 42 - Principais estruturas da pélvis e do sinsacro (adaptado de COHEN \& SERJEANTSON, 1996). .................... 126

Fig. 43 - Ossos da Cintura escapular de Gallus gallus (adaptado de COHEN \& SERJEANTSON, 1996)..................... 127

Fig. 44 Ossos dos membros anteriores de Strix varia (adaptado de GILBERT et al., 1996) ...................................... 128

Fig. 45 - Principais estruturas da escápula (adaptado de COHEN \& SERJEANTSON, 1996)..................................... 128

Fig. 46 - Principais estruturas do coracóide (adaptado de COHEN \& SERJEANTSON, 1996)....................................129

Fig. 47 - Principais estruturas do úmero (adaptado de COHEN \& SERJEANTSON, 1996)........................................ 131

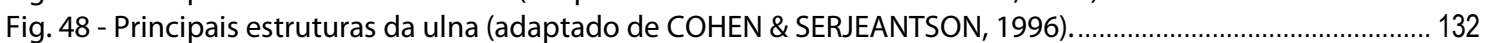

Fig. 49- Principais características do rádio (adaptado de COHEN \& SERJEANTSON, 1996)..................................... 133

Fig. 50 - Principais estruturas do carpometacarpo (adaptado de COHEN \& SERJEANTSON, 1996)......................... 134

Fig. 51 - Principais estruturas ósseas da primeira falange do dígito II (adaptado de GILBERT et al., 1996) .............. 135 Fig. 52 - Ossos da cintura pélvica, cauda e membros posteriores (retirado e adaptado de http://www.life.illinois.edu/ib/461/Internal_Anatomy.pdf, acedido em 12/03/2009) ............................................ 136

Fig. 53 - Ossos dos membros posteriores de Strix varia (adaptado de GILBERT et al., 1996) ................................... 137

Fig. 54 - Principais estruturas do fémur (adaptado de COHEN \& SERJEANTSON, 1996)....................................... 138

Fig. 55 - Principais estruturas do tibiotarso (adaptado de COHEN \& SERJEANTSON, 1996).................................... 139

Fig. 56 - Principais estruturas do tarsometatarso (adaptado de COHEN \& SERJEANTSON, 1996)............................ 140

Fig. 57 - O Archaeopteryx (desenho de Mónica Ramos) ........................................................................................... 143

Fig. 58 - O Ichtyornis, ave do grupo dos odontognatos, do Cretácico Superior (desenho de Mónica Ramos)....... 144

Fig. 59 - O Phorusrhacus, uma ave carnívora do grupo dos Paleognathae, que viveu no Miocénico, na América do

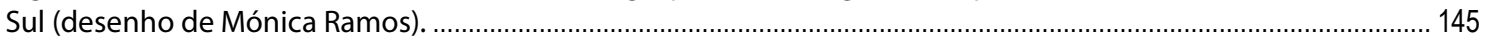

Fig. 60 - Fragmento de ulna e carpo lunar de Dromaeosaurus indet. da Praia das Aguncheiras (fotografia: S.

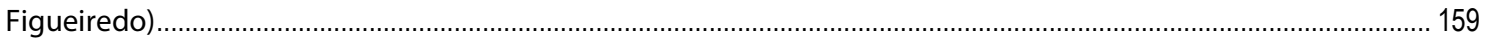

Fig. 61 - Localização das jazidas com restos de fósseis de avifauna do Mesozóico e do Cenozóico.......................... 166

Fig. 62 - Ordens de aves fósseis encontradas em Portugal, com destaque para as do Cenozóico (as bolas indicam

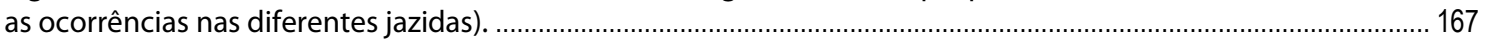
Fig. 63 - Resto atribuído por Henry Breuil a um elefante, com a respectiva ficha de inventário, onde se pode ler

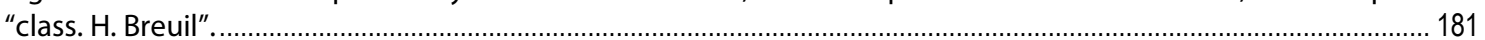
Fig. 64 - Denticulados do Paleolítico Médio da Gruta Nova da Columbeira, segundo RAPOSO \& CARDOSO, 1998194 Fig. 65 - Biface acheulense da Gruta da Furninha, in DELGADO, 1884 ............................................................... 196 Fig. 66 - Ponta gravetense (esq.) e folha de loureiro (dir.) da Gruta da Furninha, segundo ZILHÃO, 1997 .............. 198 Fig. 67 - Reprodução da figura n. ${ }^{\circ}$ 9, in ROCHE et al. 1962, onde estão representados, segundo os autores,

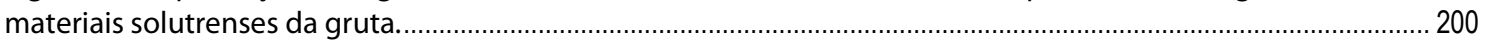
Fig. 68 - Materiais aurignacenses da Gruta do Pego do Diabo, segundo ZILHÃO, 1997..........................................201

Fig. 69 - Materiais solutrenses da Gruta da Casa da Moura, segundo ZILHÃO, 1997................................................ 203 Fig. 70 - Materiais paleolíticos da Lapa da Rainha, in ALMEIDA et al. , 1970 (nota: os autores não colocaram escala

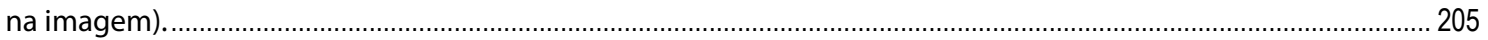
Fig. 71 - Artefactos líticos e osso ,e adornos feitos de dentes caninos de veados da Gruta do Caldeirão, segundo

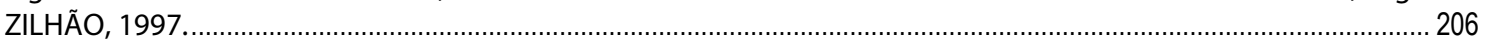
Fig. 72 - Tarsometarsos de A. rufa, da Gruta Nova da Columbeira (depois de algumas espécies de corvídeos e da $C$. livia, esta é a espécie que mais ocorre nesta jazida. À esquerda de fêmea (vista caudal) e à direita de macho (vista

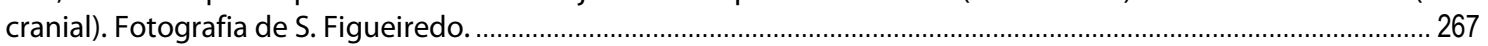
Fig. 73 - Úmero de P. graculus com pequenas marcas de dentes de pequenos roedores ou de actividade de larvas.

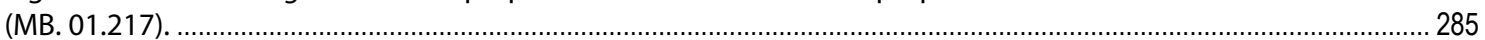
Fig. 74 - Úmero de Pinguinnus impennis (GFP.1043.28 ) encontrado na colecção osteológica da Furninha em reserva no Museu Geológico. Esquerda: vista ventral; direita: vista dorsal; direita (em baixo) pormenor da secção 
mesial do osso (fotografia de José Paulo Ruas - CIPA).

Fig. 75 - Fragmento distal de tibiotarso (vista cranial) de Larus $s p$, um género associado a ambientes costeiros.

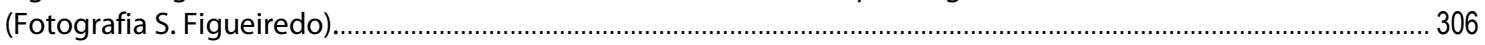
Fig. 76 - Fúrcula de cf. Somateria mollissima da Gruta da Furninha (fotografia: S. Figueiredo)................................ 313 Fig. 77 - Fragmento proximal e mesial de úmero de Phalacrocorax aristotelis, uma espécie que habita as zonas costeiras. É a terceira espécie em número total de restos da Gruta da Furninha.. Vista cranial (esquerda), vista

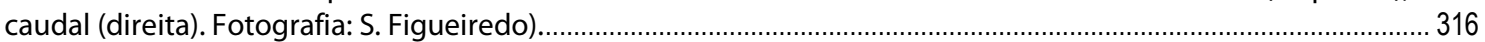
Fig. 78 - À esquerda tarsometatarso com possíveis marcas de corte e de predação. À direita fragmento de úmero com possível trabalho de talhe humano............................................................................................................. 332 Fig. 79 - Conjunto de falanges do II dígito da asa de P. graculus, da Lapa da Rainha, onde se encontrou o maior número destes ossos pertencentes ao género Pyrrhocorax. Vistas dorsais. Fotografia: S. Figueiredo. .....................354 Fig. 80 - I falange do $3^{\circ}$ dígito do membro posterior de uma ave de rapina (Accipitridae indeterminada). Á esquerda vista palmar, á direita, vista dorsal. Fotografia: S. Figueiredo......................................................................... 362 Fig. 81 - Comparação do fragmento proximal do úmero da Gruta do Pego do Diabo com o exemplar da colecção do CIPA e o desenho à escala de 1:1 de COHEN \& SERJEANTSON, 1996. Vista cranial (esquerda) e vista caudal (direita). As setas indicam as semelhanças consideradas para a classificação taxonómica. Fotografia: S. Figueiredo.

383

Fig. 82 - Comparação entre o fragmento distal de tibiotarso de M. nigra, encontrado na gruta Nova da Columbeira, com o mesmo osso de um espécime actual. As características osteológicas que permitiram a

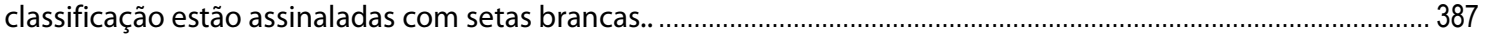
Fig. 83 - Comparação entre o fragmento do úmero de $P$. impennis identificado na Furninha (fotografia de José Paulo Ruas - CIPA) e o desenho de um úmero de $P$. impennis (adaptado de COHEN \& SERJEANTSON, 1996). As setas indicam as características que permitiram o diagnóstico da espécie. ..............................................................393 Fig. 84 - Comparação do fragmento distal de tibiotarso de Cf. Aquila adalberti, com o de um espécimen actual da colecção de referência do CIPA. As setas indicam os pontos semelhantes. Entre os dois exemplares. Fotografia: S. Figueiredo..

Fig. 85 - Principais diferenças entre alguns ossos de C. frugilegus e C. corone (ulna, coracóide e carpometacarpo). Fotografias da colecção de referência do CIPA (fotografia de S. Figueiredo). .......................................................... 411 Fig. 86 - Comparação do tibiotarso atribuído a C. cyana, da Gruta Nova da Columbeira (2), com um tibiotarso de um espécime actual (1) e com o tibiotarso de um T. merula (3), da colecção do CIPA. As setas indicam as semelhanças entre o exemplar da Columbeira e o exemplar actual e as diferenças entre o exemplar da Columbeira e o tibiotarso de T. merula. Á esquerda, vistas caudais e, á direita, vistas craniais. Fotografia: S.

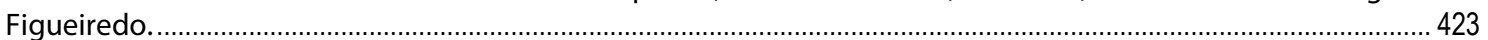

Fig. 87 - Comparação entre o úmero de cf. Ptyonoprogne rupestris, encontrado na gruta Nova da Columbeira, com o mesmo osso de um espécime actual. As características osteológicas que permitiram a classificação estão

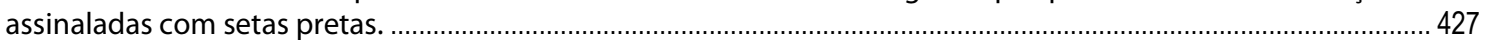
Fig. 88 - Árvore filogenética da família dos alcídeos, definida por 23 caracteres (in SATRAUCH, 1985, p. 531). Neste cladograma pode-se observar a proximidade filogenénica entre o género Pinguinus e o género Alca. Abreviaturas: Aeth = Aethia; Brac = Brachyramphus; Cepp = Cepphus; Cero = Cerorhinca; $\mathrm{Cycl}=$ Cyclorrhynchus; Endo = Endomychura; Frat = Fratercula; Lund $=$ Lunda, Ping = Pinguinus; Ptyc= Ptychoramphus; Synt $=$ Synthliboramphus.

Fig. 89 - Possivel distribuição (a verde) do P. impennis (Plistocénico e Holocénico) segundo BENGTSON, 1984 e PIMENTA, FIGUEIREDO \& MORENO GARCÍA, 2009........................................................................................... 472 Fig. 90- Desenho de Pinguinus impennis. Autor: Charles B. Cory, publicado em "Beautiful and Curious Birds of the

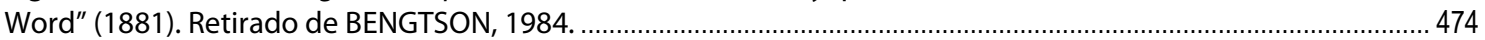
Fig. 91 - O resto de tibiotarso da Gruta Nova da Columbeira em comparação com o mesmo osso de um espécime actual. Vista caudal (esquerda) e vista cranial (direita). Fotografia: S. Figueiredo........................................................ 476 Fig. 92 - Desenho de Cyanopica Cyana. Autor: Peter Simon Pallas (1741-1811), zoólogo alemão que atribuiu a classificação científica desta $\quad$ espécie. http://en.wikipedia.org/wiki/File:Cyanopica_cyanus_by_Peter_Simon_Pallas.jpg (imagem do domínio público) . Fig. 93 - Distribuição actual e plistocénica de A. Barbara na Europa, segundo GOODERS \& HARRIS, 1990 e

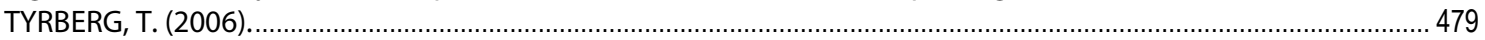
Fig. 94 - Selo de Marrocos com a representação da A. barbara. Autor: Lisete Delooz . Retirado de www.birdtheme.org/country/morocco.html (imagem do domínio público)............................................................. 483 Fig. 95 - Mapa da Europa com a distribuição actual do Phasianus colchicus e as jazidas plistocénicas com a presença desta espécie. 484 Fig. 96- Comparação do resto ósseo da Gruta do Pego do Diabo (2), com exemplares do Phasianus colchicus actual (1) e de outras espécies: Numida meleagris (3), Tetrao tetrax (4) e Gallus gallus $q$ (5) da cvolecção do CIPA. Vista cranial. Fotografia: S. Figueiredo.

Fig. 97 - Relação entre a distribuição temporal das jazidas estudadas e a evolução da temperatura (segundo GAMBLE et al., 2006 e BRADLEY, 2005). A castanho estão representadas jazidas com fauna já publicadas e não 
estudadas neste trabalho (GFP - Gruta da Furninha; GNC - Gruta Nova da Columbeira; GPD - Gruta do Pego do Diabo; GCal - Gruta do Caldeirão; GCM - Grurta da Casa da Moura; LRh - Lapa da Rainha; GFt - Gruta das Fontainhas; GSal - Gruta das Salemas; GEsc - Gruta do Escoural; GFB - Gruta da Figueira-Brava; ALV - Abrigo do Lagar Velho).

494 
Quadro 1- Enquadramento cronológico (geológico e arqueológico) das jazidas estudadas. A periodização geológica foi feita segundo a tabela de 2009, da Comissão Internacional de Geologia da UNESCO. A periodização arqueológica foi baseada em SILVA, RAPOSO \& SILVA, 1993, p. 97, quadro 1 e em MARTINS et al. 2010 (para o limite inferior do Paleolítico Médio). 49 Quadro 2 - Tabela com as SLD's (CUNHA, 1992) e o respectivo enquadramento geológico e relação com as jazidas

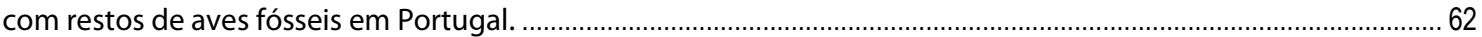
Quadro 3 - Relação entre a profundidade dos estratos sedimentares e os níveis ossíferos correspondentes,

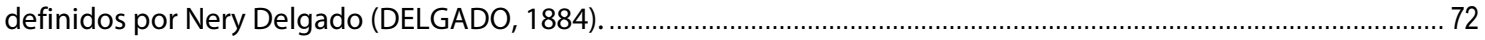
Quadro 4 - Sistemática dos anfíbios e répteis do Plistocénico português (segundo CRESPO, 2001) ....................... 107 Quadro 5 - Sistemática dos mamíferos do Plistocénico português (segundo FERREIRA, 1964, ROCHE, 1972,

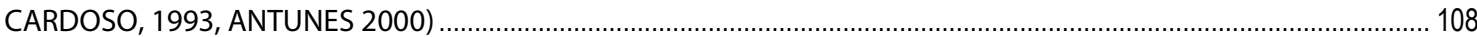
Quadro 6 - Possíveis relações filogenéticas das aves primitivas e dos grupos de dinossauros seus antepassados presentes em Portugal, enquadrando as jazidas e as respectivas SLD's................................................................ 161 Quadro 7 - Percentagem relativa dos dentes de terópodes da Mina da Guimarota ................................................ 164 Quadro 8 - Quantidade total de artefactos paleolíticos recuperados na Gruta da Furninha e a respectiva distribuição nos níveis ossíferos (segundo BREUIL \& ZBYSZEWSKI, 1945)................................................................ 195 Quadro 9 Distribuição cronológica dos artefactos recuperados do complexo 2 da Gruta da Furninha (segundo

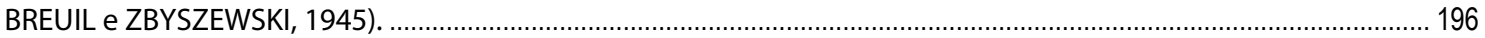
Quadro 10 - Distribuição cronológica dos artefactos recuperados do complexo 2 da Gruta da Furninha (segundo

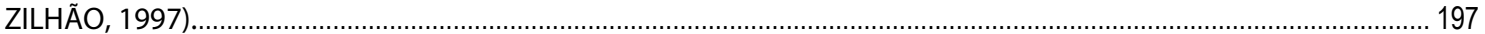
Quadro 11 - Sistemática paleontológica das aves da Gruta da Figueira-Brava (Segundo ANTUNES \& MOURER-

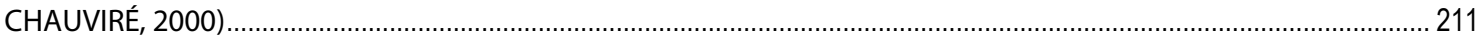
Quadro 12 - Estrutura da ficha utilizada no estudo dos ossos das jazidas apresentadas nesta tese....................... 233

Quadro 13 - Quantidades das partes do esqueleto preservadas............................................................................... 258

Quadro 14 - Atribuição das idade, por camada e números totais da amostra e respectivas percentagens............. 259

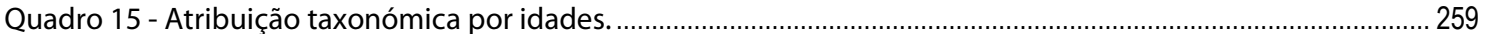

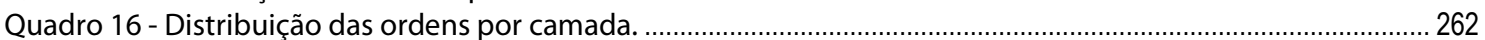

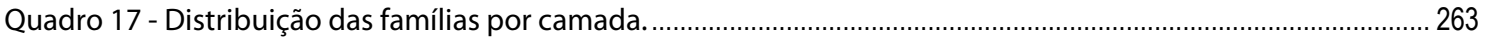

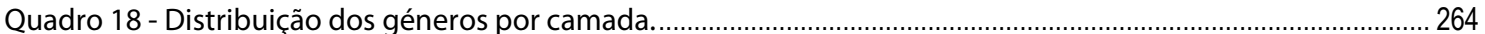

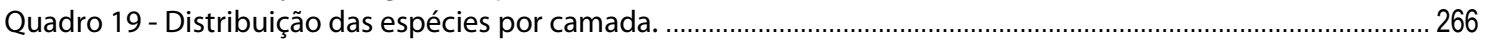

Quadro 20 - Número mínimo de indivíduos (NMI) das espécies identificadas e a sua distribuição, por camada... 281

Quadro 21 - Número mínimo de indivíduos (NMI) e número total de restos (NTR) das espécies reconhecidas e

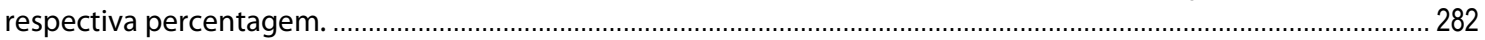
Quadro 22- Espécies e géneros identificados na Gruta Nova da Columbeira e a distribuição pelos ambientes a que estão associados. (Bos - bosques; CA - campo aberto; LAD - lagos de água doce; Mont - montanha; ZR - zonas

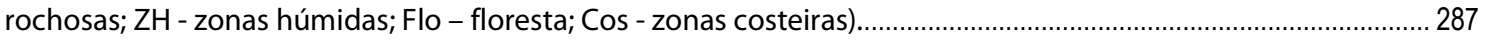
Quadro 23 - Quantidade e percentagem das partes do esqueleto representadas na avifauna da Gruta da Furninha.

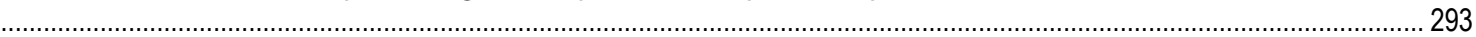

Quadro 24 - Lista das espécies atribuídas por Newton (coluna da esquerda) e a actualização da nomenclatura, ou nova atribuição taxonómica (coluna da direita)....................................................................................................... 294 Quadro 25 - Quantidade e a percentagem da totalidade de restos identificados (TRI) e não identificados (TRNI) e

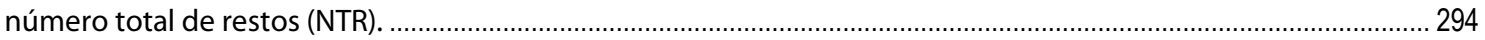
Quadro 26 - Distribuição por camada dos diferentes níveis taxonómicos identificados. .........................................295 Quadro 27 - Dados globais dos diferentes níveis taxonómicos identificados. ........................................................ 295 Quadro 28 - Número mínimo de indivíduos das espécies identificadas e a sua distribuição pelos níveis ossíferos

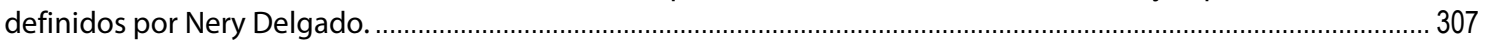
Quadro 29 - Número mínimo de indivíduos (NMI) e número total de restos (NTR) por espécie identificada.......... 308 Quadro 30 - Relação do número mínimo de individuos e do número total de restos............................................ 309 Quadro 31 - Número mínimo de indivíduos e número total de restos com as respectivas percentagens das ordens

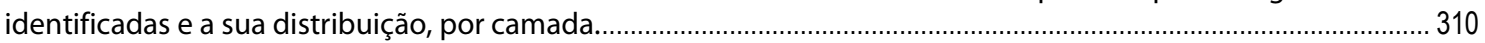
Quadro 32 - Número e percentagens da distribuição dos restos de aves pelas respectivas idades......................... 311 Quadro 33 - Número de restos de jovens e subdultos e a respectiva classificação taxonómica. ............................. 312 Quadro 34 - Espécies e géneros identificados na Gruta da Furninha e a distribuição pelos ambientes a que estão associados. (Bos - bosque; CA - campo aberto; LAD - lagos de água doce; Mont - montanha; ZR - zonas rochosas; ZH - zonas húmidas; Flo - floresta; Cos - zonas costeiras.).................................................................................. 317 Quadro 35 - Número total de restos e percentagem dos ossos identificados e não identificados taxonomicamente. 321 
Quadro 36 - Diferentes níveis taxonómicos dos restos identificados e respectiva percentagem.

Quadro 37- Número mínimo de indivíduos e número total de restos das diferentes espécies identificadas na Gruta

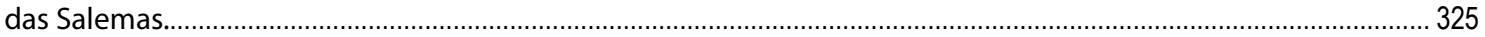
Quadro 38 - Número mínimo de indivíduos e número total de restos das ordens identificadas na Gruta das

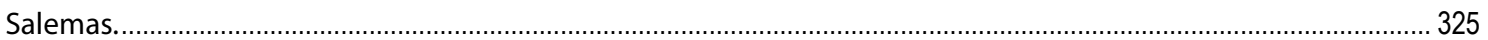
Quadro 39 - Distribuição das espécies identificadas na Gruta das Salemas, segundo os seus ambientes (Bos bosque; CA - campo aberto; LAD - lagos de água doce; Mont - montanha; ZR - zonas rochosas; ZH - zonas

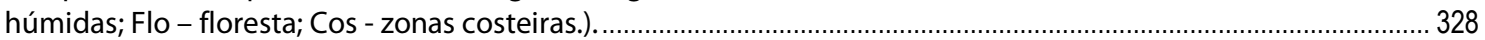
Quadro 40 - Ambientes das proximidades da gruta do Pego do Diabo, indicados pela ocorrência das espécies de aves identificadas. 333 Quadro 41 - Actualização da nomenclatura taxonómica das espécies atribuída por Harlé e Newton às aves da

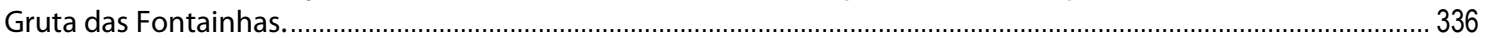
Quadro 42 - Número minino de indivíduos e número total de restos das espécies identificadas na Gruta das

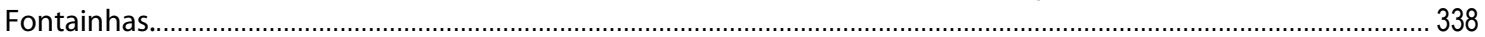
Quadro 43 - Comparação entre as espécies existentes actualmente na serra de Montejunto e as espécies identificadas nos depósitos plistocénicos da Gruta das Fontainhas............................................................................3. 339 Quadro 44 - Paleoecológia das espécies identificadas na Gruta das Fontainhas. (Bos - bosque; CA - campo aberto; LAD - lagos de água doce; Mont - montanha; ZR - zonas rochosas; ZH - zonas húmidas; Flo - floresta; Cos -

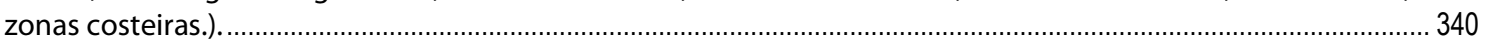
Quadro 45 - Número mínimo de individuos e número total de restos dos principais táxones reconhecidos na Casa

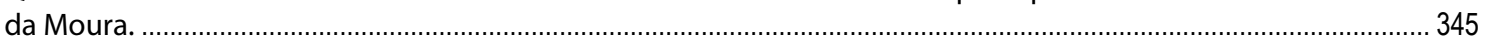
Quadro 46 - distribuição das espécies identificadas e os respectivos habitat (Bos - bosque; CA - campo aberto; LAD - lagos de água doce; Mont - montanha; ZR - zonas rochosas; ZH - zonas húmidas; Flo - floresta; Cos - zonas

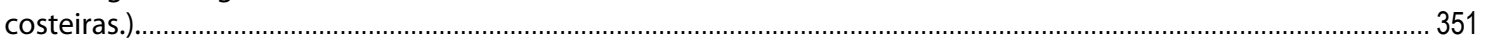

Quadro 47 - Distribuição dos ossos identificados pela correspondente parte do esqueleto................................. 354

Quadro 48- Ocorrência das diferentes idades dos individuos identificados ............................................................... 355

Quadro 49 - Número mínimo de indivíduos e número total de restos das espécies identificadas na Lapa da

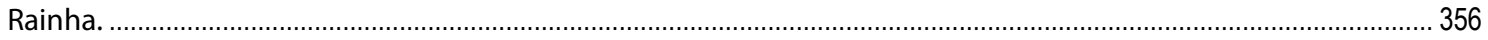
Quadro 50- Distribuição das espécies encontradas pelos seus habitat. (Bos - bosque; CA - campo aberto; LAD lagos de água doce; Mont - montanha; ZR - zonas rochosas; ZH - zonas húmidas; Flo - floresta; Cos - zonas

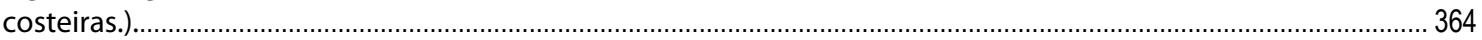
Quadro 51 - Distribuição das espécies encontradas pelos seus ambientes (Bos - bosque; CA - campo aberto; LAD lagos de água doce; Mont - montanha; ZR - zonas rochosas; ZH - zonas húmidas; Flo - floresta; Cos - zonas

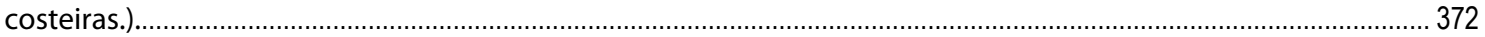
Quadro 52- Comparação do número mínimo de indivíduos e do número total de restos das espécies identificadas

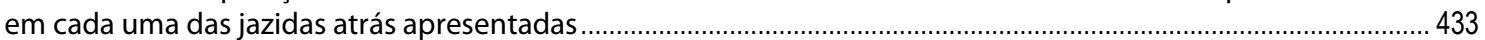
Quadro 53 - Distribuição das espécies segundo a sua ocorrência segundo a distância à costa............................... 450 Quadro 54 - Número de sítios com ocorrências de aves durante o Plistocénico, na Europa.................................... 452 Quadro 55 - Distribuição dos indivíduos de especies identificadas neste trabalho, com os climas a que estas estão

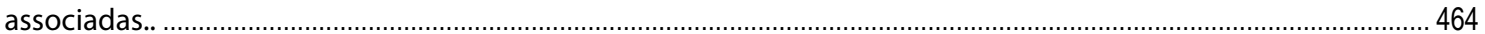
Quadro 56- Distribuição das espécies identificadas no Plistocénico português segundo a datação das jazidas onde foram reconhecidas. Ás espécies identificadas neste trabalhos, acrescentaram-se as espécies conhecidas na bibliografia sobre avifauna plistocénica de Portugal............................................................................................ 468 Quadro 57- Jazidas com avifauna plistocénica em Portugal e a sua contextualização geológica e arqueológica. 488 Quadro 58 - Número total de restos estudados e número de táxones identificados................................................. 489 Quadro 59 - Número total de espécies identificadas nas jazidas estudadas e a relação entre o número total de restos, o número total de espécies e o número total de táxones.............................................................................. 493 Quadro 60- Diferentes ambientes, segundo a ocorrência das espécies pelos respectivos habitat, em todas as jazidas estudadas (Bos - bosques; CA - campo aberto; Zh - zonas húmidas; LAD - lagos de água-doce; Mont zonas de montanha; ZR - zonas rochosas; Flo - zona de floresta; Cós - zona costeira)........................................... 495 Quadro 61 - Distribuição de todas as espécies identificadas no Plistocénico de Portugal (na bibliografia existente e neste trabalho) no respectivo ambiente. 
Gráfico 1 - Relação do número de jazidas com aves plistocénicas publicadas até 2006.

Gráfico 2 - Distribuição cronológica dos artefactos recuperados do complexo 2 da Gruta da Furninha (segundo BREUIL e ZBYSZEWSKI, 1945).

Gráfico 3 - Distribuição cronológica dos artefactos recuperados do complexo 2 da Gruta da Furninha (segundo ZILHÃO, 1997).

Gráfico 4 - Relação dos restos de aves identificados taxonomicamente com os não identificados e o total de restos, por sector de proveniência das amostras, com base nos dados de MORENO-GARCIA e PIMENTA, 2002.... 218 Gráfico 5 - Relação dos restos de aves identificados taxonomicamente com os não identificados no total de restos estudados, com base nos dados de MORENO-GARCIA e PIMENTA, 2002.

219

Gráfico 6 - Relação da ocorrência dos diferentes táxones de aves identificados no Abrigo do Lagar Velho, com

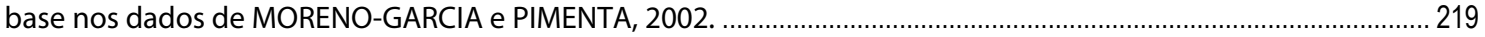
Gráfico 7 - Relação da ocorrência do número mínimo de indivíduos, por género e espécie identificados no Abrigo do Lagar Velho, com base nos dados de MORENO-GARCIA e PIMENTA, 2002 …..................................................... 220 Gráfico 8 - Relação da ocorrência dos restos dos diferentes táxones identificados na Gruta do Escoural, com base

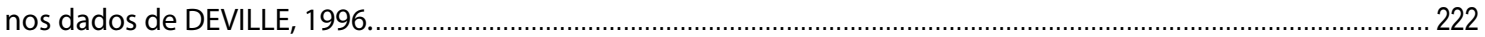
Gráfico 9 - Relação do número de restos classificados e não classificados, segundo cada uma das camadas da

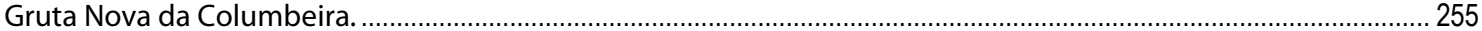

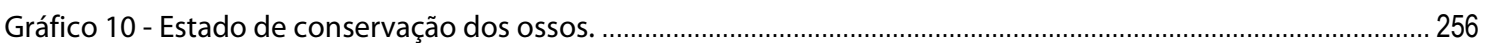
Gráfico 11 - Partes preservadas dos ossos longos fragmentados..........................................................................256 Gráfico 12 - Distribuição dos restos de aves pela sua camada de proveniência....................................................... 257

Gráfico 13 - Percentagem das partes do esqueleto representadas........................................................................ 258

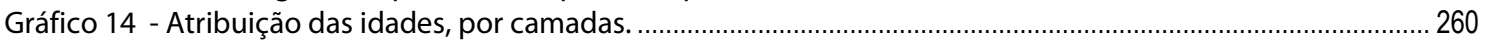

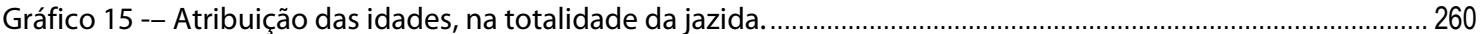

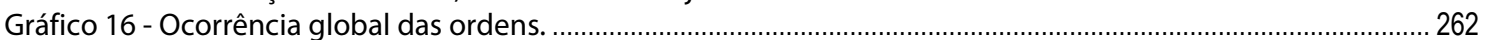

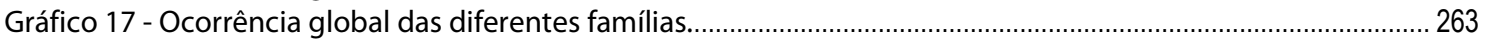

Gráfico 18 - Ocorrência global dos géneros identificados na Gruta Nova da Columbeira........................................265

Gráfico 19 - Ocorrência global das diferentes espécies, segundo o número total de restos.....................................2267 Gráfico 20 - Ocorrência total das espécies reconhecidas na Gruta Nova da Columbeira, segundo o número

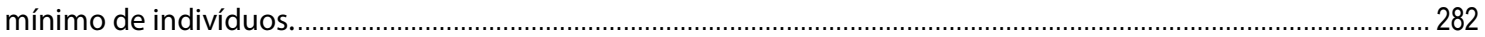
Gráfico 21 - Gráfico com o número mínimo de indivíduos (NMI) e número total de restos (NTR) por espécie

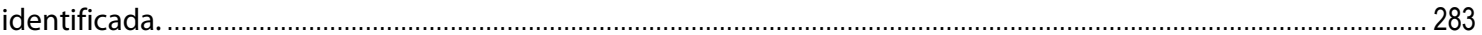

Gráfico 22 - Comparação dos ambientes das espécies de aves da Gruta Nova da Columbeira, segundo a distribuição do NMI de cada espécie pelos respectivos ambientes................................................................................ 286 Gráfico 23 - Totalidade dos paleoambientes, segundo a distribuição das espécies e dos géneros identificados.. (Bos - bosques; CA - campo aberto; LAD - lagos de água doce; Mont - montanha; ZR - zonas rochosas; ZH - zonas

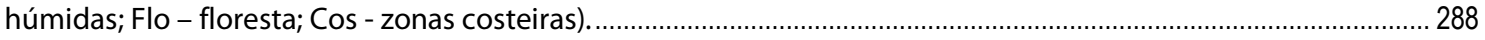
Gráfico 24 - Relação de ossos partidos e inteiros das aves da Gruta da Furninha................................................. 292 Gráfico 25 - Partes dos ossos preservados na amostra osteológica de aves da Gruta da Furninha. ........................ 292 Gráfico 26 - Partes do esqueleto que constitui a avifauna da Gruta da Furninha................................................... 293 Gráfico 27 - Percentagem e quantidade da totalidade de restos identificados (TRI) e não identificados (TRNI)... 295 Gráfico 28 - Dados globais dos diferentes níveis taxonómicos identificados.............................................................2296 Gráfico 29 - Gráfico com o número mínimo de indivíduos (NMI) e número total de restos (NTR) por espécie

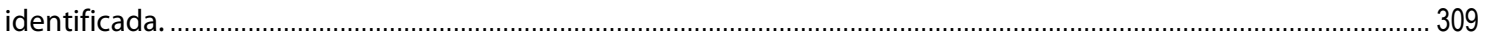
Gráfico 30 - Ocorrência do númerio mínimo de individos das diferentes ordens de aves da Gruta da Furninha... 311

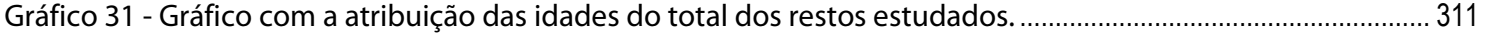
Gráfico 32 - Gráfico com a atribuição taxonómica aos indivíduos jovens. ……..................................................... 312 Gráfico 33 - Gráfico com a atribuição taxonómica dos indivíduos subadultos........................................................... 313 Gráfico 34 - Ambientes das espécies identificadas na Furninha, considerando o número mínimo de indivíduos.315 Gráfico 35 - Totalidade dos paleoambientes, segundo a distribuição das espécies e géneros identificados.. (Bos bosque; CA - campo aberto; LAD - lagos de água doce; Mont - montanha; ZR - zonas rochosas; ZH - zonas

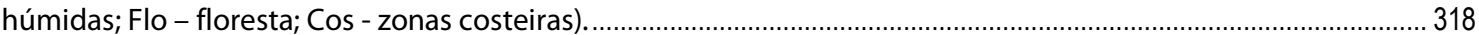

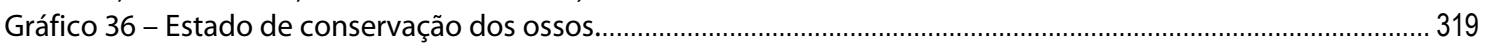
Gráfico 37 - Partes dos ossos preservadas nos restos de avifauna da Gruta das Salemas...................................... 320 Gráfico 38 - Quantidade de restos identificados e não identificados taxonomicamente......................................... 321 Gráfico 39 - Quantidade dos diferentes níveis taxonómicos dos restos identificados............................................. 322 Gráfico 40 - Relacção entre o número mínimo de indivíduos e número total de restos das diferentes espécies identificadas na Gruta das Salemas. 
Gráfico 41 - Relação entre as ordens identificadas na Gruta das Salemas.

Gráfico 42 - Distribuição e percentagem das espécies identificadas na Gruta das Salemas, segundo o número

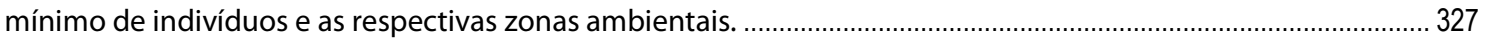
Gráfico 43 - Repartição por ocorrência das espécies, segundo os seus ambientes (Bos - bosque; CA - campo aberto; LAD - lagos de água doce; Mont - montanha; ZR - zonas rochosas; ZH - zonas húmidas; Flo - floresta; Cos -

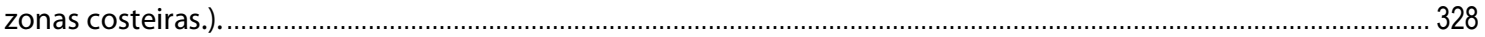
Gráfico 44 - Famílias de aves identificadas na Gruta do Pego do Diabo. .....................................................................3 330 Gráfico 45 - Distribuição das partes esqueléticas identificadas nas aves da Gruta do Pego do Diabo................... 331 Gráfico 46 - Distribuição taxonómica, segundo os seus respectivos ambientes (Bos - bosque; CA - campo aberto; LAD - lagos de água doce; Mont - montanha; ZR - zonas rochosas; ZH - zonas húmidas; Flo - floresta; Cos - zonas costeiras.)...

Gráfico 47 - Relação da ocorrência das diferentes espécies na Gruta das Fontainhas................................................ 338

Gráfico 48 - Distribuição pelas zonas ambientais, segundo o do número mínimo de indivíduos das espécies

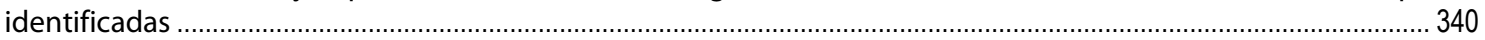
Gráfico 49 - Distribuição das espécies pelos respectivos ambientes associados (Bos - bosque; CA - campo aberto; LAD - lagos de água doce; Mont - montanha; ZR - zonas rochosas; ZH - zonas húmidas; Flo - floresta; Cos - zonas

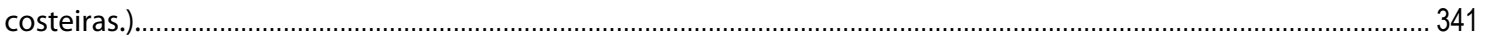

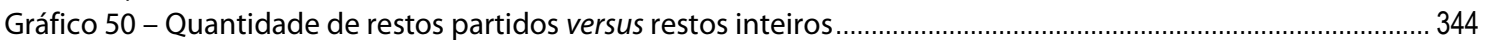

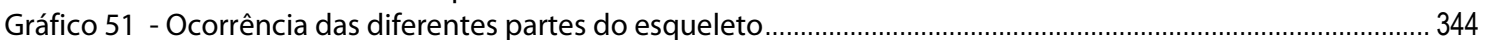
Gráfico 52 -Distribuição das diferentes espécies de aves da Gruta da Casa da Moura, pelas suas respectivas áreas ambientais, segundo o número mínimo de indivíduos........................................................................................... 350 Gráfico 53- Ocorrência das espécies e relação com os seus diferentes ambientes (Bos - bosque; CA - campo aberto; LAD - lagos de água doce; Mont - montanha; ZR - zonas rochosas; ZH - zonas húmidas; Flo - floresta; Cos -

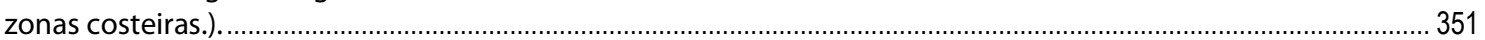
Gráfico 54 - - Relação entre ossos partidos e ossos inteiros............................................................................. 353

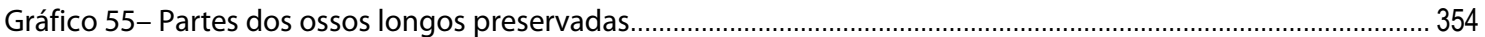

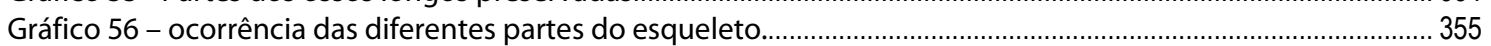
Gráfico 57 - relação entre a quantidade de jovens, subadultos e adultos das aves da Lpara da Rainha................. 355 Gráfico 58 - Relação entre o número mínimo de indivíduos e da totalidade dos restos das espécies identificadas

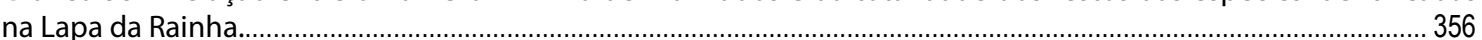
Gráfico 59 - Distribuição do número mínimo de individuos das espécies identificadas e a sua relação com as

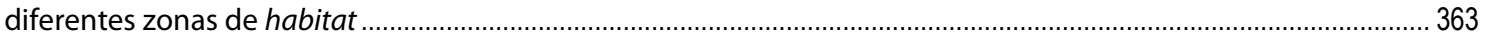
Gráfico 60 - Distribuição das espécies reconhecidas com os ambientes associados (Bos - bosque; CA - campo aberto; LAD - lagos de água doce; Mont - montanha; ZR - zonas rochosas; ZH - zonas húmidas; Flo - floresta; Cos zonas costeiras.)

Gráfico 61 - Quantidade de restos identificados e não identificados, no estudo realizados aos ossos de aves que se encontram junto com a microfauna do Caldeirão no MNHN............................................................................ 368 Gráfico 62 - Distribuição das espécies reconhecidas com os ambientes associados (Bos - bosque; CA - campo aberto; LAD - lagos de água doce; Mont - montanha; ZR - zonas rochosas; ZH - zonas húmidas; Flo - floresta; Cos -

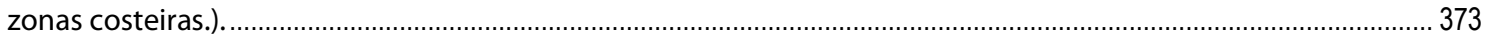
Gráfico 63 - Número de jazidas com a avifauna publicada ou referida desde 1910 até a presente tese. ................ 432 Gráfico 64 - Comparação do número mínimo de indivíduos das espécies identificadas em cada uma das jazidas

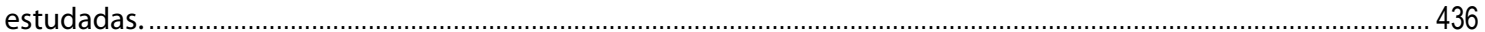

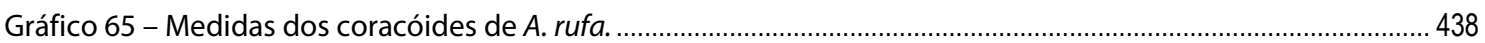

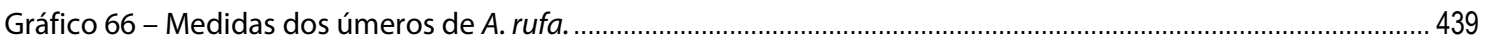

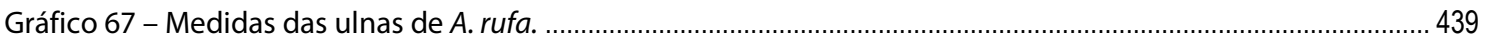

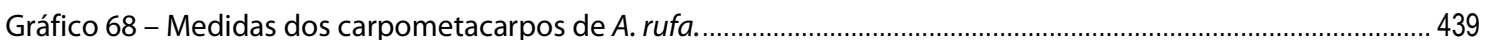

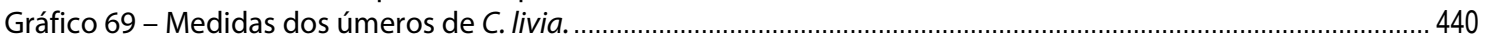

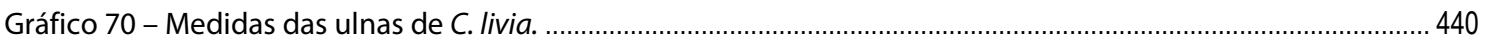

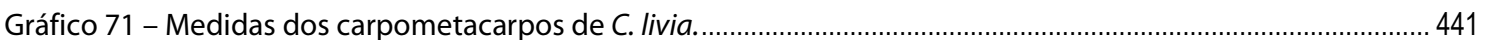

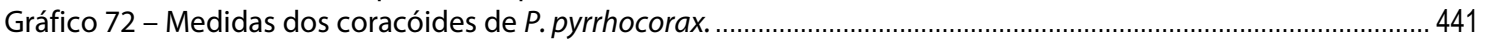

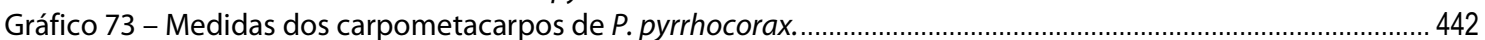

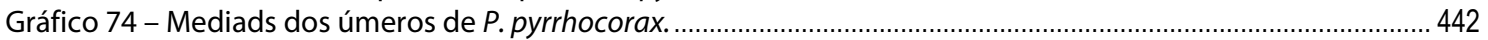

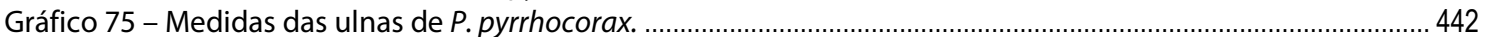

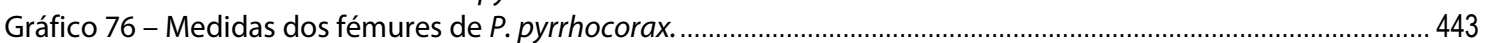

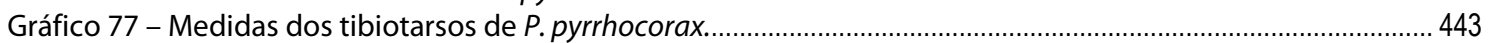

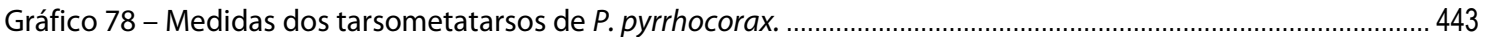

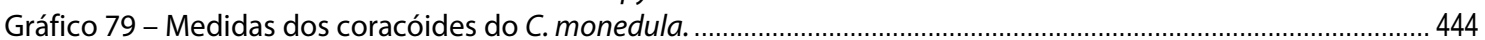

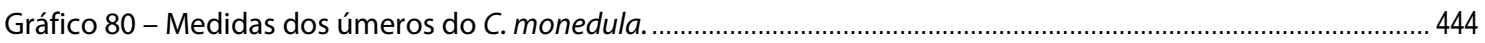

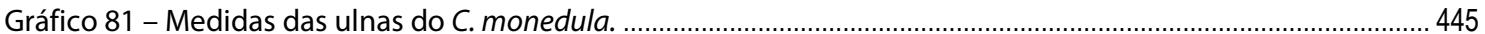

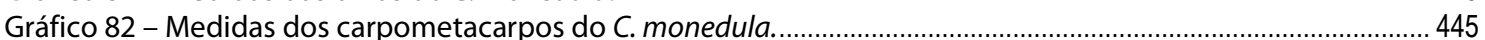

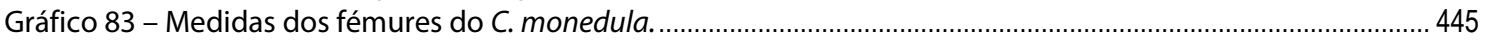


Gráfico 84 - Medidas do tibiotarso do C. monedula.

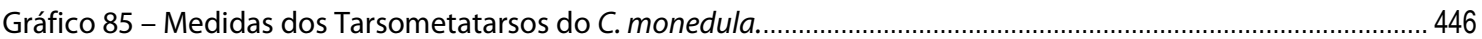

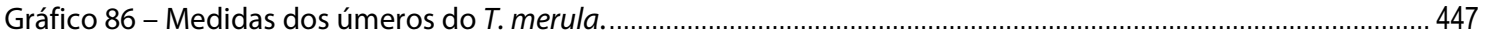

Gráfico 87 - Ocorrências das diferentes ordens segundo a distância à costa, consoante a sua presença nas

diferentes jazidas portuguesas com avifauna plistocénica. ....................................................................................... 451

Gráfico 88 - Número de jazidas com avifauna na Europa (segundo Tyrberg, 2006 e os dados obtidos neste trabalho).

Gráfico 89 - Quantidade de espécies características dos diferentes tipos de climas térmicos................................ 462

Gráfico 90 - Quantidade de espécies características dos diferentes tipo de climas, segundo o grau de humidade.

463

Gráfico 91 - Número de espécies identificadas e número de jazidas para os restos de avifauna plistocénica com

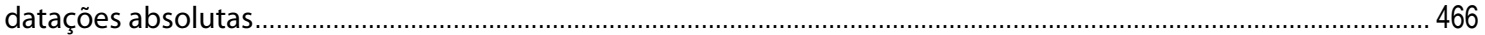
Gráfico 92 - Comparação osteométrica entre os úmeros de A. barbara identificadas na Columbeira e actuais e os úmeros das $A$. rufa actuais e plistocénicas (cm - comprimento máximo; Lp - largura proximal; Ld - largura distal).

Gráfico 93- Comparação osteométrica entre os úmeros de A. barbara identificadas na Columbeira e actuais. (cm comprimento máximo; Lp - largura proximal; Ld - largura distal).

481

Gráfico 94 - Comparação osteométrica entre os tarsometatarsos de $A$. barbara identificadas na Columbeira e actuais e os úmeros das A. rufa actuais e plistocénicas (cm - comprimento máximo; Lp - largura proximal; Ld largura distal).

Gráfico 95 - Comparação osteométrica entre os úmeros de A. barbara identificadas na Columbeira e actuais. (cm comprimento máximo; Lp - largura proximal; Ld - largura distal).

482

Gráfico 96 - Comparação osteométrica (medida da largura proximal) do resto ósseo da Gruta do Pego do Diabo (A), com exemplares do Phasianus colchicus actuais (B e C) e de outras espécies: Numida meleagris (D), Tetrao

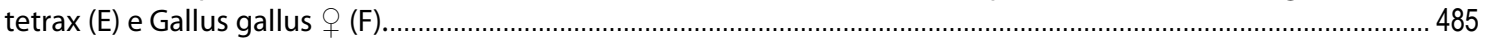

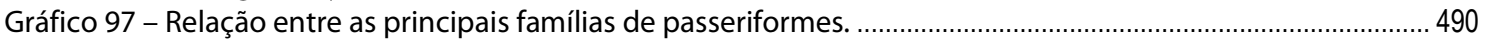

Gráfico 98 - Relação entre as ordens de aves reconhecidas neste estudo................................................................. 491 Gráfico 99 - Comparação em gráfico de barras, dos diferentes ambientes, segundo a ocorrência das espécies pelos respectivos habitat, em todas as jazidas estudadas (Bos - bosques; CA - campo aberto; Zh - zonas húmidas; LAD - lagos de água doce; Mont - zonas de montanha; ZR - zonas rochosas; Flo - zona de floresta; Cós - zona costeira). ... 496 


\title{
LISTA DE ABREVIATURAS
}

\author{
ALV - Abrigo do Lagar Velho \\ BEsc - Buraca Escura \\ Bos - Bosque \\ CA - Campo aberto
}

CIPA - Centro de Investigação de Paleoecologia Humana

CMB - Câmara Municipal do Bombarral

Cos - Zonas costeiras

CPGP - Centro Português de Geo-História e Pré-História

FENX - Foz do enxarrique

Flo - Floresta

GAIm - Grutas do Almonda

GCal - Gruta do Caldeirão

GCM - Gruta da Casa da Moura

GEPP - Grupo para o Estudo do Paleolítico Português

GEsc - Gruta do Escoural

GFB - Gruta da Figueira-brava

GFP - Gruta da Furninha

GFt - Gruta das Fontainhas

GNC - Gruta Nova da Columbeira

GPD - Gruta do Pego do Diabo

Gsal - Gruta das Salemas

IGESPAR - Instituto de Gestão do Património

IPT - Instituto Politécnico de Tomar

LAD - Lagos de água doce

LAP - Laboratório de Arqueozoologia e Paleontologia

LGM - Last Glaciar Maximum 
LPr - Lapa do Picareiro

LRh - Lapa da rainha

MB - Museu do Bombarral

MG - Museu Geológico

MNA - Museu Nacional de Arqueologia

MNHN - Museu Nacional de História Natural

Mont - Montanha

NMI - Número mínimo de indivíduos

NTE - Número toatal de espécies

NTR - Número Total de restos

Ntt - Número total de táxones

ZH - Zonas húmidas

ZR - Zonas rochosas 
Palavras-Chave: Aves, Plistocénico, Paleolítico, grutas, Portugal, taxonomia, tafonomia, paleontologia, paleoecologia, Maciço Calcário, arqueologia, paleoornitologia.

O estudo dos restos de aves plistocénicas desempenha um papel importante na compreensão da paleoecologia, pois determinadas espécies de aves vivem em ambientes específicos, podendo, desta forma, possibilitar um melhor conhecimento do meio em que viviam as comunidades humanas do Paleolítico; meio esse que se pretende caracterizar através deste estudo. Algumas estações arqueológicas do Paleolítico de Portugal são ricas em restos ósseos de vertebrados. O estudo dos testemunhos desta fauna pretérita tem incidido sobretudo sobre os mamíferos, em especial os grandes mamíferos, em detrimento dos outros grupos de vertebrados, tais como a avifauna, a herpetofauna e a ictiofauna. A presente tese tem como principal objectivo fazer um levantamento da avifauna fóssil de Portugal e contribuir para o conhecimento dessas aves, desde os vestígios mais antigos ${ }^{1}$ até aos vestígios plistocénicos, que se assumem como o tema central desta tese.

Em Portugal existem várias jazidas com restos de aves fósseis, desde o Jurássico Médio. No entanto, esse registo é escasso e só se conhecem cinco jazidas anteriores ao Plistocénico: Guimarota (Jurássico Superior); Silveirinha (Eocénico Médio); Charneca (Lisboa); Praia do Penedo (Península de Setúbal) e Amor (Leiria) (Miocénico Inferior e Superior). Do Plistocénico, o registo fóssil é muito mais abundante, conhecendo-se 15 jazidas com referência à presença de restos de aves. No entanto, todas estas jazidas encontram-se em contexto arqueológico, não tendo

1 As aves de épocas remotas, em Portugal, são mal conhecidas, dado existirem raros vestígios e poucos investigadores a trabalhar nesta área, pelo que o presente trabalho de investigação se irá basear no enquadramento paleontológico e arqueológico das aves do Plistocénico português. 
sido encontrados restos de aves plistocénicas em jazidas de contexto geológico, até á data.

Os dados agora apresentados resultam do estudo de uma amostra de 2079 restos osteológicos de aves de oito jazidas ${ }^{2}$ plistocénicas: Gruta Nova da Columbeira, Gruta das Salemas, Gruta das Fontainhas, Gruta da Furninha, Gruta do Pego do Diabo, Gruta da Casa da Moura, Gruta do Caldeirão (parcial) e Lapa da Rainha. O estudo efectuado foi complementado por outros publicados: Gruta da Figueira-Brava (MOURER - CHAUVIRÉ, \& ANTUNES, 1999), Abrigo do Lagar Velho (MORENO-GARCÍA, \& PIMENTA, 2002), Galerias Pesadas (MARKS et al.li., 2000, 2002). Gruta do Escoural (DEVILLE, 1996), Lapa do Picareiro (BICHO et al.li, 2003), a Gruta do Caldeirão (DAVIS, 2002) e a Foz do Enxarrique (BURGAL \& RAPOSO, 1999).

Alguns dos restos de aves estudados (parte dos restos da Gruta da Furninha e da Gruta das Fontainhas) já se encontravam estudados por Harlé (1910-11). Trata-se, no entanto, de estudos muito antigos, que precisavam ser revistos, especialmente no que diz respeito à atribuição taxonómica. Há também a realçar que muitos restos de aves da Gruta da Furninha não estavam estudados, encontrando-se misturados com os restos de pequenos vertebrados ${ }^{3}$. Foi então realizado um estudo de revisão taxonómica para os restos classificados e de atribuição taxonómica para os restos não classificados. Esta atribuição taxonómica foi realizada no CIPA e utilizada a colecção de referência de osteologia de aves daquele laboratório, para fazer um estudo de comparação osteológica.

Os primeiros trabalhos de escavações arqueológicas em grutas que tiveram uma preocupação com a estratigrafia, em Portugal, foram feitos a partir da década de 1960, com a colaboração de Jean Roche. Antes disso, a estratigrafia era pouco precisa. Por esta razão, o estudo das aves das jazidas escavadas no período anterior apresenta algumas dificuldades na interpretação dos dados estratigráficos.

\footnotetext{
2 Numa destas jazidas, a gruta do Caldeirão, o estudo dos restos de macrofauna foi realizado por Simon Davis (2002), no qual foram estudados também os restos de avifauna. No entanto foram identificados por nós sete ossos de avifauna (passeriformes), que estavam em conjunto com a microfauna. Estes dados utilizados para complementar os estudos de Simon Davis

3 A este respeito há a referir a presença de um fragmento proximal de úmero de Pinguinus impennis, que se encontrava no meio de um lote de ossos longos de coelho.
} 
A metodologia utilizada foi o levantamento bibliográfico dos sítios com ocorrência de aves em Portugal e o estudo taxonómico e osteométrico dos vestígios ósseos das colecções às quais se teve acesso. A revisão da atribuição taxonómica foi feita através da comparação com a colecção de referência do CIPA e do CPGP.

Pelo estudo taxonómico, com a excepção do reconhecimento de alguns (poucos) táxones já extintos, verifica-se que não se deram grandes alterações comparativamente às espécies de aves que se encontram actualmente em Portugal, ao contrário do que acontece em alguns países europeus.

O estudo efectuado teve por base principal as colecções do Museu Geológico de Lisboa, do Museu Nacional de Arqueologia e da colecção da Gruta Nova da Columbeira, do Museu Municipal do Bombarral.

Verifica-se, na avifauna plistocénica de Portugal, em especial nas jazidas estudadas neste trabalho, um predomínio dos passeriformes. Ocorrem também galliformes, columbiformes, falconiformes, strigiformes, anseriformes e charadriiformes, estes dois últimos aparecem especialmente em jazidas localizadas em zonas costeiras. As restantes ordens (podicepediformes, gruiformes, procellariformes, pelecaniformes, gaviformes, coraciformes, caprimulgiformes e cuculiformes) aparecem representadas por um número muito pequeno de restos.

No que se refere à comparação taxonómica com as aves actuais, existem poucas diferenças verificando-se uma grande quantidade de espécies que ainda ocorrem em Portugal. Comparando com as outras classes, as espécies de aves plistocénicas já extintas em Portugal são-no num número maior que as espécies de anfíbios e répteis. Contudo, em comparação com os mamíferos verifica-se o contrário.

Dos materiais estudados verifica-se uma quase ausência de marcas de corte ou de depredação, pelo que a maioria das acumulações fósseis de aves plistocénicas de Portugal são de origem natural e não antrópica.

Verifica-se que a distribuição das espécies não é homogénea nas diferentes jazidas, verificando-se uma maior biodiversidade de aves numas jazidas em relação a outras. Por outro lado, o breve intervalo de tempo geológico entre as jazidas 
estudadas impede a realização de uma biostratigrafia regional, apenas se pode ter uma ideia da distribuição temporal das diferentes espécies identificadas e dos climas associados.

Pela análise global da distribuição das espécies pelos seus habitat, verifica-se que em todas as jazidas ocorrem espécies de ambientes de bosques, campo aberto e zona costeira. O habitat que ocorre em menos jazidas é o de lagos de água-doce. Com a excepção da Gruta das Fontainhas, os habitat de zonas rochosas e montanha aparecem associados. O ambiente de floresta aparece associado a espécies da Gruta do Pego do Diabo, mas não aparece na Gruta das Salemas.

As indicações paleoecológicas são, no geral, consistentes com outros estudos feitos sobre faunas plistocénicas, como por exemplo CARDOSO, 1993. A maioria das espécies analisadas sugere uma predominância de climas temperados e secos. 
Key-Words: Birds, Pleistocene, Palaeolithic, Portugal, taxonomy, tafonomy, palaeornitology, palaeoecology, limestone massif, archaeology, palaeontology.

The study of Pleistocene birds remains plays an important role on the understanding of palaeoecology, once different birds lived on specifically distinct environments, leading thus to a better perspective of the environment where the human communities from the Palaeolithic lived. The characterization of that environment it is one of the objectives of this study.

Some archaeological sites of the Portuguese Palaeolithic are rich in bones of vertebrates. The study of this palaeofauna has mainly focused on mammals, particularly on great mammals, in determent of other vertebrate groups, such as birds, reptiles and fishes. These theses find its main goal the research of Portuguese fossil avifauna and thus contribute to the knowledge of these birds from the oldest vestiges to the Pleistocene ones, who end up being the central focus of this thesis.

There are several sites in Portugal with fossil birds remains, from the Upper Jurassic on wards. However, that is a feable record and only sites prior to the Pleistocene are known: Guimarota (Upper Jurassic), Silveirinha (Middle Eocene), Charneca do Lumiar (Lisbon), Praia do Penedo (Sesimbra - Setúbal) and Amor (Leiria) from Lower and Upper Miocene. The fossil record of birds from the Pleistocene is much more abundant, but only sites with birds remains in archaeological context are known, no sites being known in geological context.

The data here published result from a sample of 2079 osteological remains of birds from eight Pleistocene sites: Gruta Nova da Columbeira, Gruta da Furninha, Gruta das Salemas, Gruta das Fontainhas, Gruta do Pego do Diabo, Gruta da Casa da Moura, Lapa da Rainha and Gruta do Caldeirão (partial). This study was complemented by others sites already published: Gruta da Figueira-Brava (MOURER CHAUVIRÉ, \& ANTUNES, 2000), Abrigo do Lagar Velho (MORENO-GARCÍA, \& PIMENTA, 
2002), Galerias Pesadas (MARKS et al., 2000, 2002). Gruta do Escoural (DEVILLE, 1996), Lapa do Picareiro (BICHO et al, 2003) e a Gruta do Caldeirão (DAVIS, 2002), Foz do Enxarrique (BURGAL \& RAPOSO, 1999).

Some of the studied birds remains (part of those from Gruta da Furninha and from Gruta das Fontainhas) had already been studied by Newton (HARLÉ, 1910-11). Those are however very old studies, that needed to be revised specially in taxonomy. It must also be pointed out that many of the remains from Gruta da Furninha had never been studied, and were mixed among other remains of small vertebrates. A taxonomic revision study for the classified remains was therefore carried out and taxa were attributed to those not yet classified. This taxonomic attribution was done ate CIPA (IGESPAR) and LAP (CPGP-IPT) and the bird osteology reference collection of those laboratories was used for osteologic comparasion.

The first archaeological excavations in caves that took stratigraphy into account in Portugal were carried out in the 60's, with the collaboration of Jean Roche. Before, with the exception of the excavations in Gruta das Furninha by Nery Delgado, in XIXth century, the stratigraphy was not accurate. For that reason the study of birds from some sites excavated previously presents difficulties in the interpretation of stratigraphy data.

The methodology used in this work consisted in the bibliographic research of the Pleistocene sites in Portugal where birds had occurred and in the taxonomic and osteometric study of the bone remains of those collections that could be accessed. The revision of taxa was carried out through the comparison with the collections from CIPA and LAP. This study was maindly based on the collections from Museu Geológico, from Museu Nacional de Arqueologia, and from Museu do Bombarral.

There is, in the Pleistocene avifauna of Portugal, especially in the sites studied in this work, a predominance of Passeriformes. Galliformes, columbiformes, falconiformes, strigiformes, anseriformes and charadriiformes occur also. Anseriformes and charadriiformes appear especially in sites located in coastal areas. The remaining orders (podicepediformes, gruiformes, procellariformes, pelecaniformes, gaviformes, coraciiformes, caprimulgiformes and cuculiformes) are represented by a very small number of remains. 
Concerning the taxonomic comparison with the species still living today, there are few differences since most still occur in Portugal. Compared with other classes, there are more Pleistocene birds extinct in Portugal than amphibians and reptiles. However, compared with mammals, few bird species are extinct.

In the studied materials there is a near absence of cut marks or predation, so the majority of fossil accumulations of Pleistocene birds from Portugal are of natural origin and not anthropogenic.

It appears that the distribution of species is not homogeneous throughout different sites. There are a greater biodiversity of birds in some deposits than in others. Furthermore, the brief interval of geologic time between the deposits studied is an obstacle to a regional biostratigraphy: One can only guess at the distribution in time of the different species identified and associated climates.

From the overall analysis of the distribution of species by habitat, it appears that the deposits occur in all kinds of environments: forests, open fields and coastal areas. The habitat with fewer deposits is freshwater lakes. Gruta das Fontainhas excepted, rocky habitats are associated with mountainous ones. In spite of belonging to the same area, the species from Pego do Diabo are those of forest habitats and thus are not found in Gruta das Salemas.

Palaeoecological indications are generally consistent with other studies on Pleistocene faunas, (CARDOSO, 1993). Most species analysed suggest a predominance of a temperate dry climate. 


\section{PARTE |}

INTRODUÇÃO 
As estações paleolíticas em Portugal são ricas em vestígios e restos ósseos de animais do passado. O estudo destes testemunhos da fauna pretérita tem incidido sobretudo sobre os mamíferos, em especial sobre os grandes mamíferos, em detrimento dos outros grupos de vertebrados, como, por exemplo, a avifauna, a herpetofauna e a ictiofauna. A tese que se apresenta agora tem como principal objectivo fazer um levantamento das jazidas com aves fósseis e contribuir para um melhor conhecimento das aves fósseis que ocorrem em épocas remotas do território português, em particular no Plistocénico. No que respeita a outros períodos mais antigos, o conheciemnto paleornitológico ainda é mais escasso. Do Mesozóico, só se conhecem alguns dentes atribuídos ao género Archaeopterix, (WEIGERT, 1995; ZINKE, 1998) em níveis do Jurássico Superior (cerca de 150 milhões de anos) na Mina da Guimarota, em Leiria. No entanto, conhecem-se algumas jazidas com fósseis do grupo de dinossauros que deu origem às aves, jazidas que serão oportunamente referenciadas nesta tese. No que respeita ao Cenozóico há que referir, em Portugal, os achados da Silveirinha, uma jazida paleontológica do Eocénico Inferior, de importância internacional, onde se encontraram três ossos de uma ave limícola (HARRISON, 1983). Do Miocénico estão referenciadas em Amor, perto de Leiria, alguns achados dos terrenos Miocénicos da Praia do Penedo (Sesimbra), Aveiras (SANCHEZMARCO, A. S., 1996a) e a existência da parte distal de um tibiotarso dum Paleoperdix e um resto de gruidae, no Miocénico da Charneca do Lumiar, em Lisboa (MOURERCHAUVIRÉ, C \& TELLES-ANTUNES, M., 2003). Do Quaternário existe um maior número de descobertas, todas elas em contexto arqueológico. Neste caso existem algumas grutas com ocupação humana, que forneceram restos de aves plistocénicas; são exemplo as grutas da Figueira-brava, a Gruta da Furninha, a Gruta do Caldeirão, a Gruta Nova da Columbeira, a Lapa da Rainha, entre outras.

Partindo da definição das bases teóricas em que este trabalho assenta, far-se-á uma retrospectiva evolutiva e a sua adaptação paleoambiental, com vista a compreender tanto as aves actuais como as do Plistocénico. Através do estudo das aves em contexto arqueológico, poder-se-á não só conhecer a relação do homem com as aves, mas também o meio natural em que aquele se inseria. Pretende-se, 
também, através da retrospectiva evolutiva das aves, com destaque das suas características específicas, definir as aves e enquadrá-las cronologicamente no seio das linhas evolutivas dos vertebrados. O estudo foi realizado com base nas colecções do Museu Geológico, do Museu Nacional de Arqueologia, do Museu do Bombarral e em alguns materiais da Gruta do Caldeirão ${ }^{4}$, encontrados conjuntamente com a microfauna. Também se faz referência a outras jazidas com aves, entretanto já publicadas, como a Gruta da Figueira-Brava (Setúbal), cujos dados apresentados resultam do estudo publicado por C. Mourer-Chauviré e Telles Antunes em 2000 (MOURER - CHAUVIRÉ, C. \& ANTUNES, M. T.,2000). Também serão referenciadas as jazidas onde aparece citada a existência de aves, como a Buraca Escura, a Foz do Enxarrique e a Lapa do Picareiro.

A tese ora apresentada assentou no estudo dos materiais de oito jazidas arqueológicas: Gruta da Columbeira, Gruta da Furninha, Lapa da Rainha e Gruta da Casa da Moura, que forneceram a maior parte dos materiais estudados, complementadas com o estudo da Gruta das Salemas, Gruta das Fontainhas, Gruta do Pego do Diabo e alguns materiais da Gruta do Caldeirão. Com excepção da Gruta da Furninha, Gruta das Fontainhas e da Gruta do Caldeirão, em todas as outras a avifauna não estava ainda publicada ou está apenas referida superficialmente na bibliografia sobre os sítios em que se encontram.

O trabalho de identificação taxonómica e de investigação realizou-se no Museu do Bombarral (estudo dos materiais da Gruta Nova da Columbeira), no Museus Geológico (estudo dos materiais da Gruta da Furninha, da Gruta das Fontainhas, da Gruta das Salemas, da Casa da Moura e da Lapa da Rainha), no Museu nacional de arqueologia (estudo dos materiais da Gruta do Pego do Diabo), no Museu Nacional de História Natural (materiais da Gruta do Caldeirão) e no CIPA, CPGP e LAP, no estudo osteológico e comparativo entre as aves actuais e as plistocénicas. As jazidas estudadas, são todas elas em contexto de gruta e com ocupações humanas do Paleolítico Médio e Superior e com associações faunísticas plistocénicas.

A classificação taxonómica dos ossos de aves identificados nas colecções dos museus atrás referidos foi feita no laboratório de arqueozoologia do CIPA e no CPGP-

4 Os restos osteológicos de aves, da macrofauna do Caldeirão, já foram publicados por Simon Davis (Davis, 2002), pelo que os restos de aves encontrados em conjunto com a microfauna apenas virão complementar os dados já publicados. 
LAP, através da comparação com a colecção osteológica de avifauna actual

Este estudo tem como principal objectivo caracterizar a avifauna plistocénica de Portugal, mas pretende também fazer uma revisão da classificação taxonómica das aves da Gruta da Furninha, publicada em 1910-11 (HARLÉ, 1910-1911). Esta publicação apresenta alguns táxones que já não são usados. Por tal razão, foi feita a revisão taxonómica. Por outro lado, foram estudados alguns materiais não identificados no estudo de 1910. Este estudo pretende não só obter dados taxonómicos, mas também obter dados paleoecológicos e dados tafonómicos acerca das acumulações fósseis encontradas. Neste ultimo caso, depara-se com um obstáculo. Trata-se de estações escavadas há muito tempo, em especial a Furninha e a Casa da Moura, que o foram ainda no século XIX, mas com metodologias diferentes das actuais, o que acabou por levar à perda de algumas informações. Ainda por cima, durante todos estes anos em que as colecções estiveram em reserva, as mesmas foram mexidas por vários investigadores, o que, em alguns materiais, ocasionou o desaparecimento de etiquetas, levando assim à perda de certos dados, sobretudo os estratigráficos.

Pretende-se, também, complementar os dados obtidos nos estudos referidos no parágrafo anterior com os dados conhecidos de outras jazidas com avifauna plistocénica já estudada, para que se possa cumprir o principal objectivo desta tese: a caracterização da avifauna plistocénica de Portugal.

Deseja-se, igualmente, discutir as semelhanças e diferenças encontradas com outras estações do mesmo período fora de Portugal. Um ponto importante deste trabalho será estudar e relacionar a utilidade e a contribuição da avifauna, para o conhecimento das populações humanas do passado, nomeadamente para compreender a sua ecologia e o seu modo de vida.

Posto isto, esta dissertação aparece constituída por cinco partes distribuídas por dois volumes: no primeiro, constituído por três partes, apresenta na primeira a fundamentação teórica e as especificidades evolutivas e anatómicas, onde se desenvolvem as bases teóricas dos estudos paleontológicos, arqueológicos e arqueozoológicos; na Segunda Parte é apresentada a metodologia utilizada na elaboração da tese, e finalmente a terceira parte é dedicada às bases biológicas e evolutivas, onde se caracterizam as aves e se fala da sua origem. No segundo volume, 
constituído por duas partes, desenvolve, na primeira, as aves fósseis anteriores ao Plistocénico, referindo as ocorrências em Portugal das primeiras aves, dos seus antepassados e das aves presentes nas formações cenozóicas, começando entretanto por fazer uma contextualização geológica e paleontológica; na segunda parte, após uma breve caracterização da Pré-História portuguesa, falar-se-á da coexistência das aves e dos primeiros homens que habitaram o nosso território, com particular relevo do contributo daquelas para a compreensão do meio em que esses homens viveram e será feita uma contextualização paleontológica do Plistocénico português. Será também abordada, nesta segunda parte, a principal temática desta tese: o estudo paleornitológico das jazidas plistocénicas portuguesas estudadas para esta tese, bem como serão apresentadas as jazidas já publicadas por outros investigadores. No fim deste volume serão colocados os anexos da tese: quadros gerais e estampas.

Para um estudo deste tipo, é fundamental conhecer-se bem a sistemática, o estudo científico dos princípios que regem a diversidade e as relações entre os organismos. Com o progresso da paleontologia, foi desenvolvida a sistemática paleontológica, que tem como objectivo definir sistemas de classificação adaptados às contingências do seu objecto de estudo: os fósseis. Será apresentada nesta tese a sistemática paleontológica dos diferentes táxones identificados em cada uma das jazidas agora estudadas.

Para se compreender como se forma uma jazida paleontológica (ou mesmo as faunas encontradas em contexto arqueológico), a tafonomia tem um papel fundamental, pois estuda os princípios que regem a transição dos restos orgânicos da biosfera para a litosfera, ou seja, desde o momento da morte de um organismo até ao momento da sua descoberta como fóssil. Desta forma, a tafonomia é o ramo da paleontologia que estuda o enterramento e fossilização dos organismos, ou seja, todos os processos relacionados com a formação de uma jazida. No presente caso, a tafonomia é importante para se compreender as acumulações faunísticas e quais as implicações de cariz biológico ou antropológico relacionado com a presença de restos de aves nestas jazidas.

As aves são animais voadores e bípedes. Durante a sua evolução, os membros anteriores transformaram-se em asas. Em termos gerais, as aves superam qualquer outro grupo de vertebrados voadores, pela sua abundância e diversidade, quer no 
presente quer no passado. O esqueleto das aves é leve, mas robusto e elástico. A sua leveza é devida em grande parte ao facto de, em muitos dos ossos, a medula ter-se transformando em câmaras-de-ar durante o seu processo evolutivo. O grau de pneumatização varia segundo os grupos e segundo o grau de adaptação ao voo. O facto de os ossos das aves serem delgados e ocos, o que os torna mais frágeis, e a sua vivência, dificulta a respectiva fossilização. Por esta razão, os fósseis de aves são raros e, na sua maioria, são constituídos apenas por fragmentos. Esta será uma das razões que explica a relativa escassez de ossos de aves plistocénicas encontradas.

No último quarto de século, novas descobertas de fósseis e novas metodologias de estudo sugerem, de forma bastante evidente, que as aves teriam descendido de pequenos dinossauros carnívoros, do grupo dos maniraptores. No entanto, ao logo dos tempos, foram surgindo teorias que rejeitavam esta ideia, e só a partir dos anos 70 do século passado é que os dinossauros foram reconhecidos como verdadeiros antepassados das aves.

O homem, como caçador, sempre teve associados aos seus resquícios, restos de outros animais. Os restos de aves aparecem em várias estações arqueológicas, frequentemente em menor número que outros grupos. Para o caçador de então, a captura das aves seria muito difícil e não compensadora, por exigir um grande dispêndio de energia para tão pouca quantidade de carne, mas já os ovos, esses, forneciam uma boa fonte alimentar. Assim, as aves não teriam exercido, no homem do Paleolítico, um interesse, uma admiração como aconteceria em relação a outros grupos de animais, tais como os grandes mamíferos. Esta poderá ser uma das razões para a fraca presença de representações de aves na arte rupestre paleolítica, ao contrário de mamutes, cavalos, auroques e outros grandes animais. Por esta razão, a presença de vestígios de aves em estações pré-históricas poderá ser explicada por duas razões: ou trata-se de capturas esporádicas ou de aves que morreram perto de ocupações humanas.

Das estações arqueológicas estudadas para esta tese verifica-se que predominam em todas elas os ossos do esqueleto apendicular, seguidamente aparecem os ossos do esqueleto axial e, finalmente, o esqueleto cefálico, mas com uma percentagem insignificante. Este facto poderá estar relacionado com a natureza e consequente robustez de cada tipo de osso. 
Em termos ambientais, nota-se uma grande afinidade entre as estações arqueológicas localizadas no litoral e as localizadas mais no interior. Apesar de não se encontrarem grandes diferenças entre as espécies plistocénicas e as actuais, existem comparativamente, no Plistocénico, um maior número de espécies de climas frios, mas não de climas nitidamente glaciares. Pelo facto de o território não ter sofrido os picos máximos das glaciações, encontram em Portugal poucas espécies típicas desses climas, ao contrário de outros países da Europa. 


\section{1 - Estado actual do Conhecimento}

\section{1 - Enquadramento Evolutivo: aves ou dinossauros? problemática histórica, paleontológica e evolutiva}

A presente tese tem como temática principal as aves plistocénicas de Portugal e o seu enquadramento paleontológico e arqueológico. Na contextualização paleontológica serão referenciadas, apesar de não terem sido estudas para esta tese, as aves fósseis anteriores ao Plistocénico (Jurássico, Eocénico e Miocénico) conhecidas em Portugal. Por essa razão e atendendo à contextualização paleontológica e evolutiva das aves será apresentada, neste ponto, uma pequena síntese sobre a origem das aves e a sua relação com os dinossauros, seus antepassados.

\subsection{1 - Origem das aves}

As aves são o grupo de vertebrados voadores mais bem sucedido, com mais de 9000 espécies vivas (BENTON, 2005). A sua origem tem sido motivo de especulação pelos paleontólogos desde a descoberta da "primeira ave", um ano depois de Charles Darwin publicar a "Origem das espécies", em 1859. Foi então, no ano de 1860, que foi encontrada uma pena de ave fossilizada, na Alemanha, na localidade de Solnhofen, em calcários muito finos do Jurássico Superior, com cerca de 150 milhões de anos. Em 1861, foi descoberto, no mesmo local, um esqueleto de um animal com penas e asas, mas bastante diferente de uma ave moderna. A este fóssil, conhecido como o espécime de Londres ${ }^{5}$ foi-lhe dado o nome de Archaeopteryx lithographica, em 1877 foi descoberto o fóssil mais completo de Archaeopteryx, denominado de espécime de Berlim (BENTON, 2005). O Archaeopteryx é o fóssil mais arcaico de ave conhecido.

Actualmente são conhecidos oito esqueletos de Archaeopterix, todos eles descobertos nos mesmos calcários de Solnhofen. Para além dos dos dois esqueletos e

5 O primeiro exemplar de Arcaheopteryx a ser descrito e classificado, sendo portanto o holótipo da espécie. 
da pena atrás referidos, foram encontrados mais seis fósseis de archaeopterix em 1855 (só classificado em 1970), 1951, 1956, 1987, 1992 e 1997, discutindo-se se pertencem realmente à mesma espécie ou a espécies (ou mesmo genros) diferentes, pois apresentam tamanhos diferentes, desde os 30 aos $50 \mathrm{~cm}$ de comprimentos e algumas pequenas características diferentes (BENTON, 2005).

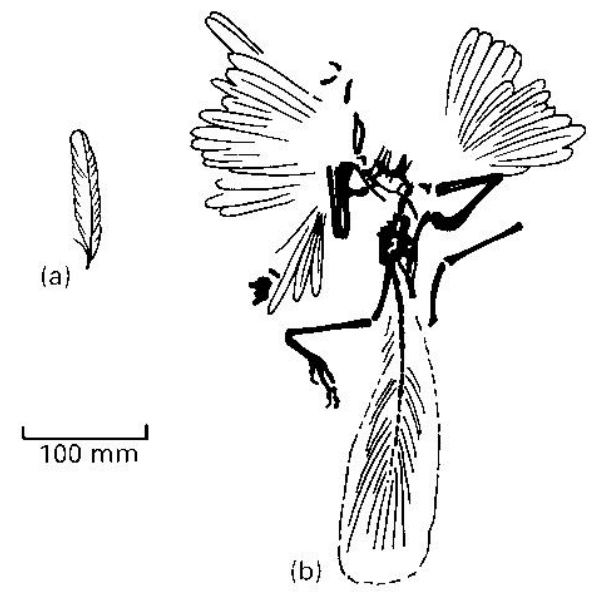

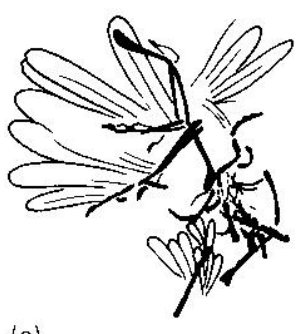

(e)

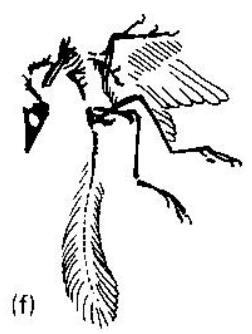

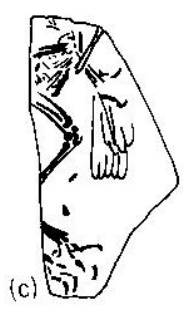
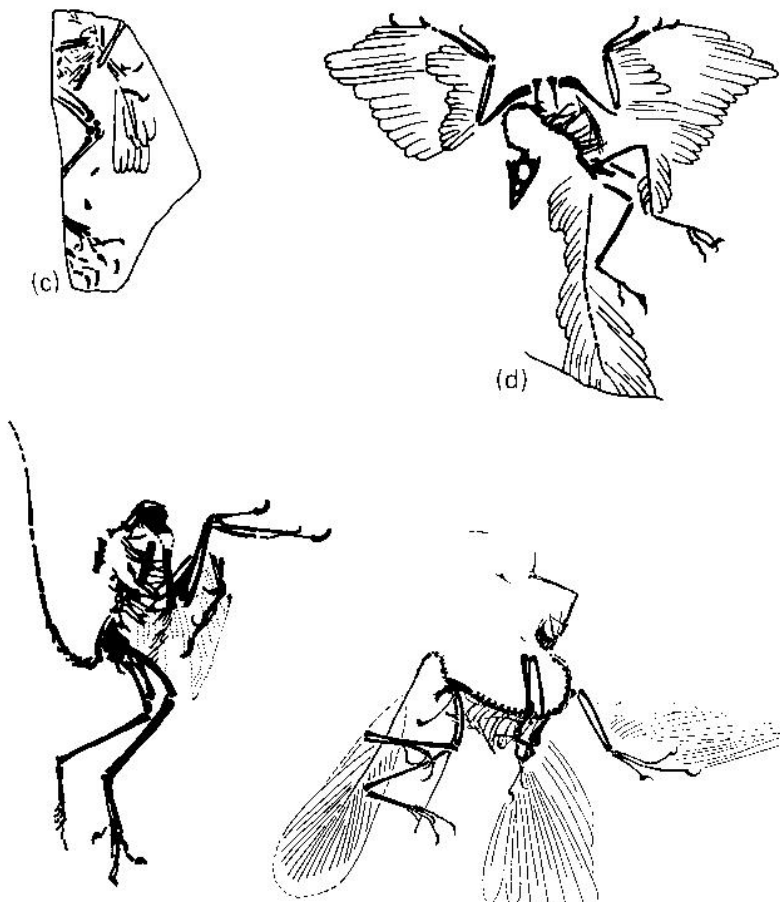

(g)

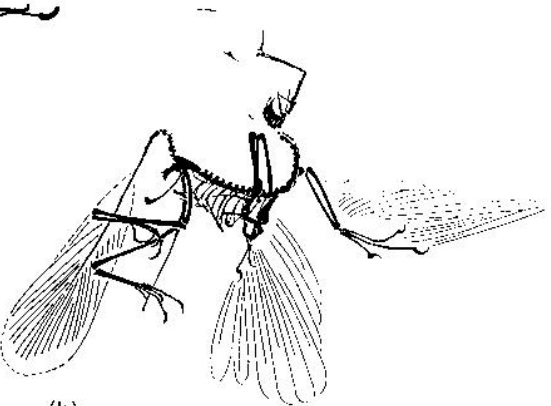

(h)

Fig. 1 - Desenho de oito dos nove especímenes de Archaeopterix conhecidos: a)Berlim / Munique (1860); b) Londres (1861); c) Haarlem (1855 - 19706); d) Berlim (1877); e) Maxberg (1956); f) Eichstall (1951); g) Solnhofen (1987); h) Munique (1992). Fonte: BENTON, 2005, p. 258..

Desde 1860 que vários grupos de tetrápodes têm sido apontados como os antepassados das aves. No entanto, actualmente, a maioria dos investigadores defende que as aves descendem de um grupo de pequenos dinossauros carnívoros, os maniraptora, mas, tal como em todos os grupos animais extintos, ainda falta bastante para se conhecerem bem os dinossauros, as aves primitivas e os elos entre estes dois grupos.

6 Este exemplar foi descoberto em 1855, mas só classificado como pertencente ao género Archaeopterix em 1970. 
Existem duas características dos dinossauros que ainda são mal compreendidas. São elas: a sua possível endotermia e a ancestralidade dinossáurica das aves. A relação entre dinossauros e aves provocou um enorme entusiasmo junto do grande público. A principal razão para criar esta excitação relaciona-se com um facto pouco referido e pouco apreciado que é a relação da origem das aves com a possível endotermia dos dinossauros. Este facto é de tal maneira importante que apoia a proposta mais radical de todas: uma reorganização da classificação dos Tetrápodes, que passa por extinguir a classe das aves, reorientando um dos ramos da árvore filética dos vertebrados (GOLD, 1980). Assim, com base nas novas descobertas de dinossauros com plumas, nos estudos de cladística e na própria genética, alguns investigadores ${ }^{7}$ propõem a divisão dos Tetrápodes mamíferos, quelónios (tartarugas) sauropterígios, que agrupariam os repteis actuais como os lagartos e as cobras, notossauros e plesiossauros, e os arcossauros, que agrupariam os crocodilos, pterossauros, dinossauros e aves, sendo estes últimos, um grupo dentro dos dinossauros. Nesta nova reorganização os ictiossauros ${ }^{8}$ ainda não têm a sua posição bem definida.

A grande semelhança entre o esqueleto do Archaeopteryx, a primeira ave conhecida, e o esqueleto de alguns pequenos dinossauros carnívoros nunca foi posta em causa. Desde o século XIX, como se verá mais à frente, que vários paleontólogos, em especial Thomas Huxley, defendem a descendência directa das aves a partir destes pequenos dinossauros. No entanto no século passado (desde o principio até à década de 70), esta ideia foi abandonada por causa de um osso, a fúrcula. A fúrcula das aves não é mais que as clavículas fundidas, dando origem a esse osso. Sabendo que os estudos evolutivos com base nas probabilidades matemáticas defendem que as estrutura complexas que, no decorrer da evolução se tenham perdido, não voltam a aparecer ${ }^{9}$, as aves não podiam ser descendentes dos dinossauros, pois não se conheciam espécies de dinossauros com clavículas. Pensava-se então que estes dois grupos teriam um antepassado comum. Talvez os Pseudosuchia, uma vez que eram

7 Como por exemplo Jacques Gauthier (GAUTHIER, 1986), Paul Sereno (SERENO, 1999, 2001), James Clark (CLARK e tal., 2002) e Luis Chiappe (CHIAPPE, 2002, CHIAPPE \& Dyke, 2002).

8 Os ictiossauros eram répteis marinhos de morfologia semelhante à dos golfinhos e à dos tubarões. 9 As estruturas complexas são constituídas por muitos genes que interactuam de um modo bastante complexo com todo o aparelho de desenvolvimento de um organismo. Se todo este sistema for desmantelado no processo evolutivo é matematicamente impossível de ser reconstituído. 
um grupo de répteis que ainda tinham as clavículas e teriam, na linha de descendência para os dinossauros perdido este osso, enquanto na linha de descendência para as aves teriam reforçado e fundido (GOLD, 1980).

O paleontólogo americano John Ostrom reviu cuidadosamente os cinco espécimes de Archaeopteryx, então conhecidos e verificou a semelhança extrema entre aves e os celurossauros. Por outro lado, foram descobertas espécies de celurossauros e outros pequenos dinossauros carnívoros com clavículas e a grande semelhança entre vários elementos esqueléticos entre o Archaeopteryx e estes dinossauros, bem como a descoberta de dinossauros com penas veio recolocar definitivamente as aves como descendentes destes últimos (OSTROM, 1976).

Ao se considerar que as aves são dinossauros sobreviventes, à primeira vista pode-se pensar que estamos perante uma revolução na árvore evolutiva dos vertebrados terrestres. Nada mais errado. Isto apenas implica uma pequena mudança nos pontos filéticos da ramificação dos dinossauros (PADIAN \& CHIAPPE, 1998).

A taxonomia cladística agrupa os organismos apenas pelos padrões de ramificação. Isto quer dizer que segundo a cladística dois grupos que se ramificam um do outro e não têm descendentes (como no caso das aves), devem ser agrupados na classificação formal antes que um deles se junto a outro (como o caso da inclusão dos dinossauros nos répteis). Assim faz todo o sentido a criação de uma nova classe que una os dinossauros e as aves, seria então a classe dinosauria. Por sua vez, a taxonomia clássica defende que há que ter em conta que os pontos de ramificação não constituem o único critério de classificação. Há também de ponderar o grau de divergência adaptativa na estrutura. O sistema taxionómico tradicional considera tanto a estrutura biológica como o padrão de ramificação, podendo classificar no mesmo grupo organismos que partilham entre si determinadas características comuns, mas que terá desenvolvido estruturas que derivaram noutros organismos, que a cladística classificaria no mesmo grupo desses outros, seus antepassados (MENDES, 1988; RIOS-NETO, 2004).

A este propósito Stephen J. Gould diz o seguinte: " No sistema cladístico, as vacas e os peixes pulmonados têm uma afinidade mais estreita do que os peixes pulmonados e os salmões, porque os antepassados dos vertebrados terrestres se 
ramificaram a partir de peixes sarcopterígios (um grupo que inclui os peixes pulmonados) após aqueles se terem já ramificado a partir de peixes actinopterígios (peixes ósseos, incluindo o salmão). No sistema tradicional consideramos tanto a estrutura biológica como o padrão de ramificação e poderemos continuar a classificar conjuntamente os peixes pulmonares e os salmões como peixes, porque partilham muitas características comuns" (GOULD, 1980). Os tetrápodes, desde os primeiros anfíbios sofreram uma grande transformação evolutiva, enquanto, por sua vez, os sarcopterígios conservaram as suas características no processo evolutivo, desde há mais de $300 \mathrm{Ma}$. O sistema tradicional admite como critério de classificação adequado as diferentes taxas evolutivas (DOMÉNECH \& MARTINELL, 1996). Isto quer dizer que depois da ramificação um grupo de organismos poderá ganhar estatuto independente em virtude da sua profunda divergência.

No que respeita a este assunto, a origem das aves, vejamos, em maior pormenor a evolução do pensamento, das descobertas e evidências sobre a origem das aves. O esqueleto do Archaeopteryx é de tal forma anatomicamente idêntico aos pequenos dinossauros carnívoros, que desde cedo, como se disse, se pôs a hipótese destes serem seus antecessores. Como também foi referido, o primeiro a avançar com esta teoria foi Thomas Huxley, um seguidor de Darwin, que apresentou um estudo donde tirou esta conclusão, na Sociedade de Geologia de Londres, no ano de 1870. O estudo de Huxley teve por base a comparação dos membros posteriores do Megalosaurus (um dinossauro terópode, de grandes dimensões) e os da avestruz. Ele descobriu 35 pontos em comum entre os dois animais, o que não ocorria entre as aves e outros grupos animais. Desta forma Huxley concluiu que as aves e os terópodes estavam relacionados entre si, concluindo que talvez fossem parentes próximos: "primos" ou mesmo as aves descendentes dos dinossauros. (WEISHAMPEL, 1990; FIGUEIREDO, 2008)

Esta teoria foi imediatamente contestada pelo paleontólogo Harry Govier Seeley, argumentando que os pontos em comum dos membros posteriores do Megalosaurus e da avestruz nada têm a ver com uma relação evolutiva, mas sim pelo facto de ambos os animais serem grandes e bípedes. Por outro lado, Seeley defendia que, para além dos Megalossauros serem maiores que as avestruzes e nenhum deles poder voar, como é que as aves voadoras poderiam descender dos dinossauros? 
(CURRIE, 1997).

Em 1916, um médico alemão, Gerhard Heilmann, interessou-se por este assunto e publicou um livro "A Origem das Aves". Neste livro, Heilmann defendeu que as aves são anatomicamente mais próximas dos dinossauros terópodes do que de outro qualquer grupo fóssil. No entanto ele apresentou uma notável discrepância: Os terópodes não apresentavam as clavículas, enquanto as aves apresentam a fúrcula, que são clavículas fundidas. Como os restantes répteis têm clavículas, Heilmann deduziu que os terópodes as perderam. Para ele, esta perda queria dizer que as aves poderão não ter evoluído dos dinossauros, pois ele estava convencido que uma característica perdida na evolução não pode ser recuperada, isto é, os terópodes não tinham clavículas enquanto as aves têm a fúrcula. Desta forma, Heilmann defendeu que as aves devem ter evoluído a partir de um grupo de répteis mais arcaicos, que possuíam clavículas. Tal como Seeley ele defendeu que as semelhanças entre terópodes e aves não são mais do que adaptação ao meio de locomoção (bipedismo) (CURRIE, 1997).

As conclusões de Heilmann influenciaram o pensamento durante muito tempo, até se encontrarem novas provas. Duas descobertas diferentes vieram indicar que afinal os terópodes tinham, de facto, clavículas. Em 1924, a publicação de um desenho anatómico do Oviraptor (um terópode de dimensão média) mostrava claramente a presença de uma espécie de fúrcula, mas esta estrutura não foi notada. Mais tarde, em 1936, Charles Camp, da Universidade da Califórnia, encontrou os restos completos de um pequeno terópode do Jurássico Inferior, o Coelophisis, que tinha clavículas. Desta forma estava posta de parte a principal objecção de Heilmann quanto à descendia das aves a partir dos terópodes. Estudos recentes comprovaram a presença de clavículas em terópodes, numa aproximação num espectro de relação dentre estes e as aves (GOULD, 1980).

Na década de 70 do século XX, John Ostrom, da Universidade de Yale, pegou novamente na ideia de Huxley e propôs de forma explícita que as aves descendem directamente dos terópodes. Na década anterior, este paleontólogo descreveu anatomia do esqueleto do Deinonychus (um dinossauro carnívoro do Cretácico Inferior, encontrado em Montana, E.U.A., do tamanho de um homem e que possuía 
uma garra muito poderosa, no terceiro dedo das patas traseiras). Derivado deste trabalho, Ostrom, publicou vários artigos (décadas de 60 e 70) em que apresentou uma série de características comuns entre este dinossauro, outros terópodes e o Archaeopteryx. Com base nestes artigos, ele conclui, na década de 70, que não há dúvidas que as aves são os descendentes directos dos pequenos dinossauros terópodes (GOULD, 1980; CURRIE, 1997).

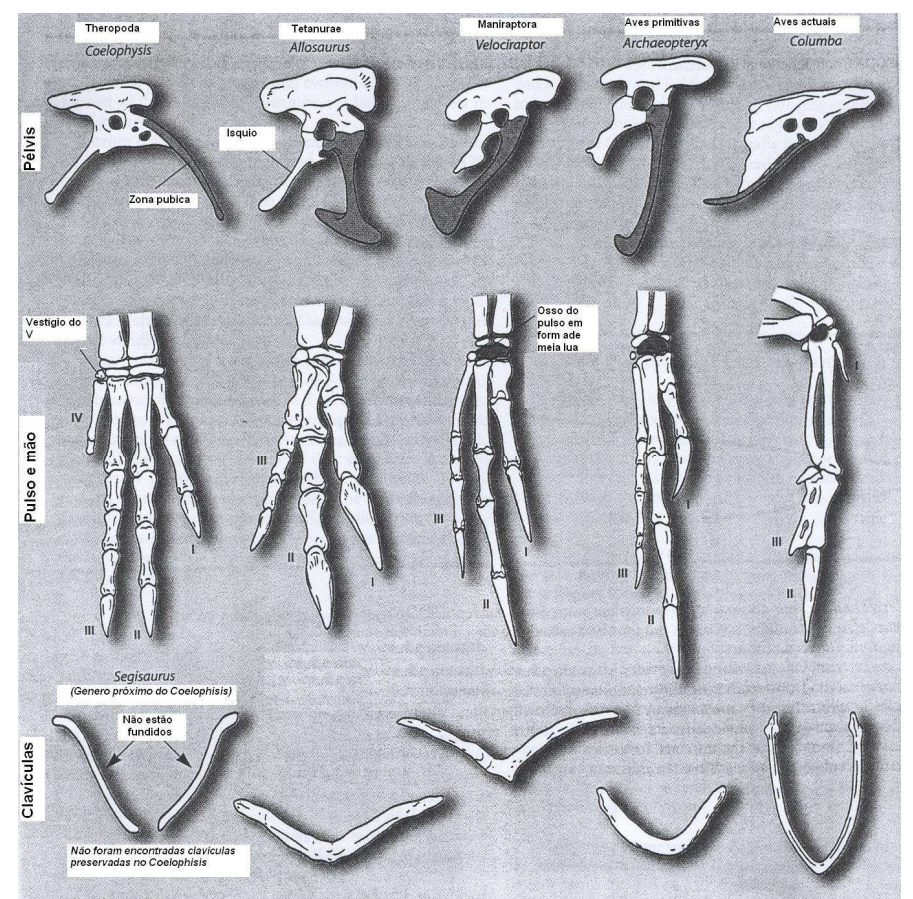

Fig. 2 - Comparação dos ossos dos membros anteriores entre alguns terópodes e as aves (adaptado de PADIAN \& CHIAPPE, 1998)

Ao mesmo tempo que Ostrom apresentava as suas conclusões, um novo método de interpretação das relações entre organismos estava a ser desenvolvido nos Museus de História Natural de Paris, Nova York e outros. Este método, designado por Sistemática Filogenética, ou, mais frequentemente, por Cladística começou então a ser o suporte da biologia comparativa (GOULD, 1980) e veio dar uma validade forte ás conclusões de Ostrom.

Ostrom não aplicou os métodos da cladística para determinar como as aves evoluíram a partir dos pequenos dinossauros terópodes. Na década de 70 a Cladística estava a desenvolver-se (GOULD, 1980) e uma década depois Jacques A. Gauthier, numa análise cladística extensiva sobre as aves, os dinossauros e os répteis seus relacionados, confirmou que as aves evoluíram a partir dos pequenos terópodes. $\mathrm{Na}$ 
verdade, um dos parentes mais próximos das aves era o Deinonychus (CURRIE, 1997), que Ostrom tinha descrito.

Hoje em dia, um cladograma com a linhagem dos terópodes para as aves mostra que a marcação da clade das aves consiste num antecessor do Archaeopteryx e todos os outros descendentes desse antecessor. Essa clade é um subgrupo de uma extensão da clade dos dinossauros terópodes maniraptores, os quais são também um subgrupo da clade dos terópodes (grupo dos tetanurae), que são descendentes dos terópodes mais arcaicos, que têm a sua origem nos dinossauros monterophoda. Actualmente os cladogramas das aves mostra que estas não são apenas descendentes dos dinossauros, mas são verdadeiros dinossauros. A diferença entre aves e dinossauros será, seguindo este raciocínio, a mesma diferença que existe entre o homem e os restantes mamíferos (FIGUEIREDO, 2008).

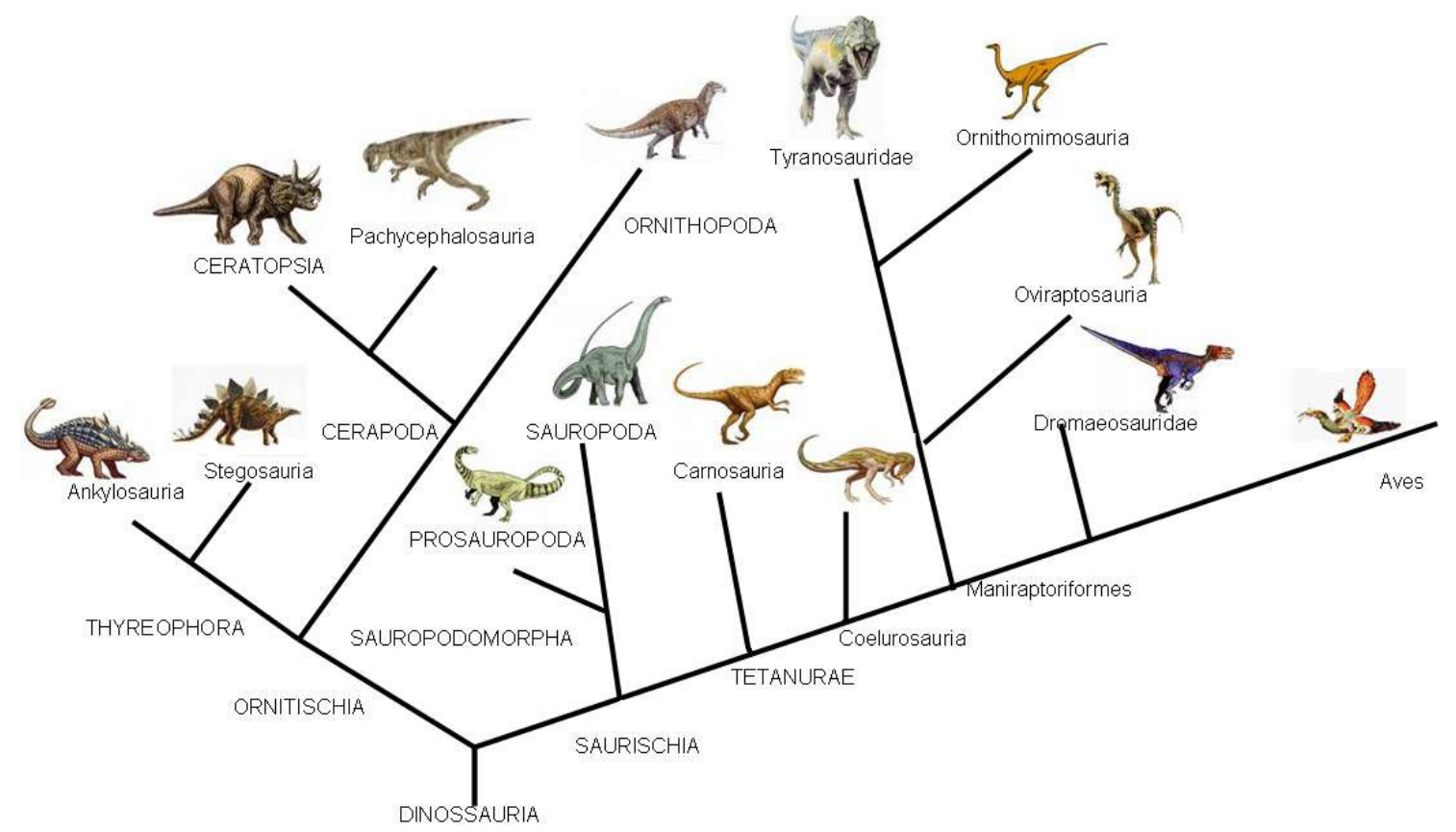

Fig. 3 - Cladograma com a relação das aves com os dinossauros (fonte: Figueiredo, 2008)

\subsection{2 - Confronto das várias teorias}

Nos últimos 30 anos, novas descobertas fósseis e novas metodologias de estudo apontam, de forma bastante evidente, para que as aves tenham descendido de pequenos dinossauros carnívoros, do grupo dos terópodes. No entanto, ao longo dos tempos surgiram teorias que rejeitavam esta ideia e só a partir dos anos 70 do 
século passado é que os dinossauros foram assumidos como os verdadeiros antepassados das aves. Até então a origem das aves estava relacionada com vários grupos de répteis do Mesozóico, como se verá mais à frente, ou apenas se referia a um "grupo desconhecido de répteis" como estando na origem das aves, como se pode ler, por exemplo em Outlines of palaeontology, de Swinnerton ( $2^{a}$ edição em castelhano, Edições Ómega, Barcelona, 1972)

\section{Arcossauros e aves}

Como se viu, os dois grupos de dinossauros evoluíram de um antepassado comum. Esse antepassado comum está entre os tecodontes, um grupo de arcossauros. Também como já foi referido, as aves foram consideradas como parentes dos dinossauros, mas não suas descendentes. Destra forma as aves eram consideradas como "primas" dos dinossauros, os quais partilhavam com estas um antepassado comum.

Assim, a origem das aves estaria nos arcossauros e não nos terópodes. Durante muito tempo, era assim que aparecia na bibliografia a sua origem, sem nunca apontarem para um grupo específico de arcossauros como o antepassado das aves. Quem defendia esta hipótese avançava com a ideia de que os antepassados das aves eram descendentes de arcossauros arborícolas (COX, 1974, pp. 120). 

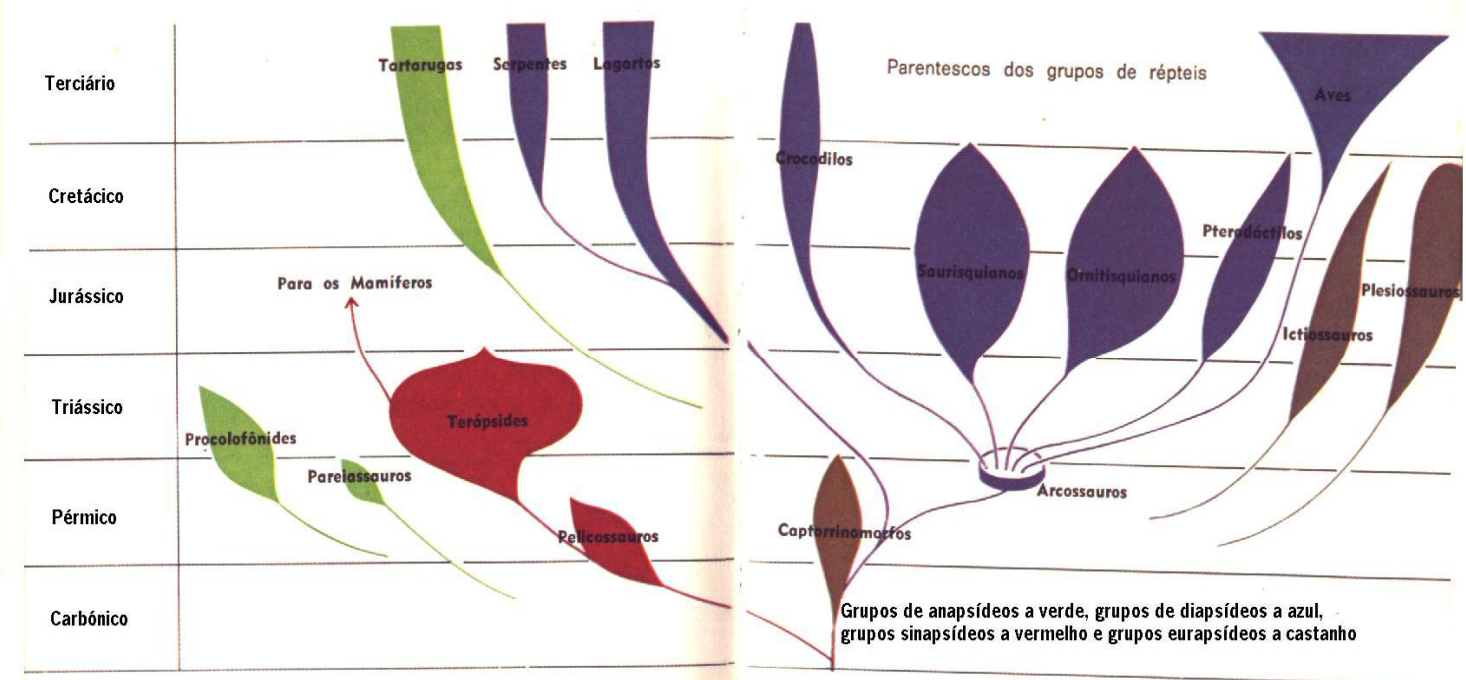

Fig. 4 - Parentesco entre os diferentes grupos de répteis, segundo Cox, 1969 (edição brasileira de 1974). Podemos verificar nesta árvore evolutiva que as aves descendem dos arcossauros. Fonte: COX, 1974, pp. 120.

\section{Ornitisquianos e aves}

Foi em 1970, que Peter Galton avançou com a ideia de que os dinossauros "com cintura pélvica de ave" (ornitísquios) seriam os parentes mais próximos das aves. Galton estava, de facto, a revitalizar uma ideia bastante antiga, descartada por Heilmann, em 1926. O seu argumento, se observado com atenção, era bastante evasivo, porque tinha de admitir que todos os dinossauros ornitísquios eram demasiado especializados para terem dado origem às aves, daí que tenha sido forçado a admitir que estas tenham evoluído a partir de um arcossauro desconhecido, no Triásico Médio, possuidor de uma pélvis semelhante à das aves. Até à data, tal criatura nunca fora encontrada, e Peter Galton admite agora estar errado e é um dos fundadores da teoria cladística que clássica as aves como dinossauros.

\section{Crocodilianos e aves}

Alick Walker, em 1972, propôs que as aves modernas partilham certas características comuns com arcossauros semelhantes aos crocodilos do Triásico, chamados Sphenosuchus. As semelhanças detalhadas eram bastante complexas, relacionadas com a disposição dos ossos do crânio, bem como outras parecenças mais gerais, relacionadas com a estrutura dos ombros, membros superiores e o tornozelo das aves primitivas e crocodilos primitivos. 
As propostas de Walker eram essencialmente que as aves teriam evoluído a partir de um grupo de arcossauros primitivo, de constituição leve, semelhantes a crocodilos, alguns dos quais tenham começado a subir ás árvores, tal como propusera Heilmann, ao passo que outros se terão tornado anfíbios e evoluído para verdadeiros crocodilos.

\section{Terópodes e aves}

Em 1973, John Ostrom reavivou a ideia de um celurossauro como antepassado das aves. Como foi referido, uma revisão cuidada da anatomia do Archaeopteryx revelou que partilhava mais de 20 características em comum com esse tipo de dinossauros. O principal problema era a falta da clavícula, nos terópodes. Este facto, como se viu, mostrou não constituir, afinal, problema algum, porque vários terópodes possuíam, de facto, clavículas.

Alguns dos pontos de Ostrom mais marcantes a favor de um terópode como antepassado do Archaeopteryx, e portanto das aves, pode ser resumido como se segue:

Primeiro, ele afirma que os ossos da cintura pélvica do Archaeopteryx não eram como as das aves, mas antes tomaram a disposição das aves, durante o processo de fossilização; em vida, portanto, podem ter-se assemelhado de perto à disposição dos dinossauros terópodes;

Em segundo lugar, os membros superiores dos terópodes e do Archaeopteryx são semelhantes de uma forma notável, até ao mais diminuto pormenor;

Em terceiro lugar, os membros anteriores e os pés do Archaeopteryx são igualmente muito semelhantes aos dos terópodes.

Ao estudar o voo das aves reparou que o bater das asas não é um simples movimento de "para baixo e para cima", mas é um movimento mais complexo, em que a asa muda de forma e de direcção, rodando à medida que é empurrada para baixo pelo ar. Neste movimento, Ostrom reconheceu a mesma acção giratória dos pulsos dos maniraptores (OSTROM, 1976). 


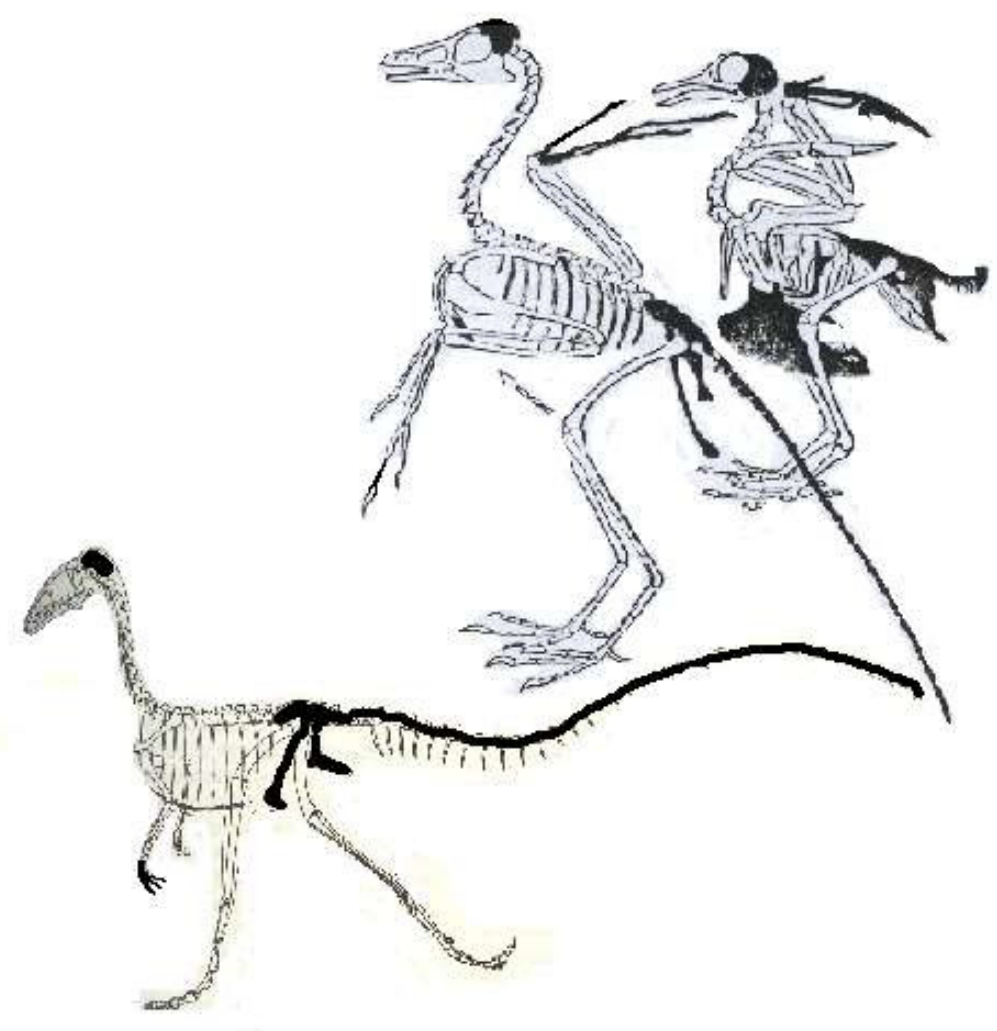

Fig. 5 - Comparação entre o esqueleto de um Compsognathus (em baixo), do Archaeopteryx (a meio) e de uma ave actual (em cima).

No entanto, à luz da longa lista de semelhanças entre aves e terópodes, de Ostrom, pode-se colocar a seguinte pergunta: poderiam todas estas semelhanças detalhadas entre aves e dinossauros ter surgido por evolução convergente? A resposta é aparentemente negativa. 


\section{2 - Investigações sobre aves fósseis portuguesas}

\subsection{1 - Investigações sobre aves meso-cenozóicas em Portugal}

Consideram-se neste ponto os estudos sobre as aves encontradas no registo fóssil até ao Pliocénico. Os estudos sobre as aves fósseis portuguesas têm sido pouco intensos e superficiais, em especial as do Mesozóico e do Cenozóico, acerca das quais se conhecem poucas referências. A maioria das publicações onde são referidas estas aves são estudos geológicos ou paleontológicos generalistas sobre algumas jazidas paleontológicas (ZBYZEWSKI \& FERREIRA, 1987; ANTUNES \& MEIN, 1981; ANTUNES \& RUSSEL,1981; MARTIN \& KREBS, 2000), ou em obras de síntese (CRESPO, 2001), em artigos muito sumários e vagos (SANCHEZ-MARCO, 1996) ou em poucos artigos dedicados especialmente ao estudo da ocorrência de aves em jazidas específicas (HARRISON, 1983; WEIGERT, 1995; MOURER-CHAUVIRÈ \& ANTUNES, 2003).

\subsection{2 - Investigações sobre aves Plistocénicas em Portugal}

Os restos de aves plistocénicas conhecidas em Portugal são provenientes de jazidas em contexto arqueológico. As poucas jazidas plistocénicas com restos de vertebrados em contexto geológico não contêm restos de aves. Os primeiros trabalhos de escavações arqueológicas em grutas que tiveram uma preocupação com a estratigrafia, em Portugal, foram feitos a partir da década de 1960, com a colaboração de Jean Roche. Antes disso, a estratigrafia era pouco precisa. Por esta razão, o estudo das aves das jazidas escavadas no período anterior apresenta algumas dificuldades na interpretação dos dados estratigráficos.

O estudo de aves plistocénicas em Portugal tem sido mais intenso que o das aves de períodos anteriores, um pouco devido ao facto atrás referido da ocorrência em jazidas arqueológicas. Existem várias publicações que referem a ocorrência aves plistocénicas. Desde artigos sobre faunas encontradas em jazidas arqueológicas, a sínteses sobre a fauna plistocénica de Portugal (HARLÉ, 1910-11; FERREIRA, 1964; ROCHE, 1971 e 1972; FIGUEIREDO, 2009) ou mesmo artigos sobre aves encontradas em jazidas arqueológicas específicas (DEVILLE, 1996; MOURER - CHAUVIRÉ e ANTUNES, 1999; MORENO-GARCIA \& PIMENTA, 2002) 
Nos estudos sobre faunas encontradas em jazidas arqueológicas, as aves sempre ocuparam um papel secundário. A primeira publicação onde foi feito um estudo desenvolvido sobre aves data de 1910-11 (HARLÉ, 1910-11). Harlé contou com a colaboração de E. T. Newton no estudo das aves da Gruta da Furninha e das Fontainhas. É também referido nesta publicação a presença de restos de aves na Gruta da Casa da Mora, sem, no entanto, apresentar um estudo dos táxones dessas aves. Desde essa altura até à década de oitenta a referência na bibliografia à existência de aves no Plistocénico português apenas revela reproduções nominativas, sem a actualização taxonómica daquela listagem de inícios do século passado (ZBYSZEWSKI, 1958; VEIGA FERREIRA, 1964; ROCHE, 1972). Nestes novos estudos apenas se actualizou o conhecimento da avifauna plistocénica de Portugal com a referência à existência de aves na Lapa da Rainha (ROCHE, 1972). Desde a década de oitenta até à actualidade novos estudos foram feitos sobre outras jazidas aumentando exponencialmente as jazidas com aves plistocénicas (DEVILLE, 1996; BRUGAL e RAPOSO 1999; BRUGAL, 2006; MOURER - CHAUVIRÉ e ANTUNES, 1999; DAVIS 2002; MARKS et al. 2002; BICHO et al. 2003, MORENO-GARCIA \& PIMENTA, 2002) No entanto, é importante referir que algumas destas publicações apenas fazem uma referência à descoberta de restos de aves em algumas jazidas, sem qualquer indicação taxonómica mais específica (BRUGAL e RAPOSO 1999; BRUGAL, 2006; BICHO et al. 2003, AUBRY et al.)

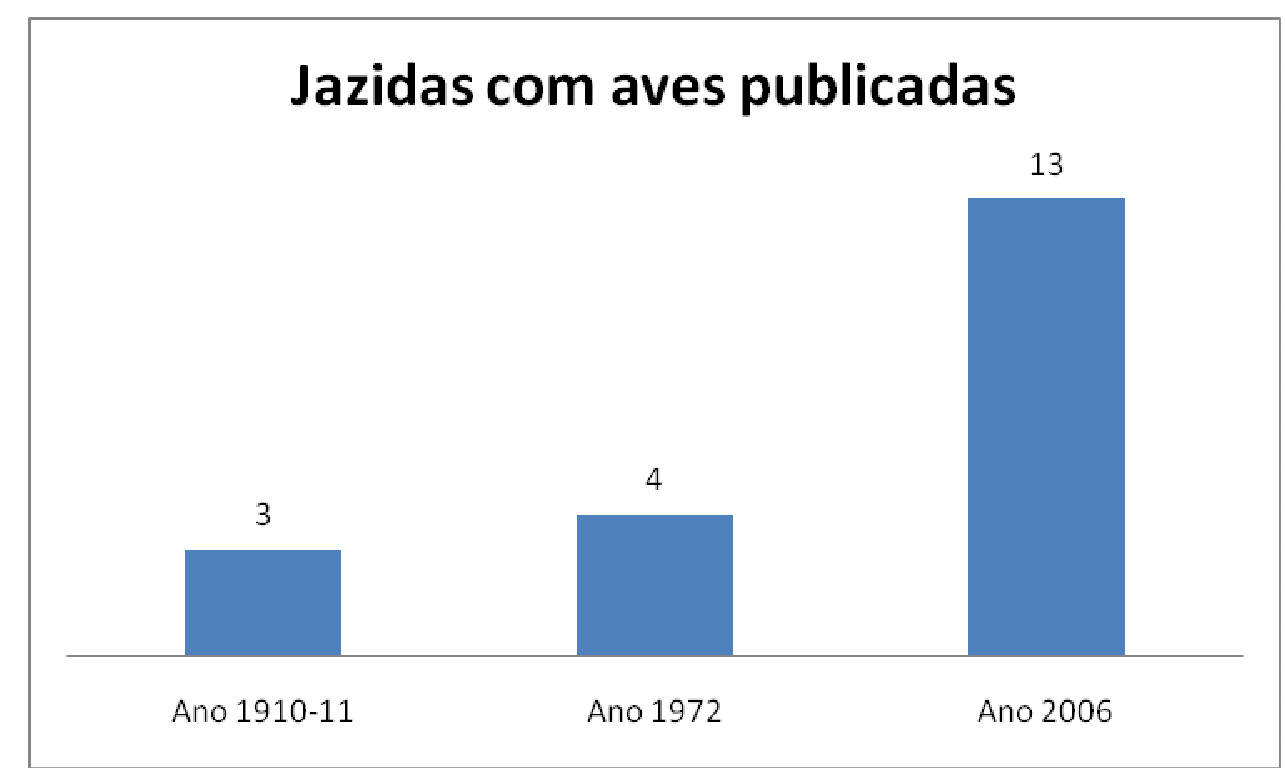

Gráfico 1 - Relação do número de jazidas com aves plistocénicas publicadas até 2006. 
O presente estudo incidiu sobre um conjunto de 2079 elementos ósseos de avifauna, provenientes de oito jazidas em contexto arqueológico: Gruta Nova da Columbeira; Gruta da Furninha (revisão taxonómica do estudo de E. T, Newton e estudo de alguns materiais inéditos); Gruta das Salemas, Gruta do Pego do Diabo, Gruta da Casa da Moura (estudo dos materiais referidos por Harlé em 1910-11 como sendo de aves, mas não estudados), Lapa da Rainha (estudo dos materiais inéditos, não publicados por Roche), Gruta do Caldeirão (estudo de alguns materiais de microvertebrados, não estudados por Davis) e Gruta das Fontainhas (revisão taxonómica do estudo de E. T. Newton). Estes materiais resultaram de escavações e recolhas efectuadas nos séculos XIX (Gruta da Furninha, Gruta das Fontainhas, e Casa da Moura) e século XX (Gruta das Salemas, Gruta Nova da Columbeira, Lapa da Rainha, Gruta do Pego do Diabo e Gruta do Caldeirão). Os materiais estão depositados no Museu Geológico (Gruta da Furninha; Gruta das Salemas, Gruta das Fontainhas, Gruta da casa da Moura e Lapa da Rainha), no Museu do Bombarral (Gruta Nova da Columbeira), no Museu Nacional de Arqueologia (Gruta do Pego do Diabo) e no CIPA - IGESPAR (Gruta do Caldeirão). No caso da Gruta do Caldeirão apenas foi estuda uma pequena amostra (sete elementos ósseos), que se encontrava junto da microfauna, a qual está a ser estudada pela Dra. Liliana Póvoas, do Museu Nacional de História Natural. Apenas foi autorizada esta pesquisa, pelo responsável das escavações na Gruta do Caldeirão: O Doutor J. Zilhão, uma vez que o resto da avifauna foi incluída no estudo da fauna desta jazida, elaborado por Simon Davis (DAVIS, 2002).

As grutas não foram utilizadas unicamente pelo homem do Paleolítico, também muitos animais se serviram delas para se abrigar e proteger. Entre estes encontram-se as aves. Algumas utilizaram as grutas, outras foram para lá levadas por acção predatória do homem ou outros predadores. Roche, em 1970, escrevia sobre os restos faunísticos encontrados em Portugal: "A documentação mais abundante e mais precisa é proporcionada pelas jazidas da província litoral da Estremadura, situada entre o baixo Tejo e o Oceano Atlântico. As indicações fornecidas por essas jazidas são de valor inquestionável." (ROCHE, 1970, p. 39). Trata-se de grutas situadas em numerosas cornijas calcárias, datadas final do Jurássico Médio, Jurássico Superior e Cretácico, sendo a maior parte do Jurássico Superior. Nestes calcários encontram-se fissuras cársicas e grutas habitadas por homens, de que são exemplo a Casa da 
Moura, a Gruta da Furninha, a Gruta Nova da Columbeira, a Lapa da Rainha e a Gruta das Salemas, ou que serviram apenas como refúgios de animais, de que é exemplo a Gruta das Fontainhas. 


\section{3 - Breve história das investigações das jazidas estudadas}

Neste ponto pretende-se abordar sucintamente a história das investigações das diferentes jazidas estudas, referindo a sua descoberta, anos de escavação e os investigadores que lá trabalharam.

A Gruta Nova da Columbeira foi descoberta acidentalmente por um tiro de pedreira, em 1962. As escavações arqueológicas foram dirigidas por Veiga Ferreira e por G. Zbyszewski e iniciadas nesse mesmo ano. Nestes trabalhos, que decorreram entre Agosto e Outubro de 1962, colaboraram vários técnicos dos então Serviços Geológicos de Portugal e alguns bombarralenses interessados na arqueologia. Os materiais resultantes destes trabalhos estão depositados no Museu Municipal do Bombarral.

Esta Gruta é uma das estações mais importantes do Paleolítico Médio de Portugal, pois é das poucas estações arqueológicas desse período que forneceu um dente de Neandertal (CARDOSO, J. L., RAPOSO, L. \& FERREIRA, V., 2002).

A Gruta da Furninha foi totalmente escavada no século XIX, por Nery Delgado, que a apresentou no IX Congresso Internacional de Antropologia e Arqueologia PréHistóricas, realizado em Lisboa, em 1880. Se se atender à época, pode dizer-se que esta gruta foi descrita com um grande rigor, por Nery Delgado (RAPOSO, 1995). Este congresso, os organizadores e o próprio local onde se realizou (o actual Museu Geológico) têm um papel relevante na história da arqueologia portuguesa. Nas respectivas actas, publicadas quatro anos depois, pela Tipografia da Academia das Ciências, a comunicação sobre a Gruta da Furninha ocupa um lugar de destaque, o que denota a importância desta jazida, no âmbito da arqueologia portuguesa.

Os materiais da Gruta da Furninha encontram-se depositados no Museu Geológico. Em 2002, foram objecto de um inventário, tendo-se mantido a organização em que se encontravam, numerando individualmente os materiais que estavam isolados e atribuindo um número de lote aos conjuntos que estavam já predefinidos. Este inventário foi orientado pelo Dr. José Brandão, à altura Conservador do Museu Geológico, e teve por objectivo organizar esta colecção, 
reacondicionar os materiais e avaliar do seu estado de conservação.

A Gruta das Salemas situa-se muito próximo de outra jazida também com faunas plistocénicas, a Pedreira das Salemas. Esta outra jazida, também denominada Diáclase das Salemas, foi descoberta aquando da abertura de uma pedreira, em pleno lapiás. Ali foram identificados alguns algares com indústrias e faunas quaternárias. Destas faunas destacam-se mamíferos como alguns felinos, hienas, ursos, cavalos, veados, lobos e coelhos.

Esta jazida, descoberta por Martins Ferreira, foi totalmente escavada em duas campanhas arqueológicas, por uma equipa dos antigos Serviços Geológicos de Portugal. A primeira foi realizada em Novembro de 1959 e a segunda entre Outubro e Dezembro de 1960, por G. Zbyszewski, J. Camarate França, I. de Albuquerque e Castro e O. da Veiga Ferreira. O estudo dos materiais foi efectuado na década de 60 do século passado e contou com a colaboração de Jean Roche.

Na Gruta do Pego do Diabo, os primeiros trabalhos realizados nesta gruta datam das décadas de 60 e de 70 do século XX. Foram realizadas por desconhecidos e os resultados não foram publicados. Em 1976, o GEPP (Grupo para o Estudo do Paleolítico Português) fez uma intervenção de limpeza da vala de uma sondagem realizada nos referidos trabalhos das décadas de 1960-70. Esta intervenção foi divulgada em 1979. Na década de 80 (1988-89) foram realizadas escavações arqueológicas nesta gruta, dirigidas por João Zilhão.

A Gruta das Fontainhas, situada na Serra de Montejunto onde, existe um conjunto de cavidades e grutas com ocupação humana, na sua maioria da préhistória recente. A maioria dos materiais arqueológicos descobertos nas grutas da Serra de Montejunto encontra-se no Museu Geológico e no Museu Nacional de Arqueologia, em Lisboa. Grande parte destas grutas foi descoberta e estudada por António Maria Garcia, professor primário, falecido em 1908. Outro nome dos primórdios dos estudos da Serra de Montejunto foi o de Leite de Vasconcellos, que chegou a ser, por dois anos, subdelegado de saúde, no Cadaval. José Leite de Vasconcellos relacionou-se com António Maria Garcia, com quem realizou alguns trabalhos naquela zona. Mas foi Nery Delgado quem descobriu e estudou 
especificamente a Gruta das Fontainhas, que foi escavada apressadamente nos anos de 1879 e de 1880 pelo colector Manuel Roque, que se limitou a recolher os materiais e entregá-los, em Lisboa, a Carlos Ribeiro, sem qualquer relato dos mesmos (CARDOSO 1993, p. 80).

No planalto da Cesareda existem algumas grutas com ocupação humana. Destas, a mais importante é a Gruta da Casa da Moura pelas suas dimensões e pela quantidade de materiais ali encontrados (DELGADO, 1867).

Esta foi a primeira jazida do Paleolítico Superior português a ser estudada. Trata-se de um estudo publicado em português e francês, datado de 1867 ("Notícia acerca das grutas da Cesareda"), onde Nery Delgado descreve os achados, em especial os restos osteológicos humanos do Paleolítico Superior, dois anos antes da descoberta de Cro-magnon. Estes materiais recolhidos e estudados por Nery Delgado foram depositados na então Comissão Geológica, nas instalações onde actualmente se encontra o Museu Geológico.

Em 1868 as colecções da Comissão Geológica foram transferidas para a Escola Politécnica (actual Faculdade de Ciências da Universidade de Lisboa - Museu Nacional de História Natural). Com esta transferência, os materiais ficaram inacessíveis a Delgado. Mais tarde, uma parte desta colecção voltou para os Serviços Geológicos, enquanto a outra parte manteve-se na Escola Politécnica, perdendo-se no incêndio que destruiu grande parte do Museu de História Natural, no ano de 1978.

A revisão das faunas das colecções dos Serviços Geológicos feitas por Harlé nos inícios do séc. XX e publicados em 1910/11 apenas incidiu sobre a parte da colecção da Casa da Moura que estava nos Serviços Geológicos. Assim, muita informação acerca desta gruta se perdeu, pois para além do estudo de 1867 feito por Nery Delgado, mais ninguém estudou a parte que se perdeu no incêndio da Politécnica.

Em 1987 foram feitas, na Gruta da Casa da Moura escavações de diagnostico chefiadas por Lawrence Guy Straus, apoiadas pela National Geographic e pela Universidade do Novo México. Os dois princiapais objectivos destas escavações foi determinar se ainda existiam depósitos do Paleolítico Superior, nesta gruta e documentar e tratar a sequência estratigráfico-cultural (SATRAUS et al., 1988).

Durante estes trabalhos foram encontrados depósitos do Paleolítico Superior, 
como também do Holocénico. Dos materiais recolhidos foram retiradas amostras e feitas várias datações no Laboratório da Universidade de Toronto. Uma delas, retirada de uma mandíbula de lobo deu uma datação de cerca de 25000 anos BP (anexo V) (SATRAUS et al., 1988).

Actualmente apenas restam os materiais da Casa da Moura que estão no Museu Geológico, instituição herdeira do espaço e colecções dos Serviços Geológicos. O último estudo sobre as faunas da Casa da Moura foi a revisão dos mamíferos feita por João Luís Cardoso (CARDOSO, 1993).

A Lapa da Rainha foi escavada, num período total de três meses no início de 1968 e no final de 1969, por uma equipa do então Museu Nacional de Arqueologia e Etnologia do Doutor Leite de Vasconcellos, actual Museu Nacional de Arqueologia e teve a colaboração dos Serviços Geológicos de Portugal e da Direcção-Geral de Minas (ALMEIDA et al., 1970).

O espólio recolhido nesta cavidade encontra-se no Museu Geológico e no Centro de Estratigrafia e Paleobiologia da Universidade Nova de Lisboa (REGALA \& GOMES, 1995, p. 20). O material osteológico de aves estuado nesta tese foi apenas o que se encontra no Museu Geológico e ainda está inédito.

A Gruta do Caldeirão está situada na Região Centro, no lugar do Alto do Caldeirão, perto de Tomar. È uma importante jazida pré-histórica, com ocupações humanas desde o Paleolítico Superior até ao século XIX, destacando-se os recolhido e datados do Paleolítico Superior e do Neolítico. Foi intervencionada de forma sistemática entre 1979 e 1988, por João Zilhão (ZILHÃO, 1997) 


\section{4 - Enquadramento teórico}

\subsection{1 - Paleoornitologia}

A paleornitologia (do grego: palaiós = antigo; ornis = ave e logós = tratado; fundamento) é o estudo das aves fósseis. Pode-se definir a paleoornitologia como o estudo da paleobiologia das aves. Nestes estudos aplicam-se muitas das metodologias e conhecimentos da ornitologia (do grego: ornis = ave e logós = tratado; fundamento) que é o ramo da biologia que se dedica ao estudo das aves a partir de sua distribuição na superfície do globo, das condições e peculiaridades do seu meio, da sua ecologia, dos modos de vida, e da sua taxonomia.

A paleoornitologia conta com as contribuições paleontologia, para o caso das aves fósseis, e da arqueozoologia, para o estudo das aves encontradas em sítios arqueológicos e relacionadas com as comunidades humanas. O estudo da paleoornitologia, tem sido levado a cabo por especialistas que investigam as colecções osteológicas com restos de aves provenientes de jazidas paleontológicas ou de sítios arqueológicos. O estudo das aves (actuais e fósseis) contribuiu de forma muito activa para o aprofundamento dos conhecimentos da biologia, da paleontologia e da evolução dos seres vivos. De citar, neste aspecto, a obra de Ernst Mayr sobre a evolução e os mecanismos do processo de formação de espécies; os estudos de Darwin sobre a diversidade dos pombos e dos tentilhões, tão importantes para a sua "Origem das Espécies" e os estudos sobre a catalogação imunológica das espécies dos colombidae e dos híbridos entre elas, bem como da importância do estudo do Archaeopteryx e dos seus antepassados, para o conhecimento da transição dinossauros - aves que resultou numa nova visão acerca quer dos dinossauros, quer das aves, pois os últimos estudos de paleoornitologia têm contribuído para compreender melhor as relações entre as aves e os seus antepassados (os dinossauros), compreender a evolução das aves e os meios que as rodeavam ${ }^{10}$. No caso dos estudos das aves em contexto arqueológico, elas assumem um importante meio para melhor conhecer o mundo em que os nossos antepassados viveram.

Nos estudos de paleoornitologia do Plistocénico é muito importante uma boa colecção de referência de ossos de aves actuais para se poder classificar os restos

10 Não se pode esquecer da importância paleoecológica das aves. 
fósseis encontrados. De qualquer forma, a atribuição a nível da espécie torna-se complicada devido às semelhanças osteológicas serem muito grandes e ao facto do registo fóssil ser, por vezes, muito fragmentado. No caso da atribuiç̧ão taxonómica das aves de períodos muito recuados é ainda mais difícil, porque, ao passo que as aves plistocénicas têm, na sua maioria, representantes vivos.

\subsection{2 - Tafonomia}

Nos estudos de restos faunísticos, quer sejam eles encontrados em contexto paleontológico, quer encontrados em contexto arqueológico, levanta-se um conjunto de problemas e perguntas, sendo que o mais importante é compreender o que se passou com estes restos, desde que o organismo a que pertenceram morreu até ao momento em que são estudados.

Assim surgiu uma nova ciência: a "tafonomia" (do grego tafos = enterramento e nomos $=$ leis). Este termo foi criado nos inícios dos anos 40 do século passado, por I. A. Efremov (O'CONNER, 2004) que a definiu como o estudo dos princípios que regem a transição dos restos orgânicos da biosfera para a litosfera, desde o momento da morte de um organismo até ao momento da sua descoberta. Desta forma, a tafonomia é o ramo da paleontologia ${ }^{11}$ que estuda o enterramento e a fossilização dos restos dos organismos que viveram num passado geológico (MENDES, 1988, SIMÕES \& HOLZ, 2004).

A fossilização de um resto de um organismo resulta de um conjunto de processos biológicos, químicos e físicos que actuam no ambiente deposicional e que condicionam, mais tarde, a própria natureza do fóssil (MENDES, 1988). Têm mais possibilidades de deixar restos fossilizados os organismos que possuem partes mineralizadas e/ou materiais orgânicos resistentes, tais como a quitina e a celulose. Só em condições muito excepcionais é que se preservam partes moles dos organismos.

11 A palavra paleontologia foi utilizada na literatura geológica pela primeira vez no ano de 1834 e é constituída por três conceitos gregos: palaiós, (antigo); ôntos, (vida) e lógos, (tratado, fundamento) (CASSAB, 2004). A paleontologia é assim, uma ciência histórica, que estuda os seres vivos do passado. A Paleontologia é uma ciência multidisciplinar que conta com a colaboração de vários domínios do conhecimento, nas áreas da Matemática, da Estatística, da Física, de Climatologia, da Química, da Ecologia, entre outros. A Paleontologia é uma ciência histórica. Assim a considera Albert Gaudry, quando escreve que "graças aos descobrimentos da Paleontologia, a história natural é História no sentido literal da palavra", dada a perspectiva temporal que the veio conferir. 
Após a morte de um organismo, normalmente as partes moles entram em decomposição por acção de bactérias, enquanto as partes duras ficam sujeitas à acção do ambiente, o que resulta na destruição total dessas partes duras. Este processo é um ciclo natural pelo qual passam todos os seres vivos após a sua morte. Deste modo, a fossilização não é mais do que a quebra de um ciclo, constituindo-se como um fenómeno excepcional que permite a preservação de apenas uma parte muito pequena de todos os organismos que viveram (e que irão viver) durante a longa história da Terra (MENDES, 1988). Por esta razão, é muito provável que se conheça apenas uma ínfima parte de todas as espécies de seres vivos, ao longo dos tempos geológicos.

Como foi referido, após a morte dos organismos, os seus restos sofrem a acção de vários factores, que favorecem a respectiva fossilização: o enterramento imediato do organismo (ou de alguns dos seus restos); a ausência de decomposição bacteriana; a composição química estrutural do organismo; o seu modo de vida; as condições químicas do meio onde o organismo ou os seus restos são depositados. A soma de alguns destes factores irá determinar o tipo de fossilização dos vestígios dos seres vivos que se encontram nas diferentes camadas geológicas disseminadas pelo mundo inteiro. No entanto não são apenas os factores que actuam após a morte de um organismo que permitem ou não a fossilização. Após os fósseis estarem formados, outros factores ocorrem que os podem destruir. São disto exemplo a erosão das águas, o vulcanismo e os eventos tectónicos ou metamórficos.

O principal objectivo da tafonomia é perceber quais os processos que estão na origem dos fósseis. Pode-se então dizer que a tafonomia estuda a história de um fóssil desde que ele pertenceu a um organismo já morto até ao momento em que este é descoberto, já como um fóssil. Os estudos tafonómicos são importantes não só para a paleontologia, mas também para a arqueologia, já que permitem perceber o processo pelo qual passou o resto de um animal caçado pelo homem, e mesmo a forma como foi caçado ou preparado para a alimentação humana.

A história da formação dos fósseis pode ser dividida em duas fases, cuja duração de cada uma delas é muito desigual: a primeira, relativamente curta, vai desde a morte de um organismo até ao seu enterramento; a segunda, de duração muito longa, tem o seu início quando os restos do organismo estão totalmente 
enterrados e termina no momento em que estes restos, já fossilizados, são recolhidos pelos investigadores (MENDES, 1988). Após a morte de um ser vivo, os seus restos ficam sujeitos a uma grande variedade de mecanismos que, na sua grande maioria impedem a preservação. Assim, os vestígios que se preservam representam apenas uma pequena parte de uma comunidade animal fóssil (SIMÕES \& HOLZ, 2004).

A tafonomia tem um importante papel no estudo da paleontologia, pois, a tafonomia ajuda a compreender a relação entre um conjunto de organismos presentes no registo fóssil com a sua comunidade original, permitindo, em certa medida, a sua reconstituição (MENDES, 1988, p. 23). O reconhecimento dos processos tafonómicos que estiveram na origem de uma associação fóssil permite obter dados sobre vários aspectos relacionados com os ambientes deposicionais e pósdeposicionais. Assim, os mecanismos que podem dar origem a um fóssil têm por base um processo lento de acumulação de sedimentos que dão origem a um somatório de preservações parciais de cada uma das comunidades que se estabeleceram nas vizinhanças desse local. As condições excepcionais de preservação de uma comunidade, como, por exemplo, uma rápida deposição de sedimentos dão origem a associações fossilíferas bem representativas dessa comunidade (SIMÕES \& HOLZ, 2004).

A tafonomia divide-se em três áreas principais: a mortalidade ou necrólise, a biostratonomia ou bioestratinomia (ligadas à primeira fase da formação dos fósseis) e a fossildiagénese ou diagénese dos fóssseis ou fossilização (ligada à segunda fase da formação dos fósseis).

A mortalidade ou necrólise estuda as causas da morte de um organismo. Estas podem ser inerentes ao próprio indivíduo (envelhecimento, patologias, entre outras) e externas ao indivíduo. As externas ao indivíduo podem ser bióticas (predação, competição) ou abióticas (alterações químicas e / ou físicas do meio ambiente).

A biostratonomia estuda o conjunto de acções que decorrem desde a morte de um organismo até ao momento em que fica salvaguardado das acções do meio ambiente pelo acarreio de sedimentos. Estuda também a evolução sedimentar do fóssil, pois este constitui-se como um elemento que pode ser erodido, transportado e depositado.

Muitas vezes a causa de morte influencia o processo de fossilização; por 
exemplo, uma acção de predação pode dar origem ao desmembramento e dispersão dos elementos esqueléticos de um vertebrado, uma derrocada e enterramento súbito de uma comunidade dá origem a grande número de indivíduos, sem desmembramento. Os estudos de biostratonomia apresentam algumas condicionantes. Estas podem ser de várias ordens e relacionadas com vários factores. Um desses factores é a natureza da matéria orgânica dos organismos: a composição química (as estruturas orgânicas duras têm diferentes composições, que podem ser de natureza orgânica, tais como as esponjas, a quitina, etc. ou de natureza mineralógica, tais como os carbonatos, os fosfatos de cálcio, etc.). Estes tipos de matérias orgânicas têm comportamentos diferentes durante o processo de enterramento, sendo que alguns deles poderão, consoante as acções a que sujeitos e resistir mais ou menos, até serem totalmente enterrados. Desta forma, existem informações que podem ser perdidas. Outra condicionante está relacionada com a dissociação de elementos esqueléticos, no caso dos organismos que têm esqueletos constituídos por várias peças articuladas: na maioria dos casos, apenas se preserva parte desses elementos. Esta dissociação poderá estar relacionada com a predação ou com o transporte post-mortem, que por sua vez pode ser condicionado pelos ambientes e modos de vida dos diferentes organismos.

Como consequência do transporte post-mortem as associações fósseis são classificadas em: Autóctones, que são associações fossilíferas localizadas in situ, ou seja, no próprio local onde os seres vivos que lhes deram origem morreram; Alóctones, associações de fósseis resultantes de um conjuntos de restos que sofreram um transporte mais ou menos intenso); Sub-autóctones associações fossilíferas que não estão in situ, mas sim nas imediações do biótopo, ou seja, sofreram um transporte pouco significativo.

Por fim, a fossildiagénese (MÜLLER, 1963) estuda o conjunto de acções que decorrem desde o enterramento de um organismo ou dos seus restos até ao momento em que são descobertos como fósseis. Pela sua natureza, as partes duras dos organismos são mais fáceis de se fossilizarem e preservarem do que as partes moles, que requerem condições de fossildiagénese muito específicas para se preservarem, como se verá mais à frente. Durante acumulação de sedimentos são desencadeadas várias acções que levam à litificação desses sedimentos. Como foi 
referido, o resto orgânico a partir do momento que se associa aos sedimentos passa a ser parte desse sedimento e assim sofre as mesmas acções. São elas: a compactação, em que o resto orgânico sofre a carga litostática da coluna sedimentar; a cimentação, em que os vestígios orgânicos sofrem a aglutinação de elementos detríticos por precipitação de compostos químicos; a metassomatose, nesta acção existe uma troca iónica entre o resto orgânico e o sedimento e a recristalização, na qual o resto orgânico sofre precipitação de cristais. São estas acções que, ao actuar sobre um resto orgânico, permitem que um resto orgânico depois de enterrado e associado aos sedimentos se fossilize (SIMÕES \& HOLZ, 2004).

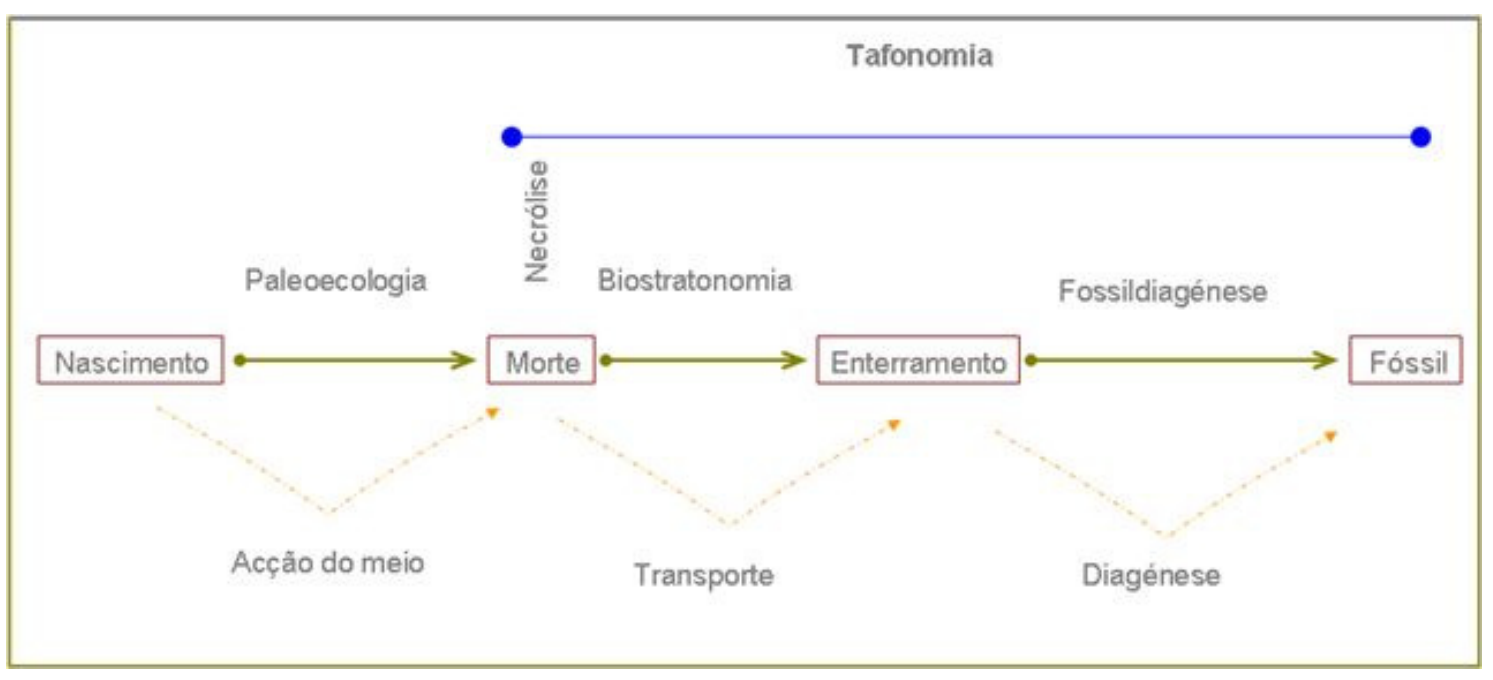

Fig. 6 - Esquema com o processo de estudo da tafonomia (construção do autor com base em Simões \& Holz, 2004, fig. 3.1, p. 20).

Durante os diferentes processos de tafonomia, os restos orgânicos passam por diversos estádios, em que cada um deles tem uma denominação específica. Assim, a uma comunidade de organismos que viveram num dado biótopo, num dado momento da história da Terra, dá-se o nome de paleobiocenose; por seu lado, à acumulação destes organismos depois de mortos de nomina-se de necrocenose; Chama-se tanatocenose à associação post-mortem de restos esqueléticos; enquanto a tafocenose é a designação dada a uma associação de restos orgânicos após transporte, para a área de sedimentação; Por fim, temos a orictocenose que designa uma associação de elementos fósseis num dado afloramento geológico (SIMÕES \& HOLZ, 2004).

Os processos de fossilização podem ser de várias ordens, consoante as 
condições químicas presentes no local de depósito dos sedimentos onde se encontram os restos orgânicos e que irão actuar sobre os restos dos organismos ali depositados (SIMÕES \& HOLZ, 2004).

Os fósseis podem ser reunidos em dois grandes grupos: os restos e os vestígios. Considera-se resto, quando se preserva alguma parte do organismo e vestígio quando apenas existem evidências indirectas do organismo ou das suas actividades (MENDES, 1988), neste ultimo caso estão incluídos os icnofósseis ${ }^{12}$.

Foi nos anos de 1980 que a tafonomia foi aplicada à arqueologia (SIMÕES \& HOLZ, 2004), especificamente aos estudos de arqueozoologia ${ }^{13}$. No entanto, já desde a década de 1960, que se tentava perceber os processos que alteram e destroem as associações ósseas, em contexto arqueológico (O'CONNOR, 2004). Em termos gerais, os princípios que se aplicam na tafonomia paleontológica também se aplicam à tafonomia arqueozoológica. Assim, enquanto os estudos de tafonomia dos vestígios de organismos encontrados em contexto paleontológico analisa os complexos fenómenos naturais pelos quais passaram os vestígios que chegaram até nós, a tafonomia aplicada a restos encontrados em contexto arqueológico estuda, para além dos fenómenos naturais atrás referidos, os fenómenos antrópicos relacionados com estes vestígios faunísticos.

Os fenómenos tafonómicos que se aplicam aos restos orgânicos encontrados em contexto arqueológico podem ser, para além dos processos naturais, que se aplicam á tafonomia paleontológica, outros de origem antrópica, pois os restos animais passam de uma parte de um ser vivo, para parte da dieta humana restos (O'CONNER, 2004). Estes processos são o transporte hidráulico, a combustão dos ossos, traços impacto de projécteis e outros fenómenos antrópicos relacionados com técnicas de caça, a localização do local de abate e de desmancho dos animais, o processo de transporte e a escolha das unidades anatómicas a transportar para os acampamentos e, finalmente, o consumo e o abandono dos restos (O'CONNER, 2004).

Para compreender as alterações de origem antrópica que as acumulações

12 Um "icnofóssil" é um vestígio fossilizado de actividade biológica, como por exemplo pegadas ou ovos.

13 Definimos aqui arqueozoologia, como a disciplina científica que estuda os restos de fauna recolhidos em sítios arqueológicos 
ósseas do passado sofrem, é necessário compreender, ou observar, os diferentes comportamentos e a interacção entre os humanos e os outros vertebrados e a forma como os depósitos ósseos se processam na actualidade (O'CONNER, 2004).

Como foi referido no ponto anterior, a tafonomia tem um importante papel no estudo da paleontologia, no entanto tem também um papel fundamental nos estudos da reconstituição arqueozoológica e pré-histórica (BICHO, 2006), pois permite reconhecer melhor a relação das comunidades pré-históricas (e não só) com as faunas que as rodeavam.

No caso da tafonomia aplicada unicamente à paleontologia, e como já foi referido, os mecanismos que podem dar origem a um fóssil têm por base um processo lento de acumulação de sedimentos. No caso dos restos faunísticos encontrados em contexto arqueológico, a estes fenómenos de acumulação de sedimentos, há também a considerar a relação das actividades humanas que influenciaram a deposição dos restos ósseos das faunas consumidas pelas comunidades humanas.

A tafonomia torna-se assim importante para os estudos de arqueozoologia, pois os estudos tafonómicos permitem reconstituir as faunas associadas às comunidades humanas ao longo da história, obter informações sobre a maneira como foram caçados e se depositaram os animais numa estação arqueológica, permite distinguir quais os animais que foram caçados e quais os animais que se depositaram naturalmente na área de uma estação arqueológica. No caso do estudo dos hominídeos primitivos é possível saber, através da tafonomia, como esses hominídeos morreram e como fossilizaram, verificar as causas de morte de comunidades humanas pré-históricas e quais as suas relações com causas ambientais, compreender as associações faunísticas associadas a comunidades humanas em tipos diferentes de estações pré-históricas (MORENO-GARCÍA, et al., 2003).

A tafonomia em arqueologia permite obter dados que ajudam na reconstituição de uma comunidade humana do passado e o seu meio envolvente. Para isso é necessária uma colaboração interdisciplinar onde se reúnam paleontólogos, antropólogos, biólogos e arqueólogos. Para os estudos tafonómicos aplicados à arqueologia é necessário não apenas o estudo de conjuntos faunísticos, como também os conjuntos líticos, cerâmicos e sedimentares associados aos restos de 
fauna encontrados numa estação arqueológica. A tafonomia reúne um conjunto muito alargado de métodos que são determinantes para responder a determinadas questões arqueológicas (BICHO, 2006).

No caso específico do estudo apresentado nesta tese, a análise tafonómica teve como objectivo a resposta a algumas perguntas, tais como:

1 - Como é que as aves estão depositadas?

2 - Porque é que estão nesse sítio?

3 - Quais as espécies mais representadas e porquê?

4 - As fracturas dos ossos são de origem biótica ou abiótica? Se forem bióticas são de origem animal ou de origem antrópica?

5 - As acumulações são bióticas ou abióticas?

Assim, foram analisados os seguintes parâmetros: existência ou não de marcas de cortes ou de predação; existência de marcas de fogo; verificação da causa das fracturas nos ossos, após a identificação do táxones e dos respectivos paleobiótopos; verificar a quantidade de espécies que vivem em grutas, pelo tamanho das espécies; verificar, em caso de consumo humano, quais poderiam apresentar marcas de corte; e, finalmente, verificar o modo como viveram das espécies identificadas.

\subsection{3 - Sistemática}

A enorme diversidade biológica ou biodiversidade ${ }^{14}$ existente levou à necessidade de sistematizar os organismos, de forma a se melhor se perceber a biosfera. Pois só "arrumando" as diferentes espécies de organismos vivos e classificando-as, se pode entender a biodiversidade que existe na Terra. Cerca de 1,4 milhões de espécies foram identificadas até agora, das quais 750000 são insectos, 250000 são plantas e 41000 são vertebrados. Nas regiões tropicais existe grosso modo o dobro das espécies presentes nas regiões temperadas. Estima-se que, por dia,

14 O Termo " diversidade biológica" foi criado em 1980 por Thomas Lovejoy para designar o número de espécies de organismos existentes na biosfera Mais tarde, em 1986, Edward Wilson propôs o termo "biodiversidade", num relatório apresentado ao primeiro Fórum Americano sobre a diversidade biológica, organizado pelo Conselho Nacional de Pesquisas dos EUA (National Research Council, NRC). A palavra "Biodiversidade" foi sugerida a Wilson pelo pessoal do NRC a fim de substituir o termo "diversidade biológica", expressão considerada menos eficaz em termos de comunicação. 
se extingue pelo menos uma espécie, devido à destruição do seu habitat.

Em 1859, a publicação da obra de Darwin, "A Origem das Espécies" trouxe uma nova consciencialização e visão do pensamento científico acerca da enorme variedade de formas de vida e houve a necessidade de aplicar a sistemática também às formas de vida fósseis, o que originou uma nova necessidade: a classificação das espécies fósseis. Assim nasceu a "sistemática paleontológica", que não é mais que a aplicação das regras da classificação dos seres vivos actuais aos fósseis, tendo em consideração os condicionalismos do registo fóssil (MENDES, 1988).

Segundo R. E. Blackwelder e Alan Boyden, em artigo publicado em 1952 e intitulado The Nature of Systematics, a sistemática ocupa-se dos diferentes animais, da sua distinção, classificação e da sua evolução. No entanto pode-se definir a sistemática como "o estudo científico das formas dos organismos, da sua diversidade e de toda e qualquer relação entre eles" (SIMPSON, 1989, p.10). Aplicando esta definição aos paleorganismos, podemos acrescentar que o estudo da sistemática se aplica quer no presente, quer no passado geológico. A sistemática vem do grego systema e pode ser então definida como o estudo científico dos princípios que regem a diversidade e as relações entre organismos, tendo em vista elaborar um sistema coerente e integrado da sua classificação, quer do arranjo entre os diferentes grupos, quer na denominação dos mesmos. A sistemática assenta no pressuposto de que o melhor processo de ordenar um conjunto diverso de objectos é através da sua sistematização, isto é, "arrumando-os" segundo uma certa ordem ou estrutura. Este processo é dito de "Classificação" - agrupar "coisas" de acordo com as suas similaridades.

O primeiro a estabelecer um sistema de classificação para o mundo vivo foi o naturalista sueco Lineu (1707 - 1778) Do seu esforço surgiram duas importantes inovações que têm guiado os trabalhos de sistemática desde então. O sistema de classificação de Lineu foi publicado em 1758, o Systema Naturae e incluía 5.897 espécies de animais e plantas. Actualmente com os avanços no conhecimento os organismos e, com as descobertas na área da paleontologia, esses número aumentou de grande forma. (falar nas categorias de Lineu e das novas). O trabalho dos naturalistas, paleontólogos amadores vieram, em grande medida, contribuir para o aumento explosivo do número de espécies conhecidas. Em 1850, por exemplo, já se 
conheciam cerca de 4.500 espécies de aves, metade do que se conhece actualmente. Está estimado em cerca de 1,7 milhões o total de todas as espécies conhecidas. Dizemos "estimado", porque não existe um catálogo geral (SIMPSON, 1989).

A estrutura sistemática é ilustrada através das chamadas Árvores filogenéticas, que são formas de representação esquemática, evidenciando as relações evolutivas entre os diversos grupos de organismos. Nelas os grupos mais primitivos e/ou mais abrangentes são representados nos troncos inferiores enquanto os mais evolucionados e/ou mais restritos aparecem representados nos ramos superiores, dos quais se bifurcam, progressivamente, ao longo do tempo, sem contudo sem se fundirem ente si, acima do ponto de onde bifurcam. O termo primitivo deverá, contudo ser tido não num sentido histórico (já que muitos deles subsistem e desenvolvem-se hoje em dia) mas sim no sentido em que eles retêm muitas das características dos grupos ancestrais (RIOS-NETTO, 2004).

A hierarquia usada em sistemática foi essencialmente desenvolvida em diversos trabalhos de naturalistas durante os séculos XVII e XVIII. Essa hierarquia tem o nome de "hierarquia lineana", porque ficou concluída, de forma quase definitiva, em 1758, com a décima edição do Systema Naturae de Lineu. Lineu avançou com uma sequência de cinco níveis: o reino, a classe, a ordem, o género e a Espécie (LINEU, 1758)

A partir de outras fontes esta hierarquia foi ampliada e foram acrescentados mais dois níveis: o filo (entre o reino e a classe) e a família (entre a ordem e o género). Novas investigações e descobertas tornaram a sequência avançada por Lineu incompleta. Assim foi aprofundada com novos estudos e técnicas de investigação, especialmente na anatomia microscópica. Para além dos sistemas de classificação outros factores influenciaram o desenvolvimento desta área: a exploração do "novo mundo", que muito contribuíram os descobrimentos portugueses, e o consequente contacto com novas espécies, com destaque para o contacto com as aves tropicais, até então desconhecidas na Europa, e a invenção do microscópio, no século XVII, que veio mostrar um outro novo mundo, o mundo dos microrganismos. Este desenvolvimento da sistemática, originado pelos factores atrás referidos, fez com que, desde 1758, para além do filo e da família muitos mais níveis fossem 
acrescentados à hierarquia da sistemática biológica (SIMPSON, 1989).

O número cada vez maior da descoberta de novos organismos levou a que o número de formas de vida para classificar seja, na actualidade, tão elevado que os sete níveis, referidos no parágrafo anterior, torna-se, na grande maioria, dos casos insuficiente. Este problema tem sido solucionado pela adição dos prefixos: "supra", quando colocado acima dos níveis, e "sub" e "infra", quando colocados abaixo dos mesmos, criando desta forma novos níveis na hierarquia. Têm sido também propostas novas adições aos sete níveis básicos da hierarquia lineana, mas tais propostas ainda não estão regulamentadas e o seu uso não é geral, no entanto têm sido usados mais frequentemente dois níveis adicionais aos outros sete: a "coorte" e a "tribo". Desta forma, conseguir-se-ia, utilizando todos os níveis possíveis de grau supra, sub e infra entre o reino e a subespécie, uma hierarquia de trinta e quatro níveis, o que seria, provavelmente mais do que o realmente é necessário na prática (SIMPSON, 1989). Em 1945, George G. Simpson, na sua obra "The Principles of Classification and a Classification of Mammals" estabeleceu uma hierarquia completa para os mamíferos, baseada em vinte e um níveis.

O uso dos sete níveis básicos da hierarquia de Lineu é obrigatório por convenção, enquanto o uso de qualquer um dos outros níveis é facultativo, dependendo das necessidades que se encontram no grupo que se está a classificar. No caso específico das aves, a classificação adoptada depende do grupo que se está a classificar, mas de uma forma geral rondará, tal como os mamíferos, a uma vintena de níveis. No que respeita unicamente à presente tese, e tendo em conta as condicionantes do registo fóssil a hierarquia utilizada será mais pequena, pensamos que 12 níveis, é suficiente para obter uma classificação aceitável para a amostra estudada, sendo que a espécie é o nível mais restrito utilizado.

No século XIX com o surgimento da paleontologia foi desenvolvida uma sistemática paleontológica, que tem como objectivo definir sistemas de classificação adaptados às contingências do seu objecto de estudo, os fósseis, que representam espécies de comunidades e grupos animais passados, que podem ou não estar extintos. Neste sentido, a sistemática paleontológica tem em conta, sempre que existam dados nesse sentido, as relações naturais, biológicas e evolutivas, entre os organismos que os fósseis representam. Na prática, quando em paleontologia se 
tenta sistematizar um grupo, trabalha-se com um conjunto de exemplares, que deverá ser uma amostra representativa de uma dada população. Para ser isso, deverá conter todas as características morfológicas que definam uma dada espécie. Nestes casos, existe o claro pressuposto de que o fenótipo preservado, ou seja, o conjunto de aspectos morfológicos que possam fossilizar reflecte o genótipo do organismo correspondente. Desta forma, o objecto de estudo é o genótipo embora este nunca possa ser observado directamente. O registo fóssil é fragmentado e nós apenas temos informação de uma parte dos organismos pretéritos. Desta forma a sistemática paleontológica (e a sistemática dos seres vivos actuais) não faz uma abordagem ideal, pois não temos acesso aos fósseis de todos os organismos e poder, desta forma, organiza-los em linhas evolutivas, desde os mais remotos antepassados até ás formas actuais (MENDES, 1988).

\section{Taxonomia}

A taxonomia é um dos conceitos de classificação, "é o estudo teórico da classificação, incluindo as respectivas bases, princípios e normas" (SIMPSON, 1989). Segundo John R. Gregg, no seu livro The Language of Taxonomy, publicado em 1954, os organismos são a matéria-prima da classificação e as classificações a matéria-prima da taxonomia (SIMPSON, 1989).

A taxonomia, do grego taxis, que significa arranjo, e nomos, que significa lei, pode ser entendida como o estudo teórico das bases, métodos e regras de classificação dos organismos. Define o método em que se baseia toda a sistemática e permite a identificação de um conjunto hierarquizado de unidades taxonómicas (ou táxones ${ }^{15}$ ). Utiliza-se o termo táxon para definir um grupo de organismos de qualquer categoria. O plural deste termo é "táxones" (em português de Portugal) e "táxons" (em português do Brasil) ${ }^{16}$. Esta forma aportuguesada da forma grega (taxa) é preferível para evitar possíveis confusões com a palavra taxa, substantivo do verbo taxar.

Qualquer sistema de classificação assenta numa estrutura hierarquizada,

15 Um táxone é um grupo de organismos reconhecido como uma unidade independente do seu nível hierárquico.

16 Segundo o Dicionário da Língua Portuguesa Contemporânea, elaborado pela Academia das Ciências de Lisboa e publicado pela Academia das Ciências de Lisboa e pela Editorial Verbo, em 2001. 
constituindo uma sequência de conjuntos subordinantes, subdivididos de forma progressiva em subconjuntos subordinados totalmente inclusos nos que lhes ficam a montante e incluindo, para jusante, subunidades de grau cada vez menor. Os sistemas hierárquicos de classificação começaram a ser desenvolvidos nos séculos XVII e XVIII, atingindo uma forma coerente e quase definitiva na décima edição da Systema naturae, a obra de C. Lineu, que foi publicada em 1758. Por este motivo é a classificação biológica é conhecida por "hierarquia lineana" e constitui a base da moderna Taxonomia (SIMPSON, 1989).

Lineu criou a Nomenclatura Binária, que tem um âmbito internacional, é sistemática, racional e neutra. Quando a Teoria da Evolução passou a ser aceite e com a utilização de novas fontes de informação como os fósseis, ampliou-se muito o âmbito da classificação que se transformou num sistema que buscava mostrar a origem e as relações entre os vários seres vivos, baseando-se em critérios anatómicos. Os taxonomistas baseiam-se em elementos da anatomia interna como o esqueleto, a musculatura, por exemplo, por serem elementos que indicam com mais exactidão a ancestralidade comum entre os vários grupos taxonómicos (MENDES, 1988).

Desde o século XVIII, que o aparecimento da paleontologia e o desenvolvimento dos estudos biológicos, levou a que aumentasse de grande forma o número e diversidade dos organismos, actuais e pretéritos, abordados nos estudos taxonómicos. Este facto levou ao aumento da complexidade desta sequência. Assim, a par de uma gradual subida de importância de muitos taxa foi necessária a criação de novas unidades (Grupo - entre o Reino e o Filo; Coorte - entre a Classe e a Ordem e Tribo - entre a família e o Género). Para além da criação de novos grupos houve igualmente a necessidade da subdivisão destes níveis pela adição dos prefixos super, sub, infra e supra, para unidades acima ou sucessivamente abaixo das já existentes. Deste modo a sequência original pode ser ampliada até um máximo de 34 níveis que, no entanto, raramente são utilizados na íntegra. Existem, em paleontologia dois principais tipos de taxonomia: a taxonomia numérica e a taxonomia cladística (RIOSNETTO, 2004).

Em 1973, P. SNEATH e R. SOKAL defendia que a taxonomia numérica é um método que se baseia na aplicação de métodos quantitativos com vista à definição e agrupamento dos vários táxones. Na Taxonomia numérica, os caracteres utilizáveis 
dizem respeito a características fenotípicas, ou seja, incluem parâmetros fisiológicos, bioquímicos, comportamentais e morfológicos. Desta forma, a taxonomia numérica não inclui os factores genéticos, biogeográficos, ecológicos e a distribuição estratigráfica. Neste sentido podemos definir a taxonomia numérica como uma classificação fenética. Assim, uma das características desta classificação taxonómica é de que os parâmetros utilizados sofrem automaticamente um tratamento matemático, em que, os caracteres codificados, têm todos um igual peso na classificação (RIOS-NETTO, 2004).

O maior dos métodos utilizados em Taxonomia numérica pode operar a qualquer dos níveis taxonómicos, pode ser uma população, uma espécie ou qualquer outra categoria taxonómica supra específica (género, família, etc.) (SIMPSON, 1989).

Foi na década de 1950, que o entomólogo alemão Henning revolucionou a sistemática, criando e desenvolvendo a taxonomia cladística, também chamada "sitemática filogenética". Este tipo de taxonomia utiliza as semelhanças morfológicas, em detrimento das evidências biostratigráficas e paleogeográficas. A sua designação deriva do termo cládio (do grego clado, que significa ramo). Este método utiliza agrupamentos filogenéticos de táxones, que partilham a mesma origem evolutiva (RIOS-NETTo, 2004). Antes de mais, a cladística é, essencialmente, um modo de estudo da evolução biológica, que defende que uma linha evolutiva se divide em duas ou mais, podendo estas se tornarem independentes. A partir de uma espécie podem-se obter duas espécies distintas devido a um isolamento geográfico, por exemplo. Em termos gerais, pode-se definir a cladística como um método de classificação dos organismos que procura encontrar a expressão das relações evolutivas de parentesco, através da semelhança morfológica global para classificar os seres vivos (GOLD, 1980; MENDES, 1988; RIOS-NETTO, 2004).

Contrariamente ao que acontecia em Taxonomia Numérica, os caracteres utilizados na taxonomia Cladística não são todos igualmente ponderados. A cladística também não se baseia num grande número de semelhanças entre os grupos, mas apenas nalgumas semelhanças. Os caracteres são interpretados em temos do seu grau de "primitividade" ou de "anterioridade" do seu aparecimento, durante a evolução de um determinado grupo. Assim, os caracteres são divididos em derivados (apomórficos) e em primitivos (plesiomórficos) para um dado nível hierárquico. $\mathrm{A}$ 
cladística não procura "elos perdidos" ou antepassados directos, mas procura encontrar caracteres evolutivos partilhados entre diferentes grupos, para assim os organizar (GOLD, 1980).

A ideia em que a cladística se baseia é muito simples: quando os caracteres apomórficos resultam, eles são transmitidos aos descendentes. Desta forma, estes caracteres derivados dão mais informações para reconstruções das relações evolutivas entre os diferentes grupos que os restantes caracteres presentes em grupos grandes. Ou seja, o relacionamento estabelecido entre os diferentes táxones não é feito em função das suas características próximas, mas em função do seu maior ou menor afastamento em relação a um ancestral comum. Assim, quanto maior for o número de caracteres apomórficos que um grupo possua tanto mais distante, em termos evolutivos, se encontra dos seus ancestrais. Quanto maior for o número de derivados, encontrados em dois grupos, mais relacionados entre si estão esses grupos. A filogenia consiste numa hierarquia de cládios expressa em cladogramas, sendo o objectivo principal da taxonomia cladística a obtenção de um sistema de classificação que reflicta a hierarquia filogenética natural. Neste caso os caracteres utilizados não são todos igualmente ponderados. È dada prioridade aos caracteres com características "primitivas" (GOLD, 1980; RIOS-NETTO, 2004).

O método tradicional de agrupamento dos grupos animais assentava nas semelhanças e diferenças entre animais e podia excluir uma espécie de um grupo. Essa espécie poderia ter uma característica não encontrada noutros membros desse grupo. Em contraste a esta situação, a cladística agrupa organismos segundo determinados traços comuns e que possam fornecer informações particulares (MENDES, 1988).

Os resultados das análises cladísticas, que geralmente examinam várias características, são representados num cladograma: uma espécie de um diagrama em árvore seguindo a ordem em que cada nova característica e as novas criaturas evoluem. Cada ponto de ramificação reflecte a emergência de um antecessor que fundou um grupo com características derivadas, que não estão presentes em grupos que evoluíram mais cedo. Este antecessor e os seus descendentes constituem a "clade" ou o grupo próximo relacionado. Actualmente a informática é muito útil à cladística, porque esta serve-se da primeira para poder comparar simultaneamente 
numerosas espécies e numerosos caracteres evoluídos (RIOS-NETTO, 2004).
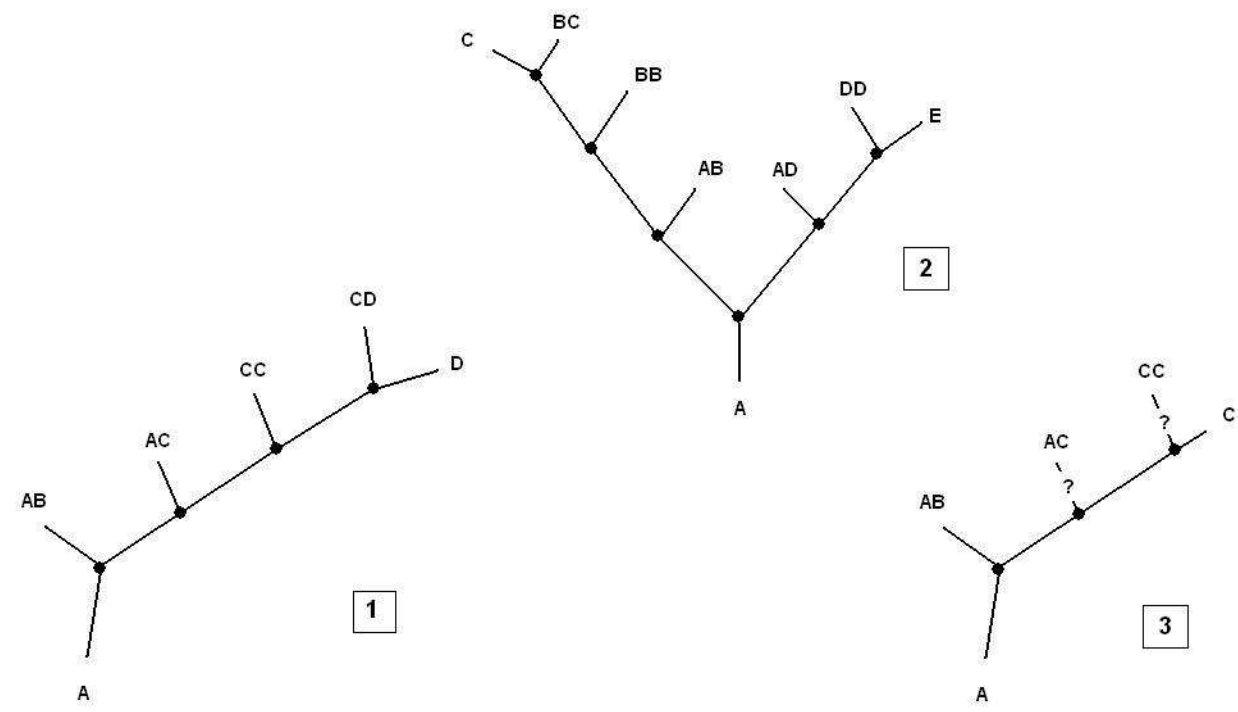

Fig. 7 - Esquemas da taxonomia cladística (construção do autor, com base em RIOS-NETTO, 2004).

A cladística baseou-se no pressuposto darwinista, segundo o qual a evolução se processa quando uma nova variedade de características aparece em alguns organismos de uma determinada espécie, que passam por via genética para os seus descendentes. Este pressuposto indica que dois grupos de animais que partilham algumas novas ou derivadas características estão mais próximos, do que dois grupos que partilhem apenas as características originais. Desta forma estudando e identificando características novas e derivadas, os especialistas em cladística podem determinar as relações entre vários organismos. Assim, os caracteres derivados, ou inovações evolucionárias, constituem-se como "informação filogenética" que ajudam a reconstituir as as relações entre grupos biológicos, ao contrário dos caracteres primitivou ou semelhanças, que não representam inovações evolutivas (GOLD, 1980; MENDES, 1988; RIOS-NETTO, 2004). Por exemplo: o polegar oponível constitui-se como um caracter derivado, que permite agrupar os primatas à parte dos outros mamíferos, ou no caso das aves e dos dinossauros avianos, as penas, que permitem agrupar estes grupos à parte dos outros dinossauros. Por outro lado, no caso dos primatas, as mãos com cinco dedos é um carácter primitivo, porque não se pode agrupar todos os animais que têm cinco dedos, excluindo todos os que não têm esta característica, porque, por exemplo, todos os mamíferos que possuem 5 dedos nas 
mãos não mais próximos filogeneticamente dos que têm dois ou três. O mesmo se passando com o facto das aves terem os membros posteriores revestidos de escamas, uma carácter claramente primitivo nas aves.

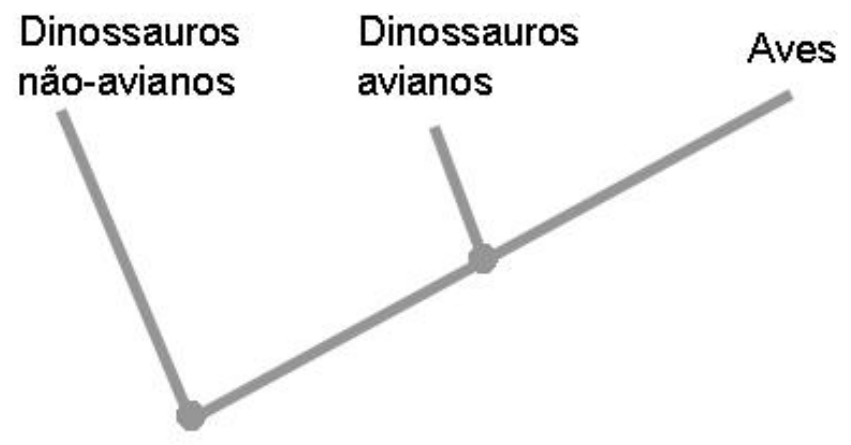

Fig. 8 - Relação (simplificada) entre dinossauros e aves, segundo os estudos de cladística.

Resumindo, pode-se dizer que a cladística propõe estudar e classificar os seres vivos unicamente pelos laços de parentesco entre organismos que se manifestam a partir dos caracteres evoluídos. A taxonomia cladística foi muito importante para compreender a origem e evolução das aves e o seu relacionamento com os pequenos dinossauros carnívoros do Jurássico. Foi graças aos estudos de cladística que se pode compreender de forma clara a relação entre os pequenos terópodes e as primeiras aves. 


\section{2 - Enquadramento Geográfico e Cronológico}

As jazidas estudadas ( 1 a 8, do mapa) localizam-se no litoral do centro do país, na antiga província da Estremadura e em termos geológicos situam-se na chamada “Bacia Lusitânica”, em zonas calcárias do Jurássico e do Cretácico (ver capítulo sobre o enquadramento da geologia de Portugal). Todas as jazidas estudadas situam-se em grutas. As outras jazidas já publicadas, ou em estudo por outros colegas, situam-se também, na sua maioria, na Orla Ocidental e em contexto de gruta, com excepção da Foz do Enxarrique que se situa em terraço plistocénico do Tejo, sobre o Maciço Antigo e a Gruta do Escoural.

Do ponto de vista geográfico, a totalidade das jazidas agora estudadas e a quase totalidade das jazidas com avifana plistocénica em Portugal, estão numa área limitada por três rios: a este pelo rio Zêzere, a sul, pelo Tejo e a norte, pelo Mondego, nos distritos de Leiria, Santarém e Lisboa. As outras fora desta área são a Foz do Enxarrique localizada no distrito de Castelo Branco, a Gruta da Figueira-Brava, no Distrito de Setúbal, a Gruta do Escoural, no Distrito de Évora.

A localização geográfica das jazidas estudadas neste trabalho é a seguinte: a Gruta Nova da Columbeira, está situada no concelho do Bombarral; a Gruta da Furninha, no Concelho de Peniche; a Gruta da Casa da Moura, no concelho de Óbidos; a Gruta das Salemas e a Gruta do Pego do Diabo, situadas no concelho de Loures; a Gruta das Fontainhas, no concelho do Cadaval, a Gruta do Caldeirão, no concelho de Tomar e a Lapa da Rainha, localizada no concelho de Torres Vedras.

A presente tese refere-se a restos de aves datados do Plistocénico Superior (cronologia geológica) ou do Paleolítico Médio e Superior (cronologia arqueológica), ver o quadro 1. Embora sejam conhecidos restos de aves do Plistocénico Médio (Paleolítico Inferior), referimo-nos aos restos de aves identificadas nas Galerias Pesadas, no Almonda, por Anthony E. Marks e datados de há cerca 241 mil anos (MARKS et al., 2000, 2002 e TRINKAUS et al., 2003). No entanto, as jazidas estudadas nesta tese estão datadas apenas do Plistocénico Superior (Paleolítico Médio e Superior), sendo a mais antiga a Gruta da Furninha, com uma datação de cerca de 80 mil anos (CARDOSO, 1993). 


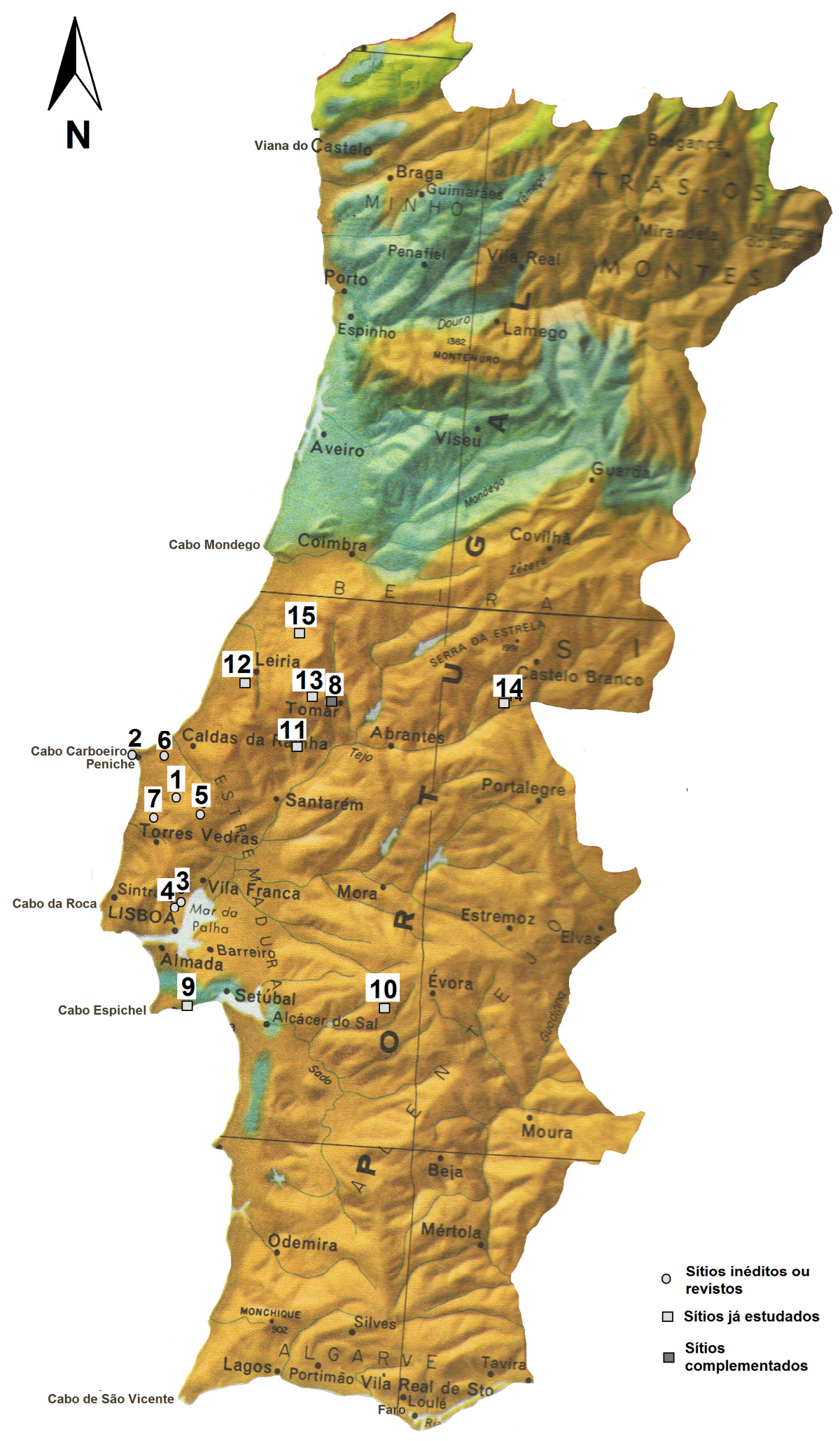

Fig. 9 - Mapa de localização geral dos sítios estudados (1 a 8) e seu enquadramento no contexto das jazidas plistocénicas com restos de aves, em Portugal (9 a 16): 1 - Gruta Nova da Columbeira; 2 - Gruta da Furninha; 3 - Gruta das Salemas; 4 - Gruta do Pego do Diabo; 5 Gruta das Fontainhas; 6 - Gruta da Casa da Moura; 7 - Lapa da Rainha; 8 - Gruta do Caldeirão; 9 - Gruta da Figueira-Brava; 10 - Gruta do Escoural; 11 - Grutas do Almonda; 12 - Abrigo do Lagar Velho; Lapa do Picareiro; 14 - Foz do Enxarrique; 15 - Buraca Escura. (Fonte: Grande Atlas Mundial - Selecções do Reader's Digest, 1978) 


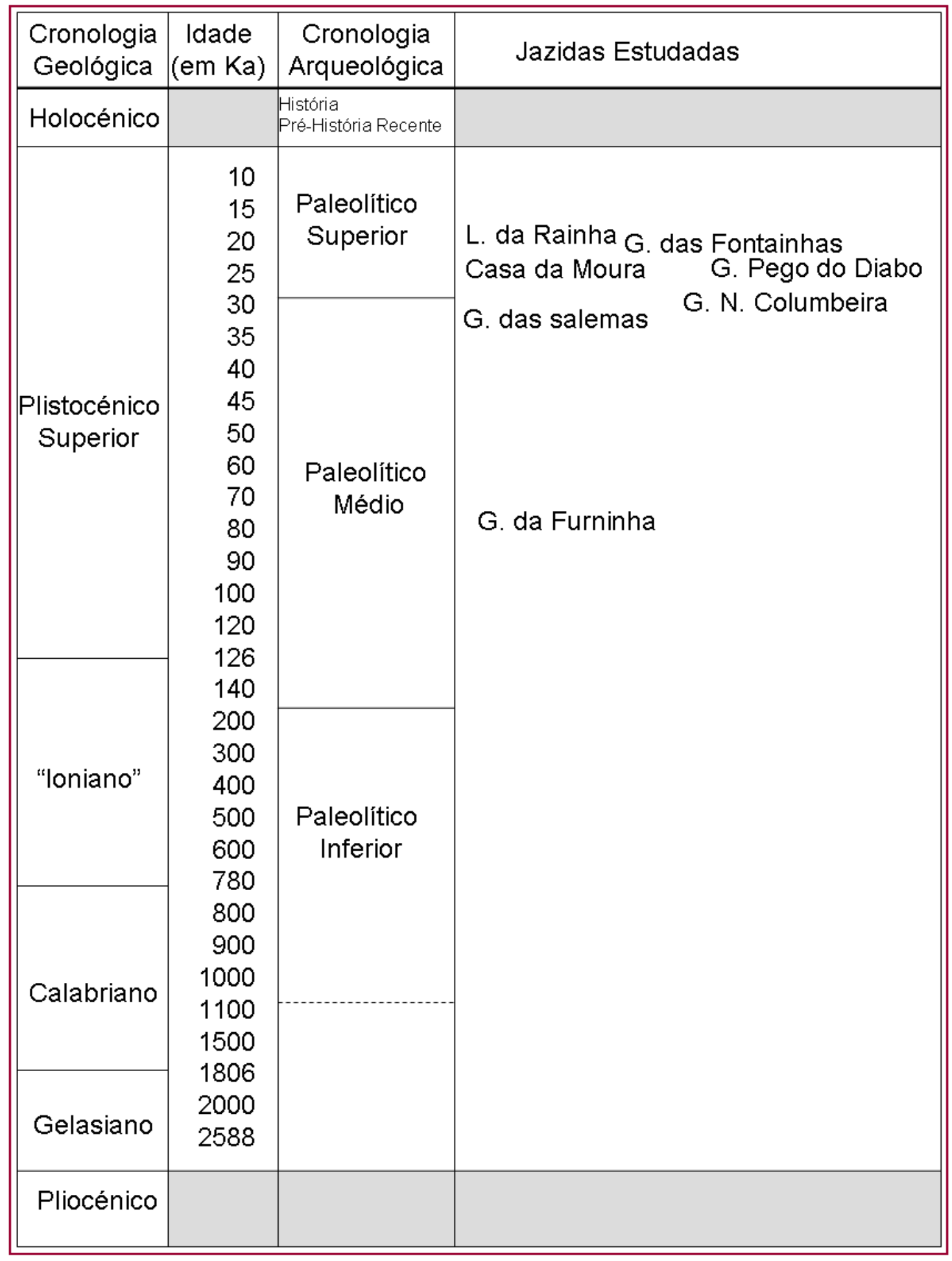

Quadro 1- Enquadramento cronológico (geológico e arqueológico) das jazidas estudadas. A periodização geológica foi feita segundo a tabela de 2009, da Comissão Internacional de Geologia da UNESCO. A periodização arqueológica foi baseada em SILVA, RAPOSO \& SILVA, 1993, p. 97, quadro 1 e em MARTINS et al. 2010 (para o limite inferior do Paleolítico Médio). 
PARTE II

Contextualização GeológicA, Paleontológica e ArQueológicA 


\section{1 - Contextualização Geológica}

\section{1 - Breve descrição geológica de Portugal}

A geologia de Portugal é constituída por quatro unidades geotectónicas: o Maciço Hespérico (também designado por Soco Varisco ou Maciço Antigo, bacias mesozóicas (Bacia Lusitânica e Bacia Algarvia) e bacias cenozóicas (com destaque para as do Mondego, do Baixo Tejo e de Alvalade).

O Maciço Hespérico é a maior unidade geológica de Portugal, ocupando cerca de três quartos do nosso território continental. É composto por formações do PréCâmbrico e Paleozóico, constituídas por rochas metamórficas e magmáticas, sobretudo rochas graníticas. As rochas das formações pré-câmbricas e paleozóicas foram afectadas, de uma forma geral, por fenómenos de metamorfismo, resultantes principalmente das diversas fases tectónicas da orogenia varisca.

\subsection{1 - O Mesozóico e o Cenozóico}

As orlas meso-cenozóicas são constituídas por formações constituídas, essencialmente, por rochas carbonatadas (calcários, margas e dolomias), argilosas e areníticas, bem como por rochas eruptivas, intrusivas ou extrusivas (ex. o complexo vulcânico de Lisboa). (SOUSA REAL, 1987), As orlas meso-cenozóicas de Portugal formaram-se nas margens continentais a oeste e a SW da Península Ibérica. Estas formações estão relacionadas com os episódios da abertura do Oceano Atlântico. Durante o Mesozóico abriu-se, onde actualmente se situa a costa ocidental portuguesa, entre Aveiro e a Península de Setúbal, uma fossa alongada na direcção NNE-SSW. No centro dessa fossa, os sedimentos apresentam uma espessura máxima de cerca de quatro quilómetros (REIS et al., 1992); uma grande parte dos sedimentos mesozóicos foram depositados em ambiente litoral e registam oscilações do nível do mar.

O Mesozóico em Portugal Continental foi marcado por avanços e recuos do 
nível marinho, dos quais resultaram várias fases de transgressão e regressão. De acordo com a natureza dos materiais, podem distinguir-se três grandes séries litológicas: rochas predominantemente detríticas, as mais abundantes, que são mais frequentes na base do Mesozóico (Reciano e Hetangiano), no Jurássico Superior, no Cretácico e, também, no Cenozóico, alternância de rochas margosas e detríticas, frequentes no Jurássico Superior e no Cretácico e rochas francamente calcárias, cujas bancadas mais espessas pertencem ao Jurássico Médio, constituindo a base dos maciços da Estremadura e da Serra da Arrábida.

Em Portugal, o Triásico caracterizou-se por um clima predominantemente quente e seco. No Jurássico, as condições climáticas eram próprias de um clima tropical húmido, com uma vegetação rica, dominada por coníferas, e uma fauna abundante, dominada por dinossauros. Durante o Jurássico e o Cretácico existiriam extensas lagoas, mares pouco profundos e deltas de rios que inundavam uma vasta região de águas calmas e mornas.

A passagem do Jurássico para o Cretácico ficou marcada pela ocorrência de importantes oscilações do nível do mar; o Cretácico Superior é caracterizado pela ocorrência de outra grande transgressão (PENA DOS REIS et al., 2000; REY et al., 2006).

No Cretácico final ocorreu uma acentuada actividade magmática, originando os maciços de Sintra, Sines e Monchique e, posteriormente, na região de Lisboa, derrames de lava basáltica e episódios de fases explosivas, bem como por actividade tectónica compressiva (CUNHA \& PENA DOS REIS, 1995; DINIS et al., 2008).

No Eocénico Médio iniciou-se a abertura de depressões alongadas de orientação nordeste-sudoeste, originando as bacias cenozóicas do Mondego e do Baixo Tejo (CUNHA, 1992; CUNHA et al., 2008; PAIS et al., in press). Até ao Miocénico Superior, durante cerca de 40 milhões de anos, a evolução geológica esteve marcada por uma progressiva e lenta erosão do Maciço Antigo, num clima ora semi-árido ora subtropical, com uma longa estação seca, o que favoreceu o aplanamento do Soco Antigo (CUNHA, 2000). Em meados do Tortoniano (Miocénico final), há cerca de 9 milhões de anos, atingiu-se o máximo da compressão bética, devido à colisão entre a placa euro-asiática e a africana. Em Portugal esta compressão originou o soerguimento da Cordilheira Central e das montanhas ocidentais (CUNHA et al., 2000; 
CUNHA \& MARTINS, 2004).

O Miocénico é caracterizado por sequências sedimentares fluvio-marinhas, essencialmente detríticas constituídas por areias, areolas, grés calcários, calcários grosseiros, arenitos, argilas e siltes (ANTUNES et al., 2000a). É de salientar o registo paleontológico proveniente da formação das "Areias de Vale de Chelas" (Langhiano 16 a 13 milhões de anos), onde se encontrou uma grande quantidade de vertebrados miocénicos, de que se destaca os mastodontes encontrados na cidade de Lisboa. Trata-se de um complexo arenoso com intercalações argilosas e greso-calcárias. Esta formação aparece na Portela, Charneca, Lumiar, Chelas, Camarate, Santa Iria e Vila Franca.

De finais do Miocénico a meados do Pliocénico, o clima era quente mas seco, e a sedimentação deu-se essencialmente em leques aluviais no sopé das escarpas de falhas activas, sem escoamento para o mar (CUNHA, 1992; CUNHA \& MARTINS, 2004). A partir de meados do Pliocénico, o clima era passou a ser muito húmido e desenvolveu-se uma rede hidrográfica exorreica, percursora da actual. Originaram-se largos vales fluviais, nas zonas de montanha e foram capturadas várias das bacias interiores e estabeleceu-se a plataforma litoral (CUNHA et al., 1993).

No Plistocénico continuou a verificar-se o soerguimento tectónico das serras (CABRAL, 1995), que conjuntamente com períodos de abaixamento do nível dos mares, que levou ao progressivo encaixe da rede hidrográfica e capturas fluviais (CUNHA et al., 2005, 2008; MARTINS et al., 2009A). Os períodos de glaciações do Plistocénico, responsáveis pelos referidos períodos de baixamento do nível dos mares, e os períodos interglaciários, responsáveis por episódios de submersão de grande parte do litoral e das embocaduras das redes hidrográficas deixaram marcas na morfologia do território, como são exemplos as praias levantadas e os terraços fluviais, originados nos inter-glaciares, e os vales em forma de " $U$ " existentes na Serra da Estrela e no Gerez, originados nos períodos glaciários (e.g. TEIXEIRA, 1979; DAVEAU, 1993; ARAÚJO, 1997; CUNHA \& MARTINS, 2004; MARTINS \& CUNHA, 2009; MARTINS et al., 2009B). 


\subsection{2 - As grandes unidades meso-cenozóicas de Portugal}

As grandes unidades geológicas do Mesozóico e do Cenozóico situam-se, como já foi referido, na Orla Ocidental e na Orla Meridional. No que respeita ao Cenozóico, para esta tese interessa essencialmente a Bacia do Mondego, do Baixo Tejo e de Alvalade porque é nestas que se situam algumas das jazidas com aves fósseis: do Eocénico inferior - Mondego (Jazida de Silveirinha - Figueira da Foz) do Miocénico (Lisboa e Praia do Penedo - Sesimbra) e do Plistocénico (Caldeirão, Almonda, Foz do Enxarrique, Salemas, Pego do Diabo e Figueira-Brava), no caso das Bacias do Tejo e de Alvalade. Nas outras bacias com formações cenozóicas não ocorrem jazidas com avifauna fóssil.

\section{Orla Ocidental}

Abriu-se, durante o Mesozóico, genericamente na faixa onde actualmente se situa a costa ocidental, uma fossa alongada na direcção NNE-SSW. No centro dessa fossa os sedimentos apresentam a sua espessura máxima. Dada a sua reduzida largura, uma grande parte dos sedimentos mesozóicos foram depositados em área litoral e registam oscilações do nível do mar, o que explica a origem das alternâncias de sedimentação grosseira e fina e as bruscas variações laterais de fácies.

No final do Cretácico, uma acentuada actividade vulcânica originou o maciço sub-vulcânico de Sintra, constituído essencialmente por granitos, sienitos e gabros, que afectou, por contacto, algumas das unidades calcárias originando calcários compactos. Esta actividade magmática originou também os maciços de Sines e Monchique e, na região de Lisboa, derrames de lava basáltica e episódios de fases explosivas, que estão na origem do complexo vulcânico de Lisboa, que se estende de Monsanto até Loures (SOUSA REAL, 1987).

\section{Orla Meridional}

A Orla Meridional (do Algarve) é constituída por uma faixa sedimentar de direcção ENE-WSW, acidentado por flexuras e falhas (TERRINHA, 1998). As séries vãose tornando mais espessas de oeste para leste e apresentam fácies de maior profundidade neste sentido, bem como para offshore (LOPES et al., 2006). 
No contacto com o Maciço Antigo ocorrem níveis de conglomerados e grés vermelhos, de calcários dolomíticos com algumas intercalações de gesso e sal-gema que, em alguns casos, apresentam interesse económico, em virtude da estrutura diapírica que caracteriza, em grande parte, a tectónica desta plataforma. Esta série inicial termina com um complexo vulcano-sedimentar. Este complexo está coberto por calcários dolomíticos, por vezes calciclásticos, aos quais se sobrepõem formações pelágicas do Jurássico Médio ao Jurássico Superior (SOUSA REAL, 1987).

\section{Bacias Cenozóicas}

O Cenozóico aparece, no contexto geológico de Portugal continental, inserido nas bacias atrás referidas. Caracteriza-se por numa mesma bacia os sedimentos apresentarem variações laterais nas fácies e na espessura (CUNHA, 1992). As variações eustáticas e climáticas do Cenozóico e a própria evolução geodinâmica da Península reflectem-se nas principais rupturas sedimentares e nas características litológicas dessas bacias, que são muito semelhantes (PAIS et al., in press). Para a presente tese apenas importa descrever as bacias cenozóicas do Mondego, do Tejo e de Alvalade, onde apareceram restos fósseis de aves.

\section{As Bacias cenozóicas do Baixo Tejo e de Alvalade}

Os depósitos das bacias do Baixo Tejo e de Alvalade são sub-horizontais e a sua espessura é muito variável, admitindo-se um máximo de 1400 m de espessura naquela e menos de 500 m nesta última. Nestas bacias predominam níveis arenosos, mais ou menos grosseiros, com intercalações conglomeráticas e argilosas, e calcários lacustres.

No Paleogénico foram depositados, na Bacia do Baixo Tejo, depósitos aluviais mal calibrados que se podem individualizar em duas unidades: a inferior, depositada em períodos de inundação, e a superior, depositada por fluxos canalizados. Este enchimento paleogénico está representado nas formações de Cabeço do Infante, de Vale do Guizo, de Monsanto e de Benfica. No Miocénico foram depositadas arcoses, de origem fluvial (Formação de Silveirinha dos Figos e Formação de Alcoentre), Na Formação de Tomar está registada uma sedimentação predominantemente lutítica de inundação e na Formação de Almoster existem calcários palustres. Do Miocénico 
nas penínsulas de Lisboa e de Setúbal estão registados sedimentos estuarinos, distribuídos por várias unidades litostratigráficas. No final do Miocénico a inícios do Pliocénico encontram-se depósitos de leque aluvial, as formações de Torre e de Monfortinho. O Pliocénico está representado pela Formação da Falagueira (Beira Baixa), Formações de Ulme, Almeirim e Vila de Rei, (a região do Médio Tejo português) e pelas Areias de Santa Marta e Conglomerado de Belverde (região de Lisboa-Setúbal).

Existem do Plistocénico e Holocénico terraços fluviais e costeiros, aluviões, dunas e outros depósitos detríticos de cobertura, onde aparecem algumas jazidas arqueológicas.

\section{Bacia do Mondego}

A abertura da bacia NE-SW do Mondego é posterior à deposição de uma sucessão que compreenderá o Cretácico final a inícios do Eocénico (do Campiano Superior ao Ipresiano), incluindo as formações de Buçaqueiro, Taveiro e de Silveirinha. Após esta deposição, a bacia do Mondego definiu uma depressão alongada no sentido nordeste - sudoeste, preenchida desde o Eocénico Médio ao Oligocénico por arcoses e conglomerados (formações de Côja e do Bom Sucesso). No Miocénico originaram-se as formações de Amor e de Lobão. No final do Miocénico e no Pliocénico inferior ocorreu deposição em leques aluviais. Os depósitos do Pliocénico superior, mais espessos, podem apresentar arenitos amarelos marinhos (Formação de Carnide), arenitos brancos deltaicos (Formação de Roussa) e areno-lutitos fluviais e palustres (Formação de Barracão). No Plistocénico formaram-se terraços, coluviões e areias eólicas e no Holocénico formaram-se campos dunares eólicos, enchimentos estuarinos e de planície aluvial (CUNHA et al., 1993; PAIS et al., in press). 


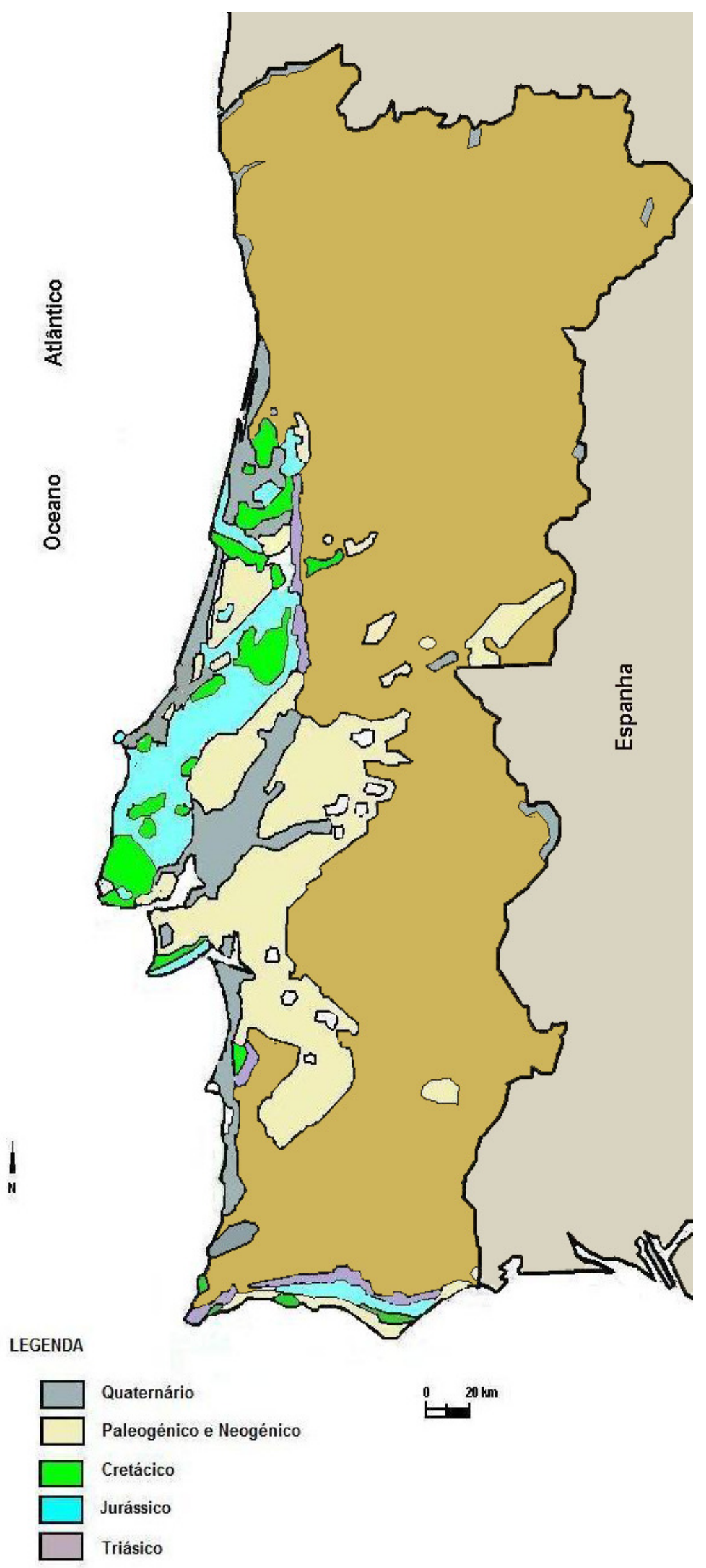

Fig. 10 - Mapa com a localização das formações mesozóicas e cenozóicas em Portugal, Adaptado da Carta Geológica de Portugal Esc. 1:1 000 000, SGP, 1968. 


\subsection{3 - Sequências Limitadas por Descontinuidades (SLD)}

No registo estratigráfico meso-cenozóico de Portugal foram diferenciadas sequências limitadas por descontinuidades com valor à escala de bacia (SLDs; CUNHA 1992) (quadro 2).

Seguidamente serão descritas as sequências limitadas por descontinuidades onde existem jazidas com aves fósseis e seus antepassados, em Portugal: SLD 2 (Jurássico), SLD 3 e SLD 5 (Cretácico), SLD 6 (Eocénico), SLD 10 e SLD 11 (Miocénico) e SLD 14 (Plistocénico).

É na SLD 2 (Oxfordiano a Berriasiano Superior), já no Cretácico Inferior que se enquadra a formação da Guimarota (Jurássico Superior).

Durante o período de sedimentação correspondente à SLD 3 (Berriasino Superior - Aptiano Superior) a bacia estruturou-se num sector central deprimido, cujas margens eram constituídas por pequenas falhas gravitacionais com o bloco central abatido. Os sedimentos da zona máxima de deposição da bacia (esta zona inclui a área onde actualmente se situa a região de Lisboa) são constituídos essencialmente por carbonatos marinhos de plataforma, que passam lateralmente a sedimentos siliciclásticos de sistemas de transição e continentais.

A SLD 5, que corresponde ao Campaniano e ao Maastrichtiano, está relacionada com a formação de Taveiro e do Viso. A partir do Campaniano Superior e sobretudo no Maastrichtiano a compressão máxima passou a ter o sentido NNW SSE, o que originou uma significativa actividade tectónica, ígnea e diapírica. O bloco NW abateu, originando a captura de umbigos de subsidência, desenvolvendo um padrão de drenagem para NW, com canais meandriformes.

Na SLD 6 a sedimentação efectuou-se em planície de inundação fluvial, no limiar de zona costeira, com fraca influência das marés do mar Ipresiano colocado a ocidente, talvez em área pantanosa justificada por frequentes episódios de 
alagamento através de canais efémeros, abertos aquando de inundações sazonais

A SLD 10 teve o seu início durante o final do Burdigaliano e terminou em finais do Tortoniano. A compressão bética deu-se no final da SLD 10 e continuou na SLD 11. O clima era subtropical; geraram-se várias formações de calcarenitos, ricas em faunas típicas de climas tropicais, tais como os bancos de ostras e as Torritella, e ainda alguns vertebrados. No Baixo Tejo formaram-se complexos arenosos com intercalações argilosas e greso-calcárias, ricos em faunas de vertebrados, como crocodilos, tartarugas e mastodontes.

Durante a SLD 10, a serra da Arrábida começou a elevar-se. Logo depois, o mar em ascensão penetrou muito para o interior. Os relevos da Arrábida, entretanto emersos formaram uma ilha. No final do Burdigaliano, o mar afastou-se de novo. $\mathrm{O}$ Pré-Tejo inundava uma planície aluvial com um extenso delta terminal, transportando para a zona de Lisboa areias grosseiras resultantes da erosão das cordilheiras de montanhas do interior de Portugal. Estes depósitos estão bem expostos nas arribas da Foz da Fonte e do Penedo.

A partir do Miocénico Médio (há cerca de $15 \mathrm{Ma}$ ) o mar começou novamente a subir, formando, na região do Baixo Tejo um enorme golfo, sobressaindo as serras da Arrábida e de Sintra, que formavam, na altura, ilhas.

Na região de Lisboa-Setúbal existiam ambientes litorais ricos de ostreídeos, alguns de enormes dimensões, como se podem observar em algumas camadas estratigráficas em Lisboa e na Arribas Fósseis da Caparica. Na região da Lagoa de Albufeira, os últimos níveis marinhos podem observar-se na praia da Foz da Ribeira da Lage, onde estão representados por areias finas, micáceas, ricas de Chlamys macrotis (Notícia Explicativa da Carta Geológica de Setúbal 1:50 000).

A SLD 14 (Plistocénico) caracteriza-se pela formação de terraços fluviais e costeiros, bem como sedimentação dunar e em grutas. 


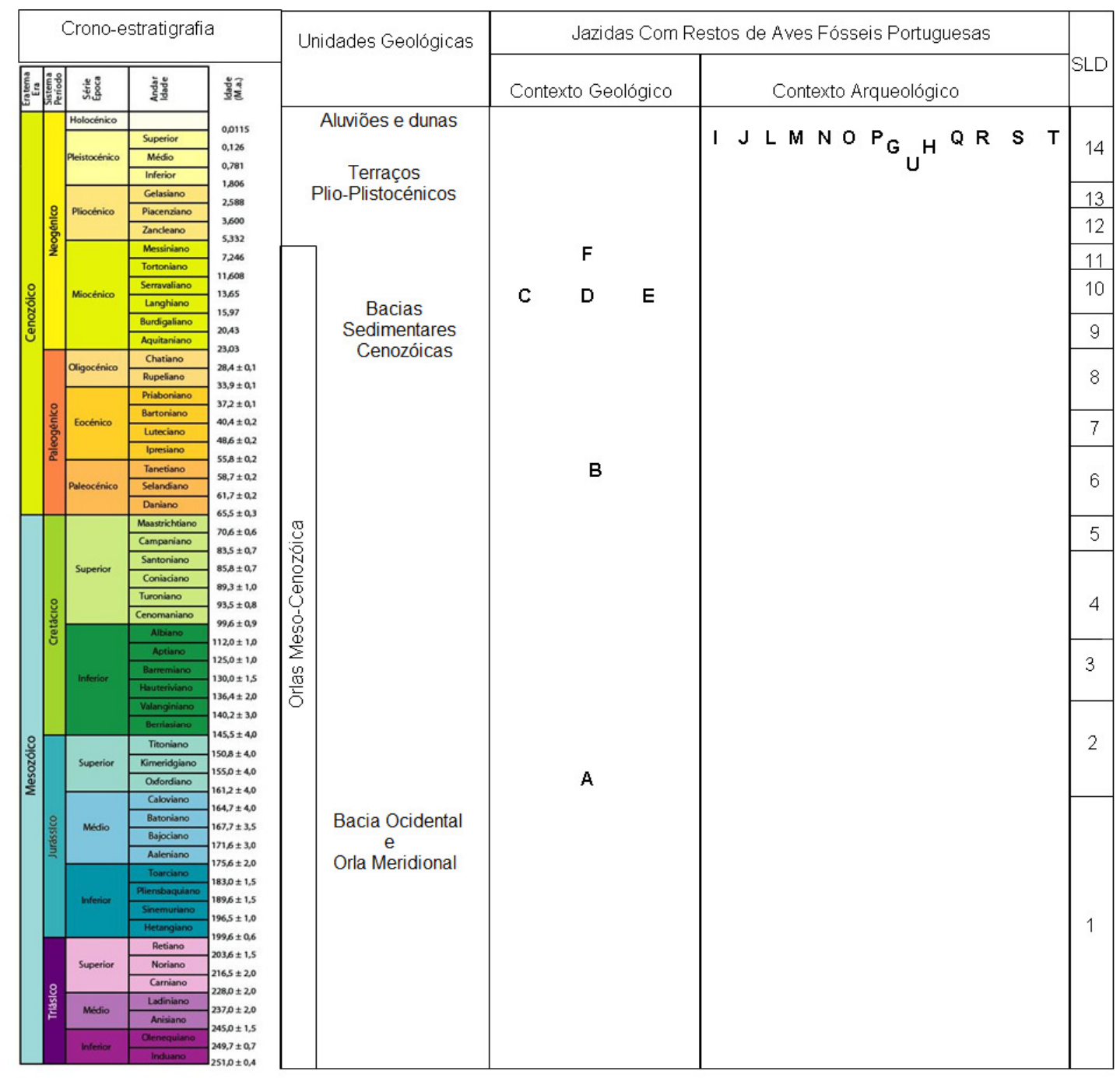

\begin{tabular}{|ll|}
\hline A - Mina da Guimarota (A rchaeopteryx) & G - Gruta da Furninha \\
B - Silveirinha (Pivialis) & H - Grutas da Oliveira \\
C - Amôr (Ave indet.) & I - Gruta da Columbeira \\
D - Penedo Norte (Ave indet.) & J - Gruta de Salemas \\
E - Lisboa - Charneca (Paieoperdix sp.) & L - Gruta do Pego do Diabo \\
F - Aveiras de Baixo (Ave indet.) & M - Gruta das Fontainhas \\
& N - Gruta da Casa da Moura \\
& O - Gruta do Caldeirăo \\
& P - Gruta da Figueira-Brava \\
& Q - Lapa da Rainha \\
& R - Lapa do Picareiro \\
& S - Abrigo do Lagar Velho - Lapedo \\
& T - Gruta do Escoral \\
& U - Galerias Pesadas \\
\hline
\end{tabular}

Quadro 2 - Tabela com as SLD's (CUNHA, 1992) e o respectivo enquadramento geológico e relação com as jazidas com restos de aves fósseis em Portugal. 
1.2 - Caracterização geográfica e geológica das jazidas estudadas

\subsection{1 - Gruta da Columbeira}

A Gruta Nova da Columbeira, situa-se no Centro de Portugal, Distrito de Leiria, Concelho do Bombarral. A gruta abre-se na encosta meridional do Vale Roto, vale este que foi moldado pela Ribeira da Columbeira, e é um afluente do Rio Real. Esta cavidade cársica encontra-se situada nas seguintes coordenadas geográficas:

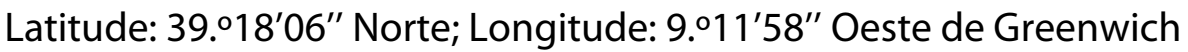

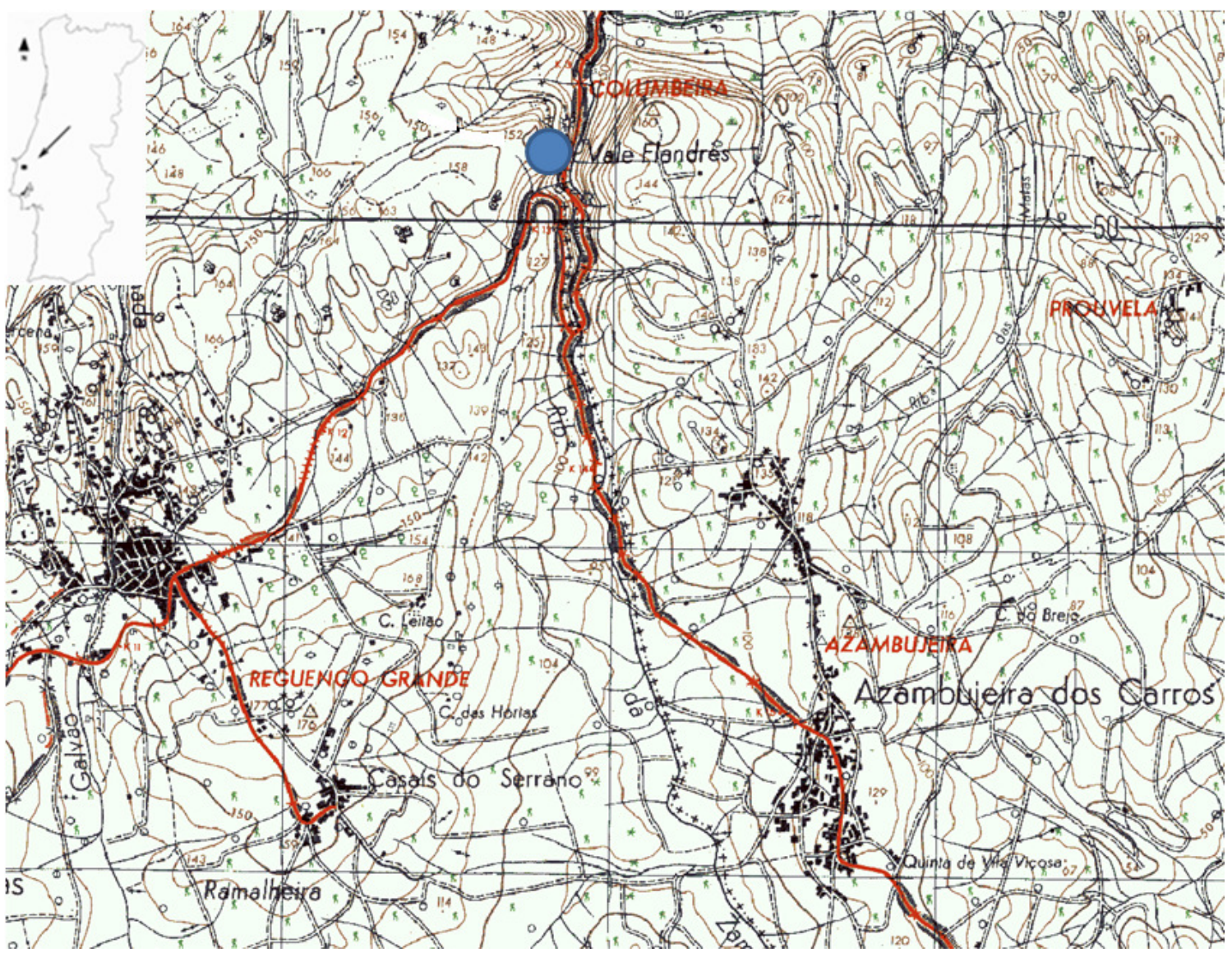

Fig. 11 - Localização na Carta Militar de Portugal, à escala de 1:25000 (folha 350), da Gruta Nova da Columbeira. Edição dos serviços cartográficos do Exército.

A actual entrada da gruta encontra-se na extremidade oposta da primitiva (CARDOSO, RAPOSO e FERREIRA, 2002, p. 10). Quanto à geometria da gruta, a actual entrada dá acesso a uma galeria com cerca de vinte metros de comprimento, cerca de quatro metros de largura e dez metros de altura, que vai estreitando até desembocar 
na câmara principal, relativamente alta, onde se concentra a ocupação humana do Paleolítico Médio. Esta câmara comunica com um estreito corredor, terminado em chaminé, a qual seria a entrada primitiva da gruta. Actualmente esta entrada está entulhada e não foi escavada. Trata-se, de uma forma geral, de uma gruta estreita e alta, de planta irregular. (CARDOSO, RAPOSO e FERREIRA, 2002., p. 10).

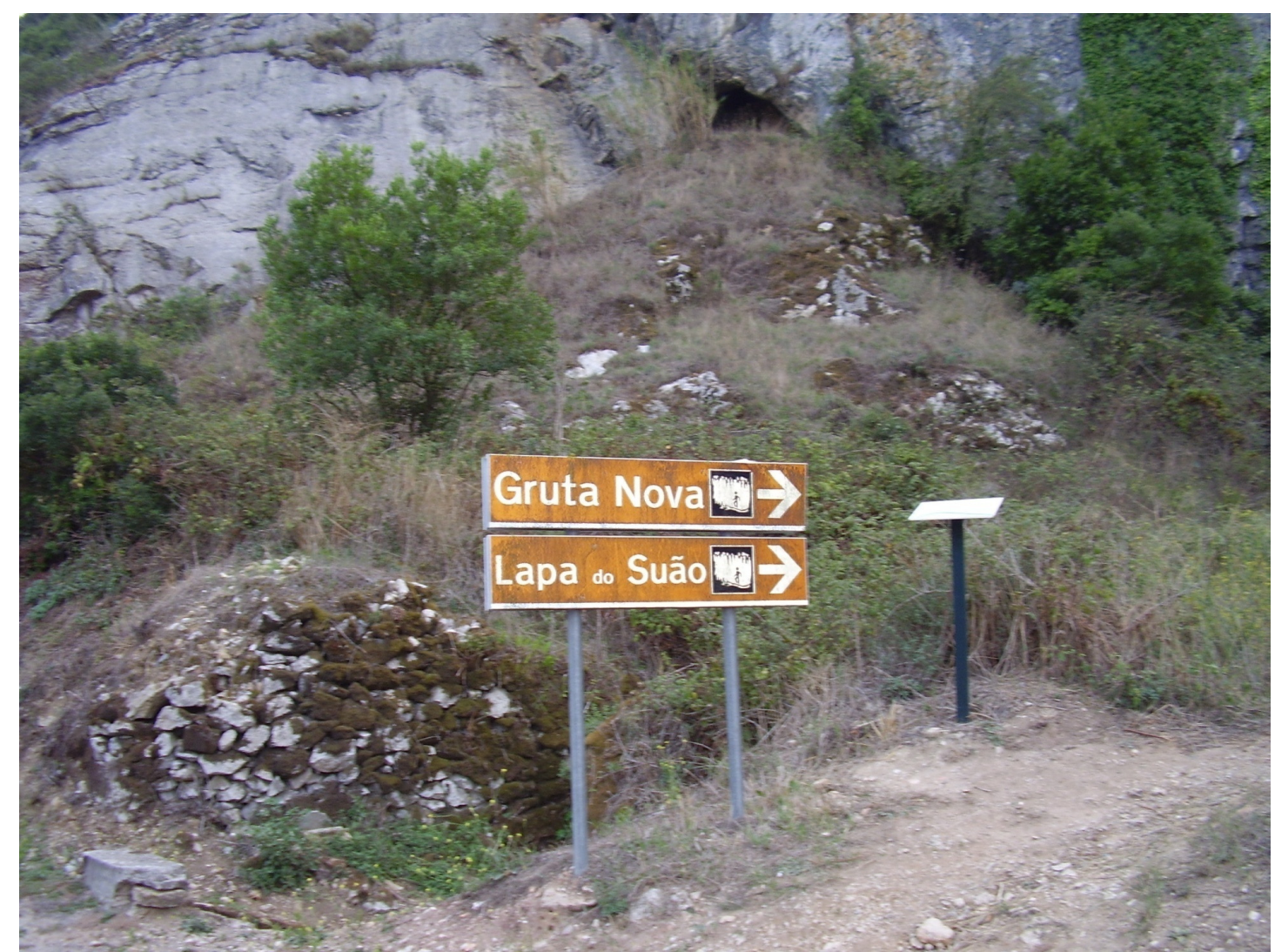

Fig. 12 - Placa sinalizadora da entrada da Gruta Nova da Columbeira (fotografia: S. Figueiredo).

O facto de a gruta se encontrar fechada até à sua descoberta, por causa da entrada primitiva estar bloqueada desde o fim do Plistocénico, tornou-se numa "bolsa" fechada do Plistocénico, pois, no seu interior, não foi encontrado qualquer vestígio de ocupação humana ou animal do Holocénico. (CARDOSO, RAPOSO e FERREIRA, 2002, p. 10).

A estação arqueológica da Gruta Nova da Columbeira situa-se numa cavidade cársica, que se abre nos calcários do Jurássico Superior, do Kimeridgiano (ZBYSZEWSKI et al., 1966), no rebordo oriental do Maciço Calcário das Cesaredas. 
Esta gruta localiza-se num vale, muito encaixado, de orientação N-S, com cotas entre os vinte metros, nas zonas mais baixas e os cerca de cento e cinquenta metros de altitude, nas zonas mais altas.

No fundo do vale se estende uma vasta planície litoral, que se encontrava inundada durante a transgressão flandriana. Segundo os dados paleogeográficos, sabe-se que a linha de costa esteve, até ao Holocénico, quase sempre junta à bordadura ocidental do maciço rochoso jurássico. Por esta razão, a referida bordadura constitui-se como uma arriba fóssil. Do lado norte deste maciço, expandese uma vasta depressão aberta, onde se instalou, durante o Holocénico, uma ampla laguna litoral, a Lagoa de Óbidos, onde desagua o Rio Real. (CARDOSO, RAPOSO e FERREIRA, 2002, p. 9).

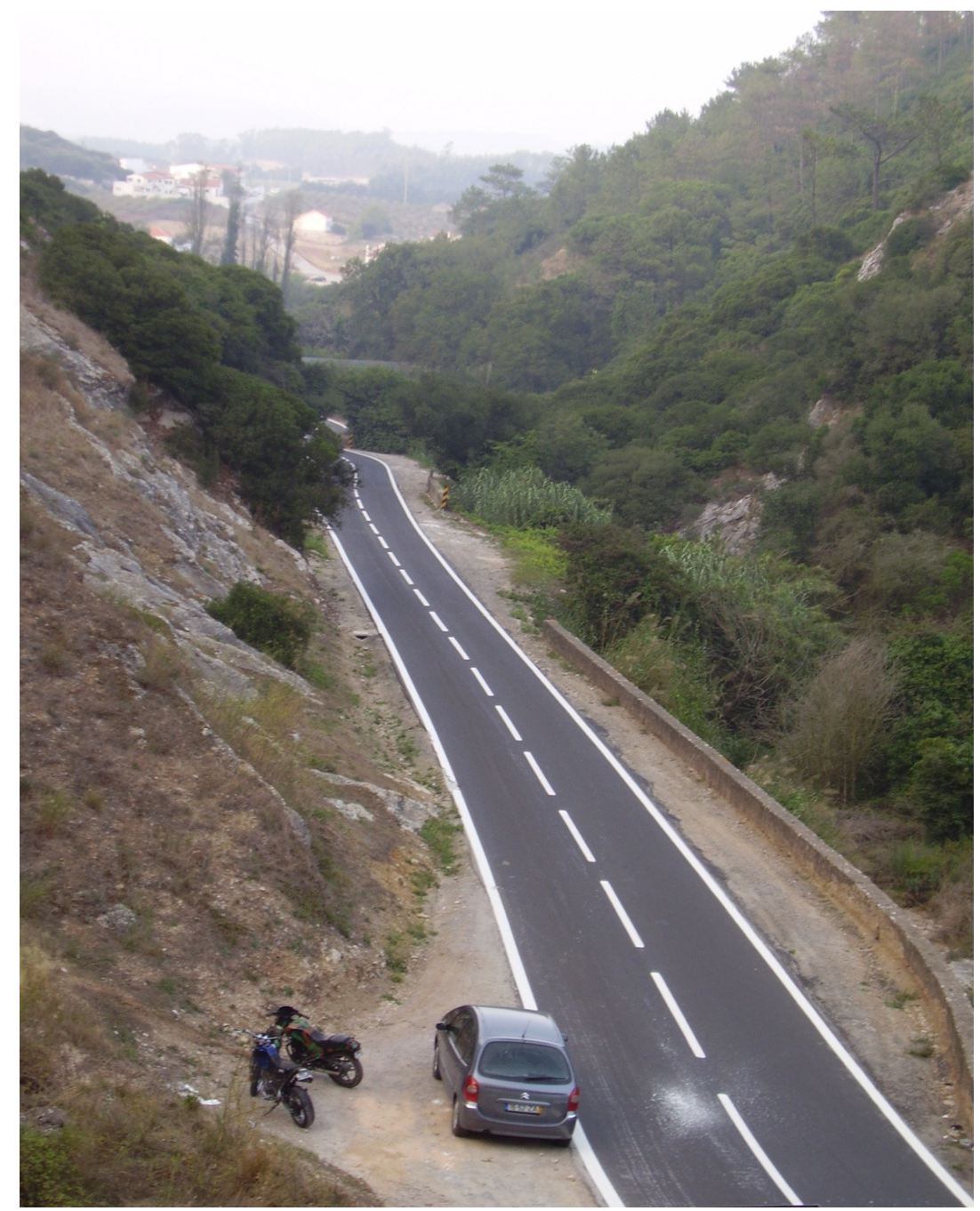

Fig. 13 - O Vale Roto visto a partir da actual entrada da Gruta Nova da Columbeira (fotografia: S. Figueiredo). 
A estratigrafia da Gruta nova da Columbeira é constituída por 10 camadas sedimentares principais e a sua sucessão foi descrita e representada, por Octávio da Veiga Ferreira, no seu caderno de campo, após a campanha arqueológica de 1962.

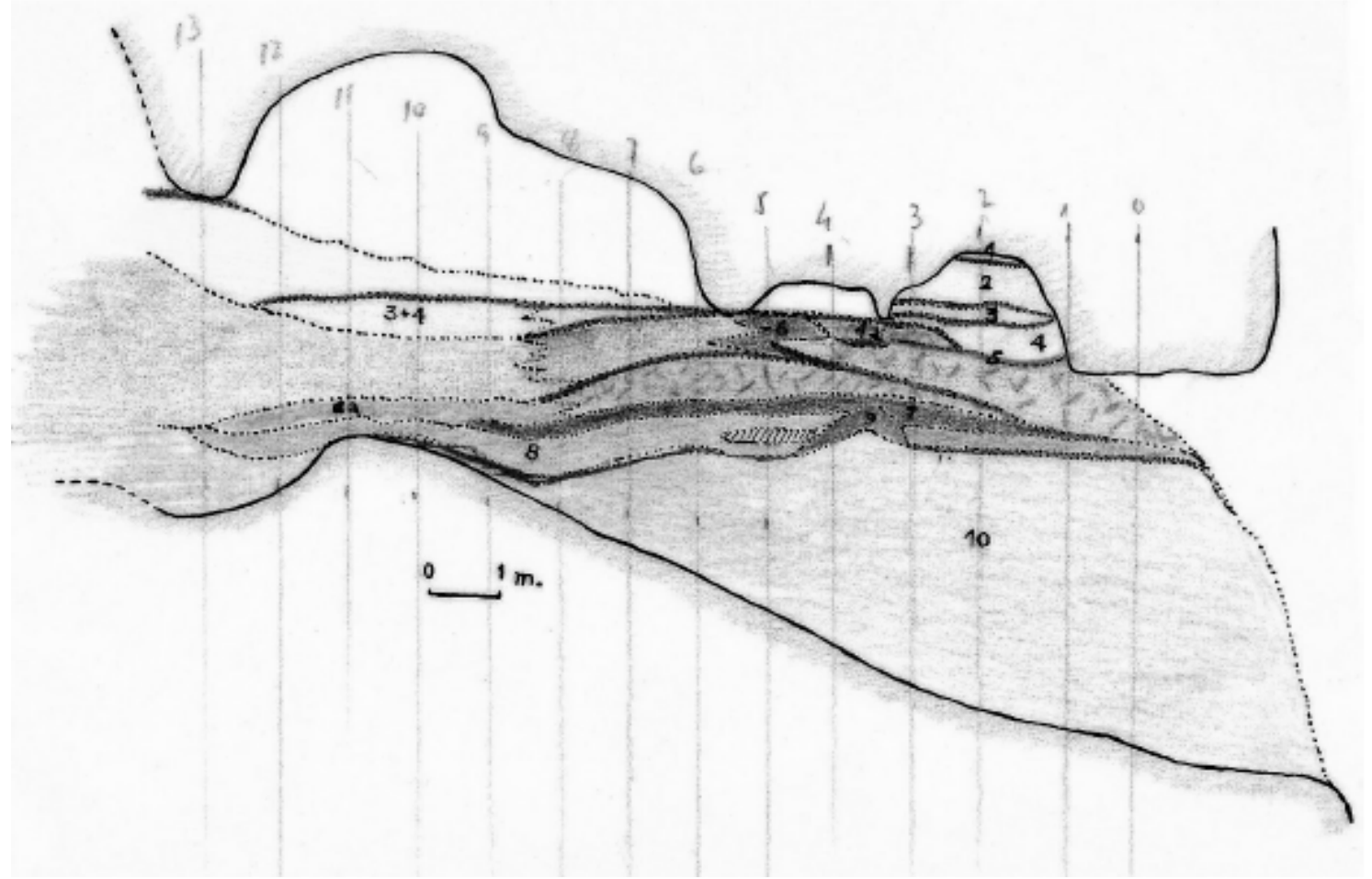

Fig. 14 - Representação estratigráfica do corte longitudinal, que serviu para a descrição da estratigrafia da gruta (excerto do caderno de campo de O. Da Veiga Ferreira, do seu seu arquivo pessoal), in CARDOSO, 2006

A estratigrafia representada, na figura anterior foi também descrita no caderno de campo de Veiga Ferreira e aparece transcrita em várias publicações sobre a Gruta nova da Columbeira (ZBYSZEWSKI, 1963, FERREIRA, 1966 e CARDOSO, RAPOSO \& FERREIRA, 2002). Assim, a sequência estratigráfica da Gruta é a seguinte (de cima para baixo):

“C. 1 - Nível estalagmítico (0,01-0,12 m.);

C. 2 - Brecha castanha, um pouco arenosa, com fragmentos $e$ concreções de calcário, ossos de animais e carvões (0,40 m.);

C.3 - Nível lenticular com concreções calcárias e ossos de animais $(0,10 \mathrm{~m})$;

C. 4 - Nível argilo-arenoso, cinzento-acastanhado, com fragmentose concreções de calcário, ossos, carvões e indústrias mustierenses raras $(0,30-0,50 \mathrm{~m}$.$) ;$ 
C. 5 - Leito siltoso $(0,02-0,03 \mathrm{~m}$.);

C. 6 - Brechas compactas, com numerosos fragmentos e concreções de calcário, ossos, carvões e indústrias mustierenses (0,80 a 1,00 m.);

C. 7 - Nível arenoso, castanho, castanho-acinzentado, com numerosos e abundantes indústrias mustierenses $(0,20 \mathrm{~m}$.);

C.8 - Terra castanha-escura e negra, mais ou menos consolidada, com acumulações de cinzas (0,30 m.);

C. 9 - Nível estalagmítico;

C.10 - Areia argilosa amarela, estéril, assentando no chão primitivo da gruta." (CARDOSO, RAPOSO \& FERREIRA, 2002, p..39).

No meio de quase todas as camadas existia uma película estalagmítica fina, o que indica uma interrupção de sedimentação entre as várias camadas identificadas por Veiga Ferreira. As primeiras três camadas (C1, C2 e C3) eram estéreis, do ponto de vista arqueológico, enquanto as camadas sete e oito foram as mais ricas em vestígios humanos, sendo identificados abundantes restos carbonosos, na $\mathrm{C} 8$, o que significa a ocorrência de combustões de longa duração. Nestas camadas apenas foram encontrados quatro restos de carnívoros (um fragmento de rádio de lobo, na C8, e três ossos de hiena, na (7) em contraponto á C6, que forneceu grande número de restos de hiena, o que reforça a ideia de alternância da ocupação da gruta entre homens e carnívoros (CARDOSO, RAPOSO e FERREIRA, 2002, pp.41 e 42), tal como acontece em outras grutas portuguesas, com sedimentos plistocénicos.

Por outro lado, covém referir que os vestígios de avifauna agora estudados e analisados, são provenientes das camadas C. 9, C. 8, C.7 e C.6.

Após as escavações foram realizados trabalhos de detalhe do registo gráfico do corte-testemunho, tendo sido identificados vinte níveis estratigráficos, que foram publicados mais tarde, por farinha dos Santos, em 1972. Nestes trabalhos posteriores às escavações foram também recolhidos carvões para se realizarem datações absolutas (CARDOSO, RAPOSO e FERREIRA, 2002, p.28). 


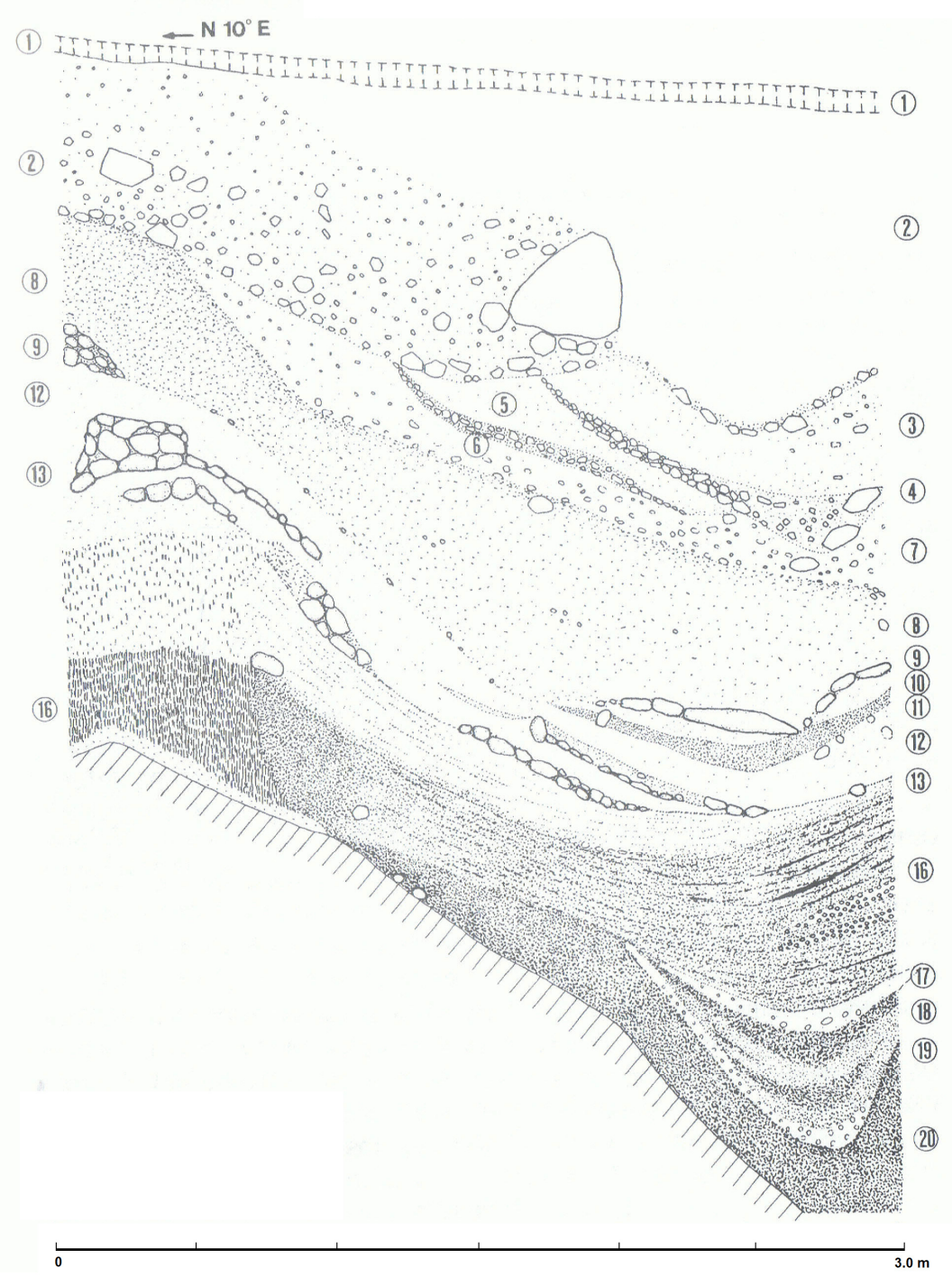

Fig. 15 - Desenho do perfil do corte estratigráfico da Gruta Nova da Columbeira, segundo SANTOS, 1972

\subsection{2 - Gruta da Furninha}

A Gruta da Furninha é uma cavidade cársica, situada a 15 metros de altitude. Localiza-se na costa sul da península de Peniche, a cerca de 850 metros a SW do Cabo Carvoeiro, na freguesia e concelho de Peniche e distrito de Lisboa e nas coordenadas geográficas 39. ${ }^{\circ} 21^{\prime} 25^{\prime \prime}$ Norte e $9 .^{\circ} 23^{\prime} 54^{\prime \prime}$ a Oeste de Greenwich. 


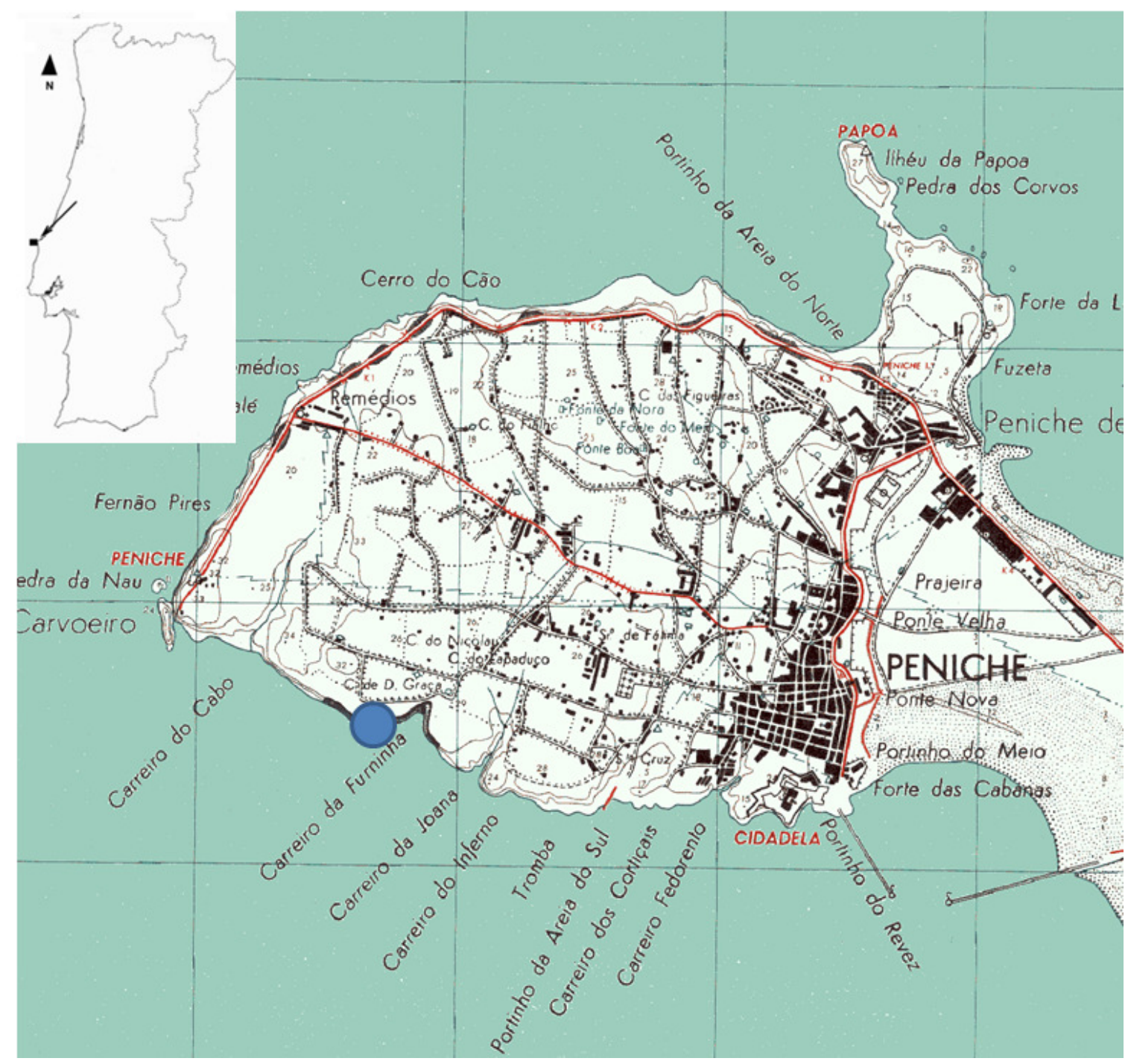

Fig. 16 - Localização na Carta Militar de Portugal, à escala de 1:25000 (folha 337), da Gruta da Furninha. Edição dos serviços cartográficos do Exército.

A entrada da gruta, em forma de ferradura, encontra-se a meia altura das arribas viradas a sudoeste (DELGADO, 1884, p. 208), da península de Peniche. A Gruta da Furninha tem cerca de 30 metros de comprimento e uma planta pouco ramificada (CARDOSO, 1993, p. 73), que pode ser dividida em cinco partes: o átrio exterior, onde aflora a rocha de base (ZILHÃO, 1997), um corredor, de orientação N-S, com cerca de 9 metros por 3 metros e que termina na sala principal, da qual parte outro corredor, em cotovelo, onde se abre um poço vertical. Do outro lado da sala principal existe uma câmara de planta oval (CARDOSO, 1993, p. 73). 

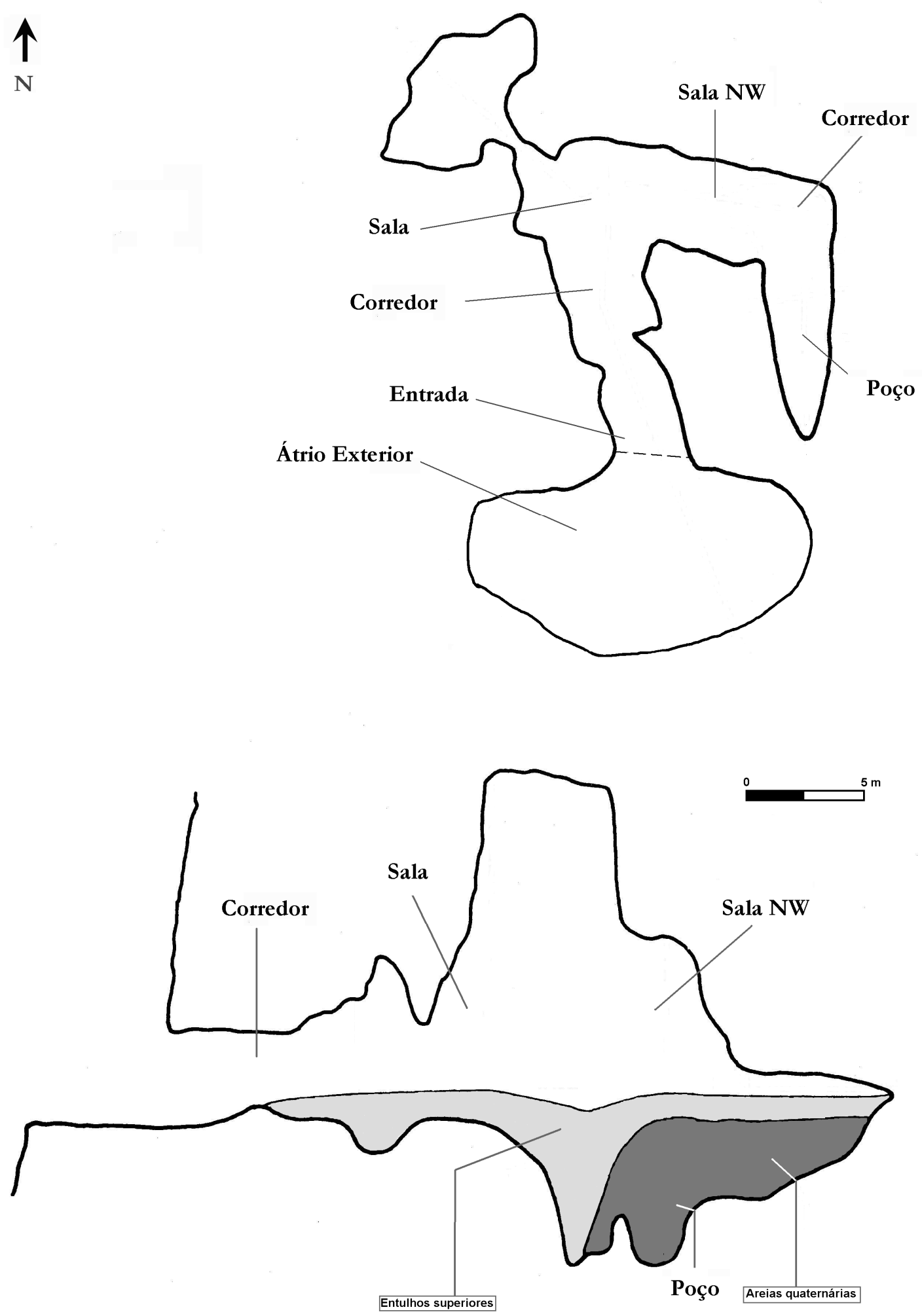

Fig. 17 - Corte longitudinal e planta da Gruta da Furninha, segundo DELGADO, 1884 (simplificado).

A gruta situa-se numa falésia abrupta, formada por calcários grosseiros, sob uma pequena plataforma de lapiás. Nery Delgado (DELGADO, 1884, p. 207) atribuiu 
estes calcários ao Jurássico Inferior e na notícia explicativa da carta geológica de Peniche (folha 26 - C, escala: 50.000) atribui ao andar Aaleniano (FRANÇA et al, 1960), na altura enquadrado no Jurássico Inferior. Actualmente, o Aaleniano está colocado na base do Jurássico Médio (Tabela Crono-Estratigráfica de 2009, da International Commission on Stratigraphy). No entanto, a formação geológica onde se encontra a Gruta da Furninha, a Formação do Cabo Carvoeiro, não tem bem definida a sua cronostratigrafia, estando atribuída ao Toarciano e ao Aaleniano (DUARTE, 2003a, 2003b), situando-se portanto na passagem do Jurássico Inferior para o Jurássico Médio, uma vez que não foram encontrados fósseis de idade17, que permitam estabelecer com rigor a idade daqueles calcários.

A falésia onde se encontra a entrada da gruta é vertical em toda a sua extensão e inacessível (DELGADO, 1884, p. 207). Actualmente existe uma escada escavada nos calcários, que permite um acesso fácil à entrada da gruta, ao contrário do que acontecia quando Nery Delgado lá efectuou as escavações.

A entrada da gruta terá sido aberta durante o último interglaciar, com a subida das águas, que depositaram um nível de praia com 15 metros, situado de fronte para a entrada da gruta, após o abixamento do mar ter-se-á formado um poço com o fundo preenchido por um conglomerado marinho (CARDOSO, 1993) e onde ficou depositada a potência estratigrafia que preservou o registo da fauna e da ocupação humana (FERREIRA, 1964).

Nery Delgado (DELGADO, 1884) definiu a estratigrafia em duas unidades principais: a primeira camada, que designou de "entulho superior", possuía materiais arqueológicos do neolítico; a segunda unidade, apenas preservada no poço, foi designada por "areias quaternárias", com materiais líticos e grande número de ossos. Esta última unidade foi dividida em vários níveis ossíferos (DELGADO, 1884). A estas duas unidades foi, mais tarde acrescentada uma terceira, de enchimento de terraço marinho do interglacias Riss-Würm (BREUIL \& ZBYSZEWSKI, 1945). Nos estudos estratigráficos efectuados foram definidas 16 camadas ou níveis, em três unidades estratigráficas, correspondentes a três tipos de depósitos diferentes:

17 Fósseis de idade ou característicos são fósseis que apresentam uma ampla distribuição geográfica e um período de existência relativamente curto, permitindo estabelecer correlações entre bacias sedimentares de áreas geográficas distantes e estabelecer uma idade rigorosa para os depósitos sedimentares onde se encontram. 
“1 - Nível superior de terras negras remexidas. Neste foi identificada uma mistura de indústrias do Neolítico, do Paleolítico Superior (Solutrense, provavelmente Perigordense e Magdalenense) e do Mustierense. Espessura: 1 metro;

2 - Complexo de 13 níveis de areias amareladas com alternância de areias estéreis e de "níveis ossiliferos". O nível superior apresenta indústrias mustierenses. Espessura aproximada: 8 metros;

3 - Dois níveis marinhos na base do enchimento, segundo Breuil e Zbyszewski (BREUIL \& ZBYSZEWSKI, 1945), estes níveis serão contemporâneos do Riss-Wurm e a plataforma lapizada, situada por cima da entrada da gruta, é o vestígio de uma antiga praia, datada do Riss." (ROCHE, 1971, p.40).

Os estratos plisitocénicos correspondem à unidade dois. Nesta unidade, com oito metros foram definidos, por Nery Delgado, um conjunto de 14 estratos de areias, onde ele definiu sete "níveis ossíferos", no poço, e dois estratos na galeria, com restos faunísticos (DELGADO, 1884).

\begin{tabular}{|c|c|c|c|}
\hline \multirow{2}{*}{$\begin{array}{c}\text { Nivel ossífero } \\
1.9 \text { nível }\end{array}$} & \multicolumn{3}{|c|}{$\begin{array}{c}\text { Estratos Sedimentares } \\
\text { (profundidade em metros) }\end{array}$} \\
\hline & 9 & 9,3 & \\
\hline 2.9 nível & 7,6 & 7,9 & \\
\hline 3.9 nível & 6 & 6,3 & 6,5 \\
\hline 4.9 nível & 5,8 & & \\
\hline 5.9 nível & 5 & & \\
\hline 6.9 nível & 3 & 3,2 & \\
\hline 7.9 nível & 1,5 & & \\
\hline Galeria & 3,5 & 5,8 & \\
\hline
\end{tabular}

Quadro 3 - Relação entre a profundidade dos estratos sedimentares e os níveis ossíferos correspondentes, definidos por Nery Delgado (DELGADO, 1884). 


\subsection{3 - Gruta das Salemas}

A Gruta das Salemas está localizada em Ponte de Lousa, a cerca de meio quilómetro a sul do povoado das Salemas, no lugar do Alto da Toupeira, na freguesia de Lousa, concelho de Loures e distrito de Lisboa. As coordenadas geográficas são: latitude de 38. $52^{\prime} 38^{\prime \prime}$ norte e longitude de 9. ${ }^{\circ} 12^{\prime} 08^{\prime \prime}$ a oeste de Greenwich. Esta estreita fissura está a 250 metros de altitude, na vertente oriental de vale muito encaixado.

A gruta encontra-se na base de uma pequena cornija que domina o flanco esquerdo do vale da Ribeira da Lage, na mesma formação de lapias da Pedreira das Salemas. A gruta configura uma pequena e estreita fissura, de planta irregular, sinuosa e estreita, resultante do alargamento de um acidente tectónico. Tem a extensão de cerca de 30 metros e a largura média de 1 metro. No chão, à entrada e ao longo da gruta encontram-se pequenas marmitas (buracos) e fracturas preenchidas na sua maioria por terra rossa, resultante da alteração do próprio calcário (ROCHE, 1972; CARDOSO, 1993). 


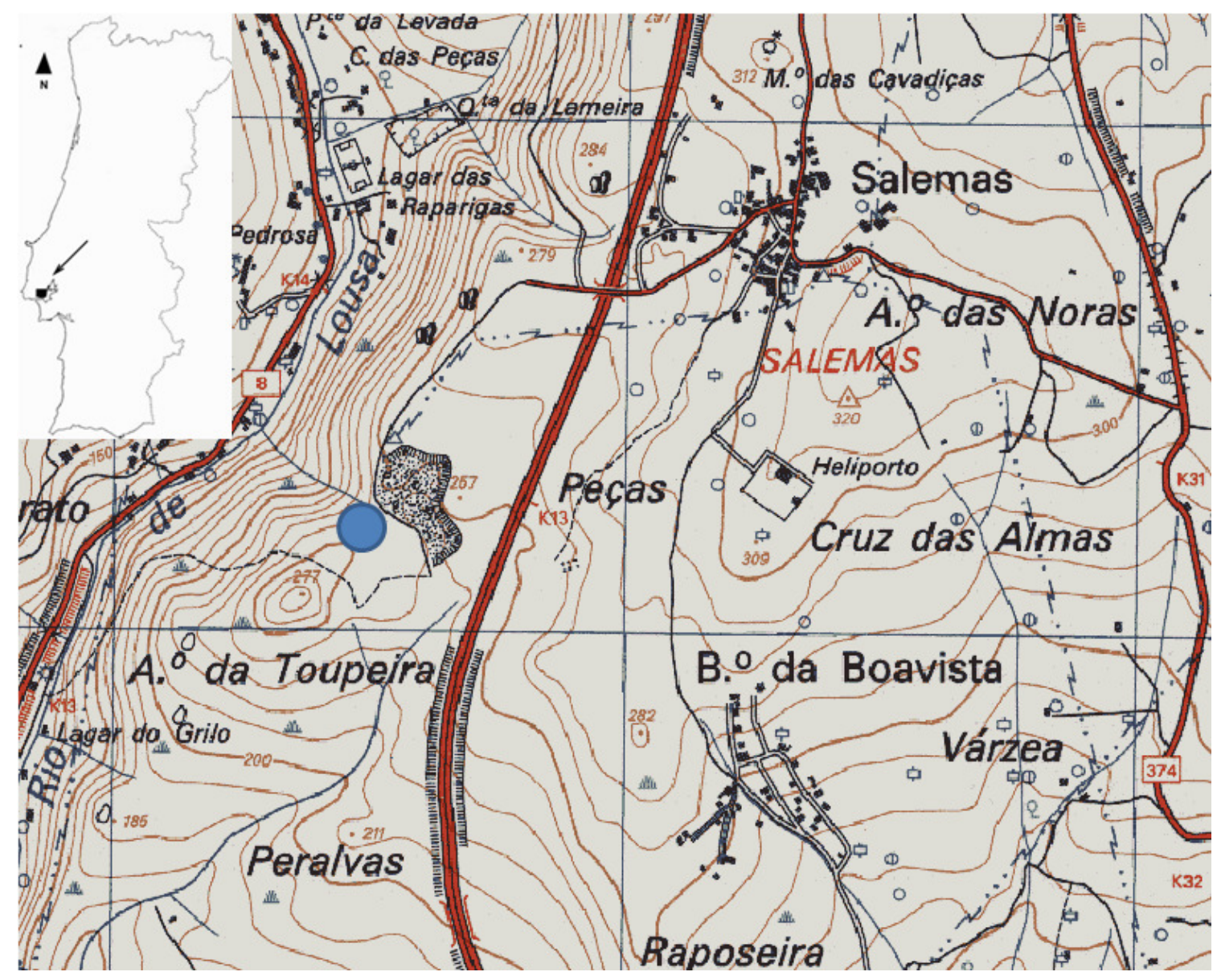

Fig. 18- Localização na Carta Militar de Portugal, à escala de 1:25000 (folha 403), da Gruta das Salemas. Edição dos serviços cartográficos do Exército.

Foram obtidas duas datações absolutas de C14, no ICEN (Instituto de Ciências e Engenharia Nucleares), actual ITN (Instituto de Tecnologia Nuclear), sobre alguns materiais ósseos (ANTUNES et al. 1989), nos níveis definidos por Roche (ROCHE et al., 1962), como Mustierense e Solutrense, que deram os seguintes resultados: o nível mustierense: $24.820 \pm 520$ e o nível Solutrense, $20.250 \pm 320$. Estas datações apontam para o Gravetense.

A gruta formou-se em calcários duros, que contêm restos de rodistas ${ }^{18}$ datados de inícios do Cretácico Superior (finais do Cenomaniano, cerca de $95 \mathrm{Ma}$ ). A sudoeste, em direcção ao Alto da Toupeira, observa-se o contacto, em discordância, desta

18 Os rodistas eram bivalves epibentónicos sésseis, do Jurássico Superior e do Cretácico, que viviam em colónias e formavam grandes recifes, cimentado as valvas direitas. Algumas espécies do Cretácico desenvolveram valvas direitas (inferiores) cónicas e as esquerdas (superior) redondas e espalmadas. Extinguiram-se no final do Cretácico Superior. 
formação calcária com o complexo vulcânico de Lisboa.

Uma parte inferior da fissura corresponde a uma fenda relacionada com o sistema cársico local, que facilitou o movimento dos depósitos mais antigos (Paleolítico Médio), até à colmatação da fenda. Os depósitos do Paleolítico Superior já se encontram num nível superior ao dessa parte inferior da fissura.

A estratigrafia geológica apenas estava bem conservada nas secções 7, 8, 9, 10 e 11. A sucessão estratigráfica foi descrita por Jean Roche e Veiga Ferreira (1970) da seguinte forma, de cima para baixo:

"C. 1 - Terras negras, ricas em matéria orgânica, ravinando as camadas subjacentes. Abundantes materiais neolíticos (líticos, cerâmicos, ósseos) correspondentes à instalação de uma necrópole; a fauna compreende pequenos animais que frequentariam a gruta $(1 \mathrm{~m}$ de espessura);

C.2 - Mistura de sedimentos neolíticos e paleolíticos. Foi possível observar, em secção, os enterramentos e encontrar ossos humanos in situ (0.10 m a $1.50 \mathrm{~m}$ de espessura);

C.3 - Topo das camadas paleolíticas, ligeiramente remexidas $(0.10$ a $0.30 \mathrm{~m})$

C. 4 - Terras cinzentas, pulverulentas, com carvões e pequenas pedras calcinadas. Nas seç̧ões 7-8-9 observaram-se blocos caídos do tecto. Nas secções 9-10-11, este nível está separado do anterior por um entroncamento contínuo de pequenos blocos, talvez a base da $\mathrm{C} 3$. Recolheram-se abundantes materiais faunísticos $e$ indústrias do solutrense superior ( 0.10 a $0.40 \mathrm{~m}$ de espessura);

C. 5 - Terras negras pulverulentas, incluindo seis lareiras sobre leitos de seixos calcinados ou fracturados pelo calor. Na lareira inferior, que abrange quase todo o comprimento da base da camada, foi recolhida a maior indústria lítica e óssea. A fauna é idêntica à da C. 4; os artefactos líticos correspondem ao Solutrense superior ( 0.10 a 0.60 m de espessura);

C. 6 - Terras cinzento-escuras, com numerosos elementos angulosos, pequenos e médios: $O$ deslizamento de sedimentos, pela acção da gravidade para a fissura no substracto começa a torna-se perceptível nas secções 8 e 9. Nas secções 7 e 8 há duas lareiras sobre as quais foram dispostos pequenos blocos, parcialmente calcinados. Indústrias e fauna 
idênticas às anteriores ( 0.18 a $0.30 \mathrm{~m}$ de espessura;

C. 7 - Terras amarelo-avermelhadas, contendo numerosos elementos pequenos e médios. O deslizamento dos sedimentos através das fissuras do substrato é nítido. A fauna é abundante, ao contrário da indústria, do tipo perigordense (0.10 a 035 m de espessura);

C. 8 - No interior das fissuras, observou-se mistura de "terra rossa" com terras argilosas castanhas. É provável que se trate de sedimentos de dois níveis diferentes. Abundante fauna. Recolheu-se um segundo molar inferior de criança de 4 a 6 anos (FEREMBACH, 1962). A indústria, pouco típica, foi recolhida nos sectores da gruta onde houve remeximentos importantes. Foi atribuída, com reservas, ao Paleolítico médio." (ROCHE \& FERREIRA, 1970; ROCHE, 1972).
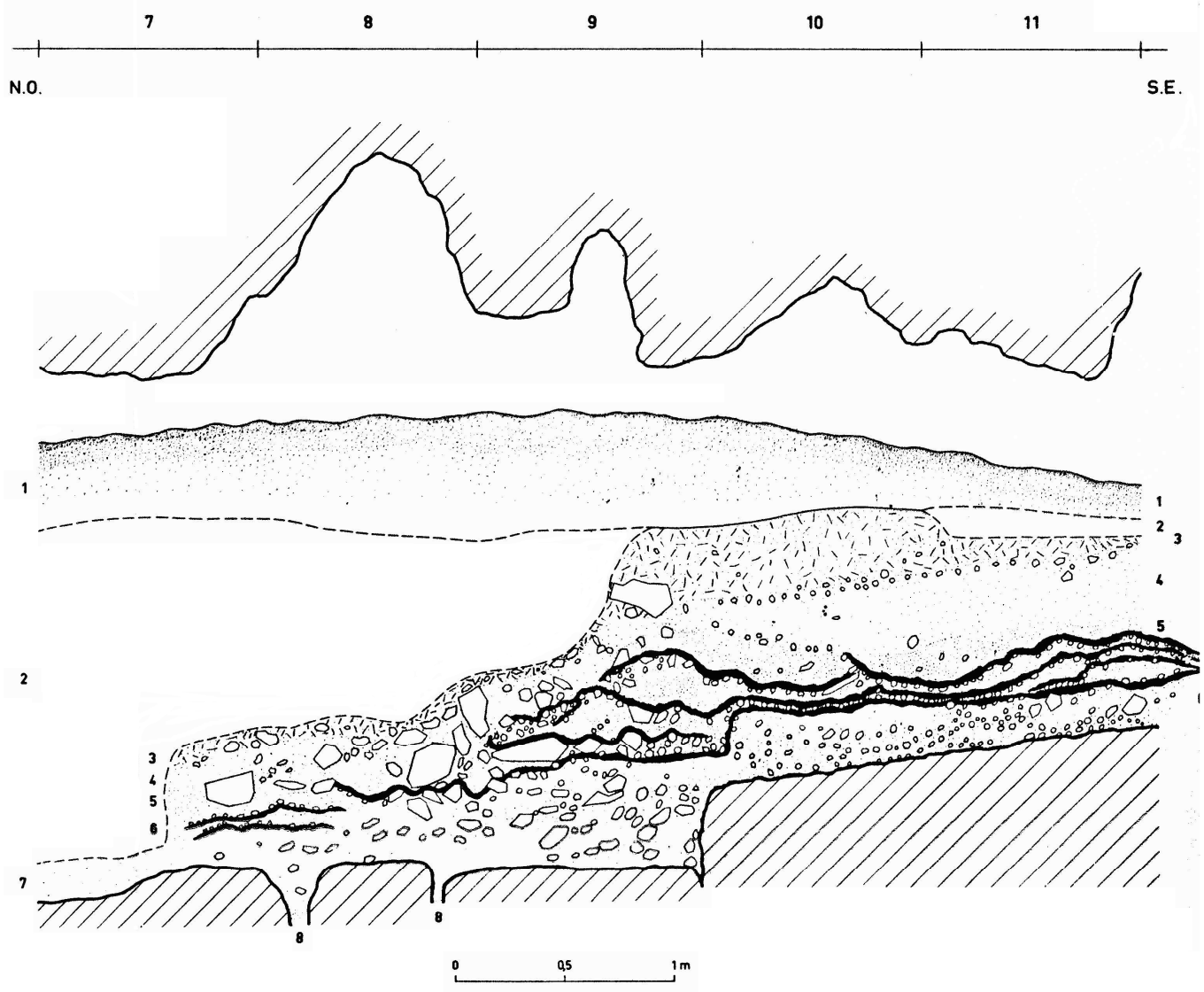

Fig. 19 - Representação da estratigrafia da Gruta das Salemas, segundo ROCHE \& FERREIRA, 1970.

\subsection{4 - Gruta do Pego do Diabo}

A Gruta do Pego do Diabo, também conhecida como Gruta ou Loca do gato, localiza-se na vertente sul do vale do Rio de Loures, no Lugar de Mingarrinhos, na 
freguesia e concelho de Loures, distrito de Lisboa. Encontra-se a uma altitude de cerca de 250 metros e as coordenadas geográficas são: 9. 13' e 6" Oeste de Greenwich e 38. 51' 52”' Norte (ZILHÃO, 1997, Vol. II).

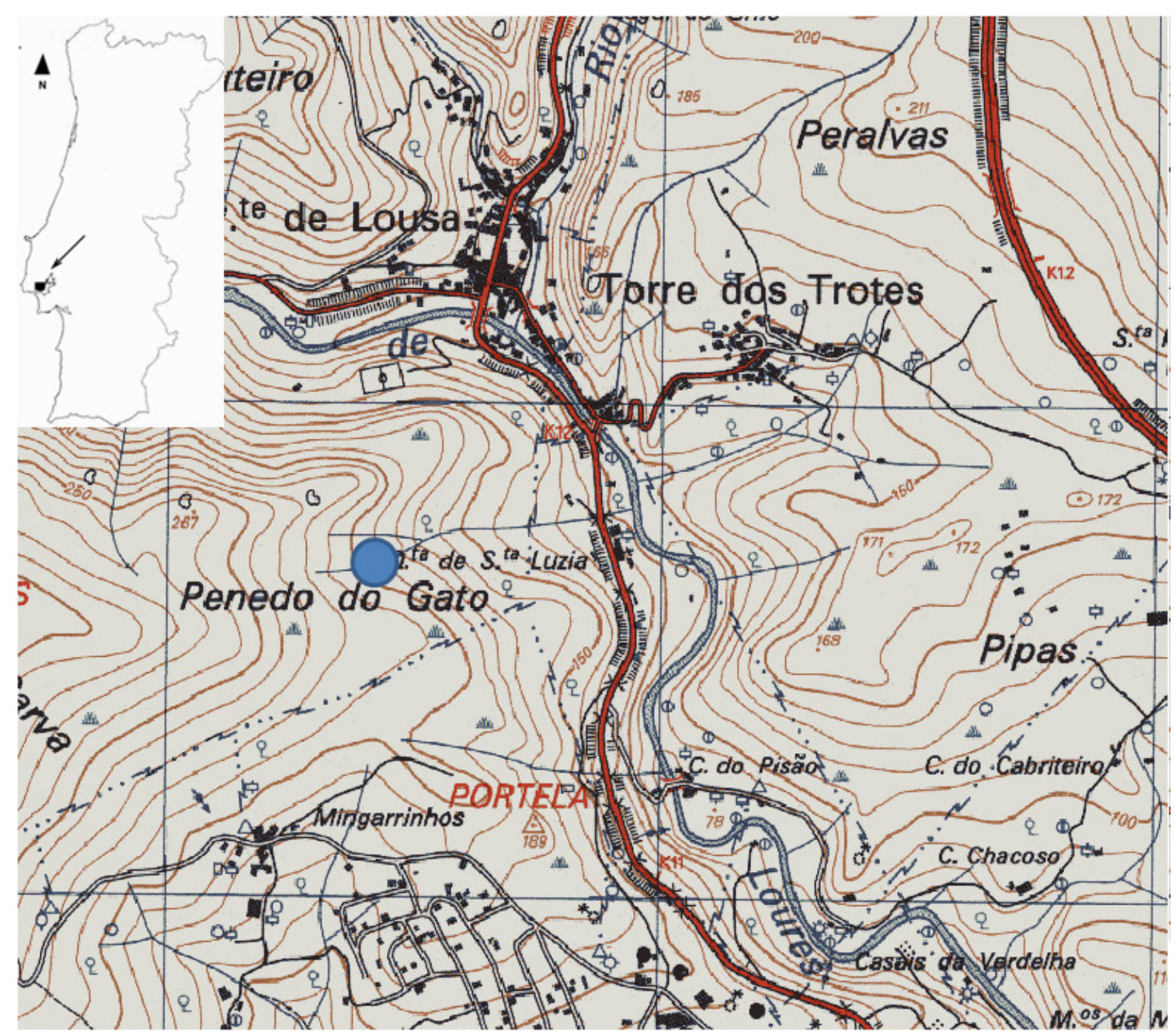

Fig. 20 - Localização na Carta Militar de Portugal, à escala de 1:25000 (folha 403), da Gruta do Pego do Diabo. Edição dos serviços cartográficos do Exército.

Situa-se na confluência de dois cursos de água: o Rio de Loures e o Rio de Lousa. A planta desta gruta é em forma de saco, em que o chão rochoso aflora à entrada, mas afunda para o interior. A gruta é constituída por uma galeria estreita, com cerca de 13 metros de comprimento e termina numa pequena câmara, com cerca de 2 metros de comprimento, disposta perpendicularmente ao eixo da galeria e dela separada por uma proeminência rochosa do tecto (ZILHÃO, 1997, p. 93).

A Gruta do Pego do Diabo é uma pequena cavidade cársica situada em calcários do Cretácico Superior (Turoniano). A planta da gruta é constituída por uma 
estreia galeria com cerca de treze metros de comprimento, que termina numa pequena câmara, com cerca de dois metros, disposta perpendicularmente ao eixo da galeria e separada desta por uma proeminência rochosa do tecto (ZILHÃO, 1988).

A forma da gruta (em saco) permitiu a conservação de uma sequência sedimentar. Esta sequência, com seis camadas naturais, foi reconhecida através de uma sondagem realizada a cerca de onze metros da entrada e que atingiu 1,40 metros de profundidade (ZilLHÃO, 1997, p. 93,94). A estratigrafia foi descrita da seguinte forma:

\section{“Camada A}

Camada de blocos em matriz argilosa, com abundantes carvões, datados de 2410 \pm 80 BP (ICEN-306). A incompatibilidade entre estas datações e o conteúdo da camada 2 indicam que os carvões serão intrusivos. Nesta camada, apenas representada na zona mais profunda da gruta, também foram encontradas cerâmicas.

\section{Camada 1}

Camada apenas visível nos quadrados situados contra a parede norte da cavidade. Trata-se de uma camada de remeximento da C.2. Nela foram encontrados restos de fauna plistocénica e alguma indústria lítica, idêntica à da C.2, e elementos intrusos como restos de faunas e cerâmicas modernas.

\section{Camada 2}

Cascalheira densa em matriz areno-argilosa de cor castanha, com cerca de $40 \mathrm{~cm}$ de espessura média. Nas escavações observaram-se dois níveis distintos, um mais argiloso que outro. O inferior, mais argiloso é encimado por grandes blocos de abatimento. Ambos os níveis possuíam artefactos do mesmo tipo e fauna plistocénica. Onde esta camada chegava à superfície tinha elementos intrusos, de que são exemplos fauna doméstica e cerâmica actuais.

\section{Camada 3}

Esta camada tem uma espessura média de $20 \mathrm{~cm}$. Tinha poucos blocos, de cor amarelada e mais argilosa que a C.2. Tinha um contexto arqueológico muito pobre apenas se encontraram seis lascas de sílex. No que respeita à fauna estão representadas menos espécies que a anterior: 
coelhos e pequenos carnívoros e fragmentos de ossos longos de animais de porte médio (talvez cervídeos).

\section{Camada 4}

Camada de argilas vermelhas com uma potência de $90 \mathrm{~cm}$. Apenas se recolheu uma faca de dorso natural de sílex muito patinado e restos de coelho.

\section{Camada 5}

Camada estéril, de textura muito fina e cor acinzentada, de areias e siltes". (ZILHÃO, 1997, Vol. II p. 94, 95).

A Camada dois continha indústria aurinhacense, enquanto as camadas três e quatro deverão ter sido depositadas no Paleolítico Médio ". (ZILHÃO, 1997, Vol. II p. $94,95)$.

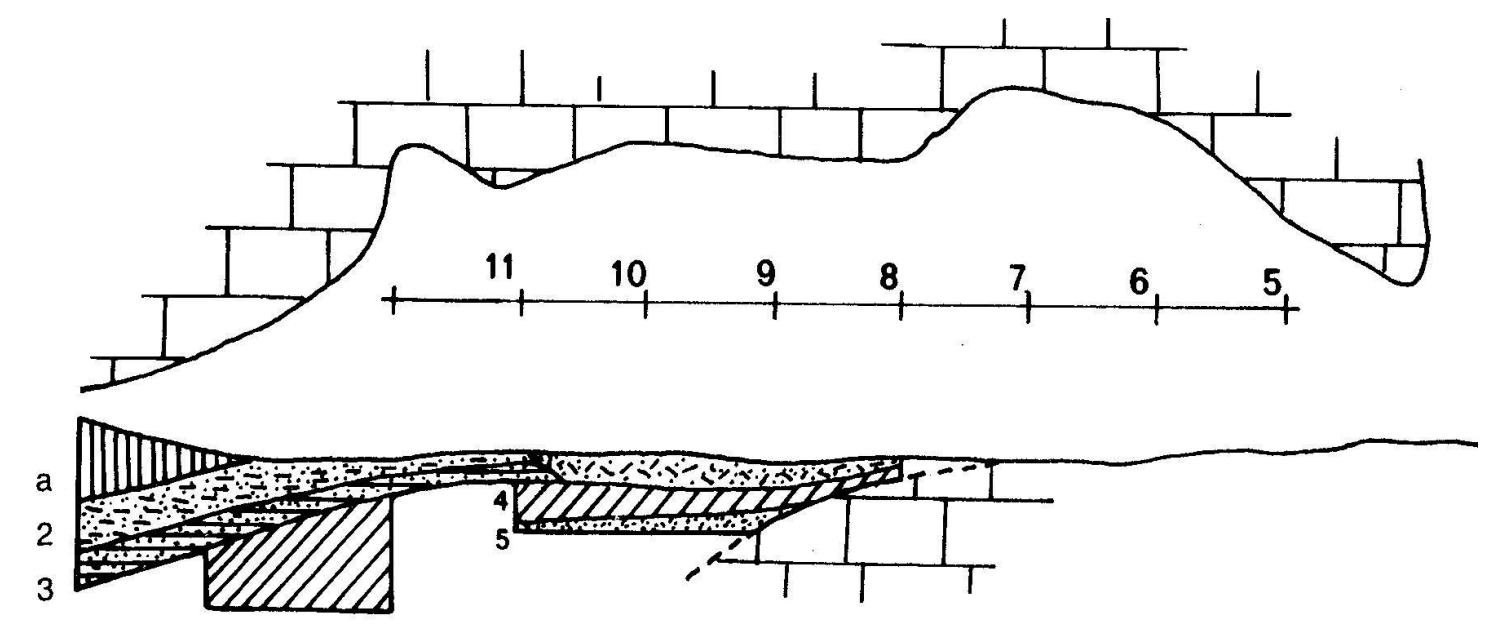

Fig. 21 - Desenho do corte estratigráfico longitudinal da Gruta do Pego do Diabo, com a indicação das camadas estratigráficas. Segundo ZILHÃO, 1997.

\subsection{5 - Gruta das Fontainhas}

A Gruta das Fontainhas localiza-se na Serra de Montejunto, alguns quilómetros a su-sudoeste da Vila do Cercal, no primeiro planalto calcário daquela serra a uma altitude de cerca de 400 metros. Administrativamente, está localizada na freguesia de Cercal, concelho de Cadaval e distrito de Lisboa; tem as seguintes coordenada geográficas: $39 .^{\circ} 11^{\prime} 37^{\prime \prime} \mathrm{N}$ e 9. $02^{\prime} 39^{\prime \prime} \mathrm{W}$ do meridiano de Greenwich. 


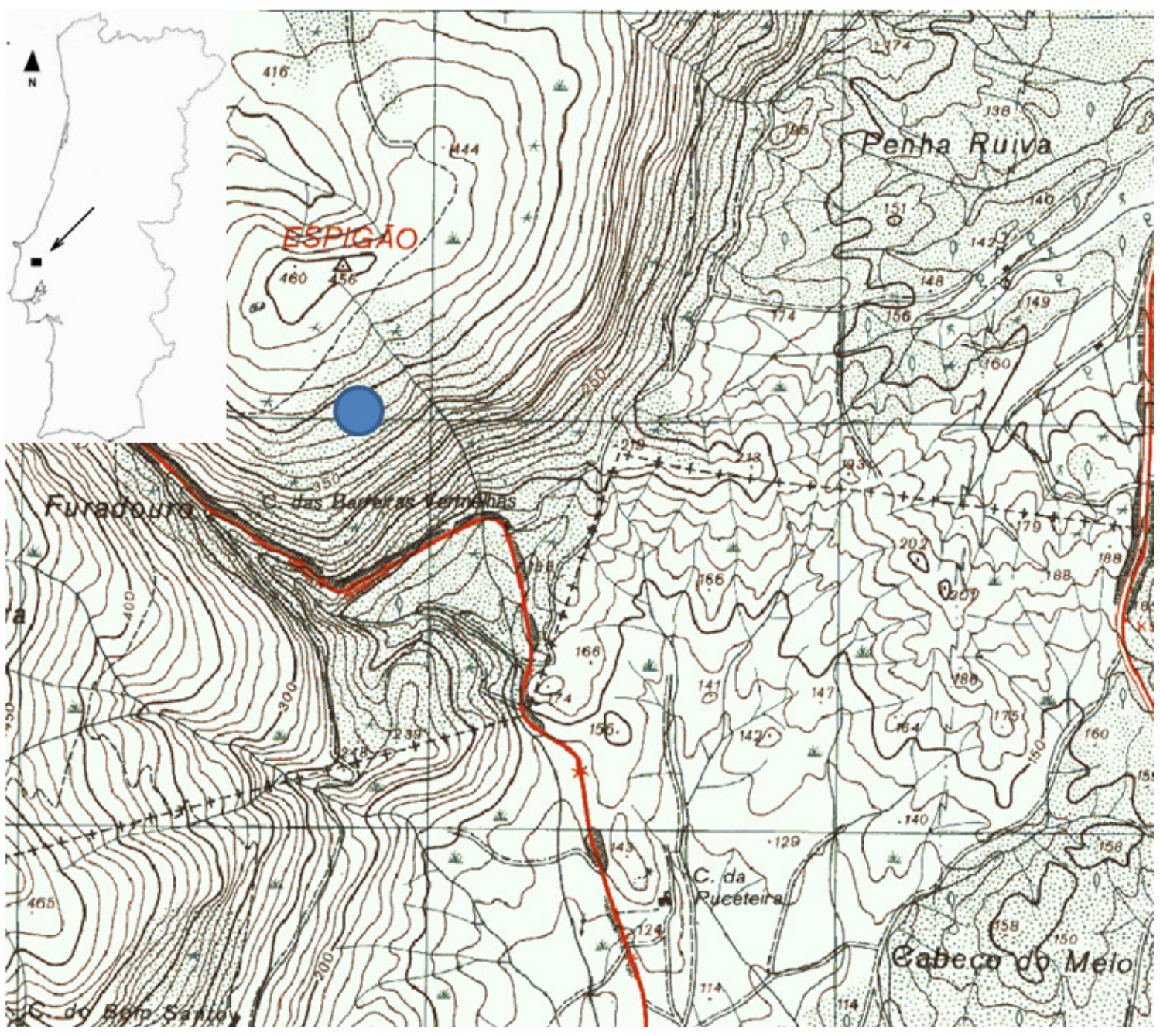

Fig. 22 - Localização na Carta Militar de Portugal, à escala de 1:25000 (folha 363), da Gruta das Fontainhas. Edição dos serviços cartográficos do Exército.

A Serra de Montejunto possui um conjunto de cavidades e grutas com ocupação humana, na sua maioria da pré-história recente. A maioria dos materiais arqueológicos descobertos nas grutas da Serra de Montejunto encontra-se no Museu Geológico e no Museu Nacional de Arqueologia, em Lisboa. Grande parte destas grutas foi descoberta e estudada por António Maria Garcia, professor primário, falecido em 1908. Outro nome dos primórdios dos estudos da Serra de Montejunto foi o de Leite de Vasconcellos, que chegou a ser, por dois anos, subdelegado de saúde, no Cadaval. José Leite de Vasconcellos relacionou-se com António Maria Garcia, com quem realizou alguns trabalhos naquela zona. Mas foi Nery Delgado quem descobriu e estudou especificamente a Gruta das Fontainhas, que foi escavada apressadamente nos anos de 1879 e de 1880 pelo colector Manuel Roque, que se limitou a recolher os materiais e entregá-los, em Lisboa, a Carlos Ribeiro, sem 
qualquer relato dos mesmos (CARDOSO 1993, p. 80).

A Gruta das Fontainhas tem uma profundidade de 57 metros e um comprimento de 90 metros, caracterizada por galerias altas e estreitas. A entrada é feita por um algar e apresenta uma sedimentação litoquímica irregular e bastante escassa.

Os materiais provenientes da gruta das Fontaínhas encontram-se no Museu Geológico de Lisboa, existindo também, dois pequenos conjuntos fora deste museu: um na Faculdade de Ciências do Porto e outro no Instituto de Antropologia da Universidade de Coimbra.

\subsection{6 - Gruta da Casa da Moura}

A gruta da Casa da Moura foi descoberta e estudada por Nery Delgado na segunda metade do século XIX e Publicada em 1867, na primeira monografia portuguesa sobre uma jazida plistocénica (CARDOSO \& GOMES, 1994). Esta gruta, com uma entrada em forma de poço, que dá para uma sala principal, é uma cavidade inserida nos calcários do Jurássico do Planalto da Cesareda.

A Casa da Moura situa-se no rebordo norte do planalto das Cesaredas, no com o mesmo nome, a $1.5 \mathrm{~km}$ a Sudeste da Serra d'El Rei. Administrativamente pertence à freguesia de Olho Marinho, concelho de Óbidos e distrito de Leiria, nas coordenadas geográficas: 39. 19' 36" Norte e 9. $15^{\prime} 14^{\prime \prime}$ a Oeste de Greenwich. O planalto onde se situa esta gruta é uma pequena elevação, que tem uma altitude de cerca de 160 metros (ZILHÃO, 1997, Vol. II p. 181). O planalto das Cesaredas é sobranceiro à planície que se estende entre Óbidos e Peniche. 


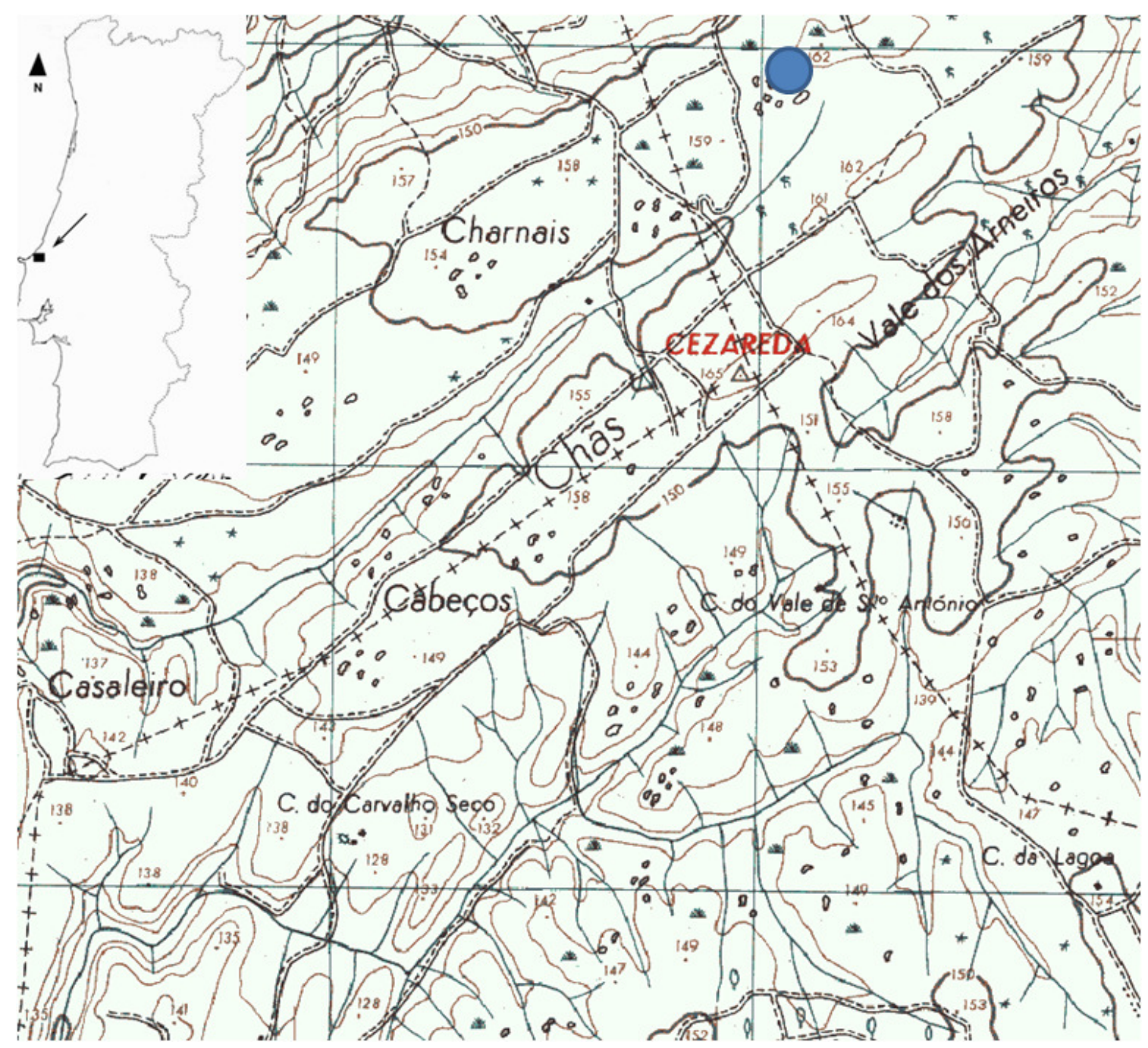

Fig. 23 - Localização na Carta Militar de Portugal, à escala de 1:25000 (folha 337) da Casa da Moura. Edição dos serviços cartográficos do Exército.

A planta da gruta é composta pela entrada e duas salas, que comunicam entre si. A entrada é em forma de poço rectangular, com cerca de três metros de largura e quatro de profundidade, que termina na primeira sala da gruta, com catorze metros de comprimento e doze de largura e quatro de altura, o tecto e as paredes são lisas. A segunda sala, transversal à primeira, tem uma abóbada irregular e tem dezasseis metros de comprimento, doze de largura e cerca de quinze de altura (DELGADO, 1867).

Esta gruta encontra-se numa formação de calcários muito compactos e rijos, que constituem o tecto da gruta (DELGADO, 1867). Estes calcários são do Jurássico Médio, do andar Batoniano.

Existem duas unidades principais, definidas por Nery Delgado (DELGADO, 1867): a unidade superior, onde se recuperaram abundantes restos humanos do 
Neolítico e Calcolítico e a unidade inferior, de idade Plistocénica, com cerca de um metro de espessura, apresenta alguns vestígios de actividade humana do Paleolítico Superior e uma abundante fauna quaternária (DELGADO, 1867).

A estratigrafia observada e publicada por Nery Delgado (DELGADO, 1867) é constituída por três camadas distintas:

Camada 1 - camada de base, constituída por um espesso estrato estalagmítico;

Camada 2 - Camada que assenta sobre a anterior, constituída por terras avermelhadas, de areias finas, muito concrecionada por placas, apresenta fauna abundante, mas indústria rara (cerca de 1 metro de espessura);

Camada 3 - Camada superior, terras argilo-arenosas escuras. Fauna abundante, vestígios de lareiras. Restos humanos abundantes (correspondentes a cerca de 150 indivíduos). Indústria rica. (DELGADO, 1867).

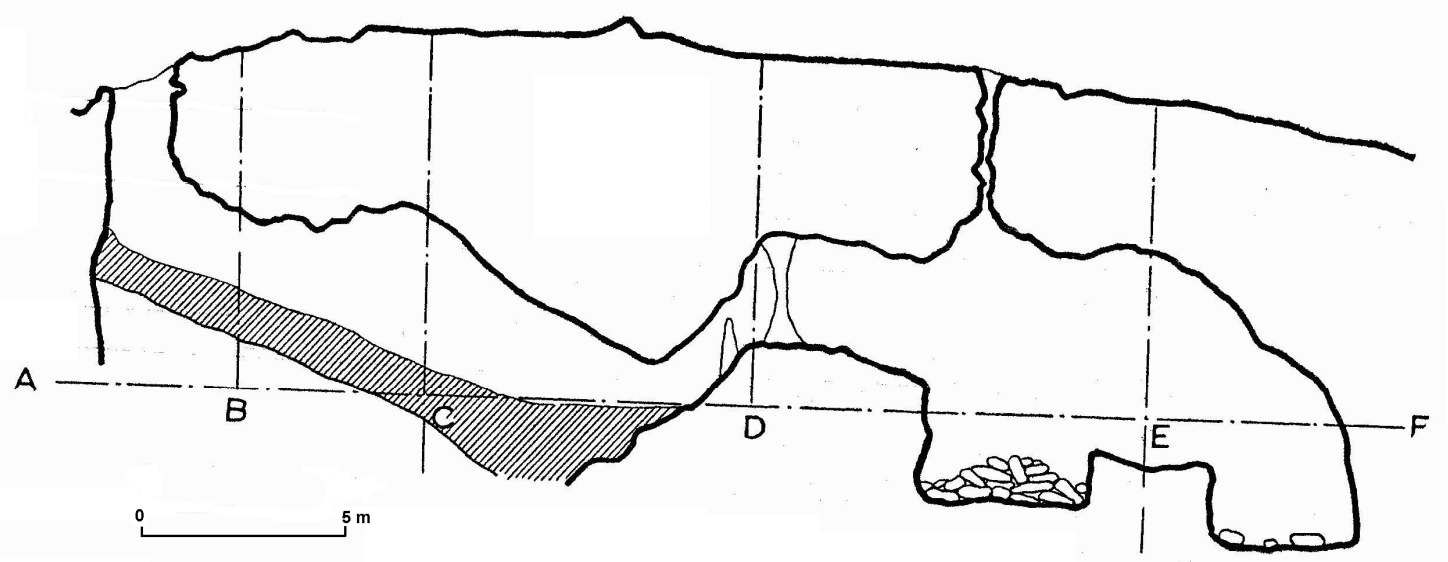

Fig. 24 - Representação do corte logitudinal da gruta da Casa da Moura, segundo ROCHE, 1951.

\subsection{7 - Lapa da Rainha}

A Lapa da Rainha situa-se perto de Maceira, a Norte de Lisboa. Trata-se de uma gruta que se abre na extremidade superior dos bordos de uma falha. É uma diáclase 
alargada, de planta sinuosa (ALMEIDA et al., 1970), constituída por uma longa galeria de cerca de 28 metros e uma largura média de 8 metros (CARDOSO, 1993).

Localizada nos terrenos da empresa que explora as águas do Vimeiro, a Lapa da Rainha situa-se perto da freguesia de Maceira concelho de Torres Vedras e distrito de Lisboa, as coordenadas geográficas são: $30^{\circ} 11^{\prime} 00^{\prime \prime}$ Norte; 9.'19'22" Oeste (Greenwich) (CARDOSO, 1993).

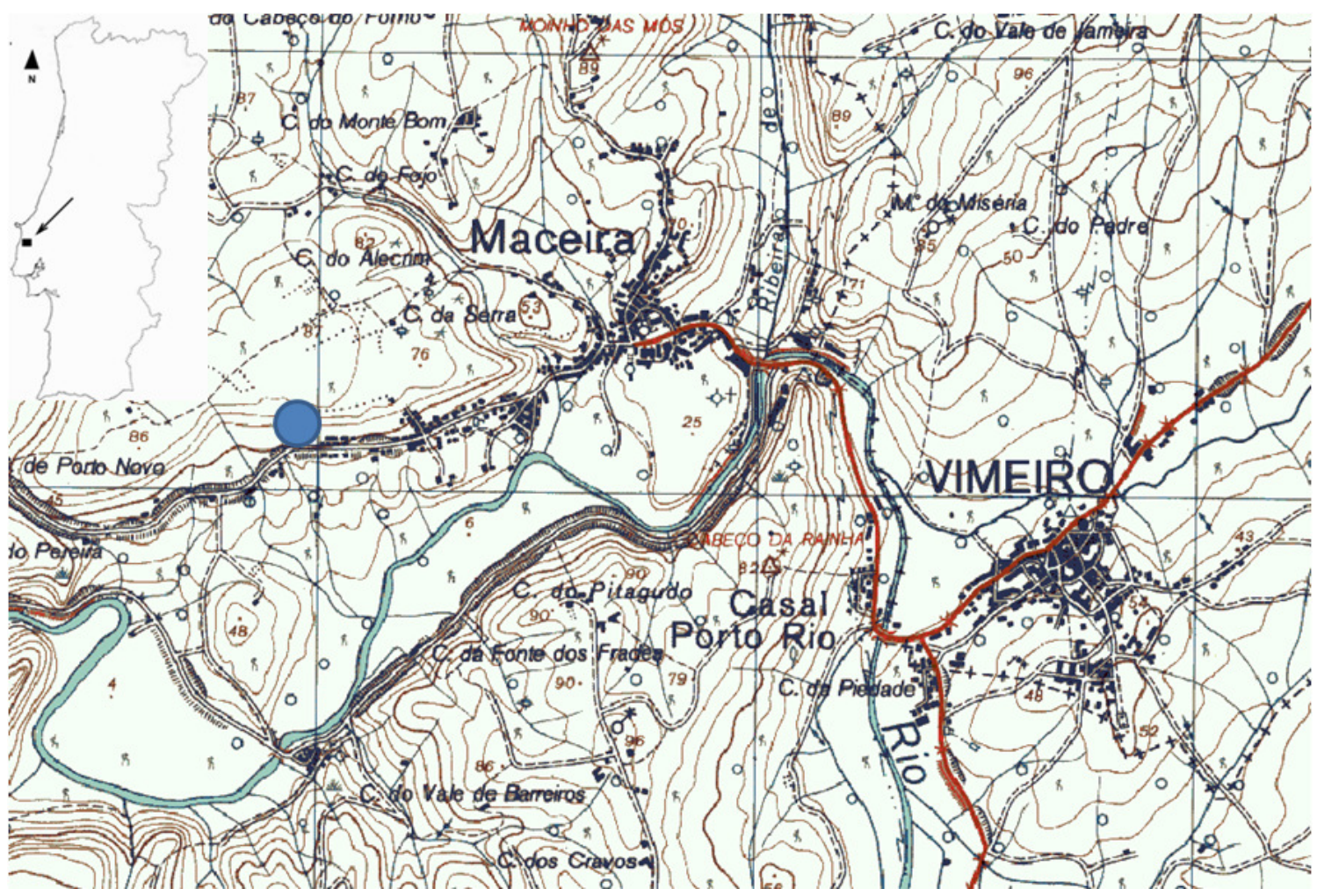

Fig. 25 - Localização na Carta Militar de Portugal, à escala de 1:25000 (folha 361), da Lapa da Rainha. Edição dos serviços cartográficos do Exército.

A actual entrada da gruta não corresponde à primitiva, que foi descoberta por um tiro de pedreira, localizando-se do lado oposto da actual. A entrada primitiva estava voltada para a actual oficina de engarrafamento das águas do Vimeiro.

A Lapa da Rainha localiza-se no vale tifónico do Rio Alcabrichel, formado em calcários do Jurássico Inferior (do andar Sinemuriano). Este vale é ladeado por falhas longitudinais e profundas. Esta gruta foi aberta por erosão cársica, através da dissolução dos calcários nas diáclases, pela água saturada de gás carbónico ácido (ALMEIDA et al., 1970).

A parte interior da gruta é constituída, na parte inferior do enchimento, por 
um depósito de terraço fluvial. Foi possível relacionar este depósito com outros exteriores à gruta, o que permite datar geologicamente a base do enchimento da gruta.

A estratigrafia foi identificada através da abertura de dois cortes. O primeiro, com 9 metros de comprimento, aberto na zona mais afastada da primitiva entrada e perpendicularmente à planta da gruta, permitiu identificar um terraço fluvial; o segundo, longitudinal à gruta, permitiu identificar as camadas estratigráficas. Jean Roche participou nestes trabalhos e foi ele quem estudou a estratigrafia, identificando seis camadas:

1- "Terras negras revolvidas. Espessura: de 0.10 a $1 \mathrm{~m}$.

2- $\quad$ Terras cinzentas claras, concreções, solo antigo sobre o qual se depositaram finas partículas de calcário proveniente da desintegração progressiva da abóbada. Espessura: $0.05 \mathrm{~m}$

3- Terras argilo-arenosas. Restos humanos. Fauna. $\mathrm{Na}$ base indústrias e lareiras. Espessura máxima: $0.05 \mathrm{~m}$

4- $\quad$ Leito de blocos que caíram da abóbada. Indústrias e faunas. Espessura média: $0.25 \mathrm{~m}$

5- $\quad$ Argilas avermelhadas. Fauna (covil de hiena). Espessura média: $0.25 \mathrm{~m}$

6- $\quad$ Depósito de terraço fluvial de 30 - 40 metros de espessura: $1 \mathrm{~m}^{\prime \prime}$. (FERREIRA, 1975, p. 43).

Segundo esta estratigrafia a primeira ocupação da gruta está documentada na camada cinco, através de restos (eufósseis e icnofósseis) de hienas. Mais tarde, nas camadas quatro e três deu-se uma nova ocupação da gruta por faunas e também por comunidades humanas. Nestas camadas foram encontrados alguns restos de carnívoros e de herbívoros, os ossos destes últimos apresentam marcas de predeção. A ocupação humana também está documentada nas camadas quatro e três. A camada quatro revelou a existência de indústrias líticas e a camada três, a existência de estruturas (lareiras e fundos de habitat), indústria lítica, restos humanos e fauna (ALMEIDA et al., 1970; CARDOSO \& GOMES, 1994). 


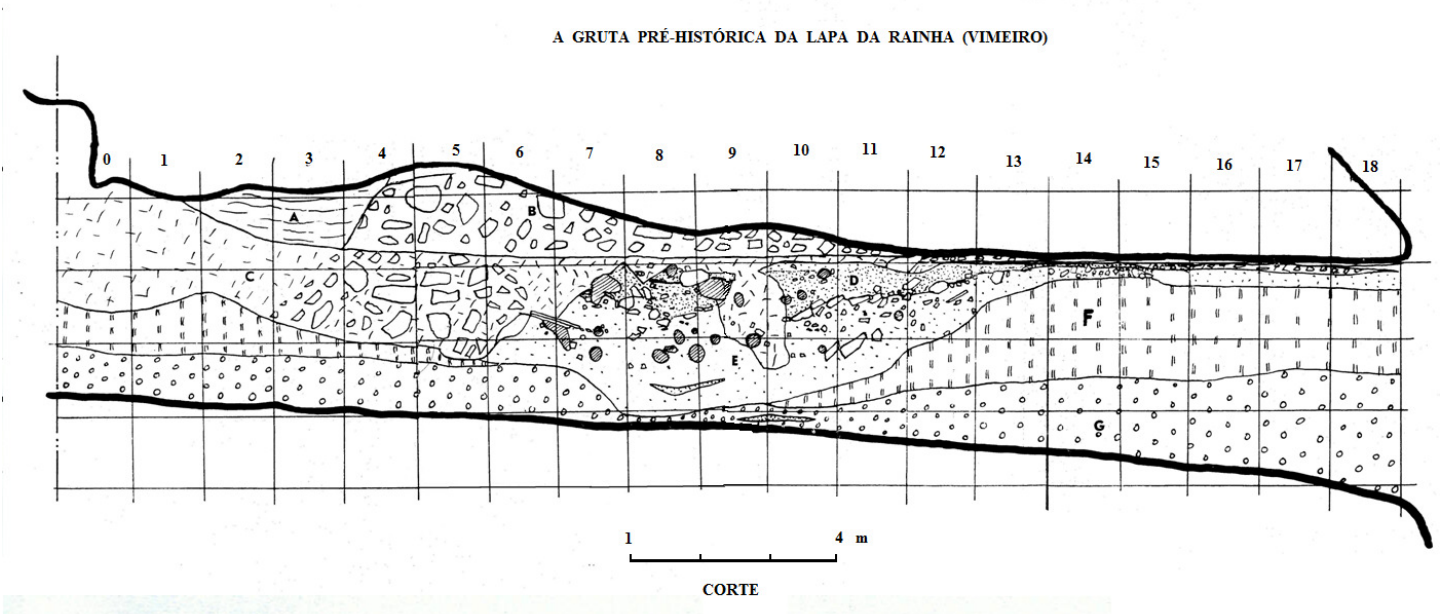

Fig. 26- Representação da estratigrafia da Lapa da Rainha, segundo ALMEIDA; SANTOS; ROCHE \& FERREIRA (1970).

\subsection{8 - Gruta do Caldeirão}

A Gruta do Caldeirão está situada na Região Centro, a cerca de 7 Km, a norte de Tomar, Freguesia de Pedreira, concelho de Tomar e distrito de Santarém. É uma cavidade localizada a cerca de 400 metros do rio Nabão, que se abre a 120 metros de altitude e tem as seguintes coordenadas geográficas: $39 .{ }^{\circ} 38^{\prime} 54^{\prime \prime}$ Norte e $8 .^{\circ} 24^{\prime} 54^{\prime \prime}$ Oeste de Greenwich (ZILHÃO, 1997, vol. II p109).

A Gruta do Caldeirão encontra-se situada num maciço calcário do Jurássico Inferior, cortado pelo Rio Nabão. Da sua entrada, virada para sul, tem-se uma vista sobre um vale muito encaixado, perpendicular ao do Nabão.

A estratigrafia da gruta é constituída por vários depósitos sedimentares que foram o resultado do transporte, para dentro da gruta, de sedimentos oriundos das formações detríticas miocénicas que se entram sobre os calcários jurássicos, onde a gruta se encontra, pelos processos erosivos ocorridos durante o Plistocénico e o Holocénico. Estes estratos sedimentares têm conservado os vestígios de ocupações humanas de várias épocas pré-históricas. A potência total da estratigrafia era de cerca de seis metros, observados no quadrado P11 (fig. 29), constituída por 19 camadas, agrupadas em três blocos sedimentares (ZILHÃO, 1997, Vol II). 


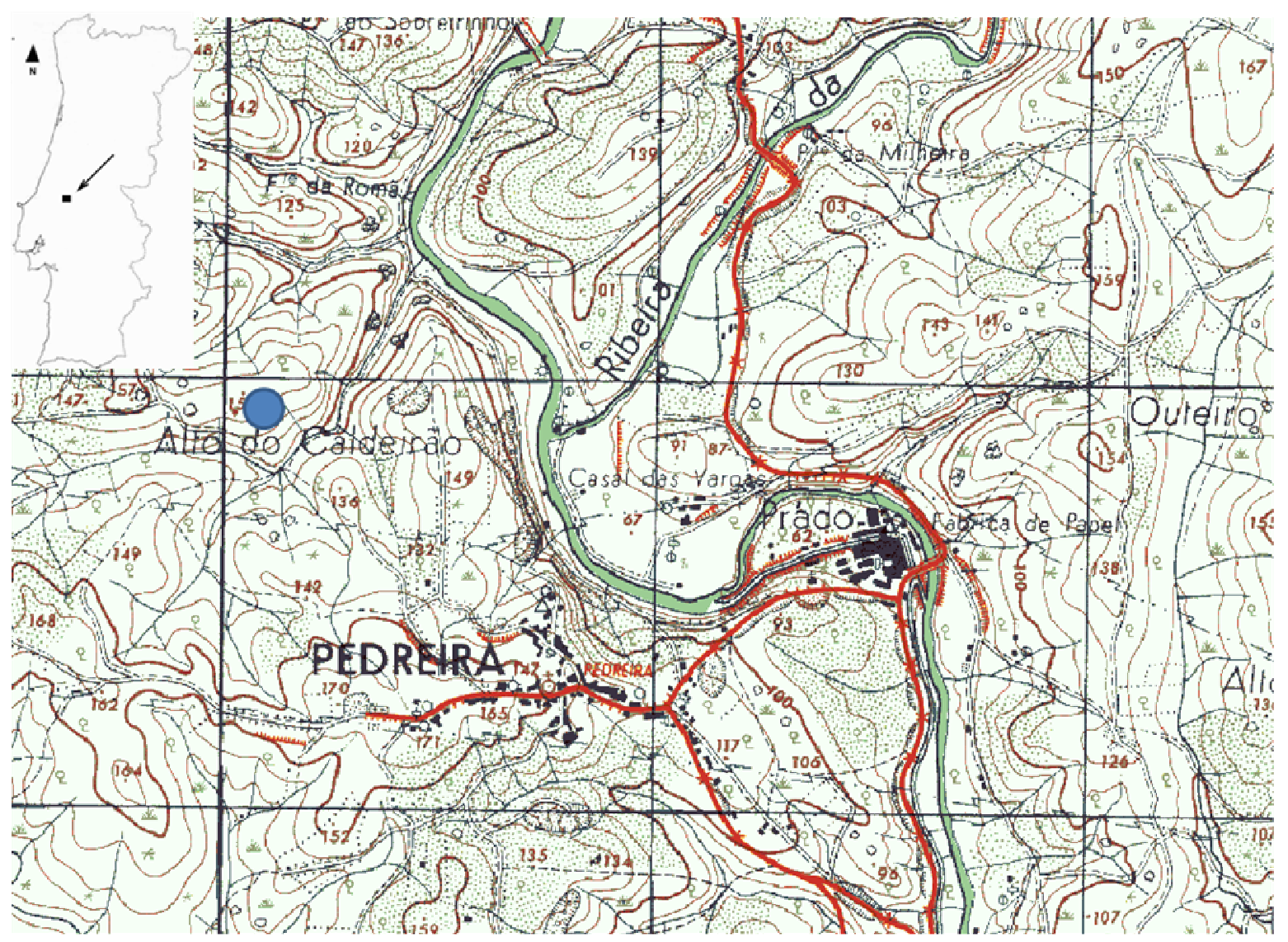

Fig. 27 - Localização na Carta Militar de Portugal, à escala de 1:25000 (folha 310), da Gruta do Caldeirão. Edição dos serviços cartográficos do Exército.

O bloco sedimentar da base da sequência, constituído por depósitos finos, de coloração negra, agrupa cinco camadas, da camada Q à camada L (figs. 29 e 30), e caracteriza-se por apresentar poucos vestígios arqueológicos, atribuídos ao Mustierense, mas abundantes restos de carnívoros, em especial de hiena, nas camadas M e L (ZILHÃO, 1997, Vol II, p. 113). A separação deste bloco, com o posterior por uma "linha" de descontinuidade, originada provavelmente por processos erosivos, que poderão estar relacionados com o interestádio de Denekamp, que ocorreu entre os 32.000 e os 29.000 BP (ZILHÃO, 1997, Vol II, p. 113).

O segundo bloco sedimentar agrupa oito camadas, da K à Fa (fig. 29). É constituído por um maior número de materiais arqueológicos, que o conjunto sedimentar anterior, ósseos e blocos de abatimento. A primeira camada (a K) terá sido depositada ainda no final do Mustierense, por volta dos 32.000 anos BP e todo este bloco, a partir da camada Jb (fig. 29), foi depositado durante o Paleolítico Superior, do Solutrense ao Magdalenense (ZILHÃO, 1997, Vol II, pp. 113-114). 


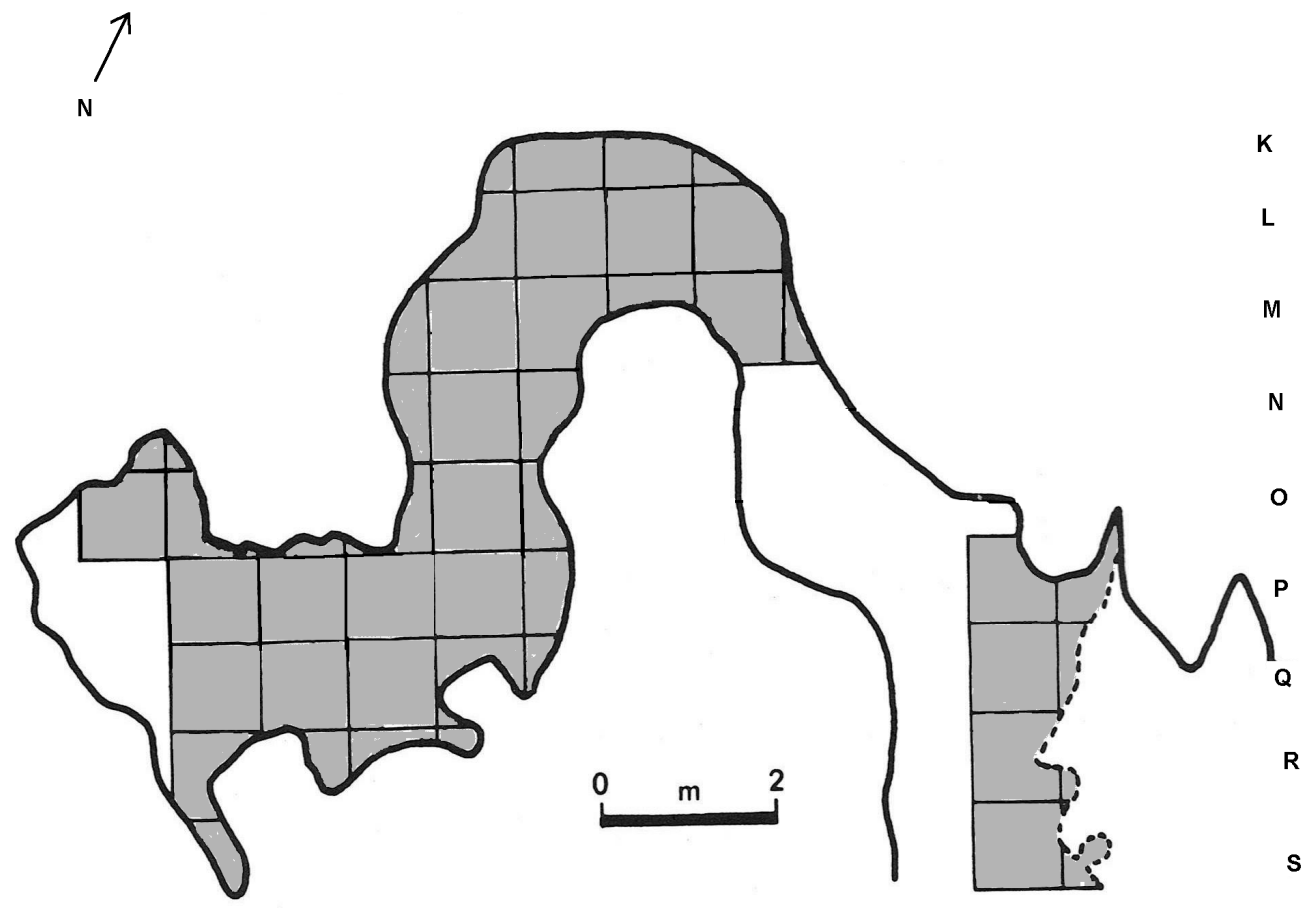

Fig. 28 - Planta da Gruta do Caldeirão, com a malha da quadriculagem e área escavada. (Adaptado de ZILHÃO, 1997, Vol II, pp. 111, 494 e 681).

O último bloco, constituído pelas últimas seis camadas, da Eb à D (fig. 29 e 30) apresenta uma primeira camada, a Eb, ainda plistocénica com datações entre cerca de 16.000 e cerca dos 10.000 anos Bp e que é apresenta uma sedimentação homogénea e materiais solutrenses, em deposição secundária, e magdalenenses, (ZILHÃO, 1997, Vol II, pp. 681-682), a camada Ea datada de entre os 6000 e os 5000 anos BP, que apresenta uma acumulação de grandes blocos de abatimento (ZILHÃO, 1997, Vol II, pp.682) e as últimas quatro atribuídas a um período de tempo que vai desde o Calcolítico até à Idade Média (ZILHÃO, 1997, Vol II, pp. 111-115). Este conjunto de camadas apresenta grandes blocos de abatimento, em especial na camada Ea (fig. 29 e 30).

A separação entre a camada Eb e a Ea, tal como na separação do bloco sedimentar de base e o bloco sedimentar sobrejacente, apresenta uma descontinuidade sedimentar, recomeçada na já no Holocénico, na camada Ea (figs. 29 e 30), o que provocou perturbações pós-deposicionais na camada Eb, especialmente na sala do fundo (ZILHÃO, 1997, Vol II, pp. 681). 


\section{Descrição das Camadas}

Foram descritos dois cortes, o perfil oeste do quadrado P11 (fig. XXX) e o corte longitudinal (fig. 30), nos quais foi observada uma potência máxima do enchimento explorado, com cerca de seis metros, como já foi referido (ZILHÃO, 1987, 1997, Vol. II). Assim foram definidas as seguintes camadas, ordenadas de cima para baixo:

$\boldsymbol{A} / \mathbf{B} / \mathbf{C} / \mathbf{D}$ - camadas com materiais com cronologias que vão do Calcolítico à Idade Média;

Ea - camada constituída por grandes blocos e materiais arqueológicos neolíticos;

Eb - camada considerada inicialmente do Neolítico antigo (Zilhão, 1985), não foi descrita em pormenor.

Fa - camada constituída, em parte, por grandes blocos, lages de abatimento do tecto e plaquetas, envolvidas por matriz areno-silto-argilosa de cor avermelhada.

Fb - camada onde predominam elementos finos com poucos fragmentos de calcário, às vezes muito corroídos, e pequenos seixos de quartzito. Na base, alguns fragmentos de calcário estão bastante arredondados.

Fc - formada por blocos e plaquetas, alguns de grandes dimensões, envolvidos por matriz castanho-avermelhada arenosilto-argilosa.

O - camada estalagmítica - descontínua na área escavada; é, às vezes, muito fina, correspondendo a um conjunto de crostas que se fragmentam com facilidade, passando, em alguns pontos, a manto mais coerente.

$\boldsymbol{H}$ - camada com blocos e placas, alguns com grandes dimensões, envolvidos por matriz muito fina. Nesta camada os blocos são mais raros, de menores dimensões e têm os cantos mais arredondados do que na camada $F c$, estando envolvidos por matriz mais silto-argilosa.

J - camada que continha fragmentos de calcário com 
angulosidade de arestas semelhante à da camada anterior, mas em maior quantidade, e alguns bastante volumosos.

$\boldsymbol{K}$ - nesta camada observou-se uma redução significativa de fragmentos de calcários com pequenas dimensões. Apresentava sedimentos finos constituem uma parte importante deste depósito. (Zilhão, 1985, 1987, 1997, Vol. II).

Segundo Zilhão (ZILHÃO, 1985, 1987, 1997 - Vol. II), abaixo desta sequência foram identificadas mais seis camadas, a $L$ e a $Q$, mas não foram descritas.

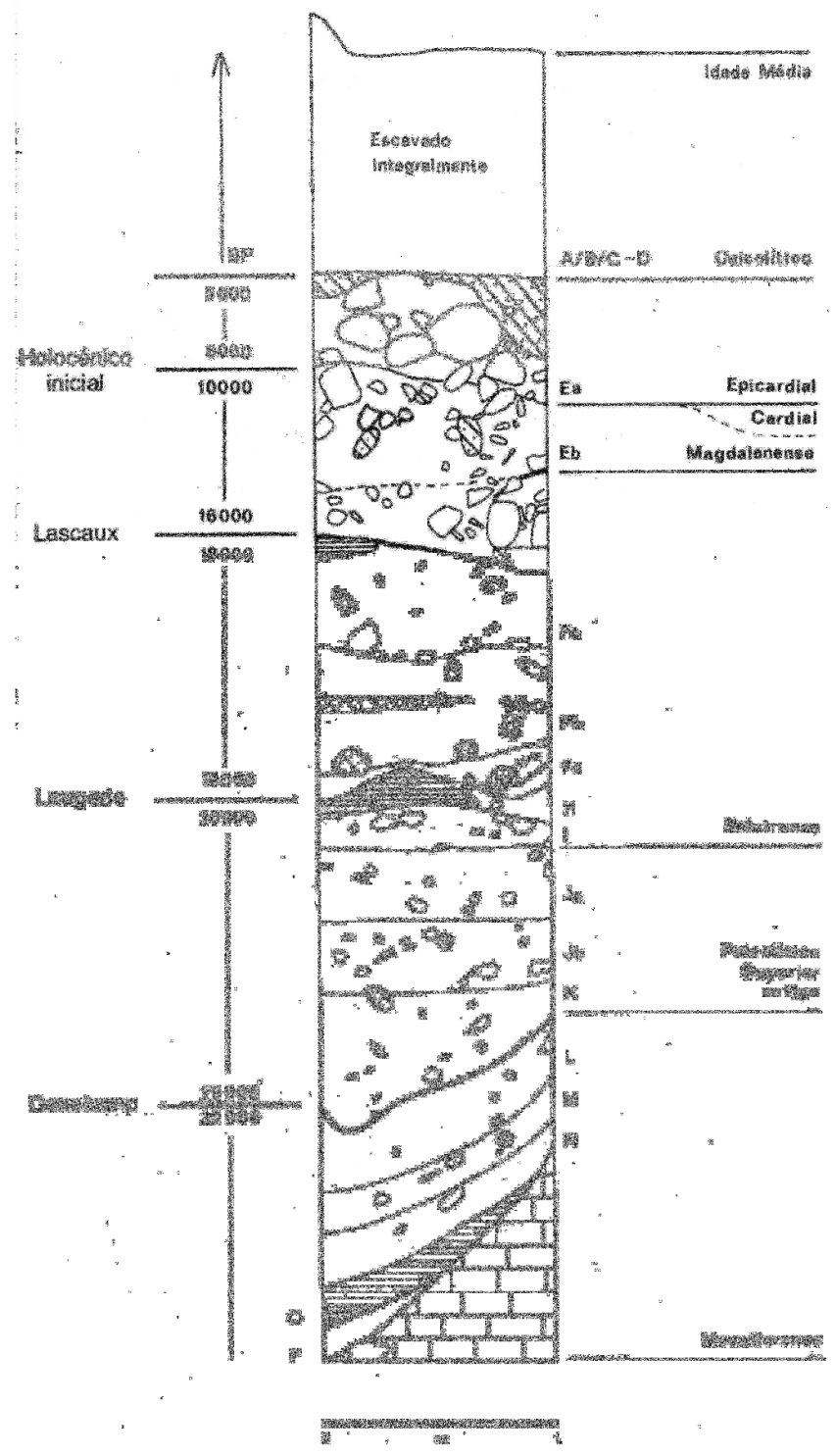

Fig. 29 - Esquema estratigráfico do perfil oeste, do quadrado P11 da Gruta do Caldeirão, segundo ZILHÃO, 1997, Vol II, p. 111. 


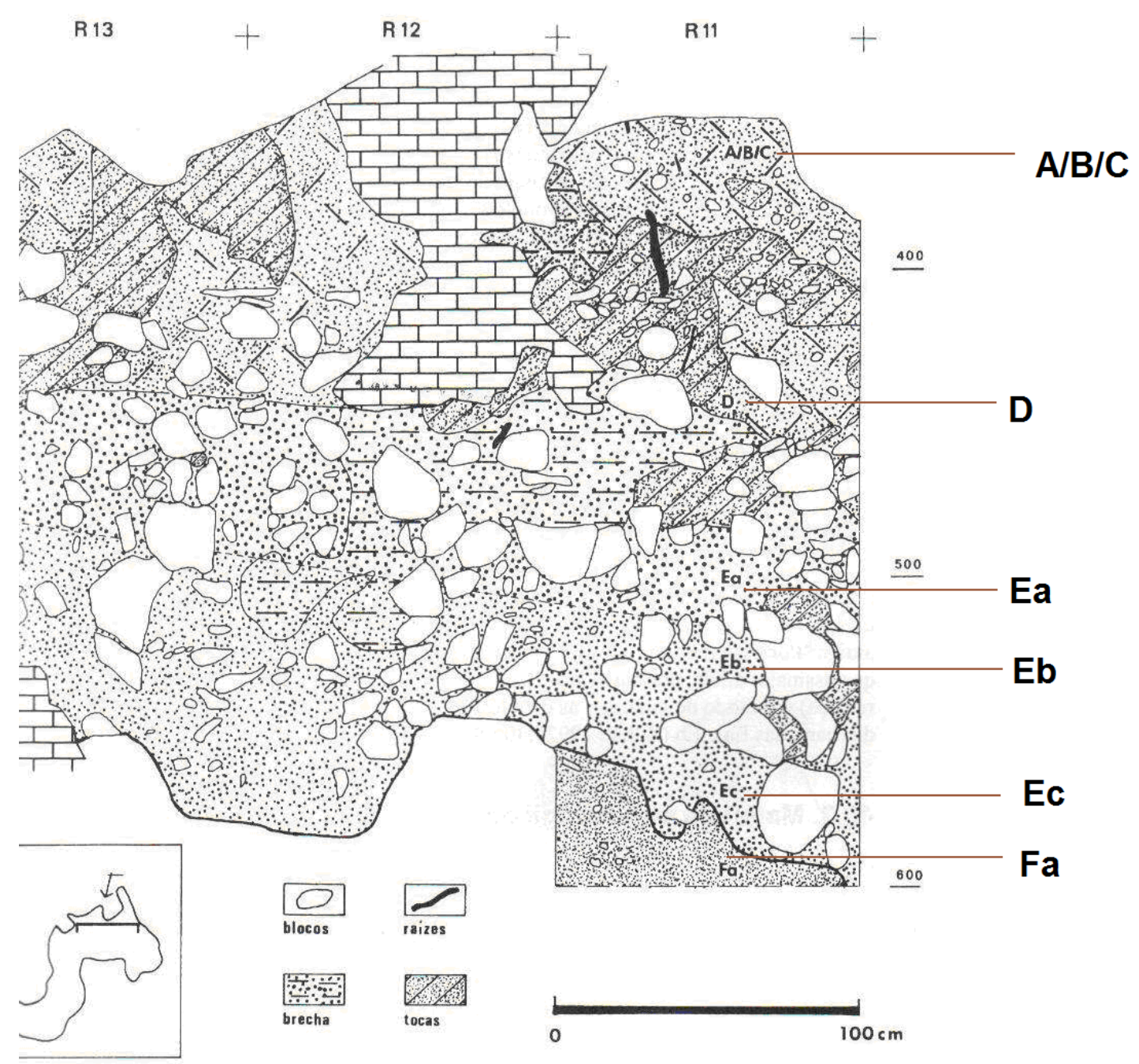

Fig. 30 - Desenho do corte longitudinal da Gruta do Caldeirão, dos quadrados Q-R, representando a respectiva estratigrafia, segundo ZILHÃO, 1997, vol. II, pp.683. 


\section{2 - Contextualização Paleontológica}

\section{1 - 0 esqueleto}

Os vertebrados constituem o grupo mais evoluído dos cordados. Caracterizam-se por possuírem um esqueleto constituído por várias peças articuladas, os ossos. O exterior dos ossos é formado por uma matriz orgânica basal endurecida por trifosfato de cálcio e o interior é esponjoso e atravessado por nervos e vasos sanguíneos. As cartilagens, por seu lado, são um tecido orgânico que raras vezes está calcificado, A diáfise é mais maciça que as epífises, que são mais esponjosas. Por esta razão a diáfise fossiliza com mais frequência que as epífises. As epífises são mais cartilaginosas nos jovens que nos adultos, pois estes possuem uma ossificação completa dos ossos longos.

O processo de ossificação é diferente entre os répteis e os mamíferos. Nos ossos longos dos primeiros, as epífises estão cobertas de cartilagens que se vão ossificando de forma gradual, enquanto o osso cresce longitudinalmente, o que implica a formação de uma articulação rígida entre os vários elementos ósseos. Por seu lado, nos mamíferos as epífises vão-se desenvolvendo durante a ontogenia e são constituídas por tecido ósseo. Entre a diáfise e as epífises existe uma banda cartilaginosa, que é paulatinamente substituída por tecido ósseo. Quando o animal atinge a idade adulta, a cartilagem desaparece e as epífises soldam-se à diáfise. Desta forma, o crescimento realiza-se independentemente das superfícies articulares, que rapidamente funcionam com a máxima eficácia, podendo o osso continuar a crescer sem modificar as articulações e sem obstáculos no seu funcionamento.

Para o estudo dos ossos encontrados em contexto paleontológico ou arqueológico, é fundamentar atribuir a esses ossos uma classificação taxonómica, pois sabendo a que táxon pertenceram, pode-se saber quais as suas principais características e saber em que ambientes viveu esse táxon, em suma, fazer uma reconstituição paleobiológica e paleoecológica. No entanto, esta classificação tornase difícil por razões tafonómicas, porque, como foi referido, a maior parte dos ossos 
aparece, na sua maioria fragmentada. No caso dos ossos das aves, a atribuição taxonómica é particularmente difícil também por razões taxonómicas, em especial as aves quaternárias, porque apesar de se conhecer bem a sua classificações, pois a grande parte ainda existe no presente, o facto é que as aves evoluíram no sentido da especialização aos diferentes ambientes em que vivem as diferentes espécies e, por isso, existem mais espécies por família, nas aves em comparação aos mamíferos. Assim, enquanto as diferenças dos esqueletos das diferentes famílias são normalmente evidentes, ao nível dos géneros, essas diferenças já são bastante ténues.

O esqueleto é o que determina a morfologia do corpo dos vertebrados, razão pela qual se pode saber a forma dos corpos dos grupos de vertebrados já extintos, como o Archaeopteryx. Esta estrutura, composta por diversos ossos e cartilagens, sustenta os outros órgãos e protege os que são vulneráveis. O esqueleto é disposto em relação à coluna vertebral e a sua forma é o resultado da adaptação ao ambiente e das formas de vida das diferentes espécies.

Os ossos são peças articuladas que variam de número consoante as espécies de vertebrados (p.e.: 205 no cavalo, 207 no homem. Consoante os diferentes grupos, os ossos apresentam morfologias diferentes. O conjunto dos ossos constitui o esqueleto dos vertebrados, que é formado por três partes diferentes: o esqueleto cefálico (crânio, maxilar e mandíbula); o esqueleto axial (vértebras e costelas); o esqueleto apendicular (membros, cintura escapular e cintura pélvica).

A diáfise é mais maciça que as epífises, que são mais esponjosas. Por esta razão a diáfise fossiliza-se com mais frequência que as epífises, que são mais cartilaginosas nos jovens que nos adultos, pois dá-se, com o tempo, uma ossificação completa dos ossos longos. 


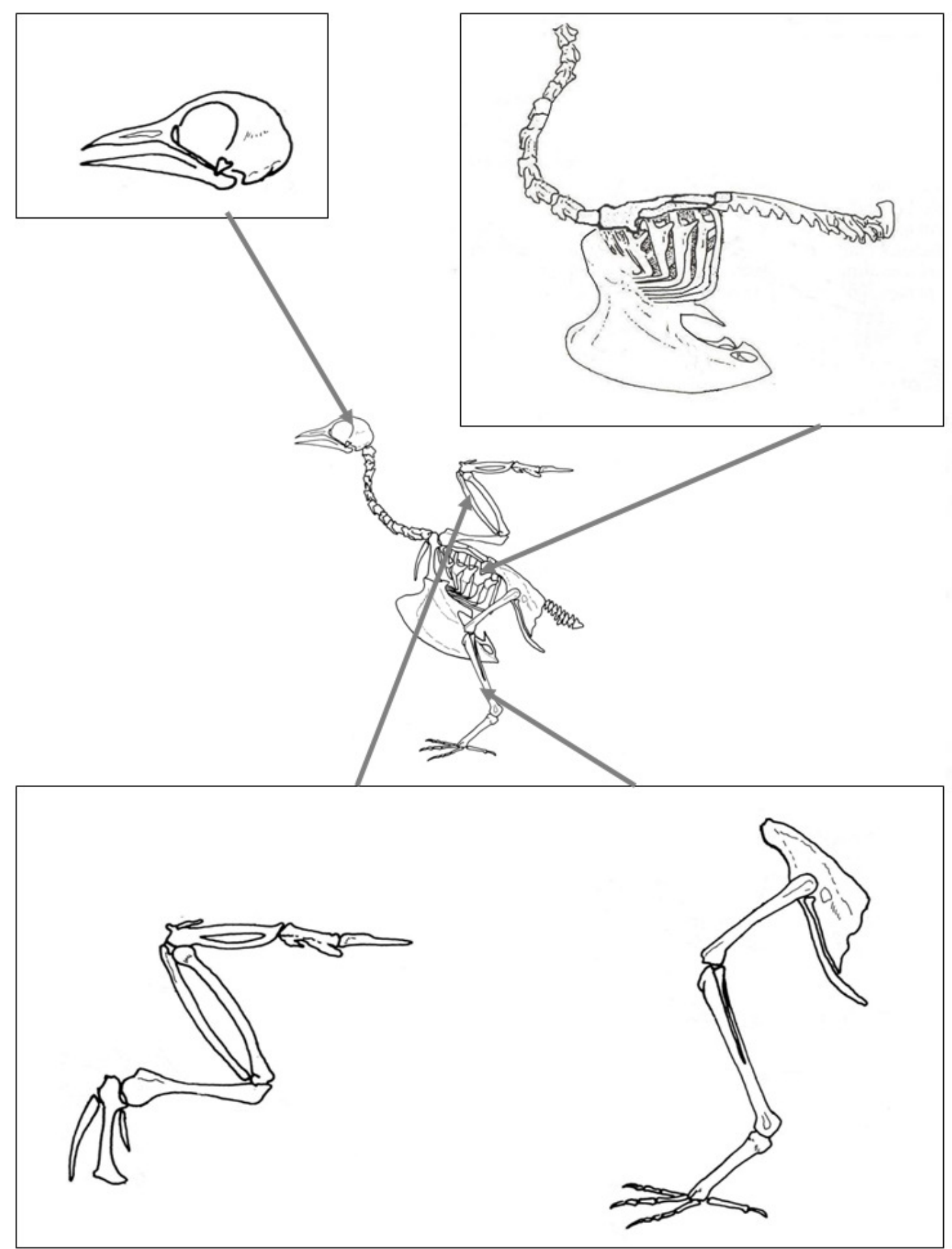

Fig. 31 - As partes do esqueleto (adaptado de COHEN \& SERJEANTSON, 1996)

Por várias razões tafonómicas, o registo fóssil de vertebrados é dominado pela ocorrência de ossos soltos ou fragmentados, sendo a preservação de esqueletos completos muito excepcional. No entanto alguns grupos, que vivem em ambientes aquáticos, têm maiores probabilidades de fossilizarem um maior número de peças ósseas pois, geralmente, estes ambientes favorecem a ocorrência de uma sedimentação fina, favorável à preservação dos elementos esqueléticos. 


\section{2 - Tetrápodes fósseis de Portugal}

Pretende-se, neste ponto, caracterizar paleontologicamente os períodos onde existem, em Portugal, vestígios de aves fósseis (ou grupos próximos). Para melhor compreender a paleobiologia em que se enquadram as aves fósseis de Portugal é importante referir brevemente as outras faunas que existiram contemporaneamente com as aves. Assim, serão referidos os vertebrados presentes no Jurássico, Cretácico, Eocénico, Miocénico e Plistocénico, que são os períodos com ocorrência de restos de aves, no nosso país.

\subsection{1 - Mesozóico}

Em Portugal são conhecidos restos de aves no Jurássico Superior; no entanto, quer no Jurássico quer no Cretácico, foram encontrados vestígios de dinossauros próximos das aves. Por essa razão será feita uma breve contextualização das faunas do Jurássico Superior e do Cretácico Inferior e Superior.

No Jurássico Superior existiam extensas manchas de florestas, onde vivia uma rica fauna de dinossauros carnívoros e herbívoros a par de outros vertebrados, tais como tartarugas, crocodilos, outros répteis e mamíferos. Nos mares próximos existia uma fauna abundante em invertebrados marinhos, peixes, ictiossauros e outros répteis marinhos.

Nas margens do mar que banhava a costa, manadas de saurópodes, como o Brachiosaurus (ou Lusotitan ${ }^{19}$ ), deslocavam-se, provavelmente em migração. Nas zonas de vegetação menos densa e margens de meios aquáticos viviam também outras espécies de herbívoros, como o Dacentrurus, um dinossauro com placas e espinhos no dorso, o Dracopelta, um pequeno dinossauro couraçado, e o Camptosaurus, um grande ornitópode bípede, que poderia optar ocasionalmente por uma postura quadrúpede. Existiam lagoas de água doce, que eram frequentadas por outros saurópodes, como o Lourinhasaurus, por exemplo. As orlas das florestas eram proposta, por M. T. Antunes e O. Mateus (2003), a atribuição de um novo género: Lusotitan. 
frequentadas por manadas de Diplodocídeos (Dinheirosaurus ${ }^{20}$ ), onde as crias encontravam protecção. Existiam também grandes terópodes, como o Megalosaurus, o Allosaurus e o Lourinhanosaurus, que ocupavam o topo da cadeia alimentar.

Entre estes animais de grande porte viviam espécies de pequenos dinossauros carnívoros, como o Compsognathus, que se alimentava de pequenos répteis e insectos, e como os dromeosaurídeos e os velocirraptorídeos, que caçavam em grupo e se alimentavam de herbívoros de pequeno porte. Nas clareiras das florestas viviam pequenos ornitópodes corredores como o Hypsilophodon, o Phyllodon e o Alocodon, animais dotados de grande agilidade e que se alimentavam de plantas baixas ou rasteiras.

São também do Jurássico Médio as várias espécies de mamíferos descobertos na mina da Guimarota, que, juntamente com os restos das espécies de répteis, de dinossauros e do Archaeopteryx, revela uma paleobiocenose muito diversificada. Os mamíferos ali encontrados pertencem à ordem dos multituberculados, a maior clade da classe dos mamíferos e que viveu durante mais de 100 milhões de anos, desde o Jurássico Médio (há cerca de $160 \mathrm{Ma}$ ) até ao final do Oligocénico (há cerca de $23 \mathrm{Ma}$ ).

As faunas da superclasse Tetrapoda (GOODRICH 1930) do Jurássico Superior encontradas em Portugal eram variadas, constituídas por diferentes grupos de anfíbios, répteis e mamíferos.

Dos anfíbios, existem restos fósseis dos Lissamphibia (HAECKEL 1866), dos Anura (FITZINGER 1843) e dos Caudata (SCOPOLI 1777).

Dos répteis, existem um grande número de restos de vários táxones, distribuídos pelos seguintes grupos: tartarugas, ordem Testudines (BATSCH, 1788), dos grupos dos Mesoquelida e dos Metaquelida (clades não hierarquizadas); diapsídeos basais Archosauromorpha, (HUENE, 1946) e Lepidosauromorpha, (BENTON, 1983); dos crocodilos foram identificados restos dos Metasuchia (clade não hierarquizada) e dos Mesosuchia (HuXLEY, 1875); são conhecidos também alguns fósseis de pterossauros indeterminados e outros das famílias Rhamphorhynchoidea (Plieninger, 1901) e Pterodactyloidea (Plieninger 1901). No caso específico dos dinossauros, estão identificados, em Portugal, 24 géneros (FIGUEIREDO, 2008). Destes,

20 Para vestígios atribuídos a Diplodocus por Zbyszewski e Lapparent, em 1957, foi, recentemente proposta, por J. F. Bonaparte e O. Mateus (1999), a atribuição de um novo género: Dinheirosaurus. 
18 são do Jurássico Superior, quatro do Cretácico Inferior, dois do Cretácico Superior e apenas um do Jurássico Inferior. Os dinossauros do Jurássico Superior de Portugal pertencem às duas sub-ordens: Saurischia (SeEleY, 1888) e Ornithischia (SeELEY, 1888). Dos saurischia foram encontrados géneros pertencentes aos Sauropoda (MARSH, 1878), e aos Theropoda (MARSH, 1881). Destes últimos, existem géneros dos Ceratosauria, (MARSH, 1884), dos Tetanurae (GAUTHIER, 1986) e dos Maniraptora (GAUTHIER, 1986). Aos maniraptora pertencem os Archaeopterygiformes (FURBRINGER 1888), a ordem que engloba as primeiras aves, dos quais também foram encontrados restos na Mina da Guimarota. Dos Ornithischia, estão identificados restos fósseis de dos Thyreophora (NOPCSA, 1915) e dos Ornithopoda (MARSH 1881). Dentro da classe dos répteis foram também identificados alguns Lepidossauros, da ordem Squamata (OPPEL 1811) e, dentro destes, das subordens Sauria (MACCARTNEY 1802) e Autarchoglossa (WAGLER, 1830).

No caso dos mamíferos, são conhecidas várias espécies da subclasse Allotheria (MARSH, 1880), provenientes, na sua maioria, da Mina da Guimarota. Alguns destes fósseis foram descritos pela primeira vez a partir dos exemplares encontrados em Portugal. Estão descritas várias espécies da ordem Multituberculata (COPE, 1884), pertencentes às famílias Paulchoffatiidae (HAHN, 1969), Pinheirodontidae (HAHN E HAHN, 1999) e Albionbaataridae (JAWOROWSKA E ENSOM, 1994).

Os fósseis do Cretácico Inferior encontrados na Bacia Lusitânica revelam que os mares e oceanos eram habitados por várias espécies de peixes, ictiossauros, mosassauros, tubarões e crocodilos. Nas praias existiam tartarugas e gastrópodes de grandes dimensões, nos mares pouco profundos e quentes apareceram os recifes de rudistas e nos mares mais profundos novas espécies de amonites.

Nas faunas terrestres, o grupo dos dinossauros caracterizou-se por um menor número de saurópodes que, neste período, tinham dimensões mais reduzidas, como o Pleurocoelus, um braquiosaurídeo que vivia nas zonas de planície litoral, nas terras lamacentas deixadas a descoberto pela baixa-mar e nos baixios que limitavam as zonas de mares pouco profundos. Por seu lado, os ornitópodes eram em maior número. Os iguanodontes, e os camptosaurus vagueavam em manada nas orlas das florestas. 
Existiam também vários carnívoros, como o Megalossauro. Novas espécies de carnívoros mais pequenos apareceram também. Em algumas zonas do nosso país, como por exemplo no Cabo Espichel, foram encontrados vestígios de dromeossaurídeos (animais do mesmo grupo de dinossauros, que no Jurássico tinham dado origem às aves) e outros pequenos dinossauros carnívoros ágeis, que viviam e caçavam em grupo as espécies de dinossauros herbívoros mais pequenas.

Nas formações do topo do Cretácico Superior, datadas de há cerca de 70 milhões de anos e localizadas nas zonas de Aveiro, Taveiro e Viso foram identificados alguns restos fósseis de pequenos dinossauros do grupo dos terópodes e alguns saurópodes de porte diminuto.

Nas praias existiam diferentes espécies de tartarugas e invertebrados e nos mares quentes diversificaram-se os recifes de rudistas. Nas terras secas viviam vários grupos de répteis e de dinossauros. Entre os herbívoros dominavam os ornitópodes. Entre os carnívoros existiam algumas espécies de pequenos megalossaurídeos, dromeossaurídeos e alguns celurossauros, como os troodontídeos e o Euronychodon.

As faunas de tetrápodes do Jurássico Superior encontradas em Portugal eram constituídas por grupos de anfíbios e répteis. Até ao momento não são conhecidos restos fósseis de mamíferos do Cretácico.

No Jurássico Superior são também conhecidos anfíbios do grupo dos Lissamphibia (HAECKEL 1866), das ordens Anura (FITZINGER 1843) e Caudata (SCOPOLI 1777). No entanto, os restos de anfíbios cretácicos estão identificados taxonomicamente como sendo anura e caudauta indeterminados, ao contrário do que acontece no Jurássico Superior, em que foi possível determinar a família de alguns restos de anfíbios e até mesmo o género, em alguns casos.

No caso dos répteis, foram identificados vários táxones, distribuídos pelos seguintes grupos: tartarugas, ordem Testudines (BATSCH, 1788), dos grupos dos Mesoquelida e dos Neoquelida (clades não hierarquizadas). Foram também identificados, no Cretácico Inferior do Espichel, restos de répteis marinhos da ordem Ichthyosauria (DE BLAINVILLE 1835) - família Ichthyosauridae (OWEN, 1839) indeterminada. Dos crocodilos, foram identificados restos dos Mesosuchia, (HUXLEY, 1875) - vários táxones da família Crocodylidae (CUVIER, 1808). No Jurássico também estão referidos alguns fósseis de pterossauros indeterminados e outros pertencentes 
às famílias Rhamphorhynchoidea (PLIENINGER, 1901) e Pterodactyloidea (PLIENINGeR 1901). Apesar de existirem menos táxones identificados, dos dinossauros do Cretácico existem fósseis dos principais grupos. Existem referências a restos das duas subordens: Saurischia (SeEley, 1888) e Ornithischia (SEELEY, 1888). Dos saurischia foram encontrados géneros pertencentes aos Sauropoda (MARSH, 1878) e aos Theropoda (MARSH, 1881). Destes últimos foram identificados restos dos Tetanurae (GAUTHIER, 1986) e dos Maniraptora (GAUTHIER, 1986). Dos Ornithischia, estão identificados restos de Thyreophora (NOPCSA, 1915) e dos Ornithopoda (MARSH 1881). Dos Lepidossauros, foram encontrados fósseis de táxones pertencenters à ordem Squamata (OPPEL 1811) e, dentro destes, das sub-ordens Autarchoglossa (WAGLER, 1830) e Serpentes (Linnaeus, 1758).

\subsection{2 - Cenozóico}

No Cenozóico estão referenciados restos de aves no Eocénico, Miocénico e Plistocénico. Serão caracterizadas, de forma sucinta, as respectivas faunas.

Durante o Eocénico, o clima em Portugal seria, de acordo com as associações fósseis conhecidas e com as informações sedimentares, do tipo tropical a subtropical e a pluviosidade seria sazonal e elevada. A fauna era bastante diversificada, constituída por mamíferos, aves, répteis e anfíbios.

Nas zonas húmidas, começaram a proliferar as primeiras ervas e existiam aves limícolas, crocodilos, tartarugas, anfíbios e alguns mamíferos. O início do Eocénico marca o aparecimento dos grupos de mamíferos actuais. Nos mares aparecem os primeiros antepassados dos cetáceos, que frequentavam as costas do que é hoje Portugal.

A partir de meados do Eocénico, o clima começou a arrefecer e, no final, as florestas de caducifólias, melhor adaptadas a amplas variações térmicas, começaram a substituir as espécies tropicais de folha perene. Nestas florestas existiam antepassados dos actuais primatas, roedores e ungulados. Estão também documentados no Eocénico português restos de carnívoros (da ordem dos Creodontes, grupo já extinto desde o Miocénico, e espécies de antepassados da actual ordem dos carnívoros). 
Taxonomicamente, foram encontrados, no Eocénico de Portugal, restos fósseis de todas as classes de Tetrápodes: anfíbios, répteis, mamíferos e aves. Neste capítulo apenas se irão referir as três primeiras, uma vez as aves do Cenozóico serão desenvolvidas em capítulo próprio.

Dos anfíbios, estão identificados alguns táxones do grupo dos Lissamphibia (HAECKEL 1866), das ordens dos Anura (FITZINGER 1843) e Caudata (SCOPOLI 1777).

Dos répteis existe um grande número de restos de vários táxones, distribuídos pelos seguintes grupos: tartarugas, ordem Testudines (BATSCH, 1788), dos grupos dos Pleurodira, (COPE, 1865) e dos Casichelydia, (GAFFNEY, 1975). Dos Lepidossauros, foram encontrados fósseis de táxones pertencentes à ordem Squamata (OPPEL 1811) e, dentro destes, das subordens Autarchoglossa (WAGLER, 1830) e Serpentes (Linnaeus, 1758).

Os mamíferos eocénicos estão bem representados em Portugal, conhecendo-se várias espécies da subclasse dos Theria (PARKER E HASWELL, 1897), quer dos marsupiais, quer dos placentários. Da infraclasse Marsupialia (ILLIGER, 1811) conhece-se um táxon; da infraclasse Eutheria (HUXLEY, 1880) conhecem-se vários táxones, distribuídos pelas seguintes ordens: Insectívora (BoWDICH, 1821), Cimolesta (MCKENNA 1975), Dermoptera (ILliger, 1811), Primata (LINNAEUS, 1758), Creodonta (COPE, 1875), Carnívora (BoWDiCH, 1821), Rodentia, (BoWDICH, 1821), Condylarthra (COPE, 1881), Artiodactyla (OWEN, 1848) e Perissodactyla (OWEN, 1848). Foram também encontrados restos fósseis classificados como llerdoryctes cf. sigei (MARANDAT, 1989), que é um táxon Insertae Sedis.

Durante o Miocénico, o clima aqueceu e arrefeceu ciclicamente, mas no geral foi menos húmido e mais quente do que o actual. Num primeiro momento, no Burdigaliano e Langhiano (entre os 20,4 e os 13,6 milhões de anos), o clima aqueceu; no Serravaliano as temperaturas caíram bruscamente, voltando a subir no Tortoniano; numa quarta fase, no Messiniano, entre os 7,2 e os 5,3 milhões de anos, as temperaturas voltaram a diminuir de forma acentuada, e o manto de gelo na Antártida era praticamente idêntico ao actual.

Em Portugal, o Miocénico foi caracterizado por várias incursões marinhas que atingiram bacias litorais, nomeadamente as do Tejo e Sado, chegando a áreas hoje tão longe do mar como Vendas Novas e Ferreira do Alentejo. Grande parte das 
formações geológicas do Miocénico português são do Langhiano, em que os mares eram quentes, e formaram-se vários recifes de coral. No amplo estuário da região de Lisboa delineou-se um golfo estreito até Almeirim; formaram-se vários bancos de ostras. Foi ainda no Miocénico que se deram os movimentos tectónicos que formaram a Arrábida, que era, nesta altura, uma ilha.

Nas praias existia uma fauna constituída por vários grupos de invertebrados, como equinodermes e moluscos, destes últimos são muito os fósseis de gastrópodes, tais como os géneros Turritella e Conus. Para além dos invertebrados são conhecidos também vários vertebrados marinhos, tais como os tubarões (de destacar o género Carcarodon), os cetáceos primitivos, as tartarugas e várias espécies de peixes. Nos lagos existiam crocodilos, tartarugas e peixes; nas margens do estuário e dos mares viviam mastodontes, rinocerontes, equídeos e felídeos.

Tal como no Eocénico, foram encontrados em Portugal, no Miocénico, restos fósseis de todas as classes de Tetrápodes: anfíbios, répteis, mamíferos e aves.

Dos anfíbios estão identificados, do grupo dos Lissamphibia (HAECKEL 1866), alguns restos indeterminados das ordens dos Anura (FITZINGER 1843) e Caudata (SCOPOLI 1777).

Dos répteis, existe um grande número de restos de vários táxones, distribuídos pelos seguintes grupos: tartarugas, ordem Testudines (BATSCH, 1788), ordem Testudines (BATSCH, 1788), dos grupos dos Mesoquelida e dos Neoquelida (clades não hierarquizada). Dos Crocodilianos estão identificados restos de táxones das famílias Crocodylidae (CUVIER, 1808) e Gavialidae (GMELIN, 1789). Dos Lepidossauros, foram encontrados fósseis de táxones pertencenters à ordem Squamata (OPPEL 1811) e, dentro destes, das subordens Autarchoglossa (WAGLER, 1830), Amphisbaenia (GRAY, 1844) e Serpentes (Linnaeus, 1758).

São conhecidos, no Miocénico português, um conjunto muito diversificado de restos fósseis de mamíferos. A maioria destes fósseis provém da bacia do Baixo Tejo (Lisboa e Península de Setúbal). Estão referenciados vários táxones, distribuídos pelas seguintes ordens: Creodonta (COPE, 1875), Sirenia (ILLIGER, 1811), Perissodactyla (OWEN, 1848), Artiodactyla (OWEN, 1848), Carnivora (BoWDITCH, 1821), Cetacea (BRISSON, 1762), Proboscidea (ILLIGER, 1811) e Multituberculata (COPE, 1884), Lagomorpha (BRANDT, 1885), Rodentia (BowDITCH 1821), Insectívora (BowDITCH 1821) 


\subsection{3 - Plistocénico}

As glaciações do Plistocénico provocaram grandes alterações climáticas em períodos de tempo relativamente curto (BRUM FERREIRA, 2000). No entanto, a localização geográfica da Península Ibérica, com a influência do Atlântico e do Mediterrâneo, bem como a existência dos Pirenéus, que constituem uma barreira entre a península e o resto da Europa continental atenuaram estas alterações e, na maior parte da península, as temperaturas médias anuais seriam positivas (BRUM FERREIRA, 2000). Estas características da Península Ibérica influenciam o clima, tanto no presente, como no passado, dando-lhe características próprias e distintas do resto do continente. Por essa razão, as glaciações não tiveram a intensidade em Portugal, como no resto da Europa. Estes factores climáticos foram importantes para a caracterização das faunas plistocénicas da Península lbérica (BRUM FERREIRA, 2000).

No início do Plistocénico, há 1,8 Ma, a Península Ibérica seria já muito idêntica ao que é na actualidade. O Estreito de Gibraltar já existiria, embora tivesse alternadamente alargado e estreitado, mediante os vários períodos glaciares, o mesmo acontecendo com a linha de costa.

A fauna do Plistocénico inferior era idêntica à fauna vilafranquiana de toda a bacia mediterrânica. Foram encontrados vestígios na península de Elephas meridionalis, Rhinoceros etruscus, Equus stenonis, Trogontherium (castor gigante) e Machairodus (tigre-dentes-de-sabre). Curiosamente, apesar de, em certas alturas, o Estreito de Gibraltar constituir uma passagem do Norte de África para a Península Ibérica, espécies de quadrúpedes, como o búfalo, a girafa e o camelo, abundantes em Marrocos e na Argélia, não aparecerem do lado norte do Estreito de Gibraltar. Nas épocas de glaciação mais intensas as faunas de temperaturas quentes concentraramse no sul da Península, enquanto nos períodos interglaciares estas faunas ocuparam o sul e o norte (SAVORY, 1985).

A Península Ibérica teve diferentes zonas climáticas durante o Plistocénico: a faixa costeira atlântica, mais inóspita durante as glaciações, terá sido habitada marginalmente, ao passo que nos períodos interglaciares terá tido um clima favorável (SAVORY, 1985). A margem mediterrânica e a Meseta Ibérica terão sido, nos períodos 
mais frios, férteis e húmidos, enquanto entre as glaciações ter-se-á tornado mais árida. Durante as glaciações, as zonas com climas mais frios terão sido os maciços montanhosos mais altos, como os Pirenéus e a Cordilheira Central e, em Portugal, a Serra da Estela e a Serra do Gerês.

Estes contrastes climáticos seriam atenuados, para a fauna, nos vales dos grandes rios como o Ebro, o Douro, o Tejo, o Guadiana, e o Guadalquivir, entre outros. Deslocavam-se grandes mamíferos, para estas zonas, em busca de ambientes mais quentes, de alimentação e água. Atrás desta fauna viriam comunidades humanas. Estes vales seriam então frequentados por várias espécies animais incluindo aves que vivem em zonas fluviais.

Durante o último interglaciário, no ocidente europeu espalhou-se uma nova fauna vinda da Ásia. Assim, vieram para a Península lbérica grandes mamíferos oriundos de climas temperados, que substituíram as faunas do Plistocénico Inferior peninsular. Entre estas faunas encontram-se o Elephas antiquus, o Rhinoceros merckii, o Hippopotamus amphibius, o Ursus spelaeus (ou Ursus $\operatorname{arctus}^{21}$ ), o Cervus elaphus, o Bos primigenius e algumas espécies dos géneros de Leo, de Hyaena e de Equus. Devidos ás condições morfológicas, geográficas e climáticas da península atrás referidas, estas faunas mantiveram-se por cá mais tempo que na restante Europa, atingindo mesmo os 30 mil anos, como o comprova, por exemplo, a megafauna da Gruta da Figueira Brava e Foz do Enxarrique (CARDOSO, 1993, ANTUNES, 2000, RAPOSO \& BRUGAL, 1999). Assim, durante a última glaciação algumas destas espécies foram-se extinguindo e introduziram-se na Península Ibérica espécies da fauna glaciar como o rinoceronte lanudo, o mamute e a rena. No entanto, pouco passaram para além dos Pirenéus e dos Montes Cantábricos. Por isso, com excepção de dois restos de mamutes, classificados com algumas reservas (ANTUNES \& CARDOSO, 1992, SOUSA \& FIGUEIREDO, 2001, FIGUEIREDO \& SOUSA, 2003) não se encontram em Portugal, mesmo no máximo da última glaciação, restos de mamutes ou de renas, por exemplo, mas sim da outra fauna atrás referida.

No que diz respeito especificamente às faunas plistocénicas de Portugal, têm

21 O esqueleto do urso das cavernas (Ursus spalaeus) é muito semelhante ao urso pardo (Ursus arctus). As maiores diferenças estão no crânio e no tamanho; o urso das cavernas era cerca de $30 \%$ maior. Devido a esta grande semelhança, muitos dos restos de ursos pardos identificados nas estações préhistóricas portuguesas poderão ser, na realidade, de urso das cavernas. 
sido encontrados vários restos de diferentes grupos taxonómicos, em diversos sítios, quer em contexto arqueológico, quer em geológico. No entanto, os mais estudados são os mamíferos. Os anfíbios e os répteis têm um reconhecimento taxonómico bem mais restrito que o dos mamíferos e só estão bem documentados num número relativamente restrito de estações. Tal como as aves, também a grande maioria dos táxones de anfíbios e répteis identificados são os mesmos que estão presentes na actualidade. Ao contrário, os mamíferos apresentam uma diferença bem maior entre as espécies identificadas no Plistocénico, e as actuais. Os tigres-dentes-de-sabre, os ursos, os leões das cavernas, o elefante antigo, o auroque e as hienas são exemplos de grupos de animais que existiam em Portugal, no Plistocénico, e que já se encontram extintos.

No que respeita à herpetofauna, apenas existe um táxon que não nos aparece na actualidade. Trata-se de uma tartaruga do género Agrionemys (=Testudo). Estas tartarugas ainda existem na actualidade na orla mediterrânica europeia, mas já não ocorrem no nosso país.

Os vestígios mais antigos de quelónios plistocénicos registados em Portugal datam, de há cerca de 80 mil anos (Plistocénico médio); trata-se de vestígios do género Agrionemys sp. e da espécie Mauremys leprosa (CRESPO, 2001). Estes achados provêm da estação arqueológica do Paleolítico médio da Mealhada, que na altura estava sob condições climáticas temperadas, relativamente húmidas e quentes, como o prova a fauna associada, típica de áreas lacustres ou fluviais de planície.

Na Gruta da Furninha (Peniche) foram identificados restos de tartarugas (Testudo graeca ${ }^{22}$ ), também atribuídos ao Plistocénico médio (FERREIRA, 1964, ROCHE, 1972, CRESPO, 2001).

De inícios do Plistocénico médio (Vilafranquiano Médio) foram encontrados vestígios de vários anfíbios não determinados, na jazida de Morgadinho - Tavira, no Algarve; estudos paleoecológicos indicaram que esta zona seria, na altura, relativamente quente e húmida (CRESPO, 2001).

Um dos sítios com uma herpetofauna mais diversificada é a Gruta da FigueiraBrava (Arrábida), já do Plistocénico superior. Ali foram referidos vários vestígios de

22 Esta classificação foi atribuída por Harlé (1910-11); Ferreira (1964) e Roche (1972). No entanto, mais recentemente uma revisão destes vestígios levaram a classifica-los como Agrionemys hermanii (J. Ménez-Fuente et al., 1998) 
répteis e anfíbios. No que respeita aos répteis, foram identificados alguns quelónios (Agrionemys hermanii, Emys orbicularis) e vários Squamata (Blanus cinereus, Lacerda lepida, Psammodromus algirus, Podarcis sp, Elaphe scalaris e Coluber hippocrepis); em relação aos anfíbios foram identificados a Salamandra salamandra, Pelobatescultripes e Bufo sp.. Há a destacar que, com a excepção da Agrionemys hermanii, todos os outros táxones identificados ainda existem em Portugal (CRESPO, 2001).

A Gruta Nova da Columbeira (Bombarral) tem uma ocupação humana com fauna associada, datada do final do Plistocénico médio, apresenta uma enorme quantidade de fósseis de fragmentos de tartaruga (atribuídos à Agrinemys hermanii e à família Emydidae ou Betagenidae), o que sugere que estes animais seriam consumidos pelos Neandertais que ocuparam esta gruta (CRESPO, 2001, CARDOSO, RAPOSO \& FERREIRA, 2002). O mesmo acontece na Gruta da Figueira-Brava e na Gruta do Caldeirão, onde a quantidade de vestígios de quelónios (LAPPARENT-DE BROIN \& ANTUNES, 2000, DAVIS, 2002) também indica que as comunidades humanas paleolíticas que as frequentaram consumiam tartarugas.

Do Plistocénico superior estão identificados restos de Agrionemys sp e Mauremys leprosa, na Gruta do Caldeirão, Agrinemys hermanii, na Gruta do Escoural, e Mauremys leprosa, no depósito de Porto Covo (CRESPO, 2001).

Já do final do Plistocénico foram encontrados nas areias de Faro-Quarteira e da Guia (Algarve), vários vestígios de herpetofauna (CRESPO, 2001). No caso dos lepidossauros estão referenciados os seguintes táxones: Blanus cinereus; Psammodromus sp, Acanthodactylus erythrurus, Lacerda lepida e natrix sp: No caso dos anfíbios estão identificadas as seguintes espécies: Pleurodeles walt; Pelobates cultripes; Bufo bufo; Bufo calamita e Rana perezi (CRESPO, 2001).

No que respeita aos mamíferos, o cenário é bastante diferente das restantes classes dos tetrápodes. Foi encontrado um conjunto considerável de vestígios de mamíferos plistocénicos portugueses. Este facto deve-se, em grande parte, a três factores: questões relacionadas com a tafonomia, como as características intrínsecas ao grupo dos mamíferos ao próprio tipo de alimentação das populações paleolíticas e, por outro lado, a questões ligadas à própria investigação arqueológica em Portugal. Assim, o tamanho dos grandes mamíferos e o grande número de determinadas espécies de pequenos mamíferos, como por exemplo os coelhos, permite que os seus 
restos fossilizem com maior facilidade; a maior parte dos vestígios de faunas plistocénicas provêm de estações arqueológicas e representam restos de alimentação das comunidades humanas. É provável que a alimentação preferida por estas comunidades fossem os mamíferos. Durante muito tempo, os arqueólogos que escavaram estas estações, por um lado, recolhiam quase só os ossos dos grandes mamíferos e não davam grande importância a pequenos ossos de outros grupos como as aves, os anfíbios e os répteis; por outro, sempre houve mais especialistas em estudar os mamíferos, deixando por estudar os outros grupos.

\subsection{4 - Sistemática dos tetrápodes plistocénicos}

Com a excepção de alguns mamíferos como por exemplo os elefantes, os auroques, os ursos e as hienas, as faunas de tetrápodes plistocénicos portugueses são as mesmas que se verificam actualmente.

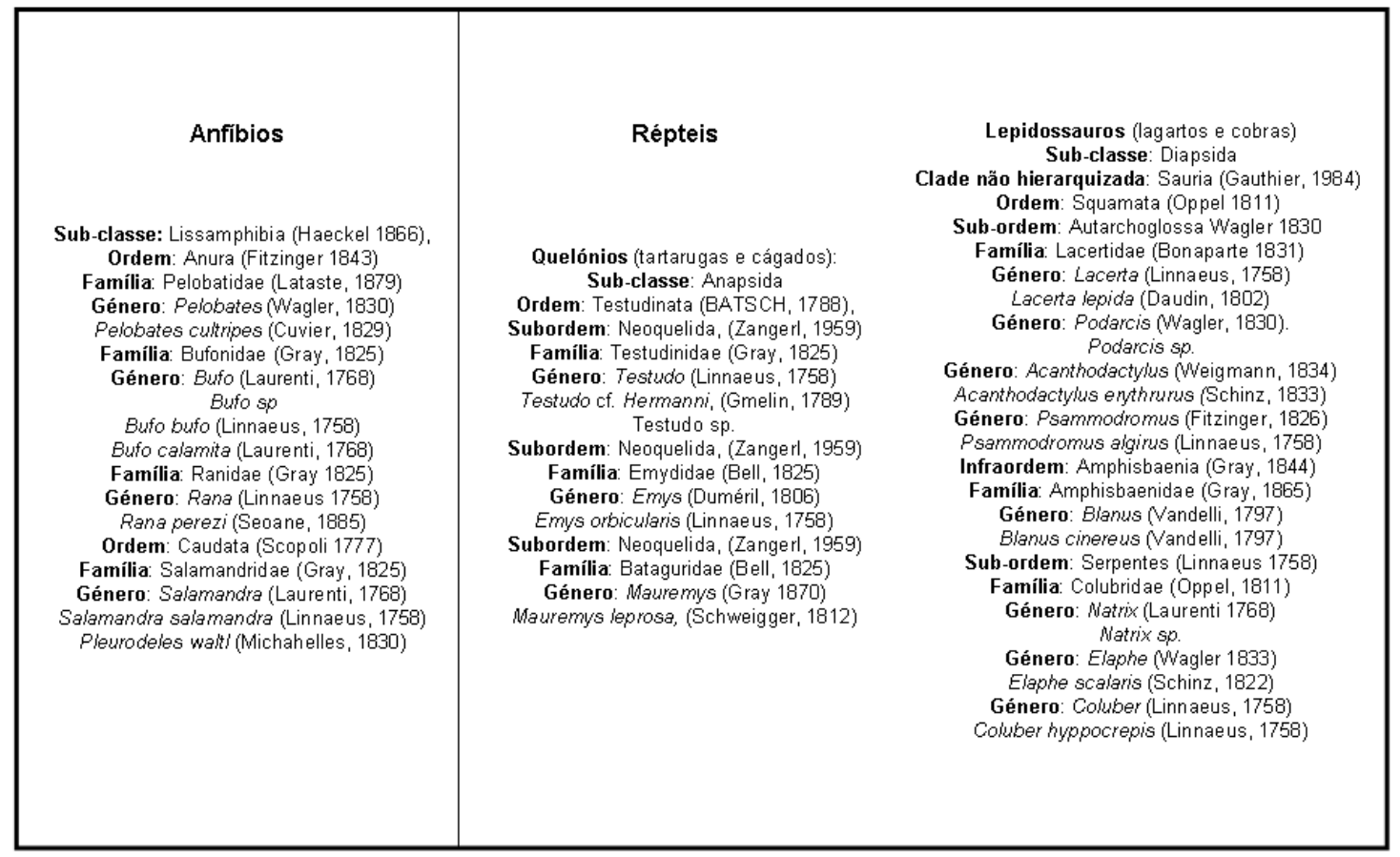

Quadro 4 - Sistemática dos anfíbios e répteis do Plistocénico português (segundo CRESPO, 2001) 


\begin{tabular}{|c|c|c|}
\hline 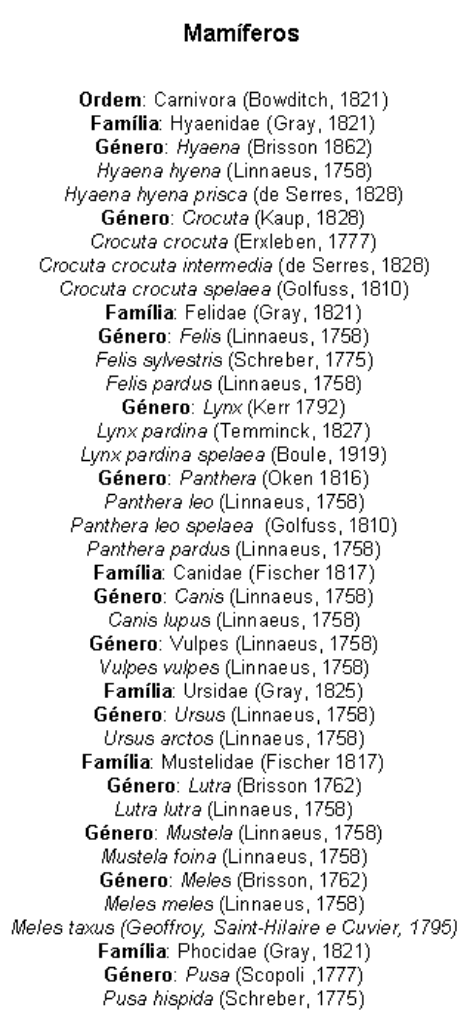 & $\begin{array}{l}\text { Ordem: Insectivora (Bowditch 1821) } \\
\text { Familia: Erinaceidae (Fischer von Waldheim 1817) } \\
\text { Género: Erinaceus (Linnaeus 1758) } \\
\text { europaeus (Linnaeus 1758) } \\
\text { Familia: Soricidae (Fischer 1814) } \\
\text { Género: Crocidura (Wagler, 1832) } \\
\text { Crocidura russula (Hermann, 1780) } \\
\text { Crocidura suaveolens (Pallas, 1811) } \\
\text { Familia: Talpidae (G. Fischer, 1814) } \\
\text { Género: Talpa (Linnaeus 1758) } \\
\text { Talpa occidentalis (Cabrera, 1907) } \\
\text { Ordem: Lagomorpha (Brandt, 1885), } \\
\text { Familia: Leporidae (Fischer de Waldheim, 1817) } \\
\text { Género: Onyctolagus (Lilljeborg, 1873) } \\
\text { Onyctolagus cuniculus (Linnaeus, 1758) } \\
\text { Género: Lepus (Linnaeus, 1758) } \\
\text { Lepus europaeus (Pallas, 1778) } \\
\text { Lepus timidus (Linnaeus, 1758) } \\
\text { Lepus cuniculus (Linnaeus, 1758) } \\
\text { Ordem: Rodentia (Bowditch 1821), } \\
\text { Familia: Castoridae Gray 1821 } \\
\text { Género: Castor (Linnaeus, 1758) } \\
\text { Castor fiber (Linnaeus, 1758) } \\
\text { Família: Cricetidae (Amori, 1996) } \\
\text { Género: Arvicola (Linnaeus, 1758) } \\
\text { Anicola terrestrs (Amori, 1996) } \\
\\
\text { Ordem: Cetacea (Brisson, 1762), } \\
\text { Família: Delphinidae (Gray 1821) } \\
\text { Género: Delphinus (Linnaeus, 1758) } \\
\text { Delphinus delphis (Linnaeus, 1758) } \\
\text { Ordem: Chiroptera (Blumenbach 1779) } \\
\text { Familia: Rhinolophidae (Gray 1825) } \\
\text { Género: Rhinolophus (Lacépède 1799) } \\
\text { Rhinolophus ferrumequinum (Schreber, 1774) } \\
\text { Rhinolophus hipposideros (Bechstein, 1800) } \\
\text { Rhinolophus euryale (Blasius 1853) } \\
\text { Família: Vespertilionidae (Gray 1821) } \\
\text { Género: Myotis (Kaup, 1829) } \\
\text { Myotis myotis (Borkhausen 1797) } \\
\text { Myotis nattereri (Kuhl, 1817) } \\
\text { Género: Miniopterus (Dobson, 1875) } \\
\text { Miniopterus schreibersi (Bonaparte, 1837) }\end{array}$ & $\begin{array}{c}\text { Ordem: Artiodactyla (Owen, 1848), } \\
\text { Família: Cervidae (Gray 1821) } \\
\text { Género: Cervus (Linnaeus, 1758) } \\
\text { Cervus elaphus (Linnaeus, 1758) } \\
\text { Género: Capreolus (Gray 1821) } \\
\text { Capreolus capreolus (Linnaeus, 1758) } \\
\text { Família: Bovidae (Gray 1821) } \\
\text { Sub-familia: Bovinae (Gray 1821) } \\
\text { Género: Bos (Linnaeus, 1758) } \\
\text { Bos primigenius (Linnaeus, 1758) } \\
\text { Género: Capra (Linnaeus, 1758) } \\
\text { Capra pyrenaica (Schinz, 1838) } \\
\text { Capra pyrenaica hyspanica (Schimper, 1848) } \\
\text { Género: Rupricapra (Blainville, 1816) } \\
\text { Rupricapra rupicapra (Linnaeus, 1758) } \\
\text { Rupricapra rupicapra pyrenaica (Bonaparte, 1845) } \\
\text { Família: Suidae (Gray 1821) } \\
\text { Género: Sus (Linnaeus, 1758) } \\
\text { Sus scropha (Linnaeus, 1758) } \\
\text { Família: Hippopotamidae (Gray 1821) } \\
\text { Género: Hippopotamus (Linnaeus, 1758) } \\
\text { Hippopotamus amphibius (Linnaeus, 1758) } \\
\text { Hippopotamus amphibius major (Linnaeus, 1758) } \\
\text { Ordem: Perissodactyla (Owen, 1848), } \\
\text { Família: Equidae (Gray 1821) } \\
\text { Género: Equus (Linnaeus, 1758) } \\
\text { Equus caballus (Linnaeus, 1758) } \\
\text { Equus hydruntinus (Regalia 1907) } \\
\text { Equus , 1989) } \\
\text { Familia: Rhinocerotidae (Owen, 1845) } \\
\text { Género: Rhinoceros (Linnaeus, 1758) } \\
\text { Rhinoceros sp } \\
\text { Género: Dicerorhinus (Gloger, 1841) } \\
\text { Dicerorhinus kirchbergensis (Jäger 1839) } \\
\text { Dicerorhinus hemitoechus (Falconer, 1868) } \\
\text { Ordem: Proboscidea (llliger, 1811) } \\
\text { Família: Elephantidae (Gray 1821) } \\
\text { Género: Elephas (Linnaeus, 1758) } \\
\text { Elephas antiquus (Falconer \& Cautley, 1847) }\end{array}$ \\
\hline
\end{tabular}

Quadro 5 - Sistemática dos mamíferos do Plistocénico português (segundo FERREIRA, 1964, ROCHE, 1972, CARDOSO, 1993, ANTUNES 2000)

\section{3 - Caracterização das aves}

As aves com excepção dos peixes são os vertebrados mais numerosos, são animais endotérmicos, em que a maioria desenvolveu a capacidade de voar, adquirindo adaptações físicas para tal, como o corpo pequeno, forte, compacto, músculos das asas poderosos, patas resistentes (VUILLEUMIER, 2001) e ossos com um elevado grau de pneumatização. O voo permitiu-lhes espalharem-se por quase todo o mundo (VUILLEUMIER, 2001). Tal como os restantes grupos de vertebrados, as aves possuem um esqueleto interno articulado, constituído por ossos. Como um grupo de vertebrados, a história evolutiva das aves está ligada às facetas evolutivas dos vertebrados. A origem das aves está num grupo de répteis diapsídeos do Triásico que terão conduzido, já no Jurássico, a que um grupo de pequenos dinossauros carnívoros, os maniraptora, se adaptasse ao voo (BENTON, 2005; CHIAPPE, 2002; 
CURRIE, 1997; HÖFLING, \& ALVARENGA, 2000) de uma forma que nenhum outro grupo de vertebrados conseguiu.

Durante a sua evolução, os membros anteriores transformaram-se em asas (KARDONG, 2002; BENTON, 2005). As aves superam qualquer outro grupo de vertebrados voadores, pela sua abundância e diversidade (VUILLEUMIER, 2001). A característica mais visível das aves é terem o corpo coberto por penas. As penas têm duas funções principais: proteger o corpo da perda de calor e auxiliar no voo (VUILLEUMIER, 2001). Nas primeiras aves e nos seus antepassados, as penas teriam funções de regulamentação da temperatura corporal e, provavelmente, com os membros anteriores abertos, seriam uma espécie de rede para capturar insectos (BENTON, 2005; CHIAPPE, 2002; CURRIE, 1997; HÖFLING, \& ALVARENGA, 2000).

Durante a sua evolução, As aves desenvolveram alterações anatómofisiológicas que estão na origem da sua endotermia e do seu encéfalo relativamente volumoso. Têm na pele glândulas que servem para segregar elementos protectores das penas. As aves aquáticas têm na cauda a glândula uropigiana para impermeabilizar as penas. (VUILLEUMIER, 2001).

O facto de os ossos das aves serem delgados e ocos, o que os torna mais frágeis, e o ambiente em que vivem, dificulta a sua fossilização. Desta forma os fósseis de aves são muito raros e, na sua maioria, são constituídos por fragmentos de ossos. Talvez esta seja uma das razões para se verificar um reduzido número de ossos de aves em contexto arqueológico.

As jazidas onde normalmente aparecem restos ósseos de aves, são normalmente formadas por calcários litográficos, correspondentes a ambientes de deposição muito lenta, como é exemplo os níveis marinhos do Jurássico de Solenhofen, onde foram descobertos sete exemplares de Archaeopteryx, ou ambientes lacustres do Cretácico Inferior de Montsec (Lleida) e Las Hoyas (Cuenca), que forneceram vários restos de aves, que apresentam características intermédias entre o Archaeopteryx e as aves de tipo moderno (ORTEGA et al., 2006). Este facto está relacionado com a fraca ocorrência de aves do Jurássico e do Cretácico em Portugal, pois estes terrenos são muito raros em Portugal. 
Outra das características que define as aves é as mandíbulas sem dentes ${ }^{23}$, em forma de bico, cujo formato e tamanho varia consoante o tipo de alimentação de cada uma das espécies (GOODERS \& HARRIS, 1990, 1993; VUILLEUMIER, 2001), representando uma das estruturas ósseas que se define consoante as várias adaptações das aves a diferentes tipos de alimentação.

Os membros das aves são estruturas que são o fruto da própria evolução destes animais. A mais evidente é a transformação dos membros anteriores dos antepassados em asas. Nas aves voadoras as asas são mais desenvolvidas que as asas das aves corredoras, por razões óbvias. As patas, por seu lado, também evoluíram, consoante a espécie se adaptou à corrida (avestruz), ao salto (lavandisca), à natação (pato), ao empoleiramento (pardal). As patas, terminadas num pé, com $2-3-4$ dedos, envolvidos por pele cornificada (VUILLEUMIER, 2001).

As aves são animais voadores endotérmicos homeotérmicos, ou seja são animais de "sangue quente". Têm o índice metabólico muito elevado. Devido ao facto de terem necessidade de transformar os alimentos em energia muito rapidamente, as aves têm a mais alta temperatura dentro dos animais de sangue quente (cerca de 43,5 $\left.{ }^{\circ} \mathrm{C}\right)$. As aves têm um órgão especial: a siringe, localizada na base da traqueia, adaptada ao canto (VUILLEUMIER, 2001).

As aves apresentam dimorfismo sexual. A fecundação é interna, ocorrendo no oviduto, onde o ovo se forma até à formação da casca calcária. A reprodução é ovípara, os ovos, constituídos pelo âmnio, cório, saco vitelino e alantóide, depois de formados são eliminados pela cloaca (VUILLEUMIER, 2001).

O voo é proporcionado pelo movimento das asas, devido principalmente aos grandes músculos peitorais, o grande peitoral que se fixa na parte externa da quilha, do esterno e na cabeça do úmero.

Tal como os répteis e os mamíferos, as aves respiram através de pulmões. $A$ respiração das é dupla, e a hematose é pulmonar. Os pulmões são compactos e muito eficientes, que estão presos às costelas e ligados aos sacos aéreos de paredes finas, que se estendem entre os órgãos internos (VUILLEUMIER, 2001). As aves são animais de circulação dupla completa. O sistema circulatório é constituído pelo coração e pelos vasos sanguíneos. O coração está dividido em 4 cavidades ( 2 aurículas e 2

23 As primeiras aves do Jurássico e algumas do Cretácico possuíam mandíbulas ainda com dentes. 
ventrículos), o sangue venoso não se mistura com o sangue arterial. Este órgão apenas apresenta o arco aórtico direito e os glóbulos vermelhos são ovais e biconvexos. (VUILLEUMIER, 2001), O sistema digestivo das aves é composto pelo tubo digestivo completo, composto pela boca, pela faringe, pelo esófago, pelo papo, pelo estômago químico (o proventrículo), pelo estômago mecânico (moela), pelo intestino, pela cloaca e pelos órgãos anexos, tais como o fígado e o pâncreas. As aves possuem também a adição de sucos digestivos no proventríciulo (HARRISON \& GREENSMITH, 1993; VUILLEUMIER, 2001),.

Como foi referido, o revestimento do corpo das aves é composto pelas penas, que são de origem dérmica e que se dividem nas: tectrizes, penugem, rectrizes e rémiges. As tectrizes são penas pequenas e revestem o corpo, a penugem, por sua vez, forma uma camada de isolamento térmico adicional. As rectrizes e as rémiges são penas longas e rijas, destinadas à função do voo. As rectrizes são as penas da cauda que são geralmente simétricas; as rémiges são as penas das asas e têm um formato triangular. As patas e os pés possuem um revestimento constituído por escamas epidérmicas (HARRISON \& GREENSMITH, 1993; VUILLEUMIER, 2001).

As penas, constituídas pela mesma substancia que se encontra nos pelos dos mamíferos e nas escamas dos répteis, a queratina (VUILLEUMIER, 2001), não são mais do que as escamas dos répteis desenvolvidas. As escamas nas patas e nos pés das aves testemunham a sua evolução a partir dos répteis (KARDONG, 2002, p. 216). Segundo este autor (2002, pp. 216 - 219), as penas distinguem as aves dos outros vertebrados. Existem quatro tipos de penas, definidas pela sua forma e função: as tectrizes, que são pequenas, têm uma função térmica e cobrem o corpo, a penugem, que se situa por baixo das tectrizes e funcionam como isolamento térmico, as rectrizes, as penas da cauda, que são frequentemente simétricas e funcionam como uma espécie de leme e as rémiges, são as penas das asas, compridas, com um formato regular, bem definido e que servem para o voo (VUILLEUMIER, 2001). 


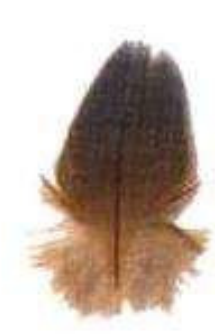

Tectriz

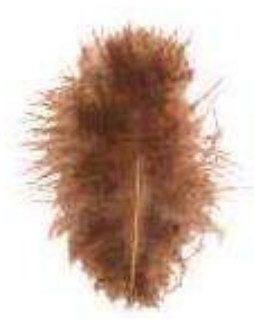

Penugem

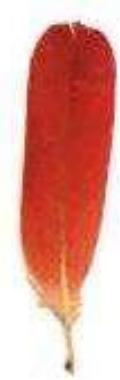

Rectriz

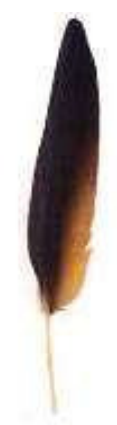

Rémige

Fig. 32 - Exemplos dos diferentes tipos de penas das aves (Fonte: HARRISON \& GREENSMITH, 1993.

As rectrizes e rémiges são constituídas pelo cálamo (zona onde se insere na pele), ráquis, prolongamento do tubo central, barbas e bárbulas que constituem a zona da superfície da pena. Para uma eficiente função de voo, as rémiges têm de ter uma superfície contínua, a fim de o ar possa deslizar por ela. Esta superfície é constituída por milhares de bárbulas, que saem de ambos os lados das barbas e se encaixam umas nas outras. Se as bárbulas se soltam a ave "penteia-as" com o bico para as por no sítio (HARRISON \& GREENSMITH, 1993; VUILLEUMIER, 2001). As penas têm funções térmicas (em especial as tectrizes e a penugem) mas a sua principal função é o voo (as rémiges e as rectrizes).

As aves são animais bípedes, tal como o Homem, no entanto, apesar de algumas semelhanças, a maneira de locomoção entre nós e as aves é bastante diferente. Como se sabe, tal como o Homem, as aves utilizam os membros posteriores para a deslocação em terra firme, a articulação coxofemural permite movimentar no plano sagital e os músculos das pernas que actuam na anca, dispõem-se sob a forma de tirantes, bem desenvolvidos nas regiões anterior e posterior. O movimento da articulação coxofemural, tal como no Homem, é feito para a frente e para trás dos membros posteriores, no entanto as aves não têm o movimento de adução e de abdução, no plano frontal, que é característico da articulação proximal do fémur humano (HARRISON \& GREENSMITH, 1993; VUILLEUMIER, 2001).

No Homem o músculo gluteus medius (médio nadegueiro) tem um apoio unipodático, o que evita a queda da anca contralateral. Nas aves esta situação é 
diferente. Existe uma segunda articulação, na extremidade proximal do fémur entre o trocânter femural e o antitrocânter do ílio, e uma estrutura ligamentar muito forte que não permite os movimentos de adução e de abdução, sendo substituídos por um movimento de rotação efectuado ao nível da articulação do joelho (MASSADA, 2001, p. 66).

Ao contrário do Homem, as aves têm o fémur horizontalizado, o que projecta os membros posteriores para a frente. As aves possuem os músculos iliotrocantéricos, que correspondem, no Homem aos músculos gluteus. Enquanto estes evitam a queda da anca contralateral durante a marcha, os iliotrocantérios imprimem um movimento de rotação interna na anca. A este músculo contrapõem-se o obturador e o isquiofemoral, que funcionam como músculos de rotação externa. Os isquiofemorais actuam fundamental como flexores do joelho e extensores da anca.

Os principais grupos de músculos implicados na locomoção das aves são massas musculares posteriores, que se situam por trás da articulação da anca (MASSADA, 2001, p. 66).

2.3.1. - Caracterização osteológica das aves: características gerais do esqueleto das aves

A evolução das aves deu-lhes um esqueleto bastante diferente dos outros vertebrados, em especial o das aves voadoras, ele é leve, mas robusto e elástico. A sua leveza é devida em grande parte ao facto de, durante o seu processo evolutivo, em muitos dos ossos a medula foi transformada em câmaras-de-ar. O grau de pneumatização varia segundo os grupos e segundo o grau de adaptação ao voo. Os ossos com maior grau de pneumatização são: os ossos do crânio, as vértebras cervicais, os úmeros e, com menor frequência, os fémures.

Durante a sua evolução, as aves desenvolveram características esqueléticas que lhes permitiram uma boa adaptação a duas formas distintas de locomoção. Estas características são: o bipedismo, pela postura parassagital, herdada dos seus antepassados, e da adaptação dos membros posteriores a este tipo de locomoção e o voo, pela adaptação dos membros anteriores, que se transformaram em asas.

As aves desenvolveram particularidades específicas do esqueleto, à medida 
que se adaptaram ao voo e à deslocação bípede: o esqueleto tornou-se mais leve, através da pneumatização de certos ossos e do estreitamento do córtex ósseo e da "perda" de ossos desnecessários. Desenvolveram estruturas ósseas, reforçadas interiormente (tal como acontece com as asas dos aviões) e vários ossos se fundiram, dispondo-se de forma de lâminas alongadas. As aves voadoras projectaram o esterno, desenvolvendo a quilha, osso onde se encerem os músculos das asas; não têm cauda (a extremidade da coluna vertebral é constituída pelo pigóstilo, onde se inserem as penas da cauda). Os membros anteriores sofreram várias transformações dos seus ossos, de forma a se transformaram em asas. Todas estas alterações esqueléticas determinaram a redução do número de articulações móveis e consequentemente das massas musculares (MASSADA, 2001).

Apesar da cavidade craniana das aves ser mais ampla que a dos répteis, o crânio das aves apresenta uma estrutura idêntica ao crânio destes últimos e caracteriza-se por os ossos da caixa craniana se encontrarem soldados. As suturas entre ossos só são visíveis nos indivíduos jovens, enquanto nos adultos, essas suturas desaparecem por completo.

O crânio articula-se com a primeira vértebra cervical por um único côndilo occipital, e a coluna vertebral tem um número de vértebras cervicais maior do que qualquer outro grupo de vertebrados. Estas vértebras são muito flexíveis pois, como foi referido na caracterização dos vertebrados, as aves têm vértebras heterocélicas.

Os membros anteriores adaptaram-se ao $v^{24}{ }^{24}$, ao se transformarem em asas. Assim, os ossos dos membros anteriores das aves desenvolveram características próprias. As falanges dos dedos dos braços transformaram-se numa estrutura bastante diferente da dos seus antepassados dinossauros, que de uma mão desenvolvida deram origem a uma disposição adaptada ao voo.

As patas das aves evoluíram no sentido do seu fortalecimento. Os pés são muito variáveis em forma e tamanho, perfeitamente adaptados aos modos de vida das diferentes espécies, quer para o poleiro, para trepar, para correr, para nadar, etc. As patas das aves terminam em quatro, três ou, como o avestruz, em dois dedos. Os ossos da parte inferior das patas são largos com a finalidade de facilitar a deslocação bípedes, a descolagem do voo e a aterragem. O tornozelo das aves apresenta 
também alterações que constituem uma das suas características próprias.

Outra das características do esqueleto destes animais é não possuírem dentes nas mandíbulas, as quais estão recobertas por uma estrutura córnea, que forma o bico. No entanto nem sempre assim foi, as aves primitivas, em particular as do Jurássico e as do Cretácico (de que o Archaeopteryx é um dos exemplo), as mandíbulas possuíam dentes. O bico é leve, mas forte e está adaptado aos diferentes tipos de alimentação e a algumas tarefas delicadas, como por exemplo limpar e "pentear" as penas (HARRISON \& GREENSMITH, 1993; VUILLEUMIER, 2001).

A coluna vertebral pode flectir-se nas zonas onde as vértebras estão afastadas, mas está rígidas nas zonas onde elas estão fundidas, como por exemplo no sinsacro. As vértebras cervicais são heterocélicas, o que Ihes permite uma grande mobilidade da cabeça. As últimas vértebras cervicais e as primeiras torácicas apresentam pequenas apófises ósseas, onde se inserem os músculos flexores do pescoço, que são longos. As vértebras dorsais são curtas e podem estar soldadas, formando uma crista dorsal. Por esta razão, a coluna vertebral das aves é muito flexível na zona cervical, muito pouco móvel, quase rígida nas zonas lombares e torácica e relativamente elástica na zona compreendida entre o sinsacro e o pigóstilo. As zonas ventrais das vértebras apresentam um nível de ossificação bastante desenvolvida devido à pressão exercida pelos músculos das asas durante o voo (GIBERT et al., 1996).

As aves desenvolveram o osso externo, que habitualmente é grande e convexo. As aves que se adaptaram de melhor forma ao voo, apresentam uma quilha central que serve para a inserção dos músculos que movem as assas. Por seu lado as aves não voadoras não possuem a quilha.

No processo evolutivo, a cauda dos antepassados das aves transformou-se, provocando uma grande modificação nas extremidades anteriores para servir de suporte ás plumas que formam a superfície de sustentação no voo e também de leme (BENTON, 2005).

Os ossos de uma ave têm uma estrutura alveolar interna, que lhes permite ter os ossos resistentes e, ao mesmo tempo, leves. Os ossos longos das aves voadoras são ocos, mas reforçados por estruturas alveolares leves. No entanto nas aves não voadoras e nas aves aquáticas, os ossos são sólidos (VUILLEUMIER, 2001).

Os fragmentos dos ossos das aves podem-se distinguir dos fragmentos dos 
ossos dos mamíferos mais pelas suas características do que pela sua morfologia. A pneumatização levou a que determinados ossos (em especial os ossos longos) sejam ocos e contenham "sacos" de ar. O grau de pneumatização dos ossos varia consoante a espécie de ave.

Assim, num lote de ossos é fácil separar os ossos de aves dos restantes, porque as aves têm, graças à sua evolução do grupo, um esqueleto notavelmente leve, delicado e com os ossos com um elevado grau de pneumatização. Existem, no entanto, uma excepção, os Struthioniformes (avestruzes e afins), cujos ossos têm um grau de pneumatização pequeno. Uma cavidade pneumática muito ampla substitui a habitual cavidade medular dos ossos dos vertebrados superiores (GILBERT et al., 1996).

Outra característica fundamental das aves é a ausência quase geral, de ossificações isoladas (as epífises) encontradas nas extremidades dos ossos dos jovens mamíferos. Um osso longo de ave forma-se a partir da ossificação de uma simples anilha (ou diapófise marginal) que garanta o crescimento conjunto das extremidades articulares dos ossos (BRUNET, 1966).

A textura dos ossos é um indicador muito coerente. Os ossos das aves são lisos, permitindo, numa jazida, apresentarem as superfícies brilhantes e praticamente nunca o aspecto poroso, característico dos outros grupos de vertebrados, salvo entre os indivíduos mais jovens (BRUNET, 1966), permitindo desta forma uma primeira identificação dos ossos das aves aquando da sua escavação.

\subsection{2 - Características específicas}

\section{O Esqueleto cranial}

O esqueleto cranial (crânio e mandíbula) não apresenta aberturas, as órbitas são, no geral, grandes e as mandíbulas não têm dentes, tendo-se transformado num bico, que apresenta várias formas consoante o tipo de alimentação da espécie a que pertence.

O esqueleto cranial é idêntico ao dos répteis, com um osso quadrado donde se suspende a mandíbula. 


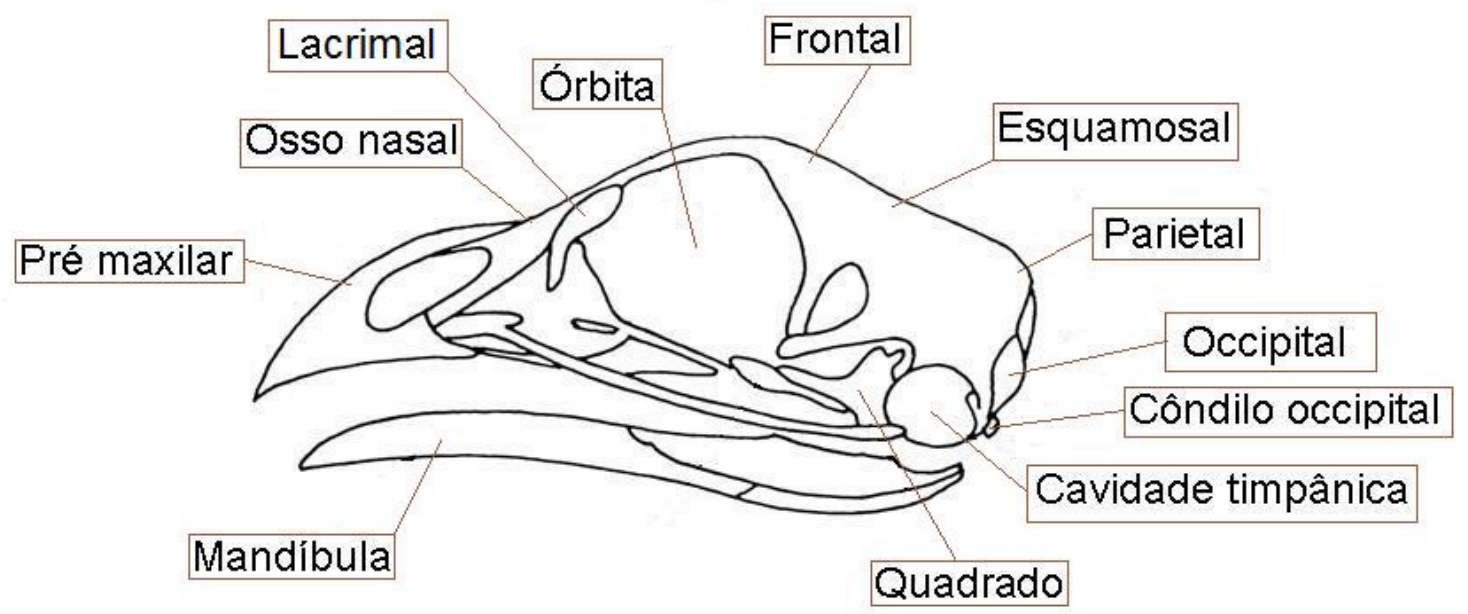

Fig. 33 - Principais ossos do crânio de um Gallus gallus (construção do autor a partir de COHEN e SERJEANTSON, 1996).

\section{O Esqueleto axial}

A coluna vertebral é constituída por um número de vértebras cervicais que varia entre oito e vinte e cinco. As vértebras dorsais superiores fundiram-se numa vértebra lombar e formam parte do sinsacro, que compreende todos esses ossos mais as vértebras sacrais e algumas caudais. A fusão destas vértebras formou uma massa óssea única, que permitiu às aves aumentar a resistência mecânica a nível do tórax. No total o sinsacro engloba uma vértebra torácica, cinco lombares, duas sacras e cinco caudais. A parte final da coluna vertebral das aves tem entre cinco a oito vértebras caudais, que se encontram fundidas, formando o uróstilo, que se liga ao pigóstilo, onde se inserem as penas caudais, as rectrizes. O Uróstilo está direccionado para cima, o que permite uma perfeita inserção das rectrizes no pigóstilo (COHEN e SERJEANTSON, 1996). 


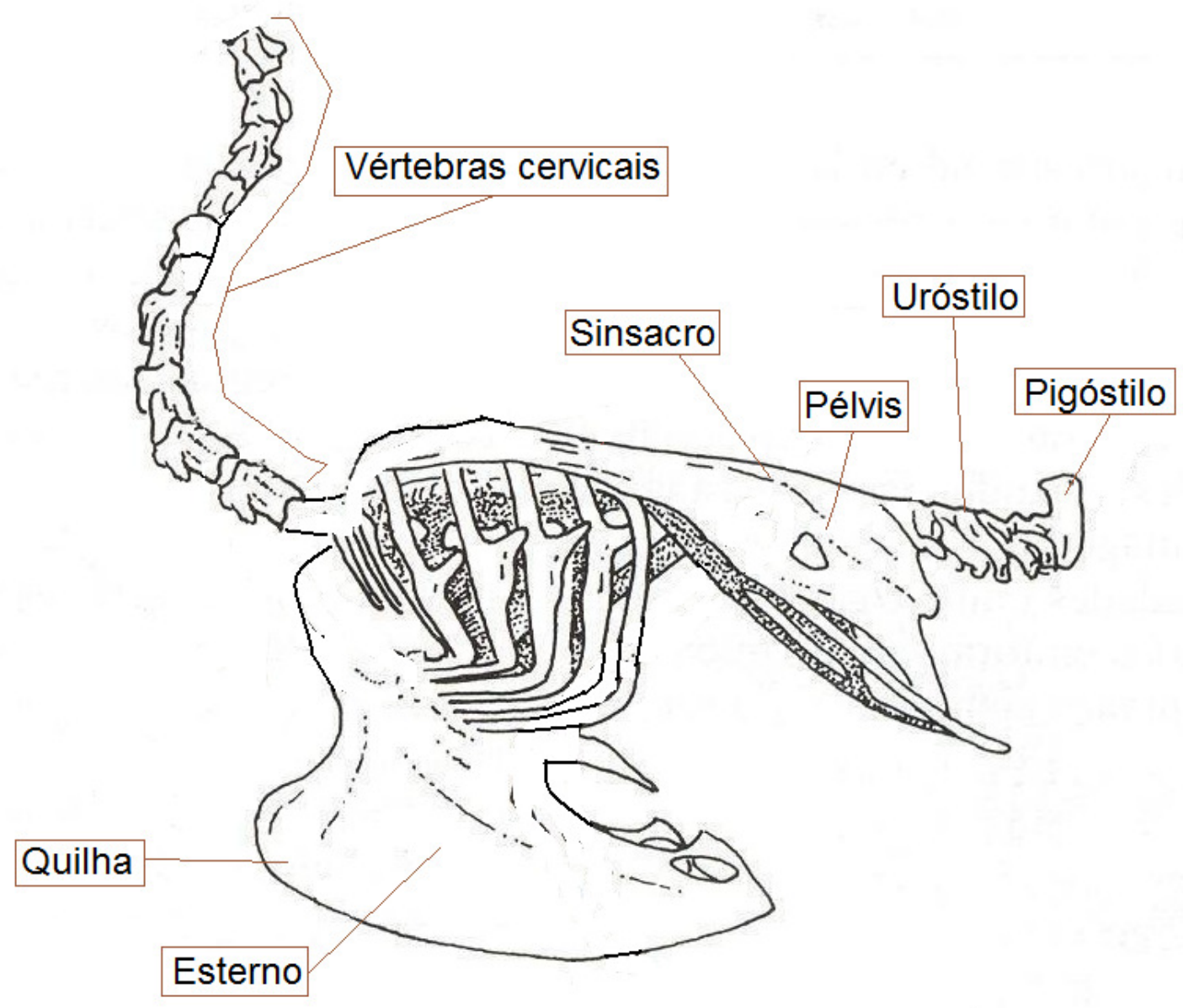

Fig. 34 - Principais ossos do esqueleto apendicular (construção do autor a partir de COHEN e SERJEANTSON, 1996).

A coluna vertebral e as cinturas escapular e pélvica adaptaram-se funcionalmente de modo a permitirem, às aves, o suporto do seu peso durante o voo ou quando se encontra em terra firme. Assim, desenvolveram-se dois suportes ósseos laminados. São eles o esterno, osso triangular com uma profunda depressão, e o sinsacro, que se encontram dispostos em direcções opostas. Durante o voo as aves exercem as forças através do músculo pectoralis major (grande peitoral), que se insere no esterno, em especial na zona da "quilha". O equilíbrio do voo é conseguido, em grande parte, porque a disposição anatómica da quilha permite um abaixamento do centro de gravidade em relação ao centro de sustentação. Por outro lado, o esterno tem uma morfologia que lhe permite reduzir as forças de atrito durante o voo. 


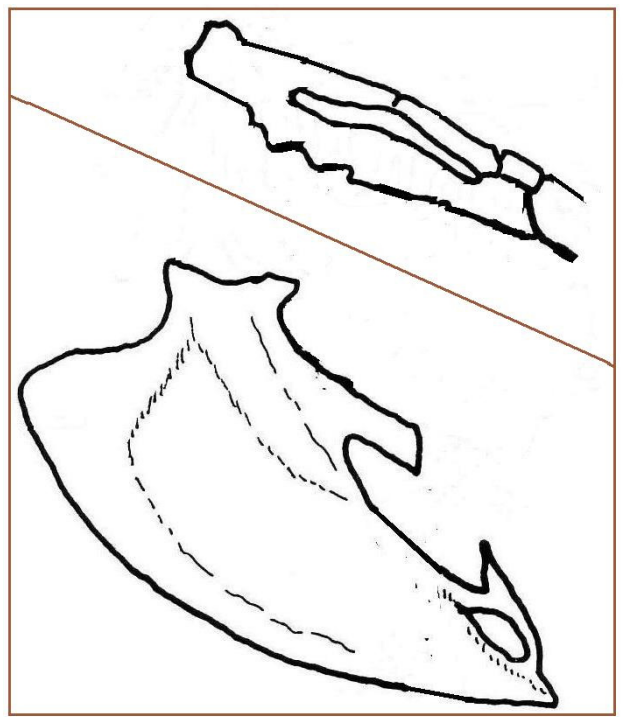

Fig. 35 - Sinsacro e esterno (desenho do autor).

Quando na locomoção em terra firma, as aves utilizam os músculos retractores dos membros posteriores. O sinsacro, quer no voo quer na deslocação em terra firme, assume-se como uma estrutura rígida de suporte dos músculos. Em terra firme o peso é suportado pelos membros posteriores, o que alterou a disposição anatómica da coluna, e parte dos esforços mecânicos são transmitidos pelas costelas e pelos músculos abdominais para os ílios. Quando está no chão, o centro de gravidade das aves voadoras abaixa-se e desloca-se posteriormente (fig. 36), quase ao nível dos pés. Esta deslocação do centro de gravidade proporciona um equilíbrio muito mais eficaz que na evolução do bipedismo no Homem (MASSADA, 2001, p. 64) e é um processo inverso dos dinossauros terópedes em o que se colocava quase na horizontal e a cauda servia como um contrapeso.
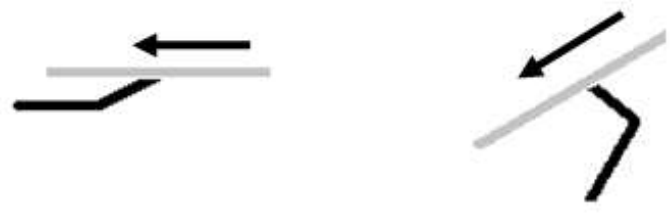

Durante o voo

Em terra firme

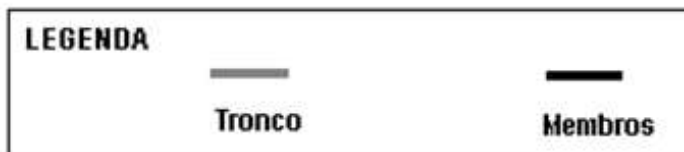

Fig. 36 - Representação esquemática da distribuição do centro de gravidade durante o voo e em terra firme, nas aves (construção do autor). 
A quilha tem uma estrutura anatómica que aumenta a resistência mecânica da caixa torácica. Apresenta uma área alongada que lhe permite a inserção dos músculos das asas e dos grupos de músculos utilizados para o apoio dos membros posteriores em terra firma (GILBERT et al., 1981).

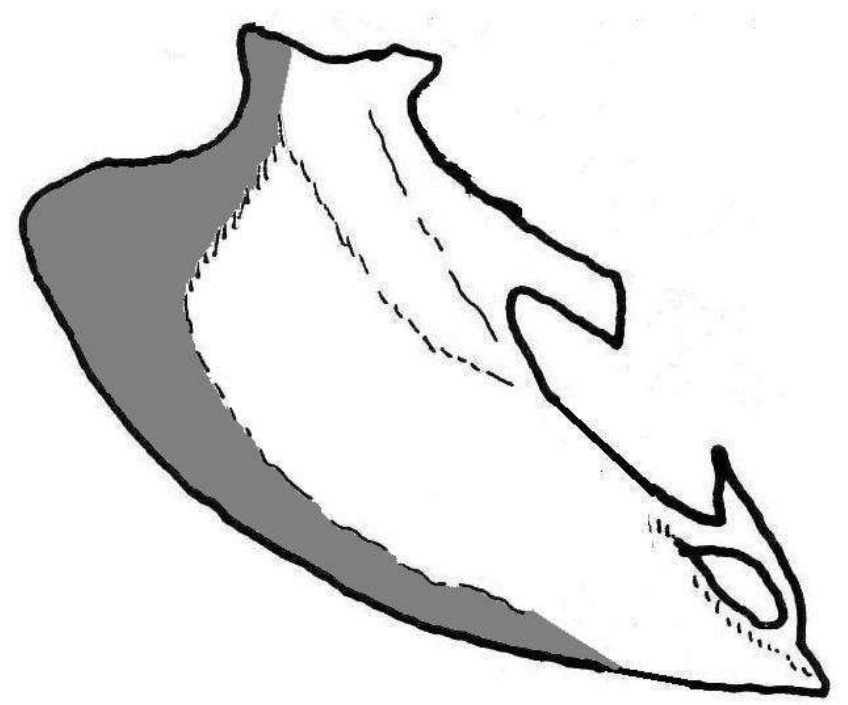

Fig. 37 - Destaque da quilha, no esterno (desenho do autor).

O tronco é mais curto nas aves, que nos outros vertebrados. O pescoço é muito móvel e flexível, e o número de vértebras, como já foi referido varia de espécie para espécie, entre um número mínimo de oito e um máximo de vinte e cinco. $A$ flexibilidade do pescoço deve-se ao facto das vértebras das aves seres do tipo heterocélico (em forma de sela de montar, cuja configuração morfológica permite uma grande elasticidade entre as diferentes vértebras).

As costelas são relativamente grandes e articulam-se com as respectivas vértebras. São reforçadas ventralmente por uma espécie de "tirantes ósseos". As apófises uncinadas, por seu turno distribuem-se de forma a aumentara resistência mecânica da cavidade torácica. As costelas torácicas estão ligadas em duas partes por uma articulação móvel.

Enquanto nos mamíferos as articulações condro-esternais são cartilaginosas, nas aves as costelas articulam-se com a quilha, por meio de articulações ósseas.

O sinsacro apresenta uma continuidade entre a última vértebra torácica e as cinco vértebras lombares seguintes e constitui-se como uma estrutura óssea lamelar 
bastante delgada e aparentemente frágil, mas que na realidade é reforçado internamente. As vértebras sacrais que fazem parte do sinsacro estão unidas à pélvis, especialmente ao ílio, nas aves adultas, formando uma estrutura óssea com uma disposição anatómica alargada, constituindo um suporte longo e parabólico. Desta forma, esta estrutura óssea das aves apresenta-se como fundamental na resistência mecânica no suporte do peso da ave. (GILBERT et al., 1981).

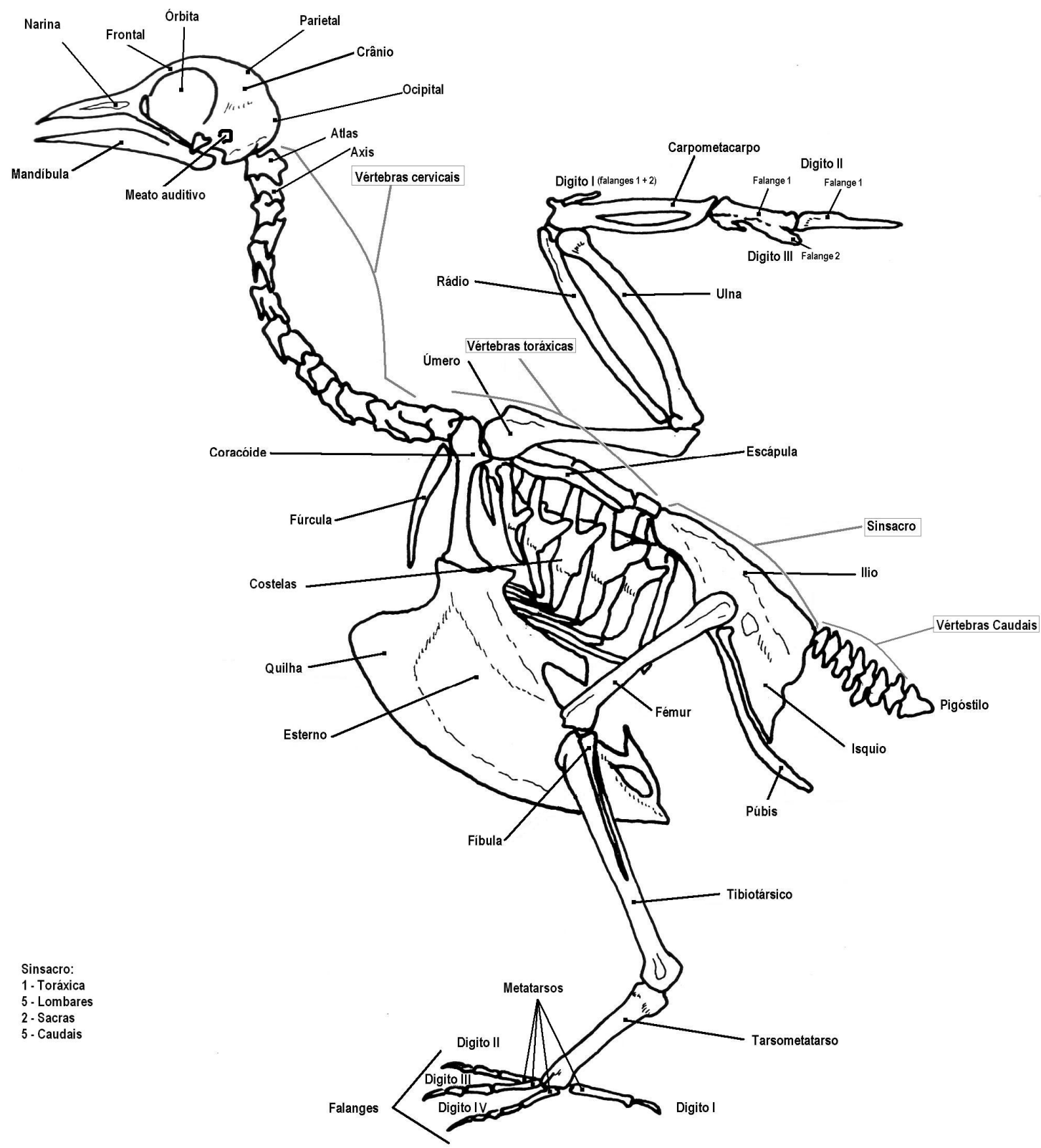

Fig. 38 - Composição do esqueleto de uma ave (gén. Columba). No canto inferior esquerdo estão assinalados os números dos diferentes tipos de vertas que constituem o sinsacro. (construção do autor a partir de Young, 1950). 


\section{O esqueleto apendicular}

O coracóide, a escápula e o par de clavículas, cuja unidade forma a fúrcula, formam a cintura peitoral. A asa compreende o úmero, a ulna, o rádio e o Carpometacarpo, estes são os dois ossos do carpo, e um número variável de falanges, das quais a maior é a primeira falange do dedo maior.

O membro posterior é composto pelo fémur, pela tibiotarso, que consiste na fusão da tíbia com a parte proximal dos tarsos. A parte distal dos tarsos está fundida com os metatarsos. As extremidades articulares do tibiotarso e dos tarsometatarsos são fundidos nos adultos, ou cartilaginosos nas aves jovens. Os dígitos II, III e IV articulam com as extremidades distais dos tarsometatarsos e estão apontados para a frente na maioria das espécies. O número das falanges dos dedos dos pés é variável (GILBERT et al., 1981).

\section{Os Membros anteriores (asas)}

As asas são das características que melhor define as aves, para além das penas e do bico. Apesar das asas não serem uma estrutura única destes animais, existindo outros grupos animais que possuem também estas estruturas, nas aves são dos elementos que maiores transformações sofreram, ao longo da sua evolução e que assumem determinadas formas consoante os ambiente a que as diversas espécies se adaptaram. Basta ter em mente a morfologia das asas de uma águia, uma cegonha, de um avestruz ou de um pinguim para se perceber da grande variedade que existe entre as asas das diferentes espécies de aves.

Em zoologia, a asa é um membro ou apêndice de um animal, desenvolvido a partir dos membros anteriores e morfologicamente adaptado ao voo livre. Esta enunciação exclui as estruturas anatómicas que possibilitam o voo deslizante, presentes, por exemplo, nos esquilos voadores e em alguns répteis (MASSADA, 2001).

As asas apareceram em grupos distintos de animais, não devido à existência de um antepassado comum, mas sim devido a fenómeno denominado de "convergência morfológica" em resposta a pressões ecológicas favoráveis à aptidão para o voo. As asas apareceram em, pelo menos, quatro fases da evolução biológica: nos insectos (ainda no Paleozóico), nas aves e nos pterossauros, (no Mesozóico) e nos morcegos, (já no Cenozóico). O registo fóssil, não permite concluir com toda a 
segurança que não houve na Terra outros grupos de seres vivos com asas. $O$ progresso da paleontologia poderá revelar, no futuro, outros grupos de animais que poderão ter tido asas.

Nos grupos de animais voadores, o aparecimento de asas deu origem a radiações adaptativas e ao aumento da biodiversidade. Desta forma, estes animais são geralmente dominantes em número de espécies dentro dos respectivos grupos.

Nas aves, as asas são formadas pelo úmero, ulna e rádio, ossos do carpo e ossos dos dedos. A primeira parte da asa é suportada pelo úmero, ulna e rádio, a segunda parte da asa é suportada pelos ossos do pulso (carpos) e pela fusão dos ossos dos dedos.

\subsection{3 - Características específicas dos ossos das aves}

Os ossos das aves apresentam características muito próprias, devido á sua evolução e adaptação aos meios aéreos, ao modo de alimentação, ao modo de deslocação em terra, etc.

As aves desenvolveram, nos ossos, um grau de pneumatização muito elevado, as mandíbulas perderam os dentes, o esterno desenvolveu-se muito, originando a quilha, as clavículas fundiram-se e deram origem à fúrcula. O crânio não apresenta aberturas, as vértebras da zona pélvica fundiram-se, formando o sinsacro, a cauda reduziu-se, não tendo mais de oito vértebras e a última transformou-se no pigóstilo, uma estrutura que suporta as penas caudais, os digitos I e III dos membros anteriores reduziram-se, tornando-se vestigiais e o dígito II desenvolveu-se, tendo as falanges desenvolvido formas muito particulares (a primeira em forma laminar e a segunda, em forma pontiaguda), a maioria dos carpos fundiu-se com os metacarpos, dando origem ao Carpometacarpo, o mesmo acontecendo com os tarsos e os metatarsos, que se fundiram no tarsometatarso. Os úmeros desenvolveram a fossa pneumatricial, para fixação dos músculos das asas e as ulnas desenvolveram uma papilas para a fixação das penas rémiges. 


\section{Esqueleto Craniano}

Crânio
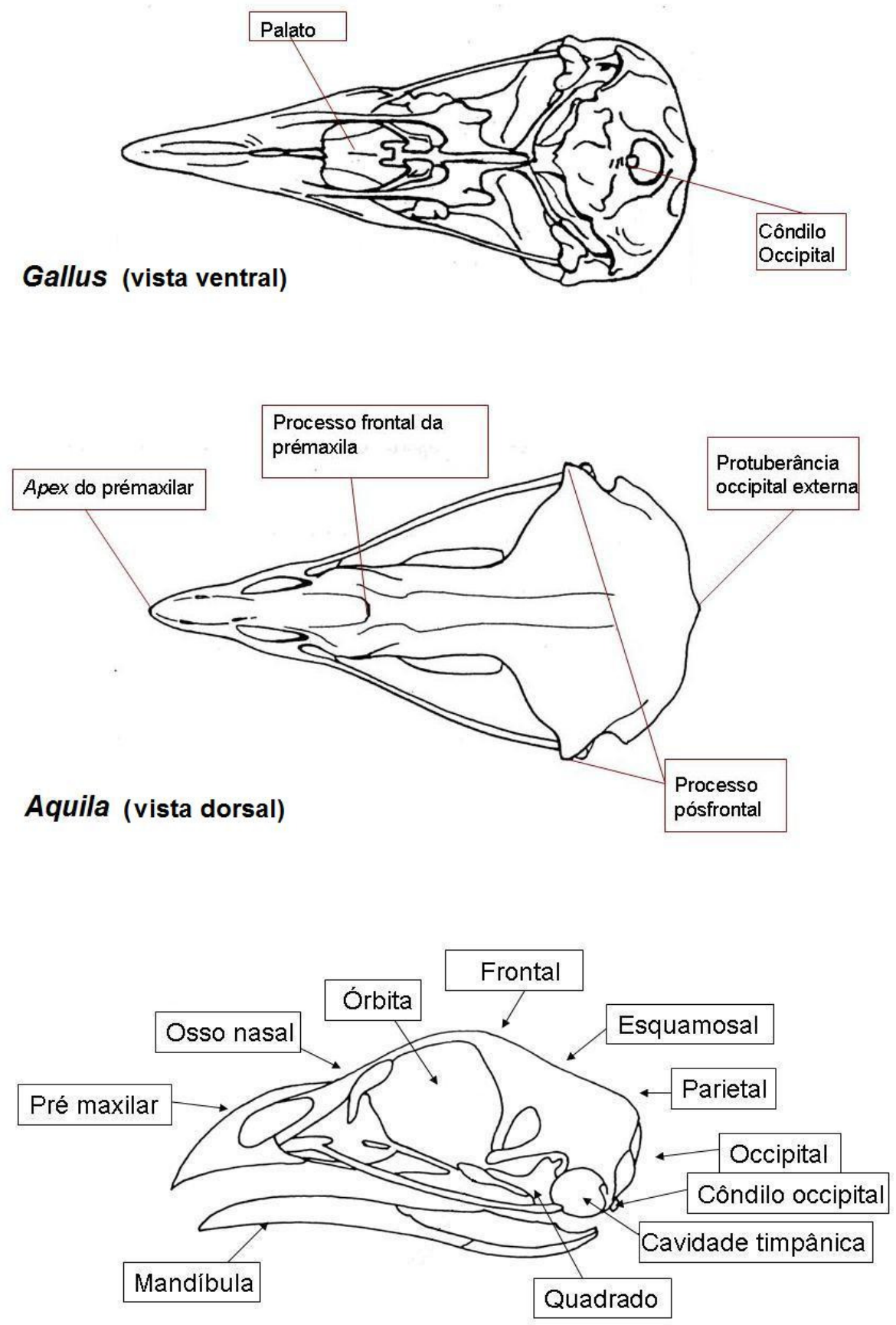

\section{Gallus (vista lateral)}

Fig. 39 - Principais ossos e estruturas dos crânios das aves (adaptado de COHEN \& SERJEANTSON, 1996 e DRIESCH, 1976).

Mandíbula 


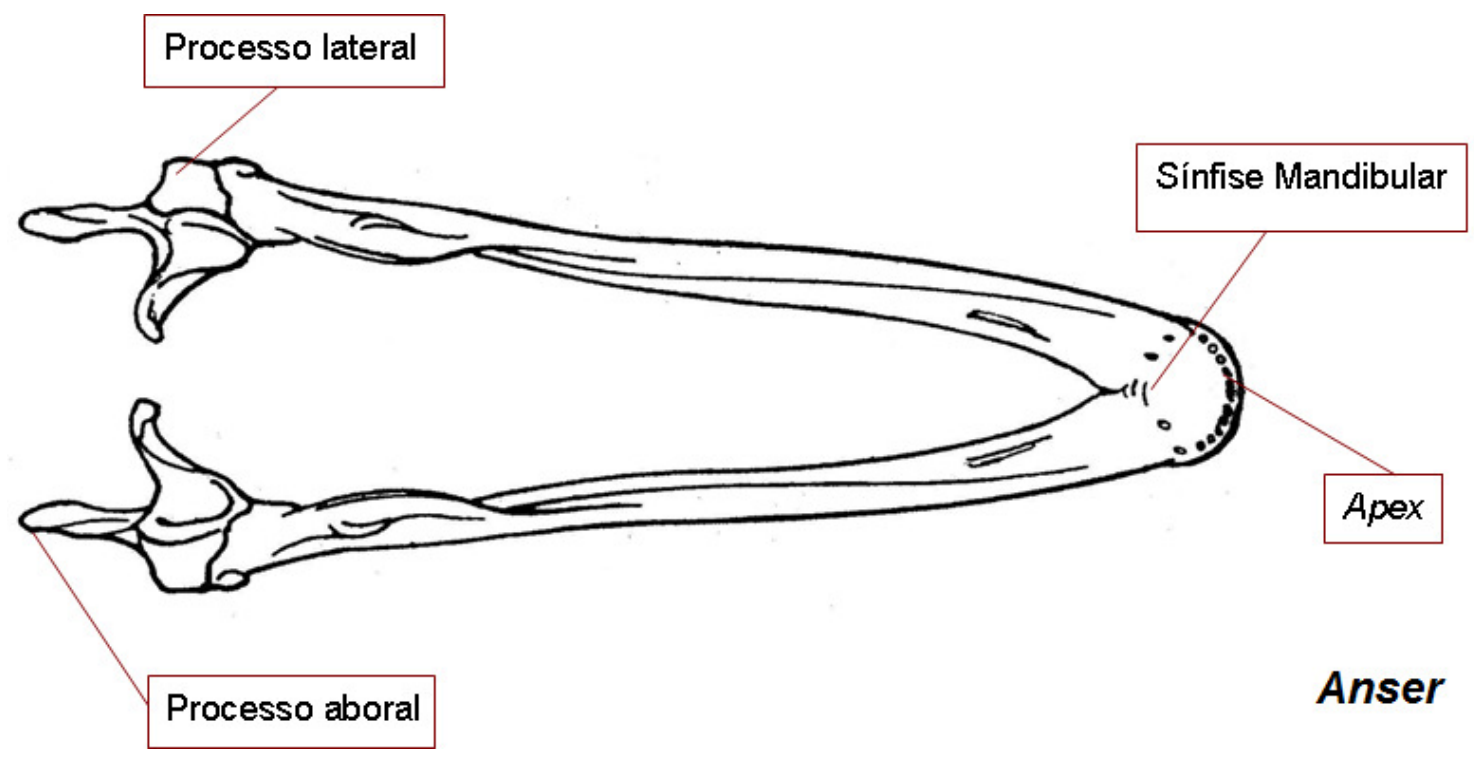

Fig. 40 - Principais estruturas da mandíbula (adaptado de COHEN \& SERJEANTSON, 1996).

\section{Esqueleto Axial}

Externo

O esterno das aves tem uma forma muito particular, porque apresenta uma estrutura desenvolvida, em forma de quilha de barco (que lhe dá o nome), e que tem como função fixar os músculos das asas. Nas Paleognathae esta estrutura não se encontra tão desenvolvida, pois as asas destas aves não voadoras não têm os músculos tão desenvolvidos como as restantes.

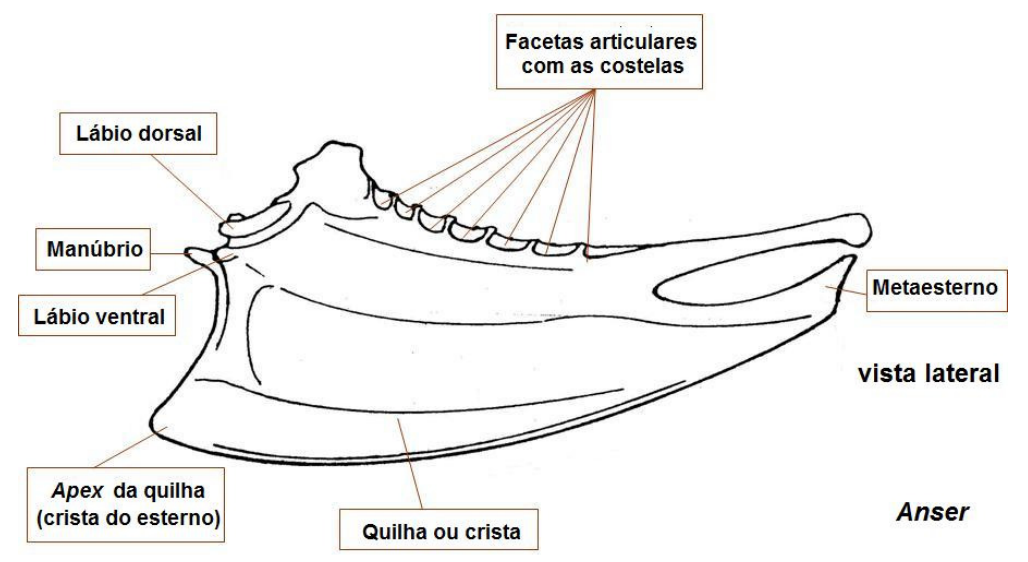

Fig. 41 - Principais estruturas do esterno das aves (adaptado de COHEN \& SERJEANTSON, 1996). 
Pélvis e sinsacro

A pélvis das aves é formada pelo ílio, pelo ísquio, pelo púbis e pelo sinsacro, que é formado pela fusão das vértebras toráxicas posteriores, todas as lombares e sacrais e pelas caudais anteriores (GILBERT et al., 1996). Este é outro osso específico das aves.

A superfície dorso-lateral e a zona proximal para o acetábulo é côncava. No plano médio-sagital, a pélvis é simétrica bilateralmente. No grupo das aves com os ossos muito pneumatizados a área proximal para o acetábulo é marcadamente maior do que da parte distal. Noutros grupos, tais como os mergulhões, a superfície distal e proximal são iguais (GILBERT et al., 1996).
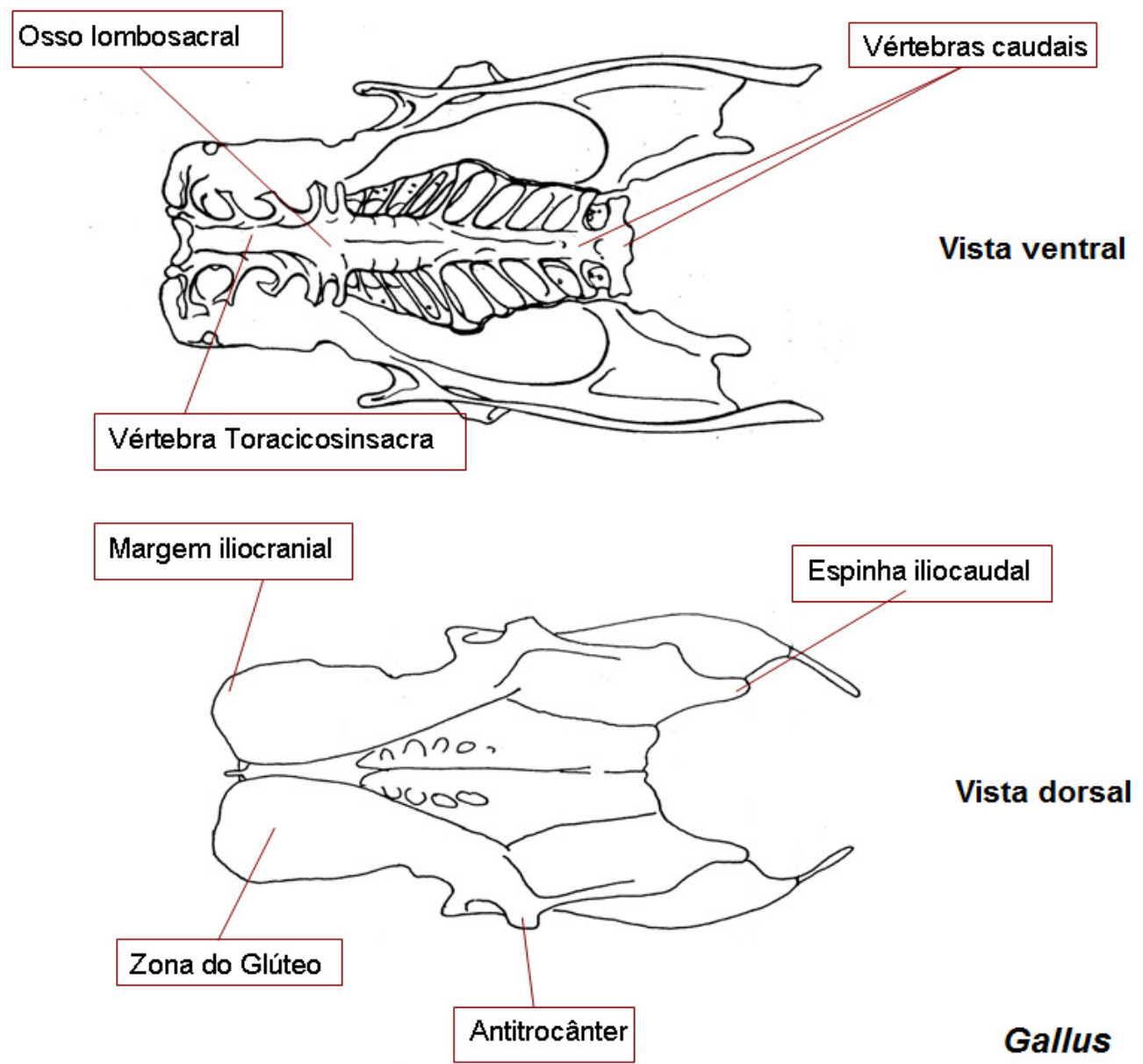

Fig. 42 - Principais estruturas da pélvis e do sinsacro (adaptado de COHEN \& SERJEANTSON, 1996). 


\section{Esqueleto Apendicular}

No estudo realizado a grande maioria dos ossos encontrados pertencem ao esqueleto apendicular, assim iremos fazer uma breve caracterização de cada um dos ossos mais representados.

\section{Membros anteriores (Asa)}

Os membros anteriores das aves contêm, com algumas transformações, os mesmos ossos que os braços dos mamíferos e dos répteis (úmero, rádio, ulna, radial e ulnar, Carpometacarpo e falanges). Nas aves, o úmero é relativamente curto, com uma crista proximal muito desenvolvida, para fixação dos músculos do voo. O rádio e a ulna formam a "asa média", a ulna tem pequenas protuberâncias, para a fixação das penas secundárias das asas. Na evolução dos braços dos antepassados das aves em asas, o Carpometacarpo resultou da fusão de vários ossos e as falanges adaptaram-se à transformação de braços em asas. O primeiro dígito, ou pollex, suporta a álula, uma pequena pena para controlo do voo.

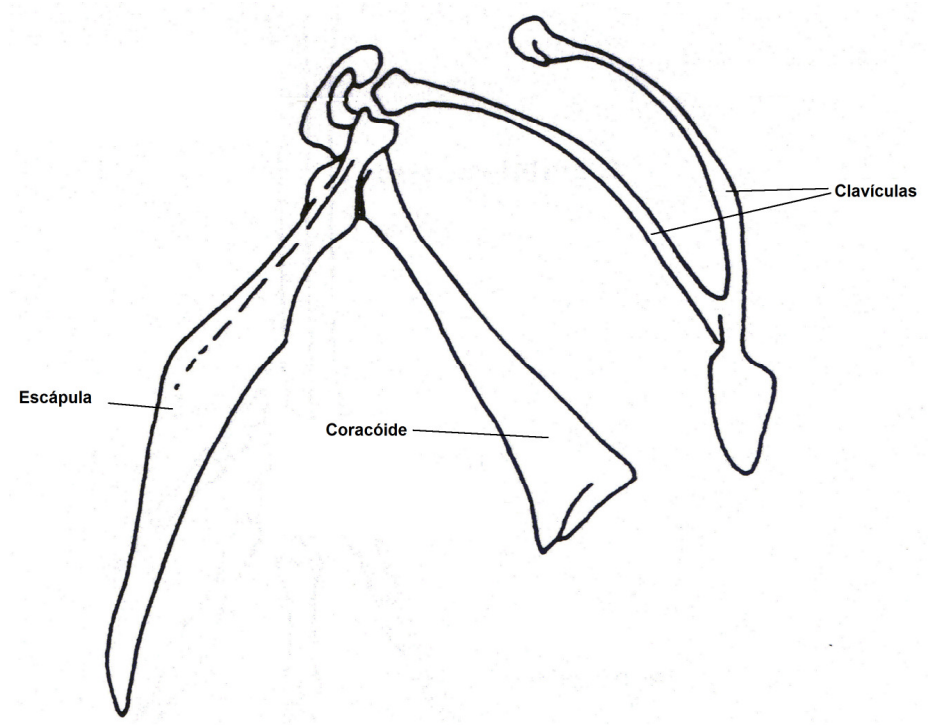

Fig. 43 - Ossos da Cintura escapular de Gallus gallus (adaptado de COHEN \& SERJEANTSON, 1996). 


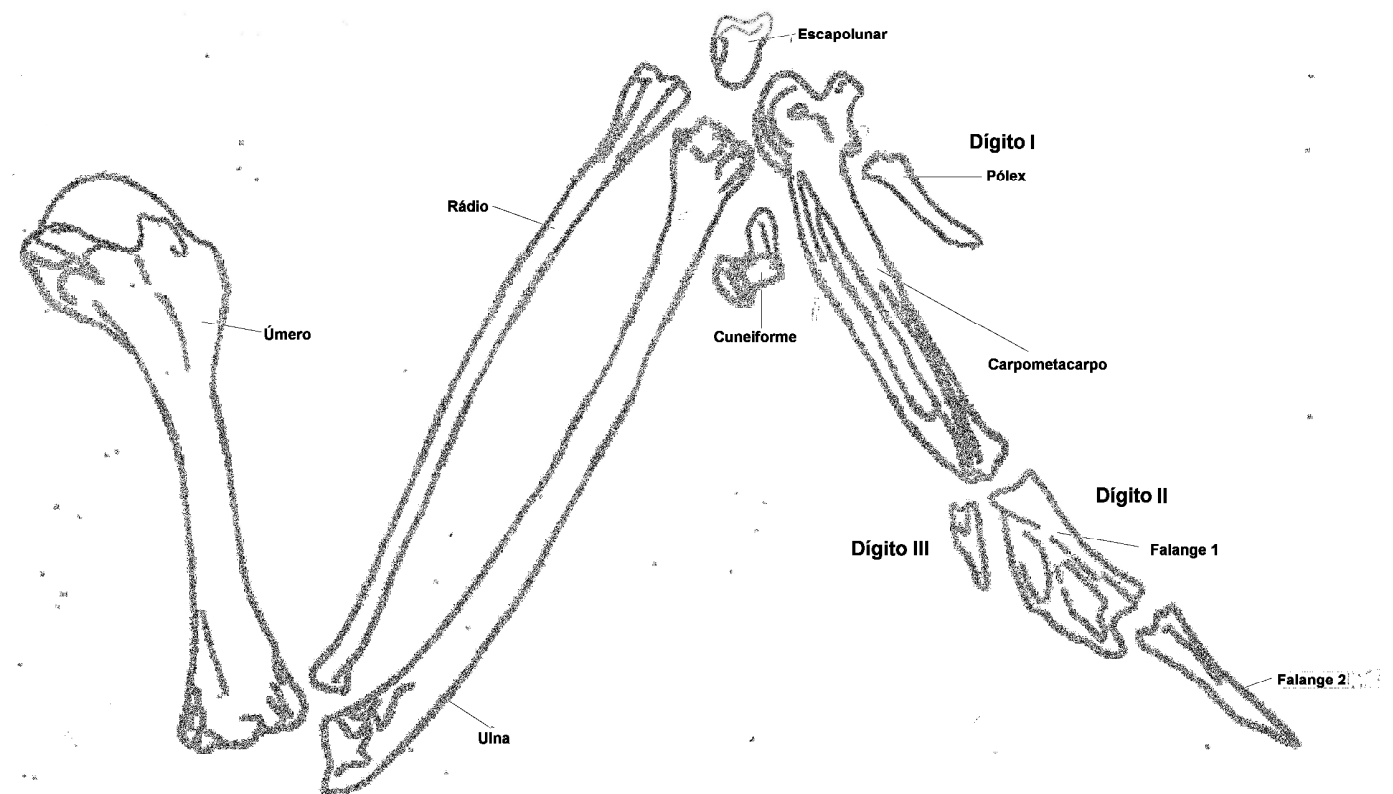

Fig. 44 Ossos dos membros anteriores de Strix varia (adaptado de GILBERT et al., 1996)

\section{Escápula}

A escápula das aves é, na maior parte dos grupos convexa no bordo vertebral e côncava ao longo do bordo lateral, côncava ao longo da superfície ventral e convexa na dorsal. Na extremidade proximal, situa-se o processo acrómio, no bordo vertebral, enquanto a faceta umeral ou glenóide, situa-se no bordo lateral (GILBERT et al., 1996; BAUMEL et al., 1993).

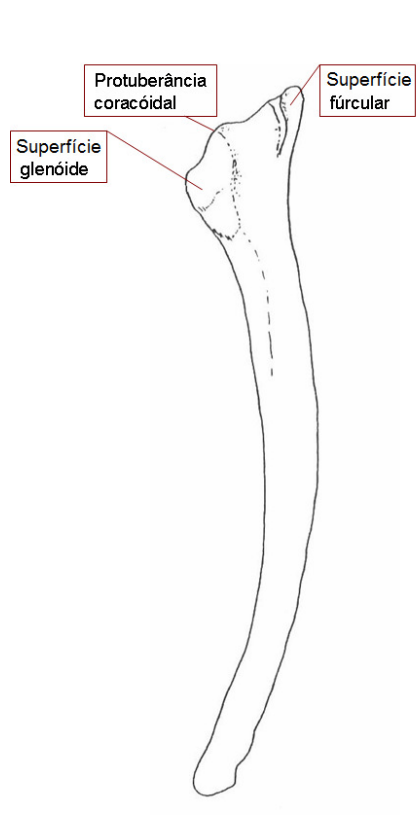

Vista lateral esquerda

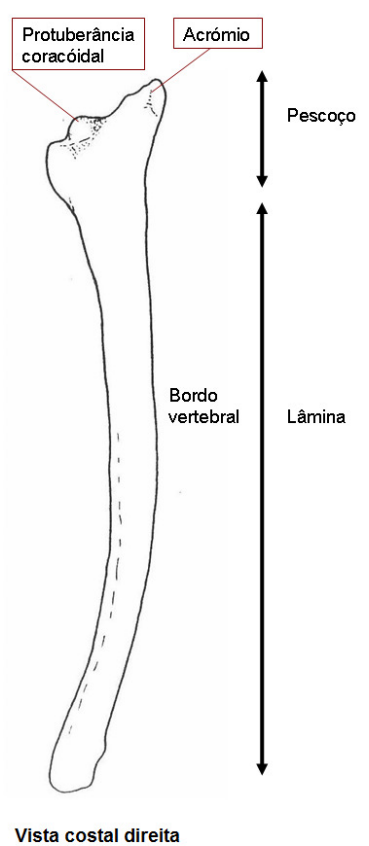

Cygnus

Fig. 45 - Principais estruturas da escápula (adaptado de COHEN \& SERJEANTSON, 1996). 


\section{Coracóide}

O coracóide actua como um apoio entre o esterno e o úmero (GILBERT et al., 1996). A extremidade esternal é um pouco ampla, semelhante à base de um triângulo isósceles. A faceta esternal ocupa quase toda a superfície da extremidade. $\mathrm{Na}$ extremidade anterior do osso, na superfície dorsal, localizam-se as facetas escapular e umeral e a faceta furcular, na superfície ventral. O processo procoracóide prolonga-se na parte mesial e dorsalmente (GILBERT et al., 1996).
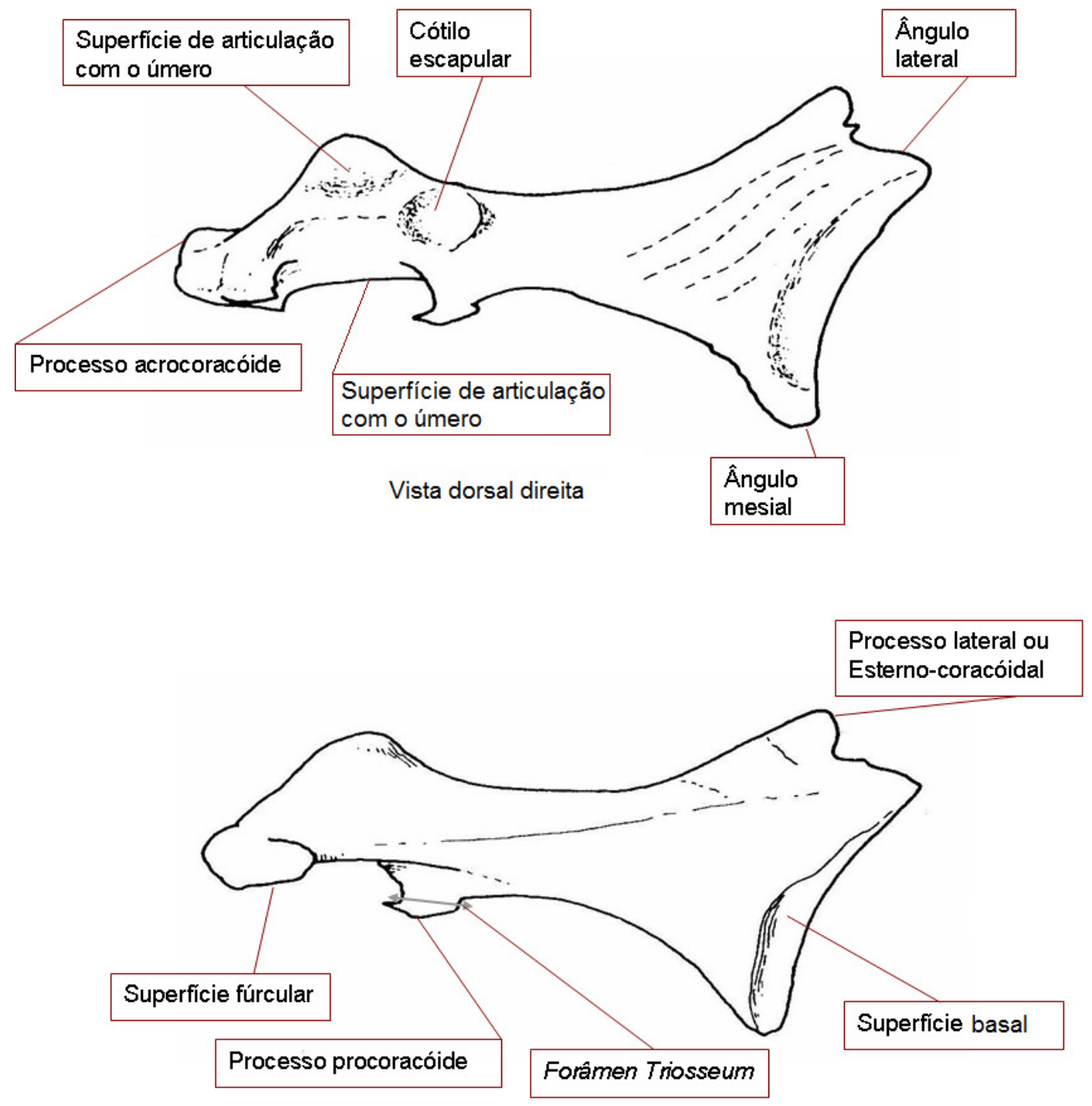

Vista ventral esquerda

Cygnus

Fig. 46 - Principais estruturas do coracóide (adaptado de COHEN \& SERJEANTSON, 1996). 
Úmero

A forma geral dos úmeros das aves é curva A superfície anterior é convexa na extremidade proximal e côncava na distal. A cabeça do úmero é oblonga mesiolateralmente. Existe uma cova, localizada entre superfície articular da cabeça do úmero e o tubérculo ventral, denominada de "sulco capital", por Howard"25 (BAUMEL et al., 1993). Por baixo desta crista encontra-se a fossa pneumatricial, que pode apresentar vários forámenes (GILBERT et al., 1996).

Na superície anterior encontra-se a crista bicipital, que se desenvolve a partir do sulco ligamentar transverso e prolonga a intumescência do úmero. Do lado oposto encontra-se a crista deltóide ou radial, onde se ligam os músculos deltóide e peitoral.

A forma da secção da diáfise do úmero é geralmente oval. A extremidade distal é convexa na face posterior e côncava na anterior. Na superfície anterior, mesmo por cima dos côndilos distais, existe uma fossa para os músculos braquiais. $\mathrm{O}$ côndilo lateral (externo) é maior e o mesial é menor. Entre eles existe o sulco intercondilar. Na superfície posterior da extremidade distal existe a fossa do olecrânio, onde articula esta parte da ulna. Nas duas faces e por cima desta fossa existem várias covas de inserção dos tendões do extensor dos músculos tricipitais (GILBERT et al., 1996).

250 termo "sulco capital", do inglês: capital groove, foi proposto por Howard em 1929 em artigo publicado pela revista de zoologia da Universidade da Califórnia e intitula "The avifauna of Emeryville Shellmond" 


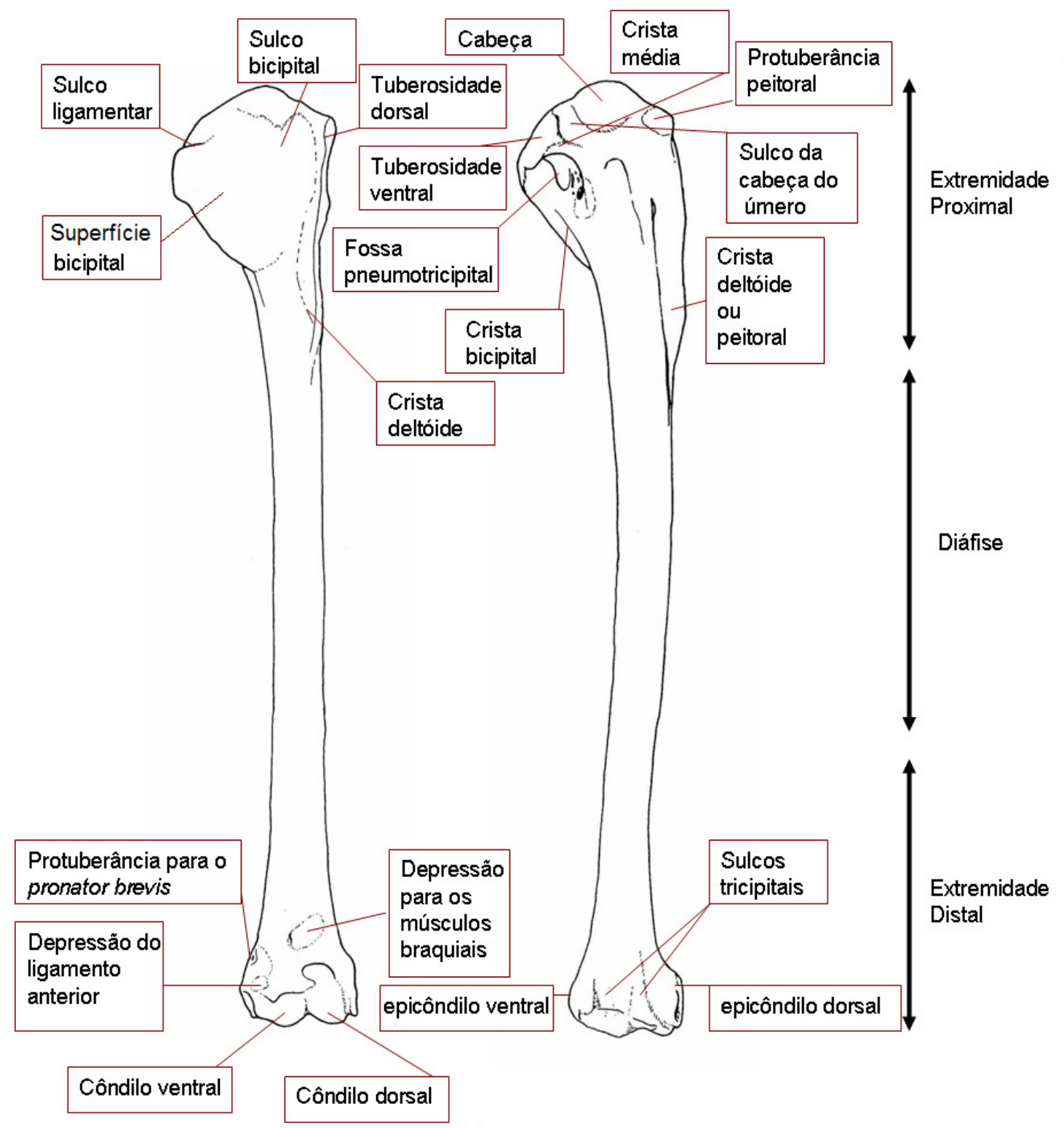

Vista caudal esquerda

Vista cranial direita

Cygnus

Fig. 47 - Principais estruturas do úmero (adaptado de COHEN \& SERJEANTSON, 1996).

Ulna

A ulna das aves caracteriza-se por, na extremidade proximal, o corte transversal ter um formato sub-triangular (GILBERT et al., 1996) e a cótila ventral côncava e grande e cótila ventral mais pequena. Na face caudal apresenta uma grande depressão (depressão braquial), onde se insere o músculo braquial (COHEN \& SERJEANTSON, 1996). Vista lateralmente, a ulna das aves é mais ou menos curva, consoante a espécie. 
A superfície dorsal apresenta papilas ósseas (GILBERT et al., 1996), mais evidentes numas espécies que noutras, que servem para fixar as rémiges.

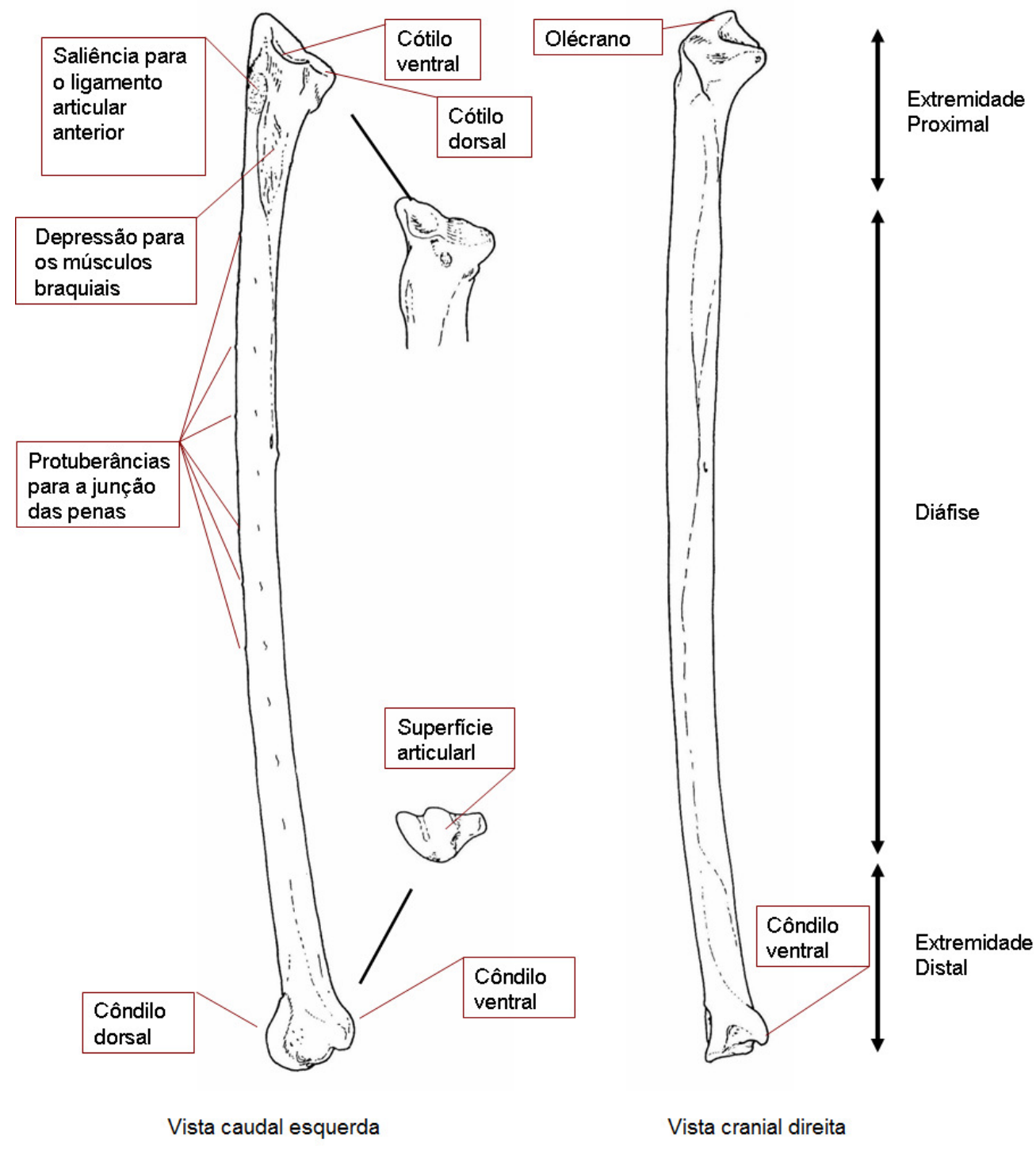

Cygnus

Fig. 48 - Principais estruturas da ulna (adaptado de COHEN \& SERJEANTSON, 1996).

Rádio

No rádio das aves, a extremidade proximal é côncava e articula com o côndilo interno da extremidade distal do úmero. Esta concavidade da articulação proximal do rádio dá-Ihe uma aparência de uma cabeça de prego (GILBERT et al., 1996). Logo por baixo da articulação proximal existe um tubérculo (bicipital radial) (GILBERT et al., 1996; BAUMEL et al., 1993). 
O rádio é um osso longo e fino, ligeiramente curvo e com a secção da diáfise Sub-triangular. A superfície dorsal é redonda, em todo o seu comprimento e em cerca de 1/3 da superfície ventral nota-se uma linha bem definida (GILBERT et al., 1996), a linha intermuscular.

A parte distal do rádio é mais larga que a diáfise (GILBERT et al., 1996) e que a extremidade proximal. Existe um sulco proeminente próximo do bordo lateral, na superfície dorsal (GILBERT et al., 1996). O sulco tendinoso (BAUMEL et al., 1993), serve para a passagem dos tendões do músculo extensor (GILBERT et al., 1996). A maior parte dos grupos tem, na extremidade distal, o processo estiloide pronunciado (GILBERT et al., 1996).

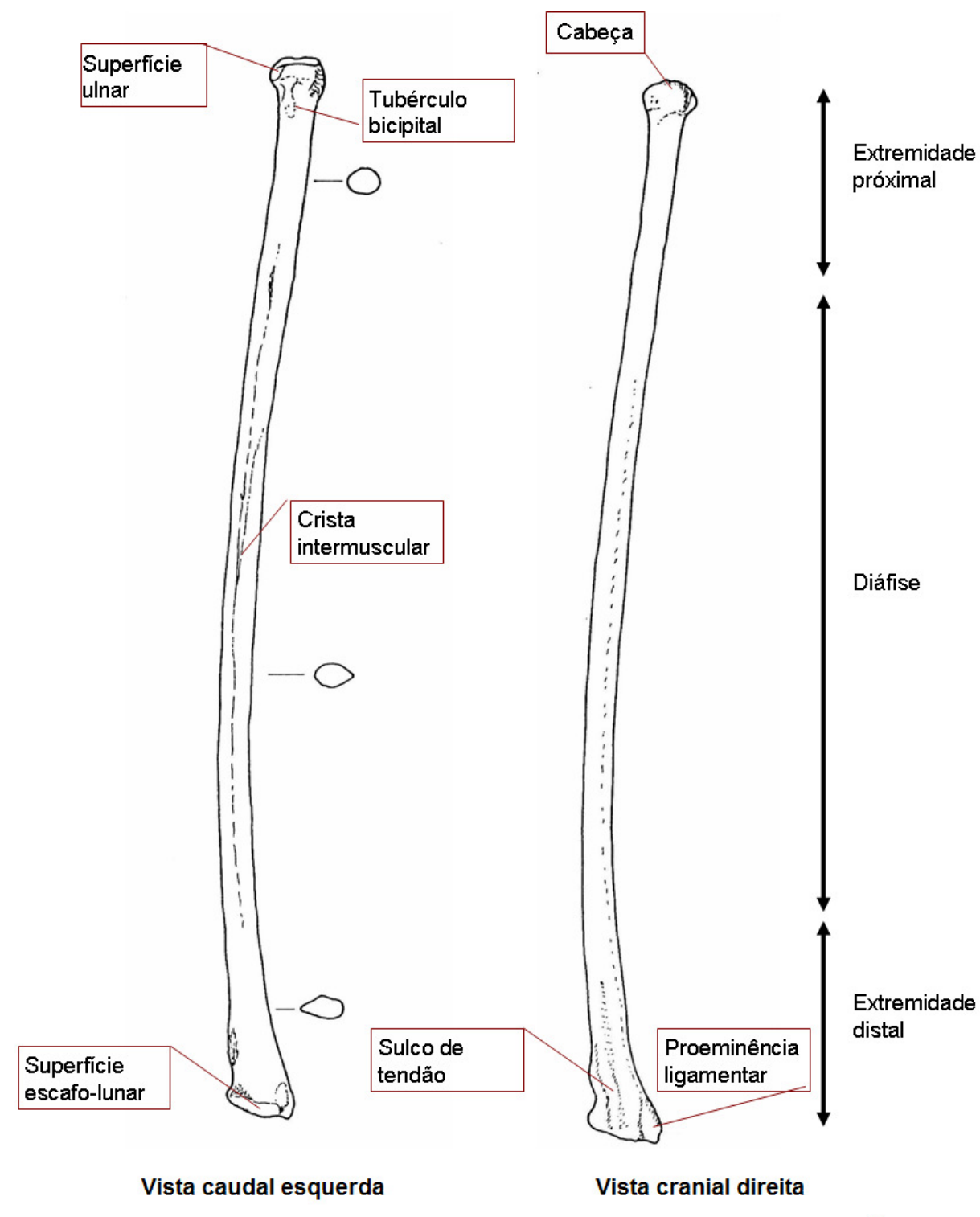

Cygnus

Fig. 49- Principais características do rádio (adaptado de COHEN \& SERJEANTSON, 1996). 


\section{Carpometacarpo}

O Carpometacarpo é um osso único das aves, que resulta, com a excepção do carpo ulnar (cuneiforme) e do carpo lunar (escafóide), da fusão dos carpos com os metacarpos (GILBERT et al., 1996).

Este osso tem uma forma semelhante a um arco de violino (GILBERT et al., 1996). O pulso é composto pelo metacarpo I (GILBERT et al., 1996), que é constituído pelo processo pisiforme e pelo processo extensor (BAUMEL et al., 1993). O processo pisiforme localiza-se na superfície palmar (GILBERT et al., 1996) e o processo extensor é bastante desenvolvido. O resto do osso é constituído pelo metacarpo II (osso metacarpo maior, segundo Baumel (BAUMEL et al., 1993) e pelo metacarpo III (osso metacarpo menor, (BAUMEL et al., 1993). Consoante as espécies, o metacarpo III pode apresentar uma curva acentuada, enquanto o metacarpo II é, de forma geral, rectilíneo. Entre estes dois metacarpos existe um espaço, designado por espaço intermetacarpal (BAUMEL et al., 1993).

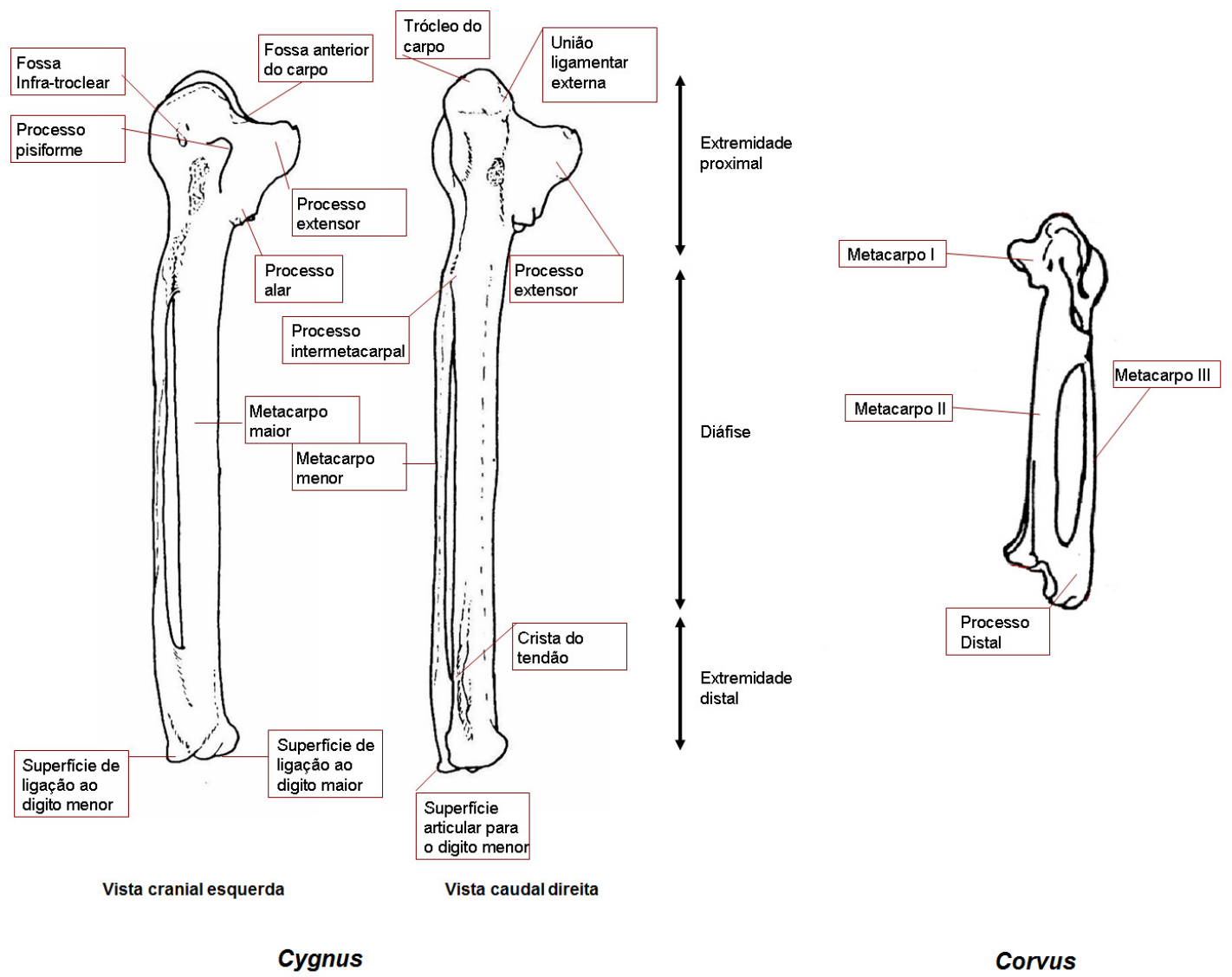

Fig. 50 - Principais estruturas do carpometacarpo (adaptado de COHEN \& SERJEANTSON, 1996). 
Primeira falange do dígito II da asa

A primeira falange do segundo dígito é o osso mais pequeno da asa, passível de ser recuperado em escavação (GILBERT et al., 1996). Tem uma forma de lâmina e é ligeiramente côncava ao longo da sua superfície palmar (GILBERT et al., 1996). Tem lateralmente uma ranhura (extensora), segundo Gilbert (GILBERT et al., 1996), que é o prolongamento da ranhura extensora do Carpometacarpo (GILBERT et al., 1996).

Apesar de neste estudo não ter sido encontrado nenhum exemplar, a falange terminal pode também, embora raramente, ser encontrada em sítios arqueológicos (GILBERT et al., 1996). Têm um formato pontiagudo, são longas e são mais achatadas na superfície palmar, que as dos mamíferos.

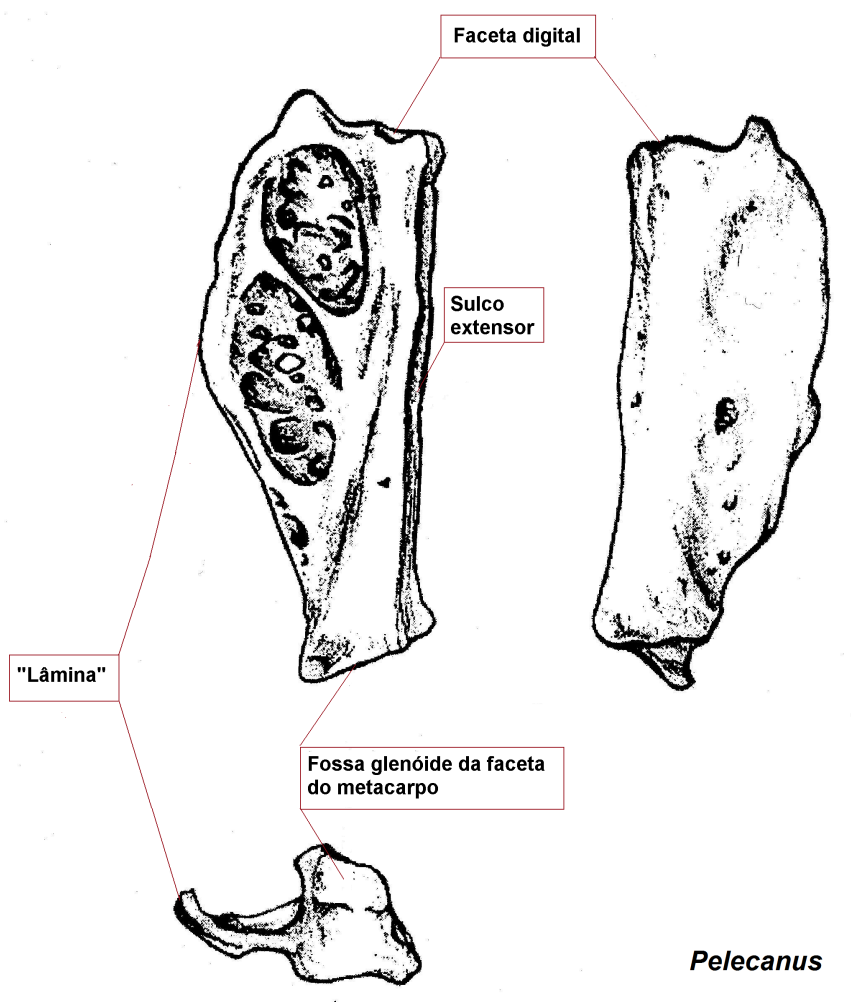

Fig. 51 - Principais estruturas ósseas da primeira falange do dígito II (adaptado de GILBERT et al., 1996)

\section{Membros posteriores}

Os membros posteriores das aves são constituídos pelo fémur, patela, fíbula, tibiotarso, tarsometatarso e pelas falanges. O fémur, adaptado ao bipedismo, não sofreu grandes modificações, ao longo da evolução das aves. No entanto, a parte 
inferior da perna e no pé, os ossos sofreram grande alteração devido à fusão de diferentes ossos. A fíbula é reduzida, a tíbia fundiu-se com alguns ossos do tarso, o mesmo acontecendo com o tarsometatarso, que resultou da fusão de vários ossos.

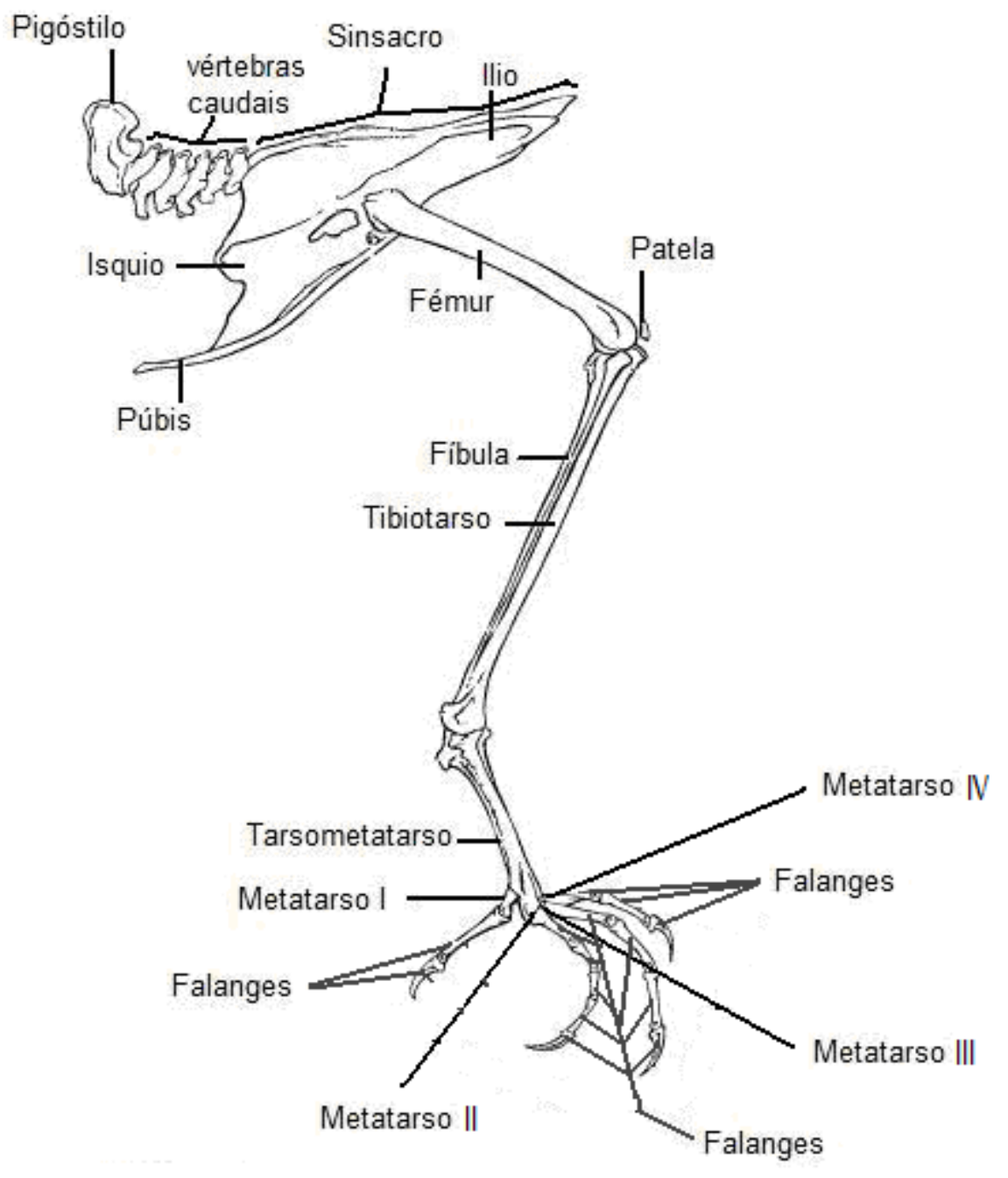

Fig. 52 - Ossos da cintura pélvica, cauda e membros posteriores (retirado e adaptado de http://www.life.illinois.edu/ib/461/Internal_Anatomy.pdf, acedido em 12/03/2009) 


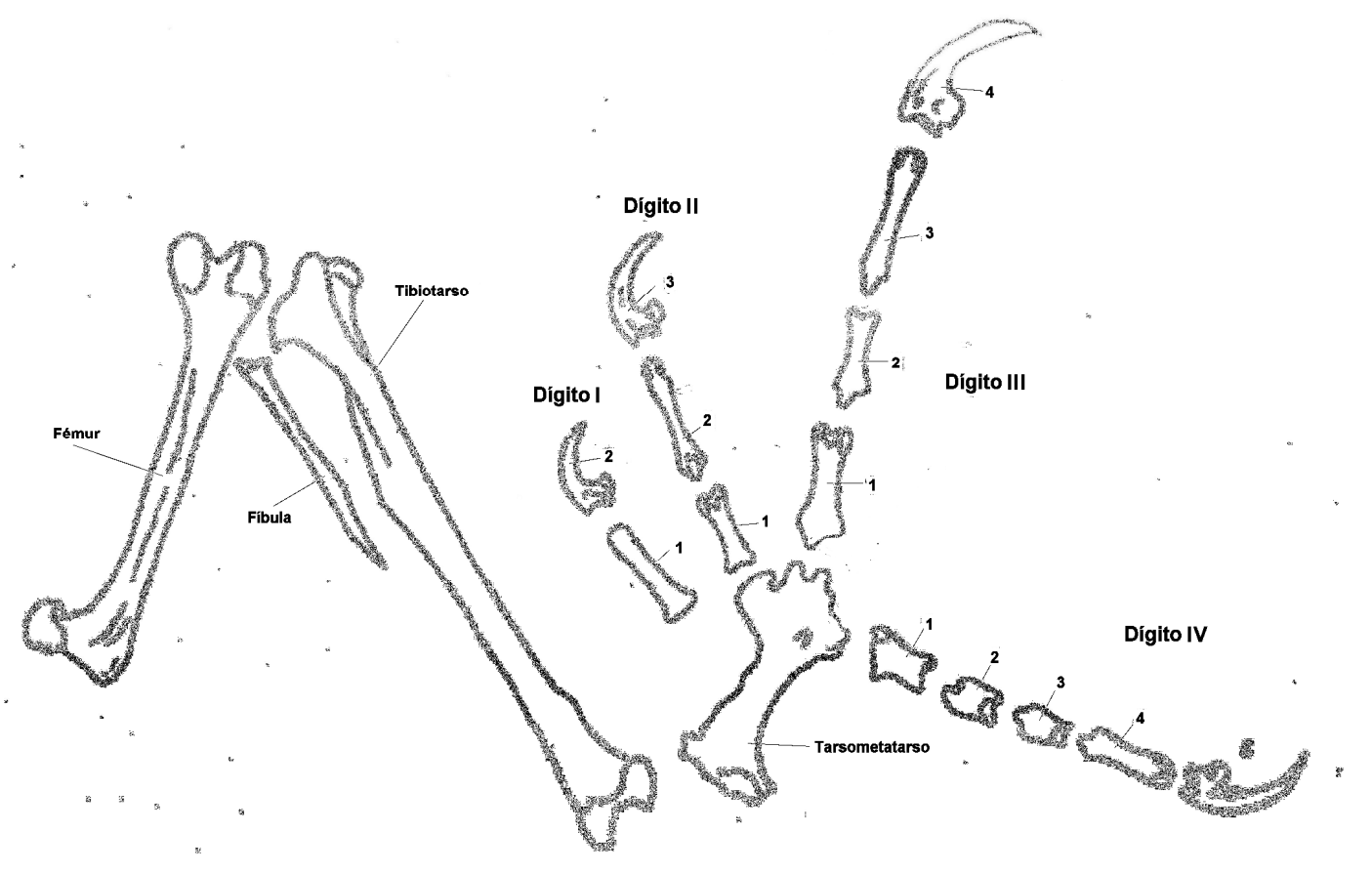

Fig. 53 - Ossos dos membros posteriores de Strix varia (adaptado de GILBERT et al., 1996)

Fémur

A forma geral dos fémures das aves é arqueada, com a superfície anterior convexa e a dorsal côncava. É um osso curto, ao contrário do que acontece em outros grupos animais. Normalmente o grande trocanter está à mesma altura da cabeça do fémur. A fóvea capital é bem evidente na cabeça do fémur. Em alguns grupos, na superfície anterior, logo por baixo do grande trocanter, e perto do bordo lateral encontra-se um forâmen pneumático (GILBERT et al., 1996).

$\mathrm{Na}$ extremidade distal, os côndilos femurais estão bem separados por um grande sulco, o sulco intercondilar (BAUMEL et al., 1993). O côndilo lateral tem o maior diâmetro antero-posterior e um sulco pronunciado; a tróclea fibular (BAUMEL et al., 1993), separa-o posteriormente, do epicôndilo lateral (GILBERT et al., 1996; BAUMEL et al., 1993). Este epicôndilo situa-se um pouco acima da articulação, ao mesmo nível do sulco patelar. 


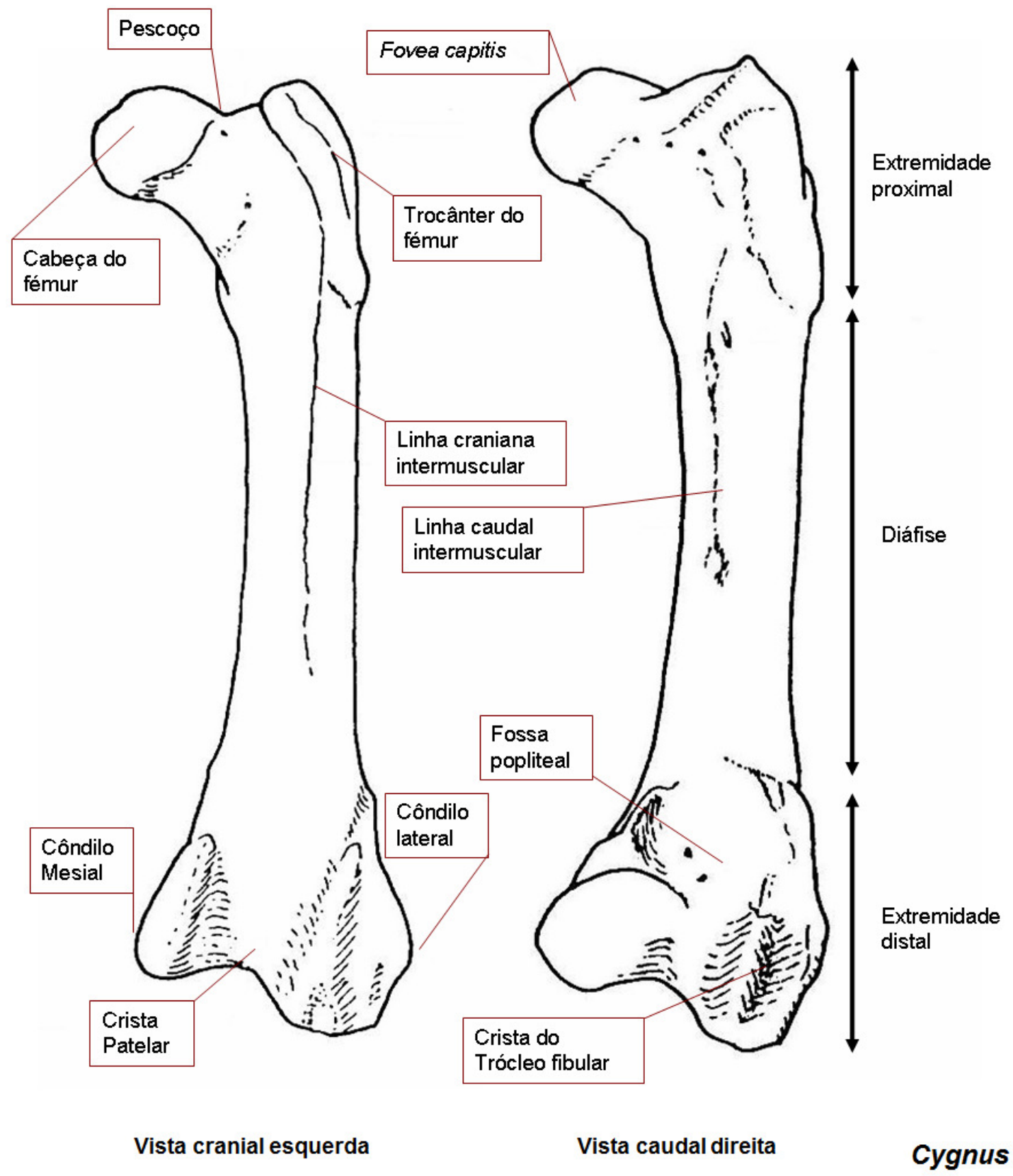

Fig. 54 - Principais estruturas do fémur (adaptado de COHEN \& SERJEANTSON, 1996).

\section{Tíbiotarso / Fíbula}

O tibiotarso das aves tem a patela fundida anteriormente, na extremidade proximal do osso, formando uma crista cnemial desenvolvida. Existe também uma outra crista cnimial que forma um gancho virado para baixo na superfície anterior à fíbula (GILBERT et al., 1996).

$\mathrm{Na}$ extremidade distal, na face anterior, existe uma fossa supra-condilar, que na maior parte dos casos apresenta uma ponte supra-tendinal para os tendões dos 
músculos extensores (GILBERT et al., 1996). Quase sempre, o côndilo mesial tem o diâmetro antero-posterior maior. A diáfise é visivelmente curva em direcção ao côndilo mesial (GILBERT et al., 1996).

Na face lateral mesial-proximal o fémur tem a crista fibular (BAUMEL et al., 1993), que é uma estrutura óssea que conecta com a fíbula.

A fíbula é um osso em forma de alfinete, com a extremidade proximal redonda ou espalmada. Está fundida com o tibiotarso na face lateral da região mesial-distal; na região mesial-proximal liga à crista fibular. Na extremidade proximal, a fíbula encosta à cabeça fibular (BAUMEL et al., 1993).

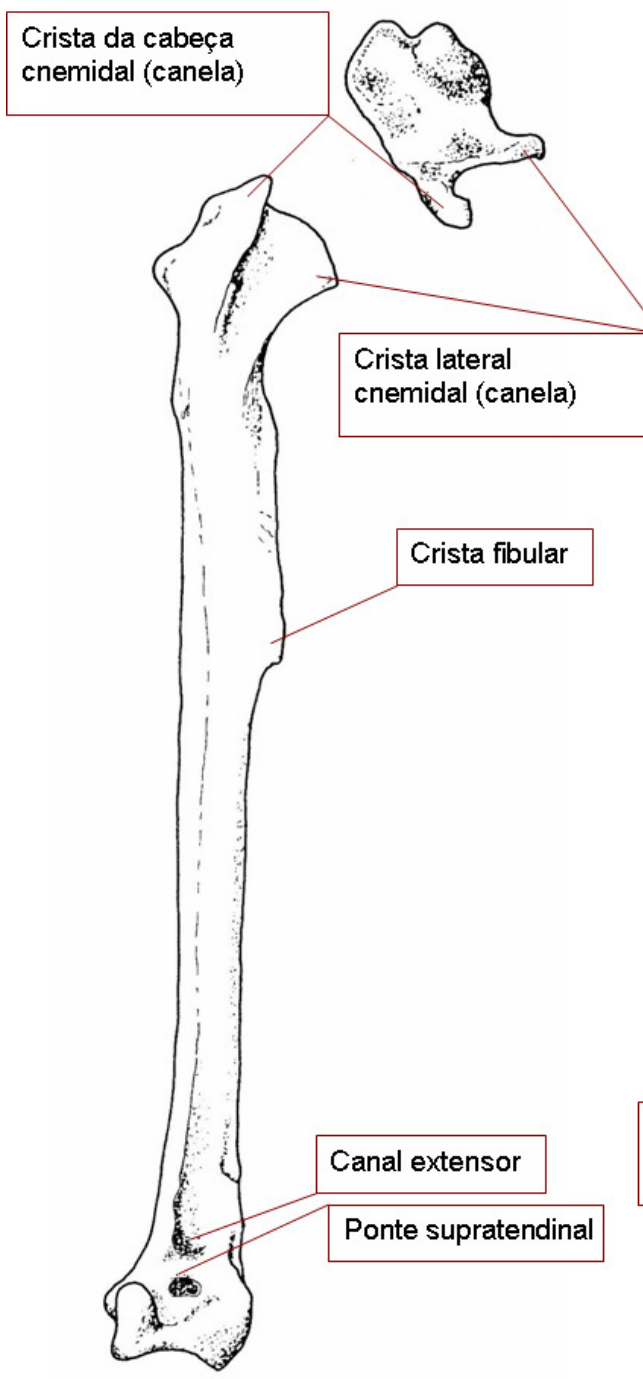

Vista cranial esquerda

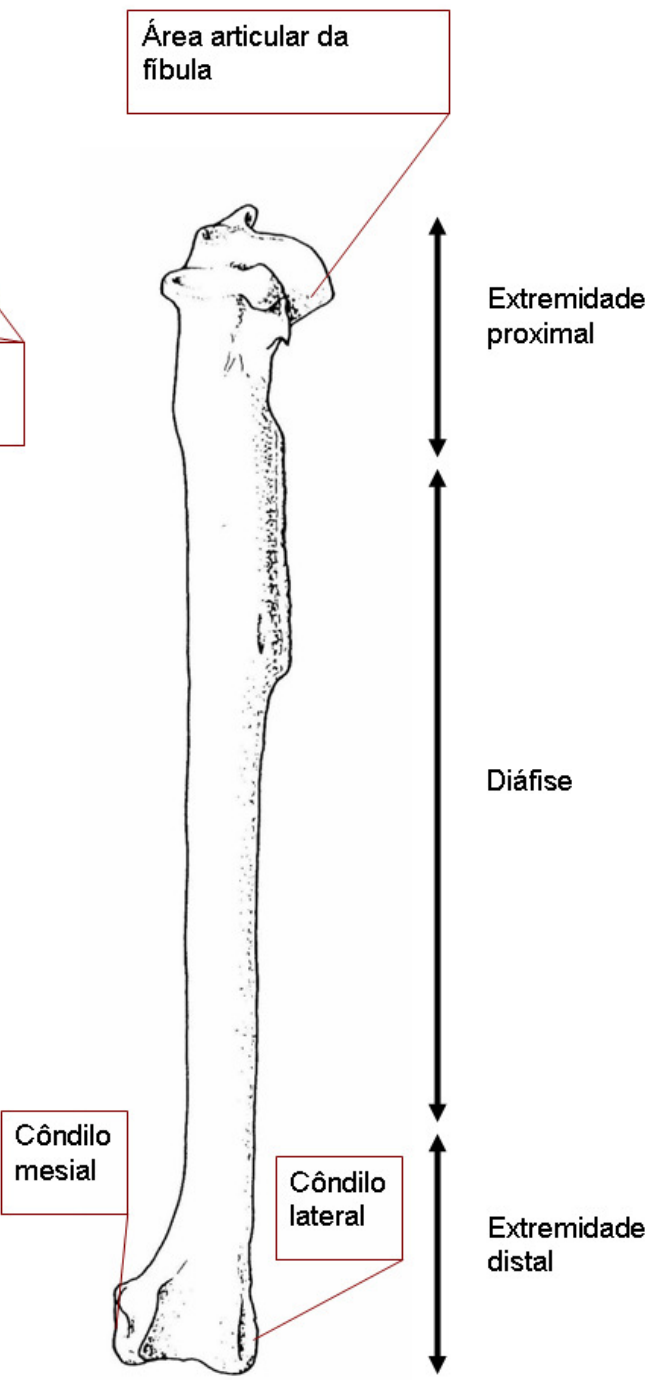

Vista caudal direita
Cygnus

Fig. 55 - Principais estruturas do tibiotarso (adaptado de COHEN \& SERJEANTSON, 1996). 
Tarsometatarso

Nas aves, os tarsos e os metatarsos estão fundidos, formando o tarsometarso. Geralmente a face caudal do tarsometatarso é mais ou menos plana, em especial nas aves de rapina, enquanto que a face cranial é convexa.

Este osso apresenta as cótilas da extremidade proximal mais ou menos concavas para, melhor articularem com os côndilos convexos do tibiotarso (GILBERT et al., 1996). Entre as cótilas existe uma saliência, a eminência intercotilar (BAUMEL et al., 1993) e a cótila mesial é, geralmente, maior e mais côncava que a lateral (GILBERT et al., 1996).

$\mathrm{Na}$ zona posterior às cótilas existem as cristas do hipotarso, que em alguns grupos apenas têm um ou mais forãmenes, que formam canais para os tendões (GILBERT et al., 1996). Na extremidade distal encontra-se as trócleas dos dígitos das patas, que na maioria dos grupos são apenas três (para os dígitos II, III e IV). No entanto, noutros grupos, tais como o dos pica-paus, têm quatro trócleas, sendo que a quarta se prolonga posteriormente (GILBERT et al., 1996) para o primeiro dígito , que usam para se agarrarem às árvores e aos galhos. No caso das aves que têm três trócleas, a faceta para o I dígito encontra-se na superfície anterior da diáfise, ao longo do bordo mesial e abaixo do nível do foramen extensor (GILBERT et al., 1996).

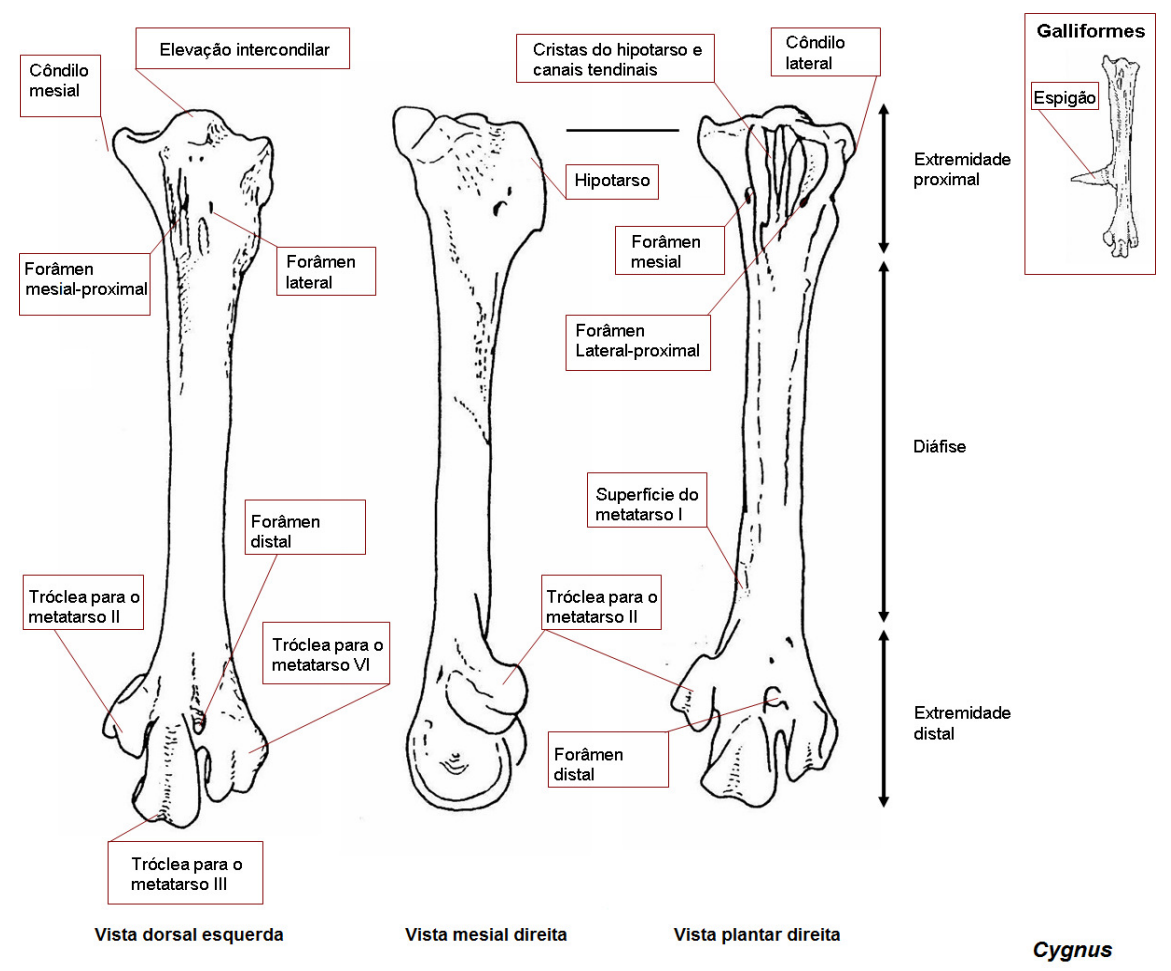

Fig. 56 - Principais estruturas do tarsometatarso (adaptado de COHEN \& SERJEANTSON, 1996). 


\subsection{4 - Sistemática das aves}

As aves são uma classe de vertebrados dividida em três subclasses, sendo que duas deles já se encontram extintas, apareceram e extinguiram-se ainda durante o Mesozóico. As subclasses são: as arqueornites (Jurássico Superior); as odontornites (Cretácico) e as neornites (do Cretácico à actualidade).

Existem várias classificações das aves propostas por investigadores de sistemática, ornitólogos e paleornitólogos. No entanto, as classificações mais aceites foram as propostas por Wetmore (1969) e Storer (1971). No entanto, nos últimos anos, a taxonomia das aves tem sido revista devido ao avanço da taxonomia cladística e dos estudos genéticos. Segundo os últimos estudos de taxonomia cladística, as aves não são mais que dinossauros, razão pela qual as aves deviam ser incluídas no grupo dos dinossauros, como se verá mais à frente. No caso da evolução dos estudos de genética, na foi apresentada, em 1990 uma nova proposta de taxonomia das aves (a taxonomia de Sibley-Ahlquist), dois investigadores norte-americanos. Fora dos meios académicos esta classificação das aves ainda não é aceite universalmente, talvez pelo facto de apresentar grandes mudanças às listas taxonómicas utilizadas pelos ornitólogos amadores, habituados à taxonomia tradicional das aves.

A taxonomia de Sibley-Ahlquist (Sibley \& Ahlquist, 1990), a adoptada nesta tese (ver metodologia) baseia-se em técnicas avançadas de biologia molecular. Este trabalho decorreu ao longo dos anos 80 e foi publicado na década de 1990. A técnica escolhida foi a hibridização de DNA ${ }^{26}$. Os dados obtidos foram interpretados de maneira a reconstituir as relações filogenéticas entre os diversos grupos de aves actuais. Os resultados do estudo, apesar de confirmarem algumas ideias da classificação tradicional, trazem mudanças radicais ao sistema classificativo das aves. Após este estudo, Sibley e Ahlquist introduziram algumas mudanças na taxonomia das aves. As principais foram introduzidas na ordem dos Ciconiiformes (o grupo das cegonhas, garças e aparentados), que foi muito alargada para além das seis famílias estabelecidas pela classificação tradicional. Segundo a taxonomia de Sibley-Ahlquist, os ciconiformes passam a incluir as famílias das antigas ordens: Sphenisciformes (pinguins), Gaviiformes (mobelha), Podicipediformes (mergulhões), Procellariiformes (albatrozes), Charadriiformes, (gaivotas), Pelecaniformes (pelicanos) e Falconiformes 
(aves de rapina diurnas). Também a ordem dos Coraciiformes sofreu uma remodelação, neste caso não foi por alargamento mas por redução. Neste caso as famílias Bucerotidae e Upupidae foram promovidas a ordem, passando a Bucerotiformes e Upupiformes, respectivamente. Outras alterações incluem a elevação de vários géneros ao grau de família, por exemplo, o género Bucorvus, que passou à família Bucurvidae, da nova ordem dos Bucerotiformes.

\section{Subclasse Arqueornites}

Este grupo de aves apenas engloba um género, o Archaeopteryx. Estes animais ocupam um lugar particular no processo evolutivo das aves, pois apresentam características intermédias de aves e os dinossauros.

A espécie Archaeopteryx lithographica tinha um tamanho idêntico ao de um pombo actual (cerca de $35 \mathrm{~cm}$ de comprimentos), a cabeça era pequena e olhos grandes, dentes pontiagudos nas mandíbulas e uma cauda constituída por ossos largos. Possuía três dedos nos membros posteriores com garras. As mãos eram largas e os braços eram asas rudimentares. Apresentava pés típicos das aves, com os ossos dos tornozelos parcialmente soldados. Os ossos das partes inferiores das patas eram largos, típicos de um animal bem adaptado à corrida, no entanto, estudos recentes demonstraram que o Archaeopteryx lithographica seria uma ave arborícola.

A morfologia dos Archaeopteryx não era totalmente semelhante à das aves actuais, ou seja, o Archaeopteryx tinha um aspecto geral ligeiramente diferente do das aves actuais. No entanto, apresentava características exclusivas deste grupo: já tinha uma fúrcula bem desenvolvida, formada pela fusão das clavículas, e possuía penas. A cauda tinha penas mais largas e maiores que as do resto do corpo. 


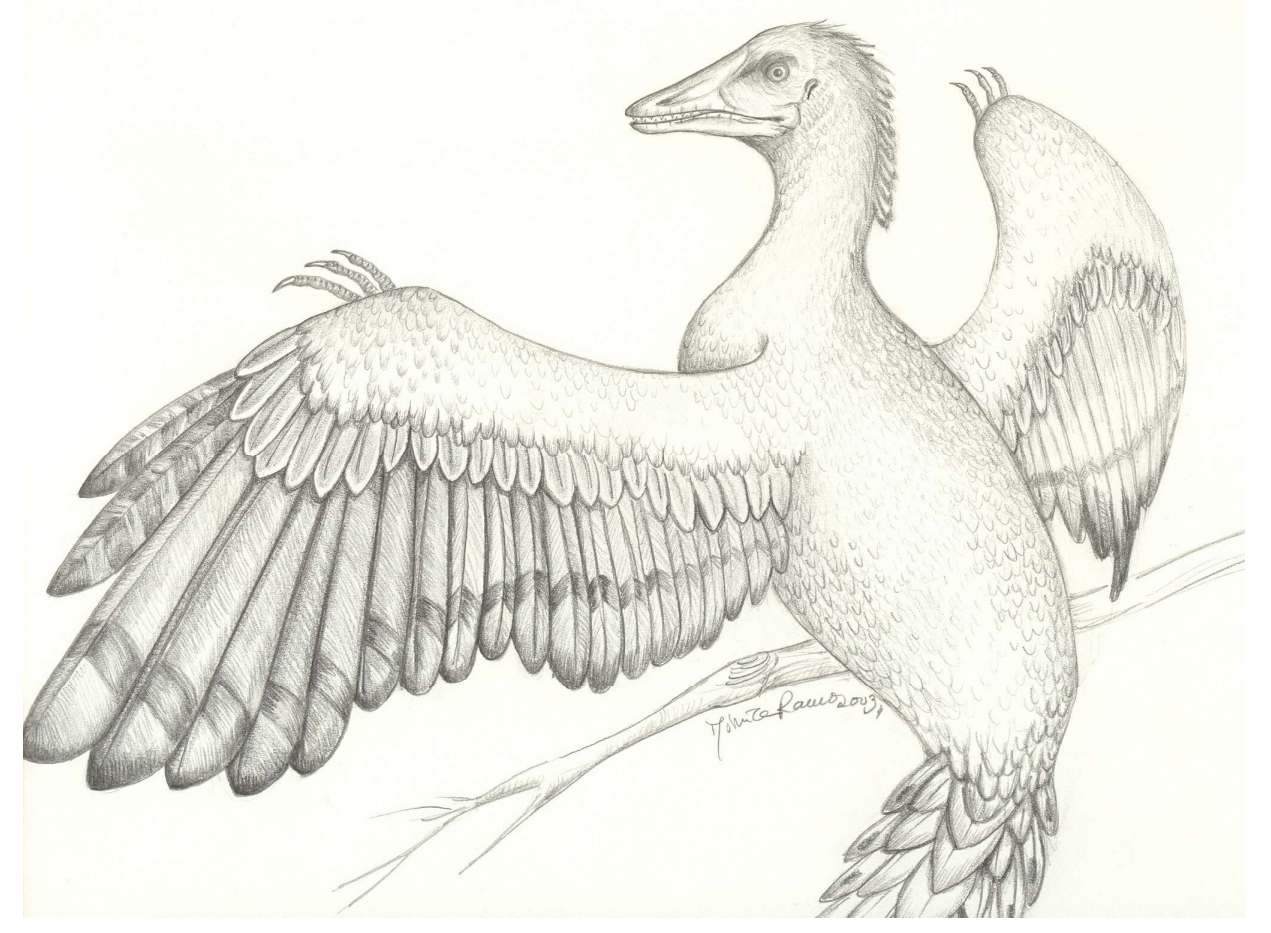

Fig. 57 - O Archaeopteryx (desenho de Mónica Ramos)

\section{Subclasse Odontornites}

Os Odontornites viveram apenas durante o Cretácico. Eram animais com características mais próximas das aves actuais que os seus antepassados do Jurássico, no entanto, ainda possuíam pequenos dentes pontiagudos nas mandíbulas. Foram os Odontornites que desenvolveram as principais características de voo contínuo. São disto exemplo o esterno amplo com quilha, onde se inseriam os músculos das assas. Ao contrário dos Arqueornites, do Jurássico Superior, estas aves já não possuíam cauda.

O género Ichtyornis, do Cretácico Superior, tinha pequenos dentes pontiagudos nas mandíbulas, já não possuía dedos nos membros posteriores, os metatarsos já se encontravam soldados, as patas eram largas e o externo encontravase bem desenvolvido. Ao contrário do Archaeopteryx, a pélvis assemelha-se mais às aves actuais do que à dos dinossauros sauripélvicos. 


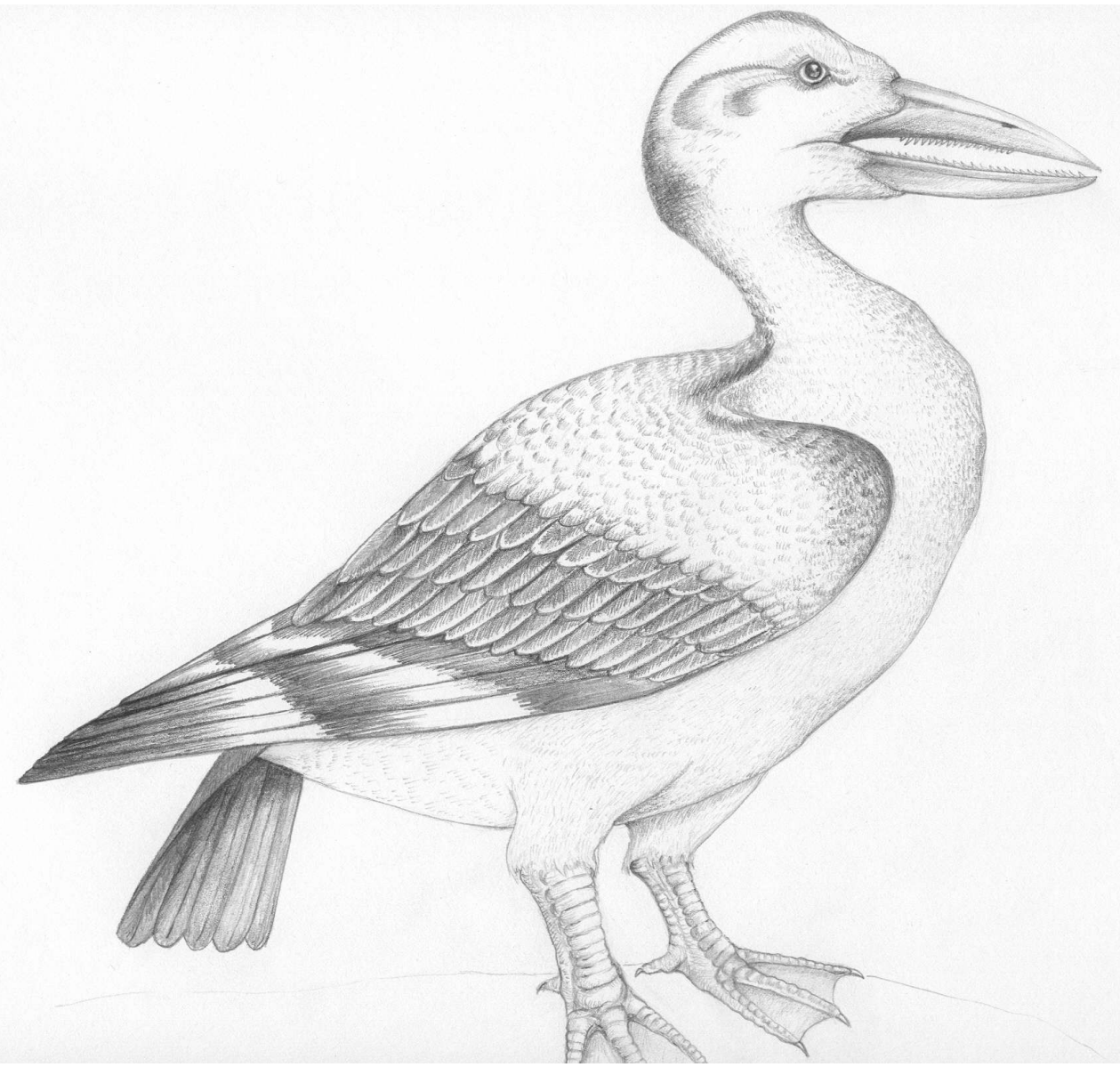

Fig. 58 - O Ichtyornis, ave do grupo dos odontognatos, do Cretácico Superior (desenho de Mónica Ramos).

\section{Subclasse Neornites}

Este grupo engloba todas as aves actuais. No início do Cretácico começou a haver uma adaptação a distintos ambientes por parte destes animais e, no Eocénico Inferior, já tinham aparecido os representantes dos principais grupos de aves que existem actualmente (ALVARENGA \& HÖFLING, 2004). Segundo as características do palato, os Neornites dividem-se em três subordens: os Odontognathae, os Paleognathae e os Neognathae (DOMÉNECH \& MARTINELL, 1996).

\section{Odontognathae:}

Estes animais viveram no Cretácico Superior e caracterizaram-se por ainda possuírem dentes nas mandíbulas, tinham as asas atrofiadas e podiam atingir cerca de 1 metro de altura. Alimentavam-se de peixes, cedo o seu meio habitual, o aquático. Seriam bons mergulhadores. 


\section{Paleognathae:}

Apareceram no Cretácico Superior (DOMÈNECH \& MARTINELL, 1996) e ainda existem alguns representantes deste grupo, de que são exemplos os kiwis, as avestruzes e a ema. Tal como os Odontognathae, estes animais têm as asas atrofiadas e todas as espécies deste grupo atingem dimensões consideráveis (VUILLEUMIER, 2001). Estas aves não voam e apresentam algumas características comuns no palato ósseo e na cintura torácica, o que nos pode indicar que talvez tivessem derivado de um grupo de aves que perderam a capacidade de voar, provavelmente derivado do ambiente em que viviam, sem predadores activos, que obrigassem ao voo. A origem destas aves remonta ao Cretácico Superior e inícios do Paleocénico, quando se tinham extinguido os dinossauros (entre eles os grandes carnívoros) e os mamíferos ainda não tinham desenvolvido novas espécies de grandes carnívoros.

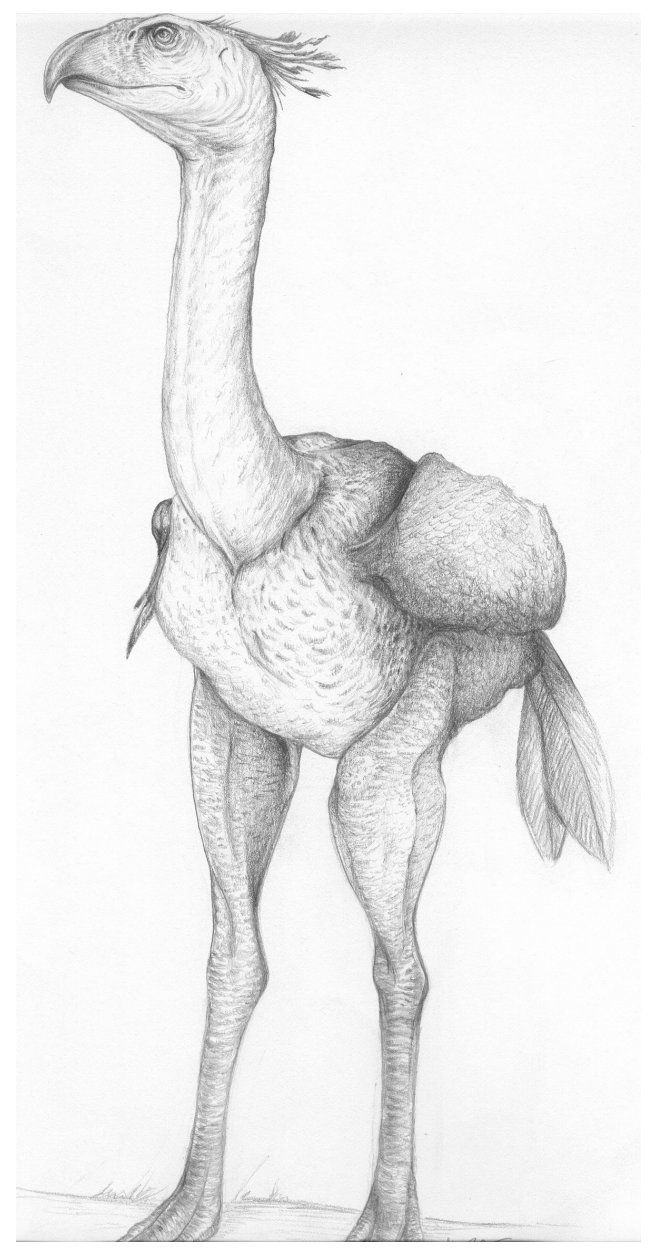

Fig. 59 - O Phorusrhacus, uma ave carnívora do grupo dos Paleognathae, que viveu no Miocénico, na América do Sul (desenho de Mónica Ramos). 


\section{Neognathae:}

Estas aves apareceram no Cretácico e representam, na actualidade as aves boas voadoras que englobam a maioria das espécies actuais, incluindo alguns grupos com asas atrofiadas de que o Diatryma é exemplo. Embora com asas atrofiadas estes grupos de Neognatos possuem o palato característico dos restantes elementos desta subordem.

Actualmente, a classe das aves inclui as superordens Paleognathae e Neognathae) apresentam cerca de 9000 espécies distribuídas por 155 ou 170 famílias, dependendo dos autores. Segundo Josep del Hoyo (DEL HOYO et al. 1992 - 2009) existem 196 famílias, distribuídas por 28 ordens.

\section{Ordem}

STRUTHIONIFORMES (LATHAM, 1790)

\section{Familias}

StRUTHIONIDAE (VIGORS, 1825) - Avestruzes

RHEIDAE (BONAPARTE, 1849) - Emas

CASUARIIDAE (KAUP, 1847) - Cassuares

DromaIIDAE (VIEILLOT, 1816) - Emas

APTERYGIDAE (SHAW, 1813) - Kiwis

\section{Ordem}

TINAMIFORMES (HUXLEY, 1872)

\section{Família}

Tinamidae (GRAY, 1840) - Tinamus

\section{Ordem}

SPHENISCIFORMES (SHARPE, 1891)

\section{Familia}

SPHENISCIDAE (BONAPARTE, 1831) - Pinguins

\section{Order}

GAVIIFORMES (WETMORE \& MILLER, 1926) 


\section{Familia}

GAVIIDAE (COUES, 1903) - Mergulhões

\section{Ordem}

PODICIPEDIFORMES (FÜRBRINGER, 1888)

\section{Família}

PODICIPEDIDAE (BONAPARTE, 1831) - Grebes

\section{Ordem}

PROCELLARIIFORMES (FÜRBRINGER, 1888)

\section{Familias}

DiomedeidAe (GRAY 1840) - Albatrozes

ProcellariIdAe (LEACH, 1820) - Pardelas

HydRoBatidae (MATHEWS, 1912) - Painhos

PeleCANoididae (Gray, 1871) - Petréis mergulhadores

\section{Ordem}

PELECANIFORMES (SHARPE, 1891)

\section{Familias}

Phaethontidae (Brandt, 1840) - Rabijuncos

Pelecanidae (Rafinesque, 1815) - Pelicanos

SUlidAe (REICHENBACH, 1849) - Alcatrazes

PhALACROCORACIDAE (REICHENBACH, 1850) - Corvos-marinhos

ANHINGIDAE (REICHENBACH, 1849) - Mergulhões-serpentes

Fregatidae (Degland \& Gerbe, 1867) - Fragatas

\section{Ordem}

CICONIIFORMES (BONAPARTE, 1854)

\section{Famílias}

ARDEIDAE (LEACH, 1820) - Garças

Scopidae (Bonaparte, 1849) - Pássaro-martelo

CICONIIDAE (GRAY, 1840) - Cegonhas 
BALAENCIPITIDAE (BONAPARTE, 1853) - Bico-sapato

THRESKIORNITHIDAE (RICHMOND, 1917) - Colhereiros

\section{Ordem}

PHOENICOPTERIFORMES (FÜRBRINGER, 1888)

\section{Família}

PHOENICOPTERIDAE (BONAPARTE, 1831) - Flamingos

\section{Ordem}

ANSERIFORMES (WAGLER, 1831)

\section{Famílias}

ANHIMIDAE (STEJNEGER, 1885) - Tachãs

ANATIDAe (VIGORS, 1825) - Patos e gansos

\section{Ordem}

FALCONIFORMES (SHARPE, 1874)

\section{Familias}

Cathartidae (LAfResnaye, 1839) - Condores

PANDIONIDAE (SCLATER \& SALVIN, 1873) - Águias-pesqueiras

ACCIPITRIDAE (VIEILLOT, 1816) - Águias e abutres

SAGITTARIIDAE (R. GRANDORI \& L. GRANDORI, 1935) - Secretários

FALCONIDAE (VIGORS, 1824) - Falcões

\section{Ordem}

GALLIFORMES (TEMMINCK, 1820)

\section{Famílias}

MeGAPODIIDAE (LeSSON, 1831) - Megapódes

CRACIDAE (VIGORS, 1825) - Araguãs e mutuns

MeleagrididAe (GRAY 1840) - Perus

TETRAONIDAE (VIGORS, 1825) - Tetrazes e lagópodes

ODONTOPHORIDAE (GOULD, 1844) - New World Quails)

PhASIANIDAE (VIGORS, 1825) - Faisões e perdizes 
NUMIDIDAE (DE SÉLYS LONGCHAMPS, 1842) - Galo-da-Guiné

\section{Ordem}

PTEROCLIFORMES (BONAPARTE, 1831)

Família

Pteroclidae (BonAparte, 1831) - Cortiçóis

\section{Ordem}

COLUMBIFORMES (LATHAM, 1790)

\section{Família}

ColumbidAe (ILLIGER, 1811) - Pombos e rolas

\section{Ordem}

PSITTACIFORMES (WAGLER, 1830)

\section{Famílias}

CACATUIDAE (GRAY 1840) - Catatuas

PSITTACIDAE (ILLIGER, 1811) - Papagaios

\section{Ordem}

CUCULIFORMES (WAGLER, 1830)

\section{Família}

MUSOPHAGIDAE (BONAPARTE 1831) - Turacos

CUCULIDAE (VIGORS, 1825) - Cucos

\section{Ordem}

OPISTHOCOMIFORMES (ILLIGER 1811)

\section{Família}

OPISTHOCOMIDAE (SWAINSON, 1837) - Jacu-cigano

\section{Ordem}

GRUIFORMES (BONAPARTE, 1854)

\section{Famílias}


MESITHORNITHIDAE (WeTMORE, 1960) - Mediadores

TURNICIDAE (GRAY, 1840) - Toirões

Gruidae (Vigors, 1825) - Grous

ARAMIDAE (BonaPARTE, 1849) - Carões

PSOPHIIDAE (BONAPARTE, 1831) - Jacanuns

RALLIDAE (BONAPARTE, 1831) - Frangos-de-água e galeirões

HELIORNITHIDAE (GRAY, 1840) - Pés-de-barbatana

RHYNOCHETIDAE (CARUS, 1868) - Cagus

EURYPYGIDAE (SELBY, 1840) - Pavão-do-pará

CARIAMIDAE (BonAPARTE, 1853) - Seriemas

OTIDIDAE (RAFINESQUe, 1815) - Abetardas

\section{Ordem}

CHARADRIIFORMES (HUXLEY, 1867)

\section{Famílias}

JACANIDAE (STEJNEGER, 1885) - JACANAS

ROSTRATULIDAE (RIDGWAY, 1919) -Narceja-de-bico-torto e Narceja-pintada

DROMADIDAE (GRAY, 1840) - Caranguejeiro

HAEMATOPODIDAE (RIDGWAY, 1919) - Narcejas

IBIDORHYNCHIDAE (BONAPARTE, 1856) - Ibisbill

RECURVIROSTRIDAE (BONAPARTE, 1854) - Alfaiates e pernilongos

BURHINIDAE (MATHEWS, 1912) - Alcaravões

GLAReolidae (CL BRehM, 1831) Perdizes-do-mar

ChARADRIIDAE (VIGORS, 1825) -Taranbolas

SCOLOPACIDAE (VIGORS, 1825) - Maçaricos e galinholas

Pedionomidae (BonAPARTE, 1856) - Toirão-imaculado

THINOCORIDAE (GRAY, 1845) - Maçaricos-granívoros

ChIONIDAE (BONAPARTE, 1832) -Pomba-antártida

STERCORARIIDAE (GRAY, 1871) - Moleiros

LARIDAE (VIGORS, 1825) - Gaivotas

STERNIDAE (BONAPARTE, 1838) - Andorinhas-do-mar

RHYNCHOPIDAE (BONAPARTE, 1838) - Talha-mar 
ALCidAe (LEACH, 1820) - Alcas

\section{Ordem}

STRIGIFORMES (WAGLER, 1830)

\section{Famílias}

TYtONIDAE (RIDGWAY, 1914) - Corujas-das-Torres

StRIGIDAE (VIGORS, 1825) - Corujas

\section{Ordem}

CAPRIMULGIFORMES (RIDGWAY, 1881)

\section{Famílias}

STEATORNITHIDAE (BONAPARTE, 1842) - Pássaros-do-petróleo

Aegothelidae (Bonaparte, 1853) Noitibó-felino

PODARGIDAE (HARTERT, ERNST, 1897) - Noitibós da Ásia

NYCTIBIIDAE (BONAPARTE, 1853) - Urutaus

CAPRIMUlgidae (VIGORS, 1825) - Noitibós

\section{Ordem}

APODIFORMES (Peters, 1940)

\section{Famílias}

APODIDAE (HARTERT, 1897) - Andorinhões

HEMIPROCNIDAE (NITZSCH, 1829) - Andorinhões-de-cauda-comprida

TROCHILIDAE (VIGORS, 1825) - Colibris e beija-flores

\section{Ordem}

COLIIFORMES (MURIE, 1872)

\section{Família}

ColiIDAE (SWAINSON, 1837) - Cólios e rabos-de-junco

\section{Ordem}

TROGONIFORMES (AOU, 1886)

\section{Família}


TROGONIDAE (LESSON, 1828) - Surucuás

\section{Ordem}

CORACIIFORMES (FORBES, 1884)

\section{Famílias}

ALCEDINIDAE (RAFINESQUE, 1815) - Guarda-rios

TODIDAE (VIGORS, 1825) - Todas

MOMOTIDAE (GRAY, 1840) - Jurovas

Meropidae (RAFINESQUe, 1815) - Abelharucos

CORACIIDAE (RAFINESQUE, 1815) - Rolieiros

BRACHYPTERACIIDAE (BONAPARTE, 1854) - Roleiros de Madagáscar

LEPTOSOMIDAE (BLYTH, 1838) - Roleiro - cuco

UPUPIDAE (LEACH, 1820) - Poupas

Phoeniculidae (BonAPARTE, 1831) - Zombeteiro e cimitarra

BUCEROTIDAE (RAFINESQUe, 1815) - Calaus

\section{Ordem}

GALBULIFORMES (GRAY, 1840)

\section{Família}

GALBULIDAE (VIGORS, 1825) - Ariramba

Bucconidae (Horsfield, 1821) - Macurus e Barbudos

\section{Ordem}

PICIFORMES (MEYER \& WOLF, 1810)

\section{Famílias}

CAPITONIDAE (BonAPARTE, 1838) - Barbaças

RAMPHASTIDAE (VIGORS, 1825) - Tocanos

INDICATORIDAE (SWAINSON, 1837) - Pássaro-indicador

PICIDAE (VIGORS, 1825) - Pica-paus

\section{Ordem}

PASSERIFORMES (LINNAEUS, 1758) 


\section{Famílias:}

EURYLAIMIDAE (LESSON, 1831) - Rabilongo e lua-crecente

PhilepitTIDAe (SHARPE, 1870)

PITTIDAE (SWAInson, 1831) - Pitas

THAMNOPHILIDAE (SWAINSON, 1824) - Formigueiros

FORMICARIIDAE (GRAY,1840) - Formicários

CONOPOPHAGIDAE (SCLATER \& SALVIN, 1873) - Chupa-dentes

RHINOCRYPTIDAE (WETMORE, 1930) - Tapaculos

COTINGIDAE (BonAPARTE, 1849) - Cotingas

PIPRIDAe (RAFINESQUe, 1815) - Pipiras

TYRANNIDAE (VIGORS, 1825) - Tiranos

ACANTHISITTIDAE (SUNDEVALL, 1872) - Mosqueteiros

ATRICHORNITHIDAE (STEJNEGER, 1885) - Falsas-carriças

MENURIDAE (LESSON, 1828) - liras

AlaUdidAe (VIGORS, 1825) - Cotovias

HIRUNDINIDAE (VIGORS, 1825) - Andorinhas

MotACILLIDAE (HoRSFIELD, 1821) - Petinhas e alvéolas

CAMPEPHAGIDAE (VIGORS, 1825) - Lagarteiros

Pycnonotidae (GRAY, 1840) - Tutas

Chloropseidae (WetMore, 1960) - Aves-folha

IRENIDAE (JERDON, 1863) - Folha-azul-asiático

AegithinidAe (GRAY, 1869) - Chapins

Ptilogonatidae (Baird, 1858) - Capulineiros

BOMBYCILLIDAE (SWAINSON, 1831) - Asas-de-lacre

HyPOCOLIIDAE (BONAPARTE, 1850) Hipocolios

DULIDAE (SCLATER, 1862) - Pardinha-de-palma

CinCLIDAE (SUNDEVALL, 1836) - Mergulhadores

TroglodYTIDAE (SWAINSON, 1832) - Carriças

MimidAe (BONAPARTE, 1853) - Momos e peixes-alecrim

PRUNeLLIDAe (RICHMOND, 1908) - Acentores

TURDIDAE (RAFINESQUE, 1815) - Tordos

MUSCICAPIDAE (VIGORS, 1825) - Papa-moscas 
Platysteiridae (SundeVall, 1872) - Papa-moscas-do-Cabo

RHIPIDURIDAE (SUNDEVALL, 1872) - Aves-de-leque

MONARCHIDAE (MONARCH-FLYCATCHERS) - Papa-moscas-monarcas

ReGULIDAE (CUVIER, 1800) - Estrelinhas

POLIOPTILIDAE (BAIRD, 1858) - Mosquiteiros

Cisticolidae (SundeVAlL, 1872) - Cisticolas

SYLVIIDAE (VIGORS, 1825) - Felosas e toutinegras

Picathartidae (SeRLE, 1952) - Picatartes

TIMALIIDAE (VIGORS \& HORSFIELD, 1827) - Zaragateiros

ORTHONYCHIDAE (GRAY, 1840) - falso-tordo

EUPETIDAE (BONAPARTE, 1850) - charlatão-malaio

PACHYCEPHALIDAE (SWAINSON, 1831) - Picanço-tordo, cabeçudo-embuçado

Petroicidae (MATHEWS, 1919-20) - rouxinóis australianos

MALURIDAE (SWAINSON, 1831) - Fadas-carriças

DASYORNITHIDAE (SCHODDE, 1975) - Pássaros-espinhosos

ACANTHIZIDAE (SUNDEVALL, 1872) - Toutinegras-australianas

NeOSITTIDAE (RIDGWAY, 1904) - descedeira-australiana

ClimacteridAe (LongChAmPS, 1839) - Trepadeiras da Oceania

PARIDAE (VIGORS, 1825) - Chapins

REMIZIDAE (OLPHE-GALLIARD, 1891) - Chapins de ninhos pendentes

AegithalidAe (ReichenBACH, 1850) - Chapins de cauda longa

SITTIDAE (LESSON, 1828) - Trepadeiras

CERTHIIDAE (LEACH, 1820) - Trepadeiras

RHABDORNITHIDAE (GREENWAY, 1967) - Trepadeiras-filipinas

NeCTARINIIDAE (VIGORS, 1825) - Nectarínias

MELANOCHARITIDAE (SiBLEY \& AHLQUIST, 1985) - Picabaias e picudos

PARAMYTHIIDAE (P.L. SClater, 1893) - Picabaias

DiCAEIDAE (BonAPARTE, 1853) - Pica-flores

PARDAlotidae (StRICKLAND, 1842) - Pardalotos

ZOSTEROPIDAE (BONAPARTE, 1853) - Olhos-brancos

Promeropidae (Vigors, 1825) - Papa-açúcar

MeLIPHAGIDAE (VIGORS, 1825) - Melífagos 
ORIOLIDAE (VIGORS, 1825) - Papa-figos

LANIIDAE (RAFINESQUe, 1815) - Picanços

MALACONOTIDAE (SWAINSON, 1824) - PicançOS

VANGIDAE (SWAINSON, 1831) - Vangas

DICRURIDAE (VIGORS, 1825) - Dongos

Callaeidae (Sundevall, 1836) - Passáros-selados

NOTIOMYSTIDAE (DRISKELL ET AL., 2007) - passáros-bordados

StRUTHIDEIDAE (MATHEWs 1924) - Apóstolo

ARTAMIDAE (VIGORS, 1825) Andorinha-pincanço

PITYRIASEIDAE (MAYR \& AMADON, 1951) - cabeças-peludas

PtILONORHYNCHIDAE (GRAY, 1841) - Construtores

PARADISAEIDAE (VIGORS, 1825) - Aves-do-paraíso

CORVIDAE (VIGORS, 1825) - Corvos e gralhas

BUPHAGIDAE (LESSON, 1828) bufágidos

StURNIDAE (RAFINESQUe, 1815) - Estorninhos

PASSERIDAE (ILLIGER, 1811) - Pardais 


\section{4 - Aves fósseis portuguesas}

O registo mais antigo de aves em Portugal data do Jurássico Médio (Kimeridgiano). Trata-se de alguns dentes de cf. Archaeopteryx encontrados na Mina da Guimarota, em Leiria (WEIGERT, 1995). Do Mesozóico não existem mais referências à ocorrência de aves em Portugal; no entanto, existem alguns vestígios do grupo dos dinossauros antepassados das aves em algumas jazidas portuguesas.

A avifauna fóssil do cenozóico de Portugal é mal conhecida, em especial a anterior ao Plistocénico. Com a excepção dos estudos efectuados por Telles Antunes, Mourer-Chauviré e Harrison, poucos estudos e pesquisas têm sido feitos, quer a nível do material conhecido, quer a nível da investigação de campo. Novas pesquisas de aves nas formações cenozóicas poderão trazer novos dados para o conhecimento das aves fósseis de Portugal. Existe no Museu Geológico de Lisboa um conjunto muito importante de restos de vertebrados cenozóicos que é necessário rever, pois poderão existir, conjuntamente com estes materiais, alguns restos de aves ainda não identificados. Por outro lado, os poucos fósseis de aves do Miocénico identificados na colecção de paleontologia do mesmo museu carecem de novos estudos, em especial taxonómicos, dado que a maioria não está estudada a fundo, e apenas têm a identificação da classe.

\subsection{1 - Antepassados das aves encontrados em Portugal}

Como se viu na primeira parte, no capítulo sobre a origem das aves, estas são, em termos evolutivos, manirraptores e o grupo de dinossauros que está na origem das aves é o dos dromeossauros. Assim, faz sentido incluir nesta tese uma breve referência aos achados, em território nacional, dos restos de dromeossauros, dos quais há alguns registos do Jurássico e do Cretácico.

Foram encontrados, na Mina da Guimarota ${ }^{27}$ (Leiria), uma jazida datada do Jurássico Superior vários restos de pequenos dinossauros carnívoros do grupo que

27 A descrição da geologia e dos trabalhos efectuados na Mina da Guimarota serão desenvolvidos mais à frente, quando da referencia aos vestígios de aves lá encontrados. 
estará na origem das Aves. Assim estão referenciados (ANTUNES e MATEUS, 2003) restos atribuídos aos géneros: cf. Compsognathus, Stokesosaurus, cf. Richardoestesia sp e Paronychodon sp e das subfamílias dromeosaurinae e velociraptorínae e da família Troodontidae.

Do Cretácico Inferior, na zona do Cabo Espichel, em particular na Praia das Aguncheiras, localizada numa faixa que vai desde a costa até à falha geológica localizada junto do Casal do Espanhol, foram descobertos quatro restos ósseos (uma ulna, um carpo, um úmero e uma vértebra) atribuídos, com algumas reservas ao grupo dos maniraptora (FIGUEIREDO, 2001; 2004; 2005, 2008). Esta jazida está inserida formação do Papo-Seco, atribuída ao Barremiano Inferior (MANUPPELLA, 1999, et al., p.54), com cerca de 127 milhões de anos. Esta formação, com 18,5 metros de espessura, caracteriza-se por apresentar margas e argilas siltosas verdes com lenhite e gesso. Apresenta intercalações de arenitos com estratificação horizontal (MANUPPELLA, 1999, et al., p.54). A fauna desta formação é constituída por restos de dinossauros, nas camadas areníticas grosseiras, e invertebrados (bivalves e gastrópodes) e ostracodos, nas margas. No limite superior desta formação encontram-se camadas de calcário siltoso bioturbado e com restos de ostreídeos (MANUPPELLA, 1999, et al., p.54).

Os elementos fósseis atrás referidos são provenientes de camadas diferentes, não sendo, portanto, contemporâneos. As camadas da Praia das Aguncheiras, com cerca de sessenta metros de altura, são constituídas por calcários, arenitos, grés e margas grosseiras (ZBYSZEWSKI et al., 1965). Os fósseis presentes nestas camadas, invertebrados e vertebrados marinhos, vegetais carbonizados e vertebrados terrestres, indicam uma alternância entre ambientes marinhos e terrestres. (FIGUEIREDO, 2001; 2004; 2005).

Sistemática paleontológica:

Dinosauria (OWEN, 1842)

Saurischia (SEELEY, 1888)

Theropoda (MARSH, 1881)

Tetanurae (GAUTHIER 1986) 


\section{Dromaeosauridae (COLBERT AND RUSSELL 1969) \\ Dromaeosauridae INDET.}

Os materiais recolhidos na zona do Cabo Espichel, durante as várias campanhas de investigação desenvolvidas naquela zona estão na colecção de paleontologia do Centro Português de Geo-História e Pré-História e foram encontrados nas campanhas de 1999, 2000 e 2005, na Praia das Aguncheiras.

O fragmento de ulna foi encontrado nas camadas de calcário margoso, na base da plataforma delimitada por duas falhas, a sul da Praia das Aguncheiras. 0 carpo, sendo por isso difícil saber qual a camada de proveniência. O úmero é proveniente das camadas margosas da Praia das Aguncheiras, que assentam nas camadas calcárias de base.

\section{Descrição}

- Dromaeosauridae indet. (COLBERT AND RUSSELL 1969)

No: CPGP.1.99.4 - fragmento distal de ulna direita, apresenta a epifise distal completa e parte da zona mesial. Na articulação distal tem o côndilo dorsal pronunciado e o sulco radial pequeno.

Medida máxima: $106.1 \mathrm{~mm}$

- Cf. Dromaeosauridae (COlBERT AND RUSSELL 1969)

No: CPGP.1.00.1 Carpo ulnar inteiro.

Medida máxima: $26.1 \mathrm{~mm}$

No: CPGP.1.05.1 - Úmero esquerdo, de secção oval, apresenta a epifise proximal mais larga que a parte mesial. A epifise proximal está deteriorada, sem a extremidade (apresenta apenas uma pequena parte da zona basal da intumescência, a face bicipital e não tem a cabeça do úmero). Não tem a epifise distal.

Medida máxima: $49.5 \mathrm{~mm}$ 


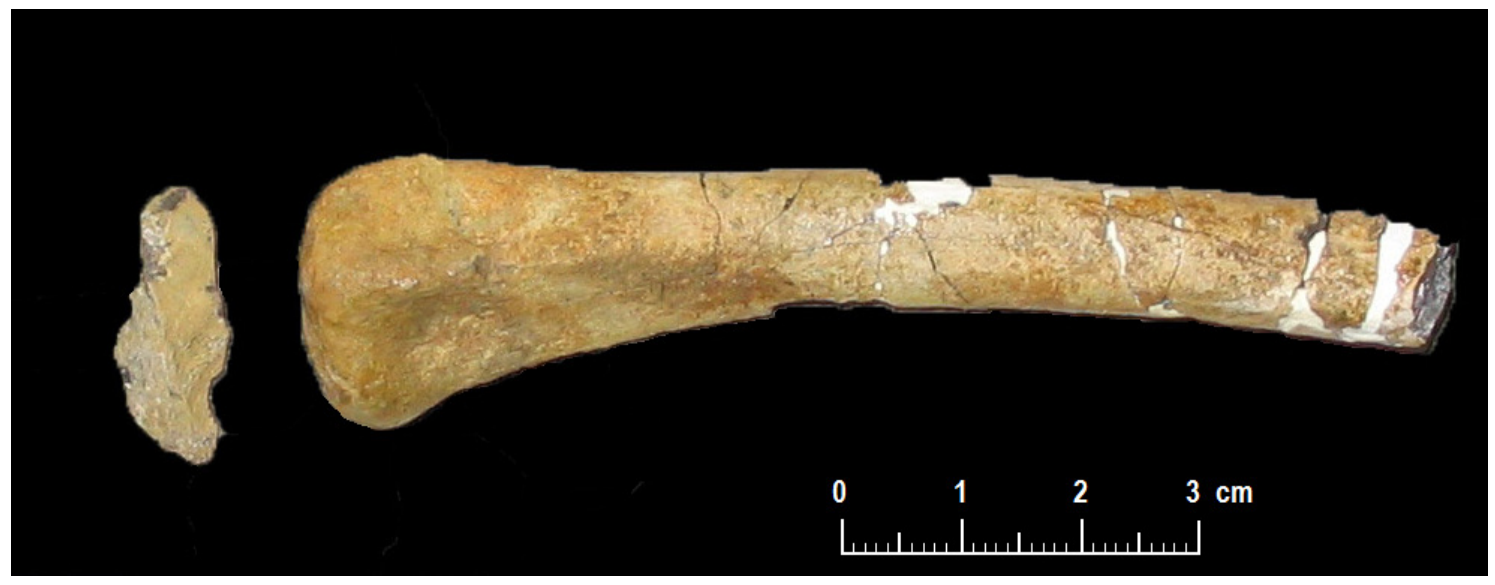

Fig. 60 - Fragmento de ulna e carpo lunar de Dromaeosaurus indet. da Praia das Aguncheiras (fotografia: S. Figueiredo)

Do Maastrichtiano (Cretácico Superior) foram descobertos, em Taveiro (junto a Coimbra) restos, três dentes de um pequeno dinossauro, o Euronychodon portucalensis, do grupo dos Troodontídeos (ANTUNES \& SIGOGNEAU-RUSSEL, 1991; ANTUNES e MATEUS, 2003, p. 90). Apesar de apenas se conhecerem três dentes, os autores defendem que estes três dentes apresentavam características diagnósticas suficientes para atribuir um novo género e espécies. (ANTUNES \& SIGOGNEAURUSSEL, 1991,)

Para além destes restos, foram também identificados por estes autores, em terrenos do Maastrichtiano em Taveiro e no Viso, restos atribuídos a Troodontidae e Dromaeosauridae (ANTUNES \& SIGOGNEAU-RUSSEL, 1991).

Sistemática paleontológica:

Dinosauria (OWEN, 1842)

Saurischia (SEELEY, 1888)

Theropoda (MARSH, 1881)

Tetanurae (GAUTHIER 1986)

Troodontidae (GILMORE 1924)

Troodontidae INDET.

Dinosauria (OWEN, 1842)

Saurischia (SEELEY, 1888) 
Theropoda (MARSH, 1881)

Tetanurae (GAUTHIER 1986)

Dromaeosauridae (COLBERT AND RUSSELL 1969)

Dromaeosauridae INDET.

Dinosauria (OWEN, 1842)

Saurischia (SEELEY, 1888)

Theropoda (MARSH, 1881)

Tetanurae (GAUTHIER 1986)

Troodontidae (GILMORE 1924)

Euronychodon (ANTUNES \& SIGOGNEAU-RUSSEL, 1991,)

Euronychodon portucalensis (ANTUNES \& SIGOGNEAU-RUSSEL, 1991,) 


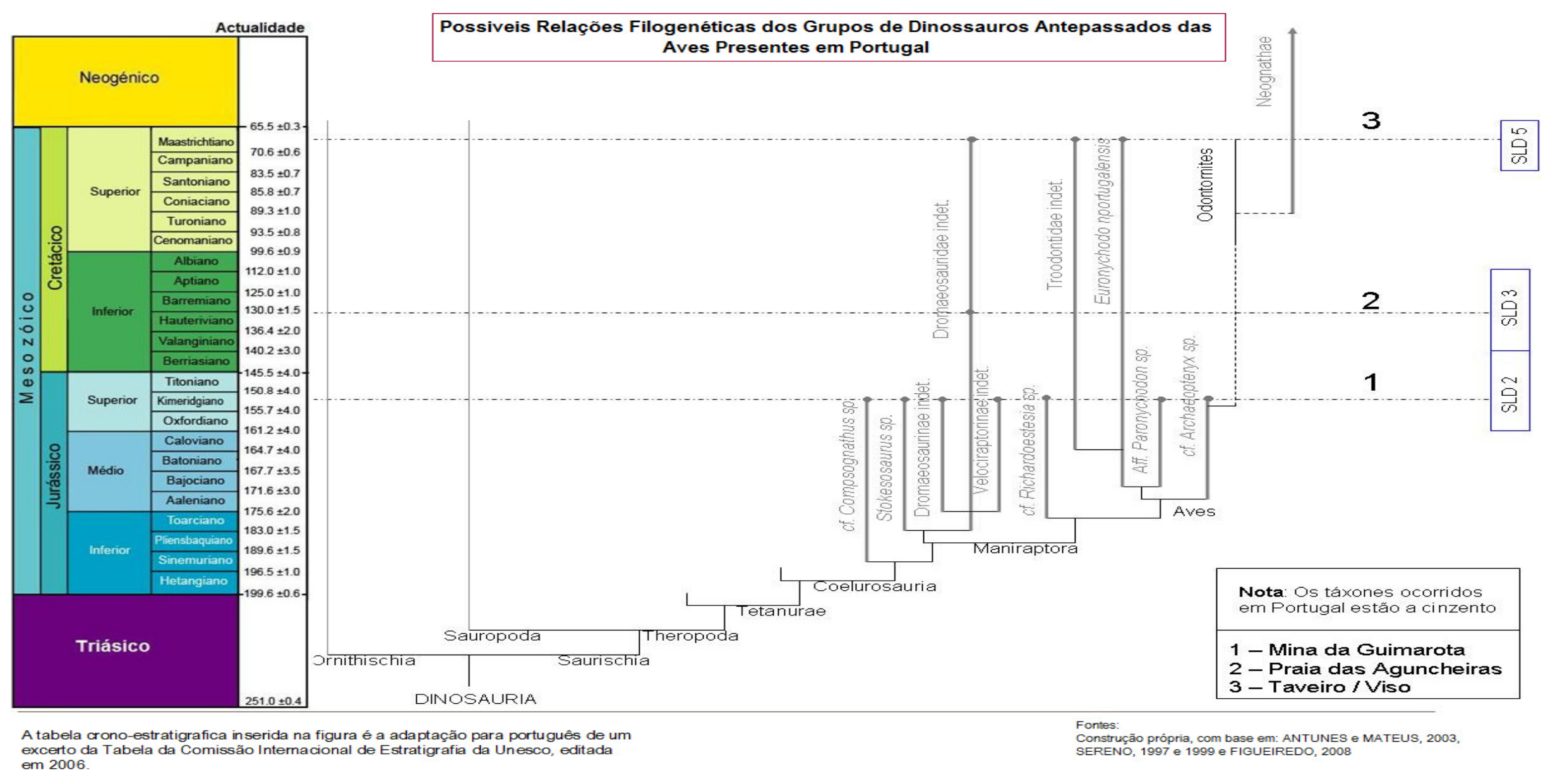

Quadro 6 - Possíveis relações filogenéticas das aves primitivas e dos grupos de dinossauros seus antepassados presentes em Portugal, enquadrando as jazidas e as respectivas SLD's. 


\subsection{2 - Aves fósseis do Jurássico Superior de Portugal}

Do Mesozóico apenas se conhece uma jazida com restos de aves. Trata-se da Mina da Guimarota, do Jurássico Superior, onde foram encontrados restos de Archaeopteryx e classificados com reservas. Confirmando-se esta traxonomia, tratam-se dos restos de aves com datação mais antiga, conhecidos no mundo. $\mathrm{A}$ formação onde se localiza a Guimarota, denominada de "Camadas de Guimarota", do Kimeridgiano, é um pouco mais antiga que a formação de Solnhofen, na Alemanha.

\subsubsection{1 - Mina da Guimarota - Leiria}

A mina da Guimarota, situada a sul de Leiria, é uma das jazidas fósseis do Jurássico Superior mais importante de Portugal e uma das mais relevantes para o conhecimento dos mamíferos fósseis desse período, em todo o mundo.

Era uma mina de exploração de lignito ${ }^{28}$ que foi fechada em 1982. O estudo paleontológico desta jazida começou em 1960, quando uma equipa de investigadores alemães, identificou esta jazida fossilífera do Jurássico Superior (Kimmeridgiano), verificando que tinha condições de preservação excepcionais e que os fósseis lá encontrados se mostravam muito relevantes para o estudo dos ecossistemas daquele período. Esta equipa era chefiada pelo Prof. Walter G. Kühne, da Universidade Livre de Berlim, iniciando-se assim a pesquisa de fósseis de vertebrados naquela mina. Kühne tinha um interesse particular em mamíferos mesozóicos. Nos anos 50 do século passado pouco se conhecia acerca destes vertebrados, na Europa. Assim, Kühne, nos inícios desta década, começou a fazer alguns trabalhos na Península Ibérica, em especial nos Pirenéus. Após ter lido uma publicação acerca dos dinossauros portugueses ${ }^{29}$ veio, em Setembro desse ano, acompanhado de Frey, um aluno seu. Fez várias prospecções no nosso país, vindo a descobrir os vertebrados da Guimarota. Começou por observar a presença de fósseis

28 O lignito é um carvão fóssil, pouco evoluído, com carbono menos concentrado que a hulha, e como tal, com menor potencial energético

29 Dinosauriens du Potugal, de Lapparent e de Zbyzewski, publicada pelos Serviços Geológicos de Portugal em 1957 
de pequenas conchas de invertebrados que indicavam uma deposição em ambientes de águas ricas de carbonato. Estas condições são favoráveis para a preservação de vertebrados fósseis. Um ano mais tarde, em 1960, regressou à Guimarota juntamente com dois estudantes de Berlim. Nesta altura foram descobertos mais vestígios fósseis de mamíferos jurássicos. O trabalho foi coadjuvado pelo capataz da mina.

Estas primeiras investigações decorreram em simultâneo com a exploração mineira, mas a partir de 1973 a 1982 a mina apenas esteve aberta para a investigação paleontológica, tendo sido recolhido um grande número de restos fósseis de vertebrados, que compreende, entre outros, tubarões, crocodilos, tartarugas, dinossauros, mamíferos e aves. Destes destacam-se os restos de mamíferos.

A mina da Guimarota possui um importante conjunto de fósseis de dinossauros, sendo os dentes de terópodes os mais abundantes (RAUHUT, 2000, p.77), e destes são os pequenos terópodes, próximos das aves, que aparecem em maior número (RAUHUT, 2000, p.77). Entre estes, os géneros mais representados são o do Compsognathus e o Archaeoptery $x^{30}$, tendo o segundo fornecido mais dentes (ZINKE, 1998, pp. 179,187). Estes dentes de Archaeopterygiformes são não só alguns dos restos atribuídos a aves mais antigos de Portugal, como também de todo o mundo, se se exceptuar o controverso fóssil do Protoavis, do Triássico. De todos os géneros de terópodes descritos na Guimarota, através de dentes lá encontrados (quadro 8), apenas duas são bem conhecidas na Europa: o compsognathus, identificado na Alemanha e na França e o Archaeopteryx, encontrado na Alemanha. São precisamente estes dois géneros os mais representados, somando um total de $34,5 \%$ do total dos dentes de terópodes (ZINKE, 1998, pp.187).

30 Os restos de aves da Guimarota são constituídos por vários dentes classificados como cf Archaeopteryx sp (WEIGERT, 1995). 


\section{Percentagem dos dentes dos diversos terópodes que ocorrem na Guimarota \\ Segundo Jens Zinke, 1998}

\begin{tabular}{|l|r|}
\hline Taxón & Percentagem \\
\hline cf. Archaeoptervx SD. & $\mathbf{2 3 , 4}$ \\
\hline cf. Compsognathus SD. & $\mathbf{1 1 , 1}$ \\
\hline cf. Richardoestesia so. & $\mathbf{9 , 1}$ \\
\hline cf. Paronvchodon sD. & $\mathbf{6 , 6}$ \\
\hline Velociraptorinae & $\mathbf{6 , 4}$ \\
\hline rroodontidae (?) & $\mathbf{3 , 2}$ \\
\hline Grandes terópodes nāo identificados & $\mathbf{2 , 9}$ \\
\hline Pequenos terópodes nāo identificados & $\mathbf{2 , 5}$ \\
\hline Alosauridae (?) & $\mathbf{1 , 1}$ \\
\hline Tyrannosauridae(?) & $\mathbf{0 , 7}$ \\
\hline cf. Dromaeosaurus SD. & $\mathbf{0 , 2}$ \\
\hline
\end{tabular}

\begin{tabular}{|l|l|}
\hline Legenda & \\
\hline$x x x x x$ & Aves e terópodes próxinos das aves \\
\hline$x x x x x$ & Terópodes mais afastados das aves \\
\hline
\end{tabular}

Quadro 7 - Percentagem relativa dos dentes de terópodes da Mina da Guimarota

Em artigo publicado em 1995, A. Weigert descreveu vários dentes semelhantes aos dos Archaeopteryx basais. Os dentes de Archaeopteryx da Guimarota permitiram, pela primeira vez, o estudo dos dentes dos archaeopterygiformes em três dimensões, o que resultou em algumas descobertas interessantes (RAUHUT, 2000, p.80). Estes dentes caracterizam-se por ter uma forma sigmoidal ${ }^{31}$ e as bordas cortantes são viradas para dentro, exibindo serrilhas rudimentares na borda cortante anterior, só visíveis através de microscópio electrónico (RAUHUT, 2000, p.80, WEIGERT, 1995, WIECHMANN \& GLOY, 2000). Apesar dos dentes dos archaeopterygiformes terem a morfologia mais primitiva que a dos dentes das aves posteriores, os dentes de Archaeopteryx da Guimarota apresentam características de transição entre os dinossauros terópodes e as aves e são muito modificados, indicando um grande grau de especialização no aparelho alimentício (RAUHUT, 2000, p.80).

\section{Sistemática paleontológica:}

AVES (LINNAEUS, 1758)

ARCHAEOPTERYGIFORMES (FURBRINGER 1888)

31 Em forma de "S". 
ARCHAEOPTERYGIDAE (Huxley 1872)

Cf. Archaeopteryx (VON MEYER 1861)

\subsection{3 - Aves fósseis do Cenozóico de Portugal}

No Cenozóico são conhecidas 6 jazidas com restos de avifauna fóssil, nas zonas de Coimbra, Leiria, Santarém, Lisboa e Sesimbra. Do Paleogénico, o registo fóssil de avifauna é escasso. Apenas se conhecem três restos de uma nova espécie, identificada na jazida do Eocénico Inferior de Silveirinha, perto da Figueira da Foz, tratando-se dos mais antigos fósseis de aves cenozóicas da Península Ibérica. 0 panorama do Neogénico altera-se, conhecendo-se algumas jazidas do Miocénico com restos fósseis de aves e um conjunto relativamente numeroso de jazidas do Plistocénico Superior com avifauna, em contexto arqueológico.

Os restos encontrados na Silveirinha estão depositados na Universidade nova de Lisboa (Sanches-SANCHEZ-MARCO, 1995) e foram recolhidos por Telles Antunes (Harrison, 1983). Os restos do Miocénico estão nas colecções do Museu Geológico e são provenientes do Penedo Norte (Sesimbra), Amôr (Leiria), Olival da Susana (Lisboa) e Quinta das Pedreiras (Lisboa). Destes restos o único estudado mais aprofundadamente é um resto atribuído a Paleoperdix, da Charneca, Lisboa (MOURER-CHAUVIRÉ \& ANTUNES, 2003). 


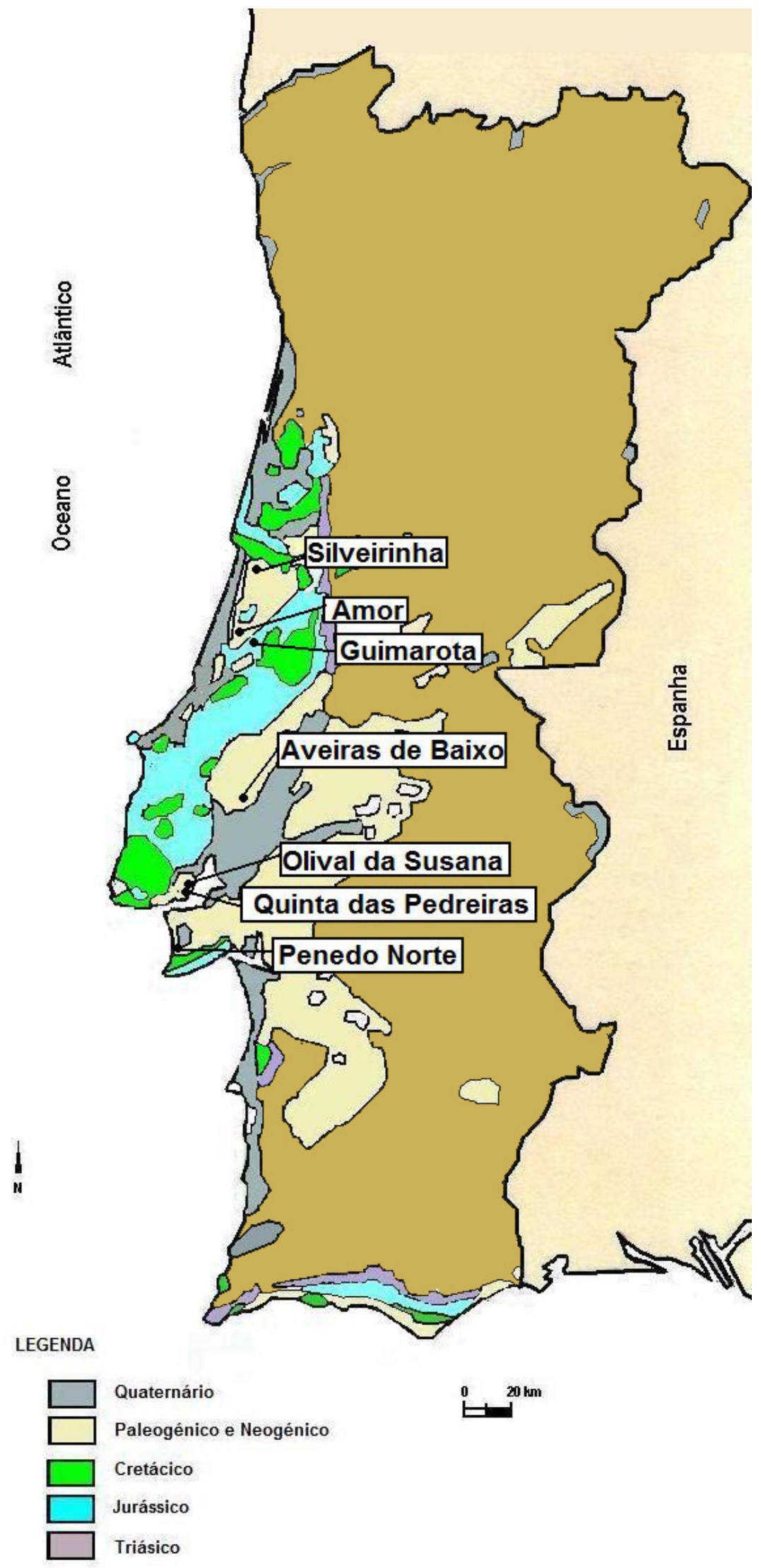

Fig. 61 - Localização das jazidas com restos de fósseis de avifauna do Mesozóico e do Cenozóico. 


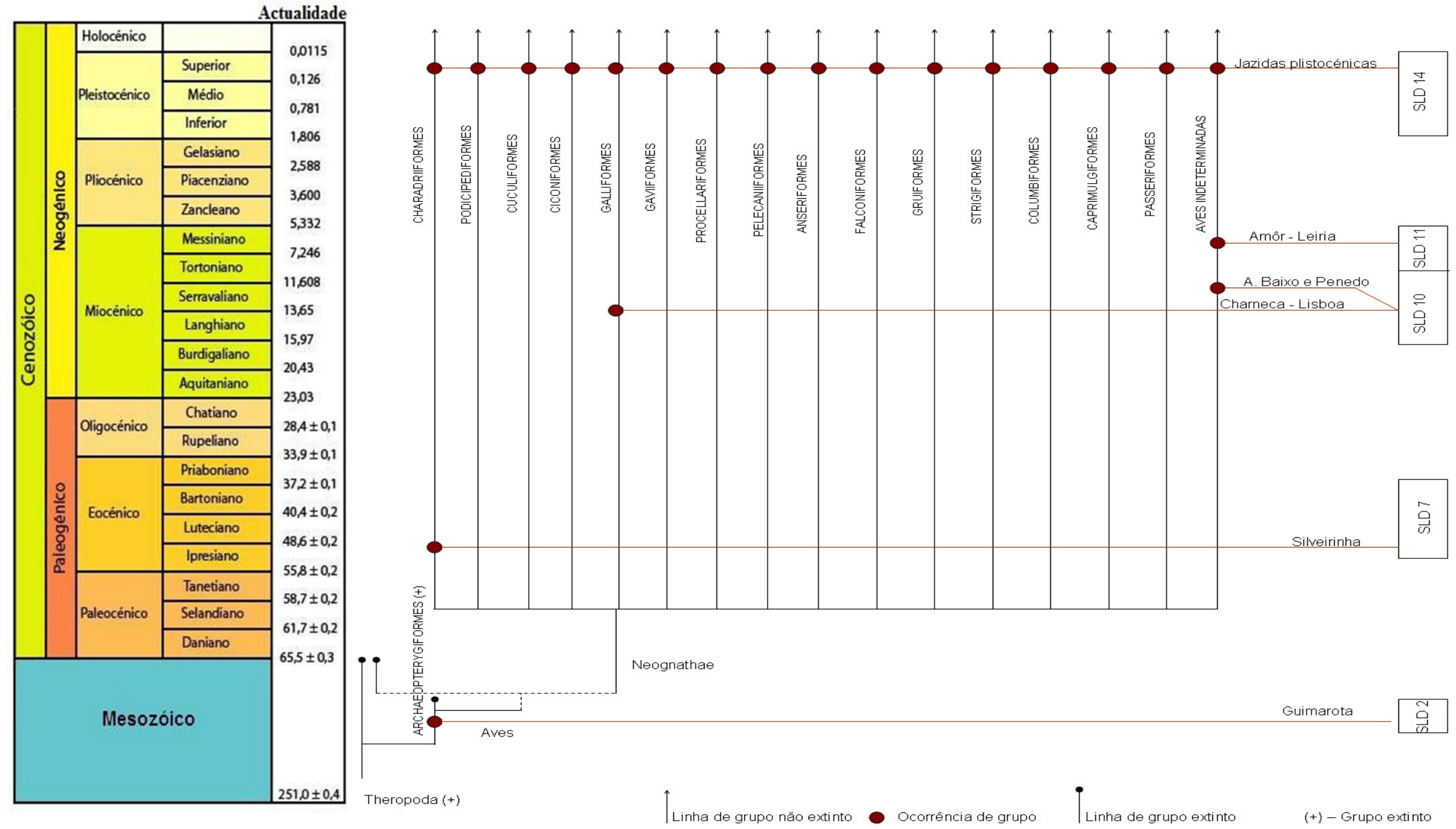

Fig. 62 - Ordens de aves fósseis encontradas em Portugal, com destaque para as do Cenozóico (as bolas indicam as ocorrências nas diferentes jazidas). 


\subsubsection{1 - Silveirinha - Figueira da Foz}

A jazida paleontológica de Silveirinha fica situada num barreiro perto da estrada nacional EN 109, a cerca de 13 km a sul da Figueira da Foz. Foi publicada pela primeira vez em 1980, por António Ferreira Soares e Rui Pena dos Reis, da Universidade de Coimbra. A sucessão sedimentar foi descrita como um depósito areno-argiloso predominantemente vermelho e fossilífero (SOARES \& PENA DOS REIS, 1980).

Os primeiros fósseis foram recolhidos em 1977, por Pena dos Reis e são eles que dão a importância da jazida, pois o estudo posterior destes e de outros fósseis provenientes da Silveirinha tornaram-na uma das mais importantes jazidas paleontológicas da Europa. Estes primeiros achados foram posteriormente entregues a Miguel Telles Antunes, que os começou a estudar, fazendo, em 1981, uma primeira listagem das espécies fósseis, publicada numa nota conjunta sobre os aspectos sedimentológicos e paleontológicos deste barreiro (SOARES, PENA DOS REIS \& ANTUNES, 1981). As espécies identificadas apontavam para o Eocénico Inferior. Este dado tornou esta jazida única e a primeira deste andar ${ }^{32}$, em Portugal. Pouco tempo depois surgiu uma nova listagem, baseada em 239 espécies, realizada por Telles Antunes e Donald Russel, do Museu Nacional de História Natural de Paris (RUSSEL \& ANTUNES, 1981). Estes dados não só reforçaram a importância desta jazida no contexto geológico e paleontológico nacional, como também lhe deram uma importância a nível europeu.

A maioria dos fósseis estudados resultou do tratamento laboratorial dos sedimentos, foram muito raros os que foram recolhidos directamente do afloramento. A importância desta jazida não está apenas na datação, mas também na quantidade dos exemplares estudados.

\section{Enquadramento Geológico}

As unidades siliciclásticas ${ }^{33}$ da Silveirinha e os afloramentos adjacentes são habitualmente denominados de Formação da Silveirinha ou Areias e Argilas da

32 Poucos anos antes, os Serviços Geológicos de Portugal tinham cartografado esta zona e atribuíram estes depósitos ao Plio-Plistocénico

33 Unidade com rochas sedimentares clásticas, compostas essencialmente de minerais do grupo dos silicatos 
Silveirinha, constituindo-se como a única desta série geológica, conhecida em Portugal. As datações efectuadas, com base na fauna (mamíferos, carófitas e ostracodos), apontam para o Ipresiano Inferior (Eocénico Inferior). A sedimentação efectuou-se em planície de inundação fluvial, no limiar de zona costeira, com fraca influência das marés. A Formação de Silveirinha insere-se na SLD 6.

Em termos litológicos, esta jazida é constituída por sedimentos argilosos, atravessados por inúmeros depósitos lenticulares, originados pelo preenchimento de antigos canais por sedimentos grosseiros (arenitos e microconglomerados). Os sedimentos argilosos apresentam uma estratigrafia composta por sequências métricas positivas ${ }^{34}$, bastante compacta e de cor avermelhada, quase sem fósseis. Por seu lado, os sedimentos grosseiros apresentam-se bastante ricos de fósseis.

Macroscópicamente, estes sedimentos são muito semelhantes aos depósitos continentais da formação de Taveiro. Por esta razão foram considerados, da perspectiva sedimentológica, como integrantes das chamadas Areias e Argilas de Taveiro. Na Silveirinha, a espessura das sequências não ultrapassa os 3 a $4 \mathrm{~m}$, com enchimento de pequenas figuras de canal. São constituídas por espessas camadas ricas de esmectite, arenitos e lentículas de conglomerados intraformacionais. Os corpos conglomeráticos, sempre lenticulares, não ultrapassam $1 \mathrm{~m}$ de espessura máxima. A Formação da Silveirinha pode ser considerada como uma sucessão posterior à do Campaniano Superior - Maastrichtiano. Uma sucessão com a mesma idade encontra-se documentada em sectores adjacentes da plataforma continental, sendo, no entanto algo mais espessa, e essencialmente carbonatada (ANTUNES \& RUSSEL, 1981).

\section{Paleoecologia}

A região onde se encontra a Silveirinha era, há cerca de $55 \mathrm{Ma}$, uma planície aluvial, recortada por canais fluviais meandriformes que se estendiam em direcção ao Oceano Atlântico e onde se depositaram os sedimentos, atrás referidos. Periodicamente, estes canais fluviais transbordavam as margens, devido a episódios de cheias, inundando as planícies contíguas, cobrindo-as de sedimentos finos. Alguns dos fósseis encontrados indicam que por vezes, de uma forma irregular, esta 
zona sofria uma fraca influência marinha, enquanto a maioria dos fósseis apontam para um ambiente claramente continental, com cursos de água doce.

A paleoflora encontrada na Silveirinha é muito pobre; apenas se recuperaram algumas sementes de carófitas, do género Nitellopsis, e algum âmbar. Apesar da fraca ocorrência de vestígios de flora nesta jazida, sabe-se que a paleoflora eocénica era característica de climas tropicais ou subtropicais, semelhante às actuais regiões húmidas e quentes do sudoeste asiático, e a região da Silveirinha, no Eocénico, não teria um clima muito diferente deste. Esta ideia é reforçada pelas espécies de ostracodos identificadas na Silveirinha, características de ambientes límnicos, subtropicais.

\section{As Faunas}

A jazida de Silveirinha apresenta uma fauna muito importante no contexto da paleontologia dos vertebrados do Eocénico europeu, em especial no que diz respeito aos mamíferos fósseis. A fauna está associada à biozona de mamíferos MP7, cuja localidade de referência é Dormaal, na Bélgica. A base de definição desta biozona é a fauna mamaliana, que permite a correlação estratigráfica entre diferentes formações continentais europeias, geralmente raras e isoladas e de difícil interpretação estratigráfica.

Nesta jazida não foram apenas recolhidos fósseis de vertebrados, mas também identificadas oito espécies de ostracodos, pertencentes à ordem Podocopida. Os holótipos das espécies Hyocypris lusitanicus e Cypris silveirinhaensis, duas das oito espécies de Podocopida identificadas na Silveirinha, foram lá encontrados e descritos em publicações sobre esta jazida.

Os moluscos também estão presentes no conjunto de fósseis recuperados nos trabalhos efectuados na Silveirinha, tendo sido identificados quatro espécies deste filo de invertebrados, duas delas novas para a ciência (Bithynia soaresi e Gyraulus antunesi). Destas quatro espécies de moluscos, duas são de gastrópodes e as outras duas são de bivalves.

Os restos de vertebrados assumem-se como os mais importantes. Foram encontrados fósseis de cinco classes de vertebrados: teleósteos (peixes), anfíbios, répteis, mamíferos e aves. 
Os restos de peixes encontrados são constituídos por materiais muito fragmentados, constituídos por elementos isolados de fragmentos de ossos do crânio, algumas vértebras e raios espinhosos de barbatanas. Estes elementos apontam para espécies de peixes ósseos, provavelmente, da subordem Percoidei.

Ao contrário dos peixes, os restos de herpetofauna (anfíbios e répteis) são muito abundantes e variados. Os anfíbios estão representados por duas espécies, uma pertencente à ordem Caudata e outra à ordem Anura; o material não permite uma classificação mais precisa.

Os répteis descritos na Silveirinha pertencem à ordem Squamata (sub-ordens Lacertilia e Ophidia) e à ordem Chelonia; destes últimos foram recuperados mais de uma centena e meia de fragmentos de carapaças e de diversos ossos.

Os mamíferos são o grupo de vertebrados mais bem representado nesta jazida. Foram identificados mais de trinta táxones, alguns deles descritos pela primeira vez e outros apenas conhecidos na América. Estes trinta táxones distribuemse pelas ordens Apatotheria, Lipotyphla, Dermoptera, Taeniodonta, Primata, Rodentia, Artiodactyla e Condylarthra, sendo que a maioria dos vestígios pertencem a esta última.

\section{As Aves de Silveirinha}

No que respeita às aves apenas foi identificada uma espécie, descrita a partir de três elementos ósseos. Esta espécie não era conhecida até então e foi descrita por Harrison, em 1983, com base em três ossos que não se encontravam em associação anatómica, mas estavam muito próximos uns dos outros, numa área inferior a meio metro quadrado. Baseado nesta circunstância e no facto de não existirem mais aves nesta jazida, Harrison avançou com a possibilidade destes três ossos pertencerem a um único individuo.

Os ossos são um fémur direito, uma parte distal de um úmero direito e a extremidade distal de um rádio direito, que foram comparados independentemente com a colecção osteológica do Museu Britânico de História Natural (HARRISON, 1983, p. 13). A configuração geral do fémur era semelhante aos dos Threskiornithidae (da ordem dos Ciconiiformes) e aos dos Charadriiformes, sendo que muitas das características apontavam para o último táxon (HARRISON, 1983, p. 13). 


\title{
Sistemática Paleontológica
}

\author{
Aves (LINNAEUS, 1758) \\ CharadRIIFORMes (HuXLeY, 1867) \\ RECURVIROSTRIDAE, (BONAPARTE, 1831) \\ Fluviatitavis, (HARRISON, 1983) \\ Fluviatitavis antunesi, (HARRISON, 1983)
}

\subsubsection{2 - O Olival da Susana e a Quinta das Pedreiras}

O Olival da Susana e a Quinta das Pedreiras localizam-se em Lisboa. A primeira, na freguesia da Charneca, pêro do limite ocidental do aeroporto da Portela; a segunda, na freguesia do Lumiar.

\section{Enquadramento Geológico}

Do ponto de vista geológico, a zona de Lisboa, é constituída por um conjunto de sedimentos miocénicos, datados do Aquitaniano ao Tortoniano inferior (Antunes et al., 2000). Oferece em interesse muito especial porque a sucessão, sobretudo de origem marinha, compreende as intercalações continentais de faunas e floras geralmente bem documentadas (MOURER-CHAUVIRÉ \& ANTUNES, 2003).

A notícia explicativa da Carta Geológica de Lisboa (ZBYSZEWSKI, 1963) enquadra esta zona como estando na formação das Areias de Vale de Chelas, que é um complexo arenoso, com intercalações argilosas e greso-calcárias, constituído por areias, areolas, grés calcários, calcários grosseiros, arenitos e argilas e siltes.

Assume-se de grande relevância o papel de G. Zbyszewski no estudo geológico e paleontológico desta região. Zbyszewski recolheu com a colaboração dos trabalhadores nos inúmeros areeiros que existiam nesta zona, a maior parte dos achados que estão patentes no Museu Geológico.

\section{Paleoecologia}

A unidade da escala estratigráfica da bacia do Baixo Tejo, área de Lisboa e 
Península de Setúbal, compreende os assentamentos marinhos litorais e de camadas de areias fluviais, que forneceram uma rica associação de mamíferos, marcados pela primeira ocorrência de Deinahreidum. O sítio mais rico foi o antigo areeiro da Quinta das Pedreiras (Lumiar). A idade radiométrica está compreendida entre os 17.8 e os 16.4 Ma. A associação de mamíferos é atribuída à biozona MN4, o equivalente, no que diz respeito à estratigrafia marinha, ao começo do Langhiano (MOURERCHAUVIRÉ \& ANTUNES, 2003).

\section{Enquadramento paleontológico}

Esta formação apresenta um conjunto de fósseis de grandes vertebrados que assumem grande interesse patrimonial e científico, destacam-se os inúmeros achados de proboscídeos na zona de Chelas, Lumiar e Charneca, e a descoberta de um crocodilo de grandes dimensões em Chelas.

A última intercalação continental, tendo deixado associações ricas em mamíferos não marinhos, é a que corresponde à divisão $\mathrm{Vb}$ da idade Langhiano (inicio do Miocénico médio, entre 16.4 e $15.3 \mathrm{Ma}$ ). A divisão Vb aparece em vários areeiros cuja exploração cessou em 1968. Nestes, ocorrem abundantes restos de ostras e de Vertebrados, inclusive de mamíferos da fauna de Hispanoterium, MN5. A maior parte desta fauna provém das areias fluviais interiores; contudo, foram recolhidos alguns destes mamíferos pequenos no cimo desta unidade (MOURERCHAUVIRÉ \& ANTUNES, 2003).

De entre outros vertebrados, pode reter-se a presença de peixes, uns de água doce e outros marinhos, mas que podiam penetrar nos rios. Há crocodilos como um Gavialis sp e um Tomistoma Lusitanica, bem como outros répteis: queloníanos, como os Tyronix e os Emidideos, e grandes Testudíneos terrestres e diversos fósseis da espécies da ordem squamata, como restos de varanos, da família boidae (Bavarioba sp.) e de víboras orientais (Vípera Sp.) (MOURER-CHAUVIRÉ \& ANTUNES, 2003).

\section{A Avifauna}

\section{Olival da Susana}

Existem, de entre os restos de vertebrados do Olival da Susana alguns muito mal conservados fragmentos de ossos de aves (MOURER-CHAUVIRÉ \& ANTUNES, 
2003). A um destes ossos, uma parte distal de um tibiotarso direito, foi possível atribuir-Ihe uma classificação taxonómica: Palaeoperdix media (MOURER-CHAUVIRÉ \& ANTUNES, 2003).

Este fóssil foi encontrado em areias fluviais do Olival da Susana, atribuídos à divisão Vb do langhiano, com cerca de 16 Ma (MOURER-CHAUVIRÉ \& ANTUNES, 2003). A espécie Palaeoperdix media é conhecida, no Miocénico, para além de Portugal, em vários países da Europa, (Turquia, Hungria, França e Espanha). Na Turquia aparece associada à biozona mamaliana MN6 e em França à MN7. Em Portugal corresponde à MN5.

\title{
Sistemática Paleontológica
}

\author{
Aves (Linnaeus, 1758) \\ Galliformes (TEMMINCK, 1820) \\ Phasianidae (VIGORS, 1825) \\ Palaeoperdix, (MILNE-EDWARDS, 1869-1871) \\ Palaeoperdix media (MILNE-EDWARDS, 1869-1871)
}

\section{Quinta das pedreiras}

Na Quinta das Pedreiras também estão referenciados restos de aves, encontrados em areias fluviais da divisão Va2 do Burdigaliano. Um desses restos, uma diáfise de tibiotarso esquerdo, com $22 \mathrm{~cm}$ de comprimento, foi atribuído à família gruidae (MOURER-CHAUVIRÉ \& ANTUNES, 2003). Os autores que atribuíram esta classificação taxonómica, não conseguiram atribuir um género específico a este resto, não possível, segundo os autores, se este tibiotarso sria do género extinto Palaeogrus (PORTIS 1884) ou ao actual género Balearica (BRISSON, 1760) (MOURERCHAUVIRÉ \& ANTUNES, 2003, pp. 195).

\section{Sistemática Paleontológica}

AVES (Linnaeus, 1758)

GRUIFORMES (BONAPARTE, 1854)

GUIDAE (VIGORS, 1825) 


\section{Outros locais com aves do Miocénico}

Estão referidas na bibliografia mais três localidades com formações miocénicas, nas quais foram encontradas aves: Amor, Aveiras de Baixo e Penedo Sesimbra. Como se tratam de aves ainda não identificadas optou-se por apenas fazer uma breve referência a estas jazidas. Será importante para um melhor conhecimento da avifauna do Miocénico em Portugal fazer-se, no futuro, um estudo taxonómico destes restos, ainda não identificados.

\subsubsection{3 - Amor}

Em Amor (Leiria) foram descobertas, na década de sessenta do século passado, três jazidas com restos fósseis (ZBYSZEWSKI \& FERREIRA, 1967).

A primeira, onde foram descobertos os primeiros achados de vertebrados fósseis, nesta zona foram feitos por G. Zbyszewski e O. da Veiga Ferreira, a 6 de Abril de 1966, num corte da então nova estrada que liga Amor a Monte Real, num afloramento atribuído ao Miocénico Médio (ZBYSZEWSKI \& FERREIRA, 1967), tratando-se de uma defesa de mastodonte e alguns fragmentos ossos, descobertos no decurso da elaboração da Carta Geológica de Leiria.

As outras duas jazidas são do Miocénico Superior (Tortoniano), localizam-se num raio de $2 \mathrm{~km}$, uma da outra e nelas foram recolhidos vários restos ósseos de tetrápodes. Uma destas jazidas localiza-se na estrada que liga Amor a Monte Real, a cerca de 600 metros da igreja de Amor e a outra localiza-se numa linha de água a noroeste da primeira (ZBYSZEWSKI \& FERREIRA, 1967).

A fauna desta jazida é bastante rica, constituída por vários restos de répteis, anfíbios e mamíferos (carnívoros, artiodáctilos, perissodáctilos, insectívoros, lagomorfos e roedores) (ANTUNES \& MEIN, 1981). Da fauna recuperada de Amôr foram recuperados alguns restos de ossos de aves muito fragmentados, sem as extremidades articulares, pelo que não foi possível determinar a classificação taxonómica desses restos (ANTUNES \& MEIN, 1981, pp. 178). 


\subsubsection{4 - Aveiras de Baixo}

Em Aveiras de baixo existe uma breve referência à identificação, num afloramento do Miocénico, de um resto de ave indeterminado (ZBYSZEWSKI, 1954).

\subsubsection{Penedo Norte (Sesimbra)}

A jazida de Penedo fica localizada nas arribas miocénicas, junto à Aldeia do Meco, freguesia do castelo, Concelho de Sesimbra e Distrito de Setúbal. O Miocénico da península de Setúbal é muito rico de fósseis, quer de invertebrados quer de vertebrados. Na zona que vai do Meco à Caparica são frequentes fósseis de grandes vertebrados marinhos, como tubarões e Cetáceos (Megalodon e Bacilosaurus).

Dos vertebrados miocénicos de Penedo, depositados no Museu Geológico de Lisboa encontram-se alguns restos de aves. Trata-se de ossos fragmentados de aves do Burdigaliano superior.

O estado de conservação dos ossos não permitiu identificar taxonomicamente estes restos. No entanto, o seu contexto, estavam em sedimentos marinhos, permitiu aos autores defini-los como sendo restos de aves marinhas (MOURER-CHAUVIRÉ \& ANTUNES, 2003, pp. 192 e 195). 


\section{5 - Breve Referência à Paleoecologia do Plistocénico em Portugal e na}

Península Ibérica

\subsection{1 - Caracterização paleoecológica do plistocénico português}

Localizado no extremo sudoeste da Europa, o território português apresenta uma grande variedade de climas: no litoral pode-se observar a transição de um clima mediterrâneo para um clima temperado atlântico, enquanto no interior assiste-se à influência da continentalidade da Meseta Ibérica, onde se verifica um clima mais quente e seco, de verão e mais frio, no inverno.

Durante o Pliocénico, o clima era diferente do actual. Esta alteração foi o resultado da acção das glaciações que afectaram o território português sem o impacto que teve noutras regiões da Europa. Até há algum tempo atrás, esta influência era conhecida apenas no vale glaciar da Serra da Estrela, marcado pela língua de cerca de $13 \mathrm{~km}$ no Vale do Zêzere e pelo Vale que atingiu a Vila de Manteigas. Mais recentes são as identificações de vestígios de glaciares, no topo das montanhas mais altas do noroeste de Portugal, que são o prolongamento de fenómenos semelhantes assinalados na Galiza (BRUM FERREIRA, A., 1972).

Os vestígios dos glaciares identificados em Portugal, são atribuídos ao último período glaciar (o Würm), em particular ao máximo glaciar, não havendo segurança quanto aos elementos que se dispõe para se poder falar de fenómenos anteriores a este período glaciar (RIBEIRO, J. P. C. 1990, p. 21) Um factor que poderá explicar este facto é a observação, já na segunda metade do século XX, na região norte das Beiras, de deslocações verticais de centenas de metros ocorridas durante o Plistocénico, nos principais maciços montanhosos. As montanhas portuguesas não têm altitude suficientemente altas para que se pudessem formar glaciares, antes do Würm, razão pela qual não se identificaram vestígios de glaciares anteriores a este período (BRUM FERREIRA, A., 1972., p. 374).

Para outros períodos do Plistocénico, mais antigos, recorre-se a outros dados para se fazer reconstituições ambientais. As praias elevadas ou os terraços fluviais, classificados normalmente com base em critérios altimétricos e eustáticos rígidos fornecem informações de validade duvidosa. Outra importante fonte de informação 
são os restos faunísticos, de que é exemplo a jazida de Algoz e Morgadinho, ambas no Algarve, datadas do inter-glaciar Riss-Würm, permitiram concluir que aquela zona teria um ambiente húmido e pantanoso, num clima relativamente quente (ANTUNES et al., 1986 a) e b)). 


\section{6 - Caracterização paleontológica das jazidas estudadas}

\subsection{1 - Gruta da Columbeira}

A maior parte dos vestígios faunísticos desta gruta provieram das camadas oito e seis, sendo que naquela aparecem sobretudo herbívoros e nesta, a seis, carnívoros. Quer numa quer noutra os herbívoros ali presentes estão relacionados com as actividades de caça tanto de homens como de hienas (CARDOSO, RAPOSO \&FERREIRA, 2002, p. 41). A este cenário contrapõem-se os vestígios de avifauna, cuja maioria está ali por outros motivos, referidos mais adiante, e que não têm que ver com as actividades de caça.

Nesta estação foram identificadas por Veiga Ferreira várias espécies de mamíferos, tais como Ursus arctus, Hyaena triata, Rhinoceros sp., Bos primigenius, Equus caballus, Cervus elaphus e Canis sp.. Segundo Cardoso (CARDOSO, 2003), as percentagens destas faunas são (segundo CARDOSO, 1993 e CARDOSO, RAPOSO e FERREIRA, 2002):

$$
\begin{aligned}
& \text { "Crocuta crocuta spelea - 9,3\% } \\
& \text { Felis sylvestris - 0,4\% } \\
& \text { Lynx pardina spelaea - 2,7\% } \\
& \text { Canis lupus - 0,8\% } \\
& \text { Ursus arctus - 0,4\% } \\
& \text { Dicerorhinus hemitoechus - 5,8\% } \\
& \text { Equus caballus - 6,2\% } \\
& \text { Cervus elaphus - 58,5\% } \\
& \text { Capreolus capreolus - 0,4\% } \\
& \text { Capra pyrenaica - 8,5\% } \\
& \text { Bos primigenius - 5,8\%" }
\end{aligned}
$$

Como se pode ver, nesta gruta predominam claramente os herbívoros. Este facto está relacionado com a ocupação humana e das hienas, que transportaram para a gruta partes das suas caçadas. De entre os herbívoros destacam-se os veados, provavelmente em grande número naquela época, e os carnívoros mais frequentes 
são as hienas.

Esta fauna indica características paleoecológicas em conjuntura com os climas de tipo temperado, mas mais frios que os actuais. Estas faunas indicam também a ocorrência de períodos de seca.

No que respeita a outros grupos, destaca-se a presença de tartarugas, em especial a espécie Agrionemys (=Testudo) hermanni. Aliás a Gruta Nova da Columbeira é a jazida plistocénica que apresenta uma maior quantidade de restos de tartarugas (CARDOSO, 1993; CARDOSO, RAPOSO e FERREIRA, 2002, p. 42). Apesar dos adultos aguentarem temperaturas que podem chegar aos $20^{\circ} \mathrm{C}$ negativos, as temperaturas de desenvolvimento do embrião rondam os $30^{\circ} \mathrm{C}$. Isto significa que antes do $\mathrm{LGM}^{35}$, no Verão, na altura em que se formou a camada oito na Gruta Nova, o clima deveria ser quente, a rondar os $30^{\circ} \mathrm{C}$. Por outro lado, quando, mais tarde, se atingiu o LGM, as temperaturas mais baixas terão sido as responsáveis pela extinção desta espécie em Portugal. Os Invernos poderiam ser frios, pois existem vestígios, nas brechas da camada seis, que indicam episódios de temperaturas baixas (CARDOSO, 1993; CARDOSO, RAPOSO e FERREIRA, 2002).

\subsection{2 - Gruta da Furninha}

Esta jazida apresenta uma fauna plistocénica muito abundante e variada. Nas actas do congresso de 1880, Nery Delgado fez o inventário da fauna, apresentando 26 espécies de mamíferos e a referência à presença de aves, tartarugas, anfíbios e algumas espécies de moluscos (DELGADO, 1884, Quadro 3). Nesta publicação Nery Delgado descreve os restos de mamíferos recuperados da Furninha, segundo cada um dos "níveis ossíferos" (DELGADO, pp. 239 - 264). Mais tarde, os mamíferos foram objecto de um inventário e de um estudo feitos por E. Harlé (1910/11) que contou, no caso do estudo das aves, anfíbios e répteis, com a colaboração de E. T. Newton. Os grandes mamíferos foram revistos e estudados mais recentemente por João Luís Cardoso (CARDOSO, 1993). O material ósseo recolhido nos sete níveis do complexo arenoso é muito uniforme (FERREIRA, 1964); por essa razão, Harlé considerou a fauna

35 Último máximo glaciar (do inglês Last Glacial Maximum). 
da Furninha como uma só (HARLÉ, 1910/11), motivo que o levou a não estudar separamente esta fauna, mediante as camadas estratigráficas de origem.

No caso dos mamíferos foram identificados carnívoros (Hyaena hyaena, Linnaeus, 1758, Lynx pardinus, Temminck, 1827, Canis lupus, Linnaeus, 1758 e Ursus arctos, LINNAEUS, 1758) cervídeos (Cervus), rinocerontes (Dicerorhinus hemitoechus, FALCONER, 1868), e bovídeos (bos, LINNAEUS, 1758 e capra, LINNAEUS, 1758) (CARDOSO, 1993). Nos materiais ósseos da Furninha, que fazem parte das colecções do Museu Geológico, estão inventariados outros restos, tais como a lontra (Lutra lutra, LINNAEUS, 1758), javali (Sus scrofa, LINNAEUS, 1758) e um resto atribuído, por Henry Breuil, com algumas reservas, a elefante. Caso se confirme esta classificação será, provavelmente de Elephas antiquus, FALCONER \& CAUTLEY, 1847. Existem também pequenos mamíferos, como lagomorfos (género Oryctolagus, LILLJEBORG 1874), ouriço e morcegos (ordem Chiroptera, BLUMENBACH 1779). Desta fauna de mamíferos existem, a par de espécies vivas, algumas extintas nos finais do Plistocénico, como é o caso da Crocuta crocuta, do Felis pardus e do Dicerorhinus kirchenbergensis. No caso dos restantes grupos (aves, répteis e anfíbios), apenas foram identificadas espécies vivas ${ }^{36}$ (ROCHE, 1970). Esta gruta foi essencialmente um abrigo de carnívoros: o conjunto faunístico apresenta uma predominância destes, com cerca de 94\% do total dos restos (CARDOSO, 1993).

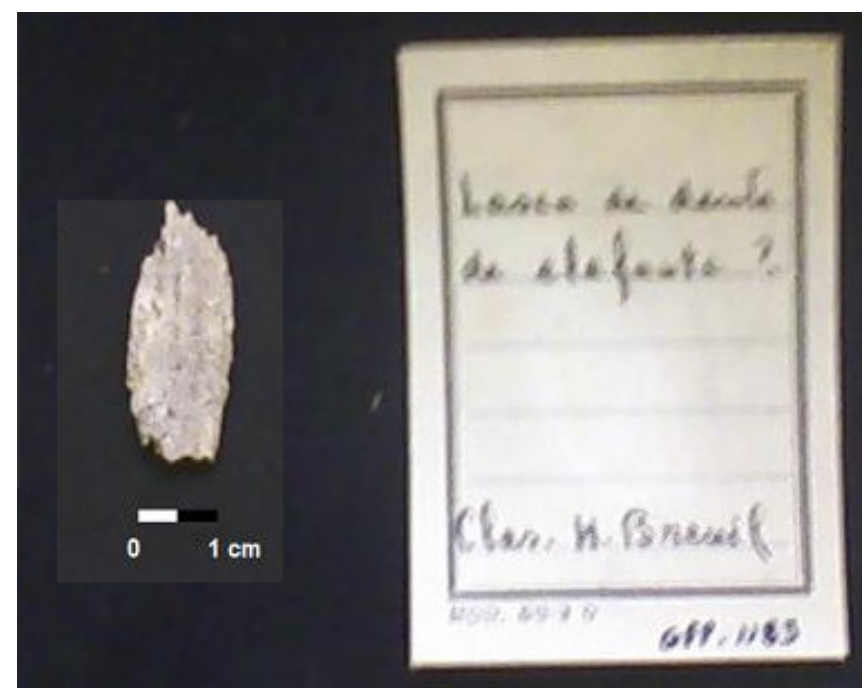

Fig. 63 - Resto atribuído por Henry Breuil a um elefante, com a respectiva ficha de inventário, onde se pode ler "class. H. Breuil".

36 Nas aves há que referir uma exepção: o agora identificado resto de $P$. impennis 


\subsection{3 - Gruta das Salemas}

A fauna da Gruta das Salemas foi estudada por Jean Roche. Foi encontrada, nesta gruta, uma rica fauna plistonénica constituida, na sua maioria, por mamíferos (ROCHE, 1972). Foram descritas as seguintes espécies: lobo (Canis lupus), raposa (Vulpes vulpes), cavalo (Equus caballus), javali (Sus scrofa), auroque (Bos primigenius), coelho (Oryctolagus cuniculus), camurça-dos-pirineus (Rupricapra rupricarpa pyrenaica), veado (Cervus elaphus), lince (Felis pardus) e o urso (Ursus arctos).

João Luís Cardoso (CARDOSO, 1993), no seu estudo sobre os grandes mamíferos plistocénicos de Portugal, verificou que, das espécies identificadas, predominam o Cervus elaphus, com 29\%, o Bos primigenius, com $25 \%$ e o Equus caballus, com $22 \%$ do total dos restos, os outros herbívoros apresentam percentagens mais baixas: Rupricapra rupricarpa pyrenaica, com 3\%, Sus scrofa, 1,7\%, Dicerorhinus hemitoechus, $0.8 \%$. Os carnívoros constituem $10,6 \%$ do total das faunas identificadas e estão representados por Lynx pardina spelaea, Ursus arctus, Phantera spelaea, Felis silvestris e Panthera pardus. (CARDOSO, 1993).

A fraca ocorrência de carnívoros faz supor que a maior parte dos restos faunísticos aqui encontrados sejam de origem antrópica. De entre dos carnívoros, a considerável percentagem de lince e gato-bravo indica uma frequência da gruta por estes animais (CARDOSO, 1993, p. 529).

\subsection{4 - Gruta do Pego do Diabo}

O estudo das faunas da Gruta do Pego do Diabo foi feito por Maria João Valente para a sua tese de mestrado, ainda não publicada. Foram também referidos por João Luís Cardoso, na sua tese de doutoramento sobre os grandes mamíferos desta gruta (CARDOSO, 1993). Este estudo incidiu sobre uma pequena parte da colecção (59 restos) (CARDOSO, 1993). Destes restos estudados por João Luís Cardoso verifica-se uma maior ocorrência da espécie Cervus elaphus, e poucos restos de ungulados. A segunda espécie mais abundante nesta gruta é o lince, parecendo indicar que a gruta serviu de abrigo para aquele carnívoro (CARDOSO, 1993).

As principais espécies descritas nesta gruta são a Crocuta crocuta, Lynx 
pardina, Cervus elaphus, e Equus caballus (ZILHÃO, 1988). Para além destas espécies foi referenciada a ocorrência de poucos restos de pequenos carnívoros e de abundantes restos de lagomorfos (ZILHÃO, 1988), há também que referir a presença de $\operatorname{Bos}^{37}$.

\subsection{5 - Gruta das Fontainhas}

A abundante fauna desta jazida, que se constitui como o principal espólio ali recolhido, foi referida, pela primeira, por Paul Choffat, que menciona a descoberta de ossos quaternários de hiena das cavernas e de urso das cavernas, de cavalo selvagem e de cervídeos (CHOFFAT, 1891). Esta fauna, que não varia muito das outras grutas com vestígios desta época, foi estudada mais tarde por Harlé.

Esta gruta serviu de abrigo a espécies de carnívoros, especialmente do urso (Ursus arctos). Foram também encontrados restos de outros carnívoros, como o lobo, a hiena e alguns felídeos. Foram ainda recuperados restos de herbívoros, como o cavalo, o javali, o veado, a cabra e o coelho. Na sua revisão destas faunas, João Luís Cardoso identificou uma nova subespécie de cavalo, o Equus caballus antunesi (CARDOSO, 1993).

\subsection{6 - Gruta da Casa da Moura}

A abundante fauna desta jazida, que se constitui como o principal espólio ali recolhido, foi referida, pela primeira, por Paul Choffat, que menciona a descoberta de ossos quaternários de hiena das cavernas e de urso das cavernas, de cavalo selvagem e de cervídeos (CHOFFAT, 1891). Esta fauna, que não varia muito da das outras grutas com vestígios desta época, foi estudada mais tarde por Harlé.

Esta gruta serviu de abrigo a espécies de carnívoros, especialmente do urso (Ursus arctos). Tal como na Gruta das Fontainhas foram também aqui encontrados restos de outros carnívoros, como o lobo, a hiena e alguns felídeos e recuperados restos de herbívoros, como o cavalo, o javali, o veado, a cabra e o coelho. Na sua

37 Observados pelo signatário aquando da procura de restos de aves no acervo da Gruta do Pego do Diabo na colecção do Museu nacional de Arqueologia. 
revisão destas faunas, João Luís Cardoso identificou uma nova subespécie de cavalo, o Equus caballus antunesi (CARDOSO, 1993).

\subsection{7 - Lapa da Rainha}

A fauna foi inicialmente estudada por Jean Roche e, mais recentemente, por João Luís Cardoso (CARDOSO, 1993). Esta fauna é muito rica em mamíferos, apresentando também restos de aves e invertebrados. Como se viu na descrição das camadas, a fauna é proveniente das camadas três, quatro e cinco. Nesta última destaca-se abundância de coprólitos de hiena, o que quer dizer que neste período a gruta foi ocupada de forma constante por estes animais.

A indústria lítica é pouco abundante e data do Paleolítico Superior: as datações absolutas realizadas deram os seguintes resultados: $25580-1490 /+1820$ (ICEN); 20300+/-330 (ICEN).

A fauna identificada nesta gruta foi: Dicerorhinus hemitoechus, Ursus arctos, Panthera pardus, Linx pardina spelaea, Felis sylvestris, Bos primigenius, Equus caballus, Canis lupus, Cervus elaphus, Capreolus capreolus, Vulpes vulpes, Meles meles, Sus scrofa, Lepus timidus, Oryctolagus cuniculus, Arvicola amphibius, Mus sp., Vespertilio murinus, Miothis sp., Rhinolophus ferrumequinum, Lacerta ocellata, Rana sp. (ROCHE, 1972; CARDOSO, 1993)

\subsection{8 - Gruta do Caldeirão}

Na Gruta do Caldeirão foram encontrados restos ósseos e coprólitos de Crocuta crocuta e Crocuta spelaea nos níveis do Paleolítico Médio, nas camadas do bloco sedimentar inferior, em especial nas camadas $L$ e $M$, e dos níveis mais antigos do Paleolítico Superior, segundo bloco sedimentar (DAVIS, 2002 e ZILHÃO, 1997, Vol. II). Esta questão levanta uma problemática na análise aqueozoológica da Gruta do Caldeirão: Quem ocupou esta gruta durante estes períodos? Os carnívoros ou o homem? (DAVIS, 2002). No que respeita a esta questão, os ossos queimados dos níveis mais antigos são raros, tornando-se mais frequentes nos períodos mais

recentes, assim como a proporção entre objectos líticos e os ossos (DAVIS, 2002), o 
que poderá indicar uma ascendência na ocupação dos carnívoros sobre a do homem. Uma das características das faunas desta gruta é de que, nos níveis mais antigos, os vestígios das espécies herbívoras de grande porte pertencem a animais jovens, revelando a incapacidade das hienas em transportar indivíduos adultos destas espécies (DAVIS, 2002).

Os restos ósseos recuperados nesta gruta revelam uma grande variedade de vertebrados, com restos de grupos taxonómicos de todas as classes, As espécies mais representadas são o veado, o cavalo, a cabra, a camurça, o auroque e o javali. Os grandes carnívoros são mais frequentes nos níveis mais antigos, sobretudo a hiena, como se viu no parágrafo anterior (DAVIS, 2002).

Os restos ósseos ali encontrados estão bem preservados, não tendo sofrido grandes alterações e danos com o tempo. A fauna encontrada apresenta restos de aves $^{38}$, de peixes, de anfíbios, de répteis, em particular de tartarugas, e de mamíferos, dos quais se destaca a presença de Ursos arctos, Crocuta crocuta, Crocuta spelaea, Lynx sp, Canis lúpus, Vulpes vulpes, Castor tiber, Meles meles, Equus caballus, Equus hydruntinus, Cervus Elaphus, Rupricapra sp, Capra sp. Capreolus capreolus, Sus scrofa, Bos primigenius e Oryctolagus cuniculus (DAVIS, 2002).

38 As aves da gruta do Caldeirão serão apresentadas na terceira parte ("Resultados e Discussão"). 


\section{3 - Contextualização Arqueológica}

A temática principal da presente tese, as aves plistocénicas, está relacionada com jazidas com ocupações paleolíticas. Por esta razão, será feita uma breve contextualização crono-cultural, caracterizando o Paleolítico português.

\section{1 - O Paleolítico em Portugal}

As evidências das primeiras populações humanas que terão chegado a Portugal ficaram registadas nas praias elevadas da costa portuguesa, em especial nas de Magoito e de Açafora, através de artefactos de talhe sumário, lá encontrados. Estas ocupações estão também presentes em outras "praias elevadas" do território português, em especial no litoral estremenho. Apesar de não existirem datações absolutas para estas estações, a sua localização (cerca de 90 metros) indica datações que poderão rondar o milhão de anos (DAVEAU, 1980, RAPOSO 1993 b. No entanto, não se sabe com rigor a datação destas primeiras ocupações humanas em Portugal (RAPOSO, 2004). Datadas de mais tarde, existem várias estações arqueológicas do Acheulense, em vários terraços do Tejo, dos quais se destacam as jazidas em Alpiarça e atribuídas ao interglaciar Mindel-Riss (RAPOSO et al., 1993), e a Ribeira da Ponte da Pedra, com datações absolutas que apontam para os 302 +/- 12 ka BP (OSL) ou 175 +/- 6 ka BP (IRSL) (ROSINA \& CURA, 2009; OOSTERBEECK et al., 2010). Existem outros sítios arqueológicos, localizados também no Vale do Tejo e já do Paleolítico Médio que rondam os 80, Santo Antão do Tojal, Loures, os 70 e os 33, Vilas Ruivas e Foz do Enxarrique, Vila Velha de Ródão, respectivamente, e os 27 mil anos BP, na Conceição, perto de Alcochete (RAPOSO, 1991, RAPOSO \& CARDOSO, 1998a, CARDOSO, 2006a e b). Do Paleolítico Superior, têm sido descobertas, em especial nos últimos anos, várias estações arqueológicas em diferentes zonas do país. No entanto, destaca-se o conjunto de jazidas da Estremadura, localizadas essencialmente em grutas do maciço calcário, a norte de Lisboa, as gravuras ao ar livre da zona nordeste de Portugal, em especial as do vale do Côa, que estão classificadas pela UNESCO, e as pinturas e 
gravuras da Gruta do Escoural, perto de Montemor-o-Novo. Das últimas descobertas ganha particular importância, quer pelo seu valor científico, quer pela discussão que gerou, o Lagar Velho (Vale do Lapedo - Leiria), onde foi encontrada, em Novembro de 1998, uma sepultura de uma criança de cinco anos, atribuída ao Gravetense, e datada de há cerca de 25 mil anos (ZILHÃO \& TRIKAUS, 2002).

As ocupações humanas paleolíticas em grutas portuguesas apresentam características de permanências episódicas, nuns casos e prolongadas e recorrentes, noutros. Estas permanências prolongadas configuram uma correspondência com outros sítios arqueológicos de tipo residencial (CARDOSO, 2006b p. 22). As ocupações esporádicas, relacionadas com actividades cinegéticas ou de exploração de recursos geológicos, alternam com ocupações dessas grutas por espécies carnívoros (CARDOSO, 2006b p. 22), como a hiena, o urso ou o lobo.

As faunas encontradas nestas grutas e relacionadas com as ocupações humanas evidenciam uma economia de subsistência não especializada, com caça de presas de grande, médio e pequeno porte. De realçar, neste último caso, a caça do coelho, acompanhada, em especial na Gruta Nova da Columbeira, pela da tartaruga terrestre (CARDOSO, 2006b). Por seu lado, a pesca apenas se evidencia nas grutas costeiras, não sendo reconhecida nas grutas do interior, o que indica que as populações paleolíticas que ocupavam as grutas tinham uma área de exploração do território relativamente limitada (CARDOSO, 2006b).

\section{O Paleolítico Inferior em Portugal}

Como se viu atrás, os primeiros habitantes do território que hoje é Portugal ocuparam as antigas praias do Calabriano, que formaram vários terraços marinhos ao longo da costa portuguesa. Também no Vale do Tejo, em especial no estuário, foram encontrados alguns artefactos atribuídos a vários horizontes pré-acheulenses: clactono-abevilenses, abevilenses-clactonenses, abevilenses, abevilensesacheulenses e abevilenses-acheulenses antigos (BREUIL \& ZBYZSEWSKI, 1942). No entanto, as datações, a individualização e caracterização destes objectos levantam fortes reservas, pois não existem datações absolutas, a atribuição cronológica foi feita tendo por base estudos geomorfológicos e estratigráficos e os sítios apresentam poucos materiais (RAPOSO et al., 1993). 
Os materiais arqueológicos encontrados nestes terraços e dunas podem-se enquadrar numa tipologia pré-acheulense, e são caracterizados pela ausência de bifaces, um elevado número de seixos talhados e artefactos de reduzidas dimensões, que Breuil e Zbyszewiski denominaram fácies lusitãnica, distinguindo, para os artefactos de dimensões diminutas, um estilo microlusitânico (RIBEIRO, 1990). Estas indústrias mais antigas encontradas em Portugal apresentam outra característica: um número reduzido de levantamentos. Por esta razão e pelo facto de se encontrarem em locais de grande energia, como são os depósitos marinhos, a atribuição cronológica deve ser analisada com algumas reservas (RAPOSO, 2004).

A quase totalidade dos sítios do Paleolítico Inferior está ao ar livre, com a excepção da Gruta da Furninha e do Almonda. Os mais importantes situam-se no Vale do Tejo. Para além dos sítios do Vale do Tejo já referenciados, serão apresentados, em seguida, outros com artefactos do Paleolítco Inferior. Estão identificados machados, triédros, denticulados e bifaces, do Acheulense Antigo e Médio, em Monte Famaco (Vila Velha de Ródão); bifaces e machados de mão do Acheulense Superior, no Samouco (Alcochete) e em Cabeço da Mina e do Acheulense Médio e Final ("Micoquense"), foram encontrados bifaces lanceolados, bifaces micoquenses, machados, utensílios sobre lascas, raspador nucleiforme, sobre seixo e núcleos, em Milharós, no Vale do Forno, perto de Alpiarça (RAPOSO et al., 1993, CARDOSO, 2006 a e b).

Do Paleolítico Inferior português são também de destacar jazidas com fauna associada a indústrias, como a da Mealhada que se localiza a $12 \mathrm{~km}$ a norte Coimbra, descoberta ainda no século XIX, por Carlos Ribeiro e escavada por Nery Delgado (FIGUEIREDO \& SOUSA, 2003). Nesta jazida foram encontrados materiais auchalenses e mustierenses, associados a uma fauna de grandes mamíferos plistocénicos como o Hippopotamus amphibius, o Homotherium latidens e Elephas antiquus, alguns dos ossos encontrados apresentam modificações antrópicas, que os transformaram em artefactos (ZBYSZEWSKI, 1977).

No Almonda existem duas jazidas do Paleolítico Inferior: A Praia dos Bifaces, onde conjuntamente com uma indústria acheulense associada, foi encontrado um resto de Elephas antiquus (ZILHÃO et al., 1991, 1993) e a Galeria Pesada, onde foi encontrado material do Paleolítico Inferior com fauna associada. Esta jazida será desenvolvida no ponto 4.3, uma vez que está identificada a presença de aves na 
fauna aí encontrada (MARKS et al., 1999, 2000).

Para além destes sítios há que referir a ocorrência de materiais do Acheulense Antigo, semelhantes aos do Monte Famaco, no Vale do Liz descoberta, e a descoberta, desde os anos 20 do século passado, no litoral do Minho, vários materiais líticos acheulenses, desde Vila Praia de Âncora até Carreço (RIBEIRO, 1990).

\section{O Paleolítico Médio em Portugal}

O Paleolítico Médio em Portugal aparece do rio Mondego para sul e podem distinguir-se cinco áreas de concentração: O Maciço Calcário, a norte do Bombarral, e a Arrábida, o Vale do Tejo, a Zona de Lisboa e arredores (incluindo o concelho de Loures), o Algarve e o Alentejo. Nesta última incluem-se o Escoural e o Alqueva. No Paleolítico Médio já se encontram muitos sítios em grutas, um pouco menos de metade do total de jazidas conhecidas.

Existem, em Portugal, várias jazidas do Paleolítico Médio com datações absolutas verificando-se que, tendo em consideração apenas estas jazidas, este período tem uma distribuição temporal entre os cerca de 81 900, em Santo Antão do Tojal, e os cerca de 26 400, na Gruta Nova da Columbeira (CARDOSO, 2006 b, tabela 1).

Os sítios de Lisboa foram descobertos ainda no século XIX e os primeiros a serem identificados localizam-se em Monsanto, onde se encontraram materiais de sílex, talhados nos nódulos que aparecem nos calcários do Cretácico da zona (CARDOSO, 2006b). Nos anos 30 e nos 40 do século XX foram encontrados inúmeros sítios não só em Lisboa, mas também nos concelhos limítrofes, como Oeiras e Loures. Em 1932, Afonso do Paço tinha localizado no mapa da zona de Lisboa 94 sítios do Paleolítico. Das estações da zona de Lisboa, há que referir a do Esteiro da Princesa, em Santo Antão do Tojal - Loures, situada num terraço, a cerca de oito metros de altitude, foram descobertos materiais líticos do Paleolítico Médio conjuntamente com restos de Elephas antiquus (FIGUEIREDO \& SOUSA, 2003) e datada pelo método das séries de urânio em 81900 + 4 000, - 3800 BP, SMU - 305 (RAPOSO, 1995) (anexo V).

Segundo Henry Breuil e Georges Zbyszewski (BREUIL \& ZBYSZEWSKI, 1943, 1945), algumas das grutas da Estremadura constituem-se como representantes de 
uma fácies mustierense bem definida no contexto do Paleolítico Médio de Portugal, ao passo que outras grutas apresentam uma indústria mustierense de características duvidosas.

A Gruta da Furninha (Peniche), a Gruta Nova da Columbeira (Bombarral), A Gruta do Correio Mor (Loures), A Gruta das Salemas (Loures), A Gruta da Ponte da Lage (Oeiras) e a Lapa do Suão (Bombarral), entre outras, têm faunas associadas ao horizonte arqueológico, com a presença comum da hiena, do lobo, do cavalo, do veado, de bovídeos, do rinoceronte, do urso, do javali, da raposa, do lince, da pantera (RAPOSO, 1983). Pode-se também considerar a Gruta da Figueira-Brava (Setúbal), Pego do Diabo (Loures), Oliveira (Almonda - Torres Novas), Caldeirão (Tomar) e Escoural (Évora) como fazendo parte de um conjunto mustierense mais vasto (RAPOSO, 1993, 1998).

Pela abundância dos materiais arqueológicos encontrados, algumas das jazidas de ar livre parecem indicar ocupações intensivas, de tipo residencial, favorecidas pela abundância de matérias-primas disponíveis nas proximidades. São exemplo as estações de Lisboa e da margem esquerda do Estuário do Tejo (CARDOSO, 2006b), bem como outras estações do Vale do Tejo, como a Ponte da Ribeira da Pedra (Vila Nova da Barquinha) ou a Foz do Enxarrique (Vila Velha de Ródão).

Os primeiros achados do Paleolítico no Algarve remontam à década de quarenta do século XX, com alguns trabalhos desenvolvidos particularmente por $\mathrm{G}$. Zbyszewski e A. Viana. Recentemente está a ser desenvolvido, por Nuno Bicho, um programa de investigação da zona oeste algarvia, do qual resultou a descoberta de alguns novos sítios, com materiais líticos, mas sem fauna, tais como Lagoa Funda, Lagoa do Bordal, Praia da Galé, e a Gruta de Ibn Amar (CARDOSO, 2006b).

\section{O Paleolítico Superior em Portugal}

Os primeiros trabalhos sobre o Paleolítico Superior em Portugal remontam ao século XIX, com os trabalhos de Nery Delgado, mas foi sobretudo durante o século $X X$ que o estudo deste período se desenvolveu com as contribuições de $\mathrm{H}$. Breuil e $\mathrm{G}$. Zbyszewski, J. Roche, O. V. Ferreira, J. L. Cardoso e J. Zilhão. (CORCHÓN, 2008). É também de destacar o grande incremento da investigação do Paleolítico Superior, 
nas décadas de 30 e de 40, de Manuel Heleno, enquanto Director do Museu Nacional de Arqueologia.

Em Portugal não existem indústrias de transição, dos inícios do Paleolítico Superior (o Castelperronense, entre os 35000 a 29000 BP) e são raros os locais no nosso território onde se comprova a sucessão das primeiras indústrias do Paleolítico Superior. A datação mais antiga do Paleolítico Superior, para o território português, é de 28000 BP, na Gruta do Pego do Diabo (ZILHÃO, 1997), correspondendo portanto ao Aurignacense (anexo V).

Até aos finais da década de oitenta, a ocupação humana no Paleolítico Superior em Portugal era conhecida sobretudo em grutas e abrigos da Estremadura, entre o Tejo e o Mondego (CORCHÓN, 2008), com algumas excepções, como a ocupação da Gruta do Escoural, que se localiza no Alentejo. Apesar de se continuar a verificar uma grande concentração de jazidas do paleolítico Superior na Estremadura, nos anos noventa, a descoberta de sítios arqueológicos e da arte rupestre na zona do Côa, e com o acompanhamento da construção da Barragem do Alqueva, a distribuição das jazidas deste período alarga-se no território português.

A concentração da ocupação do Paleolítico Superior na Estremadura, a norte de Lisboa, explica-se pelas condições mais propícias que esta área teria, durante o último período glaciar. Estas condições seriam a posição latitudinal favorável, dimensão adequada, uma considerável diversidade regional e grande variedade de matérias-primas (RAPOSO, 1993). Destas Jazidas da Estremadura pode-se destacar a Gruta do Pego do Diabo, já referida, a Gruta das Salemas, a Gruta do Caldeirão, a Lapa do Anecrial, a Casa da Moura, as grutas do Almonda, a Lapa do Suão, a Lapa do Picareiro, entre outras. Existem também alguns locais de ar livre, como Vale de Porcos I e II e Vale Comprido (ZILHÃO, 1997). Fora da zona da Estremadura há que destacar as estações arqueológicas da Gruta do Escoural e do Vale do Côa, que se destacam pela presença de arte rupestre.

O Vale do Côa alberga o principal conjunto de gravuras zoomorficas paleolíticas ao ar livre da Península Ibérica, agrupadas em extensos painéis de quinze estações arqueológicas (Foz Côa, Moinhos de Cima, Vale de Moinhos, Meijapão, Canada do Inferno, Rego da Vide, Canada do Amendoal, Vale de Videiro, Vale de Figueira, Fariseu, Ribeira de Piscos, Quinta da Barca, Penascosa e Faia). A estas estações somam-se outras jazidas também com arte paleolítica (gravuras): Alto 
Sabor, Ribeira da Sardinha, Mazouco, Ocreza e Molino Manzánez, no Guadiana (CORCHÓN, 2008). O único sítio conhecido com pinturas e com arte em gruta é o Escoural (RAPOSO, 1993). Até ao momento não se conhece a representação de aves na arte paleolítica portuguesa.

No Algarve conhece-se um sítio do Paleolítico, Vale Boi, encontrado no decorrer do projecto dirigido por Nuno Bicho e referido no ponto anterior sobre o Paleolítico Médio. Pela análise da distribuição dos sítios do Paleolítico Superior em Portugal verifica-se uma concentração de sítios de habitat principalmente no litoral e sítios com arte rupestre no interior, sobretudo ao ar livre, nos vales de rios.

Algumas destas estações do Paleolítico Médio e Superior português serão mais desenvolvidas do ponto de vista arqueológico, geológico e paleontológico, pois algumas foram objecto de estudo específico deste trabalho, por terem restos de aves. 


\section{2 - CARACTERIZAÇÃo ARQUEOLÓGICA DAS JAZIDAS ESTUDADAS}

\subsection{1 - Gruta da Columbeira}

No Vale Roto existem outras cavidades no maciço calcário jurássico com ocupação humana pré-histórica. Muito próximo da Gruta Nova situa-se a Lapa do Suão, descoberta por Carlos Ribeiro, no ano de 1880, também com presença de fauna, mas sem notícias da presença de avifauna. Nos inícios do século passado foram exploradas outras cavidades com ocupação pré-histórica: a Gruta do Palheiro, a Lapa Larga e a Caverna do Caixão. No entanto, de todas estas estações arqueológicas só a Gruta Nova da Columbeira possui restos de avifauna plistocénica.

Como foi referido, as escavações foram dirigidas por V. Ferreira e por G. Zbyszewski, nas décadas de 60 e 70. Ali foram encontradas uma importante indústria mustierense e uma colecção faunística de grande valor. A investigação arqueológica desta gruta começou com a triagem dos entulhos oriundos da limpeza da actual entrada, que, como também já foi referido, se situa na extremidade oposta da entrada primitiva da gruta. Nesses entulhos foram encontrados dentes de rinoceronte.

A Gruta Nova da Columbeira tem uma importância relevante na história da arqueologia portuguesa, em especial da arqueologia do Paleolítico, pois foi aqui que pela primeira vez se descobriu, em Portugal, um conjunto mustierense, em estratigrafia, com materiais de quartzo, quartzito e sílex de bom recorte tipológico, associado a uma abundante fauna plistocénica (CARDOSO, 1993, p.78).

Como se pode ver atrás na descrição das camadas, as primeiras três são desprovidas de vestígios de ocupação humana. Segundo Veiga Ferreira (FERREIRA, 1984), a camada oito corresponde à mais importante fase da ocupação humana desta gruta. "Abundantes restos carbonosos ali identificados teriam resultado de combustões de longa duração" (CARDOSO, RAPOSO \& FERREIRA, 2002). A camada oito e a camada sete são as que apresentam um maior número de artefactos humanos: 2433, na primeira, e 1880, na segunda (Raposo \& Cardoso 1997 e 1998).

Segundo João Luís Cardoso (CARDOSO, 1993, p. 78), existem, para além de níveis do Paleolítico Médio, níveis do Paleolítico Superior, apontando as datações 
efectuadas, para uma ocupação mais intensa durante o Paleolítico Médio. Estas datações, feitas pelo método de radiocarbono, foram obtidas sobre as recolhas efectuadas em 1971 e deram os seguintes resultados: Gif 2703 (nv. 16) 26400 +/- 750 BP; Gif 2704 (nv. 20) 28900 +/- 950 BP (CARDOSO, RAPOSO \& FERREIRA, 2002, p. 45) (anexo V).

A presença humana aparece alternada com a presença de carnívoros. Como foi referido atrás, a camada oito e a camada sete foram as que maiores quantidades de vestígios humanos forneceram. No que respeita à fauna, estas camadas deram uma enorme quantidade de restos de herbívoros, certamente relacionados com a actividade de caça dos homens de Neandertal que lá viveram, e apenas se verificou a ocorrência de um fragmento de um rádio direito de lobo (C.8) e três restos ósseos de hiena (C.7) (CARDOSO, RAPOSO e FERREIRA, 2002., p. 39) Em contrapartida, a camada seis apenas tinha 677 artefactos, mas uma abundante presença de hienas, quer somatofósseis, quer icnofósseis (coprólitos), o que sugere o estabelecimento de um covil destes animais (CARDOSO, RAPOSO e FERREIRA, 2002, p. 40), aquando da formação desta camada.
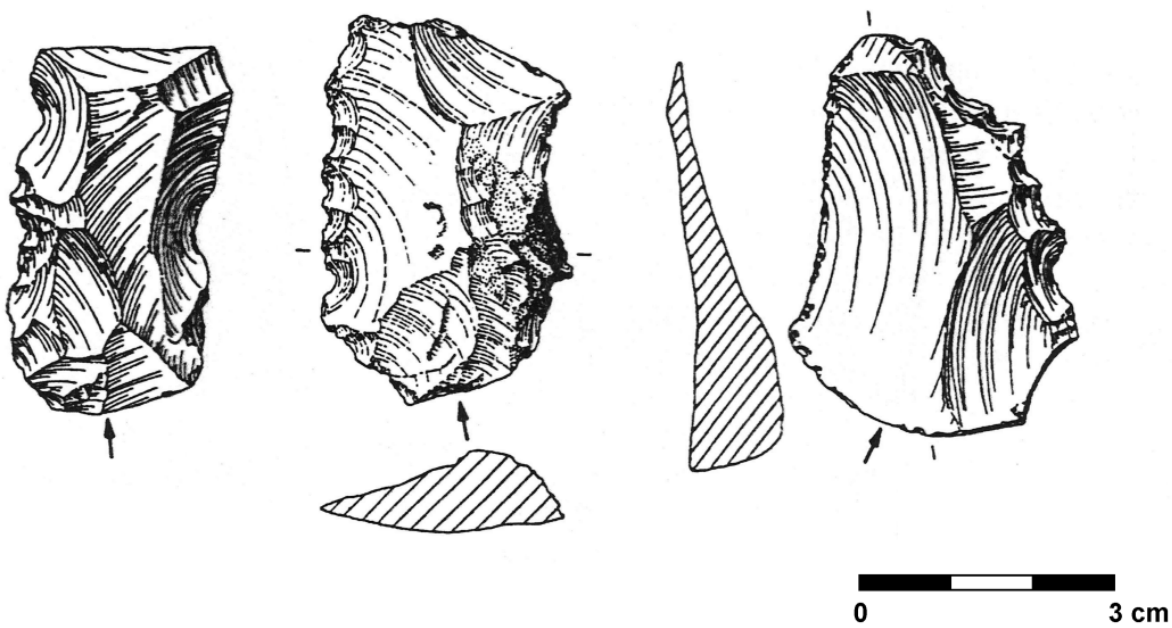

Fig. 64 - Denticulados do Paleolítico Médio da Gruta Nova da Columbeira, segundo RAPOSO \& CARDOSO, 1998

\subsection{2 - Gruta da Furninha}

A Gruta da Furninha apresenta uma ocupação humana paleolítica e outra neolítica. A primeira apareceu registada nos níveis ossíferos da segunda unidade 
estratigráfica; a segunda foi encontrada no nível superior, de terras negras remexidas. Esta ocupação neolítica forneceu uma quantidade considerável de ossos humanos (DELGADO, 1884). Foram também referidos materiais da Idade do Ferro (ZILHÃO, 1997). Na presente caracterização arqueológica, importa desenvolver a ocupação paleolítica, porque é contemporânea dos restos de aves agora estudadas e porque a ocupação neolítica não se enquadra na temática desta tese.

Apesar de a ocupação humana paleolítica da Gruta da Furninha não ter sido muito intensa, mesmo assim foi recuperada cerca de uma centena de artefactos do paleolítico, repartidos pelos sete níveis ossíferos da unidade 2, com excepção do nível 4, onde não se encontraram artefactos que documentassem a presença humana.

\begin{tabular}{crc} 
Nível ossifero & Profundidade & Artefactos \\
\hline \hline 1.9 & 9 a $9,30 \mathrm{~m}$ & 5 \\
2.9 & 7,80 a $8,80 \mathrm{~m}$ & 1 \\
3.9 & 6 a $7,50 \mathrm{~m}$ & 70 \\
4.9 & $5,5 \mathrm{~m}$ & 0 \\
5.9 & 4 a $5 \mathrm{~m}$ & 4 \\
6.9 & 3 a $3,20 \mathrm{~m}$ & 10 \\
7.9 & $1,5 \mathrm{~m}$ & 16 \\
\hline \hline Total & & 106
\end{tabular}

Quadro 8 - Quantidade total de artefactos paleolíticos recuperados na Gruta da Furninha e a respectiva distribuição nos níveis ossíferos (segundo BREUIL \& ZBYSZEWSKI, 1945).

Breuil e Zbyszsewski (1945) consideram que a ocupação humana da gruta ocorreu no Acheulense Superior, a que atribuem um único achado: um biface. Do Solutrense, foram recuperadas 40 peças, e ao Mustierense foram atribuídos a maioria dos materiais líticos (65). Breuil e Zbyszewski defendem esta atribuição pelas observações geomorfológicas que, segundo estes investigadores, são atribuíveis ao Würm Antigo (RAPOSO, 1995, p. 58). 


\begin{tabular}{lcc}
\multicolumn{1}{c}{ Período } & Artefactos & $\%$ \\
\hline \hline Acheulense Superior & 1 & 6,25 \\
Mustierense & 65 & 61,32 \\
Solutrense & 40 & 32,43
\end{tabular}

Quadro 9 Distribuição cronológica dos artefactos recuperados do complexo 2 da Gruta da Furninha (segundo BREUIL e ZBYSZEWSKI, 1945).

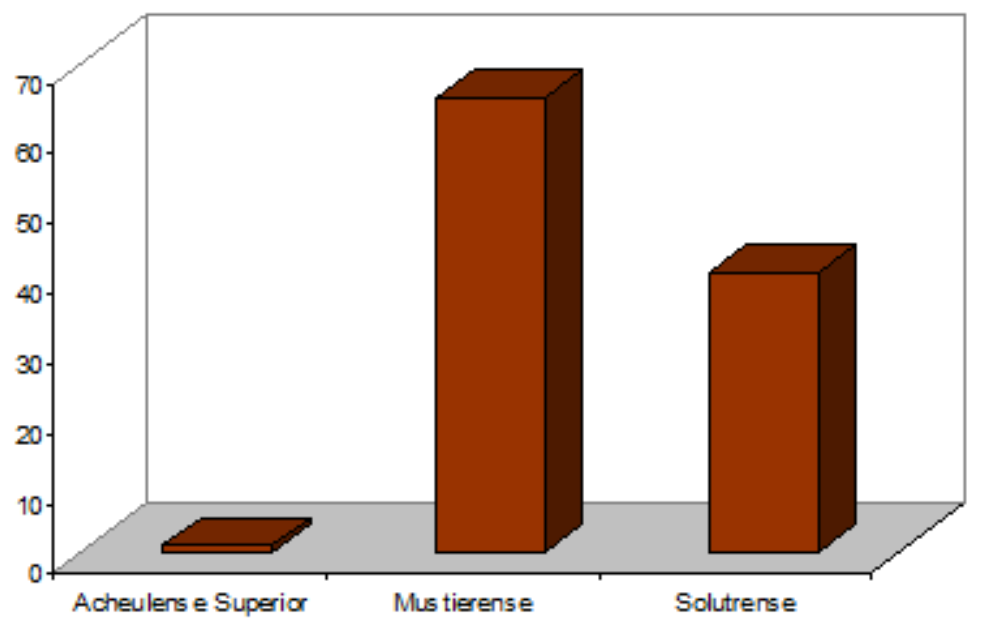

Gráfico 2 - Distribuição cronológica dos artefactos recuperados do complexo 2 da Gruta da Furninha (segundo BREUIL e ZBYSZEWSKI, 1945).
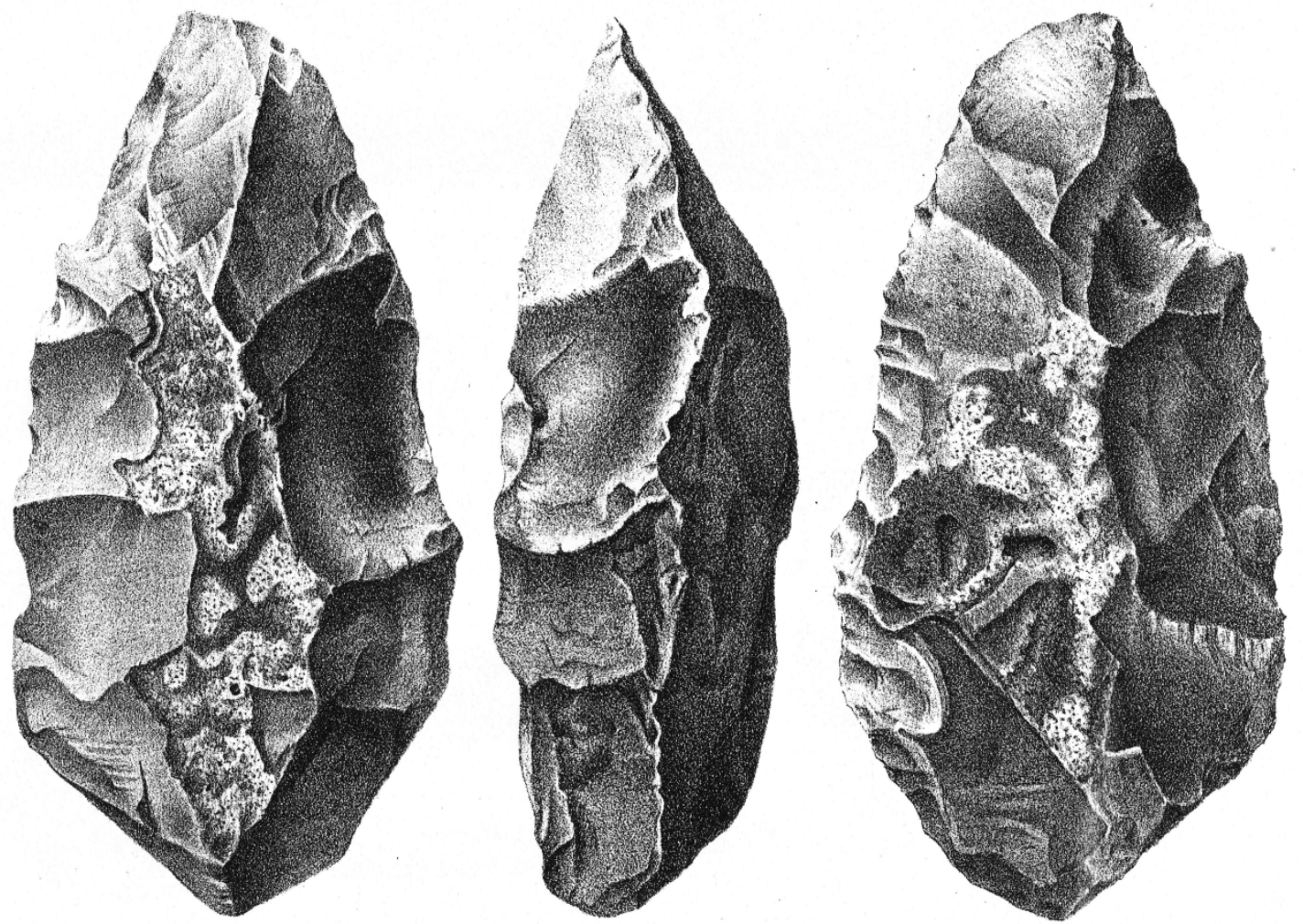

Fig. 65 - Biface acheulense da Gruta da Furninha, in DELGADO, 1884. 
Mais tarde, aquando da sua investigação de doutoramento, João Zilhão analisou os materiais que Breuil e Zbyszewski atribuíram ao Solutrense e concluiu que destes 40 artefactos, só dois apresentavam uma tipologia distintamente do Paleolítico Superior; as restantes deveriam ser de cronologia posterior, alguns de tipologia claramente neolítica (ZILHÃO, 1997, p. 590).

\begin{tabular}{lcc}
\multicolumn{1}{c}{ Período } & Artefactos & $\%$ \\
\hline \hline Acheulense Superior & 1 & 6,25 \\
Mustierense & 65 & 61,32 \\
Solutrense & 2 & 12,5 \\
Pós-Paleolítico & 38 & 19,93
\end{tabular}

Quadro 10 - Distribuição cronológica dos artefactos recuperados do complexo 2 da Gruta da Furninha (segundo ZILHÃO, 1997).

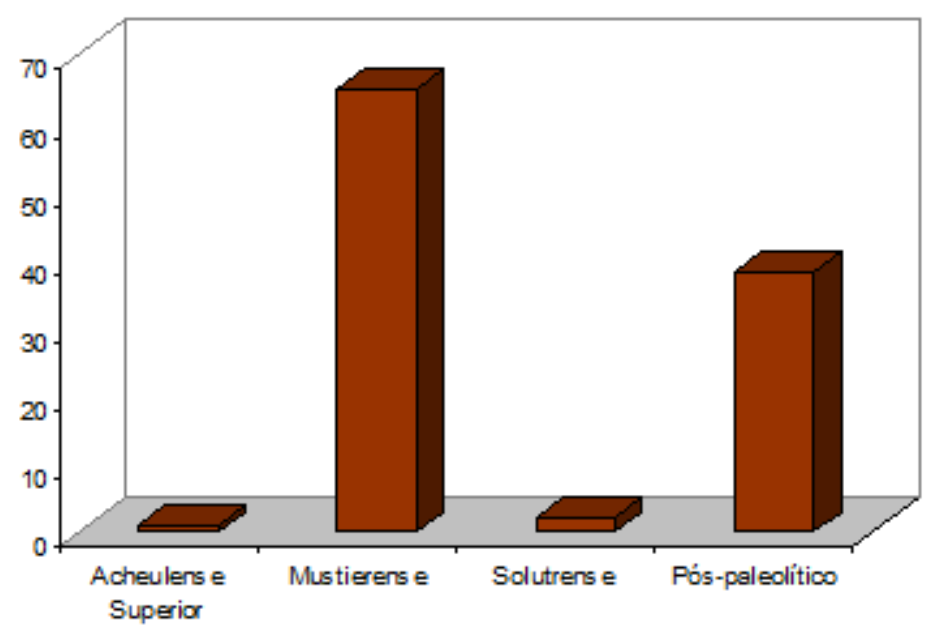

Gráfico 3 - Distribuição cronológica dos artefactos recuperados do complexo 2 da Gruta da Furninha (segundo ZILHÃO, 1997).

Foi também encontrado, nos níveis paleolíticos, um fragmento de mandíbula humana, de um indivíduo jovem, a 6 metros de profundidade, correspondentes ao 3. nível ossífero (DELGADO, 1884, p. 237). 

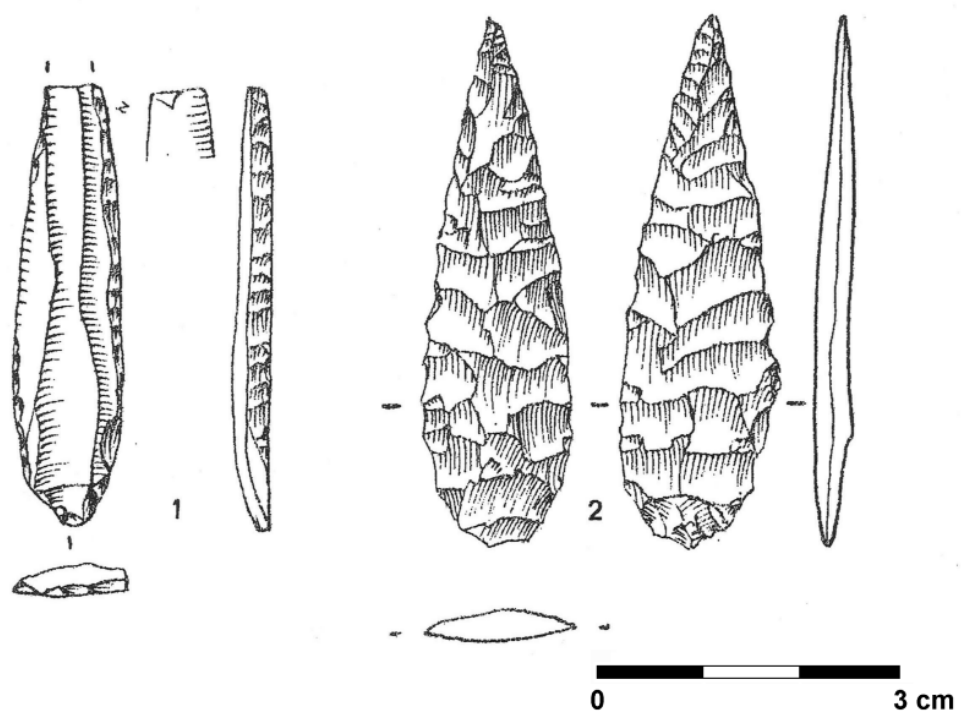

Fig. 66 - Ponta gravetense (esq.) e folha de loureiro (dir.) da Gruta da Furninha, segundo ZILHÃO, 1997

\subsection{3 - Gruta das Salemas}

A Gruta das Salemas foi ocupada no Paleolítico Médio e usada como abrigo temporário, durante o Paleolítico Superior, e como necrópole, mais tarde, já no Neolítico. O Paleolítico Médio, associado à camada 8, está representado por uma indústria misturada, pouco típica (ROCHE et al., 1962; ZBYSZEWSKI et al., 1980/81). O Paleolítico Superior, associado às camadas 4 a 7 (camadas 4, 5 e 6 com indústrias atribuídas ao Solutrense e a camada 7 com materiais atribuídos ao Perigordense), apresenta indústrias onde dominam as lamelas e as pontas de zagaia (ROCHE et al., 1962). Os materiais arqueológicos identificados na Gruta das Salemas são escassos (RAPOSO, 1995, p.61), verificando-se um maior número de artefactos de sílex. Foram também encontradas grandes quantidades de cinza. Estes dados permitem concluir que esta gruta terá servido de abrigo a caçadores durante o Paleolítico (CARDOSO, 1993, p. 529).

Identificaram-se quatro níveis arqueológicos, que foram descritos da seguinte forma:

"N. 4 - Camada negra, com cerca de 1,00 m de espessura média, correspondendo a um nível neolítico bem marcado;

N. 3 - Nível de terra acinzentada escura correspondendo ao Solutrense 
Superior, com a espessura média de $0.30 \mathrm{~m}$;

N. 2 - Nível de terra castanho-avermelhada com indústrias do Perigordense, com 0.50 m de espessura média;

N. 1 - Nível de terra rossa com indústrias do paleolítico Médio e com fauna quaternária". (FERREIRA, 1964)

Foi identificada a presença de uma ponta solutrense, entre os materiais do terceiro nível, atribuindo-o assim ao Solutrense (ROCHE et al., 1962). Esta atribuição é contestada por João Zilhão (ZILHÃO, 1997, pp.88-90), que defende a atribuição a períodos pré-solutrenses para este nível, sendo que a presença de alguns materiais solutrenses no nível três se deverá a questões tafonómicas. João Zilhão defende também que a maioria dos materiais atribuídos por Roche (ROCHE et al. 1962) ao Perigordense deve ser atribuída ao Paleolítico Superior inicial, ao Aurinhacense e ao Gravetense (ZILHÃO, 1997, p. 475).

Do Paleolítico Superior estão referidos três fragmentos de lamelas retocadas (dois mesiais e um proximal), atribuídos ao Aurignacense (ZILHÃO, 1997, p. 91), por comparação com peças tipologicamente idênticas da vizinha Gruta do Pego do Diabo, com datações que apontam para esse período (ZILHÃO, 1997). Estão também publicadas cinco zagaias desta estação atribuídas ao Solutrense (CARDOSO e GOMES, 1994). 

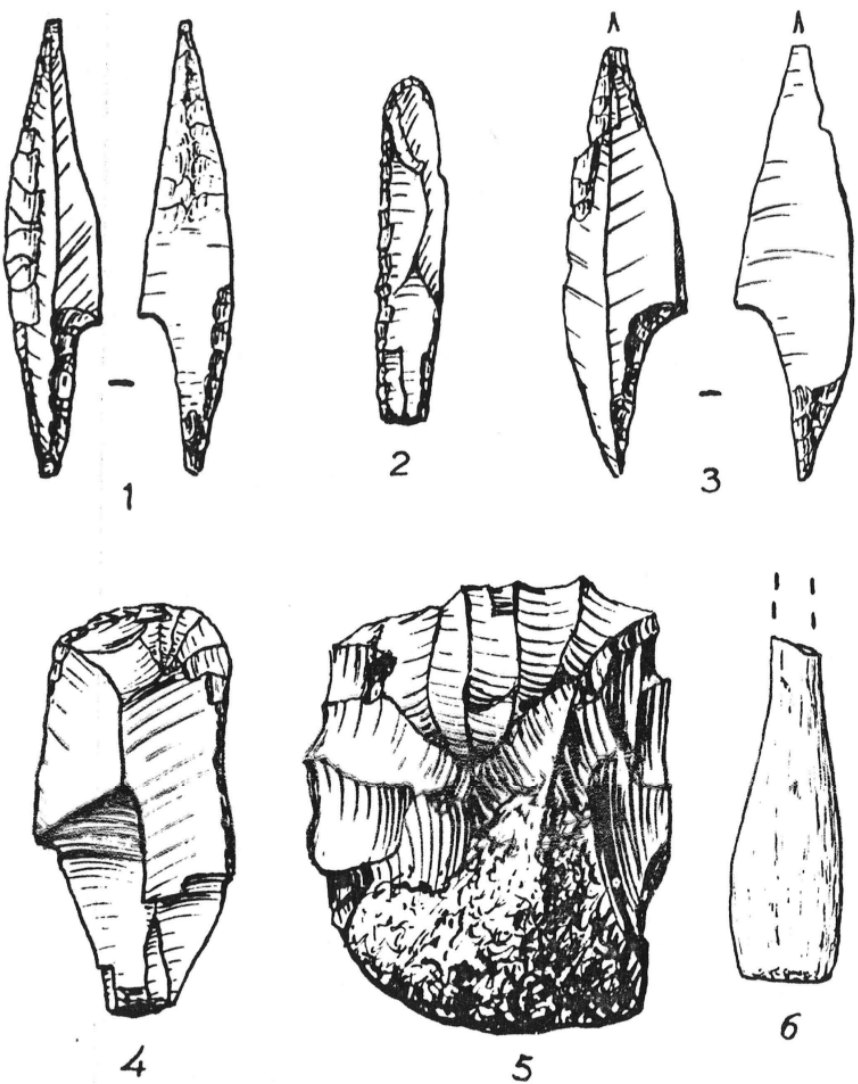

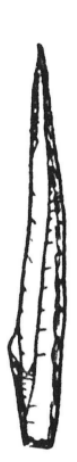

7

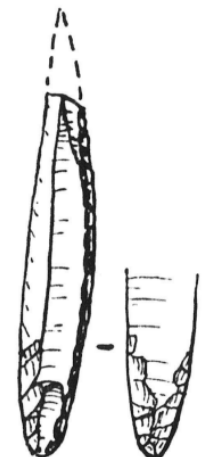

8

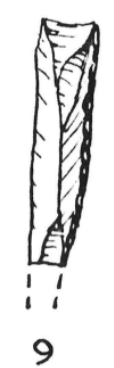

9

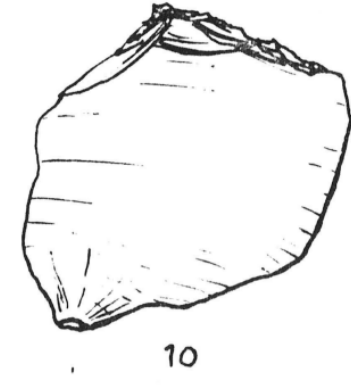

$\mathbf{0}$

Fig. 67 - Reprodução da figura n. ${ }^{\circ}$, in ROCHE et al. 1962, onde estão representados, segundo os autores, materiais solutrenses da gruta.

\subsection{4 - Gruta do Pego do Diabo}

Os primeiros trabalhos na Gruta do Pego do Diabo datam das décadas de 60 e 70 do século XX. Foram realizadas por desconhecidos e os resultados não foram publicados. Em 1976, o GEPP fez uma intervenção de limpeza da vala de uma 
sondagem realizada nos referidos trabalhos das décadas de 1960-70. Esta intervenção foi divulgada em 1979 (ZILHÃO, 1988). Na década de 80 (1988-89) foram levadas a cabo escavações arqueológicas nesta gruta, dirigidas por João Zilhão.

A Gruta do Pego do Diabo teve uma ocupação humana no Paleolítico Médio e no Paleolítico Superior (Aurignacense) (ZILHÃO, 1997). Foram feitas várias datações nesta jazida. Uma delas, já referida, foi efectuada sobre carvões intrusivos da camada A. Entretanto fizeram-se mais três datações sobre restos de fauna plistocénica. Os Obtiveram-se os seguintes resultados: duas datações feitas à macrofauna dos quadrados M11 e L11 (ICEN-490 23 080 \pm 490 e ICEN-732 28 120+860/-780), uma datação a restos de coelho e à macrofauna dos quadrados M13 e M14 (ICEN-491 18 630 \pm 640 ) (ZILHÃO, 1997, p. 94, 95). Como se viu, estas datações apontam para uma ocupação humana do Paleolítico Superior (Aurinhacense, Gravetense e Solutrense).
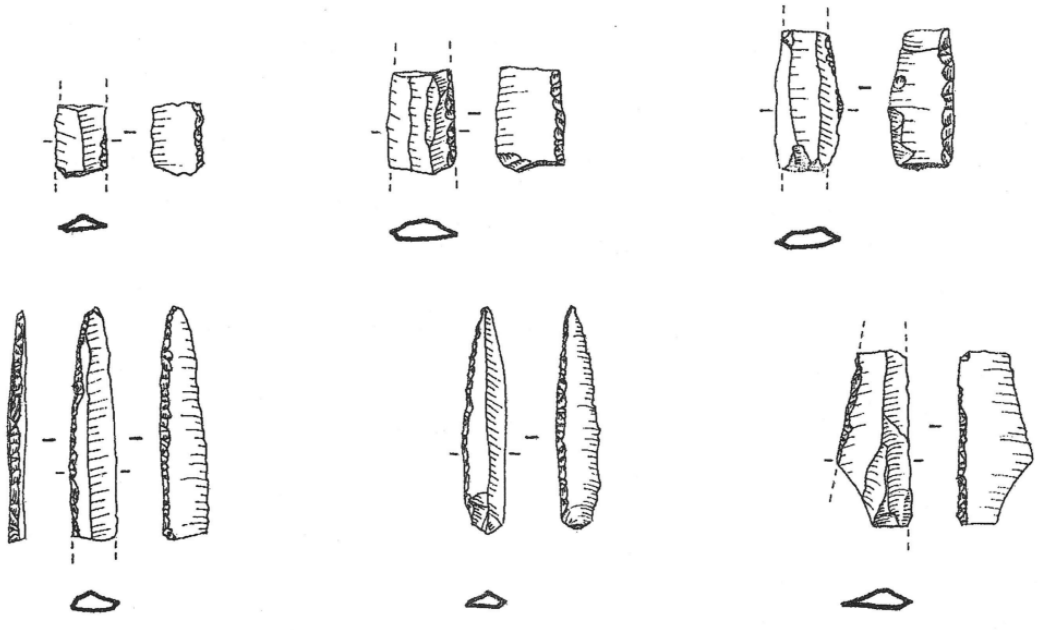

0

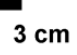

Fig. 68 - Materiais aurignacenses da Gruta do Pego do Diabo, segundo ZILHÃO, 1997.

\subsection{5 - Gruta das Fontainhas}

A ocupação humana do Paleolítico nas Fontainhas é muito residual; apenas foram encontradas algumas lascas atípicas de sílex e de quartzito. Existem também alguns materiais pós-paleolíticos, constituídos por algumas peças líticas e cerâmicas (CARDOSO, 1993). 


\subsection{6 - Gruta da Casa da Moura}

A Gruta da Casa da Moura apresenta uma ocupação humana holocénica (Neolítico e Calcolítico) muito rica, com uma indústria abundante e alguns restos de ossos humanos (DELGADO, 1867). Delgado identificou uma ocupação humana que parecia ter sido esporádica e muito antiga, provavelmente plistocénica, com condições climáticas diferentes das actuais (DELGADO, 1867). Nery Delgado identificou então os materiais paleolíticos, mas não os soube datar com precisão, uma vez que foi no ano da publicação da monografia de Delgado acerca da Casa da Moura que H. de Ferry e G. de Mortillet definiram o Solutrense. Foi já na década de 1960 que Camarate França, Jean Roche e Veiga Ferreira identificaram e atribuíram a este período alguns materiais líticos da Casa da Moura (CAMARATE FRANÇA et al., 1961)

Assim, da ocupação paleolítica desta gruta apenas existem vestígios do Paleolítico Superior, precisamente do Gravetense (ZILHÃO, 1997), Solutrense (CAMARATE FRANÇA, et al., 1961, ZILHÃO, 1997) e Magdalenense (ROCHE, 1951). No entanto, no que diz respeito à ocupação magdalenense, defendida por Roche, João Zilhão, na revisão que fez dos materiais desta gruta para a sua tese de doutoramento, conclui que os materiais considerados como magdalenses, são, na realidade, do Neolítico ou do Calcolítico (ZILHÃO, 1997, p. 185).

Pela pouca quantidade de materiais arqueológico encontrados e pela abundância de carnívoros, sobretudo do lobo, a frequência dos grupos humanos terá sido esporádica e alternava com a ocupação da gruta pelos lobos ou outros carnívoros (CARDOSO \& GOMES, 1994, p.12) 

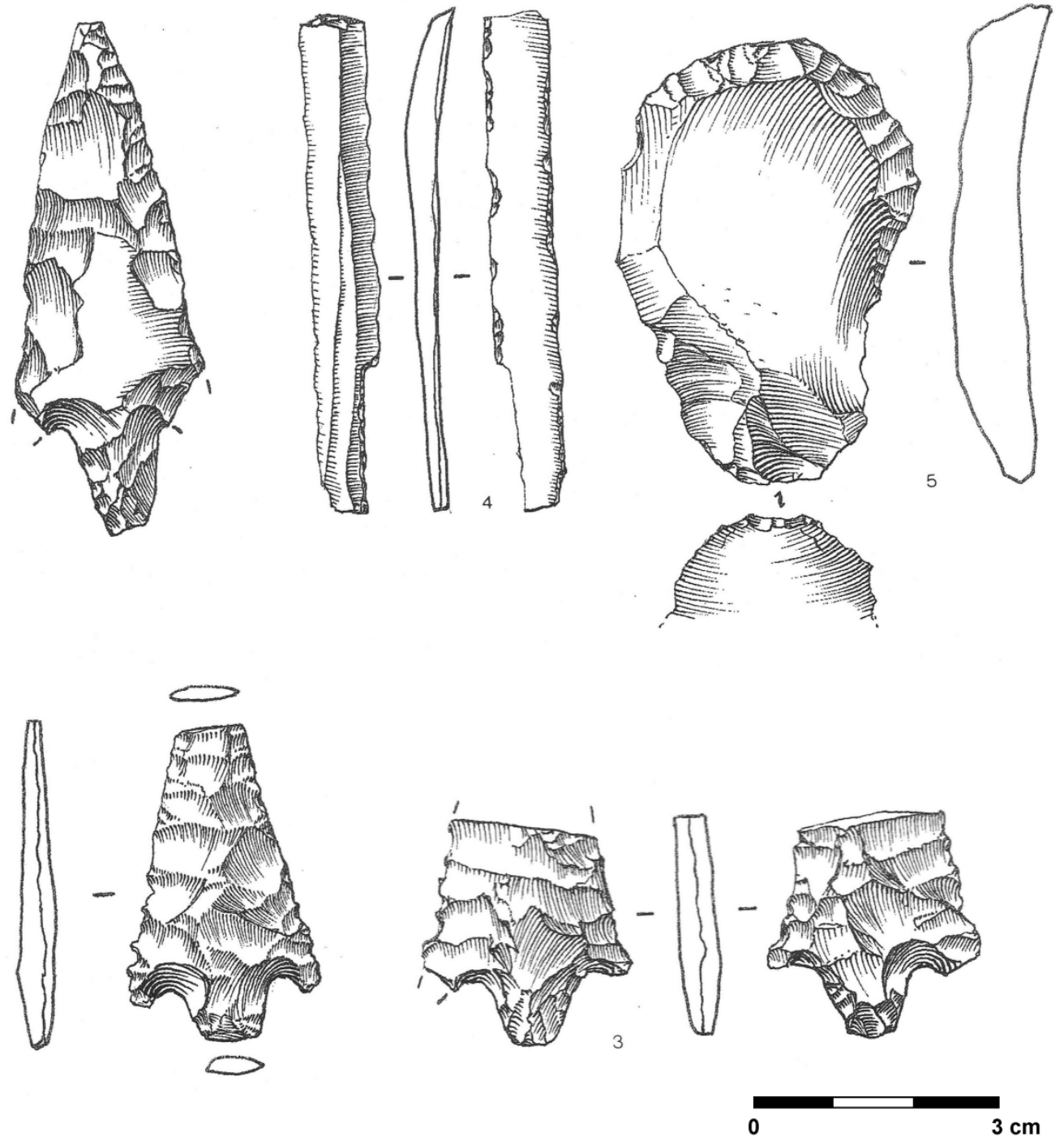

Fig. 69 - Materiais solutrenses da Gruta da Casa da Moura, segundo ZILHÃO, 1997

\subsection{7 - Lapa da Rainha}

Nos bordos superiores do vale das Termas do Vimeiro encontram-se, para além da Lapa da Rainha, mais duas grutas com ocupações humanas: a Gruta da Pedra do Sino, de interesse espeleológico, mas pouco relevante do ponto de vista arqueológico, e a Gruta do Sapateiro, onde Nery Delgado, em 1879, recolheu alguns materiais da Idade do Bronze (ALMEIDA et al.li, 1970).

A Lapa da Rainha, aberta no topo dos calcários da crista do lado este do vale, foi objecto de explorações clandestinas, em especial na sala e no corredor. Como resultado destas explorações foram deixados abandonados alguns restos de animais 
do Plistocénico (dentes), entretanto recolhidos por Leonel Trindade.

O primeiro a realizar trabalhos de investigação nesta jazida terá sido Manuel Heleno (SAAVEDRA, 1964, pp. 149), que foi o segundo director do actual Museu Nacional de Arqueologia. Estes trabalhos resultaram na recolha de alguns materiais de sílex e de um dente de hiena, depositados naquele Museu. Porém, não existe notícia dos respectivos resultados. Leonel Trindade também lá efectuou investigações, tendo recolhido alguns dentes de animais nos despojos de anteriores escavações (ALMEIDA et al., 1970).

As duas campanhas arqueológicas realizadas nesta gruta (1968 e 1969) permitiram conhecer a estratigrafia e recuperar um importante conjunto de faunas, bem como artefactos líticos, estruturas de lareiras e fundos de habitações (ALMEIDA et al. 1970).

Apesar das datações absolutas apontarem para o final do Aurinhacense e Solutrense (25 $580+1820$ / - 1490 e $20300 \pm 330$ BP) (CARDOSO, 1993; CARDOSO \& GOMES, 1994), a indústria foi atribuída ao fim do Mustierense e princípios do Aurinhacense (ALMEIDA et al., 1970). No entanto, estas datações e o reduzido conjunto de artefactos não permitem estabelecer, de forma segura, o horizonte cultural da ocupação humana da Lapa da Rainha. Sobre esta questão, Veiga Ferreira (FERREIRA, 1975, p.20) e, mais tarde, G. Zbyszewiski, M. Leitão, C. Penalva e Veiga Ferreira (ZBYSZEWISKI et al., 1980/1981, p. 14) defenderam uma atribuição ao Paleolítico Superior, provavelmente ao Aurinhacense. Mais tarde, João Zilhão e Anthony Marks realizaram uma sondagem no local, da qual resultou a descoberta de uma ponta de face plana típica, conotada com o Solutrense (ZILHÃO, 1987). Esta sondagem de João Zilhão e as opiniões de Veiga Ferreira e Zbyszwiski, atrás referidas, vêm de acordo com as datações absolutas publicadas por João Luís Cardoso.

Pela quantidade de restos osteológicos humanos (foram identificados três dentes incisivos inferiores de adulto e a parte distal de um úmero), e pela quantidade de materiais arqueológicos, pode concluir-se que a ocupação antrópica terá sido fugaz ou passageira. 

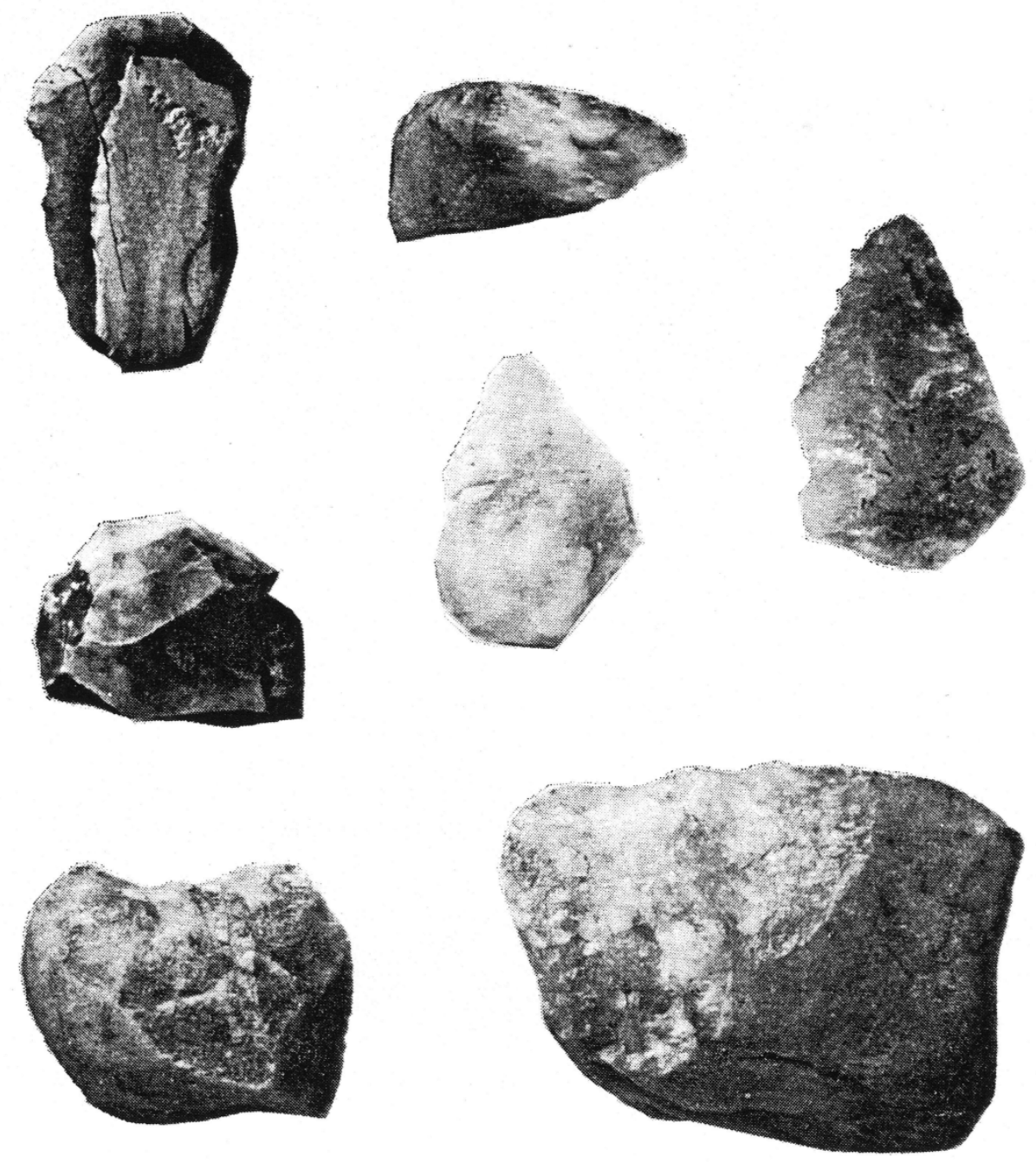

Fig. 70 - Materiais paleolíticos da Lapa da Rainha, in ALMEIDA et al. , 1970 (nota: os autores não colocaram escala na imagem).

\subsection{8 - Gruta do Caldeirão}

Os trabalhos dirigidos na Gruta do Caldeirão por João Zilhão e realizados entre 1979 e 1988, revelaram várias ocupações humanas da Pré-História antiga e recente. Ali foram identificados níveis arqueológicos do Paleolítico Médio (Mustierense) e do Paleolítico Superior (Solutrense e Magdalenense) e do Neolítico. A par dos materiais arqueológicos foi também encontrada uma fauna diversificada, como já foi referido na caracterização paleontológica.

Os primeiros trabalhos, realizados numa pequena plataforma exterior, situada na entrada da gruta, revelaram depósitos muito pobres arqueologicamente, tendo os trabalhos sido concentrados nas zonas interiores da cavidade (ZILHÃO, 1997, vol. II, p. 
109). Como foi referido na contextualização geológica, foram definidos três blocos sedimentares do Plistocénico Superior e do Holocénico. A sequência do Plistocénico foi datada por radiocarbono, através de 13 datações a ossos de Oryctolagus, Capra e Cervus. Estas datações deram resultados entre os $27600,+/-600$ e os $10700+/-380$ (ZILHÃO, 1997, vol. II, quadro 9.1, p. 113), portanto do final do Mustierense e do Paleolítico Superior.

A matéria-prima da indústria encontrada é constituída por sílex, quartzo, cristal de rocha e quartzito. Em todas as camadas domina o quartzito sobre todas as outras matérias-primas (ZILHÃO, 1997, vol. II, figura 9.5, p. 112).

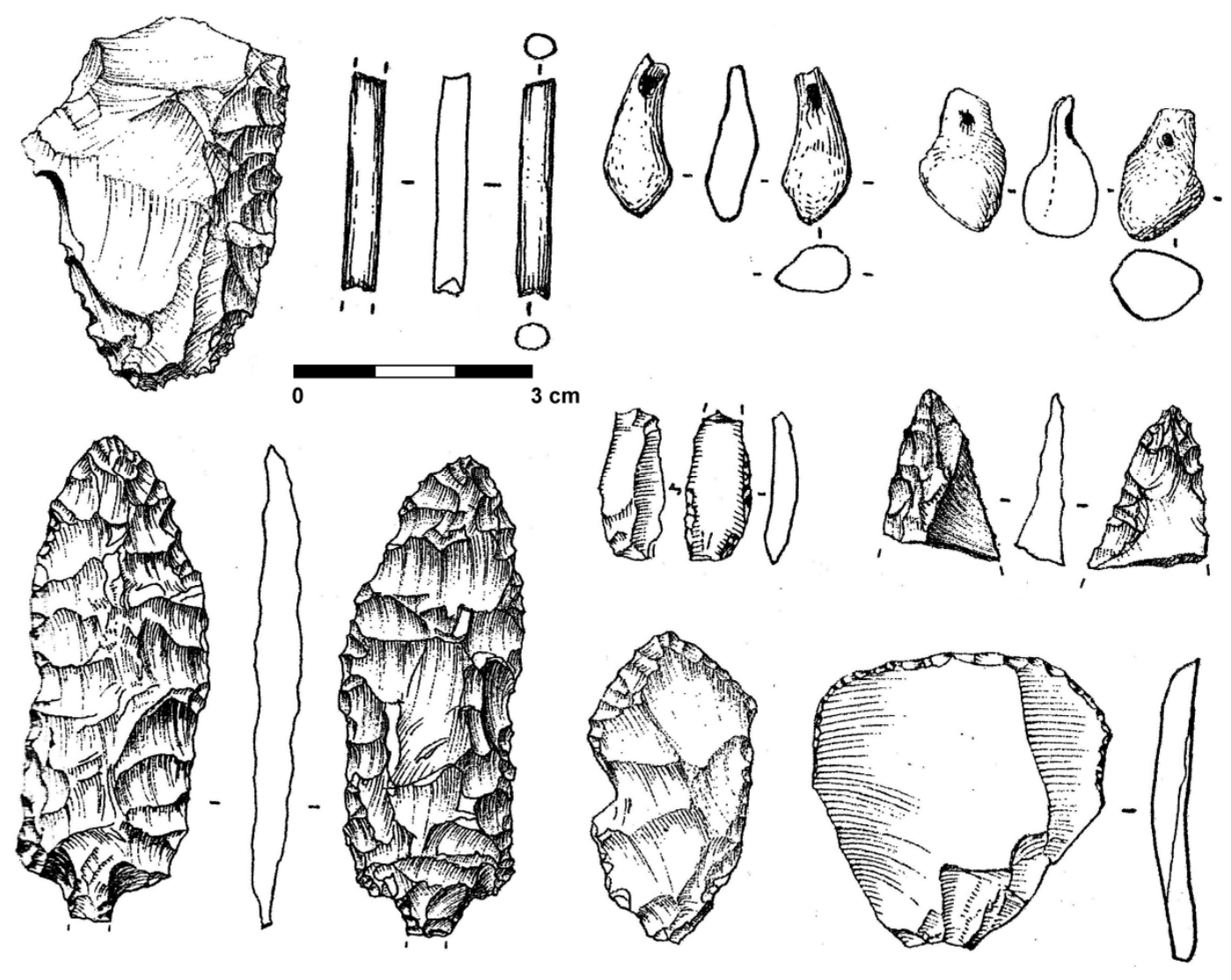

Fig. 71 - Artefactos líticos e osso,e adornos feitos de dentes caninos de veados da Gruta do Caldeirão, segundo ZILHÃO, 1997. 


\section{4 - Caracterização Arqueológica, Geológica, Paleontológica e}

Paleoornitológica das Jazidas com avifauna plistocénica publicadas

\section{1 - Gruta do Caldeirão}

Apesar de a Gruta do Caldeirão se enquadrar nas jazidas com a avifauna já publicada, o facto de terem sido estudados alguns restos inéditos desta gruta para a presente tese, levou a enquadrar esta jazida no grupo das estudadas, pelo que a caracterização arqueológica e paleontológica já foram feitas nos pontos anteriores. Por seu lado, a caracterização paleornitológica será apresentada na terceira parte "Resultados e Discussão", em conjunto com as outras jazidas estudadas.

\section{2 - Gruta da Figueira-Brava}

A Gruta da Figueira-Brava situa-se em plena Serra da Arrábida, na encosta meridional, a ocidente da estação romana do Creiro e a cerca de 700 metros a leste do Portinho da Arrábida, entre esta povoação e Alpertuche. Administrativamente pertence à Freguesia de S. Lourenço, Concelho e Distrito de Setúbal e as seguintes coordenadas geográficas desta estação arqueológica são: latitude: 38²8'23" norte e longitude 859'42" a oeste de Greenwich (RAPOSO \& CARDOSO, 1999).

Até à descoberta deste sítio, pouco se conhecia acerca da ocupação humana do paleolítico desta zona; apenas se conheciam poucos materiais líticos e faunísticos, provenientes da Lapa de Santa Margarida, também localizada perto do Portinho da Arrábida.

As primeiras referências a este local datam do ano de 1945, por G. Zbyszewski e H. Breuil. A entrada situa-se a cerca de cinco metros do nível do mar e comunica com um corredor largo, de paredes irregulares, que dá acesso a uma grande sala. Foi nesta galeria, preenchida quase na sua totalidade por depósitos plistocénicos, que foram escavados após as primeiras recolhas de fauna, em 1985, se realizaram, entre 1987 e 1990, seis campanhas arqueológicas dirigidas por Telles Antunes e João L. 
Cardoso. (FIGUEIREDO \& SOUSA, 2003, p. 9)

Como se disse, a Gruta da Figueira-Brava localiza-se no flanco sul da cadeia montanhosa da Arrábida, razão pela qual é importante fazer um pequeno enquadramento geológico desta serra. Assim, esta serra é constituída principalmente por calcários, arenitos e margas mesozóicas e cenozóicas (ZBYSZEWSKI, et al.li, 1966).

A Arrábida adquiriu as suas características estruturais durante o Miocénico, por acção das forças tectónicas, que dobraram as camadas depositadas em planos horizontais. Tem uma falha geológica denominada "Falha da Arrábida" à qual está associada a estrutura tectónica do Monoclinal do Espichel (ZBYSZEWSKI, et al.li, 1966). A deformação deu-se no Miocénico, em dois episódios compressivos principais, ocorridos no Burdigaliano (21.8 a $16.6 \mathrm{Ma}$ ) e no Tortoniano Superior (8 a 6.5 Ma), sendo a serra dominada por acidentes cavalgantes com direcção ENE-WSW e rampas laterais, com movimento esquerdo, orientadas N-S e NNE-S.

A formação da Gruta da Figueira-brava resulta de três factores geológicos: a natureza carbonatada das rochas onde a gruta se abre, a ocorrência de uma intensa actividade cársica na zona onde se situa a gruta e por se situar numa vasta plataforma de abrasão marinho, em épocas em que o nível do mar era superior ao actual. Aquela gruta situa-se em arribas escavadas pelo mar, constituídas por rochas carbonatadas detríticas, datadas do Miocénico. A estratigrafia é constituída por areias ricas de restos de conchas e ossos trazidos pelo homem, conglomerados do Terreniano III e brechas muito compactas, com calcite. As areias, com indústria mustierense associada, foram datadas de há 30 a 31 mil anos (14C e Séries U). A par da presença de objectos líticos, foi encontrado um variado conjunto faunístico e ainda uma falange e um dente de Homem de Neandertal, (ANTUNES \& CARDOSO, 1992). Durante a campanha de 1988 foi encontrado um fragmento de lamela de proboscídeo, pertencente a um dente definitivo. (FIGUEIREDO \& SOUSA, 2003, p. 9)

A estratigrafia é constituída por areias ricas de restos de conchas e ossos de origem antrópica, conglomerados do Tirreniano III e brechas muito compactas, com calcite :

“C.1-Camada contendo fragmentos de ânforas romanas, e vestígios faunísticos de idade holocénica $(0,15 \mathrm{~m})$;

C.2 - Areias de cor castanho-clara por vezes consolidadas, contendo indústria lítica Mustierense, existe alguma mistura de sedimentos com 


\section{C.1 $( \pm 0,80 m)$;}

C.3 - Areias castanhas a negras, com raros vestígios faunistícos e indústria lítica Mustierense, vestígios de estruturas de fogo $(0,25 \mathrm{~m})$;

C.4 - Areias com variados tons de castanho $(0,10 \mathrm{~m})$;

C.5 - Conglomerado marinho que cobre o substrato Miocénico Tirreniano III (0,20m)." (Antunes \& Cardoso, 2000).

Foram datadas as conchas de Pattela da camada C.2 (Mustierense Tardio) por 14C, obtendo-se os seguintes resultados: ICEN 387 - $30930 \pm 700$ BP e ICEN $386-30$ $050 \pm 550$ BP. Foram também datados os dentes de Cervus elaphus da camada C.2 por séries de urânio, que forneceram uma datação compatível com as de 14C : SMU232 - 30 561+11 759-10 725; SMU-233 - 44 806+15 889-13 959 (ANTUNES \& CARDOSO, 2000).

Apenas existem vestígios da ocupação humana pré-histórica da Gruta da Figueira-Brava do Paleolítico Médio. Desta ocupação tem destaque a presença de restos ósseos: um metacarpo e uma falange e um dente (segundo pré-molar) de Homo neanderthalensis, este último encontrado na camada 2 (ANTUNES, 1990/91; ANTUNES \& CARDOSO, 2000). O conjunto de materiais líticos mustierenses encontrava-se afectado por remeximentos posteriores, datados da época romana (RAPOSO, 1995).

Apesar de se verificarem remeximentos devidos a causas geológicas e biológicas (acção de carnívoros, répteis e pequenos mamíferos), as indústrias líticas são globalmente homogéneas (RAPOSO \& CARDOSO 1993) O conjunto destas indústrias é muito abundante e integrado num conceito amplo do Mustierense, sendo constituído por uma indústria sobre lasca (RAPOSO, 1995). A matéria-prima ali utilizada é proveniente das proximidades da gruta (domina o quartzo e o quartizito, mas também há a presença de sílex e jaspe). Os materiais encontrados na gruta, de origem mais distante, sofreram uma pré-formatação, enquanto os materiais da zona foram explorados em bruto (CARDOSO \& RAPOSO, 1993).

Foi também observada a existência de dois finos leitos basais, constituídos por cinzas e restos carbonatados, o que indica a prática do fogo no interior da gruta. A presença de calhaus com rubefacção vem reforçar esta evidência. No exterior foram observados outros leitos equivalentes a estes e com idêntica posição estratigráfica (RAPOSO \& CARDOSO, 1993). 
A Gruta da Figueira-Brava apresenta um importante conjunto faunístico constituído por invertebrados marinhos, répteis e anfíbios, aves e mamíferos (incluindo mamíferos marinhos). (ANTUNES \& CARDOSO, 1992, 2000). Foram identificadas 18 espécies de grandes mamíferos, 19 de pequenos mamíferos, 32 de aves e 8 de répteis (CARDOSO, 1993; ANTUNES (ed.), 2000). Dos grandes mamíferos domina o Cervus elaphus, com 43\%. do total dos ossos identificados, Bos primigenius (28\%) e Capra pyrenaica (22\%). Foram também reconhecidos vários carnivoros, dos quais se destaca a Crocuta crocuta spelaea (9\%) e a Panthera pardas (3\%). Também estão referenciados Pantera spelaea, Felis sylvestris, Canis lupus e Vulpes vulpes, todos estes com menos de $1 \%$.

Na campanha de 1988 foi recolhido um fragmento de lamela de proboscídeo, pertencente a um dente definitivo. Este dente caracteriza-se por ter o esmalte fino, plissado e pregueado. Esta característica levou os autores do estudo a classificá-lo, com algumas reservas, como Mammuthus primigenius, uma vez que esta espécie tem o esmalte dos dentes com um pregueado mais fino do que o do Elephas antiquus (Cardoso e Antunes, 1989). As medidas efectuadas são iguais às da lamela da Mealhada e ligeiramente inferiores às do dente do Carregado. Este fragmento de lamela encontra-se depositado no Centro de Estratigrafia e Paleobiologia da Universidade Nova de Lisboa (Campus do Monte da Caparica). Este achado é importante porque é dos poucos (só se conhece mais um) restos atribuídos a mamute, encontrados em Portugal. Trata-se de uma atribuição discutível, pois a presença destes animais em Portugal não está comprovada.

Em termos da avifauna, foram identificadas 29 espécies, por M. Telles Antunes e C. Mourer-Chauviré (ANTUNES \& MOURER-CHAUVIRÉ, 2000, pp. 129-162), distribuídas por 11 ordens. Verifica-se uma influência dos ambientes marinhos na Gruta da Figueira-Brava, que se explica pela posição geográfica da gruta, com grande influência do estuário do Sado e com a serra da Arrábida a fazer de barreira às influências continentais. A influência marinha e de climas mais frios que os actuais está patente nesta gruta, com a presença de Pinguinus impennis (ANTUNES \& MOURER-CHAUVIRÉ, 2000).

A avifauna aqui identificada apresenta algumas características semelhantes à da Gruta da Furninha. Apesar de estarem as duas grutas localizadas junto da costa, verifica-se uma maior influência dos ambientes marinhos na Gruta da Figueira-Brava, 
dominam as aves que vivem na zona marinha costeira e em zonas de rocha, o que poderá estar relacionado com a posição geográfica desta jazida.

Dos restos osteológicos de aves ali encontrados dominam os ossos do esqueleto apendicular (os membros), não tendo sido encontrados vestígios do esqueleto cefálico. As espécies identificadas por Telles Antunes e Cécile MourerChauviré indicam climas característicos do litoral, uma vez que apresentam uma percentagem maior de espécies que habitam as zonas de litoral. Verifica-se uma predominância de aves que vivem na zona marinha costeira e em zonas de rochas. Mais uma vez se verifica a influência da Arrábida no ambiente desta zona.
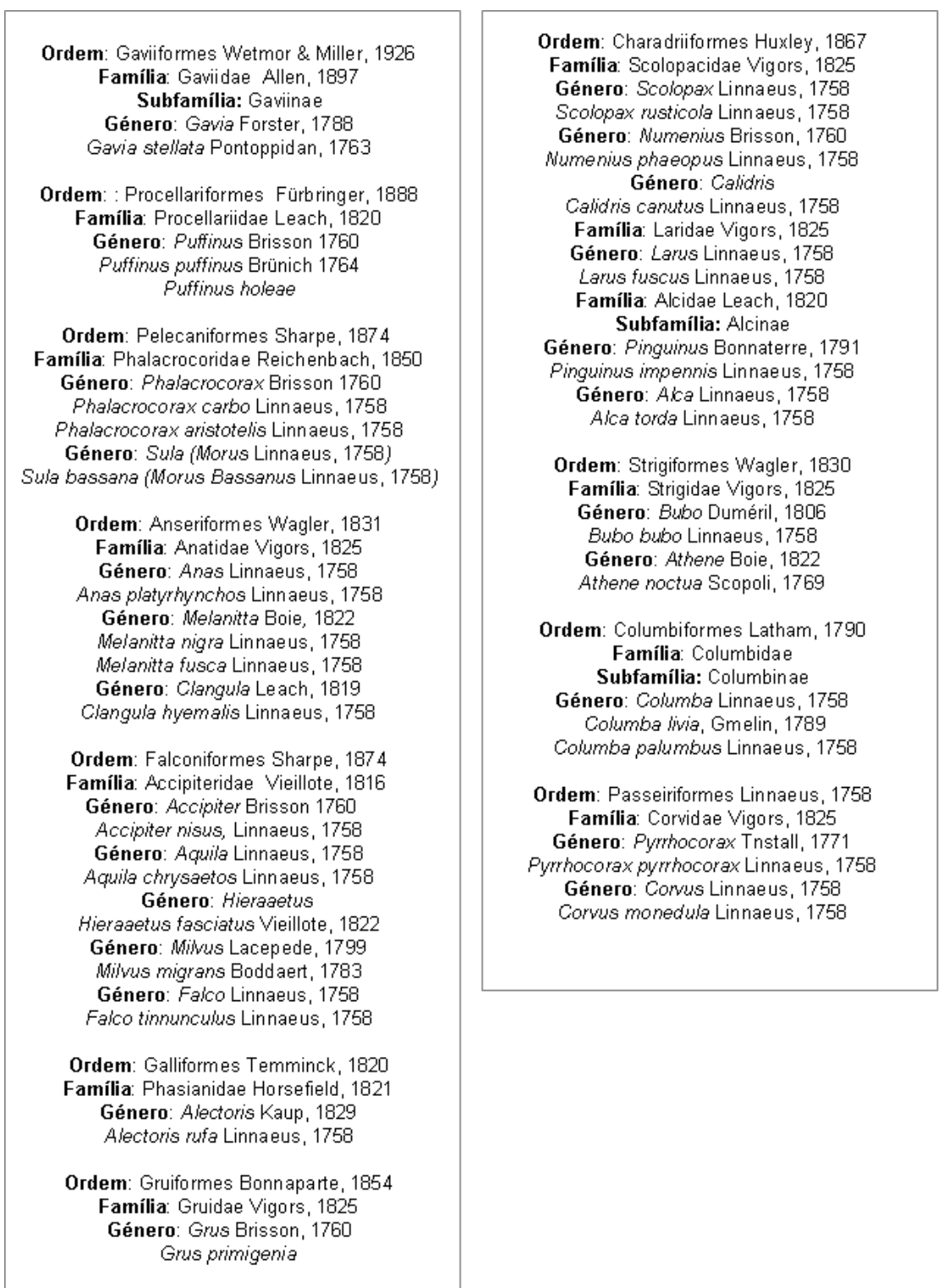

Quadro 11 - Sistemática paleontológica das aves da Gruta da Figueira-Brava (Segundo 
ANTUNES \& MOURER-CHAUVIRÉ, 2000)

\section{3 - Grutas do Almonda}

O sistema cársico do Almonda situa-se dentro do Parque Natural da Serra d'Aire, no lugar de Casais Martanes, nas freguesias de Pedrógão e Zibreira, concelho de Torres Novas e distrito de Santarém. Encontra-se a uma altitude de cerca de 80 metros e as coordenadas geográficas são: 39. 30' 23" Norte 8. $36^{\prime}$ e 49" Oeste de Greenwich (ZILHÃO, 1997). Está situado na parte distal do sinclinal da crista sudeste da serra de Aire.

Este sistema é constituído por uma rede de galerias subterrâneas que se prolongam por cerca de $8 \mathrm{~km}$. Algumas destas já estão formadas enquanto outras ainda se encontram em formação.

O nome deste conjunto de grutas deve-se ao facto de nela nascer o rio Almonda, cujo caudal elevado levou à construção de bastantes moinhos nos finais do século XIX. Actualmente, esta nascente abastece duas fábricas de papel e foram as obras de construção da barragem, para canalizar as águas para estas fábricas, que puseram a descoberto a entrada da Gruta do Almonda.

O Sistema Cársico do Almonda foi classificado como imóvel de interesse público, em 1993. Os objectos arqueológicos e restos faunísticos estão actualmente depositados no Museu Nacional de Arqueologia e na sede do Grupo de Espeleologia e Arqueologia de Torres Novas. No Almonda está identificado um conjunto de cavidades que têm ocupação humana entre os 300 mil anos e o período romano. Podem-se referir oito cavidades.

Na Galeria Pesada, explorada entre 1997 e 2002, foram encontrados restos de fauna, indústria lítica e dentes humanos. As datações apontam para 240 mil anos BP (anexo V).

Como próprio nome indica, a Galeria dos Ursos, com as mesmas datações da anterior, foram encontrados indícios de que indicam que esta gruta terá servido de abrigo a ursos, encontraram-se marcas de garras nas paredes e ninhos de hibernação no solo.

A Galeria da Fauna, ainda não estudada, apresenta muitos vestígios 
faunísticos, que lhe deram o nome.

$\mathrm{Na}$ Galeria de Maio, encontraram-se dentes de equídeos e materiais líticos atribuídos ao Mustierense e datados de cerca de 30000 BP, portanto dos últimos tempos da ocupação dos Neandertais em Portugal.

A Brecha dos Ursos é a entrada de uma cavidade abatida e colmatada por terras, ainda por explorar.

Na Gruta da Oliveira, uma das mais importantes, foram recuperados restos humanos e faunísticos e abundante indústria lítica mustierense. Foi ocupada entre os 70 e os 30 mil anos. Está a ser investigada desde 1991. Apesar de ainda não estudados, existem alguns restos de aves na Gruta da Oliveira, junto dos restos ósseos dos outros grupos de vertebrados (Jean-Philipe Burgal, comunicação pessoal). Para além destes restos de aves descobertos junto da macrofauna, foram também observados, conjuntamente com a microfauna, alguns restos de passeriformes. Tratando-se de uma importante estação arqueológica, espera-se que num futuro próximo alguém possa estudar as aves desta jazida, uma vez que o actual estudo sobre a fauna se limita aos mamíferos.

A Lapa dos Coelhos, com ocupação do Paleolítico Superior, forneceu objectos de adorno e indústrias líticas e de osso. As datações apontam para os 20 a 10 mil anos BP. Encontra-se em escavação desde 1997.

Finalmente, a Galeria da Cisterna foi utilizada como abrigo temporário. $\mathrm{O}$ material arqueológico encontrado e as datações efectuadas apontam ocupações durante vários períodos: Os vestígios mais importantes são do Paleolítico Superior (20 - 18 e 12 - 11 mil anos BP) e do Neolítico, em que serviu de necrópole; também possui vestígios da Idade do Cobre, da Idade do Bronze, da Idade do Ferro e da época romana, quando também serviu de necrópole.

A par desta ocupação humana foi encontrada, nestas grutas, uma grande quantidade de fauna constituída por carnívoros como o Lynx, Ursus, Canis e Vulpes, mas também macacos, cervídeos, equídeos, caprídeos, rinocerontes, auroques, coelhos e tartarugas. Foram também encontrados vestígios de vegetação que permitem a reconstituição da paisagem durante o Plistocénico Médio e o Superior.

Destas grutas foram também encontrados alguns vestígios ósseos de Neandertais; destes, destacam-se os mais antigos que se conhecem em Portugal. Trata-se de dois dentes de Neandertal encontrados na Galeria Pesada", datados de 
cerca 240000 BP.

De todas estas grutas, só na Galeria Pesada é que a avifauna se encontra estudada e publicada juntamente com a restante fauna de vertebrados (MARKS et al., 2000, 2002).

A Galeria Pesada foi identificada em 1991 pela equipe de João Zilhão, e as escavações arqueológicas começaram em 1997. Estas inicialmente consistiram na remoção de cerca de 123 metros quadrados de brecha e blocos de calcário, o que permitiu a escavação da entrada da cavidade (MARKS et al., 2000, 2002).

A escavação identificou vários níveis geológicos, que continham fauna e uma indústria lítica homogénea, constituída por alguns bifaces, uns tipicamente acheulenses outros pequenos e assimétricos e outros fracturados, e ainda por utensílios unifaciais (TRINKAUS et al., 2003, p. 220).

No que respeita à fauna, esta é abundante e constituída por um registo fragmentado de macromamíferos, como Macaca sylvanus, Stephanorhinus hemitoechus, Equus aff. mosbachensis, Cervus elaphus, Dama clactoniana, Ovis antiqua, cf. Hemitragus sp., Ursus arctos, Canis etruscus-mosbachensis e Cuon priscus. (TRINKAUS et al., 2003, p 220). A fauna apresenta-se como um elemento importante, porque algumas destas espécies foram referidas em Portugal pela primeira vez (TRINKAUS et al., 2003). Datações absolutas efectuadas a dentes estimam a idade destes materiais em $241+30-22$ mil anos BP (TRINKAUS et al., 2003).

Nesta cavidade foram também encontrados ossos de aves. O registo, fragmentado, permitiu identificar cerca de duas dezenas de táxones, os quais permitem explicar a presença de aves por dois factores: algumas viviam nas escarpas próximas da gruta e outras viveram na entrada (MARKS et al., 2002 - b, p.18). Como alguns dos táxones identificados são de aves de rapina, é provável que tivessem trazido para a gruta outras como presas, bem como partes de aves relativamente grandes que tivessem morrido nas proximidades. É também provável que os outros carnívoros e o próprio homem tivessem contribuído para a acumulação de aves nesta cavidade (MARKS et al., 2002 - b, p.18).

Foram então identificadas por Marks (MARKS et al. 2002 - a e b), entre outros, os seguintes táxones ainda vivos: antídeos (Anas sp, Cygnus cf. Olor e Cf. Mergus albellus), Ciconia sp, Columbiformes (Columba palumbus e Columba livia / oenas), rapinas nocturnas (Athene noctua, Bubo bubo), aves de rapina (Buteo buteo, Falco sp) e 
corvídeos (Pica pica, Pyrrhocorax graculus, Corvus monedula, Corvus corone / frugilegus) e perdizes (Alectoris sp). No caso do Cygnus olor, do Mergus albellus e do Pyrrhocorax graculus, são espécies ainda existentes, mas que já não aparecem em Portugal. Foi também identificada, com reservas, uma espécies já extinta: o Corvus antecorax, antepassado do corvo actual.

\section{4 - Abrigo do Lagar Velho - Lapedo}

O Abrigo do Lagar Velho, identificado como jazida pré-histórica em finais de Novembro de 1998, situa-se no vale do Lapedo, perto de Leiria (39. ${ }^{\circ} 5^{\prime} 25^{\prime \prime} \mathrm{N}$; $\left.8 .{ }^{\circ} 43^{\prime} 58^{\prime \prime} \mathrm{O}\right)$. O vale do Lapedo é uma garganta com cerca de $2 \mathrm{~km}$ de comprimento e 90 metros de profundidade escavada pela ribeira da Caranguejeira. $\mathrm{O}$ abrigo localizase na margem esquerda desta ribeira, junto à saída do canhão (ZILHÃO e ALMEIDA, 2002, pp. 29-30). Em termos geológicos, este vale é constituído por calcários do Cretácico Superior e encontra-se na Orla Mesozóica Ocidental ou Lusitânica.

O vale do Lapedo situa-se no limite setentrional do Maciço Calcário Estremenho, cuja composição é, principalmente, carbonatada. A composição deste Maciço Calcário e a sua situação geologicoestrutural proporcionaram a acção de processos de dissolução, levando ao desenvolvimento de cavidades de origem cársica (PEREIRA e ALMEIDA, 2005, p. 208). Segundo a Notícia Explicativa da Carta Geológica de Leiria, na Escala de 1:50 $000^{39}$, o Vale do Lapedo encontra-se numa formação datada do Turoniano e que é constituída por camadas bem estratificadas, de calcário e calcário margoso, por vezes fossilíferos e com uma espessura que varia entre um e vários metros.

No sítio arqueológico, sobre os afloramentos de base calcários, foram observados depósitos de vertente e aluviais de arenitos e areias e identificados vários complexos estratigráficos: bs (lowest slop deposit); al (alluvial); tc (transitional complex - este complexo corresponde a uma descontinuidade); ms (middle slope desposit); Is (lower slope deposit); us (upper slope deposit) e ts (top soil) (ZILHÃO e ALMEIDA, 2202, p. 30-37).

O vale do Lapedo forma uma ampla curva e a ribeira da Caranguejeira está

39 TEIXEIRA, C. \& ZBYSZEWSKI, G., 1968 Carta geológica de Portugal na escala 1/50 000.Notícia explicativa da folha 23-C, Leiria. Lisboa: Serviços Geológicos de Portugal. 
orientada a SSE-NNW e apresenta-se assimétrica, com a vertente esquerda curta e íngreme e a direita mais comprida e suave. O vale pode ser dividido em três sectores diferenciados. O primeiro, o superior, está orientado ENE-WSW; no sector mediano, a ribeira corre para SSW, o canhão atinge a sua largura mínima - aproximadamente $100 \mathrm{~m}$. No último troço, o inferior, o vale orienta-se E-W e as paredes calcárias decrescem gradualmente de altura até à desembocadura da garganta, localizada aproximadamente a $80 \mathrm{~m}$. Esta configuração topográfica é dominada por factores geológicos e, ao mesmo tempo, pela evolução morfodinâmica, ou seja, pelo embutimento, mais ou menos gradual, de um antigo meandro, sucessivamente limitado na sua expansão lateral pela presença das paredes calcárias. Sendo assim, o vale do Lapedo pode ser interpretado como um amplo meandro encaixado (PEREIRA e ALMEIDA, 2005, p.208). Virgínia Telles defende, na sua tese de mestrado, em 1992, que o encaixe do curso de água que deu origem ao vale actual se iniciou a partir de um período tardio do Cenozóico, já no Plistocénico, no Calabriano (PEREIRA e ALMEIDA, 2005, p. 208).

Esta jazida ficou conhecida internacionalmente pela identificação de um enterramento infantil do Paleolítico Superior Inicial, a apenas alguns centímetros de profundidade. Esta descoberta foi motivo de alguma controvérsia, porque a criança ali encontrada foi apontada como a prova de hibridismo entre Neandertais e homens anatomicamente modernos, pois apresenta alguns traços típicos dos Neandertais (DUARTE, 1999; ZILHÃO, 2001; ZILHÃO \& TRINKAUS, eds., 2002). Foram realizadas vinte e quatro datações por radiocarbono, em vários laboratórios, sobre amostras de diferentes camadas, o que permitiu determinar a cronologia absoluta dos depósitos e da actividade humana a eles associada (ZILHÃO e ALMEIDA, 2202, p. 30).

As datações por radiocarbono apontaram os seguintes resultados: 23 920+/220 BP (OxA-8422) e 24860 +/-200 BP (GrA-13 310) (ZILHÃO e ALMEIDA, 2002, p. 37). Estas datações e as características apontadas aos restos da criança concluem que houve um cruzamento tal entre homens modernos e Neandertais que as características destes últimos se mantiveram durante cerca de quatro mil anos após a sua extinção. Muitos foram os que se opuseram a esta hipótese, defendendo que os supostos traços de Neandertais resultam de se estar perante um jovem, com os ossos ainda não totalmente formados, ou de deformações do indivíduo, uma vez não ser possível que eventuais cruzamentos entre as duas espécies, milhares de anos antes, 
tenham dado origem a descendência fértil durante tanto tempo, o que não se observa noutras espécies, por exemplo entre os burros e os cavalos.

Quatro anos antes da sua descoberta, este sítio foi objecto de uma terraplanagem que eliminou a quase totalidade da parte superior do depósito, em dois a três metros de espessura (ZILHÃO e ALMEIDA, 2202, pp. 30).

Nesta jazida também foram recuperados alguns restos de vertebrados: mamíferos, répteis, anfíbios, peixes e aves (MORENO-GARCIA e PIMENTA, 2002, p. 120). As faunas do Lagar Velho foram estudadas por Marta Moreno e por Carlos Pimenta, do CIPA, e publicadas na monografia sobre o sítio editada em 2002. O estudo efectuado provém de três unidades arqueológicas: sector SE (quadrado K20), sector SC (quadrado J13) e Sector TP (MORENO-GARCIA e PIMENTA, 2002, p. 112).

As faunas não diferem das encontradas em outras jazidas arqueológicas do Plistocénico. Os táxones identificadas foram: mamíferos hervívoros (Bos primigenius, Cervus elaphus, Capreolus capreolus, Sus scrofa, Capra pyrenaica, Equus sp, Lepus sp, Oryctolagus cuniculus), mamíferos carnívos (Lynx pardina, canis lupus, Vulpes vulpes.); mamíferos marinhos (cf. Cetácea); pequenos mamíferos (Arvicola sapidus, Microtus, Gliriae, Erinaceus europaeus, Sorex sp, Crocidura sp, Talpa sp, Apodemus sylvaticus) répteis (Lacertidae e Colubridae), anfíbios (Anura e Salamandridae) e peixes não identificados (MORENO-GARCIA e PIMENTA, 2002, pp. 113 a 130).

No conjunto das faunas foi identificado um total de 208 restos de aves: 41 do sector SC, 3 do sector SE e 160 do Sector TP. Destes apenas 69 (3 do sector SC e 66 do sector TP) puderam ser identificados (MORENO-GARCIA e PIMENTA, 2002).

A identificação taxonómica das aves do Abrigo do Lagar Velho foi feita a nível da família, género e espécie, quando possível. Um pequeno número de restos foi identificado apenas ao nível da ordem (os passeriformes). É evidente a maior quantidade dos corvídeos e, em especial o predomínio de restos de gralhas, a seguir aos corvídeos aparecem os restos de perdizes (MORENO-GARCIA e PIMENTA, 2002, p. 127).

Trata-se de uma pequena amostra que não permite tirar conclusões paleoambientais. Alguns táxones identificados estão relacionados com paisagens rochosas, como as que se encontram neste vale (MORENO-GARCIA e PIMENTA, 2002, p. 123) As gralhas (Pyrrhocorax sp) vivem em zonas de montanha com precipícios e ravinas; enquanto as perdizes (Alectoris $s p$ ) também podem ser encontradas nestes 
ambientes (MORENO-GARCIA e PIMENTA, 2002, p. 118).

As aves identificadas por Marta Moreno-Garcia e Carlos Pimenta são as mesmas que ocorrem noutras estações do Plistocénico Superior. Foram identificados, no sector SC, uma ulna de Phyrrhocorax sp, um coracóide de Alectoris sp e tibiotarso de um passeriforme não identificado (MORENO-GARCIA e PIMENTA, 2002, p. 118). Como se viu, foi nos restos provenientes do sector TP que foram identificados o maior número de restos osteológicos de avifauna: Accipitridae, Falco tinnuculus, Alectoris sp, Corvus munedula, Pyrrhocorax sp, Corvidae, Sturnus vulgaris e Passeriformes (MORENO-GARCIA e PIMENTA, 2002, p. 126, quadro 6-9).

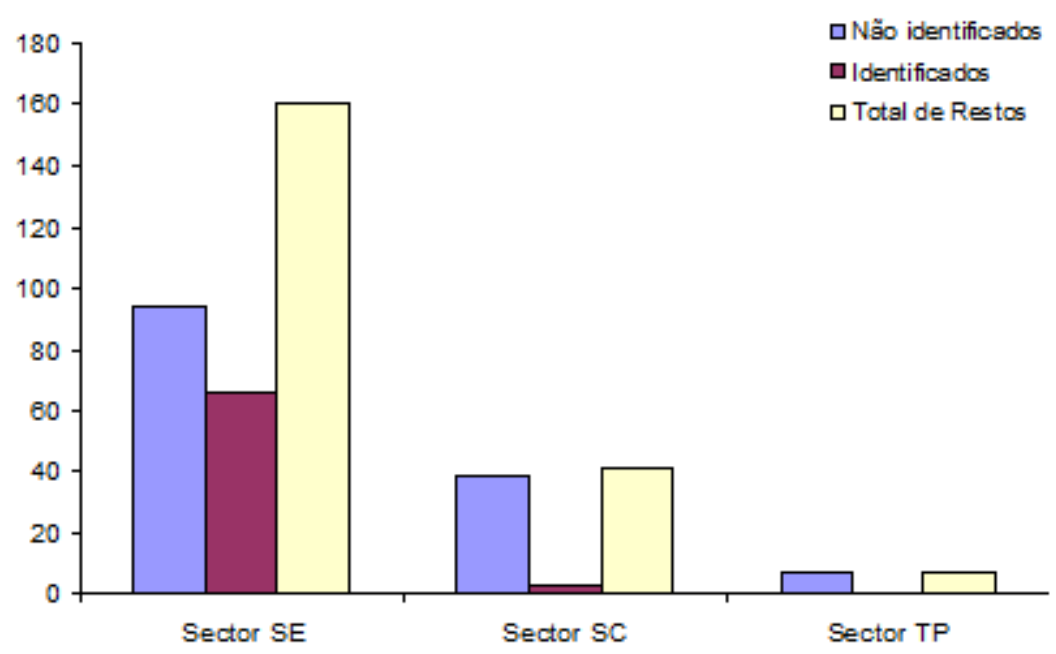

Gráfico 4 - Relação dos restos de aves identificados taxonomicamente com os não identificados e o total de restos, por sector de proveniência das amostras, com base nos dados de MORENO-GARCIA e PIMENTA, 2002. 


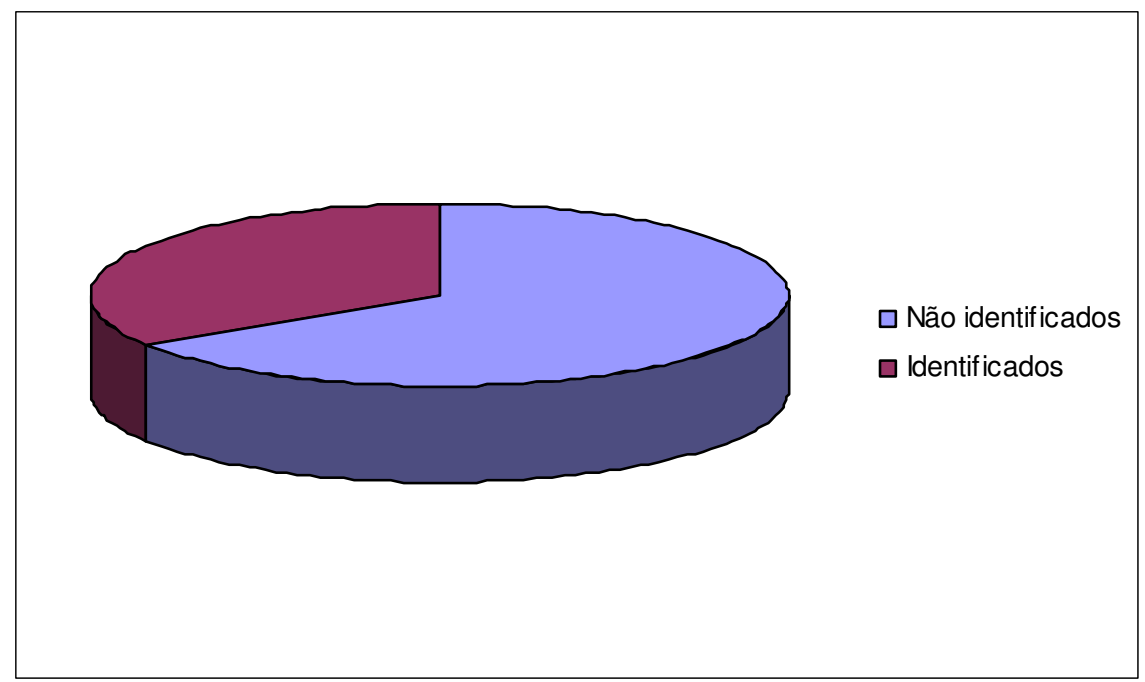

Gráfico 5 - Relação dos restos de aves identificados taxonomicamente com os não identificados no total de restos estudados, com base nos dados de MORENO-GARCIA e PIMENTA, 2002.

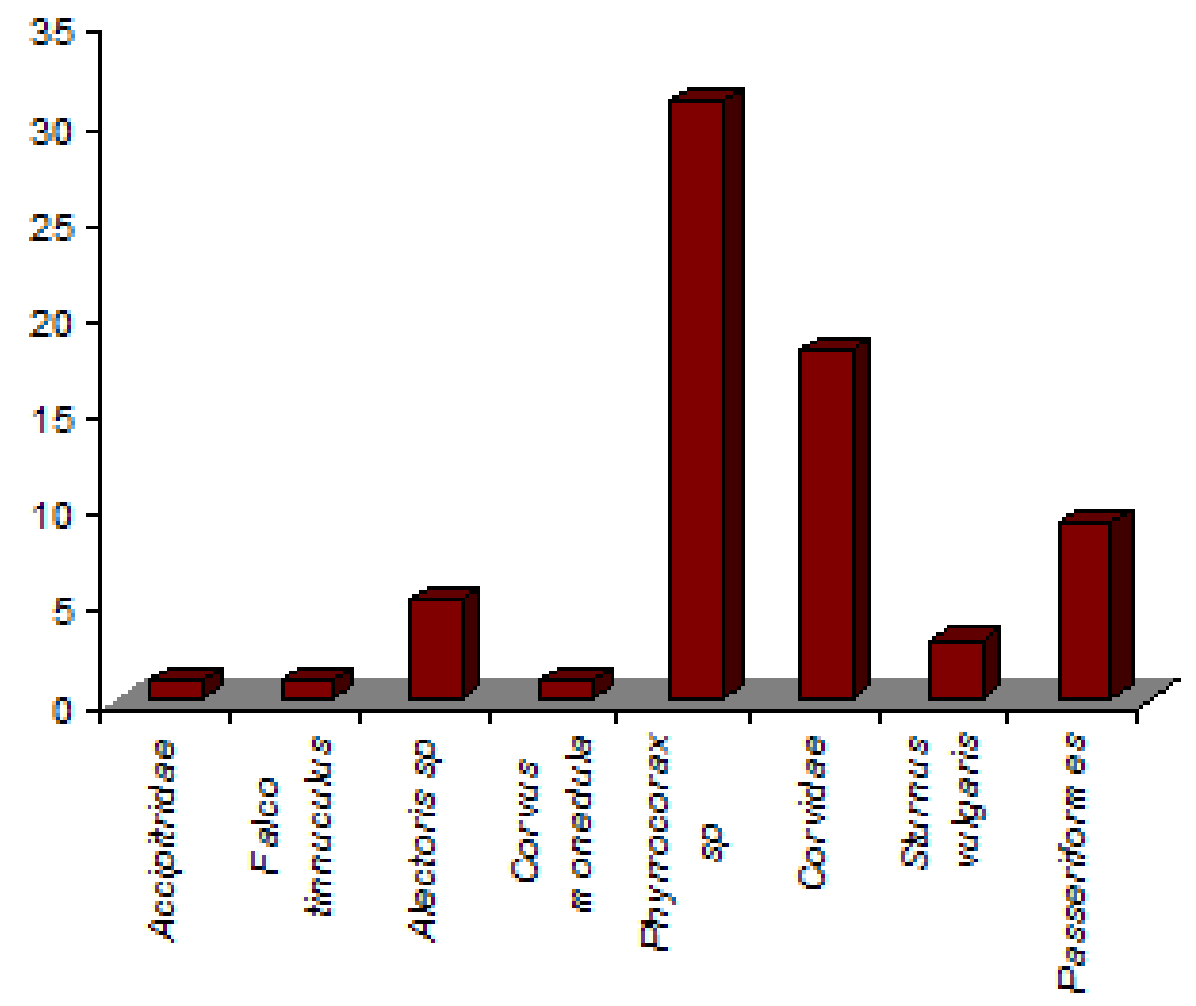

Gráfico 6 - Relação da ocorrência dos diferentes táxones de aves identificados no Abrigo do Lagar Velho, com base nos dados de MORENO-GARCIA e PIMENTA, 2002. 


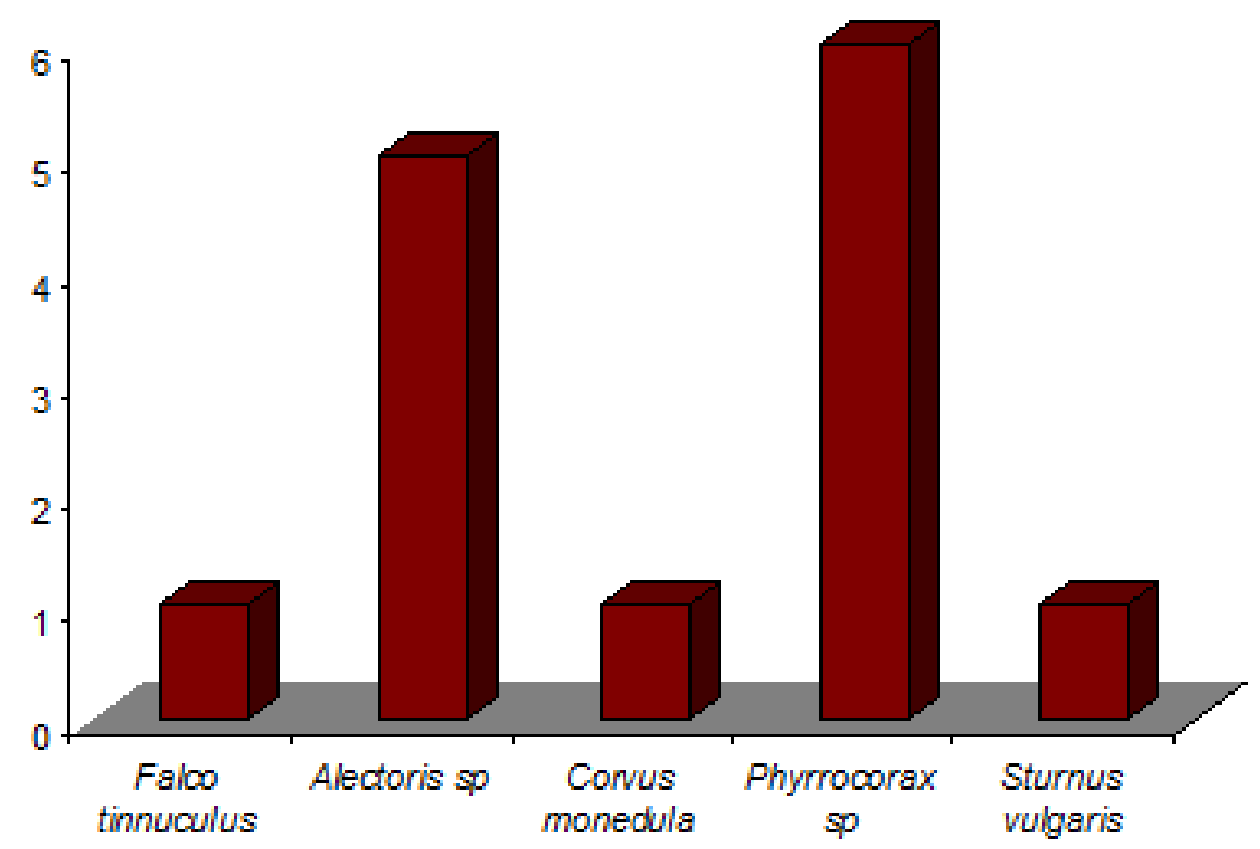

Gráfico 7 - Relação da ocorrência do número mínimo de indivíduos, por género e espécie identificados no Abrigo do Lagar Velho, com base nos dados de MORENO-GARCIA e PIMENTA, 2002.

A análise gráfica sobre a avifauna do Abrigo do Lagar Velho atrás apresentada foi feita a partir dos dados publicados por Marta Moreno-Garcia e Carlos Pimenta (MORENO-GARCIA e PIMENTA, 2002).

\section{5 - Gruta do Escoural}

A Gruta do Escoural, situada na Herdade da Sala, no concelho de Montemoro-Novo, foi descoberta em 1963, na sequência da exploração de uma pedreira. Foi estudada por M. F. Santos, e foi o primeiro sítio arqueológico com arte paleolítica descoberto em Portugal. Constitui-se actualmente como a única cavidade conhecida, no actual território português, com pinturas e gravuras rupestres realizadas no Paleolítico Superior e a mais ocidental das grutas com arte do Paleolítico europeu (RAPOSO, 2004, p. 176). Nesta gruta estão documentadas várias ocupações humanas, que cobrem um período que vai desde o Mustierense ao final do Calcolítico.

Do Paleolítico Médio foi encontrada alguma indústria lítica mustierense do Paleolítico Superior destaca-se a arte rupestre. Deste último período não se regista uma ocupação humana significativa, apenas se recolheram algumas peças do Solutrense e de horizontes do Paleolítico Superior Final ou Epipaleolítco (RAPOSO 
2004, p. 176). A arte rupestre, o principal vestígio do Paleolítico Superior, destaca-se pela sua raridade e apresenta duas fases, com cronologias de cerca 25000 a.C e 13 000 anos a.C. (SILVA et al., 1991). Encontram-se diversos temas da arte rupestre, com motivos geométricos e zoomórficos, que são os dominantes, especialmente as representações de equídeos e bovídeos.

A Gruta do Escoural é uma cavidade localizada num outeiro, de uma formação de calcários cristalinos metamorfizados. A planta é constituída por uma grande sala e múltiplas galerias. Foi classificada como monumento nacional ainda no ano da sua descoberta, pelo decreto n. ${ }^{\circ}$ 45327, de 1963.

No exterior da gruta existem vestígios de um santuário rupestre neolítico e, nas suas proximidades, encontra-se um Tholos. Estes formam um conjunto arqueológico, que, pelo largo âmbito cronológico, pela diversidade e raridade dos seus vestígios, é um SANCHEZ-MARCO importante na paisagem, como um testemunho excepcional da história das comunidades humanas que ali deixaram registada uma parte importante do seu comportamento.

As aves da Gruta do Escoural foram estudadas por Johan Deville (DEVILLE, 1996). O material estudado foi identificado taxonomicamente na colecção de referência do laboratório de arqueozoologia da Universidade Autónoma de Madrid (DEVILLE, 1996). O estudo não foi muito conclusivo na atribuição de restos a algumas espécies, muito semelhantes osteologicamente das ordens dos anseriformes, columbiformes e passeriformes: não foram especificados os restos entre Branta sp ou Anser sp; Anas platyrhyncos ou Tadorna tadorna; Columba oeanas ou Columba livia; Pyrrhocorax ou corvus; Corvus frugilegus ou Corvus corone.

Foram estudados os restos de aves das campanhas arqueológicas de 1989, 1990 e 1991, nas quais foram encontrados restos de anseriformes, galiformes, columbiformes, strigiformes e passeriformes (DEVILLE, 1996).

A acumulação dos restos de aves na Gruta do Escoural terá sido não antrópica. Estes restos terão tido duas causas: restos transportados por carnívoros (Felis sylvestris e Lynx pardina), também presentes na gruta, ou restos de aves que frequentavam a gruta. As espécies maiores de anseriformes, tais como Anas platyrhyncos, Tadorna tadorna e Mergus merganser, terão sido caçados pelo lince, enquanto as espécies mais pequenas (Alectoris rufa, Columba palumbus e Streptopelia $s p$, bem como a maioria dos passeriformes) terão sido caçadas pelo gato selvagem. A 
presença de Athene noctua estará relacionada com a frequência desta espécie nas grutas. A presença de Columba oeanas/livia terá duas explicações: ou foi também caçada pelo gato selvagem ou os restos acumularam-se naturalmente, por estas espécies construírem os ninhos nas paredes das grutas e alguns indivíduos ai morrerem (DEVILLE, 1996).

A paleoecologia da zona seria variada, com zonas com água, tal como sugere a presença dos anseriformes, e zonas secas com arbustos e árvores, onde custumam viver as espécies Allectoris rufa, Columba livia/oeanas, Columba palumbus e Streptopelia turtur e os géneros Turdus e Corvus (DEVILLE, 1996).

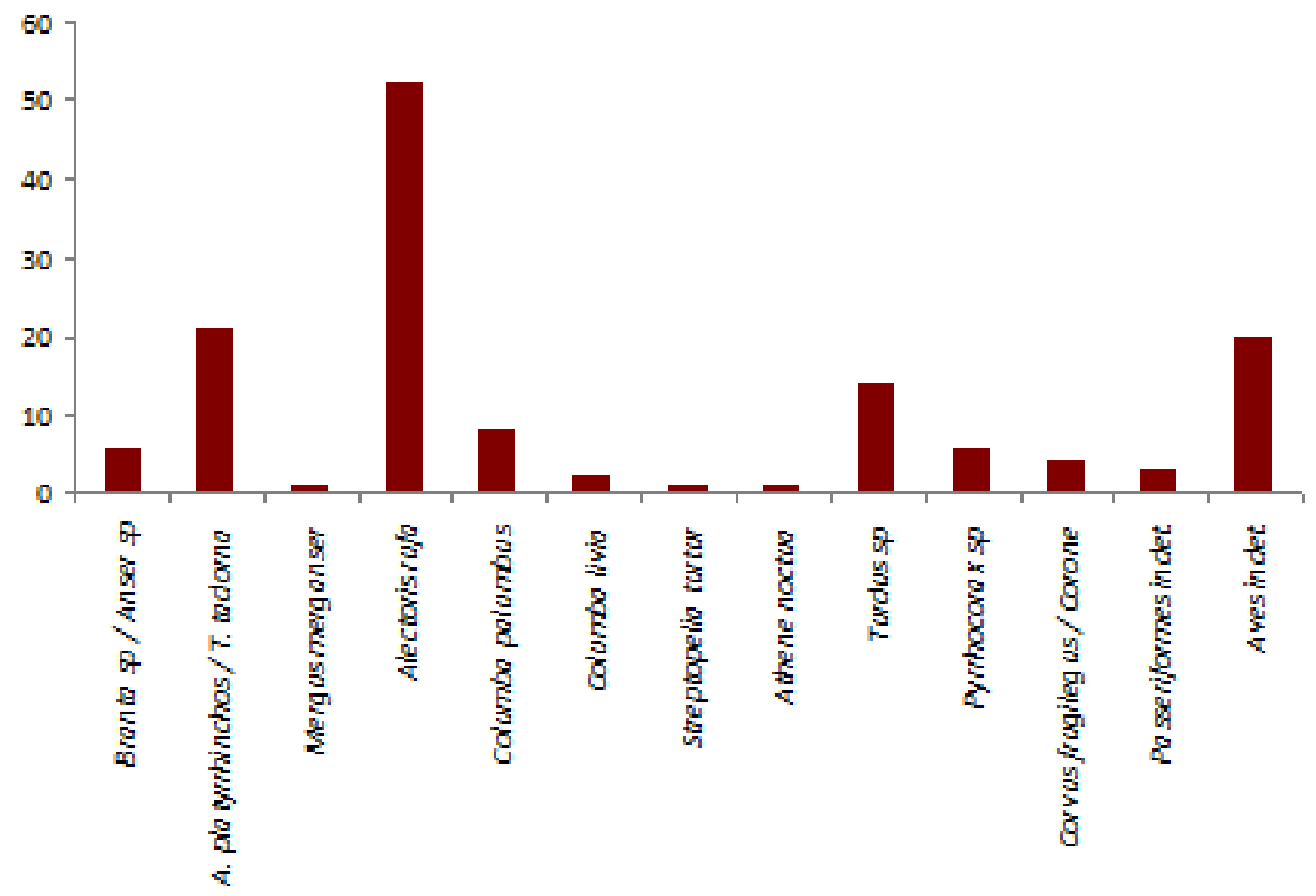

Gráfico 8 - Relação da ocorrência dos restos dos diferentes táxones identificados na Gruta do Escoural, com base nos dados de DEVILLE, 1996.

\section{6 - Outras jazidas com referências à existência de avifauna}

Na bibliografia sobre jazidas com fauna plistocénica existe, em quatro dessas jazidas (Lapa do Picareiro, Foz do Enxarrique, Buraca Escura e Lapa do Anecrial), a referência à ocorrência de aves. Algumas delas estão actualmente em estudo. Trata- 
se apenas de referências superficiais sem ser indicada a taxonomia. Com a excepção da Lapa do Pirareiro, em que, apesar de aparecerem de forma vestigial, foram encontrados restos de aves em todos os níveis arqueológicos (BICHO et al., 2003, p. 65), em todas as outras jazidas as aves são muito residuais, não ultrapassando a dezena de restos, nos totais das faunas encontradas em cada uma delas.

Para a presente investigação sobre a avifauna plistocénica de Portugal, não foram estudadas estas colecções por razões de escassez de tempo, por apresentarem um número muito reduzido de restos e por se encontrarem em estudo, no caso da Lapa do Picareiro. Desta forma, seguidamente será feita uma breve descrição das jazidas com base na respectiva bibliografia.

\section{Lapa do Picareiro}

A Lapa do Picareiro é uma abertura cársica localizada na serra d'Aire, a $10 \mathrm{~km}$ a sul de Fátima, perto do Covão do Coelho, nas seguintes coordenadas geográficas: $39^{\circ} 31^{\prime}$ 55" Norte e 8०38'10" Oeste. De planta triangular e com a entrada virada a este, esta cavidade encontra-se a uma altitude de 540 metros.

Tem cerca de 10 metros de profundidade e 8 de largura. A entrada tem menos de 1 metro de altura, a quase toda a largura da lapa (BICHO et al., 2003, p. 50). No exterior da lapa existe um cone de blocos de calcário, resultante do abatimento do tecto de um abrigo exterior, tendo-se mais tarde formado um corredor de 3 a 5 metros de largura (BICHO et al., 2003, p. 50). A potência sedimentar da lapa, no seu exterior, aproxima-se dos 8 metros, enquanto no seu interior a estratigrafia exposta pelos trabalhos arqueológicos é superior a 4 metros, revelando uma ocupação humana do Paleolítico Médio, do Superior, do Epipaleolítico, do Mesolítico, do Neolítico Antigo e da Idade do Bronze (BICHO et al., 2003 p. 50).

Os primeiros trabalhos arqueológicos realizados nesta estação foram feitos nos finais da década de 50 do século passado por Gustavo Marques e Gil Miguéis, pouco tempo depois de terem identificado a lapa. Estes trabalhos consistiram na abertura de uma sondagem de 1 metro quadrado que atingiu cerca de 1 metro de profundidade. Desta sondagem resultou a recolha de um conjunto de materiais arqueológicos que estes investigadores pensaram tratar-se de os vestígios de uma necrópole da Idade do Ferro (MARQUES e ANDRADE, 1974). A referida sondagem não 
ultrapassou o metro de profundidade, porque se encontraram materiais de cronologia mais antiga, o que não interessava à equipa de então (BICHO et al., 2003. p. 51).

Nos anos 90 a lapa foi relocalizada por uma equipa chefiada por João Zilhão. Nessa mesma época, no âmbito de vários projectos arqueológicos, Nuno Bicho realizou na gruta vários trabalhos arqueológicos: limpeza dos cortes abertos pela equipa que abriu a sondagem nos anos 50, escavação em área, e datações absolutas por radiocarbono a carvões recolhidos durante as escavações.

As escavações, que atingiram os 4 metros de profundidade, identificaram 20 camadas arqueológicas, designadas alfabeticamente desde a superfície, sendo portanto a camada "A" a superficial e a "S" a mais profunda (BICHO et al., 2003, p. 53). A estratigrafia desta gruta não está conhecida na sua totalidade, pois as escavações não atingiram a base rochosa da cavidade (BICHO et al., 2003, p. 53).

Foram realizadas doze datações absolutas a materiais retirados das camadas: C, Ca, D, E - superior, E - médio, E - inferior, F, F, G, I, J (BICHO et al., 2003., p. 53). As camadas com datações atribuídas ao Paleolítico Superior foram as camadas E, F, G, I e J, obtendo-se datações entre os $10070+/$ - 80 e os $12500+/-160$ anos BP (BICHO et al., 2003 p. 53) (anexo V).

A avifauna presente na Lapa do Picareiro é constituída por poucos vestígios de animais de alguma dimensão, do tipo do pato (BICHO et al., 2003. p. 65). Esta referência, muito superficial e pouco precisa, de 2003 foi feita com base numa primeira abordagem a estes materiais, sem terem sido identificadas as espécies.

\section{Foz do Enxarrique}

O sítio arqueológico da Foz do Enxarrique está localizado na margem direita do rio Tejo, na foz da ribeira do Enxarrique, em Vila Velha de Ródão, a cerca de $10 \mathrm{~km}$ da fronteira com a Espanha. Entre 1982 e 2001 foram realizadas várias campanhas de escavações, sob a direcção de Luís Raposo. Foi identificado um único nível arqueológico com uma indústria lítica mustierense, associada a uma rica fauna plistocénica.

Foram realizadas datações absolutas em dentes, pelo método de séries de 
urânio, que dataram o nível mustierense de 33600 +/- 500 BP (RAPOSO, 1995) (anexo V), correspondendo assim a uma fase mais recente do Paleolítico Médio. Este sítio localiza-se numa sequência estratigráfica fina de um terraço do Plistocénico do rio Tejo. A indústria lítica, constituída por materiais de quartzito, sílex e quartzo, caracteriza-se pela ocorrência de núcleos centrípetos, discóides e levallois, e uma alta incidência de subprodutos, constituídos principalmente de lascas, e onde toda a sequência de debitagem está presente. O estudo deste material lítico indica um aproveitamento oportunista da matéria-prima (RAPOSO, 1995).

O conjunto faunístico é constituído, entre outros, por equídeos, bovídeos, cervídeos e muito poucos carnívoros, o que é natural para um acampamento humano. Os restos de elefante estão representados por uma lamela de um molar superior e quatro fragmentos ósseos, classificados como Elephas antiquus. Estes restos de elefantes indicam a sobrevivência deste animal na Península lbérica até ao início da parte final da última glaciação. É um dos últimos registos de elefante conhecidos na Europa (BURGAL \& RAPOSO, 1999).

No estudo sobre as faunas da Foz do Enxarrique há uma referência à existência de aves indeterminadas nesta jazida (BRUGAL \& RAPOSO, 1999, p. 670). No âmbito da investigação da presente tese foram vistos alguns restos faunísticos da campanha de 2001, sem se ter encontrado qualquer resto de ave. Optou-se, essencialmente, por questões de tempo não continuar essa pesquisa, ficando-se apenas pela referência atrás mencionada. Será importante verificar, em proximos estudos, a existência de aves na Foz do Enxarrique, pois trata-se da única estação de ar livre do Paleolítico Médio português com a referência a aves e que tem uma acumulação faunística inequivocamente de origem antrópica.

\section{Buraca Escura}

A Buraca Escura é uma gruta situada na zona ocidental do maciço de Sicó, no sítio de Vale do Poio Novo (Poios), freguesia de Redinha, concelho de Pombal e distrito de Leiria. Apresenta uma ocupação do Paleolítico Médio e Superior (Gravetense / Gravetense Antigo, Gravetense Final e Proto-Solutrense). 
Esta jazida contém uma sequência plistocénica sob uma fina camada superficial moderna, escavada por M. H. Moura e Th. Aubry, entre 1991e 1995. Foram descritos vários conjuntos sedimentares, numa sequência estratigráfica de cerca de 3 metros (AUBRY et al., 2001, p. 19). Destes, o conjunto dois apresenta vestígios de sucessivas ocupações de época mustierense, incluindo estruturas de combustão, caracterizadas pela preponderância do quartzo. O conjunto três apresenta uma sequência com ocupações do Gravetense Antigo, do Gravetense Final e do ProtoSolutrense intercaladas entre níveis arqueologicamente estéreis, mas ricos em fauna. Foram realizadas datações absolutas, através do método de aceleração de partículas, que deram o seguinte resultado: 22 700 240 BP (OxA-5523) (anexo V) para um nível situado imediatamente sob a ocupação do Gravetense Final com lamelas de dorso bitruncado; $21820 \pm 200$ BP (OxA-5524) para um nível situado imediatamente sob a ocupação do Proto-Solutrense, com pontas de Vale Comprido. Estas datações apontam para uma ocupação da gruta anterior ao máximo glaciar. A baixa densidade de artefactos e a preponderância das armaduras apontam para uma utilização episódica da cavidade pelo homem, como refúgio ou no quadro de actividades de natureza logística. Na camada de topo da estratigrafia foram recolhidos alguns objectos da Pré-História Recente.

O espólio recolhido é constituído por uma indústria lítica e óssea, objectos de adorno e fauna dos níveis plistocénicos. Do espólio recolhido é de salientar que o material atribuído ao paleolítico se caracteriza por apresentar raridade de materiais líticos, mas ambundância de restos faunisticos, em que predominam os restos de carnívoros (AUBRY et al., 2001, p. 20).

Entre esta fauna está referenciada, no nível 2ab e a ocorrência de um resto de ave, não classificado (AUBRY et al., 2001, p. 21, tabela 1).

\section{Lapa do Anecrial}

A Lapa do Anecrial é uma gruta natural, situada no sítio das Casas dos Riscos, freguesia de Alvados, concelho de Porto de Mós e distrito de Leiria. Apresenta uma ocupação do Paleolítico Superior (Aurignacense, Proto-Solutrense e Solutrense).

Situa-se na encosta sul do polje de Alvados. A entrada, virada a norte, é 
constituída por uma pequena abertura entre blocos, através da qual, descendo um cone de abatimentos com um desnível de cerca de $2 \mathrm{~m}$, se acede a uma sala ampla, de chão horizontal, com uma superfície aproximada de $100 \mathrm{~m}^{2}$ e uma altura média da ordem dos 6 m. Esta gruta foi intervencionada nos anos de 1991 (prospecção), 1992, 1993 e 1995 (escavação). Foi integralmente escavada. As escavações revelaram uma sequência sedimentar que continha os vestígios arqueológicos. Esta sequência está localizada numa área restrita do fundo da sala e enchia um funil erosivo escavado em preenchimento cársico de argilas vermelhas. Foram diferenciados dois momentos de ocupação embalados em depósitos crioclásticos, ambos muito bem conservados, organizados em torno de lareiras: na camada 2, a indústria pertence ao Proto-Solutrense/Aurignacense $\mathrm{V}$ e as datações por radiocarbono indicam uma idade de cerca de 21600 BP. No topo da camada 1, a ocupação, separada da subjacente por cerca de $50 \mathrm{~cm}$ de depósitos estéreis, é de época solutrense (BRUGAL, 2006).

O espólio encontrado é constituído por indústria lítica, fauna e adornos. De realçar o facto de nas camadas 1 e 2 a fauna ser quase exclusivamente constituída por ossos de coelho (BRUGAL, 2006).

Na bibliografia estão referenciados 7 restos de aves, não classificadas, nesta gruta: um na camada 1 e seis na camada 2 (BRUGAL, 2006, p. 48, tabela 2). 
PARTE III

Metodologias 
Os materiais osteológicos estudados provêm de vários sítios arqueológicos descobertos e escavados no final do século XIX e durante o século XX. Estão nas colecções do Museu Geológico de Lisboa, Museu Municipal do Bombarral e Museu Nacional de Arqueologia. No Museu Geológico encontram-se os materiais das escavações de Nery Delgado, no século XIX, efectuadas na Gruta da Furninha, Gruta das Fontainhas e Gruta da Casa da Moura. Neste museu estão também os materiais escavados mais recentemente, já na década de sessenta e setenta do século passado por Veiga Ferreira, Georges Zbyszewski e Jean Roche, na Gruta das Salemas e na Lapa da Rainha. No Museu Municipal do Bombarral estão os materiais escavados por Veiga Ferreira na Gruta Nova da Columbeira. No Museu Nacional de Arqueologia foram observados os materiais recolhidos, na Gruta do Pego do Diabo, pela equipa do Grupo para o Estudo do Paleolítico Português, em 1979, e por João Zilhão, já na década de 80. Foram também, no Museu Nacional de História Natural, os restos de microfauna da Gruta do caldeirão, recolhidos entre 1979 e 1988 por João Zilhão, e que se encontram à guarda da Doutora Liliana Póvoas, que estudou essa microfauna.

Quer para a revisão das classificações antigas (Gruta da Furninha e Gruta das Fontainhas), quer para a atribuição taxonómica dos restos ainda não estudados (alguns materiais da Furninha e do Caldeirão e a totalidade dos restos de avifauna da Gruta Nova da Columbeira, Gruta da Casa da Moura, Lapa da Rainha, Gruta das Salemas, Gruta do Pego do Diabo e Lapa da Rainha) recorreu-se às colecções de referência osteológica (avifauna) do CIPA - IGESPAR e do LAP - CPGP/IPT. 


\section{1 - Metodologia Aplicada}

A primeira fase de elaboração desta tese foi constituída pelo levantamento, através de pesquisa bibliográfica e nos museus, dos sítios plistocénicos com ocorrência de aves em Portugal, cujo objectivo foi fazer um levantamento de todos os sítios com avifauna do Plistocénico aqui conhecidos. Após a conclusão desta primeira fase, foi feito um outro estudo bibliográfico acerca das bases teóricas desta tese, das ocorrências de aves anteriores ao Plistocénico, de modo a contextualizar cronoestratigraficamente e paleontologicamente as aves fósseis de Portugal, e foi feita a caracterização da geologia de Portugal, especialmente dos períodos em que ocorrem aves. Numa segunda fase, foram contactadas as instituições e os investigadores com os materiais osteológicos de aves Plistocénicas. Finalmente foi realizado o estudo taxonómico, tafonómico e osteológico dos vestígios, que se teve acesso. A revisão e a atribuição taxonómica foram feitas através da comparação com as colecções de referência do CIPA e do LAP.

Os elementos osteológicos atribuídos ao Plistocénico foram registados numa base de dados (Microsoft Excel 2003) segundo os seguintes vectores de análise: identificação das camadas (sempre que possível); classificação taxonómica; atribuição de idade; atribuição sexual e identificação do osso e do respectivo lado e estudo métrico dos ossos. Uma segunda ficha considerou os dados tafonómicos, arqueológicos e paleoecológicos.

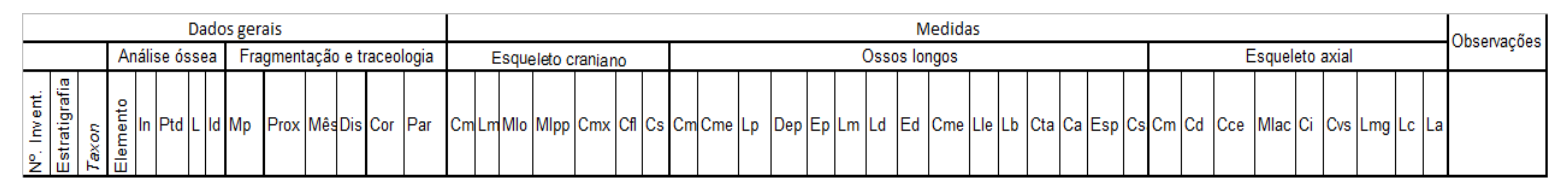

Quadro 12 - Estrutura da ficha utilizada no estudo dos ossos das jazidas apresentadas nesta tese.

Foi efectuado um estudo osteométrico dos ossos longos aos exemplares das estações plistocénicas, bem como das colecções do CIPA e do LAP (do CPGP e do IPT), para comparação entre a avifauna plistocénica e a actual.

A identificação taxonómica destes materiais foi feita revendo a classificação atribuída às colecções já estudadas, sendo que a classificação considerada correcta 
foi mantida e a que levantava dúvidas, ou que não estava atribuída, foi revista e atribuída através da comparação com as colecções de referência atrás referidas.

As medidas biométricas do conjunto de elementos osteológicos foram adaptadas de COHEN e SERJEANTSON, 1996 e DRIESCH, 1976. A nomenclatura osteológica utilizada foi, essencialmente, a seguida por Nomina Anatómica Avium (BAUMEL et al., 2003), mas também, nalguns casos foi seguida a utizada em (COHEN E SERJEANTSON, 1996, DRIESCH, 1976 e GILBERT et al., 1996). Os termos foram traduzidos para português, tendo, no caso de dúvidas, sido utilizado os Dicionários de Língua Portuguesa da Porto Editora (ALMEIDA COSTA \& SAMPAIO E MELO, 1975, 5․ Ed.) e de 2009 (vários autores) e dicionários técnicos ("ver referências bibliográficas").

Registo dos sinais tafonómicos considerados para os materiais: o grau de erosão física e química, as fracturas que apresentam, os dados de bioestratonomia, a fossildiagénese e os vestígios da acção de carnívoros e outros agentes não antrópicos, e vestígios de acção humana. Neste último caso foram considerados os seguintes sinais: vestígios de fogo, marcas de corte e fracturas (intencionais ou ocasionais). 


\section{2 - Taxonomia adoptada}

A taxonomia aplicada segue a utilizada no Handbook of the birds of the Word (Del Hoyo et al., 2004). Foram utilizados os seguintes níveis taxonómicos:

Ordem

Família

Género

Espécie.

Foi utilizada a sistemática paleontológica, já que se trata, apesar da grande maioria ser restos de aves ainda existentes, de fósseis de aves do Plistocénico, que apresentam algumas características relacionadas com as condicionantes do registo fóssil, que condicionam a atribuição taxonómica, como o grau de fragmentação, a preservação ou não de determinados elementos osteológicos, o osso preservado (existem alguns ossos aos quais é muito difícil, senão mesmo impossível, determinar o táxon, como algumas falanges e vértebras) e o grupo taxonómico conservado (por exemplo é extremamente difícil conseguir definir a taxonomia de determinados passeriformes, como os turdideos).

Assim, a uma parte dos elementos estudados não foi possível atribuir uma identificação específica, tendo sido apenas identificada a classe (ave indeterminada), uma vez que se apresentavam muito fragmentados. A outros, foi possível atribuir um táxon ao nível da ordem, família. No entanto, existe um número considerável de restos classificados a nível do género ou da espécie. 


\section{3 - Análise osteológica}

O estudo osteológico assentou, primeiramente, na identificação da parte do esqueleto dos restos identificados (esqueleto craniano, esqueleto axial ou esqueleto apendicular). Posteriormente, os ossos do esqueleto apendicular foram identificados segundo o respectivo tipo: longo ou curto. Após este estudo, foram contabilizados os ossos que estavam inteiros ou partidos. Neste ultimo caso identificaram-se qual (ou quais) as partes que estavam preservadas (parte distal, proximal ou parte mesial).

Após esta primeira abordagem osteológica, foram identificados os ossos (fémures, úmeros, coracóides, vértebras, ulnas, etc.), seguindo-se a identificação da lateralidade. Foi também identificada, sempre que possível, a idade (segundo os parâmetros jovem ou adulto) e o sexo (macho ou fêmea).

Quando se estuda um osso, esse é "colocado" como se o animal a que esse osso pertenceu estivesse virado para o investigador, recebendo, cada vista do osso, uma denominação própria: a do osso que está virado para o investigador é denominada vista anterior; por sua vez, a parte oposta a esta recebe o nome de vista posterior; a parte virada para o lado posterior do animal denomina-se de vista lateral; por fim, a parte do osso virada para o centro do animal, é denominada de vista mesial.

A nomenclatura osteológica utilizada seguiu a terminologia definida em Nomina Anatómica Avium (BAUMEL et al., 2003). Num estudo osteólogico é fundamental conhecer a nomenclatura das diferentes partes e características dos ossos. Assim, a elaboração deste estudo teve em conta as características osteológicas próprias das aves e a nomenclatura específica de cada osso. Como foi referido no capítulo "Caracterização Geral das Aves", as aves apresentam características próprias, a nível do esqueleto, resultantes da evolução do grupo, em especial a adaptação ao voo, o que levou também ao aparecimento de estruturas próprias a nível osteológico. Aqui apresenta-se a nomenclatura dos ossos das asas e das patas, ou seja, do esqueleto apendicular, pois são estes ossos que aparecem em maior número na amostra estudada

A literatura em português sobre este assunto é praticamente inexistente, pelo que grande parte do que aqui é apresentado resulta da tradução de bibliografia em 
inglês, nalguns casos com a terminologia osteológica em latim (BAUMEL et al., 2003, COHEN E SERJEANTSON, 1996, DRIESCH, 1976 e GILBERT et al., 1996).

$\mathrm{Na}$ literatura acerca da nomenclatura osteológica das aves não tem existido desejável e necessária normalização. Por isso, foi seguida, nesta tese, a nomenclatura adoptada pelos autores atrás referidos. A não existência de uma normalização da nomenclatura osteológica das aves, traz consigo algumas complicações na designação das medidas dos ossos. A agravar esta situação está o facto de os ossos das asas, consoante estas estão "abertas" ou "fechadas", apresentarem posições diferentes em relação ao corpo, o que leva a dificuldades na nomenclatura posicional de um determinado lado de um osso da asa: se se está perante o lado ventral ou dorsal, posterior ou anterior. Esta questão não se coloca noutros grupos de vertebrados, como por exemplo nos mamíferos ou nos répteis. 


\section{3 - Osteometria.}

As medidas dos ossos são muito importantes num estudo de faunas fósseis, porque fornecem dados que podem indicar uma atribuição taxonómica, dado existirem determinadas espécies ou outros grupos taxonómicos que apresentam medidas osteológicas diferentes, que possibilitam a identificação taxonómica de um determinado osso. A osteometria permite também obter alguns indicadores acerca da evolução do tamanho dos indivíduos de um determinado grupo taxonómico, entre os exemplares fósseis e os actuais. Quer num caso quer noutro, os dados obtidos são apenas indicadores, pois tudo depende do número de elementos osteológicos disponíveis, seja nas colecções fósseis, seja nas colecções de referência de ossos de animais actuais.

Foi elaborada uma base de dados que permite fazer essa comparação. Essa base de dados consiste nas medidas tiradas aos vestígios encontrados nas diferentes estações arqueológicas estudadas e na colecção de referência do CIPA e do CPGP, ao maior número de indivíduos possível, para minimizar possíveis erros devido à diversidade e ao dimorfismo sexual existente nas espécies. Infelizmente não foi possível reunir um conjunto de dados suficientemente grande, quer no caso das aves plistocénicas, que das aves actuais, de modo a obter resultados concretos. Desta forma, os dados obtidos apenas são indicadores

Para este fim apenas foram considerados quatro ossos: o coracóide, o úmero, a ulna, o carpometacarpo, o fémur, o tibiotarso e o tarsometatarso, porque por razões anatómicas pensamos serem os melhores ossos para resultados mais concretos e porque são os ossos que aparecem mais bem preservados e em maior número, na amostra estudada. Assim, foram consideradas cinco medidas: comprimento máximo $(\mathrm{Cm})$; largura máxima proximal (Lp); largura mesial (Lm); largura máxima distal (Ld) e largura basal (Lb) ${ }^{40}$. Os outros ossos, em especial do esqueleto craniano e do esqueleto axial, são em número muito baixo, o que não permitiu fazer um estudo comparativo, pois os dados fornecidos foram insuficientes.

40 Esta medida apenas para os coracóides 
No que respeita à identificação taxonómica foi desenvolvida, com base em COHEN \& SERJEANTSON, 1996 e DRIESCH, 1976, um conjunto de medidas osteológicas que permitem indicar as espécies ou os géneros dos elementos estudados. As medidas apresentadas por estes dois autores apresentam menos critérios de medição que os agora expostos. A necessidade de se tomarem mais algumas medidas osteológicos prende-se com o facto de o registo de avifauna estudado apresentar-se muito fragmentado. Assim, pretende-se conseguir identificar de forma mais rigorosa os táxones, pois os diferentes grupos adaptaram-se a ambientes e comportamentos, que deixaram marcas na morfologia dos ossos.

A razão em se apresentar apenas medidas osteológicas para o esqueleto apendicular, prende-se com o facto da maior parte da amostra estudada ser constituída por ossos dos membros. A identificação dos elementos osteológicos das outras partes do esqueleto foi feita apenas pela comparação morfológica dos ossos da amostra com os ossos das aves actuais.

A análise métrica é muito importante para se distinguir espécies relacionadas e para se conseguir identificar os sexos. Usando diferentes medidas pode-se tirar algumas indicações acerca da evolução das espécies e da própria identificação das mesmas, uma vez que se se considerar os caracteres apomórficos resultantes de adaptações dos modos de vida (neste caso das aves) e identificá-los, as suas medidas podem apontar para um determinado táxon.

Para a ajuda na atribuição taxonómica dos ossos estudados, foi tido em conta um conjunto de medidas osteológicas. Este conjunto serviu para identificar as medidas médias para diferentes partes anatómicas dos ossos, de forma a se poder comparar os dados obtidos no estudo das colecções plistocénicas com a colecção de referência do CIPA. Desta forma foi possível dispor de mais um dado comparativo que não apenas a semelhança morfológica dos ossos. Este sistema foi desenvolvido a partir do sistema exposto por COHEN \& SERJEANTSON, 1996, e por DRIESCG, 1976, tendo em conta as principais características osteológicas e morfológicas, bem como determinadas estruturas que podem individualizar através das suas medidas, diferentes espécies dentro do mesmo género. Os desenhos apresentados são desenhos de ossos de ganso (fonte: COHEN \& SERJEANTSON, 1996).

Para o presente estudo, com base em COHEN \& SERJEANTSON, 1996, e por 
DRIESCG, 1976, foram definidas várias medidas para os elementos ósseos mais importantes nas aves e os que aparecem mais no registo fóssil e, consequentemente, na amostra estudada. Assim, foram determinadas as seguintes medidas ${ }^{41}$ :

\section{Esqueleto craniano:}

Osso: crânio

Medidas:

Cm - comprimento máximo; Lm - largura máxima; Mlo - menor largura entre as órbitas; Mlpp - maior largura do processo pós-frontal; $\mathbf{C m x}$ - comprimento entre a extremedidade distal do maxilar e o processo frontal da pré-maxila.

Osso: mandíbula ${ }^{42}$

Medidas:

Cm - comprimento máximo; $\mathbf{C f I}$ - comprimento do apex ao ponto mais alto da face articular; Cs - comprimento da sínfise.

\section{Esqueleto axial:}

Osso: Esterno

Medidas:

$\mathbf{C m}$ - comprimento máximo; $\mathbf{C d}$ - comprimento dorsal; Cce - comprimento da crista do esterno ${ }^{43}$; Mlac: menor largura das facetas articulares com as costelas.

Osso: pélvis e Sinsacro

Medidas.

Cm - comprimento máximo; $\mathbf{C i}$ - comprimento do bordo caudal do ílio à espinha ílio-caudal; Cvs - comprimento das vértebras do sinsacro; Lmg - largura da zona mesial; Lc - largura cranial; La - largura dos bordos da acetábula.

\section{Esqueleto apendicular}

Osso: escápula

Medidas:

41 Apenas será apresentadas as medidas dos ossos encontrados e que são diagnósticos de uma espécie. Os ossos que apareceram em pequeno número e que apresentam um grande grau de semelhança entre os diferentes táxones, como as vértebras e as falanges dos pés, não foram medidos 42 Apesar de terem sido consideradas as medidas da mandíbula, estas não foram aplicadas, pois não foi encontrada nenhuma na amostra estudada.

43 Desde o apex da crista do esterno até ao bordo caudal do metaesterno. 
Cm - comprimento máximo; Lm - largura mesial; Lp - Largura proximal ${ }^{44}$.

Osso: coracóide

Medidas:

Cm - comprimento máximo (diagonal); Cme - Comprimento médio; Lle - largura da ligação ao esterno ${ }^{45} ;$ Lb - largura basal

Osso: úmero

Medidas:

Cm - comprimento máximo; Lp - Largura proximal; Lm - largura mesial; Ld Largura distal.

Osso: ulna

Medidas:

Cm - comprimento máximo; Lp - Largura proximal; Dep - diagonal da extremidade proximal; Lm - largura mesial; Ld - Largura distal.

Osso: rádio

Medidas:

Cm - comprimento máximo; Lp - Largura proximal; Lm - largura mesial; Ld Largura distal.

Osso: carpometacarpo

Medidas:

Cm - comprimento máximo; Lp - Largura proximal; Ded - diagonal da extremidade distal; Cta - comprimento entre as extremidades articulares ${ }^{46}$.

Osso: falange (II dígito da asa)

Medidas:

Cm - comprimento máximo; Csa - comprimento entre as superfícies articulares

Osso: fémur

Medidas:

Cm - comprimento máximo; Cme - comprimento médio; Lp - Largura proximal; Ep espessura proximal; Lm - largura mesial; Ld - Largura distal; Ed - espessura distal.

Osso: tibiotarso

44 Medida da diagonal da zona cranial.

45 Largura da face basal articular.

46 Só aplicável aos passeriformes. 
Medidas:

Cm - comprimento máximo; Ca - comprimento axial; Lp - Largura proximal; Dep diagonal da extremidade proximal; Lm - largura mesial; Ld - Largura distal; Ed espessura distal.

Osso: tarsometatarso

Medidas:

Cm - comprimento máximo; Lp - Largura proximal; Lm - largura mesial; Ld Largura distal; Esp - medida do espigão ${ }^{47}$.

Foram adoptadas essencialmente as medidas do esqueleto apendicular, que é o mais representado no conjunto de estudado.

47 Só aplicável aos galliformes. 


\section{4 - Reconstituição Paleoecológica}

A paleoecologia, termo proposto, em 1935, por O. Abel, estuda os ecossistemas do passado, ou seja, o conjunto das interacções entre organismos do passado e destes com o meio que os rodeava e as variações ambientais decorridas ao longo dos tempos geológicos (DUTRA, 2000). Numa palavra, a ecologia estuda os paleoecossistemas e tem como objectivo principal a reconstituição dos ambientes físicos do passado geológico, bem como a relação organismo com o seu ambiente. Para além disto, a paleoecologia tem desenvolvido outros estudos no âmbito da paleobiologia e da estratigrafia (MENDES, 1988), que permitem compreender melhor os organismos fósseis e os ambientes deposicionais em que os seus restos se inseriram.

Os estudos paleoecológicos têm por base os conceitos utilizados em ecologia. No entanto, obedecem a metodologias distintas devido a vários factores, que resultam, por um lado, do facto de o registo fóssil corresponder, geralmente, à preservação parcial de uma ou mais paleobiocenose (MENDES, 1988) e, por outro, ao tempo envolvido nas reconstituições paleoecológicas (enquanto a ecologia estuda fenómenos ocorridos em intervalos de tempo medidos em anos, a paleoecologia estuda fenómenos que decorreram em intervalos de tempo medidos em milhares ou milhões de anos).

Em paleoecologia existem cinco princípios fundamentais que regem os estudos e as reconstituições que são objecto desta ciência. Estes princípios são a adaptação ao ambiente, que defende que cada organismo, vivo ou fóssil, está ou esteve adaptado a um certo ambiente local e, desta forma, quer pelas evidências positivas (adaptação a um ambiente), quer pelas negativas (quando um organismo, por mudança do seu meio se extingue ou se muda para outro nicho), podem-se avaliar as condições do paleobiótopo de um organismo fóssil (DUTRA, 2000), a adaptação ao modo de vida, segundo o qual, cada organismo revela adaptações a um modo de vida. Por exemplo, grande número de organismos nectónicos revela uma estrutura hidrodinâmica. Os marsupiais australianos que ocuparam biótopos 
equivalentes aos dos placentários africanos revelam semelhanças morfológicas com estes últimos. Assim, temos roedores e carnívoros marsupiais muito semelhantes a placentários, os condicionalismos ecológicos, em que cada organismo se encontra restrito, na sua distribuição, aos limites geográficos do ambiente ao qual está adaptado, e a dependência ecológica, princípio segundo o qual, cada organismo está directa ou indirectamente dependente da maioria ou da totalidade dos membros da comunidade. Os exemplos práticos traduzem-se na representação das cadeias alimentares como diagramas interactivos e complexos. O conhecimento dos ambientes geológicos do passado é fundamental para a descrição da história da Terra e para a compreensão dos processos geológicos que se foram desenrolando ao longo dessa história. A paleoecologia utiliza, como método básico, o princípio do actualismo (ou uniformismo, para os autores anglo-saxónicos), também designado como "princípio das causas actuais". Este princípio baseia-se nos seguintes pressupostos: a ecologia dos organismos actuais serve de modelo para a interpretação dos requisitos ecológicos dos seres vivos do passado, e as exigências ambientais de organismos fósseis são as mesmas dos organismos actuais seus parentes. Porém, a aplicação deste princípio vai-se tornando cada vez menos fiável, à medida que se vai recuando na história geológica da Terra.

Como todas as outras ciências que estudam realidades que se apresentam incompletas, a paleoecologia também tem algumas limitações no seu estudo. As limitações dos estudos paleoecológicos são, em geral, de duas ordens: limitações resultantes da fossilização e limitações de interpretação. O primeiro caso resulta do facto de o registo fóssil ser incompleto, em que só se preservam, na maioria dos casos, parte dos organismos e parte das comunidades a que eles pertencem. Desta forma, a principal consequência é a obtenção de dados falseados pela abundância relativa de determinadas estruturas em determinados ambientes e modos de vida. No caso das limitações de interpretação, o problema reside no facto de as formas extintas, não aparentadas com grupos actuais, não permitirem deduções paleoecológicas directas e os raciocínios indirectos terem sempre um elevado grau de incerteza (MENDES, 1988, DUTRA, 2000).

As aves são, dentro do grupo dos vertebrados, bons indicadores paleoambientais. Apesar de algumas espécies de aves tirarem proveito de vários tipos de habitat, a grande parte delas está associada a um determinado ambiente. 
Desta forma, pode-se determinar um ambiente pela presença de uma ou mais espécies de aves. No caso específico das aves migradoras, estas têm uma distribuição por vezes muito dilatada e pode dar-se o caso, em teoria, de aparecer vestígios de uma espécie de ave migradora num ambiente estranho a essa espécie, o que pode ser explicado por uma morte ou um desvio, durante uma viagem longa de migração.

Na reconstituição paleoambiental utilizada neste trabalho seguiram-se os cinco princípios atrás referidos, o método utilizado por António Sanches Marco (SANCHEZ-MARCO, 1996 e 1999a), bem como a utilização do número mínimo de indivíduos como dado estatístico.

Partindo do princípio de que as aves vivem num ou mais biótopos, os representantes fósseis dos táxones vivos viveriam nos mesmos biótopos. Assim, este estudo adoptou os seguintes pressupostos: a) tanto no passado como no presente, os biótopos de uma mesma espécie são os mesmos; b) a probabilidade de encontrar uma espécie de ave no respectivo paleobiótopo é a mesma que na actualidade (SANCHEZ-MARCO, 1996).

Desta forma, se se encontrarem restos fósseis de uma espécie (sp1) que habita, na actualidade, num dado biótopo (a), logo o paleobiótopo (P) será o mesmo da ave a que pertenceram os restos encontrados. Posto isto, a probabilidade da espécie sp1 ter vivido no paleobiótopo a é igual a 1 e pode ser traduzida pela seguinte fórmula: $\mathrm{P}(\mathrm{sp} 1 \mathrm{a})=1$ (SANCHEZ-MARCO, 1996, 1999a). Por outro lado, uma outra espécie (sp2), que aparece em dois paleobiótopos (a e b), estará enquadrada em ambos os paleobiótopos e pode ser representada pela seguinte fórmula: $\mathrm{P}(\mathrm{sp} 1 \mathrm{a})$ $=\mathrm{P}(\mathrm{sp} 2 \mathrm{~b})=0,5$ (SANCHEZ-MARCO, A. S., 1996, 1999a), como por exemplo o Turdus merula, que vive em ambientes de charneca e de bosque.

No entanto, não quer isto dizer que existam os dois biótopos em simultâneo (SANCHEZ-MARCO, A. S., 1999a). Disto é exemplo prático a Columba livia, que vive em escarpas marinhas e zonas rochosas. No estudo agora efectuado foram encontrados restos na Gruta Nova da Columbeira e na Gruta da Furninha, a primeira situada mais para o interior, no Bombarral, e a segunda na costa de Peniche. Pela sua localização, estas duas jazidas apontam para biótopos diferentes, logo o biótopo que indica a Columba livia na Gruta da Furninha é o de escarpas marinhas, enquanto na Gruta Nova da Columbeira é o de zonas rochosas. No entanto, foi, neste trabalho contabilizada a totalidade de ambientes de todas as espécies encontradas, sendo 
destacadas, nos textos, as ocorrências descontextualizadas nas diferentes jazidas.

Os paleoecotipos foram definidos segundo os paleobiótipos identificados mediante a ocorrência do número mínimo de indivíduos (NMI). Os ecotipos são os conjuntos de espécies que têm probabilidades de aparecer em cada biótipo (SANCHEZ-MARCO, 1999a). Por seu lado, os paleoecotipos são o conjunto das espécies atribuídas aos restos fósseis identificados, e que têm probabilidades de aparecer em cada paleobiótopo determinado pela ocorrência dessa espécies. Por exemplo, o paleoecotipo de montanha de uma determinada jazida corresponde às espécies lá encontradas e que viveriam nesse mesmo ecotipo.

Assim, cada ecotipo (A) obtém um valor que é a soma das probabilidades de se encontrar no biótopo correspondente às espécies que aparecem (SANCHEZMARCO, 1999a). O valor do ecotipo é representado pela fórmula: $A=P(s p 1 a)+$ $\mathrm{P}(\mathrm{sp} 2 \mathrm{a})+\ldots+\mathrm{P}(\mathrm{spNa})($ SANCHEZ-MARCO 1999a).

No entanto, neste trabalho, foi considerada uma condicionante para definir o valor do paleoecotipo. Este valor resultou não apenas da soma das probabilidades de encontrar o número de espécies que aparecem num determinado paleobiótipo, mas também o NMI de cada uma das espécies identificadas, dado o facto de se encontrar apenas um individuo de uma espécie adaptada a um determinado biótopo, isso não tem o mesmo valor de uma outra espécie, de outro biótopo, que deixou, numa determinada jazida se um grande número de restos de vários indivíduos. Não se pode esquecer, que, pela sua mobilidade, é possível encontrar um indivíduo de uma espécie alóctone que se poderá ter "perdido" ou ter sido levado por correntes de ar para uma zona diferente do seu biótopo.

Este caso pode ser representado pela seguinte fórmula: $A=P(N M I s p 1 a)+$ $\mathrm{P}(\mathrm{NMIsp2a})+\ldots+\mathrm{P}(\mathrm{NMI}$ spNa $)$.

A atribuição paleoecológica no presente trabalho foi feita comparando a atribuição taxonómica dos restos identificados com os representantes vivos desses táxones. Esta comparação foi feita utilizando os dados sobre os habitat das aves actuais, apresentados por NICOLAl et al., 1993, HARRISON \& GREENSMITH, 1993 e GOODERS \& HARRIS, 1990. 


\section{6 - Quantificação}

O estudo agora apresentado incidiu sobre uma amostra de 2079 restos osteológicos de aves das oito jazidas já referidas. Optou-se por não se estudar outras jazidas com referências à presença de aves, ora por razões de tempo, como é o caso da Foz do Enxarrique, ora por esses restos estarem em estudo por outros colegas, como é o caso da Lapa do Picareiro ora porque não foi autorizado o acesso à colecção, no caso da Gruta da Oliveira.

As unidades elementares foram definidas como ossos fragmentados e ossos inteiros. Os ossos inteiros constituem um elemento ósseo, enquanto o fragmento se constitui como uma parte isolada de um osso, que terá tido uma continuidade (POPLIN, 1976b, p. 125) enquanto parte integrante de um elemento ósseo.

Optou-se por utilizar o termo resto ou restos para definir uma ou mais unidades básicas de estudo, sejam um fragmento ou um elemento ósseo, e não um vestígio, pois o termo resto define as partes de um organismo que ficou preservada, enquanto o termo vestígio, define apenas as evidências indirectas de um organismo ou das suas actividades (CASSAB, 2000, p. 6), como moldes externos, pegadas ou ovos.

Em seguida serão definidos os índices de quantificação utilizados para analisar os dados. Ao longo de anos de desenvolvimento da Arqueozoologia foram apresentados numerosos índices para representar os dados faunísticos (LYMAN 1994b), originando uma grande variedade e dispersão de apresentações.

Os principais índices utilizados neste trabalho são o NTR (Número Total de Restos) e o NMI (Número Mínimo de Indivíduos). Optou-se por estes índices porque apresentam problemas diferentes e respondem a questões diferentes, e o seu emprego possibilita uma análise dos dados mais rigorosa, rentabilizando assim a informação disponível. Por outro lado, são vários os autores que os usam e que defendem a sua utilização (BRUGAL, 1999, POPLIN, 1976, A KLEIN \& CRUZURIBE, 1984). Outro critério de quantificação usado neste estudo foi a estimativa da idade dos indivíduos representados. 


\section{1 - Número total de restos (NTR)}

O NTR corresponde ao número total de restos de aves identificados nas várias jazidas estudadas. A maioria dos autores que estudam restos arqueozoológicos utiliza a expressão "número de restos determinados" (NRD), correspondendo aos restos determinados anatómica e taxonomicamente, e a expressão "número de restos" (NR) não identificados anatómica e taxonomicamente. Optou-se, neste estudo, definir outro índice, o NTR, que agrupa as duas expressões atrás referidas, porque simplifica o estudo, sem Ihe retirar rigor, dando-lhe uma visão mais global da análise obtida, pois trata toda a amostra como uma unidade. Por outro lado, o estudo analisou um grupo taxonómico específico, as aves. Logo, apesar de alguns elementos ósseos terem sido identificados como pertencendo a aves indeterminadas e outros (poucos) a ossos longos indeterminados, a amostra foi toda determinada, embora com um maior ou menor grau de exactidão. Assim, não fazia sentido usar os dois índices (NRD e NR), tendo então sido definido a expressão NTR.

\subsection{Número mínimo de indivíduos (NMI)}

Os procedimentos para a obtenção do número mínimo de indivíduos, NMI, variam bastante de autor para autor. O conceito foi originalmente introduzido, em 1953, por White, e tem por objecto definir qual o número mínimo de indivíduos de uma espécie que terá sido preservado no registo fóssil.

Como foi referido, existem vários métodos para determinar este índice. A metodologia utilizada neste estudo para definir o NMI foi adaptada do método utilizado por Poplin (POPLIN, 1976b) e consistiu em, no caso dos elementos ósseos simétricos, dividi-los em esquerdos e direitos, e o número mais elevado foi considerado o NMI. No caso dos restos ósseos que estão representados no esqueleto por apenas um elemento, como o sinsacro, o crânio ou a mandíbula, foram divididos pelo número de vezes que se encontram representados. 


\section{3 - Estimativa das idades}

Foi utilizado outro critério de quantificação neste estudo, a estimativa da idade dos indivíduos representados na amostra. Foram, neste caso, estimados três índices: Jovens, Subadultos e Adultos.

Foram considerados, como pertencendo a indivíduos jovens, os elementos ósseos que apresentavam as apófises mal formadas; os subadultos, os que apresentavam as apófises praticamente formadas, mas não totalmente, os adultos, aqueles que apresentavam as apófises totalmente formadas.

\section{4 - Outros índices considerados}

Neste estudo foram também considerados outros índices que permitiram caracterizar a amostra do ponto de vista osteológico e estratigráfico. Foi então considerado o grau de fragmentação dos ossos (ossos inteiros e ossos partidos) e quantificados os ossos segundo a parte do esqueleto a que pertenciam: ossos do esqueleto cranianos (ossos do crânio), ossos do esqueleto axial (vértebras, costelas, sinsacro, pigídio e esterno) e os ossos do esqueleto apendicular (ossos dos membros, da cintura pélvica e da cintura escapular). Foi também, sempre que os dados disponíveis o indicavam, feita a distribuição dos restos, pelas camadas identificadas pelos investigadores que estudaram as jazidas. 
PARTE IV

RESULTAdOS E DisCUSSÃO 


\section{1 - Gruta Nova da Columbeira}

Dos restos faunísticos observados no Museu Municipal do Bombarral, provenientes da Gruta Nova da Columbeira, foram identificados 540 restos ósseos de aves. Destes, foi possível determinar a espécie a 294 (54 \% do total da amostra), correspondentes a 27 espécies. Dos restantes foi possível identificar outros táxones: género (81 restos), família (61 restos) e ordem (apenas 1 resto). Não foi possível determinar taxonomicamente os restantes 103 restos (19\% da amostra), por se encontrarem muito fragmentados.

Relacionando os táxones identificados com a camada estratigráfica proveniente, verificou-se que a camada que maior número de restos com táxones identificados forneceu foi a C. 7, seguida da C 6-a. O nível superior e a C9 foram os que menor número proporcionaram e os que maior quantidade relativa de materiais não identificados apresentaram (mais restos não identificados que os identificados, ao contrário das outras camadas). Nas restantes camadas foi considerável a diferença entre restos identificados e não identificados, com destaque para a C.6-a, que apresentou uma muito pequena percentagem de restos não identificados.

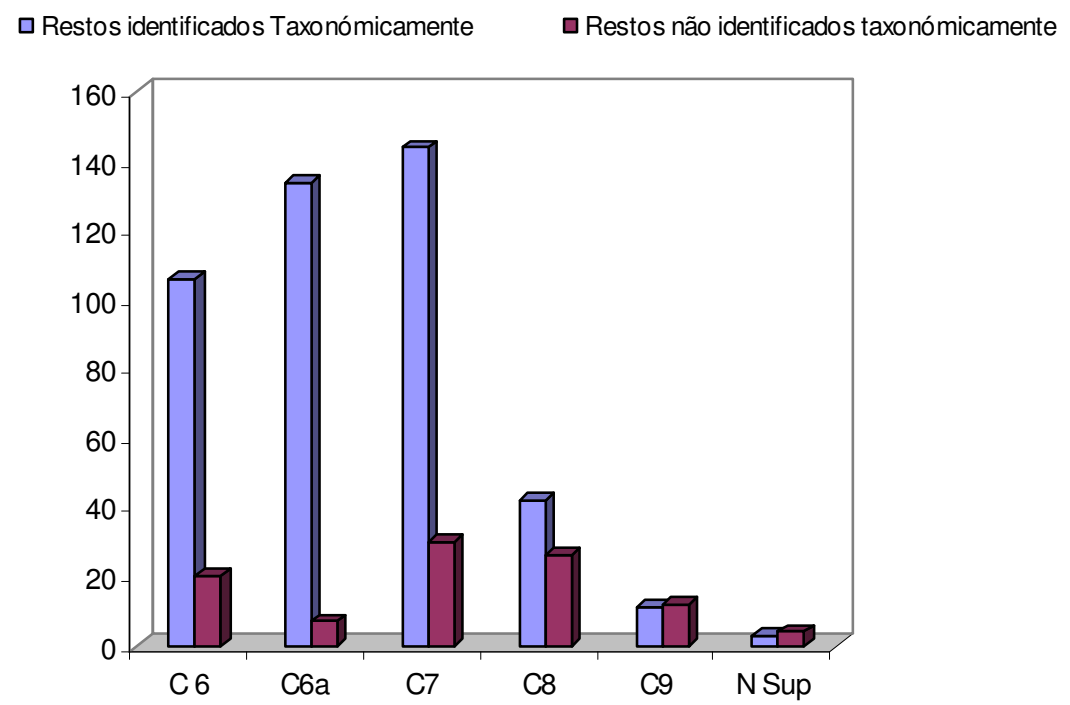

Gráfico 9 - Relação do número de restos classificados e não classificados, segundo cada uma das camadas da Gruta Nova da Columbeira.

A maioria dos restos de aves da Gruta Nova da Colombeira identificados na colecção do Museu do Bombarral, encontra-se muito fragmentada, o que explica o 
grande número de restos sem atribuição taxonómica abaixo da classe. Dos ossos fragmentados, 185 (cerca de $46 \%$ ) correspondem à parte proximal; 10 (cerca de $2 \%$ ) à parte mesial e 215 (cerca de $52 \%$ ) à parte distal.

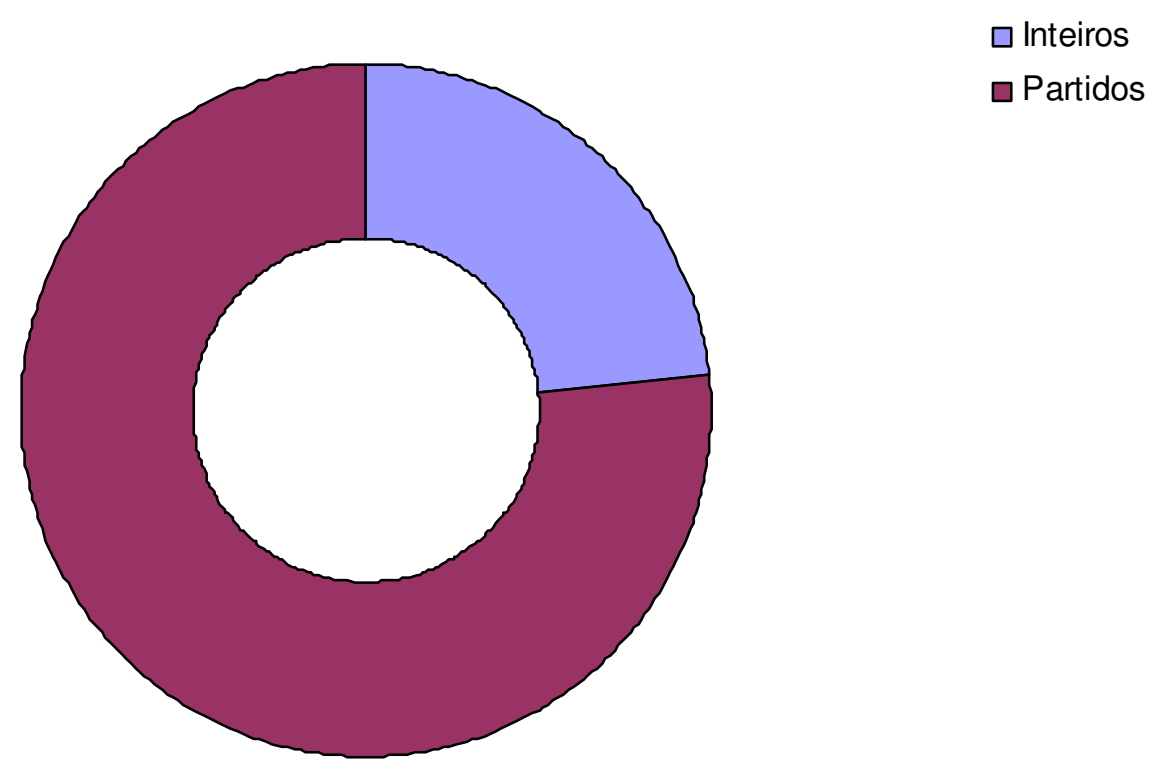

Gráfico 10 - Estado de conservação dos ossos.

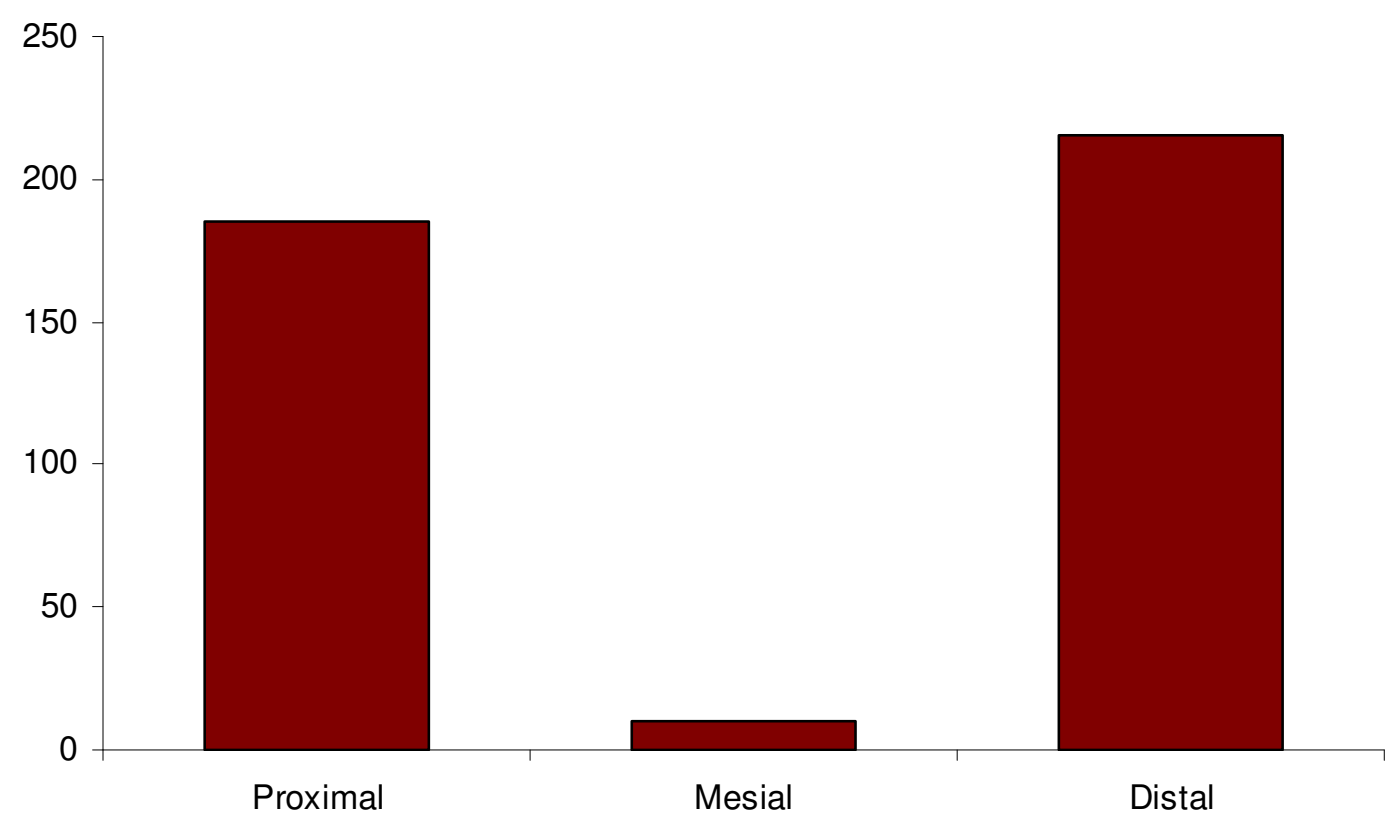

Gráfico 11 - Partes preservadas dos ossos longos fragmentados.

Como já foi referido, a proveniência estratigráfica dos materiais estudados revelou que a grande maioria foi proveniente das camadas C6, C6a e C7. A camada C8 ainda forneceu um número considerável de restos, enquanto a camada C9 e o 
nível superior forneceram um número muito baixo de restos de avifauna.

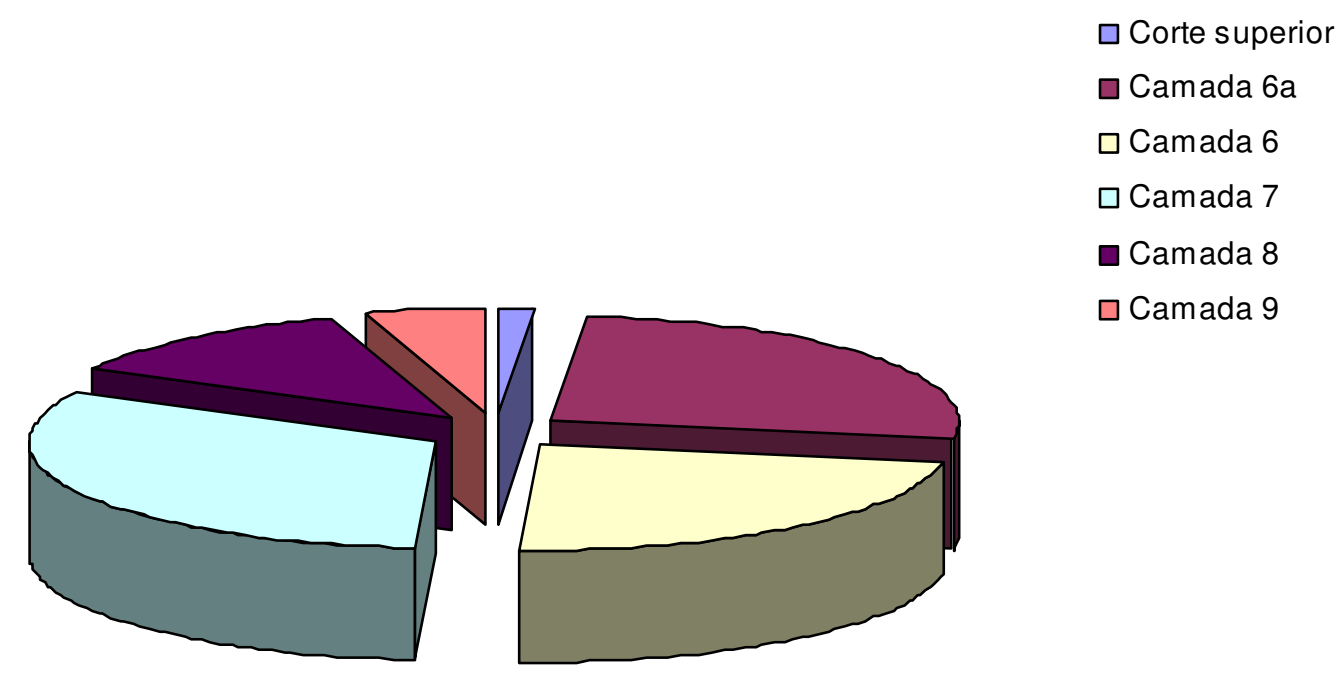

Gráfico 12 - Distribuição dos restos de aves pela sua camada de proveniência.

\subsection{Análise osteológica}

A análise osteológica assentou na quantificação, por táxon, dos ossos identificados e no consequente estudo das partes do esqueleto preservadas de restos identificados na Gruta Nova da Columbeira (quadro 13, gráfico 13). Verificouse que a grande maioria dos ossos identificados fazem parte do esqueleto apendicular, em particular os ossos dos membros. No grupo dos ossos do esqueleto apendicular não foram identificados nenhuns da cintura pélvica (o ílio, o ísquio e o púbis), pois, nas aves, estes ossos são relativamente frágeis, sendo por isso mais raros. No caso das outras partes do esqueleto, verificou-se a existência de uma pequena quantidade de ossos do esqueleto axial e não se encontraram ossos do esqueleto craniano. Estes valores explicam-se pela maior resistência dos ossos longos e consequente preservação face aos outros, nomeadamente os ossos do crânio e da cintura pélvica. 


\begin{tabular}{l|rr} 
Zona esquelética & Quantidade & Percentagem \\
\hline \hline Esq. Craniano & 0 & $0,00 \%$ \\
Esq. Axial & 15 & $2,77 \%$ \\
Esq. Apendicular & 526 & $97,23 \%$ \\
\hline \hline Total & 541 & $100,00 \%$
\end{tabular}

Quadro 13 - Quantidades das partes do esqueleto preservadas.

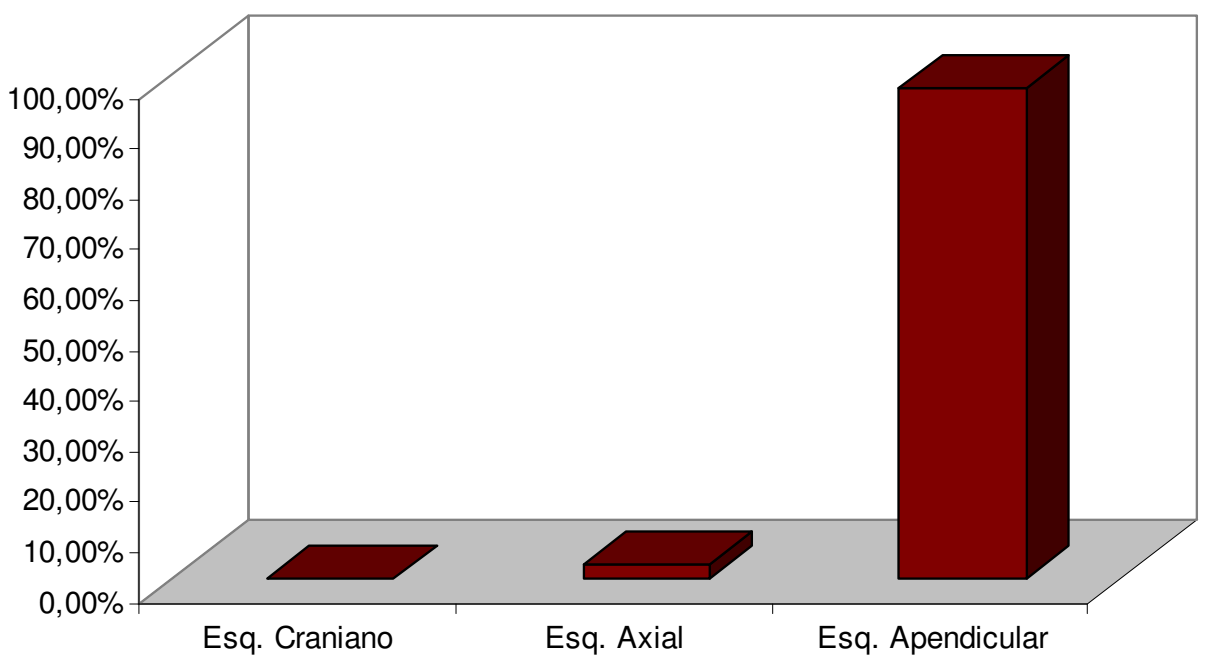

Gráfico 13 - Percentagem das partes do esqueleto representadas.

Dos elementos do esqueleto apendicular, 13 (2,4 \%) são ossos longos indeterminados, $374(73,4 \%)$ pertencem aos membros anteriores e $138(24,2)$ aos membros posteriores.

\section{2 - Identificação das idades}

Dos restos analisados, a grande maioria pertencia a adultos, mas nesta jazida existe ainda uma considerável percentagem de jovens e subadultos (cerca de $16 \%$ da totalidade da amostra). À maioria dos ossos de indivíduos jovens não foi possível atribuir-Ihe uma classificação taxonómica muito precisa, pois os jovens ainda não têm as epífises totalmente formadas, não desenvolvendo, por isso, as características próprias, que permitem a identificação ao nível da espécie. Mesmo assim, foi possível atribuir uma classificação ao nível da ordem e da família a alguns restos. No caso dos 
subadultos, que já têm os ossos quase completamente formados, foi possível atribuir uma classificação taxonómica ao nível da espécie, do género (a maioria) e da família. Os restos não identificados ocupam uma percentagem relativamente pequena, se comparados com a da percentagem dos jovens.

\begin{tabular}{l|rrrrrr|l|rrr}
\multicolumn{1}{c}{} & C6 & C6a & C7 & C8 & C9 & N Sup & \multicolumn{1}{c}{ Totais } & $\%$ \\
\hline \hline Jovens & 8 & 3 & 16 & 17 & 8 & 1 & Jovens & 53 & 9,81 \\
Subadultos & 5 & 5 & 11 & 7 & 3 & 0 & Subadultos & 31 & 5,74 \\
Adultos & 113 & 134 & 147 & 44 & 13 & 6 & Adultos & 457 & 84,45 \\
\hline \hline Totais & 126 & 142 & 174 & 68 & 24 & 7 & Totais & 541 & 100
\end{tabular}

Quadro 14 - Atribuição das idade, por camada e números totais da amostra e respectivas percentagens..

\begin{tabular}{|c|c|c|c|c|}
\hline \multirow{8}{*}{ 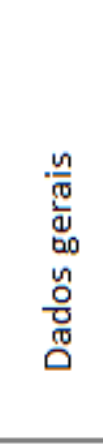 } & \multicolumn{4}{|c|}{ Atribuição taxonómica } \\
\hline & \multicolumn{2}{|l|}{ Jovens } & \multicolumn{2}{|l|}{ Subadultos } \\
\hline & Família & 14 & Espécie & 8 \\
\hline & Ordem & 1 & Género & 14 \\
\hline & Não identificada: & 38 & Familia & 4 \\
\hline & Id. Com reservas & 1 & Ordem & 0 \\
\hline & & & Não identificadas & 5 \\
\hline & & & Id. Com reservas & 1 \\
\hline \multirow{12}{*}{ 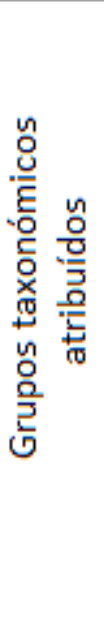 } & \multicolumn{2}{|l|}{ Jovens } & \multicolumn{2}{|l|}{ Subadultos } \\
\hline & Anatídae & 1 & Tetraonidae & 1 \\
\hline & Passeriformes & 1 & Accipitricidae & 1 \\
\hline & Cf. Corvidae & 1 & Columba sp & 3 \\
\hline & Corvidae & 12 & Corvidae & 2 \\
\hline & Ave indeterminada & 38 & Corvus sp & 1 \\
\hline & & & C. frugilegus/C. corone & 1 \\
\hline & & & C. monedula & 1 \\
\hline & & & Cf. Pyrrhocorax sp & 1 \\
\hline & & & Pyrrhocorax sp & 9 \\
\hline & & & P. pyrrocorax & 6 \\
\hline & & & Ave indeterminada & 5 \\
\hline
\end{tabular}

Quadro 15 - Atribuição taxonómica por idades. 


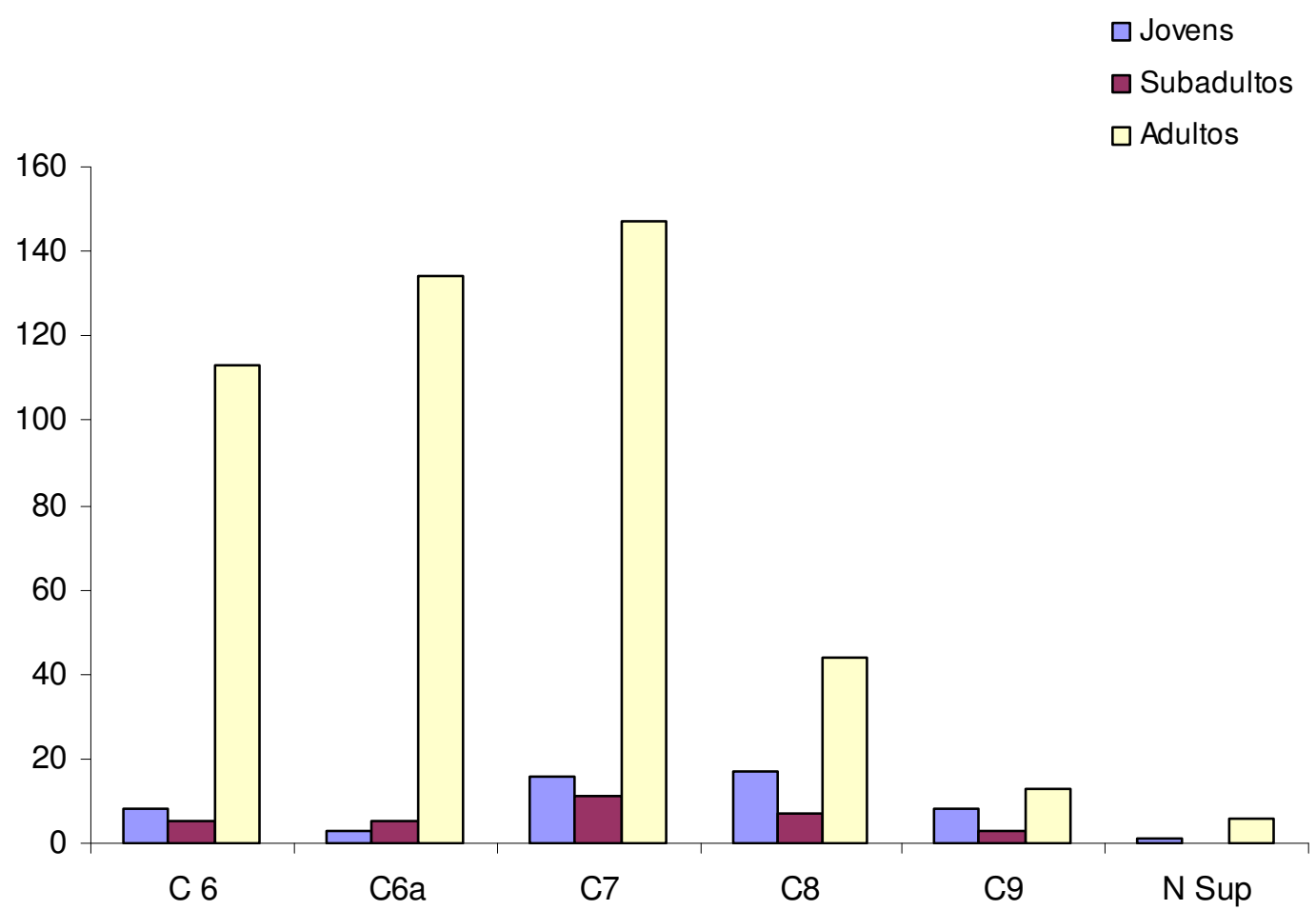

Gráfico 14 - Atribuição das idades, por camadas.

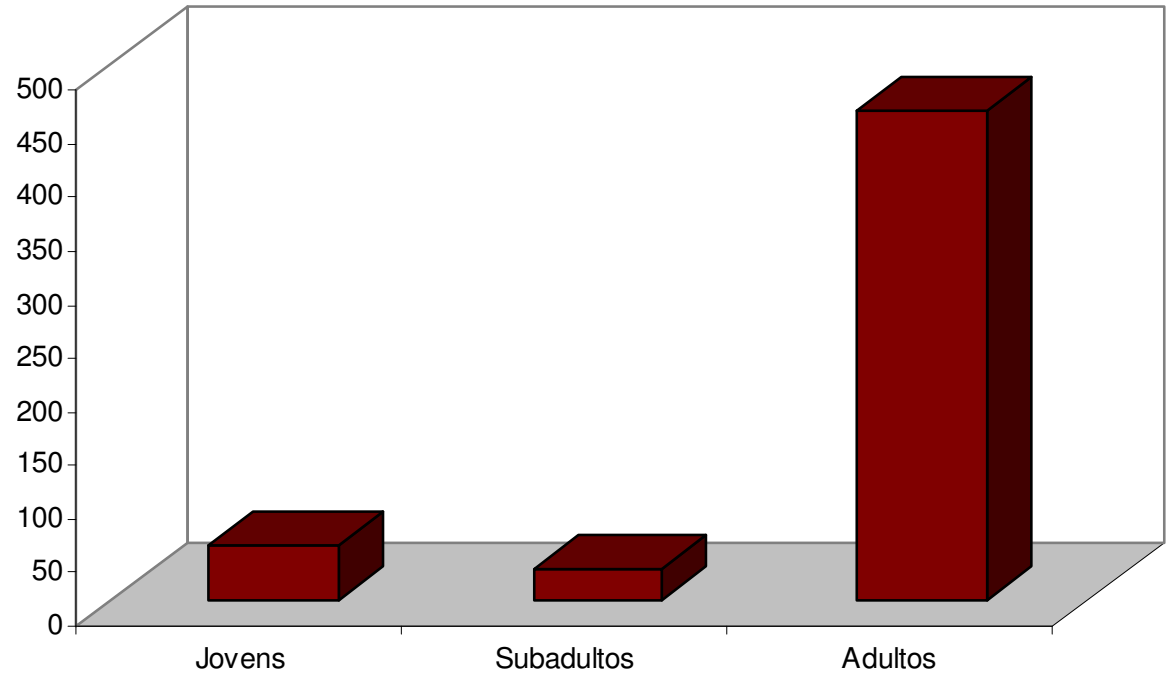

Gráfico 15 -- Atribuição das idades, na totalidade da jazida. 


\section{3 - Estudo taxonómico}

O estudo taxonómico dos restos de avifauna plistocénica da Gruta Nova da Columbeira permitiu identificar, como já foi referido, 27 espécies. Estas espécies pertencem a 19 géneros, a 12 famílias e a 9 ordens.

Existem algumas espécies que apresentam grandes semelhanças ósseas. É o caso do C. frugilegus com o C. corone e do C. monedula com o P. graculus. Nestes casos, aos restos que suscitavam dúvidas de classificação, foi-lhes atribuída as duas espécies (por exemplo: Corvus frugilegus/Corvus corone). No estudo posterior de quantificação de espécies nas diferentes análises, como por exemplo o estudo taxonómico e o paleoecológico, foram contabilizadas as duas espécies.

Das espécies identificadas nos níveis plistocénicos da Gruta Nova da Columbeira, nenhuma está actualmente extinta, em termos globais, podendo concluir-se que não há grandes diferenças entre a avifauna plistocénica e a avifauna actual. Com a excepção de três espécies, o Pyrrhocorax graculus, o Lagopus mutus e $a$ Perdix perdix, que estão actualmente extintas em Portugal, mas que existem noutras zonas da Europa, todas as restantes espécies identificadas ocupam sazonalmente ou vivem no actual território português. Das espécies já extintas em Portugal, o $P$. graculus está referenciado, na Europa, no Norte da Península Ibérica, nos Balcãs e na Grécia; o L. mutus é conhecido no Norte da Europa, Pirenéus e Alpes. Por sua vez, a $P$. perdix vive actualmente na zona das Astúrias, em Itália e nos Balcãs, no Centro da Europa e na Zona Sul do Norte da Europa (GOODERS \& HARRIS, 1990).

O estudo taxonómico foi feito segundo a sua proveniência estratigráfica. Verificou-se, nas camadas com maior número de restos, a predominância dos mesmos grupos. Verifica-se a ocorrência de apenas algumas espécies residuais diferentes nessas camadas. Analisando os dados pelos diferentes táxones, verifica-se igualmente uma maior abundância dos passeriformes e, dentre estes, o predomínio dos corvídeos, em especial do género Pyrrhocorax. Esta situação é explicável pelo tipo de jazida: uma gruta, local frequentado por estes animais. O número relativamente elevado dos galliformes (sobretudo do género Alectoris) e dos columbiformes (com destaque para a espécie Columba livia) poderá ser explicado pela zona envolvente da Gruta Nova da Columbeira: o vale, que se alarga para 
jusante da ribeira da Columbeira, formando uma área aberta que é o ambiente ideal para a ocorrência dos Alectoris, enquanto a zona de escarpa rochosa em que se enquadra a Gruta Nova é a preferida da Columba livia.

\begin{tabular}{|c|c|c|c|c|c|c|}
\hline Ordens & C 6 & C6a & $\mathrm{C7}$ & $\mathrm{C} 8$ & C9 N Sup & Totais \\
\hline Anseriformes & & & 2 & 3 & & 5 \\
\hline Galliformes & 6 & 15 & 12 & 4 & 2 & 39 \\
\hline Charadriiformes & 1 & 4 & & & & 5 \\
\hline Accipiteriformes & 1 & & 2 & 3 & & 6 \\
\hline Strigiformes & 1 & 3 & & & 1 & 5 \\
\hline Piciformes & & & & 1 & & 1 \\
\hline Columbiformes & 10 & 25 & 18 & 3 & 1 & 57 \\
\hline Passeriformes & 75 & 82 & 74 & 19 & 3 & 258 \\
\hline
\end{tabular}

Quadro 16 - Distribuição das ordens por camada.

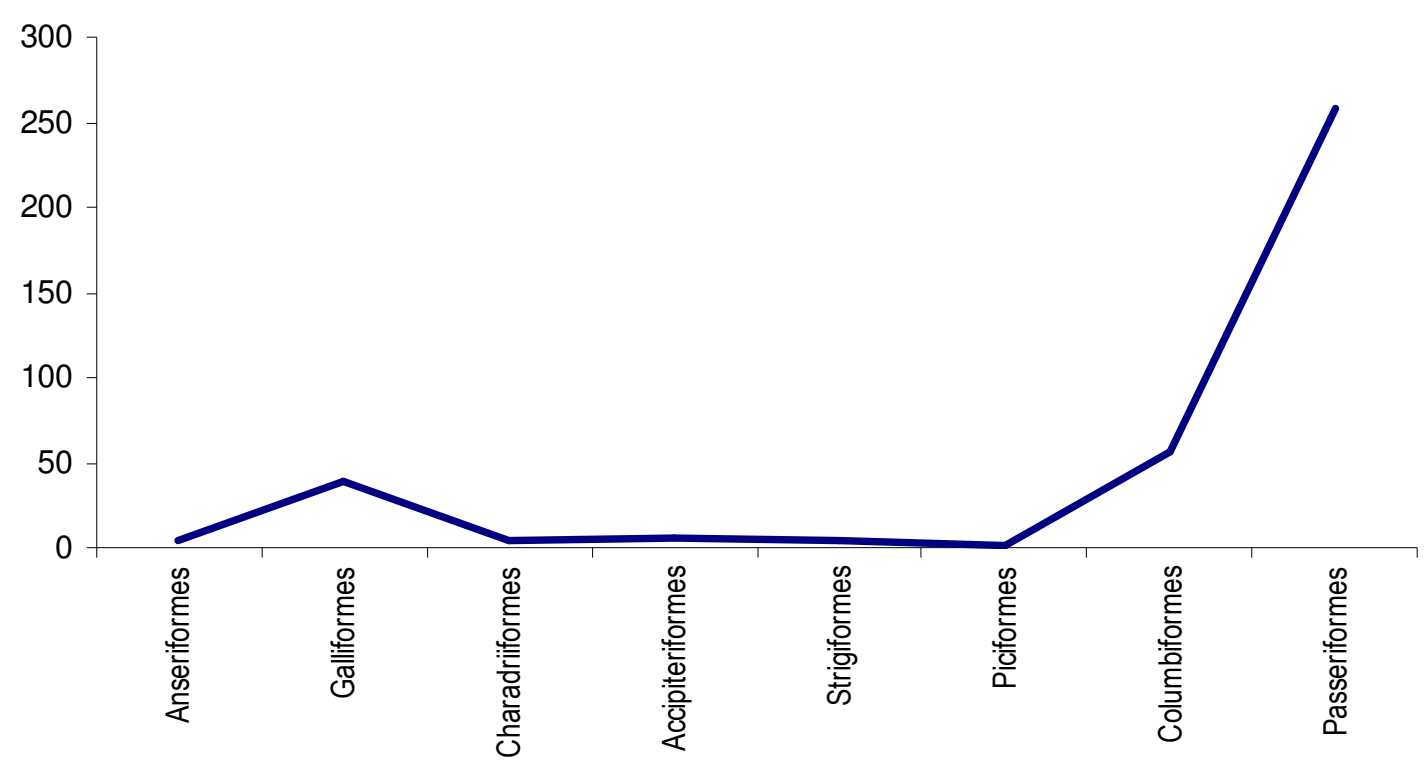

Gráfico 16 - Ocorrência global das ordens. 


\begin{tabular}{l|ccccccc}
\multicolumn{1}{r}{ Familias } & C 6 & C6a & C7 & C8 & C9 & N Sup & Totais \\
\hline \hline Anatidae & & & 2 & 3 & & 5 \\
Phasianidae & 6 & 15 & 12 & 4 & 2 & & 39 \\
Charadriidae & 1 & 2 & & & & 3 \\
Laridae & & 1 & & & & 1 \\
Scolopacidae & & 1 & & & & 1 \\
Accipiteridae & & & 2 & 2 & & & 4 \\
Falconidae & 1 & & & 1 & & & 2 \\
Strigidae & 1 & 3 & & 0 & 1 & & 5 \\
Picidae & & & & 1 & & & 1 \\
Columbidae & 10 & 25 & 18 & 3 & 1 & & 57 \\
Corvidae & 74 & 67 & 61 & 18 & 4 & 3 & 227 \\
Turdidae & 1 & 15 & 13 & 1 & 1 & & 31 \\
Fringilidae & & & 1 & & & & 1 \\
Hirundidae & & & 1 & & & & 1
\end{tabular}

Quadro 17 - Distribuição das famílias por camada.

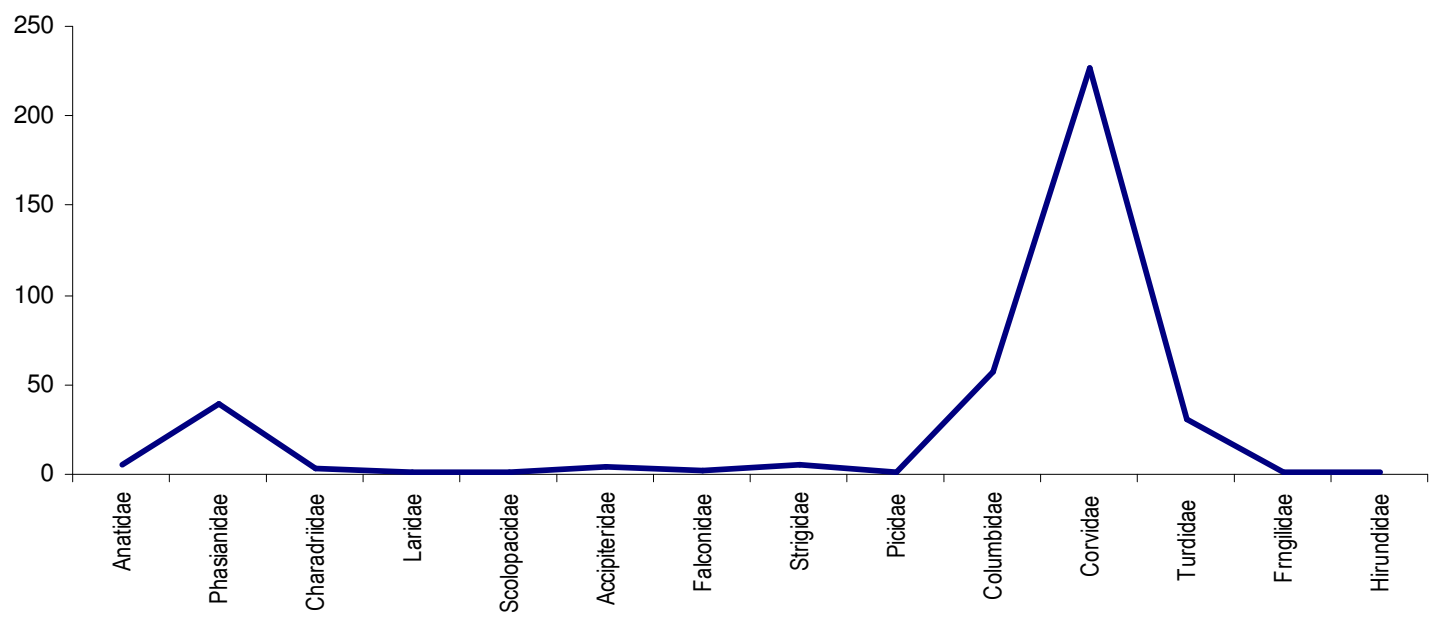

Gráfico 17 - Ocorrência global das diferentes famílias. 


\begin{tabular}{|c|c|c|c|c|c|c|}
\hline Géneros & |C 6 & C6a & C7 & $\mathrm{C} 8 \mathrm{C}$ & C9 N Sup & Totais \\
\hline Anas & & & 2 & 3 & & 5 \\
\hline Perdix & & 3 & 2 & & & 5 \\
\hline Alectoris & 6 & 12 & 8 & 4 & 2 & 32 \\
\hline Coturnix & & & 1 & & & 1 \\
\hline Lagopus & & & 1 & & & 1 \\
\hline Larus & & 1 & & & & 1 \\
\hline Limosa & & 1 & & & & 1 \\
\hline Pluvialis & & 2 & & & & 2 \\
\hline Vanellus & 1 & & & & & 1 \\
\hline Aquila & & & 2 & 2 & & 4 \\
\hline Strix & & 2 & & & & 2 \\
\hline Athene & 1 & 1 & & & 1 & 3 \\
\hline Falco & 1 & & & 1 & & 2 \\
\hline Picus & & & & 1 & & 1 \\
\hline Columba & 10 & 25 & 18 & 3 & 1 & 57 \\
\hline Pyrrhocorax & 53 & 43 & 36 & 9 & 3 & 147 \\
\hline Corvus & 16 & 18 & 24 & 9 & & 67 \\
\hline Pica & 4 & 5 & 1 & & 1 & 11 \\
\hline Garrulus & 1 & & & & & 1 \\
\hline Cyanopica & & 1 & & & & 1 \\
\hline Turdus & 1 & 15 & 13 & 1 & 1 & 31 \\
\hline Carduelis & & & 1 & & & 1 \\
\hline Ptyonoprogne & & & 1 & & & 1 \\
\hline
\end{tabular}

Quadro 18 - Distribuição dos géneros por camada. 


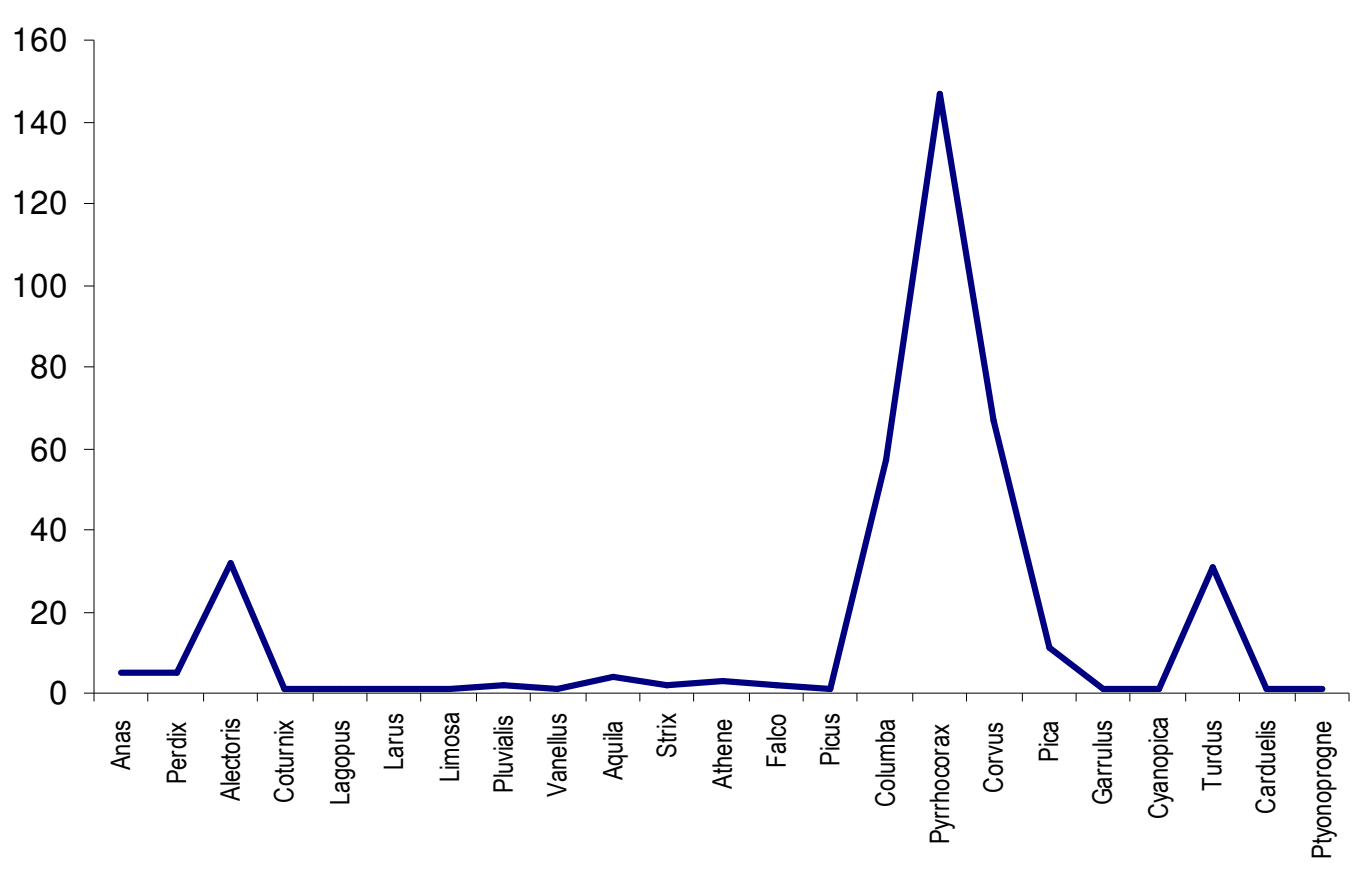

Gráfico 18 - Ocorrência global dos géneros identificados na Gruta Nova da Columbeira. 


\begin{tabular}{|c|c|c|c|c|c|c|}
\hline Espécies & $\mathrm{C} 6$ & C6a & $\mathrm{C7}$ & $\mathrm{C} 8 \mathrm{C}$ & C9 N Sup & Totais \\
\hline A. platyrhynchos & & & 1 & 1 & & 2 \\
\hline M. nigra & & & 1 & & & 1 \\
\hline P. perdix & & 2 & 2 & & & 4 \\
\hline Al. rufa & 4 & 10 & 6 & 3 & 2 & 25 \\
\hline C. coturnix & & & 1 & & & 1 \\
\hline L. mutus & & & 1 & & & 1 \\
\hline P. squatarola & & 2 & & & & 2 \\
\hline A. chrysaetos & & & & 2 & & 2 \\
\hline F. tinuculus & 1 & & & & & 1 \\
\hline A. noctua & 1 & & & & 1 & 2 \\
\hline S. aluco & & 2 & & & & 2 \\
\hline C. livia & 7 & 21 & 10 & & & 38 \\
\hline C. palumbus & 1 & 1 & 2 & 1 & & 5 \\
\hline P. pyrrhocorax & 1 & 24 & 20 & 2 & 3 & 53 \\
\hline P. graculus & 1 & 8 & 4 & & 1 & 14 \\
\hline C. monedula & 1 & 10 & 8 & 4 & & 23 \\
\hline C. corone & 1 & 1 & 1 & 1 & & 4 \\
\hline C. frugilegus & 1 & 4 & 3 & & & 8 \\
\hline C. corax & 1 & & 1 & & & 2 \\
\hline P. pica & 1 & 5 & 1 & & 1 & 8 \\
\hline G. glandarius & 1 & & & & & 1 \\
\hline C. cyanus & & 1 & & & & 1 \\
\hline T. iliacus & & & 1 & & & 1 \\
\hline T. pilaris & & 4 & 2 & & 1 & 7 \\
\hline T. philomelos & & 1 & 1 & & & 2 \\
\hline T. merula & 1 & 8 & 7 & 1 & & 17 \\
\hline C. carduelis & & & 1 & & & 1 \\
\hline P. rupestris & & & 1 & & & 1 \\
\hline
\end{tabular}

Quadro 19 - Distribuição das espécies por camada. 


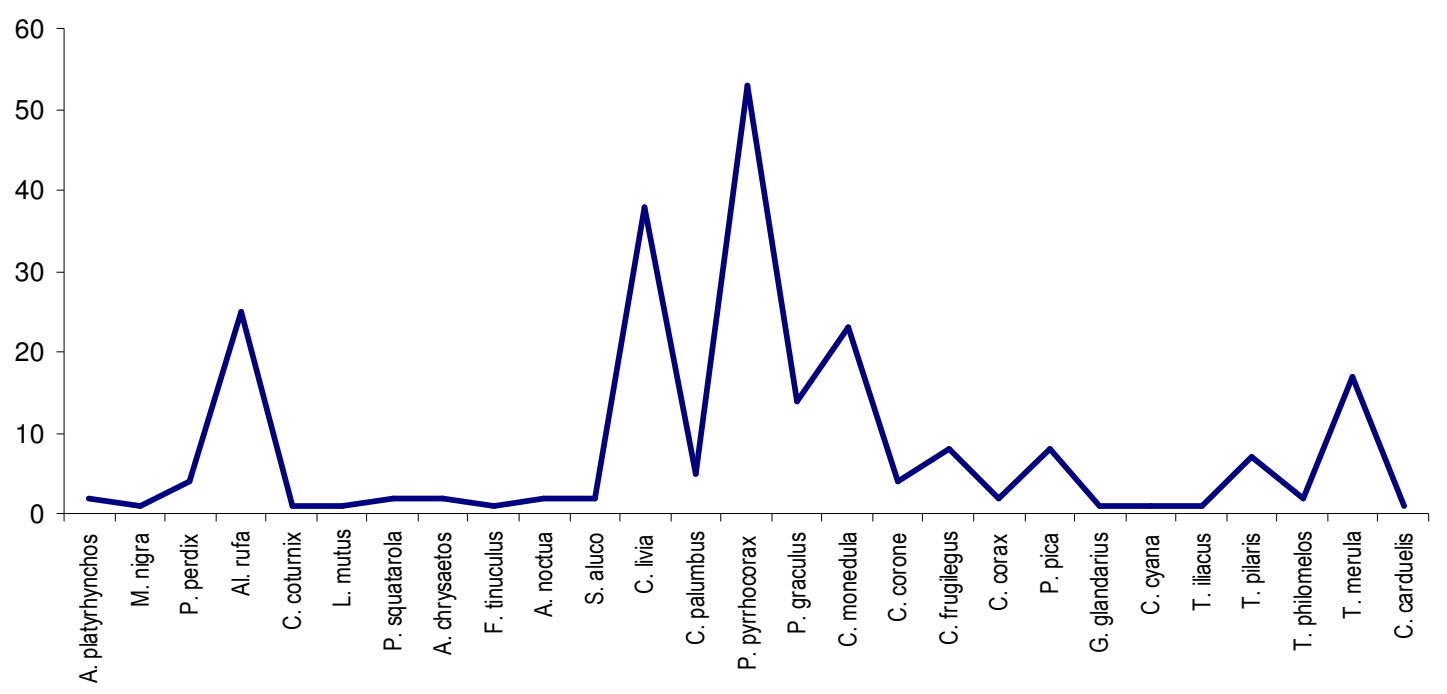

Gráfico 19 - Ocorrência global das diferentes espécies, segundo o número total de restos.

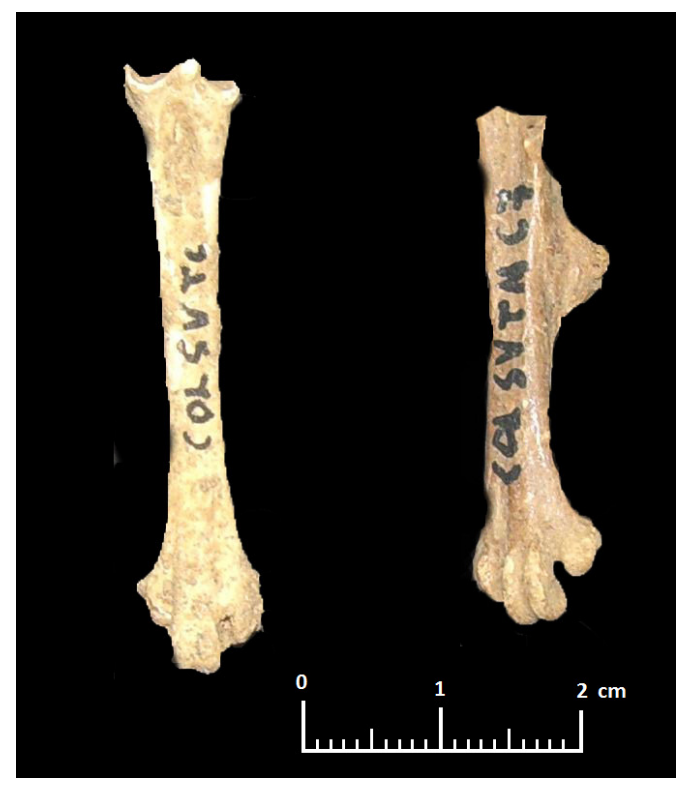

Fig. 72 - Tarsometarsos de A. rufa, da Gruta Nova da Columbeira (depois de algumas espécies de corvídeos e da C. livia, esta é a espécie que mais ocorre nesta jazida. À esquerda de fêmea (vista cranial) e à direita de macho (vista cranial). Fotografia de S. Figueiredo.

\section{Sistemática Paleontológica}

Ordem: GALLIFORMES (TEMMINCK, 1820)

Família: TETRAONIDAE (VIGORS, 1825)

TETRAONIDAE INDET.

Material: 1 ulna, 1 Carpometacarpo. 
Total de restos: 2

Ordem: GALLIFORMES (TEMMINCK, 1820)

Família: PHASIANIDAE (HORSEFIELD, 1821)

PHASIANIDAE INDET.

Material: 1 coracóide, 1 rádio, 2 tarsometatarsos.

Total de restos: 4

Ordem: GALLIFORMES (TEMMINCK, 1820)

Família: PhASIANIDAE (HORSEFIELD, 1821)

Género: Alectoris (KAUP, 1829)

Alectoris sp.

Material: 1 úmero, 6 tarsometatarsos.

Total de restos: 7

Ordem: Galliformes (TEMminCK, 1820)

Família: PHASIANIDAE (HORSEFIELD, 1821)

Género: Alectoris (KAUP, 1829)

Alectoris rufa (LINNAEUS, 1758)

Material: 1 coracóide, 1 úmero, 1 rádio, 7 carpos-mertacarpos, 12 tarsometatarsos.

Total de restos: 22

Ordem: GALLIFORMES (TEMMINCK, 1820)

Família: PHASIANIDAE (HORSEFIELD, 1821)

Género: Alectoris (KAUP, 1829)

Cf. Alectoris barbara (BONNATERRE, 1791)

Material: 1 úmero, 2 tarsometatarsos.

Total de restos: 3

Ordem: GALLIFORMES (TEMMINCK, 1820) 
Família: PHASIANIDAE (HORSFIELD, 1821)

Género: Perdix (BRISSON, 1760)

Perdix sp

Material: 2 tarsometatarsos.

Total de restos: 2

Ordem: GALLIFORMES (TEMMINCK, 1820)

Família: PHASIANIDAE (HORSFIELD, 1821)

Género: Perdix (BRISSON, 1760)

Perdix perdix (LINNAEUS, 1758)

Material: 2 tarsometatarsos, 1 Tibiotarso.

Total de restos: 3

Ordem: GALLIFORMES (TEMMINCK, 1820)

Família: PHASIANIDAE (HORSFIELD, 1821)

Género: Coturnix (BONNATERRE, 1791)

Coturnix coturnix (LINNAEUS, 1758)

Material: 1 úmero.

Total de restos: 1

Ordem: GALLIFORMES (TEMminCK, 1820)

Família: PhASIANIDAE (HORSFIELD, 1821)

Género: Lagopus (BRISSON, 1760)

Lagopus SP

Material: 2 tarsometatarsos.

Total de restos: 2

Ordem: GALLIFORMES (TEMMINCK, 1820)

Família: PhASIANIDAE (HORSFIELD, 1821)

Género: Lagopus (BRISSON, 1760) 
Material: 1 tarsometatarso.

Total de restos: 1

Ordem: ANSERIFORMES (WAGLER, 1831)

Família: ANATIDAE (VIGORS, 1825)

ANATIDAE INDET.

Material: 2 úmeros, 2 ulnas, 2 tarsometatarsos.

Total de restos: 6

Ordem: ANSERIFORMES (WAGLER, 1831)

Família: ANATIDAE (VIGORS, 1825)

Subfamília: ANATINAE (LEACH, 1820)

Género: Anas (LINNAEUS, 1758)

Anas sp.

Material: 1 úmero, 1 escápula.

Total de restos: 2

Ordem: ANSERIFORMES (WAGLER, 1831)

Família: ANATIDAE (VIGORS, 1825)

Subfamília: ANATINAE (LEACH, 1820)

Género: Anas (LINNAEUS, 1758)

Anas platyrhynchos (LINNAEUS, 1758)

Material: 2 tarsometatarsos.

Total de restos: 2

Ordem: ChARADRIIFORMES (HUXLEY, 1867)

Família: CHARADRIIDAE (VIGORS, 1825) 
Género: Pluvialis (BRISSON, 1760)

Pluvialis squatarola (LINNAEUS, 1758)

Material: 1 Carpometacarpo; 1 tarsometatarso.

Total de restos: 2

Ordem: ChARADRIIFORMES (HUXLEY, 1867)

Família: VANeLLIDAE (BONAPARTE, 1842)

Género: Vanellus (BRISSON, 1760)

Vanellus sp.

Material: 1 tarsometatarso, 1 Carpometacarpo.

Total de restos: 2

Ordem: CHARADRIIFORMES (HUXLEY, 1867)

Família: LARIDAE (VIGORS, 1825)

Género: Larus (LINNAEUS, 1758)

Larus sp.

Material: 1 úmero.

Total de restos: 1

Ordem: CHARADRIIFORMES (HUXLEY, 1867)

Família: SCOLOPACIDAE (VIGORS, 1825)

Género: Limosa (BRISSON, 1760)

Limosa sp.

Material: 1 tarsometatarso.

Total de restos: 1

Ordem: FalCONIFORMES (ShARPE 1874)

Família: FALCONIDAE (VIGORS, 1825)

Género: Falco (LINNAEUS, 1758)

Falco sp. 
Material: 1 Escápula.

Total de restos: 1

Ordem: FalConiformes (ShARPE 1874)

Família: FALCONIDAE (VIGORS, 1825)

Género: Falco (LINNAEUS, 1758)

Falco tinnuculus (LINNAEUS, 1758)

Material: 1 Fémur.

Total de restos: 1

Ordem: FAlCONIFORMES (ShARPE 1874)

ACCIPITRIDAE INDET.

Material: 1 Ulna.

Total de restos: 1

Ordem: FALCONIFORMES (SHARPE 1874)

Família ACCIPITRIDAE (VIEILLOT, 1816)

Género: Aquila (LINNAEUS, 1758)

Aquila sp

Material: 1 Ulna.

Total de restos: 1

Ordem: FALCONIFORMES (ShARPE 1874)

Família ACCIPITRIDAE (VIEILLOT, 1816)

Género: Aquila (LINNAEUS, 1758)

Aquila chrysaetos (LINNAEUS, 1758)

Material: 1 ulna.

Total de restos: 1 
Ordem: StRIGIFORMES (WAGLER, 1830)

Família: STRIGIDAE (VIGORS, 1825)

STRIGIDAE INDET.

Material: 1 tibiotarso.

Total de restos: 1

Ordem: StRIGIFORMES (WAGLER, 1830)

Família: STRIGIDAE (VIGORS, 1825)

Género: Strix (LINNAEUS, 1758)

Strix aluco (LINNAEUS, 1758)

Material: 2 fémures.

Total de restos: 2

Ordem: STRIGIFORMES (WAGLER, 1830)

Família: STRIGIDAE (VIGORS, 1825)

Género: Athene (BOIE, 1822)

Género: Athene SP.

Material: 1 úmero.

Total de restos: 1

Ordem: StRIGIFORMES (WAGLER, 1830)

Família: STRIGIDAE (VIGORS, 1825)

Género: Athene (BOIE, 1822)

Athene noctua (SCOPOLI, 1769)

Material: 1 fémur, 1 tarsometatarso.

Total de restos: 2

Ordem: Columbiformes (LATHAM, 1790)

Família: COLUMBIDAE, (ILLIGER,1811) 
Subfamília: COLUMBINAE, (ILLIGER,1811)

Columbasp.

Material: 1 coracóide, 7 úmeros, 1 rádio, 3 ulnas, 1 carpo-mertacarpo, 1 fémur, 1 falange (pé).

Total de restos: 15

Ordem: COLUMBIFORMES (LATHAM, 1790)

Família: ColumbidAe, (ILLIGER,1811)

Subfamília: COLUMBINAE, (ILLIGER,1811)

Género: Columba (LINNAEUS, 1758)

Espécie: Columba livia, (GMELIN, 1789)

Material: 8 coracóides, 21 úmeros, 5 ulnas, 3 carpos-mertacarpos, 1 tibiotarso.

Total de restos: 36

Ordem: ColumbifORMES (LATHAM, 1790)

Família: COLUMBIDAE, (ILLIGER,1811)

Género: Columba (LINNAEUS, 1758)

Espécie: Columba palumbus, (LINNAEUS, 1758)

Material: 2 úmeros, 2 tarsometatarsos.

Total de restos: 4

Ordem: PASSERIFORMES (LINNAEUS, 1758)

Família: CORVIDAE (VIGORS, 1825)

CORVIDAE INDET.

Material: 2 coracóides, 13 úmeros, 13 ulnas, 3 carpos-mertacarpos, 2 fémures; 11 tarsometatarsos.

Total de restos: 44

Ordem: PASSERIFORMES (LINNAEUS, 1758)

Família: CORVIDAE (VIGORS, 1825) 
Família: CORVIDAE (VIGORS, 1825)

Corvus sp.

Material: 2 coracóides, 2 úmeros, 3 ulnas, 4 carpos-mertacarpos, 1 fémur, 2 tarsometatarsos.

Total de restos: 14

Ordem: PASSERIFORMES (LINNAEUS, 1758)

Família: CORVIDAE (VIGORS, 1825)

Género: Corvus (LINNAEUS, 1758)

Corvus corax (LINNAEUS, 1758)

Material: 1 úmero, 1 ulna, 1 tarsos-metatarso.

Total de restos: 3

Ordem: PASSERIFORMES (LINNAEUS, 1758)

Família: CORVIDAE (VIGORS, 1825)

Género: Corvus (LINNAEUS, 1758)

Corvus frugilegus (LINNAEUS, 1758)

Material: 1 coracóides, 1 úmero, 3 ulnas, 2 carpos-mertacarpos, 1 fémur.

Total de restos: 8

Ordem: PASSERIFORMES (LINNAEUS, 1758)

Família: CORVIDAE (VIGORS, 1825)

Género: Corvus (LINNAEUS, 1758)

Corvus corone (LINNAEUS, 1758)

Material: 1 ulna, 2 carpos-mertacarpos.

Total de restos: 3

Ordem: PASSERIFORMES (LINNAEUS, 1758)

Família: CORVIDAE (VIGORS, 1825)

Género: Corvus (LINNAEUS, 1758)

Corvus corone / Corvus frugilegus

Material: 1 coracóide, 1 úmero, 1 ulna, 1 fémur.

Total de restos: 4 
Ordem: PASSERIFORMES (LINNAEUS, 1758)

Família: CORVIDAE (VIGORS, 1825)

Género: Corvus (LINNAEUS, 1758)

Corvus monedula (LINNAEUS, 1758)

Material: 1 escápula, 3 coracóides, 10 úmeros, 4 ulnas, 6 carpos-mertacarpos, 1 tarsometatarso.

Total de restos: 25

Ordem: PASSERIFORMES (LINNAEUS, 1758)

Família: CORVIDAE (VIGORS, 1825)

Género: Corvus (LINNAEUS, 1758)

Corvus monedula / Pyrrhocorax graculus

Material: 1 tarsometatarso.

Total de restos: 1

Ordem: PASSERIFORMES (LINNAEUS, 1758)

Família: CORVIDAE (VIGORS, 1825)

Género: Pica (BRISSON, 1760)

Pica pica (LINNAEUS, 1758)

Material: 2 coracóides, 3 úmeros, 1 ulna, 3 fémures, 1 tibiotarso, 2 tarsometatarsos.

Total de restos: 12

Ordem: PASSERIFORMES (LINNAEUS, 1758)

Família: CORVIDAE (VIGORS, 1825)

Género: Pyrrhocorax (TNSTALL, 1771)

Pyrrhocorax sp.

Material: 2 coracóides, 9 úmeros, 9 ulnas, 4 carpometacarpos, 6 fémures, 4 tarsometatarsos.

Total de restos: 34 
Ordem: PASSERIFORMES (LINNAEUS, 1758)

Família: CORVIDAE (VIGORS, 1825)

Género: Pyrrhocorax (TNSTALL, 1771)

Pyrrhocorax pyrrhocorax (LINNAEUS, 1758)

Material: 1 escápula, 5 coracóides, 16 úmeros, 17 ulnas, 20 carpometacarpos, 17 fémures, 7 tarsometatarsos.

Total de restos: 83

Material

Ordem: PASSERIFORMES (LINNAEUS, 1758)

Família: CORVIDAE (VIGORS, 1825)

Género: Pyrrhocorax (TNSTALL, 1771)

Pyrrhocorax graculus (LINNAEUS, 1758)

Material: 2 coracóides, 4 úmeros, 7 ulnas, 2 carpometacarpos, 1 falange (II dg), 1 fémures, 1 tarsometatarsos.

Total de restos: 18

Ordem: PASSERIFORMES (LINNAEUS, 1758)

Família: CORVIDAE (VIGORS, 1825)

Género: Garrulus (BRISSON, 1760)

Garrulus glandarius (LINNAEUS, 1758)

Material: 2 ulnas.

Total de restos: 2

Ordem: PASSERIFORMES (LINNAEUS, 1758)

Família: CORVIDAE (VIGORS, 1825)

Género: Cyanopica (BONAPARTE, 1850)

Cf. Cyanopica cyana (PALLAS, 1776)

Material: 1 tibiotarso.

Total de restos: 1 
Ordem: PASSERIFORMES (LINNAEUS, 1758)

Família: TURDIDAE (BONNAPARTE, 1850)

Material: 1 úmero.

Total de restos: 1

Ordem: PASSERIFORMES (LINNAEUS, 1758)

Família: TURDIDAE (BONNAPARTE, 1850)

Género: Turdus, (LINNAEUS, 1758)

Turdus sp.

Material: 5 úmeros.

Total de restos: 5

Ordem: PASSERIFORMES (LINNAEUS, 1758)

Família: TURDIDAE (BONNAPARTE, 1850)

Género: Turdus, (LINNAEUS, 1758)

Turdus philomelos (BREHM, 1831)

Material: 1 úmero, 1 ulna.

Total de restos: 2

Ordem: PASSERIFORMES (LINNAEUS, 1758)

Família: TURDIDAE (BONNAPARTE, 1850)

Género: Turdus, (LINNAEUS, 1758)

Turdus pilaris (BREHM, 1831)

Material: 9 úmeros, 2 ulnas, 1 Carpometacarpo.

Total de restos: 12

Ordem: PASSERIFORMES (LINNAEUS, 1758)

Família: TURDIDAE (BONNAPARTE, 1850)

Género: Turdus, (LINNAEUS, 1758)

Turdus merula (LINNAEUS, 1758) 
Material: 10 úmeros, 6 ulnas.

Total de restos: 16

Ordem: PASSERIFORMES (LINNAEUS, 1758)

Família: TURDIDAE (BONNAPARTE, 1850)

Género: Turdus, (LINNAEUS, 1758)

Turdus iliacus (LINNAEUS, 1758)

Material: 1 úmero.

Total de restos: 1

Ordem: PASSERIFORMES (LINNAEUS, 1758)

Família: HIRUNDIDAE (VIGORS, 1825)

Género: Ptyonoprogne, (REICHENBACH, 1850)

Cf. Ptyonoprogne rupestris (SCOPOLI, 1769)

Material: 1 úmero.

Total de restos: 1

Ordem: PASSERIFORMES (LINNAEUS, 1758)

Família: FrINGILLIDAE (VIGORS, 1825)

Género: Carduelis, (BRISSON, 1760)

Carduelis carduelis (LINNAEUS, 1758)

Material: 1 úmero.

Total de restos: 1

Ordem: PICIFORMES (MEYER \& WOLF, 1810)

Família: AlAUdidAE (VIGORS, 1825)

ALAUDIDAE INDET.

Material: 1 úmero.

Total de restos: 1

Ordem: PICIFORMES (MeYER \& Wolf, 1810)

Família: PICIDAE (VIGORS, 1825) 
Género: Picus, (LINNAEUS, 1758)

Cf. Picus viridis (LINNAEUS, 1758)

Material: 1 fémur

Total de restos: 1

Ordem: CUCULIFORMES (WAGLER, 1830)

Família: CUCULIDAE (VIGORS, 1825)

CUCULIDAE INDET

Material: 1 úmero

Total de restos: 1

Aos restos em que foi possível identificar a espécie foi feito um estudo sobre o número mínimo de indivíduos, tendo sido reconhecidos 111, das 27 espécies identificadas. A relação do número mínimo de indivíduos entre a espécie e a ordem permite conhecer a relação dos principais grupos de aves que foram encontrados na Gruta Nova da Columbeira.

Assim, foi possível concluir que existe uma predominância de espécies de passeriformes sobre todos os outros grupos, em especial de corvídeos, num total de 72 indivíduos (64,8 \% do total dos indivíduos). Dos outros grupos há a destacar os columbiformes, com 16 indivíduos (14,4 \%) e os galliformes, com 13 (11,7\%). Todos os restantes grupos representam apenas 9,1\% do total. 


\begin{tabular}{|c|c|c|c|c|c|c|c|}
\hline Espécies & $\mathrm{C} 6$ & $\mathrm{C6a}$ & $\mathrm{C7}$ & $\mathrm{C} 8$ & $\mathrm{C} 9$ & NS & Total \\
\hline A. platyrhynchos & & & 1 & 1 & & & 2 \\
\hline M. nigra & & & 1 & & & & 1 \\
\hline P. perdix & & 1 & 1 & & & & 2 \\
\hline Cf. A. barbra & & 2 & & & & & 2 \\
\hline A. rufa & 2 & 3 & 2 & 1 & 1 & & 9 \\
\hline C. coturnix & & & 1 & & & & 1 \\
\hline L. mutus & & 1 & 1 & & & & 2 \\
\hline P. squatarola & & 1 & & & & & 1 \\
\hline A. chrysaetos & & & & 2 & & & 2 \\
\hline F. tinuculus & 1 & & & & & & 1 \\
\hline A. noctua & 1 & & & & 1 & & 2 \\
\hline S. aluco & 2 & & & & & & 2 \\
\hline C. livia & 3 & 6 & 4 & & & & 13 \\
\hline C. palumbus & & 1 & 1 & 1 & & & 3 \\
\hline P. pyrrhocorax & 6 & 5 & 4 & 1 & 2 & 1 & 19 \\
\hline P. graculus & 4 & 2 & 1 & & & & 7 \\
\hline C. monedula & 6 & 2 & 2 & 1 & & & 11 \\
\hline C. corone & 1 & 1 & 1 & & & & 3 \\
\hline C. frugilegus & 2 & 1 & 2 & & & & 5 \\
\hline C. corax & & 1 & 1 & & & & 2 \\
\hline P. pica & 1 & & 1 & & 1 & & 3 \\
\hline G. glandarius & & & & 1 & & & 1 \\
\hline cf. C. cyana & & 1 & & & & & 1 \\
\hline T. iliacus & & 4 & 1 & & & & 5 \\
\hline T. pilaris & & 4 & 1 & & & & 5 \\
\hline T. philomelos & & 3 & 1 & & & & 4 \\
\hline T. merula & 1 & & 4 & 1 & & & 6 \\
\hline C. carduelis & & & 1 & & & & 1 \\
\hline P. rupestris & & & 1 & & & & 1 \\
\hline
\end{tabular}

Quadro 20 - Número mínimo de indivíduos (NMI) das espécies identificadas e a sua distribuição, por camada. 


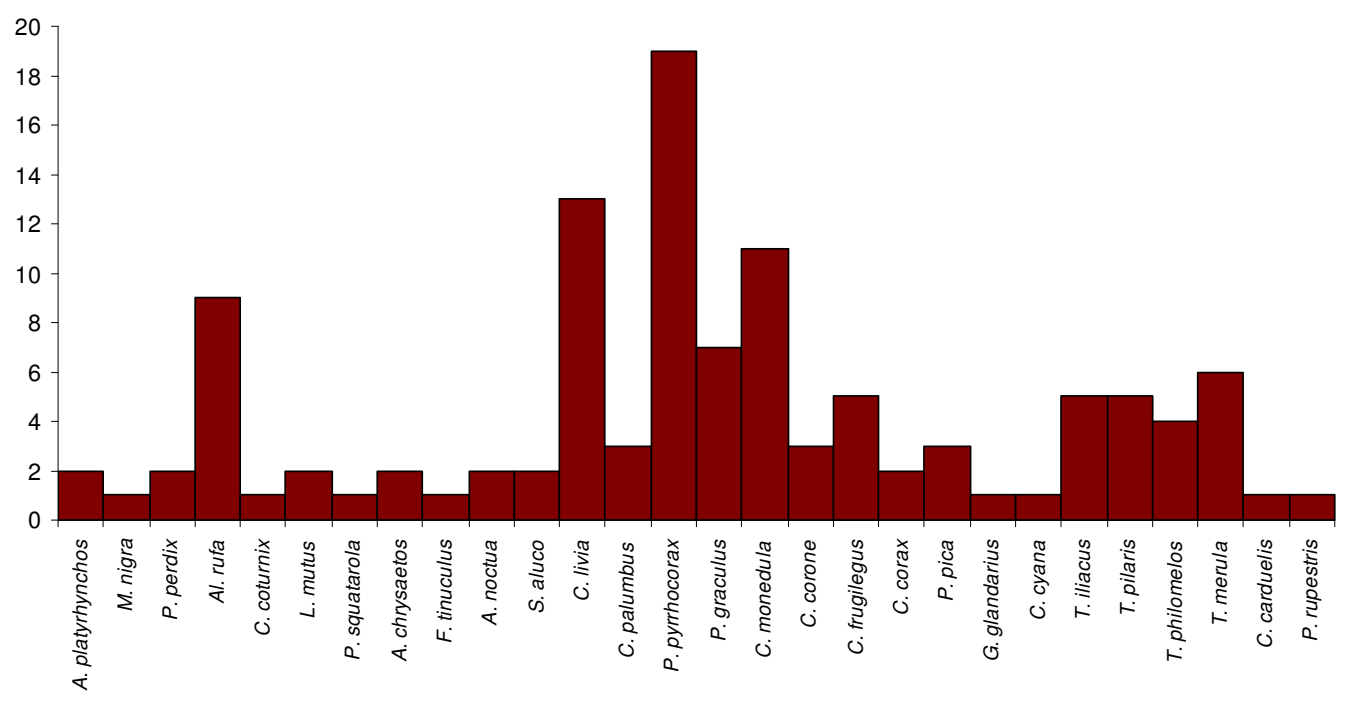

Gráfico 20 - Ocorrência total das espécies reconhecidas na Gruta Nova da Columbeira, segundo o número mínimo de indivíduos.

\begin{tabular}{l||rr||rr}
\multicolumn{1}{c||}{ Espécies } & NMI & \multicolumn{1}{c||}{$\%$} & NTR & $\%$ \\
\hline \hline A. platyrhynchos & 2 & 1.75 & 2 & 0.72 \\
P. perdix & 2 & 1.75 & 3 & 1.09 \\
Cf. A. barbara & 2 & 1.75 & 3 & 1.09 \\
A. rufa & 9 & 8.03 & 19 & 6.90 \\
C. coturnix & 1 & 0.89 & 1 & 0.36 \\
L. mutus & 2 & 1.75 & 3 & 1.09 \\
P. squatarola & 1 & 0.89 & 2 & 0.72 \\
A. chrysaetos & 2 & 1.75 & 2 & 0.72 \\
F. tinuculus & 1 & 0.89 & 1 & 0.36 \\
A. noctua & 2 & 1.75 & 2 & 0.72 \\
S. aluco & 2 & 1.75 & 2 & 0.72 \\
C. livia & 13 & 11.80 & 39 & 14.18 \\
C. palumbus & 3 & 2.67 & 4 & 1.44 \\
P. pyrrhocorax & 19 & 16.94 & 82 & 29.81 \\
P. graculus & 7 & 6.25 & 23 & 8.36 \\
C. monedula & 11 & 9.82 & 26 & 9.45 \\
C. corone & 3 & 2.67 & 6 & 2.18 \\
C. frugilegus & 5 & 4.46 & 11 & 4.00 \\
C. corax & 2 & 1.75 & 2 & 0.72 \\
P. pica & 3 & 2.67 & 10 & 3,63 \\
G. glandarius & 1 & 0.89 & 1 & 0.36 \\
Cf. C. cyana & 1 & 0.89 & 1 & 0.36 \\
T. iliacus & 5 & 4.46 & 1 & 0.36 \\
T. pilaris & 3 & 2.67 & 12 & 4.36 \\
T. philomelos & 4 & 3.50 & 2 & 0.72 \\
T. merula & 6 & 5.34 & 16 & 5.81 \\
C. carduelis & 1 & 0.89 & 1 & 0.36 \\
P. rupestris & 1 & 0.89 & 1 & 0.36
\end{tabular}

Quadro 21 - Número mínimo de indivíduos (NMI) e número total de restos (NTR) das espécies reconhecidas e respectiva percentagem. 


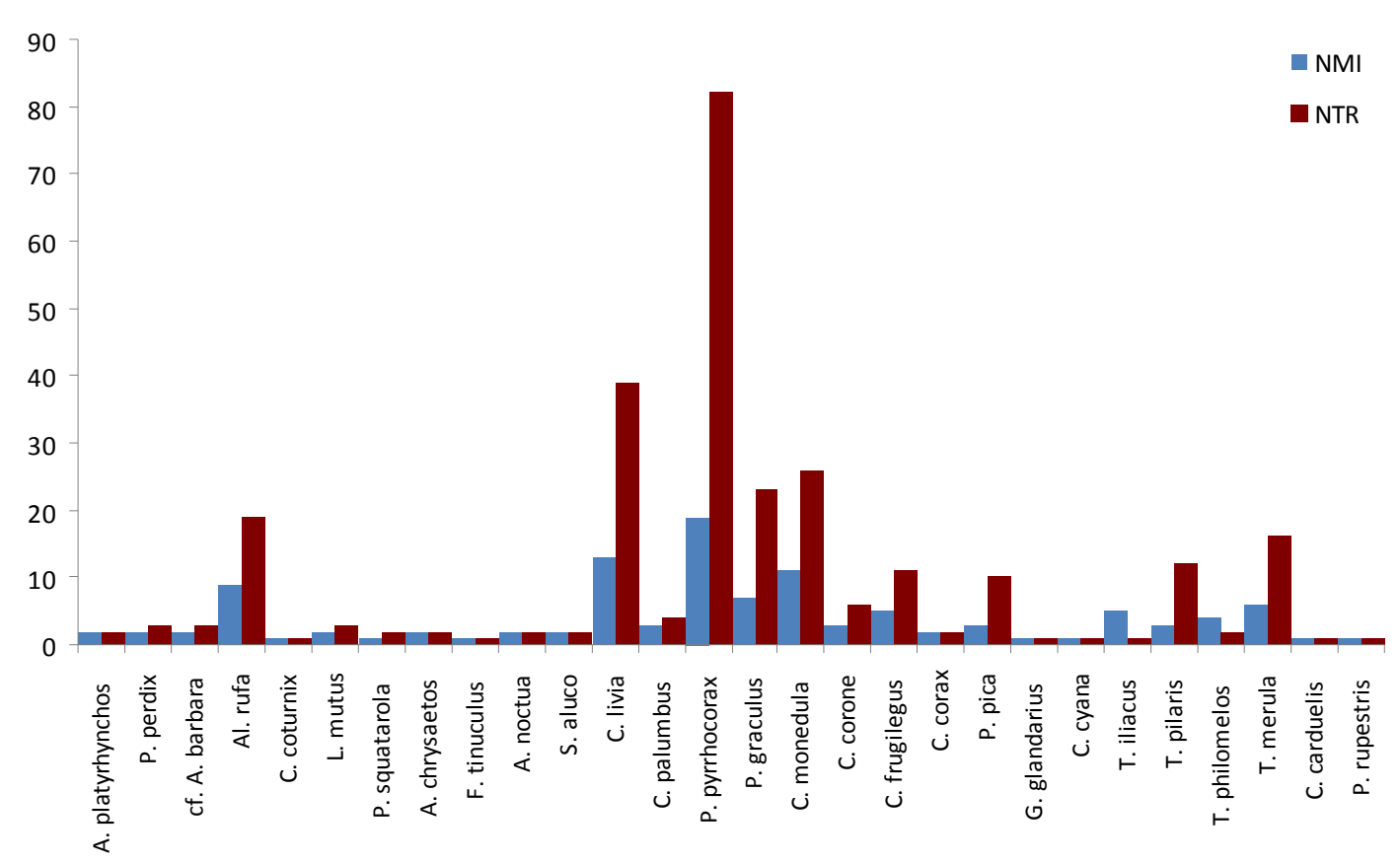

Gráfico 21 - Gráfico com o número mínimo de indivíduos (NMI) e número total de restos (NTR) por espécie identificada.

Pela análise do gráfico anterior, verifica-se uma correspondência relativa entre o número mínimo de indivíduos e o número total de restos.

Se a estes dados se acrescentar o número de indivíduos a nível da ordem, o panorama é algo semelhante. Os passeriformes continuam a ser a ordem com um maior número: 105 indivíduos (61\%). A seguir encontram-se os columbiformes, com 23 (13.3\%), enquanto os galliformes apresentam 26 indivíduos (15,1\%). As restantes ordens identificadas na Gruta Nova da Columbeira representam apenas 10,6 \% do total de indivíduos identificados.

No que diz respeito à atribuição de idades, afere-se uma maior quantidade de restos de adultos que de subadultos ou de jovens. A Gruta Nova da Columbeira é, das jazidas estudas, a que maior número de indivíduos de idade jovem ou subadulta apresenta, com mais de $16 \%$, da amostra total identificada.

Analisando especificamente os indivíduos jovens, à grande maioria deles não foi possível atribuir uma classificação taxonómica, pois ainda não têm as diáfises completamente definidas e é muito difícil, desta forma, atribuir um táxon mais específico a estes restos.

No caso dos indivíduos subadultos, o número de aves indeterminadas é 
também elevado, aparecendo no entanto em terceiro lugar. Em termos taxonómicos, verifica-se, tal como nos adultos, um predomínio dos passeriformes, em especial dos corvídeos e, dentro destes, do género Pyrrhocorax. Existe também um ligeiro destaque do género Columba, ficando mais ou menos equiparados os restantes grupos taxonómicos dos indivíduos subadultos estudados.

\section{4 - Tafonomia}

Os materiais estudados não tinham marcas de corte nem indícios de terem sido queimados. À excepção de um resto, também não foram encontradas marcas de predação nos ossos estudados. Este resto apresenta marcas que poderão ser de pequenos dentes de pequenos roedores ou de marcas de larvas, também não foram encontradas nos ossos estudados. No entanto, como se viu, a maior parte dos ossos encontra-se partida. Este facto estará ligado às condições de sedimentação e de pedogénese da gruta e não tanto a eventuais intervenções de carnívoros ou do próprio homem. É provável também que alguns dos ossos tenham sido fragmentados durante a escavação, uma vez que foi possível colar alguns dos fragmentos.

A partir do estudo tafonómico, em especial pelo facto da não se terem encontrado marcas nos ossos e pelas espécies identificadas, pode concluir-se que a grande maioria das aves presentes na amostra da Gruta Nova da Columbeira se deve a acumulações naturais de aves que a frequentavam ou lá ficavam retidas. Apenas uma pequena parte terá sido consumida pelos carnívoros ou pelos homens que também frequentaram a gruta. 


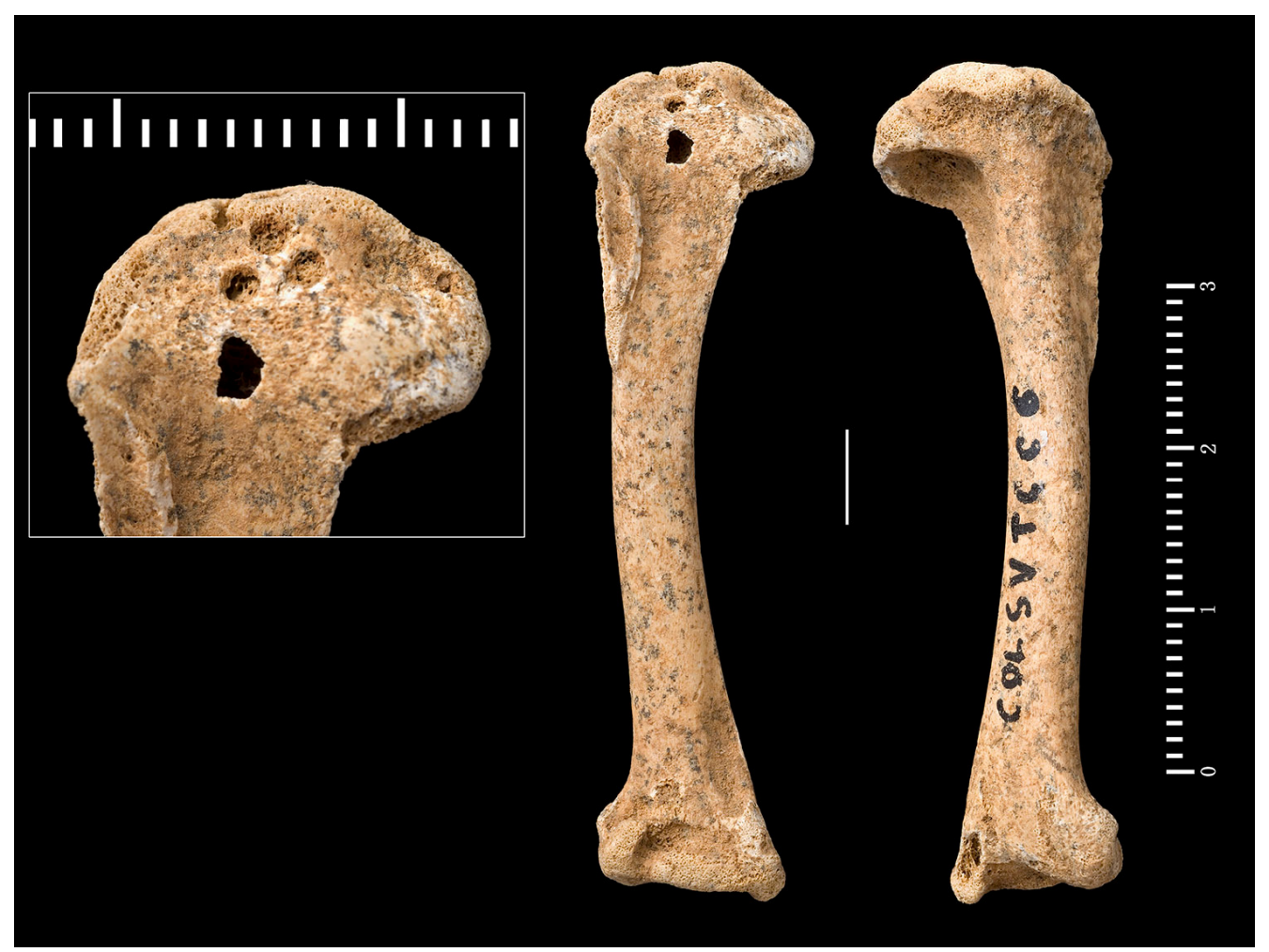

Fig. 73 - Úmero de $P$. graculus com pequenas marcas de dentes de pequenos roedores ou de actividade de larvas. (MB. 01.217).

\section{5 - Reconstituição paleoecológica}

Pela análise da avifauna da Gruta Nova da Columbeira, percebe-se o predomínio das espécies características de um ambiente de cariz mais de interior, como era de esperar, devido à sua localização geográfica. Na Gruta Nova da Columbeira, as espécies marinhas são residuais. Por outro lado, verifica-se um grande número de restos de espécies de ambientes secos (charnecas, matas e bosques) e uma quase inexistência de espécies de zonas húmidas. A grande predominância dos Phyrrhocorax está de acordo com a zona envolvente da gruta: zona de montanha e com rochedos, o habitat das duas espécies deste género ( $P$. phyrrhocorax, na montanha e nos rochedos, e $P$. graculus, na montanha).

As espécies identificadas são maioritariamente de clima temperado-frio, o que revela que, aquando da ocupação paleolítica da gruta, com temperaturas, um pouco mais baixas, correspondiam a um clima algo mais frio que o actual. Estas conclusões são dadas pela ocorrência de algumas espécies de aves características de climas mais frios, de que são exemplo o Phyrrhocorax graculus e o Lagopus mutus. 
Estes dados correspondem aos indicadores fornecidos pelos grandes mamíferos que, segundo o estudo realizado por João Luís Cardoso, indicam "um biótopo frio com uma componente de secura, embora não muito acentuada" (CARDOSO, 1993, pp. 527).

O estudo acerca da paleoecologia da Gruta Nova da Columbeira mostrou que existe uma maior quantidade de espécies e géneros de táxones de ambientes de zonas de mato e de campo aberto. No entanto, pela distribuição paleoecológica do número mínimo de indivíduos (gráfico 22), verifica-se um número mais elevado de indivíduos de espécies de montanha e de zonas rochosas. As zonas de estuário e zonas costeiras apresentam um número de indivíduos muito reduzido, o que se explica pela localização geográfica desta jazida. Existem também indivíduos de espécies que habitam zonas húmidas, em pequeno número, mas mais significativo do que os de zonas costeiras. A presença destas aves aquáticas está relacionada, no primeiro caso, com a relativa proximidade da costa - em linha recta (cerca de dez quilómetros) - no segundo caso, com a existência de duas linhas de água nas proximidades. A ribeira da Columbeira e o rio Real. Também estes dados estão de acordo com os dos grandes mamíferos que indicam espécies associadas a relevos, como a cabra montês, a espaços abertos, como o cavalo e a manchas florestais, em locais mais abrigados e húmidos, como o veado (CARDOSO, 1993, pp. 257).

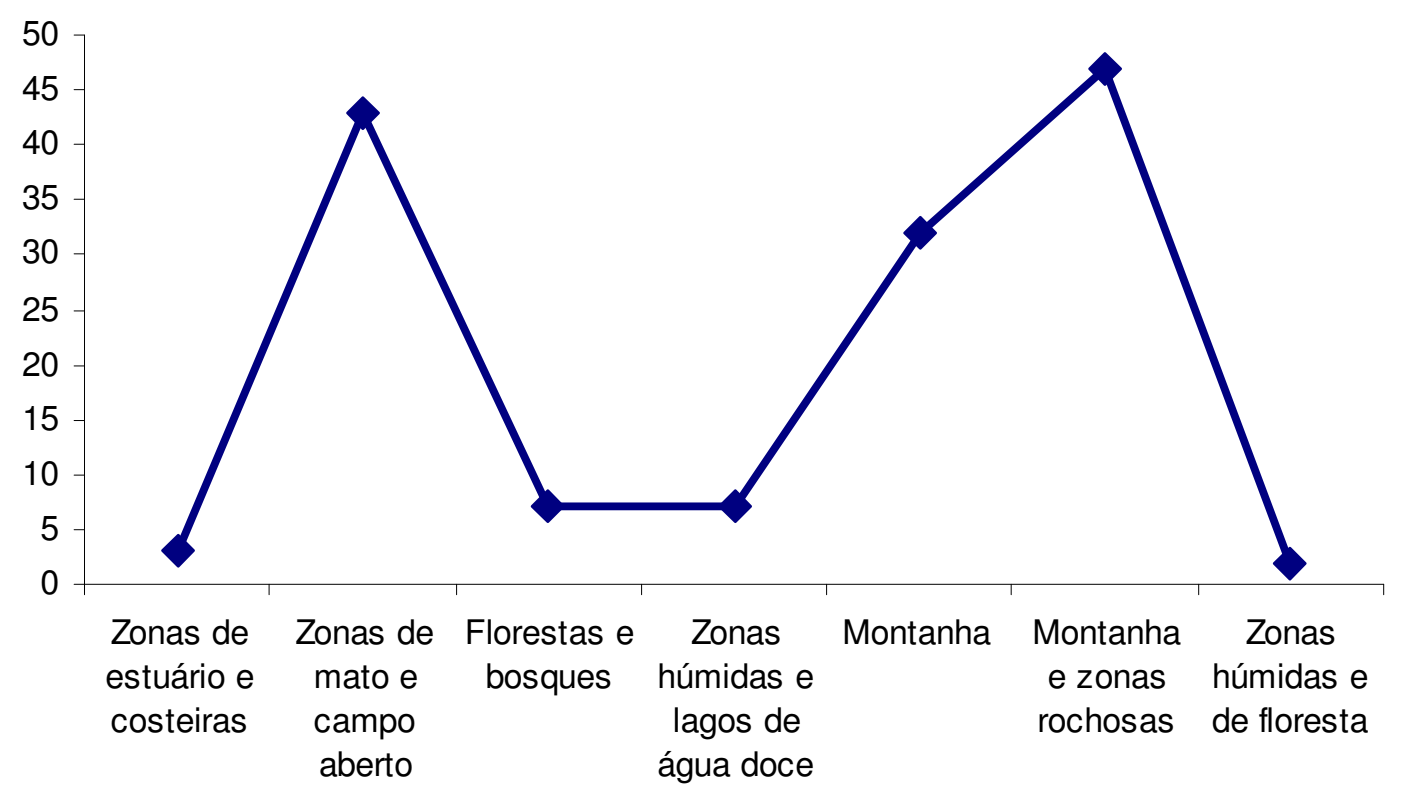

Gráfico 22 - Comparação dos ambientes das espécies de aves da Gruta Nova da Columbeira, segundo a distribuição do NMI de cada espécie pelos respectivos ambientes.. 
Na distribuição das espécies pelas probabilidades de ocorrência no ambiente (ou nos ambientes) dos seus representantes actuais (quadro 22 e gráfico23), verificase uma diferença em relação à distribuição paleoecológica, usando como critério o número mínimo de indivíduos de cada espécie. Assim, se se considerar cada espécie como uma unidade paleoecológica, verifica-se um domínio de ambientes de campo aberto e de bosques; os ambientes húmidos, de montanha e costeiros têm pouca significância e os de zonas rochosas e de água doce são escassos.

\begin{tabular}{|c|c|c|c|c|c|c|c|c|}
\hline & Bos & $\mathrm{CA}$ & $\mathrm{Zh}$ & LAD & Mont & ZR & Flo & $\mathrm{Cos}$ \\
\hline A. rufa & & 1 & & & & & & \\
\hline cf. A. barbara & & 1 & & & & & & \\
\hline P. perdix & & 1 & & & & & & \\
\hline C. coturnix & & 1 & & & & & & \\
\hline P. pica & 0,5 & 0,5 & & & & & & \\
\hline G. glandarius & & 0,5 & & & & & 0,5 & \\
\hline C. frugilegus & 0,5 & 0,5 & & & & & & \\
\hline C. corax & & 0,33 & 0,33 & & & & & 0,33 \\
\hline C. corone & 0,33 & 0,33 & 0,33 & & & & & \\
\hline P. graculus & & & & & 1 & & & \\
\hline Pyrrhocorax sp & & & & & 0,5 & & & 0,5 \\
\hline C. monedula & 0,33 & 0,33 & & & & & & 0,33 \\
\hline P. pyrrhocorax & & & & & 0,5 & & & 0,5 \\
\hline cf. C. cyana & 1 & & & & & & & \\
\hline T. iliacus & 0,5 & 0,5 & & & & & & \\
\hline T. pilaris & 0,5 & 0,5 & & & & & & \\
\hline T. philomelos & 0,5 & 0,5 & & & & & & \\
\hline T. merula & 0,5 & 0,5 & & & & & & \\
\hline C. carduelis & 0,5 & 0,5 & & & & & & \\
\hline P. rupestris & & & & & 0,5 & 0,5 & & \\
\hline F. tinuculus & & & & & & 0,5 & 0,5 & \\
\hline A. chrysaetos & & 0,33 & 0,33 & & & & 0,3 & \\
\hline Larus sp & & & & & & & & 1 \\
\hline A. platyrhynchos & & & 0,5 & 0,5 & & & & \\
\hline Limosa $s p$ & & 0,33 & 0,33 & 0,33 & & & & \\
\hline Vanellus $s p$ & & 0,33 & 0,33 & 0,33 & & & & \\
\hline L. mutus & & & 1 & & & & & \\
\hline S. aluco & 0,33 & 0,33 & & & & & 0,3 & \\
\hline A. noctua & 0,5 & 0,5 & & & & & & \\
\hline P. viridis & 0,5 & 0,5 & & & & & & \\
\hline C. livia & & & & & & 0,5 & & 0,5 \\
\hline C. palumbus & 0,33 & 0,33 & & & & & 0,3 & \\
\hline Total & $\mid 6,82$ & 111,6 & 3,15 & 1,16 & 2,5 & 1,5 & 2 & 3,16 \\
\hline
\end{tabular}

Quadro 22- Espécies e géneros identificados na Gruta Nova da Columbeira e a distribuição pelos ambientes a que estão associados. (Bos - bosques; CA - campo aberto; LAD - lagos de água doce; Mont - montanha; ZR - zonas rochosas; ZH - zonas húmidas; Flo - floresta; Cos zonas costeiras). 


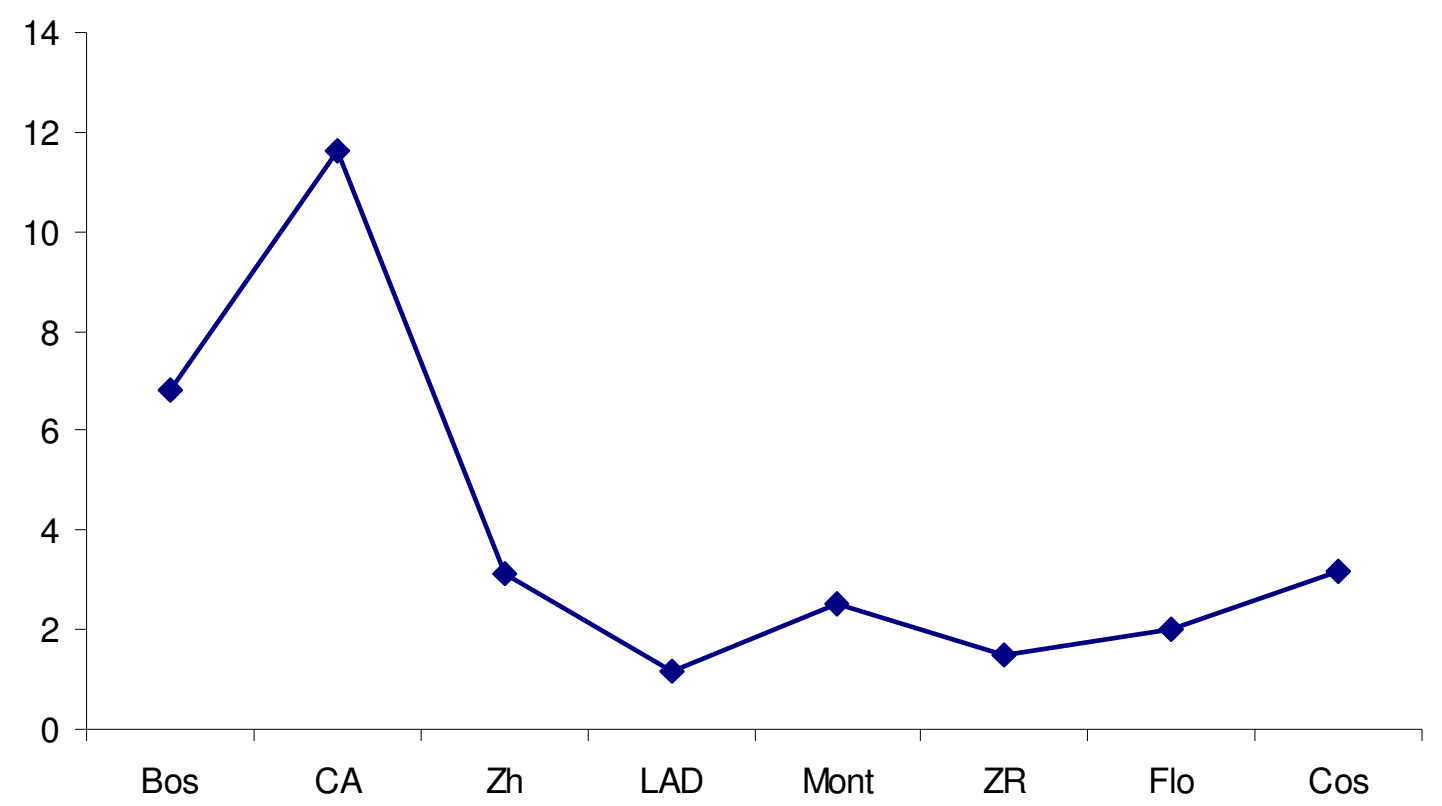

Gráfico 23 - Totalidade dos paleoambientes, segundo a distribuição das espécies e dos géneros identificados.. (Bos - bosques; CA - campo aberto; LAD - lagos de água doce; Mont montanha; ZR - zonas rochosas; ZH - zonas húmidas; Flo - floresta; Cos - zonas costeiras).

Perante os dados obtidos pelos indicadores paleoambientais das aves da Gruta Nova da Columbeira e tendo em conta os paleobiótipos indicados pelas espécies encontradas e pelo NMI, pode-se concluir que o paleoecótipo dominante da zona envolvente à Gruta Nova da Columbeira é o de campo aberto, com uma forte influência de um paleoecótipo de montanha. 


\section{2 - Gruta da Furninha}

Os primeiros estudos sobre a avifauna fóssil encontrada na Gruta da Furninha foram realizados por E. T. Newton e foram publicados em 1910/11 por Edouard Harlé (HARLÉ, 1910/11), conforme foi referido no capítulo anterior. Depois disso, novas publicações foram feitas onde são referidos os restos de aves (FERREIRA, 1964; ROCHE, 1970; ROCHE, 1972), mas todas elas apenas mantiveram os dados publicados por Harlé. Até ao momento, as referências à avifauna da Gruta da Furninha apresentam duas lacunas: a desactualização da nomenclatura taxonómica e um estudo incompleto dos restos de aves - apenas $20 \%$ da totalidade dos restos ósseos de aves forram estudados, no início do século XX.

As aves desta jazida são importantes no contexto da avifauna plistocénica portuguesa, uma vez que são relativamente abundantes: representam cerca de $10 \%$ da totalidade dos tetrápodes lá encontrados.

Dos restos de aves identificados, pela primeira vez para esta jazida, durante a investigação para a presente tese, surge em destaque um fragmento de osso encontrado no meio de outros não classificados no lote 1143 . Neste lote foram identificados 79 restos de aves; de entre estes encontrava-se um fragmento de úmero esquerdo com parte da zona mesial e com a zona proximal (número de inventário: 1143.28). Este osso apresenta características osteológicas da família Alcidae: pronunciado espalmamento longitudinal da diáfise, projecção lateral e ventral da articulação proximal do úmero e da crista peitoral pouco proeminente em relação a margem dorsal (PIMENTA, FIGUEIREDO \& MORENO-GARCIA, 2010). Através destas características, e por comparação dos úmeros das diferentes espécies de alcidae da colecção do CIPA, concluiu-se que este resto da Furninha pertence a um Pinguinus impennis. A maioria destes restos foi encontrada a 7.5 metros, enquanto este resto é proveniente dos 7 metros, o que corresponde à camada 5 da segunda unidade estratigráfica, definida por Nery Delgado. Esta camada corresponde ao 3. ${ }^{\circ}$ nível ossífero, definido por Nery Delgado (DELGADO, 1882) e a que tem o maior número de restos ósseos, e também os mais bem conservados (HARLÉ, 1910/11). Este fragmento tem um comprimento máximo de $42,9 \mathrm{~mm}$, apresenta a secção da diáfise de forma oval achatada e duas fracturas antigas, provavelmente resultantes do 
processo de deposição sedimentar. Uma das fracturas é na diáfise e a outra, oblíqua no sentido dorsal/mesial, na epifíse, ao nível da intumescência. Esta última originou a ausência do tubérculo ventral.

Tal identificação é importante por três razões: trata-se de uma espécie já extinta; está tradicionalmente associada a climas frios e trata-se do segundo vestígio desta espécie encontrado em Portugal Continental. O primeiro resto desta espécie identificado em Portugal foi referido na Gruta da Figueira-Brava (ANTUNES \& MOURER-CHAUVIRÉ, 2000). Também é conhecido um terceiro vestígio, encontrado no arquipélago da Madeira, na ilha de Porto Santo (PIEPER, 1985). Este achado, pela sua localização tão a sul, vem levantar algumas questões relacionadas com a paleogeografia e paleoambientes desta espécie, podendo esta não ser tão característica de climas frios como é vulgarmente referido (PIMENTA, FIGUEIREDO \& MORENO-GARCIA, 2010).

Foi mandada datar, por Luís Raposo, uma peça óssea proveniente deste $3 .^{\circ}$ nível ossífero (7,5 metros), pelo método das séries de urânio (informação pessoal de Luís Raposo), que deu uma datação de $80886+42423$ - 31 265, publicada por João Luís Cardoso (CARDOSO, 1993, p. 73), esta datação, embora pouco precisa, aponta para que este resto seja atribuível aos inícios do Würm. 


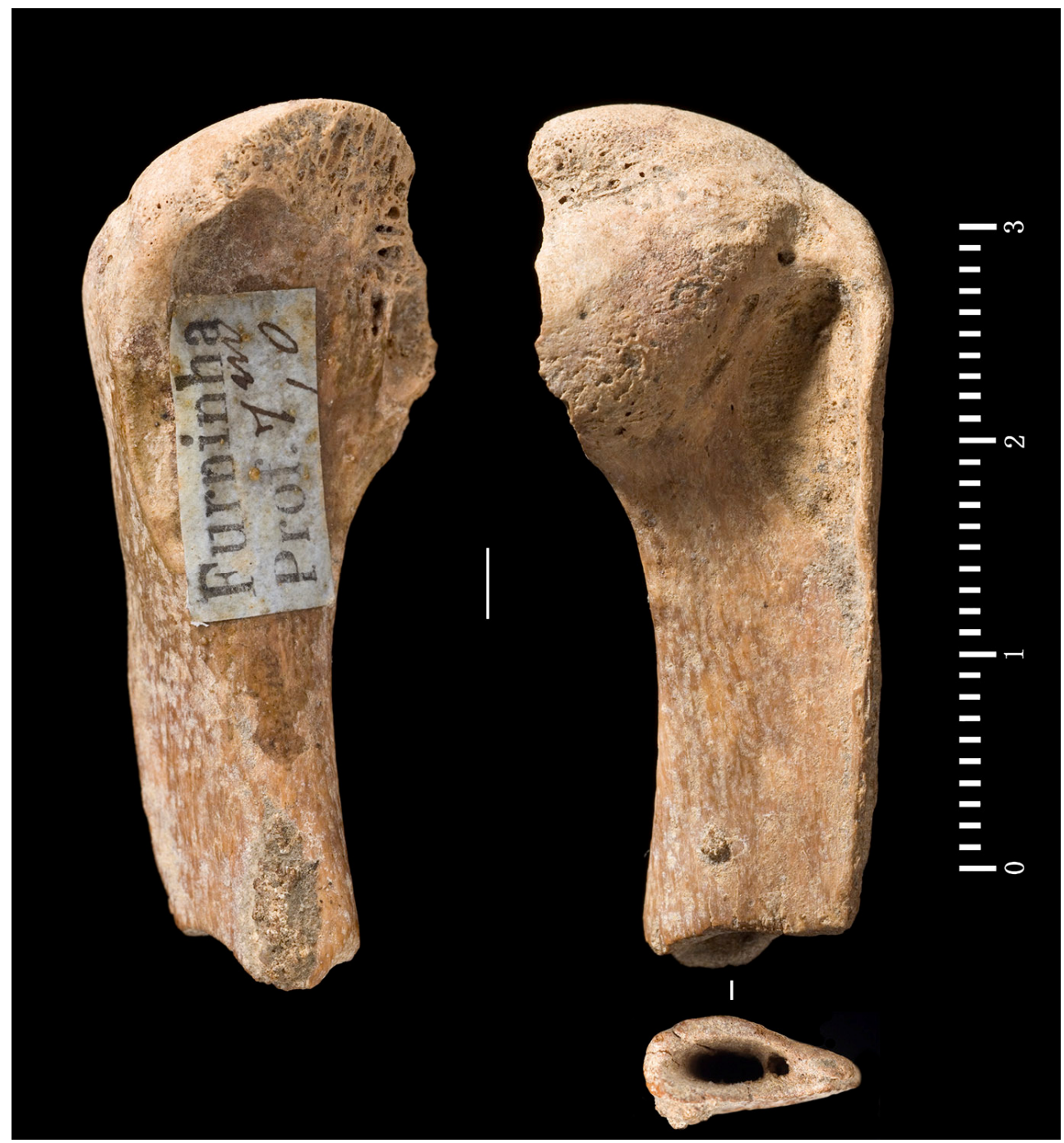

Fig. 74 - Úmero de Pinguinnus impennis (GFP.1043.28) encontrado na colecção osteológica da Furninha em reserva no Museu Geológico. Esquerda: vista ventral; direita: vista dorsal; direita (em baixo) pormenor da secção mesial do osso (fotografia de José Paulo Ruas - CIPA).

Apesar de Nery Delgado referir a presença de aves no $6 .^{\circ}$ nível ossífero (DELGADO, 1884, p. 238), no espólio estudado não foram encontrados restos de aves desse nível. Este facto poderá estar ligado à forma como os materiais foram marcados: pequenos papeis colados nos ossos. Ora alguns destes papéis descolaramse e perderam-se, desaparecendo assim a referência estratigráfica. Provavelmente, eram poucos os restos de que se perdeu a indicação estratigráfica.

No que respeita ao estado de conservação dos ossos estudados, verifica-se que a maioria se encontra fragmentada. No entanto, há ainda que registar a ocorrência de uma quantidade considerável de ossos inteiros: 151 (35\%), para 285 de partidos (65\%). Nos ossos partidos, 88 (31\%) corresponde à parte proximal, 4 (1.5\%) à parte mesial e 193 (67.5\%) à parte distal. 


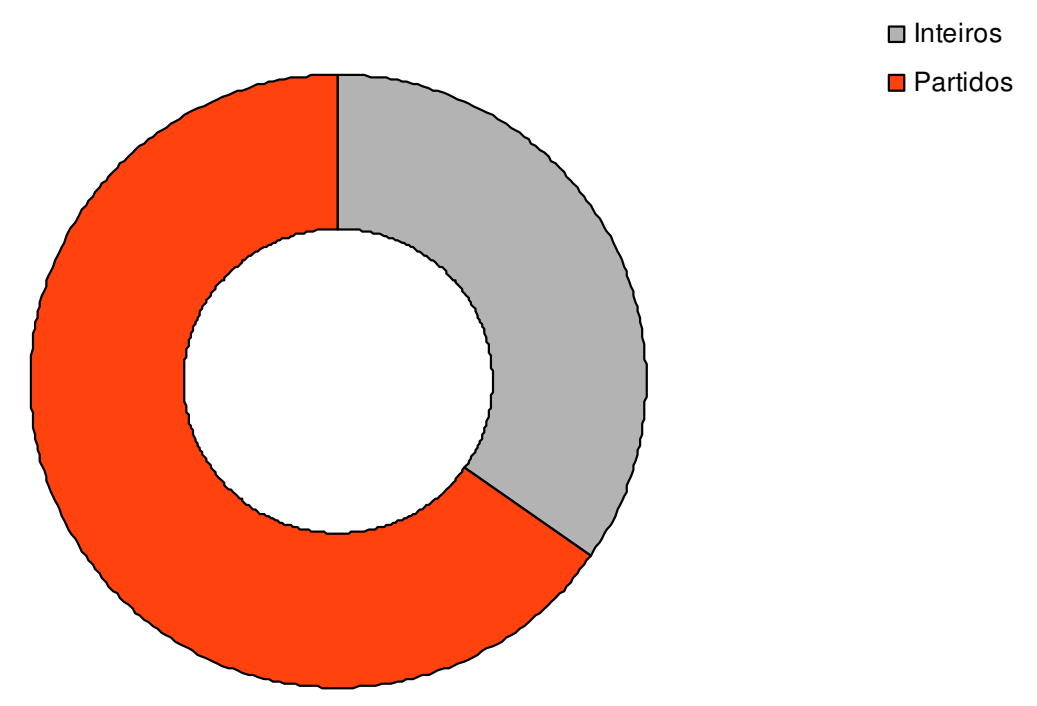

Gráfico 24 - Relação de ossos partidos e inteiros das aves da Gruta da Furninha.

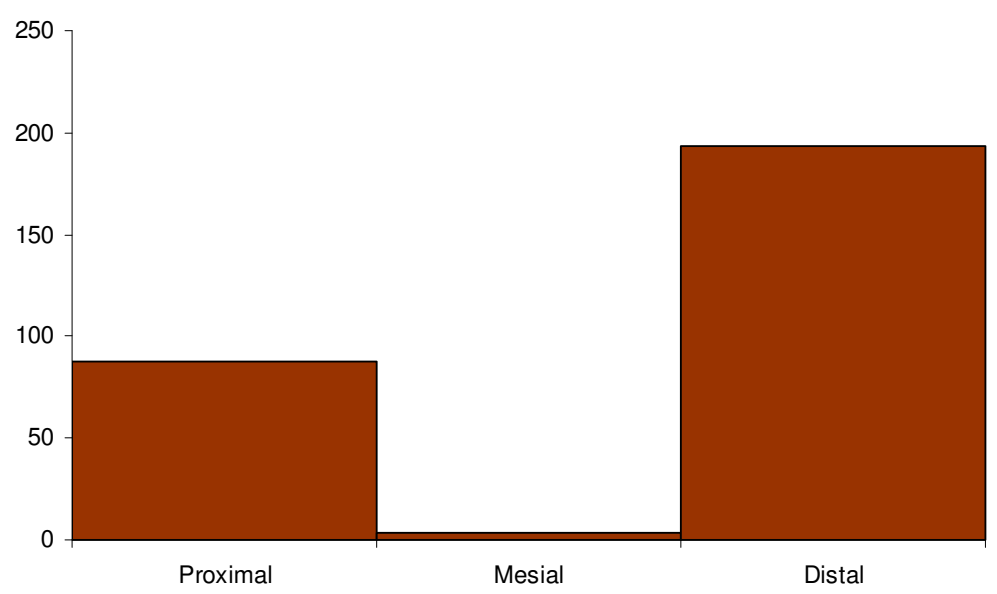

Gráfico 25 - Partes dos ossos preservados na amostra osteológica de aves da Gruta da Furninha.

\section{1 - Análise osteológica}

Os ossos de aves preservados na Furninha pertencem na maior parte (cerca de $94 \%$ ) ao esqueleto apendicular (membros), são sobretudo os ossos longos, tal como acontece nas outras jazidas. Se na Gruta Nova da Columbeira não foi encontrado nenhum elemento esquelético do esqueleto cefálico (ou craniano), já na 
Furninha foi encontrado um crânio, constituindo-se assim, conjuntamente com a Casa da Moura, como as únicas jazidas, estudadas nesta tese, que apresentam elementos cranianos.

Dos restos identificados, num total de 436, 23 pertencem ao esqueleto axial, um ao esqueleto craniano e 412 ao esqueleto apendicular. Destes não foi possível identificar 15 (3.6\%) ossos longos muito fragmentados, 151 (36,6\%) pertencem aos membros posteriores e 285 (59,8\%) aos membros anteriores.

\begin{tabular}{lrr} 
Parte do Esqueleto & NTR & $\%$ \\
\hline \hline Esqueleto Apendicular & 416 & 95,41 \\
Esqueleto axial & 19 & 4,36 \\
esqueleto craneano & 1 & 0,23 \\
\hline \hline Totais & 436 & 100
\end{tabular}

Quadro 23 - Quantidade e percentagem das partes do esqueleto representadas na avifauna da Gruta da Furninha.

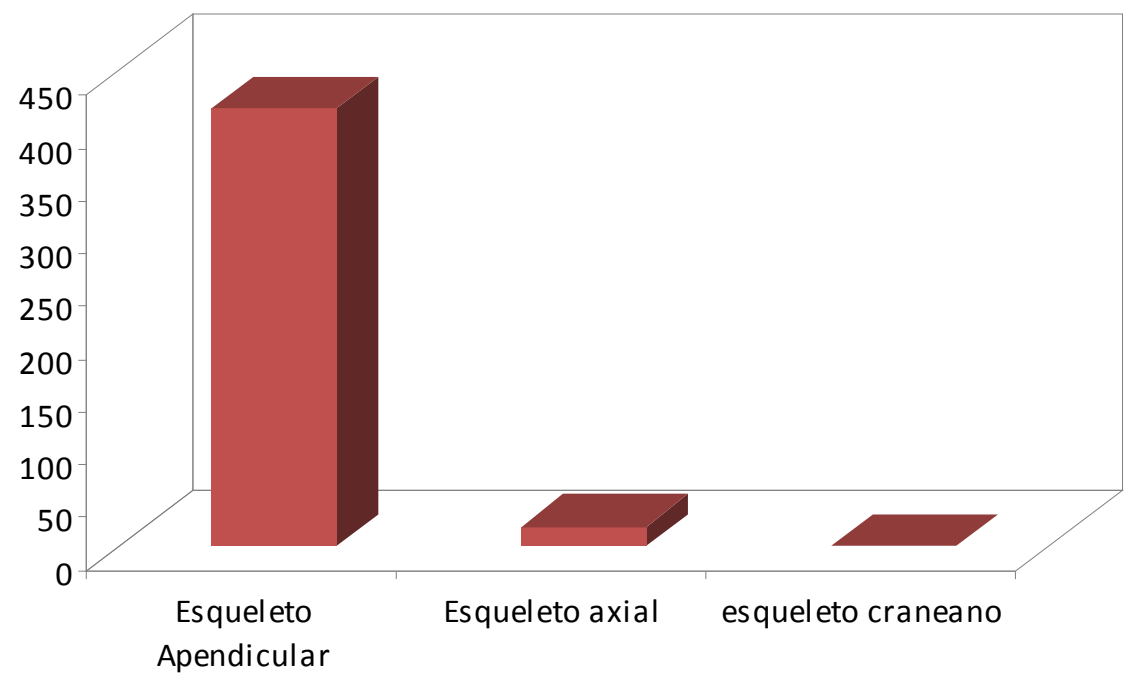

Gráfico 26 - Partes do esqueleto que constitui a avifauna da Gruta da Furninha.

\section{2 - Estudo taxonómico}

O estudo taxonómico assentou em duas vertentes: a primeira consistiu na actualização e revisão da taxonomia aplicada aos restos já estudados por E. T. Newton, e a segunda, numa atribuição taxonómica aos restos ainda inéditos. Neste estudo foram contabilizadas 31 espécies, num total de 436 ossos, que se encontram nas colecções do Museu Geológico. Destas 31 espécies, 14 (cerca de 45\%) foram 
agora identificadas pela primeira vez, nesta jazida. Das restantes 17 (que correspondem a 55\%): 10 (32\% do total das espécies presentes) foram actualizadas e revistas e 7 (23\%) mantiveram a atribuição inicial.

\begin{tabular}{c|c}
\multicolumn{2}{c}{ Revisão taxonómica (GFP) } \\
\hline \hline Designação antiga & Nova designação / atribuição \\
\hline \hline Pyrrhocorax alpinus & Pyrrhocorax graculus \\
Perdix cinerea & Perdix perdix \\
Bubo ignarus & Bubo Bubo \\
Cacabis rufa & Alectoris rufa \\
Tadorna cornuta & Tadorna tadorna \\
Tordus musicus & cf. Turdus philomelos \\
Pica rustica & Pica pica \\
Querquedula crecca & Anas crecca \\
Oedmira nigra & Melanitta nigra
\end{tabular}

Quadro 24 - Lista das espécies atribuídas por Newton (coluna da esquerda) e a actualização da nomenclatura, ou nova atribuição taxonómica (coluna da direita).

No estudo taxonómico dos restos da Furninha foi possível atribuir uma classificação taxonómica a 406 (mais de $93 \%$ do total da amostra) e a apenas 30 não se conseguiu atribuir um táxon abaixo da classe. Dos restos classificados, dois foramno ao nível da ordem, 14 ao da família, 70 ao do género e 350 ao da espécie.

\begin{tabular}{lrr}
\multicolumn{1}{r}{$\quad$} & No & \multicolumn{1}{c}{$\%$} \\
\hline \hline TRI & 406 & 93,12 \\
TRNI & 30 & 6,88 \\
\hline \hline NTR & 436 & 100
\end{tabular}

Quadro 25 - Quantidade e a percentagem da totalidade de restos identificados (TRI) e não identificados (TRNI) e número total de restos (NTR). 


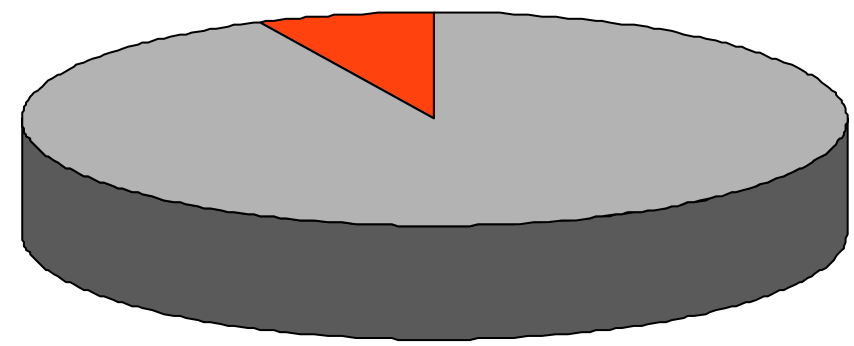

Gráfico 27 - Percentagem e quantidade da totalidade de restos identificados (TRI) e não identificados (TRNI).

\begin{tabular}{lcrrrrr|r} 
Taxon & $\mathbf{4 - 5} \mathbf{~ m}$ & $\mathbf{6 - 7} \mathbf{~ m}$ & $\mathbf{7 - 8} \mathbf{~ m}$ & $\mathbf{8 - 9} \mathbf{~ m}$ & $\mathbf{9 - 1 0 ~} \mathbf{m}$ & $\mathbf{S}$ estratig & TOTAL \\
\hline \hline Espécies & 11 & 14 & 284 & 8 & 2 & 28 & 347 \\
Género & & 2 & 17 & 7 & & 19 & 45 \\
Família & 1 & 2 & 7 & & 2 & & 12 \\
Ordem & 12 & 18 & 310 & 15 & 4 & 47 & 406
\end{tabular}

Quadro 26 - Distribuição por camada dos diferentes níveis taxonómicos identificados.

\begin{tabular}{lrr} 
Taxon & No & \multicolumn{1}{c}{$\%$} \\
\hline \hline Espécie & 347 & 85,46 \\
Género & 45 & 11,07 \\
Família & 12 & 2,96 \\
Ordem & 2 & 0,51 \\
\hline \hline TOTAL & 406 & 100
\end{tabular}

Quadro 27 - Dados globais dos diferentes níveis taxonómicos identificados. 


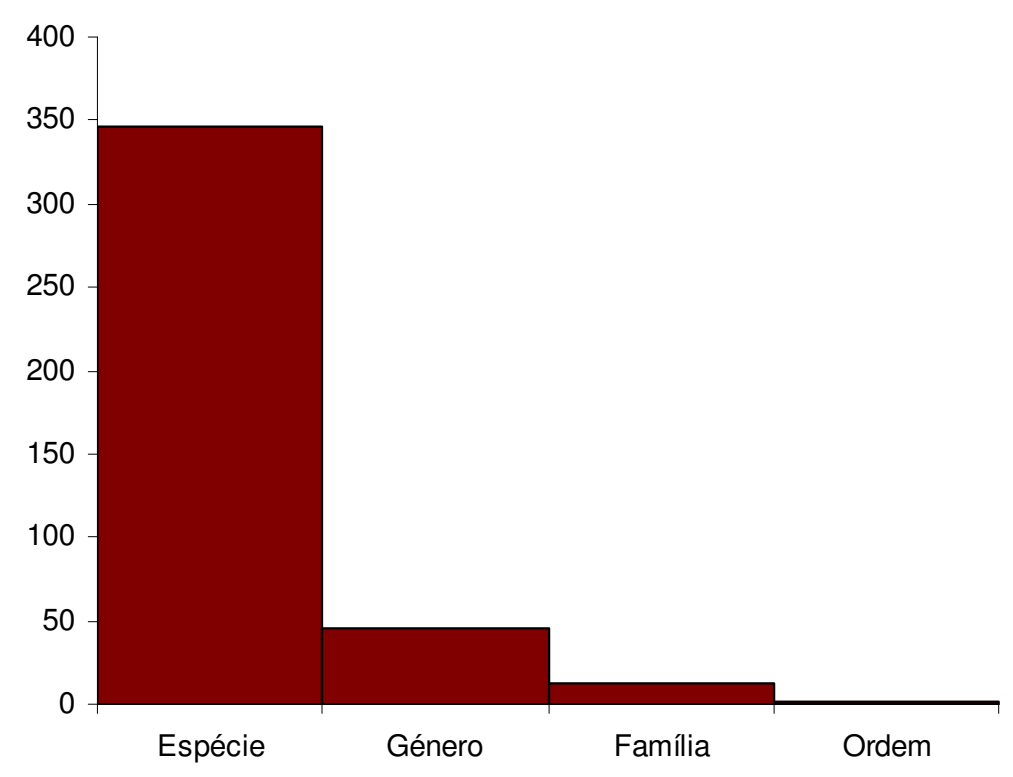

Gráfico 28 - Dados globais dos diferentes níveis taxonómicos identificados.

\section{Classificação paleontológica}

Ordem: ProcellaRIFORMES (FüRBRINGER, 1888)

Família: ProcelLARIIDAE (LEACH, 1820)

Género: Puffinus (BRISSON 1760)

Puffinus puffinus (BRUNNICH 1764)

Material: 1 úmero.

Total de restos: 1

Ordem: GALLIFORMES (TEMMINCK, 1820)

Família: PHASIANIDAE (HORSFIELD 1821)

Género: Alectoris (KAUP, 1829)

Alectoris rufa (LINNAEUS, 1758)

Material: 1 úmero, 3 ulnas, 1 Carpometacarpo, 1 fémur, 1 tarsometatarso.

Total de restos: 7

Material 
Ordem: GALLIFORMES (TEMMINCK, 1820)

Família: PHASIANIDAE (HORSFIELD, 1821)

Género: Coturnix (BONNATERRE, 1791)

Coturnix coturnix (LINNAEUS, 1758)

Material: 1 úmero.

Total de restos: 1

Ordem: Anseriformes( WAGLER, 1831)

Família: ANATIDAE (VIGORS, 1825)

ANATIDAE INDET.

Material: 1 tibiotarso, 3 rádios, 2 sinsacros.

Total de restos: 5

Ordem: ANSERIFORMES( WAGLER, 1831)

Família: ANATIDAE (VIGORS, 1825)

Género: Anas (LINNAEUS, 1758)

Anas sp

Material: 1 tibiotarso, 3 rádios, 2 ulnas.

Total de restos: 6

Cf. Anas sp

Material: 2 úmeros, 1 ulna, 1 rádio, 1 tarsometatarso, 1 esterno.

Total de restos: 6

Ordem: ANSERIFORMES (WAGLER, 1831)

Família: ANATIDAE (VIGORS, 1825)

Género: Anas (LINNAEUS, 1758)

Anas crecca (LINNAEUS, 1758)

Material: 1 úmero.

Total de restos: 1 
Ordem: ANSERIFORMES (WAGLER, 1831)

Família: ANATIDAE (VIGORS, 1825)

Género: Melanitta (BOIE,1822)

Melanitta nigra (LINNAEUS, 1758)

Material: 1 úmero.

Total de restos: 1

Ordem: ANSERIFORMES (WAGLER, 1831)

Família: ANATIDAE (VIGORS, 1825)

Género: Tadorna (BOIE,1822)

Tadorna tadorna (LINNAEUS, 1758)

Material: 1 sinsacro, 3 escápulas, 15 coracóides, 36 úmeros, 19 ulnas, 5 rádios, 13 carpometacarpos, 25 fémures. 20 tibiotarsos, 7 tarsometatarsos.

Total de restos: 144

Cf. Tadorna tadorna (LINNAEUS, 1758)

Material: 2 vértebras, 3 falanges (pé).

Total de restos: 5

Ordem: ANSERIFORMES (WAGLER, 1831)

Família: ANATIDAE (VIGORS, 1825)

Género: Tadorna (BOIE, 1822)

Tadorna tadorna/Tadorna ferruginea

Material: 1 coracóide, 10 Carpometacarpo, 1 fémur.

Total de restos: 12

Ordem: ANSERIFORMES (WAGLER, 1831)

Família: ANATIDAE (VIGORS, 1825)

Género: Somateria (LEACH 1819)

Cf. Somateria sp.

Material: 3 fúrculas.

Total de restos: 3 
Ordem: ANSERIFORMES (WAGLER, 1831)

Família: ANATIDAE (VIGORS, 1825)

Género: Somateria (LEACH 1819)

Somateria mollissima (Linnaeus 1758)

Material: 1 esterno, 2 escápulas, 9 coracóides, 9 úmeros, 14 ulnas, 23 rádios, 5 carpometacarpos, 1 falange (Il dígito da asa), 3 fémures.

Total de restos: 67

Cf. Somateria mollissima (Linnaeus 1758)

Material: 2 úmeros, 1 falange (pé).

Total de restos: 3

Ordem: ANSERIFORMES (WAGLER, 1831)

Família: ANATIDAE (VIGORS, 1825)

Género: Cygnus (BECHSTEIN, 1803)

Cf. Cygnus olor (GMeLIN, 1789)

Material: 1 úmero.

Total de restos: 1

Ordem: CHARADRIIFORMES (HUXLEY, 1867)

Família: LARIDAE (VIGORS, 1825)

Género: Larus (LINNAEUS, 1758)

Larus sp.

Material: 1 rádio, 1 tibiotarso.

Total de restos: 2

Ordem: ChARADRIIFORMES (HUXLEY, 1867)

Família: SCOLOPACIDAE (VIGORS, 1825)

Género: Gallinago (BRISSON, 1760)

Gallinago sp.

Material: 1 tibiotarso. 


\section{Total de restos: 1}

Ordem: CHARADRIIFORMES (HUXLEY, 1867)

Família: SCOLOPACIDAE (VIGORS, 1825)

Género: Numenius (BRISSON, 1760)

Numenius phaeopus (LINNAEUS, 1758)

Material: 1 ulna.

Total de restos: 1

Ordem: CHARADRIIFORMES (HUXLEY, 1867)

Família: ALCIDAE (LEACH, 1820)

Género: Pinguinus (BONNATERRE, 1791)

Pinguinus impennis (LINNAEUS, 1758)

Material: 1 úmero.

Total de restos: 1

Ordem: PeleCANIFormes (Sharpe, 1891)

Familia: PhaLACROCORACIDAE (REICHENBACH, 1850)

Género: Phalacrocorax (BRISSON, 1760)

Species: Phalacrocorax aristotelis (LINNAEUS, 1758)

Material: 1 coracóide, 10 úmeros, 4 ulnas, 2 rádios, 1 Carpometacarpo, 1 tibiotarso.

Total de restos: 19

Ordem: PHOENICOPTERIFORMES (FÜRBRINGER, 1888)

Familia: PHOENICOPTERIDAE (BONAPARTE, 1831)

Género: Phoenicopterus (LINNAEUS, 1758)

Phoenicopterus ruber (LINNAEUS, 1758)

Material: 1 ulna. 
Total de restos: 1

Ordem: FALCONIFORMES (SHARPE 1874)

Família: FALCONIDAE (VIGORS, 1825)

FALCONIDAE INDET.

Material: 2 rádios, 1 tarsometatarso.

Total de restos: 3

Ordem: FALCONIFORMES (SHARPE 1874)

Família ACCIPITRIDAE (VIEILLOT, 1816)

Género: Aquila (LINNAEUS, 1758)

Aquila sp

Material: 2 garras.

Total de restos: 2

Ordem: FALCONIFORMES (SHARPE 1874)

Família ACCIPITRIDAE (VIEILLOT, 1816)

Género: Aquila (LINNAEUS, 1758)

Aquila chrysaetos (LINNAEUS, 1758)

Material: 2 garras.

Total de restos: 2

Ordem: FALCONIFORMES (SHARPE 1874)

Família ACCIPITRIDAE (VIEILLOT, 1816)

Género: Gyps (SAVIGNY, 1809)

Gyps fulvus (HABLIZL, 1783)

Material: 1 falange ( $1^{\text {a }}$ falange do Il dígito do pé).

Total de restos: 1 
Ordem: STRIGIFORMES (WAGLER, 1830)

Família: STRIGIDAE (VIGORS, 1825)

Género: Tyto (BILLBERG, 1828)

Tyto alba (SCOPOLI, 1769)

Material: 1 tibiotarso.

Total de restos: 1

Ordem: StRIGIFORMES (WAGLER, 1830)

Família: STRIGIDAE (VIGORS, 1825)

Género: Bubo (DUMÉRIL, 1806)

Bubo bubo (LINNAEUS, 1758)

Material: 1 úmero.

Total de restos: 1

Ordem: ColumbifORMES (LATHAM, 1790)

Família: COLUMBIDAE, (ILLIGER,1811)

Subfamília: COLUMBINAE, (ILLIGER,1811)

Género: Columba (LINNAEUS, 1758)

Columba livia, (GMELIN, 1789)

Material: 4 úmeros, 2 ulnas, 2 rádios, 2 carpometacarpos, 2 fémures, 2 tibiotarsos, 2 carpometacarpos.

Total de restos: 16

Ordem: PASSERIFORMES (LINNAEUS, 1758)

PASSERIFORMES INDET.

Material: 1 úmero, 1 ulna.

Total de restos: 2

Ordem: PASSERIFORMES (LINNAEUS, 1758)

Família: CORVIDAE INDET.

Material: 1 úmero. 
Total de restos: 1

Ordem: PASSERIFORMES (LINNAEUS, 1758)

Família: CORVIDAE (VIGORS, 1825)

Género: Corvus (LINNAEUS, 1758)

Corvus corone (LINNAEUS, 1758)

Material: 1 escápula, 1 Carpometacarpo.

Total de restos: 2

Ordem: PASSERIFORMES (LINNAEUS, 1758)

Família: CORVIDAE (VIGORS, 1825)

Género: Corvus (LINNAEUS, 1758)

Corvus corone / Corvus frugilegus

Material: 1 úmero, 1 ulna, 1 Carpometacarpo.

Total de restos: 3

Ordem: PASSERIFORMES (LINNAEUS, 1758)

Família: CORVIDAE (VIGORS, 1825)

Género: Corvus (LINNAEUS, 1758)

Corvus monedula (LINNAEUS, 1758)

Material: 4 úmeros, 1 tibiotarso.

Total de restos: 5

Ordem: PASSERIFORMES (LINNAEUS, 1758)

Família: CORVIDAE (VIGORS, 1825)

Género: Corvus (LINNAEUS, 1758)

Corvus monedula / Pyrrhocorax graculus

Material: 4 úmeros, 1 tibiotarso.

Total de restos: 5

Ordem: PASSERIFORMES (LINNAEUS, 1758) 
Família: CORVIDAE (VIGORS, 1825)

Género: Pica (BRISSON, 1760)

Pica pica (LINNAEUS, 1758)

Material: 1 úmero.

Total de restos: 1

Ordem: PASSERIFORMES (LINNAEUS, 1758)

Família: CORVIDAE (VIGORS, 1825)

Género: Pyrrhocorax sp.

Material: 5 úmeros, 4 coracóides.

Total de restos: 9

Ordem: PASSERIFORMES (LINNAEUS, 1758)

Família: CORVIDAE (VIGORS, 1825)

Género: Pyrrhocorax (TNSTALL, 1771)

Pyrrhocorax pyrrhocorax (LINNAEUS, 1758)

Material: 2 úmeros, 5 ulnas, 2 carpometacarpos, 2 fémures, 1 tarsometatarso.

Total de restos: 12

Ordem: PASSERIFORMES (LINNAEUS, 1758)

Família: CORVIDAE (VIGORS, 1825)

Género: Pyrrhocorax (TNSTALL, 1771)

Pyrrhocorax graculus (LINNAEUS, 1758)

Material: 1 crânio, 1 coracóide, 5 úmeros, 4 ulnas, 2 carpometacarpos.

Total de restos: 13

Ordem: PASSERIFORMES (LINNAEUS, 1758)

Família: TURDIDAE (BONNAPARTE, 1850)

Género: Turdus sp.

Material: 9 úmeros.

Total de restos: 9 
Ordem: PASSERIFORMES (LINNAEUS, 1758)

Família: TURDIDAE (BONNAPARTE, 1850)

Género: Turdus, (LINNAEUS, 1758)

Turdus philomelos (BREHM, 1831)

Material: 2 úmeros.

Total de restos: 2

Ordem: PASSERIFORMES (LINNAEUS, 1758)

Família: TURDIDAE (BONNAPARTE, 1850)

Género: Turdus, (LINNAEUS, 1758)

Turdus merula (LINNAEUS, 1758)

Material: 2 ulnas,

Total de restos: 2

Turdus merula / Turdus pilaris (LINNAEUS, 1758)

Material: 2 úmeros, 1 ulna.

Total de restos: 3

Ordem: PASSERIFORMES (LINNAEUS, 1758)

Família: TURDIDAE (BONNAPARTE, 1850)

Género: Turdus, (LINNAEUS, 1758)

Turdus pilaris (BREHM, 1831)

Material: 5 úmeros, 1 ulna.

Total de restos: 6

Ordem: PASSERIFORMES (LINNAEUS, 1758)

Família: TURDIDAE (BONNAPARTE, 1850)

Género: Turdus, (LINNAEUS, 1758)

Turdus iliacus (LINNAEUS, 1758)

Material: 3 úmeros.

Total de restos: 2 
Ordem: CUCULIFORMES (WAGLER, 1830)

Família: CUCULIDAE (VIGORS, 1825)

Género: Cuculus (LINNAEUS, 1758)

Cuculus canorus (LINNAEUS, 1758)

Material: 3 tibiotarsos.

\section{Total de restos: 3}

Apesar de na Gruta da Furninha predominar uma espécie, a Tadorna tadorna, com 149 restos ósseos identificados, esta jazida apresenta uma grande diversidade taxonómica, quando comparada com as outras jazidas estudadas neste trabalho. Verifica-se também uma grande percentagem quer de restos de passeriformes, quer de anseriformes ${ }^{48}$. No entanto, comparativamente a outras jazidas, a Gruta da Furninha tem uma percentagem de passeriformes inferior. Verificando-se igualmente uma fraca ocorrência de aves de rapina, com uma ligeira superioridade de indivíduos das espécies diurnas sobre as espécies nocturnas (quatro, três, respectivamente). A grande ocorrência do grupo dos anseriformes, em especial das espécies marinhas, é explicado pela localização da gruta: no litoral.

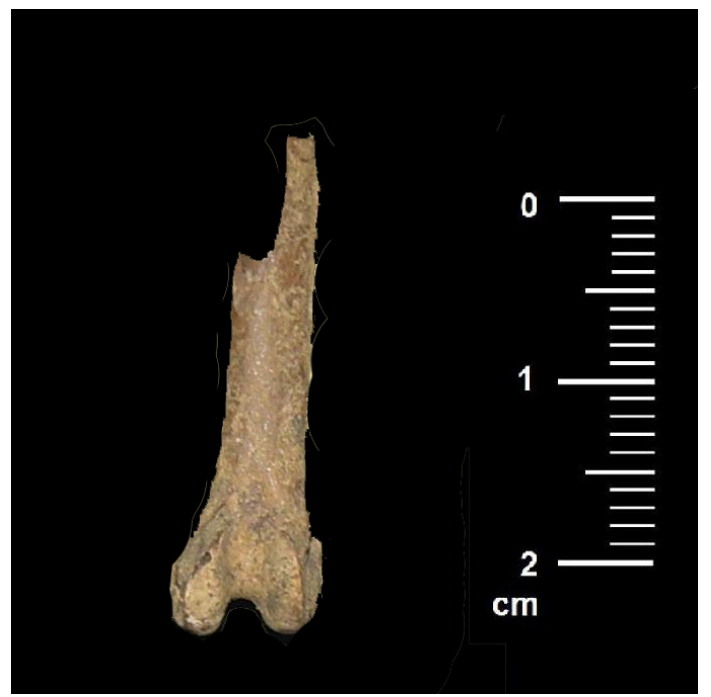

Fig. 75 - Fragmento distal de tibiotarso (vista cranial) de Larus $s p$, um género associado a ambientes costeiros. (Fotografia S. Figueiredo).

48 - A Gruta da Furninha é a que apresenta um maior número de restos e de espécies de anseriformes, no total das jazidas estudadas neste trabalho. 


\begin{tabular}{|c|c|c|c|c|c|c|c|}
\hline Espécies & 4-5m & $6-7 \mathrm{~m}$ & $7-8 \mathrm{~m}$ & $8-9 \mathrm{~m}$ & $9-10 \mathrm{~m}$ & S/estr & TOTAL \\
\hline Tadorna tadorna & 3 & 2 & 13 & & & & 18 \\
\hline Somateria mollissima & & & 10 & 1 & 1 & & 12 \\
\hline Cf. Pinguinus impennis & & & 1 & & & & 1 \\
\hline Corvus corone & & & 2 & & & & 2 \\
\hline Corvus frugilegus & & & 1 & & & & 1 \\
\hline Gyps fulvus & & & 1 & & & & 1 \\
\hline Pyrrhocorax pyrrhocorax & & & 3 & 1 & & 1 & 5 \\
\hline Pyrrhocorax graculus & 1 & 1 & 2 & & & & 4 \\
\hline Columba livia & & 1 & 2 & & & 2 & 5 \\
\hline Tadorna ferruginea & & & 3 & & & & 3 \\
\hline Alectoris rufa & & 1 & 2 & & & & 3 \\
\hline Corvus corone & & & 2 & & & & 2 \\
\hline Corvus monedula & & 1 & 1 & & & 1 & 3 \\
\hline Cuculus canorus & & & 2 & & & & 2 \\
\hline Tyto alba & & & 1 & & & & 1 \\
\hline Turdus merula & & & 2 & & & & 2 \\
\hline cf. Turdus philomelos & & & 2 & & & & 2 \\
\hline Bubo bubo & & & 1 & & & & 1 \\
\hline Puffinus puffinus & & & 1 & & & & 1 \\
\hline Turdus pilaris & & & 4 & & & 1 & 5 \\
\hline Turdus iliacus & & & 2 & & & & 2 \\
\hline Cygnus olor & & & 1 & & & & 1 \\
\hline Pica pica & & & 1 & & & & 1 \\
\hline Melanita nigra & & & 1 & & & & 1 \\
\hline Asio flammeus & & & 1 & & & & 1 \\
\hline Anas crecca & 1 & & & & & & 1 \\
\hline Phalacrocorax aristotelis & 1 & & & 1 & & 4 & 6 \\
\hline Aquila Chrysiateus & & 1 & & & & & 1 \\
\hline Falcus tinuculus & & 1 & & & & & 1 \\
\hline Coturnix coturnix & 1 & & & & & 1 & 2 \\
\hline Cf. Phoenicopterus ruber & & & & & & 1 & 1 \\
\hline Cf. Numenius phaeopus & & & & 1 & & & 1 \\
\hline TOTAIS & 7 & 8 & 62 & 4 & 1 & 11 & 93 \\
\hline
\end{tabular}

Quadro 28 - Número mínimo de indivíduos das espécies identificadas e a sua distribuição pelos níveis ossíferos definidos por Nery Delgado. 


\begin{tabular}{|c|c|c|c|c|c|c|c|}
\hline Espécies & 4-5 m & $6-7 \mathrm{~m}$ & $7-8 \mathrm{~m}$ & $8-9 \mathrm{~m}$ & $9-10 \mathrm{~m}$ & S/estr & TOTAL \\
\hline Tadorna tadorna & 6 & 7 & 136 & & & & 149 \\
\hline Somateria mollissima & & & 64 & 4 & 2 & & 70 \\
\hline Cf. Pinguinus impennis & & & 1 & & & & 1 \\
\hline Corvus corone & & & 6 & & & & 6 \\
\hline Corvus frugilegus & & & 3 & & & & 3 \\
\hline Gyps fulvus & & & 1 & & & & 1 \\
\hline Pyrrhocorax pyrrhocorax & & & 9 & & & 1 & 10 \\
\hline Pyrrhocorax graculus & 1 & 1 & 5 & 1 & & & 8 \\
\hline Columba livia & & 1 & 2 & & & 11 & 14 \\
\hline Tadorna ferruginea & & & 11 & & & & 11 \\
\hline Alectoris rufa & & 1 & 6 & & & & 7 \\
\hline Corvus corone & & & 5 & & & & 5 \\
\hline Corvus monedula & & 1 & 3 & & & 2 & 6 \\
\hline Cuculus canorus & & & 3 & & & & 3 \\
\hline Tyto alba & & & 1 & & & & 1 \\
\hline Turdus merula & & & 5 & & & & 5 \\
\hline cf. Turdus philomelos & & & 2 & & & & 2 \\
\hline Bubo bubo & & & 1 & & & & 1 \\
\hline Puffinus puffinus & & & 1 & & & & 1 \\
\hline Turdus pilaris & & & 8 & & & 1 & 9 \\
\hline Turdus iliacus & & & 3 & & & & 3 \\
\hline Cignus olor & & & 1 & & & & 1 \\
\hline Pica pica & & & 1 & & & & 1 \\
\hline Melanita nigra & & & 1 & & & & 1 \\
\hline Asio flammeus & & & 1 & & & & 1 \\
\hline Anas crecca & 1 & & & & & & 1 \\
\hline Phalacrocorax aristotelis & 1 & & & 5 & & 12 & 18 \\
\hline Aquila Chrysiateus & & 2 & & & & & 2 \\
\hline Falcus tinuculus & & 1 & & & & & 1 \\
\hline Coturnix coturnix & 1 & & & & & 1 & 2 \\
\hline Cf. Phoenicopterus ruber & & & & & & 1 & 1 \\
\hline Cf. Numenius phaeopus & & & & 1 & & 1 & 2 \\
\hline TOTAIS & 10 & 14 & 280 & 11 & 2 & 30 & 347 \\
\hline
\end{tabular}

Quadro 29 - Número mínimo de indivíduos (NMI) e número total de restos (NTR) por espécie identificada. 


\begin{tabular}{|c|c|c|}
\hline Espécies & NMI & NTR \\
\hline Tadorna tadorna & 18 & 149 \\
\hline Somateria mollissima & 12 & 70 \\
\hline Cf. Pinguinus impennis & 1 & 1 \\
\hline Corvus corone & 2 & 6 \\
\hline Corvus frugilegus & 1 & 3 \\
\hline Gyps fulvus & 1 & 1 \\
\hline Pyrrhocorax pyrrhocorax & 5 & 10 \\
\hline Pyrrhocorax graculus & 4 & 8 \\
\hline Columba livia & 5 & 14 \\
\hline Tadorna ferruginea & 3 & 11 \\
\hline Alectoris rufa & 3 & 7 \\
\hline Corvus corone & 2 & 5 \\
\hline Corvus monedula & 3 & 6 \\
\hline Cuculus canorus & 2 & 3 \\
\hline Tyto alba & 1 & 1 \\
\hline Turdus merula & 2 & 5 \\
\hline cf. Turdus philomelos & 2 & 2 \\
\hline Bubo bubo & 1 & 1 \\
\hline Puffinus puffinus & 1 & 1 \\
\hline Turdus pilaris & 5 & 9 \\
\hline Turdus iliacus & 2 & 3 \\
\hline Cygnus olor & 1 & 1 \\
\hline Pica pica & 1 & 1 \\
\hline Melanita nigra & 1 & 1 \\
\hline Asio flammeus & 1 & 1 \\
\hline Anas crecca & 1 & 1 \\
\hline Phalacrocorax aristotelis & 6 & 18 \\
\hline Aquila Chrysiateus & 1 & 2 \\
\hline Falcus tinuculus & 1 & 1 \\
\hline Coturnix coturnix & 2 & 2 \\
\hline Cf. Phoenicopterus ruber & 1 & 1 \\
\hline Cf. Numenius phaeopus & 1 & 2 \\
\hline
\end{tabular}

Quadro 30 - Relação do número mínimo de individuos e do número total de restos.

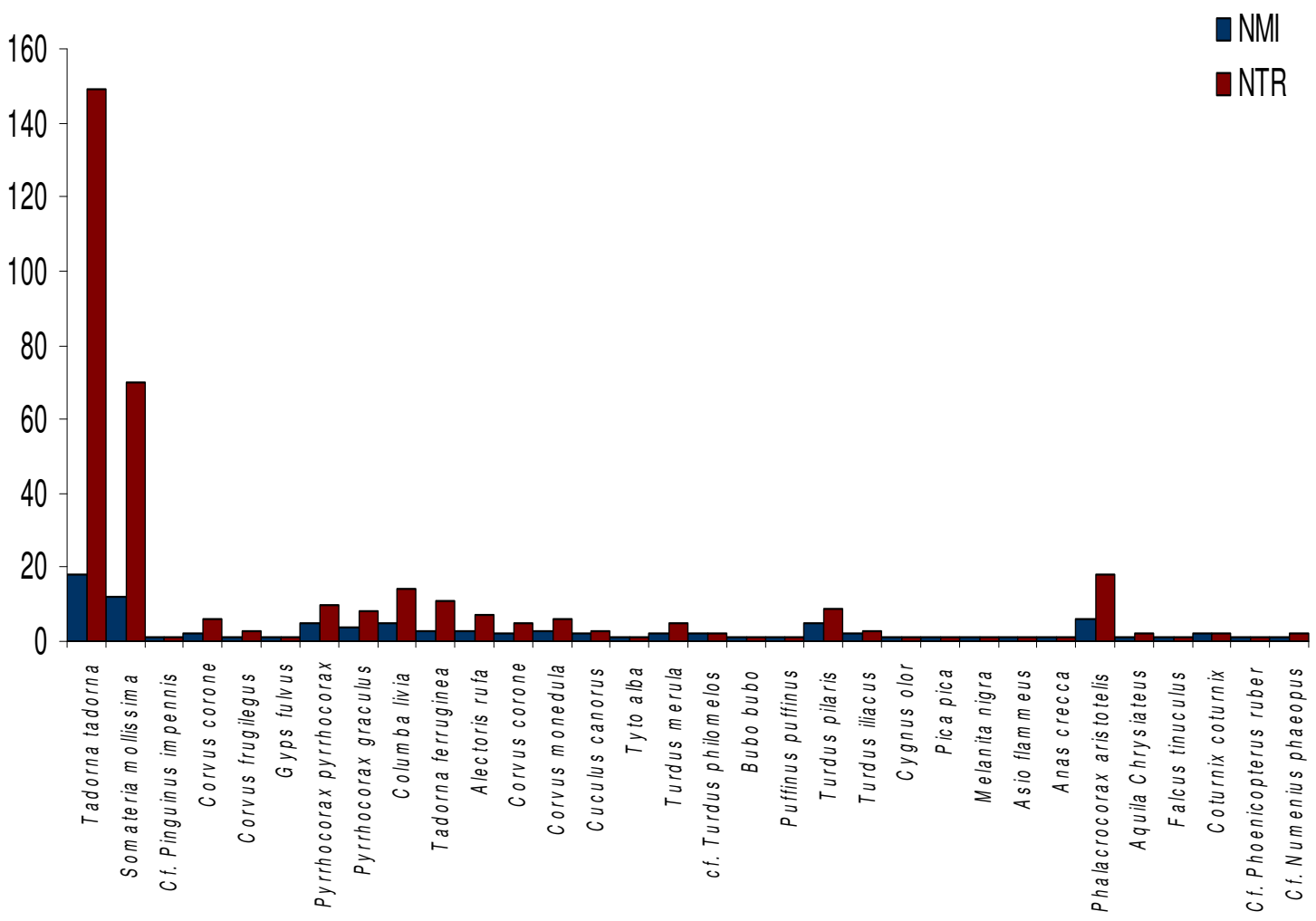

Gráfico 29 - Gráfico com o número mínimo de indivíduos (NMI) e número total de restos (NTR) por espécie identificada. 
Pela análise do gráfico anterior, nota-se uma grande diferença entre o número mínimo de indivíduos e o número total de restos das duas espécies mais frequentes, quando comparadas com espécies menos representadas. Este facto é explicado pela grande variedade de ossos que estas espécies apresentam, em que vários ossos poderão corresponder a um único indivíduo. Pelo contrário, quando uma espécie aparece apenas sinalizada por um único resto ósseo, o número mínimo de indivíduos coincide com o número total de restos.

Foi identificado um número mínimo de 93 indivíduos, distribuídos pelas 31 espécies reconhecidas através do estudo taxonómico dos restos de aves da Furninha, das quais predominam os anseriformes, com seis espécies com 36 indivíduos, equivalendo a $38,7 \%$ do total do número mínimo de indivíduos identificados; a seguir estão os passeriformes com onze espécies, com 29 individuos, correspondendo a $31.1 \%$.. Dos outros grupos destacam-se muito ligeiramente os pelecaniformes com duas espécies e seis indivíduos, no total (6,5 \%); os columbiformes, com apenas uma espécie (a Columba livia) com cinco indivíduos (5.3\%); os galliformes, com duas espécies (a Alectoris rufa e a Coturnix coturnix) também com cinco indivíduos.

\begin{tabular}{l|cc} 
Ordens & NMI & NMI \% \\
\hline \hline Anseriformes & 36 & 38,68 \\
Procellariformes & 1 & 1,06 \\
Galiformes & 5 & 5,33 \\
Columbiformes & 5 & 5,33 \\
Charadriiformes & 2 & 2,12 \\
Pelecaniformes & 6 & 6,49 \\
Phoenicopteriformes & 1 & 1,06 \\
Falconiformes & 4 & 4,26 \\
Strigiformes & 3 & 3,19 \\
Passeriformes & 29 & 31,42 \\
Cuculiformes & 1 & 1,06
\end{tabular}

Quadro 31 - Número mínimo de indivíduos e número total de restos com as respectivas percentagens das ordens identificadas e a sua distribuição, por camada. 


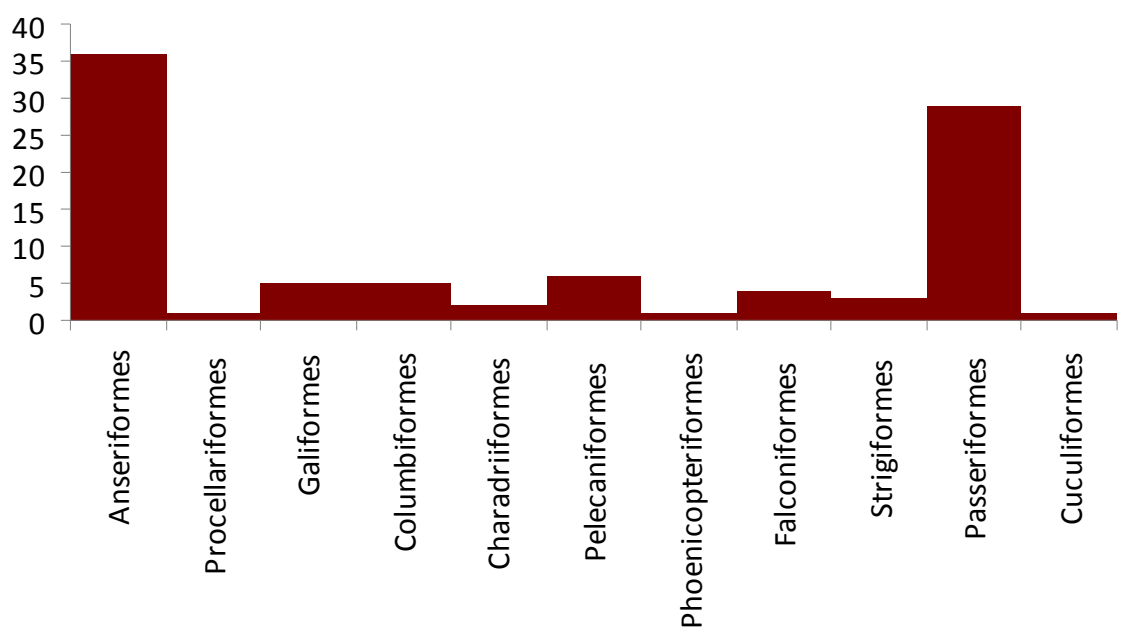

Gráfico 30 - Ocorrência do númerio mínimo de individos das diferentes ordens de aves da Gruta da Furninha.

Quanto à atribuição de idades, tal como nas restantes jazidas, há uma esmagadora maioria de indivíduos adultos (mais de $97 \%$ do total da amostra) sobre os subadultos ou jovens.

\begin{tabular}{l|cc}
\multicolumn{1}{c|}{} & NTR & \% \\
\hline \hline Jovens & 5 & 1,15 \\
Sub-adultos & 6 & 1,38 \\
Adultos & 425 & 97,47
\end{tabular}

Quadro 32 - Número e percentagens da distribuição dos restos de aves pelas respectivas idades.

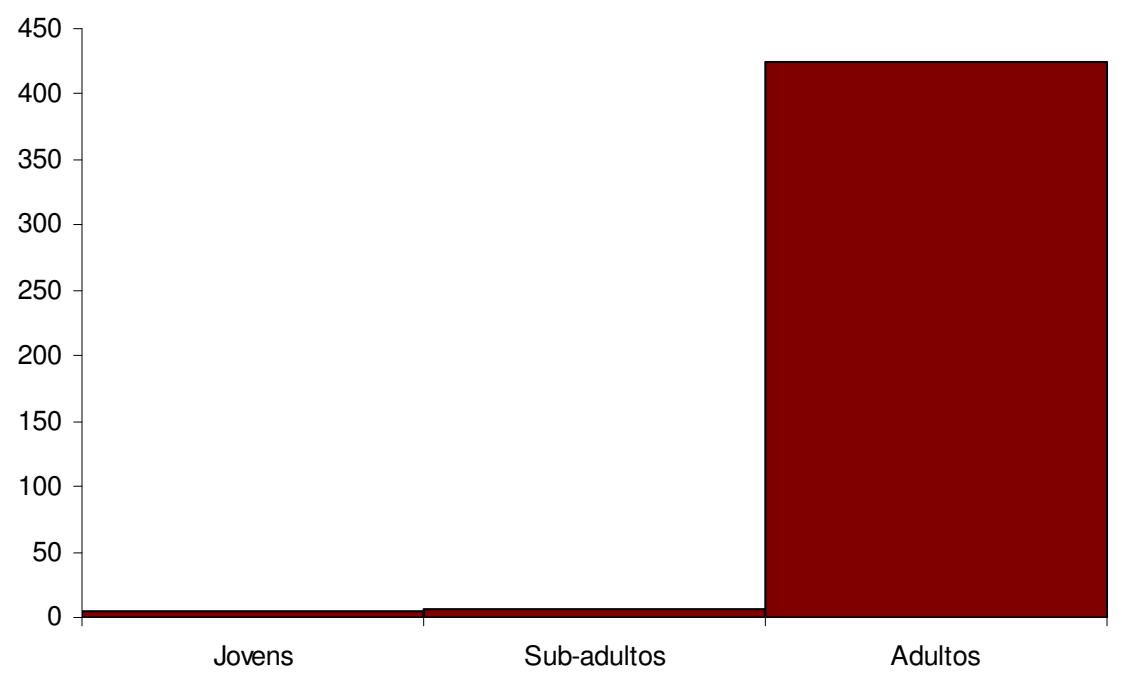

Gráfico 31 - Gráfico com a atribuição das idades do total dos restos estudados. 
No que diz respeito especificamente à classificação taxonómica dos indivíduos jovens, três foram identificados como aves indeterminadas e a dois foi possível atribuir o género. No caso dos subadultos, a quatro foi possível atribuir-seIhe a espécie, um foi classificado a nível de família e apenas um resto não foi possível classificá-lo abaixo da classe.

\begin{tabular}{lcc} 
Jovens & № & $\%$ \\
\hline \hline Id. Género & 2 & 40 \\
Não id. & 3 & 60 \\
$\begin{array}{c}\text {. } \\
\text { Sub-adultos }\end{array}$ & No & $\%$ \\
\hline \hline Id. Espécie & 4 & 77 \\
Id. Familia & 1 & 16,5 \\
Não id. & 1 & 16,5
\end{tabular}

Quadro 33 - Número de restos de jovens e subdultos e a respectiva classificação taxonómica.

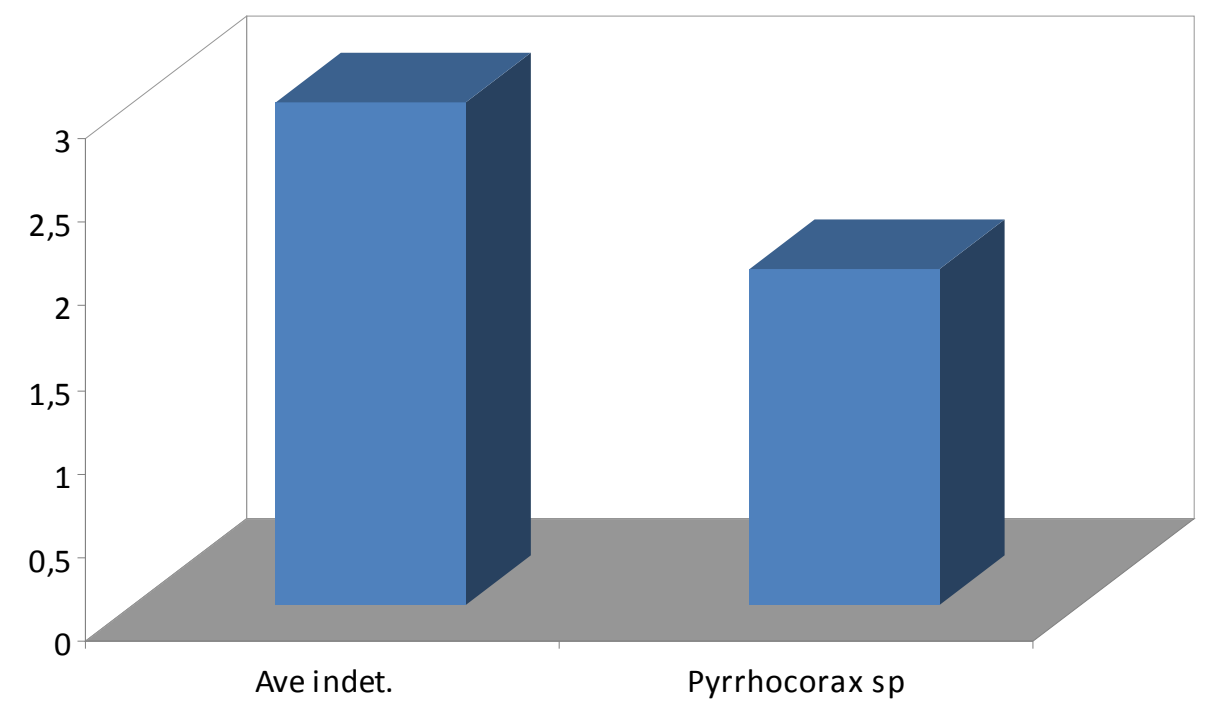

Gráfico 32 - Gráfico com a atribuição taxonómica aos indivíduos jovens. 


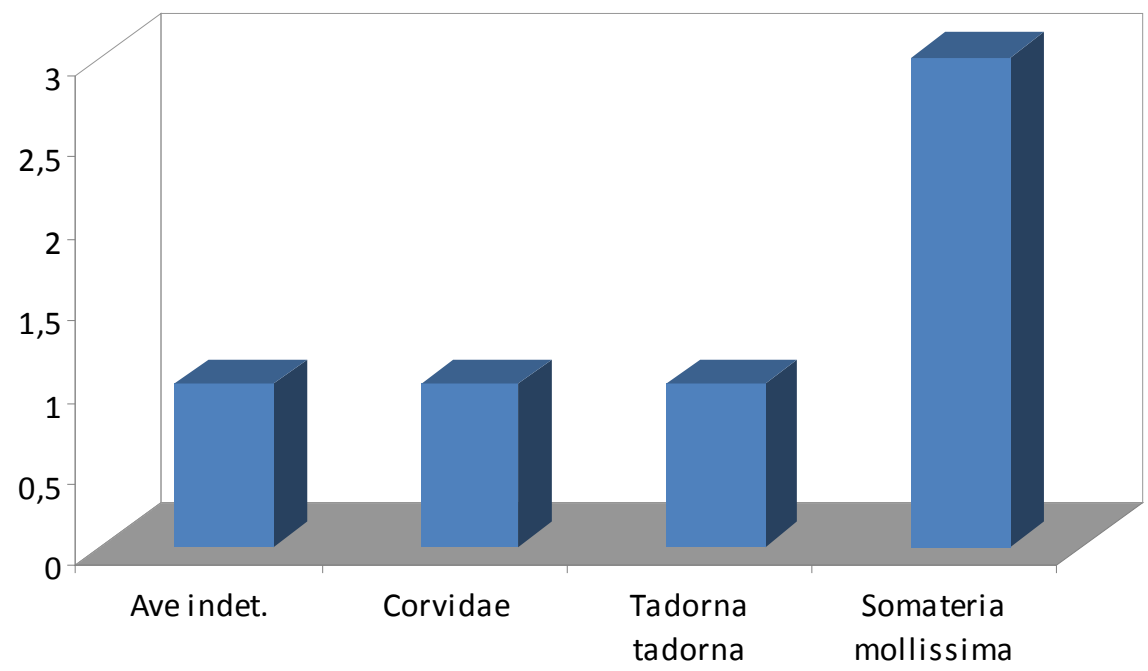

Gráfico 33 - Gráfico com a atribuição taxonómica dos indivíduos subadultos.

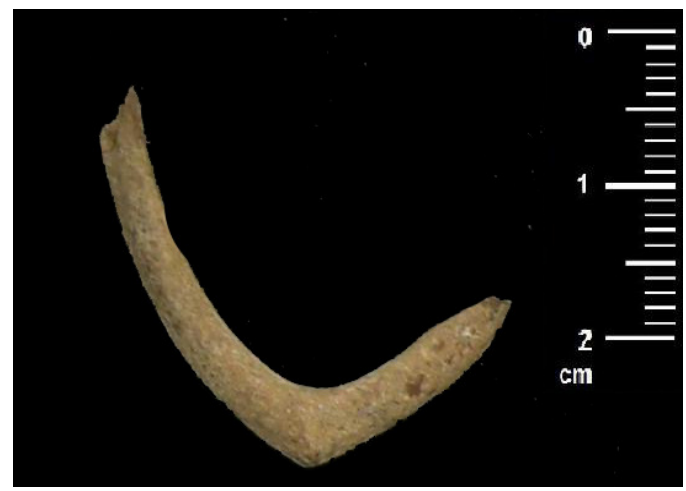

Fig. 76 - Fúrcula de cf. Somateria mollissima da Gruta da Furninha (fotografia: S. Figueiredo).

\section{3 - Tafonomia}

Não foram detectados, nos materiais da Gruta da Furninha, marcas de corte ${ }^{49}$, indícios de terem sido queimadas, nem marcas de predação. Apesar de uma quantidade considerável se encontrar inteira, a maior parte da amostra encontra-se partida. Muito embora as espécies identificadas não serem frequentadoras de grutas, são espécies marinhas e a Gruta da Furninha encontra-se numa arriba junto ao mar. Por outro lado, a formação sedimentar da gruta estará ligada ao estatismo, pelo que muitos dos restos dessas aves marinhas poderão ter sido depositados pelo próprio

49 O resto de Pinguinus impennis, que apresenta uma fractura que poderá ser de origem antrópica, será o único com marcas directas de actuação humana sobre a fauna. 
mar. É importante também referir que, como se viu na caracterização arqueológica desta gruta, a ocupação humana é pouco intensa. É ainda de realçar que muitos dos ossos de Tadorna tadorna, a espécie mais representada, se encontram inteiros, o que pressupõe um rápido enterramento e um transporte pouco intenso. No caso dos ossos partidos, é provável também que alguns deles tenham sido fragmentados durante a escavação, uma vez que foi possível colar alguns dos fragmentos.

Com base nestes dados, na ausência de marcas de corte nos ossos, e pela caracterização geológica e arqueológica da jazida, pensamos que a grande maioria das aves presentes na Gruta da Furninha se deve a acumulações naturais das aves que frequentaram ou ali ficaram presas (no caso das espécies que frequentam e vivem em grutas), e que algumas das aves marinhas tenham sido transportadas post mortem, por acção do mar. Porém, não se põe de parte a possibilidade de uma parte ter sido consumida pelos carnívoros ou pelos homens que também frequentaram a gruta.

\section{4 - Análise paleoecológica}

Das espécies estudadas verifica-se uma grande quantidade de restos, traduzidos numa percentagem considerável do número mínimo de indivíduos de aves marinhas (anseriformes e pelecaniformes). Verifica-se também a ocorrência de um pequeno número de aves de ambientes de cariz mais interior, o que é condizente com a localização geográfica desta jazida.

Desta forma, pode concluir-se que, apesar de existirem alguns pontos em comum com a actualidade, havia, naquela altura, uma maior ligação com os ambientes continentais, ao contrário do que acontece actualmente. Não se pode esquecer que durante alguns períodos do Paleolítico, em especial nos picos das glaciações, a linha de costa esteve mais afastada, em relação à actualidade.

Pelo estudo paleoecológico das aves encontradas na Gruta da Furninha pode também afirmar-se que, durante o Paleolítico, os ambientes da região onde actualmente se situa Peniche eram, para além do ambiente marinho (devido à sua localização geográfica), caracterizados por existirem nas proximidades zonas de bosques, de campos abertos, de mato, zonas húmidas, zona de água doce e zonas de 
montanha. Quanto a esta última, não é de estranhar, pois existem na área de Óbidos algumas zonas mais acidentadas.

A presença de aves como o Pinguinus impennis, a Tadorna tadorna, o Cygnus olor e a Somateria molíssima, entre outras, apontam para um clima mais frio, uma vez que são espécies típicas do Norte da Europa, região de climas mais frios que os que existem actualmente em Portugal. A presença destas aves indica valores paleoecológicos diferentes dos apontados pelo estudo dos mamíferos, o qual aponta para condições climáticas temperadas quentes e húmidas (CARDOSO, 1993, pp. 526). Assim, se, por um lado, a avifauna, tal como os mamíferos, aponta para paloeambientes húmidos, por outro lado indicam climas mais frios, ao contrário das indicações fornecidas pelos mamíferos. No entanto, existem outras espécies de aves na Gruta da Furninha, de que são exemplo o A. crecca e o N. phaeopus que se podem associar a climas mais quentes, estand0o assim mais de acordo com os indicadores dos mamíferos, pois são aves de zonas húmidas.

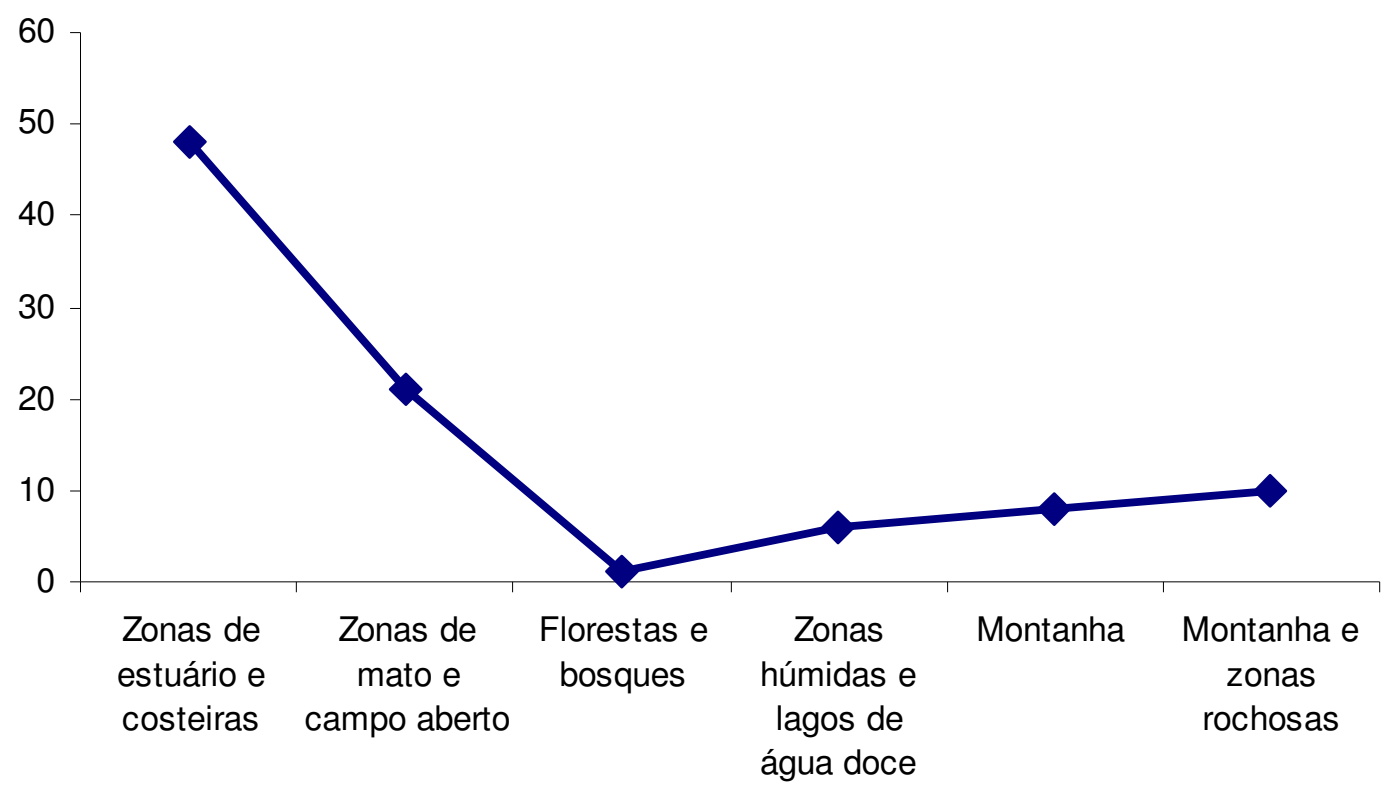

Gráfico 34 - Ambientes das espécies identificadas na Furninha, considerando o número mínimo de indivíduos.

Pela análise efectuada aos ambientes das espécies encontradas, segundo o número mínimo de indivíduos, percebe-se um claro predomínio de paleoambientes costeiros sobre paleoambientes continentais, com um número baixo de indivíduos de ambientes de floresta, montanha e zonas húmidas de água doce. 
Da análise puramente taxonómica apenas com a ocorrência dos táxones, verifica-se um panorama semelhante à análise anterior, com uma predominância clara dos ambientes costeiros sobre os continentais. Nota-se uma diferença com uma ocorrência maior de zonas de campo aberto e de bosque, na análise taxonómica, o que não é discordante com a posição geográfica da jazida.

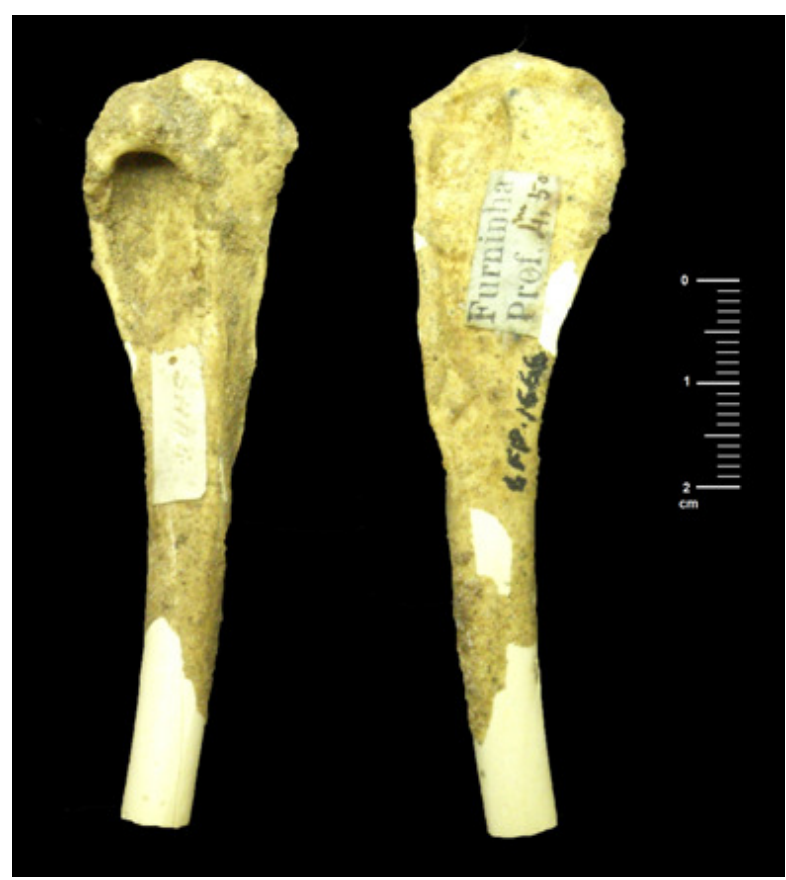

Fig. 77 - Fragmento proximal e mesial de úmero de Phalacrocorax aristotelis, uma espécie que habita as zonas costeiras. É a terceira espécie em número total de restos da Gruta da Furninha.. Vista cranial (esquerda), vista caudal (direita). Fotografia: S. Figueiredo). 


\begin{tabular}{|c|c|c|c|c|c|c|c|c|}
\hline & Bos & $\mathrm{CA}$ & $\mathrm{Zh}$ & LAD & Mont & ZR & Flo & $\operatorname{Cos}$ \\
\hline T. tadorna & & & & 0,5 & & & & 0,5 \\
\hline T. ferruginea & & & & 1 & & & & \\
\hline S.mollissima & & & & & & & & 1 \\
\hline M. nigra & & & & & & & & 1 \\
\hline Anas sp. & & & & 0,5 & & & & 0,5 \\
\hline A. Crecca & & & & 0,5 & & & & 0,5 \\
\hline Gallinago $s p$ & & 0,5 & & 0,5 & & & & \\
\hline A. rufa & & 1 & & & & & & \\
\hline P. perdix & & 1 & & & & & & \\
\hline C. coturnix & & 1 & & & & & & \\
\hline P. pica & 0,5 & 0,5 & & & & & & \\
\hline G. glandarius & & 0,5 & & & & & 0,5 & \\
\hline C. frugilegus & 0,5 & 0,5 & & & & & & \\
\hline C. corax & & 0,33 & 0,33 & & & & & 0,33 \\
\hline C. corone & 0,33 & 0,33 & 0,33 & & & & & \\
\hline P. graculus & & & & & 1 & & & \\
\hline Pyrrhocorax sp & & & & & 0,5 & & & 0,5 \\
\hline C. monedula & 0,33 & 0,33 & & & & & & 0,33 \\
\hline P. pyrrhocorax & & & & & 0,5 & & & 0,5 \\
\hline C. cyana & & & & & & & & \\
\hline C. canorus & 0,33 & 0,33 & 0,3 & & & & & \\
\hline T. iliacus & 0,5 & 0,5 & & & & & & \\
\hline T. pilaris & 0,5 & 0,5 & & & & & & \\
\hline T. philomelos & 0,5 & 0,5 & & & & & & \\
\hline T. merula & 0,5 & 0,5 & & & & & & \\
\hline C. carduelis & 0,5 & 0,5 & & & & & & \\
\hline P. rupestris & & & & & 0,5 & 0,5 & & \\
\hline F. tinuculus & & & & & & 0,5 & 0,5 & \\
\hline G. fulvus & & 0,5 & & & 0,5 & & & \\
\hline A. chrysaetos & & 0,33 & 0,33 & & & & 0,33 & \\
\hline P. impennis & & & & & & & & 1 \\
\hline P. puffinus & & & & & & & & 1 \\
\hline P. ruber & & & & & & & & 1 \\
\hline P. aristotelis & & & & & & & & 1 \\
\hline Larus sp & & & & & & & & 1 \\
\hline B. bubo & & & & & & 0,5 & 0,5 & \\
\hline S. flammea & 0,33 & 0,33 & & & & & 0,33 & \\
\hline T. alba & 0,5 & 0,5 & & & & & & \\
\hline C. livia & & & & & & 0,5 & & 0,5 \\
\hline \multirow[t]{2}{*}{ N. phaeopus } & & & 0,33 & 0,33 & & & & 0,33 \\
\hline & "5,32 & 10 & 1,62 & ב3,33 & 3 & 2 & 2,16 & $\overline{\overline{11}}$ \\
\hline
\end{tabular}

Quadro 34 - Espécies e géneros identificados na Gruta da Furninha e a distribuição pelos ambientes a que estão associados. (Bos - bosque; CA - campo aberto; LAD - lagos de água doce; Mont - montanha; ZR - zonas rochosas; ZH - zonas húmidas; Flo - floresta; Cos - zonas costeiras.) 


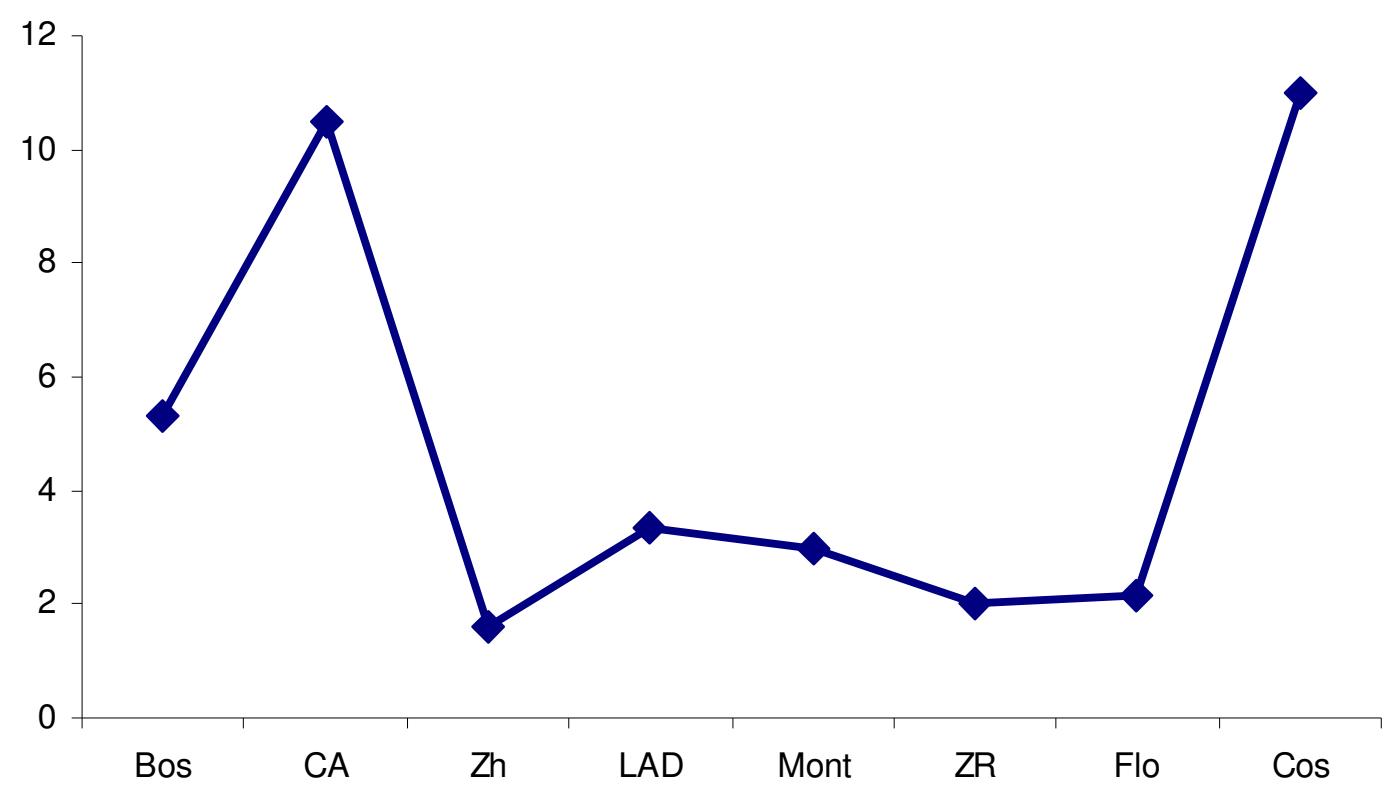

Gráfico 35 - Totalidade dos paleoambientes, segundo a distribuição das espécies e géneros identificados.. (Bos - bosque; CA - campo aberto; LAD - lagos de água doce; Mont montanha; ZR - zonas rochosas; ZH - zonas húmidas; Flo - floresta; Cos - zonas costeiras).

Perante os dados obtidos pelos indicadores paleoambientais das aves da Gruta da Furninha e tendo em conta os paleobiótipos indicados pelas espécies ali encontradas e pelo NMI, pode-se concluir que o paleoecótipo dominante da zona é o costeiro, com uma forte influência de um paleoecótipo de campo aberto. 


\section{3 - GRUTA DAS SALEMAS}

O primeiro estudo sobre as faunas da Gruta das Salemas foi feito por Jean Roche (ROCHE, 1970), no qual não são referidas quaisquer ocorrências de restos de aves. No entanto a observação dos restos ósseos encontrados nesta gruta para o presente estudo, agora apresentado, permitiu identificar 48 restos ósseos de aves. Destes foi possível identificar taxonomicamente 36 , correspondendo a perto de $70 \%$ do total da amostra.

\section{1 - Análise osteológica}

Da análise ao estado de conservação dos materiais verifica-se uma maioria muito considerável de restos partidos: cerca de $70 \%$ (35) de ossos partidos para 30\% (13) de ossos inteiros.

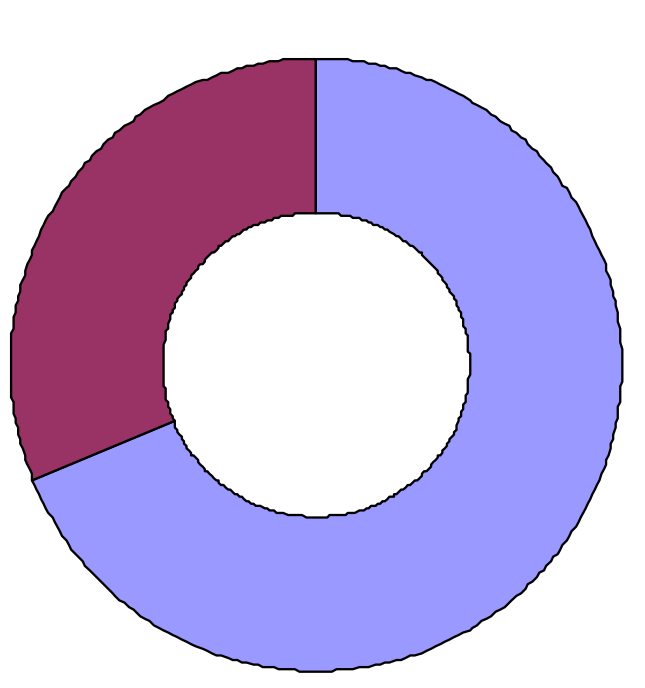

$\square$ Partidos

$\square$ Inteiros

Gráfico 36 - Estado de conservação dos ossos.

Dos ossos partidos, quinze são partes distais (40\%), cinco da zona mesial (15\%) e dezassete partes proximais (45\%). Verifica-se assim que a percentagem dos ossos que apresentam a parte distal e proximal é muito semelhante, existindo uma diferença considerável na percentagem de ossos que não apresentam a parte mesial. 
O facto de existirem muito poucos restos de partes mesiais dos ossos estará relacionada com o facto de ser muito difícil identificar taxonomicamente uma parte mesial de um osso longo.

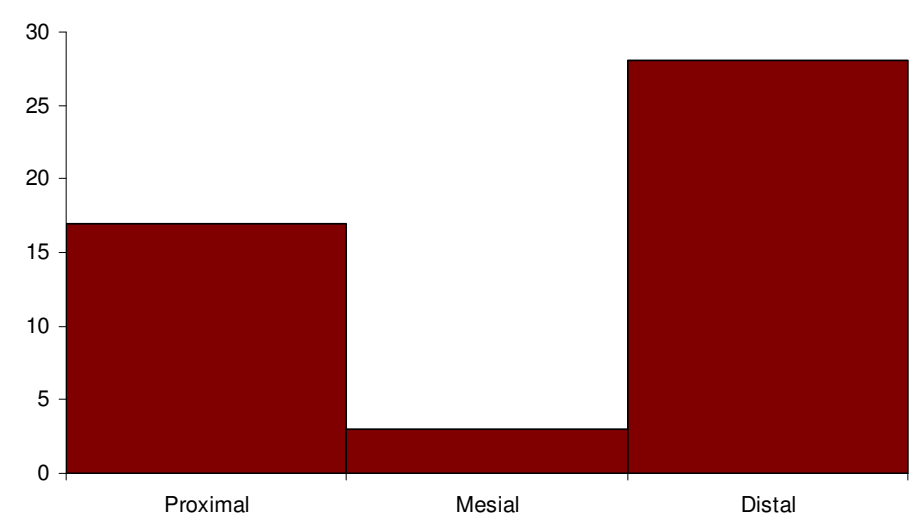

Gráfico 37 - Partes dos ossos preservadas nos restos de avifauna da Gruta das Salemas.

Pela análise da idade dos restos estudados, verifica-se que existe uma predominância de adultos (cerca de 96\%). Apenas foram identificados cinco ossos (dois carpometacarpos e três ossos longos) de aves indeterminadas.

Apenas existem restos ósseos do esqueleto apendicular, essencialmente ossos longos, estando ausentes os ossos do esqueleto axial e do esqueleto craniano. Verifica-se um maior número de ossos partidos relativamente aos ossos inteiros. De um total de 50 restos, 34 (68\%) pertencem aos membros anteriores (asas), enquanto apenas 13 (26\%) são ossos dos membros posteriores (patas). A três restos (6\%), de ossos longos, muito fragmentados, não foi possível distinguir o elemento ósseo.

\section{1 - Estudo taxonómico}

O estudo taxonómico assentou em duas vertentes: a primeira consistiu na separação dos restos de aves dos restou dos outros grupos taxonómicos, a segunda, consistiu na atribuição taxonómica dos 48 restos identificados de aves, que não tinham sido estudados por Roche e pelos investigadores que se Ihe seguiram. Neste estudo foram contabilizadas seis espécies, cinco de passeriformes (corvídeos e turdídeos) e uma de columbiformes. 


\begin{tabular}{l|ll|l} 
& & NTR & $\%$ \\
\hline \hline Identificados & 36 & 75 \\
Aves indeterminadas & 12 & 25
\end{tabular}

Quadro 35 - Número total de restos e percentagem dos ossos identificados e não identificados taxonomicamente.

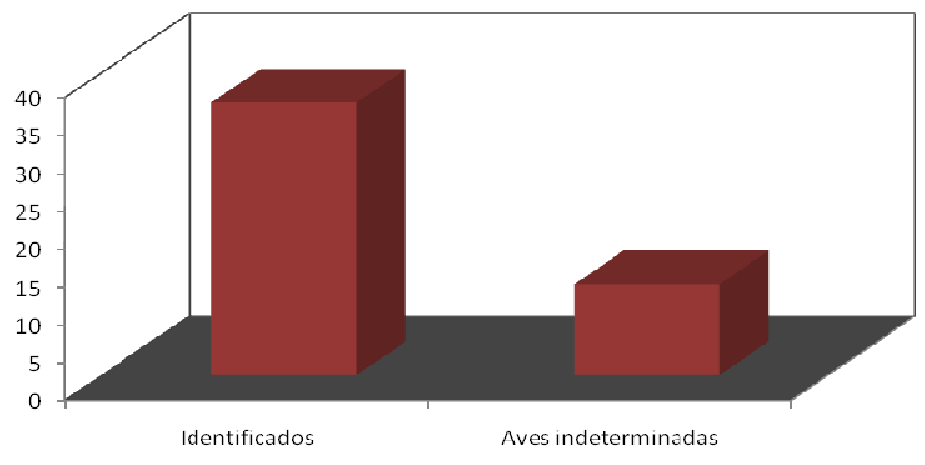

Gráfico 38 - Quantidade de restos identificados e não identificados taxonomicamente.

Como se disse, foram reconhecidos, na Gruta das Salemas, um total de 48 restos ósseos de aves. Destes 48 , foram identificados taxonomicamente 36 , ficando os restantes 12 qualificados como ave indeterminada (quadro 36 e gráfico 38).

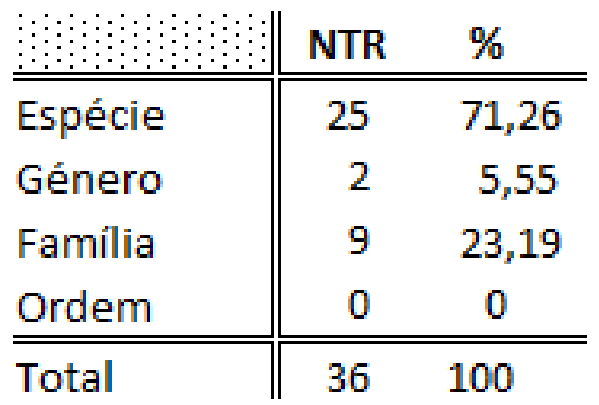

Quadro 36 - Diferentes níveis taxonómicos dos restos identificados e respectiva percentagem. 


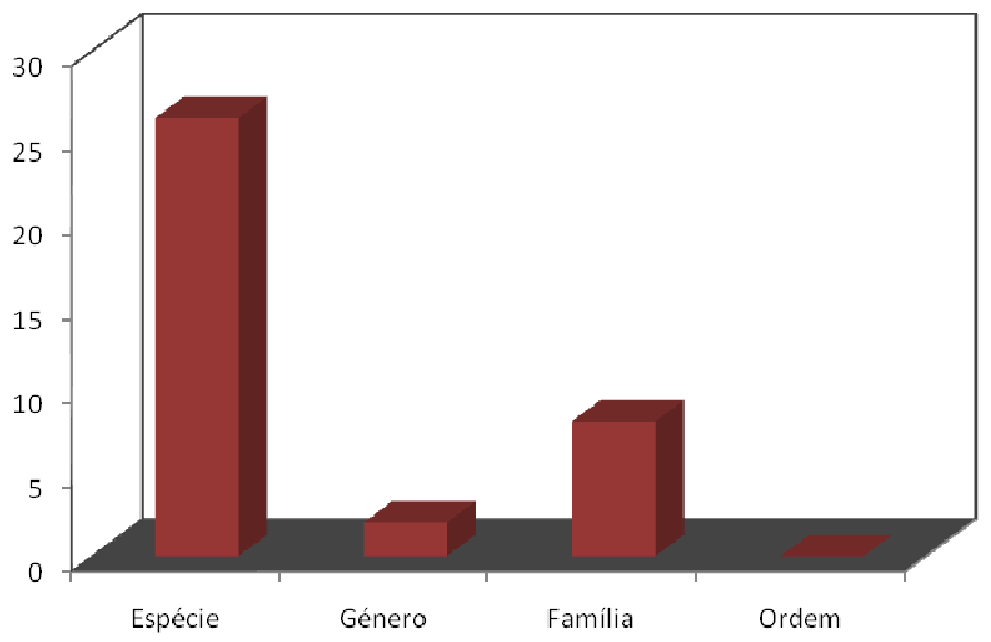

Gráfico 39 - Quantidade dos diferentes níveis taxonómicos dos restos identificados.

Dos restos identificados, 22 foram classificados ao nível da espécie, dois ao nível do género e oito ao nível da família, Nenhum dos restos foi classificado ao nível da ordem (quadro 37 e gráfico 39).

\section{Sistemática Paleontológica}

Ordem: COLUMBIFORMES, (LATHAM,1790)

Família: COLUMBIDAE, (ILLIGER,1811)

Subfamília: COLUMBINAE, (ILLIGER,1811)

Género: Columba (LINNAEUS,1758)

Columba livia, (GMELIN, 1789)

Material: 2 úmeros.

Total de restos: 2

Ordem: PASSERIFORMES (LINNAEUS, 1758)

Família: CORVIDAE (VIGORS, 1825)

Género: Corvus (LINNAEUS, 1758)

Corvus monedula (LINNAEUS, 1758)

Material: 4 fémures. 
Total de restos: 4

Ordem: PASSERIFORMES (LINNAEUS, 1758)

Família: CORVIDAE (VIGORS, 1825)

CORVIDAE INDET.

Material: 2 úmero, 6 carpometacarpos.

Total de restos: 6

Ordem: PASSERIFORMES (LINNAEUS, 1758)

Família: CORVIDAE (VIGORS, 1825)

Género: Pyrrhochorax (TUNSTALL, 1771)

Pyrrhochorax graculus (LINNAEUS, 1766)

Material: 6 ulnas, 2 metacarpos.

Total de restos: 8

Ordem: PASSERIFORMES (LINNAEUS, 1758)

Família: CORVIDAE (VIGORS, 1825)

Género: Pyrrhochorax (TUNSTALL, 1771)

Pyrrhochorax Pyrrhochorax (LINNAEUS, 1758)

Material: 1 coracoíde, 3 tarsometatarsos, 2 Ulnas.

Total de restos: 6

Ordem: PASSERIFORMES (LINNAEUS, 1758)

Família: CORVIDAE (VIGORS, 1825)

Género: Pyrrhochorax (TUNSTALL, 1771)

Pyrrhochorax sp

Material: 2 úmeros.

Total de restos: 2 
Ordem: PASSERIFORMES (LINNAEUS, 1758)

Família: CORVIDAE (VIGORS, 1825)

Género: Pica (BRISSON,1760)

Pica pica (LINNAEUS, 1758)

Material: 2 coracóides, 2 fémures.

Total de restos: 4

Ordem: PASSERIFORMES (LINNAEUS, 1758)

Família: TURDIDAE (BONNAPARTE, 1850)

Género: Turdus (LINNAEUS, 1758)

Turdus merula (LINNAEUS, 1758)

Material: 3 úmeros.

\section{Total de restos: 3}

Taxonmicamente a ordem mais abundante é a dos passeriformes, com 94\% dos restos identificados; aparecem também columbiformes (6\%) do total dos grupos identificados. Dentre os passeriformes predominam os corvídeos (91\%), enquanto os turdideos, apenas $9 \%$ do total da amostra foram identificados. Dos corvídeos foram identificados três géneros, com vinte e quatro restos (75 \%): o género Pica (espécie Pica pica) com quatro elementos ósseos (17\%); o género Corvus (espécie: Corvus monedula) também com quatro elementos (17\%) e o género Pyrrhocorax, com 16 restos (espécies Pyrrhocorax pyrrhocorax, seis restos, Pyrrhocorax graculus, oito restos e Pyrrhocorax sp, com dois), num total de desasseis elementos ósseos, o que corresponde a $66 \%$ dos restos de passeriformes identificados nesta gruta. Foram também identificados três ossos de Turdus (Turdus merula), que representam cerca de $9 \%$ dos passeriformes encontrados. 


\begin{tabular}{l|cccc} 
Taxone & NMI & NMI\% & NTR & NTR \% \\
\hline \hline Corvus monedula & 3 & 21,43 & 4 & 15,39 \\
Pyrrhochorax graculus & 4 & 28,58 & 8 & 30,76 \\
Pyrrhochorax pyrhochorax & 2 & 14,28 & 5 & 19,23 \\
Columba livia & 1 & 7,15 & 2 & 7,69 \\
Pica pica & 2 & 14,28 & 4 & 15,39 \\
Turdus merula & 2 & 14,28 & 3 & 11,54
\end{tabular}

Quadro 37- Número mínimo de indivíduos e número total de restos das diferentes espécies identificadas na Gruta das Salemas.

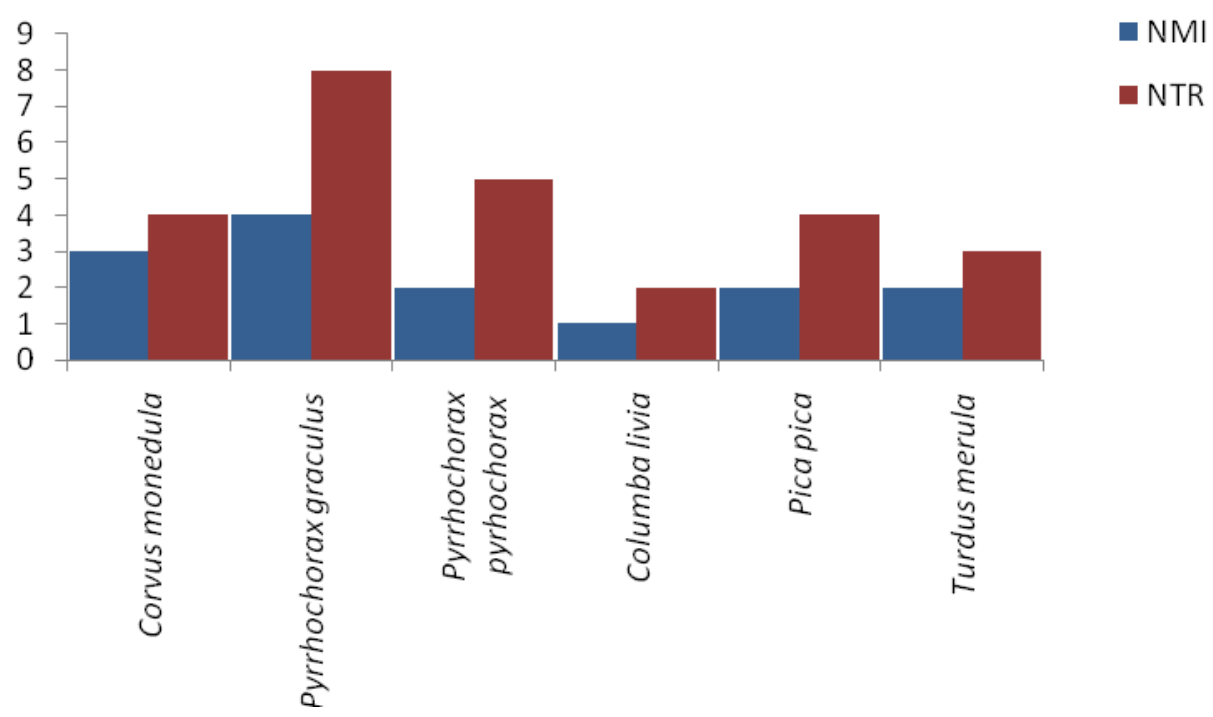

Gráfico 40 - Relacção entre o número mínimo de indivíduos e número total de restos das diferentes espécies identificadas na Gruta das Salemas.

\begin{tabular}{l|rrrr} 
Ordens & NMI & NMI\% & NTR & NTR \% \\
\hline \hline Passeriformes & 18 & 94,74 & 34 & 94,44 \\
Columbiformes & 1 & 5,26 & 2 & 5,56
\end{tabular}

Quadro 38 - Número mínimo de indivíduos e número total de restos das ordens identificadas na Gruta das Salemas. 


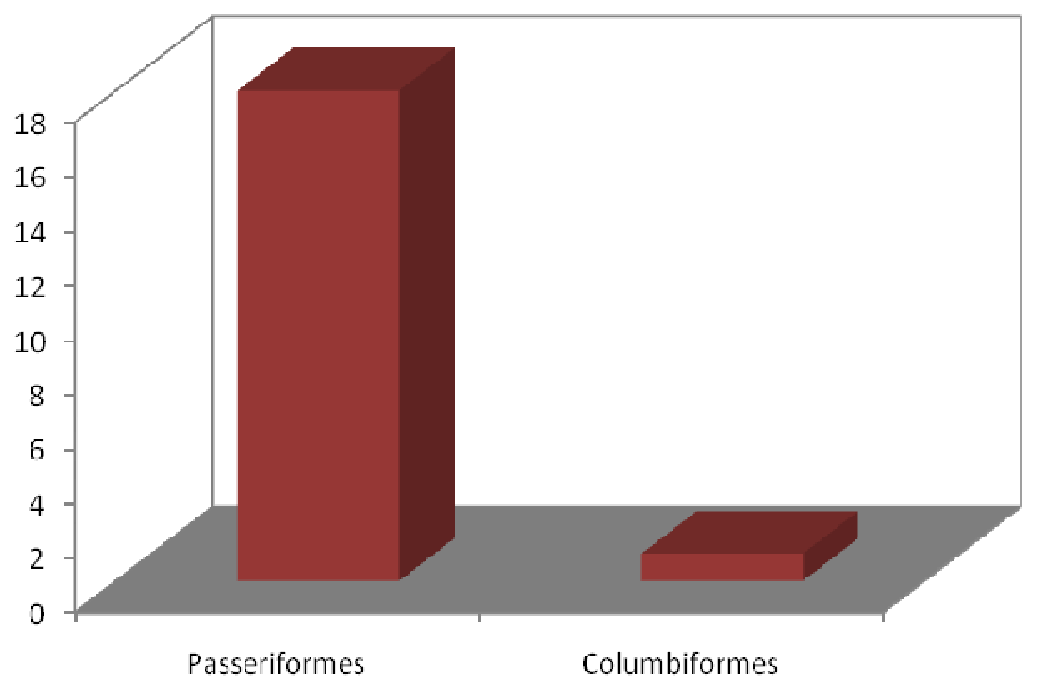

Gráfico 41 - Relação entre as ordens identificadas na Gruta das Salemas.

\section{3 - Tafonomia}

No seu estudo sobre os grandes mamíferos, João Luís Cardoso defende que a associação fóssil dos mamíferos da Gruta das Salemas é de origem antrópica (CARDOSO, 1993, p. 529). No entanto, a associação paleornitológica indica uma acumulação natural, uma vez que as espécies identificadas frequentam as cavidades e, com a excepção do Columba livia, que é a espécie menos representada, não são tradicionalmente consumidas pelo homem. Por outro lado, a fraca ocorrência de carnívoros sugere que a avifauna ali presente não terá sido transportada por esses animais para esta gruta. Assim, os dados indicam que a grande maioria, se não a totalidade das aves presentes nas Salemas, terá ali morrido naturalmente, e com a acumulação posterior dos sedimentos os seus restos ficaram ali preservados.

\section{4 - Análise paleoecológica}

A Gruta das Salemas apresenta espécies de aves características de um ambiente terrestre seco, não se tendo encontrado táxones de aves marinhas nem de ambientes húmidos nem de zonas florestais. A grande ocorrência de espécies de 
montanha e zonas rochosas corresponde à zona onde se encontra a gruta: zona elevada rochosa. Com excepção do Pyrrhocorax graculus, de climas mais frios do que os que se fazem sentir actualmente em Portugal, as restantes espécies indicam climas de temperaturas semelhantes às actuais.

Os indicadores paleoecológicos das espécies de aves identificadas diferem dos indicadores das espécies de mamíferos identificadas, que apontam para a proximidade de manchas florestais e climas mais frios (CARDOSO, 1993 p. 529).

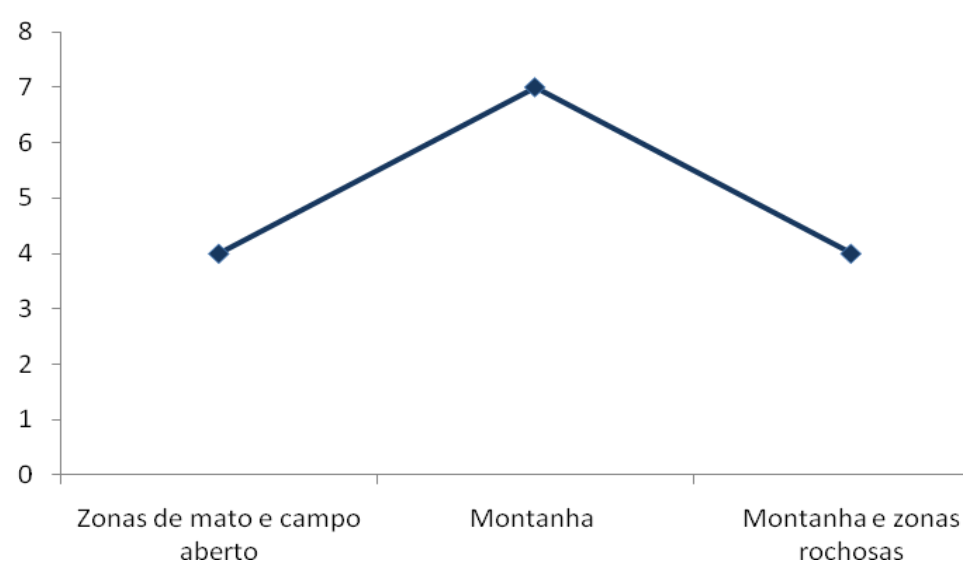

Gráfico 42 - Distribuição e percentagem das espécies identificadas na Gruta das Salemas, segundo o número mínimo de indivíduos e as respectivas zonas ambientais.

Enquanto na análise da distribuição do número mínimo de indivíduos pelas suas zonas ambientais, em que predominam ambientes de campo aberto, montanha e zonas rochososas, com destaque para as zonas de montanha, na análise segundo a ocorrência individual das espécies, pelos seus ambientes, verifica-se a existência de dois novos ambientes (o costeiro e o de bosque), os restantes estão em sintonia com a análise anterior, com a ausência de espécies de floresta e de lagos de água doce, mas um grande destaque para os ambientes de montanha, seguidos de campo aberto e de zonas rochosas. A ocorrência elevada de espécies de zonas costeiras parece estar fora de contexto, visto a Gruta das Salemas, embora localizada relativamente perto do Estuário do Tejo, se encontrar num vale encaixado, afastada de zonas costeiras. Isto explica-se pelo facto destas espécies estarem associadas a ambientes costeiros e também aparecem associadas a outros ambientes, nomeadamente de campo aberto e de montanha, o que é mais consonante com a posição geográfica da gruta. 
Com excepção desta controversa ocorrência de ambientes costeiros, a análise paleoecológica, segundo a presença unitária de espécies, está de acordo com a análise da distribuição do número mínimo de indivíduos, pela sua zona ambiental, ou seja a ausência de ambientes de flores e húmidos.

\begin{tabular}{|c|c|c|c|c|c|c|}
\hline & Bos & CA & LAD Mont & ZR & Flo & $\cos$ \\
\hline C. livia & & & & 0.5 & & 0.5 \\
\hline C. monedula & 0.33 & 0.33 & & & & 0.33 \\
\hline P. graculus & & & 1 & & & \\
\hline Pyrrhocorax sp. & & & 0.5 & & & 0.5 \\
\hline P. pyrrhocorax & & & 0.5 & & & 0.5 \\
\hline P. pica & 0.5 & 0.5 & & & & \\
\hline T. merula & 0.5 & 0.5 & & & & \\
\hline TOTAL & 1.33 & 1.33 & 2 & 0.5 & & 1.83 \\
\hline
\end{tabular}

Quadro 39 - Distribuição das espécies identificadas na Gruta das Salemas, segundo os seus ambientes (Bos - bosque; CA - campo aberto; LAD - lagos de água doce; Mont - montanha; ZR - zonas rochosas; ZH - zonas húmidas; Flo - floresta; Cos - zonas costeiras.).

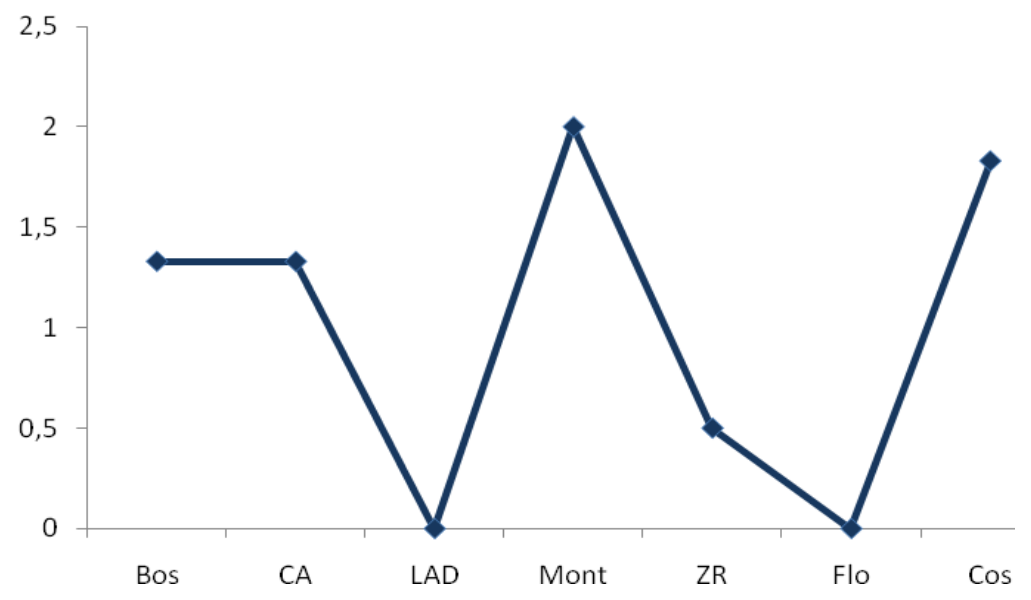

Gráfico 43 - Repartição por ocorrência das espécies, segundo os seus ambientes (Bos bosque; CA - campo aberto; LAD - lagos de água doce; Mont - montanha; ZR - zonas rochosas; ZH - zonas húmidas; Flo - floresta; Cos - zonas costeiras.).

Perante os dados obtidos pelos indicadores paleoambientais das aves da Gruta das Salemas e tendo em conta os paleobiótipos indicados pelas espécies encontradas e pelo NMI, pode-se concluir que o paleoecótipo dominante da zona é o de montanha. 


\section{4 - GrutA do PEgo do Diabo}

Dos materiais ósseos da Gruta do Pego do Diabo depositados no Museu Nacional de Arqueologia, apenas foram identificados cinco restos de aves. Destes, foi possível classificar três abaixo da classe, atribuindo aos restantes dois a classificação de ave indeterminada, o que corresponde a $60 \%$ de restos classificados e $40 \%$ de aves indeterminadas.

Do inúmero espólio ósseo que se encontra depositado no Museu Nacional de Arqueologia, apenas foram encontrados quatro restos de avifauna. Há uma grande quantidade de ossos muito fragmentados e é possível que alguns destes fragmentos sejam de aves; no entanto, o seu estado não permite obter essa confirmação. Dos ossos estudados conseguiu-se identificar duas espécies. Anser albiforns e Cf. Phasianus colchicus. Não foi possível identificar a espécie de um dos ossos, um tarsometatarso, pois não se encontrou na colecção de referência consultada qualquer paralelismo. No entanto, pela sua morfologia, chegou-se à conclusão que pertence a um anatídeo, podendo eventualmente tratar-se de uma espécie já extinta.

Os cinco restos de aves identificados nesta jazida são provenientes de duas camadas: da 1 e da 2. á camada 1 pertencem os dois restos de aves indeterminadas (um rádio e uma vértebra) e um fragmento proximal de um úmero atribuído a Phasianus colchicus. Á camada 2 pertencem os restantes lementos ósseos: uma tarsometatarso de cf. Anser sp e um carpometacarpo de Anser albifrons.

\section{1 - Estudo taxonómico}

Como já foi referido, no estudo taxonómico foram identificados três elementos ósseos, sendo que em dois deles foi possível identificar a espécie, enquanto no outro apenas se conseguiu identificar a nível da família. Por esta razão, e pelo facto de existirem muito poucos vestígios ósseos de aves nesta gruta, optouse por tratar estatisticamente os dados obtidos utilizando apenas a família, o que oferece uma maior extensão de análise e permite tirar mais conclusões acerca dos 
grupos taxonómicos mais representativos.

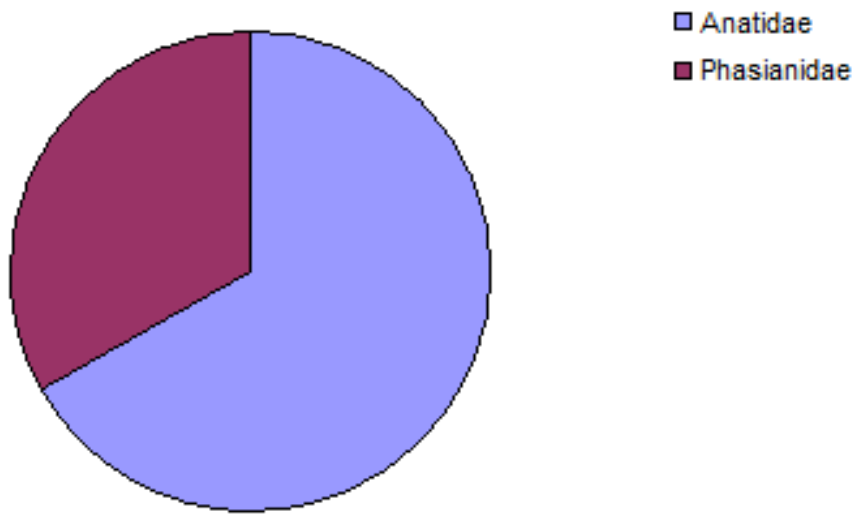

Gráfico 44 - Famílias de aves identificadas na Gruta do Pego do Diabo.

\section{Sistemática Paleontológica}

Ordem: GALLIFORMES (TEMMINCK, 1820)

Família: PHASIANIDAE (HORSFIELD 1821)

Género: Phasianus (LINNAEUS, 1758)

Cf. Cf. Phasianus colchicus (LINNAEUS, 1758)

Material: 1 úmero.

Total de restos: 1

Ordem: ANSERIFORMES (LATHAM, 1790)

Família: ANATIDAE (VIGORS, 1825)

Género: Cf. Anser sp (LINNAEUS, 1758)

Material: 1 tarsometatarso.

Total de restos: 1

Ordem: ANSERIFORMES (WAGLER, 1831)

Família: ANATIDAE (VIGORS, 1825)

Género: Anser (LINNAEUS, 1758)

Anser albifrons (SCOPOLI, 1769) 
Material: 1 Carpometacarpo.

\section{Total de restos: 1}

Como a amostra é muito pequena e apenas se encontrou um resto de cada táxon atribuído, logo apenas foi identificado um indivíduo de cada um deles: um anatídeo, um Anser albifrons e um Cf. Phasianus colchicus.

\section{Análise Osteológica}

Dos ossos analisados, a grande maioria pertence ao esqueleto apendicular e, em particular, aos membros, $80 \%$ do total da amostra de restos de aves dp pego do Diabo. A apenas foi identificada um osso do esqueleto axial, uma vértebra de ave indeterminada. Trata-se portanto de restos do esqueleto apendicular e axial.

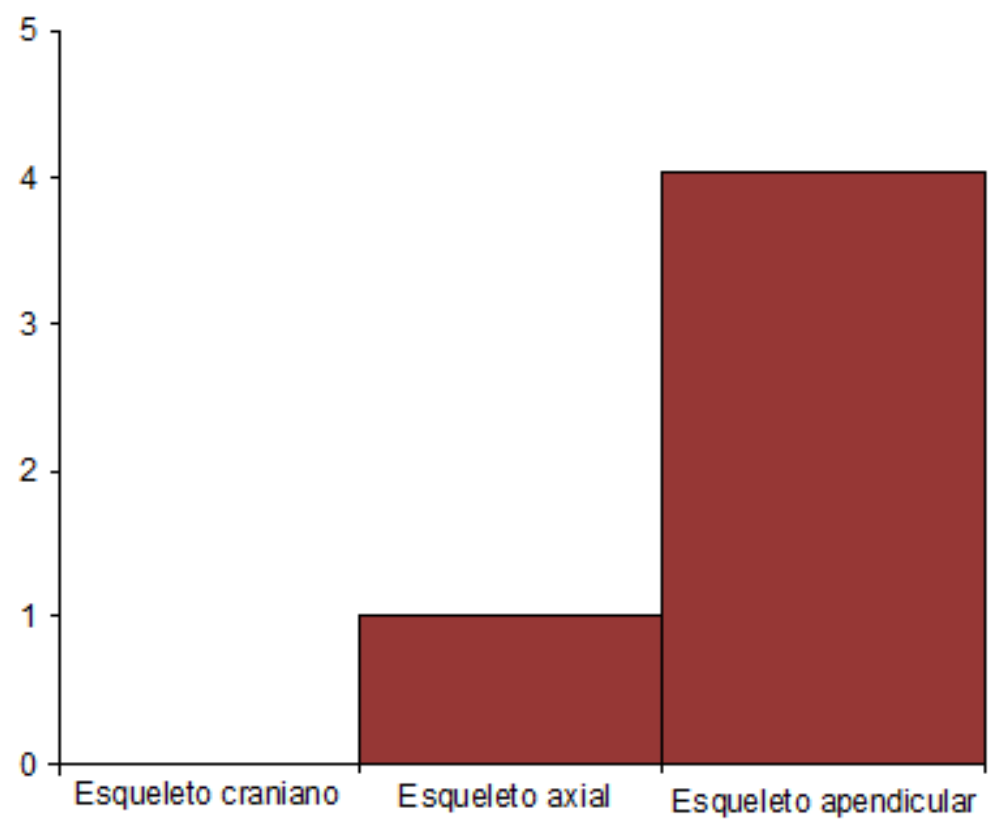

Gráfico 45 - Distribuição das partes esqueléticas identificadas nas aves da Gruta do Pego do Diabo.

\section{2 - Tafonomia}

Esta é a única estação que apresenta marcas antrópicas nos ossos encontrados. O tarsometatarso apresenta duas marcas lineares que poderão ser 
marcas de corte e a extremidade proximal apresenta-se desgastada, indicando uma fragmentação originada por mordedura. Por seu lado, o fragmento de úmero apresenta uma fractura pontiaguda, que poderá ser o resultado do talhe do osso para o transformar num furador. A acrescentar a estes dados, os grupos taxonómicos identificados, que são de aves que não frequentam grutas, indicam que a acumulação das aves nesta gruta terá resultado de acção antrópica. O facto de se terem encontrado quase na totalidade elementos do esqueleto apendicular, poderá estar relacionado com o caso destes serem os ossos mais resistentes, e por isso terem mais condições de se preservar durante o processo de fossildiagénese.
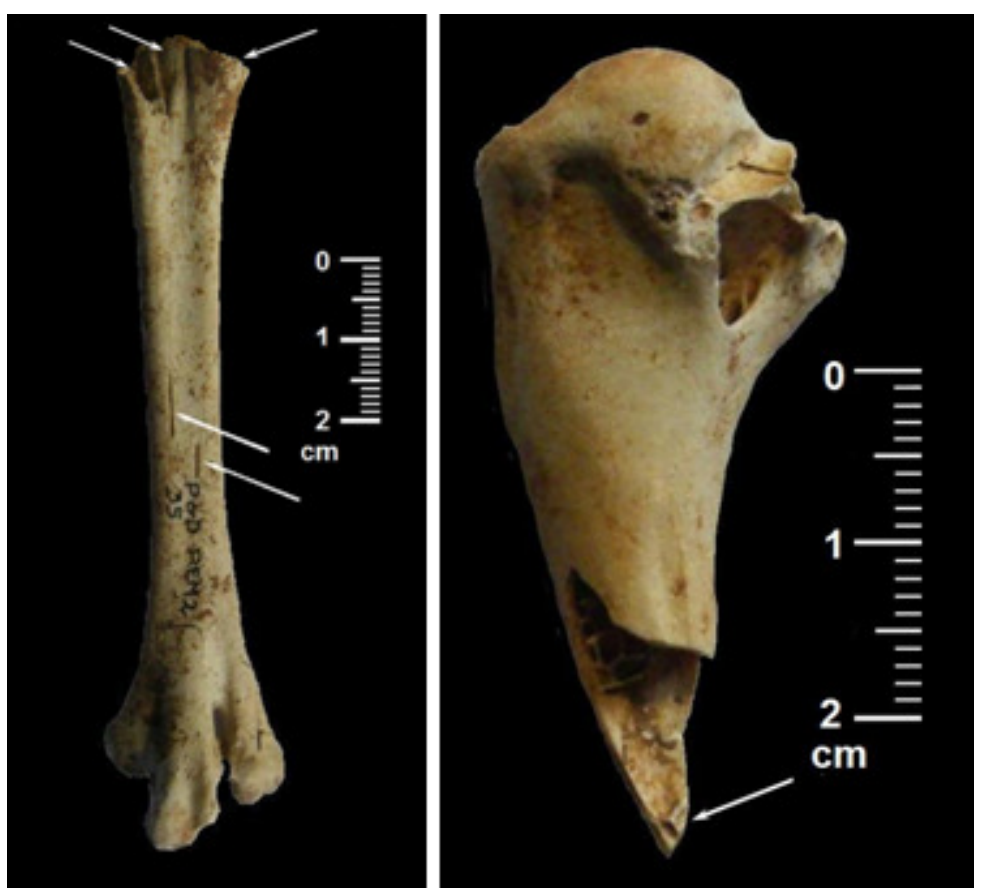

Fig. 78 - À esquerda tarsometatarso com possíveis marcas de corte e de predação. À direita fragmento de úmero com possível trabalho de talhe humano.

\section{3 - Análise paleoecológica}

Os táxones identificados indicam a existência, durante o Paleolítico na zona onde se localiza a gruta, de aves de habitat secos (mato, campo aberto, floresta e bosque) e de habitat húmidos (lagos e locais de água doce), havendo uma maior abundância de táxones de zonas húmidas. Estes indicadores estão de acordo com a localização geográfica da gruta, num local onde existem esses dois tipos de ambientes. A zona onde se encontra a gruta é uma zona de mato e bosque e está 
próxima do rio de Loures e da vázea. Esta última seria uma zona pantanosa durante alguns períodos do Plistocénico.

Se se analisarem os dados geográficos e climáticos relacionados com os táxones identificados, verifica-se que, enquanto o Cf. Cf. Phasianus colchicus está distribuído de forma residente por quase todo o continente europeu, da Inglaterra à Itália, o Anser albifrons, que não ocorre actualmente em Portugal, nidifica no extremo norte da Europa e da Ásia, passando o Inverno mais a sul e a oeste da Europa, ocupando zonas mais a sul, como a Hungria, Roménia, Sul de França, Itália e Grécia (GOODERS \& HARRIS, 1990).

\begin{tabular}{|c|c|c|c|c|c|c|}
\hline & Bos & CA & LAD Mont & ZR & Flo & $\operatorname{Cos}$ \\
\hline Phasianus colchicus & 0.33 & 0.33 & & & 0.33 & \\
\hline Anser albifrons & & & 1 & & & \\
\hline Anatidae & & & 0.5 & & & 0.5 \\
\hline TOTAL & 0.33 & 0.33 & 1.5 & & 0.33 & 0.5 \\
\hline
\end{tabular}

Quadro 40 - Ambientes das proximidades da gruta do Pego do Diabo, indicados pela ocorrência das espécies de aves identificadas.

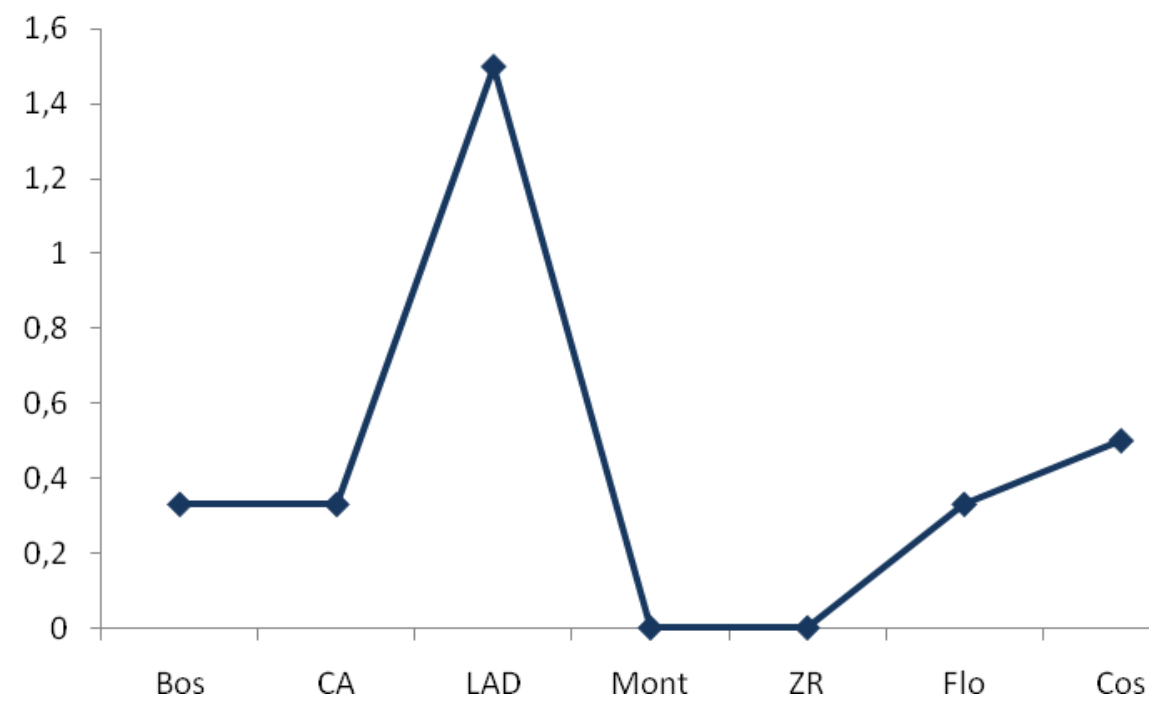

Gráfico 46 - Distribuição taxonómica, segundo os seus respectivos ambientes (Bos - bosque; CA - campo aberto; LAD - lagos de água doce; Mont - montanha; ZR - zonas rochosas; ZH zonas húmidas; Flo - floresta; Cos - zonas costeiras.).

A distribuição paleoecológica das espécies identificadas na Gruta do Pego do Diabo demonstra uma clara predominância de climas húmidos, de água doce, a 
ocorrência de florestas, bosques e campo aberto, a ausência de montanha e de zonas rochosas e a ocorrência de ambientes costeiros. A presença deste ultimo ambiente levanta as mesmas questões suscitadas pelo caso da Gruta das Salemas. Tal como em Salemas, a ocorrência deste paleoambiente no Pego do Diabo não é exclusiva, com a agravante de se tratar de uma classificação ao nível da família, o que se torna num grau de imprecisão maior.

É de realçar que a possível acumulação antrópica da avifauna plistocénica da Gruta do Pego do Diabo pode dar origem a dados paleoecológicos errados, uma vez que estas aves poderiam ter sido caçadas numa área afastada da gruta e com um ambiente diferente; por outro lado, o pequeno número de restos também não permite tirar grandes ilações paleoecológicas, nem é possível definir o paleoecótipo dominante da zona da gruta do Pego do Diabo. 


\section{5 - GRUTA DAS FONTAINHAS}

Os restos de aves da Gruta das Fontainhas estudados são provenientes da parte da colecção osteológica desta jazida que está em depósito no Museu Geológico de Lisboa. A avifauna da Gruta das Fontainhas é, comparativamente com os mamíferos, residual. Apenas foram identificados 20 restos de aves, dos quais a 19 (95\%) foi possível atribuir uma classificação taxonómica (espécie) e a um (5\%) só se conseguiu definir como ave indeterminada.

Todos estes restos de aves foram estudados e classificados por Newton e Harlé e publicados no início do século XX (HARLÉ, 1910-11, p.46). O estudo agora desenvolvido apenas confirmou esta classificação antiga e actualizou as nomenclaturas taxonómicas, atribuídas por aqueles investigadores e que na maioria das espécies já se encontram desactualizadas.

\section{1 - Análise Osteológica}

No total dos restos ósseos provenientes da Gruta das Fontainhas, apenas uma pequena parte é de ave (20) e todos eles pertencem ao esqueleto apendicular. Destes restos dominam os restos osteológios dos membros anteriores (onze), enquanto os dos membros posteriores totalizam oito. Um dos restos era apenas um fragmento de osso longo, que não se conseguiu identificar.

\section{2 - Estudo taxonómico}

O estudo taxonómico consistiu apenas na actualização e revisão da taxonomia aplicada aos restos já estudados por E. T. Newton, uma vez que na consulta da colecção não foram identificados mais ossos de aves nesta jazida. Com a excepção do resto muito fragmentado, atrás referido, a todos os outros foi possível atribuir a classificação ao nível da espécie. Das seis espécies identificadas, quatro 
foram actualizadas (cerca de $67 \%$ ) e apenas duas mantiveram a classificação de Newton e Harlé (HARLÉ, 1910/11).

Revisão taxonómica (GFP)

\begin{tabular}{c|c}
\hline \hline Designação antiga & Nova designação/atribuição \\
\hline \hline Pyrrhocorax alpinus & Pyrrhocorax graculus \\
Vanellus vulgaris & Vanellus vanellus \\
Pica rusticola & Pica pica \\
Caccabis rufa & Alectoris rufa
\end{tabular}

Quadro 41 - Actualização da nomenclatura taxonómica das espécies atribuída por Harlé e Newton às aves da Gruta das Fontainhas.

\section{Sistemática Paleontológica}

Ordem: GALLIFORMES (TEMMINCK, 1820)

Família: PHASIANIDAE (Horsefield, 1821)

Género: Alectoris (KAUP, 1829)

Alectoris rufa (LINNAEUS, 1758)

Material: 1 coracóide.

Total de restos: 1

Ordem: CharadRIIFORMES (HuXLEY, 1867)

Família: VANeLlidAe (BONAPARTE, 1842)

Género: Vanellus (BRISSON, 1760)

Vanellus Vanellus (LINNAEUS, 1758)

Material: 1 coracóide.

Total de restos: 1

Ordem: PASSERIFORMES (LINNAEUS, 1758)

Família: CORVIDAE (VIGORS, 1825)

Género: Corvus (LINNAEUS, 1758)

Corvus monedula (LINNAEUS, 1758)

Material: 1 úmero, 2 ulnas, 2 fémures, 1 tibiotarso. 
Total de restos: 6

Ordem: PASSERIFORMES (LINNAEUS, 1758)

Família: CORVIDAE (VIGORS, 1825)

Género: Pica (BRISSON, 1760)

Pica pica (LINNAEUS, 1758)

Material: 1 coracóide; 1 tibiotarso.

Total de restos: 2

Ordem: PASSERIFORMES (LINNAEUS, 1758)

Família: CORVIDAE (VIGORS, 1825)

Género: Pyrrhocorax (TUNSTALL, 1771)

Pyrrhocorax graculus (LINNAEUS, 1766)

Material: 1 coracóide, 2 úmeros, 1 ulna, 1 tibiotarso, 1 Carpometacarpo.

Total de restos: 6

Ordem: PASSERIFORMES (LINNAEUS, 1758)

Família: CORVIDAE (VIGORS, 1825)

Género: Pyrrhocorax (TUNSTALL, 1771)

Pyrrhocorax pyrrhocorax (LINNAEUS, 1766)

Material: 3 tibiotarsos.

Total de restos: 3

Das espécies identificadas dominam as pertencentes à ordem dos passeriformes e, destes, apenas existem corvídeos. As espécies dominantes são o Pyrrhocorax graculus e o Corvus monedula, com doze restos, o que corresponde a cerca de $63 \%$ da totalidade dos restos (31,5\% para cada uma destas espécies). Dos outros grupos estão representados os galliformes, com um resto de Alectoris rufa e os chadriiformes, com um resto de Vanellus vanellus. 


\begin{tabular}{l|cccc} 
Espécies & NMI & NMI \% & NTR & NTR \% \\
\hline \hline Pica pica & 1 & 11,11 & 2 & 10,53 \\
Pyrrhocorax graculus & 2 & 22,22 & 6 & 31,57 \\
Alectoris rufa & 1 & 11,11 & 1 & 5,27 \\
Vanellus vanellus & 1 & 11,11 & 1 & 5,27 \\
Corvus monedula & 2 & 22,22 & 6 & 31,57 \\
Pyrrhocorax pyrrhocorax & 2 & 22,22 & 3 & 15,79
\end{tabular}

Quadro 42 - Número minino de indivíduos e número total de restos das espécies identificadas na Gruta das Fontainhas.

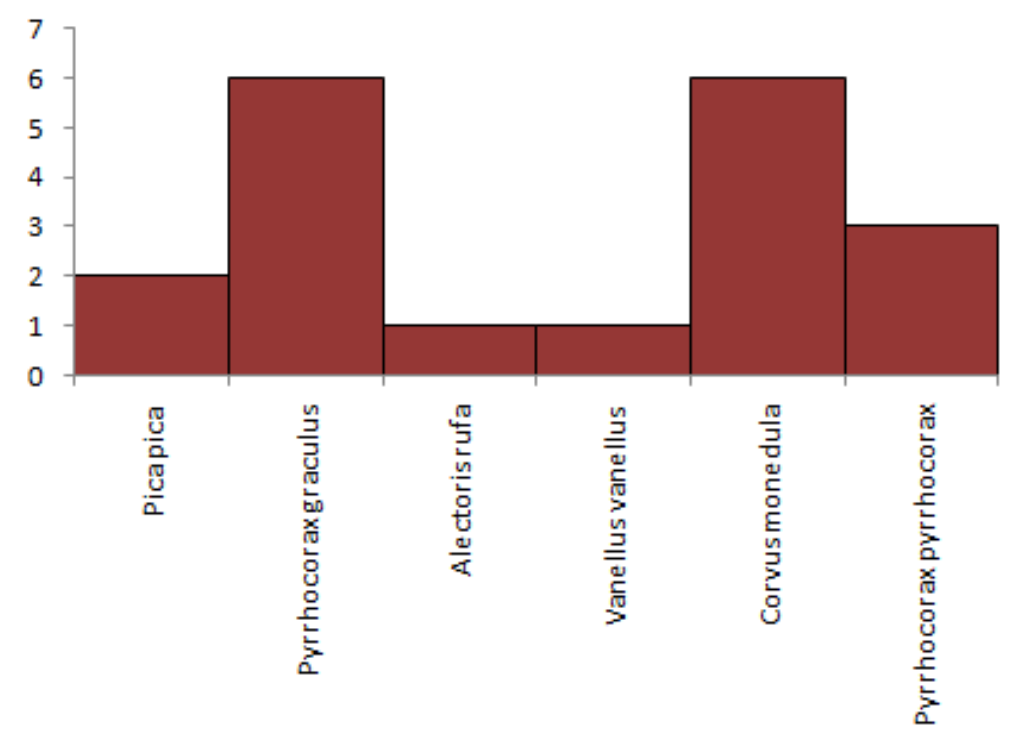

Gráfico 47 - Relação da ocorrência das diferentes espécies na Gruta das Fontainhas.

\section{3 - Análise osteológica}

De entre os ossos analisados apenas se encontraram os do esqueleto apendicular. Trata-se, na sua maioria, de ossos longos dos membros. Foram ainda encontrados ossos da cintura escapular (quatro coracóides). Quanto à atribuição das idades, apenas foram identificados restos de animais adultos.

\section{4 - Tafonomia}

Pelo estudo do estado de conservação dos ossos, verifica-se que a maioria 
(65\%) encontra-se inteira e apenas 35\% está fragmentada. Os restos não apresentam marcas de predação ou marcas de corte.

Com excepção de duas espécies (Vanellus vanellus e Alectoris rufa), cuja totalidade dos restos corresponde a apenas $10 \%$ de todos os restos de avifauna desta jazida, todas as outras espécies frequentam grutas.

Estes dados indicam que a maior parte dos restos aqui encontrados resultam de acumulações naturais e que apenas uma pequena parte poderá, mesmo apesar de não terem sido identificadas marcas de predação, ter resultado do transporte para dentro da gruta por carnívoros ou pelos homens que a utilizaram.

Para esta jazida foi feita uma comparação entre as espécies que ocorrem no Plistocénico e as espécies que ocorrem na actualidade. Verificou-se uma discordância entre as espécies de aves plistocénicas identificadas na Gruta das Fontainhas e a avifauna que actualmente é observada na serra de Montejunto, a zona onde se localiza a gruta.

\begin{tabular}{l|cc} 
Espécies & Ocorrências & Ocorrências \\
& Plistocénico & actuais \\
\hline \hline Pica pica (Pega-rabuda) & $*$ & \\
Pyrrhocorax graculus (Gralha-de-bico-amarelo) & $*$ & \\
Alectoris rufa (Perdiz-comum) & $*$ & \\
Vanellus vanellus (Abibe) & $*$ & \\
Corvus monedula (Gralha-de-nuca-cinzenta) & $*$ & \\
Pyrrhocorax pyrrhocorax (Gralha-de-bico-vermelho) & $*$ & \\
Corvus corone (Gralha-preta) & & $*$ \\
Corvus corax (Corvo-comum) & & $*$ \\
Athene noctua (Mocho-galego) & & $*$ \\
Falco tinuculus (Peneireiro-de-dorso-malhado) & & $*$ \\
Buteo buteo (Águia-de-asa-redonda) & & $*$ \\
Hieraetus fasciatus (Águia-de-boneli) & & $*$ \\
Falco peregrinus (Falcão-peregrino) & & $*$ \\
Tyto alba (Coruja-das-torres) & & $*$ \\
Bubo bubo (Bufo-real) & & $*$ \\
Elanus caeruleus (Peneireiro-cinzento) & & $*$
\end{tabular}

Quadro 43 - Comparação entre as espécies existentes actualmente na serra de Montejunto e as espécies identificadas nos depósitos plistocénicos da Gruta das Fontainhas.

\section{5 - Paleoecologia}

Pela análise taxonómica e pelo número de restos e do número mínimo de 
indivíduos de cada espécie identificada, verifica-se, em termos paleoecológicos, um predomínio de espécies de montanha e uma ocorrência relativamente fraca de aves de zonas húmidas. As aves encontradas nesta jazida indicam a proximidade de zonas de mato e de campo aberto, bem como pequenas manchas de zonas húmidas, sendo as mais abundantes as zonas de montanha rochosa.

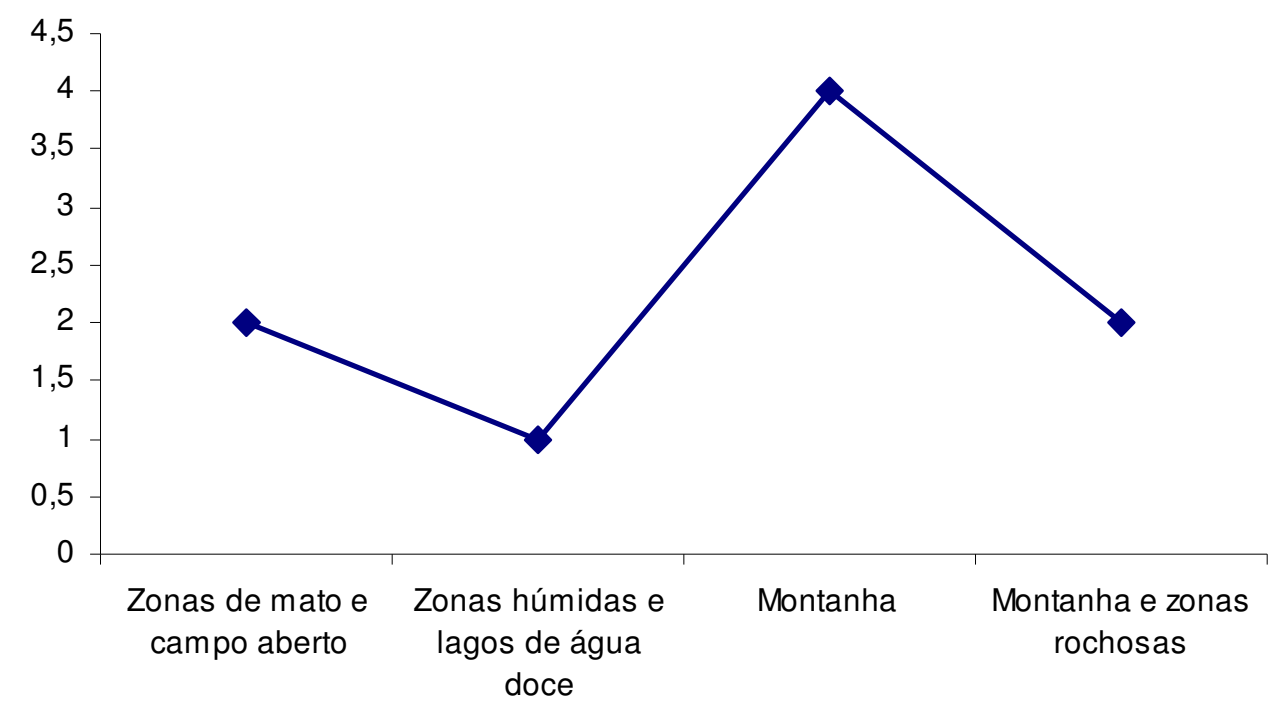

Gráfico 48 - Distribuição pelas zonas ambientais, segundo o do número mínimo de indivíduos das espécies identificadas

\begin{tabular}{|c|c|c|c|c|c|c|c|}
\hline & Bos & $\mathrm{CA}$ & $\mathrm{Zh}$ & LAD & Mont ZR & Flo & $\operatorname{Cos}$ \\
\hline A. rufa & & 1 & & & & & \\
\hline P. pica & 0,5 & 0,5 & & & & & \\
\hline P. graculus & & & & & 1 & & \\
\hline C. monedula & 0,33 & 0,33 & & & & & 0,33 \\
\hline P. pyrrhocorax & & & & & 0,5 & & 0,5 \\
\hline Vanellus $s p$ & & 0,33 & 0,33 & 0,33 & & & \\
\hline Total & 0,83 & 2,16 & 0,33 & 0,33 & 1,5 & & 0,83 \\
\hline
\end{tabular}

Quadro 44 - Paleoecologia das espécies identificadas na Gruta das Fontainhas. (Bos bosque; CA - campo aberto; LAD - lagos de água doce; Mont - montanha; ZR - zonas rochosas; ZH - zonas húmidas; Flo - floresta; Cos - zonas costeiras.). 


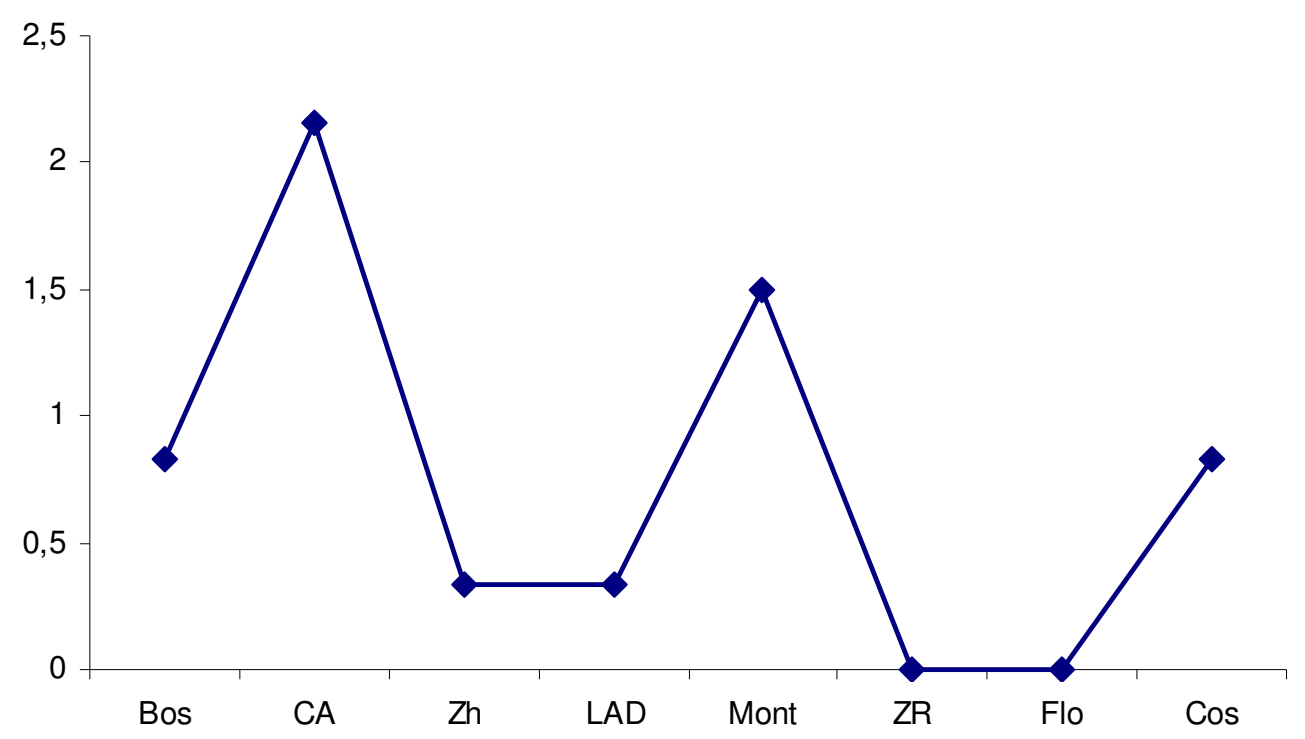

Gráfico 49 - Distribuição das espécies pelos respectivos ambientes associados (Bos - bosque; CA - campo aberto; LAD - lagos de água doce; Mont - montanha; ZR - zonas rochosas; ZH zonas húmidas; Flo - floresta; Cos - zonas costeiras.).

Verifica-se na análise da distribuição das espécies pelos seus ambientes que, ao contrário de outras jazidas, não existem grandes diferenças nos ambientes, com a análise da distribuição ambiental do número mínimo de indivíduos. A grande diferença é o aumento de ambientes de campo aberto, que ultrapassam os ambientes de montanha e a presença de ambientes costeiros, que não aparecem na distribuição do número mínimo de indivíduos, esta ultima questão pode ser explicada pelo facto de algumas espécies poderem ocorrer também em ambientes costeiros, como é o caso do C. monedula e P. pyrrhocorax.

Devido ao pequeno número de restos de aves desta jazida, não é possível definir o paleoecótipo dominante da zona Gruta das Fontainhas. 


\section{6 - Gruta da CASA da Moura}

No que respeita às aves da Gruta da Casa da Moura apenas existiam duas referências à existência de "quelques restes" de aves e répteis (HARLÉ, 1910/11, p. 50) e "fragments de crânes, os longes" de "oiseaux divers" (ROCHE, 1951p. 106). No entanto, de todas as jazidas investigadas para esta tese, foi a Gruta da Casa da Moura que maior número de restos forneceu: 615 , o que corresponde a cerca de $30 \%$ do total de restos de todas as jazidas estudadas.

Pela análise do sedimento encontrado em alguns restos de aves, verifica-se ser constituído por areias finas avermelhadas e um pouco concrecionadas, pelo grau de fossildiagénse comparado entre os restos que ainda tinham sedimento agarrado e os outros que não tinham qualquer vestígios de sedimentos, e pela catalogação de alguns ossos estudados, tudo indica que os restos de aves (e provavelmente dos outros restos faunísticos) em depósito no Museu Geológico são provenientes do nível plistocénico (camada 2) identificado por Nery Delgado.

\section{1 - Análise Osteológica}

Foram encontrados elementos de todas as partes do esqueleto, havendo, no entanto, um maior número de elementos do esqueleto apendicular. Trata-se essencialmente de restos ósseos pertencentes a indivíduos adultos, cuja percentagem é muito elevada (99.7\%), em comparação com a percentagem de jovens que é muito residual $(0,03 \%)$.

No que respeita ao estado de conservação dos restos de aves da Gruta da Casa da Moura, e ao contrário do que acontece na maioria das outras jazidas, a grande parte dos restos, cerca de $63 \%$ da totalidade, apresenta-se inteira enquanto apenas 37\% estão partidos. Estas percentagens são muito idênticas às da Gruta das Fontainhas. 


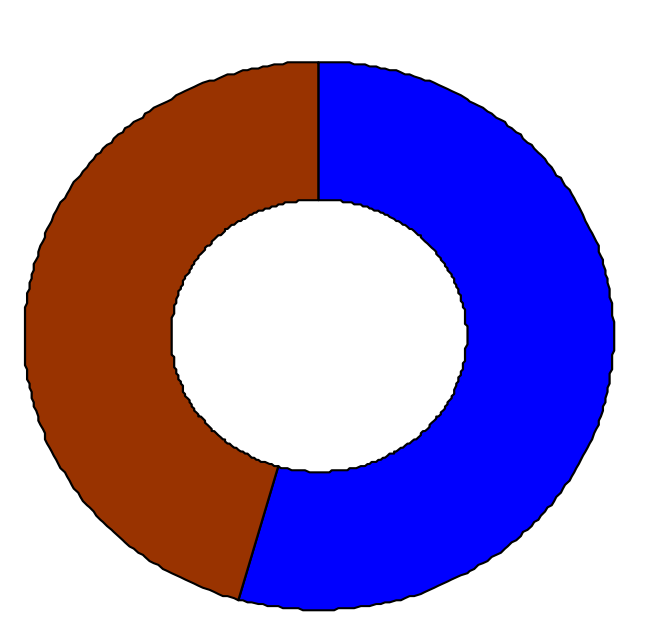

$\square$ Inteiro

$\square$ Partido

Gráfico 50 - Quantidade de restos partidos versus restos inteiros

Dos restos fragmentados, existe uma maior quantidade de partes proximais em relação às partes distais ou mesiais. Estas últimas apresentam um valor meramente residual: 6 (perto de $1 \%$ do total dos restos).

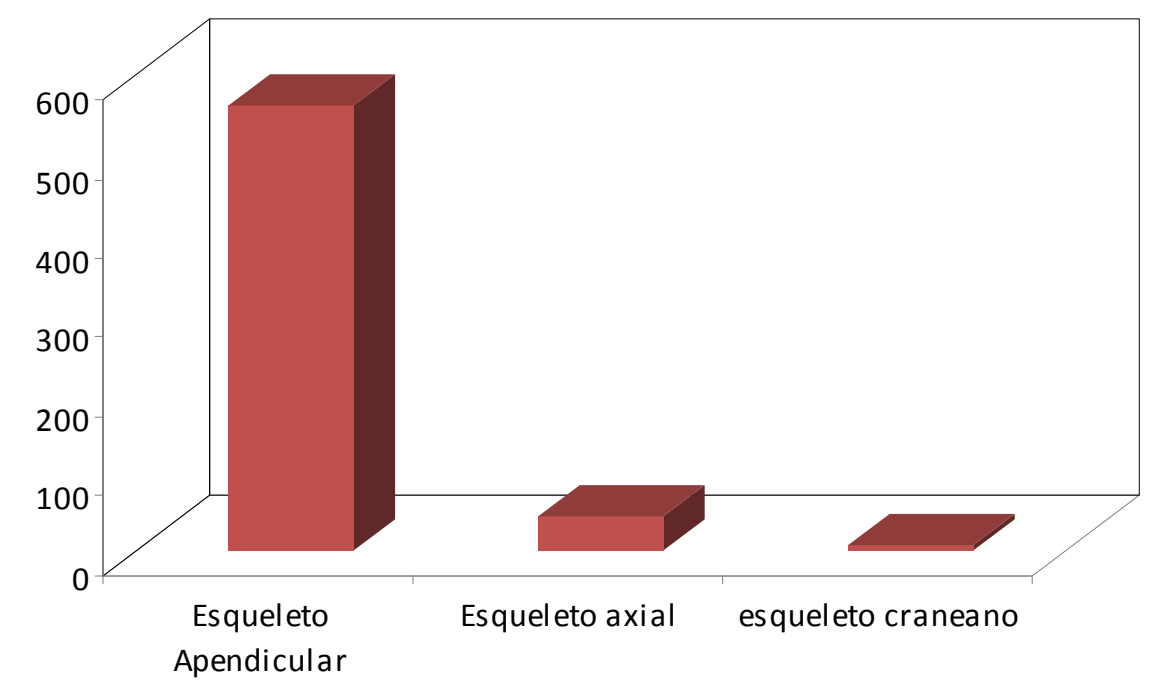

Gráfico 51 - Ocorrência das diferentes partes do esqueleto

\section{2 - Estudo taxonómico}

Apesar de ser a jazida que maior número de restos de aves forneceu, a Gruta da Casa da Moura é a que menor biodiversidade de avifauna apresenta: apenas 
foram identificadas 12 espécies.

\begin{tabular}{l|rr} 
Taxon & NMI & NTR \\
\hline \hline Pyrrhocorax pyrrhocorax & 16 & 59 \\
Pica pica & 23 & 48 \\
Accipritidae & 2 & 2 \\
Fasianidae & 2 & 2 \\
Bubo bubo & 9 & 13 \\
Corvus monedula & 92 & 277 \\
Pyrrhocorax graculus & 45 & 112 \\
Corvidae & 22 & 46 \\
Pyrrhocorax sp & 42 & 43 \\
Alectoris sp & 3 & 3 \\
Grus grus & 1 & 1 \\
Otis tarda & 2 & 2 \\
Cf. Falco rusticolus & 1 & 1 \\
Cf. Garrulus glandarius & 1 & 1 \\
Cf. Corvus corax & 1 & 1 \\
Falco sp & 1 & 1 \\
Cf. Cuculus canorus & 1 & 1 \\
Cf. Corvus frugilegus & 2 & 3
\end{tabular}

Quadro 45 - Número mínimo de individuos e número total de restos dos principais táxones reconhecidos na Casa da Moura.

Dos táxones identificados, verifica-se uma maior abundância dos passeriformes (em especial de corvídeos), com cerca de $94 \%$ do total dos restos identificados e estudados. No caso específico das aves carnívoras destacam-se as aves de rapina nocturnas, com $2 \%$ do total da amostra estudada. Os restantes $4 \%$ dividem-se por dez táxones, contendo, cada um deles, uma percentagem inferior a $1 \%$ do total dos restos identificados.

\section{Sistemática Paleontológica}

Ordem: GALLIFORMES (TEMMINCK, 1820)

Família: PhASIANIDAE (HORSEFIELD, 1821)

PhASIANIDAE INDET.

Material: 1 ulna, 1 tibiotarso.

Total de restos: 2 
Ordem: GALLIFORMES (TEMMinCK, 1820)

Família: PHASIANIDAE (HORSEFIELD, 1821)

Género: Alectoris (KAUP, 1829)

Género: Alectoris sp.

Material: 2 carposmetacarpos, 2 fémures.

Total de restos: 4

Ordem: GRUIFORMES (BONAPARTE, 1854)

Família: GRUIDAE (RAFINESQUE, 1815)

Género: Grus (LINNAEUS, 1758)

Grus grus (LINNAEUS, 1758)

Material: 1 fémur, 1 tarsometatarso.

Total de restos: 2

Ordem: GRUIFORMES (BONAPARTE, 1854)

Família: OTIDIDAE (VIGORS, 1825)

Género: Otis (BRISSON, 1760)

Otis tarda (LINNAEUS, 1758)

Material: 1 tibiotarso.

Total de restos: 1

Ordem: FALCONIFORMES (SHARPE 1874)

Família: FALCONIDAE (VIGORS, 1825)

Género: Falco (LINNAEUS, 1758)

Falco $s p$.

Material: 1 tibiotarso.

Total de restos: 1

Ordem: FALCONIFORMES (SHARPE 1874)

Família: FALCONIDAE (VIGORS, 1825) 
Género: Falco (LINNAEUS, 1758)

Falco rusticolus (LINNAEUS, 1758)

Material: 1 tarsometatarso.

Total de restos: 1

Ordem: FALCONIFORMES (SHARPE 1874)

ACCIPITRIDAE INDET.

Material: 1 crânio, 1 falange (Il dígito da asa).

Total de restos: 2

Ordem: STRIGIFORMES (WAGLER, 1830)

Família: STRIGIDAE (VIGORS, 1825)

Género: Bobu (DUMÉRIL, 1806)

Bubo bubo (LINNAEUS, 1758)

Material: 5 coracóides, 1 úmero, 2 ulnas, 1 Carpometacarpo, 1 falange (II dígito da asa), 1 fémur, 2 tibiotarsos, 1 tarsometatarso.

Total de restos: 14

Ordem: PASSERIFORMES (LINNAEUS, 1758)

Família: CORVIDAE INDET.

Material: 2 escápulas, 6 úmeros, 3 carpos-mertacarpos, 7 tibiotarsos, 6 tarsometatarsos.

Total de restos: 24

Ordem: PASSERIFORMES (LINNAEUS, 1758)

Família: CORVIDAE (VIGORS, 1825)

Género: Corvus (LINNAEUS, 1758)

Corvus corax (LINNAEUS, 1758)

Material: 1 tibiotarso.

Total de restos: 1 
Ordem: PASSERIFORMES (LINNAEUS, 1758)

Família: CORVIDAE (VIGORS, 1825)

Género: Corvus (LINNAEUS, 1758)

Corvus frugilegus

Material: 2 úmeros; 1 tibiotarso; 1 tarsometatarso.

Total de restos: 4

Ordem: PASSERIFORMES (LINNAEUS, 1758)

Família: CORVIDAE (VIGORS, 1825)

Género: Corvus (LINNAEUS, 1758)

Corvus monedula (LINNAEUS, 1758)

Material: 9 escápulas, 23 coracóides, 27 úmeros, 5 ulnas, 4 rádios, 71 carpomertacarpos, 1 falange (Il dígito da asa), 27 fémures, 51 tibiotarsos, 37 tarsometatarso.

Total de restos: 255

Ordem: PASSERIFORMES (LINNAEUS, 1758)

Família: CORVIDAE (VIGORS, 1825)

Género: Pica (BRISSON, 1760)

Pica pica (LINNAEUS, 1758)

Material: 1 crânio, 16 coracóides, 4 carpometacarpos, 1 fémur, 7 tibiotarsos, 7 tarsometatarsos.

Total de restos: 35

Ordem: PASSERIFORMES (LINNAEUS, 1758)

Família: CORVIDAE (VIGORS, 1825)

Género: Pyrrhocorax sp.

Material: 3 carpometacarpos, 39 sinsacros, 1 crânio.

Total de restos: 43

Ordem: PASSERIFORMES (LINNAEUS, 1758)

Família: CORVIDAE (VIGORS, 1825) 
Género: Pyrrhocorax (TNSTALL, 1771)

Pyrrhocorax pyrrhocorax (LINNAEUS, 1758)

Material: 1 crãnio, 5 coracóides, 16 úmeros, 2 ulnas, 21 carpometacarpos, 10 fémures, 21 tibiotarsos, 6 tarsometatarsos.

Total de restos: 81

\section{Material}

Ordem: PASSERIFORMES (LINNAEUS, 1758)

Família: CORVIDAE (VIGORS, 1825)

Género: Pyrrhocorax (TNSTALL, 1771)

Pyrrhocorax graculus (LINNAEUS, 1758)

Material: 47 coracóides, 16 úmeros, 2 ulnas, 1 rádio, 4 carpometacarpos, 30 fémures, 39 tibiotarsos, 4 tarsometatarsos.

Total de restos: 143

Ordem: CUCULIFORMES (WAGLER, 1830)

Família: CUCULIDAE (VIGORS, 1825)

Género: Cuculus (LINNAEUS, 1758)

Coculus canorus (LINNAEUS, 1758)

Material: 2 úmeros, 1 tibiotarso, 1 tarsometatarso.

Total de restos: 4

\section{3 - Tafonomia}

Pelo estado de conservação dos ossos, a maioria, 63\%, encontra-se inteira e $37 \%$ estão fragmentados. Não foram encontradas, nos restos estudados marcas de predação nem marcas de corte. Quer pelo facto de não se terem encontrado marcas de corte nos ossos, quer porque a maioria dos restos identificados são de aves que frequentam as grutas, quer ainda porque a ocupação humana desta gruta não foi muito intensa, tudo isto faz supor que esta acumulação terá sido natural. 


\section{4 - Paleoecologia}

Verifica-se, segundo a análise paleoecológica, que, pela distribuição número mínimo de indivíduos de cada espécie presente, segundo o ambiente associado, uma presença mais significativa de indivíduos de montanha e de zonas rochosas. Nota-se ainda uma ocorrência, embora de forma menos abundante, de aves de zonas húmidas e de zonas de campo aberto. Pelos dados paleoecológicos fornecidos pelo estudo das aves, conclui-se que a Gruta da Casa da Moura se caracterizava por ambientes de montanha, existindo nas proximidades zonas de mato e de campo aberto e pequenas manchas de zonas húmidas.

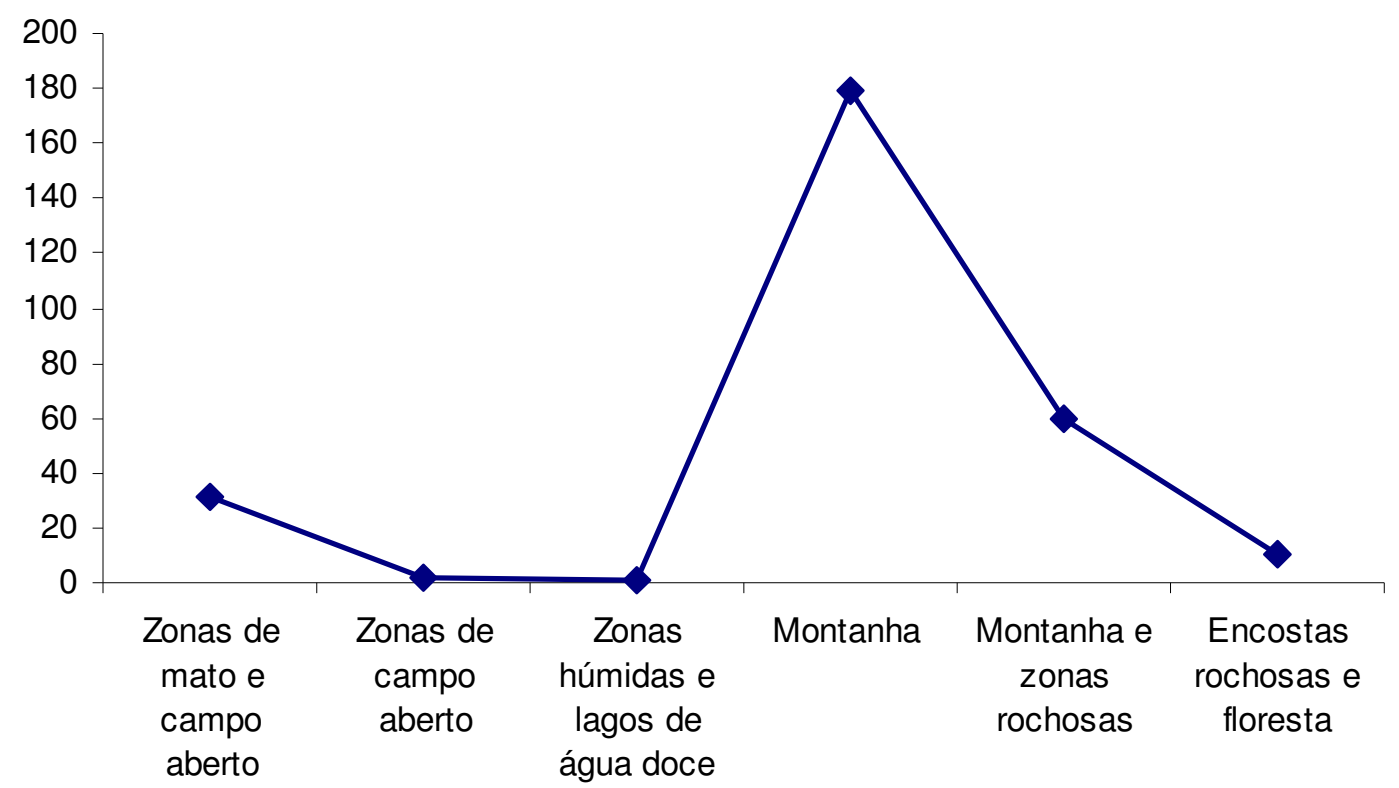

Gráfico 52 -Distribuição das diferentes espécies de aves da Gruta da Casa da Moura, pelas suas respectivas áreas ambientais, segundo o número mínimo de indivíduos. 


\begin{tabular}{|c|c|c|c|c|c|c|c|}
\hline & Bos $\mathrm{C}$ & CA 2 & $\mathrm{Zh}$ & LAD & Mon ZR & Flo & $\operatorname{Cos}$ \\
\hline Alectoris $s p$ & & 1 & & & & & \\
\hline Cuculus canorus & 1 & & & & & & \\
\hline P. pica & 0,5 & 0,5 & & & & & \\
\hline G. glandarius & & 0,5 & & & 0,5 & & \\
\hline Corvus frugilegus & 0,5 & 0,5 & & & & & \\
\hline C. corax & & 0,33 & 0,33 & & & & 0,33 \\
\hline Otis tarda & & 1 & & & & & \\
\hline Grus grus & & 0,33 & 0,33 & 0,33 & & & \\
\hline P. graculus & & & & & 1 & & \\
\hline Pyrrhocorax $s p$ & & & & & 0,5 & & 0,5 \\
\hline C. monedula & 0,33 & 0,33 & & & & & 0,33 \\
\hline P. pyrrhocorax & & & & & 0,5 & & 0,5 \\
\hline Falco sp. & & & & & 0,5 & 0,5 & \\
\hline Falco rusticolus & & & & & 0,5 & 0,5 & \\
\hline Total & 2,33 & 4,49 & 0,66 & 0,33 & 21,5 & 1 & 1,66 \\
\hline
\end{tabular}

Quadro 46 - distribuição das espécies identificadas e os respectivos habitat (Bos - bosque; CA - campo aberto; LAD - lagos de água doce; Mont - montanha; ZR - zonas rochosas; ZH zonas húmidas; Flo - floresta; Cos - zonas costeiras.).

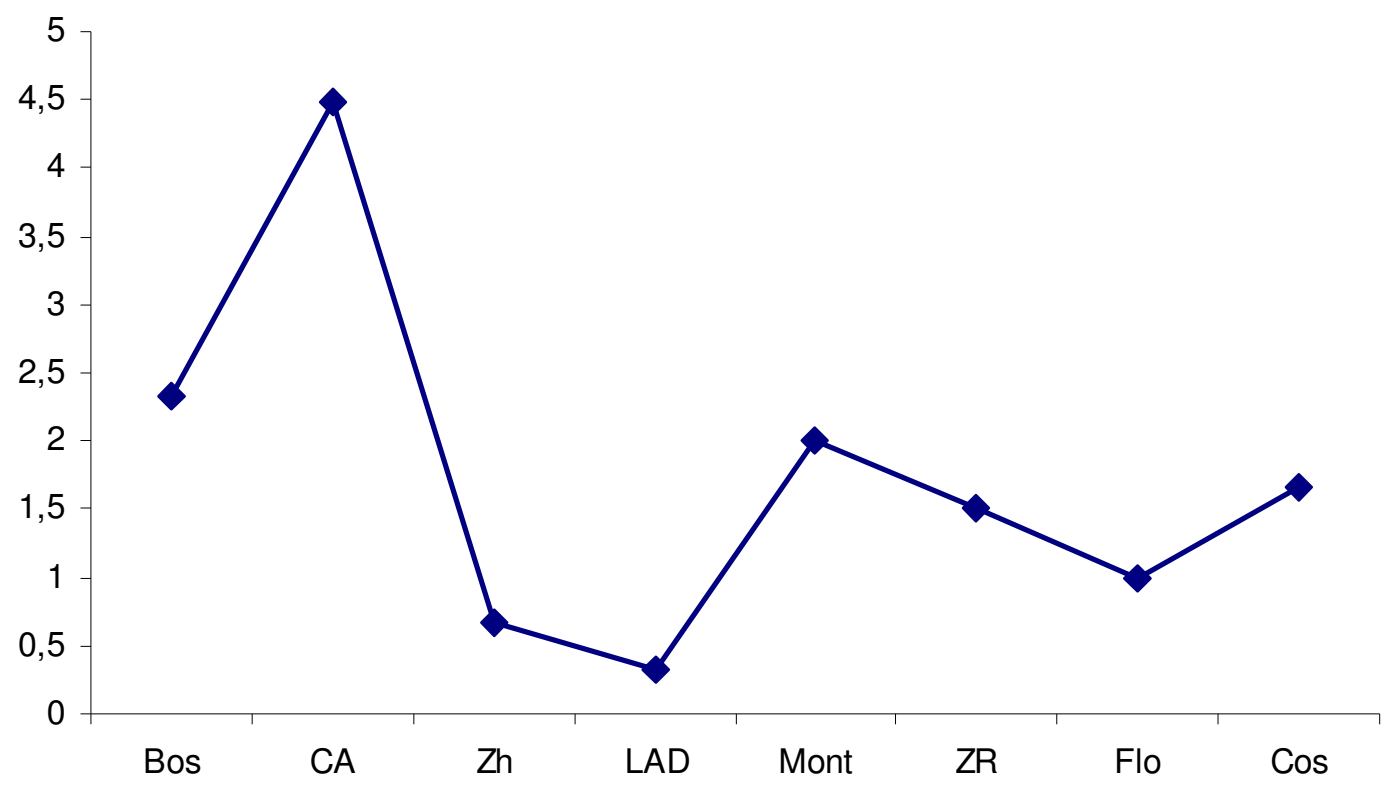

Gráfico 53- Ocorrência das espécies e relação com os seus diferentes ambientes (Bos bosque; CA - campo aberto; LAD - lagos de água doce; Mont - montanha; ZR - zonas rochosas; ZH - zonas húmidas; Flo - floresta; Cos - zonas costeiras.). 
A análise paleoecológica segundo a ocorrência de espécies e da sua distribuição pelos respectivos ambientes apresenta indicadores diferentes da distribuição do número mínimo de indivíduos. Neste caso constata-se que o ambiente de montanha já não é predominante, mas sim o campo aberto e bosques. os ambientes de montanha, zonas rochosas e floresta aparecem a seguir. Os ambientes de zonas húmidas são residuais. Pela localização geográfica, apesar da jazida se situar razoavelmente perto da costa, a ocorrência relativamente elevada de ambientes costeiros é uma anomalia e explica-se, da mesma forma de outras jazidas atrás apresentadas: as espécies assinaladas como estando ligadas ambientes costeiros, também ocorrem noutros ambientes, como os de montanha, de bosques e de campo aberto, o que se harmoniza mais com a situação geográfica da Casa da Moura.

Perante os dados obtidos pelos indicadores paleoambientais das aves da Gruta da Casa da Moura e tendo em conta os paleobiótipos indicados pelas espécies encontradas e pelo NMI, pode-se concluir que o paleoecótipo dominante da zona é o de montanha, com uma forte influência de um paleoecótipo de campo aberto. 


\section{7 - LAPA DA RAINHA}

Nos estudos atrás referidos, sobre a fauna da Lapa da Rainha (ROCHE, 1972), foram identificadas algumas aves. Estes estudos deverão ter sido feitos apenas sobre uma pequena parte dos materiais e, possivelmente, sobre os materiais que estão depositados na Universidade Nova de Lisboa, uma vez que os materiais observados no Museu Geológico aparentam não terem sido mexidos após a sua escavação, encontrando-se ainda ensacados e com as etiquetas de escavação nos respectivos sacos. Alguns destes tinham os ossos ainda embrulhados em fragmentos e páginas inteiras do jornal Diário Popular datadas de 1969.

As espécies identificadas por Roche foram: Pyrrhocorax pyrrhocorax, Corvus monedula, Pica rustica (=Pica pica) e Athene noctua (ROCHE, 1972, p. 235). Com excepção do Mocho-Galego (Athene noctua), todas as outras foram também identificadas nos materiais observados no Museu Geológico.

\section{1 - Análise Osteológica}

Dos ossos estudados verifica-se um grande predomínio de ossos partidos (75\%) face aos inteiros (25\%).

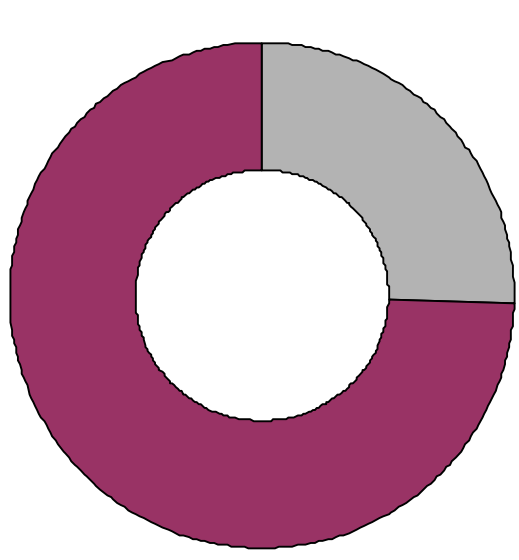

$\square$ Inteiros

$\square$ Partidos

Gráfico 54 - - Relação entre ossos partidos e ossos inteiros.

No que respeita às partes preservadas, observa-se uma diferença não muito grande entre os fragmentos distais e os proximais. De realçar a ausência de restos da zona mesial. 


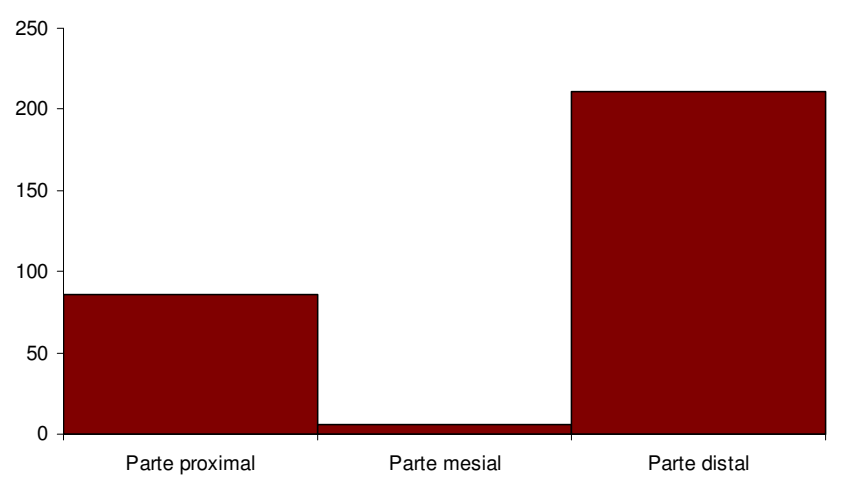

Gráfico 55- Partes dos ossos longos preservadas

Foram encontrados elementos esqueléticos apenas do esqueleto apendicular e axial, sendo deste último apenas uma presença residual. Não foram encontrados ossos do esqueleto craniano. Trata-se de restos ósseos pertencentes a indivíduos de todas as idades, no entanto a grande maioria (cerca de 97\%) é de adultos.

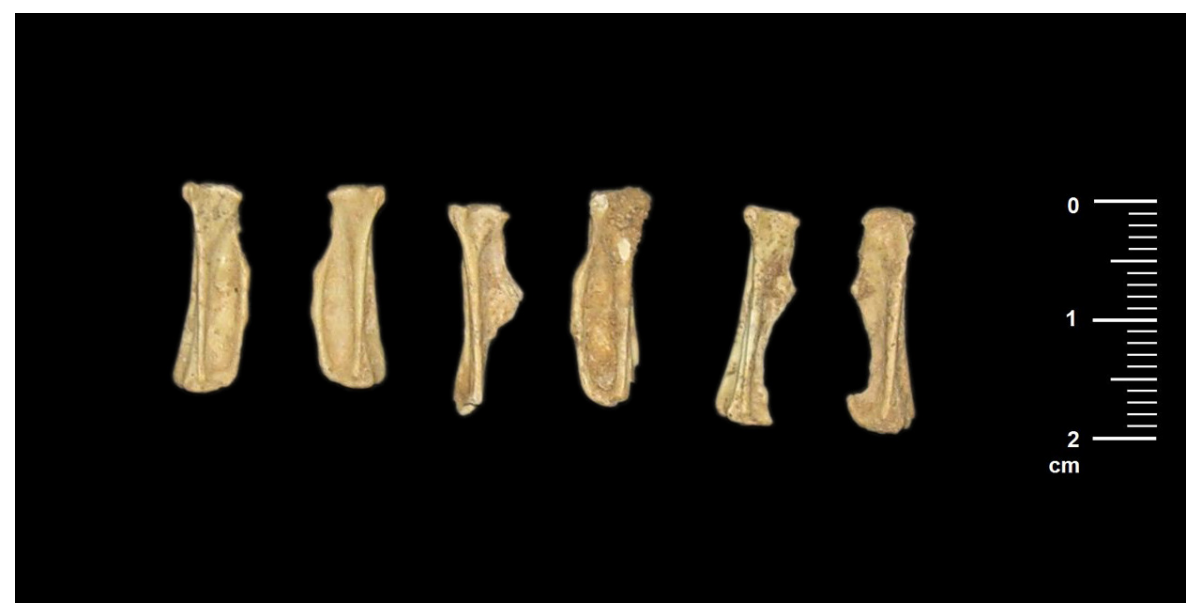

Fig. 79 - Conjunto de falanges do II dígito da asa de P. graculus, da Lapa da Rainha, onde se encontrou o maior número destes ossos pertencentes ao género Pyrrhocorax. Vistas dorsais. Fotografia: S. Figueiredo.

\begin{tabular}{l||rc} 
Zona do esqueleto & NTR & $\%$ \\
\hline \hline Esqueleto Apendicular & 402 & 98,8 \\
Esqueleto Axial & 5 & 1,2 \\
Esqueleto craniano & 0 & 0 \\
\hline \hline Total & $\mathbf{4 0 7}$ & $\mathbf{1 0 0}$
\end{tabular}

Quadro 47 - Distribuição dos ossos identificados pela correspondente parte do esqueleto. 


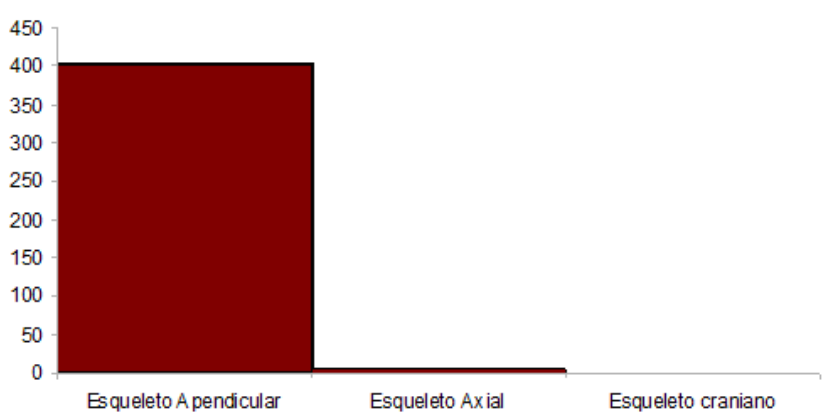

Gráfico 56 - ocorrência das diferentes partes do esqueleto.

\begin{tabular}{l||rc}
\multicolumn{1}{c||}{} & NTR & \multicolumn{1}{c}{$\%$} \\
\hline \hline Jovens & 5 & 1,22 \\
Sub-adultos & 8 & 1,67 \\
Adultos & 394 & 97,11 \\
\hline \hline Total & 407 & 100
\end{tabular}

Quadro 48- Ocorrência das diferentes idades dos individuos identificados

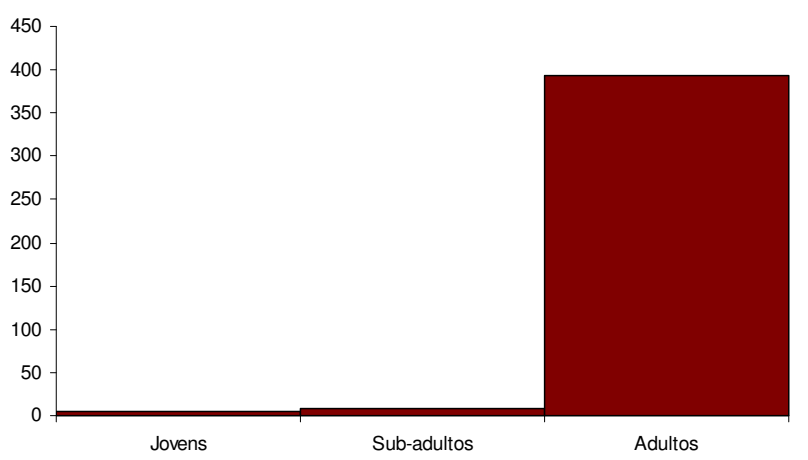

Gráfico 57 - relação entre a quantidade de jovens, subadultos e adultos das aves da Lpara da Rainha.

\section{2 - Estudo taxonómico}

Apesar de ter uma maior biodiversidade da avifauna que a Gruta da Casa da Moura, a Lapa da Rainha também apresenta um número relativamente pequeno de espécies de aves identificadas (17) em relação ao número total de restos. Foram identificados, no total entre espécies, géneros, famílias e ordens, 20 táxones.

Tal como na Casa da Moura, nesta jazida também abundam sobretudo os corvídeos e, de entre estes, o Pyrrhocorax pyrrhocorax, o Pyrrhocorax graculus e o Corvus monedula. As outras espécies apresentam quantidades pouco significativas, 
destacando-se destas a perdiz (Alectoris rufa), com cerca de 2,2\% da totalidade.

\begin{tabular}{l||rr} 
Espécies & NMI & NTR \\
\hline \hline Pyrrhocorax pyrrhocorax & 24 & 105 \\
Corvus monedula & 12 & 72 \\
Pyrrhocorax graculus & 24 & 122 \\
Corvus frugilegus & 1 & 1 \\
Alectoris rufa & 2 & 9 \\
Cf. Garrulus glandarius & 1 & 2 \\
Cf. Lagopus lagopus & 1 & 1 \\
Lagopus lagopus & 1 & 1 \\
Cf. Aquila adalberti & 1 & 1 \\
Turdus merula & 2 & 3 \\
cf. Milvus migrans & 1 & 1 \\
Columba livia & 1 & 2 \\
cf. Tetrao urugalus & 1 & 1 \\
Perdix perdix & 1 & 2 \\
cf. Motacilla alba & 1 & 1 \\
Corvus corax & 1 & 1
\end{tabular}

Quadro 49 - Número mínimo de indivíduos e número total de restos das espécies identificadas na Lapa da Rainha.

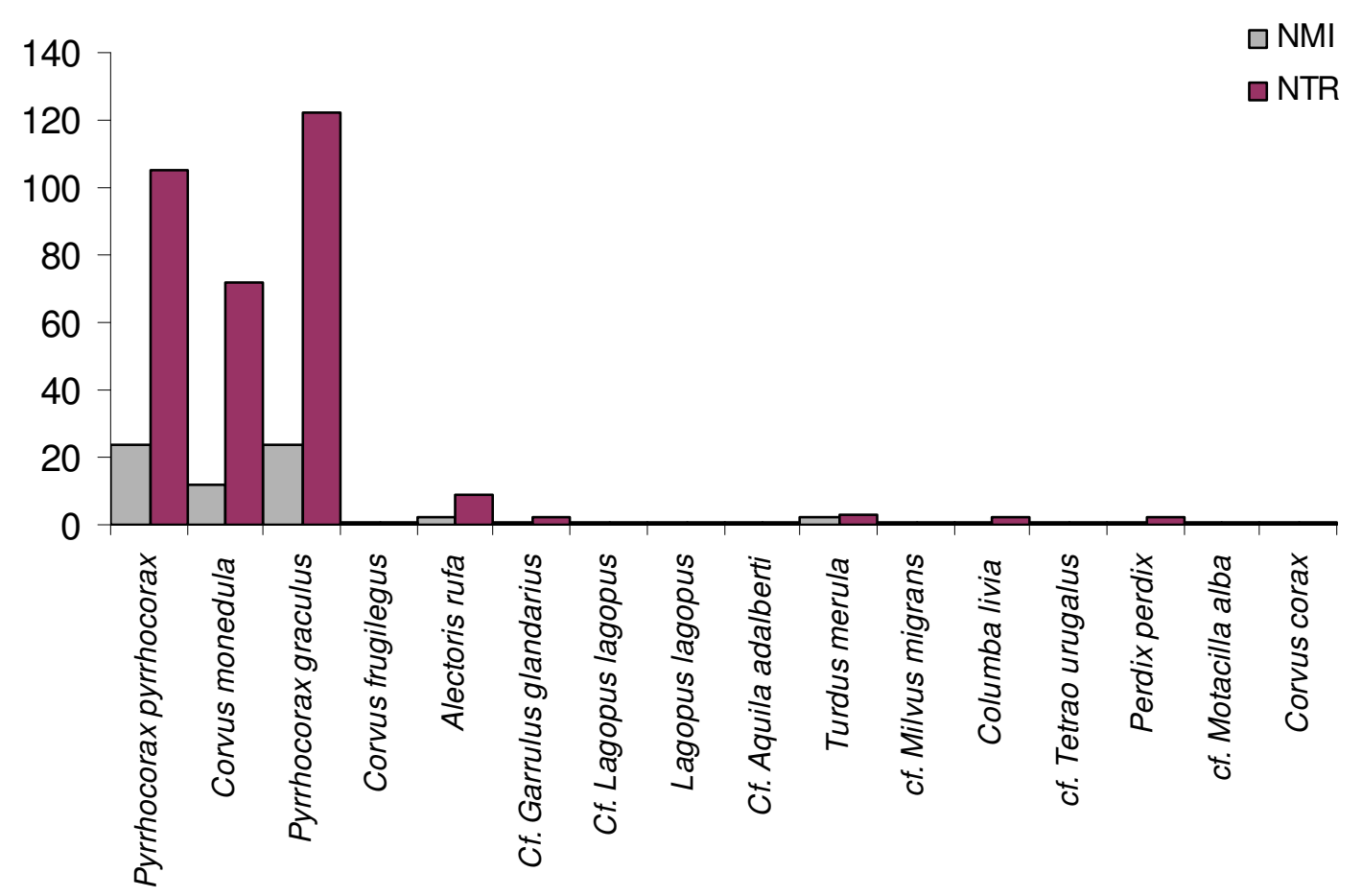

Gráfico 58 - Relação entre o número mínimo de indivíduos e da totalidade dos restos das espécies identificadas na Lapa da Rainha. 


\section{Sistemática Paleontológica}

Ordem: GALLIFORMES (TEMMINCK, 1820)

Família: TETRAONIDAE (VIGORS, 1825)

Género: Tetrao (LINNAEUS, 1758)

Cf. Tetrao urogallus (LINNAEUS, 1758)

Material: 1 tarsometatarso.

Total de restos: 1

Ordem: GALLIFORMES (TEMMINCK, 1820)

Família: PhASIANIDAE (HORSEFIELD, 1821)

Género: Alectoris (KAUP, 1829)

Alectoris sp.

Material: 1 ulna, 3 carpometacarpos.

Total de restos: 4

Ordem: GAlLIFORMES (TEMminCK, 1820)

Família: PhASIANIDAE (HORSEFIELD, 1821)

Género: Alectoris (KAUP, 1829)

Alectoris rufa (LINNAEUS, 1758)

Material: 3 úmeros, 2 ulnas, 2 carpos-mertacarpos, 3 tarsometatarsos.

Total de restos: 10

Ordem: GALLIFORMES (TEMMINCK, 1820)

Família: PHASIANIDAE (HORSFIELD, 1821)

Género: Perdix (BRISSON, 1760)

Perdix perdix (LINNAEUS, 1758)

Material: 1 coracóide, 1 úmero.

Total de restos: 2 
Ordem: GALLIFORMES (TEMMINCK, 1820)

Família: PHASIANIDAE (HORSFIELD, 1821)

Género: Lagopus (BRISSON, 1760)

Cf. Lagopus lagopus (LINNAEUS, 1758)

Material: 1 fémur, 1 tarsometatarso.

Total de restos: 1

Ordem: ChADRADRIIFORMES (WAGLER, 1830)

Família: STERNIDAE (BONAPARTE, 1838)

STERNIDAE INDET.

Material: 1 tibiotarso.

Total de restos: 1

Ordem: FAlCONIFORMES (SHARPE 1874)

Família ACCIPITRIDAE (VIEILLOT, 1816)

ACCIPITRIDAE INDET.

Material: 5 falanges (do pé).

Total de restos: 5

Ordem: FALCONIFORMES (SHARPE 1874)

Família ACCIPITRIDAE (VIEILLOT, 1816)

Género: Aquila (LINNAEUS, 1758)

Cf. Aquila adalberti (BREHM, 1861)

Material: 1 Tibiotarso.

Total de restos: 1

Ordem: FALCONIFORMES (SHARPE 1874)

Família ACCIPITRIDAE (VIEILLOT, 1816)

Género: Milvus (LACEPEDE, 1799)

Cf. Milvus migrans (BODDAERT, 1783)

Material: 1 Coracóide.

Total de restos: 1 
Ordem: Columbiformes (LATHAM, 1790)

Família: COLUMBIDAE, (ILLIGER,1811)

Género: Columba (LINNAEUS, 1758)

Espécie: Columba livia, (GMELIN, 1789)

Material: 1 úmero, 2 carpos-mertacarpos.

Total de restos: 3

Ordem: PASSERIFORMES (LINNAEUS, 1758)

Família: CORVIDAE (VIGORS, 1825)

CORVIDAE INDET.

Material: 2 coracóides, 11 úmeros, 12 ulnas, 2 falanges (Il dígito da asa), 1 falange (do pé), 1 sinsacro.

Total de restos: 31

Ordem: PASSERIFORMES (LINNAEUS, 1758)

Família: CORVIDAE (VIGORS, 1825)

Género: Corvus (LINNAEUS, 1758)

Corvus corax (LINNAEUS, 1758)

Material: 1 Carpometacarpo.

Total de restos: 1

Ordem: PASSERIFORMES (LINNAEUS, 1758)

Família: CORVIDAE (VIGORS, 1825)

Género: Corvus (LINNAEUS, 1758)

Corvus frugilegus (LINNAEUS, 1758)

Material: 1 fémur.

Total de restos: 1

Ordem: PASSERIFORMES (LINNAEUS, 1758)

Família: CORVIDAE (VIGORS, 1825)

Género: Corvus (LINNAEUS, 1758)

Corvus monedula (LINNAEUS, 1758) 
Material: 3 coracóides, 11 úmeros, 20 ulnas, 1 rádio, 10 carpos-mertacarpos, 4 fémures, 8 tibiotarsos, 13 tarsometatarsos, 3 sinsacros.

Total de restos: 73

Ordem: PASSERIFORMES (LINNAEUS, 1758)

Família: CORVIDAE (VIGORS, 1825)

Género: Pyrrhocorax sp.

Material: 2 ulnas, 4 fémures.

Total de restos: 6

Ordem: PASSERIFORMES (LINNAEUS, 1758)

Família: CORVIDAE (VIGORS, 1825)

Género: Pyrrhocorax (TNSTALL, 1771)

Pyrrhocorax pyrrhocorax (LINNAEUS, 1758)

Material: 3 coracóides, 26 úmeros, 42 ulnas, 2 rádios, 24 carpometacarpos, 1 falange (Il dígito da asa), 9 fémures, 5 tibiotarsos, 3 tarsometatarsos.

Total de restos: 116

Ordem: PASSERIFORMES (LINNAEUS, 1758)

Família: CORVIDAE (VIGORS, 1825)

Género: Pyrrhocorax (TNSTALL, 1771)

Pyrrhocorax graculus (LINNAEUS, 1758)

Material: 6 coracóides, 18 úmeros, 45 ulnas, 16 carpometacarpos, 16 falange (II dígito da asa), 6 fémures, 22 tibiotarsos, 8 tarsometatarsos.

Total de restos: 147

Ordem: PASSERIFORMES (LINNAEUS, 1758)

Família: CORVIDAE (VIGORS, 1825)

Género: Garrulus (BRISSON, 1760)

Garrulus glandarius (LINNAEUS, 1758)

Material: 1 umero, 1 fémur.

Total de restos: 2 
Ordem: PASSERIFORMES (LINNAEUS, 1758)

Família: TURDIDAE (BONNAPARTE, 1850)

Género: Turdus, (LINNAEUS, 1758)

Turdus sp.

Material: 1 tibiotarso.

Total de restos: 1

Ordem: PASSERIFORMES (LINNAEUS, 1758)

Família: TURDIDAE (BONNAPARTE, 1850)

Género: Turdus, (LINNAEUS, 1758)

Turdus merula (LINNAEUS, 1758)

Material: 2 úmeros, 1 tibiotarso.

Total de restos: 3

Ordem: PASSERIFORMES (LINNAEUS, 1758)

Família: HIRUNDIDAE (VIGORS, 1825)

Género: Ptyonoprogne, (REICHENBACH, 1850)

Cf. Ptyonoprogne rupestris (SCOPOLI, 1769)

Material: 1 úmero.

Total de restos: 1

Ordem: PASSERIFORMES (LINNAEUS, 1758)

Família: MOTACILLIDAE (HORSFIELD, 1821)

Género: Motacilla, (DumoNT, 1821)

Cf. Motacilla alba (LINNAEUS, 1758)

Material: 1 úmero.

Total de restos: 1 


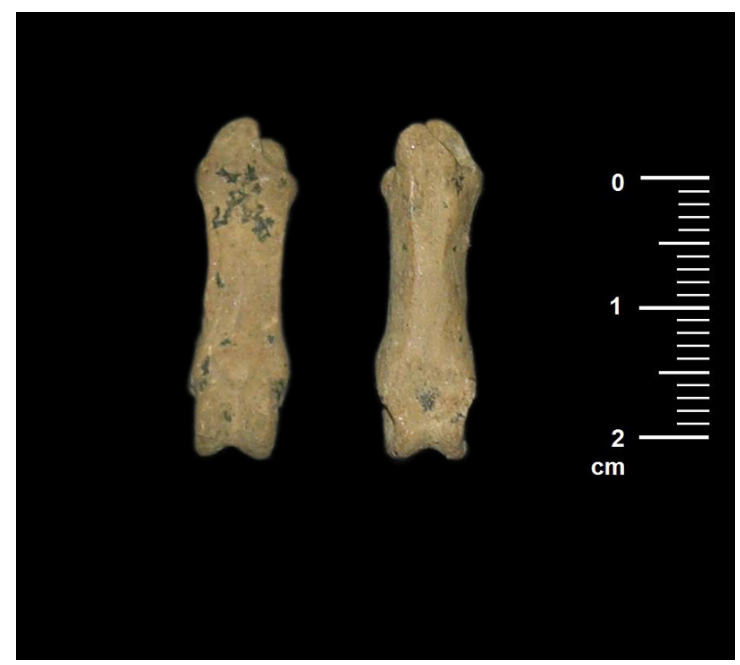

Fig. 80 - I falange do $3^{\circ}$ dígito do membro posterior de uma ave de rapina (Accipitridae indeterminada). Á esquerda vista palmar, á direita, vista dorsal. Fotografia: S. Figueiredo.

\section{3 - Tafonomia}

Nos ossos analisados não foram encontradas marcas de corte ou de predação. A grande maioria das aves é de espécies que frequentam grutas. Estes dados apontam para acumulação natural dos ossos das aves encontradas na Lapa da Rainha, tal como na maioria das outras jazidas estudadas.

A pequena percentagem das aves encontradas nesta jazida, e que não frequentam grutas, poderá ter resultado do transporte por carnívoros, por humanos ou por transporte pelos agentes de erosão do exterior para dentro da gruta. Provavelmente, esta última hipótese poderá ser a responsável pela acumulação do maior número de restos destas aves, uma vez que não têm marcas e a grande maioria se encontra partida. Estes ossos fragmentados poderão ser o resultado do transporte ou da pedogénese e acumulação de sedimentos.

\section{4 - Paleoecologia}

Os estudos paleoecológicos, resultantes da associação das espécies identificadas aos seus respectivos ambientes, concluíram que tal como na Casa da Moura se verifica, na Lapa da Rainha, um predomínio de espécies de montanha e de 
zonas rochosas. Verifica-se também uma ocorrência relativamente fraca de aves de zonas húmidas e de zonas de campo aberto. Assim, as espécies de aves indicadas na Lapa da Rainha são maioritariamente associadas a ambientes de montanha e de zonas rochosas. Outras espécies indicam a existência, nas proximidades, de áreas de mato e de campo aberto, bem como pequenas manchas de zonas húmidas.

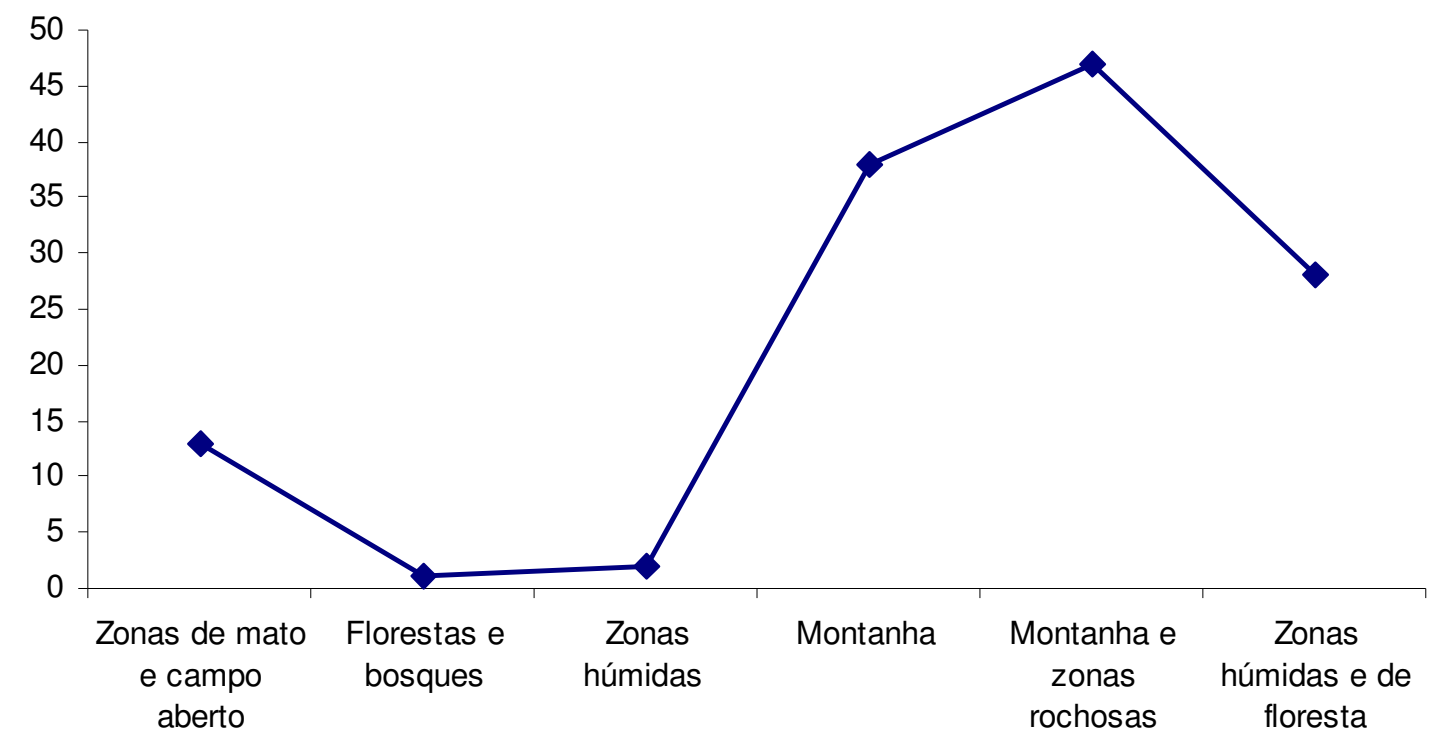

Gráfico 59 - Distribuição do número mínimo de individuos das espécies identificadas e a sua relação com as diferentes zonas de habitat 


\begin{tabular}{|c|c|c|c|c|c|c|c|}
\hline$\because 2$ & Bos & $\mathrm{CA}$ & LAD & Mont & $\mathrm{ZR}$ & Flo & $\operatorname{Cos}$ \\
\hline A. rufa & & 1 & & & & & \\
\hline Alectoris $s p$ & & 1 & & & & & \\
\hline P. perdix & & 1 & & & & & \\
\hline Tetrao urugalus & 0,5 & & 1 & & & 0,5 & \\
\hline L. lagopus & & 0,5 & & & & 0,5 & \\
\hline C. frugilegus & || 0,5 & 0,5 & & & & & \\
\hline C. corax & & 0,33 & 0,33 & & & & 0,33 \\
\hline G. glandarius & & 0,5 & & & & 0,5 & \\
\hline P. graculus & & & & 1 & & & \\
\hline Pyrrhocorax sp & & & & 0,5 & & & 0,5 \\
\hline C. monedula & 0,33 & 0,33 & & & & & 0,33 \\
\hline P. pyrrhocorax & & & & 0,5 & & & 0,5 \\
\hline M. alba & & & 1 & & & & \\
\hline Turdus sp & 0,5 & 0,5 & & & & & \\
\hline T. merula & 0,5 & 0,5 & & & & & \\
\hline P. rupestris & & & & 0,5 & 0,5 & & \\
\hline M. migrans & & 0,33 & 0,33 & & & 0,33 & \\
\hline A. Adalberti & & & 0,5 & & & 0,5 & \\
\hline C. livia & & & & & 0,5 & & 0,5 \\
\hline Total & 2,33 & 6,49 & $3,16 \quad 0$ & 2,5 & 1 & 2,33 & 2,16 \\
\hline
\end{tabular}

Quadro 50- Distribuição das espécies encontradas pelos seus habitat. (Bos - bosque; CA campo aberto; LAD - lagos de água doce; Mont - montanha; ZR - zonas rochosas; ZH - zonas húmidas; Flo - floresta; Cos - zonas costeiras.).

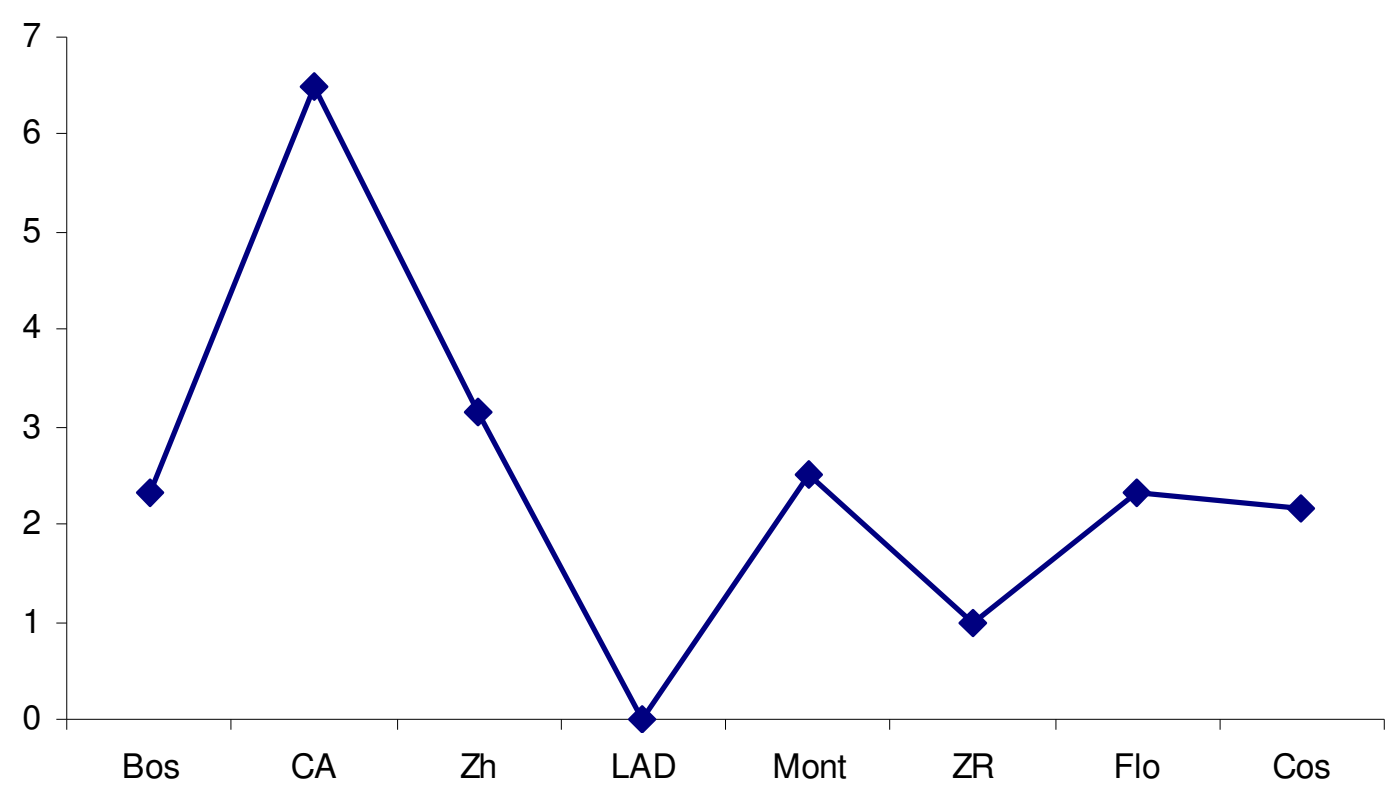

Gráfico 60 - Distribuição das espécies reconhecidas com os ambientes associados (Bos bosque; CA - campo aberto; LAD - lagos de água doce; Mont - montanha; ZR - zonas rochosas; ZH - zonas húmidas; Flo - floresta; Cos - zonas costeiras.). 
A análise paleoecológica segundo a ocorrência de espécies e a sua distribuição pelos respectivos ambientes apresenta indicadores diferentes da distribuição do número mínimo de indivíduos. Neste caso constata-se que o ambiente de montanha e de zonas rochosas já não são predominantes, mas sim os de campo aberto. os ambientes de zonas húmidas, bosques, montanha, floresta e zonas rochosas aparecem a seguir, enquanto os ambientes de lagos de água doce não aparecem Pela localização geográfica, apesar da jazida se situar perto da costa, a cerca de cinco km, a ocorrência relativamente elevada de ambientes costeiros é uma anomalia e explica-se, da mesma forma de outras jazidas atrás apresentadas. As espécies assinaladas como estando ligadas a ambientes costeiros, também ocorrem noutros ambientes, que estão mais de acordo com a situação geográfica da jazida .

Perante os dados obtidos pelos indicadores paleoambientais das aves da Lapa da rainha e tendo em conta os paleobiótipos indicados pelas espécies encontradas e pelo NMI, pode-se concluir que o paleoecótipo dominante da zona é o de montanha, com uma forte influência de um paleoecótipo de campo aberto. 


\section{8 - GRUTA DO CALDEIRÃO}

No âmbito do levantamento da avifauna para a presente tese, foi solicitado, junto do responsável pelas das escavações da Gruta do Caldeirão e da Gruta da Oliveira autorização para se estudar a avifauna desta última, mas o pedido foi recusado, sob o pretexto de a fauna está a ser estudada por um colega. Contudo, foi concedida autorização para se ver, junto da microfauna da Gruta do Caldeirão (estudada pela Doutora Liliana Povoas) a presença de aves. Por conseguinte, foram triados seis sacos de materiais provenientes de seis quadrados. Estes sacos continham vários milhares de pequenos ossos de vertebrados, no meio dos quais se identificou um conjunto de sete ossos de aves, todas elas pertencentes à ordem dos passeriformes e a maioria deles pertencentes ao esqueleto apendicular, com a excepção de uma vértebra.

Na gruta do caldeirão foram identificados cinco níveis culturais: um neolítico (camada Ea); outro magdalenense (camada Eb); outro solutrense (camadas Fa, Fb, Fc, H e I); outro dos inícios do Paleolítico Superior (camadas Ja e Jb) e outro mustierense (camadas $\mathrm{K}, \mathrm{L}, \mathrm{M}$ e $\mathrm{N}$ ), em todos eles foram encontrados restos faunísticos (DAVIS, 2002).

No que respeita ás aves, no nível mustierense foram encontrados 9 restos, no do Paleolítico Superior Inicial, 10, no solutrense, 36, magdalenense, 28 e no neolítico, apenas 5 (DAVIS, 2002). Para este trabalho só contam as aves dos níveis do Paleolítico. Os restos de aves da Gruta do caldeirão inéditos e estudado agora, pela primeira vez, são provenientes das camadas F, H e J. Assim, foram agora identificados mais 5 restos de aves do Solutrense do Caldeirão, perfazendo um total de 41 restos de aves neste nível e dois restos dos inícios do paleolítico Superior, totalizando, 12 fósseis de aves neste nível.

\section{1 - Paleoornitologia 50}

No que respeita aos táxones de aves encontramos nesta jazida são, em termos gerais, os mesmos grupos taxonómicos que encontramos nas outras estudadas neste

50 Segundo DAVIS, 2002 e trabalho de investigação realizadpo pelo autor. 
trabalho. Foram identificadas por Davis (DAVIS, 2002) doze espécies de aves, a partir de um universo de 146 ossos. Em termos taxonómicos, a ordem dos passeriformes é a mais frequente, e destes a família corvidae. Tal como nas outras jazidas de interior, os patos estão aqui muito pouco representados.

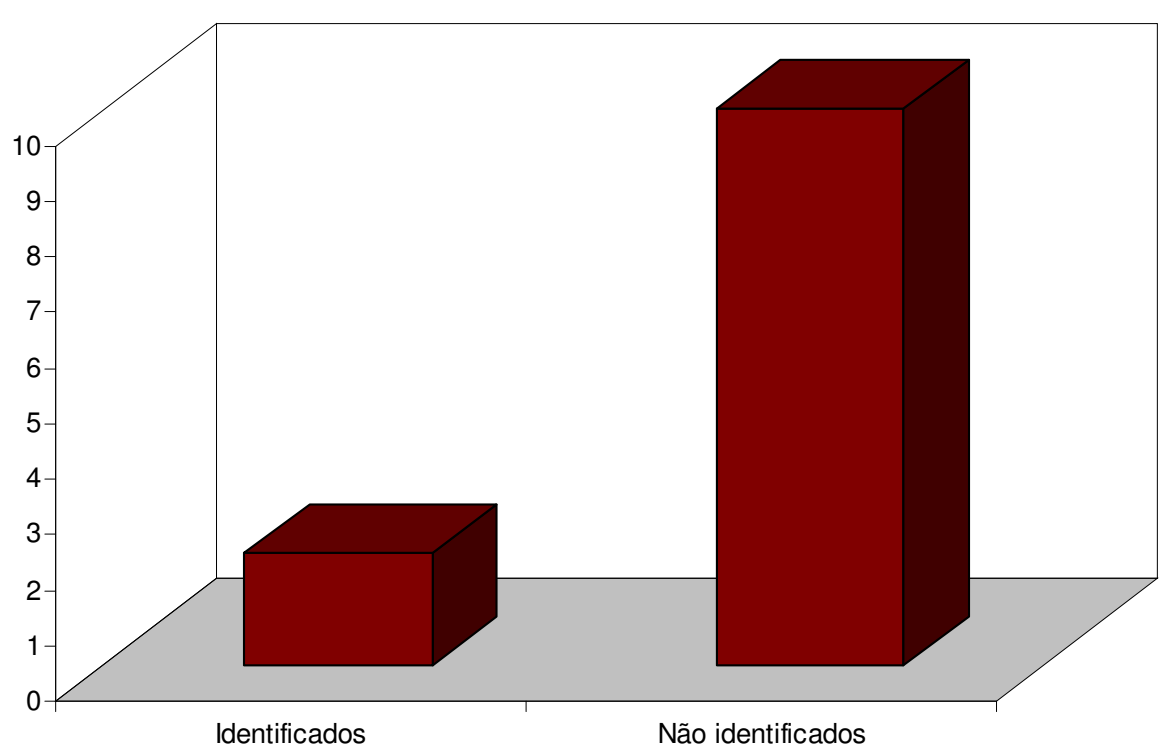

Gráfico 61 - Quantidade de restos identificados e não identificados, no estudo realizados aos ossos de aves que se encontram junto com a microfauna do Caldeirão no MNHN

\section{Sistemática Paleontológica (I) ${ }^{51}$}

Ordem: GALLIFORMES (TEMMINCK, 1820)

Família: PHASIANIDAE (HORSEFIELD, 1821)

Género: Alectoris (KAUP, 1829)

Alectoris $s p$

Ordem: GALLIFORMES (TEMMINCK, 1820)

Família: PHASIANIDAE (HORSEFIELD, 1821)

Género: Perdix (BRISSON, 1760)

Perdix perdix (LINNAEUS, 1758) 
Ordem: ANSERIFORMES (WAGLER, 1831)

Família: ANATIDAE (VIGORS, 1825)

ANATIDAE INDET.

Ordem: ANSERIFORMES (WAGLER, 1831)

Família: ANATIDAE (VIGORS, 1825)

Subfamília: ANATINAE (LEACH, 1820)

Género: Anas (LINNAEUS, 1758)

Anas sp

Ordem: FALCONIFORMES (SHARPE, 1874)

Família: AcCIPITERIDAE (VIEILLOTE, 1816) ACCIPITERIDAE INDET.

Ordem: FALCONIFORMES (SHARPE, 1874)

Família: AcCIPITERIDAE (VIEILLOTE, 1816)

Género: Aegypius (SAVIGNY, 1809)

Aegypius monachus (LINNAEUs, 1758)

Ordem: FALCONIFORMES (SHARPE, 1874)

Família: ACCIPITERIDAE (VIEILLOTE, 1816)

Género: Gyps (HABLIZL, 1783)

Gyps fulvus (HABLIZL, 1783)

Ordem: STRIGIFORMES (WAGLER, 1830)

Família: STRIGIDAE (VIGORS, 1825)

Género. Bubo (DUMÉRIL, 1806)

Bubo sp.

Ordem: STRIGIFORMES (WAGLER, 1830)

Família: STRIGIDAE (VIGORS, 1825)

Género: Bubo (DumÉRIL, 1806)

Bubo bubo (LINNAEUS, 1758) 
Ordem: STRIGIFORMES (WAGLER, 1830)

Família: STRIGIDAE (VIGORS, 1825)

Género: Athene (BOIE, 1822)

Athene noctua (SCOPOLI, 1769)

Ordem: COLUMBIFORMES (LATHAM, 1790)

Família: COLUMBIDAE (ILLIGER, 1811)

Género: Columba (LINNAEUS, 1758)

Columba livia, (GMELIN, 1789)

Ordem: ColumbifORMES (LATHAM, 1790)

Família: COLUMBIDAE (ILLIGER, 1811)

Género: Columba (LINNAEUS, 1758)

Columba palumbus (LINNAEUS, 1758)

Ordem: PASSEIRIFORMES (LINNAEUS, 1758)

Família: CORVIDAE (VIGORS, 1825)

CORVIDAE INDET.

Ordem: PASSEIRIFORMES (LINNAEUS, 1758)

Família: CORVIDAE, (VIGORS, 1825)

Género: Corvus(LINNAEUS, 1758)

Corvus corax, (LINNAEUS, 1758)

Ordem: PASSEIRIFORMES (LINNAEUS, 1758)

Família: CORVIDAE, (VIGORS, 1825)

Género: Pyrrhocorax (TNSTALL, 1771)

Pyrhochorax sp

Ordem: PASSEIRIFORMES (LINNAEUS, 1758)

Família: CORVIDAE, (VIGORS, 1825)

Género: Pyrrhocorax (TNSTALL, 1771)

Pyrhochorax graculus (LINNAEUS, 1758) 
Ordem: PASSEIRIFORMES (LINNAEUS, 1758)

Família: CORVIDAE, (VIGORS, 1825)

Género: Pyrrhocorax (TNSTALL, 1771)

Pyrrhocorax pyrrhocorax (LINNAEUS, 1758)

Ordem: PASSEIRIFORMES (LINNAEUS, 1758)

Família: CORVIDAE, (VIGORS, 1825)

Género: Pica (BRISSON, 1760)

Pica pica (LINNAEUs, 1758)

Sistemática Paleontológica (II) ${ }^{52}$

Ordem: PASSERIFORMES (LINNAEUS, 1758)

Família: PASSERIFORMES INDET.

Material: 1 vértebra, 1 rádio, 2 garras.

Total de restos: 4

Ordem: PASSERIFORMES (LINNAEUS, 1758)

Família: LANIIDAE (RAFINESQUE, 1815)

LANIIDAE INDET.

Material: 1 tarsometatarso.

Total de restos: 1

Ordem: PASSERIFORMES (LINNAEUS, 1758)

Família: PASSERIDAE (ILLIGER 1811)

Género: Passer, (BRISSON, 1760)

Passer sp.

Material: 1 coracóide.

52 A sistemática referente aos restos inétidos, estudados para esta tese. 
Total de restos: 1

Ordem: PASSERIFORMES (LINNAEUS, 1758)

Família: FRINGILLIDAE (VIGORS, 1825)

Género: Carduelis, (BRISSON, 1760)

Cf. Carduelis sp.

Material: 1 tarsometatarso.

Total de restos: 1

\section{2 - Análise Paleoecológica}

A Gruta do Caldeirão apresenta maioritariamente restos de aves características de ambientes terrestres. Porém também foram identificadas espécies de aves que podem também ocorrer em ambientes marinhos (quadro 58 e gráfico 62).,

\begin{tabular}{|c|c|c|c|c|c|c|c|c|}
\hline 6 & Bos & $\mathrm{CA}$ & $\mathrm{Zh}$ & LAD & Mont & ZR & Flo & $\mathrm{Cos}$ \\
\hline A. rufa & & 1 & & & & & & \\
\hline P. perdix & & 1 & & & & & & \\
\hline Anas sp & & & 0,5 & 0,5 & & & & \\
\hline P. pica & 0,5 & 0,5 & & & & & & \\
\hline C. corax & & 0,33 & 0,33 & & & & & 0,33 \\
\hline P. graculus & & & & & 1 & & & \\
\hline Pyrrhocorax sp & & & & & 0,5 & & & 0,5 \\
\hline P. pyrrhocorax & & & & & 0,5 & & & 0,5 \\
\hline Carduelis $s p$ & 0,5 & 0,5 & & & & & & \\
\hline G. fulvus & & 0,5 & & & 0,5 & & & \\
\hline A. monachus & & & & & 0,5 & & 0,5 & \\
\hline B. bubo & & & & & & 0,5 & 0,5 & \\
\hline A. noctua & 0,5 & 0,5 & & & & & & \\
\hline C. livia & & & & & & 0,5 & & 0,5 \\
\hline C. palumbus & 0,33 & 0,33 & & & & & 0,33 & \\
\hline$\overline{\text { Total }}$ & 1,83 & 4,66 & 0,83 & 0,5 & 3 & 1 & 1,33 & 1,83 \\
\hline
\end{tabular}

Quadro 51 - Distribuição das espécies encontradas pelos seus ambientes (Bos - bosque; CA campo aberto; LAD - lagos de água doce; Mont - montanha; ZR - zonas rochosas; ZH - zonas húmidas; Flo - floresta; Cos - zonas costeiras.). 


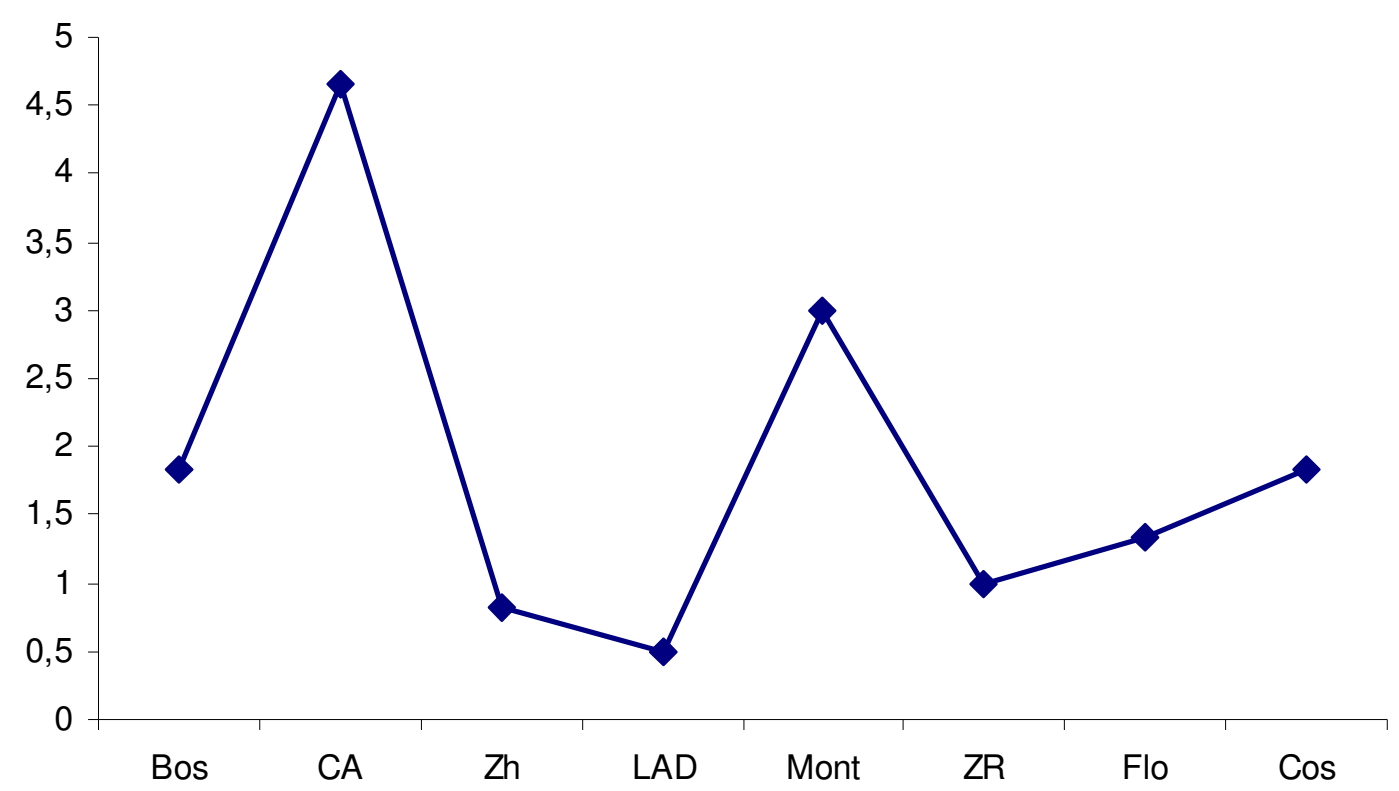

Gráfico 62 - Distribuição das espécies reconhecidas com os ambientes associados (Bos bosque; CA - campo aberto; LAD - lagos de água doce; Mont - montanha; ZR - zonas rochosas; ZH - zonas húmidas; Flo - floresta; Cos - zonas costeiras.).

A análise paleoecológica foi feita segundo a ocorrência de espécies e da sua distribuição pelos seus ambientes. Nesta jazida não foram considerados o número mínimo de indivíduos, pois a mostra consultada foi muito pequena e a publicação sobre os mamíferos e a s aves da gruta do caldeirão (DAVIS, 2002) não faz referencia ao número mínimo indivíduos dos táxones reconhecidos.

Assim, constata-se, pelo estudo paleoecológico agora realizado que os ambientes de campo aberto e de bosques são os predominantes, sobretudo o primeiro. Os ambientes de montanha, zonas rochosas e floresta aparecem a seguir. Os ambientes de zonas húmidas são pouco significativos.

Pela localização geográfica da Gruta do Caldeirão, longe da costa, a ocorrência de ambientes costeiros é elevada, verificando-se, neste caso, uma irregularidade, que se pode explicar, da mesma forma de outras jazidas atrás apresentadas. As espécies assinaladas como estando ligadas a ambientes costeiros, também ocorrem noutros ambientes, como os de montanha, de bosques e de campo aberto, zonas rochosas e zonas húmidas de interior, o que se harmoniza mais com a situação geográfica da jazida. 
Perante os dados obtidos pelos indicadores paleoambientais das aves da Lapa da rainha e tendo em conta os paleobiótipos indicados pelas espécies encontradas, pode-se concluir que o paleoecótipo dominante da zona é o de campo aberto, com uma forte influência de um paleoecótipo de montanha. 


\section{9 - CARACTERIZAÇÃO OSTEOLÓGICA DOS RESTOS IDENTIFICADOS}

A identificação taxonómica, através da análise osteológica torna-se, por vezes, difícil, visto existirem grandes semelhanças osteomorfológicas em determinados grupos taxonómicos. Assim, torna-se necessário atribuir uma classificação menos específica, como é o caso dos passeriformes. Esta dificuldade aumenta quando se está a analisar restos ósseos fragmentados, perdendo-se assim muitas das características de diagnóstico de uma espécie ou de um género. Neste estudo, quando não se conseguiu identificar a espécie, atribuiu-se o género, a família ou a ordem. No caso específico deste trabalho, a alguns restos foi possível atribuir uma classificação ao nível da espécie, através de outras análises para além da osteológica $^{53}$, como é o caso da distribuição geográfica de algumas espécies ou da frequência noutras jazidas. Por outro lado, foram importantes as classificações antigas de Newton e Harlé (HARLÉ, 1910/11), sobre as aves das Grutas da Furninha e das Fontainhas, que permitiram resolver algumas dúvidas.

\section{ProcellaRiformes}

Os procellariformes são uma ordem com 108 espécies, distribuídas por quatro famílias (DEL HOYO et al., 1992, VUILLEUMIER, 2001), contando com aves marinhas, de hábitos pelágicos. Caracterizam-se por terem o bico normalmente longo e curvo na ponta. Esta adaptação permite-lhes expulsar do corpo o sal resultante da ingestão de água do mar. Têm ainda asas compridas e estreitas, o que lhes dá uma forma aerodinâmica e minimiza a energia gasta durante os seus longos voos (VUILLEUMIER, 2001). O dedo posterior da pata encontra-se ausente ou é pouco desenvolvido. Estas aves alimentam-se de cefalópodes e de pequenos peixes. Nas jazidas estudadas neste trabalho foi apenas encontrado um resto de uma espécie de procellariformes, o Puffinus puffinus. Actualmente, esta espécie tem uma biogeografia que se estende por toda a Europa e pelo Mediterrânio (GOODERS \& HARRIS, 1990).

Os úmeros dos procellariformes apresentam as seguintes características:

53 Comparação osteomorfológica e osteometria. 
Crista deltóide proeminente, secção da diáfise redonda, na face lateral externa e espalmada, na face lateral interna, na zona proximal, e oval na zona distal, onde apresenta o processo supracondilar muito desenvolvido e projectado e a fossa do olecrano profunda.

\section{Género Puffinus}

Em todas as jazidas estudadas apenas foi identificado um resto de uma espécie desta ordem (Puffinus puffinus). Trata-se de um fragmento de um úmero direito sem a parte proximal, encontrado na Gruta da Furninha, proveniente do nível dos $7 \mathrm{~m}$.

Puffinus puffinus (BRUNNICH 1764)

\section{Descrição osteológica}

\section{Úmero}

A secção da diáfise é arredondada na parte lateral direita e mais espalmada e pontiaguda na parte lateral oposta. Já perto da zona distal, a secção da diáfise apresenta-se de forma ovalada, espalmada. Apresenta o processo supracondilar muito desenvolvido e projectado e a fossa do olecrânio profunda (Estampal-1).

\section{GALLIFORMES}

Conjuntamente com os anseriformes, os galliformes são a ordem mais antigas dos neognathae conhecida (CLARK et al., 2005). Muito diversa, esta ordem é constituída por cerca de 281 espécies, distribuídas por 61 géneros e seis famílias (VUILLEUMIER, 2001), incluindo aves domésticas, como a galinha ou o peru, e aves cinegéticas como as perdizes e os faisões.

Os galliformes ocupam uma enorme variedade de habitat (VUILLEUMIER, 2001). São aves de pequeno a médio porte, pesando entre cerca de $250 \mathrm{~g}$ e cerca de $20 \mathrm{~kg}$, robustas e com asas pequenas e arredondadas (VUILLEUMIER, 2001). O dimorfismo sexual é comum e em algumas espécies pode ser extremo. O tamanho e o tipo de cauda é também bastante diverso no grupo, variando desde a quase inexistência até cerca de um metro de comprimento, no caso do pavão. Grande parte das espécies desta ordem de aves raramente voa, vivendo mais associadas aos habitat do solo. Os galliformes têm o corpo compacto, a cabeça pequena e o bico curto e ligeiramente recurvado e as patas são grandes e robustas (VUILLEUMIER, 
2001).

Com excepção da Gruta das Salemas, em todas as outras jazidas estudadas estão representadas algumas espécies de galliformes, em especial da Alectoris rufa.

No estudo agora realizado, foram identificados ossos do esqueleto apendicular de várias espécies de galliformes.

Dos membros anteriores dos galliformes, o coracóide tem a margem distal angular, a faceta de ligação ao úmero é pouco funda e possui uma aresta desde o procoracóide até ao ângulo médio. O úmero é robusto e na diáfise é curvo, a crista deltopeitoral é curvada para o interior e a cabeça é saliente, arredondada e assimétrica. A ulna tem um formato curvo, apresenta a secção triangular, que se torna espalmada na extremidade proximal. A maioria dos galliformes tem as papilas das rémiges pouco desenvolvidas. O rádio apresenta a secção na diáfise redonda e espalmada nas epífises. Na face articular ulnar, apresentma uma protuberância projectada. Os carpometacarpos têm o metacarpo menor curvo e torcido, tornando o espaço intermetacarpal largo; têm o processo intermetacarpal proeminente e a tróclea carpal bem definida.

Dos membros anteriores dos galliformes, o fémur é robusto, a crista do trocanter é curvada para o interior. Algumas espécies têm a zona do trocanter femural pneumatizada e o medial é redondo. O tíbiotarso tem a secção redonda e a articulação distal estreita. As espécies maiores apresentam os tibiotarsos relativamente mais largos e robustos que as espécies mais pequenas. O canal extensor é grande e o sulco extensor é pouco desenvolvido. O tarsometatarso de algumas espécies de galliformes, apresenta, nos machos, um espigão. As cristas do calcâneo são proeminentes. A tróclea Il é bilobada e tem uma faceta marcada para o primeiro metatarso.

\section{Género Alectoris (KAUP, 1829)}

Com a excepção da Gruta das Salemas e da Gruta do Pego do Diabo em todas as outras jazidas em que se estudou a totalidade dos restos de aves foram identificados restos de Alectoris (na Casa da Moura apenas se identificou o género e nas restantes a espécie $A$. rufa). Na Gruta Nova da Columbeira, para além desta 
espécie, foram também classificados restos de cf. A. barbara ${ }^{54}$. Da A. rufa foram encontrados vários restos ósseos do esqueleto apendicular: coracóides, ulnas, carpometacarpos, úmeros, rádios e fémures. Da cf. $A$. barbara foram identificados um úmero esquerdo e dois tarsometatarsos, um direito e outro esquerdo.

Alectoris rufa (LINNAEUS, 1758)

\section{Descrição osteológica}

\section{Coracóide}

Tal como em todos os outros galliformes, o coracóide de $A$. rufa é longo e fino. Apresenta uma concavidade pronunciada na zona basal, na face articular externa, que é curta e relativamente larga. O processo lateral apresenta uma forma pontiaguda terminal. A zona da face articular clavicular tem um formato quadrangular e bilobado.

\section{Úmero}

O úmero do $A$. rufa apresenta a fossa pneumatricial relativamente pequena, oval e marginal. O úmero alarga-se na parte proximal, logo a partir do fim do corpo do úmero, dando origem a um ângulo acentuado para o lado ventral. $O$ tubérculo ventral é pequeno. A margem caudal é curta. $E$ a cabeça do úmero tem uma forma arredondada bem definida, central e larga, que origina uma concavidade central na face ventral da zona proximal. A incisura capital é bem definida, de forma rectangular e larga, mas pouco funda, originando um ângulo menos pronunciado, quando vista da zona dorsal. Os côndilos distais não são muito proeminentes e o sulco tricipital e a fossa do olecrânio são pouco marcados.

\section{Ulna}

A ulna do A. rufa é curva, com a cótila ventral projectada e a dorsal apresenta uma articulação pequena. Tal como nos outros galliformes, a secção mesial é espalmada e espessa. O côndilo ventral ulnar é saliente. As papilas das rémiges são muito pouco desenvolvidas.

\section{Rádio}

O rádio desta espécie apresenta duas características principais; o tubérculo 
bicipital é pouco proeminente e o cótilo umeral ocupa quase toda a superfície proximal.

\section{Carpometacarpo}

O Carpometacarpo do A. rufa apresenta o metacarpo menor, curvo, fino e torcido, com uma curvatura a cerca de 1/3, pouco saliente; o espaço intermetacarpal é relativamente largo. O processo intermetacarpal proeminente e a tróclea carpal são bem definidas.

\section{Fémur}

O fémur do $A$. rufa é longo e fino, a secção da diáfise é redonda e o trocanter femural longo, saliente e pontiagudo. A crista do trocanter é proeminente, mas não muito larga e apresenta um ângulo pronunciado, quase recto, na parte inferior da cabeça do fémur, que a une ao corpo do osso.

\section{Tarsometatarso}

Os tarsometatarsos de $A$. rufa identificados apresentam a tróclea para o III dígito mais saliente, a parte proximal rectangular com a elevação intercondilar saliente, as arestas calcaneanas e a fossa infracotilar proeminentes. Apresenta um tubérculo na tróclea do II dígito e o forâmen vascular distal pequeno. Os machos possuem, a cerca de 2/3, uma protuberância óssea, que corresponde à presença vestigial do espigão de outras espécies de galliformes.

\section{Cf. Alectoris barbara (BONNATERRE, 1791)}

\section{Descrição osteológica}

\section{Úmero e tarsometatarso}

Os ossos de $A$. barbara têm as mesmas características das de $A$. rufa, apresentado um tamanho superior ao de $A$. rufa.

\section{Género: Perdix (BRISSON, 1821)}

O género Perdix está representado em apenas duas das jazidas estudadas: Gruta Nova da Columbeira (Perdix sp e P. perdix) e na Lapa da Rainha, onde foram encontrados dois elementos ósseos de $P$. perdix 
Perdix perdix (LINNAEUS, 1758)

\section{Descrição osteológica:}

\section{Coracóide}

O coracóide da P. perdix é semelhante em tamanho e em forma ao coracóide da Alectoris rufa, mas apresenta três diferenças que o distingue: $1 .^{\mathrm{a}}$, a concavidade da face articular externa é quase inexistente e fina; 2. a apresentam um forâmen na zona esternocoracoidal; $3 .{ }^{a}$, a face articular clavicular, é arredondada e não se apresenta bilobada.

\section{Úmero}

O úmero da $P$. perdix é semelhante em tamanho e em forma ao úmero do Alectoris rufa, mas tem também três diferenças que o distingue: 1.a, a fossa

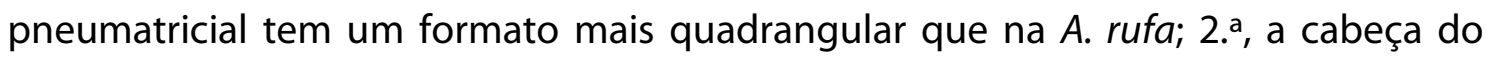
úmero é menos larga, mas mais proeminente; $3 .^{a}$, a incisura capital é mais pequena, embora mais vincada, dando origem a um ângulo agudo, quando vista da parte dorsal.

\section{Ulna}

A ulna da $P$. perdix é semelhante em tamanho e em forma à da $A$. rufa, com duas caracteísticas diferentes: a cótila ventral é menos projectada e mais arredondada e a cótila dorsal apresenta um formato mais quadrado, enquanto na $A$. rufa é mais redondo.

\section{Tibiotarso}

O tibiotarso da $P$. perdix é menos robusto que nas outras espécies de galliformes, a crista fibular é longa, mas menos proeminente que nos outros galliformes. O epicôndilo medial é pouco proeminente, a margem da tróclea cartilaginosa da tíbia é redonda (a da $A$. rufa é quadrada). A crista cnemial cranial é larga e de formato rectangular.

\section{Tarsometatarso}

O tarsometatarso da $P$. perdix é semelhante em tamanho e em forma ao da $A$. rufa, sendo diferente em dois pontos: $1 .^{\circ}$, menos robusto (mais fino); $2 .^{\circ}$ a tróclea para o III dígito é mais pequena e menos saliente. 
Género Coturnix (BONNATERRE, 1791)

O género Coturnix está representado em apenas duas das jazidas estudadas: Gruta Nova da Columbeira e na Gruta da Furninha (HARLÉ, 1910 - 11, FERREIRA, 1964, $R O C H E, 1972)$, através de dois úmeros da espécie $C$. coturnix.

Coturnix coturnix (LINNAEUS, 1758)

\section{Descrição osteológica}

\section{Úmero}

O úmero da C. coturnix tem a secção da diáfise oval; a fossa pneumatricial tem um formato ovalado; a cabeça do úmero é arredondada, mas pouco larga e pouco proeminente; a crista deltopeitoral é curvada para dentro; a incisura capital é pequena, mas mais funda; a base da cabeça do úmero, ao lado da fossa pneumatricial é bastante escavada. Na zona distal, o processo supracondilar dorsal é pouco desenvolvido; a fossa braquial é mais profunda e marcada junto ao côndilo ventral; a incisura intercondilar é pouco evidente e o processo flexor é saliente, mas fino.

\section{Género: Lagopus (BRISSON, 1760)}

O género Lagopus está representado em apenas duas das jazidas estudadas: Gruta Nova da Columbeira e na Lapa da Rainha, onde foram identificadas duas espécies: L. mutus (um tarsometatarso na Gruta Nova da Columbeira) e L. lagopus (um fragmento distal de fémur e um tarsometatarso, na Lapa da Rainha)

\section{Cf. Lagopus mutus (MONTIN, 1781)}

\section{Descrição osteológica}

\section{Tarsometatarso}

A tróclea para o III dígito, mais saliente e comprida que na P. perdix e A. rufa; a tróclea do II dígito apresenta um tubérculo; a parte proximal rectangular, com a elevação intercondilar saliente e as cristas intermédias do hipotarso proeminentes. Tem um tubérculo na tróclea do Il dígito. 
Cf. Lagopus lagopus (LINNAEUS, 1758)

\section{Descrição osteológica}

\section{Fémur}

O fémur do L. lagopus é mais robusto e maior que os do $A$. rufa e $P$. perdix, a secção da diáfise é redonda e a crista do trocanter é larga e proeminente, dando origem a uma fossa na zona subjacente. O fragmento diatl da Lpa da Rainha tem o epicôndilo lateral pouco saliente, mas largo; o côndilo lateral é redondo e proeminente; o sulco intercondilar é largo, ao passo que o medial é plano.

\section{Tarsometatarso}

A tróclea para o III dígito é mais saliente e comprida que na $P$. perdix e A. rufa; a tróclea do II dígito apresenta um tubérculo; a parte proximal rectangular tem a elevação intercondilar saliente e arestas calcaneanas proeminentes; tem também um forâmen distal entre a tróclea do III e IV dígitos. Verifica-se a presença de um tubérculo na tróclea do Il dígito. Tem o forâmen vascular distal pequeno.

\section{Género: Phasianus (LINNAEUS, 1758)}

O género Phasianus está apenas representado numa das jazidas estudadas, a Gruta do Pego do Diabo, onde se identificou a parte proximal de um úmero esquerdo de $c f$. $P$. colchicus.

\section{Cf. Cf. Phasianus colchicus (LINNAEUS, 1758)}

\section{Descrição osteológica}

\section{Úmero}

O fragmento proximal de úmero atribuído a cf. $P$. colchicus apresenta as principais caracteísticas dos úmeros dos galliformes: a fossa pneumatricial pequena, oval e marginal; alargamento na parte proximal, logo a partir do fim da diáfise, dando origem a um ângulo acentuado para o lado ventral; o tubérculo ventral é pequeno; a margem caudal é curta e a incisura capital é bem definida, de forma rectangular e larga, mas pouco funda. Por outro lado, apresenta características específicas do $P$. colchicus a crista bicipital é muito saliente na zona da fossa pneumatricial, formando um ângulo agudo (COHEN \& SERJEANTSON, 1996), a cabeça do úmero é grande, de forma arredondada, a incisura capital é maior que nos úmeros dos outros galliformes. 


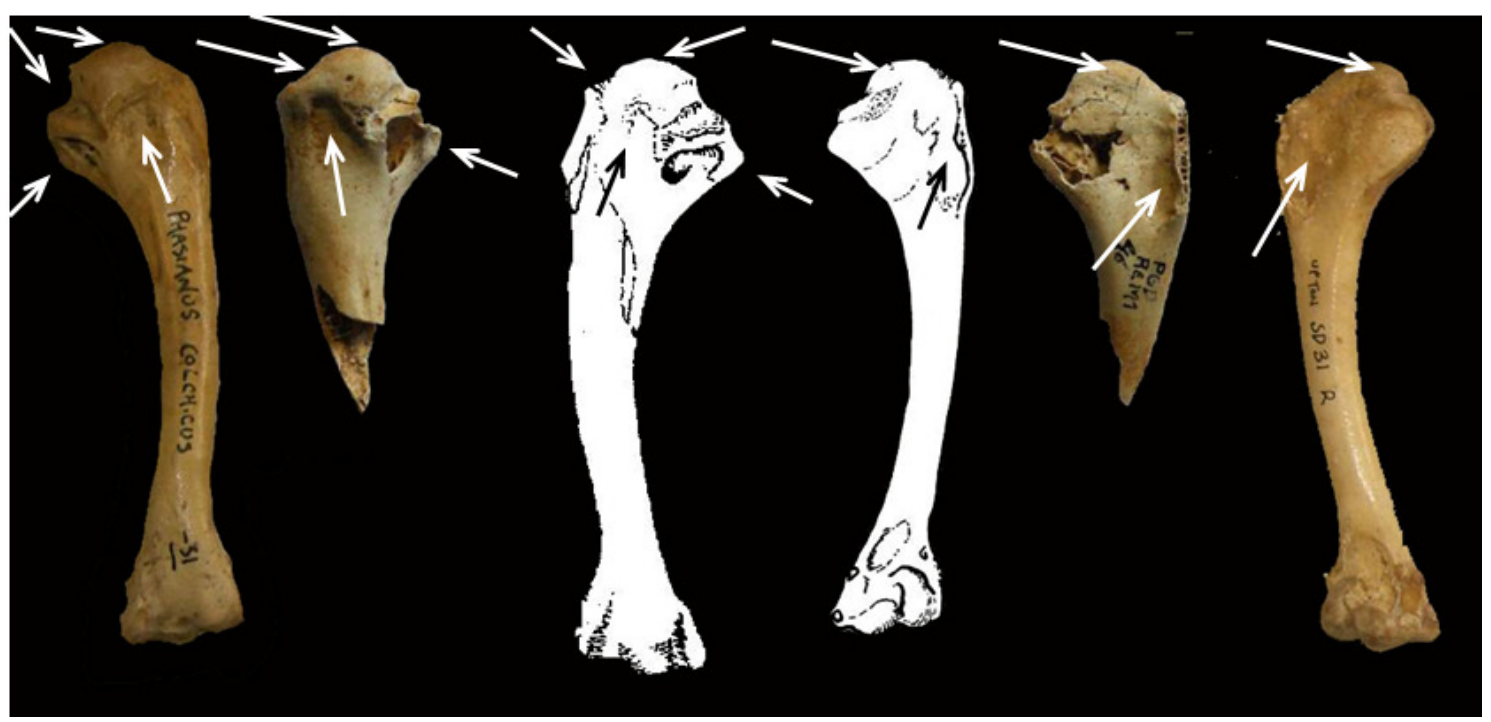

Fig. 81 - Comparação do fragmento proximal do úmero da Gruta do Pego do Diabo com o exemplar da colecção do CIPA e o desenho à escala de 1:1 de COHEN \& SERJEANTSON, 1996. Vista cranial (esquerda) e vista caudal (direita). As setas indicam as semelhanças consideradas para a classificação taxonómica. Fotografia: S. Figueiredo.

\section{ANSERIFORMES}

Os anseriformes constituem uma ordem de aves aquáticas que contém 149 espécies (VUILLEUMIER, 2001), distribuídas por 48 géneros e 4 famílias, Anatidae, Anhimidae (restritos à América do Sul), Anseranatidae e Dendrocygnidae (HÖFLING, \& ALVARENGA, 2000). As aves anseriformes habitam zonas aquáticas continentais, como lagos, pântanos, rios e estuários. No entanto, algumas espécies mudam-se para habitat marinhos durante a época de reprodução. São aves de médio a grande porte que medem entre 30 a $180 \mathrm{~cm}$ de envergadura e cujo peso varia entre 200 gramas e $20 \mathrm{~kg}$.

Os anseriformes têm o corpo roliço, cabeça pequena, cauda curta, bico largo e achatado e o pescoço comprido (VUILLEUMIER, 2001).

No estudo efectuado para esta tese, verifica-se que esta ordem está essencialmente representada nas jazidas situadas no litoral (ou próximo) e em jazidas localizadas em zonas húmidas próximas.

Os ossos de anseriformes identificados no estudo realizado foram ossos do esqueleto apendicular e um do esqueleto axial, um sinsacro, que nos anseriformes tem o antitrocanter projectado, processo pectineal atenuado, nos anserinae e ponteado nos anatinae. A faceta cranial do corpo vertebral é côncava.

Do esqueleto apendicular, os ossos dos membros anteriores dos anseriformes 
apresenta as seguintes características: a escápula tem uma projecção no acrómio e as facetas glenóides largas; o coracóide tem a cótila escapular escavada e arestas na superfície dorsal. Nos anserinae a diáfise é mais robusta que nos anatinae. O processo esterno-coracóide é quadrado nos anatinae e ondulado nos anserinae. O úmero é robusto, a crista bicipital é curva nos anserinae e recta nos anatinae. Os anatinae têm a cabeça do úmero mais saliente, enquanto os anserinae apresentam a crista mediana mais curva. A ulna tem a articulação do côndilo distal comprida. A extremidade distal é arredondada. Tal como nos galliformes, as papilas das rémiges são pouco desenvolvidas. A depressão do músculo braquial é evidente. O rádio tem a diáfise ligeiramente arqueada, a superfície articular proximal é redonda e relativamente larga. A faceta ulnar é marcadamente cavada. Na extremidade distal, a proeminência ligamentar é larga. O carpometacarpo tem o metacarpo menor linear e fino, paralelo ao maior, reduzindo o espaço intercarpal. O processo intermetacarpal é muito reduzido, ou mesmo inexistente e o processo extensor é grande e desenvolvido, e mais saliente e arredondado nos anserinae que nos anatinae.

Dos membros posteriores, o fémur caracteriza-se por ser relativamente pequeno e robusto. Apresenta a fossa popliteal funda e tem a linha intermuscular arqueada no lado lateral interno. A tróclea fibular é funda e os anserinae apresentam o tubérculo gastrocnemial medial proeminente. O tibiotarso apresenta a crista cnemial larga e projectada. A articulação distal alarga obliquamente. A ligação tendinal é transversa ao osso na diáfise. O tarsometatarso apresenta quatro cristas intermédias do hipotarso e a crista medial é longa. A tróclea do II dígito é redonda, comparada com a dos galliformes. A secção da diáfise é quadrada.

Género: Anser (LINNAEUS, 1758)

O género Anser está representado apenas numa das jazidas estudadas, a Gruta do Pego do Diabo, onde se identificou um Carpometacarpo esquerdo de Anser albifrons.

Anser albifrons (SCOPOLI, 1769)

\section{Descrição osteológica}

\section{Carpometacarpo}

O carpometacarpo de A. albifrons, encontrado na Gruta do Pego do Diabo é 
longo e comprido, com o metacarpo menor recto, paralelo e próximo do metacarpo maior; o espaço intermetacarpal é estreito e comprido; o processo extensório é saliente e arredondado, na parte terminal. Este osso tem um ângulo quase recto na zona entre a tróclea carpal para o processo extensor; o processo pisiforme é pouco proeminente. Tem o processo alular em forma de bico, já o processo intermetacarpal encontra-se quase ausente.

Género: Cygnus (BECHSTEIN, 1803)

O género Cygnus está apenas representado numa das jazidas estudadas - a Gruta da Furninha - onde se identificou um úmero direito de Cygnus olor (HARLÉ, 1910 - 11, FERREIRA, 1964, ROCHE, 1972).

Cygnus olor (GMELIN, 1789)

\section{Descrição osteológica}

\section{Úmero}

O úmero do C. olor apresenta a fossa pneumatricial relativamente pequena e arredondada. O úmero é relativamente recto, não muito rubosto e de grandes dimensões, se comparado com o dos anseriformes estudados. A crista bicipital é arredondada, o tubérculo dorsal é pouco proeminente e a cabeça do úmero tem uma forma arredondada, pouco saliente e pequena. Na zona proximal, a incisura capital é marcada e a crista deltopeitoral longa. Os côndilos distais não são muito proeminentes, o sulco tricipital e a fossa do olecrânio são pouco marcados, mas largos.

Género: Anas (LINNAEUS, 1758).

O género Anas está representado em duas das jazidas estudadas: na Gruta Nova da Columbeira e na Gruta da Furninha (HARLÉ, 1910 - 11, FERREIRA, 1964, ROCHE, 1972), onde foram identificadas duas espécies: A. platyrhynchos, na primeira (dois tarsometatarsos, um direito e um esquerdo) e $A$. creca, na segunda (um úmero direito). 
Anas platyrhynchos (LINNAEUS, 1758)

\section{Descrição osteológica}

\section{Tarsometatarso}

Tarsometatarso relativamente pequeno e robusto, com a diáfise redonda; as trócleas distais são proeminentes, com a do III dígito mais saliente; o hipotarso é grande e elevado, de formato rectangular; a parte proximal do tarsometatarso é rectangular, com a elevação intercondilar saliente.

Anas crecca (LINNAEUS, 1758)

\section{Descrição osteológica}

\section{Úmero}

A secção da diáfise do úmero é redonda; a crista deltopeitoral curta e saliente; a cabeça do úmero é proeminente; a fossa da cabeça do úmero é igualmente proeminente; tem a fossa pneumatricial pequena e o tubérculo ventral saliente; o processo flexor é pouco saliente, ausência do processo supracondilar dorsal.

Género: Melanitta (BOIE, 1822)

O género Melanitta está representada na Gruta da Furninha (HARLÉ, 1910 - 11, FERREIRA, 1964, ROCHE, 1972), onde foi identificado um fragmento proximal de um úmero direito de $M$. nigra, e na Gruta Nova da Columbeira, onde foi agora reconhecido um fragmento distal de tibiotarso.

Melanitta nigra (LINNAEUS, 1758)

\section{Descrição osteológica}

\section{Úmero}

O fragmento proximal de úmero de $M$. nigra, encontrado na Gruta da Furninha, tem a secção da diáfise redonda, a crista deltopeitoral curta e recta e a cabeça proeminente, numa posição central; a fossa da cabeça do úmero é bem marcada, enquanto a fossa pneumatricial é pequena e de formato redondo; a incisura capital é larga e pouco funda; o tubérculo dorsal pouco pronunciado.

\section{Tibiotarso}

O fragmento tibiotarso da M. nigra encontrado na Gruta Nova da Columbeira 
apresenta as seguintes características: o epicôndilo medial é pouco saliente, o sulco extensor é comprido e o canal extensor é relativamente pequeno, com a ponte tendinal estrita e situada numa posição relativamente afastada dos côndilos distais. A incisura intercondilar é larga.
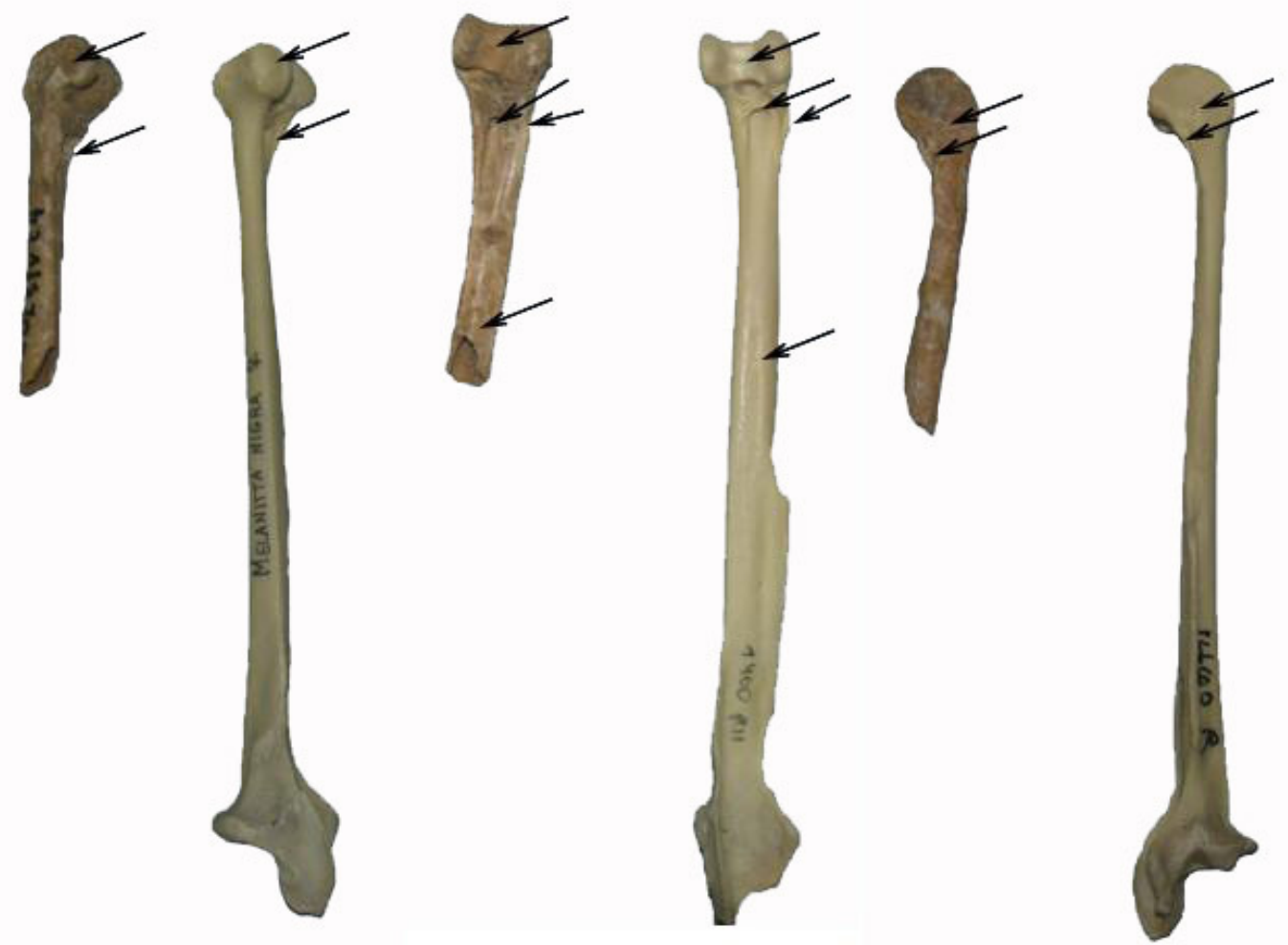

Fig. 82 - Comparação entre o fragmento distal de tibiotarso de M. nigra, encontrado na gruta Nova da Columbeira, com o mesmo osso de um espécime actual. As características osteológicas que permitiram a classificação estão assinaladas com setas brancas..

Género: Tadorna (BOIE, 1822)

O género Tadorna está apenas numa das jazidas estudadas, a Gruta da Furninha (HARLÉ, 1910 - 11, FERREIRA, 1964, ROCHE, 1972), onde foi identificada uma grande quantidade de ossos, em especial do esqueleto apendicular da espécie $T$. tadorna. Trata-se da espécie mais representada nesta jazida. A espécie T. tadorna apresenta dimorfismo sexual.

Tadorna tadorna (LINNAEUS, 1758)

\section{Descrição osteológica:}

\section{Escápula}

Extremidade cranial é espalmada e a extremidade dorsal forma um ângulo 
obtuso; o tubérculo coracóidal e o acrómio são pouco proeminentes e a face articular umeral é pouco desenvolvida.

\section{Coracóide:}

O coracóide da T. tadorna apresenta linhas perpendiculares na depressão esternocoracoidal; o processo esternocoracoidal é quadrado. A face articular com o úmero é pequena; o processo procoracóide pouco saliente e quadrado; o processo acrocoracóide é arredondado e a face articular com o esterno ocupa toda a extremidade da zona esternocoracoidal; a face articular clavicular é pouco marcada.

\section{Úmero}

O úmero da T. tadorna tem a secção da diáfise redonda; a crista deltopeitoral curta, relativamente proeminente e recta; a cabeça do úmero é proeminente e central; a fossa da cabeça do úmero é bem marcada; a fossa pneumatricial é pequena e de formato oval. A incisura capital é bem marcada; o tubérculo dorsal é pouco pronunciado e o ventral saliente; o processo flexor é pouco evidente; não tem o processo supracondilar dorsal e a fossa braquial é de formato triangular triangular.

\section{Ulna}

A ulna da T. tadorna é curva e tem a secção da diáfise arredondada. Apresenta a cótila ventral arredondada e mais pequena que a cótila dorsal. A incisura braquial é bastante marcada; o processo da cótila dorsal é alongado e fino, com um sulco a meio. O olecrânio pouco saliente, em relação à cótila ventral. Na articulação distal apresenta o côndilo ventral proeminente e o sulco radial marcado. O côndilo ventral ulnar tem uma crista arredondada. As papilas das rémiges são pouco marcadas.

\section{Rádio}

O rádio da T. tadorna apresenta o tubérculo bicipital saliente e a cótila umeral arredondada e saliente; sulco ligamentar e o sulco tendinoso da parte distal marcados; face articular ulnar proeminente.

\section{Carpometacarpo}

Osso metacarpal é recto e paralelo ao maior. O processo intermetacarpal , do carpometacarpo é pouco evidente e o processo extensório e o alular são proeminentes; o extensório apresenta um formato quase triangular; a fossa supratroclear é rectangular; existe um pequeno sulco linear a meio da zona distal da face articular com os dígitos II e III regular, em que a face articular com o dígito III não 
é saliente. O espaço intercarpal é linear, estreito e comprido.

\section{Sinsacro}

A faceta do corpo vertebral, da vértebra toracicossincral é côncava e, vista lateralmente, a sua base forma um ângulo obtuso; o osso lombossacral é comprido e largo; a faceta da última vértebra caudal do sinsacro é em forma de um "v" largo.

\section{Fémur}

O fémur da T. tadorna é pequeno e lago, apresentado robustez; a secção da diáfise é redonda e o trocanter femural longo e saliente; a crista do trocanter é larga e robusta e a fossa do trocanter bem marcada. Na parte distal, a crista tibiofibular é bem evidente; a impressão do ligamento cruciforme caudal pouco evidente; côndilo medial proeminente.

\section{Tibiotarso}

O tibiotarso da T. tadorna apresenta a crista fibular pouco proeminente; a crista cnemial cranial e a crista cnemial lateral são proeminentes e de formato triangular; o sulco intercristal é largo e fundo. O epicôndilo medial é pouco saliente, o sulco extensor é comprido e o canal extensor é relativamente pequeno. A incisura intercondilar é larga.

\section{Tarsos-metatarso}

Os tarsometatarsos de T. tadorna são curtos e largos, mostrando robustez. Apresentam a tróclea para o III dígito mais saliente e larga; a parte proximal é rectangular, com a elevação intercondilar proeminente e arredondada e as arestas calcaneanas proeminentes, mas curtas; as cristas intermédias do hipotarso são salientes; o forâmen vascular distal é pequeno. A tróclea do dígito II apresenta uma pequena protuberância.

\section{Género: Somateria $(\mathrm{LEACH}, 1819)$}

O género Somateria está apenas numa das jazidas estudadas, a Gruta da Furninha, onde foi identificada uma grande quantidade de elementos ósseos da espécie S. mollissima.

Somateria mollissima (Linnaeus 1758)

\section{Descrição osteológica}

\section{Escápula}


A escápula da S. mollissima tem o acrómio projectado, a faceta articular com a clavícula termina num "bico" largo e as facetas glenóides são largas. Apresenta um formato geral curvo e a extremidade caudal termina de forma arredondada

\section{Coracóide}

O coracóide da S. molíssima é muito semelhante ao da T. tadorna diferenciando-se essencialmente no tamanho: o coracóide da S. molíssima é maior que o da T. tadorna.

\section{Úmero}

O úmero da S. molíssima é semelhante ao da T. tadorna, diferenciando-se nas seguintes características: o tamanho é maior, a crista deltopeitoral é mais comprida e a fossa braquial é mais pequena e de formato ovalado.

\section{Ulna}

A ulna da S. molíssima é semelhante à da T. tadorna, diferenciando-se nas seguintes características: a ulna da S. molíssima é mais robusta, os côndilos da parte distal são menos proeminentes e o sulco radial é menos marcado.

\section{Carpometacarpo}

O Carpometacarpo da S. molíssima é semelhante ao da T. tadorna, diferenciando-se nas seguintes características: tem um tamanho maior, o processo extensório é menos proeminente e apresenta um formato mais próximo do rectangular que do triangular.

\section{Rádio}

O rádio da S. molíssima é semelhante ao da T. tadorna, mas maior

\section{Esterno}

O externo da S. mollissima apresenta a margem anterior ligeiramente curvada para a frente, a área ligamentar das costelas é larga. E a espinha externa pontiaguda.

\section{Fémur}

O fémur da S. molíssima é maior e mais robusto que o da T. tadorna, a crista do trocanter é maior, mais larga e robusta, a fossa patelar, na zona distal, é menos profunda, mas mais larga, que nos fémures do T. tadorna.

\section{CharadRIIFormes}

A ordem dos charadriiformes é um grupo muito diversificado que tem 
aproximadamente 343 espécies, distribuídas por cerca de 18 famílias (VUILLEUMIER, 2001). Esta ordem está espalhada por todo o mundo, constituindo um grupo muito diversificado, que explora habitat distintos, desde zonas limícolas, ribeirinhas às zonas costeiras e de mar alto (VUILLEUMIER, 2001).

Devido a este factor apresenta bastantes diferenças entre si, sobretudo a nível das patas e do bico. Por exemplo, as patas são longas nas aves limícolas, que exploram as zonas ribeirinhas, e curtas nos alcídeos, que têm membranas interdigitais nos dedos das patas e o corpo compacto (VUILLEUMIER, 2001)

Os charadriiformes estão essencialmente representados em quatro das jazidas estudadas (Gruta da Furninha, Gruta Nova da Columbeira, Gruta das Fontainhas e Casa da Moura). Na Casa da Moura apenas se conseguiu identificar um tibiotarso ao nível da família Sternidae. Nas restantes jazidas foram identificados sete géneros (Larus, Gallinago, Vanellus, Limosa, Pluvialis, Numenius e Pinguinus) e apenas quatro espécies ( $P$. squatarola, V. vanellus, $N$. phaeopes e $P$. impennis $\left.{ }^{55}\right)$. Devido ao estado de conservação dos ossos não foi possível atribuir classificação ao nível da espécie aos géneros Larus, Vanellus, Limosa e Gallinago, pois algumas estruturas distintivas das espécies não se encontram preservadas.

Os ossos de charadriiformes identificados no estudo realizado foram ossos do esqueleto apendicular. Os coracóides dos charadriiformes apresentam a face articular externa marcadamente côncava. Com excepção dos Alcidae os charadriiformes têm o processo lateral bem desenvolvido e, em alguns grupos, em forma de bico. Apresentam um forâmen que penetra o procoracóide. O úmero de charadriiforme identificado na Gruta da Furninha, da espécie $P$. impennis, apresenta as características típicas dos alcidae: pronunciado espalmamento longitudinal da diáfise, projecção lateral e ventral da articulação proximal do úmero e a crista pectoral pouco proeminente, em relação à margem dorsal. A ulna dos charadriiformes apresenta variedade, consoante o grupo: geralmente a secção é arredondada, com excepção das alcas que é oval. Nas alcas, a ulna é mais curta e robusta que nos restantes charadriiformes e o olecrânio tem o formato de gancho. Nos restantes charadriiformes, o processo da cótila dorsal é proeminente, a cótila ventral é alongada e a faceta funda. No Carpometacarpo, o metacarpo menor é 
ligeiramente curvo, largo na zona proximal e fino na zona distal; o processo extensor é saliente e de formato quadrangular (nas alcas é muito largo e pouco proeminente e a tróclea carpal dorsal é redonda). O tarsometatarso dos charadriiformes é muito fino na zona mesial, a tróclea do dígito II é projectada posteriormente, as superfícies dorsais são côncavas e as cristas intermédias do hipotarso têm o mesmo comprimento e os forâmenes proximais são pequenos. Nas alcas os tarsometatarsos são largos e robustos, os forâmenes proximais são grandes e situam-se em fossas fundas e as cristas intermédias do hipotarso são relativamente largas.

Género: Numenius (BRISSON, 1760)

O género Numenius está apenas representado numa das jazidas estudadas, a Gruta da Furninha, onde foi identificada uma ulna direita da espécie N. phaeopus.

Numenius phaeopus (LINNAEUS, 1758)

\section{Descrição osteológica}

\section{Ulna}

A ulna do N. phaeopus tem a secção da di'sfise arredondada; o processo da cótila dorsal é proeminente e a cótila ventral é alongada com a faceta funda.

Género: Pinguinus (BONNATERRE, 1791)

O género Pinguinus está apenas representado numa das jazidas estudadas, a Gruta da Furninha, onde foi identificado um úmero esquerdo da espécie $P$. impennis.

Pinguinus impennis (LINNAEUS, 1758)

\section{Descrição osteológica}

\section{Úmero}

Fragmento proximal de um úmero esquerdo, com o tubérculo dorsal partido. Apresenta as seguintes características: pronunciado espalmamento longitudinal da diáfise, projecção lateral e ventral da articulação proximal do úmero e crista deltopeitoral é pequena e pouco proeminente, em relação à margem dorsal. 


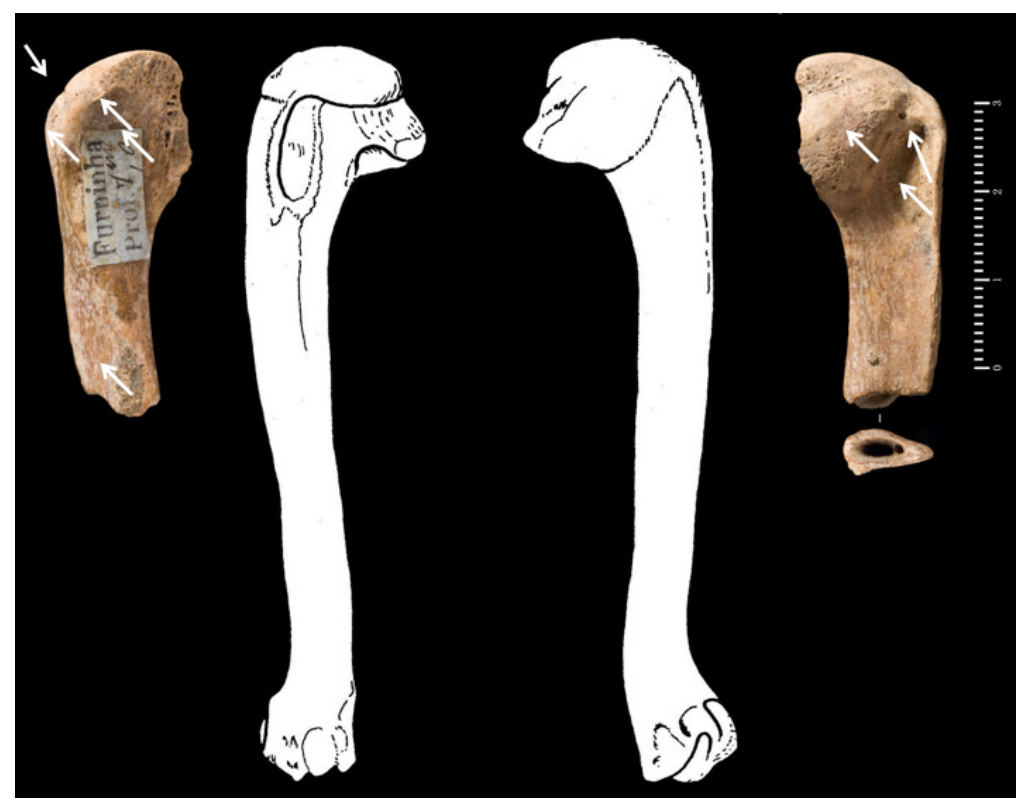

Fig. 83 - Comparação entre o fragmento do úmero de $P$. impennis identificado na Furninha (fotografia de José Paulo Ruas - CIPA) e o desenho de um úmero de $P$. impennis (adaptado de COHEN \& SERJEANTSON, 1996). As setas indicam as características que permitiram o diagnóstico da espécie.

Género: Pluvialis (BRISSON, 1760)

O género Pluvialis está representado apenas numa das jazidas estudadas, a Gruta Nova da Columbeira, onde foi identificado um Carpometacarpo esquerdo e um tarsometatarso direito da espécie $P$. squatarola..

Pluvialis squatarola (LINNAEUS, 1758)

\section{Descrição osteológica}

\section{Carpometacarpo}

O carpometacarpo do $P$. squatarola tem o metacarpo menor ligeiramente curvo, largo na zona proximal e fino na zona distal, processo extensor saliente e de formato quadrangular.

\section{Tarsometatarso}

O tarsometatarso é fino na zona mesial, a tróclea do dígito II é projectada posteriormente, as cristas intermédias do hipotarso têm o mesmo comprimento e os forâmens proximais são pequenos.

Género: Vanellus (BRISSON, 1760)

O género Vanellus está apenas representado em duas das jazidas estudadas, a 
Gruta Nova da Columbeira e a Gruta das Fontainhas (HARLÉ, 1910 - 11, FERREIRA, 1964, ROCHE, 1972). Na Columbeira foi identificada uma ulna direita de Vanellus sp. que não permitiu atribuir com exactidão a espécie, enquanto que nas Fontainhas foi encontrado um coracóide esquerdo da espécie $V$. vanellus.

Vanellus vanellus (LINNAEUS, 1758)

\section{Descrição osteológica}

\section{Coracóide}

O coracóide de Vanellus vanellus apresenta a cótila escapular funda e o processo lateral em forma de bico, a face articular externa é pequena e marcadamente côncava; apresenta um forâmen no processo pró-coracóide.

\section{Pelecaniformes}

A ordem dos pelecaniformes é constituida por seis famílias e 67 espécies. 0 grupo está distribuído à escala global e habita, sobretudo, regiões costeiras marinhas e perto de grandes lagos ou estuários. São aves de médio a grande porte, que se caracterizam pelas patas totiplamadas, com todos os quatro dedos unidos por uma membrana interdigital. A maioria das espécies tem um saco extensível, sustentado pela mandíbula inferior. O pescoço é comprido na maioria das espécies e as patas são curtas. O bico é bastante longo e em muitos casos termina num gancho. $\mathrm{A}$ maioria das espécies está especialmente adaptada para a pesca de peixes, cefalópodes e crustáceos, a partir do voo. Não apresentam dimorfismo sexual e são habitualmente gregárias, reproduzindo-se em colónias numerosas (VUILLEUMIER, 2001).

Os primeiros pelecaniformes que surgem no registo fóssil são o Protophaeton (da família Phaethontidae) e uma ave semelhante às da família Fregatidae, do Eocénico de Inglaterra. Os pelicanos evoluíram durante o Oligocénico (HÖFLING, \& ALVARENGA, 2000).

No estudo efectuado, apenas foi identificada uma espécie desta ordem, o Phalacrocorax aristotelis, numa única jazida, a Gruta da Furninha (HARLÉ, 1910 - 11, FERREIRA, 1964, ROCHE, 1972), onde foram encontrados um coracóide direito, dez 
úmeros (seis direitos e quatro esquerdos), quatro ulnas (três esquerdas e uma direita), dois rádios (um esquerdo e um direito), um metacarpo esquerdo e um tibiotarso direito.

Género: Phalacrocorax (BRISSON, 1760)

O género Phalacrocorax está apenas representado na Gruta da Furninha (HARLÉ, 1910 - 11, FERREIRA, 1964, ROCHE, 1972). Ali foram identificados 19 restos da espécie $P$. aristotelis: um coracóide direito, seis úmeros direitos e quatro esquerdos, três ulnas esquerdas e uma direita, um rádio esquerdo e um direito, um Carpometacarpo esquerdo e um tibiotarso direito.

Phalacrocorax aristotelis (LINNAEUS, 1758)

\section{Descrição osteológica}

\section{Coracóide}

O coracóide de $P$. aristotelis apresenta a face articular clavicular plana, o sulco da face articular umeral com o processo acrocoracóide é grande, a face articular externa é canelada, larga e comprida; o processo procoracóide é pequeno.

\section{Úmero}

A secção da diáfise do úmero do $P$. aristotelis é redonda; a crista deltopeitoral é longa, mas pouco proeminente; a cabeça do úmero é pouco proeminente; a fossa pneumatricial é grande e funda; o sulco dos ligamentos transversos é fundo, com uma crista marcada na zona da intumescência do úmero. Na zona distal, o côndilo dorsal é curvo, formando um pequeno bico na zona da fossa branquial. O epicôndilo interno é projectado.

\section{Ulna}

A ulna do $P$. aristotelis tem uma curvatura pouco marcada, o processo do cótilo dorsal é longo, a aresta da margem caudal fina. A secção mesial apresenta um formato triangular. O côndilo dorsal ulnar é pouco saliente e arredondado. Apresenta um pequeno tubérculo pontiagudo no sulco intercondilar. As papilas das rémiges bem evidentes.

\section{Rádio}

No rádio do $P$. aristotelis o tubérculo bicipital é arredondado e a face articular 
ulnar é côncava. Lateralmente, apresenta a cabeça ampla; o tubérculo da aponeurose ventral é saliente e forma um ângulo agudo. A face articular radiocarpal é projectada na zona lateral. A secção mesial apresenta um formato triangular.

\section{Carpometacarpo}

O carpometacarpo do $P$. aristotelis é longo e comprido, o metacarpo menor é ligeiramente curvo na zona distal e próximo do metacarpo maior, na zona proximal, afastando-se deste, na zona distal; o espaço intermetacarpal estreito e comprido (mais largo na zona distal e mais próximo na zona proximal). Processo pisiforme é ligeiramente punctiforme; o processo alular forma um ângulo agudo; o processo intermetacarpal está ausente; existe uma fossa bem marcada na zona entre o processo extensório e a face articular ulnocarpal; apresenta uma pequena fossa por baixo da tróclea.

\section{Tibiotarso}

Tem as cristas cnemiais proeminentes, mas finas e o sulco intercnemial pequeno.; a crista fibular é proeminente, a secção mesial ovalada na face cranial e quase recta na face caudal; a articulação distal é angulosa e oepicôndilo medial é pouco proeminente. O tubérculo do retináculo fibular está quase ausente, seguido por um vestígio fibular, presente nos Phalacrocorax; o canal extensório é largo.

\section{PHOENICOPTERIFORMES}

A ordem dos phoenicopteriformes é constituída apenas por uma família (Phoenicopteridae), que tem seis espécies e um só género (DEL HOYO et al., 1992). São aves de pernas extremamente alongadas, totalmente desprovidas de penas. Proporcionalmente os phoenicopteriformes têm as maiores pernas de todas as outras aves. Têm o pescoço longo e flexível, a cabeça pequena, o bico encurvado para baixo e medem entre 90 e $150 \mathrm{~cm}$. São aves gregárias, que vivem em bandos numerosos, junto a zonas aquáticas. As suas longas patas permitem-lhes passar muito tempo em zonas de águas baixas, salinas ou alcalinas, sem molharem ou sujarem a plumagem (VUILLEUMIER, 2001). Algumas espécies conseguem inclusivamente habitar zonas de salinidade extrema, como os lagos africanos do Vale do Rift. 
Género: Phoenicopterus (LINNAEUS, 1758)

O género Phoenicopterus está apenas representado na Gruta da Furninha, onde foi identificado um resto da espécie $P$. ruber: um fragmento distal de ulna direita.

Phoenicopterus ruber (LINNAEUS, 1758)

\section{Descrição osteológica}

\section{Ulna}

O fragmento de ulna encontrado na Gruta da Furninha, atribuído à espécie $P$. ruber, apresenta as seguintes características: os côndilos ventral e dorsal têm tamanhos idênticos e o côndilo ventral ulnar é largo e proeminente. A depressão radial é pequena.

\section{GRUIFORMES}

A ordem dos Gruiformes tem 11 famílias (DEL HOYO et al., 1996). É um grupo que apresenta uma grande diversidade e que integra aves como o grou, as abetardas ou as galinhas-de-água. A maioria das espécies é terrestre, mas existem também exemplos de gruiformes arborícolas. (VUILLEUMIER, 2001). Os gruiformes têm uma biogeografia muito alargada, ocupando quase todas as áereas do planeta, excepto na Antárctida e algumas ilhas oceânicas. Habitam zonas de climas e habitat diversos, desde zonas áridas ou desérticas até áreas banhadas por lagos ou rios (VUILLEUMIER, 2001).

Estas aves têm, em geral, as pernas altas e o bico fino. Como grupo de habiat muito diverficados, o seu aspecto é igualmente muito diversificado. Os que vivem em zonas húmidas, como os grous, têm os dedos longos e esguios; os que habitam terras áridas e secas, como as abetardas, têm as patas mais curtas e as pernas fortes; os que habitam os meios aquáticos, como os galeirões e as galinhas-de-água, têm as patas lobadas.; os que voam grandes distâncias, como os grous, têm as asas compridas e largas, enquanto os que raramente voam, como os toirões e os mesites, têm asas pequenas e arredondadas (VUILLEUMIER, 2001).

Género: Otis (LINNAEUS, 1758) 
O género Otis foi identificado apenas na Gruta da Casa da Moura, onde se encontrou um fragmento da parte mesial e distal de um fémur e um fragmento da parte mesial e proximal de um tarsometatarso da espécie Otis tarda.

Otis tarda (LINNAEUS, 1758)

\section{Descrição osteológica}

\section{Fémur}

O fragmento distal de fémur de Otis tarda identificado na Casa da Moura apresenta, na face cranial, os sulcos intercondilar e patelar largos e pouco fundos, o côndilo lateral grande, o epicôndilo lateral e a impressão ligamentar colateral lateral pouco desenvolvidos e a fóvea do tendão muscular tibial cranial é grande e localizada numa posição marginal do côndilo, junto ao sulco intercondilar. Na face caudal a tróclea tibular é grande e a crista tibiofibular é ligeiramente redonda.

\section{Tarsometatarso}

O fragmento proximal do tarsometatarso de Otis tarda da Casa da Moura apresenta a secção da diáfise quadrada, as cristas plantares desenvolvidas; os forâmenes vasculares proximais pequenos, o sulco extensor pouco desenvolvido, a eminência intercotilar grande, as cristas do hipotarso muito salientes e as cótilas proximais arredondadas.

\section{FALCONIFORMES}

A ordem dos Falconiformes tem cerca de 307 espécies, distribuídas por cinco famílias (DEL HOYO et al., 1994) de aves de rapina diurnas. São aves de vários tamanhos, desde o falcão-anão, pouco maior que um pardal, aos condores, que podem atingir uma envergadura de mais de três metros. Estas aves sofreram adaptações à predação, como um bico forte, curvo e aguçado, garras longas afiadas, a cabeça grande e o pescoço curto ${ }^{56}$. Em geral, a fêmea é maior do que o macho (VUILLEUMIER, 2001).

Esta ordem engloba, entre outras as espécies de falcões, de abutres, de águias de búteos e de milhafres (VUILLEUMIER, 2001). Alguns autores incluem águias búteos, abutres e aves semelhantes numa outra ordem, a dos accipitriformes. No

56 Com a excepção dos abutres, que têm um pescoço comprido para se alimentarem do interior das carcaças. 
entanto, neste trabalho seguiremos, como está referido na metodologia utilizada, a taxonomia adoptada por DEL HOYO et al., (1992 - 2009).

\section{Género: Falco (LINNAEUS, 1758)}

O género Falco está representado na Gruta Nova da Columbeira e na Gruta da Casa da Moura. Na primeira foram identificados uma escápula de Falco sp e um fragmento distal de fémur esquerdo de F. tinnuculus, ao passo que na segunda foi identificado um fragmento distal de um tibiotarso de Falco sp e um tarsometatarso esquerdo de F. rusticolus.

As primeiras falanges do III e IV dígitos dos membros posteriores dos falconiformes, em especial dos accipetridae, apresentam a zona proximal mais larga, e a distal mais estreita.

O fémur dos falconiformes têm o trocanter pneumatizado, a fóvea larga e a fossa polítea profunda, o côndilo lateral e o sulco fibular estreitos, a tróclea fibular é proeminente. O tarsometatarso é largo e pouco espesso, com a parte caudal chata e a zona proximal mais larga.

Falco tinnuculus (LINNAEUS, 1758)

\section{Descrição osteológica}

\section{Fémur.}

O fémur identificado como sendo de F. tinnuculus, encontrado na Gruta Nova da Columbeira, apresenta a fossa polítea profunda, o côndilo lateral e o sulco fibular estreitos e a tróclea fibular proeminente.

Falco rusticolus (LINNAEUS, 1758)

\section{Descrição osteológica}

\section{Tarsometatarso.}

Tal como nos restantes falconiformes, o tarsometatarso de F. rusticolus identificado na Casa da Moura é largo e pouco espesso, com a parte caudal chata e a zona proximal mais larga; Os forâmens vasculares proximais são pequenos e afastados; As trócleas da extremidade distal são de tamanho diferente, sendo a maior a II e a mais pequena a IV. O tarsometatarso encontrado e atribuído a F. rusticolus tem 
as principais características deste género, distinguindo-se essencialmente pelo tamanho. É largo e pouco espesso, com a parte caudal chata e a zona proximal mais larga. Os forâmens vasculares proximais são pequenos e afastados.

\section{Género: Aquila (LINNAEUS, 1758)}

O género Aquila está representado na Gruta Nova da Columbeira e na Lapa da Rainha. Na primeira foram identificados dois fragmentos de duas ulnas direitas de $A$. chrysaetos, enquanto que na segunda foi identificado um fragmento distal de um tibiotarso atribuído a A. adalberti. Na Gruta da Furninha foram encontradas quatro garras, que pela forma e tamanho aparento ser do género Aquila.

Aquila chrysaetos (LINNAEUS, 1758)

\section{Descrição osteológica}

\section{Ulna.}

Os dois fragmentos de ulna encontrados na Gruta Nova da Columbeira (uma ulna quase inteira, sem a parte distal e um fragmento da parte distal ${ }^{57}$ apresentam as seguintes características: a zona proximal tem a cótila dorsal longa e baixa, o tubérculo de ligação colateralventral é grande e o olecrânio é proeminente e largo. A depressão braquial é estreita e pouco profunda, apresentando uma crista na margem ventral. A diáfise apresenta-se pouco curva e as papilas das rémiges são largas. A parte distal tem a depressão radial pouco profunda, o côndilo dorsal apresenta uma crista longa e bem vincada e uma insisura dos tubérculos carpais - que são pequenos e alongados - bem marcada.

\section{Cf. Aquila adalberti (BREHM, 1861)}

\section{Descrição osteológica}

\section{Tíbiotarso}

Na Gruta da Furninha foi encontrada a extremidade distal de um tibiotarso de A. adalberti que apresenta as seguintes características: canal extensório largo, com um côndilo marginal, na ponte supratendinal, incisura intercondilar, com dois pequenos sulcos transversais, côndilo interno maior e mais arredondado que o

57 Apesar de não encaixarem, podem ser de um mesmo osso. 
externo, que é mais saliente. Apresenta um côndilo saliente na depressão epicondilar lateral.
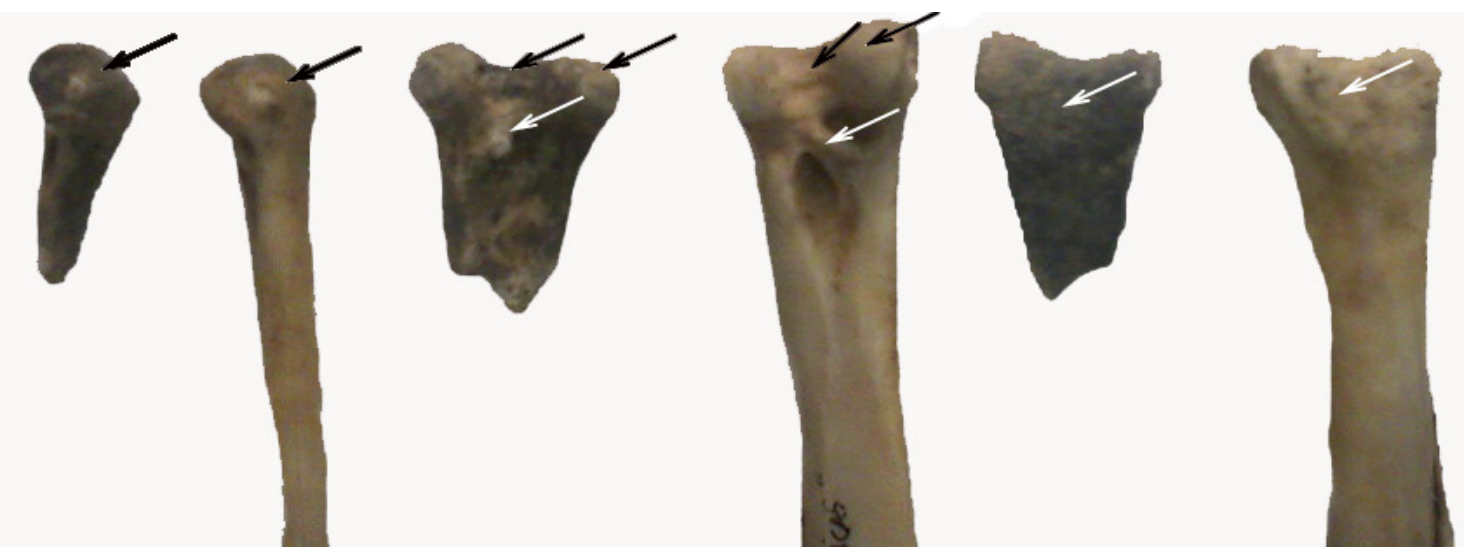

Fig. 84 - Comparação do fragmento distal de tibiotarso de Cf. Aquila adalberti, com o de um espécimen actual da colecção de referência do CIPA. As setas indicam os pontos semelhantes. Entre os dois exemplares. Fotografia: S. Figueiredo.

Género: Gyps (SAVIGNY, 1809)

Do género Gyps foi encontrada uma falange ( $1^{\text {a }}$ falange do ll dígito do pé) de um G. fulvus, na Gruta da Furninha.

Gyps fulvus (HABLIZL, 1783)

\section{Descrição osteológica}

\section{1. a falange do III dígito do membro posterior}

A falange identificada na Gruta da Furninha apresenta as seguintes características: zona proximal mais larga, mais proeminente na lateral esquerda, mais estreita na zona distal, com as depressões epicondilares laterais cavadas, em especial a esquerda.

Género: Milvus (LACEPEDE, 1799)

Do género Milvus foi identificado apenas um resto (um coracóide esquerdo) na Lapa da Rainha e atribuído a Cf. Milvus migrans.

Cf. Milvus migrans (BODDAERT, 1783)

\section{Descrição osteologica}

\section{Coracóide}

O coracóide de M. migrans identificado na Lapa da Rainha apenas preservou o corpo e a extremidade articular com o úmero. Apresenta as seguintes características: robustez, forâmen no sulco supracoracoidal bem evidente, processo procoracóide 
muito desenvolvido, de formato triangular, face articular escapular larga e o processo acrocoracíde proeminente, de formato triangular.

\section{Género: Bubo (DUMÉRIL, 1806)}

Do género Bubo foram encontrados 14 restos do esqueleto apendicular (tibiotarso, fémur, tarsometatarso, Carpometacarpo, ulna, úmero, coracóide e falange), na Gruta da Casa da Moura atribuídos à espécie B. bubo. Foi também encontrado um úmero esquerdo da mesma espécie na Gruta da Furninha.

Bubo bubo (LINNAEUS, 1758)

\section{Descrição osteológica}

\section{Coracóide}

O coracóide de $B$. bubo é robusto. Tal como noutras espécies de falconiformes, o coracóide do B. bubo apresenta um forâmen no sulco supracoracoidal bem evidente. O processo procoracóide é muito desenvolvido e curvado para o interior do sulco supracoracoidal. Na zona basal tem uma concavidade pronunciada, na face articular externa, e o processo lateral tem uma depressão em forma de " $u$ ". 0 processo acrocoracóide e a face articular clavicular são grandes e proeminentes.

\section{Úmero}

O úmero do $B$. bubo apresenta a fossa pneumatricial relativamente pequena, redonda e marginal. O úmero apresenta uma curvatura na diáfise; o tubérculo ventral relativamente pequeno; a cabeça do úmero é larga e pouco proeminente; a incisura capital é pouco profunda; a crista deltopeitoral é proeminente e de forma triangular, embora de ângulo mais aberto que nos géneros Falco e Aquila. Os côndilos distais não são muito proeminentes; o sulco tricipital e a fossa do olecrânio pouco marcados. Não apresenta o processo supra condilar dorsal e tem o epicôndilo ventral bem desenvolvido.

\section{Ulna}

A ulna do $B$. bubo é curva e a articulação proximal tem um ângulo baixo e amplo e o olecrânio baixo. A cótila dorsal prolongada, com uma crista projectada para cima e a cótila ventral pequena. A secção mesial é redonda. As papilas das rémiges são desenvolvidas. A articulação distal tem a depressão radial pouco profunda e o côndilo ventral ulnar saliente e o dorsal arrendondado. 


\section{Carpometacarpo}

O Carpometacarpo do B. bubo apresenta o metacarpo menor relativamente recto e fino e afastado do maior, formando um espaço intermetacarpal largo e comprido; o processo intermetacarpal é atrofiado, a tróclea carpal definida, o processo pisiforme desenvolvido e o processo extensor saliente. Na extremidade distal a faceta para o dígito menor é ligeiramente mais prolongada que a do maior dígito .

\section{Fémur}

O fémur do $B$. bubo é robusto e a secção da diáfise é redonda. A cabeça do fémur saliente e projectada lateralmente, com a fóvea larga, funda e de formato triangular; a zona por baixo da cabeça do fémur, entre a apófise e a diáfise é arredondada; o trocanter femural é pouco saliente e a crista do trocanter é um pouco longa, mas não muito larga; a linha intermuscular da face cranial é curta e apenas visível na zona proximal. Na zona distal, o epicôndilo da face medial situa-se numa posição distante em relação à articulação distal; o sulco patelar é largo; a fossa do poplíteo é funda e a tróclea fibular é inclinada em relação ao côndilo lateral.

\section{Tibiotarso}

No tibiotarso do $B$. bubo, as cristas cnemiais são rubustas e pouco proeminentes. As cristas cnemiais são largas e pouco salientes; a crista fibular é pouco saliente, mas larga; a secção mesial é ovalalada. Na extremidade distal, não apresenta o canal extensório, tal como acontece no género Strix; a incisura intercondilar é larga e tem a forma de " $U$ " e uma pequena crista entre os dois côndilos distais. Apresenta um pequeno côndilo na depressão epicondilar lateral.

\section{Tarsometatarso:}

Os tarsometatarsos do B. bubo identificados apresentam a fossa infracotilar dorsal medial funda e grande, com uma ponte tendinal, que também está presente nos Strigidae; a superfície dorsal é côncava; tem apenas um grande forâmen vascular proximal; a crista medial do hipotarso é grande, larga e tem uma superfície plana, de formato quase rectangular. Na zona distal as trócleas do metatarso II e IV são grandes e ado metatarso II é mais pequena e recuada; tem o forâmen vascular distal relativamente grande; a fossa supratroclear plantar é grande; ao contrário de outros falconiformes, não apresenta a fossa do metatarso I. 


\section{STRIGIFORMES}

Os Strigiformes constituem uma ordem de aves que inclui aves de rapina nocturnas. Há cerca de 200 espécies distribuídas por duas famílias (DEL HOYO et al., 1999). Têm o pescoço curto, a cabeça grande e redonda e a cauda curta.

Têm um dedo reversível, que pode ser apontado para a frente e para trás e as órbitas cilíndricas, que não podem ser rodadas. Se a ave precisa de olhar para os lados tem de mover toda a cabeça. Em compensação tem a capacidade de rodar a cabeça e o corpo a 270 graus (VUILLEUMIER, 2001).

Género: Asio (BRISSON, 1760)

O género Asio foi identificado na Gruta da Furninha, pela presença de um fémur direito da espécie $A$. flammeus, inicialmente atribuído a Strix flammeus (HARLÉ, 1910 - 11, FERREIRA, 1964, ROCHE, 1972).

Asio flammeus (PONTOPPIDAN, 1763)

\section{Descrição osteológica}

\section{Fémur}

O fémur do $A$. flammeus encontrado na gruta da Furninha apenas tem preservada a zona mesial e distal, que apresentam as seguintes características: secção da diáfise arredondada; o epicôndilo da face medial situa-se numa posição distante em relação à articulação distal; o sulco patelar é largo; a fossa do poplíteo é funda e estreita; a tróclea fibular é pouco marcada e o côndilo medial é proeminente e fino.

Género: Strix (LINNAEUS, 1758)

Do género Strix foram identificados dois fémures na Gruta Nova da Columbeira atribuídos à espécie S. aluco.

Strix aluco (LINNAEUS, 1758)

\section{Descrição osteológica}

\section{Fémur}

O fémur do S. aluco apresenta a fóvea funda. A parte inferior da cabeça do fémur, que liga ao corpo do osso, é arredondada. O trocanter femural é pouco 
saliente e largo e a crista do trocanter é longa, larga e arredondada, as impressões obturatoriae largas e bem evidentes. Na zona distal, o fémur do S. aluco é semelhante ao do A. flammeus, variando nas seguintes características: não tem o epicôndilo da face medial e a fossa do poplíteo é menos funda e mais larga.

Género: Athene (BOIE, 1822)

Do género Athene foram encontrados três restos na Gruta Nova da Columbeira: um úmero, sem atribuição de espécie (Athene sp.) e dois restos de $A$. noctua: um fémur e um tarsometatarso.

\section{Athene noctua (SCOPOLI, 1769)}

\section{Descrição osteológica:}

\section{Fémur}

Na gruta Nova da Columbeira foi encontrado um fragmento mesial e distal de fémur de $A$. noctua, com as seguintes características, que permitiram a sua identificação taxonómica: a secção da diáfise é arredondada. Na zona distal tem o epicôndilo da face medial situado numa posição distante em relação à articulação distal, o sulco patelar é largo, a fossa do poplíteo é larga e pouco funda, o côndilo medial é mais largo que o do S. aluco e do A. flammeus. A tróclea fibular é pouco marcada.

\section{Tarsometatarso}

O tarsometatarso de A. noctua identificado na Gruta Nova da Columbeira tem a superfície dorsal côncava; as cótilas da articulação proximal têm o tamanho idêntico; a crista medial do hipotarso é grande, larga, com a superfície arredondada. Na zona distal, não preservou a tróclea do metatarso I. As trócleas do metatarso II e IV são de tamanho semelhante e a do metatarso II apresenta uma pequena protuberância óssea.

\section{COLUMBifORMES}

Columbiformes é uma ordem de aves que inclui duas famílias: Os Raphidae e os Columbidae. A primeira família já se encontra extinta, à qual pertencia o Dodó. Os Columbidae, a única família desta ordem ainda existente, inclui cerca de 350 espécies 
(DEL HOYO et al. 1997) de pombos, rolas e seus afins.

Os columbiformes têm o corpo roliço e rubusto, de cabeça e bico pequenos (VUILLEUMIER, 2001). Têm o e pescoço pequeno e tal como os passeriformes têm três dedos apontado para a frente e um apontado para trás, para se agarrarem aos galhos das árvores, onde descançam.

As principais características dos ossos dos columbiformes são as seguintes: 0 coracóide tem canal triosseal fechado e o ângulo externo proeminente e pontiagudo; o úmero tem a crista deltopeitoral proeminente, a incisura capital profunda e a diáfise curta e forte; a ulna tem o processo cotilar dorsal proeminente e a diáfise encurvada; o rádio tem a articulação proximal de forma quadrada e, na extremidade distal, a depressão ligamentar do tendão profunda; o carpometacarpo tem o metacarpo menor encurvado e, na junção proximal dos dois metacarpos, apresenta uma cavidade profunda; o tibiotarso é ligeiramente encurvado e tem a crista fibular inclinada; o tarsometatarso é fino na zona mesial apresenta linhas na superfície dorsal a diáfise é curta e espalmada.

Género: Columba (LINNAEUS, 1758)

O género Columba está representado em quatro jazidas estudadas: a Gruta da Furninha, a Gruta das Salemas, a Lapa da Rainha e a Gruta Nova da Columbeira, onde foram encontrados vários restos de ossos do esqueleto apendicular das espécies $C$. livia e C. palumbus.

Columba livia, (GMELIN, 1789)

A espécie C. livia é a melhor representada do género Columba. Foi encontrado um total de 54 restos na Gruta das Salemas, na Lapa da Rainha, na Gruta da Furninha e na Gruta Nova da Columbeira. Destas jazidas, as que maior número de restos foram a Gruta da Furninha e a Gruta Nova da Columbeira, com 14 e 38 respectivamente. Nas restantes apenas foram identificados dois úmeros, em Salemas e um úmero e um Carpometacarpo na Lapa da Rainha.

\section{Descrição osteológica}

\section{Coracóide}

O coracóide de C. livia tem o canal triosseal fechado, a face articular com o 
úmero tem uma crista bem definida e a face articular clavicular é de formato quadrangular e o processo procoracóide é fino e proeminente. Na zona basal, a face articular com o esterno não é côncava, o ângulo medial é pequeno e o processo lateral é comprido, fino e encurvado.

\section{Úmero}

O úmero de C. livia tem a fossa pneumatricial redonda e marginal. O tubérculo ventral é proeminente, a incisura capital é funda e larga e a crista deltopeitoral é proeminente, de formato triangular e desenvolve-se na superfície dorsal, terminando num bico; a diáfise é curta e robusta e o côndilo distal dorsal é mais desenvolvido; a fossa braquial é pequena e a fossa do olecrânio é pequena.

\section{Ulna}

A ulna de C. livia é curva. Na articulação proximal, o olecrânio é baixo e rubusto; a cótila dorsal prolongada lateralmente, terminando numa crista; a face do tubérculo ligamentar colateral ventral é proeminente; a secção mesial é oval e as papilas das rémiges são pouco salientes. A articulação distal tem uma forma triangular e a depressão radial é pequena e pouco profunda, o côndilo dorsal ulnar saliente, formando uma crista, e o ventral é largo.

\section{Rádio}

O rádio da $C$. livia é curto e robusto; a face articular proximal tem o formato quadrangular e a face articular ulnar é proeminente. Na diáfise, a secção é oval e a linha intermuscular está bem marcada. A articulação distal é larga; o sulco tendinar é fundo; a depressão ligamentar pequena; a face de articulação rádio-carpal é desenvolvida.

\section{Carpomertacarpo}

O carpometacarpo de C. livia é robusto; tem o processo extensório desenvolvido, a fóvea carpal cranial funda e o processo pisiforme fino e punctiforme; a união entre os dois metacarpos, na zona distal forma uma ranhura cavada. 0 metacarpo menor é curvado e não tem o processo intermetacarpal. O espaço intermetacarpal é ovalado. A face articular com o dígito maior tem dois côndilos, sendo o dorsal maior.

\section{Tibiotarso}

O tibiotarso de C. livia é robusto, as cristas cnemiais são pouco proeminentes, 
sendo a cranial mais grossa que a lateral. A face lateral é, nas extremidades, ligeiramente encurvada. A crista fibular é inclinada. A secção da diáfise é redonda. Na parte distal, o canal extensor é estrito e a incisura intrer condilar é também estreita, mas funda.

\section{Tarsometatarso}

O tarsometatarso de C. livia é robusto e curto. A eminência intercolitar é baixa, a crista do hipotarso é proeminente e a fossa parahypotarsalis lateral funda. A diáfise é curta, delgada e espalmada, com a secção rectangular e face dorsal com arestas. As trócleas distais são de tamanho idêntico, sendo a do III digido mais proeminente e a do I tem uma protuberância lateral.

Espécie: Columba palumbus, (LINNAEUS, 1758)

A espécie C. palumbus apenas está presente na Gruta Nova da Columbeira, onde foram identificados 5 restos: três úmeros, um Carpometacarpo e um tarsometatarso.

\section{Descrição osteológica}

Os ossos de C. palumbus têm as características muito idênticas aos da C. livia, distinguindo-se sobretudo pelo tamanho - são maiores.

\section{PASSERIFORMES}

Os passeriformes constituem a maior ordem da classe das aves. Este grupo é bastante numeroso e diversificado, com cerca de 5400 espécies, distribuídas por 86 famílias (DEL HOYO et al., 2004 - 2009). Geralmente são aves de pequenas dimensões, canoras, com alimentação baseada em sementes, frutos e pequenos invertebrados, com as patas especializadas para se agarrarem aos ramos (VUILLEUMIER, 2001).

Têm quatro dedos nas patas, ao mesmo nível uns dos outros, três virados para a frente e um para trás. Os dedos movem-se independentemente uns dos outros e são oponíveis ao posterior. Têm os bicos de formato variável, consoante a espécie e a sua alimentação (VUILLEUMIER, 2001). Não apresentam membranas interdigitais.

Os ossos dos passeriformes apresentam as seguintes características diagnósticas. O coracóide apresenta a extremidade esternal triangular e estreita; a escápula tem a crista do acrómio elevada e a face glenóide côncava; o úmero tem a 
crista deltopeitoral longa e o processo supra-condilar dorsal bifurcado e desenvolvido e apresenta uma depressão funda, na face caudal da zona distal para a ligação muscular; a ulnaé rectilínea, e as papilas das rémiges são evidentes, a extremidade distal apresenta uma rotação e a diáfíse é muito estreita nos corvídeos; o rádio tem a cabeça proeminente, o turbérculo bicipital com rebordo e a extremidade distal é muito proeminente, terminando em bico; o carpometacarpo apresenta diferenças marcadas entre a altura dorsal e a ventral, dos lados da tróclea, o processo intermetacarpal é pronunciado e, na maioria das espécies está fundido com o metacarpo menor; o fémur tem a cabeça proeminente e a fóvea alongada, o trocanter é plano e apresenta uma fossa funda no topo do côndilo lateral; o tíbiotarso tem a crista fibular curta e os côndilos distais muito redondos; o tarsometatarso tem a eminência intercondilar elevada, os canais dos tendões fechados, as trócleas distais são pequenas e niveladas; o sinsacro tem o antitrocanter oval e longo e o foramen obturador fechado; a primeira vértebra torácica sinsacral tem a articulação em forma de "U" largo, enquanto a última vértebra caudal sinsacral tem a articulação plana.

Género: Corvus (LINNAEUS, 1758)

O género Corvus está representado em todas as jazidas estudadas, através das espécies C. corax, C. frugilegus, C. corone e C. monedula. Destes, o C. corax é o de maiores dimensões e o C. monedula, de menores, sendo, nestes casos fácil, a sua distinção pelo tamanho dos ossos analisados. O C. corone e o C. frugilegos, têm dimensões e características osteológicas semelhantes, sendo, por isso mais difícil a sua individualização.

\section{Corvus corax (LINNAEUS, 1758)}

Foram encontrados restos de C. corax em três das jazidas estudas: Casa da Moura, Lapa da Rainha e Gruta Nova da Columbeira. Na casa da Moura foi identificado um fragmento distal de tibiotarso, na Lapa da Rainha, um fragmento distal de Carpometacarpo e na Gruta Nova da Columbeira, um fragmento proximal de úmero e um fragmento distal de ulna e outro de tarsometatarso. 


\section{Descrição osteológica}

\section{Úmero}

O fragmento proximal do úmero atribuído a C. corax apresenta as seguintes características dos corvídeos: crista deltopeitoral longa, impressão coracobraquial em forma de "U" largo, insisura capital funda, o tubércolo ventral largo e comprido, mas pouco proeminente e a fossa pneumatricial grande. Dentro dos corvídeos é o que atinge maiores dimensões.

\section{Ulna}

O fragmento distal de ulna de C. corax identificada na Gruta Nova da Columbeira tem a diáfise estreita, a secção redonda e as papilas das rémiges desenvolvidas, a extremidade distal tem uma ligeira rotação em relação à diáfise e o tubérculo carpal saliente.

\section{Carpometacarpo}

O fragmento distal de Carpometacarpo do C. corax identificado na Lapa da Rainha tem a articulação do dígito menor mais proeminente que a do dígito maior, o metacarpo menor é espalmado e fino e os metacarpos são paralelos e rectos, originado o estreitamento do espaço intermetacarpal.

\section{Tibiotarso}

O fragmento distal de tibiotarso de C. corax identificado na Gruta da Casa da Moura apresenta as seguintes características: côndilos muito salientes e arredondados, formando uma crista observável lateralmente, o canal extensor é largo e curto e a tróclea cartilagínea tibial apresenta uma pequena crista a meio.

\section{Tarsometatarso}

O fragmento distal de tarsometatarso de C. corax identificada na Gruta Nova da Columbeira apresenta as trócleas pequenas e ao mesmo nível. A faceta do I metatarso é bem marcada e o forâmen vascular distal é pequeno.

\section{Corvus corone / Corvus frugilegus}

Como foi referido os ossos do C. corone e do C. frugilegus são muito idênticos, sendo difícil fazer a distinção entre as duas espécies a partir do estudo osteolíogico, em especial quando, no processo de fossildiagénese, acabam por se perder partes diagnósticas dos ossos. 
Foram identificados 25 restos destas duas espécies, em quatro das jazidas estudadas: na Casa da Moura (um tarsometatarso de $C$. frugilegus e um tibiotarso de C. corone); na Lapa da Rainha, apenas um fémur de C. frugilegus; na Gruta Nova da Columbeira, dez restos de $C$. frugilegus (dois úmeros, quatro ulnas, dois carpometacarpos, um fémur e um coracóide) e cinco de $C$. corone (dois coracóides, dois carpometacarpos e uma ulna); e na Gruta da Furninha, uma escápula de $C$. corone. Nestas duas últimas jazidas foram reconhecidos cinco restos de Corvus corone ou de Corvus frugilegus, o seu estado de conservação não permitiu distinguir entre as duas espécies (um úmero e um fémur, na Columbeira, e um Carpometacarpo, uma ulna e um úmero, na Furninha).

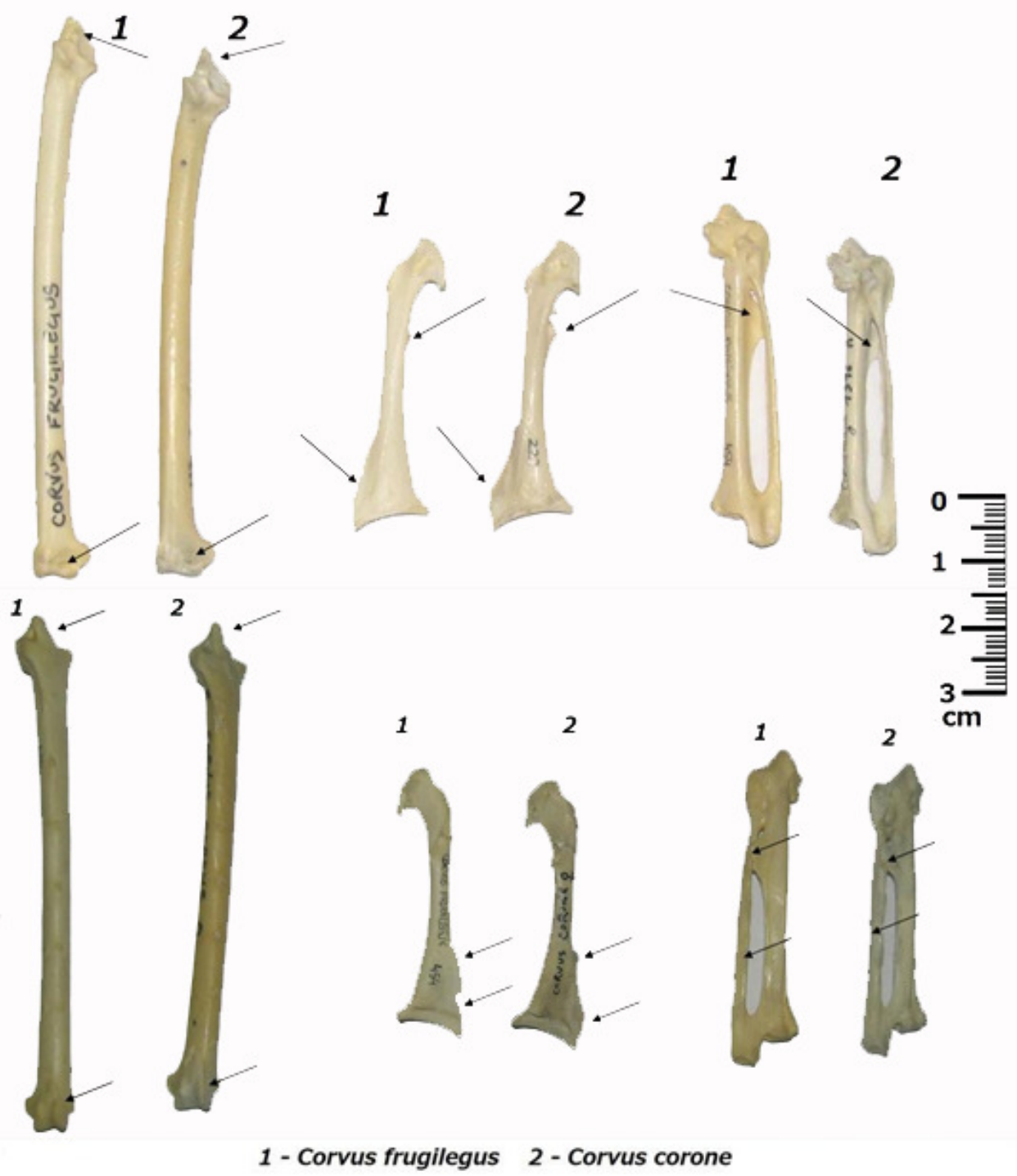

Fig. 85 - Principais diferenças entre alguns ossos de C. frugilegus e C. corone (ulna, coracóide e carpometacarpo). Fotografias da colecção de referência do CIPA (fotografia de S. Figueiredo). 
Corvus frugilegus (LINNAEUS, 1758)

\section{Descrição osteológica}

\section{Coracóide}

O coracóide do C. frugilegus apresenta as características principais dos coracóides dos restantes passeriformes: longo e fino, com a extremidade articular com o esterno de formato triangular e o sulco supracoracoidal grande e aberto. Tem o processo procoracóide pequeno e triangular e a face articular com o úmero muito estreita e comprida. O processo esternocoracoidal é recto e fino, formando um crista.

\section{Úmero}

O úmero do C. frugilegus apresenta a crista deltopeitoral longa, mas um pouco mais curta que no C. corax, incisura capital funda, o tubérculo ventral é largo e comprido, mas pouco proeminente e a fossa pneumatricial é grande. A secção da diáfise é redonda, na extremidade distal o processo supracondilar dorsal é proeminente e bifurcado, não apresenta o epicôndilo ventral, a fossa do olecrânio é larga e pouco profunda, tal como o sulco umerotricepital. Na face anterior, por cima do côndilo ventral, apresenta uma depressão de ligamento muscular, tal como os restantes corvídeos.

\section{Ulna}

A ulna do C. frugilegus, tal como nos outros corvídeos tem a secção da diáfise redonda e as papilas das rémiges salientes. É ligeiramente maior e menos robusta que a do $C$. corone e o olecrânio é um pouco mais largo e menos proeminente. A cótila dorsal é menos saliente e mais pequena que no C. corone.

\section{Carpo-mertacarpo}

O Carpometacarpo de C. frugilegus é maior que o do C. corone e apresenta menos robustez, em especial no metacarpo menor. Verifica-se, tal como nos restantes passeriformes, uma diferença bem marcada na altura do tamanho dorsal e ventral da tróclea. O processo intermetacarpal é bastante desenvolvido e encontrase fundido com o metacarpo menor. A articulação do dígito menor é mais proeminente que a do dígito maior, formando um ângulo de quase $90^{\circ}$. O metacarpo menor é espalmado e fino e os metacarpos são paralelos e rectos, originado o 
estreitamento do espaço intermetacarpal.

\section{Fémur}

O fémur do $C$. frugilegus tem a fóvea da cabeça do fémur alongada, o trocanter é horizontal e a crista do trocanter bem vincada, as impressões obturatoriais pouco salientes, a face articular antitrocantérica é plana e o trocanter femural pouco desenvolvido. A secção da diáfise é redonda e, na zona mesial, a linha intermuscular caudal pouco marcada. Na extremidade distal apresenta a depressão dorsal pequena e uma fossa funda no cõndilo lateral distal.

\section{Tarsometatarso}

O tarso-metarso do C. frugilegus apresenta a eminência intercondilar elevada, canais tendinais fechados, faceta para o primeiro metacarpo bem marcada, a secção da diáfice é rectangular, a superfície dorsal é plana e as trócleas da articulação distal são pequenas e estão niveladas.

Corvus corone (LINNAEUS, 1758)

\section{Descrição osteológica}

\section{Coracóide}

O coracóide do C. corone é muito semelhante ao do C. frugilegus apresentando as seguintes diferenças: o processo procoracóide está numa posição marginal e é mais saliente e menos pontiagudo; a crista do processo esternocoracoidal é mais curta, arredondada e côncava,; no final desta crista formase uma espécie de bico, que não está presente no C. frugilegus.

\section{Escápula}

A escápula do C. corone é convexa ao longo da margem dorsal, acentuando-se a curvatura a partir de cerca de $2 / 3$ do osso, onde se alarga ligeiramente. A extremidade cranial é delgada, o acrómio é pouco saliente, enquanto que o tubérculo coracoidal se desenvolve num pequeno bico. A crista acromial é elevada e a face articular com o úmero (faceta glenóide) é côncava. A extremidade caudal (o apex) termina em bico.

\section{Ulna $^{58}$}

58 As diferenças, aqui apontadas, entre a ulna de $C$. frugilegus e $C$. corone revelaram-se aquando da comparação dos restos encontrados nas colecções de referência consultadas. Não foi possível fazer a comparação entre restos fósseis, uma vez que do $C$. corone apenas foi encontrado um fragmento com 
Na Gruta Nova da Columbeira foi identificado um fragmento distal de ulna de C. corone, que apresenta as seguintes características: Apresenta um epicôndilo dorsal, junto do côndilo dorsal ulnar maior que no C. frugilegus; tem uma depressão na face lateral posterior, entre o côndilo ventral ulnal e o tubérculo carpal, mais larga e funda que no C. frugilegus. A articulação distal da ulna tem forma triangular.

\section{Carpomertacarpo}

O tarso-metarso do C. corone apresenta as mesmas características do tarsometatrso do $C$. frugilegus, diferenciando-se nas seguintes características: mais pequeno e robusto, o metacarpo menor é mais largo, o processo intermemetacarpal apresenta uma depressão junto ao metacarpo maior.

\section{Tibiotarso}

O tibiotarso do C. corone apresenta as características comuns aos outros corvídeos, tais como a crista fibular curta e a crista cnemial lateral proemiente, arredondada, formando um "bico de papagaio". Em relação aos tibiotarsos dos outros corvídeos, o do C. corone diferencia-se no tamanho (mais pequeno que o do C. corax e maior que o das restantes espécies: pouco maior que o do C. frugilegus e bastante maior em relação à outras espécies de corvídeos identificadas neste estudo). No estudo comparativo efectuado na colecção do CIPA, o fragmento de tibiotarso (proximal e mesial) da Gruta da Casa da Moura apresenta algumas características que permitem diferenciá-lo do tibiotarso do C. frugilegus, do qual se destacam as seguintes: as cristas cnemidais são um pouco maiores e estão mais afastadas entre elas; a cabeça fibular é mais espessa.

\section{Corvus monedula (LINNAEUS, 1758)}

O C. monedula é das espécies mais representadas no total da amostra estudada. Aparece em quase todas as jazidas: Gruta Nova da Columbeira - 27 restos (ulnas, carpometacarpos, fémures, úmeros, escápulas, coracóide, tibiotarsos e tarsometatarsos) - Lapa da rainha - 72 restos (ulnas, carpometacarpos, fémures, úmeros, rádios, coracóide, tarsometatarsos, tibiotarsos, falanges do Il dígito da asa e sinsacros) - Gruta das Salemas - quatro fémures - Gruta das Fontainhas - seis restos (um úmero, um tibiotarso, duas ulnas e dois fémures) - Gruta da Casa da Moura - 267 
(ulnas, carpometacarpos, fémures, úmeros, coracóide, tarsometatarsos, tibiotarsos e falanges do II dígito da asa.). Nesta ultima jazida foi onde se reconheceu o maior número de restos desta espécie.

\section{Descrição osteológica}

\section{Escápula}

A escápula do C. monedula apresenta características idênticas à do C. corone, diferenciando-se no tamanho (é mais pequena), na curvatura da margem dorsal que é mais constante, não se alargando a $2 / 3$, e o tubérculo coracoidal é que menos desenvolvido.

\section{Coracóide}

O coracóide do C. monedula tem as mesmas características que os coracóides do $C$. frugilegus e do $C$. corone, em que a zona de articulação ao úmero e à escápula é semelhante à do coracóide do $C$. frugilegues e a zona basal à do coracóide do $C$. corone. A grande diferença é o tamanho: o coracóide do C. modedula é mais pequeno.

\section{Úmero}

O úmero do C. monedula tem a cabeça mais proeminente, mas menos larga e o tubérculo dorsal mais desenvolvido que no úmero do dos outros corvídeos maiores (C. corax, C. corone e C. frugilegus) A crista deltopeitoral é bastante proeminente e robusta. Na extremidade distal, o processo flexor é largo e desenvolvido e os côndilos proeminentes, em especial o dorsal.

\section{Ulna}

A ulna do C. monedula, é robusta e, tal como nos outros corvídeos; tem a secção da diáfise redonda e as papilas das rémiges salientes; o olecrãnio é bastante proeminente e pontiagudo; a cótila dorsal é saliente e mais pequena que a ventral, que é redonda. A extremidade distal de ulna de $C$. corone tem um epicôndilo dorsal, junto do côndilo dorsal ulnar maior que no C. frugilegus; tem uma depressão na face lateral posterior, entre o côndilo ventral ulnal e o tubérculo carpal, mais larga e funda que no C. frugilegus; a articulação distal da ulna tem forma triangular.

\section{Rádio}


O rádio do C. monedula apresenta as principais características dos rádios dos outros corvídeos: a articulação proximal proeminente, com a cótila umeral redonda e o tubérculo bicipital, numa posição baixa e com um rebordo saliente; a extremidade distal é proeminente e com um formato triangular. Diferencia-se pelo tamanho e grau de robustez (mais pequeno que o rádio dos grandes corvídeos, maior que o da $P$. pica e menos robusto que os do género Pyrrhocorax).

\section{Carpo-mertacarpo}

O Carpometacarpo de C. monedula tem, tal como nos restantes passeriformes, uma diferença bem marcada na altura do tamanho dorsal e ventral da tróclea. $\mathrm{O}$ processo extensor é ligeiramente baixo (em comparação com os outros corvídeos maiores); o processo pisiforme é pouco desenvolvido; o processo intermetacarpal é bastante desenvolvido e robusto, estando fundido com o metacarpo menor; a articulação do dígito menor mais proeminente que a do dígito maior, formando um ângulo de quase $90^{\circ}$. O metacarpo menor é espalmado e fino e os metacarpos são paralelos e rectos, originado o estreitamento do espaço intermetacarpal.

\section{Falange do II dígito}

A falange do II dígito do C. monedula apresenta o sulco extensor marcado, fossa glenóide pouco desenvolvida, pilha cranial proeminente, e a face palmar larga e relativamente plana. A margem lateral tem a curvatura pouco acentuada.

\section{Sinsacro}

Tem uma forma geral robusta, a faceta do corpo vertebral, da vértebra toracicossincral pouco côncava e em forma de "u" aberto; vista lateralmente, a sua base forma um ângulo obtuso; o osso lombossacral é curto; a faceta da última vértebra caudal do sinsacro é quase recta.

\section{Fémur}

O fémur do C. monedula tem a fóvea da cabeça do fémur alongada, o trocanter é ligeiramente inclinado e a crista do trocanter menos vincada que no fémur do C. frugilegus, as impressões obturatoriais pouco salientes, a face articular antitrocantérica é plana e o trocanter femural pouco desenvolvido. A secção da diáfise é redonda e, na região mesial, a linha intermuscular caudal está pouco marcada. Na extremidade distal apresenta a depressão dorsal pequena e uma fossa funda no côndilo lateral distal. Distingue-se dos outros corvídeos pelo tamanho e pelo grau de robustez (mais pequeno que o rádio dos grandes corvídeos, maior que o da $P$. pica e menos robusto que os do género Pyrrhocorax). 


\section{Tibiotarso}

O tibiotarso do C. monedula apresenta as características comuns aos outros corvídeos, tais como a crista fibular curta e a crista cnemial lateral proemiente, arredondada, formando um "bico de papagaio". Na região distal apresenta os côndilos redondos e uma pequena cirstal zona média da tróclea cartilagínea tibial. Em relação aos tibiotarsos dos outros corvídeos, o do C. monedula diferencia-se no tamanho (é mais pequeno que o do $C$. corax, do $C$. frugilegus, do $C$. corone e do $P$. pyrrhocorax, maior que o do P. pica e tamanho semelhante do $P$. graculus, embora menos robusto).

\section{Tarsometatarso}

O tarso-metarso do C. monedula apresenta as pricipais características dos corvídeos: eminência intercondilar elevada, canais tendinais fechados, faceta para o primeiro metacarpo bem marcada, a secção da diáfice é rectangular, a superfície dorsal é plana e as trócleas da articulação distal são pequenas e estão niveladas, variando no tamanho e na robustez: menor que os do C. corax, C. frugilegus, C. corone e P. pyrrhocorax e maior que os dos restantes corvídeos identificados neste estudo; apresenta menor robustez que os do género Pyrrhocorax (dintingue-se do $P$. graculus pela robustez, uma vez que os tarsometatarsos do $C$. monedula e do $P$. graculus têm tamanho aproximado).

\section{Pica pica (LINNAEUS, 1758)}

Neste estudo foram identificados 64 ossos da espécie $P$. pica: 46 na Casa da Moura (um crânio, coracóides, carpometacarpos, fémures e tibiotarsos, tarsometatarsos), dois na Gruta das Fontainhas (um coracóide e um tarsometatarso), quatro na Gruta das Salemas (dois coracóides e dois fémures), onze na Gruta Nova da Columbeira (dois coracóides, três úmeros, três fémures, dois tarsometatarsos, e uma ulna) e um úmero na Gruta da Furninha.

\section{Descrição osteológica}

\section{Crânio}

Tem a zona frontal quase plana, com a depressão frontal quase inexistente, órbitas grandes e cavas, formando dorsalmente um contorno bastante côncavo; a 
caixa craniana tem um formato oval; os processos orbital e zigomático estão desenvolvidos; o forâmen magno tem a forma de meia-lua, o côndilo occipital é pequeno e pouco proeminente. O osso occipital é plano. O crânio é menor que os do P.graculus e do P. pyrrhocorax.

Os restantes ossos da espécie $P$. pica identificados neste estudo (coracóide, úmero, ulna, Carpometacarpo, fémur, tibiotarso e tarsometatarso) apresentam as principais características dos corvídeos já referidas anteriormente. O que distingue os ossos de $P$. pica é serem ligeiramente menos robustos e mais pequenos que os do $C$. monedula.

\section{Género Pyrrhocorax (TUNSTALL, 1771)}

O género Pyrrhocorax está presente em todas as jazidas estudadas, com exepção da Gruta do Pego do Diabo.

Pyrrhocorax pyrrhocorax (LINNAEUS, 1758)

Da espécie $P$. pyrrhocorax foram identificados 266 restos. A Lapa da Rainha foi a jazida com o maior número de restos (105). Nesta jazida, foram identificados fémures, ulnas, úmeros, coracóides, carpometacarpos, tibiotarsos, rádios e $1^{\text {ass. }}$ falanges do II dígito (asa). Na Gruta nova da Columbeira foram identificados 84 restos: fémures, escápulas, ulnas, úmeros, coracóides, carpometacarpos, tibiotarsos e tarsometatarsos. A Casa da Moura revelou 57: fémures, ulnas, úmeros, coracóides, carpometacarpos, tibiotarsos e um crânio. Na Gruta das Fontainhas apenas se identificaram 3 tibiotarsos e na Gruta das Salemas foram reconhecidos um fragmento distal de um coracóide, três tarsometatarsos (um fragmento proximal e dois inteiros) e um fragmento distal de ulna, num total de cinco restos. Finalmente na Gruta da Furninha foram encontrados 12 restos: dois fémures, cinco ulnas, dois tarsometatarsos, dois úmeros e um Carpometacarpo.

\section{Descrição osteológica:}

\section{Crânio}

O crânio de $P$. pyrrhocorax apresenta caracteísticas idênticas ao da $P$. pica: zona frontal quase plana, com a depressão frontal quase inexistente, órbitas grandes e cavas, formando dorsalmente um contorno bastante côncavo; a caixa craniana tem 
formato oval. Tal como nos crânios da P. pica tem os processos orbital e zigomático desenvolvidos e o forâmen magno em forma de meia-lua. O côndilo occipital é pequeno e pouco proeminente; o osso occipital é plano. O crânio é maior que o da $P$. pica e do P. graculus.

\section{Escápula}

A escápula do P. pyrrhocorax apresenta características idênticas às dos Corvus, diferenciando-se na robustez (é mais robusta), na curvatura, que é menos vincada, o corpo escapular é mais largo e espesso e o acrómio é um pouco mais desenvolvido.

\section{Coracóide}

O coracóide do P. pyrrhocorax é mais curto, largo e robusto que os do género Corvus. A zona basal é mais larga, a face articular esternal é mais espessa, o processo lateral é ligeiramente mais espesso e é côncavo e a aba do processo lateral é mais pequena. O processo procoracóide é mais proeminente.

\section{Úmero}

O úmero do P. pyrrhocorax distingue-se do úmero dos outros corvídeos pelas seguintes características: estrutura mais robusta, crista deltopeitoral mais comprida e menos saliente, impressão coracobraquial mais comprida, mas menos larga, zona proximal ligeiramente menos larga, na zona distal, o sulco escapulotricipital mais vincado.

\section{Ulna}

A ulna do P. pyrrhocorax apresenta, em comparação com os outros corvídeos, maior robustez, o olecrânio mais saliente, a cótila dorsal mais pequena e as papilas das rémiges ligeiramente menos desenvolvidas.

\section{Rádio}

Comparativamente aos outros crovídeos, o rádio do $P$. pyrrhocorax é mais robusto, o tubérculo bicipital mais desenvolvido, a cótila articular ulnar mais pequena e a extremidade distal ligeiramente mais larga.

\section{Carpometacarpo}

O carpometacarpo do $P$. pyrrhocorax tem o processo intermetacarpal menos proeminente que os outros corvídeos, não se desenvolvendo tanto para a zona proximal, originando um espaço intermetacarpal ligeiramente mais pequeno. A tróclea do dígito menor é mais proeminente e o metacarpo maior é mais robusto que 
nos carpometacarpos das espécies do género Corvus.

\section{Falange do II dígito}

A falange do II dígito do P. pyrrhocorax apresenta o sulco extensor mais marcado e é ligeiramente mais robusta que as dos restantes corvídeos.

\section{Fémur.}

O fémur do $P$. pyrrhocorax é mais robusto, tem a crista do trocanter e o trocanter levemente menos vincados e a cabeça do fémur um pouco mais saliente, com a fóvea maior.

\section{Tibiotarso}

O tibiotarso do P. pyrrhocorax é mais robusto e apresenta a crista fibular mais pequena, e as cristas da extremidade proximal mais desenvolvidas que nos outros corvídeos.

\section{Tarsometatarso}

O tarsometatarso do P. pyrrhocorax é menos largo e espesso e mais comprido e, na face dorsal apresenta as extremidades laterais proeminentes ao longo de toda a diáfise.

\section{Pyrrhocorax graculus (LINNAEUS, 1758)}

Da espécie $P$. graculus foram identificados 237 restos. Na Gruta da Lapa da rainha foi a jazida com o maior número de restos (122), foram identificados fémures, ulnas, úmeros, coracóides, carpometacarpos, tibiotarsos, tarsometatarsos e $1^{\text {a }}$ s. falanges do II dígito (asa); na Gruta nova da Columbeira, 19: um fémur, sete ulnas, quatro úmeros, dois coracóides, dois carpometacarpos, um tarsometatarsos e duas 1. as. falanges do II dígito (asa); na Casa da Moura, 78: fémures, ulnas, úmeros, coracóides, carpometacarpos tibiotarsos e tarsos-metarsos; na Gruta das Fontainhas foram identificaram seis restos: um coracóide, dois úmeros, uma ulna, um tibiotarso e um Carpometacarpo; na Gruta da Furninha, 12 restos: um crânio, um coracóide, quatro ulnas, quatro úmeros e dois carpometacarpos.

\section{Descrição osteológica}

\section{Crânio}

O crânio de $P$. graculus apresenta caracteísticas idênticas ao da $P$. pica e do $P$. pyrrhocorax: zona frontal quase plana, com a depressão frontal quase inexistente, órbitas grandes e cavas, formando dorsalmente um contorno bastante côncavo; a 
caixa craniana tem um formato oval; os processos orbital e zigomático são desenvolvidos; o forâmen magno tem a forma de meia-lua; o côndilo occipital é pequeno e pouco proeminente e o osso occipital é plano. O crânio é maior que o da P. pica e menor que o do P. pyrrhocorax.

Os restantes ossos da espécie $P$. graculus identificados neste estudo (coracóide, úmero, ulna, Carpometacarpo, 1a . falange do II dígito (asa), fémur, tibiotarso e tarsometatarso) apresentam as características dos ossos dos restantes corvídeos e, em especial, as do género Pyrrhocorax, atrás referidas, que distingue o género dos outros da família dos corvídeos. O que distingue os ossos de $P$. graculus é serem mais pequenos que os do $P$. pyrrhocorax e mais robustos que os do $C$. monedula, em realação aos quais têm um tamanho semelhante. No caso especifico do úmero o que distingue o $P$. graculus do $C$. monedula, para além da robustez é o facto de terem a crista deltopeitoral mais comprida.

Género: Garrulus (BRISSON, 1760)

Garrulus glandarius (LINNAEUS, 1758)

No estudo realizado foram identificados cinco restos da espécie G. glandarius: um fragmento distal de tarsometatarso, na Gruta da Casa da Moura; fragmento proximal de fémur e um fragmento distal de úmero, na Lapa da Rainha e dois fragmentos de ulna (um proximal e outro distal), na Gruta Nova da Columbeira.

\section{Descrição osteológica}

O que distingue os ossos desta espécie relativamente aos outros corvídeos já referidos é, essencialmente o tamanho (mais pequenos).

\section{Úmero}

O úmero do G. glandarius é ligeiramente maior que o da C. cyana. Tem a crista deltopeitoral recta, incisura capital funda, o tubérculo ventral largo e comprido, mas pouco proeminente e a fossa pneumatricial grande. A secção da diáfise é redonda, na extremidade distal o processo supracondilar dorsal é proeminente e bifurcado, não apresenta o epicôndilo ventral, a fossa do olecrânio é larga e pouco profunda, tal como o sulco umerotricepital.

\section{Ulna}

A ulna do G. glandarius apresenta a face articular proximal bastante oblíqua, a cótila dorsal pequena e pouco saliente e as papilas das rémiges bastante largas e 
proeminentes.

\section{Fémur}

O fémur do G. glandarius tem a fóvea da cabeça do fémur alongada, o trocanter é horizontal e a crista do trocanter bem vincada, as impressões obturatoriais pouco salientes, a face articular antitrocanterica é plana e o trocanter femural pouco desenvolvido. A secção da diáfise é redonda. Na extremidade distal a depressão dorsal é pequena e tem uma fossa funda no côndilo lateral distal.

\section{Tarsometatarso}

O tarso-metarso do G. glandarius apresenta as principais características dos corvídeos: a eminência intercondilar elevada, canais tendinais fechados, faceta para o primeiro metacarpo bem marcada, a secção da diáfice é rectangular, a superfície dorsal é plana e as trócleas da articulação distal são pequenas e estão niveladas.

Género: Cyanopica (BONAPARTE, 1850)

Do género Cyanopica foi apenas identificao um fragmento proximal de tibiotarso de C. cyana na Gruta Nova da Columbeira.

Cf. Cyanopica cyana (PALLAS, 1776)

\section{Descrição osteológica}

Tibiotarso.

O tibiotarso do C cyana é mais pequeno que as dos corvídeos, atrás descritos, mas maior que os dos turdídeos. A crista fibular é curta e ligeiramente côncava, mas mais proeminete e um pouco mais pequena que nos outros corvídeos. Comparativamente aos turdideos, a crista fibular do tibiotarso identificado como pertencendo a C. cyana é maior, é mais robusta e está localizada numa posição mais baixa na diafise. A crista cnemial lateral proemiente e arredondada e mais robusta que as dos turdídeos. 


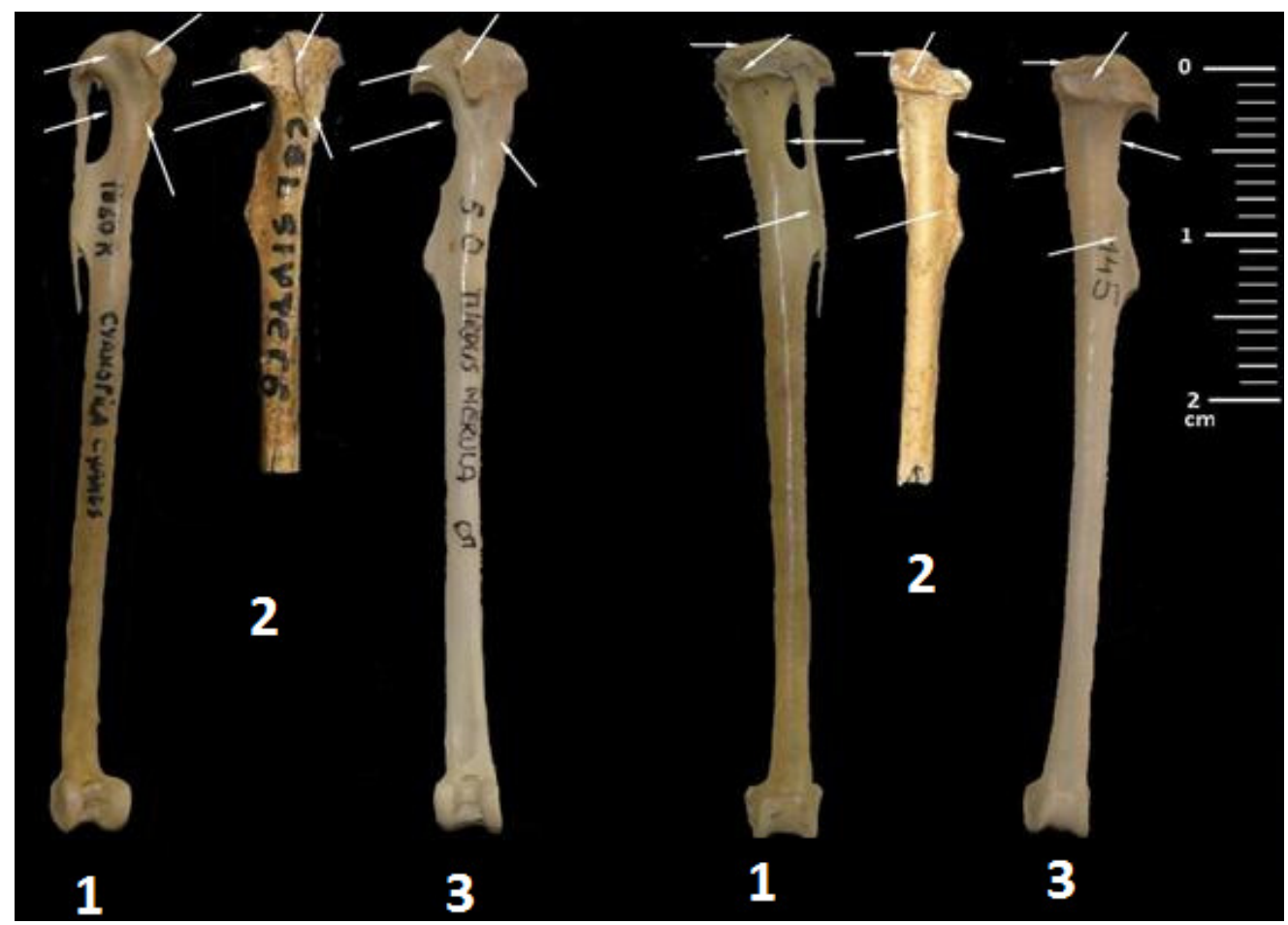

Fig. 86 - Comparação do tibiotarso atribuído a C. cyana, da Gruta Nova da Columbeira (2), com um tibiotarso de um espécime actual (1) e com o tibiotarso de um T. merula (3), da colecção do CIPA. As setas indicam as semelhanças entre o exemplar da Columbeira e o exemplar actual e as diferenças entre o exemplar da Columbeira e o tibiotarso de T. merula. Á esquerda, vistas caudais e, á direita, vistas craniais. Fotografia: S. Figueiredo.

Género: Turdus (LINNAEUS, 1758)

Foram identificados 100 restos de Turdus em quatro das jazidas estudadas (Gruta das Salemas, Gruta Nova da Columbeira, Lapa da Rainha e Gruta da Furninha). Destes restos, a 61 (61 \%) não foi possível atribuir a espécie e a 39 (39\%) foi possível identificar as espécies T. merula, T. pilaris, T. iliacus e T. philomelos. Estes 39 ossos estão distribuídos da seguinte forma: dois úmeros de T. merula, na Gruta das Salemas; uma ulna e um úmero de T. philomelos; onze úmeros e cinco ulnas de T. merula, um úmero de T. iliacus e nove úmeros, duas ulnas e um Carpometacarpo de T. pilaris, na Gruta Nova da Columbeira; dois úmeros e um tibiotarso de T. merula, na Lapa da Rainha e dois úmeros de T. philomelos, três ulnas e dois úmeros de T. merula e cinco úmeros e uma ulna de T. pilaris, na Gruta da Furninha.

\section{Descrição osteológica}

Os ossos das diferentes espécies do género Turdus são muito semelhantes entre si, tornando-se difícil a sua identificação, tanto mais quando se perdem, no 
processo de fossilização, algumas das características de diagnóstico, como aconteceu na maioria dos ossos agora estudados. Por esta razão a maioria dos elementos ósseos deste género identificados foram classificados como Turdus sp. Apesar desta situação, foi possível identificar ao nível da espécie alguns dos ossos, pelo seu excelente estado de conservação e pela observação à lupa binocular (aumento de 10 vezes). Por outro lado, de alguns dos restos da Gruta da Furninha já estudados e atribuídos a diferentes espécies de Turdus (HARLÉ, 1910/11) foi confirmada e actualizada a classificação atribuída.

Pelo tamanho é possível individualizar algumas espécies: o T. pilaris e o $T$. merula são espécies com ossos maiores e, destas, o T. pilaris é a que apresenta os ossos maiores. No caso do T. philomelos e do T. iliacus, o tamanho não é diagnóstico, pois os seus ossos têm dimensões muito idênticas.

Em seguida serão apresentadas algumas características osteológicas dos ossos que permitiram a sua identificação, ao nível da espécie.

Turdus philomelos (BREHM, 1831)

\section{Descrição osteológica}

\section{Úmero}

O úmero do T. philomelos tem a crista deltopeitoral ligeiramente arredondada marginalmente e mais proeminente que nos outros Turdus. Processo supracondilar dorsal menos proeminente e o tubérculo ventral mais largo e menos proeminente, que nos outros Turdus; a cruz dorsal da fossa pneumatricial forma uma crista evidente, que se liga à margem caudal do úmero, e dividindo a fossa pneumatricial em duas. Tal como os úmeros dos outros passeriformes, tem o processo flexor desenvolvido. Tem o tamanho idêntico ao do úmero do T. iliacus.

\section{Ulna}

A ulna do T. philomelos tem a articulação proximal ligeiramente mais obliqua que nos outros Turdus, Tal como nas outras espécies deste género, a cótila dorsal tem um formato sub-rectangular e a zona distal tem um uma curvatura mais marcada que nos corvídeos; a diáfise é mais fina e as papilas das rémiges ligeiramente menos salientes. De resto apresenta as mesmas características das ulnas dos passeriformes: 
rotação da extremidade distal; a depressão radial é pequena, mas funda; o olecrânio é proeminente; a articulação proximal é oblíqua; a cótila dorsal é pequena e saliente.

Turdus pilaris (BREHM, 1831)

\section{Descrição osteológica}

\section{Úmero}

O úmero do T. pilaris é o de maiores dimensões entre as espécies do género Turdus. Tem a crista deltopeitoral quase recta marginalmente e é menos proeminente que no T. philomelos; o processo supracondilar dorsal é proeminente e bifurcado; o tubérculo ventral é largo e pouco proeminente; a cruz dorsal da fossa pneumatricial formam uma crista evidente, que liga à margem caudal do úmero, dividindo a fossa pneumatricial em duas.

\section{Ulna}

A ulna do T. pilaris é a que tem as maiores dimensões entre as espécies do género Turdus. De resto, partilha as mesmas características principais dos restantes turdus.

\section{Carpometacarpo}

O úmero do T. pilaris é o de maiores dimensões entre as espécies do género Turdus. Tem o espaço intermetacarpal maior e o processo extensório ligeiramente mais desenvolvido, que nas outras espécies do género Turdus. Apresenta as principais características dos restantes passeriformes: uma diferença vincada na altura da tróclea, quer no lado dorsal, quer no lado ventral; o processo intermetacarpal muito desenvolvido e fundido com o metacarpo menor; a tróclea do dígito menor é mais proeminente, formando um angulo de quase $90^{\circ} \mathrm{com}$ a tróclea do dígito maior.

\section{Turdus merula (LINNAEUS, 1758)}

\section{Descrição osteológica}

\section{Úmero}

O úmero do T. merula tem a crista deltopeitoral quase recta marginalmente e é menos proeminente que a do T. philomelos; o processo supracondilar dorsal é proeminente e bifurcado; o tubérculo ventral também é proeminente.; a cruz dorsal da fossa pneumatricial forma uma crista evidente, ligando à margem caudal do 
úmero, de forma menos proeminente que no T. philomelos e no T. pilaris, mas dividindo igualmente a fossa pneumatricial em duas; o processo extensor é ligeiramente menos proeminente que no T. philomelos e no T. pilaris.

\section{Ulna}

A ulna do T. merula tem o olecrânio ligeiramente mais desenvolvido que o do T. philomelos e o do T. pilaris. È um pouco maior que a ulna do T. philomelos e T. iliacus, mas ligeiramente mais pequena que a do $T$. pilaris. De resto, partilha as mesmas características principais dos restantes Turdus.

\section{Tibiotarso}

O tibiotarso do T. merula é um pouco maior que a ulna do T. philomelos e $T$. iliacus, mas ligeiramente mais pequeno que o do T. pilaris. Tal como nos restantes Turdus, as cristas cnemiais são muito desenvolvidas e finas, a crista fibular é ligeiramente mais pequena que nas outras espécies do género Turdus e a fossa retropatelar é ligeiramente mais funda. De resto, apresenta as mesmas características dos outros passeriformes: crista fibular pequena, côndilos distais redondos, e pequena crista no centro da tróclea cartilaginosa tibial.

Turdus iliacus (LINNAEUS, 1758)

\section{Descrição osteológica}

\section{Úmero}

O úmero do T. iliacus tem a crista deltopeitoral quase recta marginalmente e é menos proeminente que no $T$. philomelos. O processo supracondilar dorsal é proeminente e bifurcado; o tubérculo ventral é igualmente proeminente; a cruz dorsal da fossa pneumatricial forma uma crista evidente, ligando à margem caudal do úmero, de forma menos proeminente que no T. philomelos e no T. pilaris, mas dividindo igualmente a fossa pneumatricial em duas; o processo extensor é ligeiramente menos proeminente que no T. philomelos e no T. pilaris. Mais pequeno que o úmero do T. pilaris e do T. merula e de tamanho semelhante ao T. philomelos.

\section{Género Ptyonoprogne (REICHENBACH, 1850)}

Do género Ptyonoprogne apenas foi reconhecido um úmero na Gruta Nova da Columbeira. 


\section{Descrição osteológica}

\section{Úmero}

O úmero do $P$. rupestris tem a zona proximal bastante larga, a crista deltopeitoral ligeiramente oblíqua marginalmente e maior que a do $\mathrm{H}$. rústica; o processo supracondilar dorsal é muito proeminente e bifurcado; o tubérculo ventral proeminente e largo; a cruz dorsal da fossa pneumatricial forma uma crista evidente e larga, ligando à margem caudal do úmero e dividindo a fossa pneumatricial em duas; a margem caudal do úmero é mais marcada que no $H$. rústica; o processo extensor é muito proeminente; o epicôndilo ventral é bem marcado e o côndilo dorsal é grande.
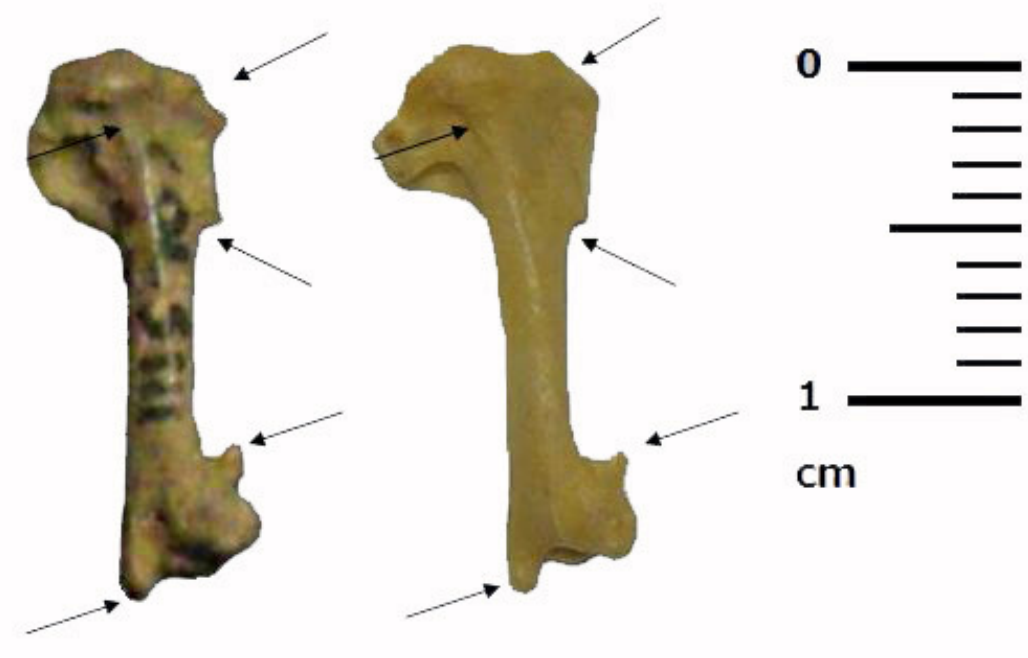

$\mathrm{cm}$

Fig. 87 - Comparação entre o úmero de cf. Ptyonoprogne rupestris, encontrado na gruta Nova da Columbeira, com o mesmo osso de um espécime actual. As características osteológicas que permitiram a classificação estão assinaladas com setas pretas.

Género Carduelis (BRISSON, 1760)

Do género Carduelis apenas foi reconhecido um úmero na Gruta Nova da Columbeira.

Carduelis carduelis (LINNAEUS, 1758)

\section{Descrição osteológica}

\section{Úmero}

O úmero do $C$. carduelis tem a cabeça do úmero larga a crista deltopeitoral ligeiramente arredondada marginalmente. O tubérculo ventral é proeminente e largo; a cruz dorsal da fossa pneumatricial é muito pequena e baixa, não dividindo a 
fossa pneumatricial em duas, tornando-a grande; o processo extensor e o supracondilar dorsal são proeminentes e, no segundo caso, bifurcado; o processo extensor é proeminente; o epicôndilo ventral é bem marcado e o côndilo dorsal é grande.

Género Motacilla (DUMONT, 1821)

O género Motacilla apenas foi identificado na Lapa da Rainha, através de um fragmento da zona mesial e proximal de um úmero da espécie Motacilla alba.

Cf. Motacilla alba (Linnaeus, 1758)

\section{Descrição osteológica}

\section{Úmero}

O fragmento proximal e mesial de úmero de $M$. alba, identificado na Lapa da Rainha, apresenta as seguintes características que permitiram a sua classificação: a cabeça do úmero larga e proeminente; a crista deltopeitoral comprida e ligeiramente côncava marginalmente.; o tubérculo ventral proeminente e fino; a cruz dorsal da fossa pneumatricial forma uma crista, alta junto do tubérculo ventral e baixa junto da margem caudal do úmero, dividindo a fossa pneumatricial em duas; a incisura capital é estreita.

\section{Piciformes}

Piciformes é uma ordem de aves que inclui animais de médias dimensões que habitam o meio arbóreo. Esta ordem tem cerca de 350 espécies distribuídas por quatro famílias (DEL HOYO et al., 2002,), inclui, entre outros os tucanos e os picapaus.

Estas aves têm o crânio espesso e o bico com uma anatomia variada: grande e serrilhado nos tucanos, cónico nos barbudos e pontiagudo e comprido nos picapaus. Têm as narinas pequenas e as patas são zigodáctilas, ou seja, têm dois dedos para a frente e dois para trás, para melhor se agarrarem aos troncos das árvores 
(VUILLEUMIER, 2001).

Género: Picus, (LINNAEUS, 1758)

O género Picus foi identificado apenas na na Gruta Nova da Columbeira, onde foi encontrado um fémur direito atribuído à espécie $P$. viridis.

Cf. Picus viridis (LINNAEUS, 1758)

\section{Descrição osteológica:}

\section{Fémur}

O fémur de $\mathrm{P}$. viridis identificado neste estudo tem, na articulação proximal, a crista troclear bem desenvolvida, a fóvea da cabeça do fémur pouco funda, a face articular antitroclear larga e a fossa do trocanter pouco funda. $\mathrm{Na}$ articulação distal o sulco intercondilar é largo e pouco fundo, o sulco patelar é um pouco mais largo e ainda menos fundo que o sulco intercondilar, o côndilo lateral redondo e bastante mais alto que o medial, tróclea fibular pequena e crista tibiofibular pouco saliente, o epicôndilo lateral, a impressão ligamentar colateral lateral e a fóvea do tendão muscular tibial cranial são muito pouco evidentes.

\section{CUCULIFORMES}

Cuculiformes é uma ordem de aves com duas famílias, com 145 espécies, classificadas em 29 géneros (DEL HOYO, et al. 1997).

De uma forma geral, a aves cuculiformes são de pequeno a médio porte, bico curto e arqueado e asas curtas. As patas são curtas e tal como os piciformes são zigodáctilas, com dois dedos para a frente e dois para trás, para melhor se agarrarem aos troncos das árvores. As espécies do grupo não apresentam dimorfismo sexual e alimentam-se sobretudo de insectos e outros pequenos invertebrados (VUILLEUMIER, 2001).

Género: Cuculus (LINNAEUS, 1758)

O género Cuculus foi identificado na Gruta da Furninha (três fragmentos distais de tibiotarsos, dois esquerdos e um direito) e na Gruta da Casa da Moura, onde foi encontrado um fragmento proximal de um tibiotarso direito. Todos estes restos foram atribuídos à espécie $C$. canorus. 
Cuculus canorus (LINNAEUS, 1758)

\section{Descrição osteológica:}

\section{Tibiotarso}

O Tibiotarso do C. canorus tem as cristas cnemiais pouco desenvolvidas e largas, a crista fibular é pequena e pouco saliente, o sulco intercnemial é pouco fundo, a crista fibular pequena e pouco proeminente; os côndilos distais redondos, 0 sulco extensor é pequeno e a incisura intercondilar é larga e funda. 


\section{0 - SÍNTESE E RESULTADOS}

Neste trabalho foram estudados restos de avifauna provenientes de oito jazidas arqueológicas. Em algumas delas, esses restos estavam ainda inéditos (Gruta Nova da Columbeira, Gruta das Salemas, Gruta do Pego do Diabo, Lapa da Rainha ${ }^{59}$, Gruta da Casa da Moura ${ }^{60}$ e Gruta do (aldeirão ${ }^{61}$ ), noutras já estavam publicados, mas necessitando de revisão, pois trata-se de estudos do início do século XX. Nestes casos foi feita a revisão desses estudos (Gruta da Furninha ${ }^{62}$ e Gruta das Fontainhas). Para além destes estudos inéditos, foi também feito um levantamento de jazidas publicadas com referência à presença de aves. Algumas delas apenas têm referências muito sumárias de estudos específicos sobre a avifauna dessas jazidas, que estão a ser feitos. Assim, o estudo agora efectuado permitiu ter um conhecimento mais aprofundado de todas as jazidas com aves do Plistocénico, rever os dados publicados sobre alguns importantantes sítios, acrescentar novos dados a quatro jazidas e conhecer a avifauna de três jazidas, cujas aves ainda eram inéditas.

$\mathrm{Na}$ evolução do estudo das aves plistocénicas verifica-se, uma estagnação quase total até aos anos 80 do século $\mathrm{XX}$, quando os estudos realizados não passavam da reprodução dos dados apresentados no estudo de referência sobre a fauna plistocénica portuguesa, efectuado por Harlé e Newton (HARLÉ, 1910-11).

59 No caso da Lapa da Rainha foram analisados os restos inéditos da colecção do Museu Geológico, não estudados por Jean Roche.

60 Existe apenas uma referência à ocorrência de aves da Casa da Moura (HARLÉ, 19910/11), não existindo ainda nenhum estudo mais aprofundado acerca destes materiais, o que foi agora feito.

61 As aves da Gruta do Caldeirão foram estudadas por Simon Davis (DAVIS, 2002), no entanto, para esta tese foram vistos uns restos de pequenos passariformes inéditos.

62 No caso da Gruta da Furninha existia um grande número de restos que ainda não tinham sido estudados. 


\section{Jazidas com aves publicadas}

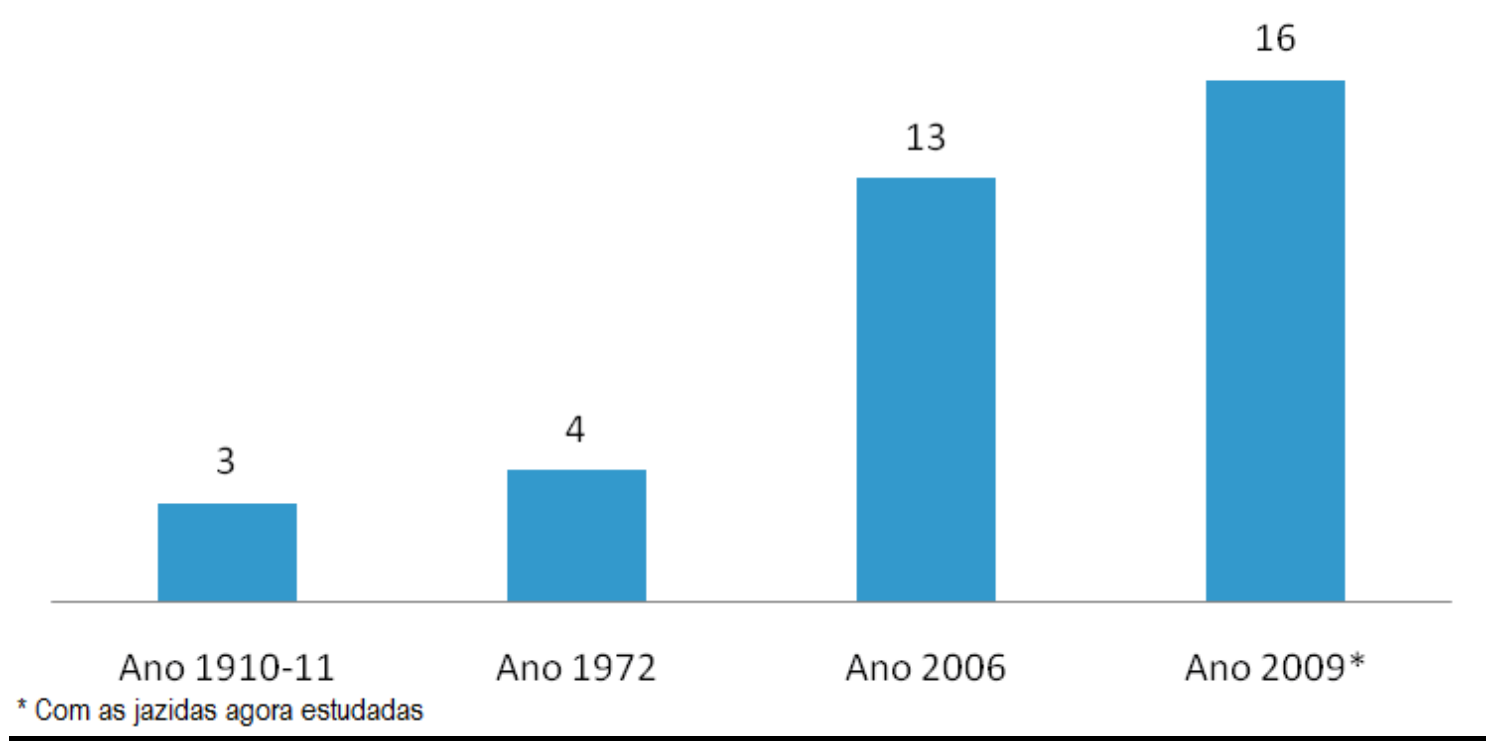

Gráfico 63 - Número de jazidas com a avifauna publicada ou referida desde 1910 até a presente tese.

\section{1 - Espécies identificadas e a sua distribuição por jazida}

Em Portugal existem dezasseis jazidas plistocénicas com a ocorrência, ou a referência em bibliografia, de aves. Destas dezasseis, como já foi referido, oito foram estudadas neste trabalho. A quase totalidade das jazidas com avifauna situa-se em cavidades cársicas, e a grande maioria localiza-se perto da costa, a uma distância inferior a $20 \mathrm{~km}$.

O táxon mais representado é a ordem dos passeriformes e, de entre estes, são os corvídeos que predominam com $83 \%$, o género Turdus aparece em segundo lugar com $14 \%$ e os restantes géneros e espécies dos passeriformes são apenas residuais, com 3\% da totalidade dos restos desta ordem. 


\begin{tabular}{|c|c|c|c|c|c|c|c|c|c|c|c|c|c|c|}
\hline \multirow{2}{*}{ Espécie } & \multirow{2}{*}{ Nome comum } & \multicolumn{2}{|c|}{ GNC } & \multicolumn{2}{|l|}{ GFP } & \multicolumn{2}{|c|}{$\mathrm{CM}$} & \multicolumn{2}{|l|}{ Gsal } & GPD & \multicolumn{2}{|l|}{ GF } & \multicolumn{2}{|l|}{ LR } \\
\hline & & NTR I & NMI & NTR NI & IMI & NTR N & NMI & NTR N & & NTR NMI & NTR NN & MI & NTR N & NMI \\
\hline Anser albifrons & Ganso-grande-de-testa-branca & & & & & & & & & 1 & & & & \\
\hline Anas platyrhynchos & Pato-real & 2 & 2 & & & & & & & & & & & \\
\hline Anas crecca & Marrequinha-comum & & & 1 & & & & & & & & & & \\
\hline Melanita nigra & Pato-preto & & & 1 & & & & & & & & & & \\
\hline Tadorna tadorna & Pato-branco & & & 162 & & & & & & & & & & \\
\hline Somateria mollissima & Eider & & & 63 & 13 & & & & & & & & & \\
\hline Tadorna ferruginea & Pato-ferrugíneo & & & 11 & & & & & & & & & & \\
\hline Cygnus olor & Cisne-branco & & & 1 & 1 & & & & & & & & & \\
\hline Perdix perdix & Perdiz-cinzenta & 2 & 2 & & & & & & & & & & 1 & 1 \\
\hline Alectoris barbara & Perdiz-moura & 3 & 2 & & & & & & & & & & & \\
\hline Alectoris rufa & Perdiz-comum & 19 & 9 & 7 & 3 & & & & & & 1 & 1 & 9 & 2 \\
\hline cf. Phasianus colchicus & Faisão-comum & & & & & & & & & 1 & & & & \\
\hline Coturnix coturnix & Codorniz & 1 & 1 & 2 & 2 & & & & & & & & & \\
\hline Tetrao urogallus & Tetraz-grande & & & & & & & & & & & & 1 & 1 \\
\hline Lagopus mutus & Lagópode-branco & 3 & 1 & & & & & & & & & & 1 & 1 \\
\hline Grus Grus & Grou-comum & & & & & 1 & 1 & & & & & & & \\
\hline Otis tarda & Abtarda-comum & & & & & 1 & 1 & & & & & & & \\
\hline Pluvialis squatarola & Tarambola-cinzenta & 2 & 1 & & & & & & & & & & & \\
\hline Puffinus puffinus & Pardela-sombria & & & 1 & 1 & & & & & & & & & \\
\hline Phalacrocorax aristotelis & Sorvo-marinho & & & 18 & 5 & & & & & & & & & \\
\hline Pinguinus impennis & Arau-gigante / Alca-imperial & & & 1 & 1 & & & & & & & & & \\
\hline cf. Aquila adalberti & & & & & & & & & & & & & 1 & 1 \\
\hline Aquila chrysaetos & Águia-real & 2 & 2 & 2 & 1 & & & & & & & & & \\
\hline Falco tinuculus & Peneireiro-vulgar & 1 & 1 & 1 & 1 & & & & & & & & & \\
\hline Falco rusticolus & Falcão-gerifalte & & & & & & & & & & & & & \\
\hline Gyps fulvus & Grifo & & & 1 & 1 & & & & & & & & & \\
\hline Milvus migrans & Milhafre-preto & & & & & & & & & & & & 1 & 1 \\
\hline Tyto alba & Coruja-das-torres & & & 1 & 1 & & & & & & & & & \\
\hline Bubo bubo & Bufo-real & & & 1 & 1 & 9 & 13 & & & & & & & \\
\hline Athene noctua & Mocho-galego & 2 & 2 & & & & & & & & & & & \\
\hline Asio flammeus & Coruja-do-nabal & & & 1 & 1 & & & & & & & & & \\
\hline Strix aluco & Coruja-do-mato & 2 & 2 & & & & & & & & & & & \\
\hline Columba livia & Pombo-das-rochas & 39 & 13 & 14 & 5 & & & 2 & 2 & & & & 2 & 1 \\
\hline Columba palumbus & Pombo-torcaz & 4 & 3 & & & & & & & & & & & \\
\hline Pyrrhocorax pyrrhocorax & Gralha-de-bico-vermelho & 82 & 19 & 10 & 4 & 16 & 59 & 6 & 2 & & 3 & 2 & 105 & 24 \\
\hline Pyrrhocorax graculus & Gralha-de bico-amarelo & 23 & 7 & 9 & 4 & 451 & 112 & 8 & 4 & & 6 & 2 & 122 & 24 \\
\hline Corvus monedula & Gralha-de-nuca-cinzenta & 26 & 11 & 6 & 3 & 922 & 277 & 4 & 2 & & 6 & 2 & 105 & 12 \\
\hline Corvus corone & Gralha-preta & 6 & 3 & 6 & 2 & & & & & & & & & \\
\hline Corvus frugilegus & Gralha-calva & 11 & 5 & 3 & 1 & 1 & 1 & & & & & & 1 & 1 \\
\hline Corvus corax & Corvo-comum & 2 & 2 & & & 1 & 1 & & & & & & 1 & 1 \\
\hline Pica pica & Pêga-rabuda & 10 & 3 & 1 & 1 & 23 & 48 & 4 & 1 & & 2 & 1 & & \\
\hline Garrulus glandarius & Gaio-comum & 1 & 1 & & & 1 & & & & & & & 1 & 1 \\
\hline cf. Cyanopica cyanus & Pêga-azul & 1 & 1 & & & & & & & & & & & \\
\hline Turdus iliacus & Tordo-ruivo & 1 & 1 & 3 & 2 & & & & & & & & & \\
\hline Turdus pilaris & Tordo-zornal & 12 & 6 & 9 & 6 & & & & & & & & & \\
\hline Turdus philomelos & Tordo-comum & 2 & 2 & & & & & & & & & & & \\
\hline Turdus merula & Melro-preto & 16 & 9 & 6 & 3 & & & 3 & 2 & & & & 3 & 2 \\
\hline Carduelis carduelis & Pintasilgo-comum & 1 & 1 & & & & & & & & & & & \\
\hline Ptyonoprogne rupestris & Andorinha-das-rochas & 1 & 1 & & & & & & & & & & & \\
\hline Phoenicopterus ruber & Flamingo & & & 1 & 1 & & & & & & & & & \\
\hline Numenius phaeopus & Maçarico-galego & & & 1 & 1 & & & & & & & & & \\
\hline Cuculus canorus & Cuco & & & 1 & 1 & 1 & 1 & & & & & & & \\
\hline Motacilla alba & Álveola-branca & & & & & & & & & & & & 1 & 1 \\
\hline Vanellus vanellus & Abibe-comum & & & & & & & & & & 1 & & & \\
\hline
\end{tabular}

Quadro 52- Comparação do número mínimo de indivíduos e do número total de restos das espécies identificadas em cada uma das jazidas atrás apresentadas 


\begin{tabular}{|ll|}
\hline & LEGENDA \\
\hline \hline GNC & Gruta Nova da Columbeira \\
GFP & Gruta da Furninha \\
Gsal & Gruta das Salemas \\
GPD & Gruta do Pego do Diabo \\
GFt & Gruta das Fontainhas \\
GCM & Gruta da Casa da Moura \\
LRh & Lapa da Rainha \\
GCal & Gruta do Caldeirão \\
\hline
\end{tabular}

As espécies mais representadas são o Corvus monedula, o Pyrrhocorax pyrrhocorax, o Pyrrhocorax graculus e a Pica pica e aparecem em maior número, por ordem decrescente, na Casa da Moura, na Lapa da Rainha e na Gruta Nova da Columbeira. Dos restantes passeriformes há que destacar a ocorrência das espécies do género Turdus, que aparecem essencialmente na Gruta Nova da Columbeira e na Gruta da Furninha.

Os anseriformes aparecem essencialmente na Gruta da Furninha, o que se explica pela sua localização, junto à costa. As excepções são o Anas platyrrhynchos, e o Anser albifrons, que aparecem em jazidas mais longe da costa, o primeiro na Gruta Nova da Columbeira e o segundo na Gruta do Pego do Diabo.

A mesma situação se passa com os pelecaniformes, em que a espécie Phalacrocorax aristotelis aparece com um número considerável de restos (18) na Gruta da Furninha, sendo apenas superada pela Tadorna tadorna (162 restos) e pela Somateria mollissima (63 restos). Todas as outras espécies, incluindo as dos corvídeos e as dos restantes anseriformes, apresentam um número total de restos inferior a 18.

Dos galliformes destaca-se o Alectoris rufa, com um número considerável de ocorrências, em especial na Gruta da Furninha e na Gruta Nova da Columbeira. As restantes espécies desta ordem são residuais aparecendo em pequeno número e apenas em uma ou duas jazidas.

Os columbiformes aparecem bem distribuídos (ocorrem na maioria das jazidas) e em número razoável, predominando essencialmente na Gruta Nova da Columbeira e na Gruta da Furninha. A Columba livia é, a seguir às espécies de corvídeos atrás referidas, a que aparece em maior número.

De entre os carnívoros, a espécies mais representada é o Bubo bubo, que aparece em grande número na Casa da Moura. Também está representado na Gruta 
da Furninha, onde foi identificado um resto. O carnívoro que aparece a seguir, em termos do número de restos, é a Aquila chrysaetos, que neste caso é a que tem uma distribuição mais lata aparece em três jazidas (Gruta Nova da Columbeira, Gruta da Furninha e Lapa da Rainha. As restantes espécies de aves carnívoras reconhecidas aparecem de forma residual (apenas um resto ou dois, no caso da Athene noctua), numa só jazida.

As restantes ordens, como por exemplo os cuculiformes, os gruiformes, os procelariformes, os podicipediformes, os procellariiformes, os charadriiformes ou os piciformes, aparecem de forma residual, em poucas jazidas e com poucas espécies. 


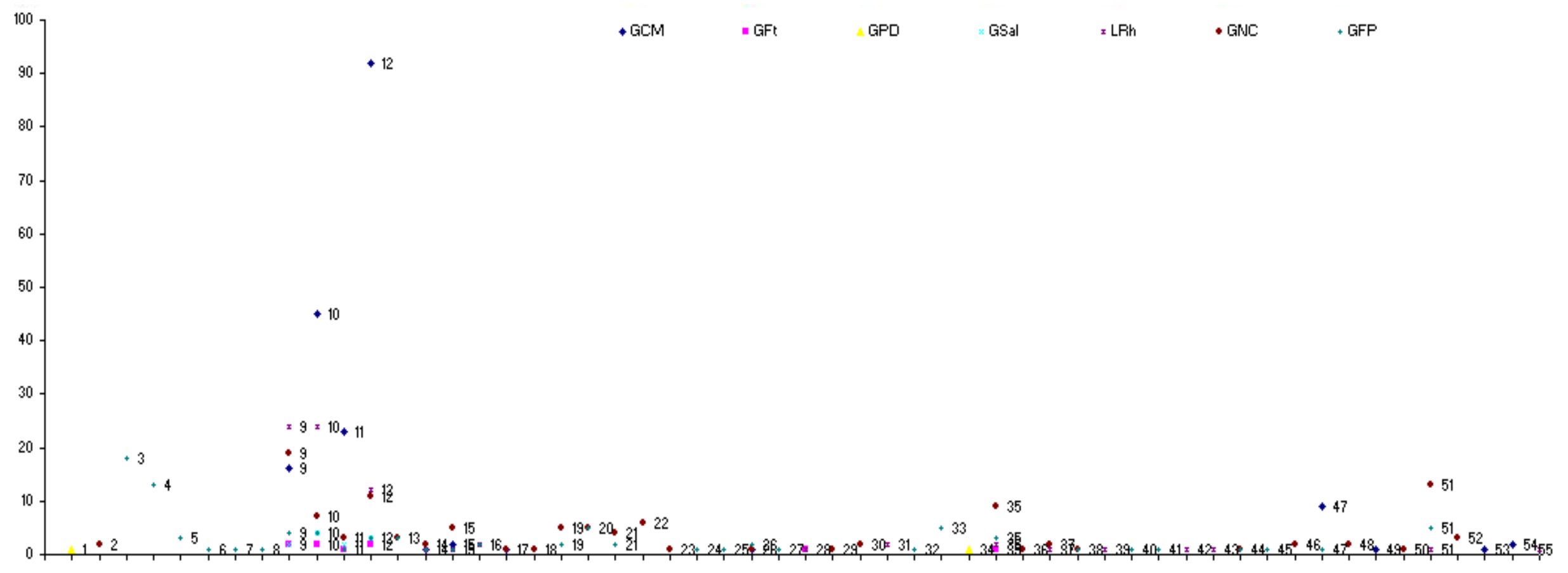

1 A. albifrons 2 A. platyrhynchos $3 \mathrm{~T}$. tadorna $\quad 4$ S. mollissima $\quad 5$ T. ferruginea $\quad 6$ C. olor $\quad 7$ A. Crecca 8 M. nigra $\quad 9$ P. pyrrhocorax 10 P. graculus 11 P. pica 12 C. monedula 13 C.corone 14 C.corax 15 C.frugilegus 16 T. merula 17 G. glandarius 18 C.cyana $\quad 19$ T. iliacus 20 T. pilaris 21 T. philomelos $22 \mathrm{C}$. carduelis $23 \mathrm{P}$. rupestris $\quad 24$ P.ruber $\quad 25 \mathrm{~N}$. phaeopus 26 C.canorus 27 P. impennis 28 V.vanellus 29 P. squatarola 30 L. mutus 31 L.lagopus 32 P. puffinus $\quad 33$ P. aristotelis $\quad 34$ P. colchicus $\quad 35$ A. rufa $\quad 36$ A. barbara $\quad 37$ P. perdix $\quad 38$ C. coturnix 39 T. urugalus $40 \mathrm{G}$, fulvus $41 \mathrm{~A}$. Flammeus $\quad 42 \mathrm{M}$. migrans $\quad 43 \mathrm{~A}$. adalberti $44 \mathrm{~A}$.chrysaetos $\quad 45 \mathrm{~T}$. alba $\quad 46 \mathrm{~S}$. aluco $\quad 47 \mathrm{~B}$, bubo $48 \mathrm{~A}$. noctua $49 \mathrm{~F}$, rusticolus 50 F. tinuculus $51 \mathrm{C}$.livia $52 \mathrm{C}$. palumbus $53 \mathrm{G}$. grus 54 O.tarda $55 \mathrm{M}$. alba

Gráfico 64 - Comparação do número mínimo de indivíduos das espécies identificadas em cada uma das jazidas estudadas. 


\section{2 - Biometria}

As medidas osteológicas são importantes para melhor se compreender as faunas do passado. Com um estudo osteométrico pode-se não só separar os sexos, ou distinguir de forma mais precisa uma espécie, mas também ter uma ideia acerca da evolução de uma determinada espécie.

Um registo consistente e bases de dados de medidas dos ossos das aves podem ajudar na obtenção de classificações mais sólidas. Os registos de dados em suporte informático universal permitem a troca de informações e um avanço nos estudos das aves fósseis ou de contextos arqueológicos. Nos últimos anos têm-se realizado vários estudos comparativos de algumas espécies e famílias, tais como GRUBER, 1990, LORCH, 1992 OTTO, 1981 e REIHER, 1986, cujas medidas osteológicas têm sido úteis para distinguir espécies.

O estudo osteométrico efectuado teve como principal objectivo ajudar na identificação taxonómica, dos restos de aves identificados neste trabalho. No entanto, foi também efectuado um estudo osteométrico comparativo que é agora apresentado neste ponto. As medidas utilizadas neste estudo osteométrico foram as descritas no ponto 3.3 da metodologia.

Este estudo é essencialmente indicativo, pois quer o número de restos plistocénicos estudados quer os espécimes actuais medidos são em número reduzido, não permitindo uma diferenciação intraespecífica significativa. Quanto maior for o número de ossos medidos mais dados fiáveis se têm, pois não são só as diferenças intraespecíficas que condicionam estes estudo, mas também o dimorfismo sexual, só observados quando se têm vários ossos dos dois sexos, para depois se comparar com as amostras paleontológicas em estudo.

Por esta razão só foram feitas as comparações osteométricas das seguintes espécies: Alectoris rufa, Columba livia, Pyrrhocorax pirrhocorax, Corvus monedula e Turdus merula (apenas o úmero). Foram apenas escolhidas estas espécies, porque apresentam um número razoável de restos, aparecem em mais do que uma jazida e nas colecções de referência foram observados e medidos ossos de vários indivíduos.

Assim, foi possível comparar as medidas dos ossos das aves das diversas 
jazidas e destas com as aves actuais. Observou-se que as diferenças entre as aves das várias jazidas plistocénicas e entre as aves plistocénicas e as actuais são pequenas, não se verificando grandes variações na robustez e tamanho das espécies analisadas.

\section{Espécies analisadas:}

\section{Alectoris rufa}

De todos os restos em que se fez um estudo osteométrico comparado, os da $A$. rufa são os que apresentam maiores diferenças, em especial os restos da Gruta Nova da Columbeira, que apresentam os valores mais elevados. As restantes apresentam medidas semelhantes entre si. No entanto, as medidas dos Carpometacarpos actuais apresentam valores mais altos, superando inclusive os restos da Gruta Nova da Columbeira.

Alectoris rufa - coracóide

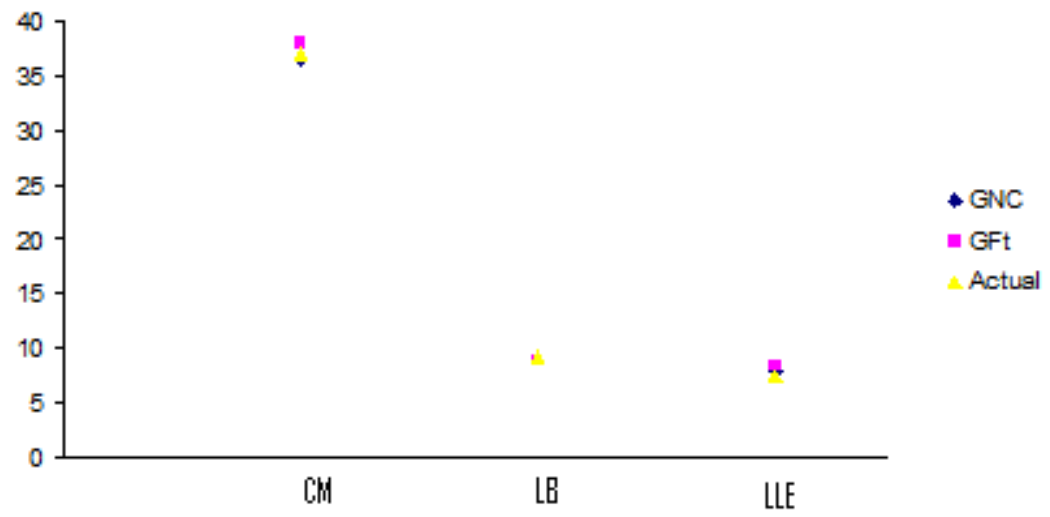

Gráfico 65 - Medidas dos coracóides de A. rufa. 


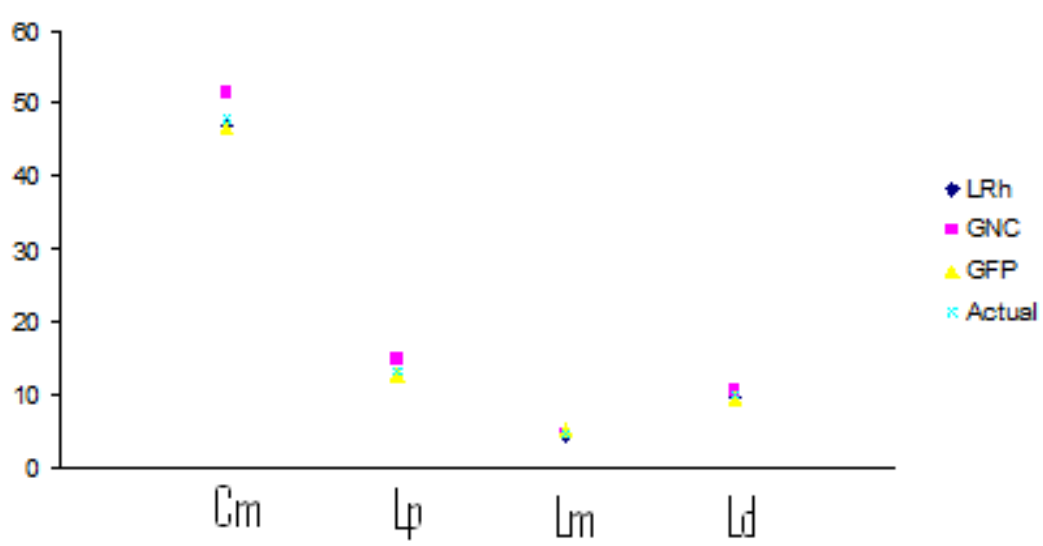

Gráfico 66 - Medidas dos úmeros de A. rufa.

Alectoris rufa - ulna

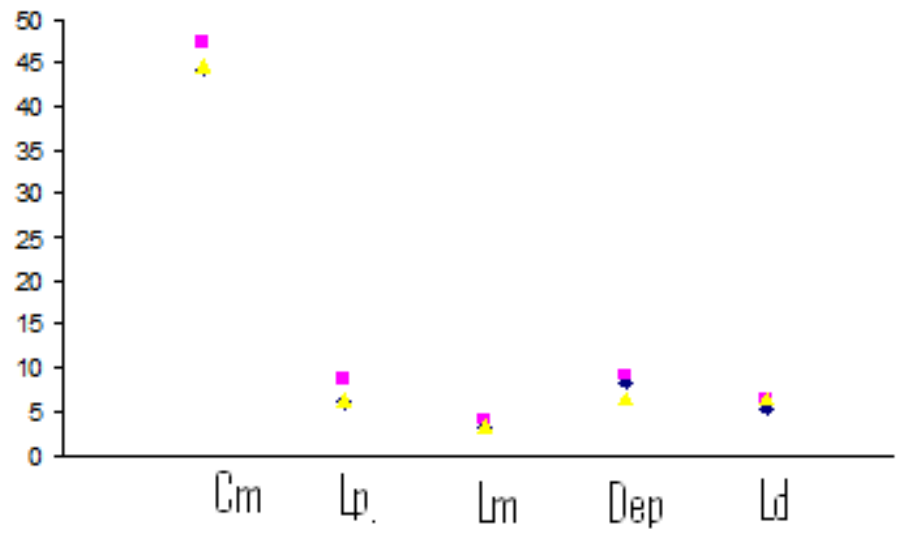

- LRh

- GFP

Actual

Gráfico 67 - Medidas das ulnas de A. rufa.

Alectoris rufa - carpometacarpo

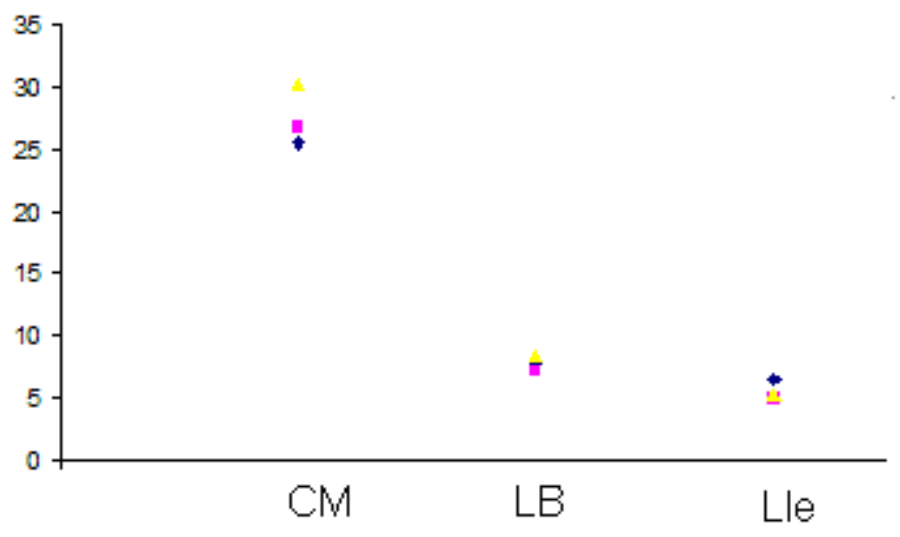

- Lrh

- Gnc

Actual

Gráfico 68 - Medidas dos carpometacarpos de A. rufa. 


\section{Columba livia}

A espécie C. livia apresenta o comprimento dos úmeros ligeiramente diferente entre as várias medidas tomadas. Nas restantes medidas e ossos, não há diferenças entre os espécimes plistocénicos e os actuais. As medidas são semelhantes

Columba livia - úmero

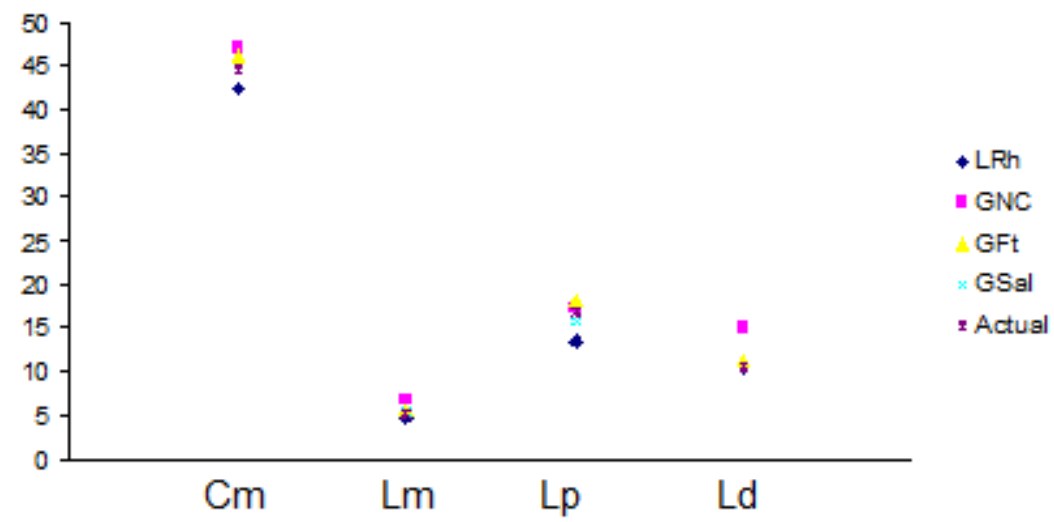

Gráfico 69 - Medidas dos úmeros de C. livia.

Columba livia - ulna

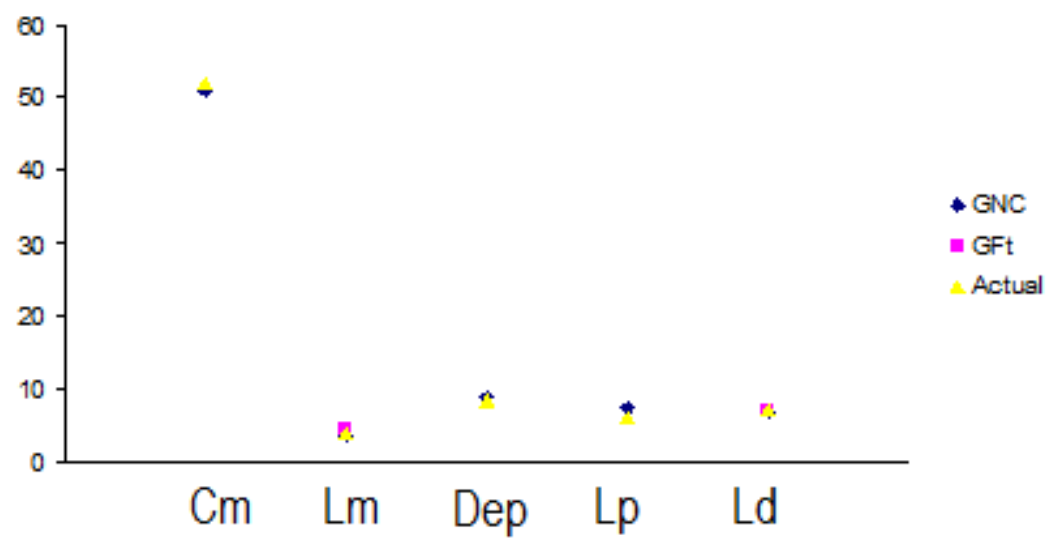

Gráfico 70 - Medidas das ulnas de C. livia. 


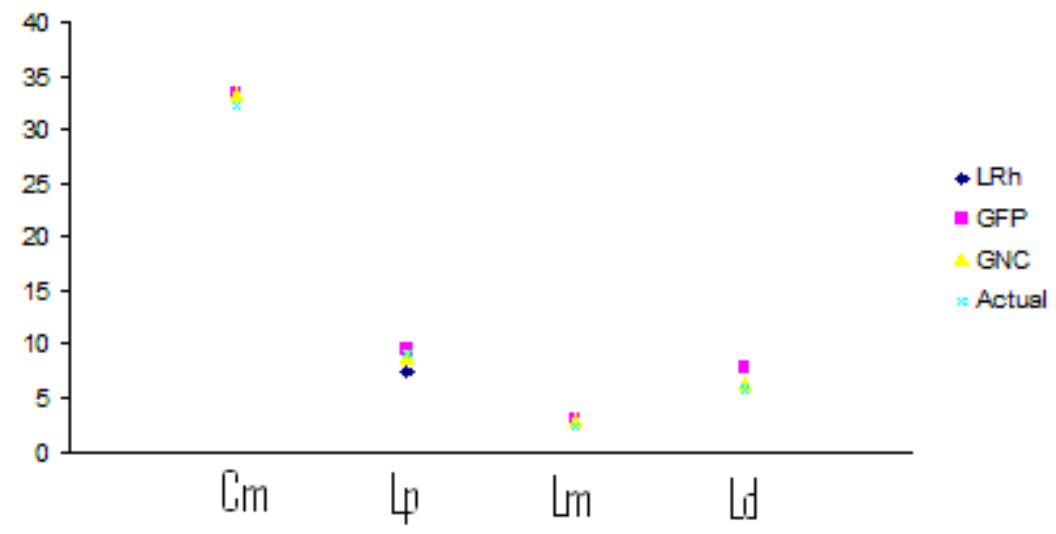

Gráfico 71 - Medidas dos carpometacarpos de C. livia.

\section{Pyrrhocorax pyrrhocorax}

Com a excepção dos tarsometatarsos do P. pyrrhocorax, em que se denota alguma diferenciação nas medidas entre as jazidas plistocénicas e entre estas e as medidas actuais, os restantes ossos desta espécie apresentam uma homogeneidade entre os restos plistocénicos e as medidas tiradas aos ossos das colecções de referência consultadas.

Pymhocorax pymhocorax - Coracóide

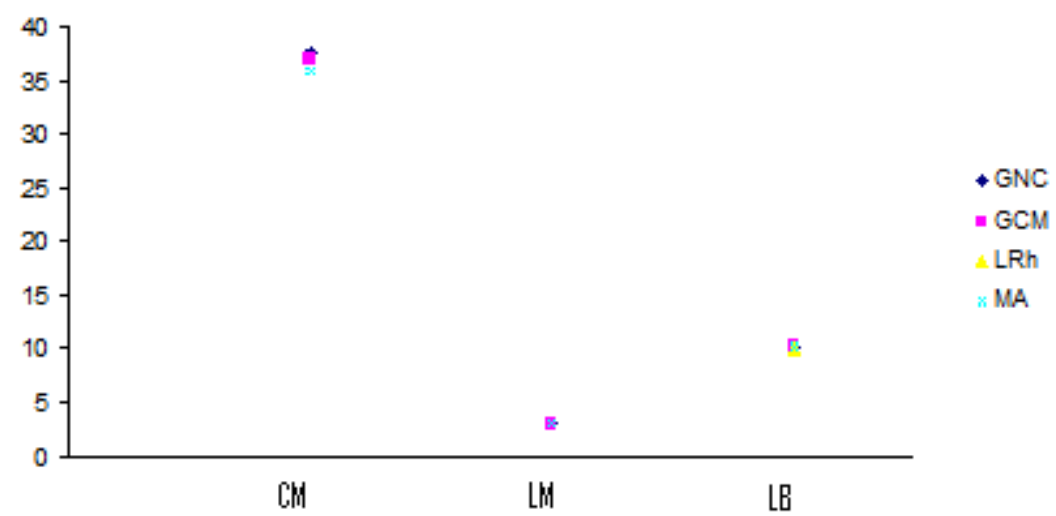

Gráfico 72 - Medidas dos coracóides de P. pyrrhocorax. 


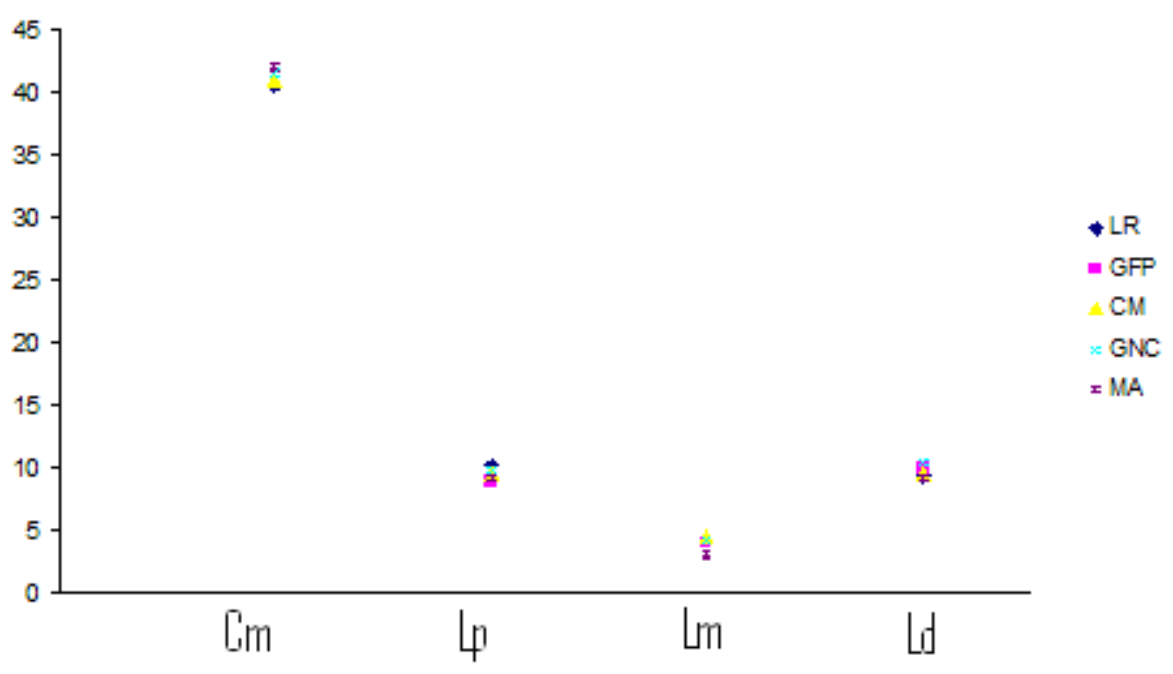

Gráfico 73 - Medidas dos carpometacarpos de P. pyrrhocorax.

Pyrrhocorax pyrrhocorax - úmero

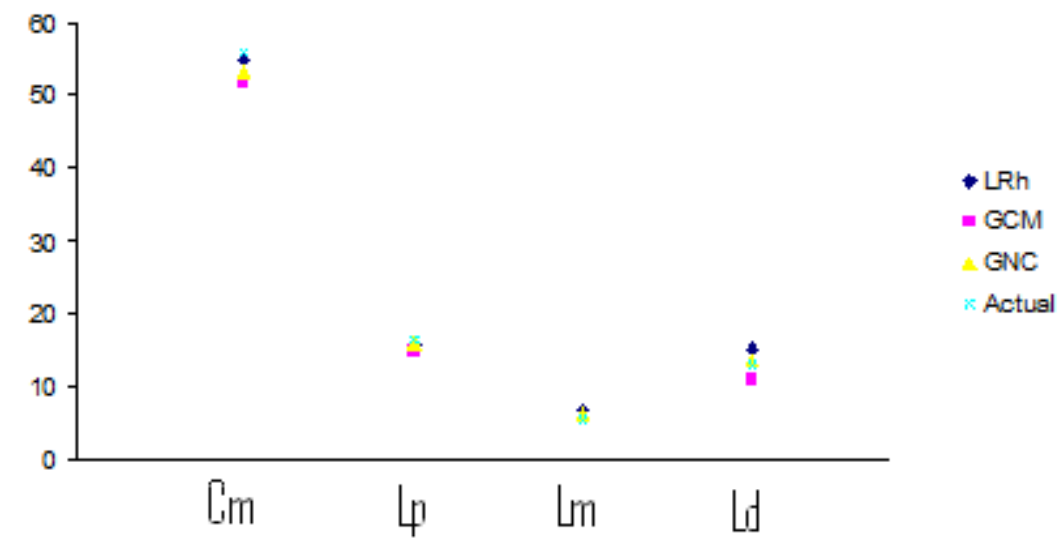

Gráfico 74 - Mediads dos úmeros de $P$. pyrrhocorax.

Pyrmocorax pyrmocorax - Ulna

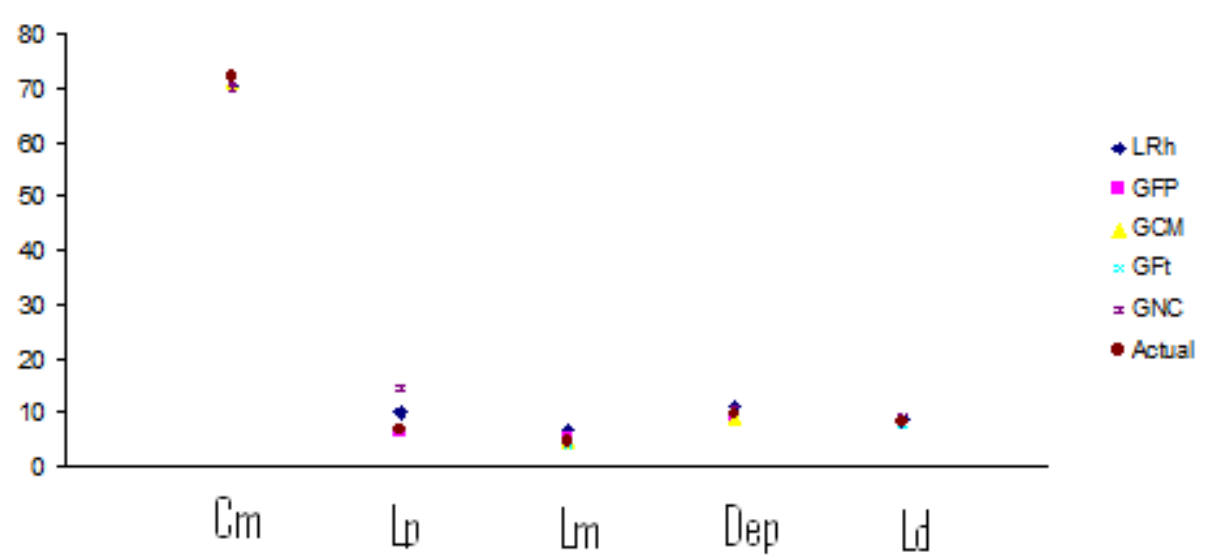

Gráfico 75 - Medidas das ulnas de P. pyrrhocorax. 
Phyrrhocorax phyrrhocorax - F émur

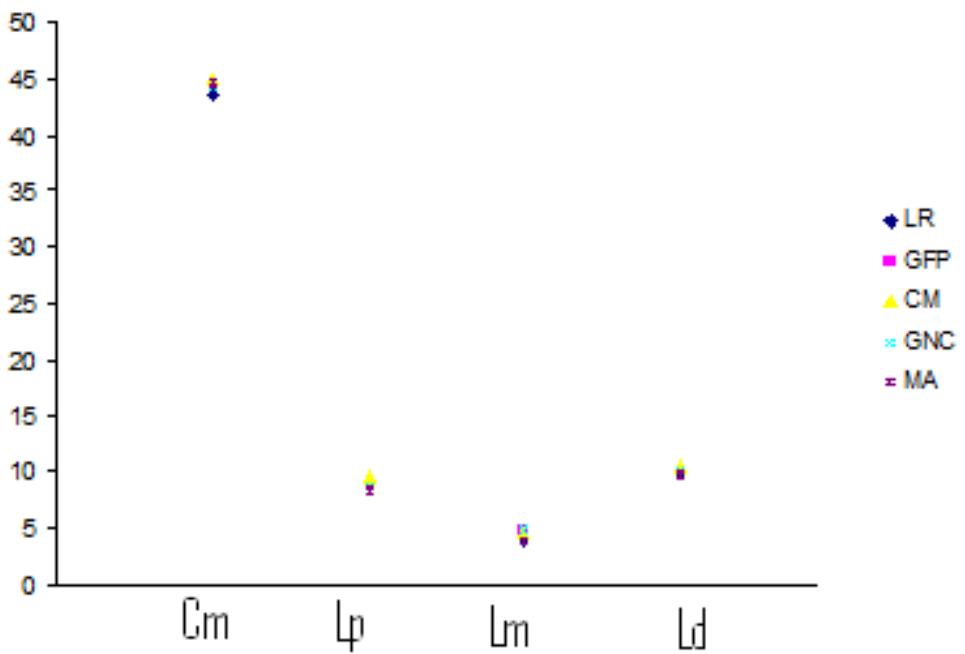

Gráfico 76 - Medidas dos fémures de P. pyrrhocorax.

Pyrmocorax pyrmocorax - Tibiotarso

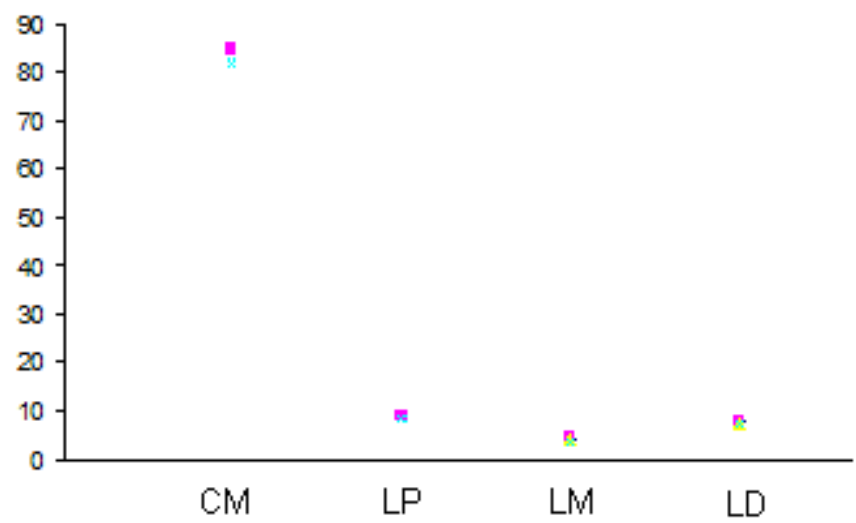

Gráfico 77 - Medidas dos tibiotarsos de P. pyrrhocorax.

Pyrrhocorax pyrrhocorax - tarsometatarso

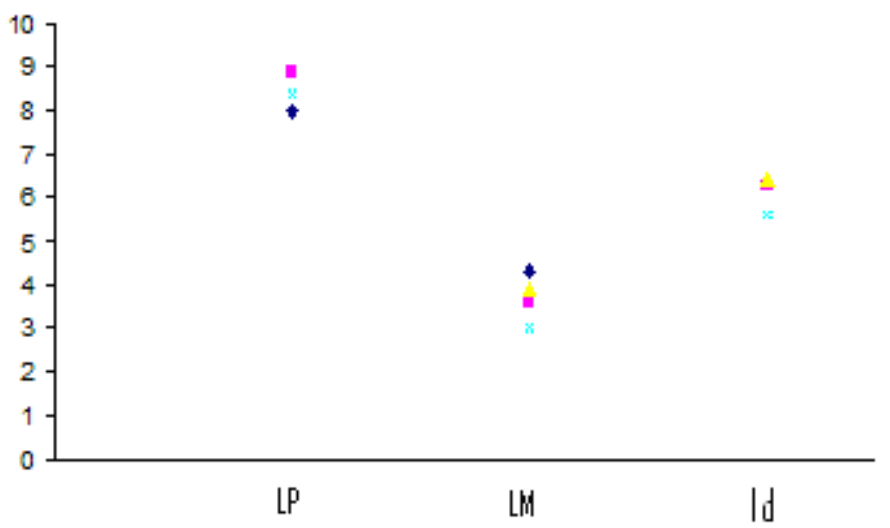

- GCM

GFt

Actual

GCM

$\times$ Actual

Gráfico 78 - Medidas dos tarsometatarsos de P. pyrrhocorax. 


\section{Corvus monedula}

$\mathrm{Na}$ análise osteométrica dos ossos do C. monedula, concluiu-se que os coracóides da Lapa da Rainha são um pouco mais pequenos que os restantes. No que respeita ao Carpometacarpo, à ulna e ao úmero, verifica-se uma ligueira diferença osteométrica entre todos, no comprimento. Os restantes ossos e medidas tomadas apresentam valores semelhantes.

Corvus monedula - coracóide

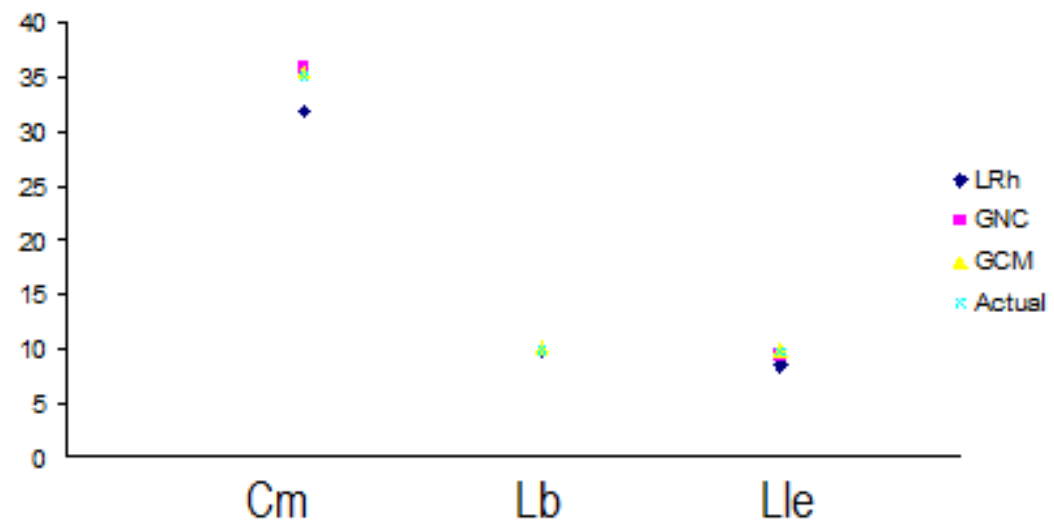

Gráfico 79 - Medidas dos coracóides do C. monedula.

Corvus monedula - úmero

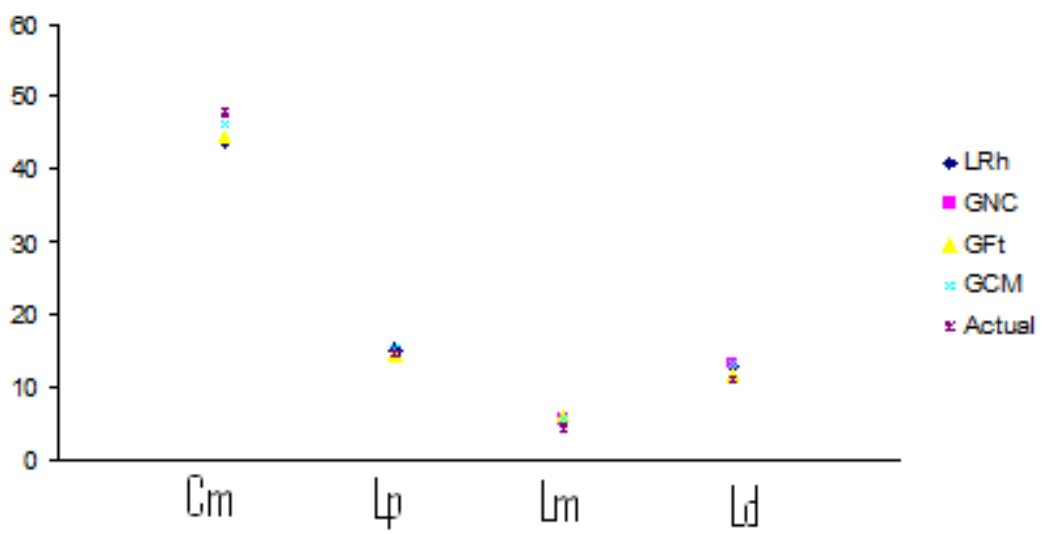

Gráfico 80 - Medidas dos úmeros do C. monedula. 
Corvus monedula - ulna

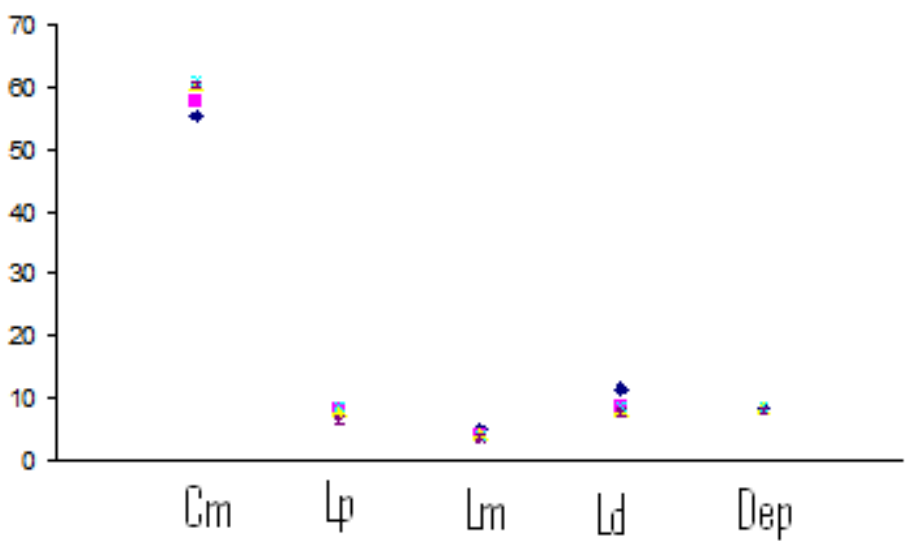

- LRh

- GNC

GCM

GFt

actual

Gráfico 81 - Medidas das ulnas do C. monedula.

Corvus monedula - carpometacarpo

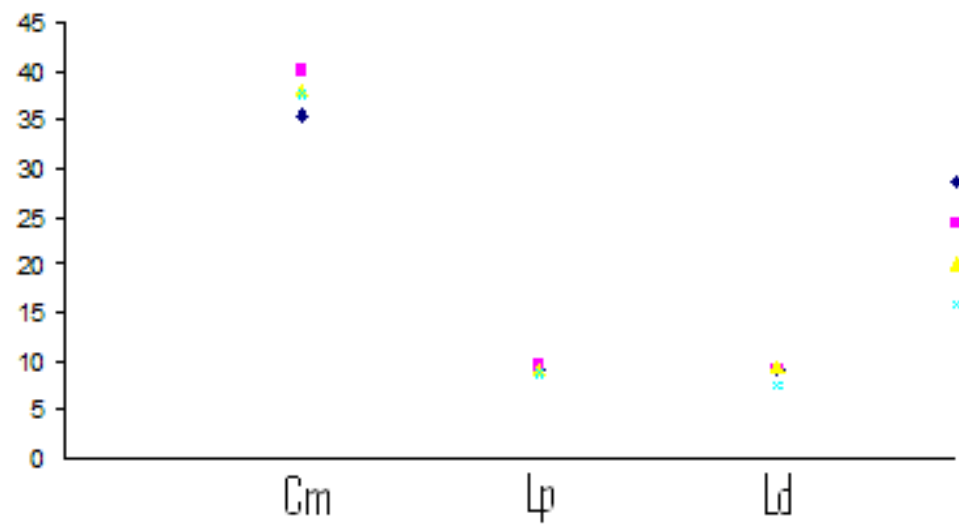

Gráfico 82 - Medidas dos carpometacarpos do C. monedula.

Corvus monedula -fémur

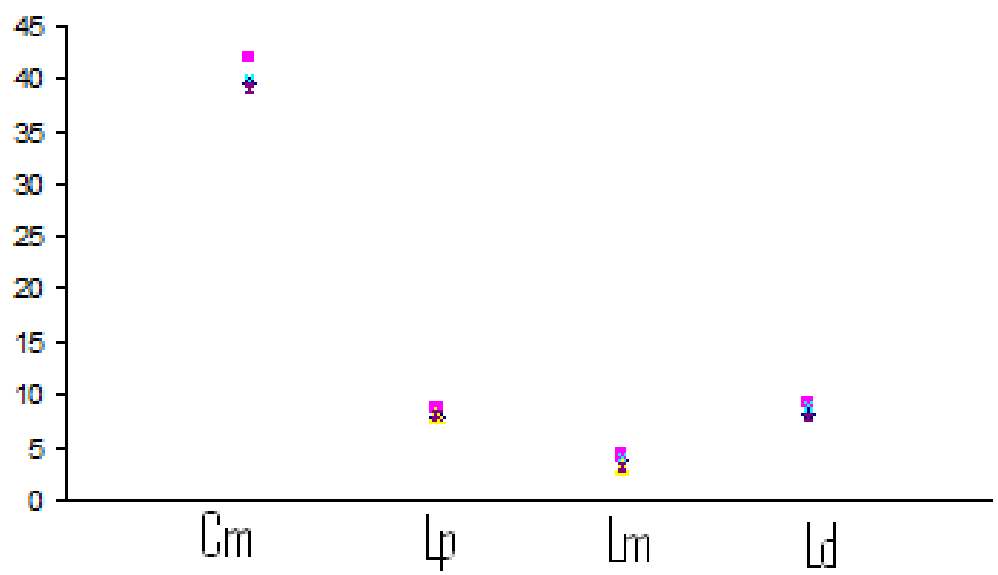

Gráfico 83 - Medidas dos fémures do C. monedula. 
Corvus monedula - tibiotarso

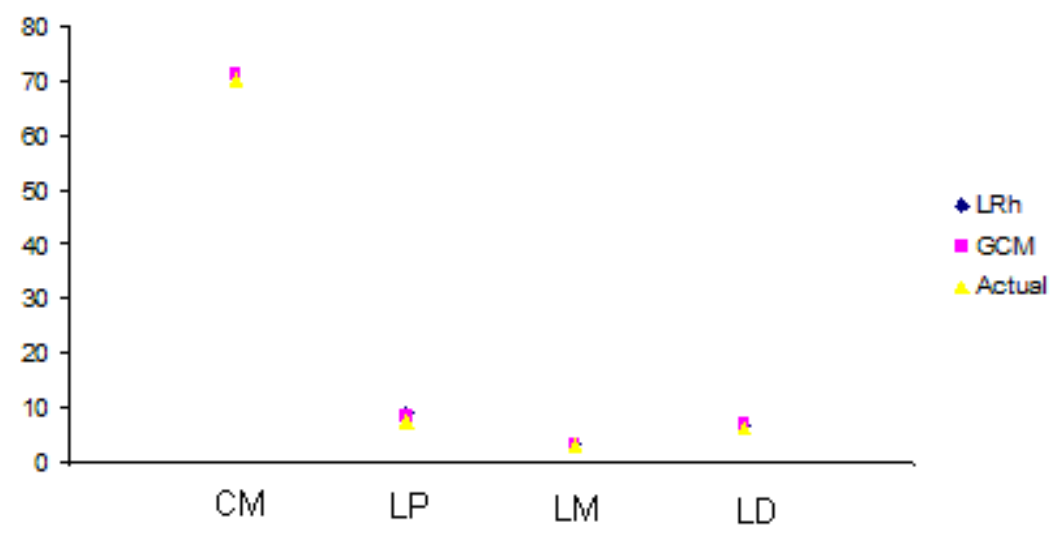

Gráfico 84 - Medidas do tibiotarso do C. monedula.

Corvus monedula - tarsometatarso

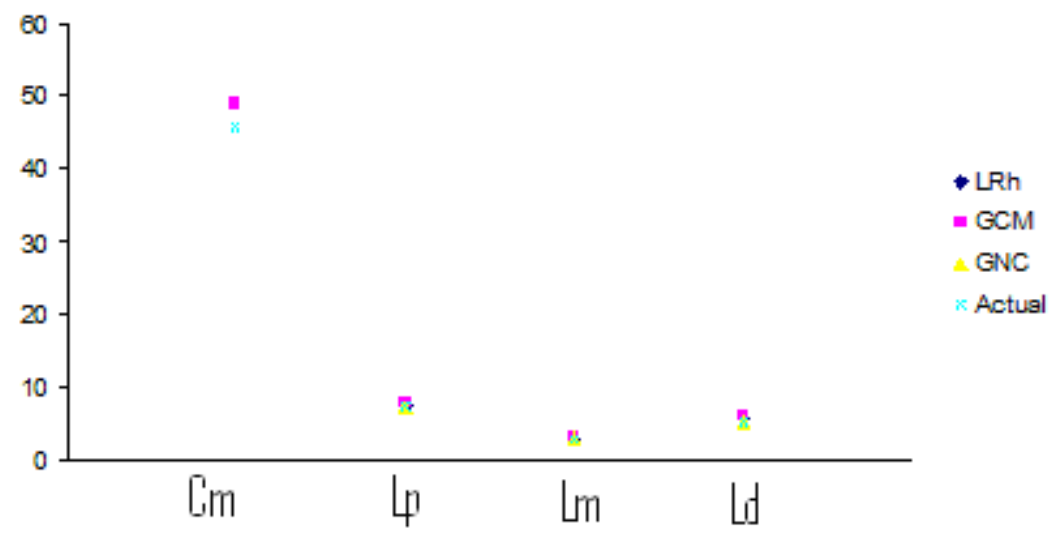

Gráfico 85 - Medidas dos Tarsometatarsos do C. monedula.

\section{Turdus merula}

Os úmeros do T. merula apresentam, entre os restos das jazidas plistocénicas e entre os ossos das aves actuais medidos, valores semelhantes. 


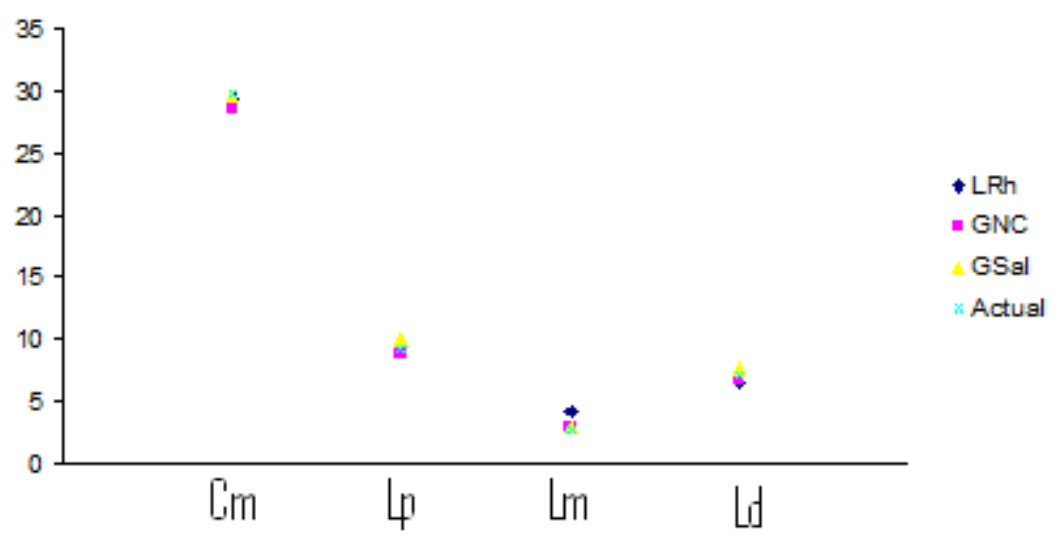

Gráfico 86 - Medidas dos úmeros do T. merula.

\section{3 - Paleobiogeografia}

Pretende-se neste ponto compreender a distribuição geográficas dos diferentes grupos de aves identificados no Plistocénico de Portugal. Para este estudo foram utilizados os dados resultantes das investigações feitas para este trabalho, bem como os dados encontrados na bibliografia sobre aves plistocénicas portuguesas. Aqui apenas foi utilizada a presença das espécies nas diferentes zonas e não qualquer outro dado como o NTR ou NMI, pois, por um lado, para esta distribuição esses dados não são significativos e, por outro, o NMI ou o NTR não aparecem na maioria da bibliografia consultada.

Foi também feita uma pesquisa bibliográfica acerca da distribuição geográfica das aves Plistocénicas na Europa e a comparação com as espécies presentes em Portugal.

\section{Paleobiogeografia das espécies identificadas em Portugal}

Foi considerada a distância ao mar como o factor de distribuição das espécies, pois denota-se desde logo uma diferença do tipo de avifauna entre as jazidas próximas da costa e as mais afastadas. Determinaram-se diferentes distâncias, consoante os diferentes grupos de jazidas: existe um grupo de jazidas localizado entre os 0 e os $5 \mathrm{~km}$ da costa, depois outro grupo (o maior) com jazidas localizadas entre os 10 e os $20 \mathrm{~km}$; outro entre os 20 e os $50 \mathrm{~km}$; finalmente o último grupo, com 
apenas três jazidas, localizado a mais de $50 \mathrm{~km}$.

É importante referir que a grande maioria das jazidas se localiza na Estremadura, nas cavidades cársicas da Bacia Lusitaniana, entre a Arrábida e Pombal (no eixo sul-norte e entre a costa ocidental e Tomar, no eixo oeste - este. As excepções a estas localizações são a Foz do Enxarrique, no vale do Tejo, em Vila Velha de Ródão e a Gruta do Escoural, no Alentejo, perto de Montemor-O-Novo.

Depois de distribuídas as espécies pelas diferentes áreas verificou-se que os corvídeos são o grupo predominante em todas as áreas, especialmente nas jazidas localizadas entre os 10 e os $20 \mathrm{~km}$ da costa. Como seria de esperar, encontram-se mais espécies marinhas nas jazidas junto à costa, de que são exemplo as espécies de pelecaniformes e phoenicopteriformes, que só aparecem nesta zona e das espécies de charadriiformes a anseriformes, que apresentam um número elevado nesta zona e não aparecem, ou são residuais, nas jazidas localizadas mais para o interior.

Os galliformes estão bem distribuídos por todas as áreas consideradas, bem como os columbiformes que aparecem distribuídos de forma idêntica .

As espécies de climas frios e húmidos, tais como o Pinguinus impennis, a Alca torda, e o Anser albifrons, ocorrem sobretudo nas jazidas próximas da costa, o mesmo acontecendo coms as espécies de climas temperados húmidos, como os casos da Tadorna tadorna e do Phalacrocoras aristotelis. No interior aparecem mais espécies de climas temperados e secos, como o Falco tinnuculus, o Perdix perdix, o Corvus corax, e o Picus viridis. Mas também existem algumas de climas frios e secos, como o Tetrao urugalus e o Falco rusticolus

No entanto, existem espécies que só aparecem no interior e que são de climas frios húmidos, como os casos do Lagopus lagopus, Lagopus mutuos e vanellus vanellus e espécies também de climas húmidos, mas menos frios,como o Anas platyrhyncos , o que sugere a presença de zonas de água doce no interior.

Por fim há que destacar espécies transversais, que ocorrem em todas as zonas, como o Pyhhhocorax pyrrhocorax e o Pyrrhocorax graculos, de climas frios e secos, o Corvus monedula e o Alectoris rufa, de climas temperados secos, e a Columba livia, de climas quentes e secos. Não existem espécies de climas húmidos que apareçam ao mesmo tempo em todas as zonas estabelecidas, o que poderá ser explicado pela especificidade destes climas. 


\begin{tabular}{|c|c|c|c|c|}
\hline Taxon & $0-5 \mathrm{Km}$ & $10-20 \mathrm{~km}$ & $20-50 \mathrm{~km}$ & $>50 \mathrm{Km}$ \\
\hline Anser albifrons & & & 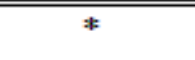 & \\
\hline Anas platyrhynchos & * & $*$ & $*$ & $*$ \\
\hline Anas crecca & * & & & \\
\hline Melanita nigra & $*$ & & & \\
\hline Melanitta fusca & * & & & \\
\hline Clangula hyemalis & * & & & \\
\hline Mergus albellus & & & $*$ & \\
\hline Tadorna tadorna & $*$ & & & $*$ \\
\hline Somateria mollissima & $*$ & & & \\
\hline Tadorna ferruginea & * & & & \\
\hline Cygnus olor & * & & * & \\
\hline Perdix perdix & * & $*$ & & \\
\hline Alectoris rufa & * & $*$ & * & $*$ \\
\hline cf. Alectoris barbara & & $*$ & & \\
\hline cf. Phasianus colchicus & & & $*$ & \\
\hline Coturnix coturnix & * & $*$ & & \\
\hline Tetrao urugalus & $*$ & & & \\
\hline Lagopus lagopus & & $*$ & & \\
\hline Lagopus mutus & & $*$ & & \\
\hline Grus primigenia & $*$ & & & \\
\hline Grus Grus & & $*$ & & \\
\hline Otis tarda & & $*$ & & \\
\hline Pluvialis squatarola & & $*$ & & \\
\hline Puffinus puffinus & $*$ & & & \\
\hline Puffinus holeae & * & & & \\
\hline Puffinus Kulhi & & & $*$ & \\
\hline Sula bassana & * & & & \\
\hline Phalacrocorax carbo & * & & & \\
\hline Phalacrocorax aristotelis & $*$ & & & \\
\hline Phoenicopterus ruber & $*$ & & & \\
\hline Gavia stellata & $*$ & & & \\
\hline Vanellus vanellus & & & * & \\
\hline Scolopax rusticola & $*$ & & $*$ & \\
\hline Calidris canutus & $*$ & & & \\
\hline Larus fuscus & * & & & \\
\hline Alca torda & $*$ & & & \\
\hline Pinguinus impennis & $*$ & & & \\
\hline
\end{tabular}




\begin{tabular}{|c|c|c|c|c|}
\hline Taxon & $0-5 \mathrm{Km}$ & $10-20 \mathrm{~km}$ & $20-50 \mathrm{~km}$ & $>50 \mathrm{Km}$ \\
\hline Podiceps nigrollis & * & & & \\
\hline Cf. Aquila adalberti & $*$ & & & \\
\hline Aquila chrysaetos & $*$ & $*$ & & \\
\hline Buteo buteo & & & $*$ & \\
\hline Accipiter nisus & * & & & \\
\hline Haliaeetus albicilla & & & * & \\
\hline Hieraaetus fasciatus & * & & & \\
\hline Falco tinnuculus & $*$ & $*$ & & \\
\hline Falco rusticolus & & $*$ & & \\
\hline Aegypius monachus & & & & * \\
\hline Gyps fulvus & * & & * & $*$ \\
\hline Milvus migrans & * & & & \\
\hline Tyto alba & * & & & \\
\hline Bubo bubo & * & * & * & * \\
\hline Athene noctua & * & $*$ & * & * \\
\hline Asio flammeus & $*$ & & & \\
\hline Strix aluco & & * & & \\
\hline Columba livia & * & * & * & $*$ \\
\hline Columba palumbus & * & $*$ & $*$ & $*$ \\
\hline Pyrrhocorax pyrrhocorax & * & $*$ & $*$ & $*$ \\
\hline Pyrrhocorax graculus & * & $*$ & $*$ & $*$ \\
\hline Corvus monedula & * & $*$ & $*$ & \\
\hline Corvus corone & * & $*$ & * & * \\
\hline Corvus frugilegus & * & $*$ & $*$ & $*$ \\
\hline Corvus antecorax & & & $*$ & \\
\hline Corvus corax & $*$ & $*$ & $*$ & $*$ \\
\hline Pica pica & * & $*$ & $*$ & $*$ \\
\hline Garrulus glandarius & & $*$ & & \\
\hline cf. Cyanopica cyana & & $*$ & & \\
\hline Turdus iliacus & * & $*$ & & \\
\hline Turdus pilaris & $*$ & $*$ & & \\
\hline Turdus philomelos & * & * & & \\
\hline Turdus merula & $*$ & $*$ & $*$ & \\
\hline \multicolumn{5}{|l|}{ Sturnus vulgaris } \\
\hline Carduelis carduelis & & $*$ & $*$ & $*$ \\
\hline Ptyonoprogne rupestris & & $*$ & & \\
\hline Numenius phaeopus & $*$ & & & \\
\hline Cuculus canorus & $*$ & * & & \\
\hline Motacilla alba & & $*$ & & \\
\hline Egreta alba & & & $*$ & \\
\hline Caprimulgus europaeus & & & $*$ & \\
\hline Picus viridus & & $*$ & $*$ & \\
\hline
\end{tabular}

Quadro 53 - Distribuição das espécies segundo a sua ocorrência segundo a distância à costa. 


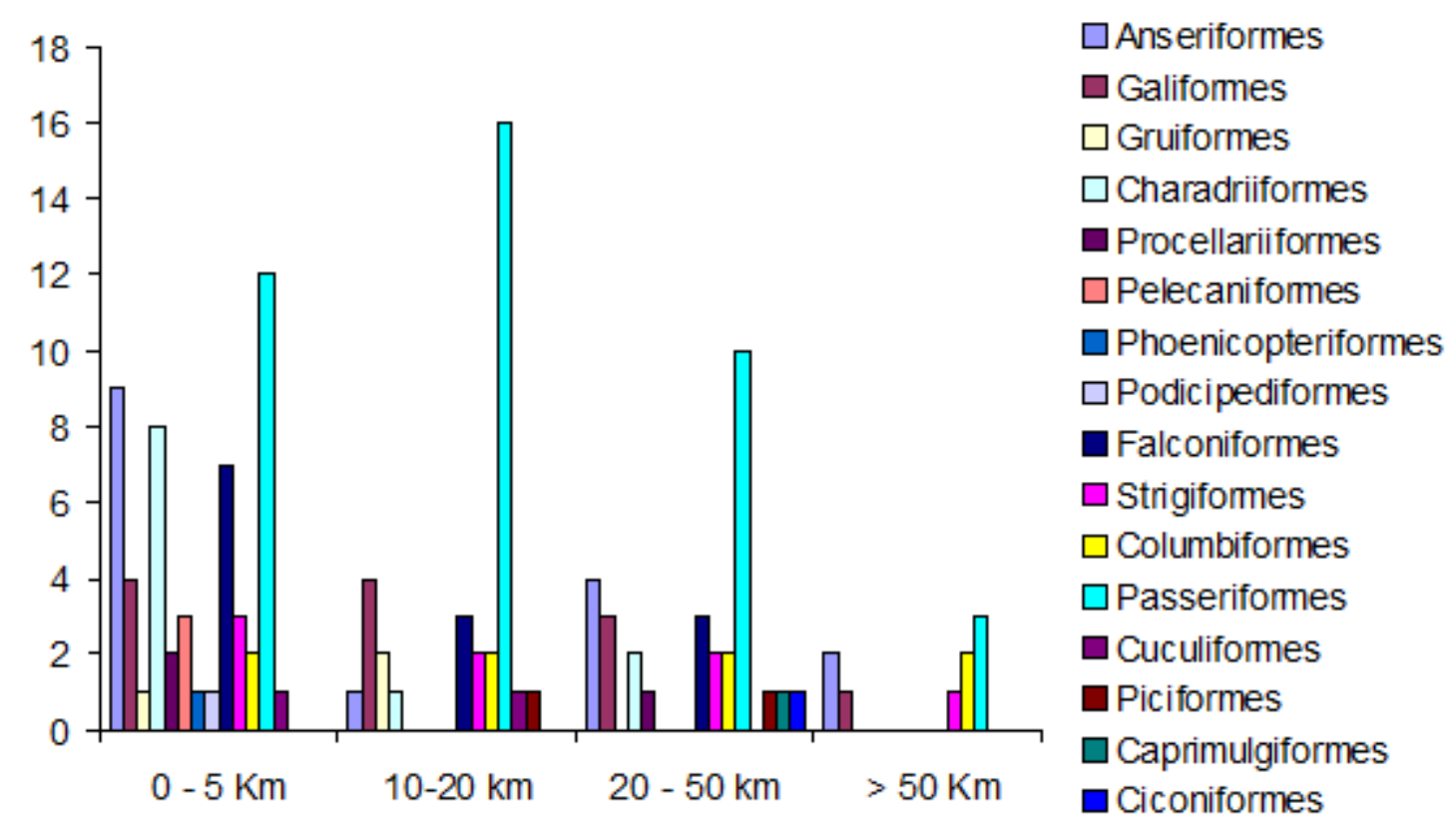

Gráfico 87 - Ocorrências das diferentes ordens segundo a distância à costa, consoante a sua presença nas diferentes jazidas portuguesas com avifauna plistocénica.

\section{Paleobiogeografia das espécies identificadas na Europa}

Desde os anos 50 do século passado que as aves plistocénicas têm sido extensivamente estudadas na Europa, particularmente na Europa Central. São de destacar os trabalhos realizados por M. Kretzoi sobre o material de Btfia, na Roménia, e por D. Janossy, na Hungria. Os estudos efectuados revelam que na Europa Central e de Leste existem restos de aves do Plistocénico Inferior, do Médio e do Superior, enquanto na Europa Ocidental apenas existem do Plistocénico Médio e Superior (MOURER - CHAUVIRÈ, 1993, p. 53) 


\begin{tabular}{|c|c|c|c|c|}
\hline \multirow{2}{*}{ País } & \multicolumn{3}{|c|}{ Ocorrências } & \multirow{2}{*}{ Total } \\
\hline & P. Inferior & P. Médio & P. Superior & \\
\hline França & 33 & 12 & 0 & 45 \\
\hline Alemanha & 32 & 5 & 0 & 37 \\
\hline Austria & 17 & 0 & 0 & 17 \\
\hline Bélgica & 1 & 0 & 0 & 1 \\
\hline Bulgária & 11 & 0 & $3 \|$ & 14 \\
\hline Geórgia & 1 & 0 & 0 & 1 \\
\hline Grécia & 13 & 0 & 0 & 13 \\
\hline Hungria & 0 & 0 & 1 & 1 \\
\hline Itália & 28 & 19 & 9 & 56 \\
\hline Moldávia & 0 & 0 & $1 \|$ & 1 \\
\hline Montenegro & 1 & 0 & 0 & 1 \\
\hline Holanda & 2 & 0 & 0 & 2 \\
\hline Noruega & 0 & 0 & 2 & 2 \\
\hline Russia & 56 & 5 & 0 & 61 \\
\hline Sérvia & 2 & 0 & 0 & 2 \\
\hline Eslováquia & 2 & 0 & $1 \|$ & 3 \\
\hline Eslovénia & 5 & 0 & 0 & 5 \\
\hline Espanha & 48 & 9 & $14 \|$ & 71 \\
\hline Suécia & 1 & 0 & 0 & 1 \\
\hline Suíça & 2 & 0 & 0 & 2 \\
\hline Turquia & 1 & 1 & 2 & 4 \\
\hline Ucrânia & 1 & 0 & 0 & 1 \\
\hline Inglaterra & 1 & 2 & 0 & 3 \\
\hline Portugal* & 0 & 1 & 15 & 16 \\
\hline Total & 258 & 54 & 48 & 360 \\
\hline
\end{tabular}

Quadro 54 - Número de sítios com ocorrências de aves durante o Plistocénico, na Europa.

\section{As aves de características tropicais do Neogénico europeu}

As aves do Miocénico e do Pliocénico da Europa incluem vários táxones cujos representantes actuais vivem em zonas de ambientes tropicais (MOURER CHAUVIRÉ, 1993, p23), como é o caso da família dos sagittariidae (especificamente o género Sagittarius), dos Trogoniformes (Surucuás - nome tradicional no Brasil), de várias espécies de Musophagiformes (turacos), Psittacidae (papagaios), e dos Coliiformes (da família dos collidae), entre outros. Foi durante o plistocénico que estas espécies de aves tropicais desapareceram na Europa, apesar de muitas delas já terem desaparecido no final do Pliocénico. 
Os principais representantes dos grupos característicos de ambientes tropicais do final do Pliocénico e inícios do Plistocénico, na Europa, são os pavões e o grupo dos galos. A espécie Pavo bravardi, actualmente extinta, é muito próxima do Pavo spiciferus. O actual género Gallus (galo e galinha) está representado por quatro espécies que vivem actualmente na índia e no Sudeste da Ásia. Contudo, foram descritas, por Mourer-Chaviré, em Perpignan (Sul de França) e em Beremend (Hungria), por Janossy, duas espécies de Gallus, do Pliocénico.

Outro género próprio de características tropicais do Pliocénico Superior europeu é o Palaeocryptonyx, encontrado em Ibiza, França, Itália e Grécia (MOURER CHAUVIRÉ, 1993, p. 54). Trata-se de uma pequena perdiz, semelhante ao actual Rollullus.

Na Europa Central o género Francolinus (da família dos Phasianidae) apresenta também características tropicais. Os actuais representes deste género vivem em regiões tropicais e temperadas, desde o Médio Oriente até ao Sul da China e em toda a África. As espécies de Francolinus encontradas no Pliocénico e Plistocénico Europeu são: F. capeki (subespécies F. capeki wenzensis; F. capeki villanyensis e F. capeki capeki; F. minor; e F. subfracolinus (MOURER - CHAUVIRÉ, 1993, p. 56). O género Francolinus desapareceu da Europa Central durante o Mindel e da Europa Ocidental no Günz ou Günz-Mindel (MOURER - CHAUVIRÉ, 1993, p. 56). A espécie F. capeki foi encontrada na Hungria, em Barany e em Borsodabaujzemplen, em formações do Pliocénico e do Plistocénico Inferior.

Algumas espécies da família dos Ciconiidae (cegonhas) são outro elemento tropical da avifauna plio-plistocénica da Europa, em especial as grandes cegonhas, tais como a espécie Pelargosteon tothi (MOURER - CHAUVIRÉ, 1993, p. 56), aparentado com o Leptoptilos crumeniferus (o Marabu africano) ${ }^{63}$. O Pelargosteon tothi foi encontrado em Betfia 5, na Roménia (início do Plistocénico Médio - MNQ 21) e referenciado por Kretzoi; outro elemento foi atribuído, por Janossy, com algumas dúvidas, esta espécie foi também encontrado na Hungria (em Budapeste-Varhegy) e datada do Mindel (MNQ 22). Apesar de muito fragmentados, outros elementos

63 O Leptoptilos crumeniferus é uma grande cegonha africana, carnívora (pode atingir uma altura de $150 \mathrm{~cm}$, um peso superior a $9 \mathrm{~kg}$ e uma envergadura de asas de 3,5 m). Tem um bico grande e muito forte e uma bolsa pneumática na base do pescoço. Nesta espécie não existe grande dimorfismo sexual. 
encontrados em Voigtstedt, na Alemanha e também datado do Mindel, foram atribuídos, por Janossy, a uma grande cegonha. Estas espécies de cegonhas são consideradas por Janossy como um relicto ${ }^{64}$ anterior ao Plistocénico. Outra ave do Plistocénico (e actual) da Europa que pode ser também ela considerada como um relicto é a Tadorna tadorna (o pato-branco). Actualmente a T. tadorrna tem uma distribuição descontínua, procurando as costas do Atlântico Norte, na Europa, enquanto na Ásia procria nas praias ou em zonas de águas salobras de lagos do interior e nas estepes, entre as latitudes $40^{\circ}$ e 50 Norte (MOURER - CHAUVIRÉ, 1993, p. 56). Em Portugal, este anatídeo acolhe uma população invernante, que compreende algumas centenas de indivíduos. Desde há alguns anos, estabeleceu-se também uma pequena população nidificante no sotavento algarvio. No passado, é natural que tenha tido uma distribuição mais alargada e contínua. Do Pliocénico Superior estão registados, por Janossy, restos desta espécie na Hungria, e do Pliocénico Médio na Alemanha e na antiga Checoslováquia, o que leva a supor que esta espécie tinha, durante o Pliocénico, uma distribuição mais continua que durante o Plistocénico e o Holocénico.

Seguidamente serão descritos os principais táxones, de características tropicais do Pliocénico e inícios do Plistocénico da Europa:

O Sagittarius serpentarius (secretário ou serpentário) é uma ave de rapina diurna, de grande porte, com cerca de 1,5 m de altura e cerca de 5 metros de envergadura, que habita todas as regiões da África, a sul do Sara, excepto zonas de floresta densa. O seu habitat preferencial é a savana, sendo também comum em áreas semi-desérticas ou com florestação esparsa. Apesar de não apresentar um dimorfismo sexual significativo, as fêmeas são ligeiramente menores que os machos. O crânio é pequeno, terminando num bico curto e encurvado típico das aves de rapina. As patas são muito longas e terminam em garras afiadas.

Os Trogoniformes, uma ordem com 39 espécies, pertencem a apenas a uma única família, Trogonidae. O grupo habita preferencialmente nas florestas. Estas aves têm geralmente um bico curto e encurvado e patas também curtas. Os dedos têm uma distribuição distintiva do grupo, estando o primeiro e o segundo dirigidos para

64 - Um relicto é uma espécie que foi muito abundante e diversificada no passado geológico, mas que na actualidade se encontra restrita a uma área mais pequena. No caso específico das grandes cegonhas, elas seriam, em tempos anteriores ao Plistocénico, muito mais abundantes e diversificadas espacialmente, mas no Plistocénico ficaram confinadas a pequenas áreas até se terem extinguido. 
a frente enquanto o terceiro e o quarto apontam para trás. A cauda é longa e as asas são curtas e arredondadas, apesar de bem adaptadas ao voo. As espécies deste grupo apresentam dimorfismo.

Os Musophagiformes constituem uma ordem de 23 espécies de turacos (ou tauracos), classificadas em cinco géneros pertencentes à família Musophagidae. Actualmente, a distribuição dos turacos está limitada à região sub-sahariana. Habitam a savana e as florestas abertas. Anteriormente pertencente à ordem dos cuculiformes, este grupo foi elevado a ordem pela taxonomia de Sibley-Alhquist. Os turacos alimentam-se essencialmente de frutos, mas também podem consumir insectos e outros pequenos invertebrados. Apesar de terem as asas curtas, estas aves são boas voadoras.

A ordem dos Psittaciformes inclui 360 espécies classificadas em 80 géneros da família Psittacidae. De forma geral, os psitaciformes caracterizam-se por terem o bico encurvado, com a mandíbula superior recurvada sobre a inferior. Esta forma de bico é uma adaptação à alimentação à base de sementes e frutos. Os psittaciformes têm distribuição geográfica vasta, ocupando as regiões quentes e temperadas de todos os continentes. A maior biodiversidade deste grupo encontra-se na Oceânia e na América Central e do Sul. A única espécie nativa do Hemisfério Norte é o Conuropsis carolinensis (Periquito-da-Carolina), originário do Sudeste da América do Norte, que se extinguiu no início do século XX. A origem deste grupo está datada do Cretácico, com a descoberta, nos Estados Unidos (no Wyoming), de uma mandíbula de um animal semelhante aos actuais piriquitões. É na Europa que se encontra a maior abundância de fósseis destas aves e os esqueletos completos mais antigos foram encontrados na Alemanha e na Inglaterra e datam do Eocénico. A taxonomia tradicional subdividia esta ordem em duas famílias: Psittacidae e Cacatuidae. A taxonomia de Sibley-Alhquist, condensa todos os géneros de psitaciformes na família Psittacidae.

A ordem dos Coliiformes está representada actualmente pela família Coliidae e suas seis espécies, classificadas em dois géneros (o género Urocolius e Colius). 0 grupo constituído por aves de pequeno porte inclui os rabos-de-junco (género Colius), que são nativos de África e actualmente confinadas à região subsariana. Estas aves alimentam-se de frutos e de rebentos e caracterizam-se por terem longas penas 
na cauda e pela morfologia das patas traseiras. Os coliiformes distinguem-se das restantes aves pela capacidade de inverter a orientação do primeiro e do quarto dedos. O registo fóssil indica que este grupo surgiu no Eocénico, há cerca de 55 milhões de anos. Foi um grupo muito diversificado desde o Paleocénio ao Miocénico. As seis espécies existentes são o que resta deste grupo, pelo que se podem considerar como "fósseis vivos".

Os francolins são aves da família Phasianidae e da ordem dos galiformes, típicas do Velho Mundo, classificadas no género Francolinus, que inclui 41 espécies, das quais 36 são exclusivas do continente africano e 7 são endémicas da Namíbia. Os seus habitat naturais são as florestas secas tropicais ou subtropicais e florestas subtropicais ou tropicais húmidas de baixa altitude. As espécies do género Francolinus são essencialmente terrestres e voam apenas em caso de extrema necessidade. A sua plumagem é em tons de castanho, que oferece excelente camufllagem nas zonas de savana e vegetação rasteira onde normalmente habitam. Alimentam-se basicamente de sementes e outros materiais vegetais e de pequenos insectos.

\section{As Aves de Características Frias da Europa}

Na Europa Ocidental os elementos típicos do Plistocénico Inferior e no Médio são o Corvus antecorax e a Perdix paleoperdix, encontrados em França (Mas Rambault), em camadas do Plistocénico Inferior e Médio, (Mourer-Chauviré) e na Espanha, em Atapuerca.

Na Europa Central, durante o Plistocénico Inferior e Médio, domina a subfamília dos Tetraoninae ${ }^{65}$, encontrados na Polónia. Estas aves estavam Adaptadas a climas muito frios. Janossy (1974) definiu uma sucessão dos Tetaorinae que evoluíram até às formas recentes (MOURER - CHAUVIRÉ, 1993, p. 56): o primeiro antepassado do actual Tetrao urogallus foi o Tetrao macropus, do Pliocénico, depois o Tetrao praeurogallus, que viveu desde o Pliocénico Superior até aos inícios do Plistocénico Médio, e finalmente o Tetrao urogallus, que apareceu no Plistocénico

65 Os Tetraoninae apareceram ainda no Pliocénico Inferior, na zona da Polónia. 
Médio. No caso dos Lyrurus tetrix, tiveram origem no Tetrao (Lyrurus) conjugens, que apareceu no Pliocénico e deu origem ao Lyrurus partium, que viveu do Pliocénico Superior, ao início do Plistocénico Médio; foi neste período que apareceu o Lyrurus tetrix (Tetraz-Lira).

No caso do Lagopus lagopus e do Lagopus mutus, conhecem-se, na Polónia (Weze) restos datados do Pliocénico do género Lagopus, sem atribuição de espécie. Estes fósseis serão os antepassados do L. lagopus e do L. mutus. Foram descobertos, já do Pliocénico Superior, fósseis de uma espécie deste género, o Lagopus atavus. Os vestígios mais antigos da actual espécie Lagopus lagopus foram encontrados em França (Les Valerots) e na Polónia (Kozi Grzbiet). A outra espécie deste género ainda existente (L. mutus) terá tido a sua origem em regiões de montanha, durante o interglaciar Mindel-Riss, uma vez que ambas as espécies ocorrem nas mesmas localidades (Fage, na França e Hunas, na Alemanha), desde o estádio glaciário Riss (MOURER - CHAUVIRÈ, 1993, p. 57).Tetrastes praebonasia, o antepassado da actual espécie Tetrastes bonasia, foi encontrado em vários locais do início do Plistocénico Médio, na Europa Central e na Europa Ocidental, nas localidades de Hundsheim, na Aústria, Tarkö, na Hungria, Montoussé 3, nos Pirenéus Franceses, e em Kozi Grzbiet, na Polónia (MOURER - CHAUVIRÉ, 1993, p. 57). Neste último caso a atribuição da espécie T. praebonasia apresenta algumas dúvidas. Segundo Janossy (1976), a actual espécie, Tetrastes bonasia, apenas se conhece a partir do interglaciar Riss-Würm, na Europa Central. Na Europa Ociental, mais especificamente em França, apenas aparece no Holocénico.

Os Tetraoninae estão sempre presentes nas avifaunas da Europa Central durante o Pliostocénico Inferior e no Médio, enquanto na Europa Ocidental só esporadicamente é que ocorrem (MOURER - CHAUVIRÉ, 1993, p. 57). Disto é exemplo o Lyrurus cf. Partium (Senèze, França), Lagopus lagopus (Les Valerots, França), Tetrao urugallus, Lyrurus tetrix e Tetrastes praebonasia (Montoussé 3, França). No entanto, estas aves não são determinantes no contexto da avifauna da altura. Por exemplo, eles estão totalmente ausentes da rica fauna, de características frias, de Saint-EstèveJanson, no Sul de França (MOURER - CHAUVIRÉ, 1993, p. 57).

Os vestígios mais antigos de Tetraoninae da Europa Ocidental foram encontrados no Sul de França, no interglaciar Mindel-Riss. Estes vestígios aparecem associados a faunas florestais. Tornaram-se mais frequentes durante o estádio glaciar 
do Riss e, já no Würm, as espécies Lagopus lagopus e Lagopus mutus tornam-se nos elementos mais comuns da avifauna deste período (MOURER - CHAUVIRÉ, 1993, p. 57).

Outra das espécies mais frequentes na Europa Ocidental é o Corvus antecocorax, antecessor do Corvus corax. Curiosamente esta espécie é quase ausente na Europa Central. Janossy, em 1986, refere a presença de Corvus cf antecorax em Tarkö, mas, em trabalhos prévios considerou que os restos do grande corvídeo de Tarkö pertenciam à subespécie extinta Corvus pliocaenus janossyi. Segundo Janossy (1979) o actual Corvus corax apenas é conhecido em poucas jazidas do Würm (MOURER - CHAUVIRÉ, 1993, p. 57).

De entre a avifauna europeia de características frias destaca-se a Coruja-dasneves (Nyctea scandiaca), encontrada em França (Bourgade), em terrenos do Plistocénico Inferior (MOURER - CHAUVIRÉ, 1980). Também aparece em Espanha, na Gruta de Erralla, em Gibraltar e em Romanelli.

Outra espécie característica de climas frios da zona mediterrânica é o corvídeo Pyrrhocorax graculus (a gralha alpina), que actualmente está confinada às zonas de montanha superiores aos 1400 metros de altitude, mas na altura das glaciações terá vivido em altitudes bem mais baixas, possivelmente até ao nível do mar. Na Europa Central, já durante o Pliocénico Inferior e o Médio, aparecem alguns fósseis de Pyrrhocorax aff. graculus e Pyrrhocorax graculus vetus, em Csarnota, Betfia2, méhész, Tarkö, Hundsheim e stranska Skala. No entanto, na Europa Ocidental este corvídeo terá aparecido apenas no Plistocénico Médio, sendo os restos encontrados na jazida de Saint-Estève-Janson, em França, muito abundantes.

Foi principalmente durante o último estádio glaciar do Würm que se encontram as espécies frias, das quais se destacam o Lagopus lagopus (a mais diversificada), Lagopus mutus, Nyctea scandiata e o Pyrrhocorax graculus. Em contrapartida os tetraoninae (Tetrao urugallus e o Lyrurus tetrix) decrescem nos períodos frios de máxima glaciação para voltarem a se desenvolver no fim do Würm e durante o Holocénico. Durante o Würm, numa altura fria, o lagopus mutus prevaleceu na Hungria e em França e o Lagopus lagopus na Hungria, em França e na Bélgica (MOURER - CHAUVIRÉ, 1993, p. 59).

Durante o Würm toda a parte Norte da Europa estava coberta por um grande manto de gelo e as espécies marinhas, como o Fulmarus glacialis, o Clangula 
hyemalis, a Melanita fusca, a Melanita nigra, a Somateria mollissima, a Branta bernicla, a Branta ruficolis e o Plautus alle, mais os géneros: Phalaropus, Stercorarius, Larus, entre outros, provavelmente nidificavam ao longo das costas do Atlântico, desde a Grã-Bretanha a Gibraltar e nas costas, ao norte do Mediterrâneo.

A Alca-Imperial (Pinguinus impennis), extinta no século XIX, habitava as costas do Atlântico e do Mediterrâneo, como o prova os restos datados do Plistocénico encontrados na Europa do Norte, em Portugal, em Espanha e em Itália.

As ilhas mediterrâneas não estavam muito distantes do continente e talvez por isso mesmo não se têm encontrado muitas espécies de aves endémicas do Plistocénico. De entre os passeriformes, uma subespécie de Corvus antecorax, viveu em Ibiza até ao Holocénico, enquanto se registou uma nova espécie da família Fringillidae, em Maiorca e, possivelmente, uma nova subespécie de Garrulus glandarius, na ilha de Creta.

De entre as espécies que já não vivem nestas ilhas, ou que muito raramente aparecem, destaca-se a Otis tarda, encontrada em Malta, em Ibiza e no Chipre, onde seria muito abundante durante o Plistocénico. Com excepção da Coturnix coturnix, que é uma ave migratória, e do Palaeocryptonix sp, encontrados em terrenos do Pliocénico Superior de Ibiza, a avifauna fóssil das Ilhas mediterrâneas caracteriza-se pela ausência dos Phasianidae.

Comparando a avifauna plistocénica da Europa com a de Portugal, verica-se a ocorrência dos principais grupos, quer em Portugal, quer no resto da Europa (anexo $\mathrm{Vl}$ ), em especial os corvídeos e, destes, o género Pyrrhocorax e Corvus.

A grande diferença que se observa entre as espécies portuguesas e as do resto da Europa é que se verifica um predomínio de espécies de climas mais frios no Centro da Europa e de climas mais temperados, em Portugal (Anexo VI), resultado da maior intensidade das glaciações.

No que respeita ao número de jazidas com avifauna, a grande diferença entre Portugal e o resto da Europa é que em Portugal existem sobretrudo jazidas do Plistocénico Superior. Do Plistocénico Médio existe apenas uma e, do Plistocénico Inferior, não se conhece, até agora, qualquer jazida com avifauna (quadro 56).

Em relação à totalidade das jazidas com aves plistocénicas, Portugal já apresenta um número significativo de jazidas, situando-se em sétimo, num total de 24 países europeus, com aves plistocénicas (gráfico 88), fruto do aumento das 
investigações e publicações de jazidas com fauna, a partir do final dos anos 70 do século passado.

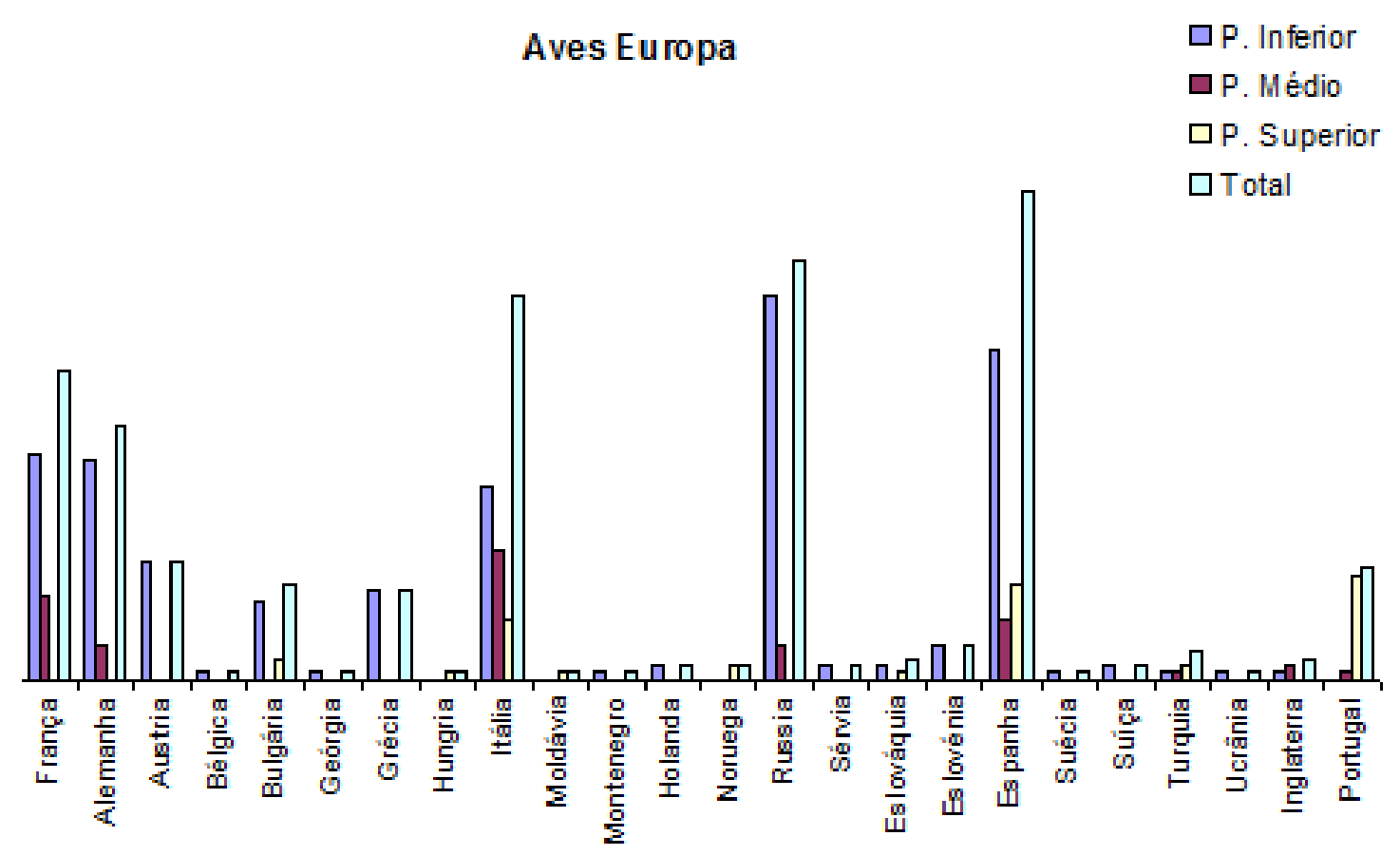

Gráfico 88 - Número de jazidas com avifauna na Europa (segundo Tyrberg, 2006 e os dados obtidos neste trabalho). 


\section{4 - Condicionantes Tafonómicas, Arqueológicas e Geológicas}

A amostra estudada é constituída na sua grande maioria por elementos do esqueleto apendicular. Este facto deve-se essencialmente a factores tafonómicos, porque, por um lado, estes ossos preservam-se com mais facilidade que outros, pois são mais resistentes, e, por outro, por razões de robustez e de anatonomia, estes ossos são menos destruídos pelo homem, no caso das espécies caçadas por este.

Com muito poucas excepções, como é o caso da Gruta do Pego do Diabo, quase a totalidade dos ossos estudados não apresentam indícios de terem tido uma acção antrópica. O facto de existirem associações fósseis de carnívoros conjuntamente com a avifauna plistocénica e de a maioria dos restos analisados serem de espécies que frequentam grutas, sugere acumulações naturais e não antrópicas, fruto de caça.

A quase totalidade das fracturas aponta para que tenham sido causadas pela pressão dos sedimentos, não tendo sido detectadas, com excepção de um resto na Gruta da Columbeira e de dois na Gruta do Pego do Diabo, marcas evidentes de corte, de fogo, ou de dentes de carnívoros, o que vem reforçar a hipótese de acumulações naturais dos restos estudados.

Desta forma, pode concluir-se que a maioria dos restos de aves plistocénicas encontrados nas grutas tenham resultem essencialmente de factores internos aos indivíduos (morte), alguma quantidade destes restos terão tido origem em factores externos aos indivíduos, resultantes de aprisionamento nas grutas e apenas uma pequena parte terá tido origem em factores externos aos indivíduos, resultantes da caça de carnívoros ou de humanos.

Após a morte dos indivíduos, os seus restos ósseos terão sido capturas e transportados pelos sedimentos que entraram nas grutas onde se encontram, incorporando-os e passando pelos mesmos processos de diagéneses que esses sedimentos passaram até ao presente. 


\section{5 - Indicadores paleoambientais}

Foi feito um estudo do tipo de clima a que as diferentes espécies estão associadas, contabilizando a totalidade do número mínimo de indivíduos cada espécie e depois foi feita a distribuição pelos climas associados.

Assim, verificou-se um maior número de indivíduos associados a climas temperados, logo seguidos por indivíduos relacionados com climas frios. O número de indivíduos associados a climas quentes é reduzido (gráfico 89)

No que respeita a climas húmidos ou secos, verifica-se um claro predomínio de indivíduos de espécies associadas a climas secos e poucos de espécies que vivem em climas húmidos (gráfico90) verificam-se, uma inversão destes valores nas jazidas localizadas junto à costa, o que se compreende pela situação geográfica.

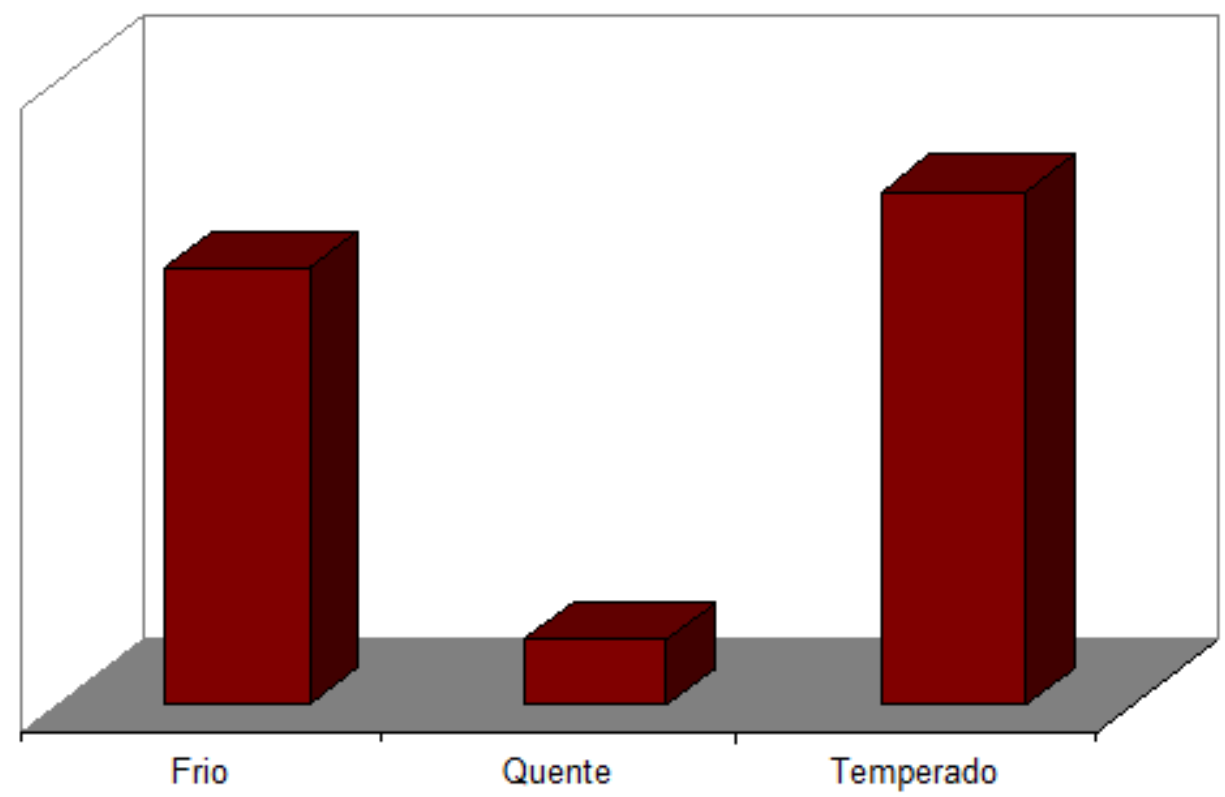

Gráfico 89 - Quantidade de espécies características dos diferentes tipos de climas térmicos. 


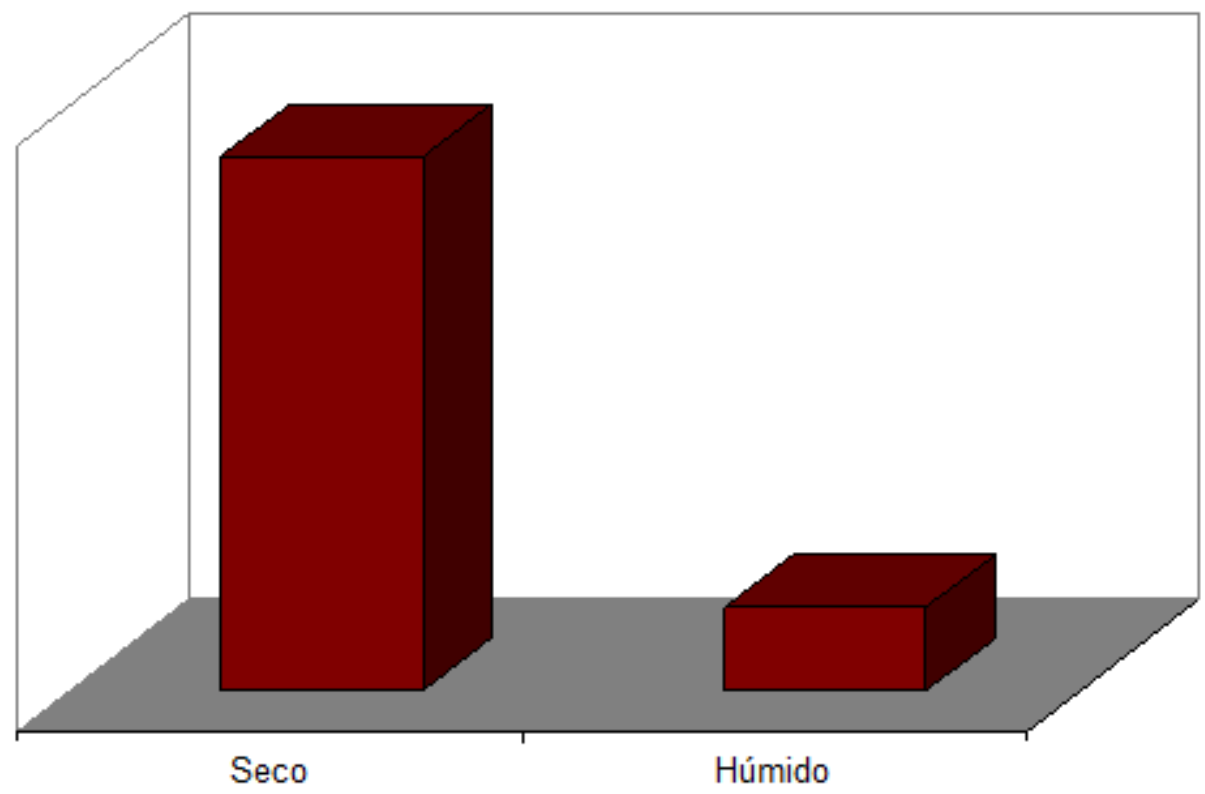

Gráfico 90 - Quantidade de espécies características dos diferentes tipo de climas, segundo o grau de humidade. 


\begin{tabular}{|c|c|c|c|c|c|}
\hline Espécie & Frio & Quente & Temperado & Seco & Húmido \\
\hline Anser albifrons & 1 & & & & 1 \\
\hline Anas platyrhynchos & & & 2 & & 2 \\
\hline Anas crecca & & & 1 & & 1 \\
\hline Melanita nigra & 1 & & & & 1 \\
\hline Tadorna tadorna & & & 18 & & 18 \\
\hline Somateria mollissima & 13 & & & & 13 \\
\hline Tadorna ferruginea & & & 3 & & 3 \\
\hline Cygnus olor & 1 & & & & 1 \\
\hline Perdix perdix & & & 3 & 3 & \\
\hline Alectoris rufa & & & 15 & 15 & \\
\hline Cf. Alectoris barbara & & 1 & & 1 & \\
\hline Cf. Phasianus colchicus & & & 1 & 1 & \\
\hline Coturnix coturnix & & 3 & & 3 & \\
\hline Tetrao urugalus & 1 & & & 1 & \\
\hline Lagopus lagopus & 2 & & & & 2 \\
\hline Lagopus mutus & 2 & & & & 2 \\
\hline Grus grus & & & 1 & & 1 \\
\hline Otis tarda & & & 1 & 1 & \\
\hline Pluvialis squatarola & & & 1 & & 1 \\
\hline Puffinus puffinus & 1 & & 1 & & 1 \\
\hline Phalacrocorax aristotelis & & & 5 & & 5 \\
\hline Phoenicopterus ruber & & 1 & & & 1 \\
\hline Vanellus vanellus & & & 1 & & 1 \\
\hline Pinguinus impennis & 1 & & & & 1 \\
\hline Cf. Aquila adalberti & & & 1 & 1 & \\
\hline Aquila chrysaetos & & & 3 & 3 & \\
\hline Falco tinuculus & & 1 & 2 & 2 & \\
\hline Falco rusticolus & 1 & & & 1 & \\
\hline Gyps fulvus & & & 1 & 1 & \\
\hline Milvus migrans & & & 1 & 1 & \\
\hline Tyto alba & & & 1 & 1 & \\
\hline Bubo bubo & 5 & & 5 & 5 & \\
\hline Athene noctua & & & 2 & 2 & \\
\hline Asio flammeus & 1 & & 1 & 1 & \\
\hline Strix aluco & & & 2 & 2 & \\
\hline Columba livia & & 20 & & 20 & \\
\hline Columba palumbus & & & 3 & 3 & \\
\hline Pyrrhocorax pyrrhocorax & 58 & & & 58 & \\
\hline Pyrrhocorax graculus & 60 & & & 60 & \\
\hline Corvus monedula & & & 57 & 57 & \\
\hline Corvus corone & & & 5 & 5 & \\
\hline Corvus frugilegus & & & 6 & 6 & \\
\hline Corvus corax & & & 5 & 5 & \\
\hline Pica pica & & & 16 & 16 & \\
\hline Garrulus glandarius & & & 3 & 3 & \\
\hline Cf. Cyanopica cyana & & & 1 & 1 & \\
\hline Turdus iliacus & 1 & & 7 & 7 & \\
\hline Turdus pilaris & 10 & & 10 & 10 & \\
\hline Turdus philomelos & 6 & & 6 & 6 & \\
\hline Turdus merula & 12 & & 12 & 12 & \\
\hline Carduelis carduelis & & & 1 & 1 & \\
\hline Ptyonoprogne rupestris & & & 1 & 1 & \\
\hline Numenius phaeopus & & & 1 & 1 & \\
\hline Cuculus canorus & & & 1 & 1 & \\
\hline Motacilla alba & & & 1 & 1 & \\
\hline Picus viridis & & & 1 & 1 & \\
\hline
\end{tabular}

Quadro 55 - Distribuição dos indivíduos de especies identificadas neste trabalho, com os climas a que estas estão associadas.. 


\section{6 - Distribuição temporal das aves plistocénicas portuguesas}

Pela distribuição temporal das espécies (quadro59) verifica-se que muitas das espécies, em especial as dos columbiformes (Columba livia) e passeriformes (várias) a parecem em todas ou quase todas as datações para as jazidas com aves plistocénicas.

No caso dos galliformes, apesar de terem espécies que também aparecem em várias datações, eles aparecem, no registo fóssil português, só a partir dos 80000 BP. O Corvus corax, aparece a partir dos cerca de $30000 \mathrm{BP}$, no entanto há o registo do seu antepassado (o Corvus antecorax), nos 240000 BP (MARKS et al. 2000 e 2002).

As aves de rapina aparecem também bem distribuídas, em especial as nocturnas como a Athene noctua e Bubo bubo, que aparecem desde os 240000 BP. No entanto outras rapinas aparecem mais tarde, como é o caso da Aquila chrysaetos que aparece a partir dos $80000 \mathrm{BP}$.

No caso dos anseriformes as espécies aparecem mais pontualmente, como é o caso do M. albellos, que aparece nos 240000 BP, da Tadorna tadorna ou o Cignus olor, que só aparecem nos 80000 BP ou do Anas platyrhynchos, que aparece nos 50000 30000 BP ou a Melania nigra, que aparece nos 80000 aos 25000 BP. Estas duas últimas espécies, as únicas que aparecem em mais que uma datação, são as espécies de anseriformes com uma distribuição temporal mais dilatada.

Os gruiformes aparecem apenas entre os 30000 e os $17000 \mathrm{BP}$, enquanto os charadriiformes aparecem entre os 80000 e os 30000 BP, o que se explica pela datação da Gruta da Furninha e da Gruta da Figueira-Brava, onde estão concentradas as espécies desta ordem, factor este explicado pela localização geográfica destas jazidas, na costa, onde ocorrem em maior número as espécies de charadriiformes. A mesma situação verifica-se com os phoenicopteriformes.

Outros grupos que ocorrem em menor frequência, como os ciconiformes só reconhecidos há 240000 BP (MARKS et al. 2000 e 2002), os cuculiformes, que ocorrem entre 80000 e os 17 000, os caprimulgiformes, há cerca de 240000 BP (MARKS et al. 2000 e 2002) ou os piciformes que aparecem desde os 240000 BP (MARKS et al. 2000 e 2002) e os 30000 BP, apresentam menos espécies, que ocorrem 
pontualmente em poucas jazidas, não apresentando, por essa razão, uma distribuição temporal muito dilatada. Por outro lado a sua própria distribuição espacial, é também, por vezes, pequena.

Estes dados não permitem ter uma visão mais alargada para determinadas datações, as de 240 000, 80 000, 50000 e 10 000, porque existem poucas espécies identificadas, devido ao facto de só se conhecer uma jazida para cada um deles. Para o período entre os cerca de 30000 aos 17000 BP existe um total de nove jazidas com várias espécies reconhecidas, permitindo ter dados mais completos para se conhecer a avifauna deste período (gráfico 91).

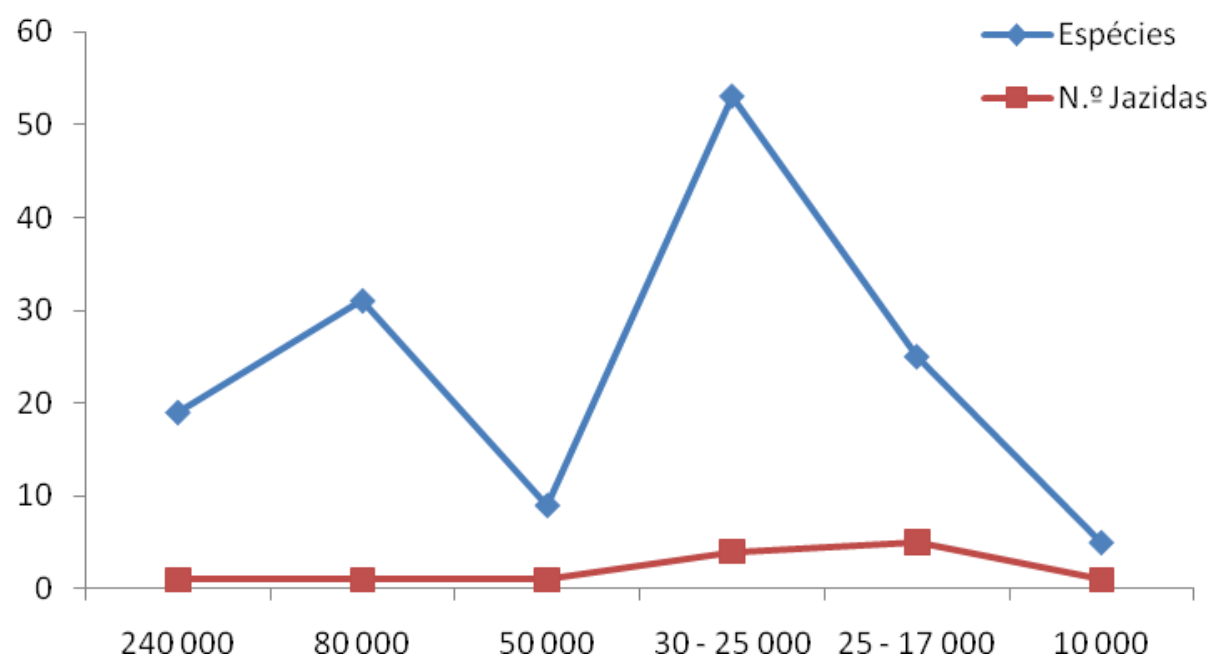

Gráfico 91 - Número de espécies identificadas e número de jazidas para os restos de avifauna plistocénica com datações absolutas 


\begin{tabular}{|c|c|c|c|c|c|c|c|}
\hline & & & & & & & $\square$ Clima temperado \\
\hline & 240 & 80 & 50 & $30-25$ & 25-17 & 10 & \\
\hline Anser albifrons & & & & * & & & $\square$ Clima frio \\
\hline Anas platyrhynchos & & & $*$ & * & & & \\
\hline Anas crecca & & * & & & & & $\square$ Clima muito frio \\
\hline Melanita nigra & & * & & * & & & \\
\hline Melanitta fusca & & & & * & & & \\
\hline Clangula hyemalis & & & & * & & & \\
\hline Mergus albellus & * & & & & & & \\
\hline Tadorna tadorna & & * & $*$ & & & & \\
\hline Somateria mollissima & & * & & & & & \\
\hline Tadorna ferruginea & & * & & & & & \\
\hline Cygnus olor & * & * & & & & & \\
\hline Perdix perdix & & & & * & * & & \\
\hline Alectoris rufa & & * & $*$ & * & * & $*(?)$ & \\
\hline cf. Alectoris barbara & & & & * & & & \\
\hline cf. Phasianus colchicus & & & & * & & & \\
\hline Coturnix coturnix & & * & & * & & & \\
\hline Tetrao urugalus & & & & & * & & \\
\hline Lagopus lagopus & & & & & * & & \\
\hline Lagopus mutus & & & & * & & & \\
\hline Grus primigenia & & & & * & & & \\
\hline Grus Grus & & & & & * & & \\
\hline Otis tarda & & & & & * & & \\
\hline Pluvialis squatarola & & & & * & & & \\
\hline Puffinus puffinus & & * & & * & & & \\
\hline Puffinus holeae & & & & * & & & \\
\hline Puffinus Kulhi & * & & & & & & \\
\hline Sula bassana & & & & * & & & \\
\hline Phalacrocorax carbo & & & & * & & & \\
\hline Phalacrocorax aristotelis & & * & & * & & & \\
\hline Phoenicopterus ruber & & * & & & & & \\
\hline Gavia stellata & & & & * & & & \\
\hline Vanellus vanellus & & & & & & & \\
\hline Scolopax rusticola & * & & & * & & & \\
\hline Calidris canutus & & & & * & & & \\
\hline Larusfuscus & & & & * & & & \\
\hline Alca torda & & & & * & & & \\
\hline Pinguinus impennis & & * & & * & & & \\
\hline Podiceps nigrollis & & & & * & & & \\
\hline
\end{tabular}




\begin{tabular}{|c|c|c|c|c|c|c|c|}
\hline & & & & & & & $\square$ Clima temperado \\
\hline & 240 & 80 & 50 & $30-25$ & 25-17 & 10 & \\
\hline cf. Aquila adalberti & & & & & * & & $\square$ Clima frio \\
\hline Aquila chrysaetos & & * & & * & & & \\
\hline Buteo buteo & * & & & & & & $\square$ Clima muito frio \\
\hline Accipiter nisus & & & & * & & & \\
\hline Haliaeetus albicilla & * & & & & & & \\
\hline Hieraaetus fasciatus & & & & * & & & \\
\hline Falco tinuculus & & * & & * & * & & \\
\hline Falco rusticolus & & & & & * & & \\
\hline Aegypius monachus & & & & & * & & \\
\hline Gyps fulvus & & $*$ & & * & & & \\
\hline Milvus migrans & & & & * & * & & \\
\hline Tyto alba & & * & & & & & \\
\hline Bubo bubo & * & * & & * & * & & \\
\hline Athene noctua & * & & $*$ & * & * & * & \\
\hline Asio flammeus & & $*$ & & & & & \\
\hline Strix aluco & & & & * & & & \\
\hline Columba livia & * & * & $*$ & * & * & & \\
\hline Columba palumbus & * & & $*$ & * & & * & \\
\hline Pyrrhocorax pyrrhocorax & & * & & * & * & & \\
\hline Pyrrhocorax graculus & * & * & & * & * & & \\
\hline Corvus monedula & * & * & & * & * & & \\
\hline Corvus corone & * & * & $*$ & * & * & & \\
\hline Corvus frugilegus & * & * & $*$ & * & $*$ & & \\
\hline Corvus antecorax & * & & & & & & \\
\hline Corvus corax & & & & * & * & $*(?)$ & \\
\hline Pica pica & * & * & $*$ & * & * & * & \\
\hline Garrulus glandarius & & & & * & * & & \\
\hline cf. Cyanopica cyana & & & & * & & & \\
\hline Turdus iliacus & & * & & * & & & \\
\hline Turdus pilaris & & * & & * & & & \\
\hline Turdus philomelos & & * & & * & & & \\
\hline Turdus merula & & * & & * & * & & \\
\hline Sturnus vulgaris & & & & & & & \\
\hline Carduelis carduelis & & & & * & & & \\
\hline Ptyonoprogne rupestris & & & & * & & & \\
\hline Numenius phaeopus & & * & & * & & & \\
\hline Cuculus canorus & & * & & & * & & \\
\hline Motacilla alba & & & & & * & & \\
\hline Egreta alba & * & & & & & & \\
\hline Caprimulgus europaeus & * & & & & & & \\
\hline Picus viridus & * & & & * & & & \\
\hline
\end{tabular}

Quadro 56- Distribuição das espécies identificadas no Plistocénico português segundo a datação das jazidas onde foram reconhecidas. Ás espécies identificadas neste trabalhos, acrescentaram-se as espécies conhecidas na bibliografia sobre avifauna plistocénica de Portugal. 


\section{1 - DISCUSSÃo}

Neste ponto pretende-se discutir alguns assuntos abordados na investigação que esteve na origem desta tese. Os temas que julgamos constituir motivo de discussão são: a relação do tamanho entre as aves plistocénicas e as actuais; o lugar das aves na dieta do homem paleolítico, os contextos das acumulações fósseis das aves plistocénicas portuguesas e a presença de três espécies identificadas neste estudo: Cyanopica cyana, Alectoris barbara e Pinguinus impennis.

Verifica-se, pela comparação entre os restos ósseos da avifauna plistocénica portuguesa estudados nesta investigação e os ossos das colecções de referência consultadas, que o tamanho das aves plistocénicas em relação às actuais não apresenta grandes diferenças.

No que diz respeito à robustez verifica-se semelhante situação não há grandes modificações. No entanto, existem duas excepções: o Phalacrocorax aristotelis e o Cygnus olor. No primeiro caso, os representantes actuais do género apresentam os úmeros mais robustos comparativamente aos restos estudados. No segundo caso, a situação é inversa, ou seja, o resto plistocénico estudado apresentase mais robusto que os da colecção de referência. No caso dos $P$. aristotelis os ossos da colecção de referência apresentam uma maior robustez em cerca de $13 \%$, enquanto o C. olor plistocénico apresenta um grau de robustez 15\% maior que os da colecção do CIPA.

Estes dados, quer os indicadores de robustez, quer os indicadores de tamanho, são discutíveis, tendo um valor mais indicativo do que conclusivo, uma vez que o número de restos plistocénicos, e o número de indivíduos da colecção de referência são reduzidos, pois a mostra do CIPA tem um número reduzido de espécimes. Todavia, este estudo fornece um esboço comparativo que indica uma diferença muito pequena em relação à robustez e tamanho das espécies plistocénicas identificadas neste estudo em comparação com as actuais, pois se houvesse grandes diferenças, essas seriam detectadas, mesmo estando perante 
amostras pequenas.

Qual a importância das aves na dieta do homem paleolítico? Estando, na maioria dos casos, os ossos das aves associados a ocupações humanas, terão sido estas as responsáveis pela presença das aves nos níveis plistocénicos das grutas estudadas?

Das espécies identificadas verifica-se, de um modo geral, que dominam os corvídeos, em especial os géneros Corvus e Pyrrhocorax. Podem-se distinguir dois grupos principais dos táxones identificados neste estudo: o primeiro constituído pelos anseriformes, columbiformes e galiformes, cuja maioria das espécies poderiam ter sido caçadas pelo homem; o segundo, constituído, por exemplo pelos passeriformes e pelos strigiformes, cuja maioria das espécies frequentam grutas e que teriam deixado os seus restos nas grutas e misturaram nos níveis estratigráficos com ocupação humana. Este segundo grupo é o que apresenta um maior número de restos e de indivíduos. Posto isto, pode concluir-se que é provável que as acumulações de restos de aves encontrados tenham origens naturais e não antrópicas, tanto mais que na quase totalidade dos ossos estudados não foram encontradas marcas de corte.

Discutem-se, assim, as causas das acumulações de avifauna plistocénica nas grutas portuguesas. Serão causas internas aos indivíduos? (morte nas grutas) ou serão externas aos indivíduos? (predação animal e humana ou cataclismos). Pelos táxones identificados, verifica-se, como já foi referido anteriormente, que a grande maioria das aves encontradas frequentavam as grutas. Há que referir ainda que quase não se encontram marcas de predação nos ossos, por outro, há a registar ocorrência de carnívoros em algumas das grutas, carnívoros estes que poderão ser responsáveis pela presença de algumas das espécies que não frequentavam as grutas (o primeiro grupo referido no parágrafo anterior) e, finalmente, a grande parte dos ossos partidos são resultado da pressão dos sedimentos e das próprias características desses ossos. A estratigrafia apresentada na bibliografia das jazidas não denota qualquer anomalia resultado de um qualquer cataclismo.

É de salientar a identificação de restos de três espécies: Pinguinus impennis, Cyanopica cyana, Alectoris rufa e de Phasianus colchicus. Discute-se, no primeiro caso qual a real importância paleoecológica, no segundo a identificação e as suas relações com as populações actuais e a terceira a sua identificação. 
Aquando do estudo dos restos de aves, não publicados, por Harlé (HARLÉ, 1910/11) foi encontrado, entre restos de pequenos mamíferos, um fragmento proximal de úmero esquerdo com um comprimento máximo de $42,9 \mathrm{~mm}$, de características osteológicas semelhantes às dos alcídeos (PIMENTA, FIGUEIREDO \& MORENO GARCÍA, 2009). A diáfise é oval longa e com um pronunciado espalmamento longitudinal, a articulação proximal do úmero é projectada lateral e ventralmente e a crista peitoral é pouco proeminente em relação à margem dorsal. Verificou-se pela comparação com os úmeros das espécies de alcídeos da colecção do CIPA (Uria algae, Alca torda, Fratercula artica, Alle alle), que este úmero é maior e apresenta características morfológicas mais próximas da $A$. torda, que de todas as espécies desta família é a que mais se aproxima do $P$. impennis, quer morfologicamente, quer filogeneticamente, distinguindo-se no tamanho, pois enquanto a $A$. torda pesa cerca de $800 \mathrm{~g}$, o $P$. impennis pesava perto de $5 \mathrm{~kg}$ (STRAUCH, 1985; MOUM, 2002 apud PIMENTA, FIGUEIREDO \& MORENO GARCÍA, 2009). Um posterior estudo osteológico foi feito, comparando as características observáveis neste fragmento de úmero com a descrição dos úmeros de $P$. impennis em COHEN \& SERJEANTSON, 1996 e verificou-se que essas características são as mesmas descritas por estes autores. Posto isto, ficou então definida a classificação taxonómica deste resto como Pinguinus impennis.

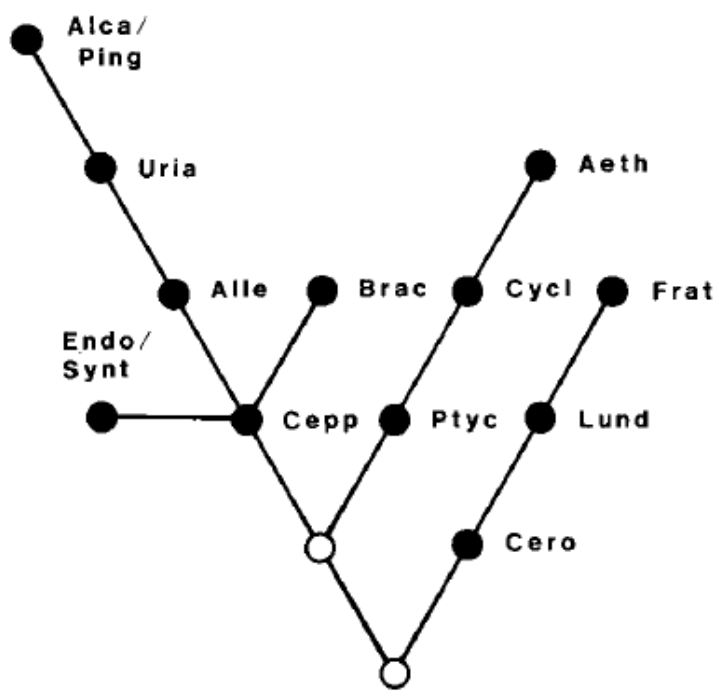

Fig. 88 - Árvore filogenética da família dos alcídeos, definida por 23 caracteres (in SATRAUCH, 1985, p. 531). Neste cladograma pode-se observar a proximidade filogenénica entre o género Pinguinus e o género Alca. Abreviaturas: Aeth = Aethia; $\mathrm{Brac}=$ Brachyramphus; Cepp = Cepphus; Cero = Cerorhinca; Cycl = Cyclorrhynchus; Endo = Endomychura; Frat = Fratercula; Lund $=$ Lunda, Ping = Pinguinus; Ptyc $=$ Ptychoramphus; Synt = Synthliboramphus. 
Discute-se agora qual a real importância paleoecológica desta espécie. Inicialmente, os naturalistas do século XIX, como Bonaparte, Temminck, Domont e Thienemann referem o P. impennis como uma espécie confinada ao Oceano Árctico (STEENSTRUP, 1855 apud BENGTSON, 1984). Actualmente esta espécie está assinalada, no estado fóssil, na Europa Ocidental (MOURER-CHAUVIRÉ E ANTUNES, 2000), na Escandinávia (BENGTSON, 1984), na Gronelândia (MELDEGARD, 1988), no Canadá (RICHARD \& STORNS, 1982), nos Estados Unidos (WEIGEL, 1958; BRADKORD, 1960 e HOBSON \& MONTEVECCHI, 1991). Pela razão de, inicialmente, ser referido como estando confinado ao Árctico ${ }^{66}$ foi associado a climas frios (STEENSTRUP, 1855 apud BENGTSON, 1984).

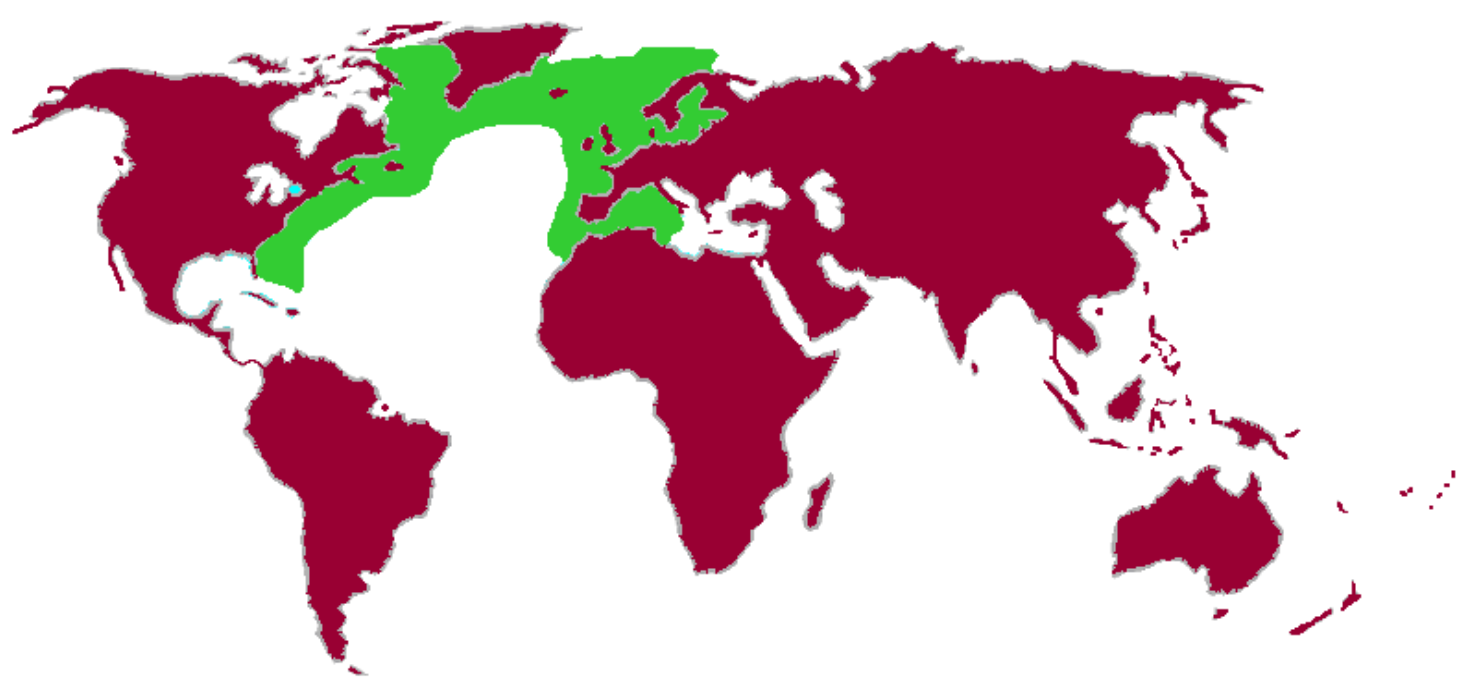

Fig. 89 - Possivel distribuição (a verde) do P. impennis (Plistocénico e Holocénico) segundo BENGTSON, 1984 e PIMENTA, FIGUEIREDO \& MORENO GARCÍA, 2009

O P. impennis extiguiu-se por volta do ano de 1844 , e os últimos casais foram observados em pequenas ilhas rochosas e rochedos da Islândia (BENGTSON, 1984), A sua própria extinção terá sido resultante de alterações climáticas (BENGTSON, 1984), que estão ligadas ao fim das glaciações ou terá sido a caça humana que terá influenciado o seu recuo para norte ${ }^{67}$, onde havia poucas ou nenhumas comunidades humanas?

660 que corresponde à realidade dos últimos representantes da espécie 67 Devido à sua dificuldade em andar em terra, o $P$. impennis era uma ave muito fácil de caçar, sobretudo em época de reprodução (PIMENTA, FIGUEIREDO \& MORENO, 2009) 
Está noticiada, como já foi referido, a descoberta de um resto de $P$. impennis na ilha do Porto Santo, no arquipélago da Madeira (PIEPER, 1985). Apesar de não haver uma datação para este achado, é o achado mais a sul desta espécie, que se conhece (PIMENTA, FIGUEIREDO \& MARENO, 2009), o que levanta questões acerca do seu paleoambiente restrito a águas frias. Terá esta espécie vivido também em zonas mais quentes ${ }^{68}$ ? Ou será que o resto da Madeira terá sido de um indivíduo que foi arrastado mais para sul?

Tendo em atenção estas questões (a presença em zonas mais quentes, como a Florida e a Madeira), no caso específico da presença do $P$. Impennis em Portugal Continental (Gruta da Figueira-Brava e Gruta da Furninha) pode dizer-se que aparecem em contexto de um clima mais frio que o actual. A Gruta da Furninha, com uma datação que ronda os 80000 inícios da última glaciação, apresenta outras aves relacionadas com climas mais frios, como é o caso da T. tadorna, que actualmente é residente nas Ilhas Britânicas e desde a costa atlântica da França à Dinamarca; a S. molíssima, que é residente na Escandinávia, Islândia e Ilhas Britânicas, o género Pyrrhocorax, em especial a espécie $P$. graculus associada à fauna glaciar e actualmente vive em zonas mais frias nas montanhas europeias, e os géneros Turdus e Gallinago, que apesar de se encontrarem em zonas da Europa do Sul, também são observáveis na Europa do Norte e na Escandinávia (GOODERS \& HARRIS, 1990). No caso da Gruta da Figueira-Brava, com datação que ronda os 30000 BP, já em na última glaciação, o registo de $P$. impennis aparece associado a faunas frias (CARDOSO, 1993; ANTUNES (ed.), 2000).

68 Não se pode esquecer que existe uma espécie de pinguim (pinguim-das-galápagos Spheniscus mendiculus) que vive $\mathrm{n}$ uma zona quente, junto do equador. 


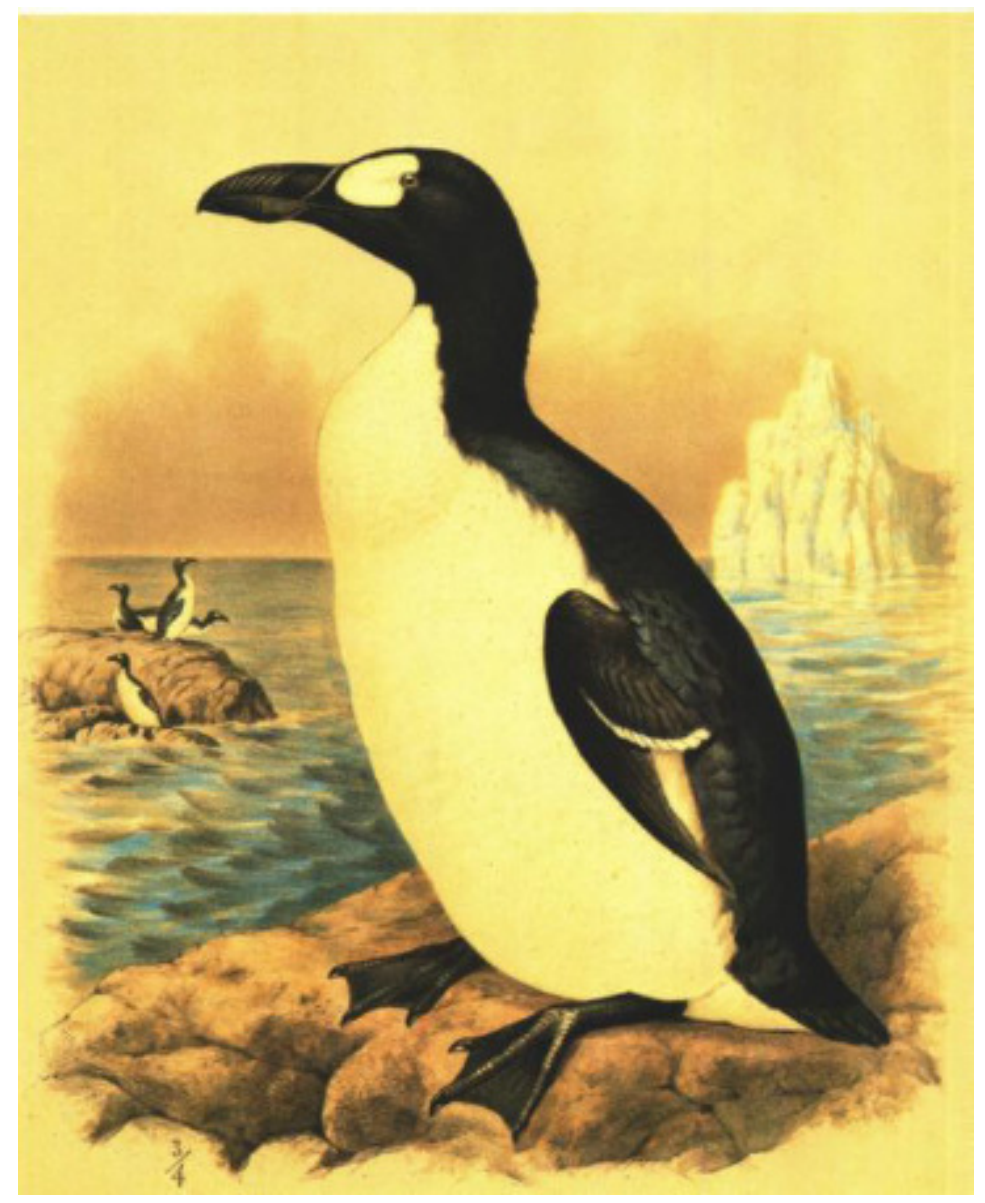

Fig. 90- Desenho de Pinguinus impennis. Autor: Charles B. Cory, publicado em "Beautiful and Curious Birds of the Word" (1881). Retirado de BENGTSON, 1984.

Uma outra questão é a presença de Cyanopica cyana. A presença desta espécie vem trazer um interessante dado acerca da avifauna plistocénica de Portugal, porque a presença desta espécie na Península Ibérica no Plistocénico é discutida devido à sua actual distribuição geográfica disruptiva. Esta distribuição é das mais notáveis entre as aves e tem sido tema de interesse desde meados do século XIX (FOK et al., 2002).

Actualmente, esta espécie está confinada a duas populações separadas: uma na Península Ibérica (Portugal e Sul da Espanha) e outra no oriente asiático (Sul da Rússia, Norte da Mongólia, China, Coreia e Japão) (HARRISON \& GREENSMITH, 1993). Para explicar esta situação existem duas teorias: uma que defende que a população da Península Ibérica foi estabelecida no século XVI, pela introdução da espécie pelos navegadores portugueses, que chegaram ao Extremo Oriente e trouxeram de lá alguns especímenes, introduzindo a espécie na Península Ibérica (SACARRÃO, 1974 apud FOK et al., 2002). Esta teoria é denominada a "teoria da 
introdução" (FOK et al., 2002); a segunda, a "teoria do refúgio" (FOK et al., 2002) defende que a população da Península é o resultado de um grupo europeu destas aves que se manteve em Portugal e na Espanha, onde encontrou um refúgio de climas mais quentes que no resto da Europa, onde as glaciações acabaram por extinguir a restante população (SACARRÃO, 1974; HARRISON, 1982).

A descoberta de restos ósseos de Cyanopica cyana em Gibraltar, em depósitos do Plistocénico Superior, com 44100 anos BP (COOPER \& VOOUS, 1999 apud FOK et al., 2002; COOPER, 2000 apud FOK et al., 2002), vieram comprovar que a espécie é nativa do Ocidente Europeu e não é uma introdução recente (COOPER \& VOOUS, 1999; COOPER, 2000). No entanto, a simples descoberta de restos desta espécie no Plistocénico peninsular pode excluir a "teoria da introdução", mas não exclui uma "teoria da reintrodução". Quer-se com isto dizer que uma população plistocénica europeia ter-se-a extinguido, mas, mais tarde, a espécie, terá sido reintroduzida pelos navegadores seiscentistas.

A reforçar a "teoria do refúgio" há a dizer que as alterações climáticas do Plistocénico têm sido apontadas como responsáveis pela existência de populações disjuntivas de animais em habitat de refúgio e que estas alterações têm um papel importante na diversificação intra-específica e na variedade das espécies (KLICKA \& ZINK, 1997; AVISE \& WALKER, 1998).

Um recente estudo genético (FOK et al., 2002) concluiu que o género Cyanopica forma um grupo monofilético bem definido e que a actual distribuição tão particular deve-se à fragmentação de uma população original contínua que se estendia desde a Península Ibérica ao Extremo Oriente, há cerca de 1,2 milhões de anos, pois os halótipos CR indicam duas unidades filogenéticas, uma correspondente à população asiática e a outra correspondente à população ibérica (FOK et al., 2002). Estas formas separaram-se a partir de uma clade basal de Cyanopica cyana, originando uma diferença genética clara entre as aves ibéricas e as asiáticas (FOK et al., 2002).

Esta divisão deveu-se às alterações climáticas provocadas pela última Idade do Gelo: a redução da temperatura foi tão acentuada que fez com que as populações desta espécie tivessem desaparecido da Europa de Leste e do Médio Oriente, resistindo apenas as populações situadas nos extremos do continente euro-asiático. Aí encontraram refúgio, pois as temperaturas eram mais toleráveis (FOK et al., 2002). 
Como todos os outros pequenos passeriformes, a classificação taxonómica deste resto (um fragmento proximal de um tibiotarso direito) torna-se difícil. No que respeita à classificação pelo tamanho, nota-se que o tamanho dos ossos da Cyanopica cyana é semelhante aos de algumas espécies de Turdus, no entanto, como pertencente a uma família distinta, os corvídeos, apresentam algumas características que permite diferencia-los dos turdídeos (ver ponto 9 - "Caracterização Osteológica dos Restos Identificados").

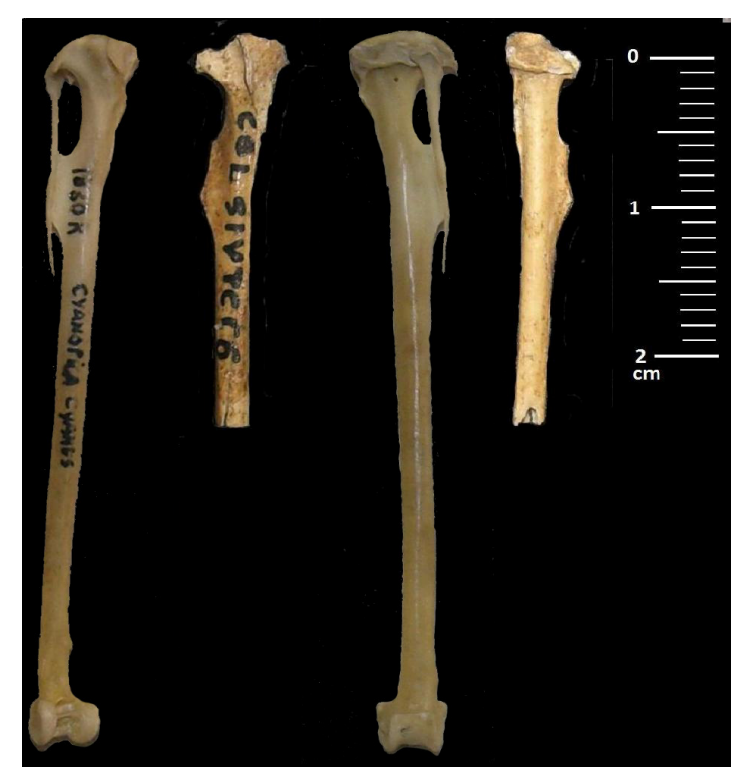

Fig. 91 - O resto de tibiotarso da Gruta Nova da Columbeira em comparação com o mesmo osso de um espécime actual. Vista caudal (esquerda) e vista cranial (direita). Fotografia: S. Figueiredo

A identificação de um resto como sendo de cf. Cyanopica cyana vem reforçar a teoria do "teoria do refúgio" para a actual população desta espécie, na Península Ibérica. A par do resto de Gibraltar, trata-se de um dos poucos restos plistocénicos conhecidos. 


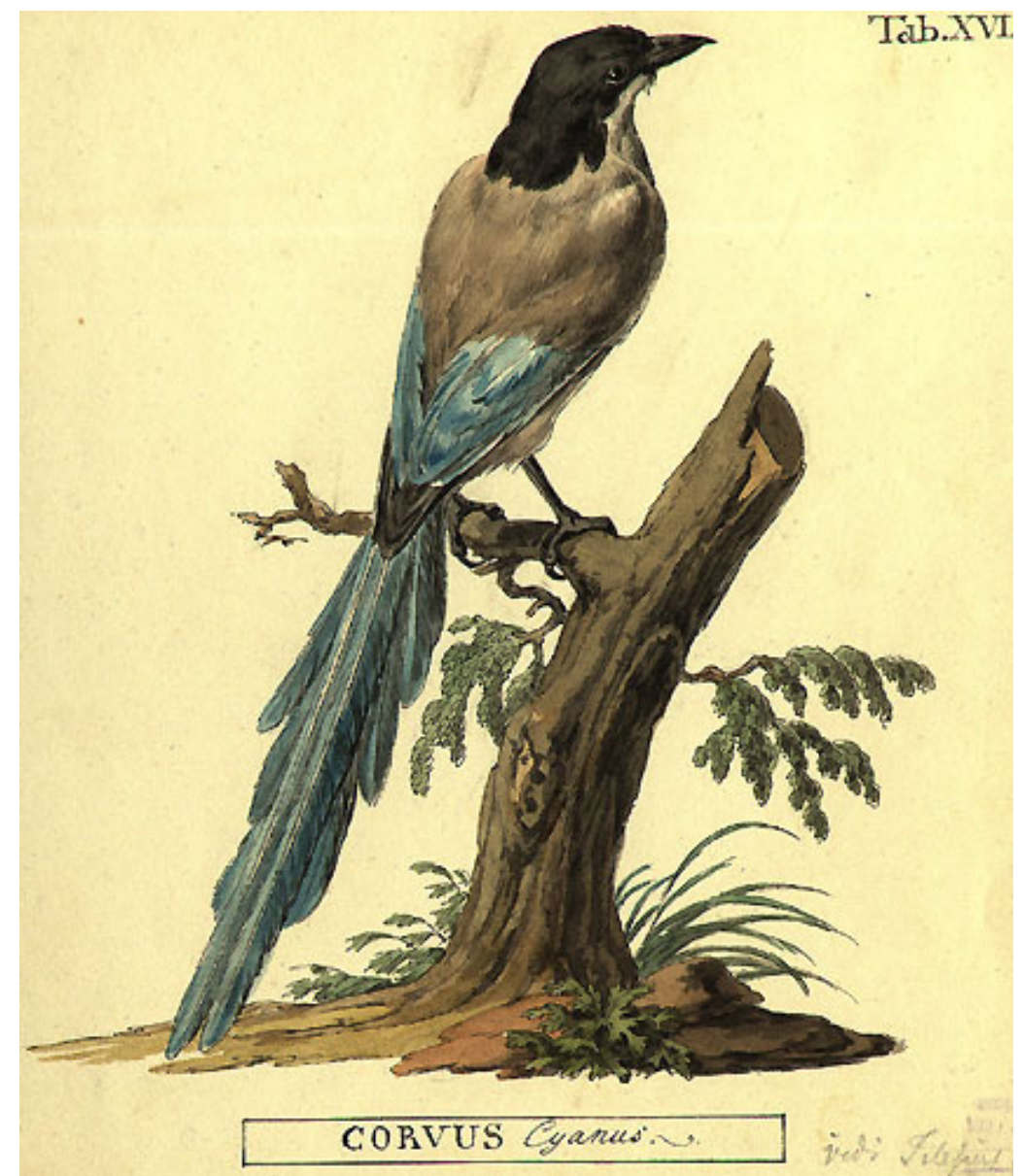

Fig. 92 - Desenho de Cyanopica Cyana. Autor: Peter Simon Pallas (1741-1811), zoólogo alemão que atribuiu a classificação científica desta espécie. Retirado de http://en.wikipedia.org/wiki/File:Cyanopica_cyanus_by_Peter_Simon_Pallas.jpg (imagem do domínio público)

A identificação de três ossos (um úmero e dois tarsometatarsos) na Gruta Nova da Columbeira e atribuídos a cf. Alectoris barbara, pode gerar alguma discussão. Tratam-se dos primeiros restos desta espécie identificados no plistocénico de Portugal. Esta é uma espécie que não ocorre actualmente e que está adaptada a climas quentes e secos. Esta atribuição taxonómica foi fundamentada com a osteometria e anatomia osteológica, bem como pela sua paleobiogeografia. Estes ossos apresentam as principais características ósseas do género Alectoris e medidas próximas da espécie $A$. barbara. Foi também feito um levantamento, na bibliografia, dos sítios plistocénicos europeus, com a presença de restos desta espécie, verificando-se a sua presença em várias jazidas espanholas, francesas e italianas, algumas delas a latitudes superiores à da Gruta Nova da Columbeira.

No Plistocénico europeu está registada em França (três jazidas), na Itália (duas jazidas) e na Espanha (cinco jazidas) (SANCHEZ-MARCO, 2004; TYBERG, 2006). 
Em França a espécie ocorre em Fontéchevade, próximo da costa oeste e em Orgnac 3 e Lazaret, perto da costa mediterrânea. Todas estas jazidas são do Paleolítico Inferior (Plistocénico Médio). Em Orgnac e Lazaret aparecem também restos de A. graeca, em Fontéchevade apenas aparecem restos de A.barbara (SANCHEZ-MARCO, 2004). Em Espanha a A. barbara está identificada em Abric Romani, (VILLALTA, 1964 apud TYBERG, 2006, VILLALTA, 1964 apud SANCHEZ-MARCO, 2007). Esta jazida, onde também foi identificada a Alectoris rufa, é um abrigo sob rocha situado perto de Barcelona (SANCHEZ-MARCO, 2004), os restos de A. barbara são provenientes de um nível mustierense (Plistocénico Superior), do interestadial Würm II-III, com datação por TL de 48+/-3 Ka BP (SANCHEZ-MARCO, 2004). Também perto de Barcelona situase outra cavidade, Toll, do Plistocénco Médio (interestadial Würm I - II) onde também foram identificados restos de A. barbara e A. graeca (VILLALTA, 1964 apud SANCHEZMARCO, 2007). Outra jazida, na região de Barcelona, com presença de A. barbara é a Cueva de la Guinéu, já do Epipaleolítico (Holocénico) e onde se identificou também A. rufa/graeca (ZAPATA, 1998 apud TYBERG, 2006). Cingle Vermell é a quarta jazida da região de Barcelona que apresenta restos de $A$. barbara, neste caso não se identificaram restos de outras espécies do género Alectoris (VILLALTA, 1964 apud SANCHEZ-MARCO, 2004). Trata-se de um abrigo perto de Vilanova de Sau, onde a avifauna foi encontrada num nível datado do tardiglacial (11 620 +/- 140 BP), com características mediterrâneas (SANCHEZ-MARCO, 2004). Outro sítio com restos de $A$. barbara na Península Ibérica é Devil's Tower, em Gibraltar (BATE, 1928 apud SANCHEZ-MARCO, 2004). Também nesta jazida não se encontram outras espécies de Alectoris (BATE, 1928 apud SANCHEZ-MARCO, 2004). Trata-se de um abrigo do Plistocénico Superior (SANCHEZ-MARCO, 2004) com os restos desta espécie localizados mais a sul, na Europa. Em Itália aparece na Grotta del Fossellone, perto de Lázio, no nível Aurignacense (Plistocénico Superior), juntamente com outras espécies de Alectoris, a A. graeca, a A. rufa e A. sp (ALHAIQUE, 1998 apud TYBERG, 2006) e na Grotta Breuil, perto de Latina, no nível 3 atribuído ao Mustierense, também Plistocénico Superior e associado também a outras espécies de Alectori, a A. graeca e a A. rufa s (RECCHI, 1996 apud TYBERG, 2006).

A distribuição actual de A. barbara está confinada ao Norte de África e na Europa apenas está presente no Sul da Espanha, em Gibraltar, onde foi introduzida, e na Sardenha, onde não se sabe se é endémica ou se também foi introduzida pelo 
homem (GOODERS e HARRIS, 1990, p. 167). Quer na Sardenha quer em Gibraltar não existem outras espécies de perdizes (GOODERS e HARRIS, 1990, p. 167).

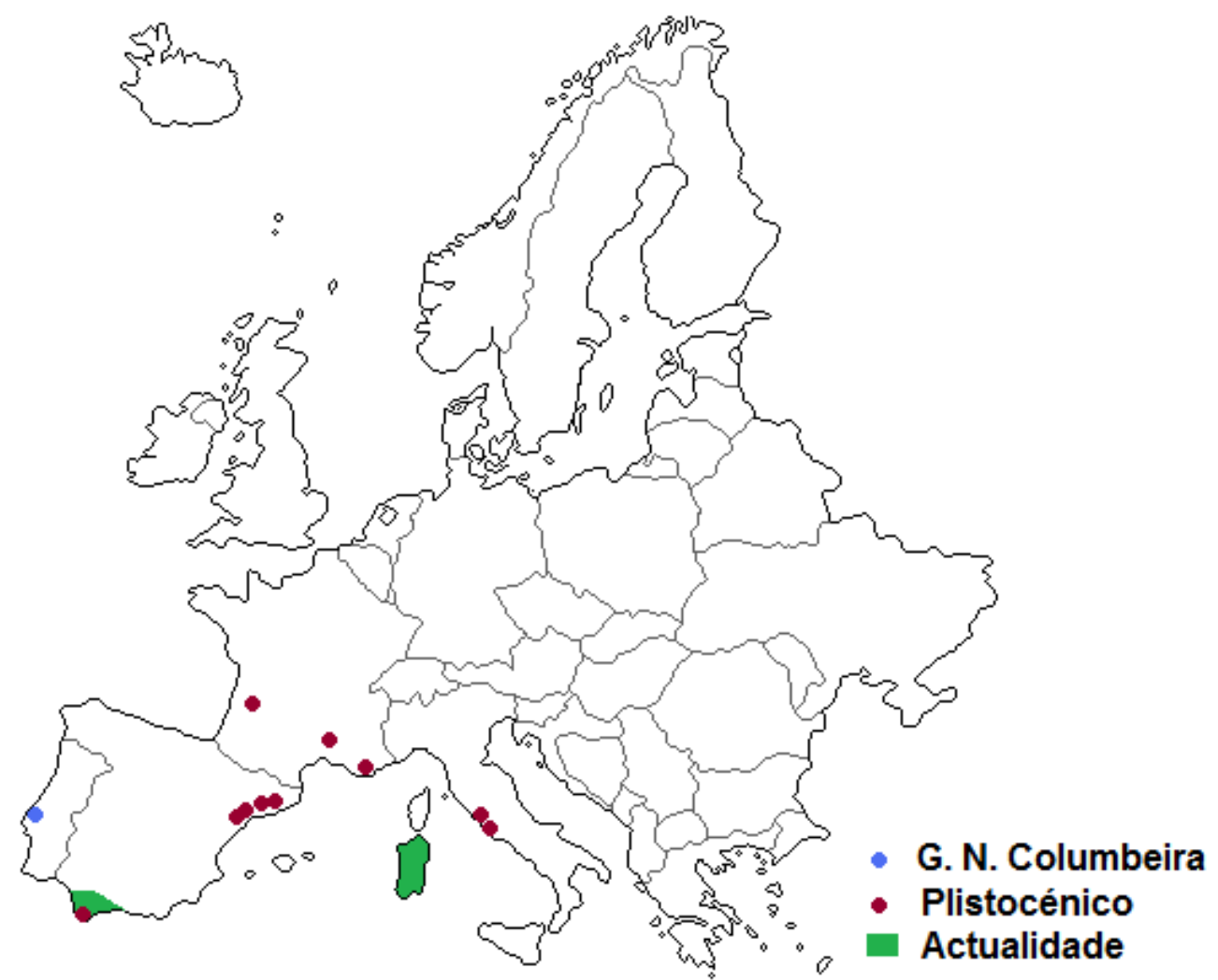

Fig. 93 - Distribuição actual e plistocénica de A. Barbara na Europa, segundo GOODERS \& HARRIS, 1990 e TYRBERG, T. (2006).

A distribuição actual (Sul da Europa e Norte de África) deixa perceber que esta espécie está mais ligada a ambientes mais quentes e secos, como já foi referido. Relacionando esta questão com os paleoambientes da Gruta Nova da Columbeira, chega-se à conclusão que as espécies de avifauna são maioritariamente de clima seco, temperado a frio, como aliás se comprova pela ocorrência de algumas espécies de aves características de climas secos, como a A. rufa e a C. coturnix, e de climas mais frios, como o Phyrrhocorax graculus e o Lagopus mutus, e que os grandes mamíferos indicam "um biótopo frio com uma componente de secura, embora não muito acentuada" (CARDOSO, 1993, pp. 527).

No que se refere à datação da Gruta Nova da Columbeira, com valores que variam entre os cerca de 26000 e os cerca de 28000 BP (DELIBRIAS et al. 1986) (ver anexo 4), verifica-se que se enquadra nas datações das jazidas ibéricas com $A$. barbara. Por outro lado, a situação geográfica da Gruta Nova da Columbeira, a relativa proximidade do mar e a latitude, é idêntica à da maioria das jazidas 
europeias com esta espécie, e também na Columbeira existe a presença de outras espécies do género Alectoris, neste caso, A. rufa.

No que diz respeito ao estudo osteológico, os restos identificados (um úmero e dois tarsometatarso) apresentam características típicas do género Alectoris e, pelo tamanho, aproxima os restos identificados com a espécie A. barbara.

O úmero apresenta a fossa pneumatricial pequena, oval e marginal, alargase na parte proximal, logo a partir do fim da diáfise, para o lado ventral. Tem o tubérculo ventral pequeno e a margem caudal curta. A cabeça do úmero é arredondada e bem definida, central e larga. A íncisura capital é bem definida, de forma rectangular e larga, mas pouco funda. Os côndilos distais não são muito proeminentes e o sulco tricipital e a fossa do olecrânio pouco marcados. Em termos osteométricos verifica-se, como se pode ver nos gráficos 92 e 93, que o úmero atribuído a $A$. barbara se aproxima dos úmeros das $A$. barbara actuais e diferem das $A$. rufa (das actuais e das plistocénicas).

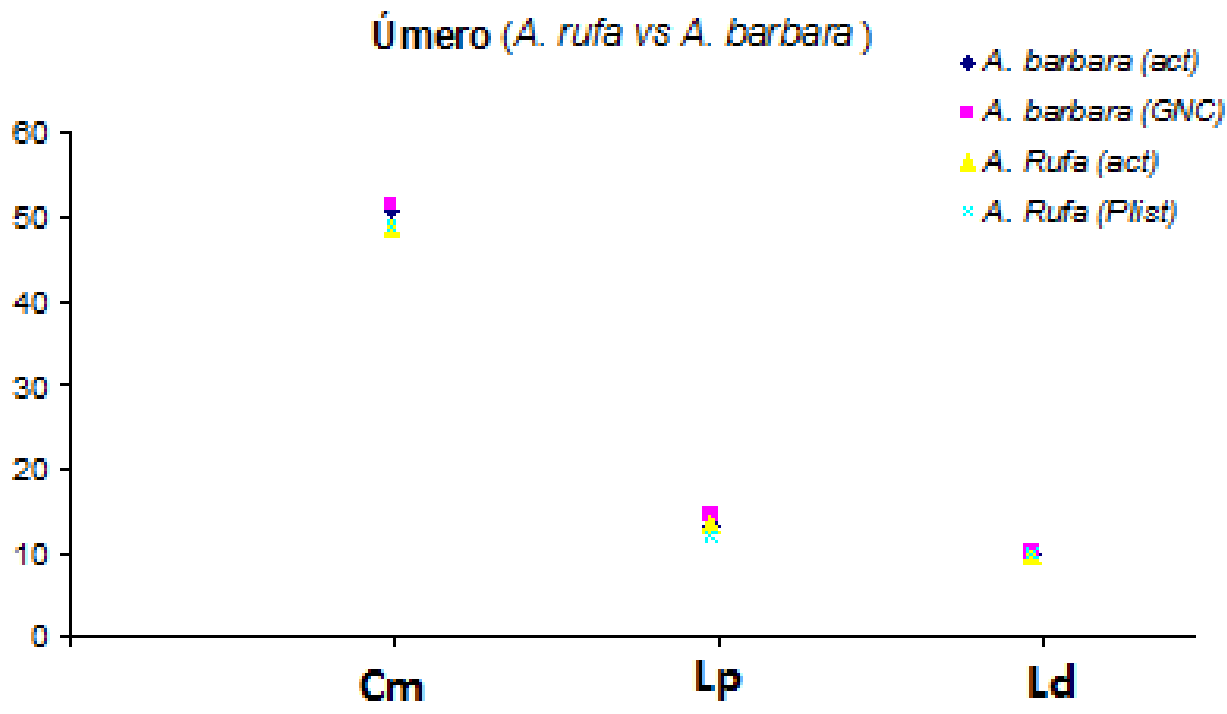

Gráfico 92 - Comparação osteométrica entre os úmeros de $A$. barbara identificadas na Columbeira e actuais e os úmeros das $A$. rufa actuais e plistocénicas $(\mathrm{cm}$ - comprimento máximo; Lp - largura proximal; Ld - largura distal). 


\section{Úmero}

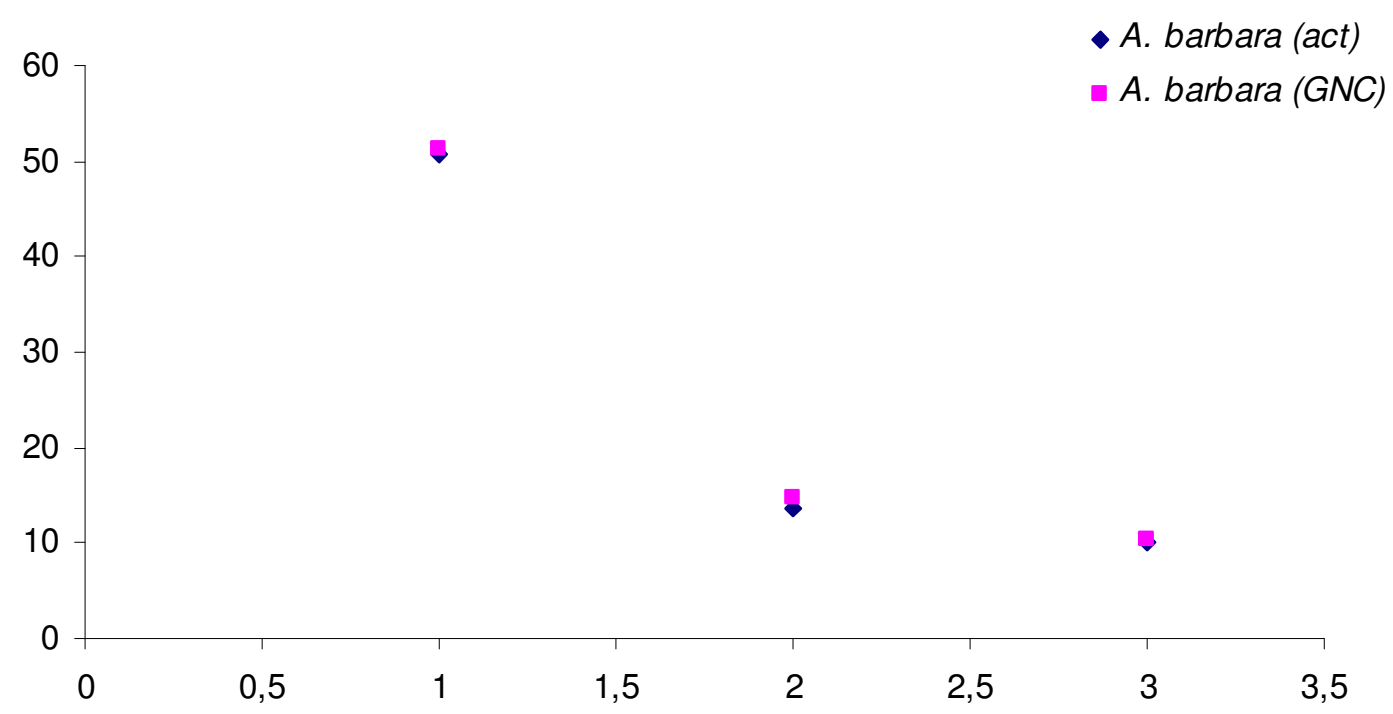

Gráfico 93- Comparação osteométrica entre os úmeros de $A$. barbara identificadas na Columbeira e actuais. (cm - comprimento máximo; Lp - largura proximal; Ld - largura distal).

O tarsometatarso apresenta a tróclea para o III dígito, mais saliente, a parte proximal rectangular, com a elevação intercondilar saliente e as arestas calcaneanas proeminentes. A fossa infracotilar é proeminente e tem um tubérculo, na tróclea do II dígito. O forâmen vascular distal pequeno. Em termos osteométrico verifica-se, com os tarsometatarsos a mesma situação do úmero, como se pode ver no gráfico 94 e 95. Ou seja, a A. Barbara da Columbeira aproxima-se das A. Barbara actuais e difere das $A$. rufa (das actuais e das plistocénicas). Com a excepção do comprimento máximo, que se destaca em relação a todas as outras. 


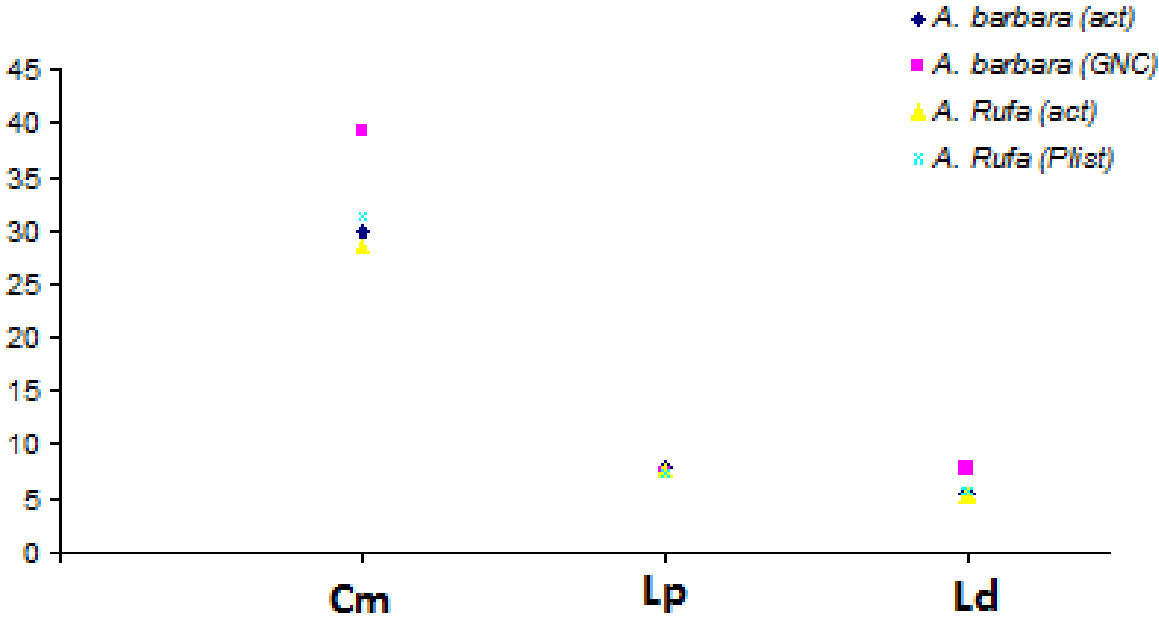

Gráfico 94 - Comparação osteométrica entre os tarsometatarsos de A. barbara identificadas na Columbeira e actuais e os úmeros das $A$. rufa actuais e plistocénicas ( $\mathrm{cm}$ - comprimento máximo; Lp - largura proximal; Ld - largura distal).

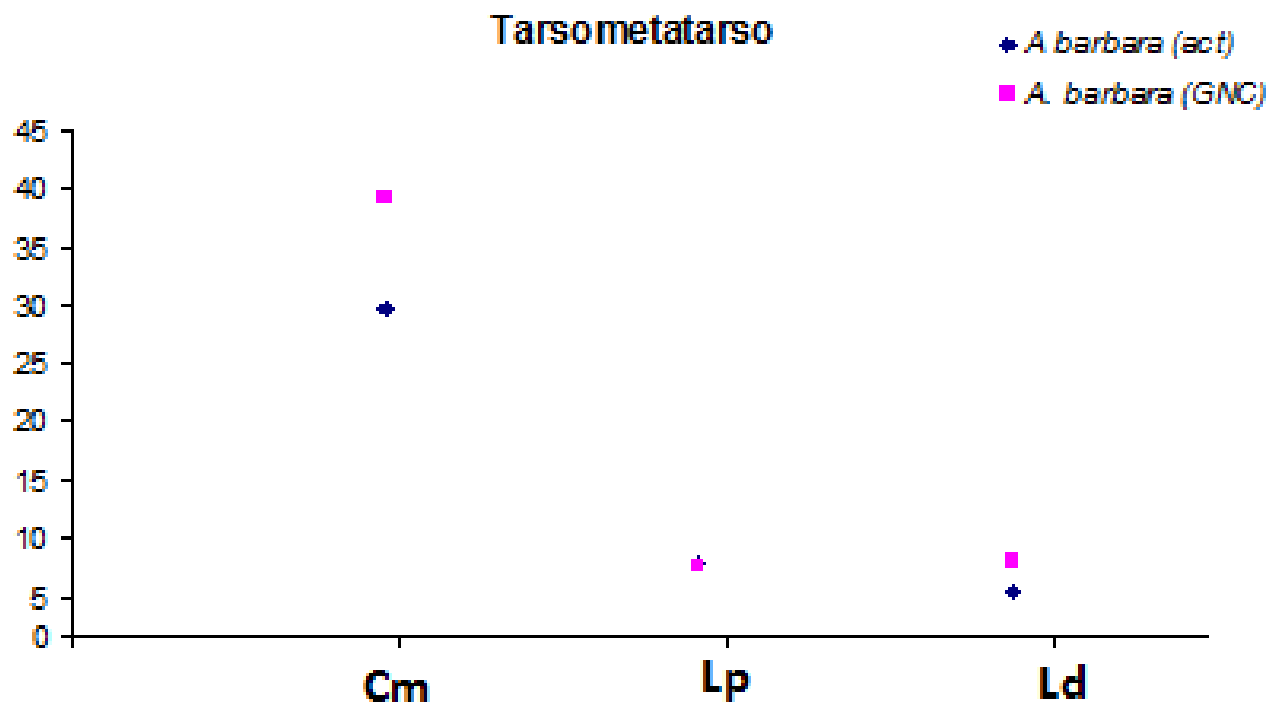

Gráfico 95 - Comparação osteométrica entre os úmeros de $A$. barbara identificadas na Columbeira e actuais. (cm - comprimento máximo; Lp - largura proximal; Ld - largura distal). 


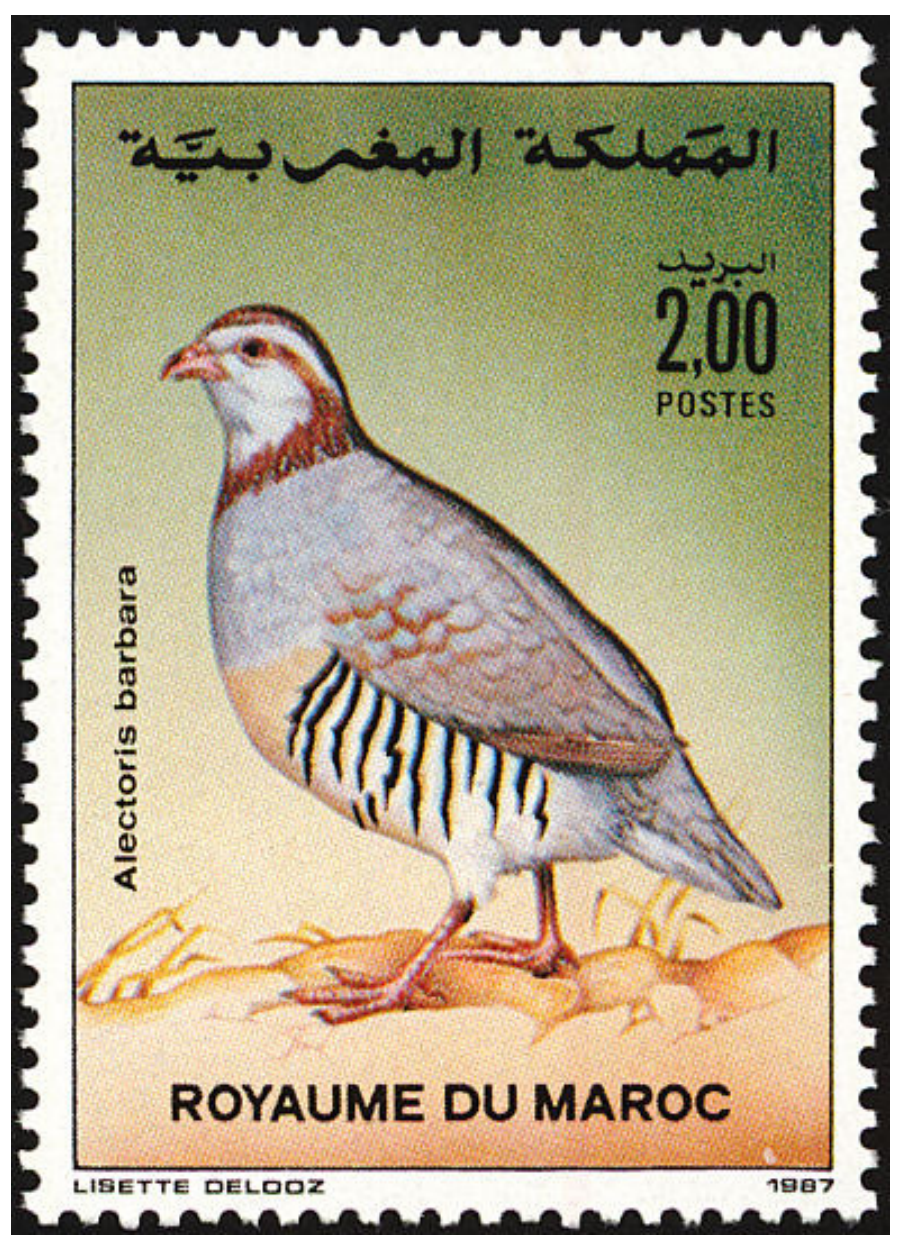

Fig. 94 - Selo de Marrocos com a representação da A. barbara. Autor: Lisete Delooz . Retirado de www.birdtheme.org/country/morocco.html (imagem do domínio público).

A identificação de um resto (um úmero) da Gruta do Pego do Diabo como cf. Phasianus colchicus, pode também gerar discussão. Trata-se, tal como caso anterior, do primeiro osso desta espécie identificados no plistocénico português. Apesar de o faisão existir actualmente em Portugal, a ocorrência desta espécie deve-se a uma introdução antrópica.

A actual biogeografia do Phasianus colchicus caracteriza-se por uma distribuição alargada, no hemisfério Norte: toda a Europa, com excepção da Islândia, do Norte da Escandinávia, da Grécia, do Sul da Itália, Sardanha e Sicília, Sul de Espanha e Portugal; Centro e Extremo Oriental da Ásia e Norte dos estados Unidos da América (GOODERS \& HARRIS, 1990; HARRISON \& GREENSMITH, 1993).

A paleobiogeografia desta espécie, no Plistocénico europeu está confinada a sete jazidas distribuídas pela França, Croácia, Bulgária, Geórgia e Israel. Na França está referencia a presença de Phasianus colchicus em Fontéchevade, jazida localizada no Sudoeste de França e datada do Plistocénico Médio. Na Croácia existem dois sitio, 
onde foram identificados restos desta espécie: Sandalja, junto á costa mediterrânica e Vindija, localizado a norte do país, ambas do final do Plistocénico Superior, com níveis de ocupação solutrense. Na Bulgária o Phasianus colchicus aparecem em Bevetashka, em estratigrafia do Plistocénico Superior, com níveis mustierenses, datados de há cerca de 70 mil BP, e em Cave N: 0 16, com datações entre os 40 e os 18 mil BP. Na Geórgia, esta espécie está referenciada numa jazida também com ocupação mustierense (Okumi). Por fim, em Israel, aparece em Hayomin, um sítio datado de 12 a 14 mil BP (SANCHEZ-MARCO, 2004; TYBERG, 2006).

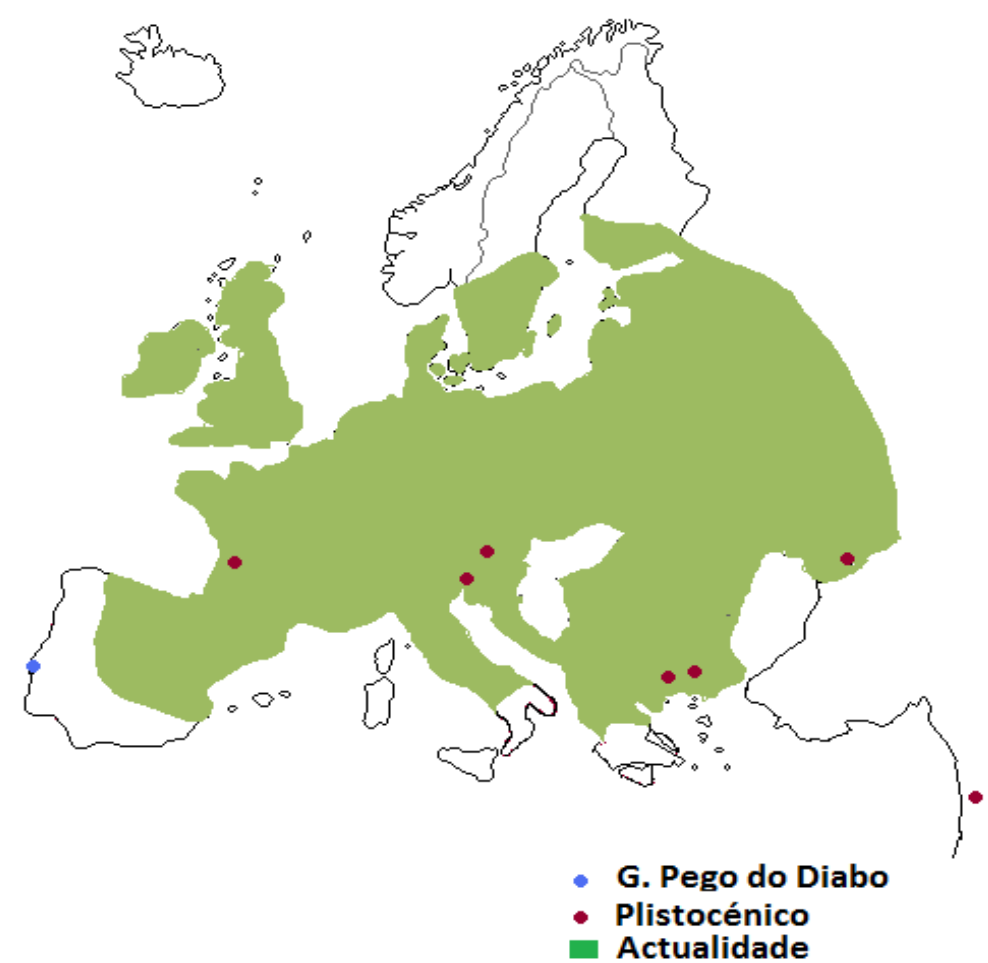

Fig. 95 - Mapa da Europa com a distribuição actual do Phasianus colchicus e as jazidas plistocénicas com a presença desta espécie.

A atribuição deste do fragmento de úmero da Gruta do Pego do Diabo á espécie Phasianus colchicus teve por base o estudo biométrico e a comparação das características osteológicas entre o fragmento da Gruta do Pego do Diabo e os exemplares actuais de algumas espécies de galliformes.

Em relação ao estudo biométrico, verificou-se uma grande proximidade da medida da largura proximal (a única possível, dado o estado de conservação do osso) do resto do Pego do Diabo, com a mesma medida de Phasianus colchicus actuais e divergindo de outras espécies de galliformes próximas (gráfico 96). 
Úmero P. colchicus

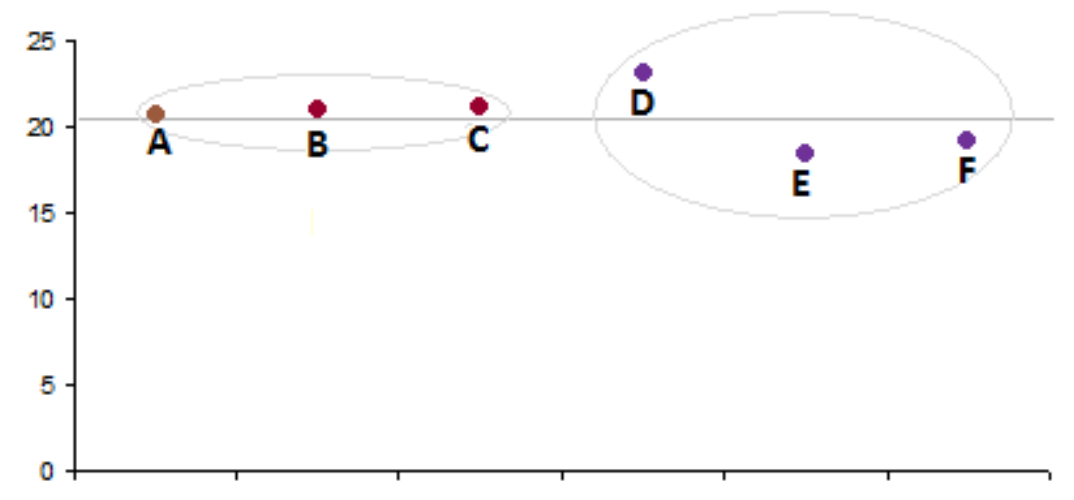

Gráfico 96 - Comparação osteométrica (medida da largura proximal) do resto ósseo da Gruta do Pego do Diabo (A), com exemplares do Phasianus colchicus actuais (B e C) e de outras espécies: Numida meleagris (D), Tetrao tetrax (E) e Gallus gallus $q$ (F).

Pelo estudo comparativo conclui-se que existe um conjunto de características comuns entre os resto da Gruta do Pego do Diabo e os úmeros de Phasiuanus colchicus (fig. 80). Comparando com outras espécies de galliformes, como o Numida meleagris, o Tetrao tetrax e o Gallus gallus (fêmea), encontra-se, em comum, as características dos galliformes, mas verificam-se algumas pequenas diferenças que 0 aproximam ao Phasianus colchicus, como o formato da cabeça do úmero, da crista bicipital e a da incisura capital.
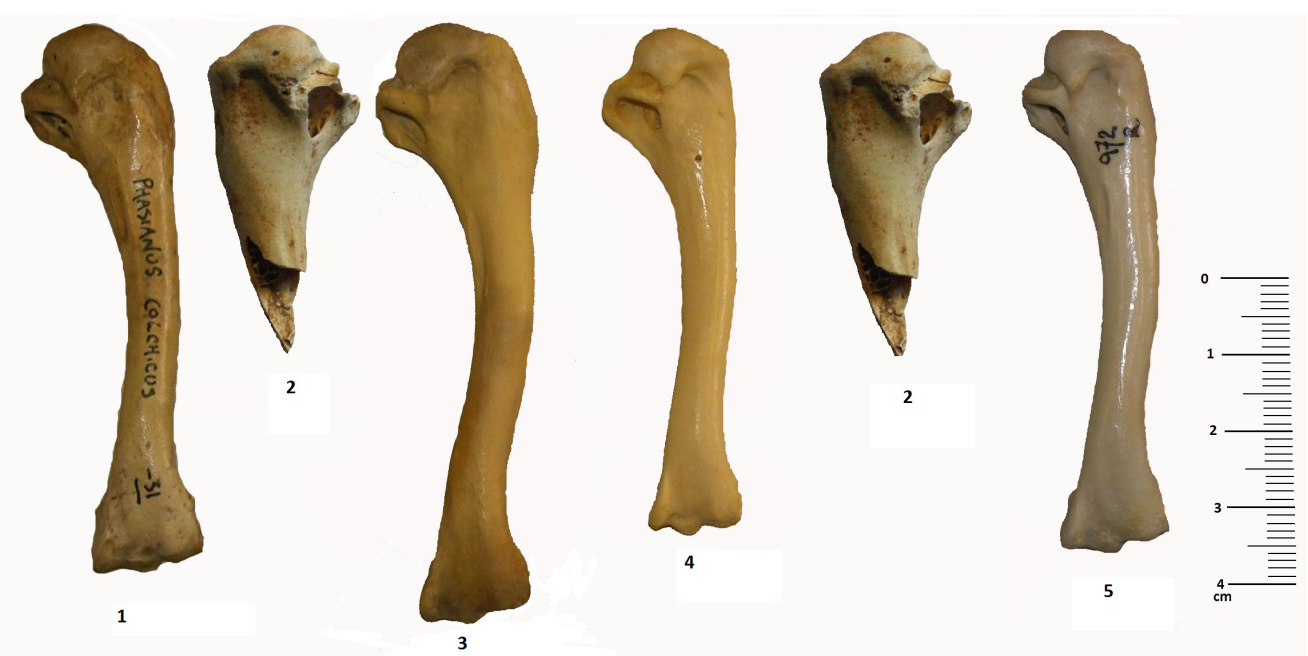

Fig. 96- Comparação do resto ósseo da Gruta do Pego do Diabo (2), com exemplares do Phasianus colchicus actual (1) e de outras espécies: Numida meleagris (3), Tetrao tetrax (4) e Gallus gallus $q$ (5) da cvolecção do CIPA. Vista cranial. Fotografia: S. Figueiredo. 


\section{CONCLUSÕES}

A avifauna fóssil de Portugal é, no geral, mal conhecida, existindo poucos estudos sobre esta temática publicados. No entanto, a partir da década de $1980^{69}$, verificou-se um aumento de publicações, especialmente sobre a avifauna plistocénica portuguesa. Dos períodos geológicos anteriores pouco se continua a conhecer: do Mesozóico, existe apenas a referência a alguns dentes atribuídos a Cf. Archaeopteryx, provenientes da Mina da Guimarota, perto de Leiria. Do Cenozóico, conhecem-se seis jazidas com restos de aves: uma do Eocénico e cinco do Miocénico. Do Plistocénico, estão identificadas mais jazidas com restos de aves (quinze), o que permite ter uma ideia da diversidade da avifauna que existia na altura, ao contrário dos períodos geológicos anteriores.

Ao contrário dos mamíferos, a avifauna do Plistocénico de Portugal foi, durante muito tempo, relegada para "segundo plano" nos estudos e levantamentos das faunas plistocénicas. A grande maioria dos restos de avifauna plistocénica descoberta em Portugal é proveniente de grutas com ocupação humana do Plistocénico Superior (Paleolítico Médio e Superior). Do Plistocénico Inferior e Médio não foram recuperados restos de aves, e mesmo de outras faunas foram encontrados poucos restos.

Neste trabalho foi feito um estudo de levantamento de todas as jazidas com referência à presença de aves no Plistocénico português. Foram assim identificadas 16 jazidas, das quais a quase totalidade se situa em cavidades cársicas e, apenas, a Foz do Enxarrique, que tem uma breve referência, não confirmada, à presença de aves (BRUGAL e RAPOSO, 1999), se situa ao ar livre, num terraço quaternário do Tejo (quadro 61).

69 Até esta data, as publicações não passavam da reprodução dos dados apresentados no estudo de referência sobre a fauna plistocénica portuguesa, efectuado por Harlé e Newton (HARLÉ, 1910-11). 


\begin{tabular}{clllll}
$\begin{array}{c}\text { N.o de } \\
\text { ordem }\end{array}$ & \multicolumn{1}{c}{ Jazida } & Tipo & Cronoestratigrafia & Datação Arqueológica & Datação Geológica \\
\hline \hline 1 & Gruta da Furninha & C. C. & Jur. & P. Inf., Méd. e Sup. & Plistocénico Sup. \\
2 & Gruta da Figueira-Brava & C. C. & Mio. & P. Médio & Plistocénico Sup. \\
3 & Gruta da Lapa da Rainha & C. C. & Jur. & P. Médio & Plistocénico Sup. \\
4 & Gruta da Casa da Moura & C. C. & Jur. & P. Superior & Plistocénico Sup. \\
5 & Gruta Nova da Columbeira & C. C. & Jur. & P. Médio & Plistocénico Sup. \\
6 & Abrigo do Lagar Velho & C. C. & Cret. & P. Superior & Plistocénico Sup. \\
7 & Lapa do Anecrial & C. C. & Jur. & P. Superior & Plistocénico Sup. \\
8 & Gruta do Pêgo do Diabo & C. C. & Cret. & P. Médio & Plistocénico Sup. \\
9 & Gruta das Salemas & C. C. & Cret. & P. Médio & Plistocénico Sup. \\
10 & Gruta das Fontainhas & C. C. & Jur. & P. Superior & Plistocénico Sup. \\
11 & Lapa do Picareiro & C. C. & Jur. & P. Superior & Plistocénico Sup. \\
12 & Buraca Escura & C. C. & Jur. & P. Med. e Sup. & Plistocénico Sup. \\
13 & Grutas do Almonda & C. C. & Jur. & P. Inf. e Méd & "loniano" e Plis. Sup. \\
14 & Gruta do Caldeirão & C. C. & Jur. & P. Superior & Plistocénico Sup. \\
15 & Gruta do Escoral & C. C. & Pré-Cam & P. Superior & Plistocénico Sup. \\
16 & Foz do Enxarrique (?) & T & Quater. & P. Médio & Plistocénico Sup. \\
& & C. C. & cavidade cársica & & \\
& & T & terraço & &
\end{tabular}

Quadro 57- Jazidas com avifauna plistocénica em Portugal e a sua contextualização geológica e arqueológica.

Este trabalho representa um primeiro levantamento geral da avifauna fóssil portuguesa, quer em colecções de museus, quer na bibliografia e tem como principal objectivo caracterizar essas aves. Este levantamento é também uma actualização do conhecimento acerca desta temática, com especial relevo para a avifauna do Plistocénico Superior de Portugal. Assim, as principais contribuições desta tese são: o levantamento das jazidas plistocénicas com restos de aves; a revisão de estudos já efectuados e que necessitavam de uma actualização; a apresentação de novos dados, relativos a restos ainda não vistos em jazidas já publicadas e outros totalmente novos de jazidas cuja avifauna ainda não tinha sido estudada.

No trabalho agora apresentado, foram estudados 2079 restos de aves em oito das jazidas identificadas. Foram reconhecidos 88 táxones (153 no total se se contabilizarem todos os táxones identificados em todas as jazidas), ver quadro 60 . 
Avifauna Plistocénica de Portugal

(Número total de restos e de táxones)

\begin{tabular}{|c|c|c|c|}
\hline Sítio & N.@ Total de Restos & N. de táxones por sítio & N.o total de táxones \\
\hline Gruta da Furninha & 436 & 40 & \\
\hline G. Nova da Columbeira & 541 & 48 & \\
\hline Gruta das Salemas & 48 & 8 & \\
\hline Lapa da Rainha & 407 & 24 & \\
\hline Gruta das Fontainhas & 20 & 6 & \\
\hline Casa da Moura & 615 & 20 & \\
\hline Pêgo do Diabo & 5 & 3 & \\
\hline$\underline{\text { Gruta do Caldeirão* }}$ & 7 & 5 & \\
\hline Totais & 2079 & 154 & 88 \\
\hline
\end{tabular}

Quadro 58 - Número total de restos estudados e número de táxones identificados.

Do ponto de vista paleontológico, foram reconhecidos 88 táxones de aves plistocénicas; destes, doze, são pela primeira vez reconhecidos em Portugal. São doze espéces distribuídas por seis ordens: anseriformes (Anser albifrons e Somateria molíssima), galliformes (cf. Alectoris barbara, Tetrao urugallus e Cf. Phasianus colchicus), gruiformes (Grus grus e Otis tarda), charadriiformes (Pluvialis squatarola), falconiformes (Falco rusticolus e cf. Aquila adalbertis) e passeriformes (cf. Cyanopica cyana). Outro táxon, o Pinguinus impennis é, pela segunda vez, identificado em Portugal Continental, trazendo-se, desta forma, novos indicadores paleoambientais para a Gruta da Furninha. Foram também revistos, actualizados e reclassificados dez táxones atribuídos à Gruta da Furninha e à Gruta das Fontainhas (quadros 96 e 97) por Newton (HARLÈ, 1910/11).

O grupo mais representado é a ordem dos passeriformes, com $61 \%$ da totalidade dos restos identificados e, entre os passeriformes, há um predomínio claro dos corvídeos, com 83 \%, seguidos dos tordídeos com 14 \% (gráficos 97 e 98). 


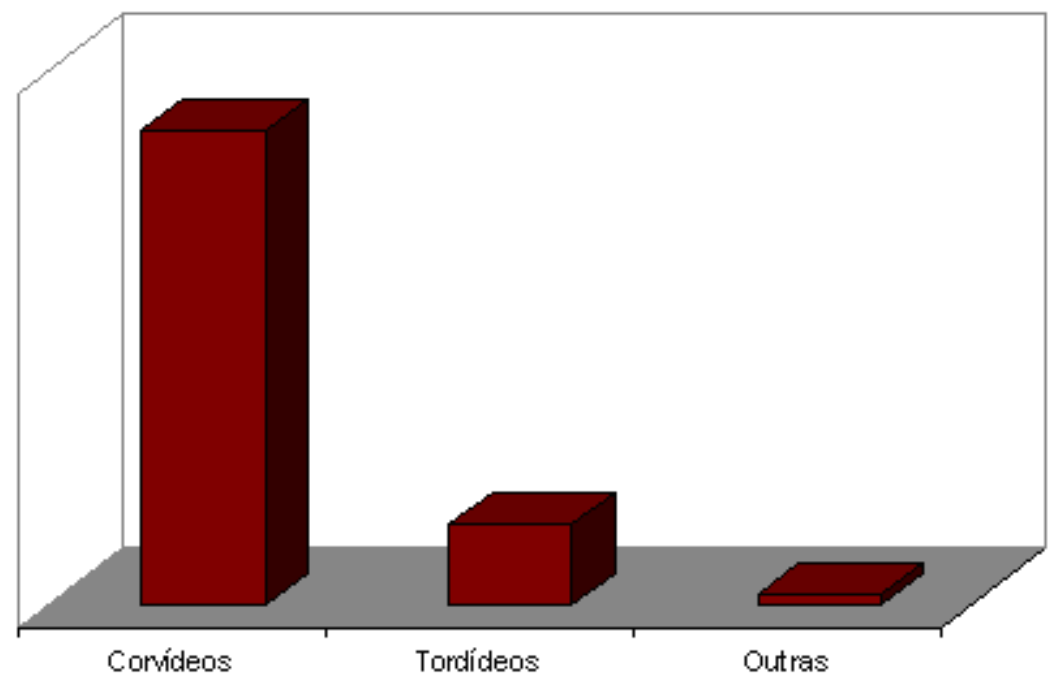

Gráfico 97 - Relação entre as principais famílias de passeriformes.

Das restantes ordens destacam-se os columbiformes, galliformes, falconiformes e strigiformes. O número relativamente elevado de anseriformes devese à grande quantidade de restos de Tadorna tadorna e Somateria molíssima da Gruta da Furninha, que vieram empolar o valor, o mesmo acontecendo com os pelicaniformes, que se destacam pela grande quantidade de Phalacrocorax aristotelis, também da Gruta da Furninha. As restantes ordens são residuais, não ultrapassando a meia dezena de restos. 


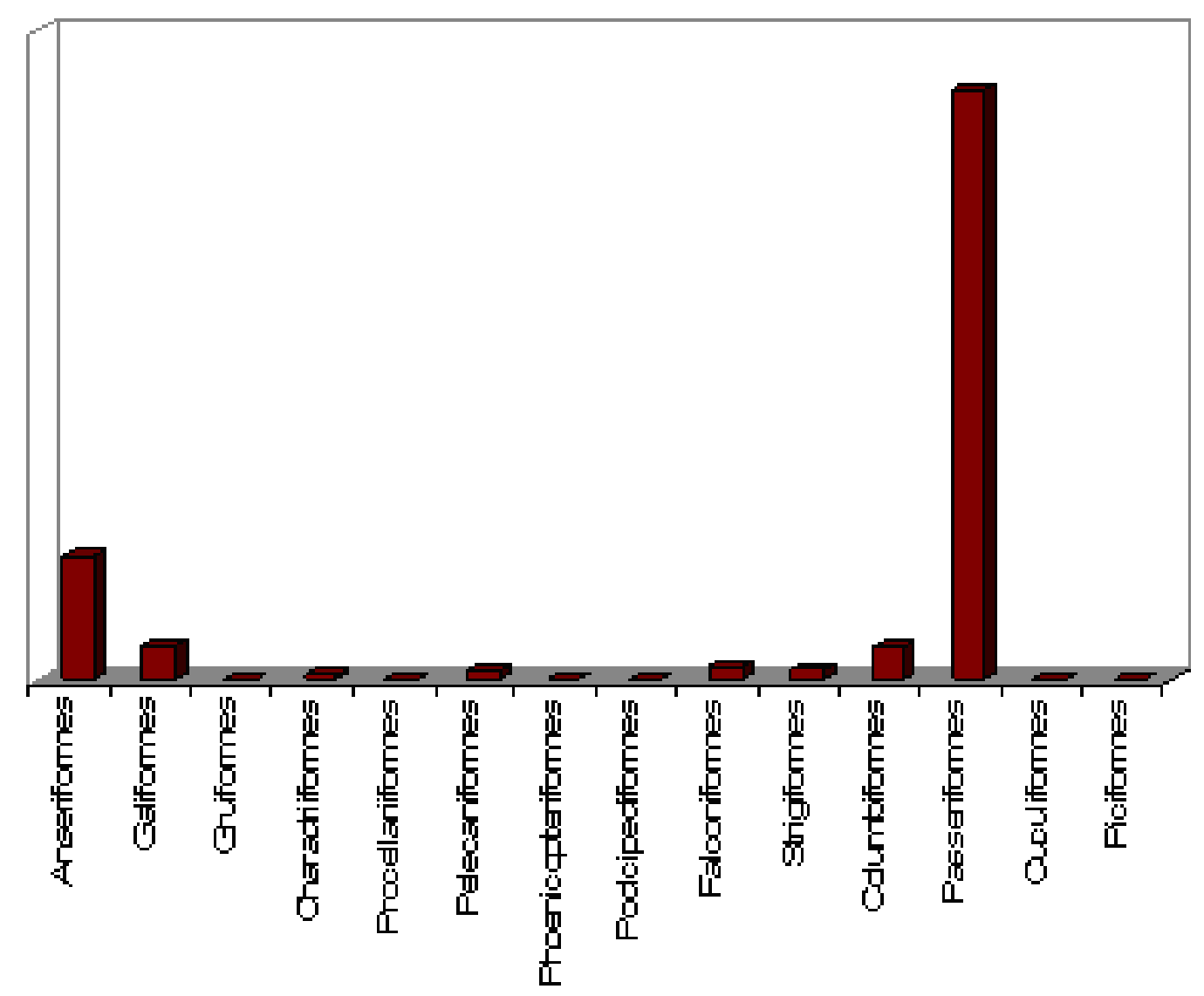

Gráfico 98 - Relação entre as ordens de aves reconhecidas neste estudo

Foi possível fazer um estudo comparativo com a avifauna actual. Todavia, no caso da comparação anatómica, este estudo é apenas indicativo, pois os dados recolhidos foram insuficientes para se fazer uma análise aprofundada, uma vez que o número de restos das espécies plistocénicas (com poucas excepções, como no caso da Tadorna tadorna) e o número de espécimes das colecções de referência consultadas são relativamente escassos. Verificou-se, assim, neste estudo comparativo, que a avifauna plistocénica portuguesa pouco se diferenciou da actual, quer a no que respeita à anatomia quer relativamente à taxonomia.

Relativamente à anatomia, verifica-se que existem poucas mudanças quanto à robustez, quanto ao tamanho das aves plistocénicas em relação às actuais. As maiores excepções encontraram-se em duas espécies: o Phalacrocorax aristotelis e o Cygnus olor, sendo que no primeiro caso os representantes actuais do género apresentam os úmeros mais largos cerca de $13 \%$ em relação aos representantes do género do Plistocénico, no segundo caso, a situação é inversa, ou seja, os cisnes do 
Plistocénico apresentavam os úmeros mais grossos que os actuais cerca de $15 \%$. Nestas observações há que ter em conta que as colecções de referência e as colecções plistocénicas estudadas têm um número reduzido de espécimes dos grupos taxonómicos analisados. Logo as ilações tiradas em relação à variedade intraespecíficas são apenas um esboço comparativo das espécies plistocénicas e das actuais. No entanto, pode-se concluir que existem poucas alterações entre o Plistocénico e a actualidade, pois caso se verificassem grandes diferenças essas seriam detectadas, mesmo no caso de amostras pequenas.

No que se refere à comparação taxonómica, existem, apesar das poucas diferenças encontradas, maiores alterações do que no estudo anatómico, pois algumas das espécies plistocénicas identificadas neste estudo já estão extintas ou, pelo menos, já não são observadas em Portugal. As espécies de aves Plistocénicas que já não são observadas em Portugal, mas que ainda ocorrem noutras zonas da Europa, são, por exemplo, o Pyrrhocorax graculus, identificado em quase todas as jazidas; o Cygnus olor, indentificado na Furinha (HARLÉ, 1910/11) e na Galeria Pesada (MARKS et al. 2000), a Melanita fusca identificada na Gruta da Figueira-Brava (MOURER-CHAUVIRÉ \& ANTUNES, 2000), o Anser albifrons, agora identificado na Gruta do Pego do Diabo (FIGUEIREDO, 2009) e o Mergus albellus, identificado também na Galeria Pesada (MARKS et al. 2000). As espécies já extintas são, por exemplo, o Grus primigenia e o Pinguinus impennis, identificado na Gruta da Figueira-Brava (MOURERCHAUVIRÉ \& ANTUNES, 2000); o P. impennis, foi também agora identificado na Gruta da Furninha (PIMENTA, FIGUEIREDO \& GARCIA-MORENO, 2009); o Corvus antecorax, na Galeria Pesada (MARKS et al. 2000). Verificou-se, na análise agora efectuada à avifauna plistocénica portuguesa, que da totalidade das espécies identificadas, cerca de 30 por cento já não se encontram, na actualidade, em Portugal.

Comparando com as outras classes, verifica-se que as espécies de aves plistocénicas já extintas em Portugal são-no num número maior que as espécies de anfíbios e répteis plistocénicos portugueses, dos quais apenas uma espécie de tartarugas já está extinta em Portugal, as restantes mantiveram-se. Contudo, em comparação com os mamíferos verifica-se o contrário, ou seja existe um maior número de espécies de mamíferos plistocénicas já extintas, comparativamente às aves. 
Verifica-se que a distribuição das espécies não é homogénea nas diferentes jazidas. A Gruta da Furninha e a Gruta Nova da Columbeira apresentam uma maior biodiversidade, enquanto a Gruta da Casa da Moura e a Lapa da Rainha mostram uma biodiversidade menor, comparativamente ás outras duas jazidas atrás referidas. Apesar de a Gruta Nova da Columbeira apresentar a maior biodiversidade, com um maior número de táxones e de espécies identificados, é a Gruta da Furninha que apresenta um melhor índice entre o número total de espécies e o número total de táxones (NTR/NTE e NTR/NTT), com o número total de restos, representando a jazida com a maior biodiversidade, nesta relação. A Gruta do Caldeirão, com 90 restos, a Gruta das Salemas, com 48, a Gruta das Fontainhas, com 20 a e a Gruta do Pego do Diabo, com cinco, apresentam os melhores índices NTR/NTE e NTR/NTT melhores, mas o seu número de restos, inferior a uma centena, é pequeno (em especial as duas últimas), para serem consideradas nesta questão (quadro 61).

\begin{tabular}{|c|c|c|c|c|}
\hline Sítio & N.o de Espécies por sítio & Relação NTR/NTE* & Relação NTR/NTT** & NTE* $^{*}$ \\
\hline Gruta da Furninha & 32 & 13,62 & 10,9 & \\
\hline G. Nova da Columbeira & 34 & 15,91 & 11,27 & \\
\hline Gruta das Salemas & 6 & 8 & 6 & \\
\hline Lapa da Rainha & 16 & 25,43 & 16,95 & \\
\hline Gruta das Fontainhas & 6 & 3,33 & 3,33 & \\
\hline Casa da Moura & 12 & 54,25 & 30,75 & \\
\hline Pêgo do Diabo & 2 & 2,5 & 1,66 & \\
\hline Gruta do Caldeirão*** & 11 & 8,18 & 3,91 & \\
\hline Totais & 119 & & & 56 \\
\hline \multicolumn{2}{|c|}{${ }^{*}$ Número total de espécies } & \multicolumn{3}{|c|}{ ** Número total de táxones } \\
\hline
\end{tabular}

Quadro 59 - Número total de espécies identificadas nas jazidas estudadas e a relação entre o número total de restos, o número total de espécies e o número total de táxones.

O breve intervalo de tempo geológico entre as jazidas estudadas (todas datadas do Plistocénico Superior), em que diferem em cerca de 70000 anos as idades entre a mais antiga e a mais recente e em que a maioria se situa entre os 30000 e os 20000 BP (Quadro 1, fig. 95 e anexo V) impede a realização de uma biostratigrafia regional, apenas se pode ter uma ideia da distribuição temporal das diferentes 
espécies identificadas e dos climas associados a essas datações (figura 95). De realçar que a quase totalidade das jazidas, com excepção da Gruta da Furninha e do nível Magdalenense da Gruta do caldeirão, se encontra num período de tempo entre os cerca de 30000 aos $17000 \mathrm{BP}$, o que reduz mais ainda os limites temporais dos diferentes sítios com avifauna plistocénica, em Portugal.

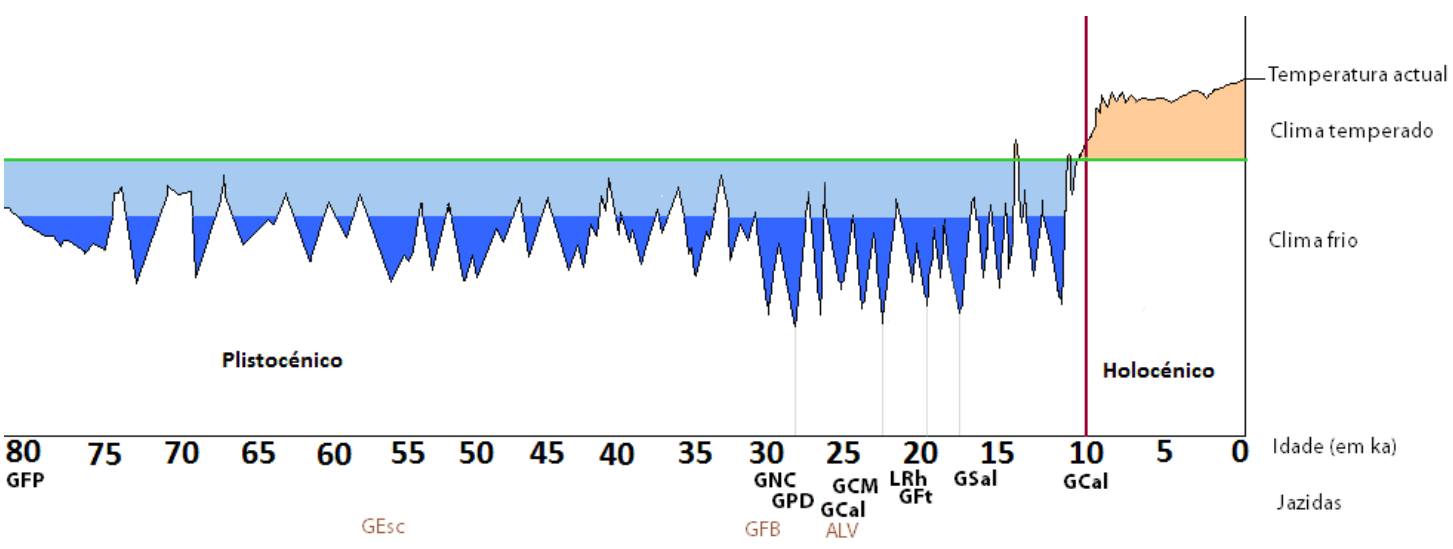

Fig. 97 - Relação entre a distribuição temporal das jazidas estudadas e a evolução da temperatura (segundo GAMBLE et al., 2006 e BRADLEY, 2005). A castanho estão representadas jazidas com fauna já publicadas e não estudadas neste trabalho (GFP - Gruta da Furninha; GNC - Gruta Nova da Columbeira; GPD - Gruta do Pego do Diabo; GCal - Gruta do Caldeirão; GCM - Grurta da Casa da Moura; LRh - Lapa da Rainha; GFt - Gruta das Fontainhas; GSal - Gruta das Salemas; GEsc - Gruta do Escoural; GFB - Gruta da FigueiraBrava; ALV - Abrigo do Lagar Velho).

A análise dos ossos não revelou, na quase totalidade da amostra, a presença evidente de marcas de corte e poucos apresentam marcas de carnívoros. Este dado e a análise da outra fauna associada às aves, bem como a identificação taxonómica, em que se verificou, como já foi referido, uma abundância de corvídeos, em especial das espécies que frequentam grutas, sugere que as acumulações, ou grande maioria dos restos de avifauna nas jazidas plistocénicas, são naturais: de origem biótica interna aos próprios indivíduos (aves que frequentam grutas e que ali morreram) ou de ordem biótica externa aos indivíduos (aves transportadas e consumidas nas grutas por carnívoros). Poucos restos terão origem antrópica. Assim, das espécies analisadas distinguem-se dois grupos: o primeiro, constituído, por exemplo, pelos anseriformes e galliformes, que são espécies que poderiam ser caçadas pelo homem ou pelos carnívoros que frequentavam aquelas grutas; o segundo, constituído por grupos como o dos passeriformes ou o dos Strigiformes, que seriam animais que 
frequentavam as grutas ocupadas, alguns dos quais lá morreram. Este segundo grupo é o que apresenta um maior número de restos e de indivíduos, reforçando a ideia de que a maioria das aves plistocénicas encontradas em contexto arqueológico não seriam caçadas pelas comunidades humanas suas contemporâneas.

Pela análise global da distribuição das espécies pelos seus habitat, verifica-se que em todas as jazidas ocorrem espécies de ambientes de bosques, campo aberto e zona costeira (quadro 62). A ocorrência deste último habitat é estranha, nas jazidas do interior, no entanto é explicada, como foi referido na análise paleoecológica das jazidas, pela presença de espécies que ocorrem vários habitat de litoral e interior. $\mathrm{O}$ habitat que ocorre em menos jazidas é o de lagos de água doce. Com a excepção da Gruta das Fontainhas, os habitat de zonas rochosas e montanha aparecem associados. O ambiente de floresta aparece associado a espécies da Gruta do Pego do Diabo, mas não aparece na Gruta das Salemas, o que é estranho porque as duas jazidas estão relativamente próximas. Este facto poderá ser explicado pelo pequeno número de restos de aves encontrados nestas jazidas.

\begin{tabular}{l|crrrrrrr} 
& Bos & CA & Zh & LAD & Mont & ZR & Flo & Cos \\
\hline \hline Gruta Nova da Columbeira & 6,8 & 10,6 & 3,15 & 1,16 & 2,5 & 1,5 & 2 & 3,16 \\
Gruta da Furninha & 5,32 & 10,5 & 1,62 & 3,33 & 3 & 2 & 2,16 & 11 \\
Gruta das salemas & 1,33 & 1,33 & & & 2 & 0,5 & & 1,83 \\
Gruta do Pego do Diabo & 0,33 & 0,33 & 1,5 & & & & 0,33 & 0,5 \\
Gruta das Fontainhas & 0,83 & 2,16 & 0,33 & 0,33 & 1,5 & & & 0,83 \\
Gruta da Casa da Moura & 2,33 & 4,49 & 0,66 & 0,33 & 2 & 1,5 & 1 & 1,66 \\
Lapa da Rainha & 2,33 & 6,49 & 3,16 & & 2,5 & 1 & 2,33 & 2,16 \\
Gruta do Caldeirão & 1,83 & 4,66 & 0,83 & 0,5 & 3 & 1 & 1,33 & 1,83
\end{tabular}

Quadro 60- Diferentes ambientes, segundo a ocorrência das espécies pelos respectivos habitat, em todas as jazidas estudadas (Bos - bosques; CA - campo aberto; $\mathrm{Zh}$ - zonas húmidas; LAD - lagos de água-doce; Mont - zonas de montanha; ZR - zonas rochosas; Flo zona de floresta; Cós - zona costeira).

Na representação gráfica (gráfico 99) verifica-se que os ambientes de campo aberto predominam em todas as jazidas, com a excepção da Gruta da Furninha, onde, pela sua localização geográfica, predominam os ambientes de zonas costeiras. Os ambientes de bosques aparecem, em quase todas as jazidas, a seguir aos de campo aberto, enquanto os restantes, com excepção dos já referidos ambientes 
costeiros de grande parte das espécies da Gruta da Furninha, aparecem com valores mais baixos e idênticos entre si.

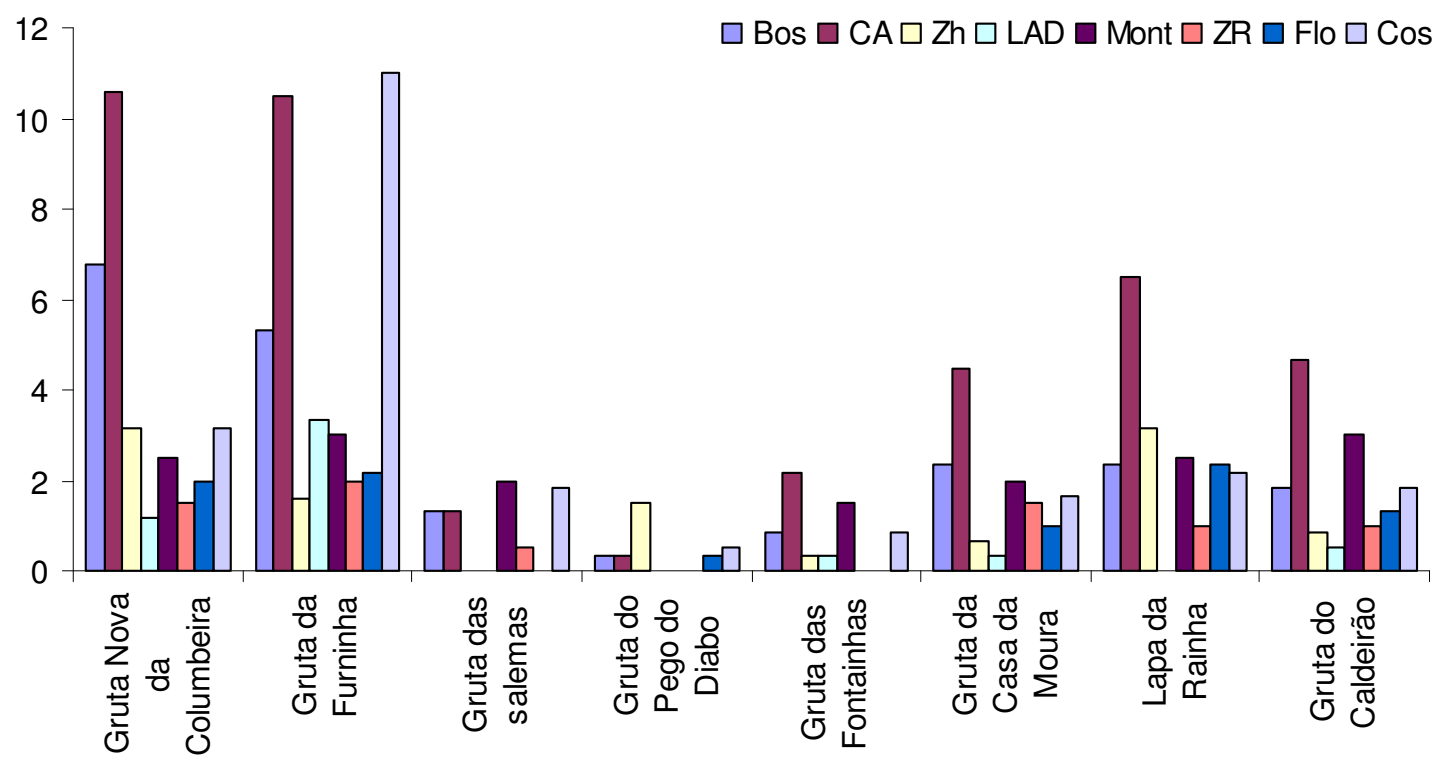

Gráfico 99 - Comparação em gráfico de barras, dos diferentes ambientes, segundo a ocorrência das espécies pelos respectivos habitat, em todas as jazidas estudadas (Bos bosques; CA - campo aberto; $\mathrm{Zh}$ - zonas húmidas; LAD - lagos de água doce; Mont - zonas de montanha; ZR - zonas rochosas; Flo - zona de floresta; Cós - zona costeira).

As indicações paleoecológicas são, no geral, consistentes com outros estudos feitos sobre faunas plistocénicas, como por exemplo CARDOSO, 1993. A maioria das espécies analisadas sugerem uma predominância de climas temperados e secos (quadro 64), no entanto a presença de espécies como o Pinguinus impennis, a Somateria molíssima, a Melanita fusca, o Cignus olor, Pluvialis squatarola, o Lagopus lagopus, o Lagopus mútuos, e a Alca torda, sugerem climas frios e húmidos, enquanto as espécies Falco rusticolus, Pyrrhocorax Pyrrhocorax e o Phyrrocorax graculus, sugerem climas frios e secos. No geral, as primeiras ocorrem ou abundam em jazidas junto á costa, enquanto as segundas ocorrem ou abundam em jazidas localizadas mais para o interior. 
Indicadores Paleoambientais

\begin{tabular}{|c|c|c|c|c|c|}
\hline Espécie & Frio & Quente & Temperado & Seco & Húmido \\
\hline Anser albifrons & * & & & & * \\
\hline Anas platyrhynchos & & & $*$ & & $*$ \\
\hline Anas crecca & & & $*$ & & $*$ \\
\hline Melanita nigra & * & & & & * \\
\hline Melanitta fusca & $*$ & & & & * \\
\hline Clangula hyemalis & $*$ & & & & $*$ \\
\hline Mergus albellus & $*$ & & & & $*$ \\
\hline Tadorna tadorna & & & * & & * \\
\hline Somateria mollissima & $*$ & & & & $*$ \\
\hline Tadorna ferruginea & & & $*$ & & $*$ \\
\hline Cygnus olor & $*$ & & & & * \\
\hline Perdix perdix & & & $*$ & * & \\
\hline Alectoris rufa & & & $*$ & $*$ & \\
\hline cf. Alectoris barbara & & * & & * & \\
\hline cf. Phasianus colchicus & & & * & * & \\
\hline Coturnix coturnix & & * & & * & \\
\hline Tetrao urugalus & * & & & $*$ & \\
\hline Lagopus lagopus & $*$ & & & & $*$ \\
\hline Lagopus mutus & $*$ & & & & * \\
\hline Grus primigenia & & & $*$ & & * \\
\hline Grus Grus & & & $*$ & & $*$ \\
\hline Otis tarda & & & $*$ & $*$ & \\
\hline Pluvialis squatarola & & & $*$ & & * \\
\hline Puffinus puffinus & $*$ & & $*$ & & * \\
\hline Puffinus holeae & & & $*$ & & $*$ \\
\hline Puffinus Kulhi & & & $*$ & & * \\
\hline Sula bassana & & & $*$ & & * \\
\hline Phalacrocorax carbo & & & $*$ & & * \\
\hline Phalacrocorax aristotelis & & & $*$ & & * \\
\hline Phoenicopterus ruber & & * & & & * \\
\hline Gavia stellata & & & $*$ & & $*$ \\
\hline Vanellus vanellus & & & $*$ & & * \\
\hline Scolopax rusticola & & & $*$ & $*$ & \\
\hline Calidris canutus & * & & $*$ & & $*$ \\
\hline Larus fuscus & & & $*$ & & * \\
\hline Alca torda & $*$ & & * & & * \\
\hline Pinguinus impennis & $*$ & & & & * \\
\hline Podiceps nigrollis & & & $*$ & & * \\
\hline Cf. Aquila adalberti & & & $*$ & * & \\
\hline Aquila chrysaetos & & & * & * & \\
\hline
\end{tabular}




\begin{tabular}{|c|c|c|c|c|c|}
\hline Espécie & Frio & Quente & Temperado & Seco & Húmido \\
\hline Buteo buteo & & * & $*$ & * & \\
\hline Accipiter nisus & & & * & * & \\
\hline Haliaeetus albicilla & & & * & * & \\
\hline Hieraaetus fasciatus & & & * & * & \\
\hline Falco tinuculus & & * & * & * & \\
\hline Falco rusticolus & * & & & * & \\
\hline Aegypius monachus & & & * & * & \\
\hline Gyps fulvus & & & * & * & \\
\hline Milvus migrans & & & * & * & \\
\hline Tyto alba & & & * & * & \\
\hline Bubo bubo & * & & * & * & \\
\hline Athene noctua & & & * & * & \\
\hline Asio flammeus & * & & * & * & \\
\hline Strix aluco & & & * & * & \\
\hline Columba livia & & * & & * & \\
\hline Columba palumbus & & & * & * & \\
\hline Pyrrhocorax pyrrhocorax & * & & & * & \\
\hline Pyrrhocorax graculus & * & & & * & \\
\hline Corvus monedula & & & * & * & \\
\hline Corvus corone & & & * & * & \\
\hline Corvus frugilegus & & & * & * & \\
\hline Corvus antecorax & & & * & * & \\
\hline Corvus corax & & & * & * & \\
\hline Pica pica & & & * & * & \\
\hline Garrulus glandarius & & & * & * & \\
\hline cf. Cyanopica cyana & & & * & * & \\
\hline Turdus iliacus & * & & * & * & \\
\hline Turdus pilaris & * & & * & * & \\
\hline Turdus philomelos & * & & * & * & \\
\hline Turdus merula & * & & * & * & \\
\hline Sturnus vulgaris & & & * & * & \\
\hline Carduelis carduelis & & & * & * & \\
\hline Ptyonoprogne rupestris & & & * & * & \\
\hline Numenius phaeopus & & & * & * & \\
\hline Cuculus canorus & & & * & * & \\
\hline Motacilla alba & & & * & * & \\
\hline Egreta alba & & & * & & * \\
\hline Caprimulgus europaeus & & * & * & * & \\
\hline Picus viridis & & & * & * & \\
\hline
\end{tabular}

Quadro 61 - Distribuição de todas as espécies identificadas no Plistocénico de Portugal (na bibliografia existente e neste trabalho) no respectivo ambiente. 


\section{REFERÊNCIAS BIBLIOGRÁFICAS}

ALBERDI, M. T., ANTUNES, M.T., SONDAAR, P.Y. \& ZBYSZEWSKI, G. (1978), Les Hipparion du Portugal, Ciências da Terra, n4, UNL, Lisboa,pp.129-156, X.

ALMEIDA, F.; SANTOS, M. F.; ROCHE, J. \& FERREIRA, O. V. (1970), Notícia Preliminar Sobre as escavações Feitas na Lapa da Rainha (Vimeiro), in Actas das I Jornadas Arqueológicas, Lisboa, pp. 273-288.

ALMEIDA, F. BRUGAL, J-P., ZILHÃO, J., PLISSON, H. (2004), An Upper Paleolithic Pompeii: Technology, subsistence and paleoethnography at Lapa do Anecrial, in Actas do IV Congresso de Arqueologia Peninsular, Universidade do Algarve, Faro.

ANTUNES, M.T. \& CARDOSO, J.L. (1992). Quaternary elephants in Portugal: new data, in Ciências da Terra. 11: 17-37

ANTUNES, M. T., MATEUS, O.(2003) Dinosaurs of Portugal, in C. R. Palvol, n. 2, pp. 77 95, s./l.,

ANTUNES, M. T. \& MEIN P. (1981) - Vertebrés du Miocéne Moyen de Amor (Leiria). Importance Stratigraphique. in Ciências da Terra, n 6, p.169-188. Universidade Nova de Lisboa, Lisboa.

ANTUNES, M.T, MEIN, P.\& PAIS, J.(1986) Depósitos Messinianos do Sul de Portugal, Mamíferos (incluindo rodentia e lagomorpha) e idade K-Ar, in Ciências da Terra No8, UNL, Lisboa, pp.55-64

ANTUNES, M.T., PEIXOTO CABRAL, J.M., CARDOSO, J.L, PAIS, J \& MONGE SOARES, A.(1989) Paleolítico Médio e Superior em Portugal: as datas 14C, estado actual dos conhecimentos, síntese e discussão, In Ciências da Terra No 10, UNL,Lisboa, pp.127-138

ANTUNES, M. T. \& RUSSEL, D. E. (1981) - Le gisemente de Silveirinha (Bas Mondego, Portugal): La plus anciente faune de vertebrés Éocènes connue en Europe. in Comptes Rendus Hebdomadaires dês Séances de l'Academie dês Sciences, n²93, p.1099-1102. Paris.

ANTUNES, M.T.\& MAZO, A.V (1983)., Quelques mastodontes miocénes du Portugal, 
Ciências da Terra, UNL, Lisboa, pp.115-128.

ANTUNES, M. T. (2000) "The Pleistocene Fauna From Gruta da Figueira-Brava: A Synthesis", in actas do colóquio Últimos Neandertais em Portugal, evidência, odontológica e outra, pp. 259 - 282, Academia das Ciências, Lisboa.

ANTUNES, M. T. \& CARDOSO, J. L., (2000a) Gruta Nova da Columbeira, Gruta das Salemas and Gruta da Figueira-Brava. Stratigraphy and Chronology of The Pleistocene Deposits, in Memórias da academia das Ciências, Classe das Ciências, XXXVIII, pp. 23-67. Lisboa.

ANTUNES, M.T.; LEGOINHA, P.; CUNHA, P.P. \& PAIS, J. (2000 a) - High resolution stratigraphy and Miocene facies in Lisbon and Setúbal Peninsula (Lower Tagus Basin, Portugal), in Ciências da Terra (UNL), no 14, pp. 183-190.

ARAÚJO, M. A. 1997. A plataforma litoral da região do Porto: Dados adquiridos e perplexidades, in Estudos do Quaternário, 1, APEQ, Edições Colibri, pp. 3-12.

AUBRY, T., BRUGAL, J.-Ph., CHAUVIÉRE, F.-X., MOURA, M. H. \& PLISSON, H.(2001), Modalités d'Occupations au Paléolithique Supérieur dans la Grotte de Buraca Escura (Rendinha, Pombal, Portugal), in Revista Portuguesa de Arqueologia, Vol. 4, n०2, pp. 19-46, IPA, Lisboa

BALÃO, L. \& CABEDAL, V. (2006) Arqueologia do Concelho de Setúbal in Actas do I Seminário de Arqueologia e Paleontologia do Estuário do Tejo, Edições Colibri e Câmara Municipal de Montijo, Montijo (pp.165-172).

BAUMEL, J. J. (2003), Nomina Anatómica Avium, Academic Press, Londres.

BENTON, M. J. (2005) Vertebrate Palaeontology (3a. Ed.), Blackwell Publishing, Oxford. BERMUDEZ DE CASTRO, J. M., DIEZ, J. C., MOSQUERA, M. NICOLAS, M. E. PEREZ, A. RODRIGUEZ, J. \& SANCHEZ-MARCO, A. S. (1995) El nicho ecológico de los hominidios del Pleistoceno Medio de Atapuerca, in Complutum, 6, pp. 9 - 56.

BICHO, N. F., HAWS, J., HOCKETT, B., MARKOVA, A., BELCHER, W. (2003), Paleoecologia e Ocupação Humana da Lapa do Picareiro: resultados preliminares, in Revista Portuguesa de Arqueologia, Vol. 6, №. 2, pp49-81, IPA

BICHO, N. F., (2006), Manual de Arqueologia Pré-Histórica, Edições 70, Lisboa BOTEQUILHA, H. \& MARTINS, A. (2003) As Grutas dos Nossos Avós, in Revista Visão, nº 551 de Set. 2003, pp. $118-128$.

BRÉZILLON, M. (1969), Dicionário de Pré-História, Edições 70, 1989, Lisboa

BREUIL, H \& ZBYSZEWSKI, G. (1942) Contribution à I'Etude des Industries 
Paléolithiques du Portugal et de Leurs Rapports avec la Géologie du Quaternaire, in Comunicações dos Serviços Geológicos de Portugal, Tomo:XXIII, Serviços Geológicos de Portugal, pp. 1-394, Lisboa

BREUIL, H \& ZBYSZEWSKI, G. (1945) Contribution à I'Etude des Industries Paléolithiques du Portugal et de Leurs Rapports avec la Géologie du Quaternaire, in Comunicações dos Serviços Geológicos de Portugal, Tomo: XXIV, Serviços Geológicos de Portugal, pp. 1 - 678, Lisboa.

BREUIL, M. (1997) Dicionário das Ciências da Terra e da Vida, Climepsi Editores, 2001, Lisboa.

BRODKORB, P. (1960), Great Auk and Common Murre from a Florida Midden., In Auk vol. 77 no. 3, pp. 342-343.

BRUGAL, J-P. (1995), Archéologie et Zoologie pour un Nouveau Concept, la Paléoéthologie Humaine, in Préhistoire Anthropologie Mediterranéennes, t. 4, pp. 17-26.

BRUGAL, J-P. (2006), Petit Gibier et Fonction de Sites au Paléolithique Supérieur: Les Ensembles Fauniques de la Grotte d'Anecrial (Porto de Mós, Estremadure, Portugal), in Paléo, n 18, pp 45 a 68.

BRUGAL, J-P e RAPOSO, L. (1999) Foz do Enxarrique (Ródão - Portugal): Preliminary Results of the Analysis of a Boné Assemblage From A Midle Palaeolithic Open Site in The Role of Early Humans in the Accumulation of European Lower and Middle Palaeolithic Boné Assemblages, pp. 367-379, Mainz,.

BRUNET, M, 1966 "Atlas de Préhistoire", Tomo III, Editions N. Boubée et ce, Paris,

CABRAL, J., 1995. Neotectónica de Portugal continental in Memórias do Instituto Geológico e Minineiro, 31, 265 p, Lisboa Elsevier Science Publishers, Amsterdam, 64, pp. 271-298.

CALLAPEZ, P., 2003, "Moluscos Marinhos e Fluviais do Paleolítico Superior da Gruta do Caldeirão (Tomar, Portugal): evidências de ordem sistemática, paleobiológica e paleobiogeográfica" Revista Portuguesa de Arqueologia, volume 6.no: 1., Lisboa, pp.5-15

CAMARATE FRANÇA, J., ROCHE, J., FERREIRA, O V. (1961), Sur léxistence probable d'un niveau solutréen dans les couches de la Grotte de la Casa da Moura (Cesareda), in Comunicações dos serviços Geológicos de Portugal, Tomo XLV, Direcção Geral de Minas e Serviços Geológicos, Lisboa, pp. 365-370. 
CARDOSO, J.L. (1993): Contribuição para o conhecimento dos grandes mamíferos do Plistocénico Superior de Portugal. Câmara Municipal de Oeiras, Oeiras.

CARDOSO, J. L. (2002) Pré-História de Portugal, Editorial Verbo, Lisboa

CARDOSO, J. L. (2006a) A Pré-História de Entre o Tejo e Sado in Actas do / Seminário de Arqueologia e Paleontologia do Estuário do Tejo, Edições Colibri e Câmara Municipal de Montijo, Montijo (pp.11-42)

CARDOSO, J. L. (2006b) The Mouterian Complex in Portugal in Zephyrus LIX, Uni. Salamanca, Salamanca (pp.21-50)

CARDOSO, J. L. \& RAPOSO, L. (1993): 0 Paleolítico Médio da Gruta da Figueira-brava. Actas da III Reuníão do Quaternário Iberico. Coimbra.

CARDOSO, J. L., RAPOSO, L. \& FERREIRA, V., (2002): A Gruta Nova da Columbeira Bombarral, Câmara Municipal do Bombarral, Bombarral.

CARDOSO, J. L. \& GOMES, M. V. (1994) Zagaias do Paleolítico Superior de Portugal, Portugália, Nova série, Vol. XV, pp. 7-31.

CARVALHO, A. M. G. (1968) Contribuição Para o Conhecimento Geológico da Bacia Terciária do Tejo, Memórias dos Serviços Geológicos de Portugal (Nova Série), nº 15, Serviços Geológicos de Portugal, Lisboa.

CARVALHO, I. S., Editor, (2000), Paleontologia, (2a. Edição) Editora Interciência, Rio de Janeiro.

CASSAB, R. C. T. (2000) Objectivos e Princípiosilização, in Paleontologia (Ismar de Sousa Carvalho, editor), (2a . Edição), pp. 3 - 11, Editora Interciência, Rio de Janeiro.

CHIAPPE, L.M. (2002) Basal bird phylogeny, problems and solutions, in Mesozoic Birds: Above the Heads of Dinosaurs (eds L.M.Chiappe and L.M.Witmer), University of California Press, Berkeley, pp. 448-72.

CHIAPPE, L.M. and DYKE, G.J. (2002) The Mesozoic radiation of birds, in Annual Reviews in Ecology and Systematics, no. 33, pp. 91-124.

CHOFFAT, Paul - 1891 - Passeio geológico de Lisboa a Leiria in Revista Educação e Ensino vol. VI p. 289-340.

CLARKE, J.A.; TAMBUSSI, C.P.; NORIEGA, J.I.; ERICKSON, G.M. \& KETCHAM, R.A. (2005): Definitive fossil evidence for the extant avian radiation in the Cretaceous, in Nature no. 433, pp. 305-308

CLARK, J.M., NORELL, M.A. AND MAKOVICKY, P.J. (2002) Cladistic approaches to the 
relationships of birds to other theropod dinosaurs, in Mesozoic Birds: Above the Heads of Dinosaurs (eds L.M. Chiappe and L.M.Witmer), University of California Press, Berkeley, pp. 31-61.

COHEN, Alan \& SERJEANTSON, Dale, A Manual for the identifications of Birds from Archaeological sites, Academic Press, California.

CRÉMADÈS, M. (1993), Les Oiseaux, in Lárt Pariétal Paléolithique, Techniques et méthodes d'étude, pp. 173 - 180, Ministère de Lénseignement Supérieur et de la Recherche, Paris

CRESPO, E. G. (2001), Paleo-Herpetofauna de Portugal, Publicações Avulsas,2a Série, No7, Museu Bocage - M.N.H.N., Lisboa.

CORCHÓN RODRÍGUEZ, M. S. (2008) El Solutrense y el Arte Rupestre En Portugal. Reflexiones Acerca de la Obra de O. Da Veiga Ferreira y Su Proyección Actual, in Estudos Arqueológicos de Oeiras, C. M. Oeiras, pp. 183-234.

CUNHA, P.P. (1992) - Estratigrafia e sedimentologia dos depósitos do Cretácico Superior e Terciário de Portugal Central, a leste de Coimbra. Dissertação de Doutoramento em Ciências, na Universidade de Coimbra (especialidade de Estratigrafia, Paleontologia e Geoistória), Coimbra, 262 p.

CUNHA, P.P. (2000) - Paleoalterações e cimentações nos depósitos continentais terciários de Portugal central: importância na interpretação de processos antigos in Ciências da Terra (UNL), n 14, pp. 145-154.

CUNHA, P.P. \& MARTINS, A.A. (2004) - Principais aspectos geomorfológicos de Portugal central, sua relação com o registo sedimentar e a importância do controlo tectónico, in: Geomorfologia do NW da Península Ibérica. M.A. Araújo \& A. Gomes (Editores), Faculdade de Letras da Universidade do Porto, pp. 155182.

CUNHA, P.P. \& PENA DOS REIS, R. (1995) - Cretaceous sedimentary and tectonic evolution of the northern sector of the Lusitanian Basin, in Cretaceous Research, 16, pp. 155-170.

CUNHA, P.P., PIMENTEL, N. \& PEREIRA, D.I. (2000) - A assinatura tectono-sedimentar do auge da compressão bética em Portugal: a descontinuidade sedimentar Valesiano terminal-Turoliano, in Ciências da Terra (UNL), nº 14, pp. 61-72.

CUNHA, P.P., BARBOSA, B.P. \& REIS, R. PENA DOS (1993) - Synthesis of the Piacenzian onshore record, between the Aveiro and Setúbal parallels (Western 
Portuguese margin), in Ciências da Terra, Univ. Nova de Lisboa, no 12, pp. 3543.

CUNHA, P.P.; MARTINS, A.A.; DAVEAU, S. \& FRIEND, P.F. (2005) - Tectonic control of the Tejo river fluvial incision during the late Cenozoic, in Ródão - central Portugal (Atlantic Iberian border), in Geomorphology

CURRIE, P., Dir. (1997), Encyclopaedia of Dinossaurs, Academic press, California.

DANTAS, P., Dinossáurios de Portugal, Gaia, n. 2, pp. 17 - 26, Museu Nacional de História Natural, Lisboa, Dezembro de 1990.

DARWIN, C (1859) A Origem das Espécies, Lello \& Irmão Editores, s/d, Porto

DAVEAU, S. (1980), Espaço e Tempo. Evolução do ambiente geográfico de Portugal ao longo dos tempos pré-históricos. Clio, 2, p. 13-37.

DAVEAU, S., 1993. Evolução Quaternária da Plataforma Litoral, in O Quaternário em Portugal Balanço e Perspectivas, Colibri Ediç. pp. 35-41.

DAVID B. (1999), As Aves, Enciclopédia Visual, Editorial Verbo, Lisboa

DAVIS, S., 2002, The mammals and birds from the Gruta do Caldeirão, Portugal, Revista Portuguesa de Arqueologia. Volume 5, nº. 2, Lisboa, pp.29-98

DELGADO, J. F. N (1882) La Grotte de Furninha - Peniche, in Actas do IX Congresso Internacional de Antropologia e Arqueologia Pre-Histórica, Lisboa.

DELGADO, J. F. N. (1867) Notícia Acerca das Grutas da Cesareda, Typographia da Academia Real das Ciências, Lisboa.

DEL HOYO, ELLIOT, A. \& CHRISTIE, D. A. (Edit.), (1992), Handbook of the Birds of the World,(vol 1) Lynx Editions, Barcelona.

DEL HOYO, ELLIOT, A. \& CHRISTIE, D. A. (Edit.), (1994), Handbook of the Birds of the World,(vol 2) Lynx Editions, Barcelona.

DEL HOYO, ELLIOT, A. \& CHRISTIE, D. A. (Edit.), (1996), Handbook of the Birds of the World,(vol 3) Lynx Editions, Barcelona.

DEL HOYO, ELLIOT, A. \& CHRISTIE, D. A. (Edit.), (1997), Handbook of the Birds of the World,(vol 4) Lynx Editions, Barcelona.

DEL HOYO, ELLIOT, A. \& CHRISTIE, D. A. (Edit.), (1999), Handbook of the Birds of the World,(vol 5) Lynx Editions, Barcelona.

DEL HOYO, ELLIOT, A. \& CHRISTIE, D. A. (Edit.), (2002), Handbook of the Birds of the World,(vol 7) Lynx Editions, Barcelona. 
DEL HOYO, ELLIOT, A. \& CHRISTIE, D. A. (Edit.), (2004), Handbook of the Birds of the World,(vol 9) Lynx Editions, Barcelona.

DEL HOYO, ELLIOT, A. \& CHRISTIE, D. A. (Edit.), (2005), Handbook of the Birds of the World,(vol 10) Lynx Editions, Barcelona.

DEL HOYO, ELLIOT, A. \& CHRISTIE, D. A. (Edit.), (2009), Handbook of the Birds of the World,(vol 14) Lynx Editions, Barcelona

DEVILLE, J. (1996), Restes dÓiseaux de la Grotte d'Escoural, in Recherches Prehistoriques a la Grotte d'Escoural, Portugal, pp. 337 - 331, Marcel Otte e António Carlos Silva, Dir. (Etudes et Recherces Archéologiques de l'Université de Liège, no 65), Liége

DINIS, J.; REY, J.; CUNHA, P.P.; CALLAPEZ, P. \& PENA DOS REIS, R. (2008) - Stratigraphy and allogenic controls of the western Portugal Cretaceous: an updated synthesis, in Cretaceous Research, 29, 772-780.

DRIESCH, A. V.,(1976), A Guide to the Measurement of Animal Bones From Archaeological Sites, in Peabody Museum Bulletin, 1, Harvard University, Harvard.

DOMÉNECH, Rosa \& MARTINELL, Jordi,( 1996): Introducción a los Fossiles, Masson, Barcelona.

DUARTE, L. V. (2003a), Contribuição para a Valorização do Património Geológico da Costa Ocidental Porrtuguesa. O Interesse das Falésias Calcárias de S. Pedro de Moel e Peniche, in Ciências da Terra (UNL), Lisboa, nº esp. V, CD-Rom, pp. 136139.

DUARTE, L. V. (2003b), O Jurássico do Cabo Carboeiro, 20 Milhões de Anos de Histórias Geológicas com Valor Patrimonial, in Actas do III Seminário Recursos Geológicos, Ambiente e Ordenamento do Território. Departamento de Geologia, U.T.A.D., Vila Real, pp. 263-272.

DUTRA, T. L., (2000), Paleoecologia, in Paleontologia, (Ismar de Sousa Carvalho, editor), (2ª Edição), pp. 235 - 246 Editora Interciência, Rio de Janeiro.

EFREMOV, I. A. (1940) Taphonomy; new branch of Paleontology, in Pan-American Geology, no. 74, pp 81-93.

ELORZA, M.; SÁNCHEZ SANCHEZ-MARCO, A. (1993), Post glacial fossil Great Auk and associated avian fauna from the Biscay Bay in Munibe. 45, p. 179-185, San Sebastián. 
ESTRAVÍS, C. (2000), Nuevos mamíferos del Eoceno Inferior de Silveirinha( Baixo Montego, Portugal), in Colóquios de Paleontología, pp.281-311.

FERREIRA, A. B. (2000), Considerações Acerca do Arrefecimento Plistocénico em Portugal, in Finisterra, Vol. XXXV, no 70, pp. 89-101

FERREIRA, O. V. (1964), Jazidas quaternárias com fauna de vertebrados encontradas em Portugal. Arqueologia e História, 8a. Série, 11, p. 39-57

FERREIRA, O. V. (1975), Rinocerontes Quaternários encontrados em Portugal, in Comunicações dos Serviços Geológicos de Portugal, Tomo: LIX, Serviços Geológicos de Portugal, Lisboa

FERREIRA, O. da V., LEITÃO, M. Portugal Pré-Histórico: seu enquadramento no mediterrâneo, Publicações Europa-América, 2a ${ }^{\text {a }}$ Ed., Nem -Martins, s/d.

FIGUEIREDO, F. \& GALLO, V. (2000) Paleobiogeografia, in Paleontologia, (Ismar de Sousa Carvalho, editor), (2ª. Edição), pp. 247 - 266, Editora Interciência, Rio de Janeiro.

FIGUEIREDO, S (2004) Os Dinossauros da Arrábida, in Revista Tecne, no 9 pp Arqueojovem, Tomar (pp. 285-290)

FIGUEIREDO, S (2006) Os Dinossauros do Cabo Espichel in Actas do I Seminário de Arqueologia e Paleontologia do Estuário do Tejo, Edições Colibri e Câmara Municipal de Montijo, Montijo (pp.81-90).

FIGUEIREDO, S. (2006) A Avifauna do Plistocénico de Portugal, (no prelo) XV Congresso UISPP, Lisboa, 2006.

FIGUEIREDO, S.(2008), Os Dinossauros de Portugal, Colecção “ Entre o Homem, a Terra e a vida", Edições Cosmos, Chamusca,

FIGUEIREDO, S. (2009) - Aves Plistocénicas do Vale do Tejo, in Actas das Jornadas de Arqueologia do Vale do Tejo em Território Português, Centro Português de GeoHistória e Pré-História, Palmela, pp. 167-178.

FIGUEIREDO, S \& SOUSA, V, (2003) As Aves do Paleolítico da Gruta Nova da Columbeira - Bombarral, comunicação apresentada ao Congresso Nacional de Espeleologia, Leiria

FIGUEIREDO, S. \& SOUSA, M. F. (2003), Os Elefantes Pleistocénicos de Portugal, Separata da Revista Evolução n¹, Centro Português de Geo-História e Pré-História, Lisboa,

FIGUEIREDO, S., CARVALHO, J. \& NOBRE, L. (2005), A Estação Arqueológica do Campo 
de Futebol de Santo Antão do Tojal, in Actas do IV Congresso de arqueologia Peninsular, pp. 349 - 364, Faro

FIGUEIREDO, S. \& CARVALHO, J. (2007) A Pré-História do Espichel, Centro Português de Geo-História e Pré-História e Ed. Cosmos, Chamusca.

FRANÇA, J. C., ZBYSZEWSKI, G., e MOITINHO DE ALMEIDA, F., Notícia Explicativa da Folha 30B (Peniche) da Carta Geológica de Portugal, Serviços Geológicos de Portugal, Lisboa, 1960

GAMBLE, C, DAVIS, W., PETTIT, P., HAZLWOOD, L. \& RICHARDS, M., (2006), The Late Ancestry of Europeans: Combining genetic and archaeological evidence, in Documenta Praehistorica, vol. XXXIII, Universidade de Ljubljani, pp 1 - 10.

GILBERT, B. M., MARTIN L.D., SAVAGE, H.G. (1996), Avian Osteology, University College London Library, Londres.

GINSBURG, L., ZBYSZEWSKI, G. (1964-65) Découverte de Vertébrés Paléogènes dans la falaise de Feligueira Grande entre S. Pedro de Muel et Nazaré, Separata do Tomo XLVIII das Comunicações dos Serviços Geológicos de Portugal, Lisboa.

GOOLD, S. J. (1989) A Vida é Bela: O Xisto de Burgess e a Natureza da História, Gradiva, 1995, Lisboa

GOOLD, S. J. (1980) O Polegar do Panda: Reflexões sobre História Natural, Gradiva, 3aa. Edição 2002, Lisboa

GOODERS, J. \& HARRIS, A. (1990): Guia de Campo das Aves de Portugal e da Europa, Temas e debates, 2a . Edição, 2000, Lisboa.

HARLÉ, E. (1910-11) - Les mammifères et oiseaux quaternaires connus jusqu'ici en Portugal. Mémoire suivi d'une liste générale de ceux de la Péninsule Ibérique. Comunicações dos Serviços Geológicos de Portugal, VIII, p. 22-85

HARRISON, C. \& GREENSMITH, A., (1993): Aves do Mundo, Bertrand Editora, 1996, Lisboa.

HARRISON, C.J.O. (1983) - A New Wader, Recurvirostridae (Charadriiformes), from the early Eocene of Portugal. in Ciências da Terra, n 7, p.9-16. Universidade Nova de Lisboa, Lisboa.

HARTMANN-PETERSEN \&PIGFORD, J. N. (1984), Dicionário de Ciência, Publicações D. Quixote, 1991, Lisboa.

HOBSON, K.A. \& MONTEVECCHI, W.A (1991), Stable isotopic determinations of trophic relationships of great auks. In Oecologia, nº. 87, pp. 528-531. 
HÖFLING, E. \& ALVARENGA, H. (2000) Aves, in Paleontologia, (Ismar de Sousa Carvalho, editor), (2a . Edição), pp. 817 - 832, Editora Interciência, Rio de Janeiro.

JORDAN, R. H. \& OLSON, S. L. (1982): First Record of the Great Auk (Pinguinus impennis) from Labrador. In Auk vol. 99, n. 1, pp. 167-168.

KLEIN, R. G. \& CRUZ-URIBE, K. (1984) - The analysis of animal bones from archaeological sites. Chicago: University of Chicago Press.

KARDONG, K. V. (2002) Vertebrates: comparative anatomy, function, evolution (3a. Ed.), Mc Graw Hill, Nova York.

LAMBERT, O. ESTEVENS, M. \& SMITH, R. (2005) A New Kentriodontine dolfin from the middle Miocene of Portugal, in Acta Palaeontologica Polononica, 50, pp. 239 $248, \mathrm{~s} / \mathrm{l}$.

LAPPARENT-DE BROIN \& ANTUNES, M. T. (2000) "Pleistocene Chelonians From Gruta da Figueira-Brava (Arrábida, Portugal", in actas do colóquio Últimos Neandertais em Portugal, evidência, odontológica e outra, pp. 105 - 116, Academia das Ciências, Lisboa.

LIVEZEY, B. C. (1988). Morphometrics of flightlessness in the Alcidae. Auk Vol. 105, nº. 4, pp. 681-698.

LYMAN, R. L. (1994) - Quantitative units and terminology in Zooarchaeology, in American Antiquity, n० 59(1), pp. 36-71.

LYMAN, R. L. \& POWER, E. (2003) - Quantification and Sampling of Faunal Remains in Owl Pellets, in Journal of Taphonomy, Vol. 1, pp. 3 - 14.

LYMAN, R. L. (2004) - The Concept of Equifinality in Taphonomy, in Journal of Taphonomy, Vol. 2(1), pp. 15 - 26.

LOPES, F.C.; CUNHA, P.P. \& LE GALL, B. (2006) - Cenozoic seismic stratigraphy and tectonic evolution of the Algarve margin (offshore Portugal, southwestern Iberian Peninsula). Marine Geology, vol. 231, pp. 1-36.

LOPES, F. C.; CUNHA, P.P.; BERNAD, LE GAL \& MENDES-VICTOR, L. (2008) - Tectónica salífera cenozóica na Margem Algarvia, in: A Terra: Conflitos e Ordem. Livro de Homenagem ao Professor A. F. Soares, Coimbra, pp. 231-242.

MACHADO J. L. S. (1964) - Subsídios para a história do Museu Etnológico do Dr. Leite de Vasconcelos, in O Arqueólogo Português, N. S., vol. V.

MAIA, Celestino \& COSTA, Filinto (1957) Compêndio de Mineralogia e Geologia, 
Edições Marânus, Porto

MARÇAL, F. \& MARTINS, F. (2006) A Arrábida: um olhar por dentro e por fora in Actas do I Seminário de Arqueologia e Paleontologia do Estuário do Tejo, Edições Colibri e Câmara Municipal de Montijo, Montijo (pp.111-125).

MARTINS, A., CUNHA, P. P., BUYLAERT, J.-P., HUOT, S., MURRAY A.S., DINIS, P. \& STOKES, M. (2010), K-feldspar IRSL dating of a Pleistocene river terrace staircase sequence of the Lower Tejo River (Portugal, western Iberia), Quaternary Geochronology, n., pp. 5 176-180.

SANCHEZ-MARCO, A. S., (1987) L'Evolution dês Oiseaux d'Après le Témoignage dês Fossiles, in Docum. Lab. Géologique d'Lyon, n. 99, p. 193-196, Lyon

SANCHEZ-MARCO, A. S., (1996) Tertiary Avian Localites of Portugal, in Acta Universitatis Carolinae Geologica, n. 39, p. 699-701, s/l

SANCHEZ-MARCO, A. S., (1996), Aves Fosiles del Pleistoceno Iberico: rasgos climáticos, ecológicos Y zoogeograficos, in Ardeola, n 43(2), p. 207-219, Madrid.

SANCHEZ-MARCO, A. S. (1999a). Aves del yacimiento mesopleistoceno de Galería (sierra de Atapuerca). Patrones ecológicos en el Pleistoceno médio, in Atapuerca: ocupaciones humanas y paleoecología delyacimiento de Galeria (E. Carbonell, A. Rosas \& J. C. Díez - Eds.), Arqueología en Castilla y León, 7, pp. 211-224

SANCHEZ-MARCO, A. S. (1999b). Implications of the avian fauna for paleoecology in the Early Pleistocene of the Iberian Peninsula. In Journal of Human Evolution, 37, pp. 375-388.

SANCHEZ-MARCO, A. S., (2004), Avian Zoogeographical Patterns During the Quaternary in the Mediterranean Region and Paleoclimatic interpretation, in Ardeola, no 51(1), p. 91-132, Madrid

MARKS, A.E., BRUGAL, J.P., CHABAI, V.P., MONIGAL, K.,GOLDBERG, P., HOCKETT, B., PEMAN, E., ELORZA, M., MALLOLL,C. (2002). Le gisement Pléistocéne moyen de Galeria Pesada, (Estrémadure, Portugal): premiers résultats, in Paléo no. 14, 77-100.

MARKS, A.E., MONIGAL, K., CHABAI, V.P. (1999) Report on the initial excavations of Brecha das Lascas and Galeria Pesada (Almonda, Portuguese Estremadura). In Journal of Iberian Archaeology, №. 1, pp. 237-250. 
MARKS, A.E., BRUGAL, J.P., GOLDBERG, P., HOCKETT, B., PEMAN, E., ELORZA, M., MALLOL, C. (2000) Excavations at the Middle Pleistocene cave site of Galeria Pesada, Portuguese Estremadura: 1997-1999, in O Arqueólogo Português Série IV,no. 18, pp. 29 - 40, Museu Nacional de Arqueologia, Lisboa.

MARQUES, G., ANDRADE, G. M. (1974), Aspectos da Protohistória do Território Português. 1 - Definição da Cultura de Alpiarça (Idade do Ferro), Actas do 3.․ Congresso Nacional de Arqueologia, Porto, pp. 125-148.

MARTINS, A.A. \& CUNHA, P.P. (2009) - Terraços do rio Tejo em Portugal, sua importância na interpretação da evolução da paisagem e da ocupação humana, in Actas das Jornadas de Arqueologia do Vale do Tejo em Território Português, CPGP, Lisboa, pp. 167-178.

MARTINS, A.A., CUNHA, P.P.; HUOT, S.; MURRAY, A. \& BUYLAERT, J.P. (2009a) Geomorphological correlation of the tectonically displaced Tejo River terraces (Gavião-Chamusca area, central Portugal) supported by luminescence dating, in Quaternary International, Elsevier Science Publishers, 199, pp. 75-91.

MARTINS, A.A., CUNHA, P.P., BUYLAERT, J.-P., HUOT, S, MURRAY, A.S., DINIS, P., STOKES, M. (2009b) - K-Feldspar IRSL dating of a Pleistocene river terrace staircase sequence of the Lower Tejo River (Portugal, western Iberia), in Quaternary Geochronology, doi: 10.1016/j.quageo.2009.06.004

MARTIN, T \& KREBS, B, (2000) Eds, Guimarota - a Jurassic Ecosystem, Verlag (Dr. F. Pfeil), Miinchen

MASSADA, J. L. (2001) O Bipedismo no Homo Sapiens: postura recente. Nova patologia, Ed. Caminho, Lisboa

MELDEGAARD, MORTEN (1988) The Great Auk, Pinguinus impennis (L.) in Greenland. Historical Biology 1, pp. 145-178

MENDES, J. C. (1988), Paleontologia Básica, Ed. Da Universidade de São Paulo, S. Paulo MORENO-GARCÍA, M \& PIMENTA, C. M. (2002) The Abrigo do Lagar Velho: the paleofaunal context, in Portrait of the Artist as a Child: the gravettian human skeleton from the Abrigo do Lagar Velho and its Archaeological context , pp. 112 - 131, João Zilhão e Erik Trinkaus, eds (Trabalhos de arqueologia, no 22), Instituto Português de Arqueologia, Lisboa.

MORENO-GARCÍA, M, DAVIS, S. \& PIMENTA, C. M. (2003) Arqueozoologia: estudo da fauna do passado in Paleoecologia Humana e Arqueociências - Um Programa 
Multidisciplinar para a Arqueologia sob a Tutela da Cultura in Paleoecologia Humana e Arqueociências: um Programa Multidisciplinar para a Arqueologia sob a Tutela da Cultura, pp. 192 - 199, José Eduardo Mateus e Marta MorenoGarcía, eds (Trabalhos de arqueologia, no 29), , Instituto Português de Arqueologia, Lisboa.

MOURER-CHAUVIRÉ, C.; ANTUNES, M. T. (1991), Presence of Great Auk, Pinguinus impennis, (Aves, Charadriiformes) in the Pleistocene of Portugal, in Geobios, 24, 2, pp. 201-205, Lyon.

MOURER-CHAUVIRÉ, C., (1993). The Pleistocene avifaunas of Europe, in Archaeofauna $2,53-66$.

MOURER - CHAUVIRÉ, C. \& ANTUNES, M. T.,(2000) “L'Avifaune Pléistocène et Holocene de Gruta da Figueira Brava", in actas do colóquio Últimos Neandertais em Portugal, evidência, odontológica e outra, pp. 129 - 162, Academia das Ciências, Lisboa.

MOURER-CHAUVIRE, C. \& ANTUNES, M.T. (2003), Présence de Palaeoperdix media (Aves, Galliformes, Phasianidae) et d'autres oiseaux dans le Miocéne du Portugal, in Ciências da Terra No 15, UNL, Lisboa,pp 191-198

MOUM, T.; ARNASON, U. \& ÁRNASON, E. (2002): Mitochondrial DNA Sequence Evolution and Phylogeny of the Atlantic Alcidae, Including the Extinct Great Auk (Pinguinus impennis). In Molecular Biology and Evolution Vol. 19 n. 9, pp. 1434-1439.

NICOLAI, J, SINGER, D. \& WOTHE, K. (1994) Birds of Britain \& Europe, in Collins Nature Guides, HarperCollinsPublishers, Londres.

OLIVEIRA, A. C. \& SILVA, A. R. (2000), Carta Arqueológica do Município de Loures, Câmara Municipal de Loures, Loures.

OOSTERBEeK, L., GRIMALDI, S., ROSINA, P., CURA, S, CUNHA, P. P. \& MARTINS, A. (2010), The earliest Pleistocene archaeological sites in western Iberia: Present evidence and research prospects, Quaternary International, pp. 1-9.

PARKER, S. (1997) Ossos e Estruturas Ósseas, Enciclopédia Visual, Editorial Verbo, Lisboa

O'CONNOR, T. (2004), The Archaeology of Animal Bones, Sutton Publishing OSTROM, J. H. (1976). Archaeopteryx and the origin of bird, Biological Journal of the Linnean Society 8 (2), pp. 91- 182. 
PADIAN, K. \& CHIAPPE, L. M., (1998), "The Origin of Birds" and their Flight, in Scientific America, pp. 38 - 47.

PAIS, J.; CUNHA, P.P. \& LEGOINHA, P. (2009, in press) - Uma proposta litostratigráfica para o Cenozóico de Portugal, in Livro Branco da Geologia.

PENA DOS REIS, R.; CORROCHANO, A.; BERNARDES, C.M. ; CUNHA, P.P. \& DINIS, J.M.L. (1992) - O Meso-Cenozóico da margem atlântica portuguesa. Livro editado pelo III Congreso Geologico de España e VIII Congreso Latinoamericano de Geologia (Guias de las excursiones geológicas), Salamanca, pp. 115-138.

PENA DOS REIS, R.; CUNHA, P.P.; DINIS, J.L. \& TRINCÃO, P.R. (2000) - Geologic evolution of the Lusitanian Basin (Portugal) during the Late Jurassic, in GeoResearch Forum, Transtec Publications, Zurich, vol. 6, pp. 345-356.

PIEPER, H. (1985) - The fossil land birds of Madeira and Porto Santo, in Bocagiana, 88, pp. $1-6$, Funchal.

PIMENTA, C., FIGUEIREDO, S. MORENO-GARCIA, M. (2009, no prelo), Novo registo de Pinguim (Pinguinus impennis) no Plistocénico de Portugal.

POPLIN, F. (1976a) - A propos du nombre de restes et du nombre d'individus dans les échantillons d'ossements, in Cahiers du centre de Recherches Préhistoriques, nº 5, pp. 61 - 75.

POPLIN, F. (1976b) - Remarques théoriques et pratiques sur les unités utilisées dans les études d'ostéologie quantitative, particulièrement en Archéologie Préhistorique, in Actas dolX Congresso da U.I.S.P.P. pp. 124-141, Nice.

RAMALHO, M. M. (2004), Património Geológico Português, importância científica, pedagógica e sócio-económica, Geonovas, 18, pp. 5 - 12, Associação Portuguesa de Geólogos.

RAPOSO, L. (1983), As Comunidades de Caçadores Recolectores do Paleolítico, in História de Portugal, Dir. José Hermano Saraiva, Vol. 1, Ed. Alfa, Lisboa, pp. 31 62

RAPOSO, L. (1991) - Campanha de Escavações Arqueológicas no Sítio da Foz do Enxarrique. Alto Tejo, in Boletim Informativo do Núcleo Regional de Investigação Arqueológica, n॰ 9, pp. 1 - 2.

RAPOSO, L (1993a) O Paleolítico Médio, in O Quaternário em Portugal - balanço e Perspectivas, pp. 147-161. APEQ, Ed. Colibri, Lisboa

RAPOSO, L (1993b) O Paleolítico, in Pré-História de Portugal, (cood. Armando Coelho 
da Silva), Universidade Aberta, Lisboa

RAPOSO, L. (1995) Ambientes, Territorios y Subsistencia en el Paleolítico Medio de Portugal, Complutum, 6, pp. 57 - 77, Madrid.

RAPOSO, L. (1998) O Paleolítico, in História de Portugal, pp. 65-244, Dir. João Medina, Vol. I, Ediclube, 2004, Amadora

RAPOSO, L. (2001) O Paleolítico da Região de Loures, in Catalogo da Exposição "Redescobrir a Várzea de Loures", pp. 41-50, Câmara Municipal de Loures, Loures.

RAPOSO, L. (2004) O Paleolítico in História de Portugal, pp. 65-244, Dir. João Medina, Vol. I, Ediclube, Amadora

RAPOSO, L. (2006) Algumas Considerações acerca da Ocupação Humana do Paleolítico Inferior e Médio na Zona do do Estuário do Tejo in Actas do I Seminário de Arqueologia e Paleontologia do Estuário do Tejo, Edições Colibri e Câmara Municipal de Montijo, Montijo (pp.43-62).

RAPOSO, L. \& CARDOSO, J. L. (1998a) Las Industrias Líticas de la Gruta Nova de Columbeira (Bombarral, Portugal) en el Contexto del Mustierense Final de la Peninsula Ibérica, Trabajos de Prehistoria, 55, no 1, pp 39 - 62, Cosejo Superior de Investigaciones Cientificas, Madrid,.

RAPOSO, L. \& CARDOSO, J. L. (1998b), O Paleolítico Médio da Conceição (Alcochete), Lusoponte/CEMA, Lisboa

RAPOSO, L.., SALVADOR, M. M. \& CARREIRA, J. R. (1993) O Acheulense no Vale do Tejo, em Território Português, in Arqueologia e História, Série X - Vol. III, Lisboa (рp.3-30).

RAPOSO, L. \& CARREIRA, J. R. (1994) Os Primeiros Habitantes da Região de Lisboa", in Catalogo da Exposição "Lisboa Subterrânea", Museu Nacional de Arqueologia, Lisboa (pp.31-38).

REGALA, F. T. \& GOMES, E (1995). Grutas Arqueológicas da Maceira in Trogle, n 4, pp. 12-21, Torres Vedras.

REY, J.; DINIS, J.L.; CALLAPEZ, P. \& CUNHA, P.P. (2006) - Da rotura continental à margem passiva. Composição e evolução do Cretácico de Portugal, in Cadernos de Geologia de Portugal, INETI (Ed.), Lisboa, 75 p.

RIBEIRO, J. P. C. (1990) Portugal das Origens à Romanização - Os Primeiros Habitante, in Nova História de Portugal, Coor. Jorge de Alarcão - I Vol. Editoral Presença, 
Lisboa (pp. 16-74).

RIOS-NETO, A. M. (2000) Taxonomia e Sistemática, in Paleontologia (Ismar de Sousa Carvalho, editor), (2a . Edição), pp. 129 - 142, Editora Interciência, Rio de Janeiro.

RICH, P. V., RICH, T. H., FENTON, M. A. \& FENTON, C. L. (1996): The Fossil Book, Dover Publications, Nova York.

ROCHE, J., (1951), Le Niveau Paleolithique Supérior de la Grotte de Casa da Moura (Cesareda), in Comunicações dos serviços Geológicos de Portugal, Tomo XXXII, Direcção Geral de Minas e Serviços Geológicos, Lisboa, pp 103-123.

ROCHE, J. (1971), Le Climat et les Faunes du Paléolithique Moyen et Supérieur de la Province d'Estremadura, in Actas do II Congresso Nacional de Arqueologia, p. $39-48$

ROCHE, J. (1972), Faunes du Pléistocène Supérieur et Final de l'Estremadura, Portugal. Annales de Paléontologie (Vértébrés), 58 (2), p. 229-242

ROCHE, J., CAMARATE FRANÇA, J., FERREIRA, O V., ZBYSZEWSKI, G. (1962), Le Paleolithique Supérior de la Grotte de Salemas (ponte da Lousa), in Comunicações dos serviços Geológicos de Portugal, Tomo XLVI, Direcção Geral de Minas e Serviços Geológicos, Lisboa, pp. 187-207.

ROCHE, J., FERREIRA, O. V. (1970), Stratigraphie et Faune des Neveaux Paleolithiques de la Grotte de Salemas (ponte da Lousa), in Comunicações dos serviços Geológicos de Portugal, Tomo LIV, Direcção Geral de Minas e Serviços Geológicos, Lisboa, pp. 263-269.

ROSINA, P.\& CURA, S. (2009) Crono-estratigrafia e Indústrias Líticas dos Sítios Paleolíticos do Alto Ribeatejo (Fonte da Moita, Ribeira da Atalaia e Santa Cita), in Actas das Jornadas de Arqueologia do Vale do Tejo, em Território Português, Centro Português de Geo-História e Pré-História, pp. 143-158, Lisboa

SANCHIDRIÁN, J. L. (2001) Manual de Arte Préhistórico (1ª. Edição), Editorial Ariel, Barcelona

SANTOS, M. F. (1985): Pré-História de Portugal (3ª. Edição ), Ed. Verbo, Lisboa.

SAVORY, H. N.(1985): Espanha e Portugal, Ed. Verbo, Lisboa.

SERENO, P.C. (1999) The Evolution of Dinosaurs, in Science, no. 284, pp. 2137-47.

SERENO, P.C. (2001) Alvarezsaurids: birds or ornithomimosaurs?, in New Perspectives on the Origin and Early Evolution of Birds (eds J. Gauthier and L.F. Gall), Yale 
Peabody Museum, New Haven, pp. 69-98.

SIMÕES, M. G. \& HOLZ, M. (2000) Tafonomia: Processos e Ambientes de Fossilização, in Paleontologia (Ismar de Sousa Carvalho, editor), (2ª. Edição), pp. 19 - 46, Editora Interciência, Rio de Janeiro.

SIMPSON, G. G. (1989), Princípios de Taxonomia Aminal (2ª. Ed.), Fundação Calouste Gulbenkian, Lisboa.

SOARES, A. M. (2004) - Identificação e caracterização de eventos climáticos na costa portuguesa, entre o final do Plistocénico e os tempos históricos - o papel do Radiocarbono, in Actas do Colóquio sobre Evolução Geohistórica do litoral português e fenómenos correlativo, pp. 171-199, Lisboa.

SOUSA, M. F e FIGUEIREDO, S. M., (2001), The Pleistocene Elefants of Portugal, actas do Congresso La Terra degli Elefanti, pp 611 - 616,Roma.

STRAUS, L., ALTUNA, J., JACKES, M. \& KUNST, M. (1988) New Excavations in Casa da Moura (Serra D'El Rei, Peniche) Anda t the Abrigos de Bocas (Rio Maior), Portugal, in Arqueologia, n 18, Grupo de estudos Arqueológicos do Porto (GEAP), pp. 65-93, Porto.

TEIXEIRA, C., (1979). Plio-Plistocénico de Portugal, in Comunicações dos Serviços Geológicos de Portugal, Lisboa, 65, pp. 35-46.

TERRINHA, P. A. C. (1998) - Structural Geology and Tectonic Evolution of the Algarve Basin. Tese de Doutoramento, Universidade de Lisboa.

TYRBERG, T. (1998), Pleistocene birds of the Palearctic. A catalogue, Nuttall Ornithological Club, No. 27, Cambridge (Massachusetts), pp. 720.

TRINKAUS, E.; MARKS, A. E.;BRUGAL, J.-P.; BAILEY, S. E.; RINK, W.J. \& RICHTER, D.( 2003), Later Middle Pleistocene Human Remains from the Almonda Karstic System, Torres Novas, Portugal in Journal of Human Evolution, n 45, pp. 219-226.

VALENTE, M. J. (1994) - Uma disciplina chamada Tafonomia. In Al-madan. 3(IIa Série), pp. 14-17, Almada.

VALENTE, M. J. (1997) - A quantificação faunística: principais unidades, alguns parâmetros, regras e problemas, in Estudos do Quaternário. 1, pp. 83-96.

VUILLEUMIER, F. (2001) Aves, in Grande Enciclopédia Animal (Ed. David Burnie), pp. 258 - 361, Civilização Editores, 2002, Porto

WEIGEL, P. H. (1958), Great Auk Remains from a Florida Shell Midden. In Auk Vol. 75, no. 2, pp. 215-216. 
WEIGELT, J. (1919) Geologie und Nordseefauna, in Der Steinbruch, 14, pp. 228-231; 244-246.

WEIGERT, A. (1995), Isolierte Zähne von cf. Archaeopteryx sp. Aus dem Oberen Jura der Kohlengrube Guimarota (Portugal), N. Jb. Geol. Paläont. Mh.9 562 - 576.

WEISHAMPEL, D. B., Dir (1990): The Dinosauria, University of California Press, California.

ZBYSZEWSKI, G. (1954), Découverte d'une mandibule de "Palaeziphius" dans le Miocéne de Melides, Separata do Tomo XXXV das Comunicações du Portugal, Lisboa.

ZBYSZEWSKI, G. (1954), Découverte d'une mandibule de "Palaeziphius" dans le Miocéne de Melides, Separata do Tomo XXXV das Comunicações du Portugal, Lisboa.

ZBYSZEWSKI, G, (1954) L'Aquitanien supérieur de Lisbonne et du Ribatejo, Separata do Tomo XXXV das Comunicações dos Serviços Geológicos de Portugal, Lisboa

ZBYSZEWSKI, G. (1958) - Le Quaternaire du Portugal, in Boletim da Sociedade Geológica de Portugal, 13 (1 e 2), pp. 3-227, Lisboa.

ZBYSZEWSKI, G. (1964), Notícia Explicativa da Folha 2 (Loures) da Carta Geológica dos Arredores de Lisboa, Serviços Geológicos de Portugal, Lisboa.

ZBYSZEWSKI, G. (1964), Nova Contribuição para o conhecimento da Jazida Quaternária da Mealhada, in Memórias e Notícias. Museu L. M. G. Uni. Coimbra, n 84, pp. 1 37.

ZBYSZEWSKI, G. FERREIRA, O da V. (1967) Découverte de vertébrés Fossiles dans le Miocéne de la Région de Leiria, in Comunicações dos Serviços Geológicos de Portugal, no. 52, p. 5 - 10, Serviços Geológicos de Portugal, Lisboa

ZBYSZEWKI, G. \& LAPPARENT, F. de (1957), Les Dinosauriens du Portugal, Serviços Geológicos de Portugal, Lisboa.

ZBYSZEWSKI G., LEITÃO M. PENALVA C. \& FERREIRA O. V. (1980/81) Paleoanthropologie du Würm au Portugal. Setúbal Arqueológica, Vol. VI / VII, pp.7-23.

ZBYSZEWSKI, G., FERREIRA, O V., MANUPPELLA, G. e ASSUNÇÃO, C. T. (1966), Notícia Explicativa da Folha 30B (Bombarral) da Carta Geológica de Portugal, Serviços Geológicos de Portugal, Lisboa.

ZBYSZEWSKI, G., e MOITINHO DE ALMEIDA, F. (1960), Notícia Explicativa da Folha 26 D (Caldas da Rainha) da Carta Geológica de Portugal, Serviços Geológicos de 
Portugal, Lisboa.

ZILHÃO J. (1985) - Néolithique ancien et Paléolithique Supérieur de la Gruta do caldeirão (Tomar, Portugal) - fouilles 1979 - 1984, in Actas da I Reunião do quaternário Ibérico, 2 vol., pp. 101 - 112, Lisboa.

ZILHÃO J. (1987a) - O Solutrense da Estremadura Portuguesa: Uma proposta de interpretação paleoantropológica, in Trabalhos de Arqueologia, no. 4, pp. 94. Dep. de Arqueologia do Instituto Porctuguês do Património Cultural, Lisboa.

ZILHÃO J. (1987b) - A Gruta do caldeirão (Tomar, Portugal) - Balanço de sete ano de escavações arqueológicas 81979 - 1985), in Algar, no. 1, pp. 29-38, Sociedade Portuguesa de Espeleologia, Lisboa.

ZILHÃO, J. (1993) - As origens da arqueologia paleolítica em Portugal e a obra metodologicamente precursora de J. F. Nery Delgado, in Arqueologia e História, Série X, Vol. III, pp. 3-17, Lisboa.

ZILHÃO, J. (1997): O Paleolítico Superior da Estremadura Portuguesa, ed. Colibri, 2 vol., Lisboa

ZIHÃO, J., (2000) Nature and culture in Portugal from 30000 to 20000 BP, in Hunters of the golden Age, the mid upper Palaeolithic of Eurasia 30000-20000 BP, University of Leiden, p.337-354

ZILHÃO, J. (2001) O Paleolítico Superior em Loures, in Catalogo da Exposição "Redescobrir a Várzea de Loures", Câmara Municipal de Loures, Loures (pp.55$62)$.

ZILHÃO, J., MAURÍCIO, J., SOUTO, P., (1991). A Arqueologia do Almonda. Resultados das escavações de 1988-1989, in Actas das IV Jornadas Arqueológicas (Lisboa, 1990), Lisboa, associação dos Arqueólogos Portugueses, pp. 161-171.

ZILHÃO, J., MAURíCIO, J., SOUTO, P., (1993). Jazidas arqueológicas do sistema cársico da nascente do Almonda in Nova Augusta, Rev. Cult. pp. 35-52.

ZILHÃO, J. \& TRINKAUS, E. (eds.) (2002) Portrait of the Artist as a Child, Trabalhos de Arqueologia, $n^{\circ} .22$, pp. 609, IPA, Lisboa 


\section{Internet:}

BRADLEY, D. M. (2005) Implications of Late Pleistocene Climatic Change on the Morpholical Variations of the Neanderthal [Tese de Mestrado, o line] http://etd.gsu.edu/theses/available/etd11282005134926/unrestricted/bradle y_dawn_m_200512_mast.pdf [consultado em 15/01/2010]

PENA DOS REIS, R. (2002), Evolução Geológica da bacia Lusitânica, Dep. Ciências da Terra - Universidade de Coimbra, [online] http://www1.ci.uc.pt/cienterra/ect/2003ResCursoAPGp5-9.pdf [acedido em 8/10/2008].

SILVA, C. M. (2005) - Guia do Professor. Exposição “Plumas em Dinossáurios! Afinal nem todos se extinguiram “. Museu Nacional de História Natural da Universidade de Lisboa [consultado em 12/10/2008]

TYRBERG, T. (2006) Pleistocene birds of the Paleartic, web.telia.com/ u11502098/pleistocene.pdf [consultado em 27/9/2007]

SANCHEZ-MARCO, A. (2007), Yacimientos del Cuaternario: descripción, antecedentes y registro aviar, http://www.avesfosiles.com/OtraDoc/Yacimientos.html [consultado em 24/10/2009] 
ESTAMPAS 


\section{Estampa I}

1 - Úmero direito de Puffinus puffinus da Furninha. Vista cauda I(esquerda), vista cranial (direita).

2 - 3 - Ossos de de Alectoris rufa da gruta das Fontainhas (2) e da Gruta Nova da Columbeira(3):

2 - Coracóide esquerdo. Vista cranial (em cima) e caudal (em baixo).

3 - Tarsometarso direito. Vista cranial (esquerda), vista caudal (direita).

4 - Úmero direito Perdix perdix, da Lapa da Rainha. Vista caudal (esquerda) e vista cranial (direita).

5 - Fragmento distal de fémur direiro de Lagopus lagopus, da Lapa da rainha. Vista cranial (esquerda) e vista caudal (direita).

6 - Fragmento proximal de úmero esquerdo de Cf. Phasianus colchicus da Gruta do Pego do Diabo. Vista cranial (esquerda), vista cauda (direita). 


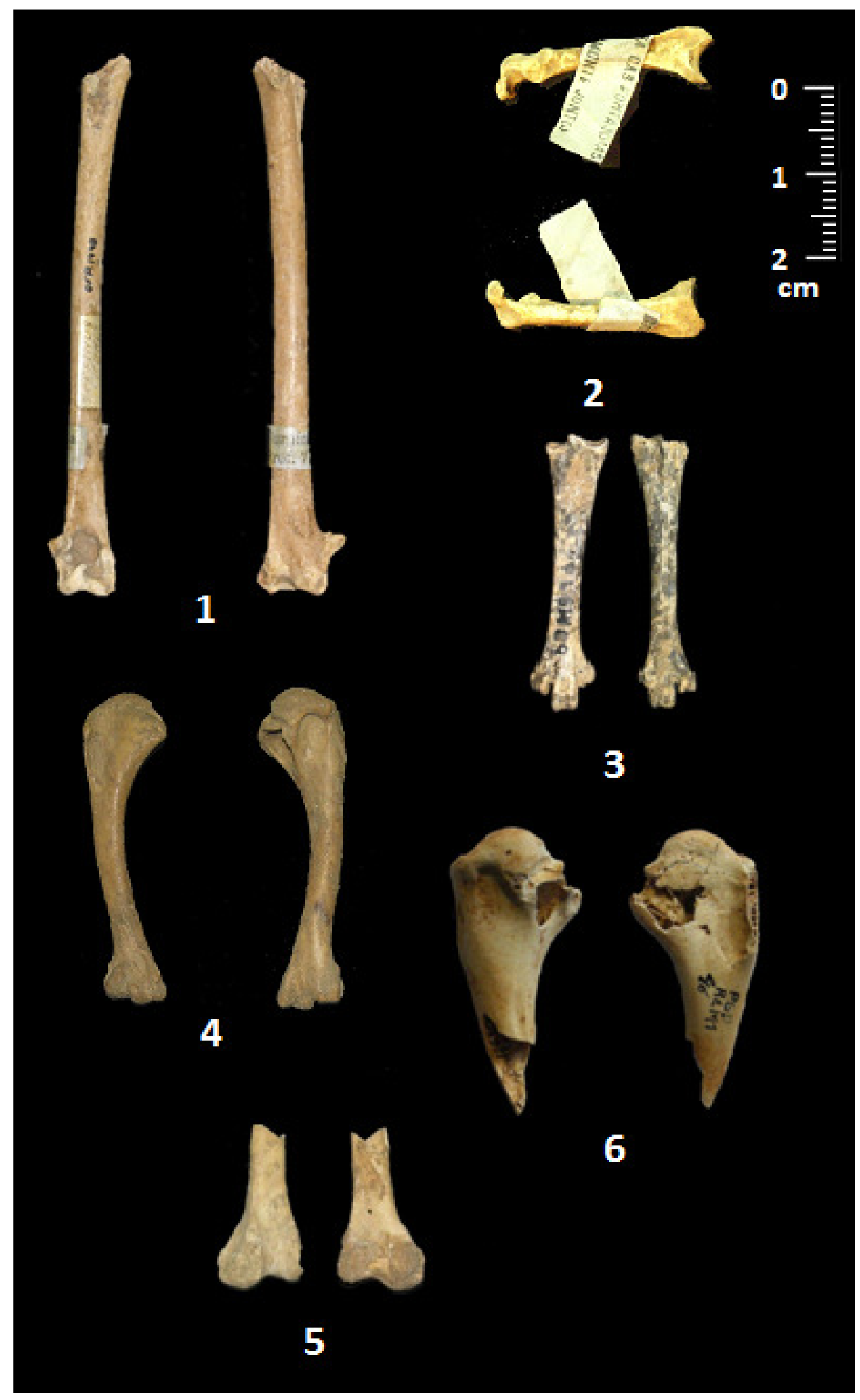




\section{Estampa II}

1 - Carpometacarpo direito de Anser albifrons da Gruta do Pego do Diabo (vista dorsal)

2 - Úmero direito de Anas creca da Gruta da Furninha. Vista caudal (esquerda) e vista cranial (direita).

3 - Úmero esquerdo de Cignus olor da Furninha (vista cranial).

4 - 5 - Restos de de Melanita nigra da Gruta da Furninha (4) e Gruta Nova da Columbeira (5):

4 - Úmero esquerdo. Vista caudal (direita), vista cranial (esquerda);

5 - Fragmento distal de tibiotarso esquerdo. Vista cranial (direita), vista lateral (ao meio) e vista caudal (esquerda). 


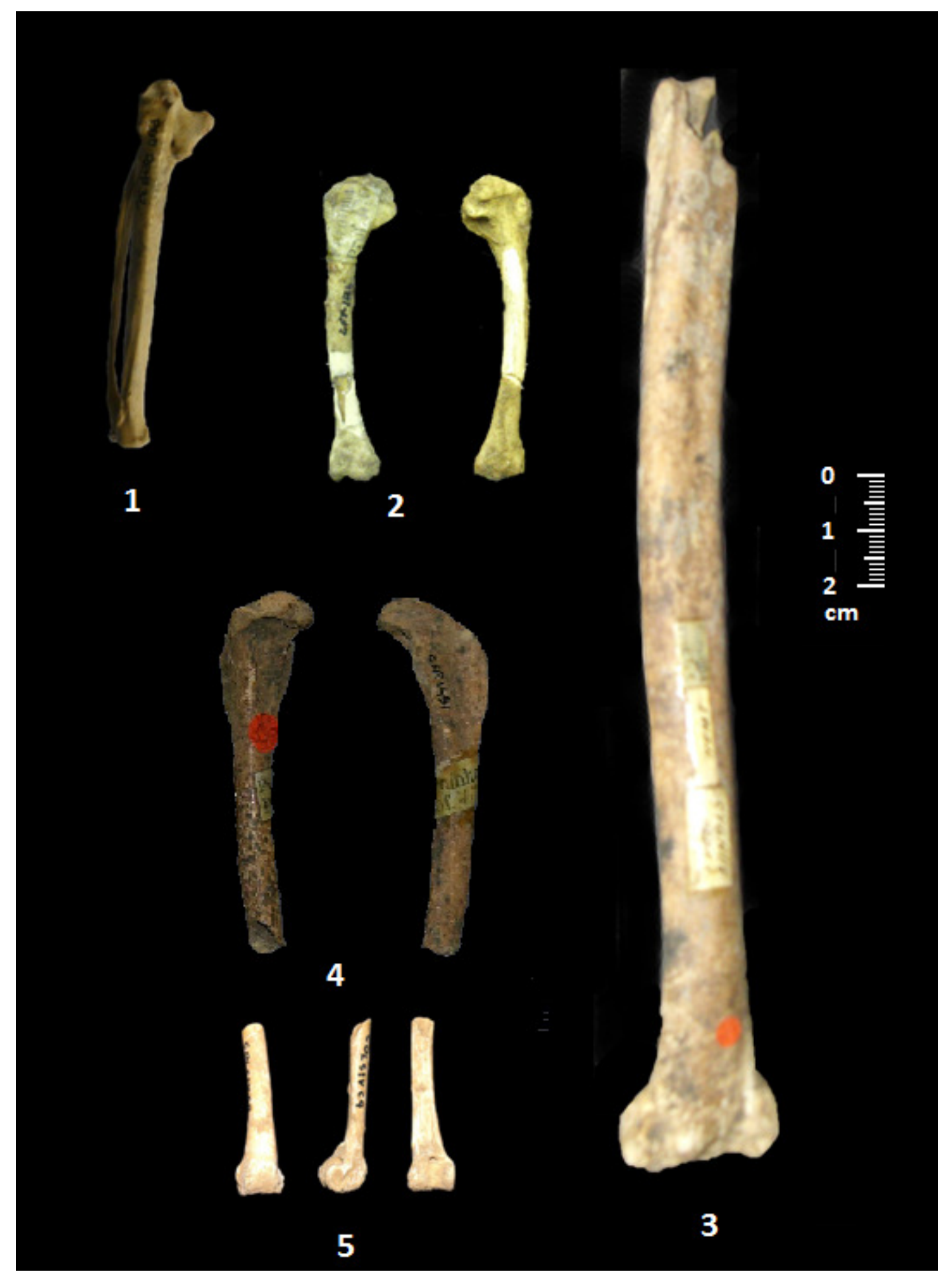




\section{Estampa III}

Conjunto de ossos de Tadorna tadorna da Gruta da Furninha:

1 - Coracóide direito. Vista cranial (em cima), vista caudal (em baixo).

2 - Úmero direito. Vsta cranial (direita) e vista caudal (esquerda).

3 - Ulna direita. Vista caudal (esquerda) e vista cranial (direita).

4 - Carpometacarpo direito. Vista ventral (esquerda), vista dorsal (direita).

5 - Fémur direito. Vista cranial (esquerda) e vista caudal (direita).

6 - Tarsometatarso direito. Vista cranial (esquerda), vista lateral (centro) e vista caudal (direita). 


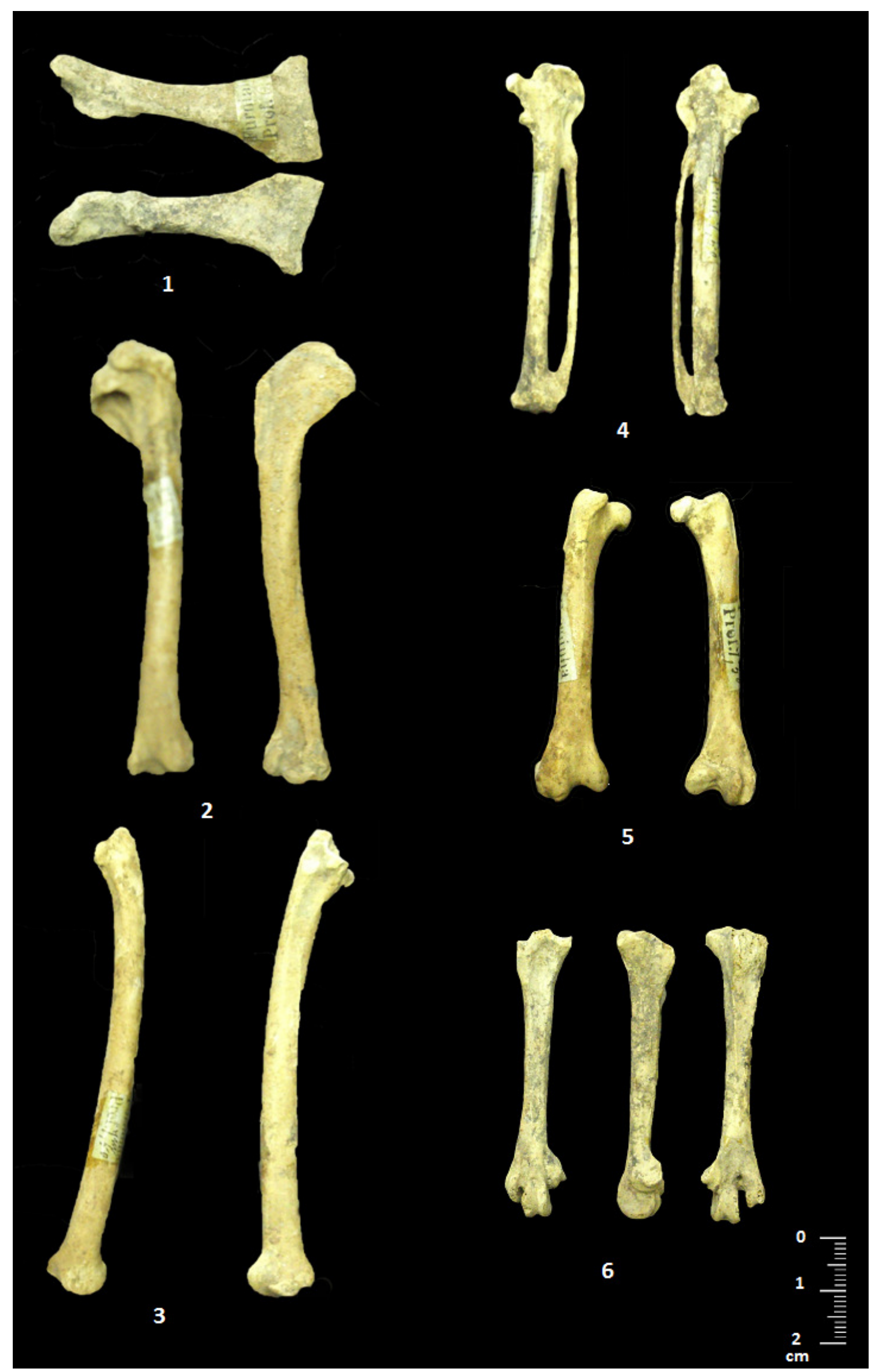




\section{Estampa IV}

Conjunto de ossos de Somateria mollissima da Gruta da Furninha:

1 - Escápula direita. Vista lateral (esquerda), vista costal (direita).

2 - Coracóide esquerdo. Vista cranial (em cima), vista caudal (em baixo)

3 - Úmero esquerdo. Vista cranial (esquerda), vista caudal (direita).

4 - Ulna esquerda. Vista cranial (esquerda), vista caudal (direita).

5 - Carpometacarpo direito, Vista ventral (esquerda), vista dorsal (direita).

6 - Fémur direito. Vista cranial (esquerda) e vista caudal (direita).

7 - Tibiotarso direito. Vista cranial (esquerda) e vista caudal (direita).

8 - Tarsometatarso esquerdo. Vista cranial (esquerda) e vista caudal (direita). 


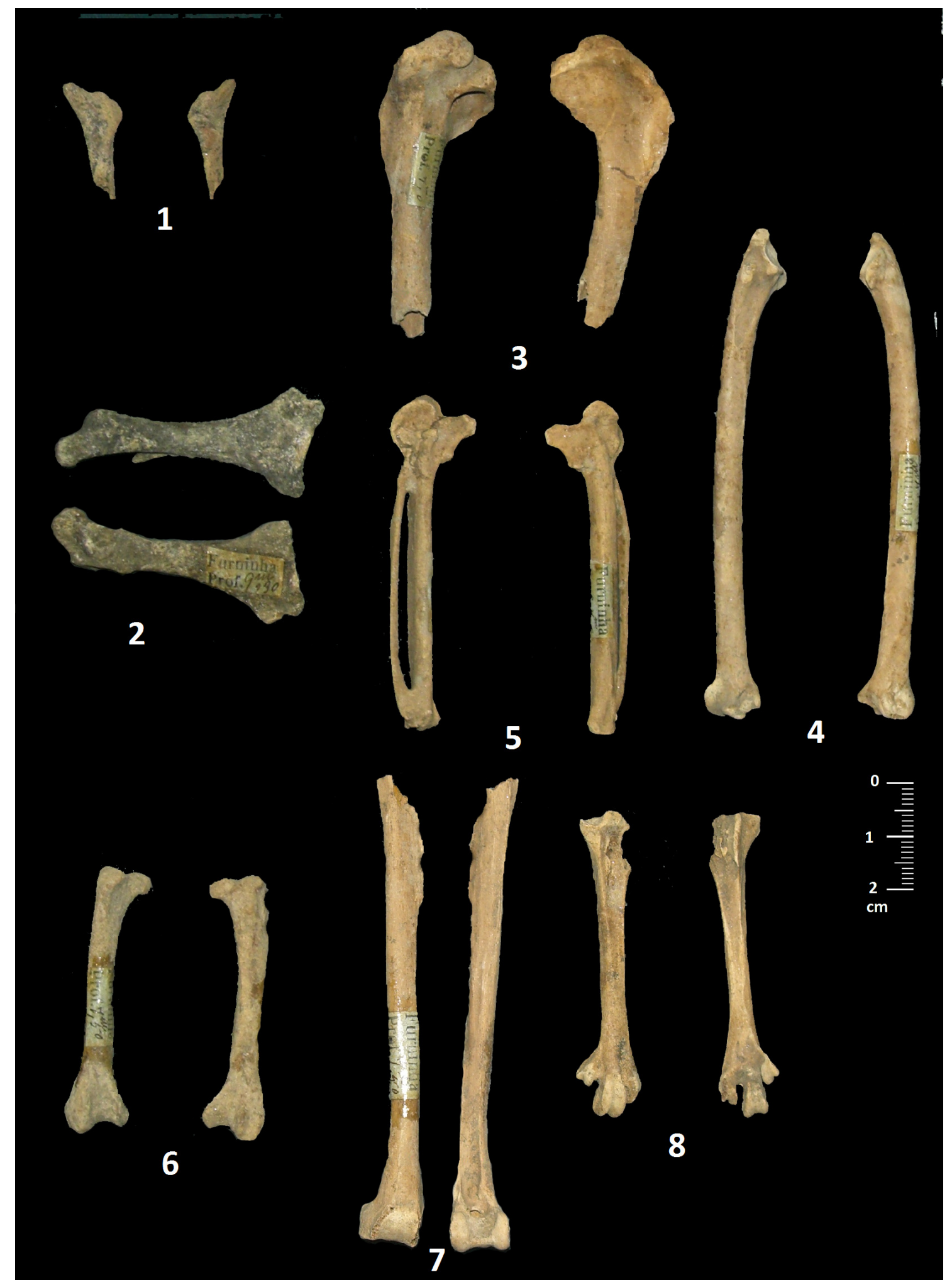




\section{Estampa V}

1 - Úmero esquerdo de Pinguinus impennis, identificado na Gruta da Furninha. Vista cranial (esquerda), vista caudal (direita). Fotografia de José Paulo Ruas - CIPA

2 - Coracóide esquerdo de vanellus vanellus. Vista ventral.

3 - 6 - Ossos de Phalacrocorax aristotelis da Gruta da Furninha:

3 - Úmero esquerdo (á esquerda) e direito (á direita). Vista cranial;

4 - Ulna direita (á esquerda )e esquerda (á direita). Vista cranial;

5 - Rádio esquerdo (á esquerda) e direito (á direita). Vista cranial

6 - Tibiotarso esquerdo. Vista cranial.

7 - 8 Restos ósseos de Otis tarda da Gruta da Casa da Moura:

7 - Fragmento distal de fémur direito. Vista cranial, (esquerda), e vista caudal (direita);

8 - Fragmento proximal e mesial de tarsometatarso esquerdo. Vista cranial. 


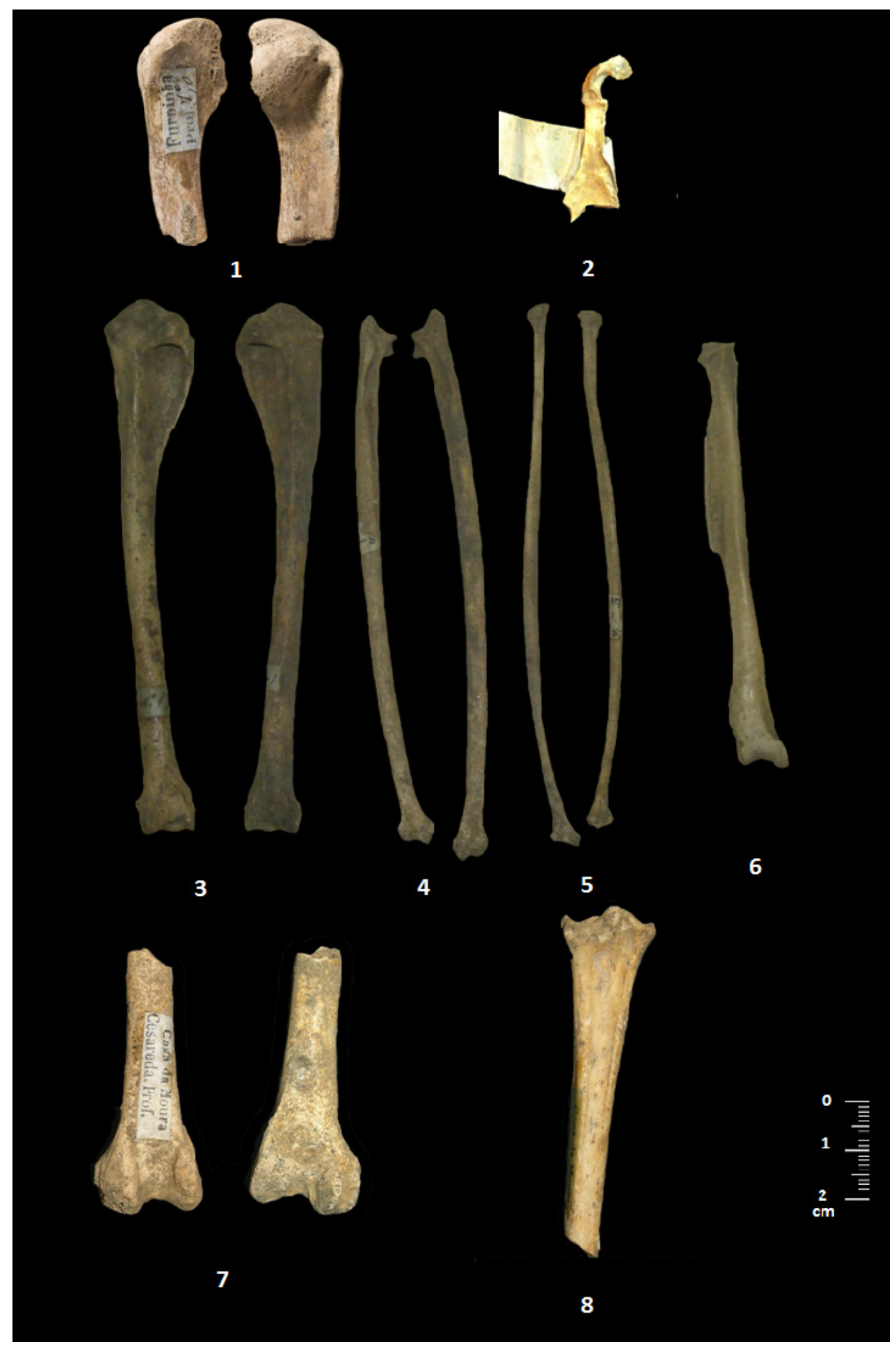




\section{Estampa VI}

1 - Tarsometatarso de Falco rusticolus. Vista caudal (esquerda), vista cranila (direita). 2 - Fragmento distal de tibiotarso de Cf. Aquila adalberti, encontrado na Lapa da Rainha. Vista cranial (esquerda) e vista caudal (direita).

3 - Fragmentos de ulna direita de Aquila chrysaetos encontrados na Gruta Nova da Columbeira. Parte mesial e proximal, o maior (vistacaudal), e parte distal, o menor (vista cranial).

4 - Falange de Gyps fulvus da Gruta da Furninha. Vista dorsal (esquerda), vista palmar (direita).

5 - Fragmento basal e mesial de coracóide de Milvus migrans. Vista dorsal (esquerda), vista ventral (direita).

6 - 11- Restos ósseos de Bubo bubo da Gruta da Casa da Moura:

6 - Parte mesial e distal de úmero direito (vista cranial);

7 - Tarsometatarso esquerdo (vista cranial);

8 - Parte distal de ulna esquerda (vista caudal);

9 - Parte proximal e mesial de carpometacarpo direito (vista ventral);

10 - Parte proximal e mesial de um fémur esquerdo (vista cranial);

11 - Parte mesial e distal de um tibiotarso esquerdo (vista cranial). 


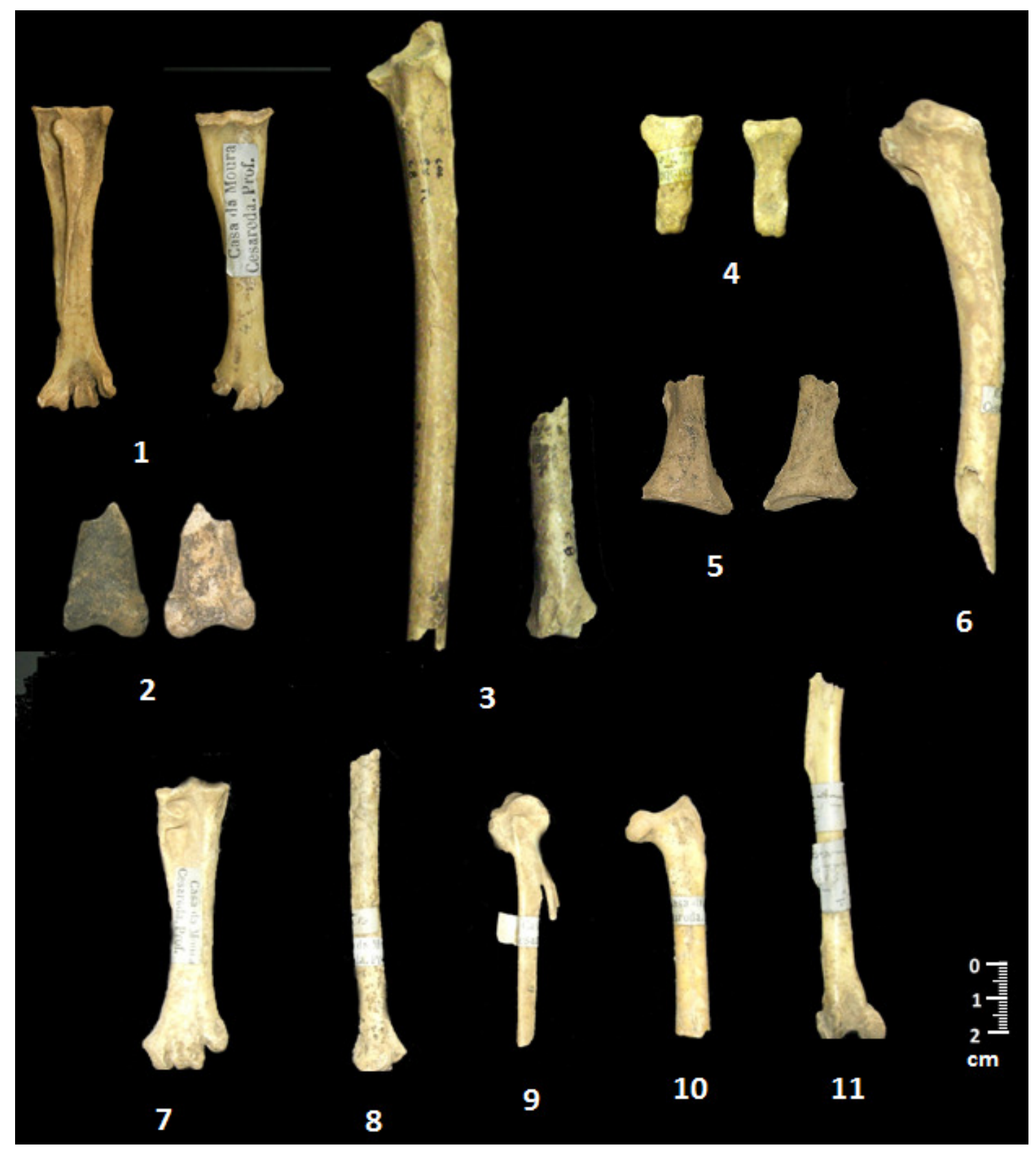




\section{Estampa VII}

1 - 2 - Restos ósseos de Atene noctua da Gruta Nova da Columbeira:

1 - Parte distal e mesial de fémur esquerdo: Vista cranial (esquerda) e vista caudal (direita);

2 - Tarsometatarso direito. Vista cranial (esquerda) e vista caudal (direita).

3 - 4 - Restos ósseos de Columba livia da Gruta da Furninha:

3 - Úmero esquerdo (vista cranial);

4 - Carpometacarpos. À esquerda um esquerdo e á direita um fragmento distal de um carpometacrapo direito (vista ventral).

5 - Fragmento proximal de úmero esquerdo de Corvus corax da Gruta Nova da Columbeira. Vista cranial (esquerda), vista caudal (direita).

6 - Fragmento distal de úmero esquerdo de Corvus frugilegus da Gruta Nova da Columbeira. Vista cranial (esquerda), vista caudal (direita). 


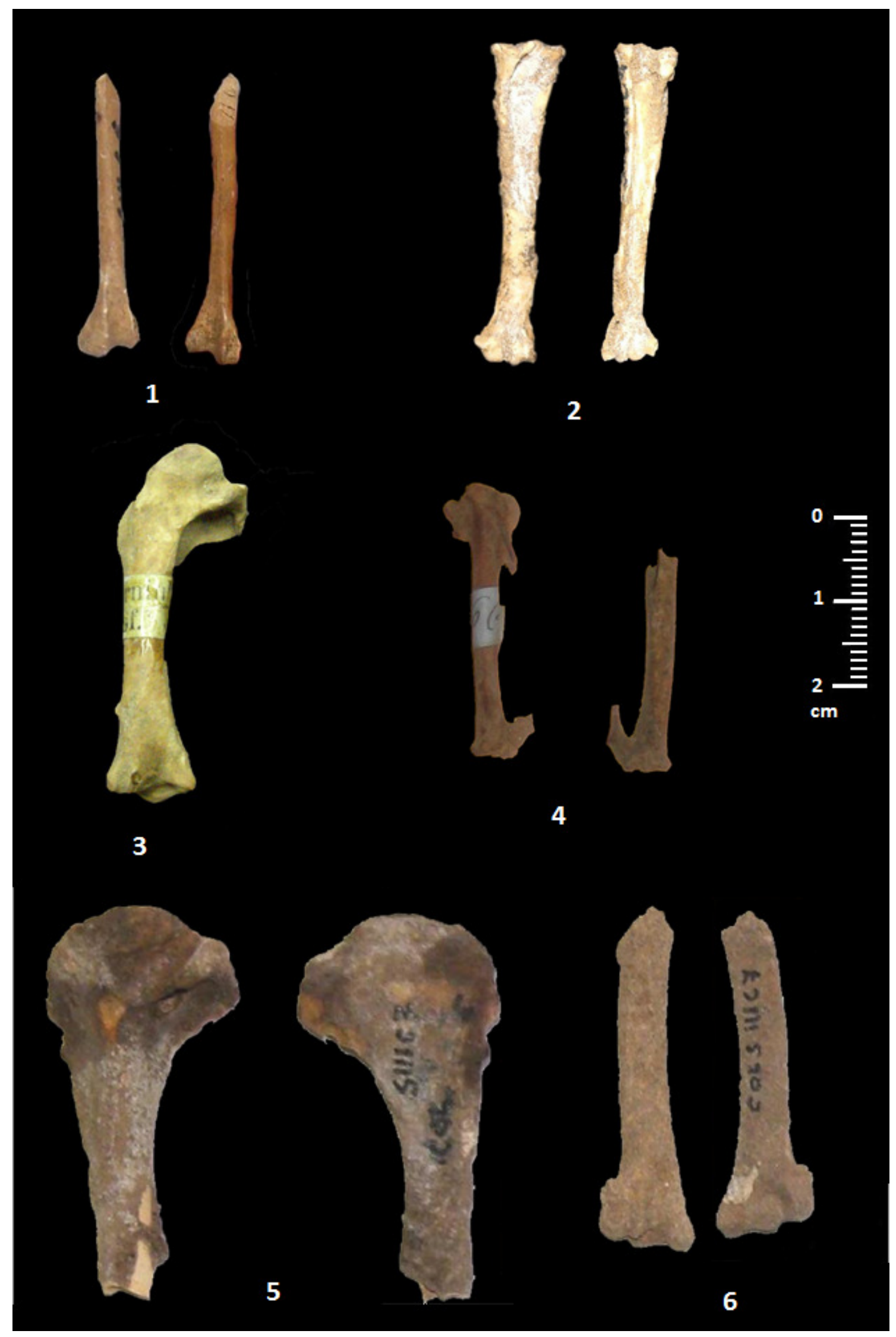




\section{Estampa VIII}

1 - 3 - Restos ósseos de Corvus monedula da Gruta da Casa da Moura (1 e 3) e da Lapa da Rainha (2):

1 - Carpometacarpo direito (vista dorsal);

2 - Sinsacro. Vista ventral (em cima) e vista dorsal (em baixo);

3 - Tibiotarso esquerda (vista caudal).

4 - 6 - Ossos de Pica pica, provenientes da Gruta da Casa da Moura (4) e da Gruta das Fontainhas (5 e 6):

4 - Crânio. Vista dorsal

5 - Coracóide esquerdo. Vista ventral (em cima ) e vista dorsal (em baixo);

6 - Tibiotarso direito. Vista cranial (esquerda), vista lateral (ao centro) e vista caudal (esquerda, 


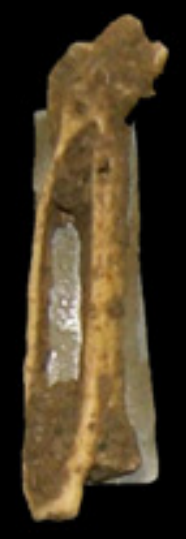

1

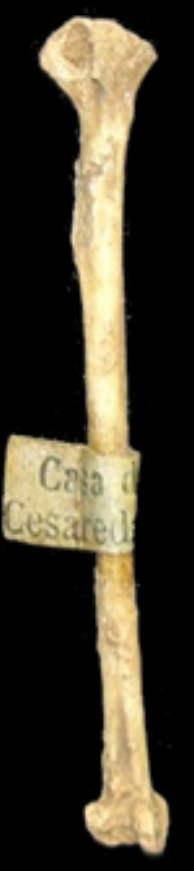

3
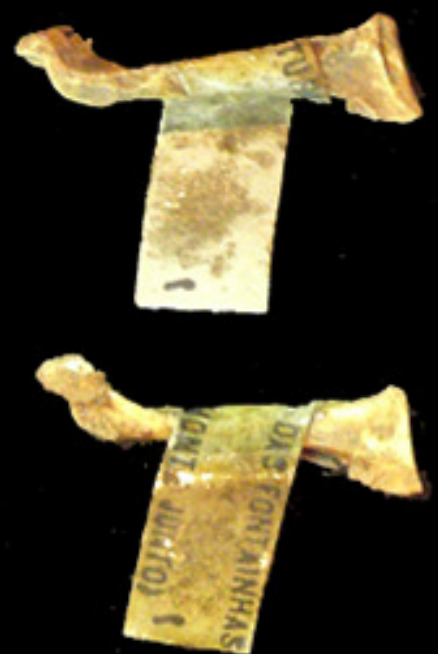

5
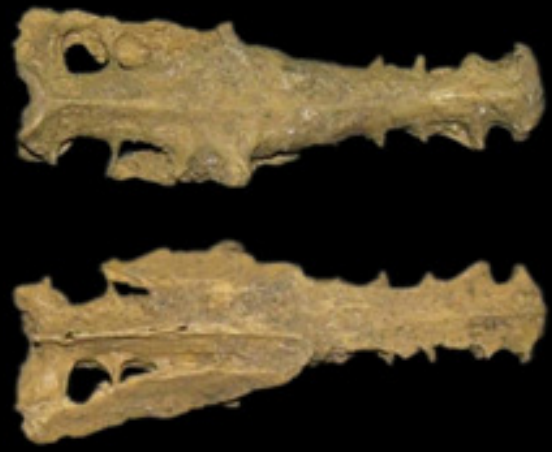

2

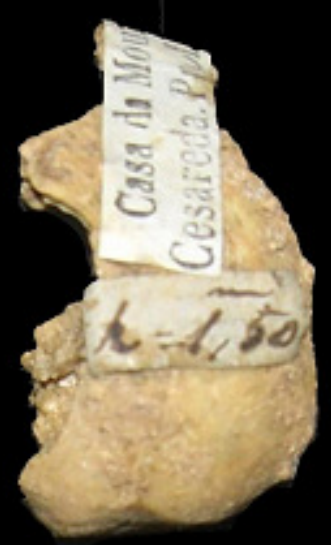

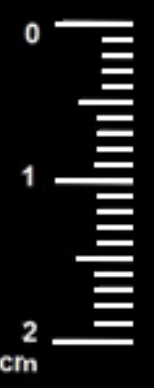

4
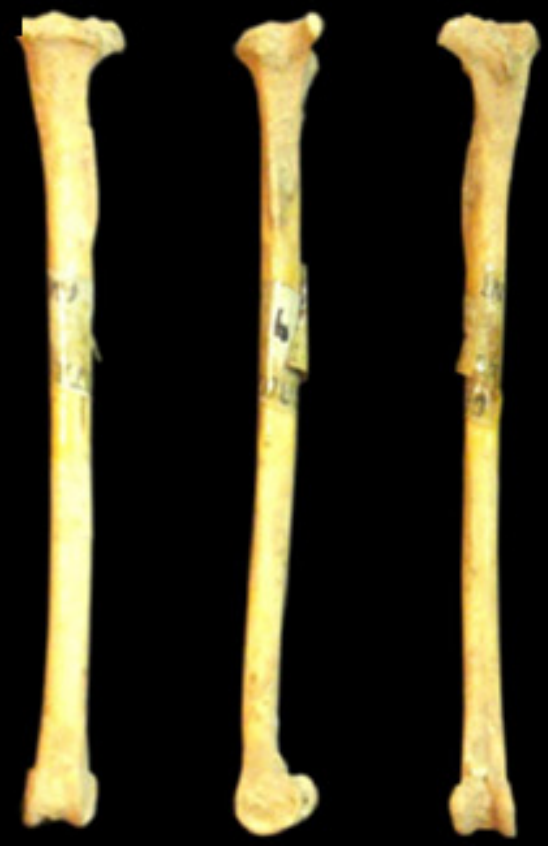

6 


\section{Estampa IX}

Restos ósseos de Pyrrhocorax pyrrhocorax da Gruta da Casa da Moura (1, 4 e 7), Gruta Nova da Columbeira (2), Gruta das Salemas (3), Gruta da Furninha (5 e 8) e da Lapa da Rainha (6):

1 - Crânio. Vista dorsal;

2 - Úmero esquerdo (vista cranial). Fotografia de Jacinta Costa.

3 - Rádio direito. Vista cranial (esquerda) e vista caudal (direita).

4 - Ulna esquerda (vista caudal).

5 - Carpometacarpo esquerdo (vista dorsal);

6 - Falange do dígito II da asa direita. Vista palmar (esquerda), vista dorsal (direita);

7 - Tibiotarso direita (vista cranial).

8 - Tarsometatarso esquerdo. Vista caudal (esquerda) e vista cranial (direita). 


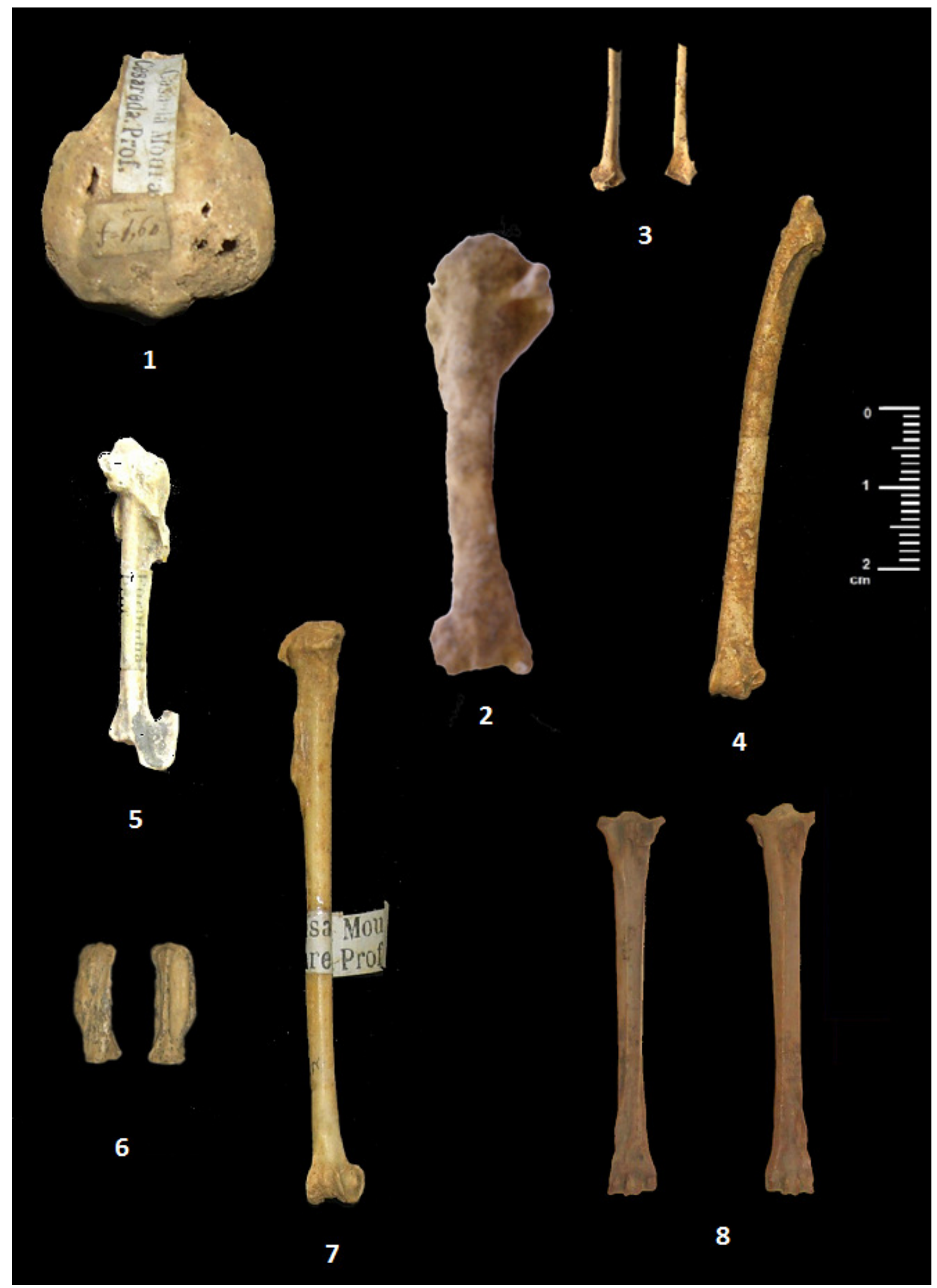




\section{Estampa X}

Restos ósseos de Pyrrhocorax pyrrhocorax da Gruta da Furninha (1,2 e 3), Gruta Nova da Columbeira (4a) e da Lapa da Rainha (4b e 5):

1 - Crânio. Vista cauda, (esquerda) onde se nota a forma em meia-lua do forâmen magno, vista dorsal (centro), onde se nota o contorno côncavo na zona das órbitas e vista frontal (direita), onde se pode observar as órbitas grandes e cavas;

2 - Úmero esquerdo. Vista cranial (esquerda), vista caudal (direita);

3 - Carpometacarpo esquerdo. Vista ventral (esquerda), vista dorsal (direita);

4 - Falanges do dígito II da asa direita. Nas extremidades, vistas dorsais, ao centro, vistas palmares;

5 - Tibiotarso direito. Vista cranial (esquerda), vista lateral (centro ) e vista caudal (direita). 


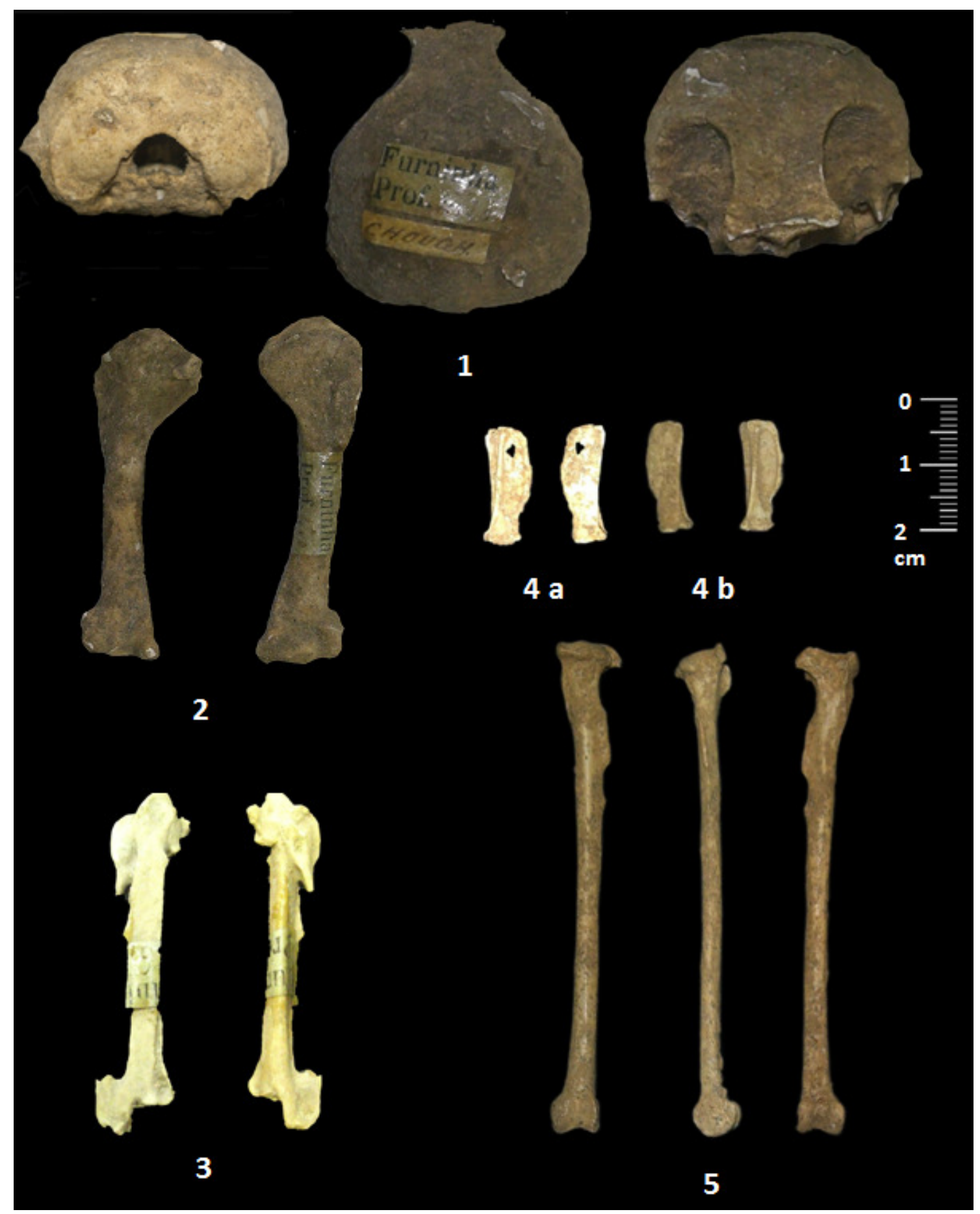




\section{Estampa XI}

1 - Úmero direito de Garrulus glandarius da Gruta da Furninha. Vista cranial (esquerda) e vista caudal (direita).

2 - Tibiotarso direito de C. cyana da Gruta Nova da Columbeira. Vista caudal (esquerda), vista cranial (direita).

3 - Úmero direito de Turdus philomelos da Gruta da Furninha (vista cranial).

4 - 5 - Restos de Turdus pilaris da Gruta Nova da Columbeira (4a) e da Gruta da Furninha (4b e 5):

4 - Umero esquerdo (a) e direito (b). Vista cranial (4 a, esquerda e 4b) , vista caudal (4 a - direita) Falanges do dígito II da asa direita. Nas extremidades, vistas dorsais, ao centro, vistas palmares;

5 - Ulna esquerda (vista caudal).

6 - Úmeros de Turdus merula direito (a), da Lapa da Rainha, e esquerdo (b), da Gruta Nova da Columbeira. Vista caudal ( 6 a - esquerda), vista craniai (6 a direito e 6 b). 


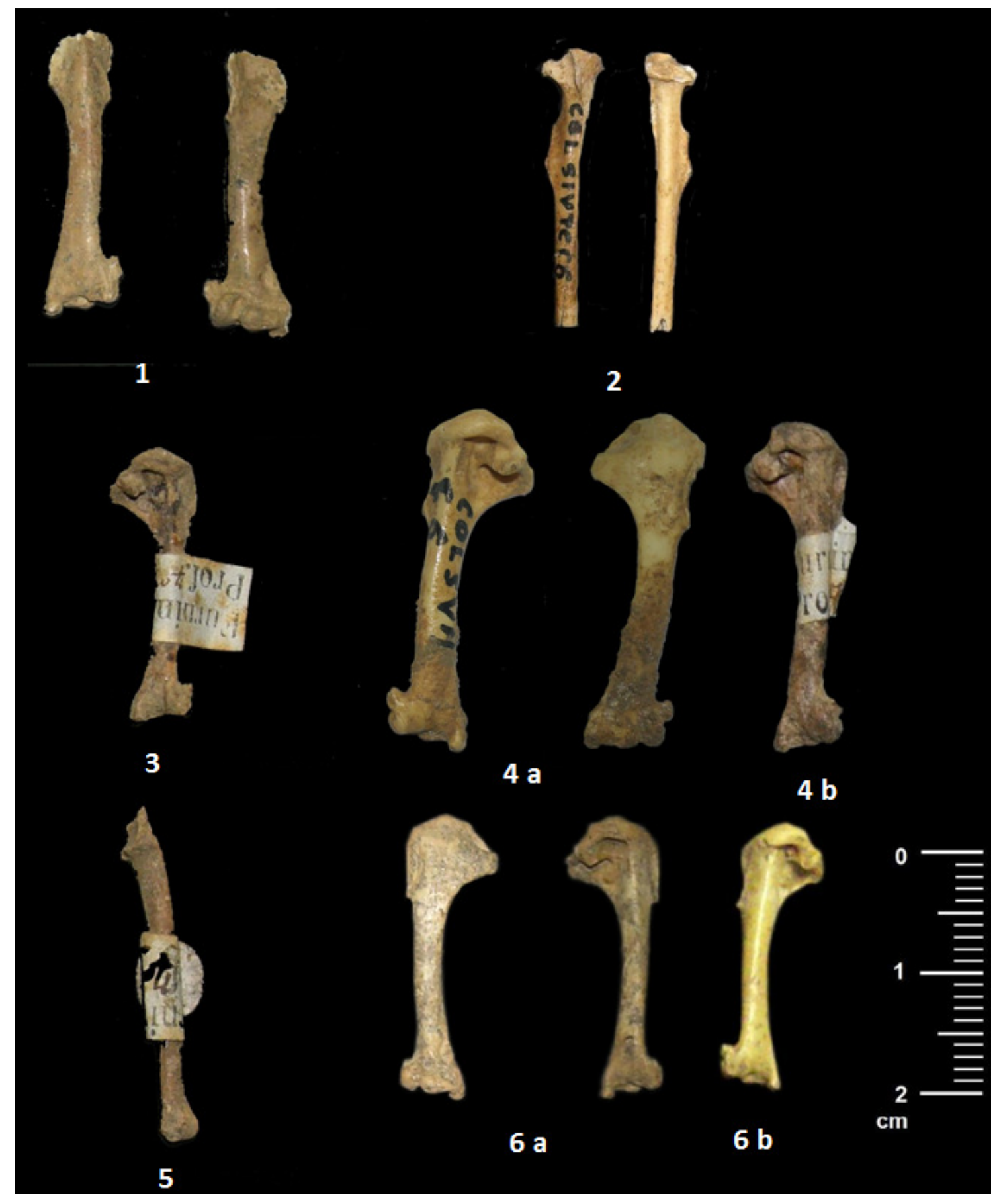




\section{Estampa XII}

1 - Úmero esquerdo de cf. Ptyonoprogne rupestris da Gruta Nova da Columbeira (vista cranial)

2 - Úmero direito de Carduelis carduelis da Gruta da Nova da Columbeira. Vista cranial (esquerda), vista caudal (direita).

3 - Fragmento proximal e mesial de úmero direito de Motacilla alba da Lapa da Rainha. Vista cranial (esquerda), vista caudal (direita).

4 - Partes distais de tibiotarsos de Cuculus canorus - Gruta da Furninha. Vista cranial (esquerda) e vista caudal (direita). 


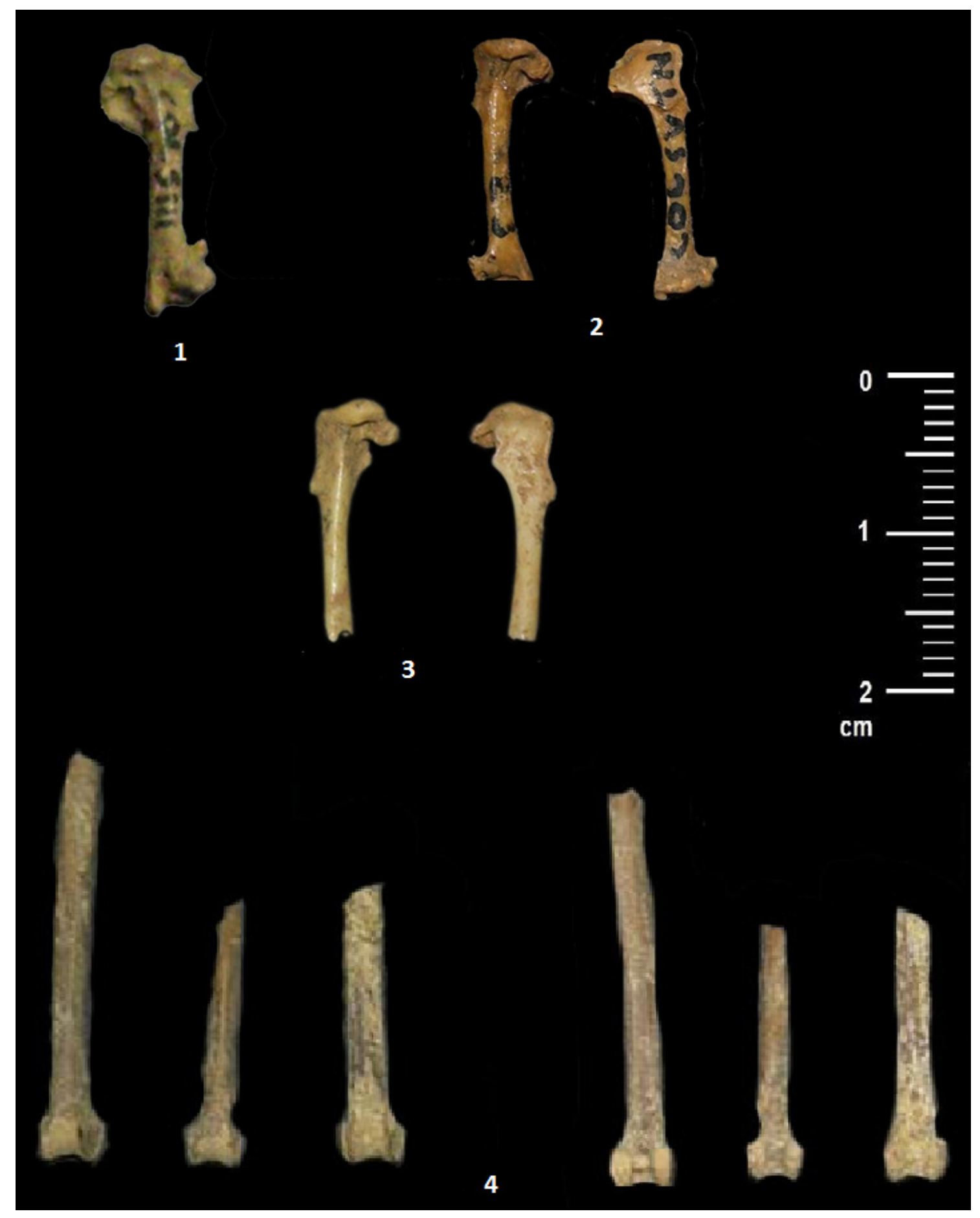




\section{Estampa XIII}

Conjunto de desenhos de ossos de aves reconhecidos na Gruta Nova da Columbeira (desenhos de Ana Catarina Ferreira):

1 - Carpometacarpo esquerdo de Corvus monedula. Vista ventral (esquerda), vista dorsal (direita);

2 - Úmero esquerdo de Pyrrhocorax pyrhocorax. Vista cranial (esquerda), vista caudal (direita);

3 - Úmero direito de Pyrrhocorax pyrhocorax. Vista cranial (esquerda), vista caudal (direita);

4 - Ulna direita de Pyrrhocorax pyrhocorax. Vista cranial (esquerda), vista caudal (direita);

5 - Ulna direita de Turdus merula. Vista cranial (esquerda), vista caudal (direita);

6 - Úmero esquerdo de Columba palumbus (Vista cranial);

7 - Úmero direito de Columba livia. Vista cranial (esquerda), vista caudal (direita);

8 - Úmero esquerdo de Turdus pilaris. Vista cranial (esquerda), vista caudal (direita);

9 - Úmero direito de Turdus merula. Vista cranial (esquerda), vista caudal (direita);

10 - Úmero esquerdo de Turdus merula. Vista cranial (esquerda), vista caudal (direita);

11 - Úmero direito de Carduelis carduelis. Vista cranial (esquerda), vista caudal (direita);

12 - Fémur esquerdo de Corvus monedula. Vista cranial (esquerda), vista caudal (direita);

13 - Tarsometatarso esquerdo de Alectoris rufa. Vista caudal (esquerda), vista cranial (direita);

14 - Fragmento distal de tarsometatarso de anatidae indet. Vista caudal (esquerda), vista cranial (direita);

15 - Fragmento distal de úmero de passeriforme indet. Vista cranial (esquerda), vista caudal (direita);

16 - Escápula direita de de passeriforme indet. Vista lateral (esquerda), vista costal (direita). 

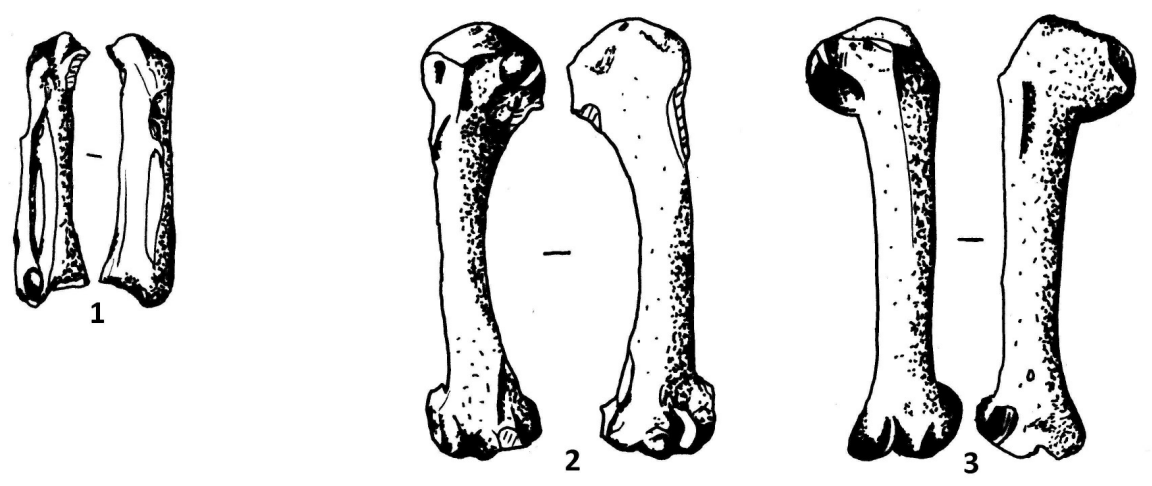

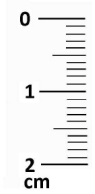
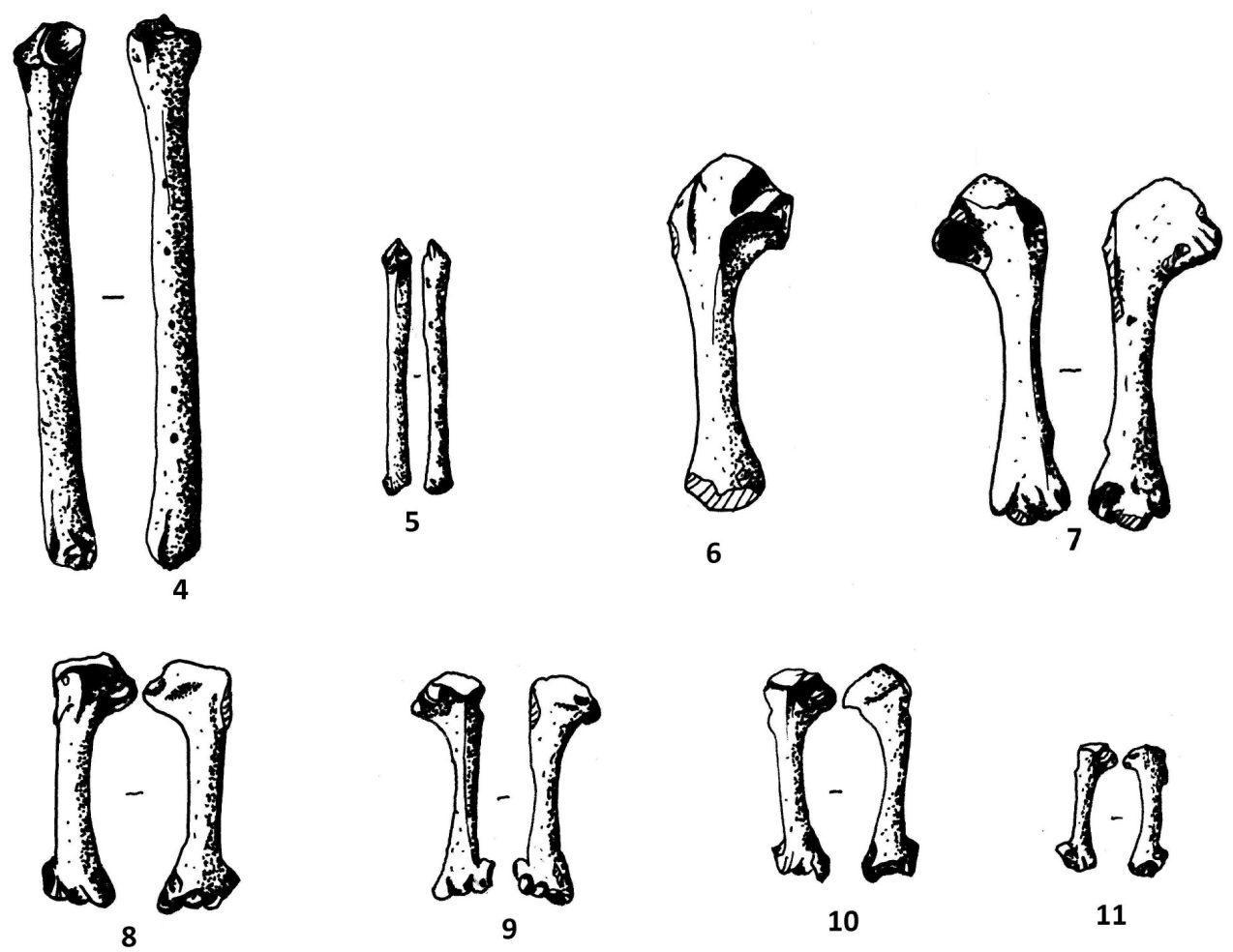

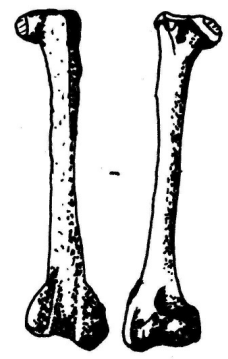

12

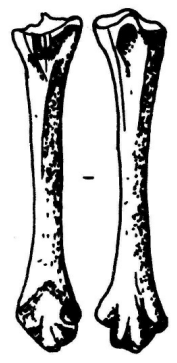

13

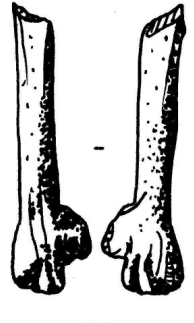

14

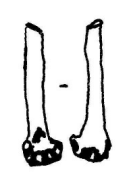

15

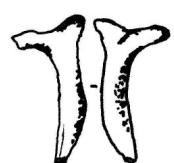

16 
AnEXOS 
ANEXO I

CLADOGRAMA COM A EVOLUÇÃO DOS PRINCIPAIS GRUPOS DE AVES 
O cladograma apresentado em seguida foi elaborado com base na informação disponível no projecto "Tree of Live Web Project", disponível em http://tolweb.org/tree/, que é um projecto que tem como principal objectivo recolher informação acerca da biodiversidade e a partir dai construir cladogramas com a relação entre os diversos grupos existentes e extintos. 


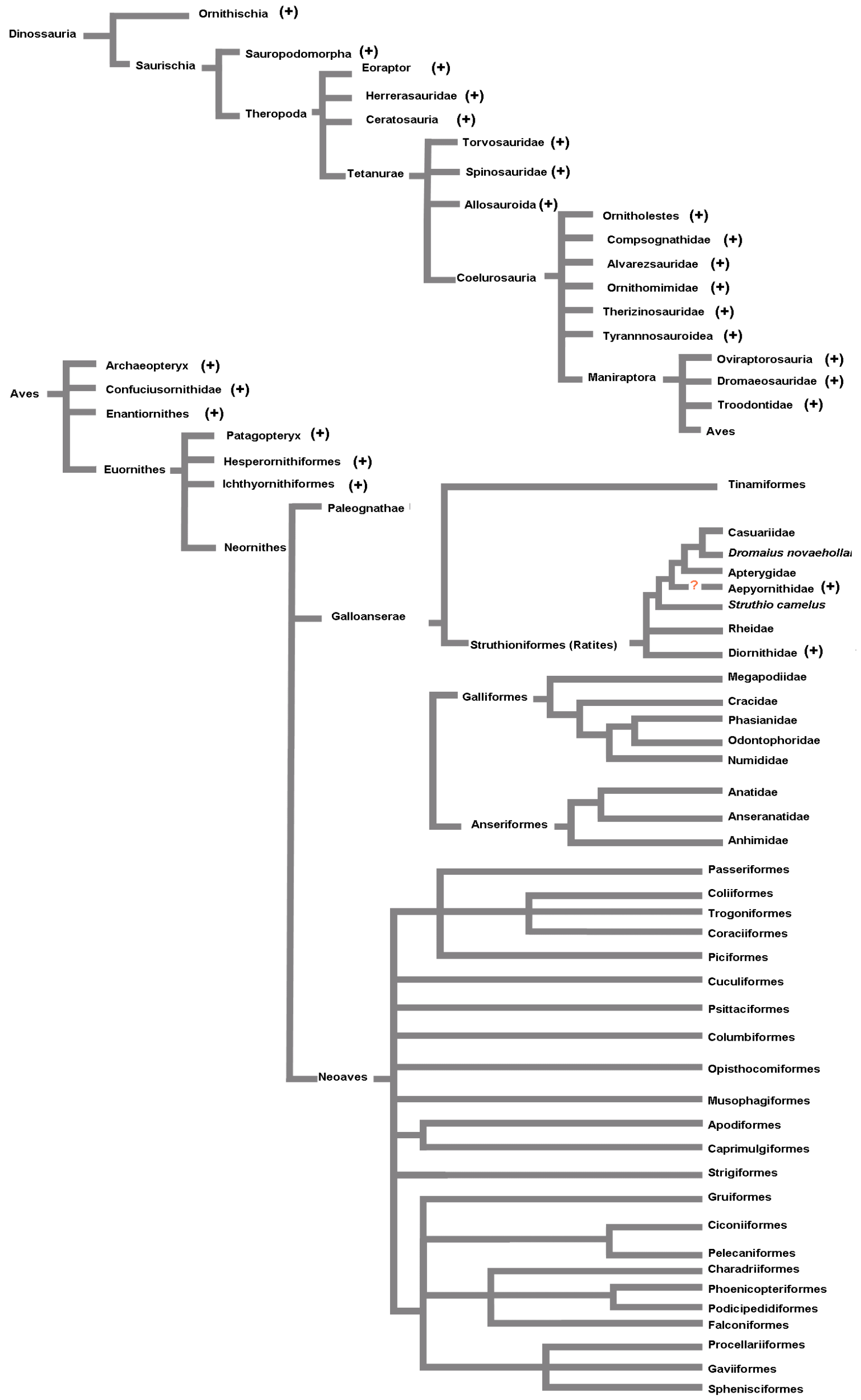


ANEXO II

ILUSTRAÇÃO DAS MEDIDAS TOMADAS PARA IDENTIFICAÇÃO DAS ESPÉCIES 
As ilustrações apresentadas neste anexo foram retiradas de Driesch, 1976 e de Cohen e Serjeantson, 1996. Serão apresentados apenas os ossos mais diagnósticos para uma atribuição taxonómica, bem como os que mais apareceram nas jazidas estudadas

\section{Esqueleto Craniano}

1 - Crânio

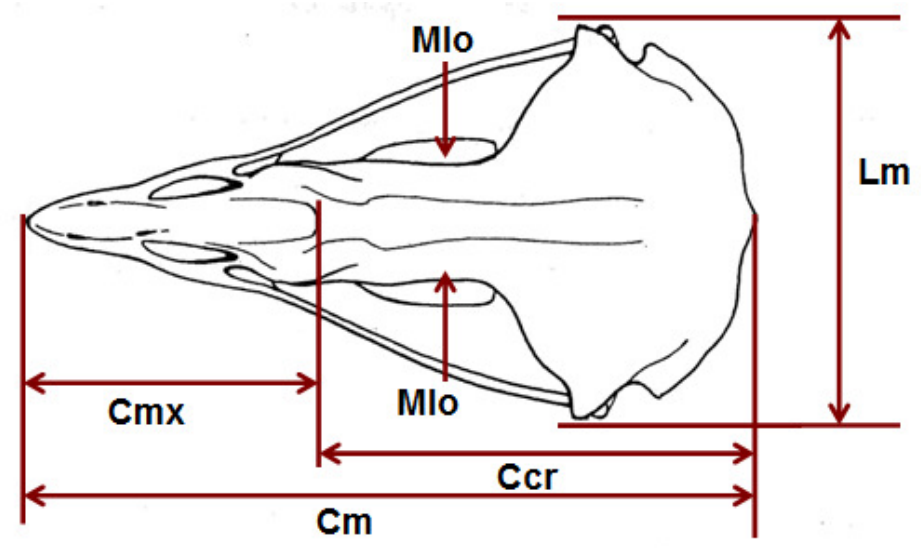

Aquila (vista dorsal)

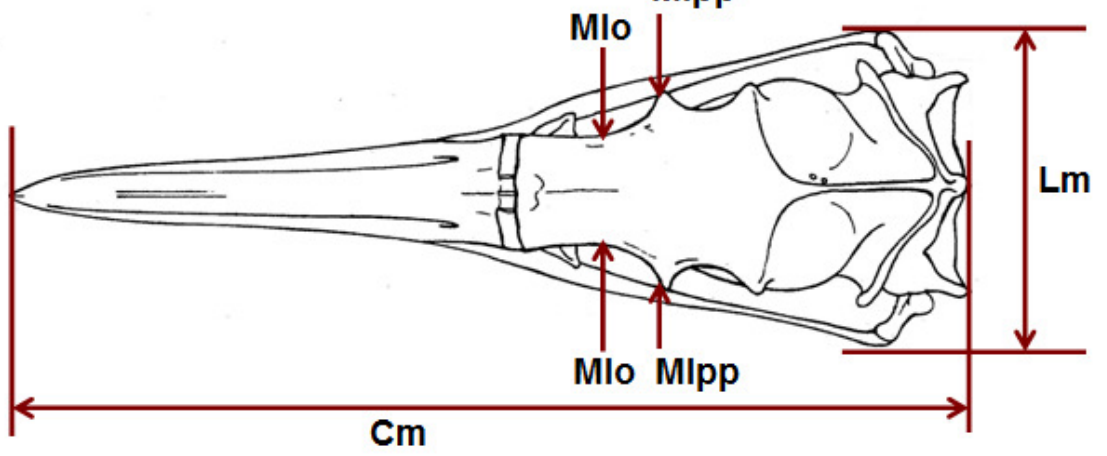

Phalacrocorax (vista dorsal)

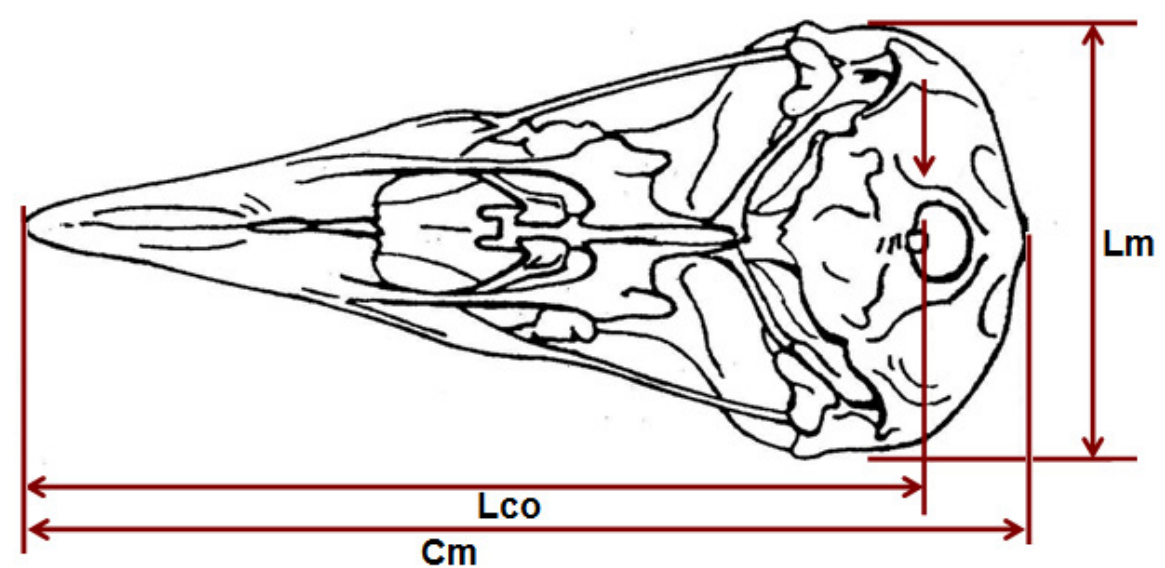

Gallus (Vista basal) 
2 - Mandíbula

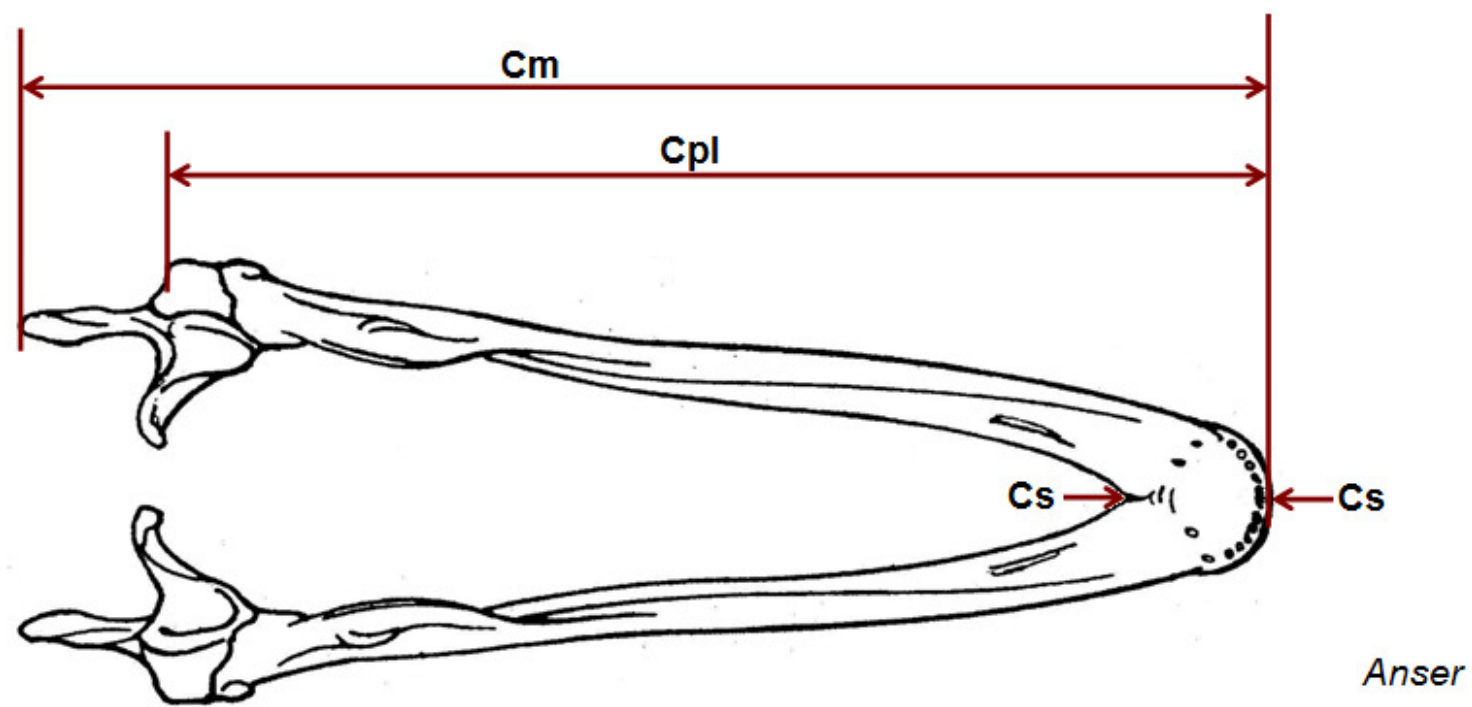




\section{Esqueleto Axial}

1 - Externo
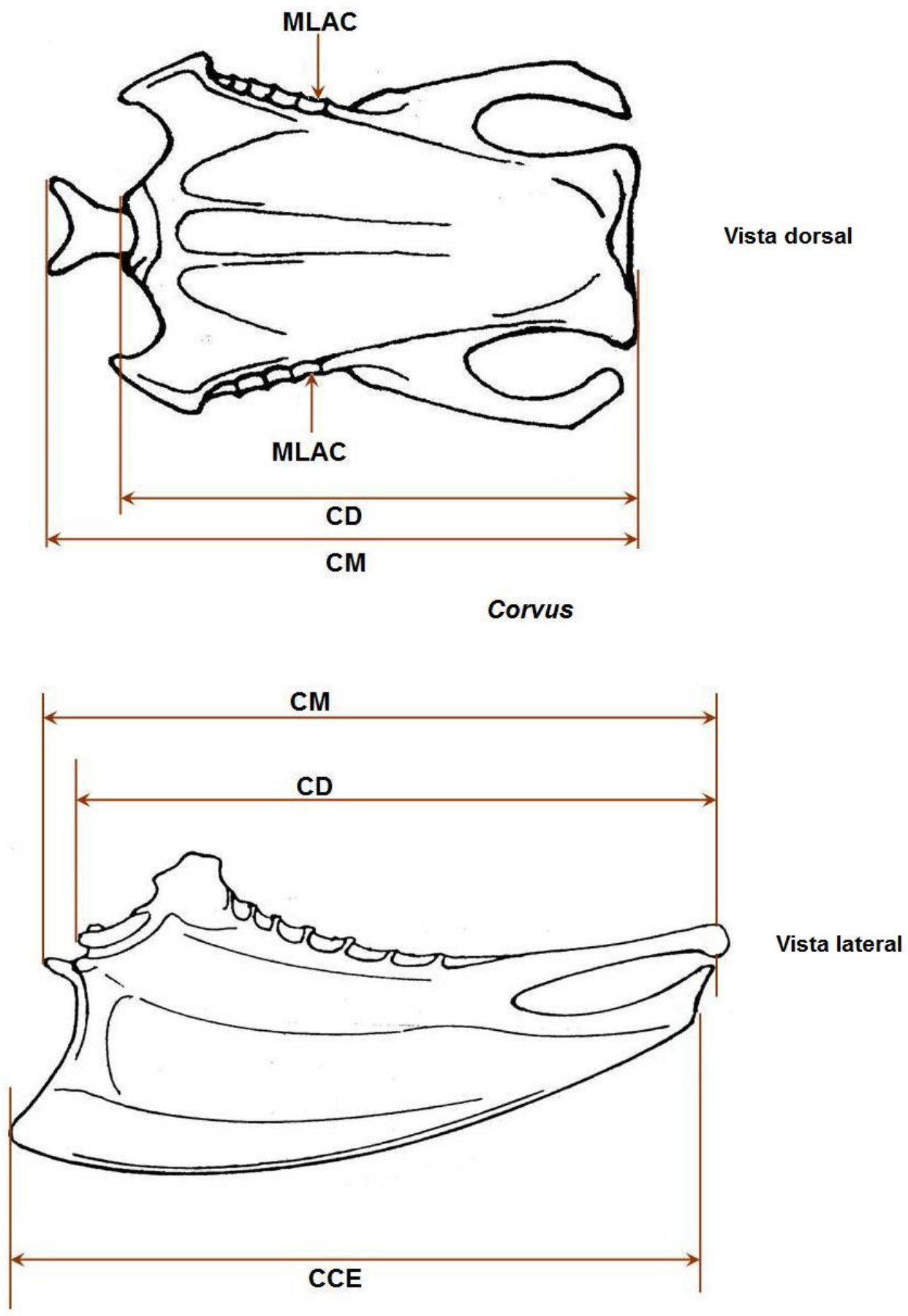

Anser 
2 - Pélvis e sinsacro

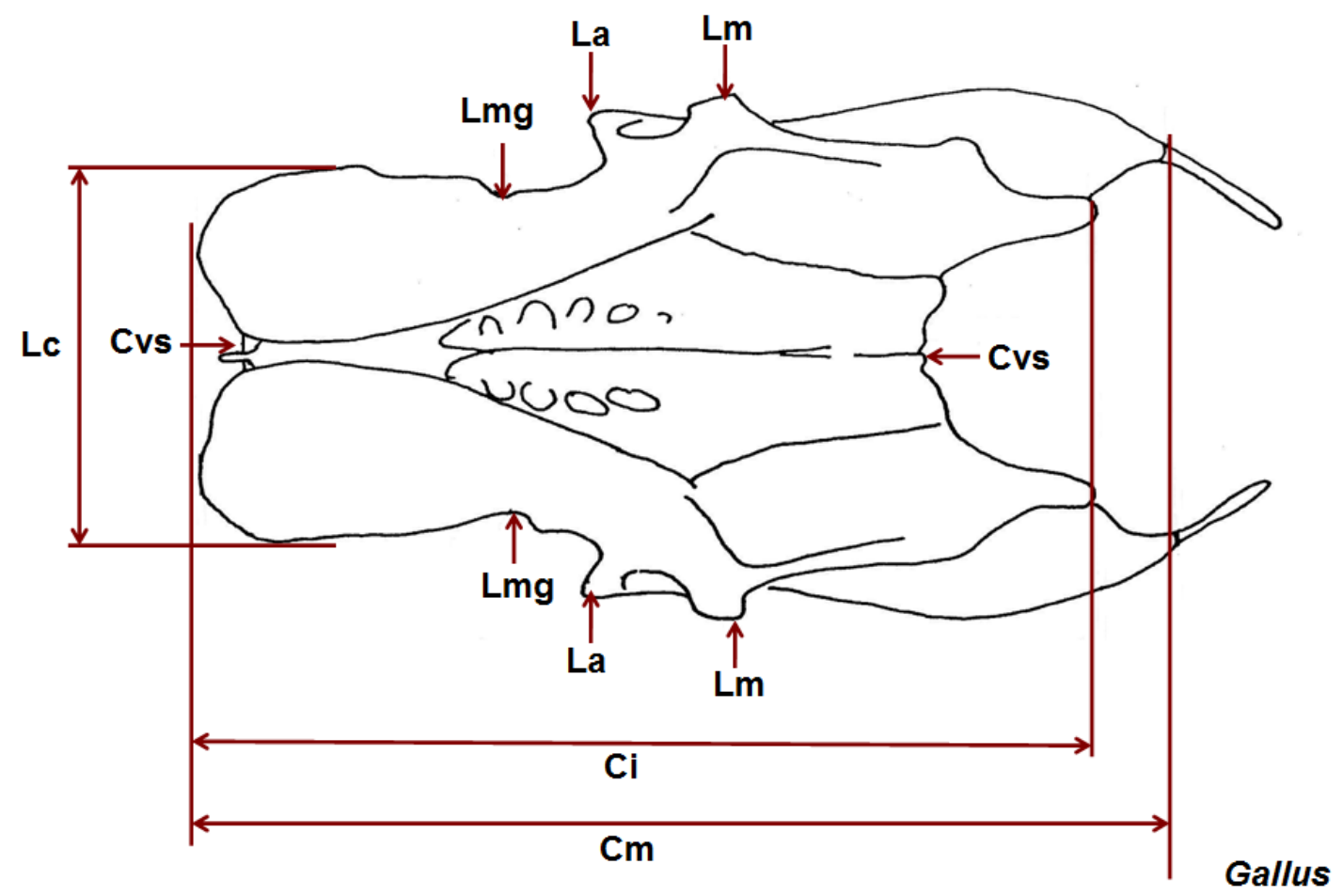


Esqueleto Apendicular

1 - Escápula

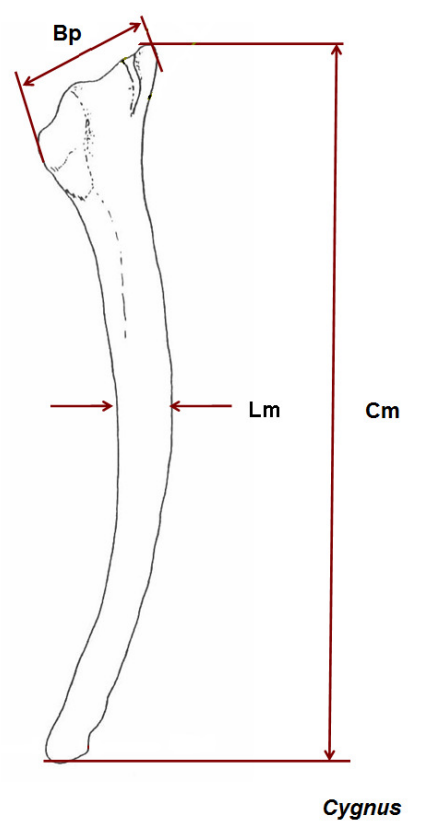

2 - Coracóide

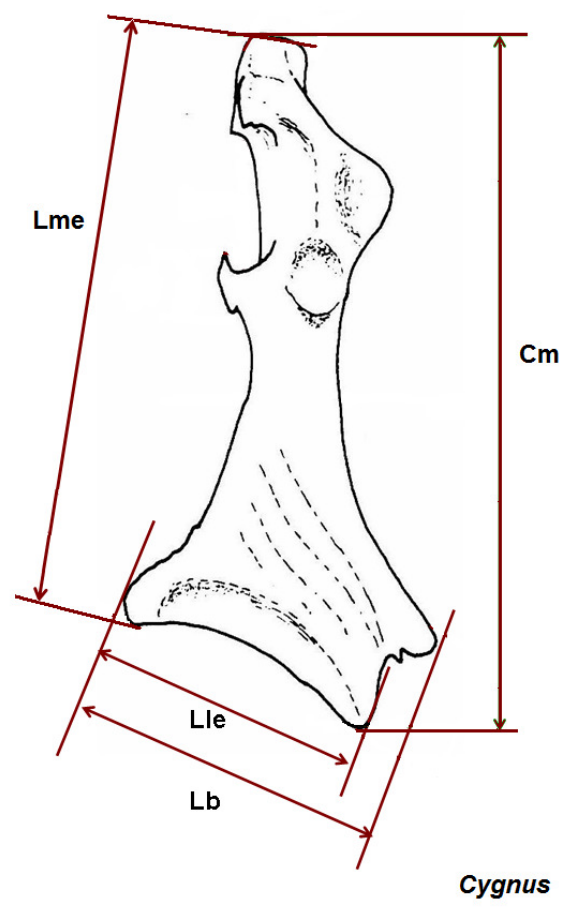


3 - úmero

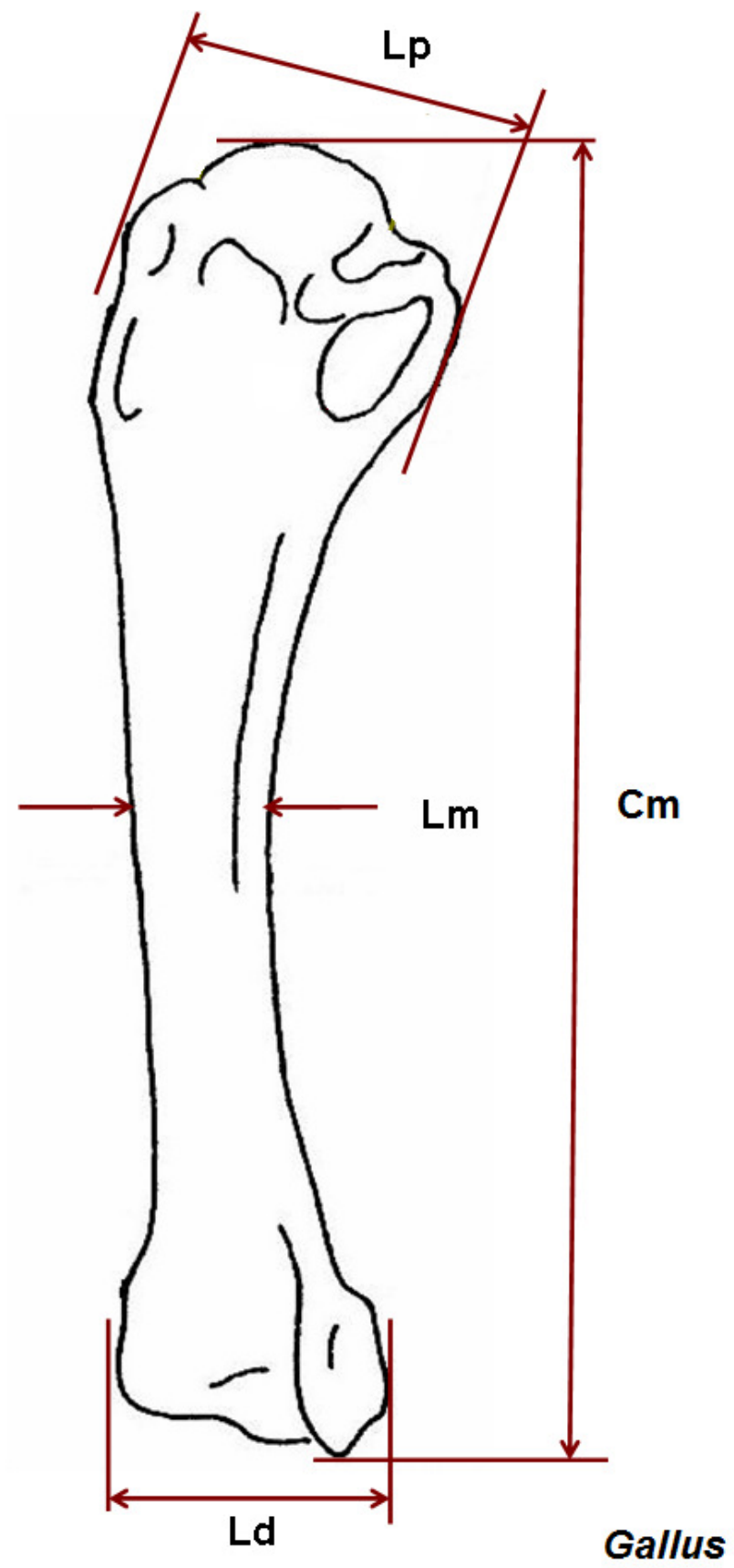


4- Ulna
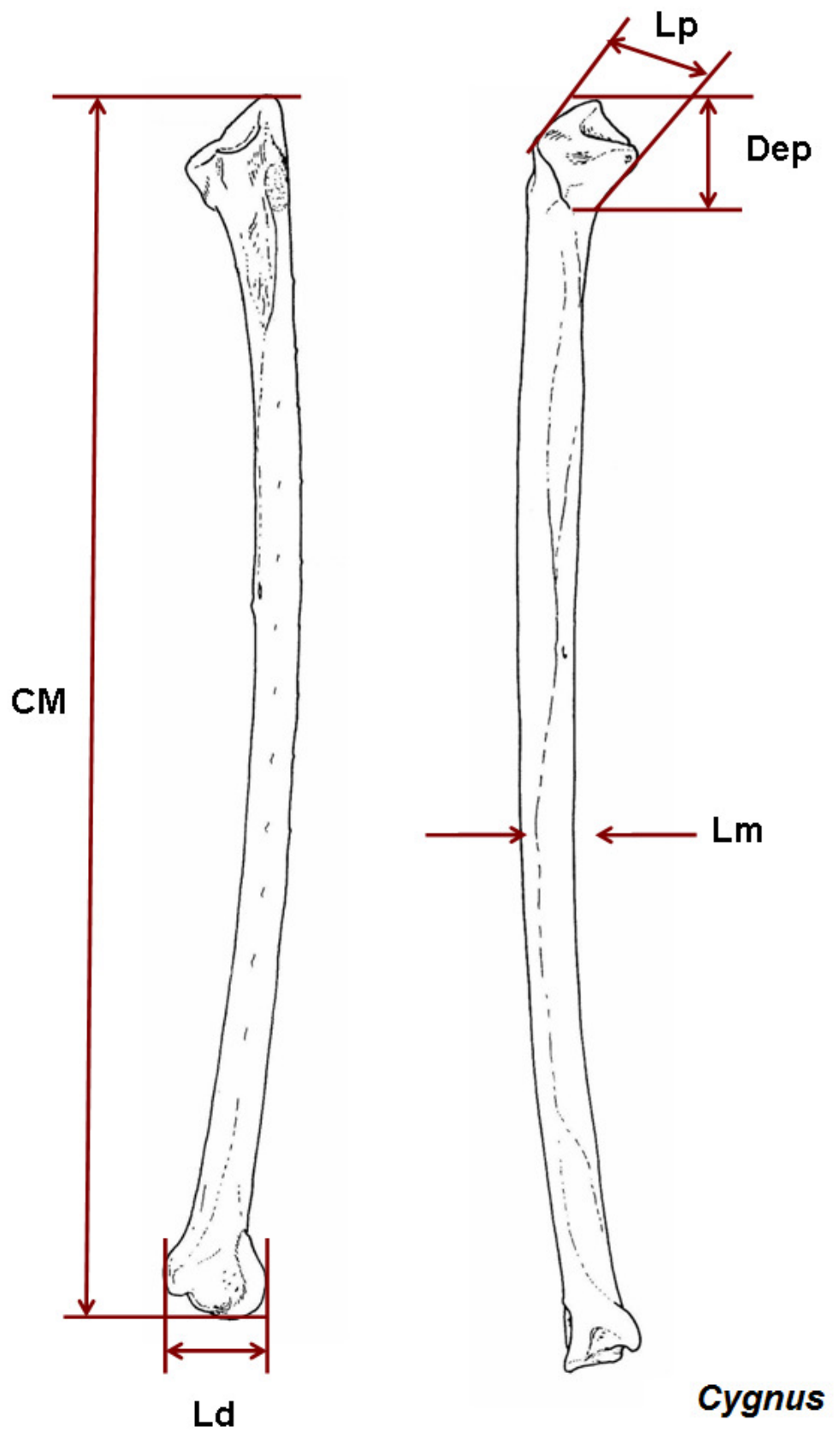
5 - Rádio

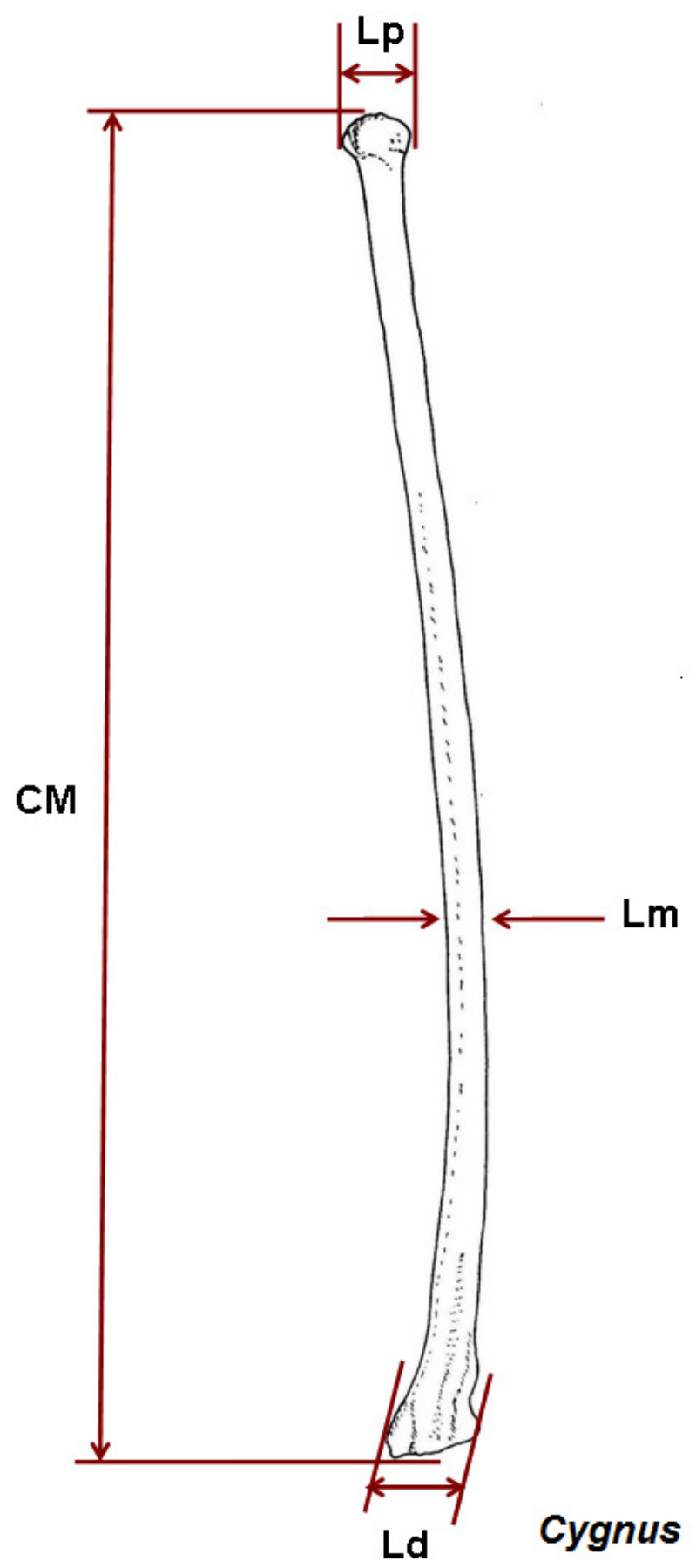


6 - Carpometacarpo

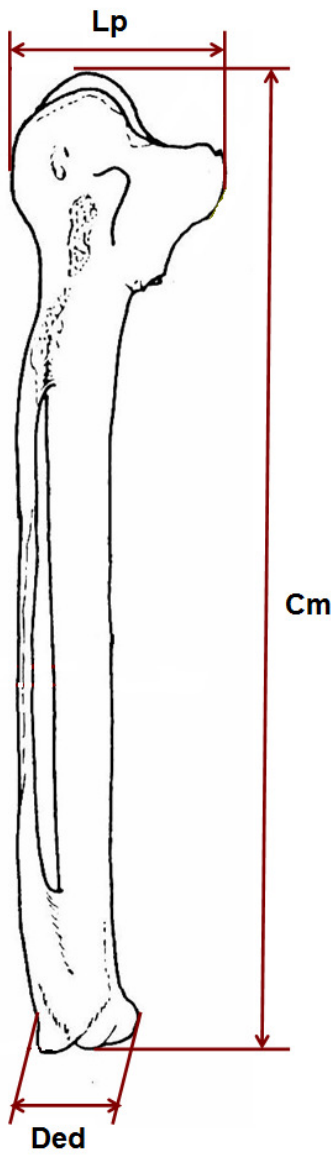

Cygnus

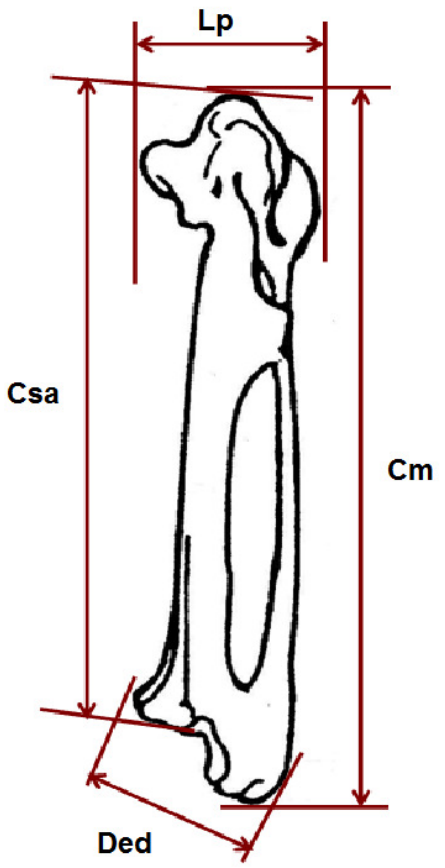

Corvus

7 - Falange (Il dígito )

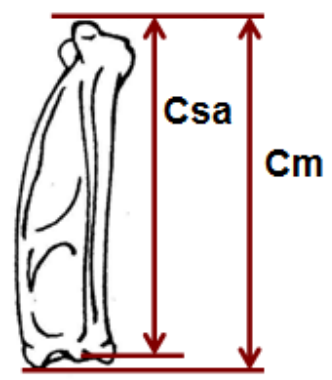

Anser 
8 - Fémur

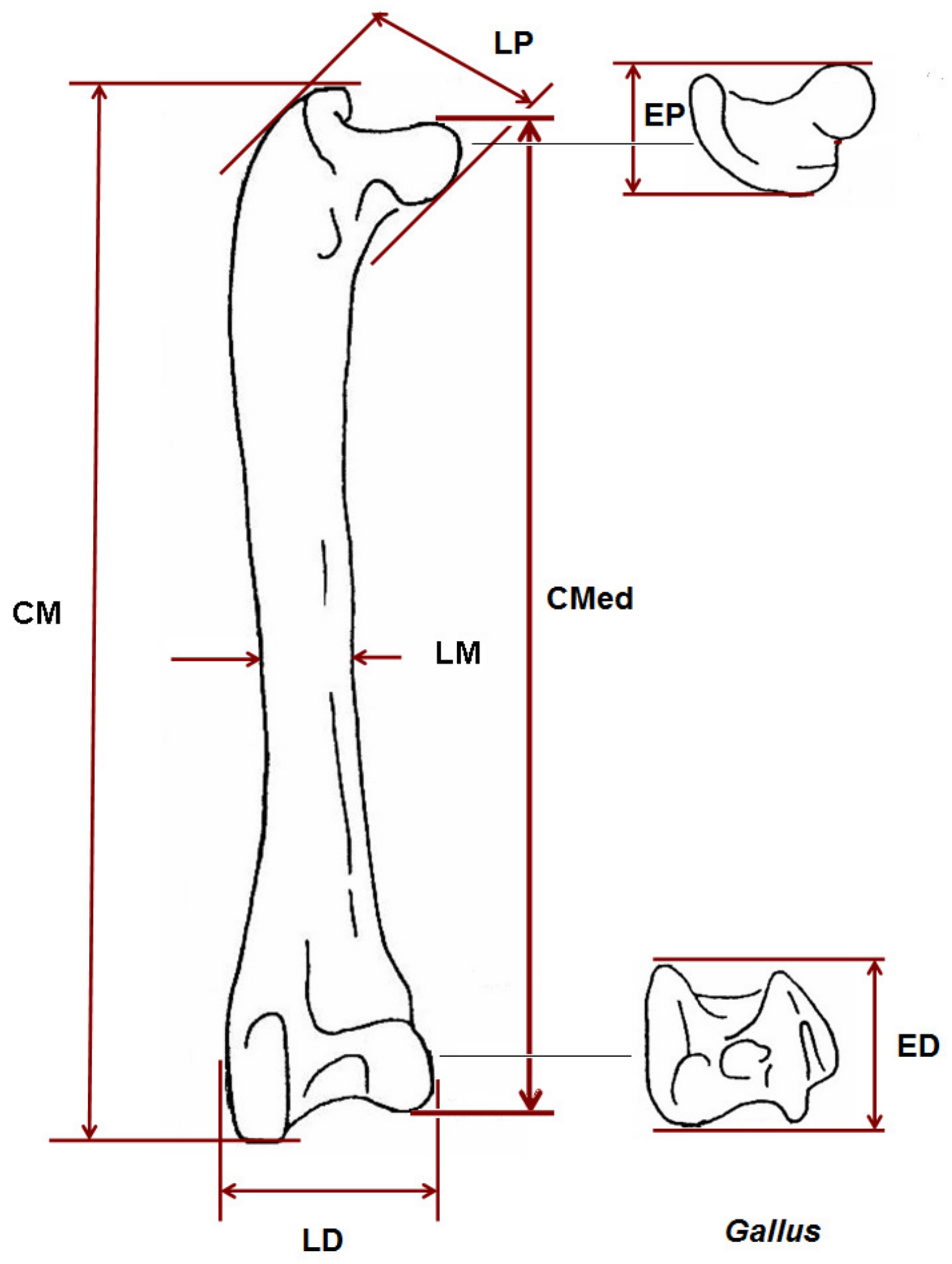


9 - Tibiotarso

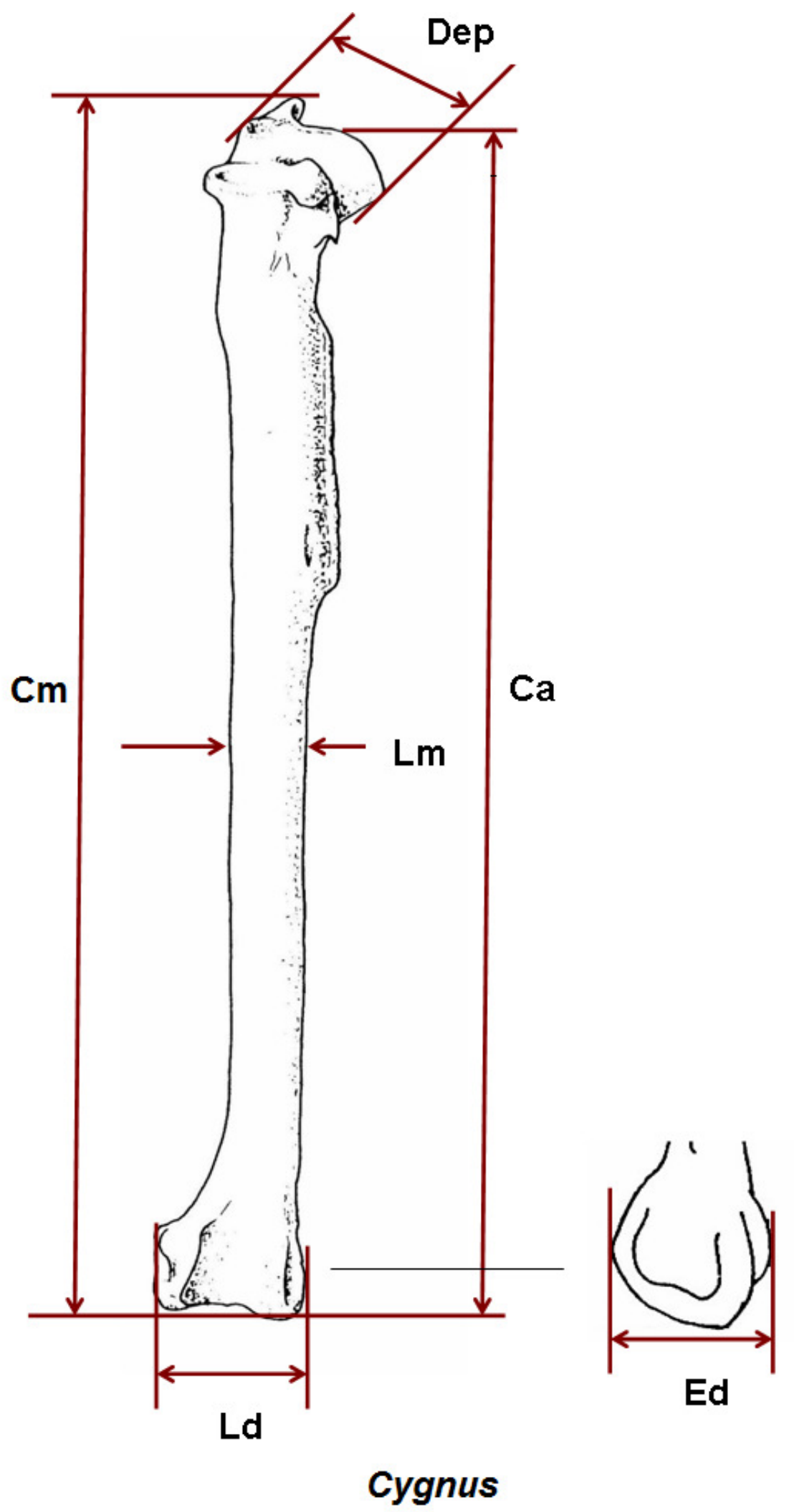


10 - tarsometatarso

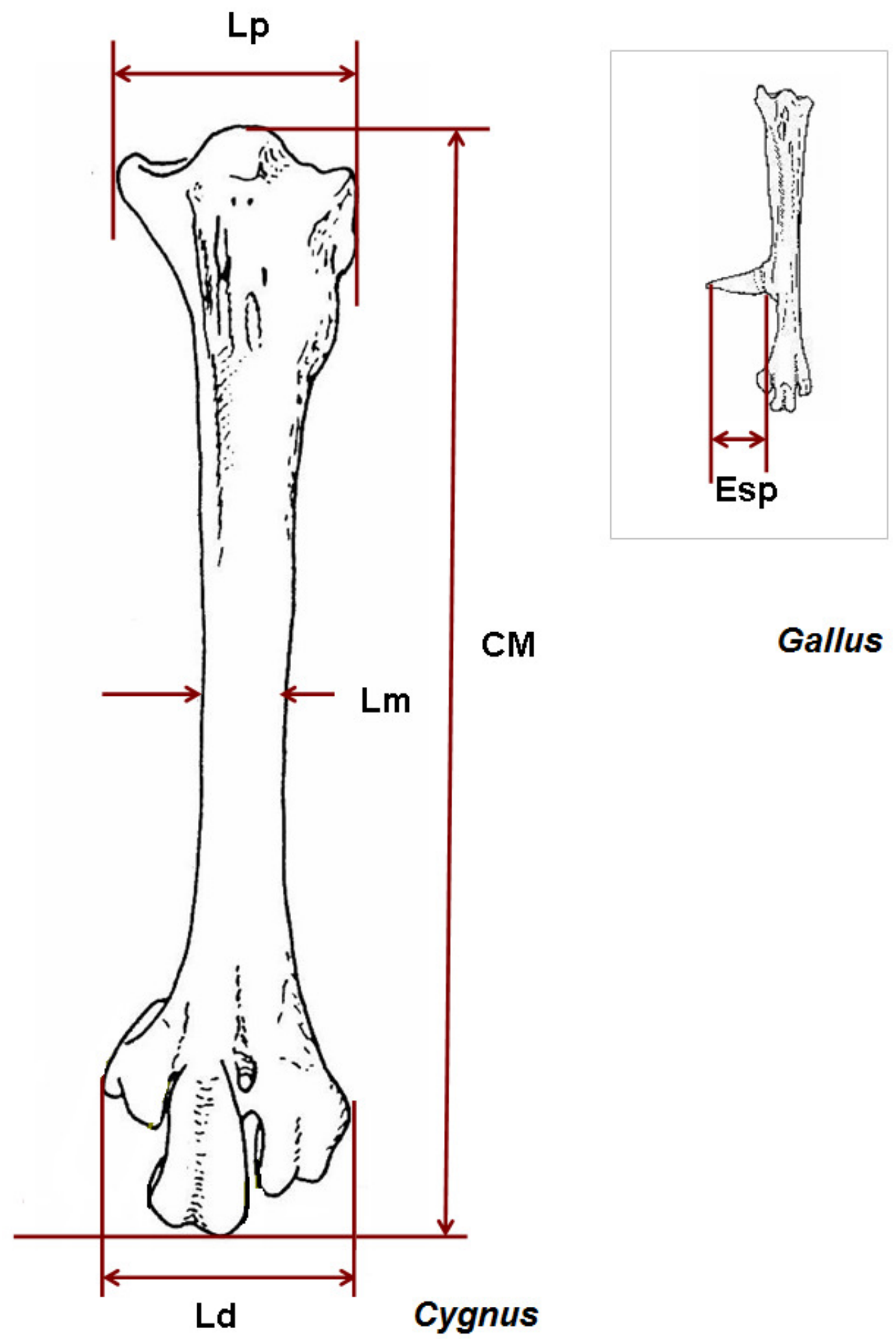


ANEXO III

LISTA DAS ESPÉCIES DE AVES FóSSEIS ENCONTRADAS EM PORTUGAL 


\section{1 - Jurássico}

Ordem: ARCHAEOPTERYGIFORMES (FURBRINGER 1888)

Família: ARCHAEOPTERYGIDAE (Huxley 1872)

Género: Cf. Archaeopteryx (VON MEYER 1861)

\section{2 - Eocénico}

Ordem: ChARADRIIFORMES (HUXLEY, 1867)

Família: RECURVIROSTRIDAE, (BONAPARTE, 1831)

Género: Fluviatitavis, (HARRISON, 1983)

Espécie: Fluviatitavis antunesi, (HARRISON, 1983)

\section{3 - Miocénico}

Classe: Aves (LINNAEUS, 1758)

AVES IND.

Ordem: GALLIFORMES (TEMMINCK, 1820)

Família: PhASIANIDAE (HORSEFIELD, 1821)

Subfamília: PHASIANIDAE (VIGORS, 1825)

Género: Palaeoperdi, (MILNE-EDWARDS, 1869-1871)

Espécie: Palaeoperdix media (MILNE-EDWARDS, 1869-1871)

Ordem: GRUIFORMES (BONAPARTE, 1854)

Família: GRUIDAE (VIGORS, 1825)

Distribuição dos táxones por jazidas (aves fósseis anteriores ao Plistocénico)

\begin{tabular}{|c|c|c|c|c|c|c|c|c|}
\hline \multirow{4}{*}{ Taxon } & \multirow{3}{*}{\begin{tabular}{|r|} 
Era \\
Período \\
Idade \\
\end{tabular}} & \multirow{3}{*}{\begin{tabular}{|c|} 
Mesozóico \\
Jurássico \\
Superior
\end{tabular}} & \multicolumn{6}{|c|}{ Cenozóico } \\
\hline & & & \multirow{2}{*}{$\begin{array}{l}\text { Paleogénico } \\
\text { Eocénico }\end{array}$} & \multicolumn{5}{|c|}{ Neogénico } \\
\hline & & & & Miocénico & Miocénico & Miocénico & Miocénico & Miocénico \\
\hline & Jazida & Guimarota & Silveirinha & O. Susana & Q. Pedreiras & Amôr & A. Baixo & Penedo \\
\hline \multicolumn{2}{|c|}{$\begin{array}{c}\text { Ave ind. } \\
\text { Cf. Archaeopteryx }\end{array}$} & * & & & & * & * & * \\
\hline \multicolumn{2}{|c|}{$\begin{array}{l}\text { Fluviatitavis antunesi } \\
\text { Palaeoperdix media }\end{array}$} & & * & * & * & & & \\
\hline
\end{tabular}




\section{4 - Plistocénico}

Ordem: GALLIFORMES

Família: TETRAONIDAE

PHASIANIDAE

Género: Tetrao

Alectoris

Perdix

Phasianus

Lagopus

Espécie: Tetrao urugallus

Alectoris rufa

Alectoris barbara

Perdix perdix

Coturnix coturnix

Cf. Phasianus colchicus

Lagopus lagopus

Lagopus mutus

Ordem: ANSERIFORMES

Família: ANATIDAE

Subfamília: ANATINAE

MERGINAE

ANSERINAE

Género: Anas

Melanitta

Tadorna

Somateria

Mergus

Querquedula 
Anser

Cignus

Espécie: Anas platyrhynchos

Anas acuta

Anas crecca

Melanitta nigra

Melanitta fusca

Clangula hyemalis

Tadorna tadorna

Tadorna ferruginea

Somateria mollisima

Mergus albellus

Anser albifrons

Cygnus cygnus,

Ordem: CHARADRIIFORMES

Família: SCOLOPACIDAE

LARIDAE

ALCIDAE

ChARADRIDAE

Subfamília: ALCINAE

Género: Larus

Scolopax

Numenius

Calidris

Scolopax

Pinguinus

Alca

Vanellus

Espécie: Scolopax rusticola

Numenius phaeopus

Calidris canutus 
Larus fuscus

Pinguinus impennis

Alca torda

Vanellus vanellus,

Pluvialis squatarola

Ordem: PODICIPEDIFORMES

Família: PODICIPEDIDAE

Género: Podiceps

Espécie: Podiceps nigricollis

Ordem: GRUIFORMES

Família: GRUIDAE

OTIDIDAE

Género: Grus

Otis

Espécie: Grus grus

Grus primigenia

Otis tarda

Ordem: ProcelLARIFORMES

Família: ProcelLARIIDAE

Género: Puffinus

Espécie: Puffinus puffinus

Puffinus holeae

Ordem: PeLECANIFORMES

Família: PHALACROCORIDAE

SULIDAE

Género: Phalacrocorax

Sula

Espécie: Phalacrocorax aristotelis 
Phalacrocorax carbo

Sula bassana

Phoenicopterus ruber

Ordem: GAVIIFORMES

Família: GAVIIDAE

Género: Gavia

Espécie: Gavia stellata

Ordem: FALCONIFORMES

Família: ACCIPITERIDAE

FALCONIDAE

Género: Accipiter

Aquila

Milvus

Falco

Hieraaetus

Aegypius

Gyps

Buteo

Haliaeetus

Espécie: Accipiter nisus,

Aquila chrysaetos

Aquila adalberti

Milvus migrans

Falco tinnunculus

Falco rosticolus

Hieraaetus fasciatus

Aegypius monachus,

Gyps fulvus,

Buteo buteo

Haliaeetus albicilla 
Ordem: STRIGIFORMES

Família: STRIGIDAE

Género: Bubo

Athene

Strix

Asio

Espécie: Bubo bubo

Athene noctua

Strix aluco

Asio flammeus

Ordem: COLUMBIFORMES

Família: COLUMBIDAE

Subfamília: COLUMBINAE

Género: Columba

Espécie: Columba livia,

Columba palumbus

Ordem: CORACIFORMES,

Família: CORCIDAE

Género: Coracias,

Espécie:Coracias garrulus

Ordem: CICONIIFORMES

Família: ARDEIDAE

Género: Egretta

Espécie: Egretta garzetta

Ordem: PASSERIFORMES

Família: CORVIDAE

TURDIDAE 
PICIDAE

FRINGILLIDAE

PASSERIDAE

STURNIDAE

HIRUNDINIDAE

\section{Subfamília:}

Género: Pyrrhocorax

Corvus

Pica

Turdus

Garrulus

Picus

Cyanopica

Sturnus

Carduelis

Ptyonoprogne

Phoenicopterus

Motacilla

Espécie: Pyrrhocorax pyrrhocorax

Pyrhycorax graculus

Corvus monedula

Corvus corax

Corvus corone

Corvus frugilegus

Corvus antecorax

Pica pica

Turdus iliacus

Turdus pilaris

Turdus philomelos

Turdus merula

Garrulus glandarius

Picus viridus 

Cyanopica cyana
Sturnus vulgaris
Carduelis carduelis
Ptyonoprogne rupespris
Motacilla alba

Ordem: CAPRIMULGIFORMES

Família: CAPRIMULGIDAE,

Género: Caprimulgus

Espécie Caprimulgus europaeus

Ordem: CUCULIFORMES

Família: CUCULIDAE

Género: Cuculus

Espécie Cuculus canorus 


\section{Anexo IV}

Distribuição das espécies pelas jazidas portuguesas com avifauna plistocénica

\begin{tabular}{|c|c|}
\hline & LEGENDA \\
\hline GNC & Gruta Nova da Columbeira \\
\hline GFP & Gruta da Furninha \\
\hline Gsal & Gruta de Salemas \\
\hline GPD & Gruta do Pego do Diabo \\
\hline GFt & Gruta das Fontainhas \\
\hline GCM & Gruta da Casa da Moura \\
\hline LRh & Lapa da rainha \\
\hline GCal & Gruta do Caldeirão \\
\hline GFB & Gruta da Figueira-brava \\
\hline $\mathrm{LPr}$ & Lapa do Picareiro \\
\hline GAIm & Grutas do Almonda \\
\hline ALV & Abrigo do Lagar Velho \\
\hline GEsc & Gruta do Escoral \\
\hline FENX & Foz do enxarrique \\
\hline BEsc & Buraca Escura \\
\hline
\end{tabular}


GNC GFP GSI GPD GFt GCM LRh GCal GFB LPr GAIm ALV GEsc FENX LAne BEsc

Ave ind

* *

Anser albifrons

Anas platyrhynchos

Anas crecca

Melanita nigra

Melanitta fusca

Clangula hyemalis

Mergus albellus

Tadorna tadorna

Somateria mollissima

Tadorna ferruginea

Cygnus olor

Perdix perdix

Alectoris rufo

Alectoris barbara

Phasianus colchicus

Coturnix coturnix

Tetrao urugalus

Lagopus lagopus

Lagopus mutus

Grus primigenia

Grus Grus

Otis tarda

Pluvialis squatarola

Puffinus puffinus

Puffinus holeae

Puffinus Kulhi

Sula bassana

Phalacrocorax carbo

Phalacrocorax aristotelis

Phoenicopterus ruber

Gavia stellata

Vanellus vanellus

Scolopax rusticola

Calidris canutus

Larus fuscus

Alca torda

Pinguinus impennis

Podiceps nigrollis

Cf. Aquila adalberti

Aquila chrysaetos

Buteo buteo

Accipiter nisus

Haliaeetus albicilla

Aegypius monachus

Hieraaetus fasciatus

Falco tinuculus

Falco rusticolus

Gyps fulvus

Milvus migrans

Tyto alba

Bubo bubo

Athene noctua

Asio flammeus

Strix aluco

Columba livia

Columba palumbus

Pyrrhocorax pyrrhocorax

Pyrrhocorax graculus

Corvus monedula

Corvus corone

Corvus frugilegus

Corvus antecorax

Corvus corax

Pica pica

Garrulus glandarius

Cyanopica cyana

Turdus iliacus

Turdus pilaris

Turdus philomelos

Turdus merula

Sturnus vulgaris

Carduelis carduelis

Ptyonoprogne rupestris

Numenius phaeopus

Cuculus canorus

Motacilla alba

Egreta alba

Caprimulgus europaeus

Picus viridus

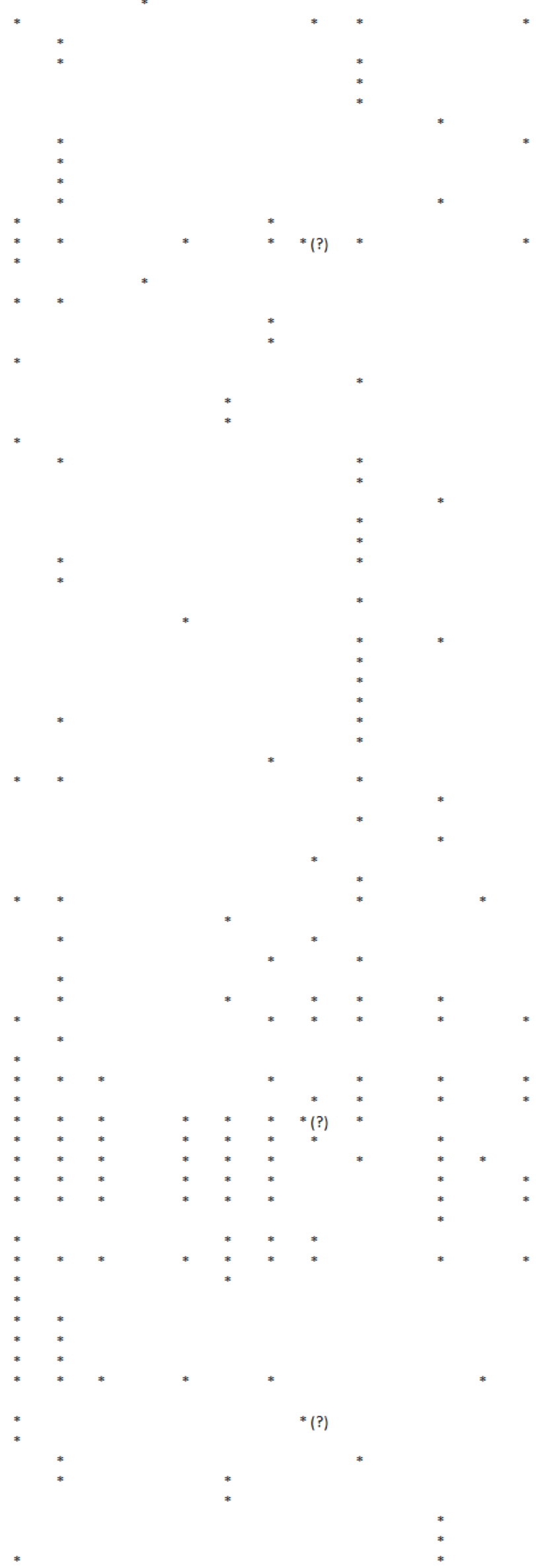


Anexo V

Datações absolutas das jazidas portuguesas com avifauna 


\begin{tabular}{|c|c|c|c|c|c|c|c|c|c|}
\hline Jazida & Datação & Ref. Bibliográfica & Método & Lab. & Referência & N. dat. & Amostra & Estratigrafia & Obs. \\
\hline G. Caldeirão & $\begin{array}{c}27600 \pm 600 \text { a } 10700 \\
\pm 380 \mathrm{BP}\end{array}$ & ZILHÃO, 1991 & C 14 & DXA & 1941 & 1 & Osso & $\begin{array}{l}\text { Cam. Sup. do } \\
\text { nivel } K\end{array}$ & \\
\hline Furninha & $\begin{array}{c}80880+42420 \\
-31260 \mathrm{BP}\end{array}$ & CARDOSO, 1993 & Th / U & SMU & (?) & 1 & Dente & 7,5 metros & $\begin{array}{l}\text { Datações mandadas fazer por L. } \\
\text { Raposo e publicadas por J. L. } \\
\text { Cardoso. }\end{array}$ \\
\hline Columbeira & $\begin{array}{c}26400 \pm 700 \text { a } 28900 \\
\pm 950 \mathrm{BP}\end{array}$ & DELIBRIAS et al. 1986 & C 14 & Gif & 2703 e 2704 & 2 & Carvões & Nivel 16 e 20 & \\
\hline Fontaínhas & $\begin{array}{c}22730+890-790 \\
B P\end{array}$ & ANTUNES et all, 1989 & C 14 & ICEN & 348 & 1 & Osso & & \\
\hline Casa da Moura & $25090 \pm 220 \mathrm{BP}$ & STRAUS et all, 1988 & C 14 & & & & & & \\
\hline Lapa da Raínha & $\begin{array}{c}20300 \pm 330 \mathrm{a} \\
25580-1490 \mathrm{BP}\end{array}$ & CARDOSO, 1993 & C 14 & ICEN & 789 e 790 & 2 & Osso & Corte II & \\
\hline G. Salemas & $\begin{array}{c}17770 \pm 420 \mathrm{a} \\
30930 \pm 420 \mathrm{BP}\end{array}$ & ANTUNES et all, 1989 & C 14 & ICEN & $\begin{array}{l}367,376,379 \\
383,384,385\end{array}$ & 6 & Osso & Nivel inferior & \\
\hline G. Figueira- Brava & $\begin{array}{c}30050 \pm 550 \mathrm{a} \\
30930 \pm 700 \mathrm{BP}\end{array}$ & ANTUNES et all, 1989 & C 14 & ICEN & 387 e 387 & 2 & Concha & Nivel inferior & \\
\hline G. Figueira- Brava & $\begin{array}{c}30560-10725 \mathrm{BP} \text { a } \\
44806-15889+ \\
13959 \mathrm{BP}\end{array}$ & $\begin{array}{l}\text { ANTUNES et all, } \\
1990 / 91\end{array}$ & Th / U & SMU & 233 e 233 & 2 & Dente & Nivel 2 & 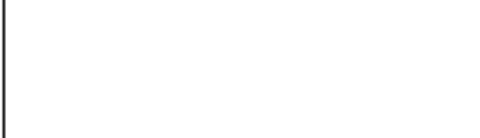 \\
\hline G. Escoural & $\begin{array}{l}19300+/-115 \mathrm{a} \\
15250+/-95 \mathrm{BP}\end{array}$ & SILVA et all, 1991 & C 14 & $\mathrm{MBN}$ & 406 e 407 & 2 & $\begin{array}{l}\text { "Placas" } \\
\text { estalagmít } \\
\text { icas }\end{array}$ & $\begin{array}{l}\text { Camadas } \\
\text { inferiores }\end{array}$ & $\begin{array}{l}\text { Estas datações não devem } \\
\text { corresponder á principal } \\
\text { acumulação de restos } \\
\text { paleontológicos, que será mais } \\
\text { antiga (CARDOSO, 1993). }\end{array}$ \\
\hline G. Escoural & $\begin{array}{c}48900+58007- \\
5500 \mathrm{BP}\end{array}$ & ARAÚJO et all, 1995 & Th / U & SMU & 250 & 1 & Dente & $\begin{array}{c}\text { S3a - Nivel: } 60- \\
70\end{array}$ & \\
\hline
\end{tabular}




\begin{tabular}{|c|c|c|c|c|c|c|c|c|c|}
\hline Jazida & Datação & Ref. Bibliográfica & Método & Lab. & Referência & N. dat. & Amostra & Estratigrafia & Obs. \\
\hline G. Pego do Diabo & $\begin{array}{c}28120+860 /-780 \\
B P-18630 \mathrm{BP} \pm 640\end{array}$ & ZILHÃO, 1993 & C 14 & ICEN & $490,491,732$ & 3 & Osso & camadas 2 e 3 & \\
\hline Foz do Enxarrique & $\begin{array}{l}32938 \pm 1055 \mathrm{e} \\
34093 \pm 920 \mathrm{BP}\end{array}$ & RAPOSO, 1995 & Th / U & SMU & $224,225,226$ & 3 & Dentes & Nivel C & \\
\hline $\begin{array}{l}\text { G. Oliveira } \\
\text { (Almonda) }\end{array}$ & Ca. 70000 a 35000 & ZILHÃO, 1993 & Th / U & SMU & $?$ & $?$ & Dentes & $?$ & $\begin{array}{l}\text { Segundo informação pessoal de } \\
\text { McKinney (1991). }\end{array}$ \\
\hline $\begin{array}{l}\text { Galerias Pesadas } \\
\text { (Almonda) }\end{array}$ & $\begin{array}{c}241000+30000 \\
-22000 \mathrm{BP}\end{array}$ & TRINKAUS et al, 2003 & Th / U & (?) & (?) & 1 & Dentes & (?) & \\
\hline Lagar Velho I & $\begin{array}{c}23920 \pm 220 \text { a } 24660 \\
\pm 260 \mathrm{BP}\end{array}$ & PETTITT et alli, 2002 & C 14 & OxA & $\begin{array}{c}8421,8422 \\
8423\end{array}$ & 3 & Ossos & & Sepultura. \\
\hline Lagar Velho I & $24860 \pm 200 \mathrm{BP}$ & PETTITT et alli, 2002 & C 14 & GrA & 13310 & 1 & Ossos & & Sepultura. \\
\hline Lagar Velho & $\begin{array}{c}20200 \pm 180 \mathrm{a} \\
22670 \pm 160 \mathrm{BP}\end{array}$ & PETTITT et alli, 2002 & C 14 & OxA & $\begin{array}{c}8418,8419 \\
8420,8424 \\
8425,8426 \\
10303\end{array}$ & 7 & Ossos & $\begin{array}{c}\text { Nivel } 1,6,7,8 \mathrm{e} \\
9\end{array}$ & $\begin{array}{l}\text { Níveis de ocupações posteriores } \\
\text { à da sepultura da criança. }\end{array}$ \\
\hline Lagar Velho & $21380 \pm 810 \mathrm{BP}$ & PETTITT et alli, 2002 & C 14 & Sac. & 1561 & 1 & Ossos & Nivel 6 & $\begin{array}{l}\text { Níveis de ocupações posteriores } \\
\text { à da sepultura da criança. }\end{array}$ \\
\hline Lapa do Picareiro & $\begin{array}{c}10070 \pm 80 \text { a } 12500 \\
\pm 120 \mathrm{BP}\end{array}$ & $\mathrm{BICHO}$ et alli, 2003 & C 14 & Wk & $\begin{array}{c}4217,4218, \\
4219,5431, \\
6677,6678 \\
10433,10434\end{array}$ & 8 & Carvões & Camdas: $\mathrm{E}, \mathrm{Fe} J$ & \\
\hline Lapa do Picareiro & $12320 \pm 90 \mathrm{BP}$ & $\mathrm{BICHO}$ et alli, 2003 & C 14 & OxA & 5527 & 1 & Carvões & Camada: G & \\
\hline Buraca Escura & $\begin{array}{c}21820 \pm 200 \text { e } 22700 \\
\pm 240 \mathrm{BP}\end{array}$ & AUBRY et alli, 2001 & C 14 & OxA & 5523 e 5524 & 2 & Ossos & $\begin{array}{c}\text { Camada } 2 a \mathrm{e} \\
\text { nivel } 2 \mathrm{e}\end{array}$ & \\
\hline Buraca Escura & $26560 \pm 450 \mathrm{BP}$ & AUBRY et alli, 2001 & C 14 & GifA & 97258 & 1 & Ossos & Unidade $2 \mathrm{f}$ & \\
\hline
\end{tabular}


Anexo VI

Distribuição europeia das espécies identificadas em Portugal (Fonte: TYBERG, 2006) 
Portugal Azerbeijão Alemanha Chipre França Georgia Hungria Austria Italia Malta Moldavia Roménia Bégicica R. Unido Russia Bulgária

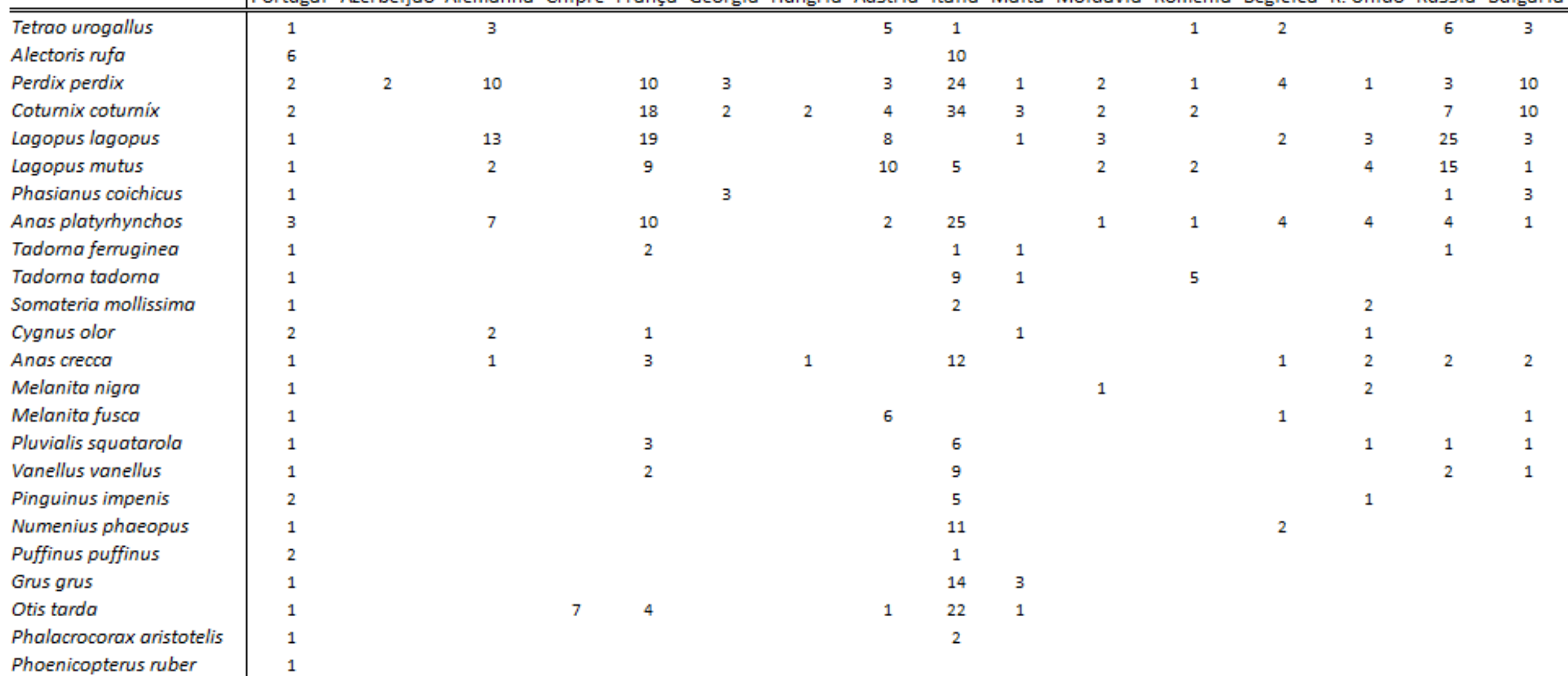


Portugal Azerbeijão Alemanha Chipre França Georgia Hungria Austria Italia Malta Moldavia Roménia Bégicica R. Unido Russia Bulgária

Aquila chrysaetos

Aquila adalberti

Gyps fulvus

Milvus migrans

Falco rusticolus

Falco tinnunculus

Tyto alba

Athene noctua

Bubo bubo

Asio flammeus

Strix aluco

Columba livia

Columba palumbus

Corvus corax

Corvus corone

Corvus frugilegus

Corvus monedula

Pica pica

Pyrrhocorax graculus

Pyrrhocorax pyrrhocorax

Turdus iliacus

Turdus merula

Turdus philomelos

Turdus pilaris

Garrulus glandarius

Cyanopia cyana

Carduelis carduelis

Motacila alba

Ptyonoprogne rupestris

Cuculus canorus

13

2

2

1

14

3

2
1

2

232

9

1

ça Georgia Hungria Austria Ita

3

1

\begin{tabular}{|c|c|c|c|c|c|c|c|c|}
\hline 5 & 31 & 2 & \multicolumn{2}{|l|}{1} & \multirow[t]{2}{*}{1} & & 11 & 8 \\
\hline & 3 & 1 & & & & & & \\
\hline & 25 & & & & & 2 & 6 & \\
\hline & 16 & & & 1 & 3 & 1 & 3 & 1 \\
\hline 3 & 10 & 2 & 1 & 1 & & 1 & 16 & 1 \\
\hline & 13 & 1 & 1 & & & 1 & 3 & 1 \\
\hline & 36 & 1 & 1 & 1 & & & 6 & 2 \\
\hline 1 & 24 & 1 & & & 1 & 1 & & \\
\hline 2 & 20 & 1 & 1 & 1 & 1 & & 9 & 2 \\
\hline 1 & 24 & 1 & & 1 & & & 6 & 2 \\
\hline & 5 & 1 & & & 1 & & & 2 \\
\hline 4 & 22 & 2 & 3 & 3 & & 1 & 3 & 16 \\
\hline 2 & 18 & & 1 & 1 & 1 & & 14 & 6 \\
\hline 10 & 43 & & & 1 & & & 9 & 8 \\
\hline 3 & 33 & & & 2 & & & 21 & 5 \\
\hline 1 & 8 & & & & & 1 & & 2 \\
\hline & 8 & 1 & 1 & 1 & & 1 & & 5 \\
\hline 3 & 3 & 1 & & & & 1 & 2 & 3 \\
\hline & 8 & & & 2 & 2 & & 1 & 1 \\
\hline 3 & 8 & 2 & & 1 & 1 & 1 & & 4 \\
\hline & & & & 1 & & & & \\
\hline & 4 & & & & & & & 2 \\
\hline & 4 & & & & & & 3 & 1 \\
\hline
\end{tabular}


Holanda Noroega Arménia Polónia Suécia Suiça Sérvia Eslováqia Eslovénia Turquia Espanha Grécia Montegro

\begin{tabular}{|c|c|c|c|c|c|c|c|c|c|c|c|c|}
\hline Tetrao urogallus & & & & 13 & & 1 & 2 & 1 & & & & \\
\hline Alectoris rufa & & & & & & & & & & 13 & & \\
\hline Perdix perdix & & & & 9 & & & & 1 & & 17 & & \\
\hline Cotumix cotumix & & & & 5 & & & 2 & & & 37 & 1 & \\
\hline Lagopus lagopus & 1 & 1 & & 29 & & & & 4 & & 3 & & 1 \\
\hline Lagopus mutus & 1 & 2 & & 17 & & & 1 & 3 & & 2 & & \\
\hline \multicolumn{13}{|l|}{ Phasianus coichicus } \\
\hline Anas platyrhynchos & 1 & & 1 & 16 & 1 & & & 1 & 1 & 19 & & \\
\hline Tadoma ferruginea & & & & & & & & & 1 & 3 & & \\
\hline Tadorna tadorna & & & & & & & & & & 2 & & \\
\hline Somateria mollissima & & 1 & & 1 & & & & & & & & \\
\hline Cygnus olor & & & & & & & & & & 1 & & \\
\hline Anas crecca & & & & 7 & & & & & 1 & 10 & & \\
\hline Melanita nigra & & 1 & & 3 & & & & & & 1 & & \\
\hline Melanita fusca & 1 & & & & & & & & 2 & & & 1 \\
\hline Vanellus vanellus & & & & & & & & & & 8 & & \\
\hline Pinguinus impenis & & & & & & & & & & 1 & & \\
\hline Numenius phaeopus & & & & 4 & & & & & & & & \\
\hline Puffinus puffinus & & & & & & & & & & 3 & & \\
\hline Grus grus & & & & 1 & & & & & & 5 & & \\
\hline Otis tarda & & & & 1 & & & & 1 & & 9 & 3 & \\
\hline Phalacrocorax aristotelis & & & & & & & & & & & & \\
\hline Phoenicopterus ruber & & & & & & & & & & & & \\
\hline
\end{tabular}


Anexo VII

Distribuição dos indicadores paleoambientais das espécies de aves identificadas em Portugal, pelos períodos arqueológicos das jazidas estudadas e publicadas 
Agrupando todas as espécies de aves reconhecidas no Plistocénico de Portugal (as identificadas neste trabalho e as já publicadas e referidas no ponto 4 da Parte II) pelos climas a elas associados e distribuindo-as pelos períodos arqueológicos de cada jazida, verifica-se valores mais elevados no Paleolítico Médio, devido ao facto de haver um maior número de espécies reconhecidas nesse período. Em relação aos ambientes constata-se que existe em todos os períodos uma predominância de climas temperados e secos. Os climas húmidos têm um grande pico no paleolítico Médio, a que deve ao facto de as Grutas da Furninha e da Figueira-Brava, que se localizam na costa, estarem datadas deste período, enquanto no final do Paleolítico Superior a ocorrência deste clima é muito fraca. No Paleolítico Superior, apesar de se manter um predomínio dos climas secos e temperados, verifica-se uma subida comparativa dos valores de climas frios.

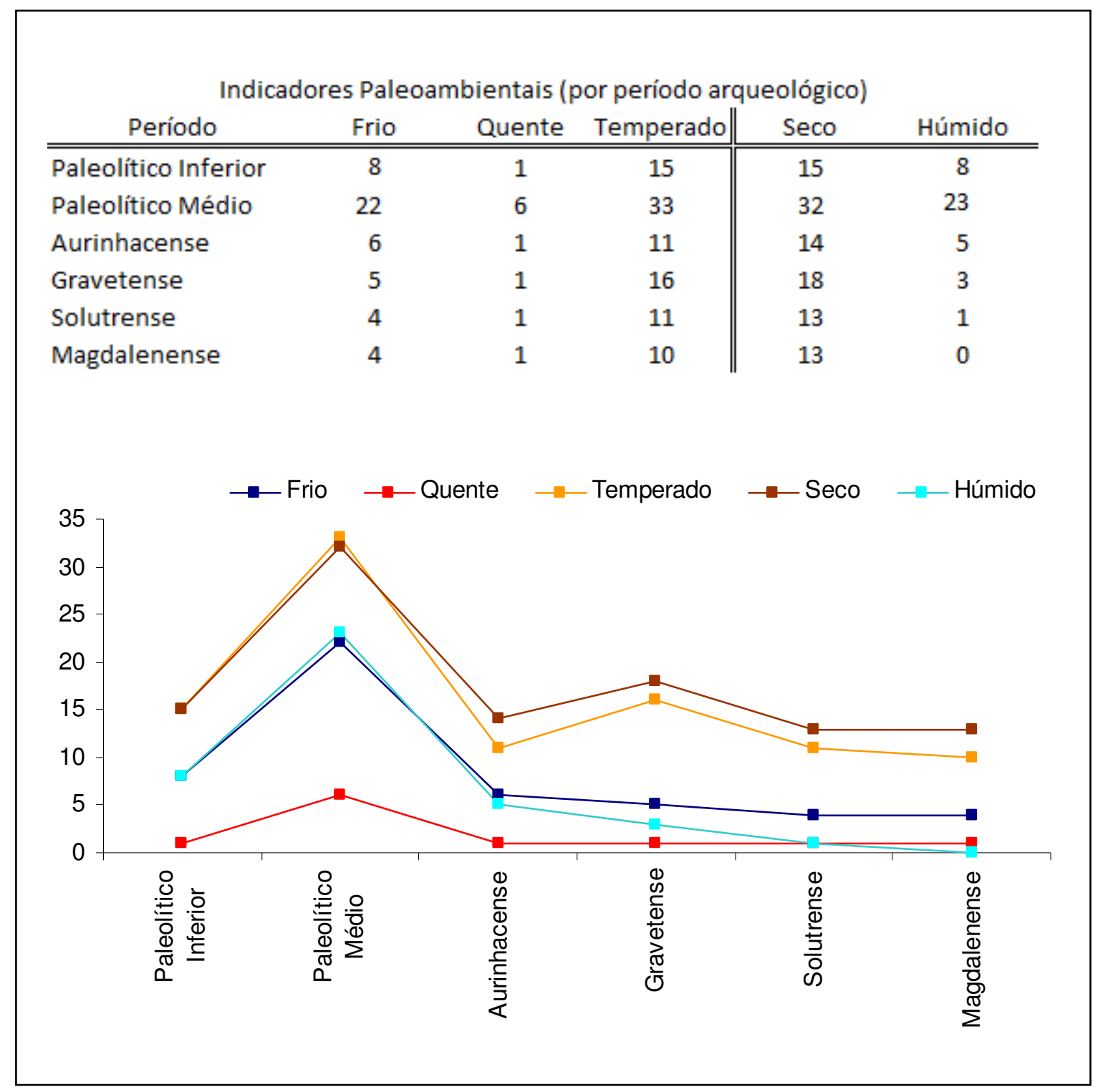

